Universidad deValladolid

\author{
PROGRAMA DE DOCTORADO EN \\ INGENIERÍA INDUSTRIAL \\ INGENIERÍA ENERGÉTICA
}

TESIS DOCTORAL:

\title{
“DETERMINACIÓN DE LA EFICIENCIA ENERGÉTICA ALCANZADA EN LA RED DE DISTRIBUCIÓN DE CALOR DE LA UNIVERSIDAD DE VALLADOLID, MEDIANTE LA MODELIZACIÓN Y TRATAMIENTO DE LAS LÍNEAS BASE DE LOS CONSUMOS DE LOS EDIFICIOS CONECTADOS"
}

\author{
Presentada por Ana $\mathrm{M}^{\mathrm{a}}$. Marina Domingo, para \\ optar al grado de \\ Doctor/a por la Universidad de Valladolid
}

\author{
Dirigida por: \\ D. Francisco Javier Rey Martínez \\ D. Julio San José Alonso
}




\section{Dedicatoria}

A David y Alicia:

Lo mejor de mi vida, mi mayor regalo

"Lo difícil se consigue, lo imposible se intenta"

(Napoleón Bonaparte)

"Nunca es demasiado tarde para ser la persona que podrías haber sido"

(George Eliot) 


\section{Agradecimientos}

A mis padres con su apoyo incondicional, a mi famila por su comprensión, a mis hijos por su infinito cariño y a todos aquellos que sin entender el por qué, ni el para qué, lo han respetado.

A D. Julio Francisco San José Alonso, por sus ánimos, consejos, paciencia y múltiples revisiones, a D. Sergio Lorenzo González, por toda la información facilita, a D. Francisco Javier Rey Martínez por su apoyo, a D. Javier Mạ Rey Hernández y Dña Raquel Mata Crespo por sus aportes en el proceso.

Al resto del departamento de Ingeniería Energética D. Eloy Velasco Gómez y Dña Ana Tejero González, por sus constantes ánimos y palabras de aliento.

A la Universidad de Valladolid (UVA) a la Sociedad Pública de Infraestructuras y Medio Ambiente de la Junta de Castilla y León (SOMACYL), al Instituto de las Tecnologías Avanzadas de la Producción (ITAP), y a los integrantes del proyecto: GIRTER (Nuevo Gestor Inteligente para Redes Térmicas), proyecto financiado por Fondo Europeo de Desarrollo Regional a través del Programa RETOS COLABORACIÓN 2016 del Ministerio de Economía, Industria y Competitividad, y dentro del objetivo temático: Promover el desarrollo tecnológico, la innovación y una investigación de calidad. 


\section{Resumen}

Las redes de calor se han convertido en una apuesta indiscutible para todas aquellas ciudades que desean disminuir sus emisiones de $\mathrm{CO}_{2}$, gracias, sobre todo, a la posibilidad de sustituir los combustibles fósiles de los sistemas convencionales de calefacción por energías renovables como la biomasa. A finales de 2015, se inauguró la red de calor urbana con biomasa forestal de la Universidad de Valladolid (UVA), proyecto que comenzó atendiendo la demanda térmica de 27 edificios, 23 de los cuales pertenecen a la Univesridad, distribuidos entre el Campus Universitario Miguel Delibes y el Río Esgueva. En el año 2019, se conecto el Hospital Clinico y en un futuro próximo se conectarán otros tres edificios de la UVA: Palacio de congresos Conde Ansúrez, la Biblioteca Reina Sofía y la Casa del Estudiante, la infraestructura dará servicio a un total de 31 edificios públicos.

Esta tesis analiza la eficiencia energética alcanzada en cada uno de los edificios de la UVA conectados a la red y cuantifica las emisiones de $\mathrm{CO}_{2}$ evitadas, dado que uno de los objetivos del proyecto era obtener un ahorro anual en calefacción de al menos el 15\%. La presente tesis verifica el grado de consecución de dicho objetivo, obteniendo los modelos matemáticos que representan la interacción multivariable de la tendencia del consumo frente a las condiciones climáticas, con un alto coeficiente de determinación. Para ello, siguiendo la opción C de la metodología EVO, basada en el procesado y tratamiento de consumos globales, se han recopilado datos de dos años antes de la implementación del proyecto y datos de tres años posteriores a la ejecución de la red de calor, de los 23 edificios de la UVA que están conectados a la red y de las variables independientes que pudieran condicionarlos. Esos datos han sido procesados estadísticamente con el programa SPPS.

Como resultado se ha llegado a la cuantificación de la influencia de los parámetros analizados en el consumo térmico de cada uno de los edificios, obteniendo las correlaciones existentes entre las distintas variables y la fuerza de asociación entre las mismas, de manera que considerando los modelos matemáticos obtenidos como las líneas base de sus consumos térmicos, se han predecido con unos residuos admisibles y una variabilidad acotada en el 95 \% de nivel de confianza, los consumos esperados. La tesis presenta la metodología estadística empleada para la aceptación de esos modelos, seleccionando las variables climáticas más influyentes; y explica como de la comparación estadística entre las predicciones y los valores reales de los datos obtenidos en los tres años de funcionamiento de la red de calor, se ha podido verificar si las diferencias encontradas son estadísticamente significativas y en caso de aceptación, éstas han sido cuantificadas. 


\section{Abstract}

District Heatings have become an undeniable bet for all those cities that wish to reduce their $\mathrm{CO}_{2}$ emissions, due to the possibility of replacing fossil fuels with renewable energies such as biomass. At the end of 2015, the University of Valladolid inaugurated a heating network to satisfiy to the thermal demand of 27 buildings, 23 of which belong to the University, distributed between two university campus: Miguel Delibes and Esgueva. In 2019, the Clinical Hospital was connected and in the near future, three other UVA buildings will be connected: Conde Ansúrez Conference Center, Reina Sofía Library and Student House, then infrastructure will provide service to 31 public buildings.

This thesis analyzes the energy efficiency achieved in each of the UVA buildings connected to the grid and quantifies avoided $\mathrm{CO}_{2}$ emissions, given that one of the objectives of the project was to obtain an annual heating savings of at least $15 \%$. The present thesis verifies the degree of achievement of such objective, obtaining the mathematical models that represent the multivariable interaction between consumption tendency and climatic conditions, with a high coefficient of determination. In order to make this possible, option $\mathrm{C}$ of the EVO methodology, based on the processing and treatment of global consumption, was followed. Data had been collected for two years before the implementation of the project and for three years after heating network, of the 23 UVA buildings, which were connected to the network. These data have been processed statistically with SPPS software.

As a result, the influence of the analyzed parameters of thermal consumption of each of the buildings has been quantified, obtaining correlations among different variables, so considering the mathematical models as baselines of their thermal consumption, forecasted consumption could be predicted with a confidence level of $95 \%$. The thesis presents the statistical methodology used to accept these models and it explains how statistical comparisons between predictions and real operation values, has been able to verify whether the found differences are statistically significant and in case of acceptance, these have been quantified. 


\section{ÍNDICE}

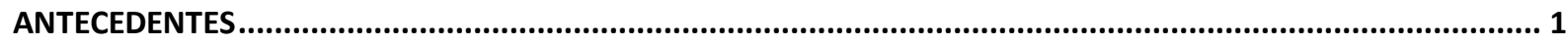

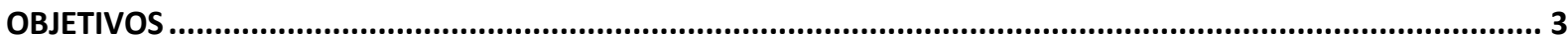

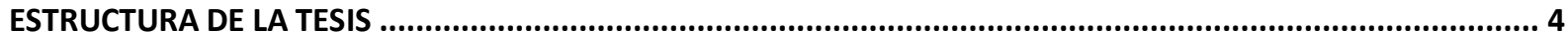

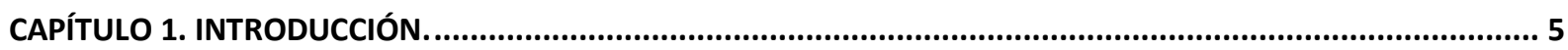

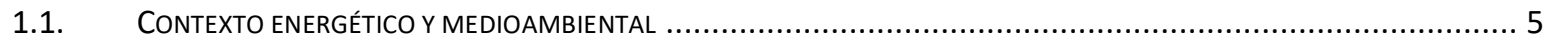

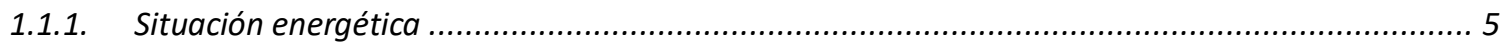

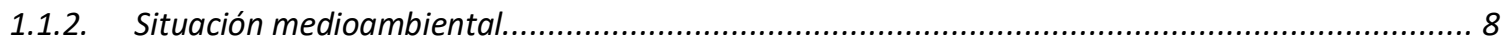

1.1.3. Medidas a implantar para un Desarrollo Sostenible .............................................................11

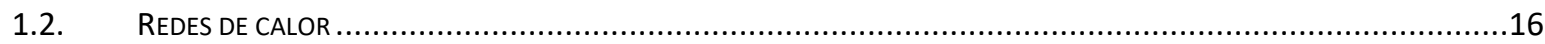

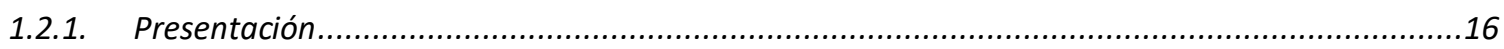

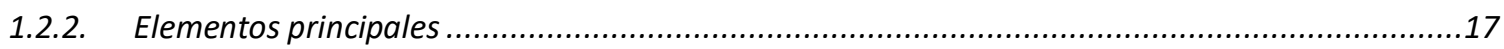

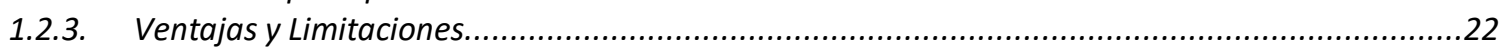

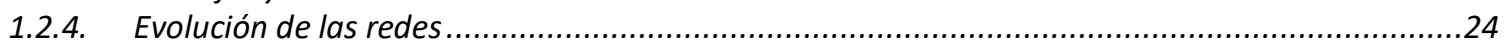

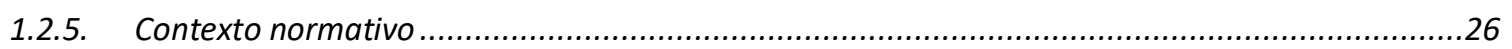

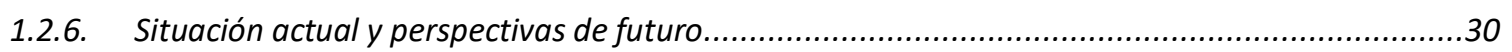

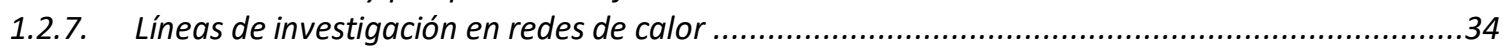

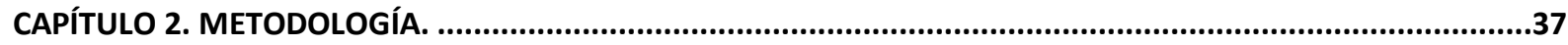

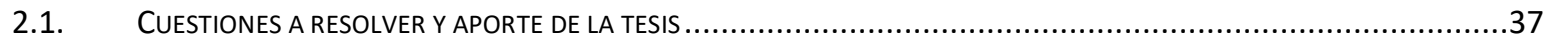

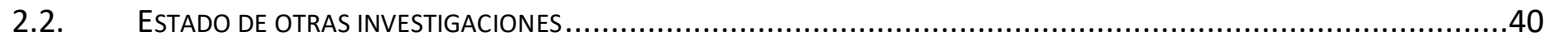

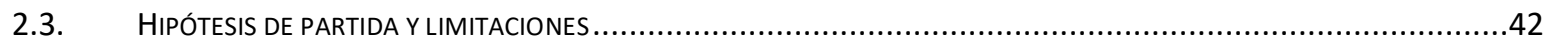

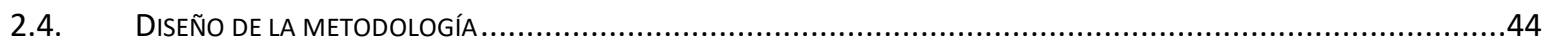

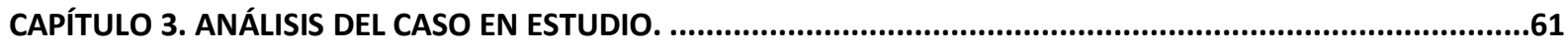

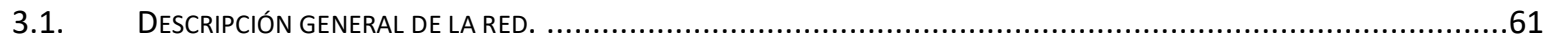

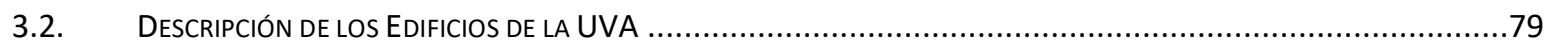

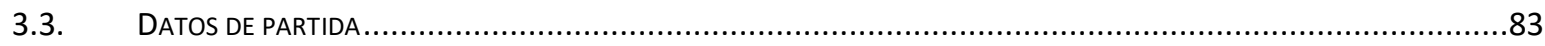

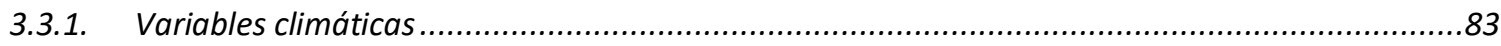

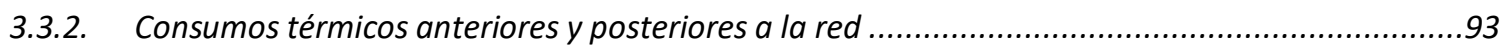

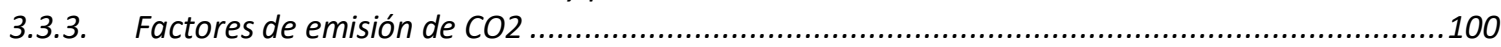

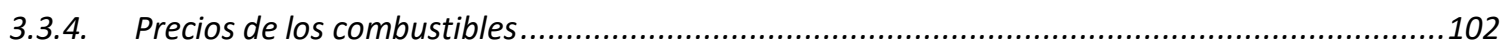

CAPÍTULO 4. RESULTADOS Y DISCUSIÓN. CAMPUS MIGUEL DELIBES. ..........................................................106

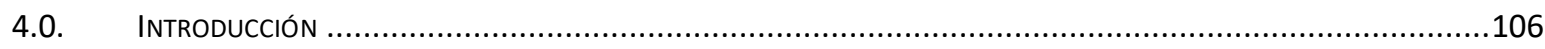

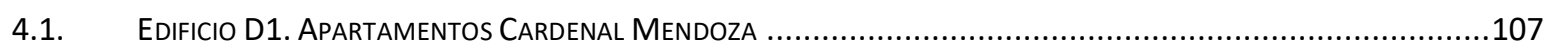

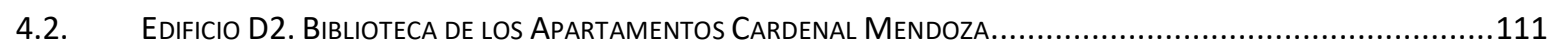

4.3. Edificio D3. CENTRO de TRANSFERENCIA de TECNOLOGÍAS APLICADAS. CTTA ..........................................115 
Índice

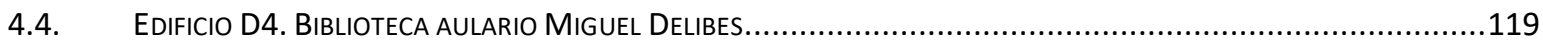

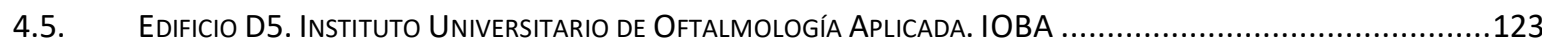

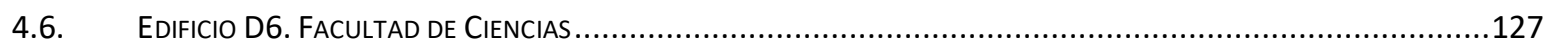

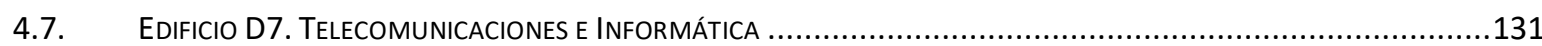

4.8. EDIFICIO D8. EdIFICIO DE QUÍMICA FINA Y MATERIALES AVANZADOS. QUIFIMA .....................................135

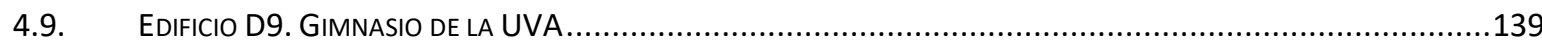

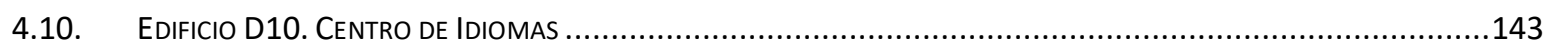

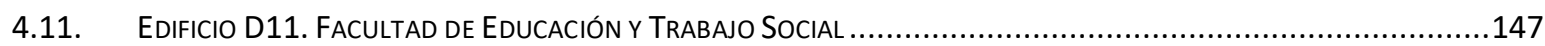

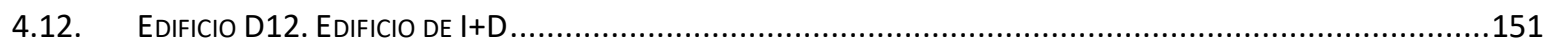

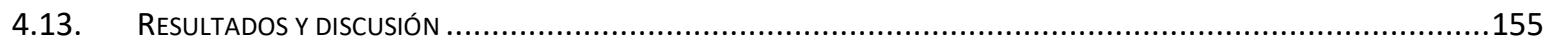

CAPÍTULO 5. RESULTADOS Y DISCUSIÓN. CAMPUS RÍO ESGUEVA. ......................................................165

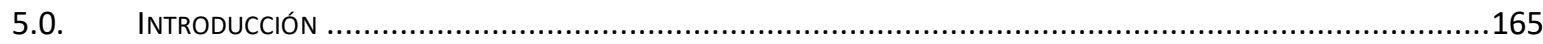

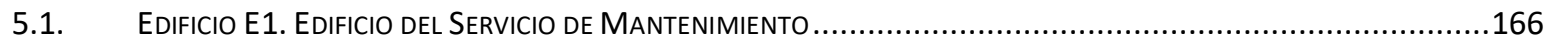

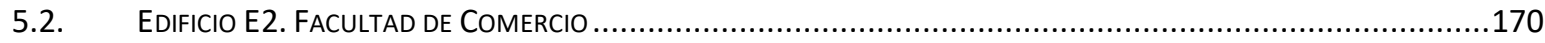

5.3. EDIFICIO E3. FACULTAD DE FILOSOFÍA Y LETRAS.............................................................174

5.4. Edificio E4. Escuela de Ingenierías Industriales. Antigua FaCultad de Ciencias ...............................178

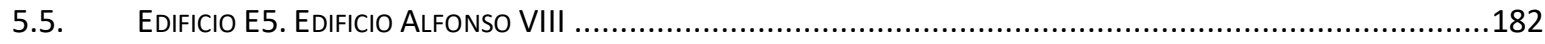

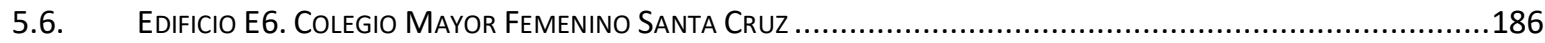

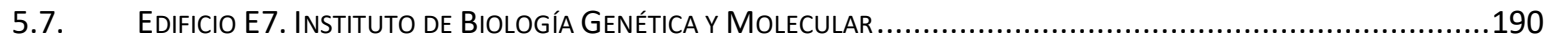

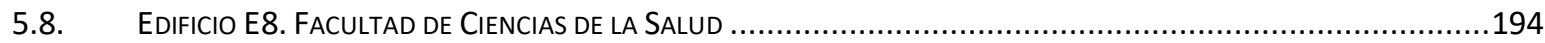

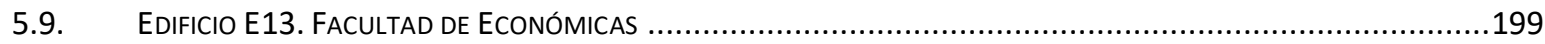

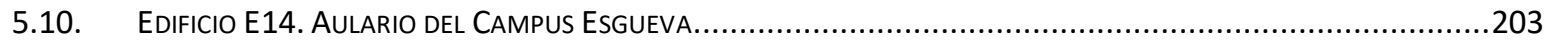

5.11. EdifiCIO E15. EsCUela de Ingenierías Industriales (SEDE PASEO del CAUCE) .................................207

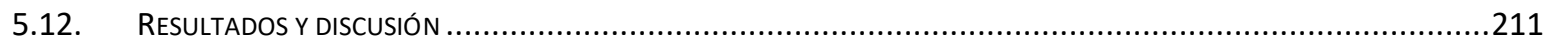

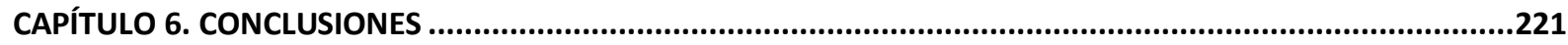

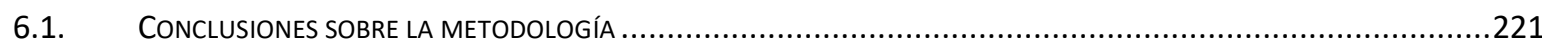

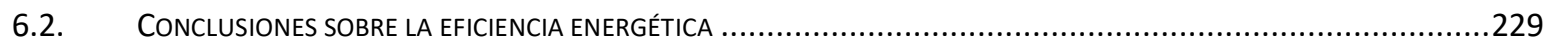

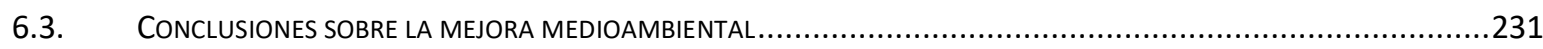

6.4. FUtURO DE LA RED. NUEVAS LÍNEAS DE INVESTIGACIÓN ............................................................232

ANEXO I. PROTOCOLOS DE MEDIDA Y VERIFICACIÓN ......................................................................235

ANEXO II. TRATAMIENTO ESTADÍSTICO DE LOS DATOS....................................................................239

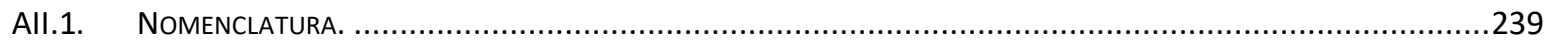

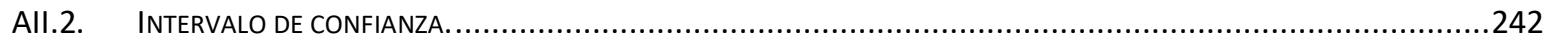

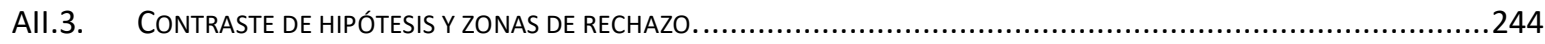

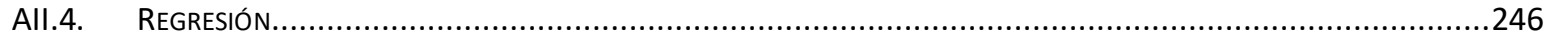

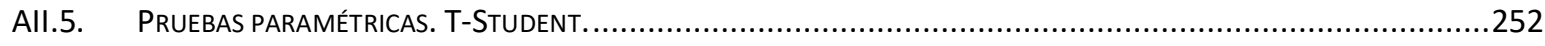

ANEXO III. DESCRIPCIÓN DE LOS EDIFICIOS DE LA RED DE CALOR DE LA UVA........................................255

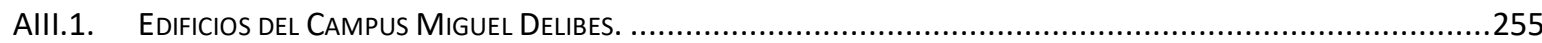

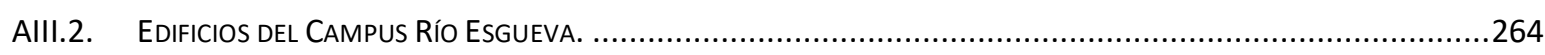

ANEXO IV. DESARROLLO DEL ANÁLISIS DE LOS EDIFICIOS DEL CAMPUS MIGUEL DELIBES..........................273

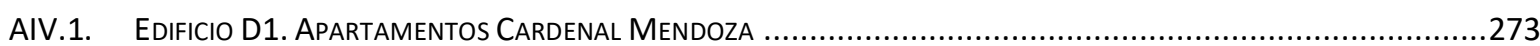

AIV.1.1. Obtención de la línea base de referencia energética.......................................................273

AIV.1.2. Verificación del cumplimiento de los supuestos estadísticos .............................................278

AIV.1.3. Obtención de los consumos térmicos previstos......................................................284

AIV.1.4. Estudio de la existencia de diferencias significativas.................................................285 
Índice

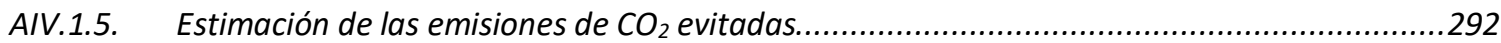

AIV.1.6. Estimación del precio máximo de compra a la red............................................................293

AIV.2. EDIFICIO D2. BiblioteCA DE los Apartamentos CARdenal MendozA..................................................29

AIV.2.1. Obtención de la línea base de referencia energética.........................................................294

AIV.2.2. Verificación del cumplimiento de los supuestos estadísticos ..............................................297

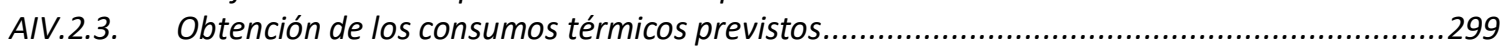

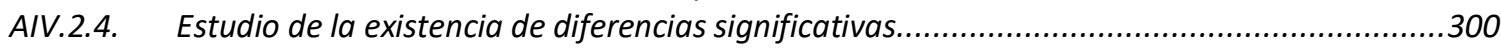

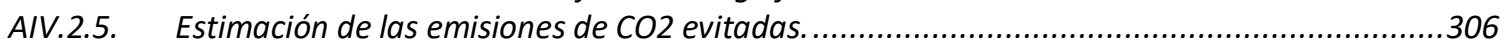

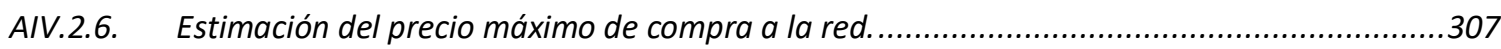

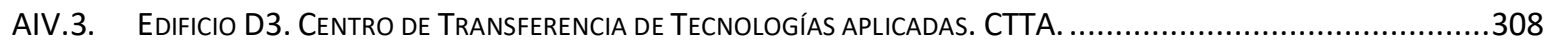

AIV.3.1. Obtención de la línea base de referencia energética.........................................................308

AIV.3.2. Verificación del cumplimiento de los supuestos estadísticos ...............................................310

AIV.3.3. Obtención de los consumos térmicos previstos....................................................................

AIV.3.4. Estudio de la existencia de diferencias significativas.............................................................

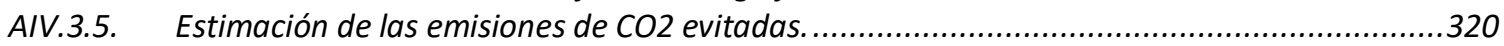

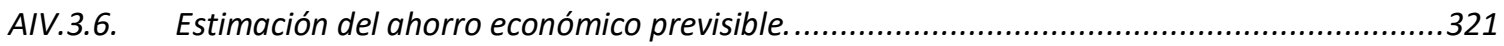

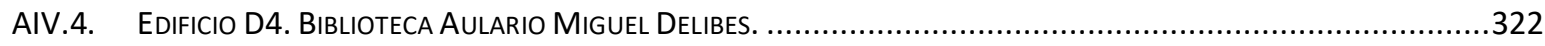

AIV.4.1. Obtención de la línea base de referencia energética..........................................................322

AIV.4.2. Verificación del cumplimiento de los supuestos estadísticos ................................................324

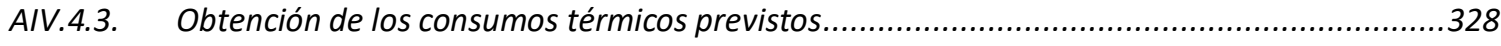

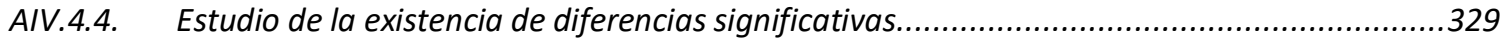

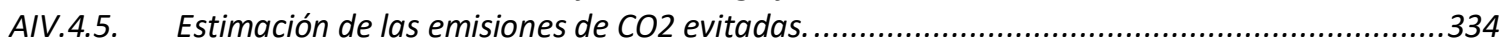

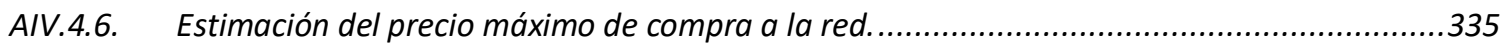

AIV.5. EDIFICIO D5. INSTITUTO UNIVERSITARIO DE OfTALMOLOGÍA APLICADA. IOBA. .........................................336

AIV.5.1. Obtención de la línea base de referencia energética........................................................336

AIV.5.2. Verificación del cumplimiento de los supuestos estadísticos ...............................................338

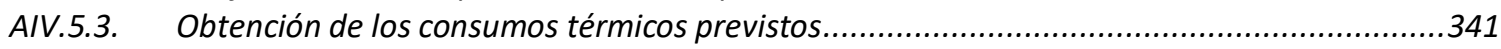

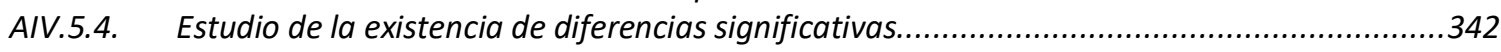

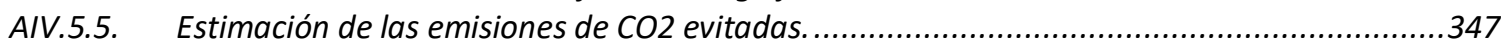

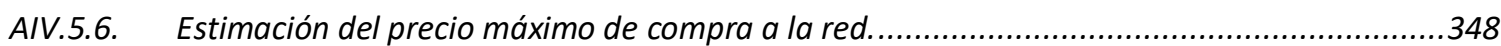

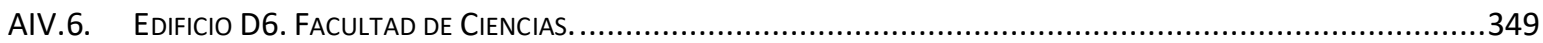

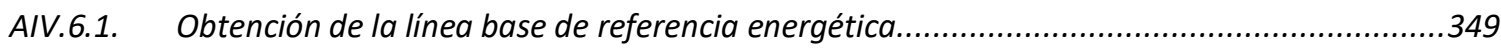

AIV.6.2. Verificación del cumplimiento de los supuestos estadísticos ................................................351

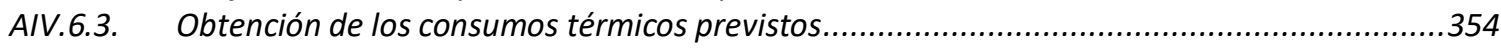

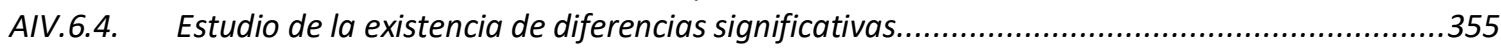

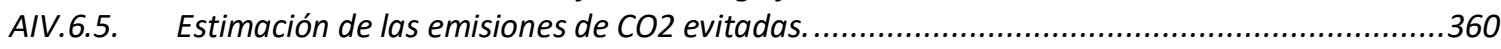

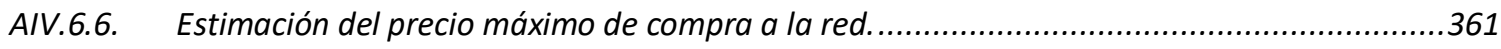

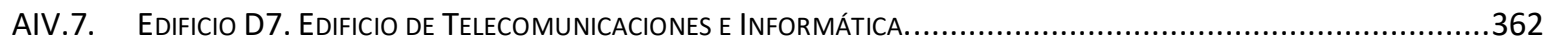

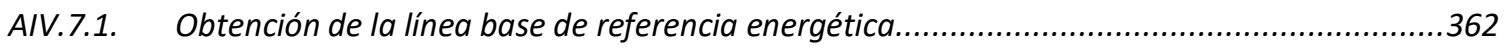

AIV.7.2. Verificación del cumplimiento de los supuestos estadísticos .................................................364

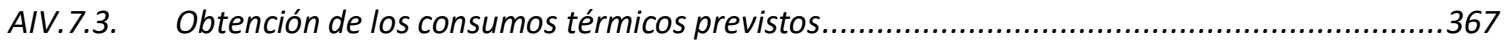

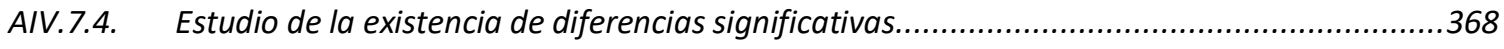

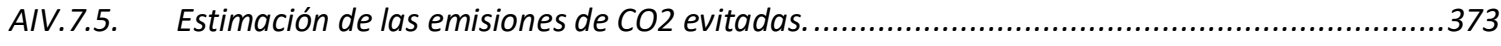

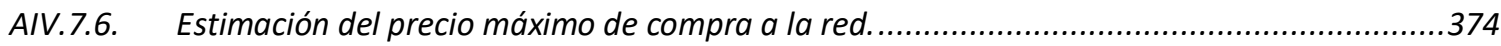

AIV.8. EDIFICIO D8. EDIFICIO DE QUÍMICA FINA Y MATERIALES AVANZADOS (QUIFIMA).....................................375

AIV.8.1. Obtención de la línea base de referencia energética............................................................

AIV.8.2. Verificación del cumplimiento de los supuestos estadísticos .................................................380

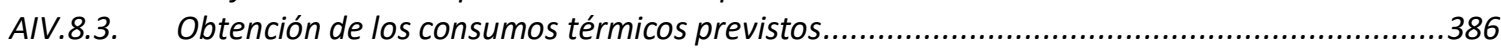

AIV.8.4. Estudio de la existencia de diferencias significativas..........................................................38

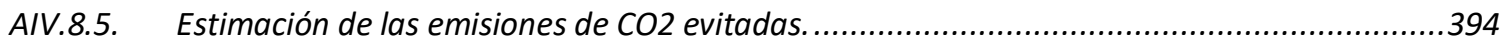


Índice

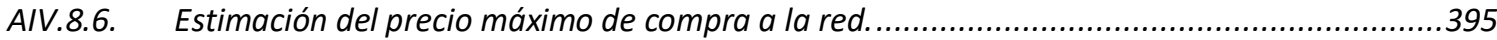

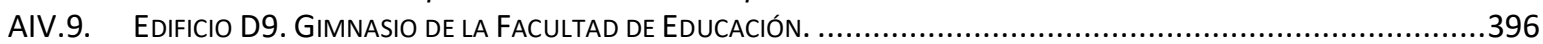

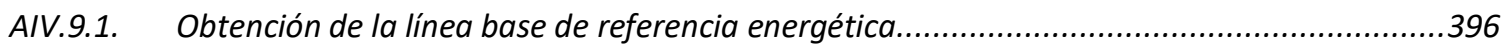

AIV.9.2. Verificación del cumplimiento de los supuestos estadísticos ..............................................398

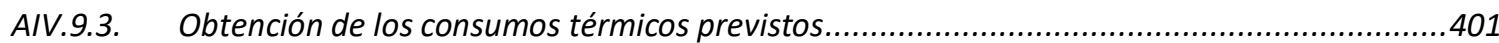

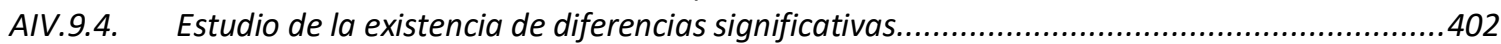

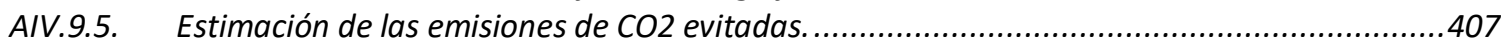

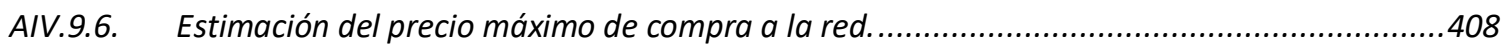

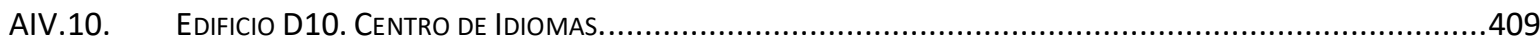

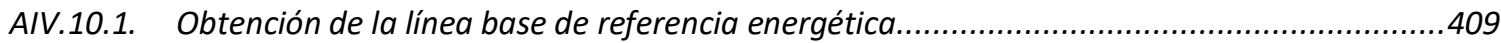

AIV.10.2. Verificación del cumplimiento de los supuestos estadísticos ...............................................411

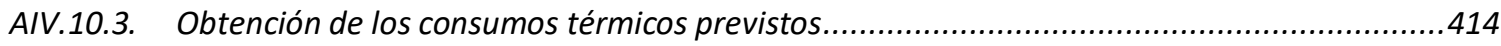

AIV.10.4. Estudio de la existencia de diferencias significativas..........................................................415

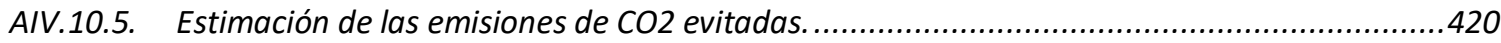

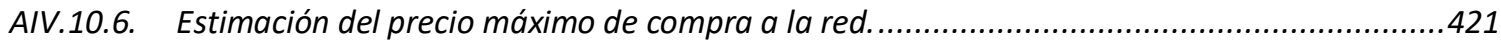

AIV.11. EDIFICIO D11. FACULTAD DE EdUCACIÓN Y TRABAJO SOCIAL. .........................................................422

AIV.11.1. Obtención de la línea base de referencia energética........................................................422

AIV.11.2. Verificación del cumplimiento de los supuestos estadísticos ...............................................426

AIV.11.3. Obtención de los consumos térmicos previstos................................................................432

AIV.11.4. Estudio de la existencia de diferencias significativas........................................................433

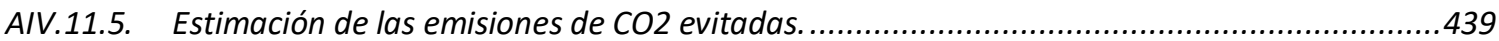

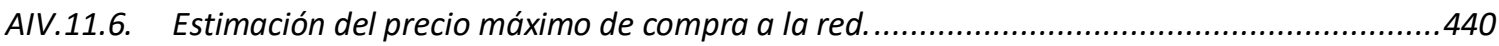

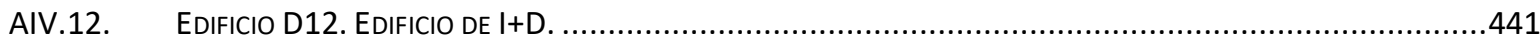

AIV.12.1. Obtención de la línea base de referencia energética........................................................441

AIV.12.2. Verificación del cumplimiento de los supuestos estadísticos ...............................................443

AIV.12.3. Obtención de los consumos térmicos previstos................................................................446

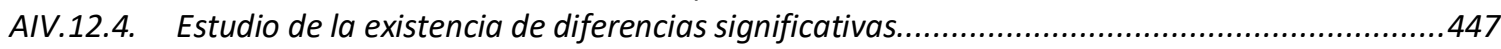

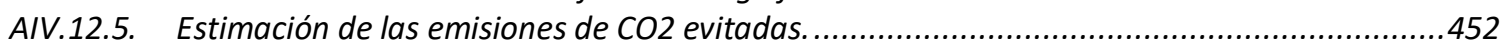

AIV.12.6. Estimación del precio máximo de compra a la red...........................................................453

ANEXO V. DESARROLLO DEL ANÁLISIS DE LOS EDIFICIOS DEL CAMPUS RÍO ESGUEVA...................................455

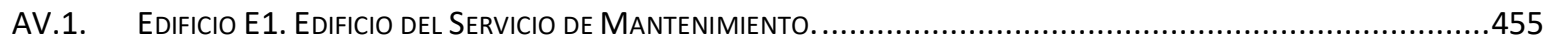

AV.1.1. Obtención de la línea base de referencia energética........................................................455

AV.1.2. Verificación del cumplimiento de los supuestos estadísticos ...............................................458

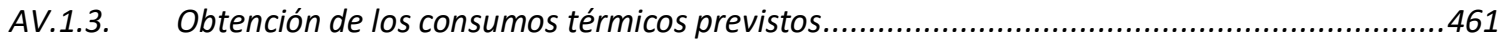

AV.1.4. Estudio de la existencia de diferencias significativas.........................................................462

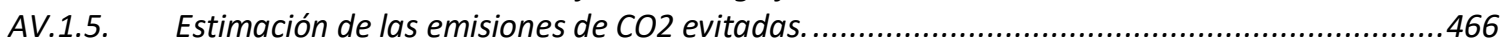

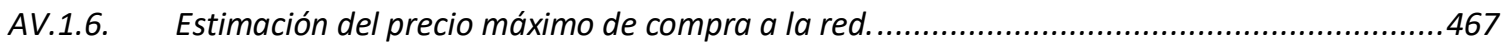

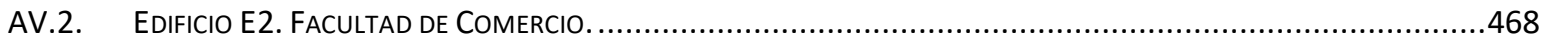

AV.2.1. Obtención de la línea base de referencia energética.........................................................468

AV.2.2. Verificación del cumplimiento de los supuestos estadísticos ...............................................470

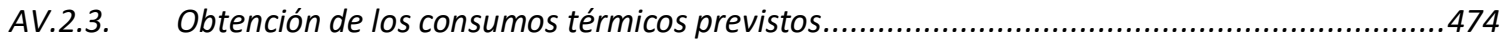

AV.2.4. Estudio de la existencia de diferencias significativas........................................................475

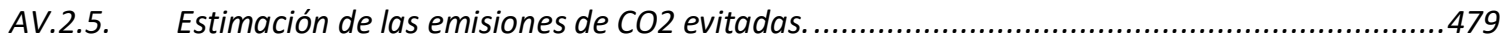

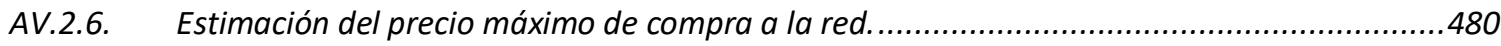

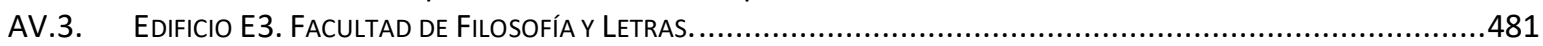

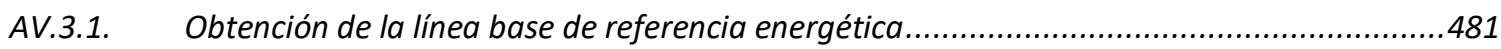

AV.3.2. Verificación del cumplimiento de los supuestos estadísticos .............................................486

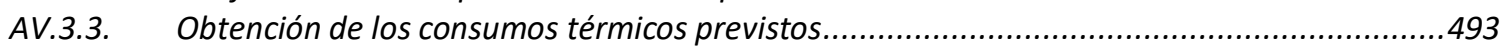

AV.3.4. Estudio de la existencia de diferencias significativas.........................................................494 
Índice

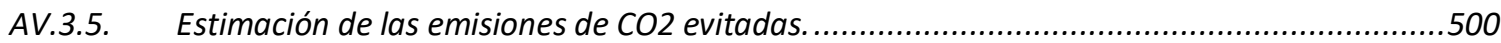

AV.3.6. Estimación del precio máximo de compra a la red...........................................................501

AV.4. EDIFICIO E4. ESCUELA DE INGENIERÍAS INDUSTRIALES (ANTIGUA FACULTAD DE CIENCIAS) .............................502

AV.4.1. Obtención de la línea base de referencia energética.......................................................502

AV.4.2. Verificación del cumplimiento de los supuestos estadísticos .............................................504

AV.4.3. Obtención de los consumos térmicos previstos.............................................................507

AV.4.4. Estudio de la existencia de diferencias significativas........................................................508

AV.4.5. Estimación de las emisiones de $\mathrm{CO} 2$ evitadas...................................................................512

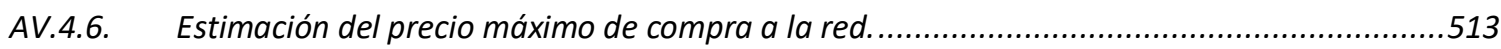

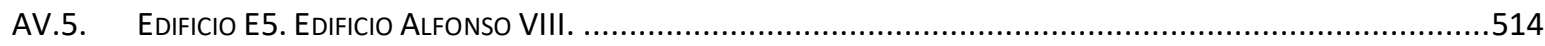

AV.5.1. Obtención de la línea base de referencia energética.......................................................514

AV.5.2. Verificación del cumplimiento de los supuestos estadísticos .............................................516

AV.5.3. Obtención de los consumos térmicos previstos.................................................................519

AV.5.4. Estudio de la existencia de diferencias significativas.......................................................520

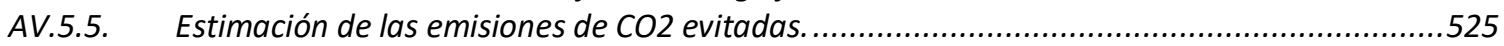

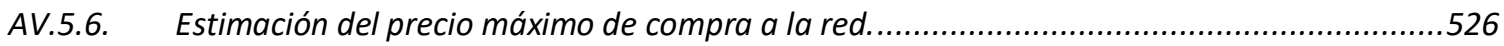

AV.6. EdificIO E6. ColegIo MAYOR FEMENINO SANTA CRUZ. ................................................................527

AV.6.1. Obtención de la línea base de referencia energética.........................................................527

AV.6.2. Verificación del cumplimiento de los supuestos estadísticos ..............................................529

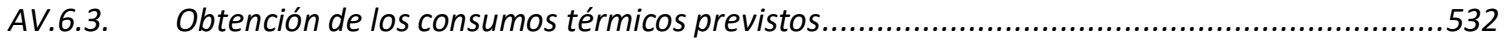

AV.6.4. Estudio de la existencia de diferencias significativas..........................................................53

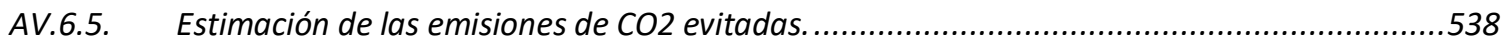

AV.5.6. Estimación del precio máximo de compra a la red..........................................................539

AV.7. EDIFICIO E7. INSTITUTO DE BIOLOGíA GenÉTICA Y MoleCULAR...........................................................540

AV.7.1. Obtención de la línea base de referencia energética......................................................540

AV.7.2. Verificación del cumplimiento de los supuestos estadísticos .............................................542

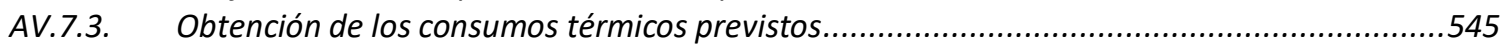

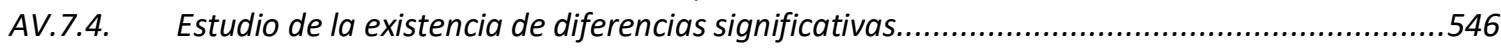

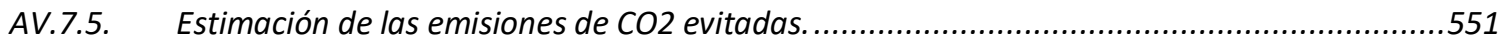

AV.7.6. Estimación del precio máximo de compra a la red..........................................................552

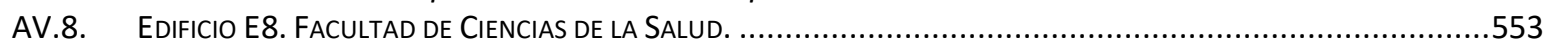

AV.8.1. Obtención de la línea base de referencia energética.....................................................553

AV.8.2. Verificación del cumplimiento de los supuestos estadísticos ..............................................558

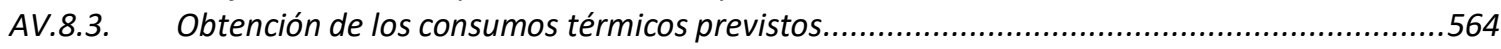

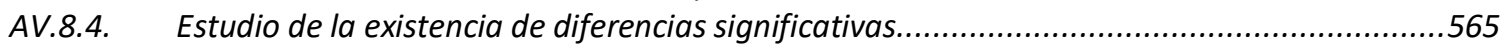

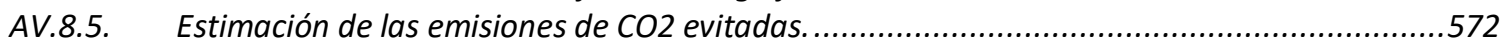

AV.8.6. Estimación del precio máximo de compra a la red...........................................................573

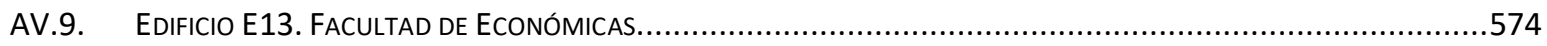

AV.9.1. Obtención de la línea base de referencia energética......................................................574

AV.9.2. Verificación del cumplimiento de los supuestos estadísticos ...............................................576

AV.9.3. Obtención de los consumos térmicos previstos................................................................58

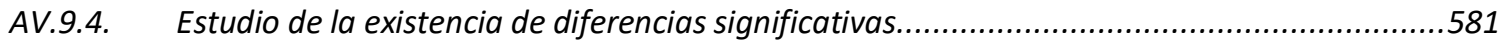

AV.9.5. Estimación de las emisiones de CO2 evitadas...................................................................58

AV.9.6. Estimación del precio máximo de compra a la red..........................................................58

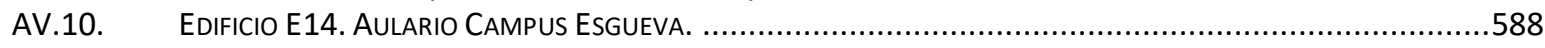

AV.10.1. Obtención de la línea base de referencia energética.......................................................58

AV.10.2. Verificación del cumplimiento de los supuestos estadísticos ..............................................590

AV.10.3. Obtención de los consumos térmicos previstos.............................................................593

AV.10.4. Estudio de la existencia de diferencias significativas.........................................................594

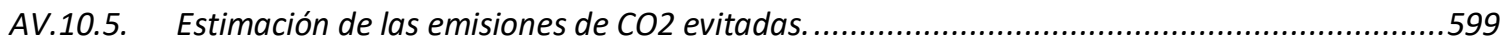


Índice

AV.10.6. Estimación del precio máximo de compra a la red..........................................................600

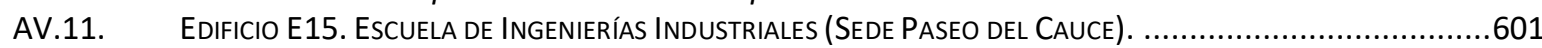

AV.11.1. Obtención de la línea base de referencia energética...................................................601

AV.11.2. Verificación del cumplimiento de los supuestos estadísticos .............................................606

AV.11.3. Obtención de los consumos térmicos previstos..........................................................612

AV.11.4. Estudio de la existencia de diferencias significativas...................................................613

AV.11.5. Estimación de las emisiones de CO2 evitadas. ..................................................................619

AV.11.6. Estimación del precio máximo de compra a la red...........................................................620

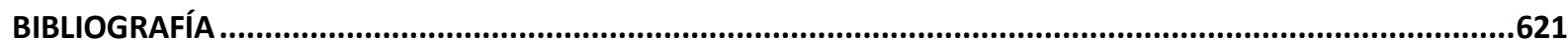

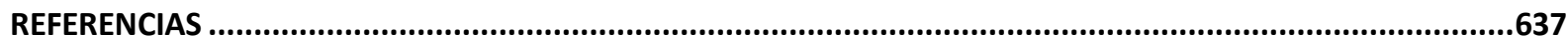

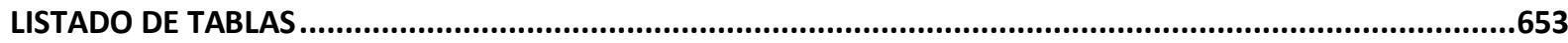

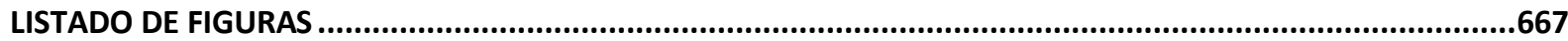




\section{ANTECEDENTES}

A finales de 2015, se inauguró la red de calor urbana con biomasa forestal de la Universidad de Valladolid. Durante las tres primeras temporadas de funcionamiento, la red atendió la demanda térmica de 27 edificios: 4 pertenecientes a la Junta de Castilla y León y 23 a la Universidad de Valladolid, de los que 12 se agrupan en el Campus Universitario Miguel Delibes y 11 en el Campus del Río Esgueva. Durante el verano de 2018 se incorporó el Hospital Clínico Universitario y próximamente se añadirán otros tres edificios de la Universidad: el Palacio de Congresos Conde Ansúrez, la Biblioteca Reina Sofía y la Casa del Estudiante, con lo que la red dará servicio a un total de 31 edificios públicos.

Uno de los objetivos con los que se ideó la red era obtener un ahorro anual en calefacción de al menos el 15\%; El ahorro energético es una magnitud que no puede ser medida directamente, pues se trata de cuantificar "aquello que se deja de consumir"; por lo que no puede ser calculado por mera diferencia entre el consumo final y el consumo inicial dado que para que la diferencia fuera coherente, al menos, sería necesario contar con las mismas condiciones climáticas en ambos escenarios.

Para crear esas mismas condiciones es necesario investigar y desarrollar modelos matemáticos que representen la interacción multivariable de la tendencia de los consumos frente a las condiciones climáticas con un alto coeficiente de determinación, un nivel de confianza del $95 \%$ y que cumplan todas las hipótesis estadísticas necesarias que validen los modelos de regresión obtenidos.

Uno de los resultados de la obtención de esos modelos es poder cuantificar la influencia de los parámetros analizados en el consumo global de cada uno de los edificios, obteniendo las correlaciones existentes entre las distintas variables y la fuerza de asociación entre las mismas, de manera que el modelo matemático conseguido pueda predecir con unos residuos admisibles y una variabilidad acotada, el consumo esperado y puedan convertirse en los patrones de las líneas base de los consumos térmicos esperados. 
De la comparación entre las predicciones de los modelos para las temporadas posteriores a la construcción de la red, con el valor real de los datos obtenidos en los años de funcionamiento de la red de calor y utilizando técnicas estadísticas de contraste de hipótesis, se verificará si las diferencias encontradas son estadísticamente significativas, permitiendo aceptar o rechazar la hipótesis nula de igualdad de medias entre poblaciones de muestras relacionadas y cuando las diferencias sean significativas serán cuantificadas para obtener el grado de ahorro térmico alcanzado.

Para ello, siguiendo la opción C de la metodología EVO, basada en el procesado y tratamiento de consumos globales, se han recopilado datos de dos temporadas anteriores a la red y de tres temporadas después de la implementación del proyecto, de los 23 edificios de la UVA que están conectados a la red y de las variables climáticas independientes que pudieran condicionarlos. Esos datos han sido procesados estadísticamente con el programa SPSS.

Los datos procesados son los relativos a la energía final comprada por la UVA, en dos momentos distintos: durante las dos temporadas de calefacción anteriores a la construcción de la red, donde la energía final comprada provenía de los suministradores de gas natural y gasóleo y durante las tres temporadas de calefacción siguientes al funcionamiento de la red calor; donde la energía final comprada por la UVA viene dada en su mayor parte por la compra de la energía al gestor de la red de calor, medida en el secundario del intercambiador de cada edificio más la energía que se ha seguido comprado a los suministradores de gas natural y gasóleo como apoyo puntual a la energía proporcionada por la red.

Además de la comprobación de los ahorros de energía suministrada, se ha simulado el ahorro en emisiones de $\mathrm{CO}_{2}$ asociado a la energía final comprada por la UVA en las dos situaciones señaladas y fijando un ahorro económico en la compra de la energía final del $15 \%$, el precio que debería tener la energía comprada al gestor de la red para obtener ese ahorro del $15 \%$, para lo cual se ha partido de unos precios medios estadísticos de los combustibles fósiles utilizados. 


\section{OBJETIVOS}

El objetivo fundamental de la presente tesis es conocer y cuantificar el ahorro de energía final suministrada a los edificios de la Universidad de Valladolid, alcanzado durante las tres primeras temporadas de calefacción posteriores a la ejecución de red en los 23 edificios pertenecientes a la Universidad de Valladolid.

En resumen el presente trabajo de investigación permitirá:

- Poder predecir el consumo de energía térmica de los edificios de la Universidad al modificar las variables climáticas que más le influyan

- Determinar cuáles son las variables más influentes en el consumo térmico representado en la línea base

- Obtener una curva matemática que represente la línea base y tenga en cuenta la variación de los parámetros definidos como los más representativos

- Conocer cuantitativamente la evolución temporal del consumo térmico antes de la red de calor.

- Conocer con exactitud la reducción obtenida en el consumo térmico y por tanto poder estimar el ahorro en emisiones de $\mathrm{CO}_{2}$ que ha supuesto la implantación de la red de calor

- Estimar cuál pueden ser los consumo futuros esperados

- Servir de herramienta para poder comparar los consumos futuros esperados con los obtenidos en la realidad

- En base a ese conocimiento a futuro, poder implementar las medidas oportunas para corregir cualquier desviación detectada asociada a la eficiencia de los sistemas

- Poder dar explicación a las desviaciones que se detecten de la línea base establecida para el siguiente periodo de demanda.

- Servir de base para la implantación de un sistema de gestión energética en la red 


\section{ESTRUCTURA DE LA TESIS}

La tesis está estructurada en seis capítulos y cinco anexos.

En el Primer Capítulo se realiza una pequeña introducción a la situación energética y medioambiental que ha motivado el auge de las redes de calor, además se presenta las principales características de las redes de calor, sus perspectivas de futuro y las líneas de investigación abiertas

El Segundo Capítulo recoge las cuestiones que se presenten resolver con la tesis, el estado de otras investigaciones, las hipótesis tenidas en cuenda y se expone la metodología utilizada.

El Tercer Capítulo se describe el funcionamiento general de la red de calor, los edificios de la Universidad de Valladolid (UVA) conectados a la misma y los datos de partida tenidos en cuenta para la realización del estudio, tanto los relativos a las variables climáticas como los datos de la energía final comprada por la UVA desde el 2012 hasta el 2018.

En el Cuarto Capítulo se resumen los resultados obtenidos para cada uno de los doce edificios del Campues Miguel Delibes conectados a la red de calor, siguiendo la metodología explicada en el Segundo Capítulo y en el Quinto Capítulo los resultados obtenidos para cada uno de los once edificios del Campues Río Esgueva conectados a la red de calor.

La tesis finaliza con el Capítulo Sexto, donde se recopilan las conslusiones obtenidas y se avanzan cuáles podrían ser los siguientes pasos a analizar en un futuro.

Los cinco anexos, suministran una información extra en cuanto a los protocolos de medida y verificación utilizados internacionalmente, los coceptos básicos de estadística utilizados según la metodología de la tesis, una descripción más detallada de cada uno de los edificios de la UVA conectados a la red de calor y el desarrollo completo del análisis realizado para cada edificio. 


\section{CAPÍTULO 1. INTRODUCCIÓN.}

\subsection{Contexto energético y medioambiental}

\subsubsection{Situación energética}

La energía es sinónimo de actividad, de riqueza y de progreso, de hecho los países más avanzados del mundo son los que más energía consumen, además ese consumo lejos de disminuir sigue aumentando con el paso del tiempo.

Hoy consumimos unas 20 veces más energía que a principios del siglo XX. La población humana se ha multiplicado desde entonces por un factor algo superior a 6, lo cual quiere decir que los 7.000 millones de seres humanos actuales consumimos, en promedio, unas 3 veces más energía per cápita que el ser humano de principios del siglo XX. (Prieto, 2011) [1]

El problema del consumo energético, se asocia directamente con el problema medioambiental que ocasiona; sobre todo por las emisiones que producen los combustibles fósiles que han estado presentes durante toda la historia, con mayor o menor protagonismo.

Durante la revolución industrial de los siglos XVIII y XIX, el carbón fue la energía primaria más utilizada; pero con la llegada de la era del transporte en el siglo XX, el petróleo se convierte en el combustible fósil más consumido, hasta que las crisis de 1973 y 1979 provocan que el precio del barril pase de 5 a 45 dólares americanos, lo que hace que el carbón y la energía nuclear se coloquen en los primeros puestos del consumo energético mundial.

En el siglo XXI, el petróleo vuelve a estar a la cabeza de los combustibles más utilizados. En el 2017, la energía total primaria consumida en el mundo fue de 13.511 millones de toneladas de petróleo equivalente (Mtep). 
En ese mismo año, la Unión Europea consumió 1.689 Mtep, lo que representa el 12,5\% del total y España 139 Mtep (el 1\% del consumo mundial) (BP, 2018) [2]. España se convierte, así, en el decimonoveno país más consumidor del mundo. Siendo China el primer consumidor mundial con un porcentaje del 23\%, seguido por Estados Unidos con el $17 \%$ e India con el 6\%.

En el 2017, más de las tres cuartas partes del consumo energético, tanto en el mundo (85\%), como en Europa (75\%) o en España (76\%), tuvieron su origen en los combustibles fósiles. Se estima que en el año 2040, el consumo de combustibles fósiles en el mundo se habrá reducido hasta representar el 75\%, la energía nuclear se incrementará en tres puntos y en siete puntos las energías renovables, ascendiendo el consumo total mundial a 17.934 Mtep. (International Energy Agency (IEA), 2017) [3]. Aunque el uso de combustibles fósiles rondará, todavía, las tres cuartas partes del consumo mundial, el aumento en la utilización de energías renovables, permitirá que países como España (octavo país con más dependencia energética de la Unión Europea, con un porcentaje del $72,9 \%$, siendo la media europea del 53,1 \%. (Díaz, 2016) [4]) reduzcan su dependencia energética.

En el 2014, de los 118,4 Mtep de energía primaria consumidos por España, en Castilla y León se consumieron 8,94 Mtep, lo que representa el 7,5\% del consumo primario español. (Ente Regional de la Energía de Castilla y León (EREN). Junta de Castilla y León, 2016) [5].

En cuanto a los sectores, el mayor consumidor a nivel mundial, según datos de la Agencia Internacional de la Energía (AIE), en el 2016, fue la industria con un 37\%, seguido del transporte con un $29 \%$, el sector residencial con un $22 \%$, sector servicios con un $8 \%$ y la agricultura y resto de consumos con un $4 \%$.

Sin embargo, en la Unión Europea (UE) y en España, en el 2016, el mayor sector consumidor fue el transporte, con un 33 \% en la UE (Eurostat, 2018) [6] y con un $43 \%$ en España (Mártil, 2014) [7].

El sector residencial llegó al 26\% en la UE y al 18\% en España. Esta distribución por sectores, para el mundo, la Unión Europea y España se muestra en la Figura 1. 

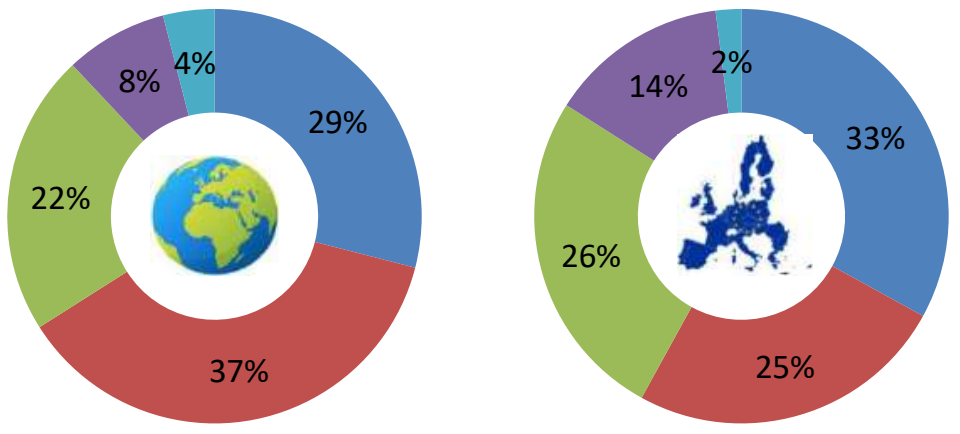

Transporte
Industria
Residencial
Servicios

Agricultura y Otros
- Transporte

- Industria

Residencial

- Servicios

Agricultura y Otros

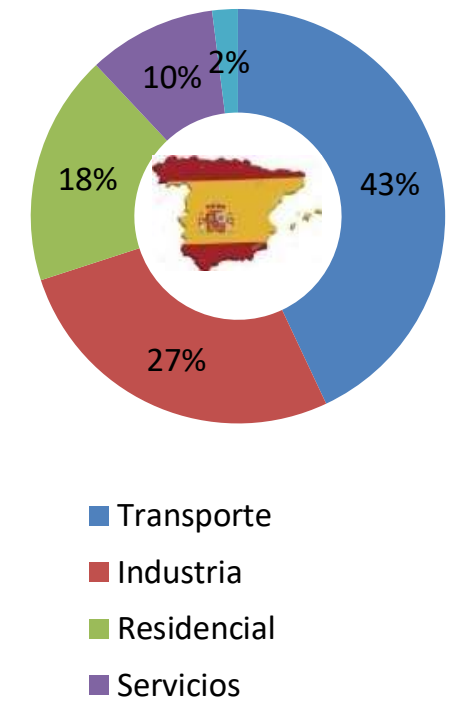

Agricultura y Otros

Figura 1. Distribución del consumo de energía final por sectores en el mundo, UE y España. 2016

Castilla y León, sigue la tendencia de Europa y España, poniendo el transporte a la cabeza de los sectores más consumidores, seguido por la industria y el sector residencial, como se aprecia en la Figura 2. (Ente Regional de la Energía de Castilla y León (EREN). Junta de Castilla y León, 2016) [5]

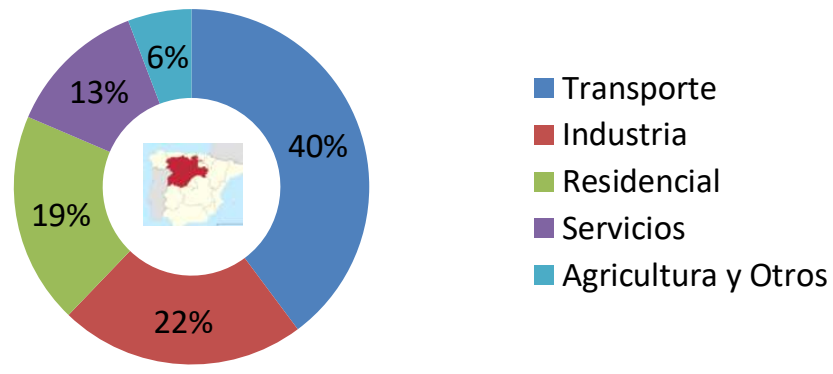

Figura 2. Distribución del consumo de energía final por sectores en Castilla y León. 2014

Durante el 2017, en España, el sector de los edificios alcanzó un peso del $30 \%$ en el consumo de energía final, distribuyéndose con un $18 \%$ el consumo de los edificios del sector residencial y con un $12 \%$ el consumo de los edificios integrado por los servicios y las Administraciones Públicas. (Ministerio de Fomento. Gobierno de España, 2017) [8].

En Castilla y León, en el 2014, el consumo del sector de los edificios, representó un 32\%, distribuyéndose con un $17 \%$ el consumo residencial, un $13 \%$ los edificios del sector servicios y Administraciones Públicas y un $2 \%$ otros edificios. (Ente Regional de la Energía de Castilla y León (EREN). Junta de Castilla y León, 2016) [5] 
En España, de todo el consumo del sector edificatorio, más del 65\% es utilizado para paliar las necesidades de calefacción, que son satisfechas en un $82 \%$ de los casos con sistemas individuales de calefacción y en un $8 \%$ con sistemas centralizados. La energía mayoritariamente utilizada en los sistemas de calefacción son: la electricidad en un $46 \%$ de los casos y el gas natural en un 32\%. (IDAE, 2011) [9].

Con todo esto, se puede afirmar que el sector de los edificios consume alrededor de una tercera parte de la energía que se consume en el mundo y es, por lo tanto, el responsable del $30 \%$ de las emisiones de $\mathrm{CO}_{2}$.

\subsubsection{Situación medioambiental}

El consumo de energía siempre ha desembocado en el aumento de emisiones contaminantes; pero este problema no se identificó hasta el siglo XIX, cuando se empezó a hablar del efecto invernadero y del resto de los problemas medioambientales asociados como la lluvia ácida o la reducción de la capa de Ozono. Fue en 1950, cuando se comienza a recoger datos de las concentraciones de $\mathrm{CO}_{2}$ y en 1980 se observa que dichas concentraciones había aumentado muy rápidamente (Convención Marco de las Naciones Unidas sobre el Cambio Climático, 2007) [10], es entonces cuando los países empiezan a proponer medidas para frenar y reducir este aumento de emisiones.

En 1979, se celebra la primera conferencia mundial sobre el Clima, en 1988 se crea el Grupo Intergubernamental sobre Cambio Climático (IPCC por sus siglas en inglés) y en 1990 se presenta el primer informe donde se afirmaba que el calentamiento atmosférico era cierto y se aconsejaba iniciar medidas para evitar que siguiera aumentando.

En 1992, en Río de Janeiro, se celebra la conocida "Cumbre para la Tierra", donde se firma la Convención Marco de las Naciones Unidas sobre el Cambio Climático, ratificada por 195 miembros, los denominados "Partes en la Convención".

La Convención nace como documento marco al que irán incorporándose otros textos más concretos y específicos, así en 1997, se incorporará el Protocolo de Kyoto que entrará en vigor en el 2005, cuando con la firma de Rusia, logró ser ratificado por las Partes que representasen al menos el 55 \% del total de las emisiones de dióxido de Carbono. El objetivo de la Convención es estabilizar las emisiones de gases de efecto invernadero a un nivel que impida interferencias peligrosas en el sistema climático, estableciendo que ese nivel debería lograrse en un plazo suficiente para permitir que el desarrollo económico prosiga de manera sostenible. 
El año de referencia para establecer los objetivos de emisiones se fijó en el 1990, los países más industrializados son los que debían evitar en mayor medida seguir aumentando sus niveles de emisiones.

El primer periodo de compromiso 2008-2012, tuvo por objetivo reducir al menos un 5\% las emisiones de 1990, para lograr este objetivo se aprobaron varias herramientas, como el libre comercio de los permisos de emisión, con la idea de lograr un balance mundial de reducción de emisiones, sin importar donde se reduzcan las emisiones siempre y cuando se eliminen de la atmósfera del planeta. La secretaria de la Convención, en Born, Alemania, fue nombrada para llevar el registro internacional de transacciones y comprobar que eran acordes a las reglas de Protocolo.

Para el primer periodo de compromiso del protocolo de Kioto, la Unión Europea, se fijó como objetivo una reducción del $8 \%$ respecto a las emisiones de 1990, y finalmente logró reducir un 19,2 \% (Secretariado de REN21 Renewable Energy Policy Network for the 21st Century, 2016) [11].

En el 2012, las Partes se reunieron en Doha, Qatar, donde se lanzó un nuevo periodo de compromiso del Protocolo de Kyoto (2013-2020), que se ratificó en el 2015 en París.

En diciembre de 2015, 195 países firmaron el Acuerdo de París, con el nuevo compromiso de reducir las emisiones de gases de efecto invernadero para evitar que la temperatura del Planeta suba más de $2^{\circ} \mathrm{C}$ respecto a la era preindustrial y proseguir los esfuerzos para que ese aumento no supere los $1,5^{\circ} \mathrm{C}$. Esto, según el escenario que contendría las medidas de reducción más ambiciosas, se traduce en que las emisiones deberían empezar a reducirse antes del año 2015 y en el 2050 se deberían haber reducido al menos un $50 \%$ respecto al 2000 y un $80 \%$ comparadas con las de 1990 .

Según datos publicados por la Agencia Internacional de la Energía (International Energy Agency (IEA), 2018) [12], las emisiones del mundo en el año 2000 fueron de 23,01 gigatoneladas de $\mathrm{CO}_{2}$ (Gt CO2) y en el año 2015 habían ascendido a 32,11 Gt CO2, bajando en el 2016 a 32,08 Gt CO2, pero volviendo a incrementarse en el 2017 hasta los $32,53 \mathrm{Gt}$ $\mathrm{CO} 2$, como puede verse en la Figura 3.

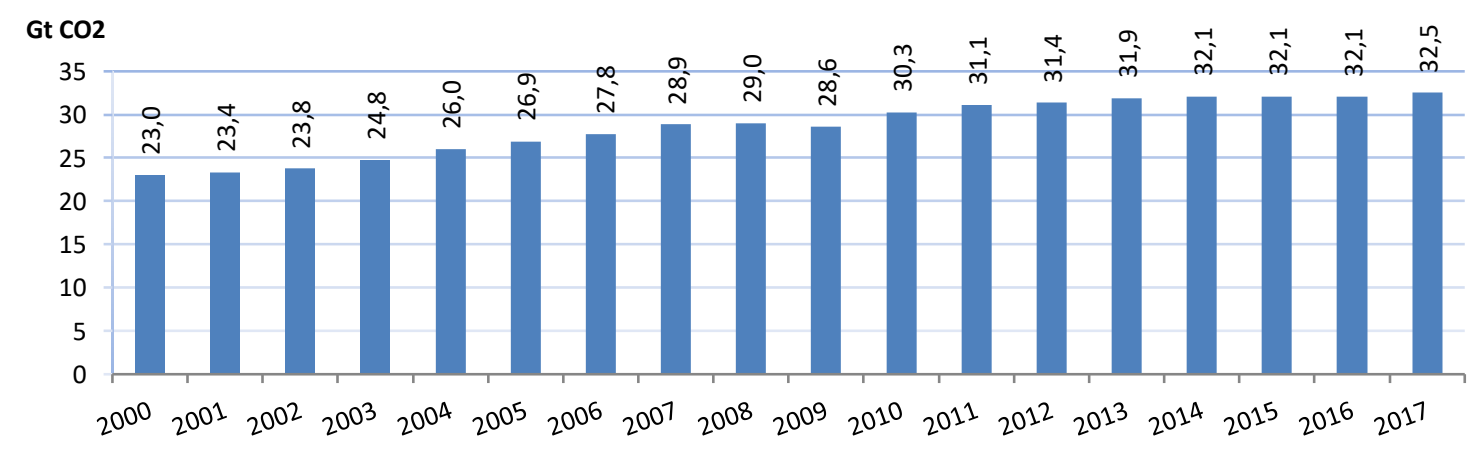

Figura 3. Evolución de las emisiones de $\mathrm{CO}_{2}$ mundiales desde 2000 hasta 2017 
Para conseguir los acuerdos alcanzados en París, La Unión Europea se fijó para el periodo 2013-2020, el compromiso de una reducción del 20 \% sus emisiones de gases de efecto invernadero respecto a los niveles del año 1990 y para el periodo 2021-2030, en una reducción del al menos un 40 \% en comparación con los niveles de 1990 (Ministerio de Agricultura y Pesca, alimentación y Medio Ambiente. MAPAMA, 2016) [13]

Para lograr el compromiso conjunto, a cada país se le fijó un objetivo diferente, en función de variables económicas y medioambientales, desde el una reducción del $21 \%$ para Alemania, hasta un aumento del 27 \% para Portugal. España tenía que no aumentar más del $15 \%$ sus emisiones, tomando como base las 290.735 toneladas de $\mathrm{CO}_{2}$ equivalente emitidas en 1990, el objetivo fijado para el 2012 era no superar las 334.346 toneladas de $\mathrm{CO}_{2}$ equivalente; pero durante el periodo 2008 - 2012, España, supera el 23,7\% y debido a este incumplimiento, tuvo que adquirir derechos de emisión, concretamente pagó 800 millones de euros a Polonia por contaminar los miles de toneladas que Polonia no emitió. (Eurostat, 2015) [14]

A finales del 2013, España cumplió el objetivo fijado para el 2012, emitiendo un 110,8 \% más que en 1990 (inferior al objetivo de no superar el $115 \%$ ), pero en el 2015 y 2017 volvió a situarse por encima con unos índices del 115,6 \% y 116,3\% respectivamente. (Tsolar, 2018) [15], (Ministerio para la Transición Ecológica. Gobierno de España, 2018) [16], (Ministerio de Agricultura y Pesca, Alimentación y Medio Ambiente. Gobierno de España, 2018) [17]. Esta evolución se puede apreciar en la Figura 4.

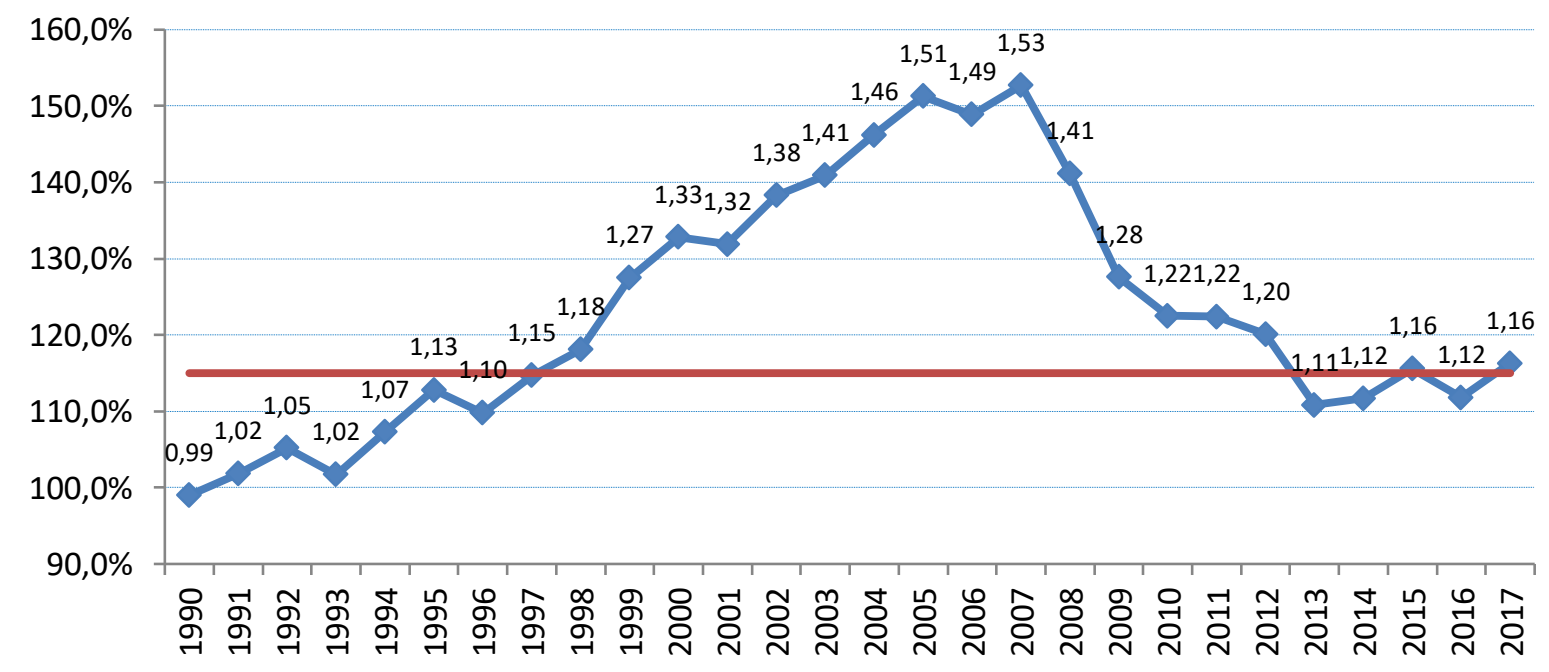

Figura 4. Índice de evolución de las emisiones de CO2 en España (1990-2017) 
A partir del 2013, se fijan nuevos objetivos para los países miembros de la Unión Europea y para España se fija el objetivo de reducir en un $26 \%$ sus emisiones de gases de efecto invernadero en el 2030 comparados con los emitidos en el 2005 (European Parliament, 2018) [18]. Las emisiones en el 2005 fueron de 439.556 toneladas de $\mathrm{CO}_{2}$, por lo que en el 2030, España no deberá superar las 325.271 toneladas de $\mathrm{CO}_{2}$; esto comparado con las emisiones de 1990, supone no superar el 112\% de las emisiones de 1990.

Castilla y León, que con el $9 \%$ de todas las emisiones de $\mathrm{CO}_{2}$ de España, es la quinta Comunidad más contaminante, superada por Andalucía (19\%), Asturias (16\%), Galicia (11\%) y Cataluña (10\%) (Europa Press, 2017) [19], posee una Estrategia Regional de Cambio Climático 2009-2012-2020, integrada en la Estrategia de Eficiencia Energética de Castilla y León 2016-2020 (Ente Regional de la Energía de Castilla y León (EREN). Junta de Castilla y León, 2016) [5], que fija como objetivo la reducción de un 30\% las emisiones de $\mathrm{CO}_{2}$ asociadas al consumo de energía en Castilla y León, respecto a las emisiones de 1990.

Durante los próximos años, Castilla y León y España tendrán que seguir haciendo un gran esfuerzo para poder cumplir los compromisos medioambientales asumidos y lograr que España se mantenga en una cifra no superior a las $325 \mathrm{Mt}$ de $\mathrm{CO}_{2}$.

\subsubsection{Medidas a implantar para un Desarrollo Sostenible}

Según la Agencia Internacional de la Energía, (Internacional Energy Agency (IEA), 2017) [20], en el año 2040, bajo el escenario de Desarrollo Sostenible, la eficiencia energética se habrá mejorado enormemente, la generación de energía estará casi descarbonizada, siendo la participación de las energías renovables en más del 60\% y de la energía nuclear en el $15 \%$.

Para lograr ese escenario, la Agencia (Internacional Energy Agency (IEA), 2016) [21], enumera una serie de medidas que serían necesarias implantar, medidas que se centran en cinco grandes bloques:

- Aumentar la eficiencia energética en los sectores de la industria, los edificios y los transportes;

- Reducir progresivamente el uso de las centrales de carbón menos eficientes y prohibir su construcción;

- Incrementar las inversiones en tecnologías renovables en el sector eléctrico

- Eliminar progresivamente las restantes subvenciones a los combustibles fósiles.

- Reducir las emisiones de metano en la producción de gas y petróleo. 
Dos de estas soluciones se centran en la mejora de la eficiencia energética del sector de los edificios que con sus $9 \mathrm{Gt}$ de $\mathrm{CO}_{2}$ equivalente (Internacional Energy Agency (IEA), 2017) [22], se ha visto que es el responsable del $30 \%$ de las emisiones de $\mathrm{CO}_{2}$ mundiales y en el fomento de las energías renovables.

En la Unión Europa, el sector de los edificios es responsable del 36\% de todas las emisiones de $\mathrm{CO}_{2}$, consumiendo casi el $50 \%$ de la energía total demanda, de la que el $80 \%$ es destinado a satisfacer la demanda de calefacción y refrigeración. (El Parlamento Europeo y el Consejo de la Unión Europea, 2018). [23]

Es por ello, que uno de los principales esfuerzos de la Unión Europea es renovar su parque inmobiliario impulsando la eficiencia energética, aplicando el principio reducir el consumo lo máximo posible y después satisfacerlo con energías renovables, apostando por una clara descarbonización del sector.

La calefacción y la refrigeración procedentes de energías renovables son vitales para la descarbonización. Es necesario un cambio en el consumo de energía que favorezca a las fuentes de energía con baja emisión de carbono y producidas localmente (incluidas las bombas de calor y los calentadores de acumulación) y las energías renovables (por ejemplo, calefacción solar, geotérmica, de biogás, de biomasa), también a través de redes de calefacción urbana. (Commission to the European Parliament, 2017) [24]

Las Directivas del Parlamento Europeo y del Consejo que fundamentalmente potencian esta medidas son:

- Directiva 2009/28/UE de 23 de abril de 2009 relativa al fomento del uso de energía procedente de fuentes renovables y por la que se modifican y se derogan las Directivas 2001/77/CE y 2003/30/CE. (El Parlamento Europeo y el Consejo de la Unión Europea, 2009) [25]

- Directiva 2010/31/UE de 19 de mayo de 2010 relativa a la eficiencia energética de los edificios. (El Parlamento Europeo y el Consejo de la Unión Europea, 2010) [26]

- Directiva 2012/27/UE de 25 octubre de 2012, relativa a la eficiencia energética, por la que se modifican las Directivas 2009/125/CE y 2010/30/UE, y por la que se derogan las Directivas 2004/8/CE y 2006/32/CE. (El Parlamento Europeo y el Consejo de la Unión Europea, 2012) [27]

- Directiva 2018/844 de 30 de mayo de 2018 por la que se modifica la Directiva 2010/31/UE relativa a la eficiencia energética de los edificios y la Directiva 2012/27/UE relativa a la eficiencia energética. (El Parlamento Europeo y el Consejo de la Unión Europea, 2018) [23] 
Además está la recomendación (UE) 2016/1318 de la Comisión, de 29 de julio de 2016, sobre las directrices para promover los edificios de consumo de energía casi nulo y las mejores prácticas para garantizar que antes de que finalice 2020 todos los edificios nuevos sean edificios de consumo de energía casi nulo (DO L 208 de 2.8.2016, p. 46). (La Comisión Europea, 2016) [28]

El objetivo fijado por la Unión Europea para el periodo 2021-2030, es obtener, al menos un $27 \%$ de mejora de eficiencia energética respecto al 2007.

El ratio que refleja en gran manera, del grado de eficiencia energética de un país, es el llamado índice de intensidad energética, que se calcula como el cociente entre el consumo energético y el producto interior bruto, de manera que cuanto menor es la intensidad energética el país necesitará menos energía para producir más riqueza, por lo que cuanto menor es ese índice más competitivo resultará ser el país.

Entre 2010 y 2015, este ratio disminuyó un 2,1 \%, lo que implica que aunque la economía mundial ha ido creciendo y la demanda energética ha seguido aumentando de manera constante, se está consumiendo de una forma más eficiente. (REN21. Renewable Energy Policy Network fot the 21st Century, 2017) [29]

En cuanto al objetivo fijado para el impulso de las Energías renovables es llegar al $27 \%$ de energía generada a partir de energías renovables en el 2030, este cierra el marco de clima y energía fijado por la Unión Europea para el 2030, que como se ha señalado se centra en tres objetivos:

- Reducción del $40 \%$ de las emisiones de gases de efecto invernadero en relación con los niveles de 1990

- Al menos un $27 \%$ de cuota de energías renovales

- Al menos un $27 \%$ de mejora de la eficiencia energética, objetivo que será revisado en el 2020 para llegar al 30\%.

En España, ha habido numerosas iniciativas para reducir el consumo energético, en el 2003, se aprobó la Estrategia Española de Ahorro y Eficiencia Energética (E4), con objeto de reducir los consumos energéticos en los principales sectores consumidores, pero no se concretaban las acciones específicas, los plazos, las responsabilidades, ni los mecanismos de financiación; todo lo cual, se tuvo que ir concretando en los diferentes Planes de acción aprobados por el Gobierno, los llamados PAE.

El PAE del periodo 2008-2012, centró sus objetivos acorde a los objetivos de la UE de lograr en el 2020, un ahorro del $20 \%$ en la demanda que resultaría en caso de no adoptar nuevas medidas de intensificación del ahorro y la eficiencia energética. 
En el 2004, se produce en España un cambio en la tendencia de la evolución de la intensidad energética, lo que origina una aproximación de España a los niveles de la UE. La reducción experimentada en España, se debió, fundamentalmente al incremento del consumo de energías renovables y a la generación eléctrica de alta eficiencia con centrales de gas de ciclo combinado, así como a la cogeneración.

En el periodo 2004-2010, la intensidad energética primaria de España, bajó un 14,2 \%, la crisis económica contribuyó significativamente a la reducción de la demanda energética en 2008 y 2009, pero el cambio de tendencia en la intensidad energética se inició en el 2004, tres años antes, como consecuencia de la introducción de las políticas de ahorro y eficiencia energética.

En la actualidad el Plan Nacional de Acción de Eficiencia Energética 2017-2020 (PNAEE 2017-2020), con el que España da cumplimiento al artículo 24.2 de la Directiva 2012/27/UE relativa a la eficiencia energética, (Ministerio de Energía, Turismo y Agenda Digital. Gobierno de España, 2017) [30] se centra en una reducción del 24,7\% del consumo de energía primaria en el 2020 respecto al consumo base de 2007, que se situó en 162,8 Mtep, por lo tanto el objetivo se centra en no superar la cifra de 122,6 Mtep en el 2020.

En cuanto a las Energías Renovables, el Plan de Energías Renovables (PER) 2011-2020, fija el objetivo para el año 2020 de que al menos el 20\% del consumo de final bruto de energía proceda del aprovechamiento de las fuentes renovables. (Consejo de Ministros. Gobierno de España, 2011) [31]

El pasado marzo de 2019, el Ministerio para la Transición Ecológica del Gobierno de España, envió a la comisión Europea para su aprobación el borrador del Marco estratégico de Energía y Clima. Este Marco persigue la descarbonización, mediante las energías renovables, para ello el borrador del Plan Nacional Integrado de Energía y Clima (PNIEC) 2021 - 2030, (Ministerio para la Transición Ecológica (MITECO). Gobierno de España, 2019) [32] establece los siguientes objetivos:

- $21 \%$ de reducción de emisiones de gases de efecto invernadero (GEI) respecto a 1990.

- $42 \%$ de renovables sobre el uso final de la energía.

- $39,6 \%$ de mejora de la eficiencia energética.

- $74 \%$ de energía renovable en la generación eléctrica.

En Castilla y León, la Estrategia de Eficiencia Energética 2016-2020 (Ente Regional de la Energía de Castilla y León (EREN). Junta de Castilla y León, 2016) [5], establece como objetivo la reducción de un $10 \%$ del consumo de energía primaria con respecto al año 2014, lo que implica una disminución del 32,45 \% con respecto al año base de 2007. 
En cuanto a las energías renovables, se propone elevar al 33,62\% la contribución de las energías renovables al consumo final bruto de Castilla y León en el 2020, superándose con ambos objetivos los establecidos por la Unión Europea para ese periodo.

Con todo esto los objetivos para La Unión Europea, España y Castilla y León, quedan resumidos en laTabla 1.

Tabla 1. Objetivos energéticos y medioambientales en la Unión Europea y España

\begin{tabular}{|c|c|c|c|}
\hline & UNIÓN EUROPEA & ESPAÑA & CASTILLA Y LEÓN \\
\hline $\begin{array}{l}\text { Gases de efecto } \\
\text { invernadero (GEI) }\end{array}$ & $\begin{array}{l}\text { En el año } 2030, \\
\text { reducción del } 40 \% \\
\text { con respecto a } \\
1990\end{array}$ & $\begin{array}{l}\text { En el 2030, aumento } \\
\text { máximo de } 112 \% \text { respecto a } \\
1990 \text { (Actual PNAEE 2017- } \\
2020) \\
\text { En el } 2030,21 \% \text { de } \\
\text { reducción respecto a } 1990 . \\
\text { (PNIEC } 2021 \text { - 2030) }\end{array}$ & $\begin{array}{l}\text { En el año } 2020, \\
\text { reducción del 30\% } \\
\text { con respecto a } \\
1990\end{array}$ \\
\hline Energías Renovables & $\begin{array}{l}\text { Al menos una } \\
\text { cuota del } 27 \% \text { en } \\
\text { el } 2030 .\end{array}$ & $\begin{array}{l}\text { Al menos una cuota del } 20 \% \\
\text { en el } 2020 \text { (Actual PNAEE } \\
2017-2020 \text { ). } \\
42 \% \text { de renovables sobre el } \\
\text { uso final de la energía en el } \\
2030 . \\
74 \% \text { de energía renovable } \\
\text { en la generación eléctrica } \\
\text { en el } 2030 \text { (PNIEC } 2021 \text { - } \\
2030 \text { ) }\end{array}$ & $\begin{array}{l}\text { Al menos una } \\
\text { cuota del 33,62\% } \\
\text { en el } 2020\end{array}$ \\
\hline Eficiencia Energética & $\begin{array}{l}\text { Al menos un } 27 \% \\
\text { de mejora de la } \\
\text { eficiencia } \\
\text { energética en el } \\
2030 \text { respecto al } \\
2007 \text {. }\end{array}$ & $\begin{array}{l}\text { Reducción en el } 2020 \text { del } \\
\text { consumo de energía } \\
\text { primaria del } 24,7 \% \text { respecto } \\
\text { el } 2007 \text {. (Actual PNAEE } \\
2017-2020) \text {. } \\
39,6 \% \text { de mejora de la } \\
\text { eficiencia energética (PNIEC } \\
2021-2030 \text { ) }\end{array}$ & $\begin{array}{l}\text { Reducción en el } \\
2020 \text { del consumo } \\
\text { de energía } \\
\text { primaria del } \\
32,45 \% \text { respecto el } \\
2007\end{array}$ \\
\hline
\end{tabular}

Tanto la utilización de energías renovables como el aumento de la eficiencia energética de los sistemas de climatización en los edificios son unas de las metas que se persiguen con las redes de calor, convirtiéndose así, en una de las principales herramientas que se emplean para conseguir los objetivos energéticos y medioambientales fijados por la Unión Europea. 


\subsection{Redes de calor}

\subsubsection{Presentación}

Las redes de calor, son consideradas como una de las mejores soluciones a los problemas energéticos del sector edificatorio; por una parte por la posibilidad de ahorrar energía en el consumo de calefacción respecto a los sistemas individuales y por otra, por la posibilidad de mejorar la descarbonización de las ciudades al fomentar la sustitución de combustibles fósiles por biomasa y otras energías renovables o calores residuales, con lo que se logran paliar los problemas medioambientales de los grandes núcleos urbanos.

Es por ello, que la tecnología de la redes de climatización, "District Heating" o "calefacción de distrito", convierte a las ciudades en actores clave para lograr la descarbonización, de hecho numerosas administraciones confían en ella, en su camino hacia una reducción efectiva de los Gases de Efecto Invernadero.

Uno de los principales objetivos de las redes de calor, es la utilización de una energía térmica residual, procedente de procesos industriales, fuentes naturales geotérmicas, valorización de residuos sólidos urbanos o el aprovechamiento de las fuentes renovables como la biomasa o la energía solar.

Como su nombre indica, las redes de distrito para la distribución de calor y/o frío son un entramado de tuberías aisladas mediante el cual se distribuye energía térmica desde una central de generación hasta un conjunto de consumidores. Siendo sus elementos principales:

- La central térmica

- La red de distribución

- Sistema de bombeo o de impulsión del fluido térmico.

- Las subestaciones de conexión con los consumidores finales.

La Figura 5, muestra un esquema sencillo de una red de calor o district heating. 


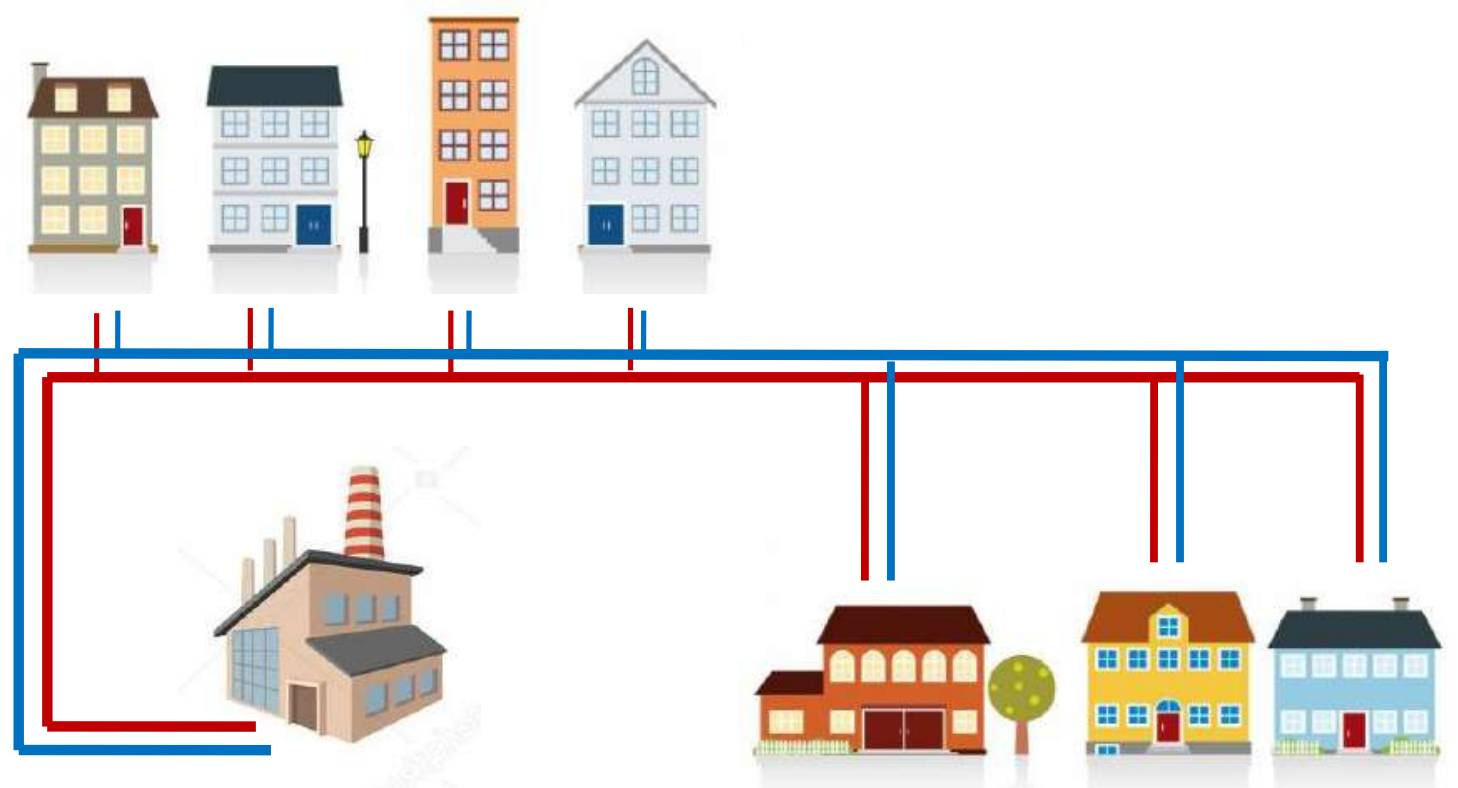

Figura 5. Esquema de una red de calor

La empresa AIGUASOL Sistemes Avancats d'Energia Solar Tèrmica S.C.C.L., elaboró por encargo del Institut Català d'Energia de la Generalitat de Catalunya, en 2011, una guía de redes de calor y frío (Generalitat de Catalunya. Institut Català d'Energia. Asociación de Empresas de Redes de Calor y Frío. ADHAC, 2011) [33] y en el 2012, la empresa COFELY (GDF SUEZ) elaboró otra guía integral de desarrollo de proyectos de redes de distrito de calor y frío, también por encargo del Institut Català d’Energia de la Generalitat de Catalunya, (Generalitat de Catalunya. Institut Català d'Energia. Asociación de Empresas de Redes de Calor y Frío. ADHAC, 2012) [34]; ambas guías recogen los principios fundamentales a tener en cuenta en el diseño y ejecución de las redes de calor.

\subsubsection{Elementos principales}

\section{Central Térmica}

La central térmica se diseña para que el sistema de generación, distribución, regulación y control pueda ajustarse a la curva de demanda total de calefacción, refrigeración y de agua caliente sanitaria para la que ha sido planificada.

Para generar energía térmica en forma de calor, se utilizan calderas, que son sustituidas por motores o turbinas en el caso de la cogeneración. La generación se puede combinar con energías renovables, en este caso la central térmica también incluirá los componentes del sistema de energías renovables (biomasa, solar térmica, solar fotovoltaica o geotermia), como depósitos de acumulación, paneles, bombas de calor, etc. 
Para generar energía térmica en forma de frío, generalmente se elige un sistema de refrigeración por compresión que se alimenta mediante energía eléctrica. Existe la posibilidad de utilizar en paralelo sistemas de absorción o adsorción alimentados por fuentes de calor, estos sistemas se suelen emplear cuando en la generación de calor se utilizan energías renovables, residuos o cogeneraciones.

En función de la energía primaria utilizada en la central térmica, la red puede estar basada en:

- La utilización de combustibles fósiles para cogeneración, uno de los más utilizados es el gas natural, es el tipo de fuente de calor más común en las redes de distrito de todo el mundo ( $46 \%$ del total del calor generado en redes de distrito). (Riga, Varsovia, Praga, Copenhague, Mannheim, Cerdanyola).

- La utilización de residuos es la segunda fuente más utilizada después de la cogeneración con combustibles fósiles. (Barcelona, Uppsala (Suecia), Sheffield (RU), Praga y Brno (República Checa), París, Múnich, Copenhague y Budapest).

- Utilización de calores residuales de procesos productivos que puede aprovecharse para producir calefacción, refrigeración o agua caliente sanitaria. (Papelera: Varberg en Suecia, metalurgia: Vänersborg en Suecia, refinería de petróleo: Göteborg en Suecia; Pzock en Polonia, Química: Puzawy en Polonia)

- Empleo de energías renovables locales:

- Geotermia: Ferrara, Pomarance y Monterotondo (Italia), Southampton (Reino Unido), Reikiavik (Islandia), Lund (Suecia).

- Solar: Marstal (Dinamarca), Neckarsulm (Alemania)

- Biomasa: Sant Pere de Torelló (Cataluña), Molins de Rei (Cataluña), Cuéllar (Segocia), Universidad de Valladolid (Valladolid)

- Biogás: Tub verd de Mataró (Cataluña)

Además del aprovechamiento de recursos renovales como fuente de energía primaria, se pueden aprovechar los ríos o incluso el mar, para la refrigeración de las máquinas enfriadoras, la temperatura inferior de los ríos y mares logra mejorar el rendimiento medio anual de producción de frío, sin consumo neto de agua, dado que el agua se devuelve al medio de origen. (Barcelona y Helsinki, con agua de mar; en Zaragoza, con agua de río; en Mataró, con agua freática o en Toronto, con agua de lago) 


\section{Sistema de Distribución. Tuberías, Aislamiento}

Este sistema está compuesto con el entramado de tuberías con aislamiento y el resto de accesorios necesarios como codos, bridas o empalmes.

Las primeras redes de calor se encontraron el problema de la corrosión de las tuberías de acero, de ahí surgen las tuberías plásticas pre-asiladas flexibles, este producto fue llamado Flexalen, y nació en 1982. En el año 2000 se desarrolló de un nuevo sistema más económico y resistente, el Flexalen 600 , con una pérdida de calor menor a $1^{\circ} \mathrm{C}$ por kilómetro.

En las redes de calor, cuyo fluido caloportador supera los 90 드, se utilizan las tuberías de acero preaislado con espuma de poliuretano; pero si la red es de temperaturas bajas $\left(70^{\circ} \mathrm{C}\right.$ ), lo más habitual son las tuberías de polietileno reticulado preaislado (PEXa, que presentan una reticulación superior al 70\%). La Figura 6, muestra una tubería preaislada PEXa.

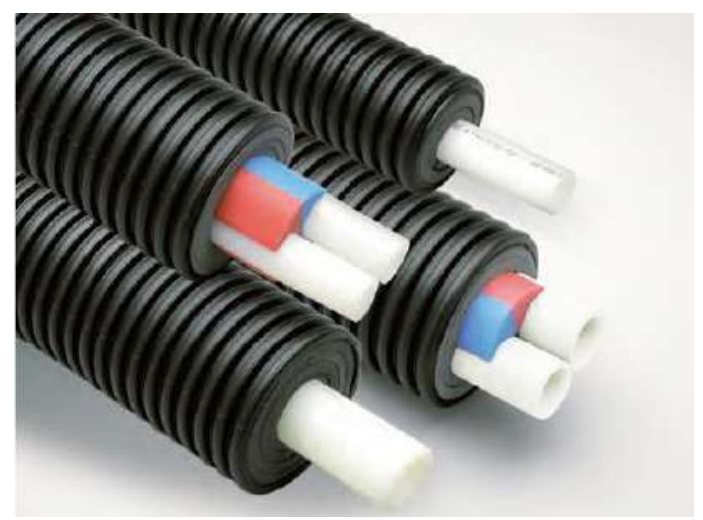

Figura 6. Tubería preaislada PEX (UPONOR) [50]

Las tuberías PEX, son tuberías plásticas flexibles de diámetros entre 20 y $160 \mathrm{~mm}$, con tubo envolvente $(\mathrm{PE})$ de polietileno de alta densidad o baja densidad y aislamiento de polietileno reticulado (PEXa) o espuma de poliuretano (PUR)

También existen tuberías flexibles de cobre y recubrimiento de polietileno o de acero inoxidables con espuma de poliuretano. Las tuberías rígidas pueden ser de acero con aislamiento de espuma de poliuretano inyectado y con diámetro de 20 a $1000 \mathrm{~mm}$ o incluso tuberías de hormigón.

La Tabla 2 muestra las particularidades de las tuberías de acero y de plástico, más utilizadas en las redes térmicas. (Generalitat de Catalunya. Institut Català d'Energia. Asociación de Empresas de Redes de Calor y Frío. ADHAC, 2012) [34] 
Capítulo 1: Introducción

Tabla 2. Características de las tuberías según su material

\begin{tabular}{lcc}
\hline Material tubería & ACERO & PLÁSTICO \\
\hline Formato de suministro & Tuberías de hasta $12 \mathrm{~m}$ & Bobinas de tubería \\
\hline Servicio & Calor / frío & Calor / frío \\
\hline Temperatura máxima & $148^{\circ} \mathrm{C}$ (aislamiento) & $90^{\circ} \mathrm{C}$ (tubería) \\
\hline Presión máxima de servicio & 16 bar & 6 bar \\
\hline Diámetros comerciales & $\geq$ DN 800 & $\leq$ DN 200 \\
\hline
\end{tabular}

El fluido caloportador más habitual en la actualidad es el agua caliente, aunque también se puede utilizar agua sobrecalentada o vapor.

Este fluido es conducido por el circuito de ida hasta los usuarios donde cede el calor o el frío y es reconducido otra vez a la central térmica por el circuito de retorno, es decir se trata de un circuito primario cerrado que cede el calor a los circuitos secundarios existentes en cada subestación, esta cesión se suele producir en un intercambiador ubicado en las subestaciones de conexión. El entramado de tuberías discurre por zanjas a través de las calles del municipio.

La red de tuberías puede dividirse en tres grupos, tal como se aprecia en la Figura 7:

- Red troncal: conduce el calor (o el frío) desde la central de generación hasta las redes locales de distribución.

- Ramales: conducen el calor (o el frío) desde la red troncal hasta las tuberías de servicio. Las tuberías principales suelen seguir la dirección de las calles o carreteras.

- Acometidas o ramales de servicio a clientes: son las tuberías de interconexión desde los ramales hasta cada edificio o subestación.

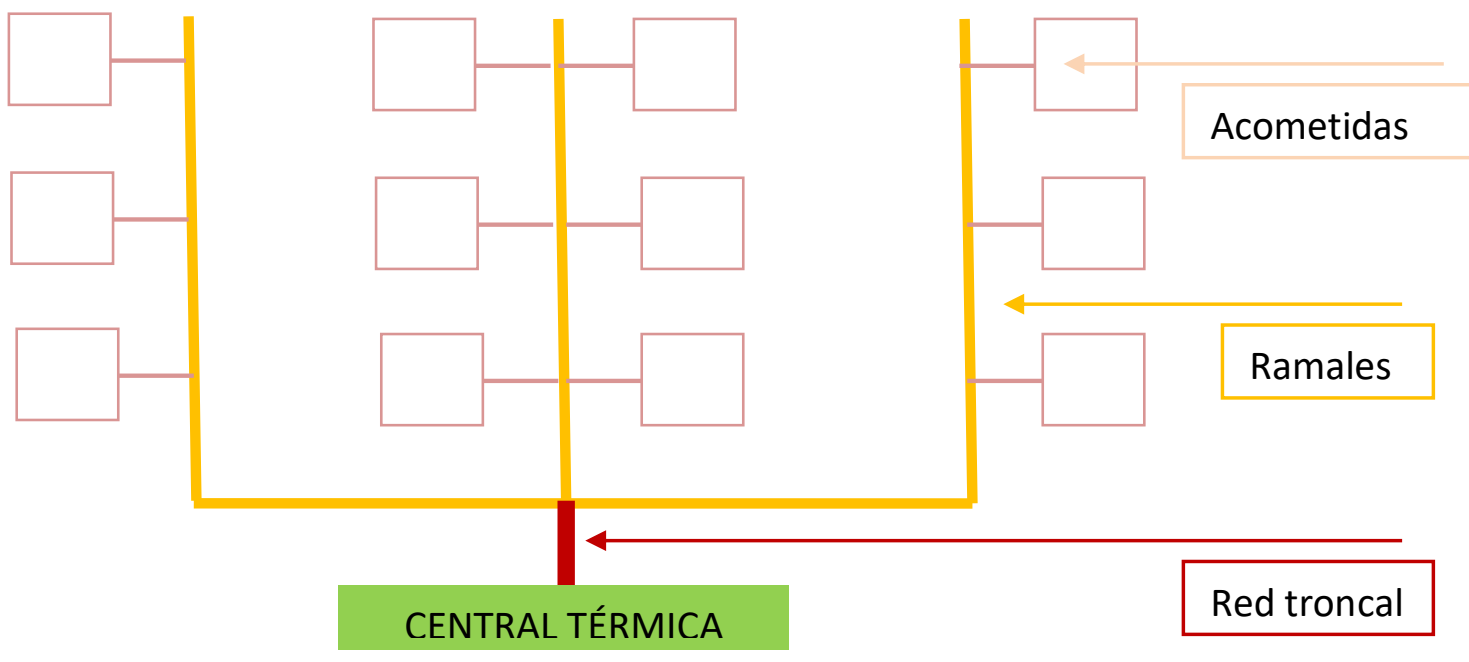

Figura 7. Tipos de tuberías de una red térmica 


\section{Sistema de bombeo}

El sistema de regulación de caudal que acompaña al sistema de bombeo puede ser desde simples válvulas de estrangulamiento, bypass o bombas de velocidad variable, en este último caso los sistemas trabajan a temperatura de impulsión fija y se regulan al variar el caudal en función de la temperatura de retorno de la red.

Los sistemas de bombeo pueden diseñarse de diversas formas:

- Bombeo centralizado. Un grupo de bombeo principal impulsa el fluido por toda la red, habitualmente el sistema está ubicado en la propia central térmica.

- Bombeo primario-secundario estándar. Existen unas bombas primarias que impulsan el fluido por la central térmica y las secundarias por los ramales de distribución.

- Bombeo primario-secundario-terciario estándar. Al sistema anterior se le añaden las bombas de cada circuito de distribución en las acometidas.

- Bombeo distribuido. Con esta configuración, cada equipo generador y cada edificio consumidor dispone de su grupo de bombeo, con ello se evitan interacciones entre las presiones de los diferentes grupos.

\section{Subestaciones}

Cuando el fluido llega al edificio cede su calor o frío en una subestación compuesta por un intercambiador y elementos de medición, regulación y control y en ocasiones por sistemas de almacenaje o depósitos de acumulación.

Las acometidas son las tuberías de conexión entre la red y la subestación del cliente, normalmente llegan al edificio del cliente por debajo del nivel de la calle. En las subestaciones se ajustan la presión y la temperatura de la red de distribución a las condiciones demandadas y se garantizan los saltos de temperatura necesarios.

Existen principalmente dos tipos de subestaciones:

- las de conexión directa, sin diferencia entre el circuito de red y el del usuario

- y las subestaciones de conexión indirecta, donde existe un intercambiador de calor que separar la red de la instalación interior.

El sistema de agua caliente sanitaria (ACS) del usuario siempre será un circuito independiente de la red. 


\subsubsection{Ventajas y Limitaciones}

Las redes de calor y frío presentan las siguientes ventajas:

- Pueden ser consideradas como el método más barato de reducir el uso del carbón, además tiene una de las huellas de carbono más bajas de todas las plantas de generación basadas en combustibles fósiles

- Posibilitan nuevos negocios con viabilidad a largo plazo, sobretodo para las empresas de servicios energéticos (ESE), dado que pueden convertirse en suministradores de la energía contenida en el agua o vapor que transportan las redes.

- Activan la economía industrial al requerir el suministro de los equipos de los proveedores de calderas, tuberías depósitos, bombas, ....

- Ahorran espacio útil dedicado a la sala de instalaciones en los edificios y viviendas

- Mejoran la estética de las ciudades, al desaparecer las chimeneas y las torres de refrigeración, mejorando el paisaje urbano.

- Reducen vibraciones y ruidos en las viviendas.

- Contribuyen al fomento de proyectos que mejoran la calidad del municipio donde están ubicados, al reducir el impacto medioambiental y el consumo energético.

- Suponen una ayuda para el cumplimiento de los objetivos marcados en las políticas energéticas y medioambientales europeas, nacionales y regionales a cumplir por las Administraciones.

- Posibilitan el uso de energías renovables y otros residuos locales

En general la centralización de las instalaciones térmicas permite una mejora en el rendimiento de generación que compensa las pérdidas de distribución del sistema, por lo que en su conjunto se consideran sistemas más eficientes.

Si además de centralizar la generación con un district heating, se añaden las ventajas de la cogeneración, y del uso de energías renovables o residuales, la eficiencia energética es innegable, lo que hace de las redes de calor una de las mejores alternativas para mejorar el comportamiento medioambiental de las ciudades, como ha sido demostrado en numerosos programas europeos. (United Nations Environment Programme (UNEP), 2015) [35]

Por lo tanto, parece lógico asumir que una red de calor que genera el calor a gran escala, será más económica y eficiente que la suma de multitud de instalaciones de generación individuales. (Van Deventer, Derhamy, Atta, \& Delsing, 2017) [36]. 
Esto ha sido demostrado en numerosos lugares como: Seúl (Lee, Kim, \& Im, 2017) [37], Suiza (Ericsson \& Werner, 2016) [38], Suecia (Sandvall, Ahlgren, \& Ekvall, 2017) [39], Lucerna en Italia, (Delmastro, Mutani, \& Schranz, 2015) [40], Reino Unido (Bush, Bale, \& Taylor, 2016)[41], Singapur (Wouters, 2015) [42], California (Hanna, Ghonima, Kleissl, Tynan, \& Victor, 2017) [43], Polonia (Wojdyga \& Chorzelski, 2017) [44] o Dinamarca (Lund, Möller, Mathiesen, \& Dyrelund, 2010) [45]

\section{$\underline{\text { Limitaciones }}$}

Sin embargo, el rendimiento energético de las redes de calor dependen de muchos factores que pueden minorar la eficiencia con la que habían sido planificadas: la regulación (Kolokotsa, 2016) [46], las pérdidas de calor en la distribución (Laakkonen, y otros, 2017) [47] o las fugas de agua. Unido a estos inconvenientes, es habitual que estos sistemas deban competir con tecnologías predominantes como las redes de gas natural; siendo este el caso de Reino Unido (Bush \& Bale, The role of intermediaries in the transition to district heating, 2017) [48] y Letonia (Ziemele, Gravelsins, Blumberga, \& Blumberga, 2016) [49].

Además del estudio de la eficiencia energética real de las redes, existen otros aspectos que son necesarios tener en cuenta para valorar la viabilidad y conveniencia de una red de calor, como:

- La obra civil necesaria en el espacio público, que podrá afectar a servicios generales de electricidad, gas, agua, telecomunicaciones, transporte público y calles cortadas.

- Potenciales averías por rotura en la ejecución de la obra civil.

- Necesidad de un correcto dimensionamiento, dado que sobredimensionar es caro en instalación y funcionamiento, mientras que subdimensionar es limitar el crecimiento del sistema.

- Previsión de la necesidad de realizar intervenciones dentro de viviendas y aprobación previa de las mismas por parte de los propietarios.

- Previsión de paradas técnicas de la Central y previsión de sistemas de generación en paralelo que puedan dar servicio a las demandas térmicas en dichas paradas, lo que obliga, en ocasiones, a no poder prescindir del mantenimiento de los sistemas iniciales.

- Para que el sistema logre ser eficiente será necesario diseñar el sistema de tal forma que las pérdidas de distribución sean admisibles y las mínimas posibles.

- El sistema de regulación deberá poder satisfacer las demandas con el máximo rendimiento, por lo que será imprescindible dotarle de un buen sistema de regulación, medida y control. 
- Necesidad de conocer las demandas iniciales reales, la previsión de su evolución y cambio a largo plazo, dado que los proyectos de redes de calor se conciben a rentabilidades de largo plazo.

Todo ello hace que las redes de calor deban ser cuidadosamente planificadas, diseñadas, ejecutadas, mantenidas, reguladas y optimizadas para que realmente logren alcanzar los objetivos con los que habían sido diseñadas.

\subsubsection{Evolución de las redes}

Aunque la aparición de las conducciones de fluidos térmicos por las calles, se podría fechar en tiempos de los romanos cuando el agua caliente circulaba por canales abiertos para suministrar calefacción a los edificios y a los baños, es en el siglo XIV en Francia, cuando se habla por primera vez de redes de calor (Lake, Rezaie, \& Beyerlein, 2017) [51], el agua caliente era distribuida por conductos de madera.

El año 1877, Birdsill Holly estableció el primer sistema comercial de DH (district heating) en Estados Unidos (Nueva York). Como central térmica utilizó una caldera en el sótano de su casa y construyó un anillo con tuberías de vapor, radiadores y líneas de retorno de condensados. Al principio, el sistema tenía 14 clientes y hacia el año 1880 suministraba a varias fábricas y a algunas viviendas nuevas; el sistema de tuberías se extendió hasta alcanzar aproximadamente $5 \mathrm{~km}$ de longitud. (Generalitat de Catalunya. Institut Català d'Energia. Asociación de Empresas de Redes de Calor y Frío. ADHAC, 2012) [34]

A esta experiencia le siguió Alemania en 1893, en Hamburgo, con un sistema de calefacción que aprovechaba el calor residual de una central eléctrica y en el siglo XX muchas ciudades de Estados Unidos y Escandinavia ya contaban con redes de distrito que utilizaban el vapor como fluido caloportador.

En 1891, se ejecutó el primer District Heating en Dinamarca, a las afueras de Copenhague, que suministraba calor a un hospital y varios edificios públicos. En 1930, se construye la primera red en Paris que hoy en día todavía funciona.

A partir de la Segunda Guerra Mundial, en Estados Unidos se empezaron a construir grandes centrales térmicas a las afueras de las ciudades, pero no fueron rentables debido a los bajos precios de la electricidad, el petróleo y el gas natural. En Europa, donde la electricidad y el gas natural tenían precios más elevados, la rentabilidad de las redes urbanas combinadas con la cogeneración hizo que prosperaran con mayor facilidad, sobre todo en Escandinavia (en 1953, se construye la red de Estocolmo (Suecia)). 
A raíz de las crisis petrolíferas de los años 70, países como Suecia y Dinamarca cuya dependencia del petróleo rondaba el 90\%, buscaron nuevos combustibles para las centrales térmicas de los district heating, utilizando calores procedentes de la incineración de residuos en combinación con energías renovables, incluso se ha llegado a utilizar el calor sobrante de centrales nucleares o de la incineración de cadáveres como en una ciudad Sueca de Racksta.

En Japón las primeras redes nacen también en la década de los 70, y veinte años después ya tenían más de 120 redes de calor funcionando, de las que un $60 \%$ son de calor y el resto de frío.

En China, las primeras redes comienzan en los 80 y en la actualidad más del $50 \%$ de las grandes urbes cuentan con sistemas de redes de calor.

Desde sus comienzos hasta ahora, se habla de cuatro generaciones de redes de calor (Werner, District heating and cooling in Sweden., 2017) [52]:

- La primera generación (1880-1930) caracterizada por la utilización de vapor como fluido térmico.

- La segunda (1930-1980) en la que el vapor es sustituido por agua a alta temperatura conducida a través de tuberías de hormigón.

- La tercera (1980-2020) que se basa en temperaturas medias del agua en tuberías prefabricadas directamente enterradas en el suelo.

- La cuarta que será la de futura generación, (2020-2050), se centrará en una distribución a bajas temperaturas (Schmidt, y otros, 2017) [53], esto es: suministro inferior a $50^{\circ} \mathrm{C}$ y retorno cercano a los $20^{\circ} \mathrm{C}$ (Averfalk \& Werner, 2017) [54] o entre $70^{\circ} \mathrm{C}$ y $30^{\circ} \mathrm{C}$ (Rämä \& Sipila, 2017) [55], utilizará calores residuales (Wahlroos, Pärssinen, Manner, \& Syri, 2017) [56], residuos sólidos urbanos (Persson \& Münster, 2016) [57], energías renovables (Nord, Schmidt, \& Dagmar, 2017) [58], podrán ser combinadas con plantas de cogeneración (Castro Flores, Lacarriere, Chiu, \& Martín, 2017) [59] y ser integradas en redes de energía inteligentes (Lund, y otros, 2014) [60].

Este último sistema de cuarta generación será el óptimo para los edificios de nueva construcción ejecutados con las directrices de los edificios de energía casi cero (nearly zero energy buildings (nZEB) (El Parlamento Europeo y el Consejo de la Unión Europea, 2010) [26] y de altos estándares de eficiencia energética (El Parlamento Europeo y el Consejo de la Unión Europea, 2012) [27]. 


\subsubsection{Contexto normativo}

Casi el $50 \%$ de los edificios de la Unión Europa tienen calderas individuales instaladas antes de 1992 cuyo rendimiento estacional de un 60\% o inferior. De los sistemas de calefacción, el $22 \%$ son calderas de gas, el $34 \%$ son aparatos eléctricos directos, el $47 \%$ son calderas de gasóleo y el $58 \%$ son calderas de carbón que han llegado ya al final de su ciclo de vida. (Comisión Europea, 2016) [61]

El 18\% del suministro de energía primaria para climatización tuvo su origen en las energías renovables y el $75 \%$ en combustibles fósiles. La biomasa es la fuente de energía renovable más utilizada para calefacción, representando alrededor del 90\%. (Comisión Europea, 2016) [61]

Teniendo en cuenta la importancia de fomentar las energías renovables en la edificación, en el año 2009, se aprueba la Directiva 2009/28/CE, relativa al fomento del uso de energía procedente de fuentes renovables, que promueve estas instalaciones y donde se considera que es necesario establecer mecanismos para fomentar sistemas de calefacción y refrigeración urbana a partir de energía procedente de fuentes renovables por parte de los estados miembros. (El Parlamento Europeo y el Consejo de la Unión Europea, 2009) [25]

En el 2010, la Directiva 2010/31/CE, relativa a la eficiencia energética de los edificios, define "sistema urbano de calefacción" y "sistema urbano de refrigeración" como una distribución de energía térmica en forma de vapor, agua caliente o fluidos refrigerantes, desde una fuente central de producción a través de una red, hacia múltiples edificios o emplazamientos, para la calefacción o la refrigeración de espacios o procesos. (EI Parlamento Europeo y el Consejo de la Unión Europea, 2010) [26]

En el artículo 6, de la citada Directiva, se establece que los Estados miembros tomarán medidas para garantizar que los edificios nuevos cumplan los requisitos mínimos de eficiencia energética y velarán porque, antes de que se inicie la construcción, se consideren y tengan en cuenta la viabilidad técnica, medioambiental y económica de instalaciones alternativas de alta eficiencia como la calefacción o refrigeración urbana o central, en particular si se basa total o parcialmente en energía procedente de fuentes renovables.

Finalmente en el Anexo I, de esta Directiva hace una valoración "Positiva" de los Sistemas Urbanos de Calefacción en las Certificaciones.

Dos años después, con la Directiva 2012/27/CE, se invita a los estados miembros a evaluar el potencial de las redes de climatización urbanas y a adoptar planes nacionales que constituyan los planes de calefacción y refrigeración regionales y locales (Artículo 14, Anexo VIII) (El Parlamento Europeo y el Consejo de la Unión Europea, 2012) [27] 
En el mismo artículo, se anima a realizar análisis de costes y beneficios en determinadas nuevas instalaciones térmicas o renovación, realizadas tras el 5 de junio de 2014.

En el Anexo IX, se recoge cómo llevar a cabo el análisis de costes y beneficios, dicho análisis afectará a instalaciones térmicas de generación nuevas o renovadas, así como instalaciones industriales y Redes Urbanas, con potencia térmica superior a $20 \mathrm{MW}$, según Anexo IX (parte 2)

En dicha Directiva, se afirma que las redes urbanas de calor y frío proporcionan una respuesta inteligente al reto planteado de reducción de emisiones, incremento de la eficiencia y ahorro energético para 2020, explica, también que los sistemas urbanos de climatización tienen un potencial significativo de ahorro de energía primaria que, en general, está poco explotado en la Unión.

En el Artículo 2.41. se define un sistema Urbano Eficiente de Calefacción y Refrigeración, como todo sistema urbano de calefacción o refrigeración que utilice al menos un $50 \%$ de energía renovable, un $50 \%$ de calor residual, un $75 \%$ de calor cogenerado o un $50 \%$ de una combinación de estos tipos de energía y calor.

En España, a raíz de los Reales Decretos 47/2007, de 19 de enero, por el que se aprueba el Procedimiento básico para la certificación de eficiencia energética de los edificios de nueva construcción y el Real Decreto 235/2013, para la Certificación Energética de edificios existentes, se elabora un procedimiento específico para Redes: POSTCALENER. (Desarrollado por ADHAC. (Asociación de Empresas de Redes de Calor y Frío), que se convierte en documento Reconocido y demuestra que la conexión a Redes supone una mejora automática en la certificación energética de edificios.

A partir del 2013, se abre un nuevo marco normativo para la rehabilitación, regeneración y renovación urbana, con la Ley 8/2013, el Real Decreto 233/2013 del Plan estatal de fomento del alquiler, rehabilitación edificatoria, regeneración y renovación urbana 20132016 y el Plan R3E de Rehabilitación Energética Edificios Existentes.

El 30 de abril de 2014 el Ministerio de Industria, Energía y Turismo lanza el PNAEE 2014 2020 (Plan Nacional Activación Eficiencia Energética) en el que se analiza, entre otros temas:

- Situación actual de las redes de Calor y Frío en España.

- Evaluación del potencial de las redes de Calor y Frío.

- Promoción eficiencia en producción y uso de Calor y Frío.

- Análisis coste - beneficio redes de Calor y Frío 
Finalmente, el 13 de febrero de 2016, se publicó en el BOE, el Real Decreto 56/2016, por el que se transpone parcialmente la Directiva 2012/17/UE, en lo relativo a auditorías energéticas, acreditación de proveedores de servicios energéticos y auditores y promoción de la cogeneración de alta eficiencia. Este Real Decreto entró en vigor el 14 de febrero de 2016.

El Capítulo IV, está dedicado a la producción y uso de calor y frío y es donde se mencionan los sistemas urbanos de calefacción y refrigeración. Se establece un registro quinquenal que España debe aportar a la UE (Disposición adicional 2a) junto a la evaluación de la rentabilidad global de esos proyectos (Anexo III y IV), lo que da cumplimiento al artículo 14 de la Directiva y se abre la posibilidad de implantación de redes de calor en los municipios donde sean viables.

Todo esto enmarca a las redes de calor en España como una herramienta apoyada y fomentada por el Gobierno de la Nación, por una parte para la mejora de sus políticas energéticas y medioambientales y por otra para cumplir con los requerimientos que la Unión Europea hace a todos los países miembros.

\section{Barreras legales y técnicas}

En España, aunque como se ha mencionado existe un procedimiento o herramienta específica (Postcalener) para evaluar el uso de redes de calor a la hora de la certificación energética de un edifico, el Código Técnico de la Edificación, sigue obligando a los edificios de nueva construcción a cubrir parte de la demanda de agua caliente mediante energía solar térmica u otros sistemas igual de eficientes, con independencia de que el edificio esté incluido en una red de calor.

Sería lógico suponer que los edificios abastecidos por una red de calor deberían estar exentos de la obligatoriedad de instalar captadores solares, pero si la red, no incluye ni cogeneración ni el uso de un calor residual, el edificio se vería obligado a cubrir parte de la demanda de agua caliente mediante energía solar, por lo tanto, existe un vacío legal para estas situaciones.

También existe otro vacío en la Ley sobre derechos de emisiones (Ley 1/2005). La potencia de generación de la central térmica de una red suele ser inferior a la suma de las potencias de las instalaciones individuales a la que abastece; no obstante, como es un único punto con una potencia elevada, si supera el límite que marca esta ley, $20 \mathrm{MW}$, deberá emprender el comercio de los derechos de emisión de gases de efecto invernadero, mientras que las instalaciones individuales (aunque más emisoras de $\mathrm{CO}_{2}$ en conjunto) nunca se verían afectadas. 
Otro de los puntos críticos es la obtención de licencias y permisos municipales como la licencia de actividad o la licencia de obras. Son procesos administrativos largos, que dificultan la planificación de los trabajos y el acopio de materiales, puesto que el comienzo de los trabajos está condicionado al hecho de obtenerlos. Si la red utiliza sistemas de cogeneración, todavía los procedimientos administrativos de legalización, se hacen más tediosos al implicar el consentimiento de las compañías distribuidoras, la concesión de puntos de acceso y conexión a la red, ...

Una de las soluciones planteadas por ADHAC. (Asociación de Empresas de Redes de Calor y Frío) es la inclusión de las redes de distrito en la normativa de instalaciones térmicas, en los planes urbanísticos municipales y en los planes energéticos, de tal manera que las zonas de nueva urbanización pudieran incluir este tipo de sistemas de calor y frío, como una opción altamente eficiente, razón por la cual podrían, además, concederse incentivos fiscales.

Estas medidas también ayudarían a dar a conocer estos sistemas, fomentando una mayor sensibilización y evitando los recelos que existen entre la población que se resiste a cambiar su sistema propio individual para depender de uno central colectivo.

Añadidos a estas limitaciones legales y normativas, a la hora de dimensionar y diseñar el proyecto de una red de distrito, es necesario tener en cuenta los siguientes condicionantes técnicos que en ocasiones son limitativos:

- La previsión de nuevas urbanizaciones

- La previsión de concentración o dispersión de los barrios.

- La densidad de la demanda de calor y frío, cuyo valor resultará ser un factor determinante para la viabilidad de una red de distrito

La viabilidad disminuye al bajar la densidad de edificación y la demanda energética, por lo que la inversión específica por unidad de superficie por climatizar $\left(€ / \mathrm{m}^{2}\right)$ aumenta a medida que disminuye la densidad de la demanda.

- Grado de incertidumbre para estimar un ratio de densidad mínima para que un proyecto de red sea viable.

- Fiabilidad en la estimación o medida de las demandas mínimas de calor y frío que hacen viable el proyecto.

- Definición del modelo de negocio de la red, estimando los costes de operación, mantenimiento, gestión técnica, administrativa con facturación a clientes, incluida, etc.)

- Previsión de la existencia de sistemas duplicados de forma individual para satisfacer las demandas de frío y calor que satisface la red de distrito y medición del consumo de estos sistemas para descontarlo de los consumos asociados a la red. 


\subsubsection{Situación actual y perspectivas de futuro}

En el 2012, había más de 5.000 redes de calor en Europa, que cubrían el $10 \%$ de la demanda de calor de la Unión Europea, pero con una gran desigualdad entre los países miembros, desde los que prácticamente no poseen ninguna red a los que mediante redes satisfacían el $70 \%$ de su demanda térmica, como es el caso de los países nórdicos o incluso el 90\% de la demanda como en Copenhague o Helsinki. (DHC Technology Platform, 2012) [63]

En Dinamarca, más del $60 \%$ de la producción de calor y agua caliente se basa en este sistema, y está basada en un $80 \%$ en instalaciones de cogeneración, y el $20 \%$ restante de la quema de residuos urbanos.

En Suecia el 90\% de la energía que se utiliza en las redes de calor, es renovable o proviene de los residuos sólidos urbanos, además en un caso llegan a aprovechar del calor residual de la energía nuclear de la central de Agesta.

En Finlandia y en Rusia, el $50 \%$ del calor que se utiliza en las redes proviene de cogeneraciones y el resto de la incineración de residuos sólidos y energías renovables, en su mayor parte biomasa.

En el hemisferio Norte y fuera del continente europeo, la calefacción de distrito también es utilizada en países como Estados Unidos y Canadá, estando en Nueva York, como se ha comentado, una de las mayores redes a nivel mundial, una red de vapor que se construyó en 1882 y que, en la actualidad cuenta con 1.650 clientes y $169 \mathrm{~km}$ de tuberías. (Lissardy, 2017) [62]

En cuanto a la refrigeración, se satisface el 2\% de toda la demanda de la Unión Europea.

En Europa el $73 \%$ de la población vive en ciudades y se estima que ese ratio crezca hasta el $80 \%$ en el 2030 , es por ello que el $69 \%$ de la demanda de energía primaria se concentra en esas áreas urbanas donde las redes de calor son especialmente beneficiosas. (DHC Technology Platform, 2012) [63]

El $82 \%$ de las redes de calor de la Unión Europea utilizan calores residuales y energías renovables, lo que ayuda a reducir la demanda de energía primaria y evitar emisiones de $\mathrm{CO}_{2}$. 
En España la primera red de calor se construyó en 1932, en la ciudad universitaria de Madrid. (Cano Herrador, Valbuena García, Muñoz Martín, Rey Martínez, \& Navas Gracia, 2014) [64] y a finales del 2018, según el último censo publicado por la Asociación de empresas de redes de calor y fío: ADHAC, había 402 redes en España, con más de $680 \mathrm{~km}$ y más de 5.000 edificios conectados. La evolución del crecimiento del número de redes en España, puede apreciarse en la Figura 8. (Asociación de Empresas de Redes de Calor y Frío ADHAC, 2018). [65]

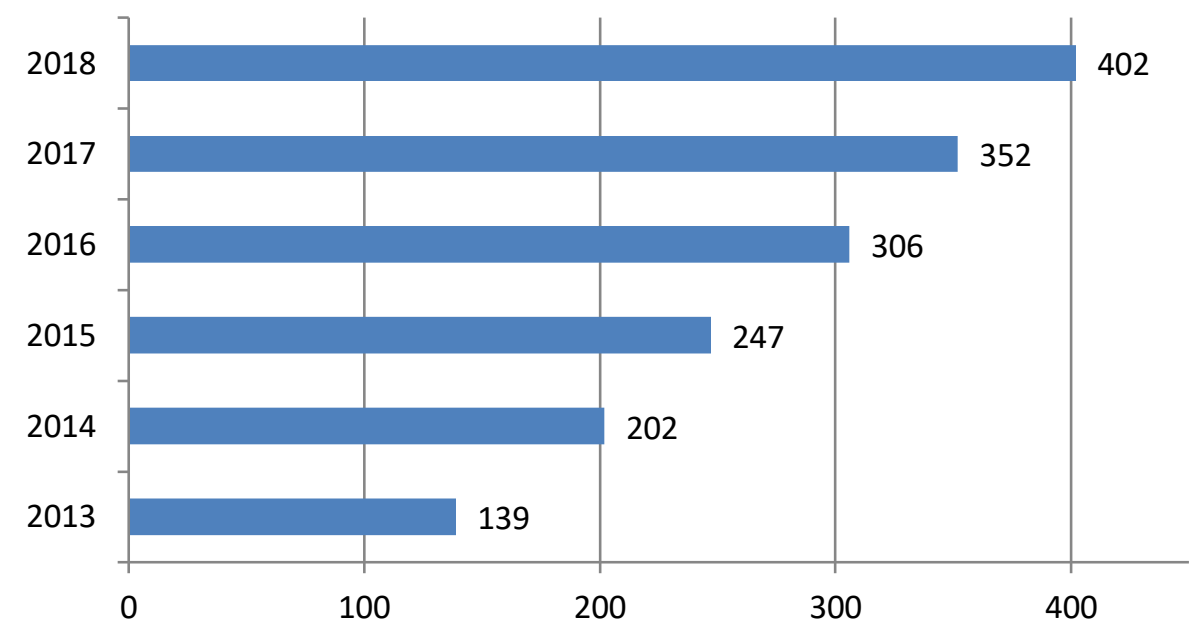

Figura 8. Evolución del número de redes de calor y frío en España (2013-2018)

Los clientes de las redes de calor españolas pertenecen mayoritariamente al sector terciario (68\%), seguido del sector residencial (24\%) y del industrial (8\%). El $49 \%$ de las redes son de titularidad pública, otro $47 \%$ de titularidad privada y un $4 \%$ de titularidad mixta. El $72 \%$ de las redes emplean energías renovables, (69\% de las redes utilizan como fuente de energía primaria la biomasa), el $14 \%$ el gas natural y el $17 \%$ restante otras combinaciones de energía (gas-oíl, electricidad, calores residuales)

De las 402 redes, 130 (un 32\%) se ubican en Cataluña, 59 (un 15\%) en Castilla y León, 38 (un 9\%) en Navarra, 36 (un 9\%) en el País Vasco, 35 (un 9\%) en Madrid y las otras 104 en el resto de comunidades, tal como aparece en la Figura 9 y Figura 10. De todas de redes, 362 (un 90\%) son redes únicamente de calor, 35 (un 9\%) son redes de calor y frío y 5 (un 1\%) son redes sólo de frío. 


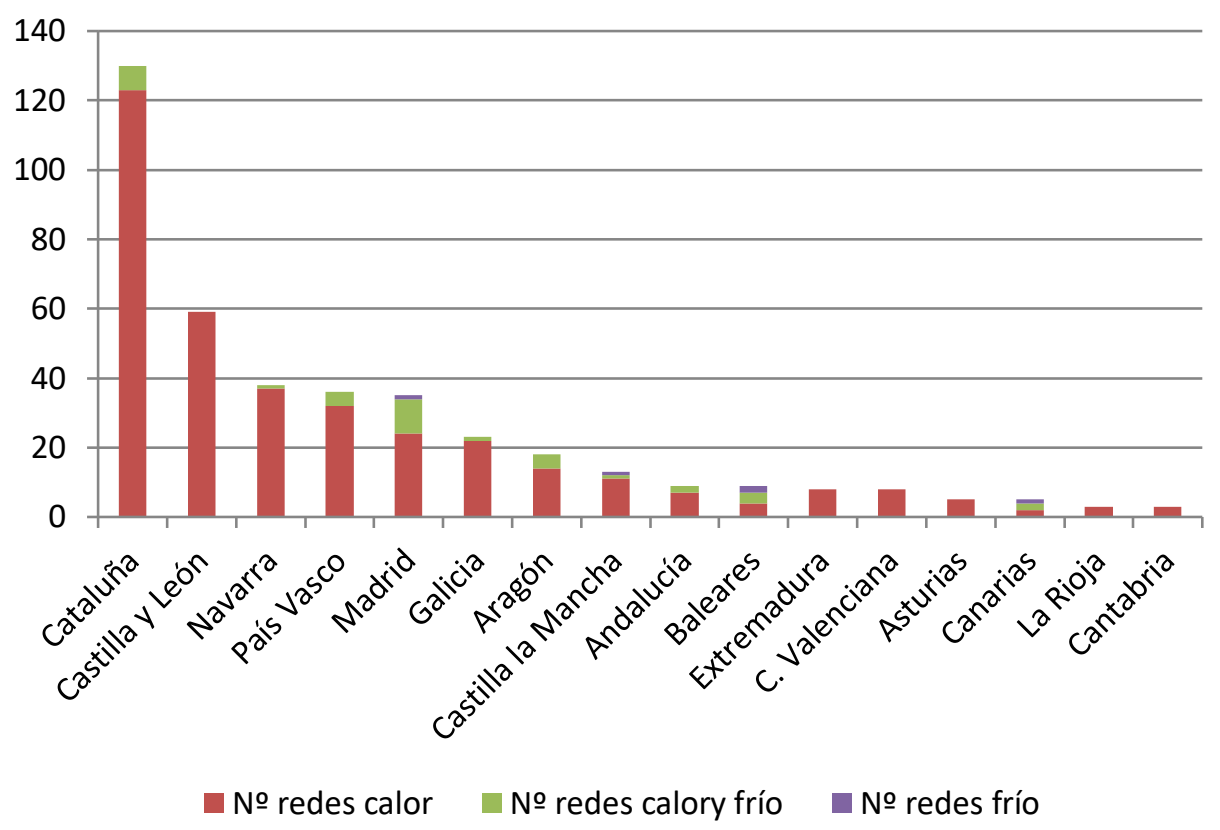

Figura 9. Distribución del número de redes en España por Comunidades. 2018

La potencia total instalada en esas 402 redes es de $1.448 \mathrm{MW}$, de los cuales $1.057 \mathrm{MW}$ (un $73 \%$ ) son de calor y $391 \mathrm{MW}$ (un 27\%) de frío. El 70\% de la potencia instalada se concentra en Cataluña con $495 \mathrm{MW}$ (un 34\% de la potencia total), Madrid con $342 \mathrm{MW}$ (un 24\%) y Navarra con 176 MW (un 12\%), la distribución por Comunidades Autónomas se puede apreciar en la Figura 10 y Figura 11.

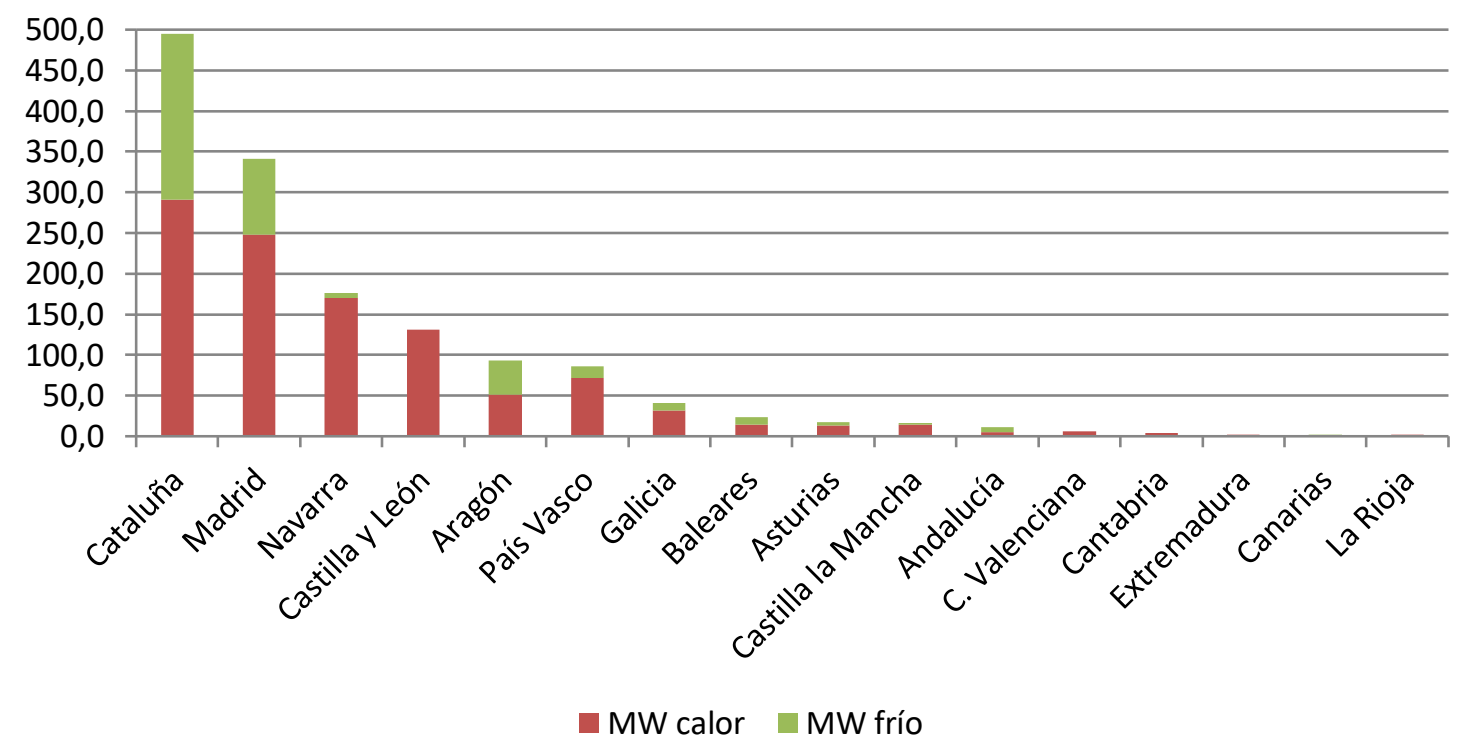

Figura 10. Distribución de la potencia instalada en redes en España por Comunidades. 2018 


\section{Número de redes por Comunidades}

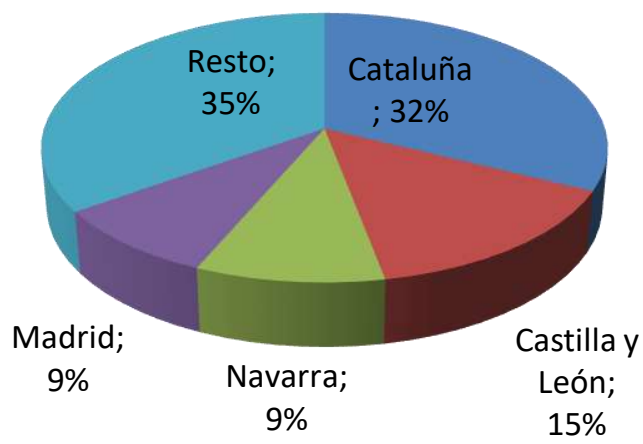

Potencia instalada en las redes por Comunidades

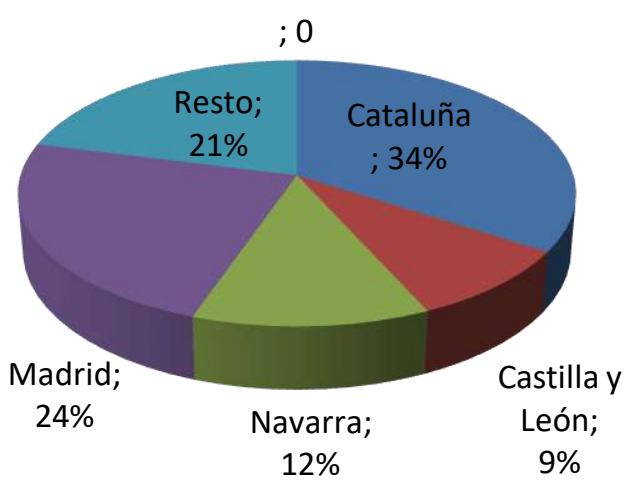

Figura 11. Distribución porcentual del número de redes y potencia por Comunidades. 2018

\section{Perspectivas de futuro}

La evolución natural de las redes de calor y frío es la conversión paulatina en redes de 4a generación, lo que implica el abandono de las fuentes de combustibles fósiles para el uso de calores residuales, energías renovables y residuos sólidos urbanos, e incluso en combinación con la trigeneración (calor, frío y electricidad) esto llevaría a un aumento considerable en su eficiencia energética.

Se espera que las redes de calor doblen su cuota de mercado en el 2020, mientras que las de frío logren pasar del 2\% al 25\%. En este sentido los países Escandinavos, y los Emiratos (UAE) serán los líderes, de ahí el ejemplo de la red de Dubái. Los Hoteles para turismo en las áreas tropicales y sub-tropicales ya se están equipando con sistemas centrales de distribución de agua helada que alimentan las unidades de aire acondicionado. En el 2030, se hablará de redes de calor y frío inteligentes que llegarán a la optimización casi perfecta en la interacción entre generación, distribución y demanda. (DHC Technology Platform, 2012) [63].

Se hablará de redes de calor o frío como uno de los sistemas energéticos más avanzados de las ciudades, llamándolas: red inteligente, micro red, planta de energía virtual, sistema multienergético (Howell, Rezgui, Hippolyte, Jayan, \& Li, 2017) [66], 'smart grid', 'microgrid', 'virtual power plant' and 'multi-energy system'. 
Para llegar ahí, será necesario integrar multitud de sensores y monitorizar todos los parámetros para su gestión, lo que se ha dado en llamar el BEMS (Building Energy Management Systems) (Ahmad, Mourshed, Mundow, Sisinni, \& Rezgui, 2016) [67]

Será, entonces, cuando se conjugará con exactitud la interrelación entre la generación y los prosumidores (prosumers) (consumidores y productores) y la perfecta armonía entre la producción, el consumo y el almacenamiento de energía en las ciudades, considerando cada elemento como un holón, lo que desembocará en la gestión de la energía holística (Holistic energy management) (Ferreira, Ferreira, Cardin, \& Leitao, 2015) [68], (Reynolds, Rezgui, \& Hippolyte, 2017) [69]

\subsubsection{Líneas de investigación en redes de calor}

Por su potencial descarbonizador, las redes de calor se han convertido en una de las mejores soluciones para reducir el impacto medioambiental de los sistemas de calefacción, es por ello que en la actualidad hay abiertas varias líneas de investigación que se centran en la optimización de las redes actuales para transformarlas en redes inteligentes de cuarta generación, en las que se integren las tecnologías renovables de la generación distribuida. (Mazhar, Liu, \& Shukla, 2018) [70]

Pero esta integración no sólo deberá considerar las necesidades térmicas de calor y frío, sino que deberá tener en cuenta las necesidades eléctricas, de manera las nuevas tecnologías interrelacionen ambas demandas y el exceso de la producción eléctrica renovable pueda ser utilizado para la producción de calor o el exceso de calor pueda ser utilizado para la producción de frío por absorción.

Por lo tanto, estas optimizaciones van encaminadas a adaptar las redes térmicas inteligentes en paralelo con las redes eléctricas inteligentes en el concepto de ciudades inteligentes con una implicación directa de los consumidores para que sean capaces de gestionar sus consumos a distancia ahorrando energía activamente y estableciendo un control automático de la red con un funcionamiento sin supervisión. (Gaoa, y otros, 2017) [71]

Otro de los aspectos clave para la obtención de redes inteligentes de cuarta generación es la investigación en el paso a redes de baja temperatura que permitan acoplar con mayores eficiencias los sistemas solares y geotérmicos, lo que implica la optimización de los sistemas de acumulación que puedan satisfacer demandas puntas puntuales. (Lund, Duic, Alberg-Ostergaard, \& Mathiesen, 2018) [72] 
Hay estudios que afirman que tanto los edificios existentes, como los nuevos pueden integrarse en redes de cuarta generación de bajas temperaturas sin sobrecostes importantes dado que se ven rentabilizados por la reducción de las pérdidas energéticas en la distribución. (Lund, y otros, 2018) [73]

Dar el paso a redes de cuarta generación, también incluye la integración de tecnologías de refrigeración en las redes térmicas mediante la utilización de bombas de calor por absorción (Dorotić, Pukšec, \& Duić, 2018) [74]

En Europa la investigación en redes térmicas, tiene como objetivo proporcionar sistemas con mayor seguridad energética, competitividad y rentabilidad, para ello se centra en tres áreas:

- Su integración con fuentes de energía renovables

- El aumento de la eficiencia energética de los sistemas

- El estudio del impacto en el medio ambiente y en la salud humana

Para la integración de todos los elementos en redes más eficientes, se requiere sistemas de energía más flexibles con automatizaciones que hagan participar de forma más dinámica a los prosumidores (productores + consumidores) (Sayegh, y otros, 2017) [75]

Todo ello obliga a tener una visión holística o integradora de la red, teniendo en cuenta que todos los agentes deben interactuar de forma coordinada: consumidores, productores, distribuidores energéticos, comercializadores, gestores, mantenedores, .... (Good, Martínez Ceseña, \& Mancarella, 2017) [76]

En resumen, estas líneas se basan principalmente en la búsqueda de:

- La integración de múltiples fuentes de energía sostenibles, centralizadas y descentralizadas en la red térmica.

- El aumento de la eficiencia energética del conjunto (calor, frío y electricidad)

- La gestión de los edificios conectados en su globalidad, dado que cualquier edificio podrá funcionar como una fuente de energía o como un sumidero según las necesidades del conjunto en diferentes momentos, integrando el concepto de prosumidor en las redes térmicas.

- Nuevas técnicas más precisas de medición de calor con flujos de energía bidireccionales, con contadores automatizados y transparentes con cifras en tiempo real disponibles para los usuarios que permitan una gestión eficiente de sus equipos para ahorrar energía. 
- La optimización de las tecnologías de comunicación e interacción con la electricidad, el gas y el transporte, lo que implica nuevas implementaciones para la gestión automática de aparatos eléctricos y térmicos en edificios.

- Integración de los sistemas de refrigeración con bombas de calor por absorción en las redes térmicas

Unido a esta búsqueda en la eficiencia energética de los sistemas que integran las redes térmicas, se encuentra la búsqueda de herramientas que permitan obtener edificios de energía casi cero. En este contexto las redes que integran a las energías renovables se convierten en una de las herramientas más prometedoras, no sólo para conseguir edificios de consumo casi nulo, sino para obtener distritos de consumo casi cero, lo que abre un nuevo campo de investigación que se va más allá de los límites de los edificios individuales para considerar la influencia del consumo en el contexto urbano, adecuando las metodologías de evaluación del rendimiento energético de los edificios a los distritos y teniendo en cuenta elementos urbanos clave como la morfología de las ciudades, el clima y los espacios públicos. (Amaral, Rodrigues, Rodrigues Gaspar, \& Gomes, 2018) [77] 


\section{CAPÍTULO 2. METODOLOGÍA.}

\subsection{Cuestiones a resolver y aporte de la tesis}

El proyecto de la red de calor de la UVA, ideado en el año 2013, tuvo en cuenta las demandas térmicas de los edificios que iban a formar parte de la red de distribución, sin embargo no se llegó a construir la línea base de estos consumos, que sirviera de referencia para evaluar los potenciales ahorros energéticos que se obtendrían con la red.

Según la Norma UNE-EN ISO 50.001, (AENOR. Asociación Española de Normalización, 2018) [78]

Una línea base es una referencia cuantitativa que proporciona la base de comparación del desempeño energético. (El desempeño energético son los resultados medibles relacionados con la eficiencia energética, el uso de la energía y el consumo de energía).

Una línea de base energética refleja un periodo especificado

Una línea de base energética puede normalizarse utilizando variables que afecten al uso y/o consumo de la energía, por ejemplo: nivel de producción, grados-día (temperatura exterior), etc.

La línea de base energética también se utiliza para calcular los ahorros energéticos, como una referencia antes y después de implementar las acciones de mejora del desempeño energético"

Así pues, una de las cuestiones que se pretende resolver en la investigación es el conocimiento de la línea de base energética del periodo anterior al funcionamiento de la red de calor, para lo cual habrá que determinar cuáles son las variables más influentes en el consumo energético representado en la línea base y obtener una curva matemática que represente esa línea base y tenga en cuenta la variación de los parámetros definidos como los más representativos. 
La red de calor de la Universidad de Valladolid, fue ideada para proporcionar además del suministro térmico de los edificios conectados, un ahorro de emisiones y un ahorro energético.

La Red de Calor Urbana en la Universidad de Valladolid permitirá la reducción de 6.800 toneladas anuales de emisiones de $\mathrm{CO} 2$ y un ahorro del $15 \%$ anual en calefacción. (PREFIERES. Portal de Eficiencia y Rehabilitación, 2016) [79]

En el 2016, se hablaba de un $15 \%$ de ahorro energético anual, como uno de objetivos a cumplir por la red de calor, este ahorro no ha sido cuantificado hasta el momento y determinarlo es otra de las cuestiones a resolver con la presente tesis.

A la hora de determinar el ahorro conseguido con la implementación de medidas es necesario inferir éste a partir de datos obtenidos mediante medición. Numerosos protocolos de medida y verificación (M\&V), explicados en el Anexo I, detallan cómo podría realizarse esta estimación, sin embargo el seguimiento de estos protocolos no garantiza el éxito en la estimación correcta del ahorro. Es necesario aplicar de manera estricta técnicas de inferencia estadística y de análisis de regresión que llevan asociadas una serie de hipótesis que necesitan ser ratificadas, puesto que sin su cumplimiento, los resultados obtenidos no pueden ser considerados como válidos.

Los errores detectados en la aplicación de los protocolos de medida y verificación, suelen deberse a la falta de un análisis exploratorio de los datos de partida, a la incorrecta elaboración de los modelos de regresión y sobre todo a la ausencia de la validación de las hipótesis de los modelos de la línea base de referencia.

Uno de los focos de atención de esta investigación es el estudio de una metodología correcta que, aplicando los protocolos de $M \& V$, detalle y desarrolle unas técnicas estadísticas que permitan obtener unas conclusiones fiables.

El protocolo seleccionado en esta investigación es el Protocolo Internacional de Verificación y Medida (IPMVP), en su opción C de verificación de toda la instalación. Se han tomado como medidas los datos de los contadores propiedad de la Universidad y el periodo en estudio ha sido de más de dos años, por lo que se cumplen todos los supuestos establecidos en el protocolo para poder aplicar la Opción C.

La medida que se verifica con la aplicación del protocolo se traduce en la comprobación del ahorro que supone el cambio del sistema térmico basado en calderas individuales para cada edificio a un suministro de energía útil proveniente de un sistema central que utiliza biomasa como combustible. 
Según el Artículo 2.41. de la Directiva 2012/27/CEE, (El Parlamento Europeo y el Consejo de la Unión Europea, 2012) [27], se define un sistema Urbano Eficiente de Calefacción y Refrigeración, como todo sistema urbano de calefacción o refrigeración que utilice al menos un $50 \%$ de energía renovable, un $50 \%$ de calor residual, un $75 \%$ de calor cogenerado o un $50 \%$ de una combinación de estos tipos de energía y calor.

Dado que la red de calor de la Universidad utiliza calderas de biomasa para satisfacer la demanda de los edificios conectados, según esta definición, se podría considerar como un sistema Urbano Eficiente de Calefacción, sin cuantificar el ahorro energético conseguido.

No obstante, en esta investigación se plantea el suministro de energía proveniente de la red de calor como un sistema de mejora de la eficiencia energética con respecto el sistema de calefacción anterior, es decir se plantea la conexión a la red de calor como una Medida de Mejora de Eficiencia Energética (MMEE), y se utiliza el protocolo IPMVP para cuantificar el ahorro conseguido, este planteamiento con redes de calor no ha sido encontrado en ningún estudio de redes de calor, por lo que se considera otro aspecto innovador en la investigación realizada.

Una vez obtenido el modelo la línea base del consumo térmico y una vez ajustado a la variación de las variables independientes que lo condicionan para los periodos de predicción del consumo, se podrá emplear para pronosticar el consumo energético que hubieran tenido los edificios conectados de no haberse construido la red. Con ello se estimarán cuáles hubieran sido los consumos futuros esperados y tras la comparación de los consumos futuros esperados con los obtenidos en la realidad después de la implantación de la red de distribución de calor, se podrá determinar si existe una diferencia significativa y cuantificarla.

Este proceso de comparación no ha sido establecido por ninguno de los protocolos de $M \& V$, que simplemente se paran en la obtención de los modelos de la línea base. La investigación llevada a cabo en esta tesis da un paso más allá y desarrolla una metodología estadística que, basada en pruebas paramétricas y contrate de hipótesis, ofrece una solución a la interpretación correcta de los resultados obtenidos entre los datos pronosticados y los datos reales obtenidos de la medición de los consumos.

En resumen, el proceso seguido en la investigación realizada, da respuesta a las preguntas reflejadas en la Figura 12.

¿Se pueden determinar cuáles son las variables

más influentes en el

consumo térmico de

los edificios conectados a la red?

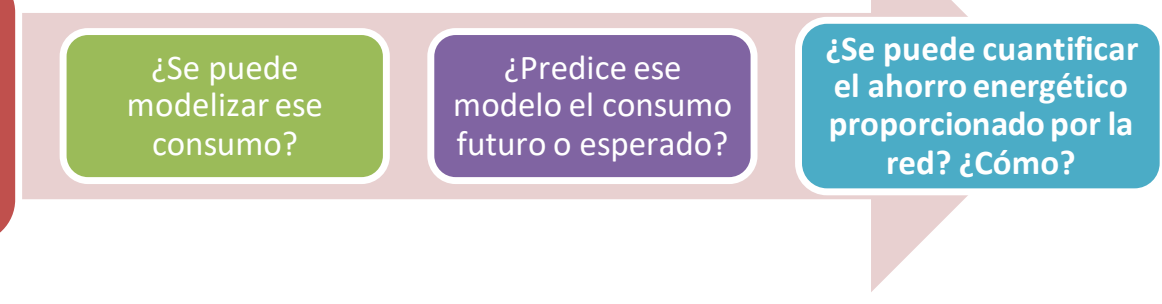

Figura 12. Planteamiento de las cuestiones a resolver 
En el 2016, también se estimó el ahorro de emisiones anuales de $\mathrm{CO}_{2}$ que se pretendía obtener con la red; una vez se haya comprobado la existencia de diferencias significativas en el consumo térmico, se podrá obtener el consumo de energía ahorrada y de ahí el ahorro de emisiones de $\mathrm{CO}_{2}$, siendo este último paso otra de las cuestiones a la que se dará respuesta con esta tesis.

Paralelamente, una vez se cuantifiquen los ahorros obtenidos se podrá verificar si como cabría esperar en un principio la situación energética de los edificios tras la conexión a la red de calor presenta mejor eficiencia que la situación inicial con el funcionamiento de los sistemas individuales.

Se calcula que los sistemas de gran potencia tiene rendimientos un $10 \%$ superiores a los sistemas centralizados de edificio y entre un 30 y un $40 \%$ superiores a los individuales de vivienda. (Huerta, Portela, \& Pastor, 2010) [80]

\subsection{Estado de otras investigaciones}

La regresión se ha aplicado en múltiples ocasiones para poder estimar la tendencia que siguen los datos y predecir su comportamiento en un futuro. En el campo de la energía, es habitual emplearlo para estimar los consumos esperados en una instalación o un edificio. Autores como Bilous emplean modelos de regresión no lineales (Bilous, Deshko, \& Sukhodub, 2018) [81]; pero lo más frecuente es utilizar modelos de regresión lineales: (Permai \& Tanty, 2018) [82], (Roth \& Rajagopal, 2018) [83], (Fumo \& Rafe Biswas, 2015) [84], (Arregi \& Garay, 2017) [85], (Aranda, Ferreira, Mainar-Toledo, Scarpellini, \& Llera Sastresa, 2012) [86].

Otros estudios analizan las variables de las que dependen la demanda de calor de los edificios sin recurrir a modelos de regresión de lineal, como es el caso de Werner que explicó que la demanda óptima de calor debe ser proporcional a la raíz cuadrada de los grados día, siendo los grados día de los países europeos del Norte unas veinte veces mayores a los del Sur. (Werner, International review of district heating and cooling, 2017) [87]

En numerosos casos la demanda y el consumo térmico de un edificio son función de los grados día, en estos casos, la base tomada para calcular los grados día puede variar desde $15^{\circ} \mathrm{C}$ a $22^{\circ} \mathrm{C}$, por ejemplo las predicciones del consumo de calefacción realizado para Debrecen (Hungría), se basaron en los grados-día, en base a la temperatura de consigna interior de $20^{\circ} \mathrm{C}$ y $22^{\circ} \mathrm{C}$. (Verbai, Lakatos, \& Kalmár, 2014) [88] 
La variable grados-día, se ha utilizado en numerosos estudios: estudios sobre comportamientos del consumo térmico en instalaciones industriales (Golden, Woodbury, Carpenter, \& O'Neill, 2017) [89], en edificios no residenciales (Meng \& Mourshed, 2017) [90], edificios residenciales (Verbai, Lakatos, \& Kalmár, 2014) [88], en aplicaciones energéticas (Atalla, Gualdi, \& Lanza, 2018) [91] o para estimar la demanda de instalaciones de calor y frío (De Rosa, Bianco, Scarpa, \& Tagliafico, 2014) [92]

En cuanto a la metodología para la obtención de los ahorros, existen trabajos que también aplican una sistemática que verifica la diferencia encontrada entre el consumo antes y después de la puesta en marcha de un determinado proyecto; construyendo, para ello, una línea base que representa el consumo esperado que se hubiera tenido, caso de no realizar el proyecto. (Sathayea, y otros, 2004) [93]

En Japón, (Sakamoto, Takase, Matsuhashi, \& Managi, 2016) [94] también se utilizó la metodología de la línea base para predecir la demanda energética del 2030, pero añadiendo a las variables climáticas otras que contemplaban aspectos socio-económicos del país, el resultado apuntó hacia un descenso en el consumo industrial y un aumento en el sector edificios, al contrario de la previsible tendencia en Europa (El Parlamento Europeo y el Consejo de la Unión Europea, 2010) [26].

También en Reino Unido, se empleó dicha metodología para predecir consumos en aras al establecimiento de políticas energéticas. (Strachan, 2011) [95]

En Estados Unidos, (Liang, Hong, \& Qiping Shen, 2016) [96] se utilizaron modelos de línea base mejorados no sólo con datos de temperatura exterior, sino con datos de ocupación.

En el estudio de la ciudad de Ginebra (Quiquerez, Lachal, Monnard, \& Faessler, 2017) [97], la demanda futura resultó estar determinada por dos variables fundamentales: el crecimiento de la población y el descenso de los grados día, esta predicción fue utilizada para estimar que el ahorro a obtener con la aplicación de medidas de eficiencia energética en los edificios si se combinaban con la implantación de redes de calor, podría llegar a ser del $17 \%$ de la energía demandada.

Como se observa, en números estudios se ha aplicado la regresión, como método predictivo, se supone que en todos ellos se han comprobado el cumplimiento de los supuestos estadísticos para que esa regresión sea considerada como válida, pero no se han encontrado evidencias de tales comprobaciones.

Tampoco se han encontrado estudios que utilicen la prueba paramétrica $t$-Student para la comprobación de diferencias estadísticamente significativas entre los resultados de los consumos reales y los predichos, mediante la comparación de las medias de los datos observados. Los estudios que estiman el ahorro obtenido con la aplicación de una mejora, lo hacen comparando un solo dato como puede ser el resultado anual del consumo, pero sin utilizar ningún test estadístico. 


\subsection{Hipótesis de partida y limitaciones}

Como se ha comentado, con el desarrollo de la tesis se desea comprobar si el ahorro energético esperado con la ejecución del district heating, estimado en un $15 \%$, es el que se está produciendo.

Para verificar la certeza de esta hipótesis de partida y poder dar explicación a cualquier desviación que se detecte, se establecerá la línea base relativa a los consumos energéticos de los edificios con las siguientes hipótesis y limitaciones:

- Se analizarán los 23 edificios que forman parte de la red de distribución de la Universidad de Valladolid

- Los consumos que serán analizados se corresponden únicamente con los consumos térmicos, provenientes del consumo de combustibles fósiles: gas natural, gasóleo y del consumo de biomasa (astilla). No serán analizados los consumos eléctricos de los edificios.

- El consumo térmico será considerado en su totalidad, sin desglose del consumo debido a calefacción y del consumo debido al agua caliente sanitaria (ACS), empleándose para la estimación del ahorro energético la Opción $\mathrm{C}$ del protocolo IPMVP.

Tal opción implica analizar un periodo demostrativo de ahorro igual o superior a dos años o considerar un ahorro superior al $10 \%$ de la energía de referencia (En este trabajo se cumplen ambas posibilidades).

- Los datos de los consumos, tal como indica el protocolo IPMVP, consideran la totalidad de las instalaciones térmicas de cada edificio y han sido facilitados por la Universidad de Valladolid, en base a los registros de sus propios contadores de la energía suministrada a cada edificio por la red de calor, en base a la lectura de sus propios contadores del consumo de gasóleo de las instalaciones térmicas de los edificios con gasóleo y en base a las facturas de gas natural de las instalaciones térmicas de los edificios con este combustible. La frecuencia de los datos de estos consumos es mensual.

- Como periodo representativo inicial de su consumo, se tomarán dos temporadas completas de calefacción, desde octubre de 2012 hasta mayo de 2013 y desde octubre de 2013 hasta mayo de 2014.

- Como periodo representación del consumo obtenido tras la implantación de red de calor, o periodo demostrativo de ahorro, se tomarán tres temporadas completas de calefacción, desde octubre de 2015 a mayo de 2016, de octubre de 2016 a mayo de 2017 y de octubre de 2017 a mayo de 2018.

- La temporada comprendida entre octubre de 2014 y mayo de 2015, no se tendrá en cuenta por considerarse el periodo de construcción de la red. 
- Los modelos de predicción del consumo han sido ajustados por las variables climáticas que han resultado ser estadísticamente significativas en los modelos de regresión lineal simple múltiple, estos ajustes se corresponderían con los ajustes rutinarios marcados por el protocolo IPMVP.

- Los ajustes no rutinarios debidos a cambios de los tamaños de las instalaciones, cambio en los parámetros de diseño y de consigna interior, tipo y número de ocupantes, hábitos de los usuarios, horarios de funcionamiento de las instalaciones, etc., es decir los parámetros que no se prevén que cambien con el tiempo, no han sido tenidos en cuenta al considerarse constantes durante el periodo demostrativo del ahorro (desde octubre de 2015 hasta mayo de 2018) e iguales al periodo inicial que ha servido de base para la construcción del modelo (desde octubre de 2012 hasta mayo de 2014)

- Los precios de los combustibles fósiles han sido estimados partiendo de datos oficiales publicados, dado que los costes pagados por la Universidad de Valladolid, se han considerado como datos confidenciales. Partiendo de esos datos tan sólo se ha podido estimar el precio máximo al que la Universidad podría adquirir la energía suministrada por la red de calor para obtener un ahorro económico del $15 \%$, ahorro marcado como uno de los objetivos de la red. 


\subsection{Diseño de la metodología}

Con objetivo final citado de verificar si el ahorro conseguido con la red, se corresponde con el inicialmente previsto, se ideó una metodología basada en el análisis estadístico de los consumos antes y después de la construcción de la red. Para ello se siguieron los pasos esquematizados en la Figura 13

- Obtención y tratamiento de las variables climáticas (datos cada 30 minutos).
- Obtención de consumos térmicos antes y después de la red. (Consumos térmicos mensuales).
- Selección de las variables más significativas.
- Obtención de los modelos matemáticos que representen la tendencia de cada consumo térmico.
- Comprobación del cumplimiento de las hipótesis estadísticas para validar cada modelo.
- Predicción, utilizando los modelos válidos, de los consumos que se hubieran tenido de no haberse
construído la red.

- Comprobación estadística de la existencia de diferencias significativas entre el consumo predicho que se hubiera tenido sin la red de calor y el consumo real con la red.

-Análisis de las posibles causas que justifiquen los resultados obtenidos.

- Conclusiones.

Figura 13. Metodología utilizada en la investigación

A continuación se detallan los pasos seguidos en la investigación:

\section{1) Obtención y tratamiento de las variables climáticas.}

Las variables, susceptibles de ser los parámetros independientes que modelasen el consumo esperado de cada edificio, se obtuvieron cada 30 minutos de los últimos 6 años (2012 al 2018) de una estación climática ubicada en Zamadueñas (Valladolid), propiedad del Instituto Tecnológico Agrario de Castilla y León (InfoRiego) [98] y fueron las relativas a: 
- Temperaturas: medias, medias diurnas, máximas y mínimas.

- Grados día: base 15 y base 20.

- Humedades relativas: medias, diurnas, máximas y mínimas.

- Radiación: Intensidad de radiación

- Velocidades del viento: medias, diurnas, nocturnas y máximas.

- Recorrido del viento.

- Precipitación acumulada.

- Horas de sol.

En el estudio que se presenta, las temperaturas, humedades, velocidades, recorrido del viento y precipitaciones, se procesaron para obtener promedios, máximos, mínimos y acumulados mensuales.

En el caso de los Grados día se empleó la siguiente Ecuación 1.

Donde:

$$
\text { GD Base mes }=\sum_{i=1}^{n}\left(\text { Base }-T_{i}\right)
$$

Base $=15^{\circ} \mathrm{C}$ ó $18^{\circ} \mathrm{C}$

$\mathrm{T}_{\mathrm{i}}=$ Temperaturas medidas registradas cada 30 minutos menores a $15^{\circ} \mathrm{C}$ ó a $18^{\circ} \mathrm{C}$

$\mathrm{n}=$ Número de intervalos de 30 minutos existentes en cada mes ó

$\mathrm{n}=$ Número de días de cada mes $\left({ }^{*}\right)$

Los grados día fueron calculados de dos formas con datos tomados cada 30 minutos y con datos medios diarios.

Los grados-días son valores que expresan diferencias de temperatura acumuladas; se calculan de acuerdo con la norma UNE-EN ISO 15927-6: 2009 (AENOR. Asociación Española de Normalización, 2009) [99]. Su cálculo se basa en el concepto de temperatura base, a partir del cual el edificio necesita calefacción.

\section{2) Obtención de los consumos térmicos antes y después de la red de calor.}

Se recopilaron los consumos térmicos mensuales desde el 2012 al 2018, correspondientes a los 23 edificios de la Universidad de Valladolid, datos propiedad de la UVA.

La red de calor fue construida en el año 2015, por lo que, como se ha indicado, las temporadas de calefacción de octubre de 2012 a mayo de 2013 y de octubre de 2013 a mayo de 2014, se consideraron como los periodos de referencia anteriores a la red y las temporadas 2015 - 2016, 2016 - 2017 y 2017 - 2018, como periodos posteriores. 
Estos consumos, siguiendo el protocolo de medida y verificación: IPMVP, en su Opción C, correspondiente a la verificación del ahorro con ajuste estadístico de toda la instalación, fueron tomados de las facturas energéticas y de los contadores disponibles en las salas de calderas de las centrales de calefacción, propiedad de la UVA.

Los datos de las temporadas octubre 2012 - mayo 2013 y octubre 2013 - mayo 2014, se corresponden con la energía térmica comprada a las compañías suministradoras de gas natural y gasóleo para su suministro a las salas de calderas de los edificios y medida antes de las calderas. Viene dado por la Ecuación 2.

Los datos de las temporadas octubre 2015 - mayo 2016, octubre 2016 - mayo 2017 y octubre 2017 - mayo 2018, se corresponden con la suma de energía térmica comprada a:

- El suministrador de la energía térmica procedente de la central térmica de Biomasa, Sociedad Pública de Infraestructuras y Medio Ambiente de Castilla y León, S.A (SOMACyL), medida a la salida del intercambiador de calor de la subestación de cada edificio

- A las compañías suministradoras de gas natural y gasóleo para su suministro a las salas de calderas de los edificios y medida antes de las calderas. Energía que sirve de apoyo a la energía suministrada por la red de calor.

Esta energía viene dada por la Ecuación 3.

$$
\begin{aligned}
& C_{\mathrm{GI}}=\frac{D}{\eta_{\mathrm{SIG}}} \\
& C_{\mathrm{F}}=C_{G F}+C_{r e d}=\frac{D}{\eta_{\mathrm{SF}}} \\
& C_{G F}=\frac{D_{G}}{\eta_{\mathrm{SFG}}}
\end{aligned}
$$

Siendo:

$C_{\mathrm{GI}}=\quad$ Consumo térmico inicial de los edificios antes de la implantación de la red, es la energía comprada a las compañías suministradoras de gas natural y gasóleo para su suministro a las salas de calderas de los edificios y medido antes de las calderas, es la Energía final consumida con anterioridad a la red de calor $(\mathrm{kWh})$

$D=\quad$ Demanda térmica de los edificios o Energía final útil consumida (kWh)

$\eta_{\text {SIG }}=$ Rendimiento estacional inicial del sistema térmico que había antes de la conexión del edificio a red de calor 
$C_{\mathrm{F}}=\quad$ Consumo térmico final de los edificios después de la implantación de la red (kWh), es la energía comprada a las compañías suministradoras de gas natural y gasóleo para el suministro de apoyo a las salas de calderas de los edificios y medido antes de las calderas más la Energía comprada de la red de calor, es la Energía final total consumida con posterioridad a la red de calor (kWh)

$C_{G F}=\quad$ Consumo térmico final de los edificios después de la implantación de la red (kWh), es la energía comprada a las compañías suministradoras de gas natural y gasóleo para el suministro de apoyo a las salas de calderas de los edificios y medido antes de las calderas, es la Energía final consumida proveniente de los suministradores de gas y gasóleo ( $\mathrm{kWh}$ )

$C_{\text {red }}=$ Compra de energía térmica a la red que coincide con la demanda térmica de los edificios después de la implantación de la red, satisfecha con la energía comprada a la red de calor ( $\mathrm{kWh}$ ), puesto que es medida después del intercambiador de la subestación, es la Energía final consumida proveniente del gestor de la red de calor de biomasa $(\mathrm{kWh})$.

$\eta_{\mathrm{SF}}=\quad$ Rendimiento estacional final del sistema térmico que hay después de la conexión del edificio a la red de calor

$D_{G}=\quad$ Demanda térmica de los edificios o energía final útil consumida (kWh) después de la implantación de la red, no satisfecha con la energía térmica comprada a la red de calor.

$\eta_{\mathrm{SFG}}=$ Rendimiento estacional final de las calderas después de la red de calor

Como la demanda térmica de los edificios ha permanecido constante en las temporadas anteriores y posteriores a la red de calor, se cumplen las siguientes Ecuaciones 5, 6, 7 y 8 :

$$
\begin{aligned}
& D=D_{G}+C_{r e d} \\
& C_{\mathrm{GI}} * \eta_{\mathrm{SIG}}=C_{G F} * \eta_{\mathrm{SFG}}+C_{r e d} \\
& C_{r e d}=C_{\mathrm{GI}} * \eta_{\mathrm{SIG}}-C_{G F} * \eta_{\mathrm{SFG}} \\
& \eta_{\mathrm{SIG}}=\frac{C_{G F} * \eta_{\mathrm{SFG}}+C_{r e d}}{C_{\mathrm{GI}}}
\end{aligned}
$$


En el estudio se ha considerado cada edificio como un sistema donde la energía entrante es la energía comprada a los suministradores y la energía saliente es, por una parte la energía pérdida por el uso de las calderas y resto de equipos del sistema térmico, medida a lo largo de toda una temporada de calefacción, es decir la energía perdida debido al rendimiento estacional de las calderas y por otra la energía térmica útil disponible para satisfacer las necesidades térmicas del edificio.

En la situación anterior a la conexión del edificio a la red de calor, la única energía entrante es la comprada a los suministradores de gas o gasóleo, en la situación posterior a la incorporación del edificio a la red de calor, hay dos energías entrantes, la comprada al gestor de la red de calor y la comprada al suministrador de gas o gasóleo para satisfacer la demanda térmica que no ha podido satisfacer la red de calor.

En ambas situaciones la energía térmica útil disponible para satisfacer las necesidades térmicas se considera la misma, al no haberse producido ninguna mejora en la envolvente del edificio, ni modificaciones en el horario y uso de los sistemas térmicos. En la Figura 14, se esquematiza el proceso ideado para cada edificio. Al mantenerse la demanda, la variable que se modifica en una situación respecto a la otra es el rendimiento estacional de los sistemas térmicos. Uno de los factores que determinan ese rendimiento son las pérdidas por los arranques y paradas, es decir por la disponibilidad de las calderas (a mayor número de arranques y paradas, existirán más pérdidas que en un funcionamiento de manera continuada).

De modo que si toda la demanda térmica fuera satisfecha con la energía comprada a la rede de calor, el ahorro que se obtendría con la conexión a la red, sería el debido al rendimiento estacional de los sistemas iniciales de cada edificio.

A medida que los sistemas térmicos de cada edificio, necesitan entrar para satisfacer parte de la demanda que la energía comprada a la red no satisface, la eficiencia de la conexión se empeora, tanto así, que pudiera llegar a consumir más energía que en la situación inicial. 


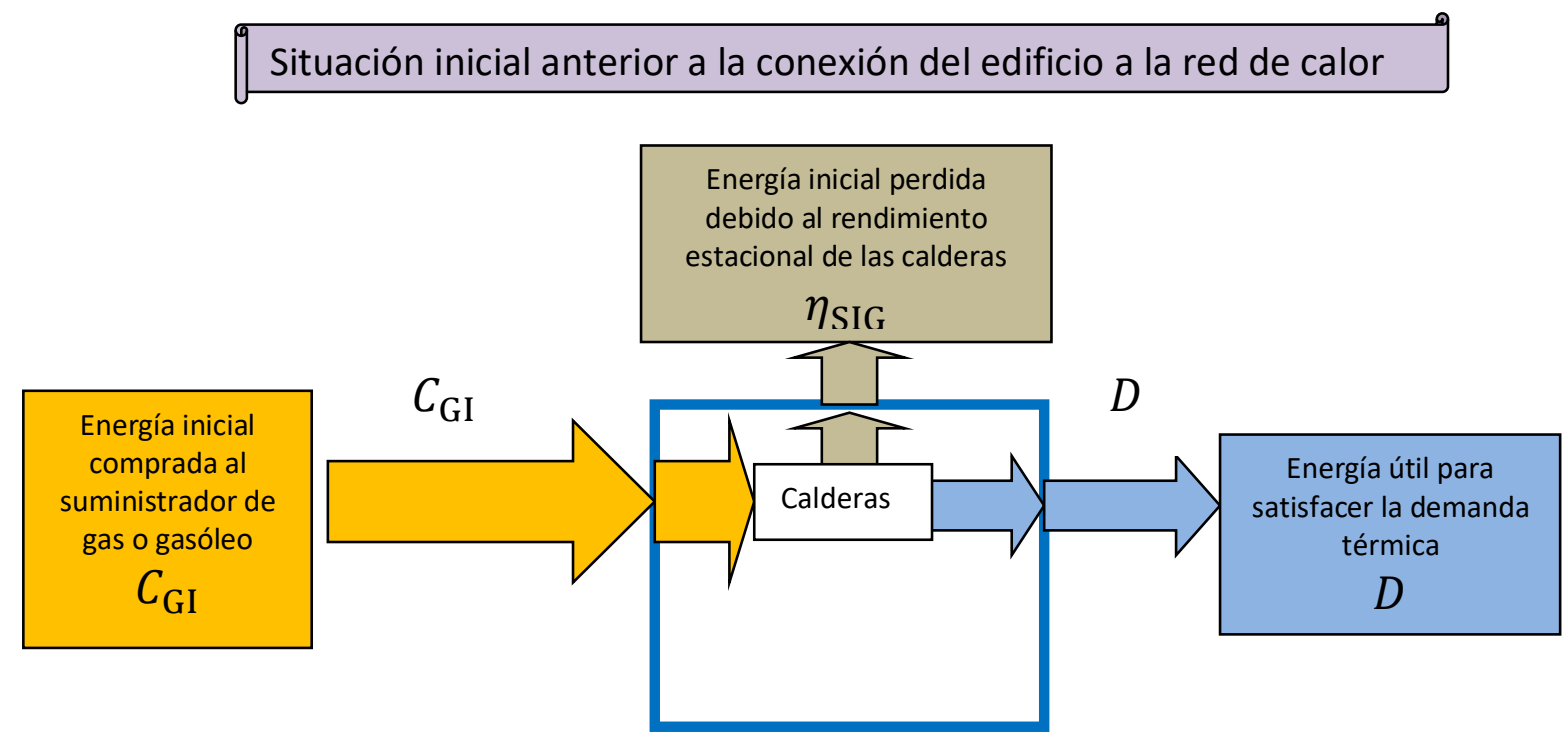

Situación final posterior a la conexión del edificio a la red de calor

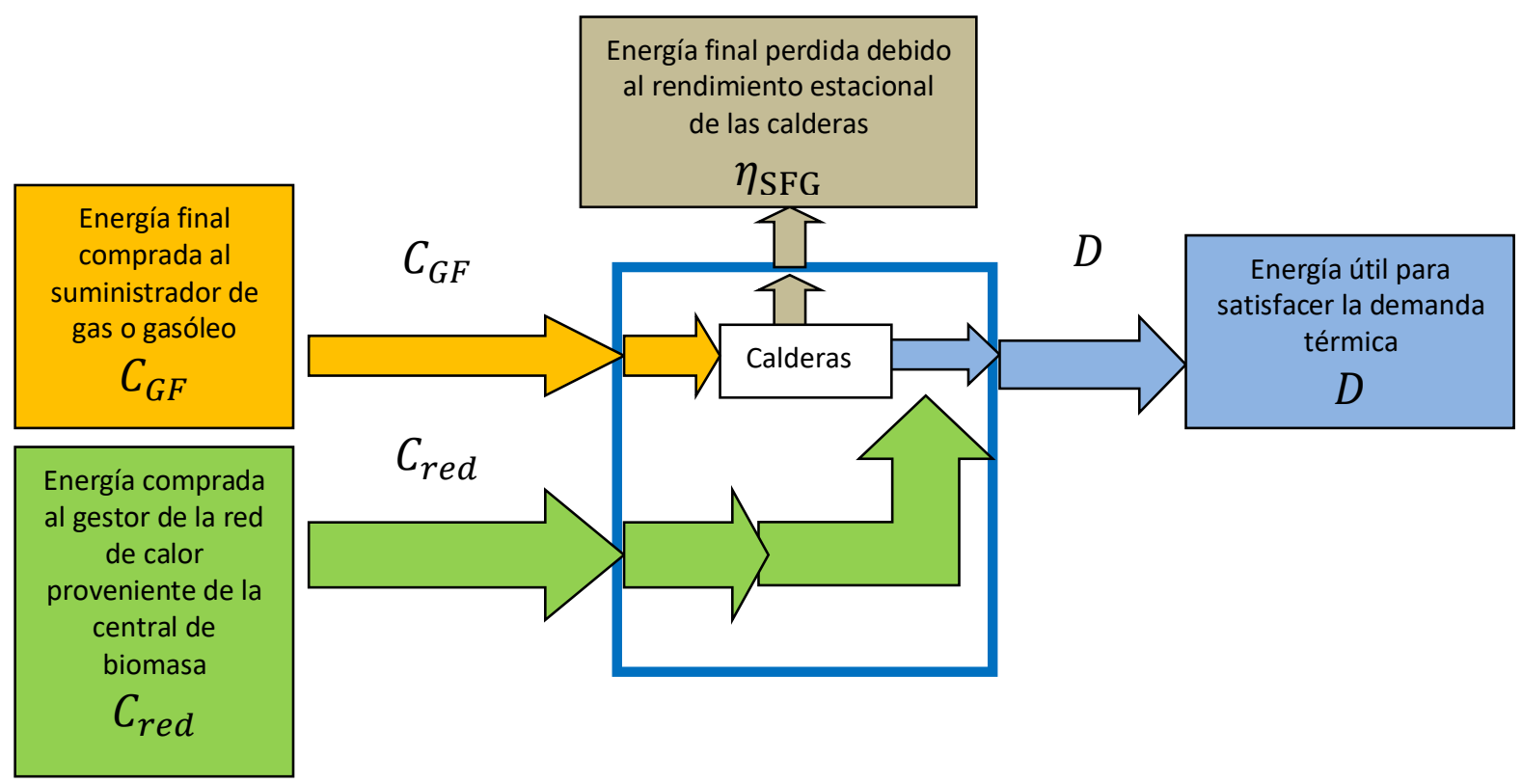

Figura 14. Esquema de la situación de los edificios antes y después de su conexión a la red 


\section{3) Análisis estadístico de las variables correlacionadas con el consumo.}

En este estudio, el software estadístico empleado ha sido SPSS (IBM, 2011) [100] y se ha utilizado el contraste de hipótesis en todo el proceso, de manera que se establece una hipótesis estadística que puede ser cierta o no y con la información extraída de las muestras de los consumos se contrasta para aceptarla o rechazarla.

Así, partiendo de los datos de estudio, se define un estadístico de contraste, un valor que depende de la muestra en estudio, calculado a partir de los datos de la muestra, y cuya distribución de probabilidad es conocida. Para poder conocer esa distribución se establecen varios supuestos referidos a dos aspectos: (Universidad de Sevilla) [101]

- Características de los datos, lo habitual es un supuesto de independencia de los mismos.

- Forma de la distribución de partida, generalmente se parte del supuesto de normalidad de los datos.

De tal forma que si se cumplen esos supuestos, la distribución muestral del estadístico de contraste es conocida y a partir de ella se puede tomar la decisión de rechazar la hipótesis nula cuando el estadístico presente bajas probabilidades de que ocurra, es entonces cuando el estadístico estará en la región de rechazo (conjunto de valores que es más improbable bajo la hipótesis formulada). Por lo tanto si el estadístico en estudio está dentro de este intervalo de rechazo, la hipótesis nula será rechazada.

Cuando no se cumplen los supuestos, no se sabe la distribución de probabilidades del estadístico por lo que no se puede asegurar que las conclusiones obtenidas son válidas, de ahí la importancia de comprobar los supuestos bajo los que los resultados estadísticos pueden ser considerados como fiables.

En la investigación se ha fijado el nivel de confianza $(1-\alpha) \%$, en el $95 \%$, o lo que es lo mismo se ha establecido un nivel de significación o riesgo mínimo de $\alpha=0,05$, lo que indica que se acepta un riesgo del $5 \%$ de estar equivocado al rechazar la hipótesis nula.

El nivel de confianza de una investigación expresa en qué medida los resultados obtenidos no dependen del azar ni se ven influenciados por factores de ruido, difíciles de controlar. Resultados obtenidos con niveles de confianza del $95 \%$ se pueden considerar estadísticamente relevantes, asegurando que los resultados son estables. (Adobe Experience Cloud Help) [102] 
Un primer paso para determinar los modelos matemáticos que simularon los consumos térmicos, fue determinar las variables climáticas independientes para cada edificio y con peso significativo en la regresión, siendo la variable dependiente: el consumo de cada edificio durante el periodo octubre 2012 hasta mayo 2014.

En la relación lineal que existe entre las variables regresoras, explicativas o independientes y la variable respuesta o dependiente, se fueron eligiendo las variables regresoras que debían formar parte del modelo de regresión con el método Stepwise "paso a paso" o "pasos sucesivos".

Con este procedimiento el programa va eligiendo las variables regresoras que deben formar parte del modelo de regresión. Según este método, se parte inicialmente del modelo sin ninguna variable regresora, solo con el término independiente, y en cada paso se introduce en el modelo la variable independiente más significativa.

Para introducir cada variable independiente se utiliza el test de significación de la regresión, donde la hipótesis nula considerada $\left(H_{0}\right)$ es que la pendiente de la variable independiente en el modelo de regresión sea igual a 0 , frente a la hipótesis alternativa $\left(\mathrm{H}_{1}\right)$ consistente en que la pendiente sea distinta de 0.

Para poder aceptar o rechazar $\mathrm{H}_{0}$, se observa el "p-valor" o probabilidad de cometer un error por rechazar la hipótesis nula siendo cierta, del test realizado.

Van entrando en el modelo aquellas variables que rechacen la hipótesis nula, que son las que poseen una pendiente estadísticamente significativa y esto ocurre si "p-valor" $\leq$ nivel de significación $(\alpha)$. En el estudio se establece un valor del nivel de significación de 0,05 (5\%) o lo que es lo mismo un valor del nivel de confianza, representado en estadística por (1- $\alpha$ ) del 95\%. Este nivel de confianza indica que aceptamos los resultados con un riesgo a estar equivocados del 5\%, o lo que es lo mismo el nivel de significación aceptado indica que las posibilidades de fallar en la estimación son del $5 \%$.

Por lo tanto, el primer paso para que una variable entre en el modelo es que cumpla la regla de entrada que es considerar el $p$-valor $\leq 0,05$. Una vez que ha entrado la primera variable independiente que, además de superar el criterio de entrada, más alto correlaciona (en valor absoluto) con la variable dependiente, se continúa seleccionando la variable independiente que además de superar el criterio de entrada, posee el coeficiente de correlación parcial más alto (en valor absoluto). Cada vez que se introduce una nueva variable independiente, se cuestiona si todas las variables introducidas deben permanecer en el modelo, siendo el criterio de salida del modelo que las variables tengan un " $p$-valor" $\geq 0,1$ ( $p$-valor de salida). Si alguna variable cumple el criterio de salida es eliminada del modelo. El proceso concluye cuando no entran ni salen más variables. 


\section{4) Obtención de los modelos de regresión.}

Se buscan los modelos de regresión que representen la tendencia de los consumos de cada edificio, validando las hipótesis estadísticas del modelo de regresión lineal simple y múltiple.

En los modelos de una variable, la recta de regresión lineal simple está indicada en la Ecuación 9:

$$
\mathrm{kWh}=\text { Cte }+\beta \mathrm{x} \text { Variable }
$$

(Ecuación 9)

Para los modelos multivariables o de regresión múltiple, que contienen más de un regresor la recta es, la mostrada en la Ecuación 10:

$$
\mathrm{kWh}=\text { Cte }+\beta 1 \times \text { Variable_1 }+\beta 2 \times \text { Variable_2 }
$$

(Ecuación 10)

A continuación se detallarán las hipótesis bajo las que se construyen los modelos de regresión lineal y cómo han sido comprobadas en la investigación.

Las condiciones que se deben cumplir en un modelo de regresión son:

- Linealidad de las variables, las variables se encuentran relacionadas de forma lineal.

Para comprobarlo, mediante un test de contraste se verifica que el coeficiente de Correlación de Pearson es distinto de cero $(R \neq 0)$. El coeficiente de correlación de Pearson indica el grado de dependencia entre las variables independientes y la variable dependiente, $(R=-1$ indica correlación perfecta inversa, $R=0$ indica que no existe ninguna correlación y $\mathrm{R}=1$ indica correlación perfecta directa).

Por lo tanto, si la probabilidad del estadístico utilizado en el test de contraste es menor o igual al nivel de significación (valor de la significación es $\leq 0,05$ ), la hipótesis nula establecida como $R=0$, será rechazada y aceptaremos que hay correlación significativa entre las variables y por tanto linealidad entre las variables. 
- Normalidad. Todos los valores obtenidos para la variable dependiente (Y), deben estar distribuidos normalmente en cada valor de las variables independientes (X).

Se comprueba la normalidad de las variables y de los residuos mediante el Test de Shapiro - Wilk para muestras pequeñas (menores a 30 observaciones).

Mediante un test de contraste se comprueba que se acepta la hipótesis nula que afirma que las variables se distribuyen según una normal (Ho = la distribución es Normal), luego si la probabilidad del estadístico del test es menor o igual al nivel de significación 0,05, la hipótesis nula será rechazada y sólo aceptaremos que las variables se distribuyen según una Normal cuando el valor de la significación sea mayor que 0,05 (valor de la significación >0,05) en el Test de Shapiro Wilk.

- Independencia de los errores. Los errores asociados a los valores de la variable respuesta $(Y)$ deberán ser independientes unos de otros, si esto no ocurriera da idea de que los errores contienen cierta persistencia y por lo tanto no se deben a factores únicamente aleatorios, desconectados o independientes unos de otros. Por lo tanto cuando existe autocorrelación, el error cometido en un momento del tiempo estará influenciado por el error de periodos previos. (Mahía, 2010) [103]

Para la comprobación se utiliza el estadístico de Durbin -Watson, definido según la Ecuación 11.

$$
D W=\frac{\sum_{i=1}^{n}\left(\varepsilon_{i}-\varepsilon_{i-1}\right)^{2}}{\sum_{i=1}^{n} \varepsilon_{i}^{2}}
$$

Donde:

- $\mathrm{n}=$ Número de observaciones.

- $\varepsilon_{\mathrm{i}}=$ error o residuo de cada observación.

En el caso de autocorrelación máxima y positiva $\mathrm{DW}=0$

En el caso de autocorrelación máxima y negativa $\mathrm{DW}=4$

En el caso de que no exista autocorrelación $\mathrm{DW}=2$

La distribución de este estadístico no sólo depende de los grados de libertad con los que se calcula, sino también de los valores de las variables independientes. Es decir en algunas regresiones el valor del estadístico DW tiende a acercarse más a 2 que en otras, lo que impide utilizar valores tabulados exactos para contrastar la hipótesis de ausencia de autocorrelación, no obstante, con ayuda de las tablas de Durbin Watson, se puede establecer áreas de certeza de no autocorrelación. 
Para un determinado nivel de significación, las tablas del DW dan dos valores, uno $\mathrm{dL}$ inferior y otro dU superior, ambos valores están entre 0 y 3

- El intervalo [dU, 4-dU], intervalo centrado en el 2, indica la ausencia de autocorrelación.

- Los intervalos [0, dL] y [4-dL, 4] son zonas de rechazo, indican autocorrelación positiva o negativa

- Las zonas [dL, dU] y [4-dU, 4-dL], son zonas de incertidumbre, en las que el estadístico DW no permite rechazar o aceptar la hipótesis nula. Como se puede apreciar en la Figura 15.

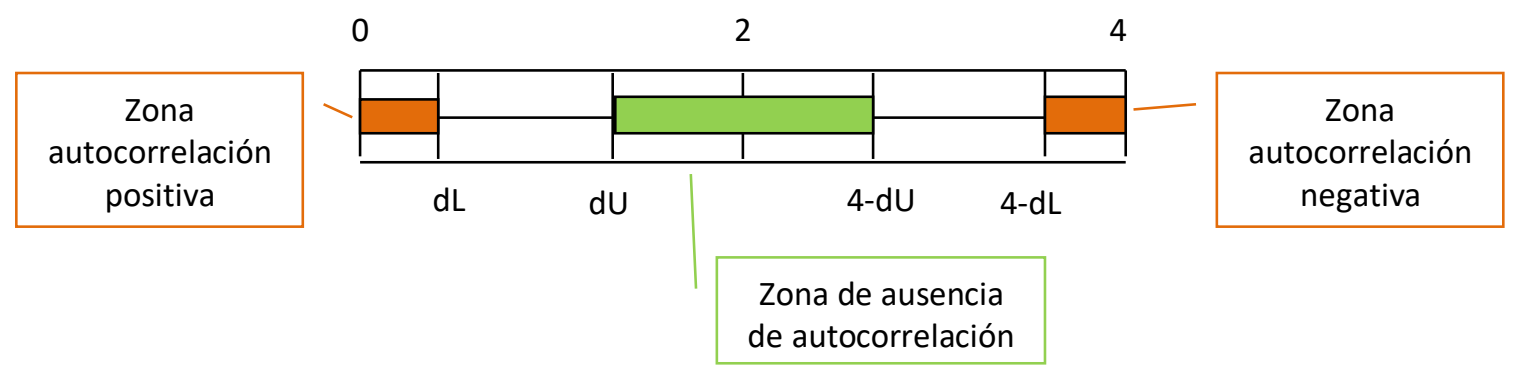

Figura 15. Intervalos de rechazo de autocorrelación según el estadístico DW

A continuación se muestra la Tabla 3 del Estadístico de Durbin Watson para un nivel de significancia del $5 \%$, donde $n$ es el tamaño de la muestra y $k$ el número de variables independientes del modelo. (Antunez) [104] 
Capítulo 2.Metodología

Tabla 3. Estadístico de Durbin Watson para $\alpha=0,05$

\begin{tabular}{|c|c|c|c|c|c|c|c|c|c|c|c|c|c|c|c|c|c|c|c|c|}
\hline$n \backslash k$ & $1 \mathrm{dL}$ & $1 \mathrm{dU}$ & $2 \mathrm{dL}$ & $2 \mathrm{dU}$ & $3 \mathrm{dL}$ & $3 \mathrm{dU}$ & $4 \mathrm{dL}$ & $4 \mathrm{dU}$ & $5 \mathrm{dL}$ & $5 \mathrm{dU}$ & $6 \mathrm{dL}$ & $6 \mathrm{dU}$ & $7 \mathrm{dL}$ & $7 \mathrm{dU}$ & $8 \mathrm{dL}$ & $8 \mathrm{dU}$ & 9dL & $9 \mathrm{dU}$ & $10 \mathrm{dL}$ & $10 \mathrm{dU}$ \\
\hline 6 & 0,610 & 1,400 & & & & & & & & & & & & & & & & & & \\
\hline 7 & 0,700 & 1,356 & 0,467 & 1,896 & & & & & & & & & & & & & & & & \\
\hline 8 & 0,763 & 1,332 & 0,559 & 1,777 & 0,367 & 2,287 & & & & & & & & & & & & & & \\
\hline 9 & 0,824 & 1,320 & 0,629 & 1,699 & 0,455 & 2,128 & 0,296 & 2,588 & & & & & & & & & & & & \\
\hline 10 & 0,879 & 1,320 & 0,697 & 1,641 & 0,525 & 2,016 & 0,376 & 2,414 & 0,243 & 2,822 & & & & & & & & & & \\
\hline 11 & 0,927 & 1,324 & 0,758 & 1,604 & 0,595 & 1,928 & 0,444 & 2,283 & 0,315 & 2,645 & 0,203 & 3,004 & & & & & & & & \\
\hline 12 & 0,971 & 1,331 & 0,812 & 1,579 & 0,658 & 1,864 & 0,512 & 2,177 & 0,380 & 2,506 & 0,268 & 2,832 & 0,171 & 3,149 & & & & & & \\
\hline 13 & 1,010 & 1,340 & 0,861 & 1,562 & 0,715 & 1,816 & 0,574 & 2,094 & 0,444 & 2,390 & 0,328 & 2,692 & 0,230 & 2,985 & 0,147 & 3,266 & & & & \\
\hline 14 & 1,045 & 1,350 & 0,905 & 1,551 & 0,767 & 1,779 & 0,632 & 2,030 & 0,505 & 2,296 & 0,389 & 2,572 & 0,286 & 2,848 & 0,200 & 3,111 & 0,127 & 3,360 & & \\
\hline 15 & 1,077 & 1,361 & 0,946 & 1,543 & 0,814 & 1,750 & 0,685 & 1,977 & 0,562 & 2,220 & 0,447 & 2,471 & 0,343 & 2,727 & 0,251 & 2,979 & 0,175 & 3,216 & 0,111 & 3,438 \\
\hline 16 & 1,106 & 1,371 & 0,982 & 1,539 & 0,857 & 1,728 & 0,734 & 1,935 & 0,615 & 2,157 & 0,502 & 2,388 & 0,398 & 2,624 & 0,304 & 2,860 & 0,222 & 3,090 & 0,155 & 3,304 \\
\hline 17 & 1,133 & 1,381 & 1,015 & 1,536 & 0,897 & 1,710 & 0,779 & 1,900 & 0,664 & 2,104 & 0,554 & 2,318 & 0,451 & 2,537 & 0,356 & 2,757 & 0,272 & 2,975 & 0,198 & 3,184 \\
\hline 18 & 1,158 & 1,391 & 1,046 & 1,535 & 0,933 & 1,696 & 0,820 & 1,872 & 0,710 & 2,060 & 0,603 & 2,258 & 0,502 & 2,461 & 0,407 & 2,668 & 0,321 & 2,873 & 0,244 & 3,073 \\
\hline 19 & 1,180 & 1,401 & 1,074 & 1,536 & 0,967 & 1,685 & 0,859 & 1,848 & 0,752 & 2,023 & 0,649 & 2,206 & 0,549 & 2,396 & 0,456 & 2,586 & 0,369 & 2,783 & 0,290 & 2,974 \\
\hline 20 & 1,201 & 1,411 & 1,100 & 1,537 & 0,998 & 1,676 & 0,894 & 1,828 & 0,792 & 1,991 & 0,691 & 2,162 & 0,595 & 2,339 & 0,502 & 2,521 & 0,416 & 2,704 & 0,336 & 2,885 \\
\hline 21 & 1,221 & 1,420 & 1,125 & 1,538 & 1,026 & 1,669 & 0,927 & 1,812 & 0,829 & 1,964 & 0,731 & 2,124 & 0,637 & 2,290 & 0,546 & 2,461 & 0,461 & 2,633 & 0,388 & 2,806 \\
\hline 22 & 1,239 & 1,429 & 1,147 & 1,541 & 1,053 & 1,664 & 0,958 & 1,797 & 0,863 & 1,940 & 0,769 & 2,090 & 0,677 & 2,246 & 0,588 & 2,407 & 0,504 & 2,571 & 0,424 & 2,735 \\
\hline 23 & 1,257 & 1,437 & 1,168 & 1,543 & 1,078 & 1,660 & 0,986 & 1,785 & 0,895 & 1,920 & 0,804 & 2,061 & 0,715 & 2,208 & 0,628 & 2,360 & 0,545 & 2,514 & 0,465 & 2,670 \\
\hline 24 & 1,273 & 1,446 & 1,188 & 1,546 & 1,101 & 1,656 & 1,013 & 1,775 & 0,925 & 1,902 & 0,837 & 2,035 & 0,750 & 2,174 & 0,666 & 2,318 & 0,584 & 2,464 & 0,506 & 2,613 \\
\hline 25 & 1,288 & 1,454 & 1,206 & 1,550 & 1,123 & 1,654 & 1,038 & 1,767 & 0,953 & 1,886 & 0,868 & 2,013 & 0,784 & 2,144 & 0,702 & 2,280 & 0,621 & 2,419 & 0,544 & 2,560 \\
\hline
\end{tabular}

Se comprueba que el Estadístico de Durbin Watson para el nivel de significancia del $5 \%$, y para el tamaño de la muestra " $n$ " y el número de variables independientes del modelo " $k$ ", se encuentra en el intervalo [dU, 4-dU], intervalo centrado en el 2 , que indica la ausencia de autocorrelación.

Si la prueba resultada no concluyente, se verificará la ausencia de correlación, mediante los gráficos de los residuos frente al tiempo.

- Homocedasticidad de la varianza. Se pretende comprobar que la varianza de los errores $\left(\sigma^{2}\right)$ (Ecuación 12) es constante para cualquier valor de la(s) variable(s) independiente(s) $(X)$, es decir que el valor medio del cuadrado de la desviación de los errores respecto a su media es constante. 


$$
\sigma^{2}=\frac{1}{n} \sum_{i=1}^{n}\left(\varepsilon_{i}-\vec{\epsilon}\right)^{2}
$$

(Ecuación 12)

Donde:

- $\varepsilon_{i}=$ Cada error $\mathrm{Y}_{\mathrm{i}}-\hat{\mathrm{Y}}_{\mathrm{i}}$

- $Y_{i}=$ Cada uno de los valores de la variable dependiente, en nuestra investigación es el consumo real de cada edificio

- $\hat{Y}_{i}=$ Cada uno de los valores pronosticados de la variable dependiente, en nuestra investigación es el consumo pronosticado con el modelo de regresión

- $\bar{\epsilon}=$ media de los errores

- $\mathrm{n}=$ número de errores.

Esta condición indica que el error es una variable aleatoria que tomará un valor distinto cada vez que se ejecute el modelo y que no existe correlación entre los residuos y los pronósticos.

La forma de comprobar la homocedasticidad es verificando si el coeficiente de determinación $R^{2}$, que indica la proporción de la variable dependiente $\left(\begin{array}{l}Y \\ 0\end{array}\right.$ consumo del edificio) que puede ser explicada por la variación de las variables independientes (las variables climatológicas), en las relaciones: residuos y predicciones y entre residuos y variables independientes es nulo o muy próximo a cero, lo que indicará que no existe ningún tipo de correlación en los residuos y que éstos son aleatorios.

Se grafican los diagramas de dispersión de esas relaciones, comprobando que se corresponden a nubes de puntos totalmente aleatorias, sin tendencias ni patrones en sus representaciones gráficas.

Estas condiciones se traducen en que la distribución de la variable dependiente $(\mathrm{Y})$ es Normal, con varianza constante $\sigma^{2}$ y media que varía linealmente con la(s) variables independiente $(\mathrm{s})(\mathrm{X})$, dada por $\beta \mathrm{X}+$ cte y los valores pronosticados de la variable dependiente $(\mathrm{Y})$ son independientes entre sí.

- Cuando la regresión sea lineal múltiple, se comprueba la falta de multicolinealidad - No-Colinealidad entre las variables independientes, es decir que las variables que forman parte del modelo no están correlacionadas entre ellas. 
Si dos variables independientes están muy relacionadas entre sí y se incluyen en el modelo es muy probable que ninguna de las dos resulte estadísticamente significativa.

En cambio, si se incluye una sola de ellas, sí podría resultar estadísticamente significativa, para analizar si el modelo se vuelve inestable al introducir una nueva variable, se estudian los índices de colinealidad.

De acuerdo con los estudios realizados por Belsley, Kuh y Welsch (Belsley, Kuh, \& Welsch, 2005) [105], tanto con datos observados como con datos simulados, el problema de la multicolinealidad es moderado cuando el índice de condición toma un valor entre 20 y 30 y es grave cuando el índice de condición toma un valor superior a 30 .

En la investigación se ha obtenido el índice de condición para los modelos de regresión múltiple, comprobándose que es inferior a 20. A mayores se analizaron unos índices estadísticos de colinealidad como son los niveles Tolerancia y su inverso que son los Factores de Inflación de la Varianza (FIV). El nivel de tolerancia se obtiene restando a 1 el coeficiente de determinación (R2), si la Tolerancia toma un valor próximo a la unidad no existirá colinealidad (a mayor tolerancia menor colinealidad), por lo que se podrá deducir que no existe multicolinealidad entre las variables independientes. Pueden existir problemas de colinealidad si algún FIV es superior a 10.

\section{5) Predicción de los consumos esperados.}

Para los periodos posteriores a la construcción de la red, utilizando los modelos de regresión y las variables climáticas de los periodos posteriores, se pronosticaron los consumos que se hubieran tenido sin la red de calor y se calcularon los consumos acumulados. Estos consumos se compararon con los consumos acumulados obtenidos realmente, durante las temporadas: 2015 - 2016, 2016 - 2017 y 2017 - 2018.

\section{6) Comprobación estadística de la existencia de diferencias significativas.}

Se analizó si la diferencia entre los consumos predichos que se hubieran tenido de no haber construido la red $y$ el consumo real tras haber construido la red, era estadísticamente significativa, con un nivel de confianza del 95\%.

Para ello, se procedió a comparar las medias de ambas poblaciones independientes con técnicas de inferencia estadística, realizando un contraste de hipótesis para la diferencia de medias y como estadístico de contraste en la prueba para muestras relacionadas la " $\mathrm{t}$ " de Student. 
En el estudio se ha utilizado el contraste de hipótesis para la comparación de medias con varianzas desconocidas e iguales, es decir la prueba para muestras relacionadas, especialmente indicada para la comparación de las medias de dos grupos cuando existe algún tipo de relación entre los individuos de ambos grupos.

En el estudio, la relación era que los consumos estaban asociados a la misma instalación, pero en diversos periodos de tiempo.

Por tanto, se calcularon las diferencias entre los valores de las variables y se contrastó si la diferencia de medias difería de cero $\left(\mathrm{H}_{0}\right.$ : diferencia de medias $=0, \mathrm{H}_{1}=$ diferencia de medias $\neq 0$ ). Aunque en los estadísticos descriptivos se pueda comprobar que las medias de los consumos pronosticados son superiores o inferiores a los consumos reales, se recurre a la prueba de contraste de medias para verificar si esta diferencia es estadísticamente significativa.

De este modo, si el "p-valor" o la probabilidad del estadístico del contraste de hipótesis resulta ser $\leq 0,05$ (nivel de significación considerado), se rechaza la hipótesis nula con un riesgo de error inferior o igual al $5 \%$, es decir se puede afirmar que existen diferencias significativas. En caso contrario, si el "p-valor" del contraste de hipótesis resulta $>0,05$, no se rechaza la hipótesis nula de igualdad de medias, se podría aceptar esta hipótesis con una certeza del $95 \%$, concluyendo que las diferencias encontradas no son estadísticamente significativas y no van más allá de lo que sería esperable por azar.

Luego si la probabilidad del estadístico es menor al nivel de significación 0,05, la hipótesis nula será rechazada.

En resumen, los contrastes de hipótesis utilizados en esta investigación son los referidos a:

- Normalidad de las variables

- Existencia de correlación entre las variables

- Existencia de peso de una variable en una correlación (pendiente distinta de cero)

- Diferencias de medias entre poblaciones 
En la Tabla 4 se muestran las hipótesis nulas y alternativas establecidas para cada contraste y cuando se considera rechazada la hipótesis nula

Tabla 4. Hipótesis nulas y alternativas de la investigación

\begin{tabular}{|c|c|c|c|c|}
\hline Contrastes & $\begin{array}{l}\text { Hipótesis nula: } \\
\qquad \mathrm{H}_{0}\end{array}$ & $\begin{array}{c}\text { Hipótesis } \\
\text { alternativa: } \\
\mathrm{H}_{1}\end{array}$ & $\begin{array}{l}\text { Valor de la } \\
\text { significación: } \\
\text { p-valor ó Sig }\end{array}$ & Decisión \\
\hline $\begin{array}{c}\text { Normalidad de las } \\
\text { variables }\end{array}$ & $\begin{array}{c}\mathrm{H}_{0}=\text { las variables se } \\
\text { distribuyen según } \\
\text { una distribución } \\
\text { Normal }\end{array}$ & $\begin{array}{c}\mathrm{H}_{1}=\text { la distribución } \\
\text { de las variables no } \\
\text { es según una } \\
\text { distribución Normal }\end{array}$ & $\leq 0,05$ & $\begin{array}{l}\text { Rechazo } \mathrm{H}_{0} \text {. La } \\
\text { distribución de las } \\
\text { variables no es } \\
\text { según una } \\
\text { distribución } \\
\text { Normal }\end{array}$ \\
\hline $\begin{array}{c}\text { Existencia de } \\
\text { correlación entre las } \\
\text { variables }\end{array}$ & $\begin{array}{l}\text { R (Correlación de } \\
\text { Pearson) = } 0 . \\
\text { No hay correlación } \\
\text { entre las variables }\end{array}$ & $\begin{array}{l}\text { R (Correlación de } \\
\quad \text { Pearson) } \neq 0 \text {. } \\
\text { Hay correlación } \\
\text { entre las variables }\end{array}$ & $\leq 0,05$ & $\begin{array}{c}\text { Rechazo } \mathrm{H}_{0} . \\
\text { Hay correlación } \\
\text { significativa entre } \\
\text { las variables }\end{array}$ \\
\hline $\begin{array}{l}\text { Existencia de peso de } \\
\text { una variable en una } \\
\text { correlación }\end{array}$ & $\begin{array}{c}\beta \text { (la pendiente de } \\
\text { una variable en una } \\
\text { ecuación) }=0 . \\
\text { La variable no entra } \\
\text { a formar parte de la } \\
\text { ecuación }\end{array}$ & $\begin{array}{c}\beta \text { (la pendiente de } \\
\text { una variable en una } \\
\text { ecuación) } \neq 0 . \\
\text { La variable entra a } \\
\text { formar parte de la } \\
\text { ecuación }\end{array}$ & $\leq 0,05$ & $\begin{array}{l}\text { Rechazo } \mathrm{H}_{0} \text {. } \\
\text { La variable entra a } \\
\text { formar parte de la } \\
\text { ecuación con un } \\
\text { peso significativo }\end{array}$ \\
\hline $\begin{array}{l}\text { Diferencias de medias } \\
\text { entre poblaciones }\end{array}$ & $\begin{array}{l}\text { Media de una } \\
\text { población = Media } \\
\text { de otra población. } \\
\text { No hay diferencias } \\
\text { entre las medias de } \\
\text { dos poblaciones }\end{array}$ & $\begin{array}{l}\text { Media de una } \\
\text { población } \neq \text { Media } \\
\text { de otra población. } \\
\text { Hay diferencias } \\
\text { entre las medias de } \\
\text { dos poblaciones }\end{array}$ & $\leq 0,05$ & $\begin{array}{c}\text { Rechazo } \mathrm{H}_{0} \text {. } \\
\text { Hay diferencias } \\
\text { significativas entre } \\
\text { las medias de dos } \\
\text { poblaciones }\end{array}$ \\
\hline
\end{tabular}

\section{7) Análisis de las posibles causas que justifiquen los resultados obtenidos.}

Como último paso del estudio se analizaron las posibles causas que pudieran justificar los resultados estadísticos de existencia o no de diferencias significativas antes y después de la puesta en marcha de la red de calor. 


\section{CAPÍTULO 3. ANÁLISIS DEL CASO EN ESTUDIO.}

\subsection{Descripción general de la red.}

Durante el año 2013, la Consejería de Fomento y Medio Ambiente de la Junta de Castilla y León, a través de SOMACyL (Sociedad Pública de Infraestructuras y Medio Ambiente de Castilla y León, S.A), inició la promoción de un proyecto de calefacción de distrito. El resultado fue la ejecución, en el 2015, de una red de calor, por parte de la UTE: RebiCofely, con los siguientes datos básicos:

- 27 edificios conectados

- 14,1 MW térmicos instalados inicialmente en 3 calderas

- 80.000 litros de acumulación en dos depósitos de 40.000 I

- $12 \mathrm{~km}$ de longitud de la red

- $\quad$ 7.800 Toneladas / año de consumo de Biomasa (astilla forestal)

- $22.000 \mathrm{MWh} / \mathrm{año}$ de demanda de calor atendida

- $\quad 6.800$ Toneladas de CO2 / año de reducción de emisiones

- $5.000 .0000 €$ más IVA de presupuesto total

- 15 años de amortización con cargo al ahorro generado por el propio proyecto.

- $15 \%$ anual de ahorro en el coste energético de calefacción

Esta red fue diseñada para suministrar 22.069.734 $\mathrm{kWh}$ anuales al conjunto de los edificios conectados, de los cuales $17.187 .869 \mathrm{kWh}$ pertenecían al consumo de la UVA $(77,87 \%), 515.180 \mathrm{kWh}$ correspondían a edificios del Ayuntamiento de Valladolid (2,33\%) y 4.366.685 kWh a edificios de la Junta de Castilla y León (19,80\%).

Para satisfacer estos consumos se estimó la necesidad de 7.886 Toneladas / año de astilla. (Cano Herrador, Valbuena García, Muñoz Martín, Rey Martínez, \& Navas Gracia, 2014) [64] 
Las emisiones de $\mathrm{CO}_{2}$ evitadas a la atmósfera fueron estimadas en 6.800 toneladas de $\mathrm{CO}_{2}$ / año, de las cuales la UVA evitaría 5.446 t CO $2 /$ año, el Ayuntamiento 170 t CO $/$ anuales, y la Junta de Castilla y León 1.195 t CO 2 / anuales. Esta reducción de emisiones, permitiría que la Universidad de Valladolid disminuyera considerablemente su Huella de Carbono, puesto que supondría una reducción de un $75 \%$ de las emisiones asociadas al suministro térmico de calefacción, así mismo permitiría mejorar en 1 ó 2 letras, la calificación energética de los edificios conectados.

La central térmica, donde se ubican las calderas se sitúa en la zona Norte del Campus Miguel Delibes, en una parcela anexa al edificio Lucia; (ver Figura 16) está compuesta por dos naves adosadas de una superficie total de $1.400 \mathrm{~m}^{2}$, en una sala se ubican las calderas caldera y en la otra sala se ubica el silo de una capacidad de $1800 \mathrm{~m}^{3}$.

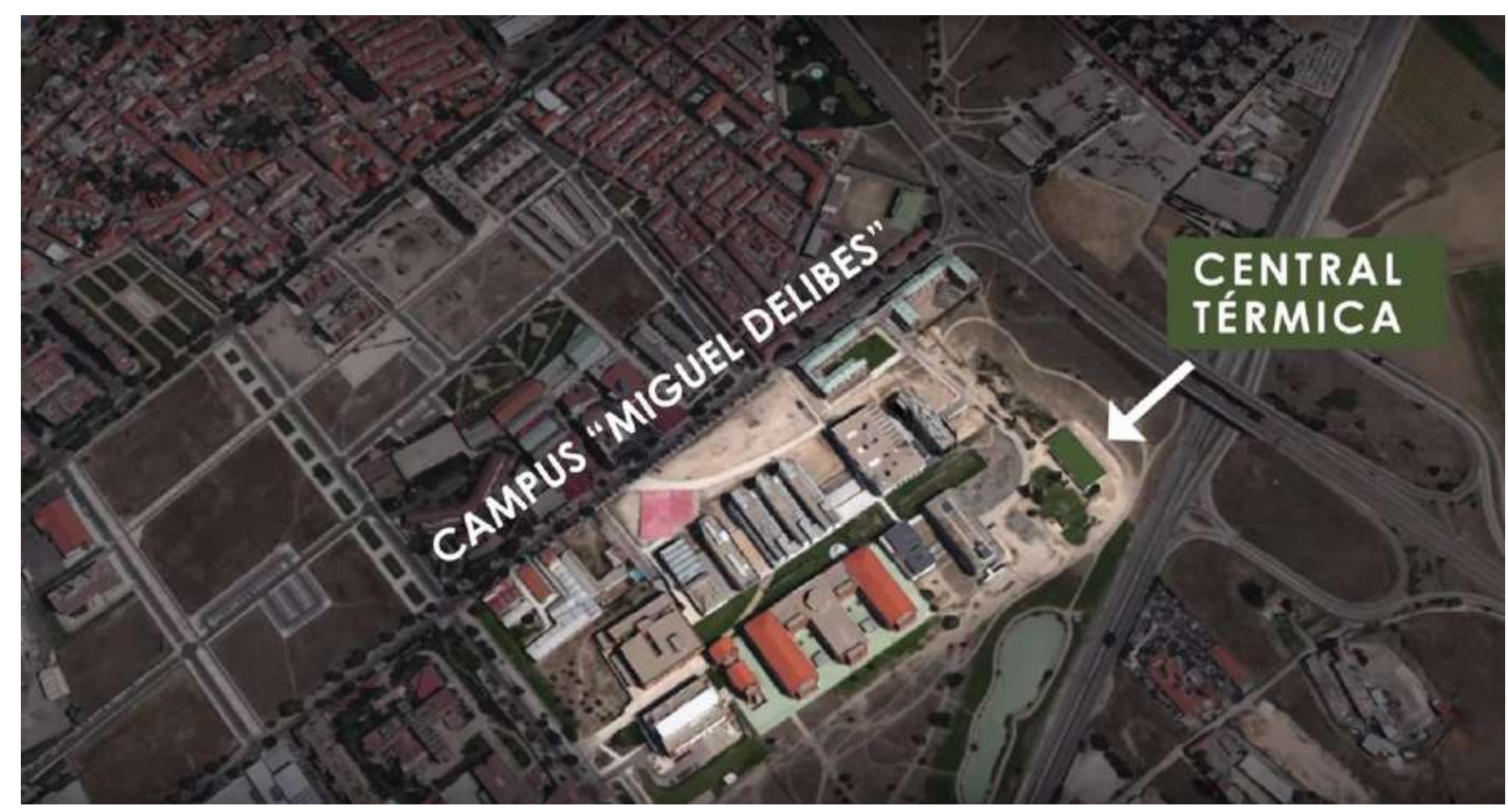

Figura 16. Ubicación de la Central Térmica.

(Universidad de Valladolid (UVA), Junta de Castilla y León, Sociedad Pública de Infraestructuras y Medio Ambiente (SOMACyL), 2015) [106]

De la central térmica parten dos circuitos o ramales de tubería de acero preaislado, como se aprecia en la Figura 17. 


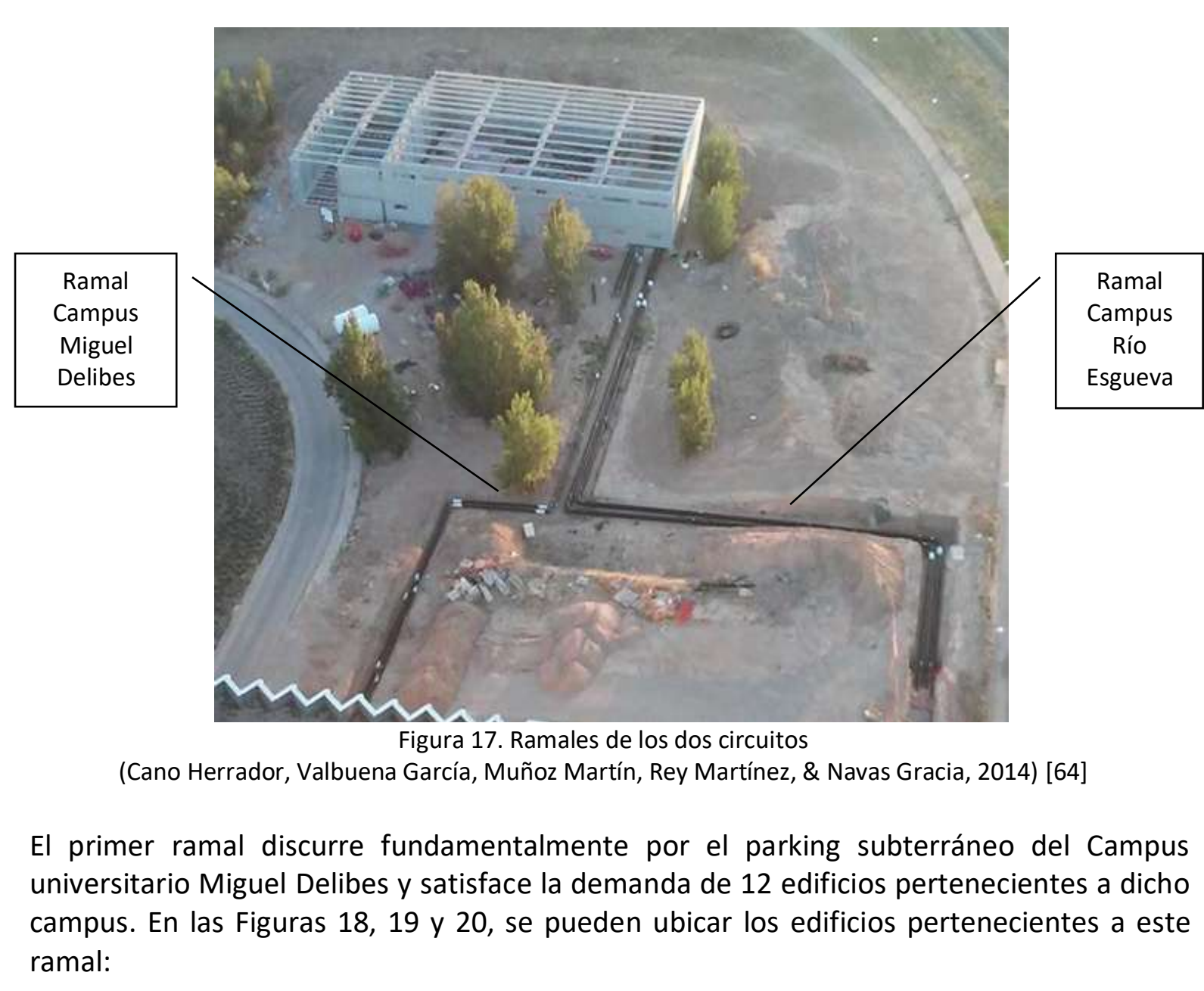

\section{Ramal del Campus Universitario Miguel Delibes, Edificios conectados}

D1. Apartamentos Cardenal Mendoza

D2. Biblioteca de los Apartamentos Cardenal Mendoza

D3. Centro de Transferencia de Tecnologías Aplicadas (CTTA)

D4. Aulario - Biblioteca Miguel Delibes

D5. Edificio IOBA (Instituto Universitario de Oftalmología Aplicada)

D6. Nueva Facultad de Ciencias

D7. ETSI. Telecomunicaciones e Escuela de Ingeniería Informática

D8. Edificio QUIFIMA (Química Fina y Materiales Avanzados)

D9. Gimnasio de la Facultad de Educación

D10. Centro de Idiomas

D11. Facultad de Educación y Trabajo Social

D12. Edificio I +D 

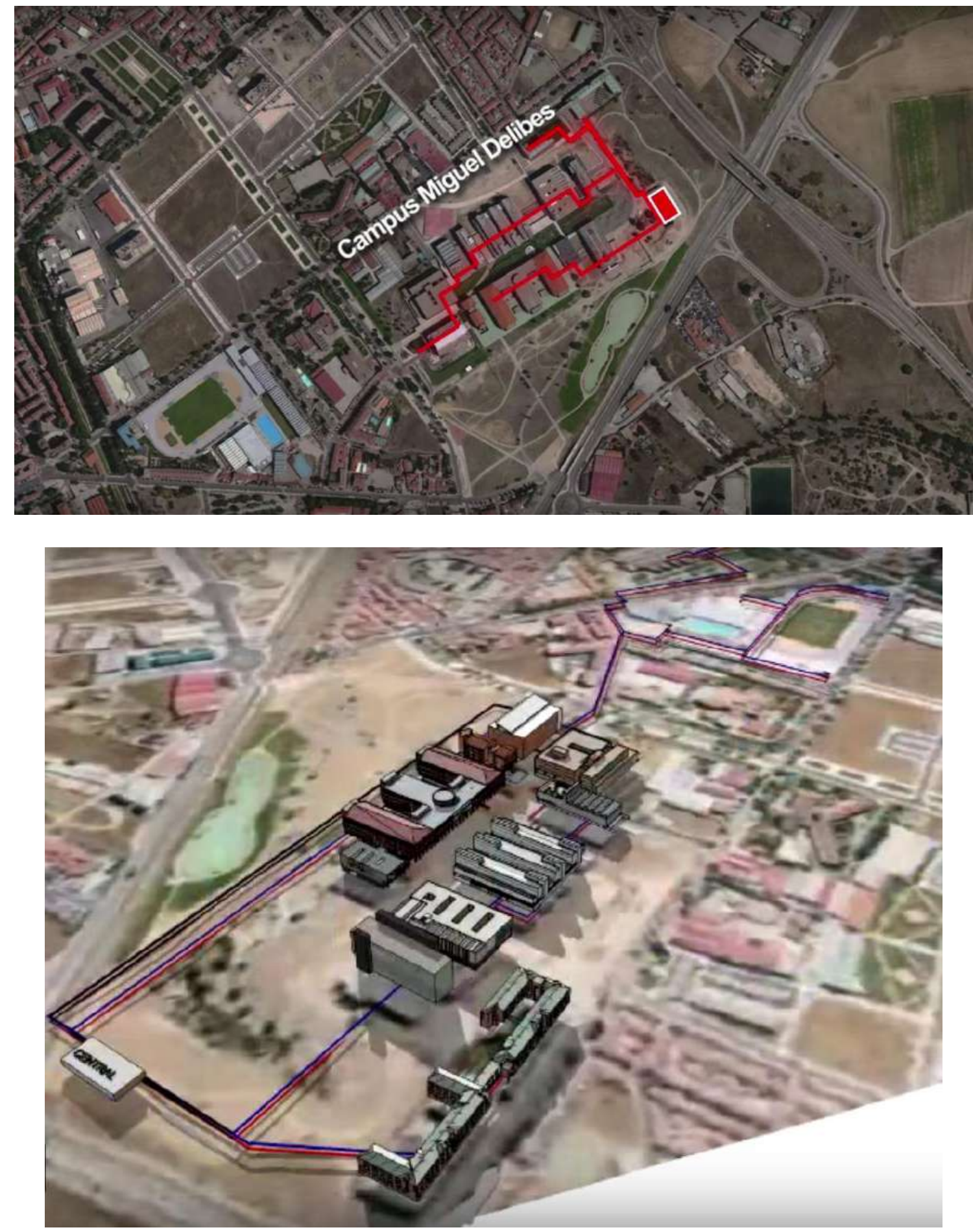

Figura 18.Ubicación de la red del Campus Miguel Delibes.

(Universidad de Valladolid (UVA), Junta de Castilla y León, Sociedad Pública de Infraestructuras y Medio Ambiente (SOMACyL), 2015) [106] 


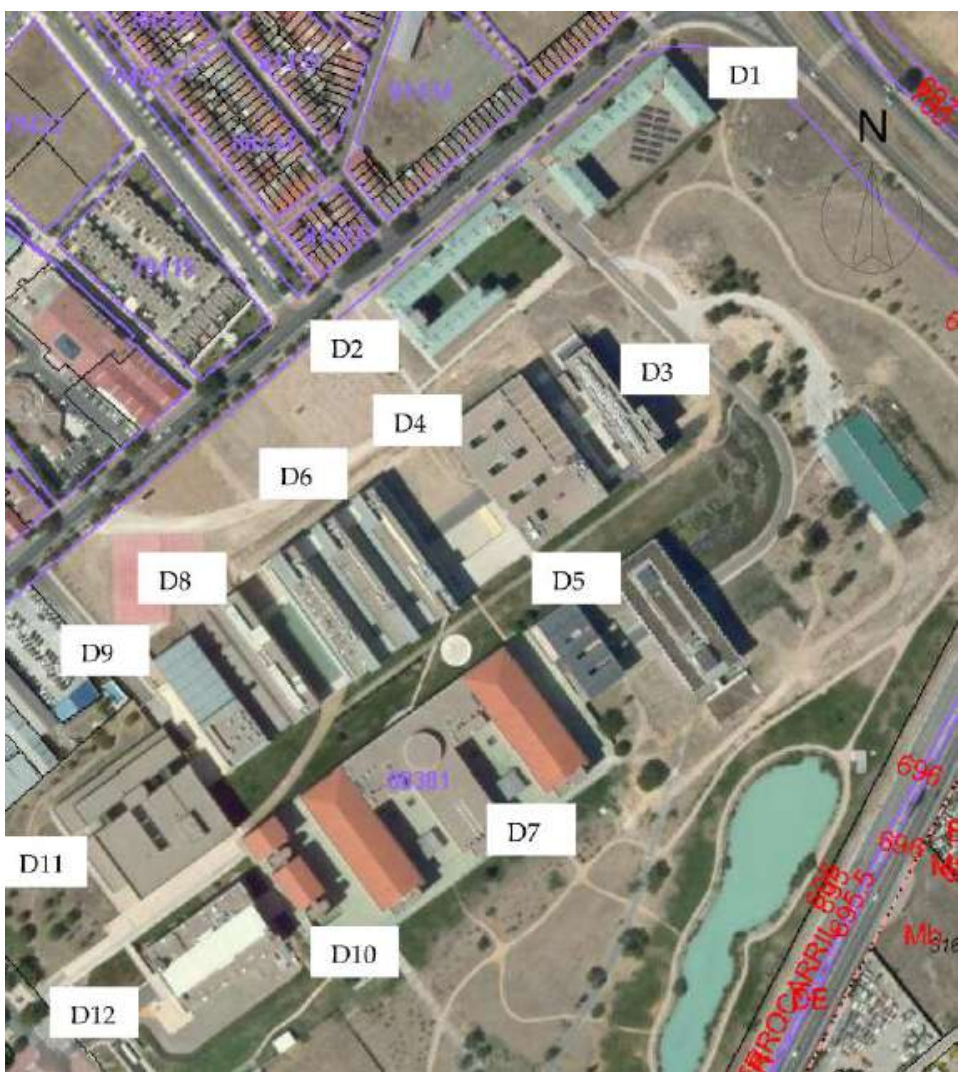

Figura 19. Campus Miguel Delibes

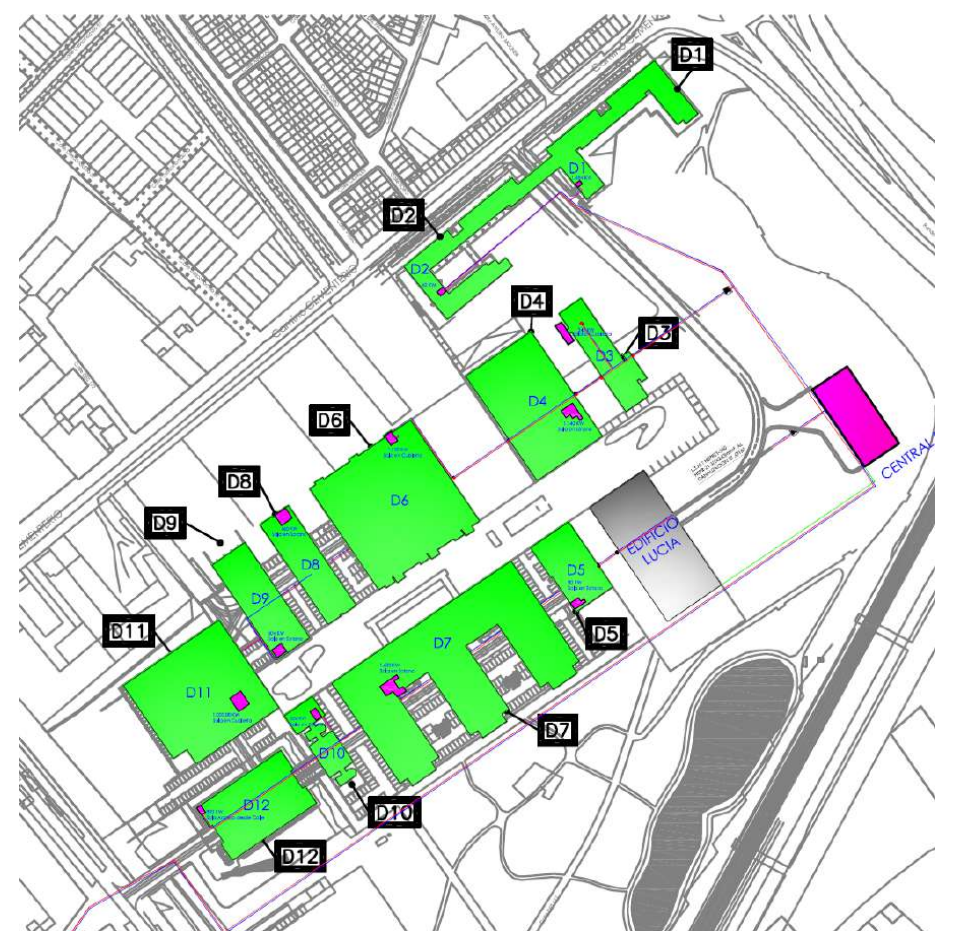

Figura 20. Esquema de ubicación de los edificios del Ramal del Campus Miguel Delibes

\section{D1. Apartamentos Cardenal Mendoza}

D2. Biblioteca de los Apartamentos Cardenal Mendoza

D3. Centro de Transferencia de Tecnologías Aplicadas (CTTA)

D4. Aulario - Biblioteca Miguel Delibes

D5. Edificio IOBA (Instituto Universitario de Oftalmología Aplicada)

D6. Nueva Facultad de Ciencias

D7. ETSI. Telecomunicaciones e Escuela de Ingeniería Informática

D8. Edificio QUIFIMA (Química Fina y Materiales Avanzados)

D9. Gimnasio de la Facultad de Educación

D10. Centro de Idiomas

D11. Facultad de Educación y Trabajo Social

D12. Edificio I +D 
El segundo ramal comunica la central térmica con otros 11 edificios pertenecientes al campus universitario Río Esgueva y otros 4 edificios más de la Junta de Castilla y León. Este segundo ramal se puede apreciar en las Figuras 21, 22 y 23.

\section{Ramal del Campus Universitario Río Esgueva. Edificios de la UVA conectados}

E1. Edificio del Servicio de Mantenimiento

E2. Facultad de Comercio

E3. Facultad de Filosofía y Letras

E4. Escuela de Ingenierías Industriales (Sede Mergelina)

E5. Edificio Residencia Universitaria Alfonso VIII

E6. Edificio Colegio Mayor Femenino Santa Cruz

E7. Edificio IBGM (Instituto de Biología y Genética Molecular)

E8. Facultad de Medicina y Facultad de Enfermería

E13. Facultad de Ciencias Económicas y Empresariales

E14. Aulario Campus Río Esgueva

E15. Escuela de Ingenierías Industriales (Sede Paseo del Cauce)

\section{Ramal del Campus Universitario Río Esgueva. Edificios de la Junta de Castilla y León (Deportes) conectados}

J1. Residencia Deportiva Río Esgueva

J2. Centro de Atletismo de Alto Rendimiento

J3. Piscinas Climatizadas Río Esgueva

J4. Pabellón Polideportivo Río Esgueva

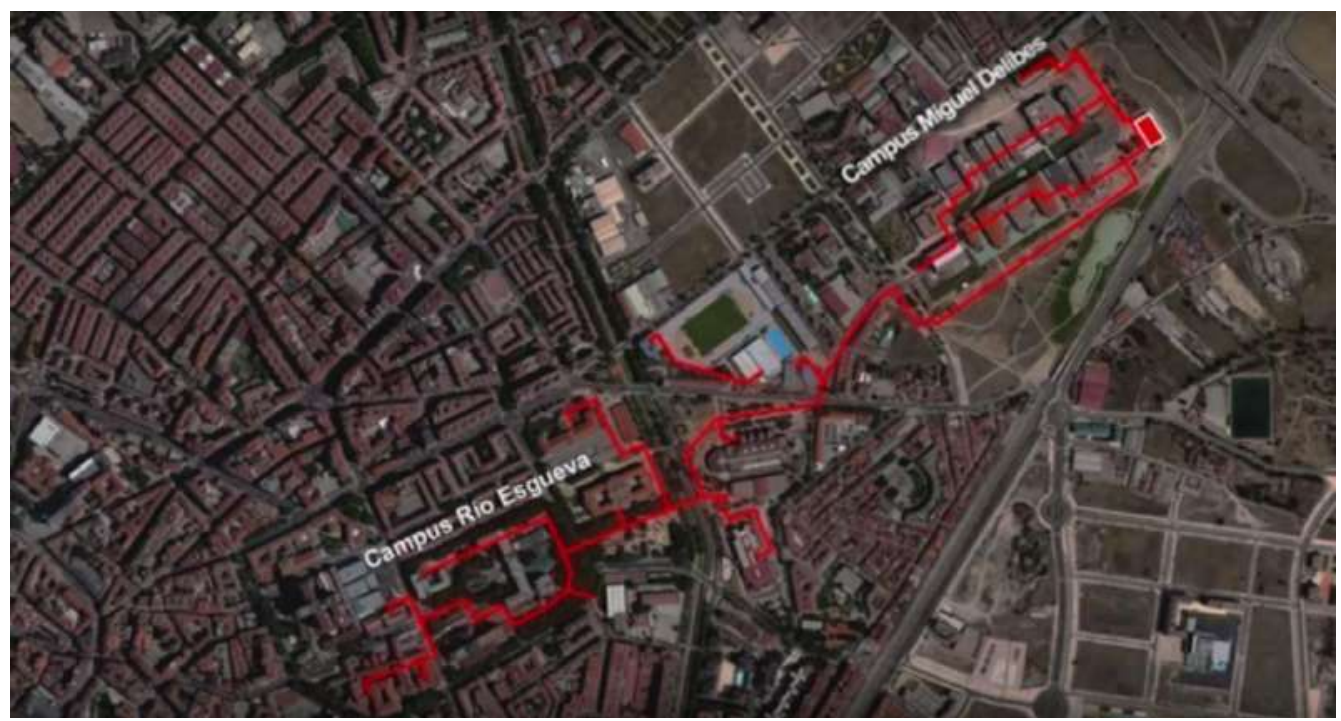

Figura 21. Ubicación del segundo ramal. Campus Río Esgueva y Zonas deportivas

(Universidad de Valladolid (UVA), Junta de Castilla y León, Sociedad Pública de Infraestructuras y Medio Ambiente (SOMACYL), 2015) [106] 


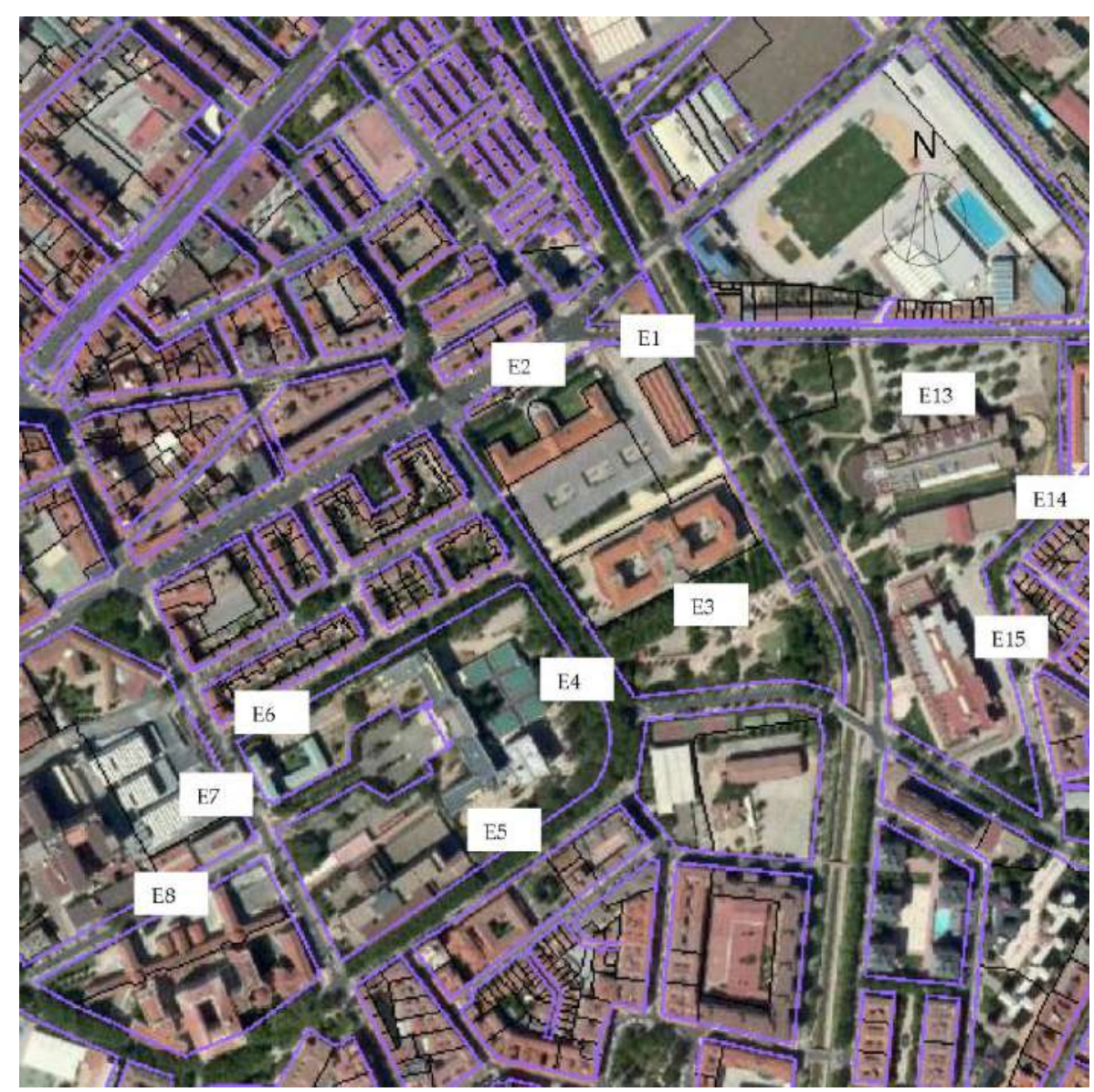

Figura 22. Ubicación del Campus Río Esgueva

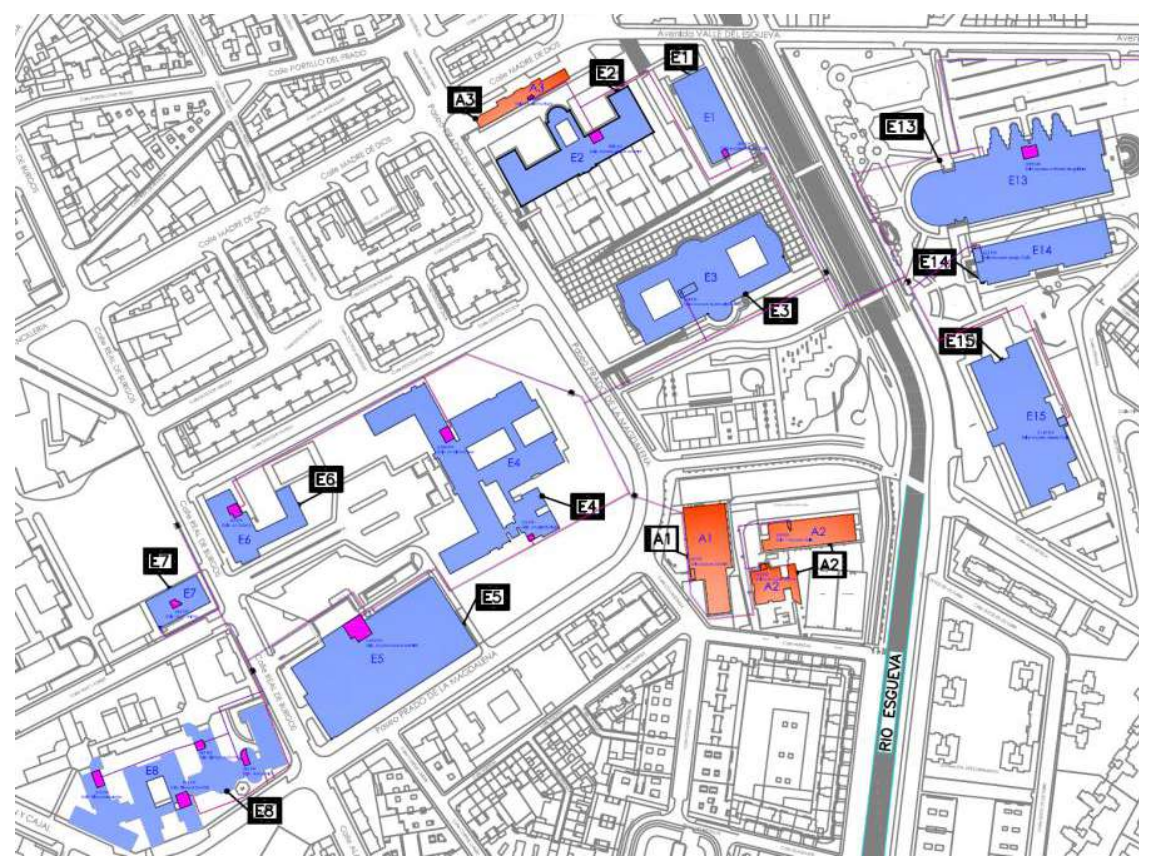

Figura 23. Esquema de ubicación de los edificios de la UVA del Ramal del Campus Río Esgueva
E1. Edificio del Servicio de Mantenimiento

E2. Facultad de Comercio

E3. Facultad de Filosofía y Letras

E4. Escuela de Ingenierías Industriales (Antigua

Facultad de Ciencias. Sede Mergelina)

E5. Edificio Residencia Universitaria Alfonso VIII

E6. Edificio Colegio Mayor Femenino Santa Cruz

E7. Edificio IBGM (Instituto de Biología y Genética Molecular)

E8. Facultad de Medicina y Facultad de Enfermería

E13. Facultad de Ciencias Económicas y

Empresariales

E14. Aulario Campus Río Esgueva

E15. Escuela de Ingenierías Industriales (Sede Paseo del Cauce) 
En un futuro, el Ramal del Campus Universitario Río Esgueva, se podría ampliar para satisfacer la demanda de otros edificios públicos y privados del entorno:

\section{Edificios del Ayuntamiento}

A1. Polideportivo Miriam Blasco

A2. Colegio García Lorca

A3. Centro Cívico

\section{Edificios de la JCYL (Sanidad)}

Hospital Clínico Universitario

En el verano de 2018, se conectó el Hospital Clínico Universitario a la red y en un futuro próximo se prevé la conexión de otros tres edificios pertenecientes a la Universidad de Valladolid: el edificio de la Casa del Estudiante, la Biblioteca Reina Sofía y el Palacio de Congresos Conde Ansúrez.

En la Figura 24 , se muestra el esquema general de la red

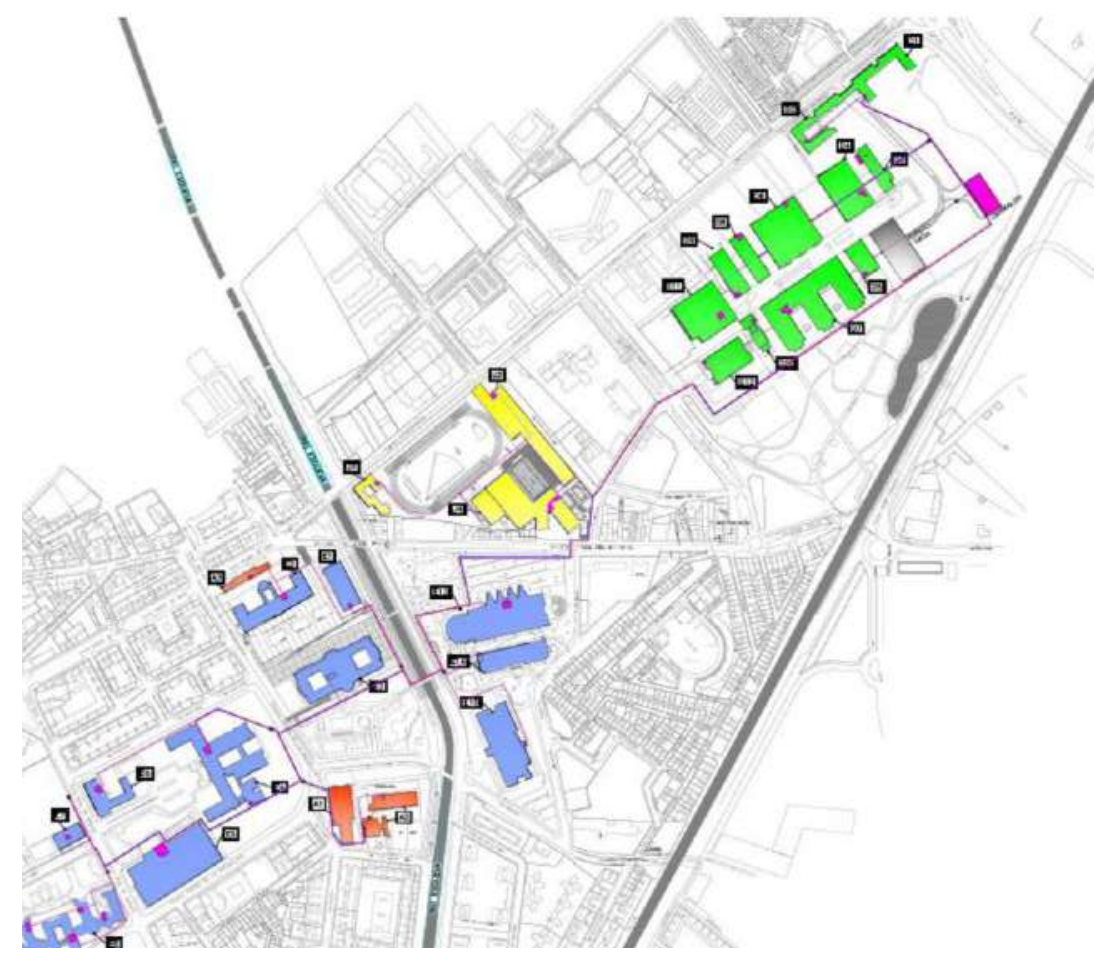

Figura 24. Esquema general de la red de calor.

(Cano Herrador, Valbuena García, Muñoz Martín, Rey Martínez, \& Navas Gracia, 2014) [64] 
En total, se construyó una red de calor de $12 \mathrm{~km}$ de longitud, con tuberías de diámetro DN32 y DN350, que impulsa agua caliente a $90^{\circ} \mathrm{C}$ y la retorna a $70^{\circ} \mathrm{C}$.

La Central Térmica se ubica en una parcela anexa al Edificio Lucia, es un edificio de 1.400 $\mathrm{m}^{2}$ de superficie. En dicho edificio está la nave ocupada por las calderas y la nave ocupada por el silo. En las Figuras 25, 26, 27, 28, 29 y 30 se muestran varias fotografías y esquemas de la misma.

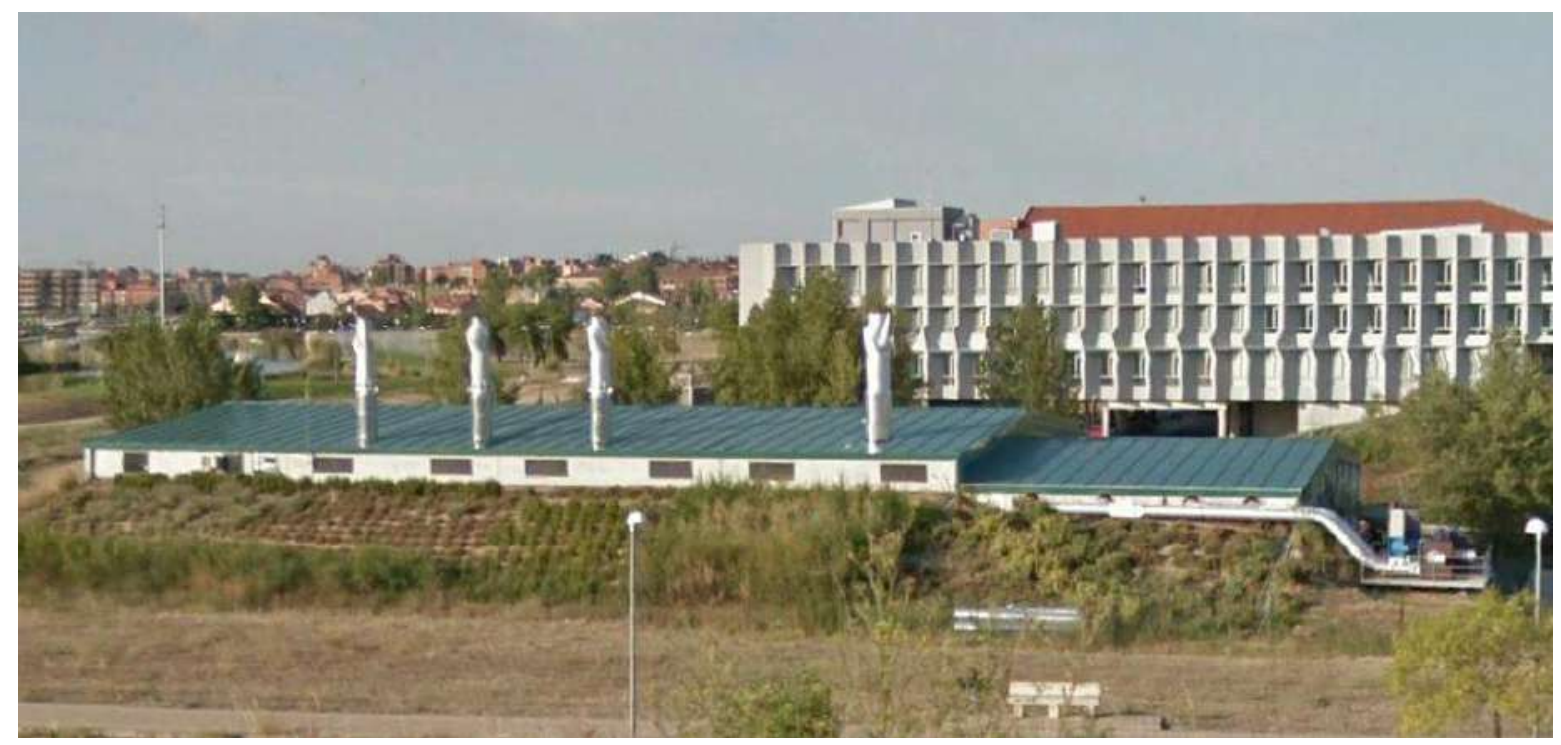

Figura 25. Vista posterior de la Central Térmica. Fachada Noroeste

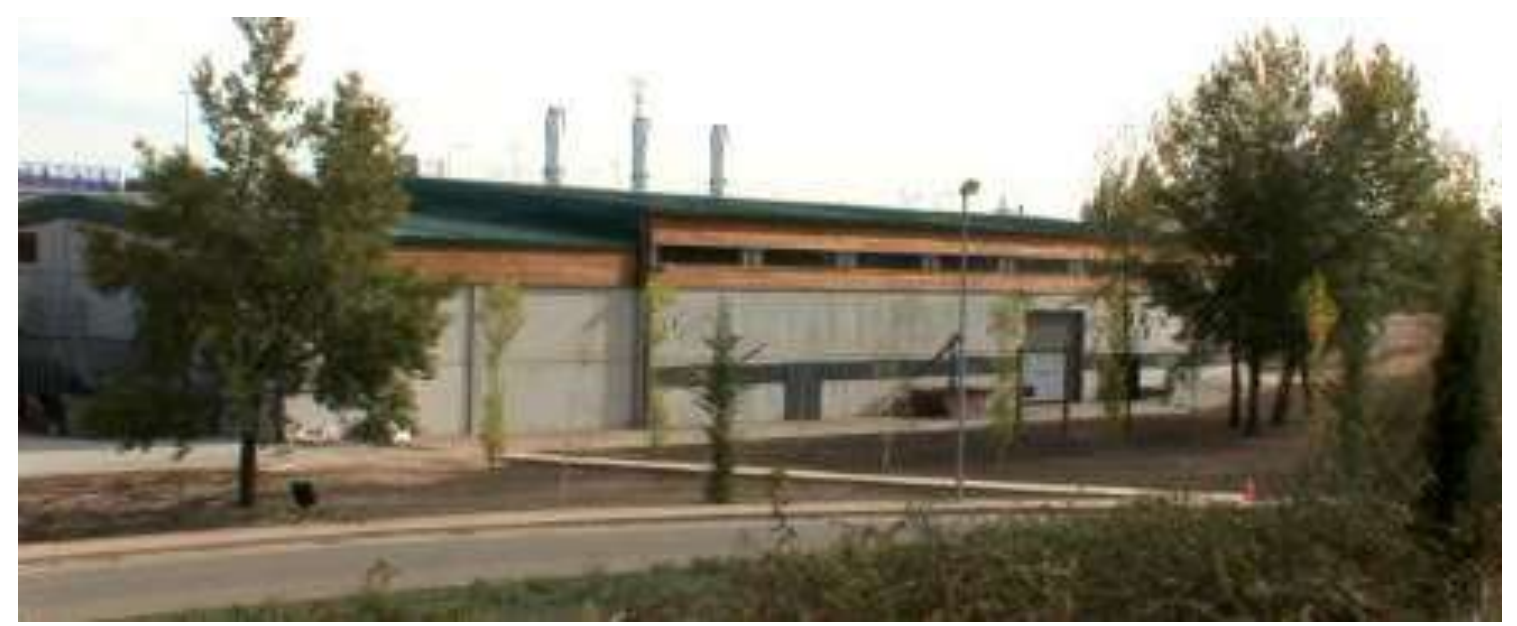

Figura 26. Fachada principal de la Central Térmica. Suroeste. (Lorenzo, 2017) [107] 


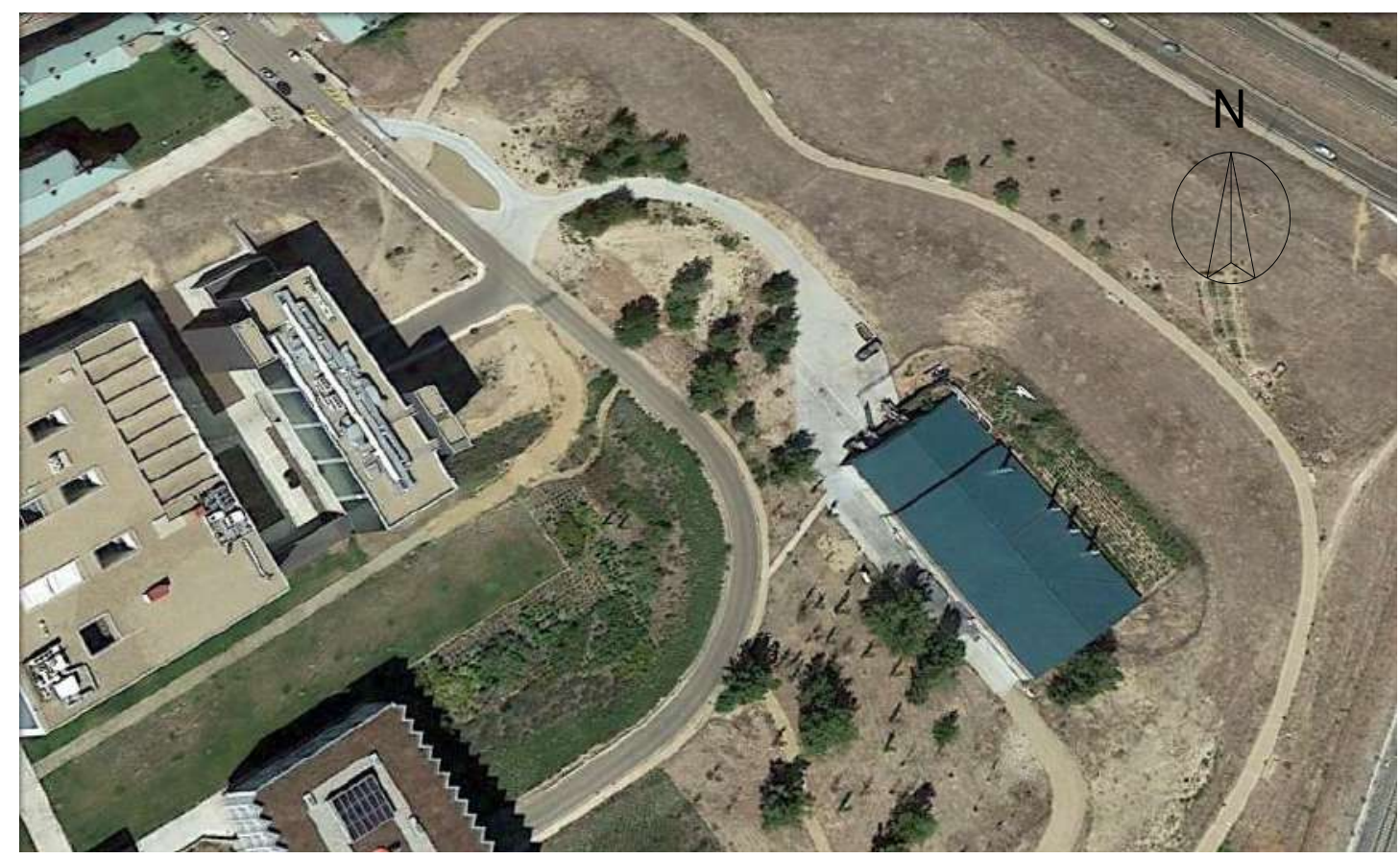

Figura 27. Vista aérea de la Central Térmica

Inicialmente se instalaron 3 calderas de biomasa 4,7 MW cada una, y durante la temporada 2017 - 2018, se instaló la cuarta caldera de $5 \mathrm{MW}$, para poder la demanda del Hospital Clínico de Valladolid. Lo que hace un total de 19,1 MW de potencia total instalada en la actualidad. El rendimiento mínimo de estos equipos es del $86 \%$.

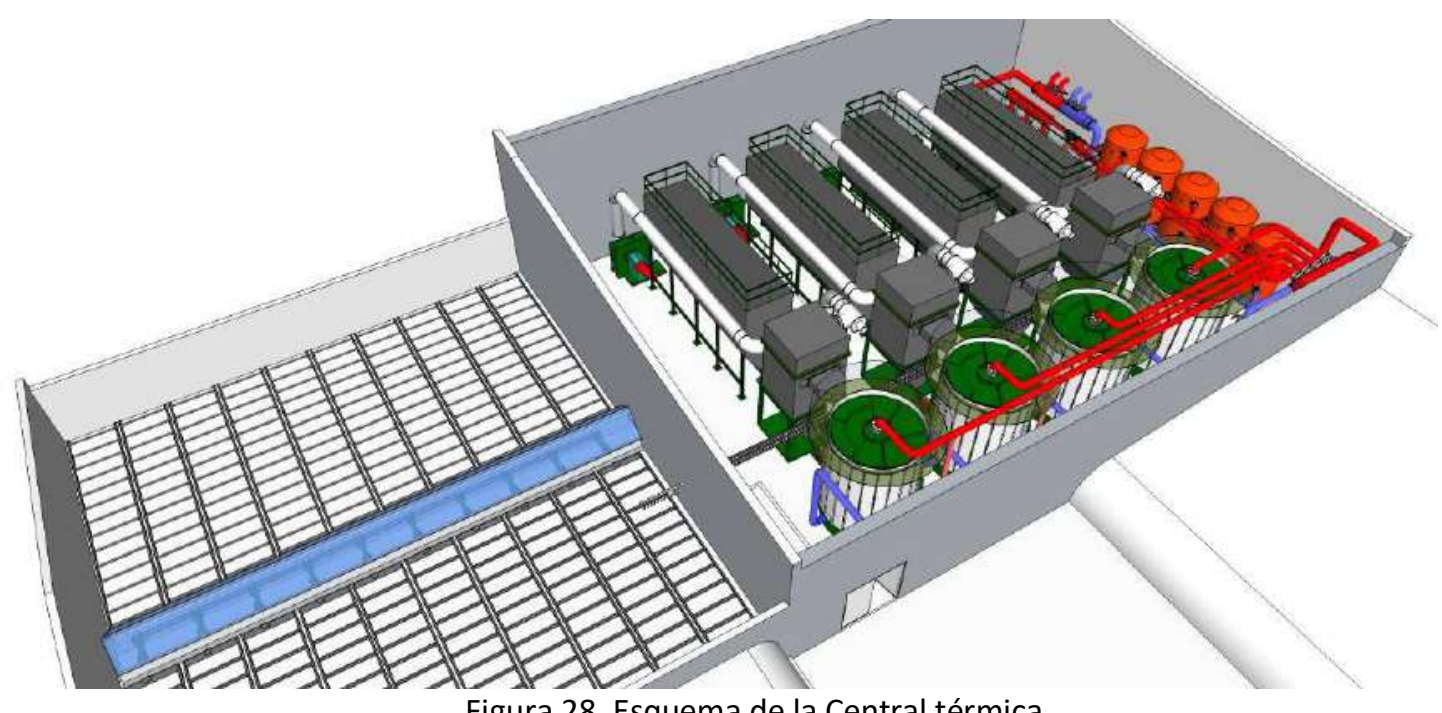

Figura 28. Esquema de la Central térmica.

(Cano Herrador, Valbuena García, Muñoz Martín, Rey Martínez, \& Navas Gracia, 2014) [64] 


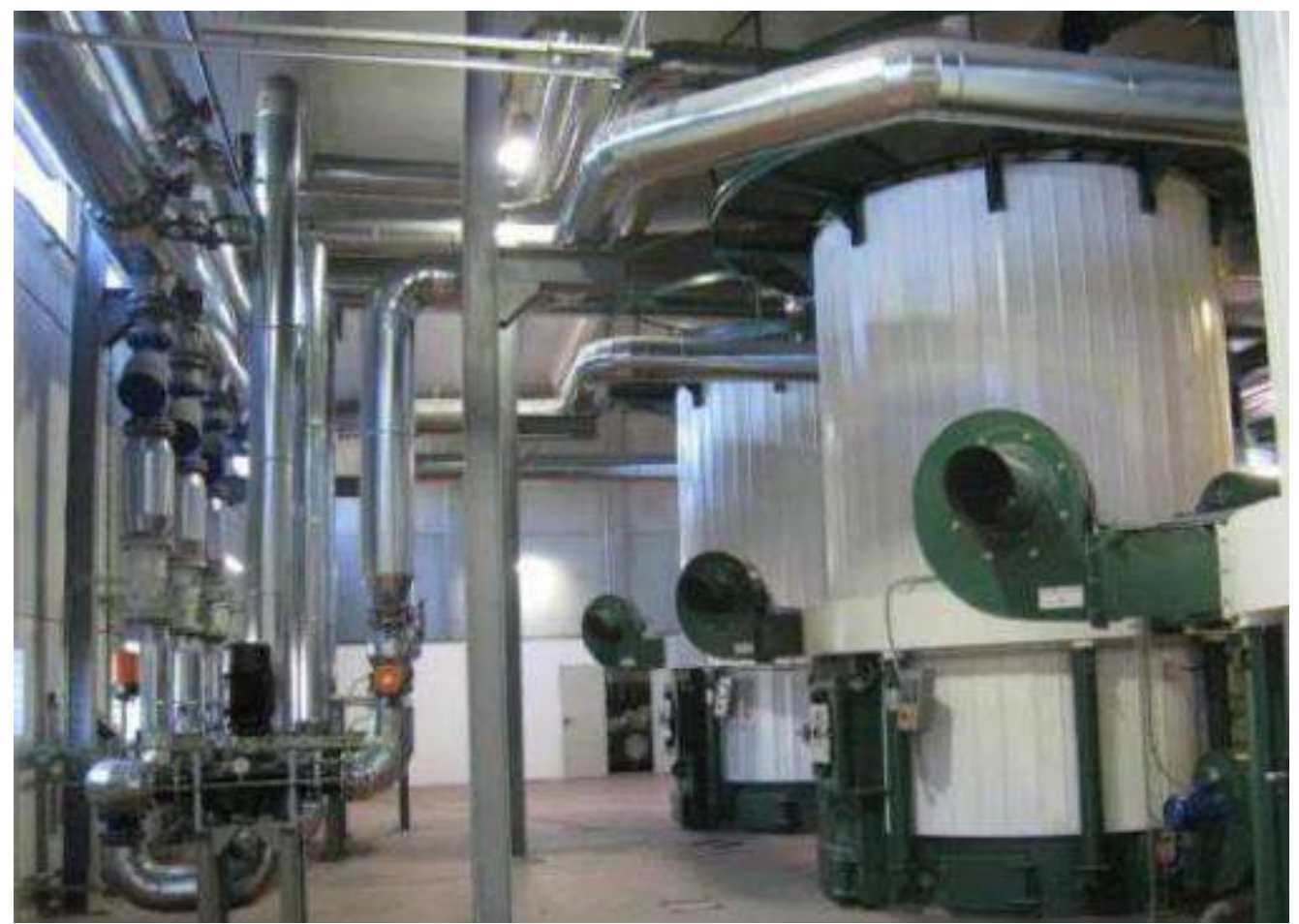

Figura 29. Calderas iniciales. . (Lorenzo, 2017) [107]

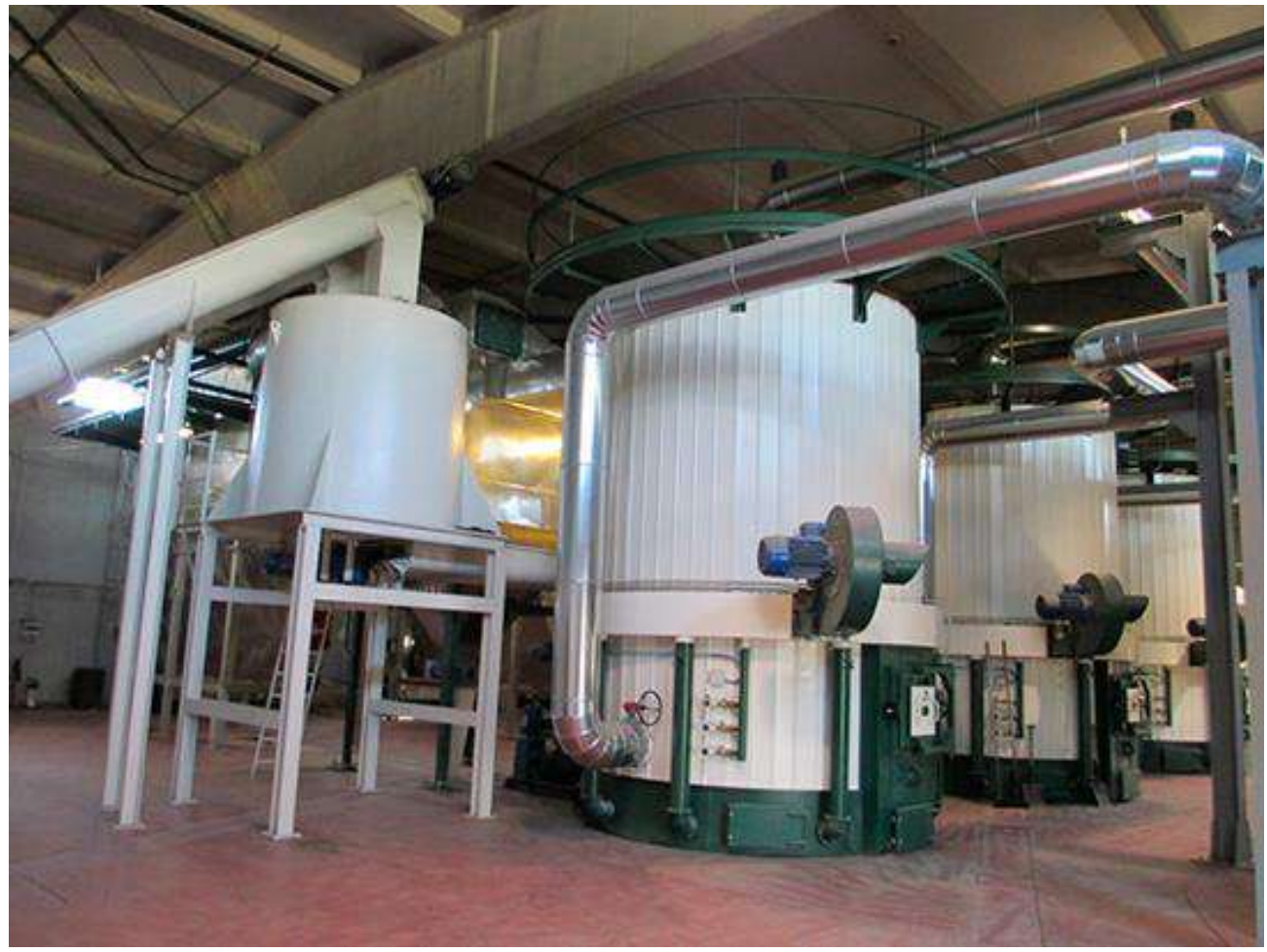

Figura 30. Sistema de alimentación a las calderas.

(PREFIERES. Portal de Eficiencia y Rehabilitación, 2016) [79] 
El silo, tiene un volumen de $1.800 \mathrm{~m}^{3}$, espacio suficiente para unas 540 toneladas de astilla de granulometría G50 a G100 (ver Figura 31). Se estima un consumo de 7.886 toneladas / año. El silo fue dimensionado para atender una demanda en los periodos más desfavorables de 15 días.

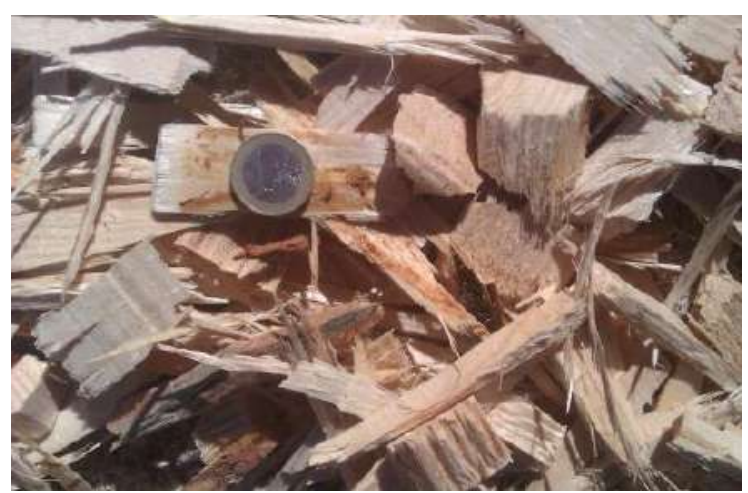

Figura 31. Granulometría de la astilla. (Lorenzo, 2017) [107]

La astilla , con un poder calorífico superior (PCS) de $20 \mathrm{MJ} / \mathrm{kg}$ y un poder calorífico inferior $(\mathrm{PCl})$ de $18,7 \mathrm{MJ} / \mathrm{kg}$, procedente de los camiones es introducida al silo mediante dos líneas de llenado neumático con cribadora a una velocidad de carga de 20 toneladas/h, como se aprecia en las Figuras 32 y 33.

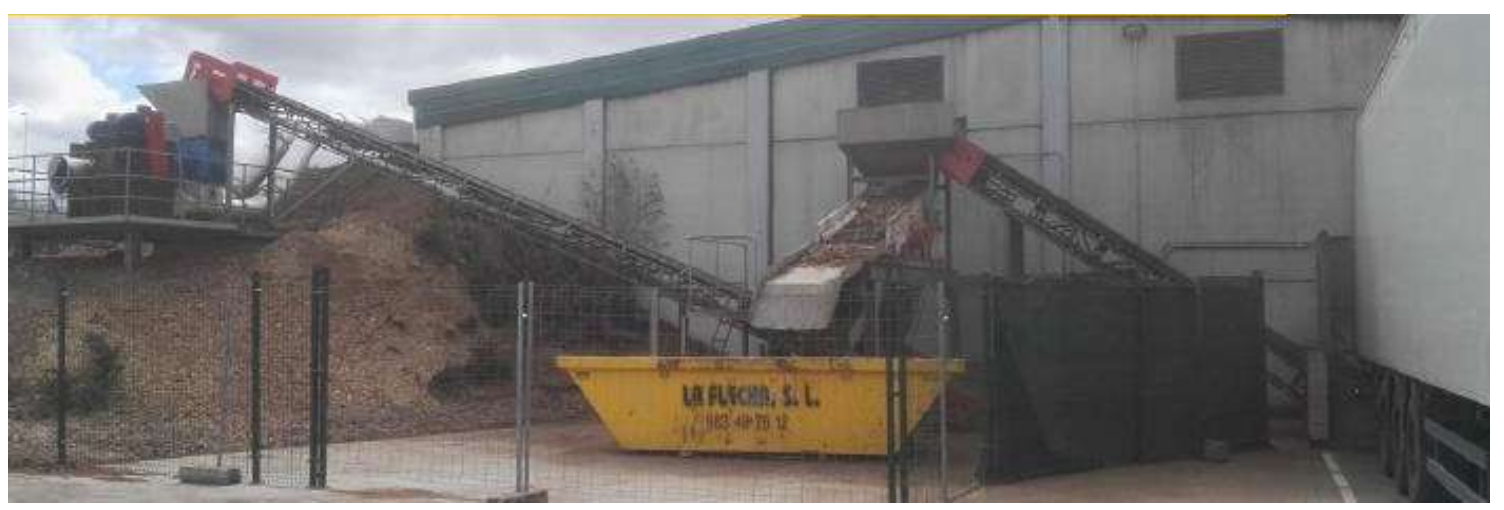

Figura 32. Líneas de llenado del silo. (Lorenzo, 2017) [107]

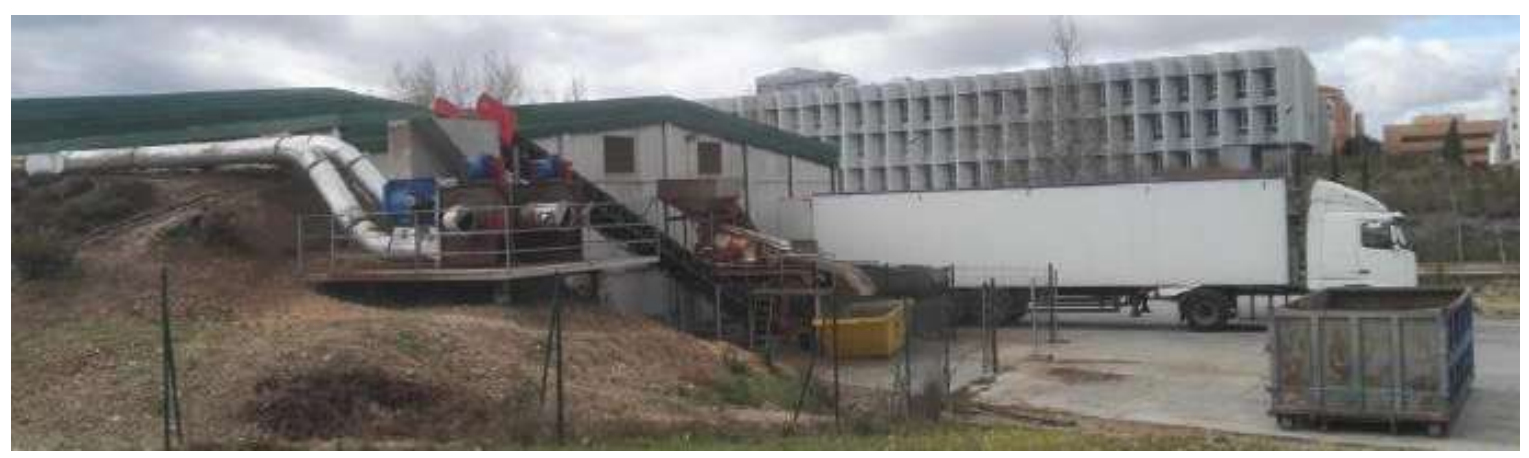

Figura 33. Descarga camión de astilla. (Lorenzo, 2017) [107] 
El silo tiene 14 líneas de piso móvil divididas en dos sectores que permiten extraer la astilla por medio de dos tornillos sinfines independientes, llevando la astilla desde el silo hasta la alimentación de las calderas, como se muestra en las Figuras 34 y 35.

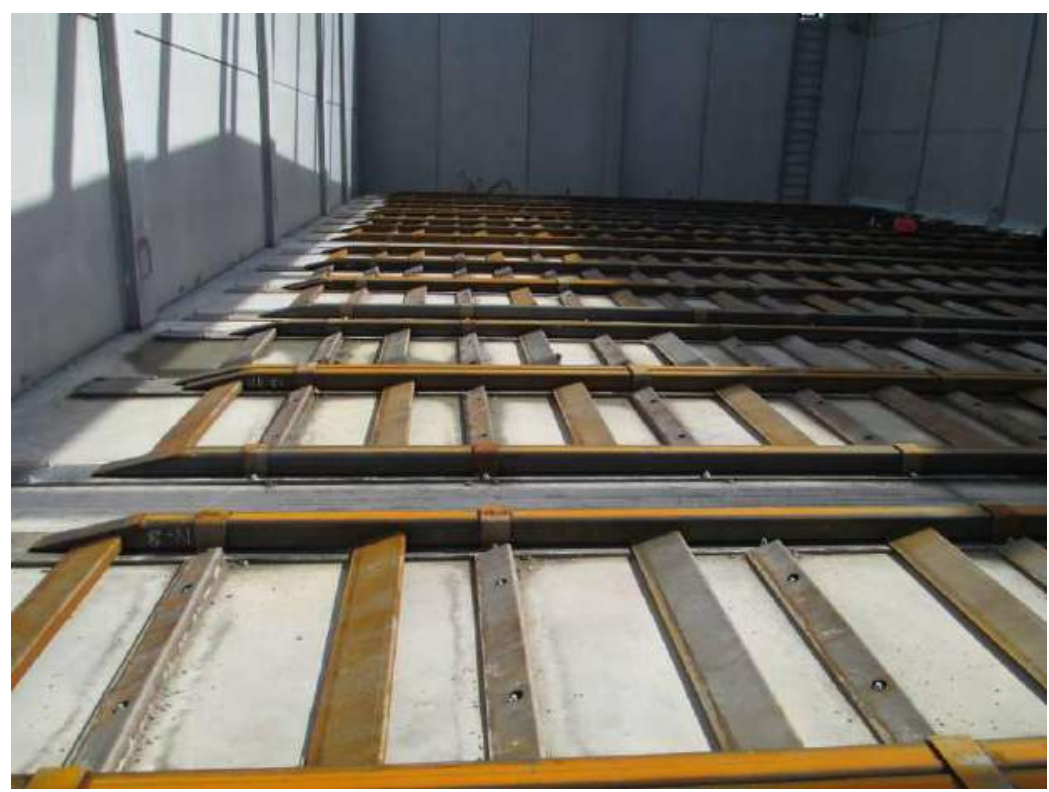

Figura 34. Piso móvil del silo.

(Cano Herrador, Valbuena García, Muñoz Martín, Rey Martínez, \& Navas Gracia, 2014) [64]

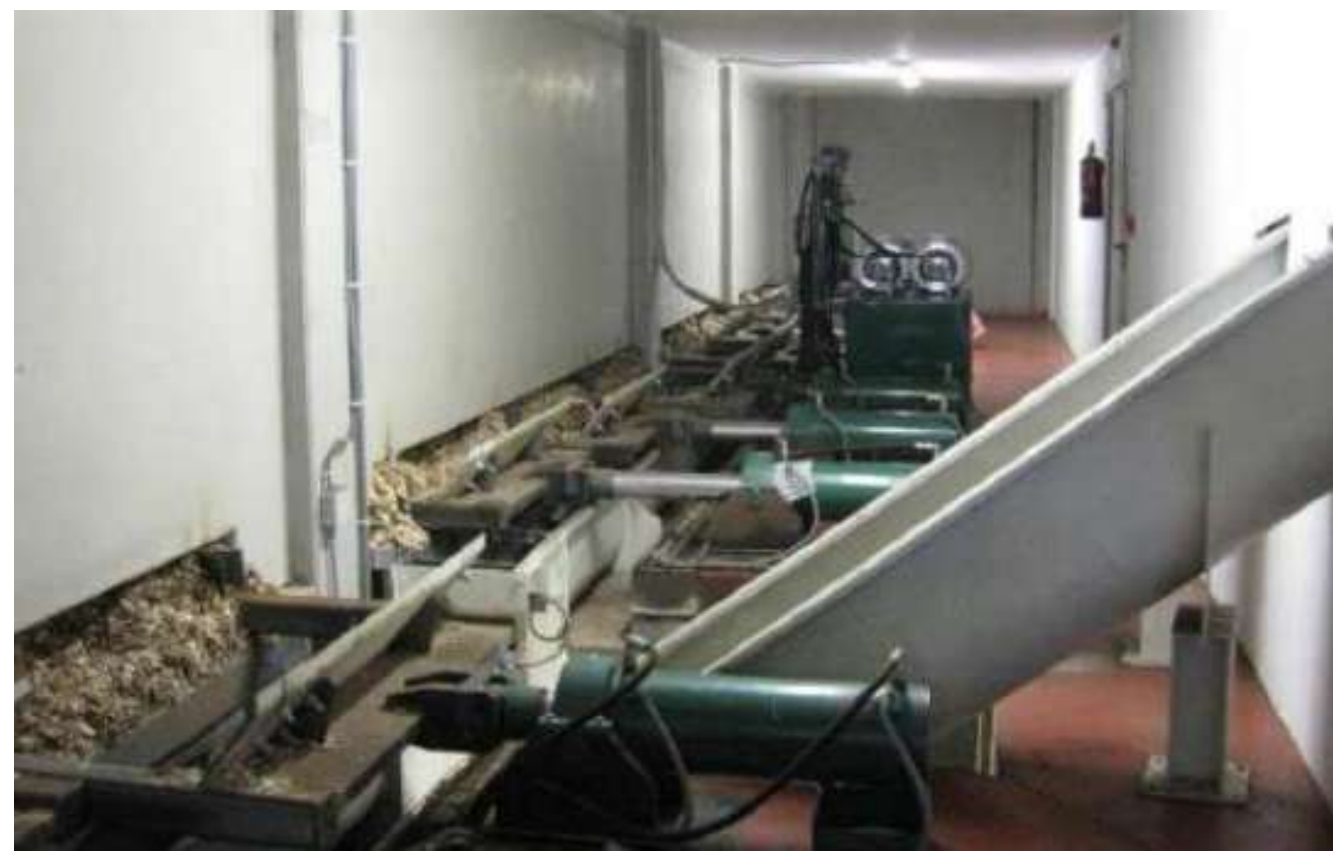

Figura 35. Tornillo sinfín desde el silo a la alimentación de las calderas. (Lorenzo, 2017) [107] 
La central térmica cuenta con dos depósitos de inercia de 40.000 litros cada uno conectados en paralelo, que apoyan al sistema en los momentos de arranque y demandas pico puntuales. Estos depósitos se pueden ver en la Figura 36.

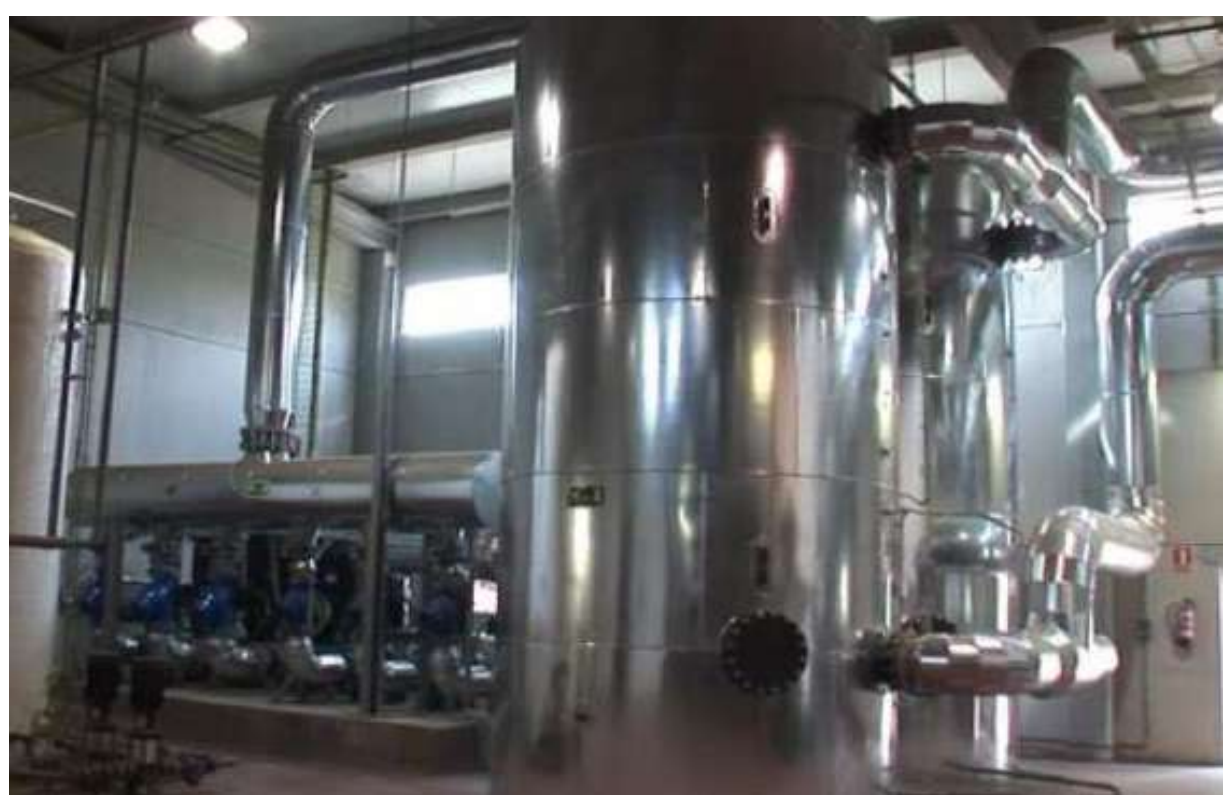

Figura 36. Depósitos de inercia. (Lorenzo, 2017) [107]

El sistema de filtrado o depurador de humos consiste en un sistema multiciclónico que separa las partículas hasta $5 \mu \mathrm{m}$ y filtro de mangas, con el que se filtran partículas hasta $0,01 \mu \mathrm{m}$. (Figura 37). Finalmente las cenizas son extraídas mediante tornillos sinfines hasta un contenedor estanco ubicado en el exterior de la Central.

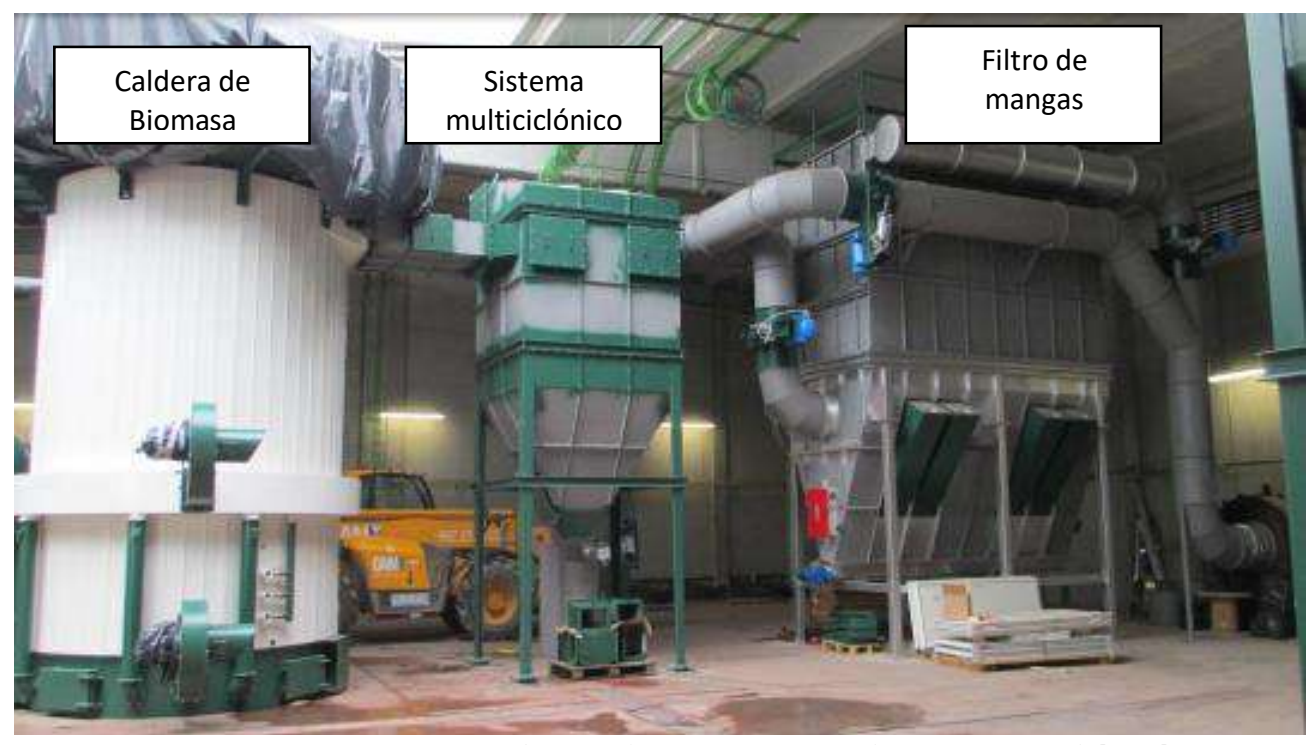

Figura 37. Sistema multiciclónico y filtro de mangas. (Lorenzo, 2017) [107] 
El agua caliente generada a $90{ }^{\circ} \mathrm{C}$ en cada caldera es impulsada mediante las bombas circuladoras del circuito primario de cada caldera al colector de impulsión y de ahí a los depósitos de inercia del circuito secundario, de donde es enviada, mediante dos grupos de bombeo, a los dos circuitos de distribución independientes. (Figura 38)

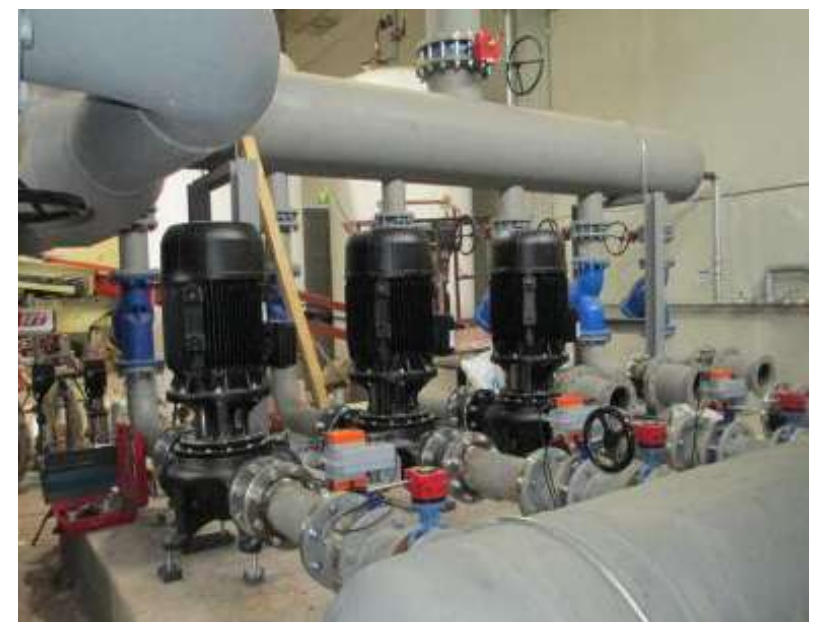

Figura 38. Grupos de bombeo del circuito secundario. (Lorenzo, 2017) [107]

En la Figura 39, se muestra el esquema de principio inicial con las tres calderas previstas, los dos depósitos de inercia y los dos circuitos de distribución.

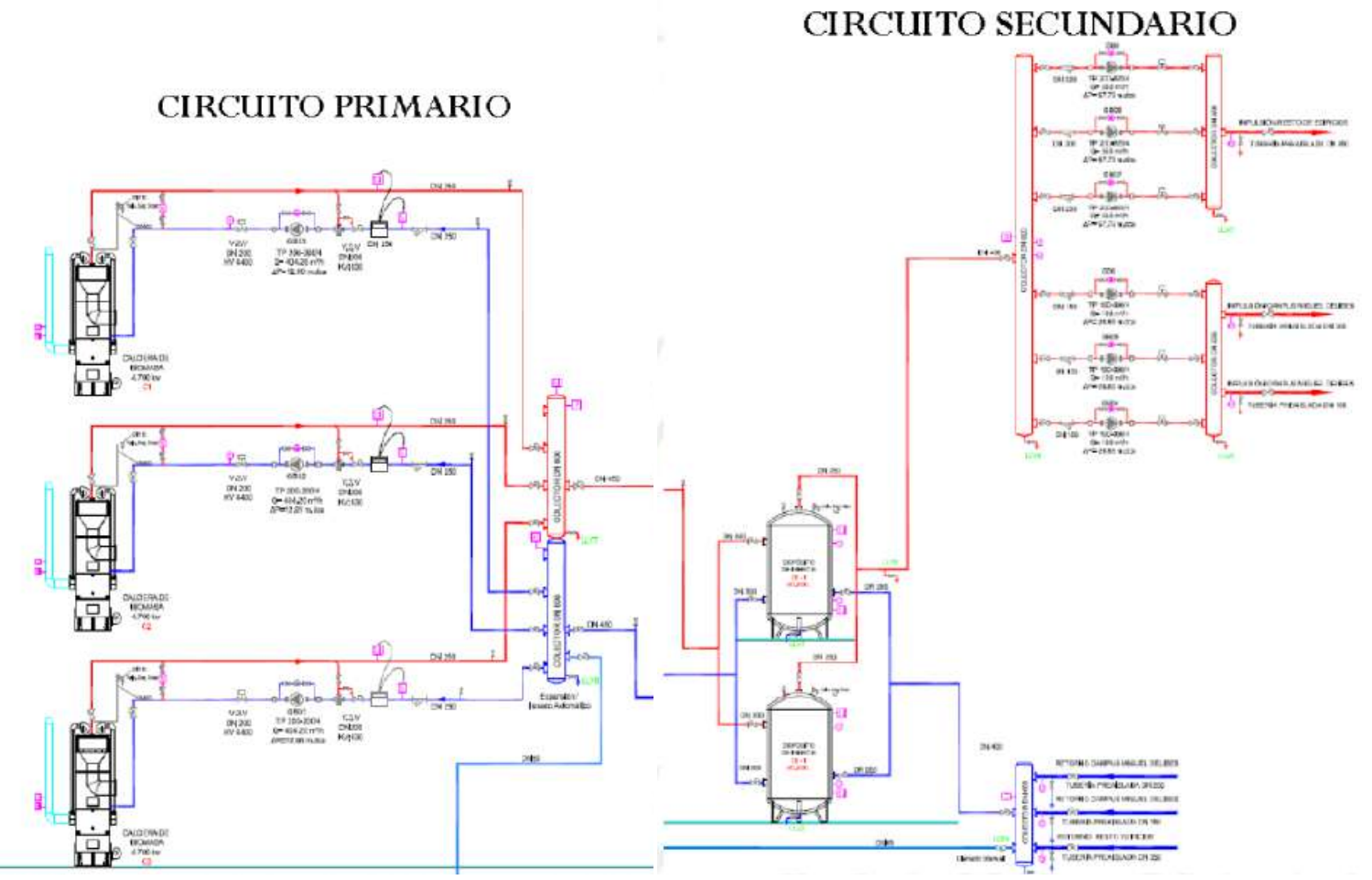

Figura 39. Esquema de principio. (Lorenzo, 2017) [107] 


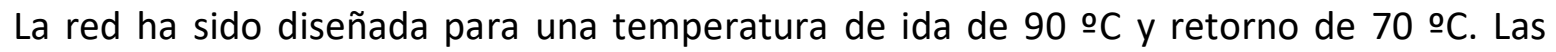
tuberías de distribución son de acero pre-aislado con espuma rígida de poliuretano. Utilizándose diámetros de tubería desde los $32 \mathrm{~mm}$ a los $350 \mathrm{~mm}$. (Ver Figura 40). En las tuberías se incorporan dos hilos de cobre para la detección de humedad en el aislamiento y por lo tanto la detección de fugas de agua en la red.

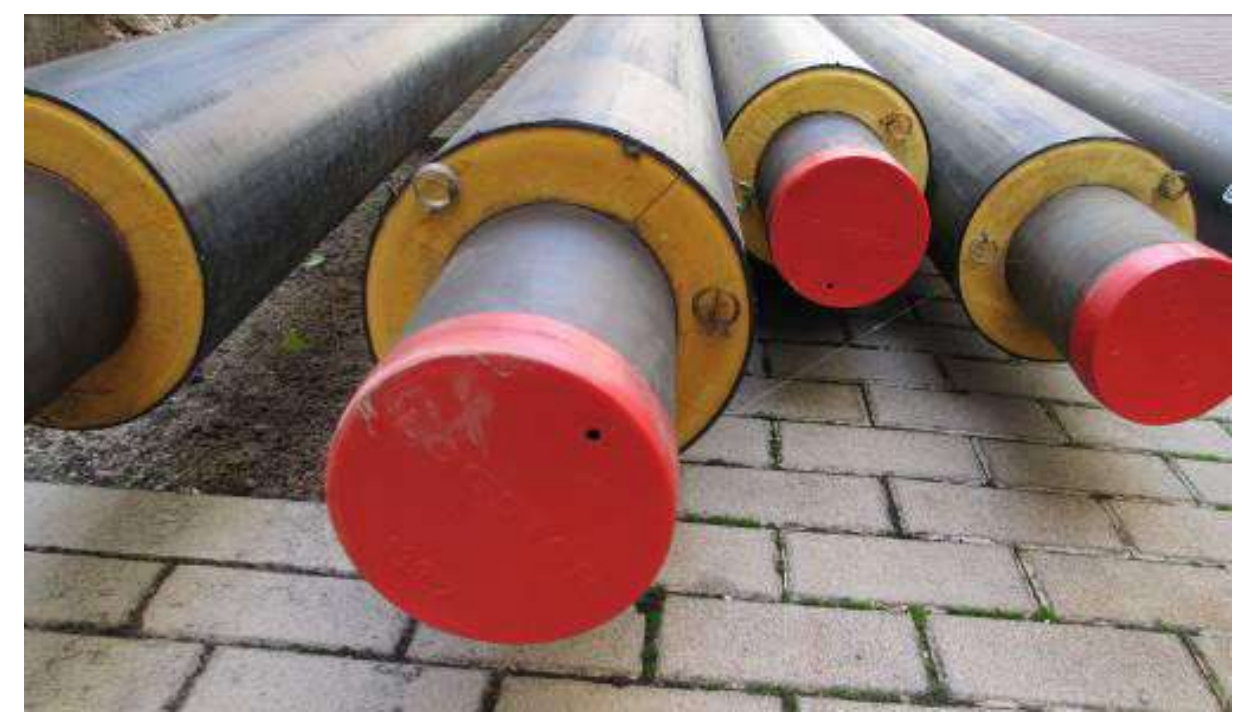

Figura 40. Tuberías de acero pre-aislado.

(Cano Herrador, Valbuena García, Muñoz Martín, Rey Martínez, \& Navas Gracia, 2014) [64]

La red de distribución se compone de un total de $11.300 \mathrm{~m}$ y discurre tanto enterrada como al aire, atravesando el parking de la Universidad e incluso el Río Esgueva, como se aprecia en las fotografías de las Figuras 41 y 42.
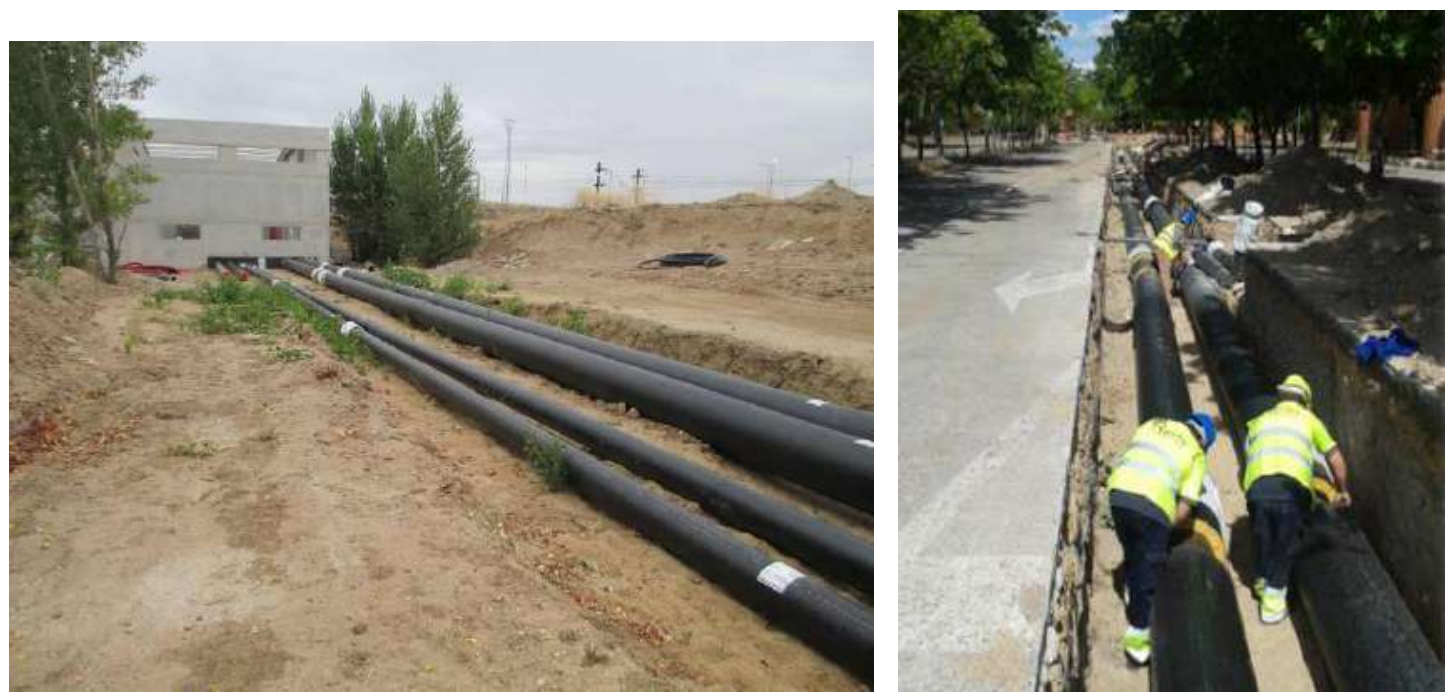

Figura 41. Red de distribución enterrada. (Lorenzo, 2017) [107] 


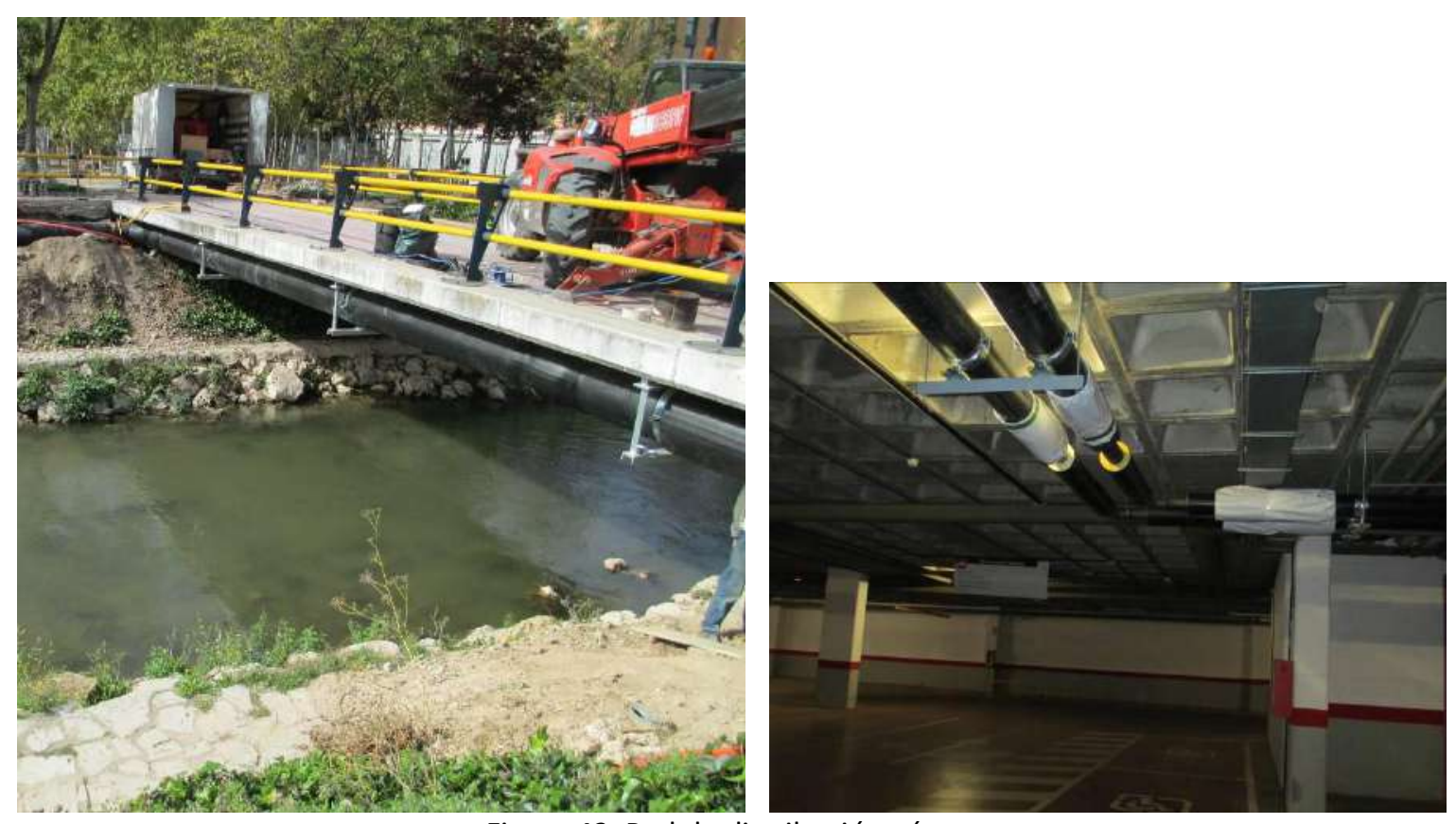

Figura 42. Red de distribución aérea.

(Cano Herrador, Valbuena García, Muñoz Martín, Rey Martínez, \& Navas Gracia, 2014) [64]

El agua transportado por la red de distribución llega hasta las salas de calderas de cada uno de los edificios donde se ubica la subestación del edificio, compuesta por un intercambiador agua / agua de placas, que además de transmitir el calor al circuito del edificio, independiza el circuito de agua de la red de calor con el circuito de agua del edificio. A este intercambiador se conecta el sistema de calefacción y ACS del edificio, mediante una bomba de circulación en el secundario. El circuito de intercambio se ha diseñado para una temperatura de entrada de $80 \stackrel{\circ}{\circ}$ y de salida de 65 ㄷ․ Las subestaciones han sido diseñadas en función de las necesidades térmicas de cada edificio desde $45 \mathrm{~kW}$ hasta $3.500 \mathrm{~kW}$.

Existe un contador de energía en el retorno del secundario del intercambiador que mide la energía consumida por cada edificio proveniente de la red de calor, siendo éste el equipo de medida que ha registrado los datos que han servido para la realización de la investigación, además de las facturas de gas natural y gasóleo de las instalaciones antiguas de cada edificio que han permanecido operativas como instalación complementaria de seguridad, para el caso de parada de la red. En las Figuras 43, 44 y 45 se pueden ver el esquema y varias fotografías de subestaciones.

La instalación dispone de un sistema de telegestión mediante fibra óptica que permite el seguimiento en continuo del funcionamiento de cada elemento. 
La red óptica se ha dispuesto de forma paralela a la red hidráulica. Cada subestación dispone de un autómata desde el cual se puede acceder a la información propia de cada edificio y que comunica los datos a la central general ubicada en la oficina de control de la Central térmica.

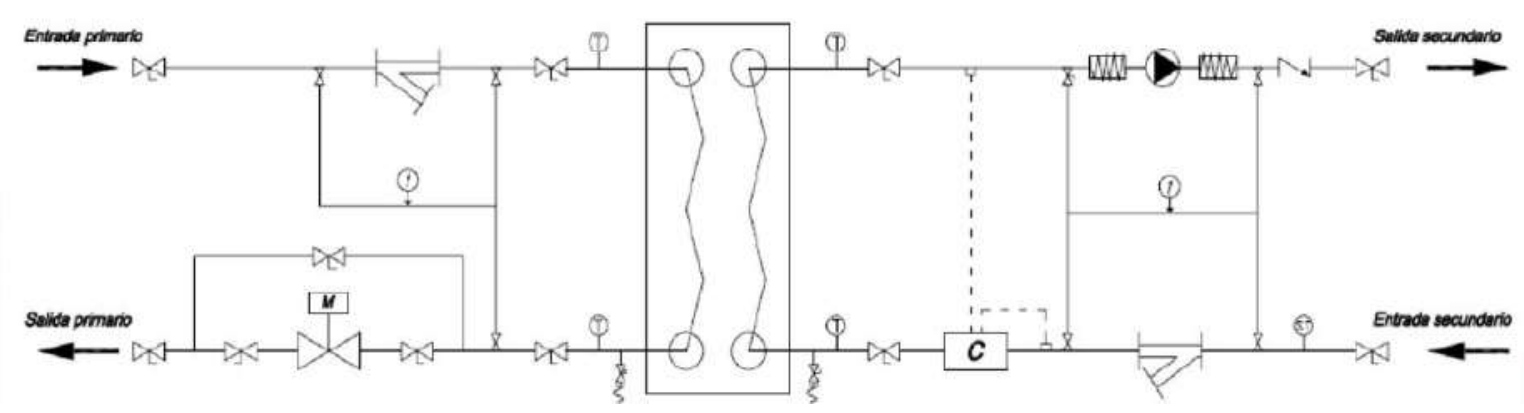

Figura 43. Esquema de la subestación de intercambio en cada edificio. (Lorenzo, 2017) [107]

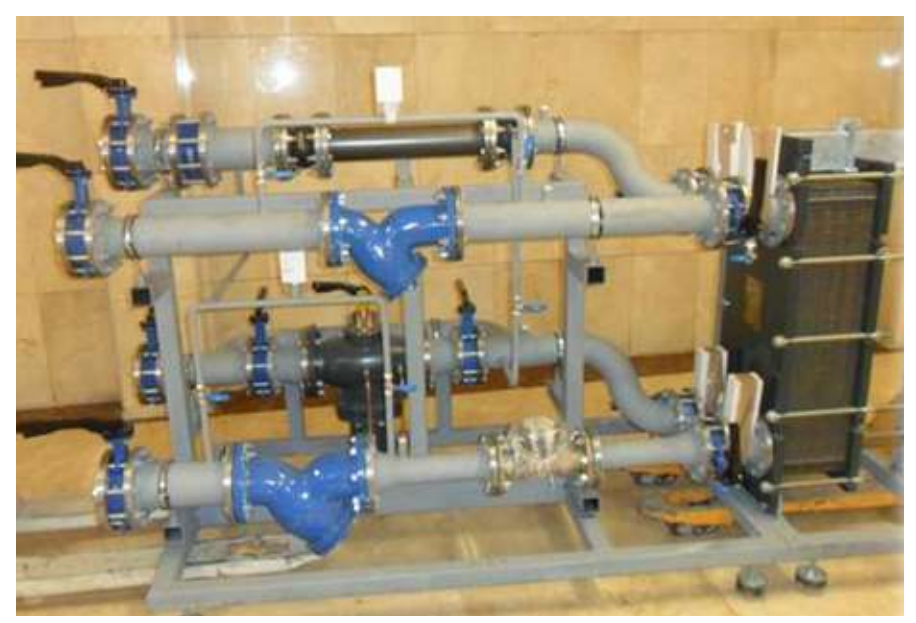

Figura 44. Subestación de calor. (Lorenzo, 2017) [107]

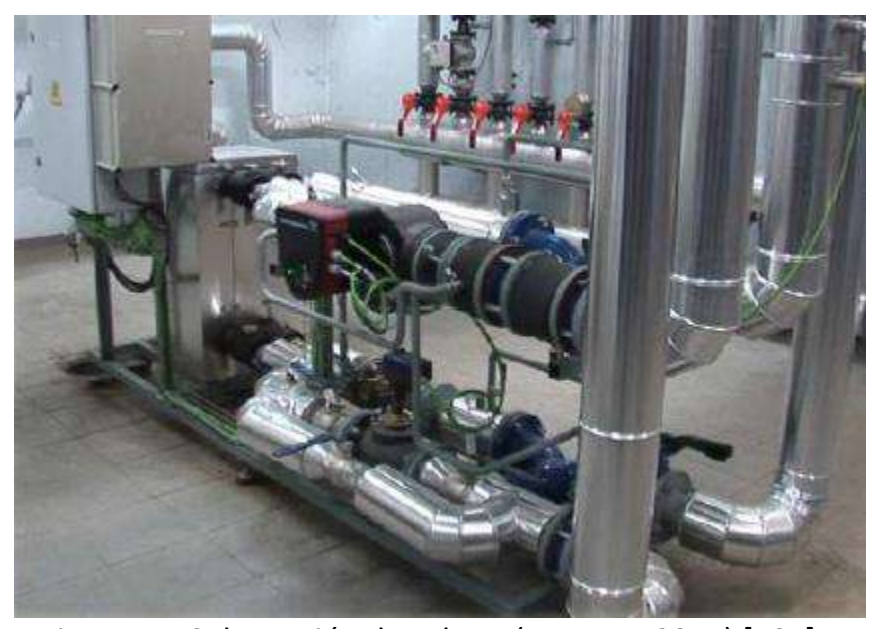

Figura 45. Subestación de calor. . (Lorenzo, 2017) [107] 


\subsection{Descripción de los Edificios de la UVA}

A continuación se muestra unas tablas que resume las características de los edificios y en el Anexo III, se detalla la descripción de cada uno de los edificios de la Universidad de Valladolid que forman parte de la red de calor y que han sido objeto de la investigación.

En la Tabla 5, se muestra el número de calderas y la potencia de cada una, así como la potencia total y la potencia de la subestación de intercambio con la red de calor de los edificios del Campus Miguel Delibes conectados a la red. Las superficies han sido obtenidas de la Relación de bienes inmuebles de la Universidad de Valladolid (Universidad de Valladolid (UVA)) [108]

Tabla 5. Resumen de características de los Edificios del Campus Miguel Delibes

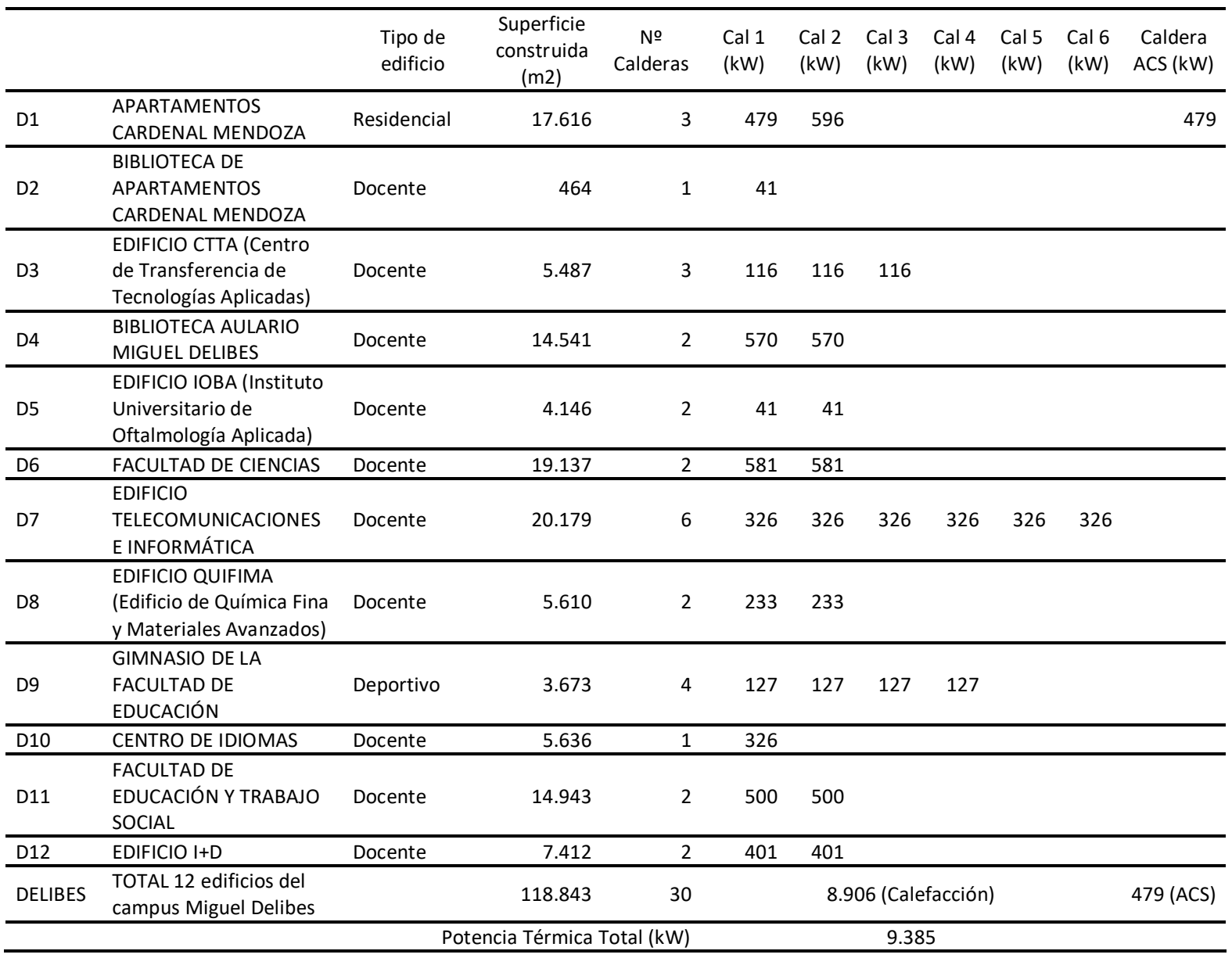


Capítulo 3. Análisis del Caso en Estudio

\begin{tabular}{|c|c|c|c|c|c|c|c|}
\hline & & $\begin{array}{l}\text { Tipo de } \\
\text { edificio }\end{array}$ & $\begin{array}{l}\text { Superficie } \\
\text { construida } \\
\quad(\mathrm{m} 2)\end{array}$ & $\begin{array}{c}\text { № } \\
\text { Calderas }\end{array}$ & $\begin{array}{l}\text { TOTAL } \\
\text { potencia } \\
\text { inicial } \\
\text { instalada } \\
(\mathrm{kW})\end{array}$ & $\begin{array}{c}\text { kW de la } \\
\text { subestación } \\
\text { de } \\
\text { intercambio } \\
\text { con la red }\end{array}$ & $\begin{array}{l}\text { Año de } \\
\text { puesta en } \\
\text { marcha }\end{array}$ \\
\hline D1 & $\begin{array}{l}\text { APARTAMENTOS } \\
\text { CARDENAL MENDOZA }\end{array}$ & Residencial & 17.616 & 3 & 1.554 & 1.454 & 1996 \\
\hline D2 & $\begin{array}{l}\text { BIBLIOTECA DE } \\
\text { APARTAMENTOS } \\
\text { CARDENAL MENDOZA }\end{array}$ & Docente & 464 & 1 & 41 & 42 & 1996 \\
\hline D3 & $\begin{array}{l}\text { EDIFICIO CTTA (Centro de } \\
\text { Transferencia de } \\
\text { Tecnologías Aplicadas) }\end{array}$ & Docente & 5.487 & 3 & 348 & 342 & 2007 \\
\hline D4 & $\begin{array}{l}\text { BIBLIOTECA AULARIO } \\
\text { MIGUEL DELIBES }\end{array}$ & Docente & 14.541 & 2 & 1.140 & 1.140 & 2012 \\
\hline D5 & $\begin{array}{l}\text { EDIFICIO IOBA (Instituto } \\
\text { Universitario de } \\
\text { Oftalmología Aplicada) }\end{array}$ & Docente & 4.146 & 2 & 81 & 80 & 2008 \\
\hline D6 & FACULTAD DE CIENCIAS & Docente & 19.137 & 2 & 1.162 & 1.120 & 2009 \\
\hline D7 & $\begin{array}{l}\text { EDIFICIO } \\
\text { TELECOMUNICACIONES E } \\
\text { INFORMÁTICA }\end{array}$ & Docente & 20.179 & 6 & 1.956 & 1.620 & 1997 \\
\hline D8 & $\begin{array}{l}\text { EDIFICIO QUIFIMA (Edificio } \\
\text { de Química Fina y } \\
\text { Materiales Avanzados) }\end{array}$ & Docente & 5.610 & 2 & 466 & 460 & 2008 \\
\hline D9 & $\begin{array}{l}\text { GIMNASIO DE LA FACULTAD } \\
\text { DE EDUCACIÓN }\end{array}$ & Deportivo & 3.673 & 1 & 508 & 504 & 2001 \\
\hline $\mathrm{D} 10$ & CENTRO DE IDIOMAS & Docente & 5.636 & 1 & 326 & 326 & 1996 \\
\hline D11 & $\begin{array}{l}\text { FACULTAD DE EDUCACIÓN } \\
\text { Y TRABAJO SOCIAL }\end{array}$ & Docente & 14.943 & 2 & 1.000 & 1.000 & 2001 \\
\hline $\mathrm{D} 12$ & EDIFICIO I+D & Docente & 7.412 & 2 & 802 & 802 & 2007 \\
\hline DELIBES & $\begin{array}{l}\text { TOTAL } 12 \text { edificios del } \\
\text { campus Miguel Delibes }\end{array}$ & & 118.843 & 27 & 9.385 & 8.890 & \\
\hline
\end{tabular}

La potencia inicialmente instalada en calderas era de $9.385 \mathrm{~kW}$, las subestaciones instaladas suma una potencia total de $8.890 \mathrm{~kW}$.

La temporada de calefacción para todos los edificios es desde el 15 de Octubre al 15 de Mayo. Todos los edificios inicialmente funcionaban con gas natural y en función del horario de calefacción se diferencian tres tipologías de edificios:

- Edificios docentes que funcionan de lunes a viernes en horario de calefacción de 6:00 a 22:00 h, con parada en navidades del 24 de diciembre al 8 de enero.

- Edificios residenciales que funcionan toda la semana con un horario de calefacción de $24 \mathrm{~h}$.

- Edificios deportivos, que funcionan toda la semana con un horario de calefacción de $10: 00$ a $14: 00$ y de $16: 00$ a 22:00. 


\section{Edificios del Campus Río Esgueva}

En la Tabla 6, se muestra el número de calderas y la potencia de cada una, así como la potencia total y la potencia de la subestación de intercambio con la red de calor de los edificios del Campus del Río Esgueva Delibes conectados a la red. Las superficies han sido obtenidas de la Relación de bienes inmuebles de la Universidad de Valladolid (Universidad de Valladolid (UVA)) [108]

Tabla 6. Resumen de características de los Edificios del Campus Río Esgueva

\begin{tabular}{|c|c|c|c|c|c|c|c|c|c|c|}
\hline & & $\begin{array}{l}\text { Tipo de } \\
\text { edificio }\end{array}$ & $\begin{array}{l}\text { № } \\
\text { Salas }\end{array}$ & $\begin{array}{l}\text { № } \\
\text { calderas }\end{array}$ & Combustible & $\begin{array}{l}\text { Cal } 1 \\
(\mathrm{~kW})\end{array}$ & $\begin{array}{l}\text { Cal } 2 \\
(\mathrm{~kW})\end{array}$ & $\begin{array}{l}\text { Cal } 3 \\
(\mathrm{~kW})\end{array}$ & $\begin{array}{l}\text { Cal } 4 \\
(\mathrm{~kW})\end{array}$ & $\begin{array}{l}\text { Caldera } \\
\text { ACS (kW) }\end{array}$ \\
\hline E1 & $\begin{array}{l}\text { EDIFICIO DEL } \\
\text { SERVICIO DE } \\
\text { MANTENIMIENTO }\end{array}$ & Docente & 1 & 1 & Gasóleo & 291 & & & & \\
\hline E2 & $\begin{array}{l}\text { ESCUELA } \\
\text { UNIVERSITARIA DE } \\
\text { EMPRESARIALES. } \\
\text { FACULTAD DE } \\
\text { COMERCIO } \\
\end{array}$ & Docente & 1 & 3 & Gasóleo & 407 & 291 & 291 & & \\
\hline E3 & $\begin{array}{l}\text { FACULTAD DE } \\
\text { FILOSOFÍA Y LETRAS }\end{array}$ & Docente & 1 & 2 & Gas & 465 & 465 & & & \\
\hline E4 & $\begin{array}{l}\text { ANTIGUA FACULTAD } \\
\text { DE CIENCIAS }\end{array}$ & Docente & 2 & 3 & Gasóleo & 1.453 & 930 & 756 & & \\
\hline E5 & EDIFICIO ALFOLSO VIII & Residencial & 1 & 3 & Gasóleo & 2.326 & 2.326 & & & 291 \\
\hline E6 & $\begin{array}{l}\text { EDIFICIO COLEGIO } \\
\text { MAYOR FEMENINO } \\
\text { SANTA CRUZ } \\
\end{array}$ & Residencial & 1 & 2 & Gas & 358 & 358 & & & \\
\hline E7 & $\begin{array}{l}\text { INSTITUTO DE } \\
\text { BIOLOGÍA Y GENÉTICA } \\
\text { MOLECULAR (IBGM) }\end{array}$ & Docente & 1 & 2 & Gas & 233 & 233 & & & \\
\hline E8 & $\begin{array}{l}\text { FACULTAD DE } \\
\text { CIENCIAS DE LA } \\
\text { SALUD } \\
\end{array}$ & Docente & 4 & 8 & Gas & $\begin{array}{c}265+ \\
75\end{array}$ & $\begin{array}{c}265+ \\
705\end{array}$ & $\begin{array}{c}285+ \\
285\end{array}$ & $\begin{array}{c}265+ \\
175\end{array}$ & \\
\hline E13 & $\begin{array}{l}\text { FACULTAD DE } \\
\text { ECONÓMICAS } \\
\end{array}$ & Docente & 1 & 2 & Gas & 802 & 802 & & & \\
\hline E14 & $\begin{array}{l}\text { AULARIO CAMPUS } \\
\text { ESGUEVA }\end{array}$ & Docente & 1 & 2 & Gasóleo & 233 & 174 & & & \\
\hline E15 & $\begin{array}{l}\text { ESCUELA DE } \\
\text { INGENIERÍAS } \\
\text { INDUSTRIALES (SEDE } \\
\text { PASEO DEL CAUCE) } \\
\end{array}$ & Docente & 1 & 4 & Gas & 581 & 581 & 581 & 581 & \\
\hline $\begin{array}{l}\text { ESGUE } \\
\text { VA }\end{array}$ & $\begin{array}{l}\text { TOTAL } 11 \text { edificios del } \\
\text { campus Río Esgueva }\end{array}$ & & 15 & 32 & & \multicolumn{4}{|c|}{17.838 (Calefacción) } & 291 (ACS) \\
\hline \multicolumn{6}{|c|}{ Potencia Térmica Total (kW) } & & & 18.129 & & \\
\hline
\end{tabular}


Capítulo 3. Análisis del Caso en Estudio

\begin{tabular}{|c|c|c|c|c|c|c|c|}
\hline & & $\begin{array}{l}\text { Tipo de } \\
\text { edificio }\end{array}$ & $\begin{array}{l}\text { Superficie } \\
\text { construida } \\
\text { (m2) }\end{array}$ & Combustible & $\begin{array}{l}\text { TOTAL } \\
\text { potencia } \\
(\mathrm{kW})\end{array}$ & $\begin{array}{c}\mathrm{kW} \text { de la } \\
\text { subestación } \\
\text { de } \\
\text { intercambio } \\
\text { con la red } \\
\end{array}$ & $\begin{array}{l}\text { Año de } \\
\text { puesta } \\
\text { en } \\
\text { servicio }\end{array}$ \\
\hline $\mathrm{E} 1$ & $\begin{array}{l}\text { EDIFICIO DEL SERVICIO } \\
\text { DE MANTENIMIENTOO }\end{array}$ & Docente & 1.681 & Gasóleo & 291 & 291 & 1940 \\
\hline E2 & $\begin{array}{l}\text { ESCUELA } \\
\text { UNIVERSITARIA DE } \\
\text { EMPRESARIALES. } \\
\text { FACULTAD DE } \\
\text { COMERCIO }\end{array}$ & Docente & 11.160 & Gasóleo & 989 & 988 & 1994 \\
\hline E3 & $\begin{array}{l}\text { FACULTAD DE } \\
\text { FILOSOFÍA Y LETRAS }\end{array}$ & Docente & 21.709 & Gas & 930 & 929 & 1997 \\
\hline E4 & $\begin{array}{l}\text { ANTIGUA FACULTAD DE } \\
\text { CIENCIAS }\end{array}$ & Docente & 32.305 & Gasóleo & 3.139 & 2.384 & 1968 \\
\hline E5 & EDIFICIO ALFOLSO VIII & Residencial & 20.016 & Gasóleo & 4.943 & 3.800 & 1991 \\
\hline E6 & $\begin{array}{l}\text { EDIFICIO COLEGIO } \\
\text { MAYOR FEMENINO } \\
\text { SANTA CRUZ }\end{array}$ & Residencial & 6.660 & Gas & 716 & 560 & 1981 \\
\hline E7 & $\begin{array}{l}\text { INSTITUTO DE } \\
\text { BIOLOGÍA Y GENÉTICA } \\
\text { MOLECULAR (IBGM) }\end{array}$ & Docente & 3.919 & Gas & 466 & 465 & 2005 \\
\hline E8 & $\begin{array}{l}\text { FACULTAD DE CIENCIAS } \\
\text { DE LA SALUD }\end{array}$ & Docente & 29.802 & Gas & 2.320 & 2.172 & 1960 \\
\hline E13 & $\begin{array}{l}\text { FACULTAD DE } \\
\text { ECONÓMICAS }\end{array}$ & Docente & 17.776 & Gas & 1.604 & 1.624 & 1982 \\
\hline E14 & $\begin{array}{l}\text { AULARIO CAMPUS } \\
\text { ESGUEVA }\end{array}$ & Docente & 7.569 & Gasóleo & 407 & 425 & 1986 \\
\hline E15 & $\begin{array}{l}\text { ESCUELA DE } \\
\text { INGENIERÍAS } \\
\text { INDUSTRIALES (SEDE } \\
\text { PASEO DEL CAUCE) }\end{array}$ & Docente & 18.512 & Gas & 2.324 & 2.160 & 1985 \\
\hline ESGUEVA & $\begin{array}{l}\text { TOTAL } 11 \text { edificios del } \\
\text { campus Río Esgueva }\end{array}$ & & 171.109 & & 18.129 & 15.798 & \\
\hline
\end{tabular}

La potencia inicialmente instalada en calderas era de $18.129 \mathrm{~kW}$, las subestaciones instaladas suma una potencia total de $15.798 \mathrm{~kW}$.

La temporada de calefacción para todos los edificios, al igual que en el Campus Miguel Delibes es desde el 15 de Octubre al 15 de Mayo.

En función del horario de calefacción se diferencian dos tipologías de edificios:

- Edificios docentes que funcionan de lunes a viernes en horario de calefacción de 6:00 a 22:00 h, con parada en navidades del 24 de diciembre al 8 de enero.

- Edificios residenciales que funcionan toda la semana con un horario de calefacción de $24 \mathrm{~h}$. 


\subsection{Datos de partida}

\subsubsection{Variables climáticas}

Las variables climáticas, susceptibles de ser los parámetros independientes que modelasen el consumo esperado de cada edificio, se obtuvieron cada 30 minutos de los últimos seis años y medio de una estación climática ubicada en Zamadueñas (Valladolid) (InfoRiego) [98], desde octubre de 2012 hasta septiembre de 2018, correspondientes a seis temporadas de calefacción, dos anteriores a la construcción de la red de calor y tres posteriores a la ejecución del district heating:

- Octubre 2012 hasta mayo 2013. Temporada previa a la implantación de la red

- Octubre 2013 hasta mayo 2014. Temporada previa a la implantación de la red

- Octubre 2014 hasta mayo 2015. Temporada de implantación de la red

- Octubre 2015 hasta mayo 2016. Temporada posterior a la implantación de la red

- Octubre 2016 hasta mayo 2017. Temporada posterior a la implantación de la red

- Octubre 2017 hasta mayo 2018. Temporada posterior a la implantación de la red.

La estación de recogida de datos es propiedad del Instituto Tecnológico Agrario de Castilla y León y se encentra situada a $8 \mathrm{~km}$ del Centro de Valladolid. En la Figura 46, se puede observar dicha estación meteorológica.
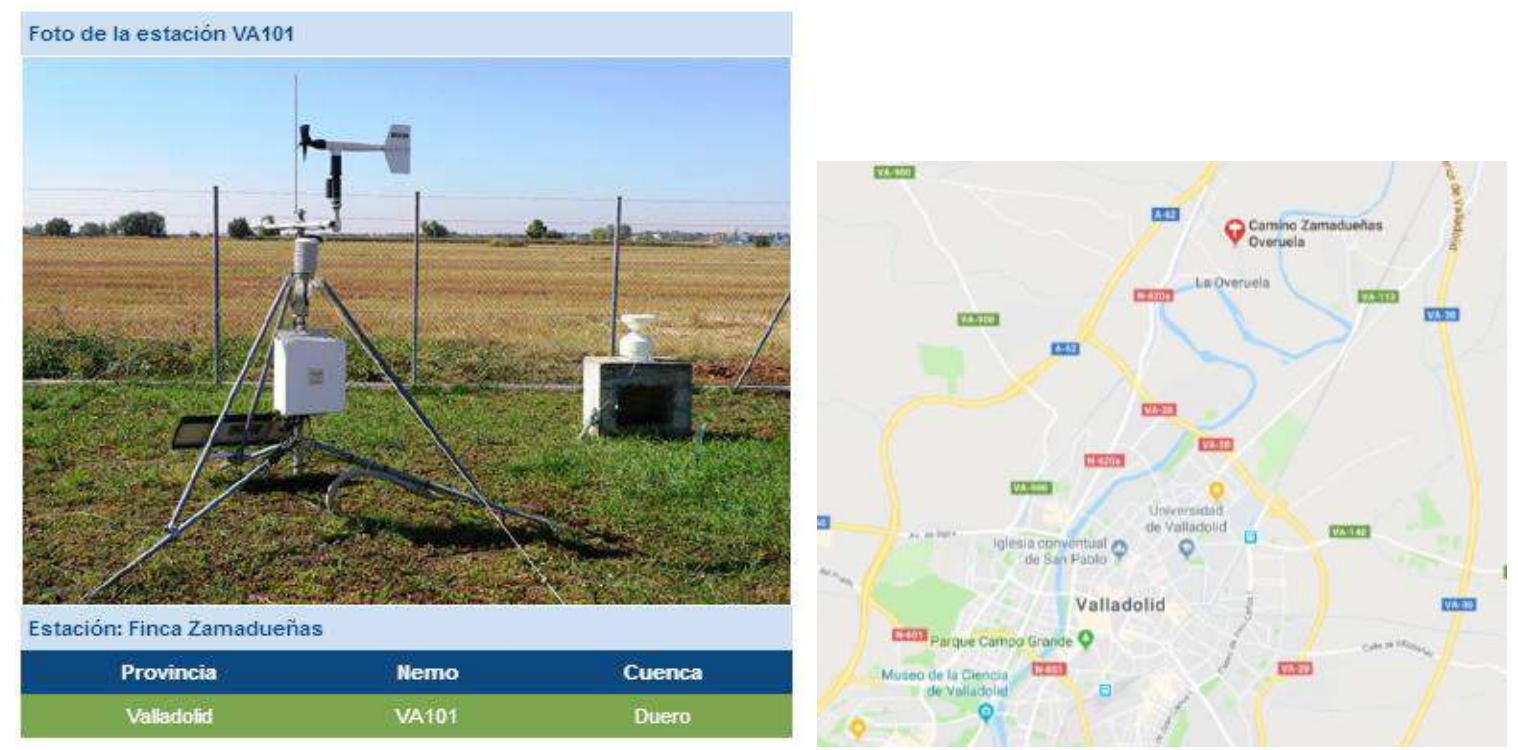

Figura 46. Estación meteorológica en Zamadueñas [98] 
Las variables climáticas obtenidas fueron las relativas a:

- Temperaturas: medias, medias diurnas, máximas y mínimas.

- Grados día: base 15 y base 20.

- Humedades relativas: medias, diurnas, máximas y mínimas.

- Radiación: Intensidad de radiación

- Velocidades del viento: medias, diurnas, nocturnas y máximas.

- Recorrido del viento.

- Precipitación acumulada.

- Horas de sol.

En el caso de los Grados día se empleó la expresión de la Ecuación 13:

Siendo:

$$
\text { GD Base mes }=\sum_{i=1}^{n}\left(\text { Base }-T_{i}\right)
$$

Base $=15^{\circ} \mathrm{C}$ ó $18^{\circ} \mathrm{C}$

$\mathrm{Ti}=$ Temperaturas medidas registradas cada 30 minutos menores a $15 \circ \mathrm{C}$ ó a $18 \mathrm{C}$

$\mathrm{n}=$ Número de intervalos de $\mathbf{3 0}$ minutos existentes en cada mes

$\mathrm{n}=$ Número de días de cada mes $(*)$

(*) Los grados día fueron calculados de dos formas con datos tomados cada 30 minutos y con datos medios diarios.

Los Grados día son valores que expresan diferencias de temperatura acumuladas; se calculan de acuerdo con la norma UNE-EN ISO 15927-6: 2009 (AENOR. Asociación Española de Normalización, 2009)[99]. Su cálculo se basa en el concepto de temperatura base, a partir del cual el edificio necesita calefacción. Esta variable se ha utilizado en numerosos estudios como por ejemplo en: (Verbai, Lakatos, \& Kalmár, 2014) [88], (Golden, Woodbury, Carpenter, \& O’Neill, 2017) [89]. (Meng \& Mourshed, 2017) [90], (Atalla, Gualdi, \& Lanza, 2018) [91] y (De Rosa, Bianco, Scarpa, \& Tagliafico, 2014) [92]

También se calcularon los Grados día tomando como referencia en lugar de las temperaturas medias de cada treinta minutos, las temperaturas medias diarias, aunque este cálculo arroja un mayor error en la determinación de los Grados día. Los datos se muestran en la Tabla 7 y Figura 47. A continuación se presentan, las temperaturas, humedades, velocidades, recorrido del viento y precipitaciones, que fueron procesadas para obtener promedios, máximos, mínimos y acumulados mensuales, los resultados obtenidos se muestran en las Tabla 7, 8, 9, 10 y 11. 
Capítulo 3. Análisis del Caso en Estudio

Tabla 7. Datos climáticos utilizados en la investigación. Grados día

\begin{tabular}{|c|c|c|c|c|}
\hline & GD15 $(0,5 h)$ & GD $20(0,5 h)$ & GD15 (día) & GD 20 (día) \\
\hline oct-12 & 132,46 & 257,91 & 112,07 & 248,81 \\
\hline nov-12 & 230,75 & 379,14 & 229,14 & 379,14 \\
\hline dic-12 & 306,53 & 461,53 & 306,57 & 461,57 \\
\hline ene-13 & 323,69 & 478,69 & 323,68 & 478,68 \\
\hline feb-13 & 308,46 & 448,46 & 308,49 & 448,49 \\
\hline mar-13 & 244,21 & 399,01 & 244,01 & 399,01 \\
\hline$a b r-13$ & 184,10 & 318,85 & 167,60 & 315,24 \\
\hline may-13 & 146,97 & 282,21 & 126,36 & 280,27 \\
\hline oct-13 & 91,51 & 214,89 & 72,50 & 212,23 \\
\hline nov-13 & 249,23 & 396,82 & 247,15 & 396,83 \\
\hline dic-13 & 380,33 & 535,33 & 380,33 & 535,33 \\
\hline ene-14 & 281,21 & 436,20 & 281,20 & 436,20 \\
\hline feb-14 & 267,82 & 407,82 & 267,81 & 407,81 \\
\hline mar-14 & 206,36 & 349,44 & 193,95 & 348,95 \\
\hline$a b r-14$ & 102,66 & 219,39 & 69,37 & 208,88 \\
\hline may-14 & 89,32 & 200,72 & 50,64 & 183,90 \\
\hline oct-14 & 63,33 & 171,73 & 22,68 & 154,81 \\
\hline nov-14 & 175,40 & 321,67 & 171,67 & 321,67 \\
\hline dic-14 & 347,23 & 502,23 & 347,24 & 502,24 \\
\hline ene-15 & 411,70 & 566,70 & 411,68 & 566,68 \\
\hline feb-15 & 299,27 & 439,24 & 299,22 & 439,22 \\
\hline mar-15 & 224,62 & 363,33 & 205,55 & 360,55 \\
\hline abr-15 & 120,29 & 247,78 & 96,73 & 244,73 \\
\hline may-15 & 65,05 & 165,97 & 31,24 & 138,92 \\
\hline oct-15 & 97,04 & 225,08 & 73,45 & 222,62 \\
\hline nov-15 & 208,36 & 351,64 & 200,93 & 350,93 \\
\hline dic-15 & 300,09 & 454,79 & 299,81 & 454,81 \\
\hline ene-16 & 271,93 & 426,74 & 271,76 & 426,76 \\
\hline feb-16 & 266,36 & 411,35 & 266,33 & 411,33 \\
\hline mar-16 & 276,34 & 429,56 & 274,57 & 429,57 \\
\hline$a b r-16$ & 181,04 & 326,98 & 176,98 & 326,98 \\
\hline may-16 & 99,34 & 222,01 & 67,12 & 213,46 \\
\hline oct-16 & 97,34 & 217,30 & 53,51 & 202,11 \\
\hline nov-16 & 245,69 & 393,06 & 242,95 & 392,95 \\
\hline dic-16 & 337,25 & 492,25 & 337,22 & 492,22 \\
\hline ene-17 & 386,98 & 541,98 & 387,00 & 542,00 \\
\hline feb-17 & 226,76 & 365,14 & 225,13 & 365,13 \\
\hline mar-17 & 203,17 & 338,84 & 179,51 & 334,51 \\
\hline abr-17 & 129,72 & 240,18 & 79,64 & 222,69 \\
\hline may-17 & 54,86 & 144,29 & 25,53 & 111,78 \\
\hline oct-17 & 92,31 & 197,68 & 46,09 & 164,47 \\
\hline nov-17 & 271,60 & 417,33 & 267,29 & 417,29 \\
\hline dic-17 & 341,26 & 496,26 & 341,27 & 496,27 \\
\hline ene-18 & 327,94 & 482,94 & 327,96 & 482,96 \\
\hline feb-18 & 321,27 & 461,22 & 321,20 & 461,20 \\
\hline mar-18 & 255,02 & 409,12 & 254,12 & 409,12 \\
\hline abr-18 & 143,31 & 271,81 & 123,88 & 265,61 \\
\hline may-18 & 78,41 & 193,71 & 46,83 & 185,14 \\
\hline
\end{tabular}


Capítulo 3. Análisis del Caso en Estudio

Tabla 8. Datos climáticos utilizados en la investigación. Temperaturas

\begin{tabular}{|c|c|c|c|c|}
\hline & T med (oC) & T media día (oC) & $\mathrm{T} \max (\stackrel{\circ}{ } \mathrm{C})$ & $\mathrm{T} \min \left({ }^{\circ} \mathrm{C}\right)$ \\
\hline oct-12 & 11,97 & 14,79 & 18,53 & 6,22 \\
\hline nov-12 & 7,36 & 9,14 & 12,30 & 3,05 \\
\hline dic-12 & 5,11 & 6,47 & 9,38 & 1,29 \\
\hline ene-13 & 4,56 & 5,91 & 9,02 & 0,69 \\
\hline feb-13 & 3,98 & 6,26 & 9,81 & $-0,85$ \\
\hline mar-13 & 7,13 & 9,09 & 12,17 & 2,94 \\
\hline$a b r-13$ & 9,49 & 12,26 & 15,36 & 3,77 \\
\hline may-13 & 10,96 & 14,30 & 17,46 & 4,75 \\
\hline oct-13 & 13,15 & 15,69 & 19,18 & 8,28 \\
\hline nov-13 & 6,77 & 8,70 & 11,83 & 2,24 \\
\hline dic-13 & 2,73 & 4,51 & 8,40 & $-1,56$ \\
\hline ene-14 & 5,93 & 7,11 & 10,07 & 2,32 \\
\hline feb-14 & 5,43 & 6,98 & 10,05 & 1,34 \\
\hline mar-14 & 8,74 & 11,97 & 15,82 & 2,23 \\
\hline$a b r-14$ & 13,04 & 16,54 & 19,96 & 6,39 \\
\hline may-14 & 14,07 & 18,05 & 21,54 & 6,64 \\
\hline oct-14 & 15,01 & 18,56 & 22,84 & 9,38 \\
\hline nov-14 & 9,28 & 10,95 & 13,56 & 5,26 \\
\hline dic-14 & 3,80 & 5,20 & 8,15 & 0,38 \\
\hline ene-15 & 1,72 & 3,63 & 7,34 & $-2,38$ \\
\hline feb-15 & 4,31 & 6,48 & 9,74 & $-0,27$ \\
\hline mar-15 & 8,37 & 11,99 & 16,04 & 1,31 \\
\hline abr-15 & 11,84 & 15,11 & 18,61 & 5,62 \\
\hline may-15 & 15,69 & 20,10 & 23,40 & 8,11 \\
\hline oct-15 & 12,82 & 15,67 & 19,10 & 7,50 \\
\hline nov-15 & 8,30 & 10,33 & 14,00 & 4,16 \\
\hline dic-15 & 5,33 & 7,10 & 11,21 & 1,20 \\
\hline ene-16 & 6,23 & 7,45 & 10,33 & 2,63 \\
\hline feb-16 & 5,82 & 7,90 & 11,01 & 1,30 \\
\hline mar-16 & 6,14 & 9,25 & 12,83 & 0,20 \\
\hline$a b r-16$ & 9,10 & 12,01 & 15,40 & 3,83 \\
\hline may-16 & 13,11 & 16,73 & 20,04 & 6,63 \\
\hline oct-16 & 13,40 & 17,24 & 21,78 & 7,14 \\
\hline nov-16 & 6,90 & 9,23 & 12,44 & 2,23 \\
\hline dic-16 & 4,12 & 5,87 & 9,53 & 0,57 \\
\hline ene-17 & 2,52 & 5,41 & 9,88 & $-2,83$ \\
\hline feb-17 & 6,96 & 9,25 & 12,59 & 2,19 \\
\hline mar-17 & 9,21 & 12,81 & 16,71 & 2,59 \\
\hline abr-17 & 12,58 & 17,38 & 21,07 & 3,83 \\
\hline may-17 & 16,69 & 20,71 & 24,49 & 9,02 \\
\hline oct-17 & 14,71 & 14,71 & 24,51 & 6,71 \\
\hline nov-17 & 6,09 & 6,09 & 14,38 & $-0,28$ \\
\hline dic-17 & 3,99 & 3,99 & 9,18 & $-0,44$ \\
\hline ene-18 & 4,42 & 4,42 & 8,99 & 0,66 \\
\hline feb-18 & 3,53 & 3,53 & 9,79 & $-1,96$ \\
\hline mar-18 & 6,80 & 6,80 & 11,48 & 2,74 \\
\hline abr-18 & 11,15 & 11,15 & 17,30 & 5,73 \\
\hline may-18 & 14,03 & 14,03 & 20,59 & 7,82 \\
\hline
\end{tabular}


Capítulo 3. Análisis del Caso en Estudio

Tabla 9. Datos climáticos utilizados en la investigación. Humedad Relativa

\begin{tabular}{|c|c|c|c|c|}
\hline & HR (\%) & HR media día (\%) & HR max (\%) & HR $\min (\%)$ \\
\hline oct-12 & 75,30 & 64,82 & 94,62 & 46,12 \\
\hline nov-12 & 84,15 & 78,04 & 96,65 & 61,93 \\
\hline dic-12 & 87,88 & 83,18 & 97,36 & 68,94 \\
\hline ene-13 & 87,09 & 82,71 & 97,38 & 69,38 \\
\hline feb-13 & 79,09 & 70,23 & 95,76 & 52,73 \\
\hline mar-13 & 80,13 & 73,10 & 95,00 & 56,22 \\
\hline$a b r-13$ & 70,79 & 59,95 & 91,02 & 44,71 \\
\hline may-13 & 69,64 & 55,28 & 94,26 & 38,92 \\
\hline oct-13 & 79,39 & 68,85 & 95,82 & 50,77 \\
\hline nov-13 & 79,66 & 72,26 & 94,44 & 58,52 \\
\hline dic-13 & 87,24 & 81,39 & 97,49 & 65,35 \\
\hline ene-14 & 86,45 & 82,21 & 96,65 & 68,32 \\
\hline feb-14 & 81,52 & 75,46 & 94,92 & 58,78 \\
\hline mar-14 & 65,19 & 53,16 & 89,93 & 36,44 \\
\hline$a b r-14$ & 67,37 & 53,71 & 92,00 & 36,67 \\
\hline may-14 & 57,11 & 41,11 & 88,56 & 26,64 \\
\hline oct-14 & 75,87 & 61,72 & 96,99 & 42,50 \\
\hline nov-14 & 86,38 & 80,20 & 97,49 & 67,12 \\
\hline dic-14 & 89,45 & 85,03 & 98,22 & 73,06 \\
\hline ene-15 & 90,92 & 84,84 & 99,37 & 71,51 \\
\hline feb-15 & 78,56 & 69,66 & 94,83 & 53,62 \\
\hline mar-15 & 67,00 & 54,60 & 92,62 & 38,61 \\
\hline abr-15 & 69,64 & 56,84 & 93,55 & 40,30 \\
\hline may-15 & 61,46 & 45,05 & 90,99 & 31,75 \\
\hline oct-15 & 75,43 & 63,79 & 95,26 & 46,95 \\
\hline nov-15 & 89,45 & 83,12 & 99,51 & 67,08 \\
\hline dic-15 & 94,18 & 89,57 & 100,00 & 75,01 \\
\hline ene-16 & 94,73 & 91,16 & 99,99 & 78,26 \\
\hline feb-16 & 85,39 & 77,10 & 98,62 & 60,11 \\
\hline mar-16 & 78,33 & 66,30 & 99,02 & 46,99 \\
\hline abr-16 & 80,64 & 68,62 & 99,78 & 49,42 \\
\hline may-16 & 73,63 & 57,44 & 98,63 & 40,99 \\
\hline oct-16 & 71,40 & 57,19 & 95,75 & 38,38 \\
\hline nov-16 & 86,41 & 77,32 & 98,88 & 62,31 \\
\hline dic-16 & 93,56 & 88,84 & 99,20 & 75,69 \\
\hline ene-17 & 84,69 & 73,44 & 99,51 & 54,44 \\
\hline feb-17 & 79,67 & 69,90 & 97,06 & 52,21 \\
\hline mar-17 & 72,22 & 58,33 & 98,67 & 37,58 \\
\hline abr-17 & 51,11 & 35,13 & 85,81 & 22,46 \\
\hline may-17 & 64,45 & 47,49 & 97,72 & 30,62 \\
\hline oct-17 & 56,92 & 56,92 & 87,15 & 26,93 \\
\hline nov-17 & 77,16 & 77,16 & 99,36 & 42,97 \\
\hline dic-17 & 88,22 & 88,22 & 98,75 & 67,84 \\
\hline ene-18 & 90,74 & 90,73 & 98,63 & 72,80 \\
\hline feb-18 & 81,14 & 81,14 & 100,00 & 51,26 \\
\hline mar-18 & 85,17 & 85,17 & 99,91 & 58,51 \\
\hline abr-18 & 82,87 & 82,87 & 100,00 & 50,20 \\
\hline may-18 & 77,49 & 77,49 & 99,83 & 45,02 \\
\hline
\end{tabular}


Capítulo 3. Análisis del Caso en Estudio

Tabla 10. Datos climáticos utilizados en la investigación. Velocidad del viento

\begin{tabular}{|c|c|c|c|c|}
\hline & $V(m / s)$ & V día $(\mathrm{m} / \mathrm{s})$ & V noche $(\mathrm{m} / \mathrm{s})$ & $V \max (\mathrm{m} / \mathrm{s})$ \\
\hline oct-12 & 1,37 & 1,87 & 0,87 & 5,68 \\
\hline nov-12 & 1,61 & 2,04 & 1,19 & 6,07 \\
\hline dic-12 & 2,05 & 2,44 & 1,65 & 6,21 \\
\hline ene-13 & 2,48 & 2,81 & 2,14 & 7,12 \\
\hline feb-13 & 2,25 & 2,79 & 1,70 & 7,26 \\
\hline mar-13 & 3,02 & 3,73 & 2,32 & 9,20 \\
\hline abr-13 & 2,77 & 3,39 & 2,14 & 8,42 \\
\hline may-13 & 1,80 & 2,25 & 1,35 & 6,17 \\
\hline oct-13 & 1,48 & 2,00 & 0,95 & 5,73 \\
\hline nov-13 & 2,15 & 2,62 & 1,72 & 7,17 \\
\hline dic-13 & 1,89 & 2,12 & 1,67 & 5,77 \\
\hline ene-14 & 2,76 & 3,22 & 2,31 & 7,80 \\
\hline feb-14 & 3,56 & 4,28 & 2,84 & 9,72 \\
\hline mar-14 & 2,51 & 3,10 & 1,91 & 7,89 \\
\hline$a b r-14$ & 2,12 & 2,71 & 1,55 & 7,23 \\
\hline may-14 & 2,19 & 2,75 & 1,63 & 7,31 \\
\hline oct-14 & 1,39 & 1,79 & 1,45 & 5,25 \\
\hline nov-14 & 1,94 & 2,32 & 0,97 & 6,39 \\
\hline dic-14 & 1,05 & 1,26 & 0,93 & 4,41 \\
\hline ene-15 & 1,55 & 1,93 & 1,22 & 5,33 \\
\hline feb-15 & 2,61 & 3,13 & 2,12 & 7,71 \\
\hline mar-15 & 1,73 & 2,12 & 1,34 & 6,26 \\
\hline abr-15 & 1,63 & 2,07 & 1,21 & 6,26 \\
\hline may-15 & 1,81 & 2,23 & 1,26 & 6,88 \\
\hline oct-15 & 1,41 & 1,72 & 1,11 & 5,64 \\
\hline nov-15 & 1,13 & 1,25 & 1,12 & 4,31 \\
\hline dic-15 & 0,81 & 0,97 & 0,67 & 3,53 \\
\hline ene-16 & 2,21 & 2,53 & 1,89 & 6,82 \\
\hline feb-16 & 2,84 & 3,30 & 2,41 & 8,02 \\
\hline mar-16 & 2,03 & 2,66 & 1,44 & 7,14 \\
\hline abr-16 & 1,91 & 2,67 & 1,18 & 7,49 \\
\hline may-16 & 1,57 & 2,13 & 1,02 & 5,79 \\
\hline oct-16 & 0,87 & 1,08 & 0,67 & 4,22 \\
\hline nov-16 & 1,35 & 1,61 & 1,24 & 3,95 \\
\hline dic-16 & 0,87 & 0,99 & 0,77 & 1,81 \\
\hline ene-17 & 1,01 & 1,31 & 0,74 & 2,53 \\
\hline feb-17 & 2,52 & 2,79 & 2,27 & 4,48 \\
\hline mar-17 & 2,14 & 2,69 & 1,62 & 4,15 \\
\hline abr-17 & 2,11 & 2,53 & 1,69 & 3,86 \\
\hline may-17 & 1,61 & 2,07 & 1,16 & 4,92 \\
\hline oct-17 & 1,22 & 1,50 & 1,21 & 5,22 \\
\hline nov-17 & 1,07 & 1,42 & 0,69 & 4,89 \\
\hline dic-17 & 1,96 & 2,28 & 1,66 & 4,94 \\
\hline ene-18 & 1,89 & 2,23 & 1,58 & 3,73 \\
\hline feb-18 & 1,88 & 2,42 & 1,37 & 6,32 \\
\hline mar-18 & 3,66 & 4,38 & 2,99 & 10,33 \\
\hline abr-18 & 2,19 & 2,77 & 1,63 & 7,49 \\
\hline may-18 & 1,67 & 2,00 & 1,35 & 6,46 \\
\hline
\end{tabular}


Capítulo 3. Análisis del Caso en Estudio

Tabla 11. Datos climáticos. Recorrido, precipitación, horas de sol y radiación

\begin{tabular}{|c|c|c|c|c|}
\hline & Recorrido viento (km) & Precipitación acumulada (mm) & Horas de sol & Radiación $\left(\mathrm{W} / \mathrm{m}^{2}\right)$ \\
\hline oct-12 & 118,32 & 72,60 & 8,80 & 125,34 \\
\hline nov-12 & 139,40 & 60,40 & 6,45 & 73,14 \\
\hline dic-12 & 176,66 & 21,40 & 5,35 & 53,15 \\
\hline ene-13 & 213,92 & 36,80 & 5,87 & 60,12 \\
\hline feb-13 & 193,99 & 31,20 & 8,28 & 92,29 \\
\hline mar-13 & 261,08 & 117,96 & 9,07 & 112,62 \\
\hline$a b r-13$ & 239,02 & 28,60 & 11,00 & 187,67 \\
\hline may-13 & 155,84 & 27,99 & 11,93 & 228,11 \\
\hline oct-13 & 127,66 & 23,20 & 8,01 & 117,44 \\
\hline nov-13 & 185,72 & 3,20 & 6,66 & 81,20 \\
\hline dic-13 & 163,68 & 1,80 & 5,54 & 62,62 \\
\hline ene-14 & 238,67 & 22,80 & 5,27 & 56,16 \\
\hline feb-14 & 307,51 & 48,16 & 7,10 & 93,08 \\
\hline mar-14 & 216,60 & 11,00 & 9,69 & 174,56 \\
\hline abr-14 & 182,88 & 22,40 & 10,69 & 209,40 \\
\hline may-14 & 188,84 & 18,80 & 12,41 & 281,26 \\
\hline oct-14 & 119,81 & 37,00 & 8,54 & 130,57 \\
\hline nov-14 & 167,33 & 71,40 & 5,66 & 63,15 \\
\hline dic-14 & 90,74 & 17,20 & 5,46 & 55,53 \\
\hline ene-15 & 134,24 & 28,00 & 6,21 & 74,94 \\
\hline feb-15 & 225,47 & 16,40 & 7,66 & 109,00 \\
\hline mar-15 & 149,70 & 16,80 & 9,45 & 171,80 \\
\hline abr-15 & 140,67 & 66,00 & 10,72 & 212,32 \\
\hline may-15 & 156,35 & 19,80 & 12,44 & 302,81 \\
\hline oct-15 & 121,37 & 54,20 & 8,17 & 134,16 \\
\hline nov-15 & 98,00 & 46,80 & 6,32 & 79,71 \\
\hline dic-15 & 70,34 & 18,40 & 5,22 & 55,03 \\
\hline ene-16 & 190,85 & 116,00 & 5,45 & 57,01 \\
\hline feb-16 & 245,64 & 38,80 & 7,13 & 106,38 \\
\hline mar-16 & 175,29 & 32,20 & 9,52 & 166,79 \\
\hline abr-16 & 164,93 & 99,40 & 10,42 & 208,60 \\
\hline may-16 & 135,35 & 47,46 & 11,78 & 253,32 \\
\hline oct-16 & 74,65 & 46,20 & 8,60 & 149,04 \\
\hline nov-16 & 116,31 & 48,87 & 6,20 & 80,38 \\
\hline dic-16 & 75,56 & 12,63 & 5,84 & 61,61 \\
\hline ene-17 & 87,43 & 10,38 & 6,59 & 78,91 \\
\hline feb-17 & 217,31 & 39,99 & 7,51 & 118,25 \\
\hline mar-17 & 184,88 & 6,00 & 9,42 & 165,47 \\
\hline$a b r-17$ & 182,50 & 3,80 & 11,54 & 271,82 \\
\hline may-17 & 139,29 & 42,00 & 11,89 & 262,36 \\
\hline oct-17 & 105,13 & 7,20 & 9,06 & 160,79 \\
\hline nov-17 & 92,33 & 17,60 & 7,54 & 105,79 \\
\hline dic-17 & 169,67 & 26,26 & 5,81 & 63,91 \\
\hline ene-18 & 163,66 & 51,42 & 6,16 & 68,53 \\
\hline feb-18 & 162,25 & 37,64 & 7,75 & 118,13 \\
\hline mar-18 & 316,42 & 111,60 & 8,93 & 154,29 \\
\hline abr-18 & 188,87 & 69,20 & 10,53 & 212,70 \\
\hline may-18 & 144,48 & 80,40 & 11,72 & 270,36 \\
\hline
\end{tabular}


A continuación se muestran las gráficas de los datos tabulados.

En la Figura 47, se observa como los grados día calculados a partir de las temperaturas medias diarias son ligeramente inferiores a los grados día calculados a partir de las temperaturas cada media hora.

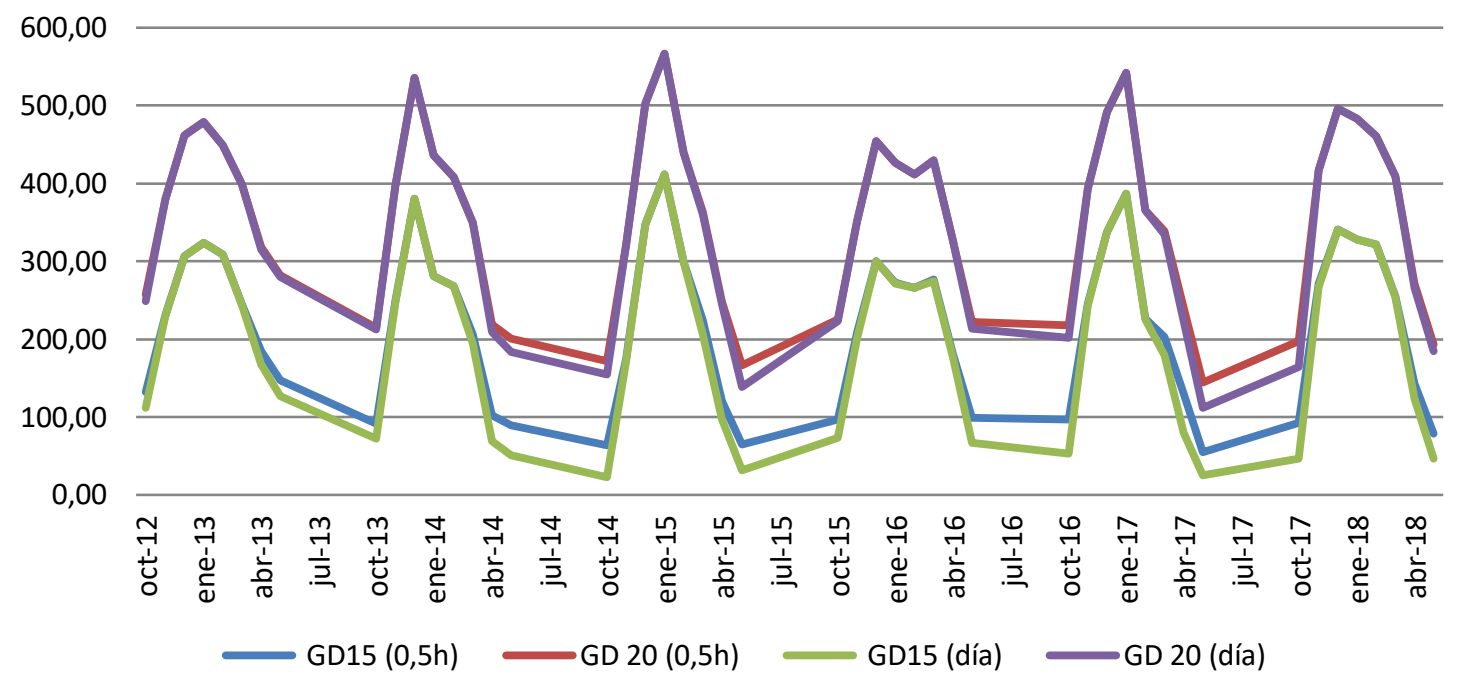

Figura 47. Grados día en base 15 y 20.

La Figura 48, representa las temperaturas medias mensuales, medias diarias, máximas y mínimas.

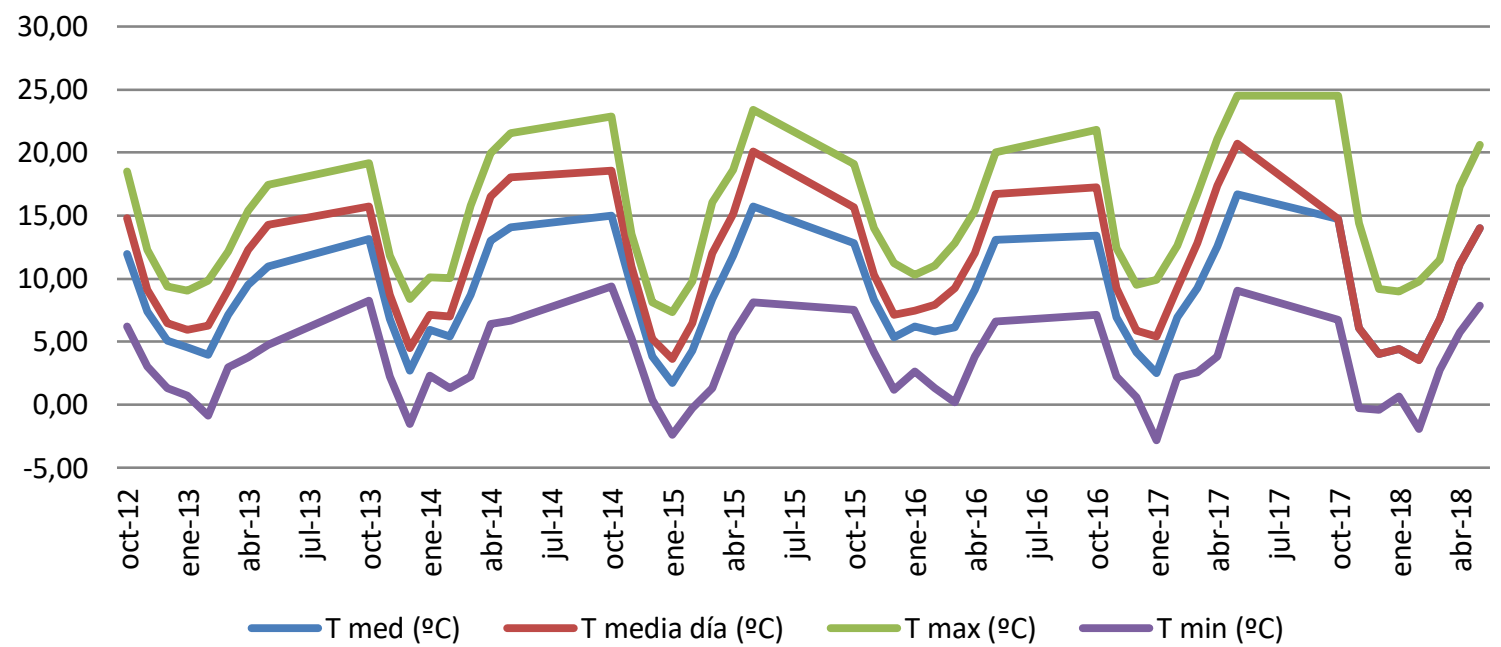

Figura 48. Temperaturas (으) 
La Figura 49, muestra la humedad relativa media mensuales, media diaria, máxima y mínima.

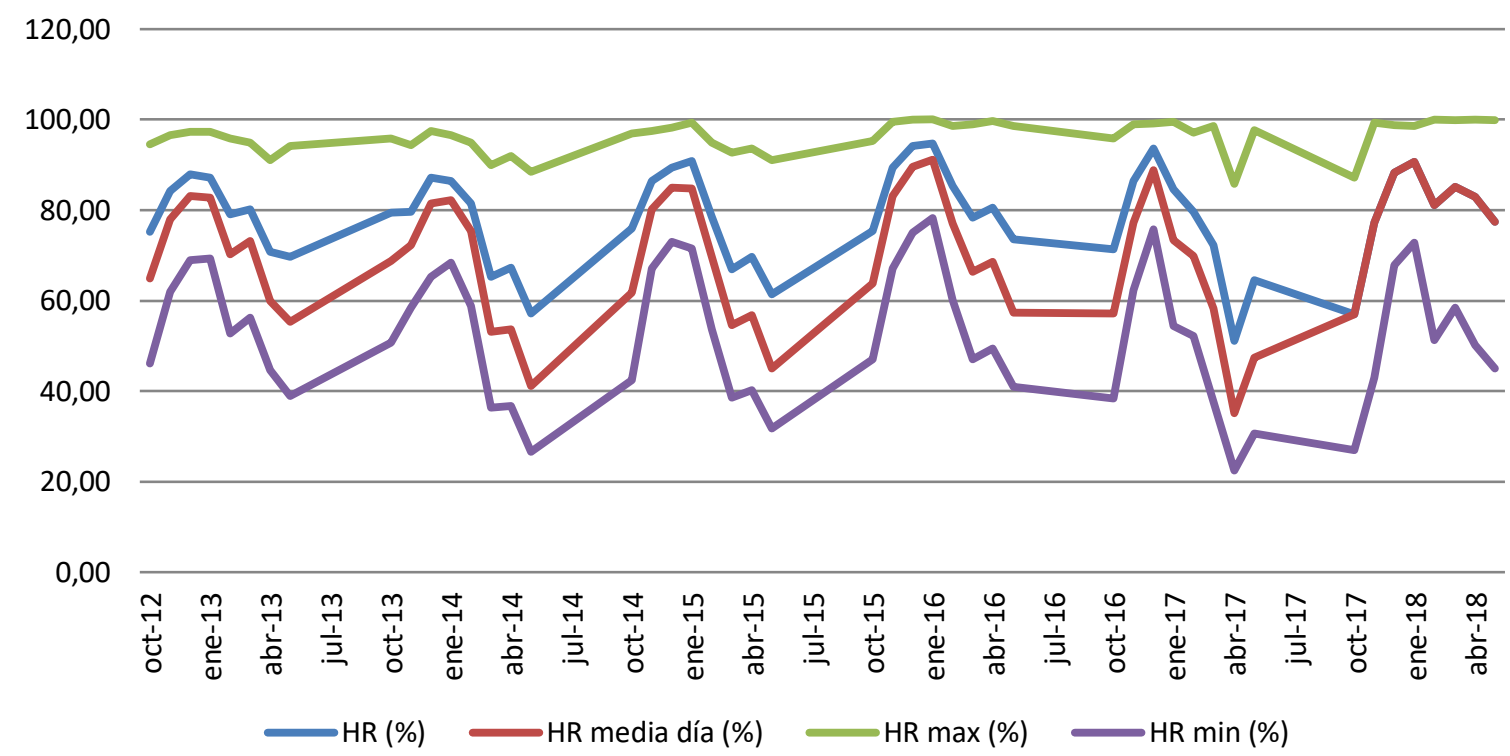

Figura 49. Humedad Relativa (\%)

La Figura 50, expone las velocidades del viento medias mensuales, medias diurnas, medias nocturnas y máximas.

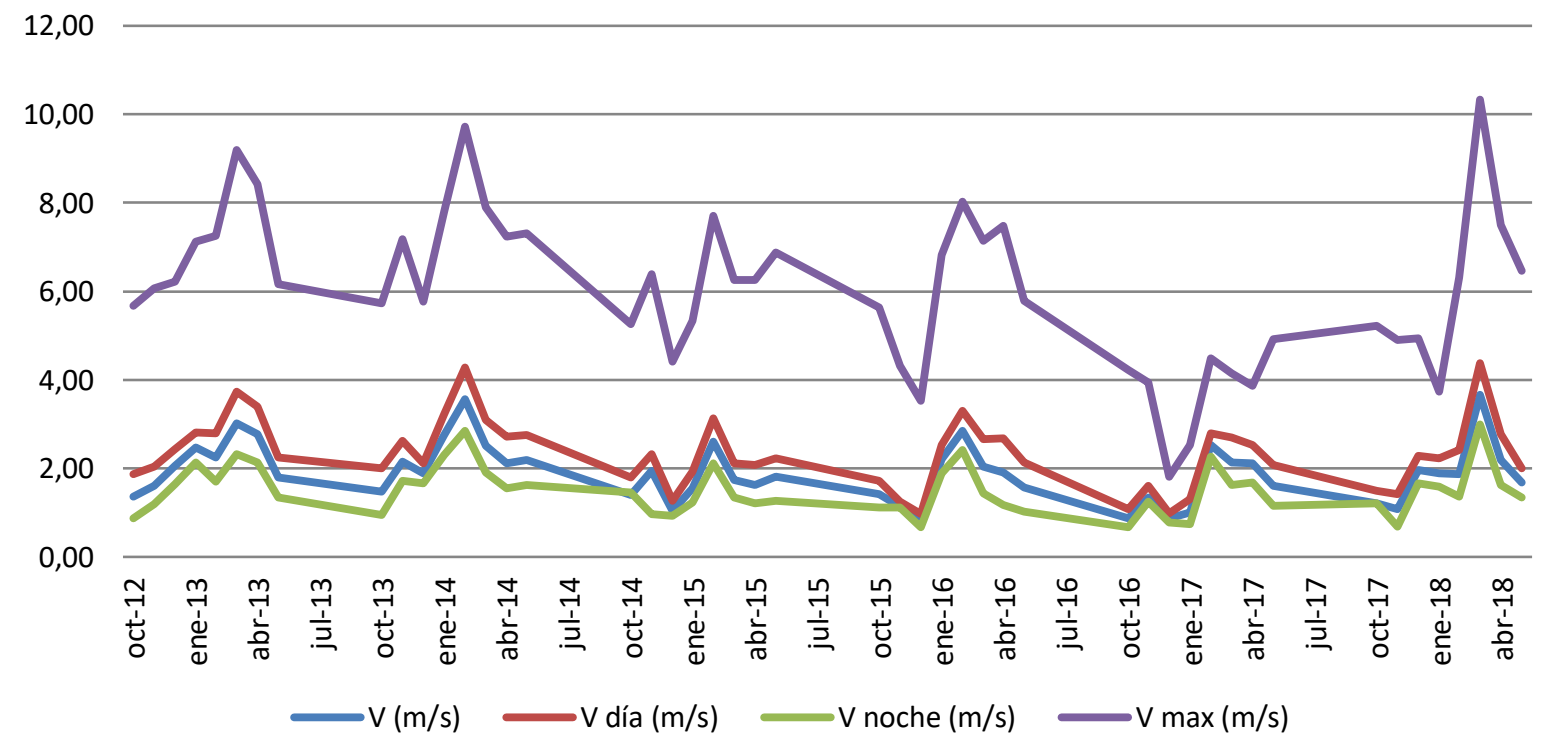

Figura 50. Velocidad del viento $(\mathrm{m} / \mathrm{s})$ 
En la Figura 51, se grafican el recorrido del viento en $\mathrm{km}$ y la Radiación media mensual en $\mathrm{W} / \mathrm{m}^{2}$.

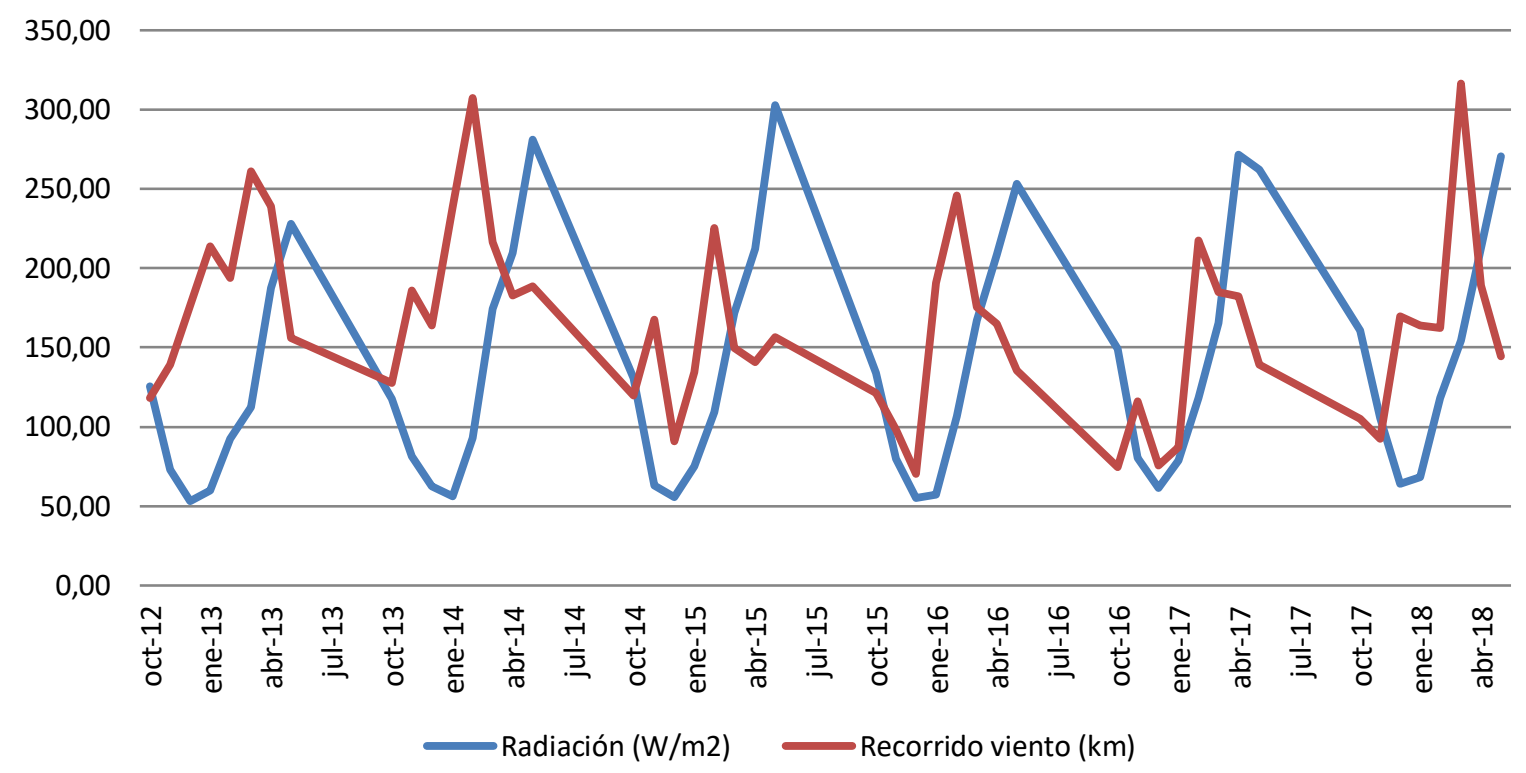

Figura 51. Recorrido del viento $(\mathrm{km})$ y Radiación $\left(\mathrm{W} / \mathrm{m}^{2}\right)$

La Figura 52, muestra la precipitación acumulada mensual $(\mathrm{mm})$ y las horas de sol mensuales (h).

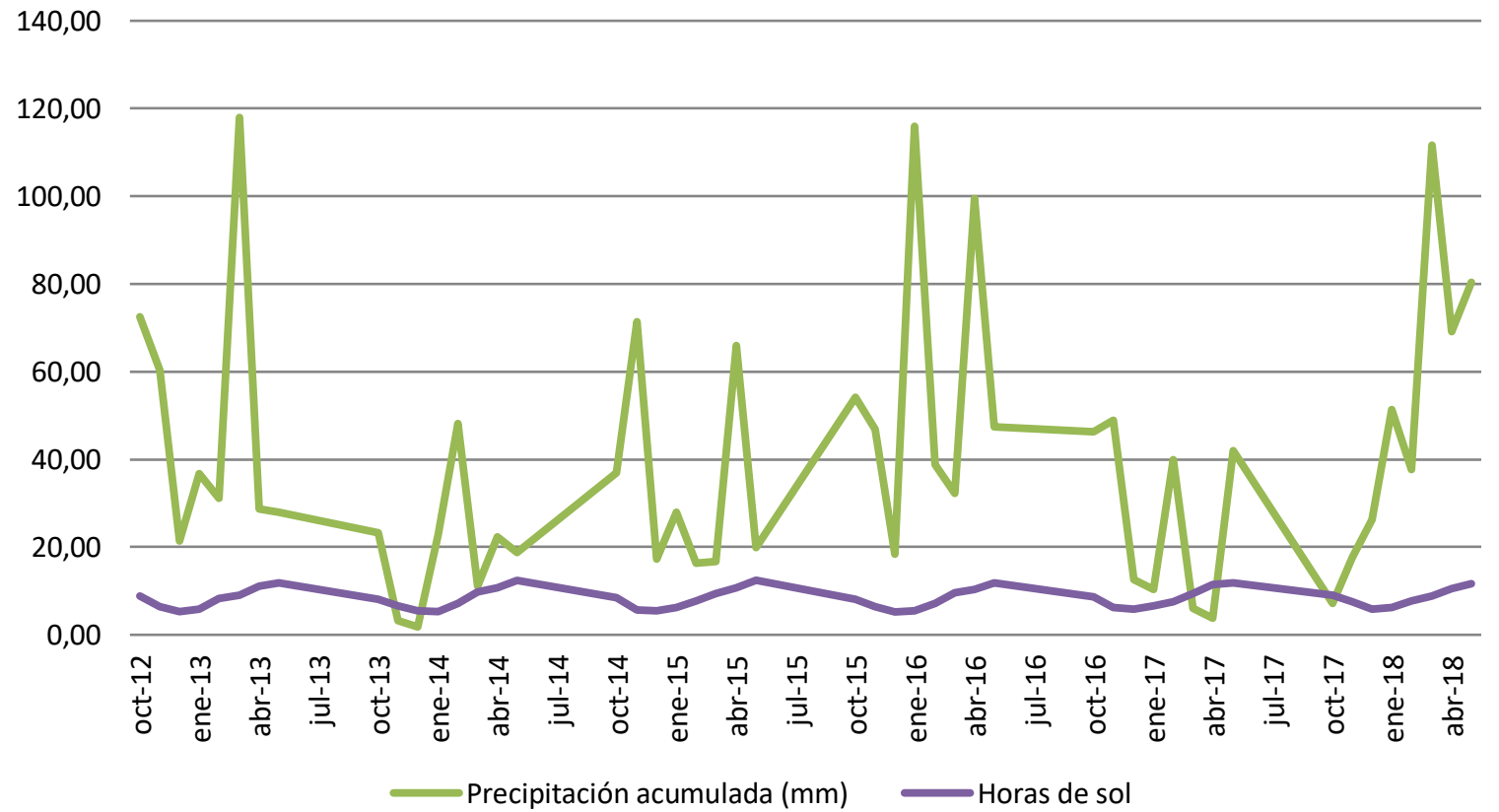

Figura 52. Precipitación acumulada (mm) y Horas de sol 


\subsubsection{Consumos térmicos anteriores y posteriores a la red}

Se recopilaron los consumos térmicos mensuales desde octubre de 2012 a mayo de 2018, correspondientes a los doce edificios del Campus Miguel Delibes y a los once edificios del Campus del Río Esgueva, estos datos fueron facilitados por la Universidad de Valladolid. La red de calor fue construida en el año 2015, por lo que las temporadas de calefacción de octubre de 2012 a mayo de 2013 y de octubre de 2013 a mayo de 2014, se consideraron como los periodos de referencia anteriores a la red y las temporadas octubre 2015 - mayo 2016, octubre 2016 - mayo 2017 y octubre 2017 - mayo 2018, como periodos posteriores.

La temporada desde octubre de 2014 hasta mayo de 2015, se considera periodo de puesta en marcha de la red de calor y los datos no han sido tenidos en cuenta.

En las siguientes tablas se muestran los datos de consumos facilitados.

Las Tablas 12, 13, 14, son las relativas a los consumos de los edificios del Campus Miguel Delibes, la Tabla 12 muestra los consumos de los combustibles fósiles, en este caso, todos los consumos se deben al gas natural, la Tabla 13, recoge los consumos de biomasa y la Tabla 14 agrupa el consumo térmico total de los edificios del Campus en kWh.

Las tablas 15, 16, 17, son las relativas a los consumos de los edificios del Campus Río Esgueva, la Tabla 15 muestra los consumos de los combustibles fósiles, debidos al consumo de gas natural y gasóleo, la Tabla 16, recoge los consumos de biomasa y la Tabla 17 agrupa el consumo térmico total de los edificios del Campus en kWh. 
Capítulo 3. Análisis del Caso en Estudio

Tabla 12. Consumo de combustibles fósiles de los edificios del Campus Miguel Delibes (kWh)

\begin{tabular}{|c|c|c|c|c|c|c|c|c|c|c|c|c|}
\hline & Gas Natural & Gas Natural & Gas Natural & Gas Natural & Gas Natural & Gas Natural & Gas Natural & Gas Natural & Gas Natural & Gas Natural & Gas Natural & Gas Natural \\
\hline & D1 & D2 & D3 & D4 & D5 & D6 & D7 & D8 & D9 & D10 & D11 & D12 \\
\hline oct-12 & 52.823 & 2.973 & 15.679 & 38.678 & 5.298 & 65.093 & 75.227 & 28.190 & 16.335 & 9.525 & 15.176 & 20.755 \\
\hline nov-12 & 220.904 & 8.215 & 34.701 & 195.712 & 12.464 & 145.750 & 163.403 & 44.053 & 31.692 & 24.605 & 121.937 & 39.191 \\
\hline dic-12 & 228.313 & 11.245 & 47.474 & 176.685 & 16.625 & 194.289 & 217.741 & 58.473 & 42.168 & 51.330 & 93.881 & 52.395 \\
\hline ene-13 & 239.241 & 12.064 & 61.790 & 191.773 & 17.744 & 207.050 & 231.815 & 61.638 & 44.716 & 43.452 & 112.357 & 55.517 \\
\hline feb-13 & 273.273 & 11.615 & 51.895 & 201.662 & 17.029 & 198.500 & 222.100 & 71.642 & 42.732 & 53.877 & 146.609 & 53.024 \\
\hline mar-13 & 210.397 & 9.500 & 35.453 & 143.416 & 13.786 & 160.192 & 178.875 & 64.884 & 34.135 & 36.141 & 90.810 & 42.283 \\
\hline abr-13 & 219.730 & 6.534 & 33.758 & 118.693 & 9.765 & 114.486 & 128.571 & 45.407 & 25.105 & 23.334 & 67.242 & 31.248 \\
\hline may-13 & 135.157 & 5.196 & 16.401 & 57.071 & 7.775 & 91.192 & 102.436 & 20.377 & 20.021 & 5.546 & 35.376 & 24.925 \\
\hline oct-13 & 35.931 & 3.398 & 9.887 & 51.998 & 5.004 & 58.407 & 65.408 & 21.697 & 12.629 & 9.525 & 7.360 & 15.683 \\
\hline nov-13 & 0 & 8.280 & 32.104 & 103.055 & 12.654 & 149.340 & 168.407 & 32.562 & 33.422 & 24.605 & 86.849 & 41.737 \\
\hline dic-13 & 322.634 & 14.205 & 64.828 & 225.143 & 20.880 & 243.583 & 272.681 & 76.564 & 52.571 & 51.330 & 128.882 & 65.261 \\
\hline ene-14 & 320.896 & 11.133 & 59.681 & 153.040 & 16.068 & 186.405 & 207.919 & 67.774 & 39.501 & 43.452 & 938 & 48.884 \\
\hline feb-14 & 307.368 & 351 & 53.522 & 201.660 & 14.051 & 165.006 & 185.496 & 75.981 & 36.368 & 53.877 & 160.288 & 45.304 \\
\hline mar-14 & 165.884 & 6.636 & 20.039 & 116.269 & 10.258 & 121.453 & 137.241 & 50.114 & 27.453 & 36.141 & 92.685 & 34.339 \\
\hline abr-14 & 156.449 & 3.899 & 25.860 & 53.303 & 5.701 & 66.396 & 74.250 & 20.141 & 14.255 & 23.334 & 53.233 & 17.680 \\
\hline may-14 & 28.883 & 3.318 & 9.813 & 32.040 & 4.886 & 57.028 & 63.862 & 18.148 & 12.328 & 5.546 & 2.142 & 15.308 \\
\hline oct-15 & 0 & 0 & 0 & 0 & 0 & 0 & 0 & 0 & 0 & 0 & 0 & 0 \\
\hline nov-15 & 0 & 0 & 0 & 0 & 0 & 0 & 0 & 0 & 0 & 0 & 0 & 0 \\
\hline dic- 15 & 0 & 0 & 0 & 0 & 0 & 0 & 0 & 0 & 0 & 0 & 0 & 0 \\
\hline ene-16 & 0 & 0 & 0 & 0 & 0 & 0 & 0 & 0 & 0 & 0 & 0 & 0 \\
\hline feb-16 & 86.660 & 7.347 & 24.492 & 46.776 & 16.962 & 101.645 & 60.146 & 20.417 & 10.984 & 13.866 & 76.228 & 12.177 \\
\hline mar-16 & 12.299 & 24 & 666 & 14.117 & 3.621 & 15.254 & 26.749 & 3.564 & 1.364 & 520 & 6.040 & 2.793 \\
\hline abr-16 & 325 & 422 & 2.038 & 714 & 1.356 & 2.159 & 2.760 & 211 & 1.242 & 114 & 284 & 0 \\
\hline may-16 & 195 & 0 & 0 & 16 & 1.510 & 41 & 170 & 0 & 81 & 0 & 0 & 0 \\
\hline oct-16 & 23.450 & 160 & 3.032 & 11.633 & 5.921 & 1.656 & 2.264 & 7.817 & 3.328 & 864 & 12.513 & 1.800 \\
\hline nov-16 & 9.577 & 672 & 11.777 & 1.264 & 88 & 9.745 & 496 & 10.737 & 232 & 288 & 3.736 & 0 \\
\hline dic- 16 & 2.480 & 760 & 10.865 & 5.785 & 16 & 536 & 536 & 1.536 & 160 & 16 & 2.232 & 72 \\
\hline ene-17 & 3.600 & 0 & 0 & 88 & 56 & 1.408 & 3.984 & 576 & 0 & 8 & 10.209 & 128 \\
\hline feb-17 & 88 & 584 & 3.368 & 136 & 1.120 & 5.753 & 760 & 328 & 0 & 8 & 64 & 63 \\
\hline mar-17 & 1.184 & 448 & 704 & 0 & 32 & 0 & 536 & 272 & 208 & 344 & 0 & 265 \\
\hline abr-17 & 360 & 0 & 1.216 & 536 & 8 & 96 & 0 & 144 & 0 & 0 & 568 & 0 \\
\hline may-17 & 560 & 1.544 & 856 & 88 & 408 & 832 & 0 & 0 & 0 & 32 & 0 & 368 \\
\hline oct-17 & 15.266 & 8 & 0 & 56 & 4.889 & 0 & 384 & 0 & 2.160 & 0 & 0 & 0 \\
\hline nov-17 & 544 & 40 & 0 & 1.080 & 40 & 3.312 & 1.000 & 152 & 144 & 0 & 416 & 88 \\
\hline dic-17 & 1.872 & 0 & 0 & 1.080 & 0 & 0 & 2.088 & 328 & 128 & 24 & 2.032 & 0 \\
\hline ene-18 & 1.064 & 0 & 0 & 0 & 0 & 81 & 688 & 184 & 0 & 96 & 560 & 8 \\
\hline feb-18 & 848 & 0 & 0 & 512 & 56 & 0 & 3.376 & 912 & 0 & 40 & 0 & 0 \\
\hline mar-18 & 0 & 0 & 0 & 912 & 80 & 0 & 4.304 & 1.512 & 624 & 272 & 2.544 & 888 \\
\hline abr-18 & 0 & 0 & 0 & 0 & 0 & 0 & 384 & 168 & 56 & 136 & 440 & 112 \\
\hline may-18 & 0 & 0 & 0 & 0 & 0 & 0 & 0 & 0 & 0 & 0 & 0 & 0 \\
\hline
\end{tabular}


Capítulo 3. Análisis del Caso en Estudio

Tabla 13. Consumo de biomasa de los edificios del Campus Miguel Delibes ( $\mathrm{kWh}$ )

\begin{tabular}{|c|c|c|c|c|c|c|c|c|c|c|c|c|}
\hline & Gas Natural & Gas Natural & Gas Natural & Gas Natural & Gas Natural & Gas Natural & Gas Natural & Gas Natural & Gas Natural & Gas Natural & Gas Natural & Gas Natural \\
\hline & D1 & D2 & D3 & D4 & D5 & D6 & D7 & D8 & D9 & D10 & D11 & D12 \\
\hline oct-12 & 0 & 0 & 0 & 0 & 0 & 0 & 0 & 0 & 0 & 0 & 0 & 0 \\
\hline nov-12 & 0 & 0 & 0 & 0 & 0 & 0 & 0 & 0 & 0 & 0 & 0 & 0 \\
\hline dic-12 & 0 & 0 & 0 & 0 & 0 & 0 & 0 & 0 & 0 & 0 & 0 & 0 \\
\hline ene-13 & 0 & 0 & 0 & 0 & 0 & 0 & 0 & 0 & 0 & 0 & 0 & 0 \\
\hline feb-13 & 0 & 0 & 0 & 0 & 0 & 0 & 0 & 0 & 0 & 0 & 0 & 0 \\
\hline mar-13 & 0 & 0 & 0 & 0 & 0 & 0 & 0 & 0 & 0 & 0 & 0 & 0 \\
\hline$a b r-13$ & 0 & 0 & 0 & 0 & 0 & 0 & 0 & 0 & 0 & 0 & 0 & 0 \\
\hline may-13 & 0 & 0 & 0 & 0 & 0 & 0 & 0 & 0 & 0 & 0 & 0 & 0 \\
\hline oct-13 & 0 & 0 & 0 & 0 & 0 & 0 & 0 & 0 & 0 & 0 & 0 & 0 \\
\hline nov-13 & 0 & 0 & 0 & 0 & 0 & 0 & 0 & 0 & 0 & 0 & 0 & 0 \\
\hline dic-13 & 0 & 0 & 0 & 0 & 0 & 0 & 0 & 0 & 0 & 0 & 0 & 0 \\
\hline ene-14 & 0 & 0 & 0 & 0 & 0 & 0 & 0 & 0 & 0 & 0 & 0 & 0 \\
\hline feb-14 & 0 & 0 & 0 & 0 & 0 & 0 & 0 & 0 & 0 & 0 & 0 & 0 \\
\hline mar-14 & 0 & 0 & 0 & 0 & 0 & 0 & 0 & 0 & 0 & 0 & 0 & 0 \\
\hline abr-14 & 0 & 0 & 0 & 0 & 0 & 0 & 0 & 0 & 0 & 0 & 0 & 0 \\
\hline may-14 & 0 & 0 & 0 & 0 & 0 & 0 & 0 & 0 & 0 & 0 & 0 & 0 \\
\hline oct-15 & 34.650 & 810 & 0 & 30.770 & 4.908 & 32.180 & 22.220 & 8.364 & 10.847 & 4.183 & 8.810 & 6.590 \\
\hline nov-15 & 162.230 & 2.643 & 28.683 & 117.720 & 16.749 & 128.080 & 128.080 & 48.422 & 35.070 & 26.851 & 71.160 & 36.550 \\
\hline dic-15 & 192.680 & 11.959 & 50.191 & 91.520 & 16.244 & 147.210 & 124.770 & 52.355 & 21.527 & 32.026 & 68.390 & 34.820 \\
\hline ene-16 & 182.730 & 6.666 & 38.231 & 116.430 & 10.727 & 172.470 & 163.370 & 56.577 & 27.599 & 33.481 & 77.420 & 39.180 \\
\hline feb-16 & 205.420 & 5.112 & 43.938 & 149.030 & 13.214 & 247.290 & 237.190 & 73.275 & 44.179 & 40.181 & 111.170 & 46.300 \\
\hline mar-16 & 183.100 & 5.215 & 41.109 & 118.560 & 15.045 & 211.400 & 173.610 & 61.801 & 35.187 & 39.467 & 80.530 & 41.970 \\
\hline abr-16 & 140.490 & 3.519 & 22.617 & 90.660 & 12.416 & 148.810 & 137.130 & 42.874 & 28.354 & 29.343 & 60.370 & 27.410 \\
\hline may-16 & 50.100 & 405 & 7.268 & 30.710 & 6.416 & 28.010 & 25.020 & 8.549 & 7.634 & 6.620 & 11.790 & 6.310 \\
\hline oct-16 & 36.970 & 5 & 679 & 16.490 & 5.198 & 19.540 & 31.170 & 0 & 6.839 & 5.397 & 10.900 & 5.800 \\
\hline nov-16 & 175.520 & 4.391 & 23.675 & 137.030 & 9.555 & 181.180 & 175.080 & 53.081 & 43.045 & 30.495 & 97.720 & 35.820 \\
\hline dic-16 & 230.410 & 6.637 & 34.750 & 110.200 & 17.894 & 206.960 & 145.300 & 83.456 & 37.469 & 42.230 & 61.860 & 39.800 \\
\hline ene-17 & 241.460 & 7.617 & 47.454 & 231.590 & 20.262 & 272.070 & 254.280 & 95.488 & 55.750 & 51.725 & 133.300 & 47.420 \\
\hline feb-17 & 181.370 & 6.403 & 29.736 & 137.800 & 12.008 & 185.560 & 181.790 & 66.543 & 42.290 & 35.279 & 88.590 & 33.330 \\
\hline mar-17 & 142.890 & 7.173 & 24.475 & 104.060 & 12.183 & 147.550 & 150.360 & 61.320 & 34.922 & 30.031 & 69.390 & 32.930 \\
\hline$a b r-17$ & 56.230 & 3.584 & 15.456 & 60.510 & 8.722 & 64.110 & 55.650 & 28.029 & 8.288 & 12.121 & 31.820 & 12.700 \\
\hline may-17 & 37.840 & 22 & 11.266 & 22.340 & 7.177 & 21.230 & 14.320 & 9.028 & 1.706 & 4.079 & 9.030 & 1.950 \\
\hline oct-17 & 27.790 & 2 & 4.697 & 9.650 & 2.131 & 10.750 & 9.500 & 5.806 & 2.406 & 3.499 & 5.700 & 3.530 \\
\hline nov-17 & 160.230 & 4.173 & 37.870 & 132.050 & 11.944 & 144.720 & 123.350 & 64.210 & 36.958 & 27.035 & 71.140 & 33.700 \\
\hline dic-17 & 249.300 & 10.407 & 48.468 & 158.000 & 15.343 & 222.510 & 170.930 & 111.222 & 53.691 & 41.827 & 122.790 & 46.710 \\
\hline ene-18 & 241.600 & 9.738 & 48.828 & 188.850 & 14.960 & 275.170 & 188.200 & 90.885 & 45.982 & 43.660 & 122.850 & 51.520 \\
\hline feb-18 & 245.330 & 10.737 & 48.728 & 197.930 & 19.500 & 293.190 & 241.850 & 94.399 & 43.599 & 44.721 & 137.100 & 59.290 \\
\hline mar-18 & 208.040 & 939 & 28.432 & 160.000 & 15.575 & 219.610 & 213.010 & 76.142 & 50.667 & 38.651 & 108.100 & 51.330 \\
\hline abr-18 & 132.930 & 5.172 & 19.765 & 510 & .055 & 102.000 & 98.630 & 36.304 & 23.951 & 23.342 & 55.140 & 29.150 \\
\hline may-18 & 53.590 & 7 & 13.337 & 34.320 & 13.273 & 29.180 & 23.570 & 15.896 & 7.171 & 6.241 & 15.860 & 5.570 \\
\hline
\end{tabular}


Capítulo 3. Análisis del Caso en Estudio

Tabla 14. Consumo total térmico de los edificios del Campus Miguel Delibes (kWh)

\begin{tabular}{|c|c|c|c|c|c|c|c|c|c|c|c|c|}
\hline & GN+Biomasa & GN+Biomasa & N+Biomasa & GN+Biomasa & GN+Biomasa & GN+Biomasa & GN+Biomasa & GN+Biomasa & GN+Biomasa & GN+Biomasa & GN+Biomasa & GN+Biomasa \\
\hline & D1 & D2 & D3 & D4 & D5 & D6 & D7 & D8 & D9 & D10 & D11 & $\mathrm{D} 12$ \\
\hline oct-12 & 52.823 & 973 & 15.679 & 38.678 & 5.298 & 65.093 & 75.227 & 28.190 & 16.335 & 9.525 & 15.176 & 20.755 \\
\hline nov-12 & 220.904 & 8.215 & 34.701 & 195.712 & 12.464 & 145.750 & 163.403 & 44.053 & 1.692 & 24.605 & 121.937 & 39.191 \\
\hline dic-12 & 228.313 & 11.245 & 47.474 & 176.685 & 16.625 & 194.289 & 217.741 & 58.473 & 2.168 & 51.330 & 93.881 & 52.395 \\
\hline ene-13 & 239.241 & 12.064 & 61.790 & 191.773 & 7.744 & 207.050 & 231.815 & 61.638 & 4.716 & 43.452 & 112.357 & 55.517 \\
\hline feb-13 & 273.273 & 11.615 & 51.895 & 201.662 & 17.029 & 198.500 & 222.100 & 71.642 & 2.732 & 53.877 & 146.609 & 53.024 \\
\hline mar-13 & 210.397 & 500 & 35.453 & 143.416 & 13.786 & 160.192 & 178.875 & 4.884 & 135 & & & \\
\hline abr-13 & 30 & & 3.758 & & & & 128 & 5.407 & & & & \\
\hline may-13 & 5.157 & & .401 & .071 & 775 & 192 & 102.436 & 0.377 & & 546 & & \\
\hline oct-13 & & & & & 04 & & & .697 & & 25 & & \\
\hline nov-13 & 0 & & & & & & & & & & & \\
\hline dic-13 & 322.634 & & & & & & & & & & & \\
\hline ene-14 & & & & & & & & & & & & \\
\hline feb-14 & & & & & & & & & & & & \\
\hline mar-14 & & & & & & & & & & & & \\
\hline abr-14 & 156. & & .860 & & & & & & & & & \\
\hline may-14 & & & 813 & & & & & & & & & \\
\hline oct-15 & 34.650 & & 0 & & 908 & & 22.220 & 364 & & 183 & & 590 \\
\hline nov-15 & 162.230 & 2.643 & 28.683 & 117.720 & 16.749 & 080 & 128.080 & 48.422 & .070 & 5.851 & 160 & 36.550 \\
\hline dic- 15 & 192.680 & 11. & & & 244 & & 124.770 & 2.355 & 527 & & & .820 \\
\hline ene-1 & 2.730 & & 231 & & 727 & 470 & 163.370 & .577 & & & & 180 \\
\hline feb-16 & 2.080 & & & & 176 & & & 692 & & & & .477 \\
\hline mar-16 & 5.399 & & 41.775 & & 666 & & 200 & .365 & & & & 44.763 \\
\hline abr-16 & 0.815 & & 655 & & 3.772 & 150 & 139 & .085 & 596 & .457 & & 7.410 \\
\hline may-16 & .295 & & 68 & .726 & 926 & 051 & 190 & 549 & 715 & 620 & & 6.310 \\
\hline oct-16 & 0.420 & & 711 & .123 & 11.119 & 21.196 & 33.434 & 817 & 167 & 261 & 413 & 7.600 \\
\hline nov-16 & 185.097 & .063 & .452 & 138.294 & 643 & 190.925 & 175.576 & 3.818 & 277 & .783 & & 35.820 \\
\hline dic-16 & .890 & 97 & 5.615 & & .910 & 207.496 & 145.836 & .992 & 629 & 246 & 092 & .872 \\
\hline ene-17 & .060 & & .454 & & 318 & 478 & 258.264 & .064 & .750 & .733 & 509 & \\
\hline feb-17 & & & & & & & & & & & & 33.393 \\
\hline mar-1 & 4.074 & & 179 & & & & & & & & & 195 \\
\hline abr-17 & 6.590 & & & & & & & 173 & & & & 12.700 \\
\hline may-17 & & 1.566 & & & & & & & & & & 318 \\
\hline oct-17 & & & & & & & & & & & & 530 \\
\hline nov-17 & & & & & & & & & & & & \\
\hline dic-17 & & & & & & & & & & & & 46.710 \\
\hline ene-18 & 242.664 & & & & & & 188.888 & & & & & 51.528 \\
\hline feb-18 & & & & & & & & & & & & 9.290 \\
\hline mar-18 & & & & & & & & & & & & \\
\hline abr-18 & & 5.172 & & & & & & & & & & 29.262 \\
\hline may-18 & 53.590 & 7 & 13.337 & & 13.273 & & 23.570 & 15.896 & 7.171 & 6.241 & 15.860 & 5.570 \\
\hline
\end{tabular}


Capítulo 3. Análisis del Caso en Estudio

Tabla 15. Consumo de combustibles fósiles de los edificios del Campus Río Esgueva (kWh)

\begin{tabular}{|c|c|c|c|c|c|c|c|c|c|c|c|}
\hline & Gasóleo & Gasóleo & Gas Natural & Gasóleo & Gasóleo & Gas Natural & Gas Natural & Gas Natural & Gas Natural & Gasóleo & Gas Natural \\
\hline & $\mathrm{E} 1$ & E2 & E3 & E4 & E5 & E6 & E7 & E8 & E13 & E14 & E15 \\
\hline oct-12 & 18.417 & 36.834 & 17.828 & 14.142 & 117.869 & 26.717 & 7.328 & 44.728 & 26.441 & 25.019 & 14.487 \\
\hline nov-12 & 32.083 & 64.166 & 158.718 & 111.738 & 205.331 & 70.411 & 29.013 & 187.155 & 233.547 & 65.981 & 211.446 \\
\hline dic-12 & 16.491 & 47.219 & 168.403 & 153.434 & 303.000 & 69.423 & 34.243 & 192.809 & 246.803 & 70.700 & 285.072 \\
\hline ene-13 & 17.414 & 49.862 & 195.511 & 181.744 & 323.200 & 60.486 & 30.880 & 342.443 & 231.986 & 56.717 & 254.609 \\
\hline feb-13 & 16.595 & 84.570 & 241.484 & 239.369 & 296.940 & 77.600 & 32.427 & 348.845 & 231.133 & 54.283 & 314.998 \\
\hline mar-13 & 21.438 & 66.955 & 169.961 & 118.256 & 303.000 & 62.022 & 23.298 & 381.056 & 192.983 & 40.277 & 236.366 \\
\hline$a b r-13$ & 16.161 & 50.475 & 122.600 & 79.149 & 195.940 & 47.899 & 18.563 & 183.948 & 106.846 & 32.185 & 146.559 \\
\hline may-13 & 12.902 & 30.436 & 66.794 & 11.169 & 101.000 & 31.816 & 7.021 & 62.781 & 53.047 & 28.487 & 50.082 \\
\hline oct-13 & 6.409 & 18.951 & 8.427 & 25.730 & 81.374 & 20.432 & 12.346 & 39.057 & 22 & 1.616 & 2.235 \\
\hline nov-13 & 17.455 & 51.613 & 111.525 & 127.313 & 221.626 & 61.042 & 26.338 & 237.231 & 143.684 & 55.254 & 187.533 \\
\hline dic-13 & 26.636 & 120.015 & 235.091 & 148.502 & 303.000 & 86.228 & 41.230 & 443.980 & 273.337 & 69.059 & 318.094 \\
\hline ene-14 & 14.990 & 88.737 & 192.743 & 114.800 & 298.152 & 67.999 & 36.151 & 349.596 & 336.166 & 51.061 & 258.821 \\
\hline feb-14 & 14.276 & 84.512 & 242.403 & 109.572 & 204.363 & 79.509 & 29.124 & 496.930 & 259.725 & 53.630 & 276.638 \\
\hline mar-14 & 11.000 & 78.485 & 160.164 & 80.574 & 101.667 & 51.450 & 24.955 & 367.450 & 148.360 & 46.470 & 208.852 \\
\hline$a b r-14$ & 5.472 & 39.045 & 100.428 & 30.084 & 163.647 & 41.877 & 15.668 & 219.679 & 86.292 & 17.641 & 116.325 \\
\hline may-14 & 4.761 & 33.971 & 11.239 & 14.875 & 142.383 & 22.289 & 11.334 & 11.049 & 13.279 & 8.218 & 18.881 \\
\hline oct-15 & 0 & 0 & 0 & 0 & 0 & 0 & 0 & 0 & 0 & 0 & 0 \\
\hline nov-15 & 0 & 0 & 0 & 0 & 0 & 0 & 0 & 0 & 0 & 0 & 0 \\
\hline dic-15 & 0 & 0 & 0 & 0 & 0 & 0 & 0 & 0 & 0 & 0 & 0 \\
\hline ene-16 & 0 & 0 & 0 & 0 & 0 & 0 & 0 & 0 & 0 & 0 & 0 \\
\hline feb-16 & 10.217 & 65.280 & 65.139 & 104.006 & 94.059 & 25.685 & 30.727 & 69.449 & 99.226 & 37.866 & 44.811 \\
\hline mar-16 & 101 & 4.645 & 2.078 & 14.373 & 9.087 & 4.595 & 739 & 6.275 & 27.252 & 2.470 & 9.303 \\
\hline$a b r-16$ & 76 & 1.880 & 65 & 8.345 & 2.436 & 1.502 & 73 & 528 & 3.239 & 1.441 & 0 \\
\hline may-16 & 8 & 59 & 32 & 2.689 & 565 & 2.841 & 24 & 0 & 0 & 3.018 & 11.633 \\
\hline oct-16 & 378 & 4.695 & 6.169 & 5.050 & 23.832 & 9.665 & 4.184 & 14.513 & 5.081 & 2.706 & 8.497 \\
\hline nov-16 & 262 & 3.770 & 2.328 & 2.459 & 4.634 & 776 & 328 & 4.184 & 3.160 & 1.103 & 6.697 \\
\hline dic-16 & 0 & 1.079 & 888 & 13.261 & 2.999 & 16 & 48 & 424 & 120 & 3.832 & 4.136 \\
\hline ene-17 & 23 & 3.207 & 2.712 & 3.639 & 7.078 & 1.072 & 0 & 3.744 & 80 & 54 & 496 \\
\hline feb-17 & 39 & 2.529 & 1.016 & 5.991 & 1.234 & 40 & 0 & 3.304 & 600 & 31 & 0 \\
\hline mar-17 & 54 & 0 & 240 & 917 & 1.234 & 32 & 0 & 1.128 & 640 & 0 & 664 \\
\hline$a b r-17$ & 0 & 77 & 1.320 & 2.837 & 524 & 32 & 0 & 464 & 0 & 601 & 0 \\
\hline may-17 & 77 & 355 & 0 & 3.184 & 2.691 & 48 & 496 & 224 & 0 & 31 & 0 \\
\hline oct-17 & 0 & 0 & 80 & 0 & 0 & 11.185 & 3.048 & 1.808 & 0 & 0 & 672 \\
\hline nov-17 & 0 & 0 & 2.408 & 0 & 0 & 144 & 24 & 1.968 & 0 & 0 & 464 \\
\hline dic-17 & 0 & 0 & 408 & 0 & 0 & 104 & 0 & 2.056 & 0 & 0 & 320 \\
\hline ene-18 & 0 & 0 & 848 & 0 & 0 & 264 & 112 & 2.944 & 0 & 0 & 0 \\
\hline feb-18 & 0 & 0 & 1.208 & 0 & 0 & 72 & 128 & 944 & 0 & 0 & 16 \\
\hline mar-18 & 0 & 0 & 1.656 & 0 & 0 & 976 & 168 & 1.464 & 4.120 & 0 & 864 \\
\hline$a b r-18$ & 0 & 0 & 96 & 0 & 0 & 0 & 424 & 280 & 944 & 0 & 48 \\
\hline may-18 & 0 & 0 & 0 & 0 & 0 & 0 & 0 & 0 & 0 & 0 & 0 \\
\hline
\end{tabular}


Capítulo 3. Análisis del Caso en Estudio

Tabla 16. Consumo de biomasa de los edificios del Campus Río Esgueva (kWh)

\begin{tabular}{|c|c|c|c|c|c|c|c|c|c|c|c|}
\hline & Gasóleo & Gasóleo & Gas Natural & Gasóleo & Gasóleo & Gas Natural & Gas Natural & Gas Natural & Gas Natural & Gasóleo & Gas Natural \\
\hline & E1 & E2 & E3 & E4 & E5 & E6 & E7 & E8 & E13 & E14 & E15 \\
\hline oct-12 & 0 & 0 & 0 & 0 & 0 & 0 & 0 & 0 & 0 & 0 & 0 \\
\hline nov-12 & 0 & 0 & 0 & 0 & 0 & 0 & 0 & 0 & 0 & 0 & 0 \\
\hline dic- 12 & 0 & 0 & 0 & 0 & 0 & 0 & 0 & 0 & 0 & 0 & 0 \\
\hline ene-13 & 0 & 0 & 0 & 0 & 0 & 0 & 0 & 0 & 0 & 0 & 0 \\
\hline feb-13 & 0 & 0 & 0 & 0 & 0 & 0 & 0 & 0 & 0 & 0 & 0 \\
\hline mar-13 & 0 & 0 & 0 & 0 & 0 & 0 & 0 & 0 & 0 & 0 & 0 \\
\hline abr-13 & 0 & 0 & 0 & 0 & 0 & 0 & 0 & 0 & 0 & 0 & 0 \\
\hline may-13 & 0 & 0 & 0 & 0 & 0 & 0 & 0 & 0 & 0 & 0 & 0 \\
\hline oct-13 & 0 & 0 & 0 & 0 & 0 & 0 & 0 & 0 & 0 & 0 & 0 \\
\hline nov-13 & 0 & 0 & 0 & 0 & 0 & 0 & 0 & 0 & 0 & 0 & 0 \\
\hline dic-13 & 0 & 0 & 0 & 0 & 0 & 0 & 0 & 0 & 0 & 0 & 0 \\
\hline ene-14 & 0 & 0 & 0 & 0 & 0 & 0 & 0 & 0 & 0 & 0 & 0 \\
\hline feb-14 & 0 & 0 & 0 & 0 & 0 & 0 & 0 & 0 & 0 & 0 & 0 \\
\hline mar-14 & 0 & 0 & 0 & 0 & 0 & 0 & 0 & 0 & 0 & 0 & 0 \\
\hline abr-14 & 0 & 0 & 0 & 0 & 0 & 0 & 0 & 0 & 0 & 0 & 0 \\
\hline may-14 & 0 & 0 & 0 & 0 & 0 & 0 & 0 & 0 & 0 & 0 & 0 \\
\hline oct-15 & 2.410 & 7.380 & 15.000 & 8.100 & 46.600 & 18.867 & 4.549 & 52.860 & 34.000 & 9.687 & 53.000 \\
\hline nov-15 & 6.295 & 49.410 & 96.450 & 73.400 & 200.500 & 72.507 & 15.559 & 288.652 & 203.190 & 38.632 & 173.200 \\
\hline dic-15 & 5.973 & 46.960 & 72.750 & 59.700 & 153.300 & 53.670 & 11.035 & 212.113 & 149.940 & 55.921 & 126.100 \\
\hline ene-16 & 4.501 & 32.190 & 100.640 & 42.100 & 143.600 & 57.688 & 30.213 & 274.832 & 165.700 & 39.537 & 167.500 \\
\hline feb-16 & 12.681 & 79.180 & 130.730 & 93.700 & 262.450 & 84.131 & 32.940 & 383.315 & 268.660 & 64.606 & 224.400 \\
\hline mar-16 & 10.745 & 55.330 & 106.530 & 82.600 & 204.250 & 62.953 & 31.695 & 310.542 & 209.660 & 39.978 & 164.700 \\
\hline abr-16 & 8.465 & 41.350 & 76.990 & 57.500 & 195.000 & 60.303 & 22.042 & 265.968 & 172.710 & 30.550 & 122.200 \\
\hline may-16 & 2.436 & 10.910 & 16.750 & 13.500 & 58.700 & 19.842 & 8.194 & 56.485 & 32.710 & 8.069 & 23.400 \\
\hline oct-16 & 1.716 & 10.330 & 16.160 & 8.200 & 39.000 & 18.517 & 5.522 & 56.002 & 24.900 & 5.106 & 28.700 \\
\hline nov-16 & 8.419 & 64.950 & 136.550 & 40.900 & 194.000 & 76.505 & 26.013 & 333.473 & 259.220 & 37.482 & 186.100 \\
\hline dic-16 & 8.311 & 64.250 & 116.420 & 36.800 & 189.900 & 77.568 & 33.208 & 303.010 & 218.270 & 59.367 & 177.400 \\
\hline ene-17 & 15.868 & 95.660 & 231.590 & 49.500 & 262.300 & 92.057 & 37.659 & 436.855 & 386.700 & 70.832 & 283.300 \\
\hline feb-17 & 10.566 & 69.230 & 175.430 & 43.200 & 217.700 & 76.891 & 25.322 & 343.825 & 263.970 & 40.692 & 205.600 \\
\hline mar-17 & 9.767 & 51.050 & 150.220 & 50.200 & 186.400 & 67.081 & 21.876 & 293.874 & 179.040 & 31.425 & 169.800 \\
\hline$a b r-17$ & 3.962 & 18.640 & 51.990 & 14.400 & 86.400 & 32.472 & 13.691 & 114.055 & 78.670 & 12.000 & 53.800 \\
\hline may-17 & 958 & 3.610 & 13.640 & 0 & 38.900 & 20.701 & 7.282 & 29.719 & 23.570 & 738 & 13.800 \\
\hline oct-17 & 1.462 & 5.110 & 11.840 & 4.400 & 31.700 & 12.813 & 2.345 & 27.453 & 18.590 & 1 & 8.100 \\
\hline nov-17 & 9.358 & 48.158 & 132.090 & 0 & 183.300 & 77.749 & 21.813 & 238.822 & 176.720 & 24.942 & 137.100 \\
\hline dic-17 & 12.659 & 80.392 & 173.260 & 95.300 & 252.700 & 98.174 & 36.608 & 314.827 & 264.900 & 69.441 & 219.700 \\
\hline ene-18 & 14.052 & 79.450 & 197.380 & 48.500 & 228.300 & 88.788 & 38.003 & 333.010 & 287.620 & 62.464 & 247.100 \\
\hline feb-18 & 17.125 & 99.180 & 256.010 & 64.100 & 296.600 & 108.745 & 43.010 & 398.085 & 307.970 & 65.539 & 267.200 \\
\hline mar-18 & 14.234 & 78.870 & 212.540 & 55.500 & 236.500 & 89.789 & 32.577 & 349.870 & 248.910 & 48.603 & 227.000 \\
\hline abr-18 & 6.280 & 33.930 & 97.750 & 24.100 & 114.600 & 41.843 & 21.713 & 153.107 & 117.120 & 29.414 & 96.300 \\
\hline may-18 & 2.132 & 9.060 & 22.440 & 8.600 & 51.300 & 25.939 & 12.372 & 38.661 & 22.920 & 5.144 & 26.700 \\
\hline
\end{tabular}


Capítulo 3. Análisis del Caso en Estudio

Tabla 17. Consumo total térmico de los edificios del Campus Río Esgueva ( $k W h$ )

\begin{tabular}{|c|c|c|c|c|c|c|c|c|c|c|c|}
\hline & Gasóleo+Bio & Gasóleo+Bio & G.Natural+Bio & Gasóleo+Bio & Gasóleo+Bio & G.Natural+Bio & G.Natural+Bio & G.Natural+Bio & G.Natural+Bio & Gasóleo+Bio & G.Natural+Bic \\
\hline & E1 & E2 & E3 & $\mathrm{E} 4$ & E5 & E6 & E7 & E8 & E13 & E14 & E15 \\
\hline oct-12 & 18.417 & 36.834 & 17.828 & 14.142 & 117.869 & 26.717 & 7.328 & 44.728 & 26.441 & 25.019 & 14.487 \\
\hline nov-12 & 32.083 & 64.166 & 158.718 & 111.738 & 205.331 & 70.411 & 29.013 & 187.155 & 233.547 & 65.981 & 211.446 \\
\hline dic-12 & 16.491 & 47.219 & 168.403 & 153.434 & 303.000 & 69.423 & 34.243 & 192.809 & 246.803 & 70.700 & 285.072 \\
\hline ene-13 & 17.414 & 49.862 & 195.511 & 181.744 & 323.200 & 60.486 & 30.880 & 342.443 & 231.986 & 56.717 & 254.609 \\
\hline feb-13 & 16.595 & 84.570 & 241.484 & 239.369 & 296.940 & 77.600 & 32.427 & 348.845 & 231.133 & 54.283 & 314.998 \\
\hline mar-13 & 21.438 & 66.955 & 169.961 & 118.256 & 303.000 & 62.022 & 23.298 & 381.056 & 192.983 & 40.277 & 236.366 \\
\hline$a b r-13$ & 16.161 & 50.475 & 122.600 & 79.149 & 195.940 & 47.899 & 63 & & 106.846 & 32.185 & 146.559 \\
\hline may-13 & .902 & 30.436 & .794 & 1.169 & 101.000 & 31.816 & & & 047 & & 50.082 \\
\hline oct-13 & 409 & 18.951 & 427 & 5.730 & 74 & 432 & & & 22 & 616 & 2.235 \\
\hline nov-13 & 17.455 & 51.613 & 111.525 & 127. & 526 & 61.042 & & & & 55.254 & 37.533 \\
\hline dic-13 & 26.636 & 120.015 & 091 & 148 & & 86.228 & & & 337 & 059 & .094 \\
\hline ene-14 & 14.990 & 3.737 & 192.743 & 114 & & 67.999 & & & 166 & & 821 \\
\hline feb-14 & 14.276 & 84.512 & 242.403 & 109.572 & & 79.509 & & & 725 & & 638 \\
\hline mar-14 & 11.000 & 78.485 & 160.164 & 574 & & 51.450 & & & 360 & & \\
\hline abr-14 & 172 & 39.045 & 100. & & & 41.877 & 68 & & 292 & 17.641 & 325 \\
\hline may-14 & 4.761 & 33.971 & 239 & 14.875 & 142 & 22.289 & .334 & & 3.279 & 8.218 & 881 \\
\hline oct-15 & 410 & 380 & 15.000 & 100 & .600 & 18.867 & 549 & & 4.000 & 9.687 & .000 \\
\hline nov-15 & 6.295 & 49.410 & 96.450 & 73.400 & 200.500 & 72.507 & 15.559 & 288.652 & 203.190 & 38.632 & 173.200 \\
\hline dic- 15 & 5.973 & 46.960 & 72.750 & 59.700 & 153.300 & 53.670 & .035 & 113 & 149.940 & 55.921 & 100 \\
\hline ene-16 & 4.501 & 32.190 & 100.640 & 42.100 & 143.600 & 57.688 & .213 & 274.832 & 165.700 & 39.537 & 167.500 \\
\hline feb-16 & 22.898 & 144.460 & 195.869 & 197.706 & 356.509 & 109.816 & 3.667 & 452.764 & 367.886 & 102.472 & 269.211 \\
\hline mar-16 & 10.846 & 59.975 & 108.608 & 96.973 & 213.337 & 67.548 & .434 & 316.817 & 236.912 & 42.448 & 174.003 \\
\hline abr-16 & 541 & 43.230 & 7.055 & 65.845 & 197.436 & 61.805 & 2.115 & 266.496 & 175.949 & 31.991 & 122.200 \\
\hline may-16 & 444 & 10.969 & 16.782 & 16.189 & 59.265 & 22.683 & 8.218 & 56.485 & 32.710 & 11.087 & 35.033 \\
\hline oct-16 & 2.094 & 15.025 & 22.329 & 13.250 & 62.832 & 28.182 & 9.706 & 70.515 & 29.981 & 7.812 & 37.197 \\
\hline nov-16 & 8.681 & 68.720 & 138.878 & 43.359 & 198.634 & 77.281 & 26.341 & 337.657 & 262.380 & 38.585 & 192.797 \\
\hline dic-16 & 8.311 & 65.329 & 117.308 & 50.061 & 192.899 & 77.584 & 33.256 & 303.434 & 218.390 & 63.199 & 181.536 \\
\hline ene-17 & 15.891 & 98.867 & 234.302 & 53.139 & 269.378 & 93.129 & 37.659 & 440.599 & 386.780 & 70.886 & 283.796 \\
\hline feb-17 & 10.605 & 71.759 & 176.446 & 49.191 & 218.934 & 76.931 & 5.322 & 347.129 & 264.570 & 40.723 & 205.600 \\
\hline mar-17 & 321 & 51.050 & 150.460 & 51.117 & 187.634 & 67.113 & 1.876 & 295.002 & 179.680 & 31.425 & 170.464 \\
\hline abr-17 & 962 & 18.717 & 53.310 & 17.237 & 86.924 & 32.504 & .691 & 519 & 78.670 & 12.601 & 53.800 \\
\hline may-17 & 35 & 365 & 640 & 84 & .591 & 20.749 & 7.778 & 29.943 & 3.570 & 769 & 13.800 \\
\hline oct-17 & 462 & 5.110 & 11.920 & 4.400 & & 23.998 & 393 & 29.261 & 18.590 & 1 & 8.772 \\
\hline nov-17 & 9.358 & 48.158 & 134.498 & 0 & 183.300 & 77.893 & 1.837 & 240.790 & 176.720 & 24.942 & 137.564 \\
\hline dic-17 & 12.659 & 80.392 & 173.668 & & 252.700 & 98.278 & 5.608 & 316.883 & 264.900 & 69.441 & 220.020 \\
\hline ene-18 & 14.052 & 79.450 & 198.228 & 48.500 & 228.300 & 89.052 & 38.115 & 335.954 & 287.620 & 62.464 & 247.100 \\
\hline feb-18 & 17.125 & 99.180 & 257.218 & 64.100 & 296.600 & 108.817 & 3.138 & 399.029 & 307.970 & 65.539 & 267.216 \\
\hline mar-18 & 14.234 & 78.870 & 214.196 & 55.500 & 236.500 & 90.765 & 32.745 & 351.334 & 253.030 & 48.603 & 227.864 \\
\hline abr-18 & 6.280 & 33.930 & 97.846 & 24.100 & 114.600 & 41.843 & 22.137 & 153.387 & 118.064 & 29.414 & 96.348 \\
\hline may-18 & 2.132 & 9.060 & 22.440 & 8.600 & 51.300 & 25.939 & 12.372 & 38.661 & 22.920 & 5.144 & 26.700 \\
\hline
\end{tabular}




\subsubsection{Factores de emisión de $\mathrm{CO2}$}

Entendiendo energía primaria como la energía disponible en la naturaleza antes de ser transformada, es decir como la proveniente de los combustibles fósiles: gas natural, petróleo y carbón, la proveniente de combustibles nucleares y la proveniente de recursos renovables como la biomasa, del calor de la tierra del viento o del sol; y entendiendo la energía final como la energía primaria ya transformada y transportada, lista para el consumo en cualquier aplicación. (EOI. Escuela de Organización Industrial, 2015) [109]

Las energías que compraba la Universidad para satisfacer sus necesidades térmicas, antes de conectar sus edificios a la red de calor, eran energías finales que provenían de la energía primaria del gas natural y gasóleo.

Tras conectar sus edificios a la red de calor, la energía final comprada proviene, además de las energías primarias del gas natural y gasóleo de la biomasa.

Según el Documento Reconocido del Reglamento de Instalaciones Térmicas en los Edificios (RITE), emitido como Resolución conjunta de los Ministerios de Industria, Energía y Turismo, y Ministerio de Fomento: "Factores de emisión de $\mathrm{CO}_{2}$ y coeficientes de paso a energía primaria de diferentes fuentes de energía final consumidas en el sector de edificios en España", con obligación de aplicarse a partir del 14 de enero de 2016. (Ministerios de Industria, Energía y Turismo y Ministerio de Fomento, 2014) [110], los factores de emisión de $\mathrm{CO} 2$ que sirven para pasar de $\mathrm{kWh}$ de Energía final a $\mathrm{kg}$ de $\mathrm{CO}_{2}$ emitidos, son los mostrados en la Tabla 18.

Tabla 18. Factores de emisiones de $\mathrm{CO}_{2}$

\begin{tabular}{lc}
\hline & $\mathrm{kg} \mathrm{CO}_{2} / \mathrm{kWh} \mathrm{E.} \mathrm{final}$ \\
\hline Electricidad convencional Nacional & 0,357 \\
\hline Electricidad convencional peninsular & 0,331 \\
\hline Electricidad convencional extrapeninsular & 0,833 \\
\hline Gasóleo calefacción & 0,311 \\
\hline Gases Licuados del Petróleo (GLP) & 0,254 \\
\hline Gas Natural & 0,252 \\
\hline Carbón & 0,472 \\
\hline Biomasa & 0,018 \\
\hline
\end{tabular}

Donde la biomasa es tratada como energía final una vez transportada a la central térmica donde será quemada. 
Para pasar de esa energía final puesta a las puertas de la central térmica a la energía final disponible para ser utilizada en cada uno de los edificios de la UVA que han sido conectados a la red de calor, hay que tener en cuenta las pérdidas que se producen en esta segunda transformación, como se aprecia en la Figura 53.

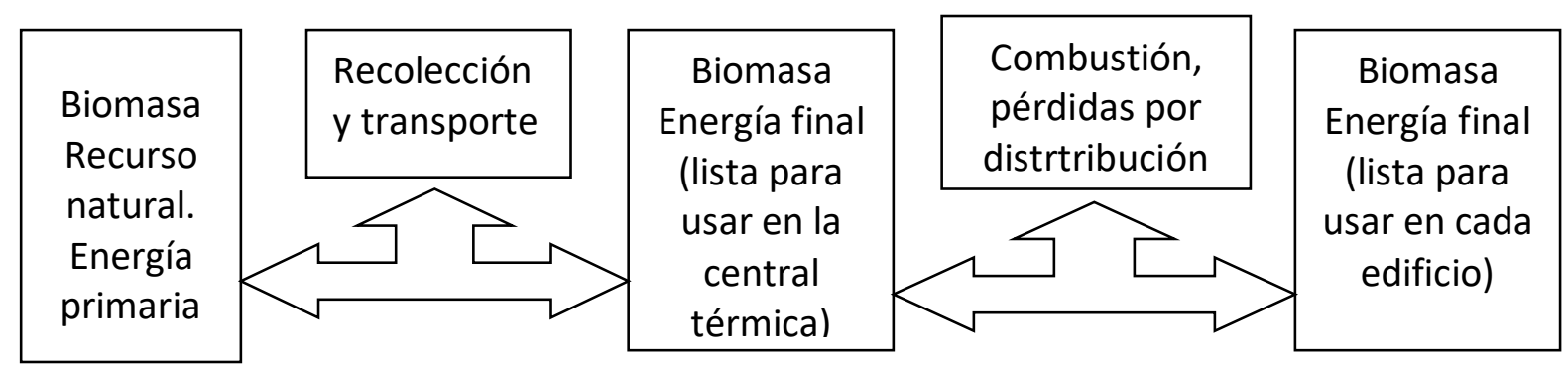

Figura 53. Transformaciones de la Biomasa

Según los gestores de la red de calor, las calderas de biomasa presentan unos redimientos superiores al $86 \%$ (Lara, 2017) [111] y las pérdidas de distribución, aunque dependen de la cantidad de energía transportada, se mueven en un rango del $10 \%$ para los días de diario de mayor consumo y un $23 \%$ para los fines de semana con bajo consumo.

Tomando como rendimiento estacional de generación y distribución el resultado de multiplicar 0,86 ×0,90 =0,774, se podría considerar que la transformación de la energía final lista para usar en la central térmica a energía final lista para usar en cada edificio, debe ser afectada por el coeficiente 0,744 .

Por lo tanto la emisiones asociadas a la biomasa (energía final lista para usar en cada edificio será $=0,018 / 0,744=0,024 \mathrm{~kg} \mathrm{CO}_{2} / \mathrm{kWh}$. final a usar en cada edificio.

Estas emisiones, junto con las asociadas a la energía final del gas natural y gasóleo, serán las utilizadas para el cálculo de emisiones ahorradas en cada uno de los edificios conectados a la red de calor. 


\subsubsection{Precios de los combustibles}

Según las estadísticas de Eurostat, la evolución de los precios de gas natural en $€ / \mathrm{kWh}$, para el sector doméstico (consumo inferior a $55.555 \mathrm{kWh} / \mathrm{año}$ ) y sector no doméstico, para los años 2015, 2016 y 2017, es la mostrada en la Tabla 19. (Eurostat, 2018) [112]

Tabla 19. Precios del Gas natural 2015, 2016y 2017

\begin{tabular}{ccccccc}
\hline & \multicolumn{3}{c}{ Doméstico $(€ / \mathrm{kWh})$} & \multicolumn{3}{c}{ No doméstico $(€ / \mathrm{kWh})$} \\
\hline & 2015 & 2016 & 2017 & 2015 & 2016 & 2017 \\
\hline EU-28 & 0,0711 & 0,0636 & 0,0633 & 0,0344 & 0,0299 & 0,0281 \\
\hline Euro área & 0,0770 & 0,0719 & 0,0719 & 0,0347 & 0,0313 & 0,0293 \\
\hline España & 0,0956 & 0,0857 & 0,0865 & 0,0317 & 0,0260 & 0,0267 \\
\hline
\end{tabular}

Atendiendo a las sucesivas publicaciones en el Boletín Oficial del Estado, (Dirección General de Política Energética y Minas, 2016) [113], (Dirección General de Política Energética y Minas, 2017) [114], [115], [116], [117], (Dirección General de Política Energética y Minas, 2018) [118], [119], [120] la variación del precio del coste del gas como materia prima se muestra en la Tabla 20.

Tabla 20. Coste de la materia prima de gas natural 2017 y 2018

\begin{tabular}{|c|c|c|c|c|c|c|c|c|}
\hline $\begin{array}{c}\text { Coste de } \\
\text { la } \\
\text { materia } \\
\text { prima }\end{array}$ & $\begin{array}{l}\text { Resolución } \\
\text { de } \\
29 / 12 / 2016\end{array}$ & $\begin{array}{l}\text { Resolución } \\
\text { de } \\
24 / 03 / 2017\end{array}$ & $\begin{array}{c}\text { Resolución } \\
\text { de } \\
28 / 06 / 2017\end{array}$ & $\begin{array}{l}\text { Resolución } \\
\text { de } \\
25 / 09 / 2017\end{array}$ & $\begin{array}{l}\text { Resolución } \\
\text { de } \\
26 / 12 / 2017\end{array}$ & $\begin{array}{l}\begin{array}{c}\text { Resolución } \\
\text { de }\end{array} \\
22 / 03 / 2018\end{array}$ & $\begin{array}{c}\text { Resolución } \\
\text { de } \\
28 / 06 / 2018\end{array}$ & $\begin{array}{c}\text { Resolución } \\
\text { de } \\
25 / 09 / 2018\end{array}$ \\
\hline $\begin{array}{l}\text { A partir } \\
\text { de: }\end{array}$ & $1 / 01 / 2017$ & $1 / 04 / 2017$ & $1 / 07 / 2017$ & $1 / 10 / 2017$ & $1 / 01 / 2018$ & $1 / 04 / 2018$ & $1 / 07 / 2018$ & $1 / 10 / 2018$ \\
\hline$c € / k W h$ & 1,927731 & 2,041418 & 1,978795 & 1,896592 & 2,252409 & 2,043030 & 2,256600 & 2,767891 \\
\hline $\begin{array}{c}\mathrm{c} € / \mathrm{kWh} \\
\text { promedio }\end{array}$ & \multicolumn{4}{|c|}{1,961134} & \multicolumn{4}{|c|}{ 2,3299825 } \\
\hline $\begin{array}{c}\% \\
\text { aumento }\end{array}$ & & & & & \multicolumn{4}{|c|}{$118,8 \%$} \\
\hline
\end{tabular}

Durante el año 2018, el precio del coste de la materia prima subió un $18,8 \%$ con respecto a los precios del 2017

Según esas mismas Resoluciones, la evolución de las Tarifas de Último Recurso T1 (consumo $\leq 5.000 \mathrm{kWh} /$ año) y T2 $(5.000<$ consumo $\leq 50.000 \mathrm{kWh} /$ año $)$ de gas natural, fueron las recogidas en la Tabla 21 
Capítulo 3. Análisis del Caso en Estudio

Tabla 21. Evolución de las Tarifas de Último Recurso T1 y T2, 2017 y 2018

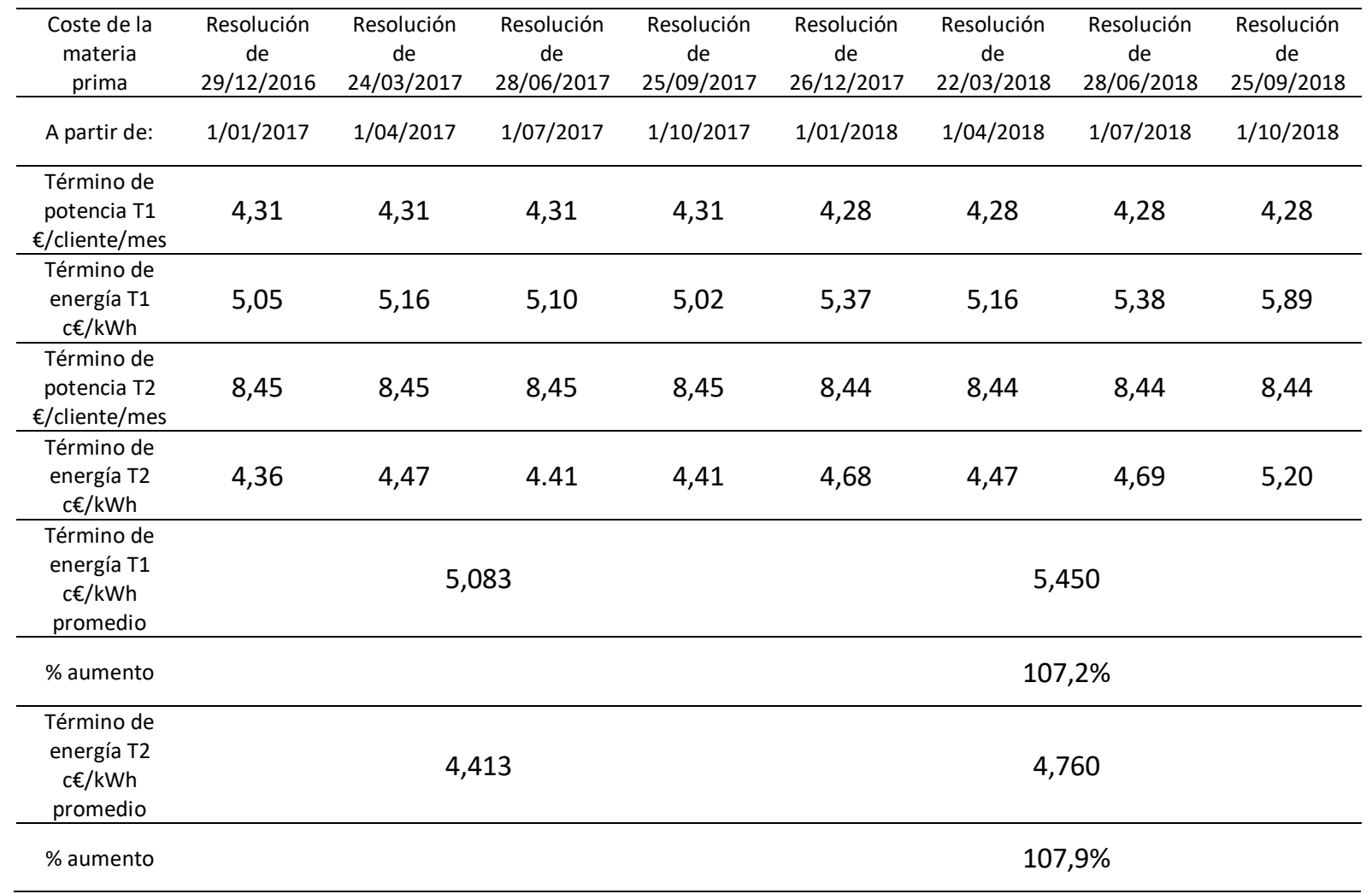

Durante el año 2018, el precio del térmico de energía para la Tarifa T1, subió un 7,2 \% y el precio del término de energía para la Tarifa T2, un 7,9 5 con respecto a los precios del 2017.

Considerando un aumento en el precio del 7,2\%, el precio estimado para el gas natural en el año 2018, para el sector no doméstico sería de 0,0267 x 1,072 =0,0286 €/kWh En cuanto al Gasóleo de calefacción y la biomasa, según los datos publicados por el IDAE, (IDAE. Dirección de Energías Renovables. Departamento de Biomasa y Residuos, 2018) [121], la evolución de los precios en $c € / k W h$ sin incluir el IVA, se muestra en la siguiente Tabla 22, donde se aprecia como el precio de la biomasa ha permanecido más estable. 
Capítulo 3. Análisis del Caso en Estudio

Tabla 22. Precios del Gasóleo C y de la Biomasa 2015, 2016, 2017 y 2018

\begin{tabular}{|c|c|c|c|c|c|c|c|c|c|c|c|c|c|}
\hline $\begin{array}{c}\text { Precios en } \\
\text { c€/kWh }\end{array}$ & $\begin{array}{c}2 T \\
2015 \\
\end{array}$ & $\begin{array}{c}3 T \\
2015 \\
\end{array}$ & $\begin{array}{c}4 T \\
2015 \\
\end{array}$ & $\begin{array}{c}1 T \\
2016 \\
\end{array}$ & $\begin{array}{c}2 T \\
2016 \\
\end{array}$ & $\begin{array}{c}3 T \\
2016 \\
\end{array}$ & $\begin{array}{c}4 T \\
2016 \\
\end{array}$ & $\begin{array}{c}1 T \\
2017\end{array}$ & $\begin{array}{c}2 T \\
2017 \\
\end{array}$ & $\begin{array}{c}3 T \\
2017 \\
\end{array}$ & $\begin{array}{c}4 T \\
2017 \\
\end{array}$ & $\begin{array}{c}1 T \\
2018 \\
\end{array}$ & $\begin{array}{c}2 T \\
2018 \\
\end{array}$ \\
\hline GASOIL C & 5,69 & 5,11 & 4,71 & 3,82 & 4,31 & 4,63 & 4,74 & 5,44 & 4,96 & 4,74 & 4,81 & 5,39 & 5,82 \\
\hline $\begin{array}{c}\text { Promedio. } \\
\text { Gasoil C }\end{array}$ & \multicolumn{3}{|c|}{5,170} & \multicolumn{4}{|c|}{4,375} & \multicolumn{4}{|c|}{4,988} & \multicolumn{2}{|c|}{5,605} \\
\hline $\begin{array}{c}\text { Pellet } \\
\text { certificado } \\
\text { A1 a } \\
\text { granel }\end{array}$ & 3,78 & 3,68 & 3,51 & 3,55 & 3,52 & 3,49 & 3,58 & 3,68 & 3,59 & 3,74 & 3,66 & 3,76 & 3,74 \\
\hline $\begin{array}{c}\text { Pellet no } \\
\text { certificado } \\
\text { a granel }\end{array}$ & 3,69 & 3,45 & 3,51 & 3,60 & 3,51 & 3,61 & 3,63 & 3,60 & 3,63 & 3,54 & 3,52 & 3,47 & 3,48 \\
\hline $\begin{array}{c}\text { Astilla } \\
\text { elaborada }\end{array}$ & 2,84 & 2,76 & 2,71 & 2,47 & 2,52 & 2,64 & 2,60 & 2,74 & 2,43 & 2,53 & 2,46 & 2,35 & 2,43 \\
\hline $\begin{array}{c}\text { Promedio } \\
\text { Astilla }\end{array}$ & \multicolumn{3}{|c|}{2,770} & \multicolumn{4}{|c|}{2,558} & \multicolumn{4}{|c|}{2,540} & \multicolumn{2}{|c|}{2,390} \\
\hline
\end{tabular}

En resumen la evolución de los precios de los combustibles desde el año 2015 al 2018, se muestran en la Tabla 23 y Figura 54

Tabla 23.Precios de referencia variables para Gas natural, Gasóleo y Astilla 20152018.

\begin{tabular}{ccccc}
\hline Precios $(€ /(\mathrm{kWh})$ & 2015 & 2016 & 2017 & 2018 \\
\hline Gasóleo C & 0,0517 & 0,0437 & 0,0499 & 0,0560 \\
\hline Gas Natural & 0,0317 & 0,0260 & 0,0267 & 0,0286 \\
\hline Astilla & 0,0277 & 0,0256 & 0,0254 & 0,0239 \\
\hline
\end{tabular}

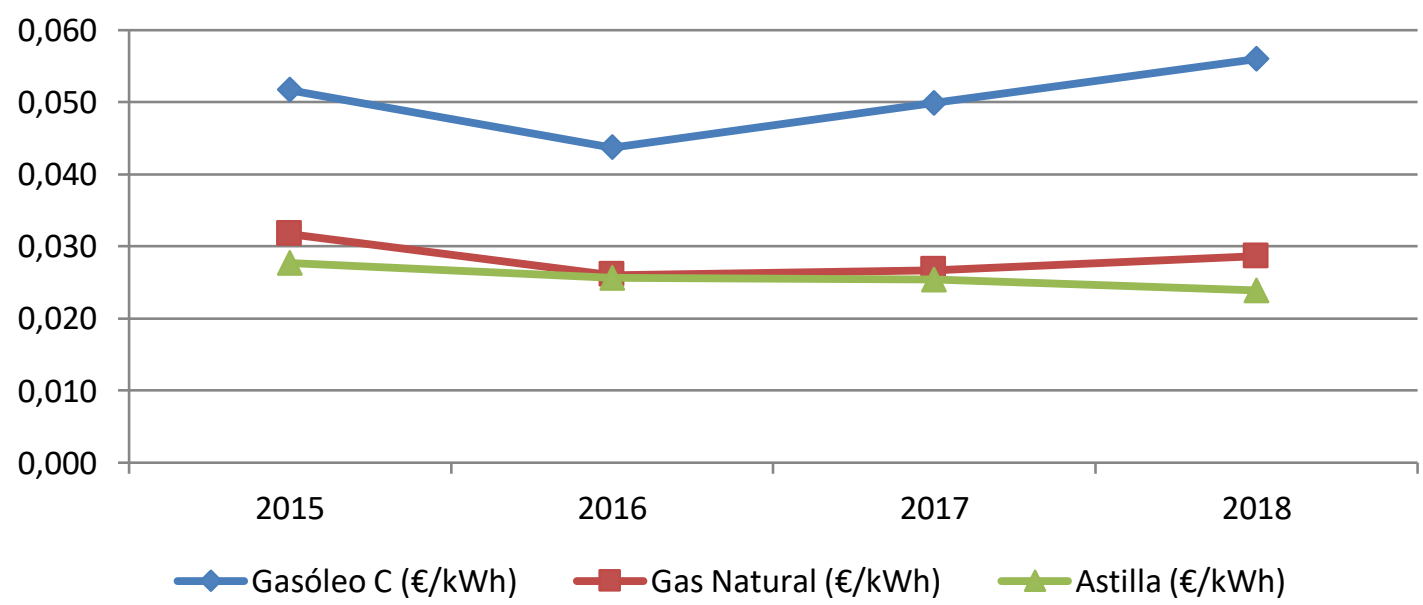

Figura 54. Evolución de los precios de los combustibles 2015-2018 
El término variable de una factura de gas, puede representar el $85 \%$ de la factura total, el otro $15 \%$, se debe al término fijo, alquiler de equipos e impuesto sobre el gas natural. Luego para obtener el precio de gas natural multiplicaremos el término variable por $(100 / 85=1,18)$, quedando los precios reflejados en la Tabla 24 :

Tabla 24.Precios de referencia totales para Gas natural, Gasóleo y Astilla 20152018.

\begin{tabular}{ccccc}
\hline Precios $(€ /(\mathrm{kWh})$ & 2015 & 2016 & 2017 & 2018 \\
\hline Gasóleo C & 0,0517 & 0,0437 & 0,0499 & 0,0560 \\
\hline Gas Natural & 0,0373 & 0,0306 & 0,0314 & 0,0336 \\
\hline Astilla & 0,0277 & 0,0256 & 0,0254 & 0,0239 \\
\hline
\end{tabular}

El precio que paga la Universidad por la energía suministrada procedente de la red de calor no es el precio de la astilla, dado que dicho precio debe verse influenciado por todo el rendimiento del sistema de generación, distribución, regulación e intercambio hasta llegar a la salida del intercambiador de cada edificio, además del beneficio industrial que aplique el suministrador de la energía.

Habiendo estimado el precio de los combustibles fósiles utilizados en cada edificio, se estimará el precio máximo de los kWh útiles comprados a la red de calor que tendría que haber pagado la Universidad para conseguir el objetivo del 15\% de ahorro durante las tres primeras temporadas. 


\section{CAPÍTULO 4. RESULTADOS Y DISCUSIÓN. CAMPUS MIGUEL DELIBES.}

\subsection{Introducción}

En este capítulo se irán analizando cada uno de los doce edificios de la Universidad de Valladolid, pertenecientes al Campus Miguel Delibes, que están conectados a la red de calor.

Para cada uno de ellos se irá aplicando la metodología descrita en el capítulo 3:

- Se irá obteniendo el modelo o modelos que pueda predecir su consumo térmico en función de la o las variables climáticas que más influencia tengan sobre el consumo.

- Se comprobará el cumplimiento de todos los supuestos de la regresión lineal simple o múltiple, en función de los modelos obtenidos.

- Se verificará la existencia de diferencias significativas entre las medias de los consumos reales obtenidos para cada una de las tres temporadas posteriores a la puesta en marcha de la red y para las tres temporadas en su conjunto.

- Se estimaran las emisiones de $\mathrm{CO}_{2}$ ahorradas en cada edificio, en las tres temporadas de funcionamiento de la red, por utilizar energía procedente de la red de calor.

- Se calculará el precio máximo de la energía térmica comprada a la red para que el ahorro económico que se experimente en las tres temporadas de funcionamiento de la red, llegue a ser del $15 \%$ con respecto al coste hubiera tenido la Universidad si el edificio no se hubiera conectado a la red de calor.

En este capítulo se mostrará únicamente el resumen de los resultados de cada edificio, recogiéndose el desarrollo de la metodología completa para cada edificio en el Anexo IV. 


\subsection{Edificio D1. Apartamentos Cardenal Mendoza}

Edificio de tipo residencial que empezó a funcionar en el año 1996, cuenta con una superficie construida de $17.616 \mathrm{~m}^{2}$. Inicialmente la calefacción y el agua caliente sanitaria eran suministradas mediante tres calderas de gas natural de una potencia total de 1.554 kW. La subestación de intercambio con la red de calor construida en el año 2015, cuenta con una potencia de $1.454 \mathrm{~kW}$. En la Figura 55 se marca la ubicación del edificio

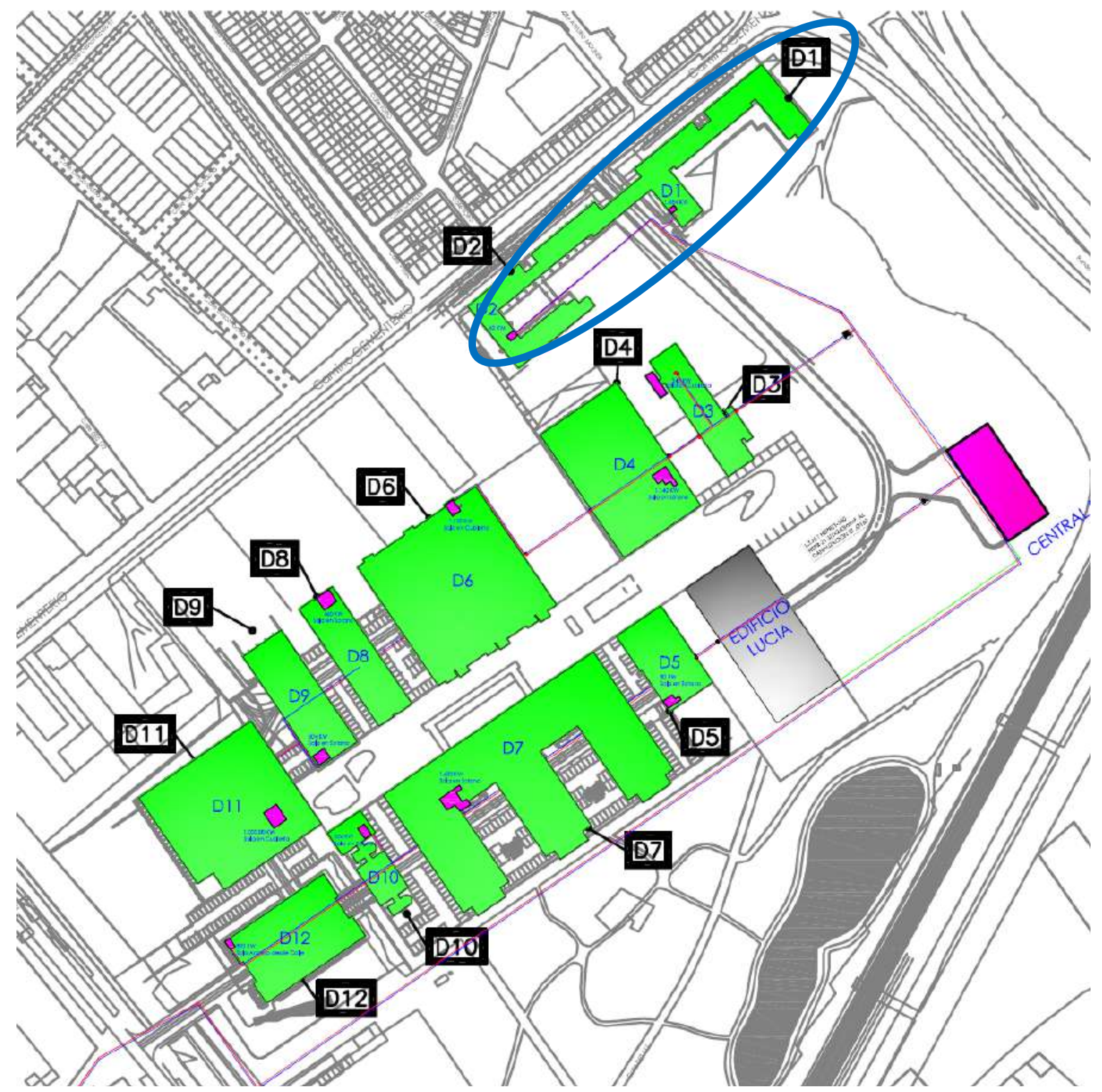

Figura 55. Ubicación del Edificio D1 en el croquis del campus Miguel Delibes 
Los modelos encontrados para predecir el consumo térmico del Edificio, fueron

Modelo 1: $\quad$ kWh_D1 $=391.037,854-23.838,939 \times$ T_med

Modelo 2: kWh_D1=271.370,906-20.045,184xT_med +50.568,513 x V_viento_nocturna

El resumen de los modelos, con los coeficientes de correlación de Pearson (R) y el coeficiente de determinación $\left(R^{2}\right)$ se muestra en la Tabla 25 y en la Tabla 26, el resultado de la verificación de los supuestos de la regresión lineal.

Tabla 25. Resumen de los modelos encontrados para el Edificio D1

\begin{tabular}{cccrrr} 
& $\begin{array}{c}\text { Variables } \\
\text { independientes }\end{array}$ & Constante & B & R & $\mathrm{R}^{2}$ \\
\hline D1_Modelo 1 & Tmed & $391.037,854$ & $-23.838,939$ & $-0,899$ & 0,808 \\
\hline D1_Modelo 2 & Tmed / V_nocturna & $271.370,906$ & $-20.045,184 / 50568,513$ & $-0,931$ & 0,866 \\
\hline
\end{tabular}

Tabla 26. Resumen del cumplimiento de los supuestos de regresión. Edificio D1

\begin{tabular}{lll}
\hline \multicolumn{1}{c}{ Cumplimiento de supuestos de la regresión lineal } & Modelo 1 & Modelo 2 \\
\hline 1. Linealidad de las variables & Cumple & Cumple \\
\hline 2. Normalidad de variables & Cumple & Cumple \\
\hline 3. Independencia de los errores o no autocorrelación de los residuos & Cumple & Cumple \\
\hline 4. Homocedasticidad de la varianza, los errores son aleatorios & Cumple & Cumple \\
\hline 5. Falta de multicolinealidad entre las variables independientes. & & Cumple \\
\hline
\end{tabular}

En la Figura 56, se representan los consumos reales y los pronosticados con los modelos de regresión obtenidos, en $\mathrm{kWh}$.

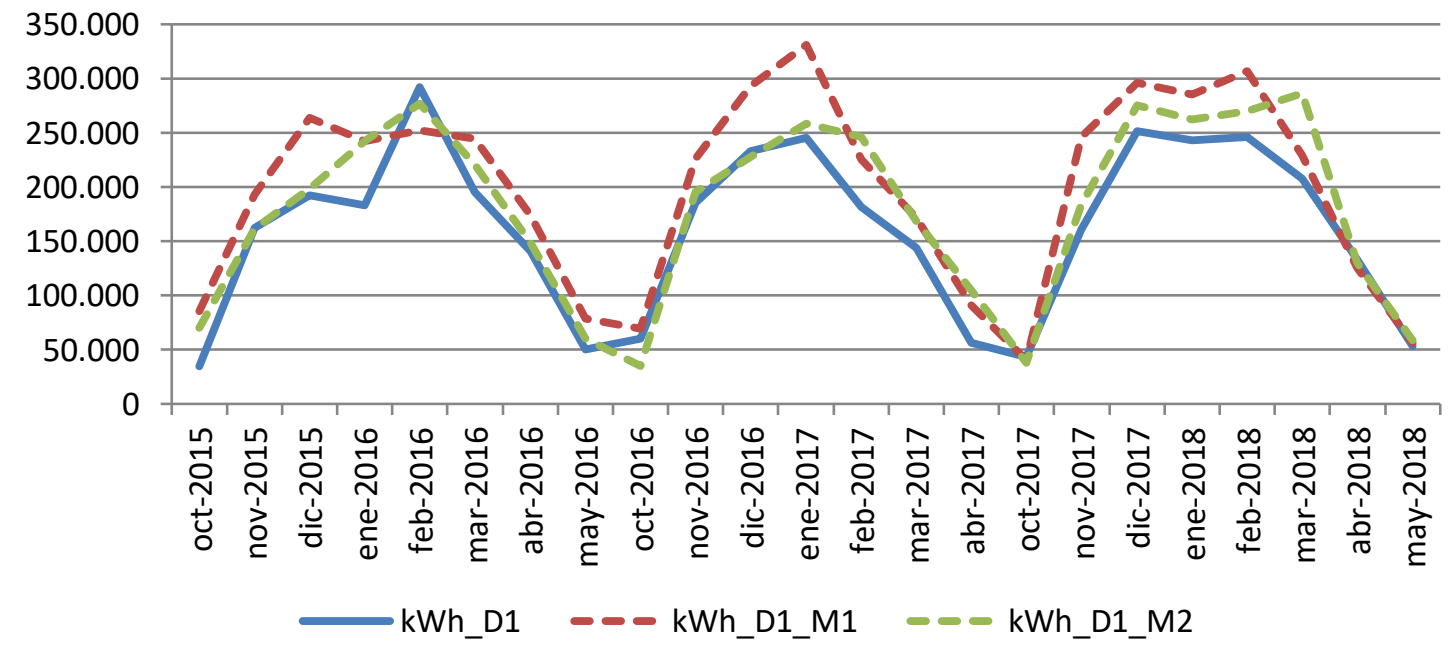

Figura 56. Representación de los consumos pronosticados para el Edificio D1. 2015-2018 
En la mayoría de los meses los consumos pronosticados con el modelo 1, son superiores a los pronosticados con el Modelo 2

Los resultados de las diferencias entre las medias de los consumos, se exponen en la Tabla 27

Tabla 27. Resultado de las diferencias significativas encontradas. Edificio D1

\begin{tabular}{ccccccccc}
\hline & $\begin{array}{c}\% \\
\text { Diferencia } \\
2015-2016\end{array}$ & Significativo & $\begin{array}{c}\% \\
\text { Diferencia } \\
2016-2017\end{array}$ & Significativo & $\begin{array}{c}\% \\
\text { Diferencia } \\
2017-2018\end{array}$ & Significativo & $\begin{array}{c}\% \\
\text { Diferencia } \\
2015-2018\end{array}$ & Significativo \\
\hline D1_Modelo 1 & $22,7 \%$ & SI & $27,3 \%$ & SI & $18,5 \%$ & SI & $22,5 \%$ & SI \\
\hline D1_Modelo 2 & $10,2 \%$ & No & $11,8 \%$ & No & $12,4 \%$ & No & $11,5 \%$ & $\begin{array}{c}\text { Consumos } \\
\text { predichos no } \\
\text { Normal }\end{array}$ \\
\hline
\end{tabular}

En la Figura 57 se grafican los consumos reales y pronosticados para el periodo Octubre 2015 - Mayo 2018 para el Edificio D1, y las medias de dichos consumos. Según la prueba paramétrica realizada únicamente es estadísticamente significativa la diferencia encontrada entre el consumo real y el pronosticado por el Modelo 1, esta diferencia implica que utilizando la línea base establecida en el Modelo 1, se ha logrado un ahorro del $22,5 \%$ con la implantación de la red de calor, durante las tres temporadas octubre 2015 - mayo 2018, para un nivel de confianza del $95 \%$.

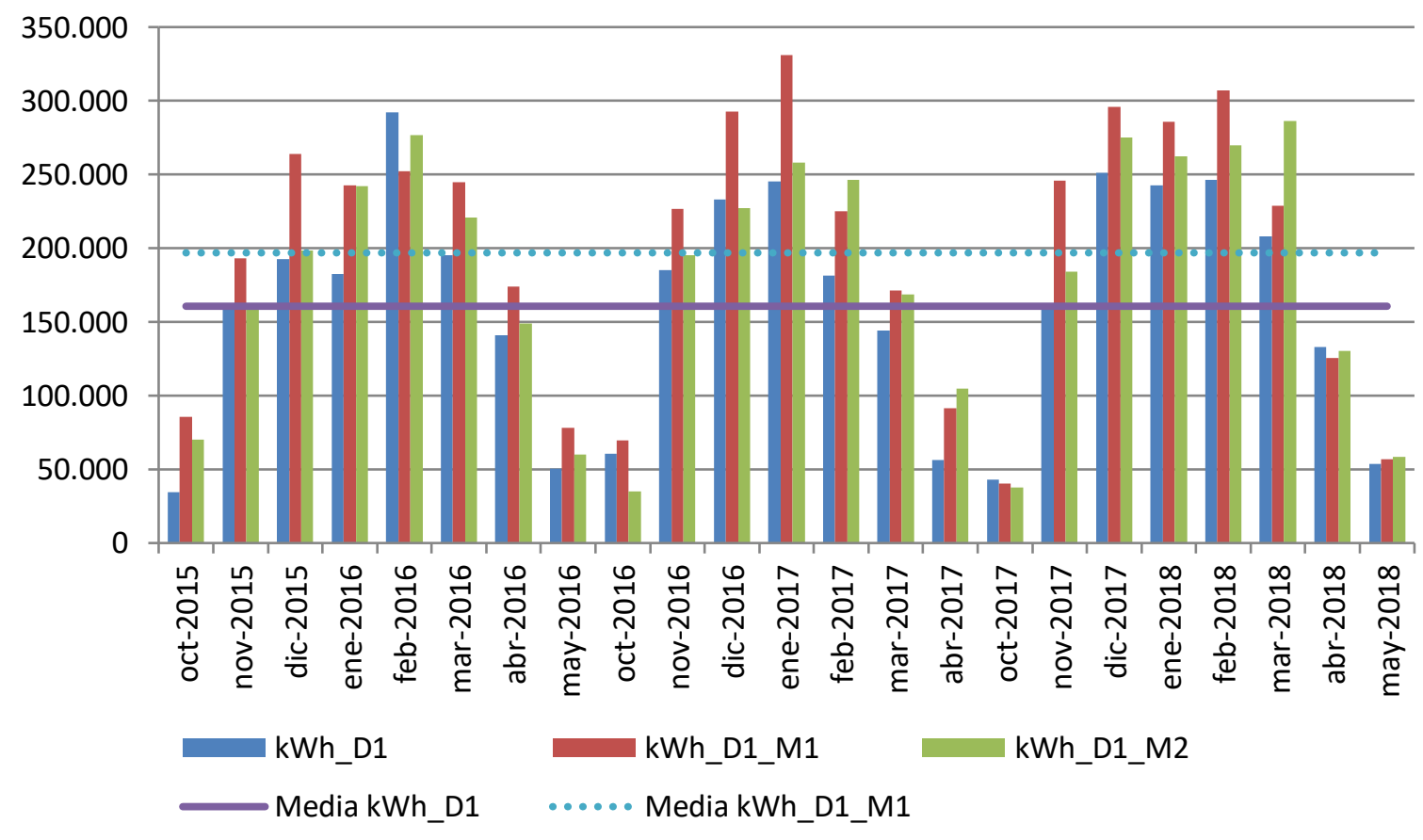

Figura 57. Consumos reales y pronosticados Octubre 2015-Mayo 2018. Edificio D1 
En la Figura 58, se observa el consumo real del Edificio D1, en comparación con el consumo pronosticado acumulado con el Modelo 1 que hubiera tenido el Edificio de no haberse incorporado a la red de calor.

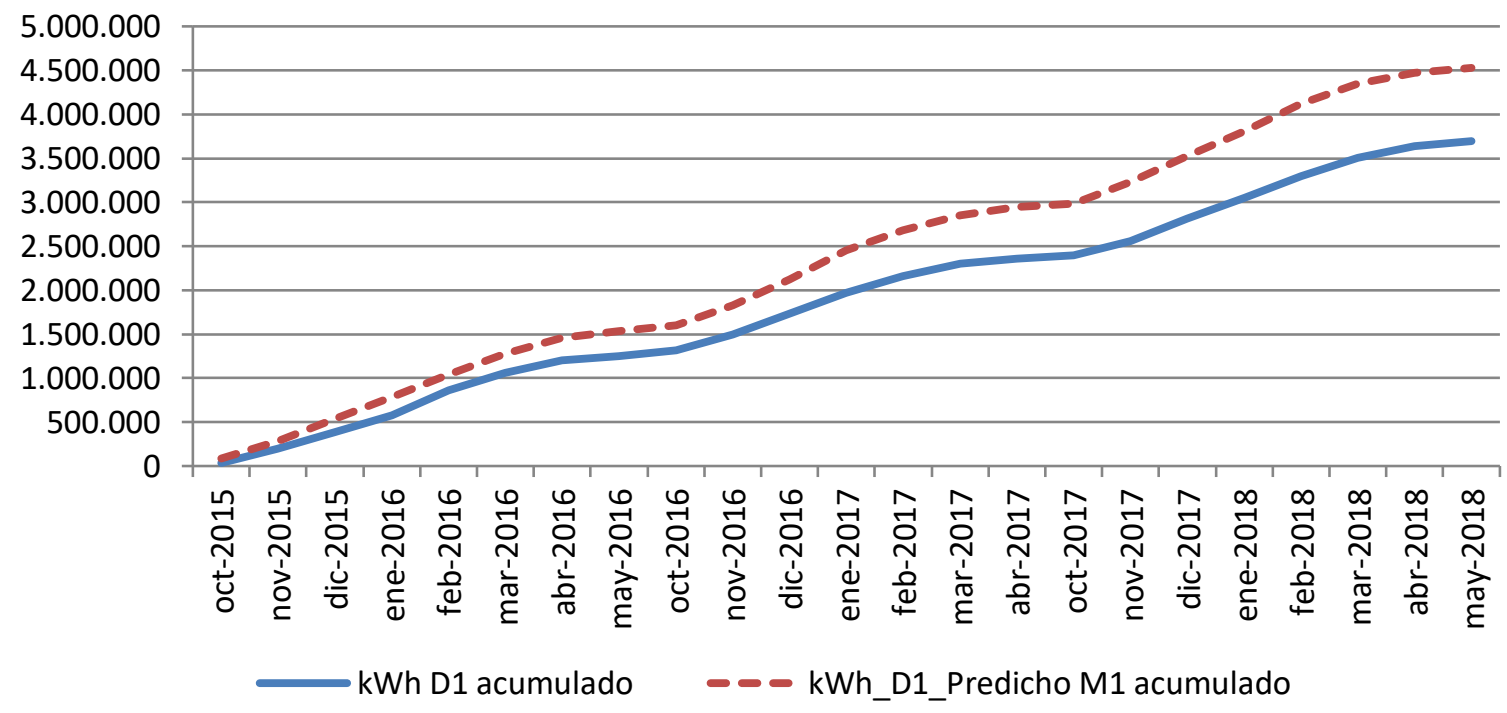

Figura 58. Consumo acumulado real y pronosticado. Octubre 2015-Mayo 2018. Edificio D1

Los resultados del ahorro de consumos, emisiones y precio máximo de la energía útil comprada a la red para un ahorro económico del 15\%, se muestra en la Tabla 28.

Tabla 28. Resumen de resultados. Edificio D1

\begin{tabular}{lcc}
\hline $\begin{array}{l}\text { Diferencia significativa encontrada entre las medias de los } \\
\text { consumos 2015-2018 }\end{array}$ & $22,5 \%$ & $196.862 \mathrm{kWh}$ \\
\hline $\begin{array}{l}\text { Ahorro de consumo térmico durante las tres temporadas } \\
\text { posteriores a la construcción de la red respecto a lo que se hubiera } \\
\text { consumido de no ser por la red }\end{array}$ & $18,4 \%$ & $832.961 \mathrm{kWh}$ \\
\hline Ahorro de emisiones de $\mathrm{CO}_{2}$ & $89,0 \%$ & $1.016 \mathrm{t} \mathrm{CO}$ \\
\hline $\begin{array}{l}\text { Precio máximo de kWh útiles comprados a la red para obtener un } \\
\text { ahorro del 15\% }\end{array}$ & $\begin{array}{l}0,0338 \\
€ / \mathrm{kWh}\end{array}$ & $21.919 €$ \\
\hline
\end{tabular}




\subsection{Edificio D2. Biblioteca de los Apartamentos Cardenal Mendoza}

Edificio de tipo docente que empezó a funcionar en el año 1996, cuenta con una superficie construida de $464 \mathrm{~m}^{2}$. Inicialmente la calefacción era suministrada mediante una caldera de gas natural de una potencia de $41 \mathrm{~kW}$. La subestación de intercambio con la red de calor construida en el año 2015, cuenta con una potencia de 42 kW. En la Figura 59 se marca la ubicación del edificio

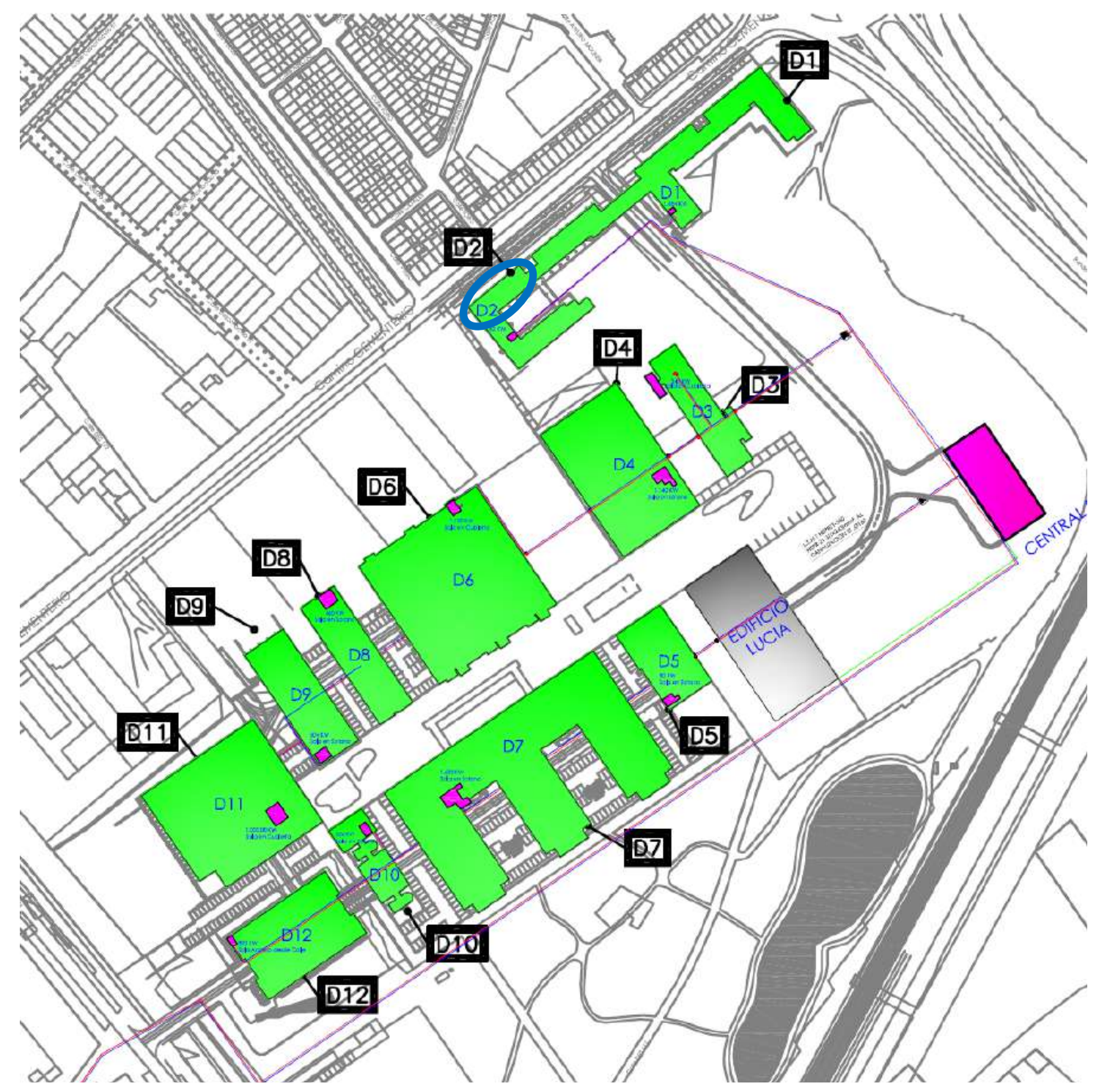

Figura 59. Ubicación del Edificio D2 en el croquis del campus Miguel Delibes 
El modelo encontrado para predecir el consumo térmico del Edificio, fue

$$
\text { kWh_D2_Pronosticado }=-663,338+38,971 \times \text { GD15_30min }
$$

El resumen del modelo, con el coeficiente de correlación de Pearson ( $R$ ) y el coeficiente de determinación $\left(R^{2}\right)$ se muestra en la Tabla 29 y en la Tabla 30, el resultado de la verificación de los supuestos de la regresión lineal.

Tabla 29.Resumen de los modelos encontrados para el Edificio D2

\begin{tabular}{cccccc}
\hline & $\begin{array}{c}\text { Variable } \\
\text { independiente 1 }\end{array}$ & Constante & B & $R$ & $R^{2}$ \\
\hline D2 & GD15_30min & $-663,338$ & 38,971 & 0,985 & 0,970 \\
\hline
\end{tabular}

Tabla 30. Resumen del cumplimiento de los supuestos de regresión. Edificio D2

\begin{tabular}{ll}
\hline \multicolumn{1}{c}{ Cumplimiento de supuestos de la regresión lineal } & Modelo \\
\hline 1. Linealidad de las variables & Cumple \\
\hline 2. Normalidad de variables & Cumple \\
\hline 3. Independencia de los errores o no autocorrelación de los residuos & Cumple \\
\hline 4. Homocedasticidad de la varianza, los errores son aleatorios & Cumple \\
\hline
\end{tabular}

En la Figura 60, se representan el consumo real y el pronosticado con el modelo de regresión obtenido, en kWh.

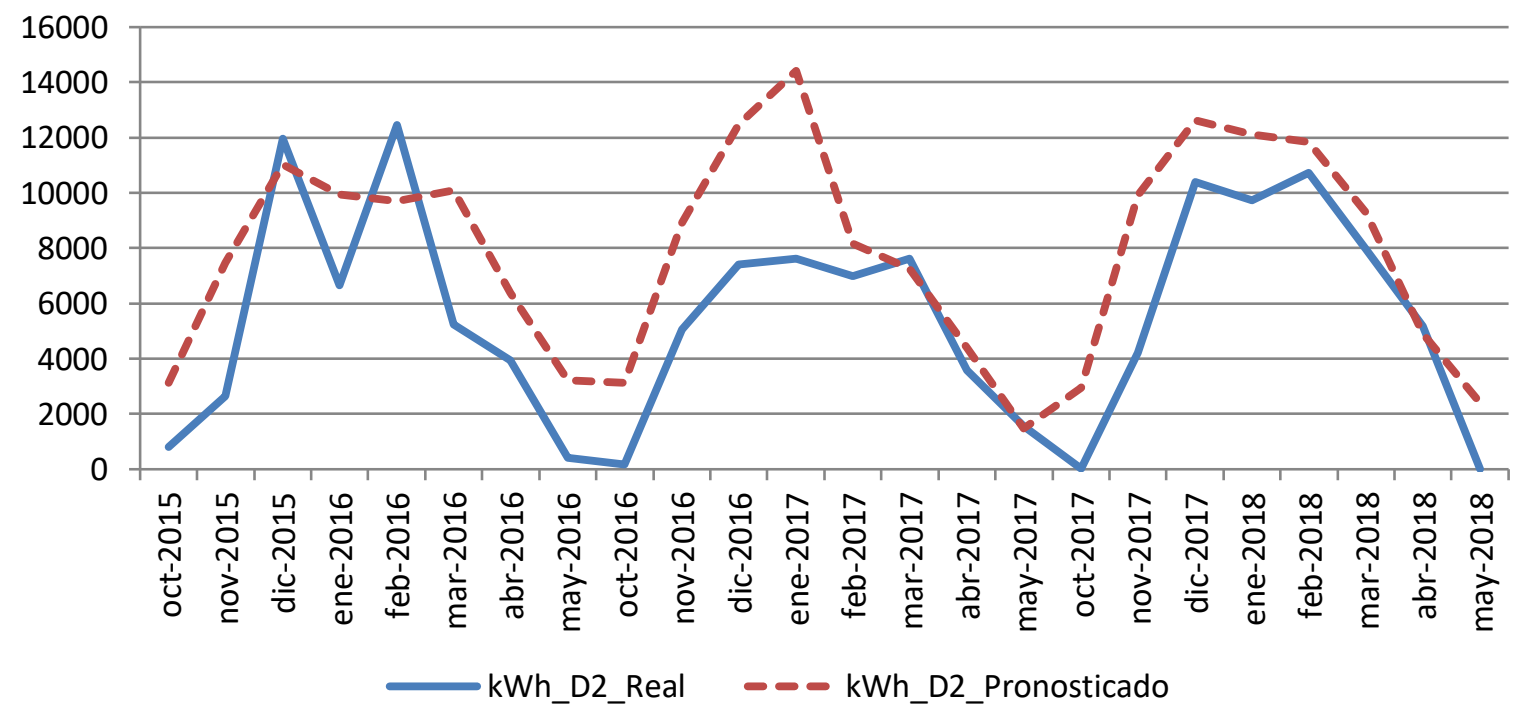

Figura 60. Representación de los consumos pronosticados para el Edificio D2. 2015-2018 
Los resultados de las diferencias entre las medias de los consumos, se muestra en la Tabla 31

Tabla 31. Resultado de las diferencias significativas encontradas. Edificio D2

\begin{tabular}{cccccccccc}
\hline & $\begin{array}{c}\% \\
\text { Diferencia } \\
2015-2016\end{array}$ & Significativo & $\begin{array}{c}\% \\
\text { Diferencia } \\
2016-2017\end{array}$ & Significativo & $\begin{array}{c}\% \\
\text { Diferencia } \\
2017-2018\end{array}$ & Significativo & $\begin{array}{c}\% \\
\text { Diferencia } \\
2015-2018\end{array}$ & Significativo \\
\hline D2 & $38,2 \%$ & No & $50,6 \%$ & SI & $37,0 \%$ & SI & $41,5 \%$ & SI \\
\hline
\end{tabular}

En la Figura 61, se grafican los consumos reales y pronosticados para la temporada Octubre 2015 - Mayo 2018 para el Edificio D2, y las medias de dichos consumos. Según la prueba paramétrica realizada las diferencias encontradas son estadísticamente significativas, con un riesgo a estar equivocados del $5 \%$

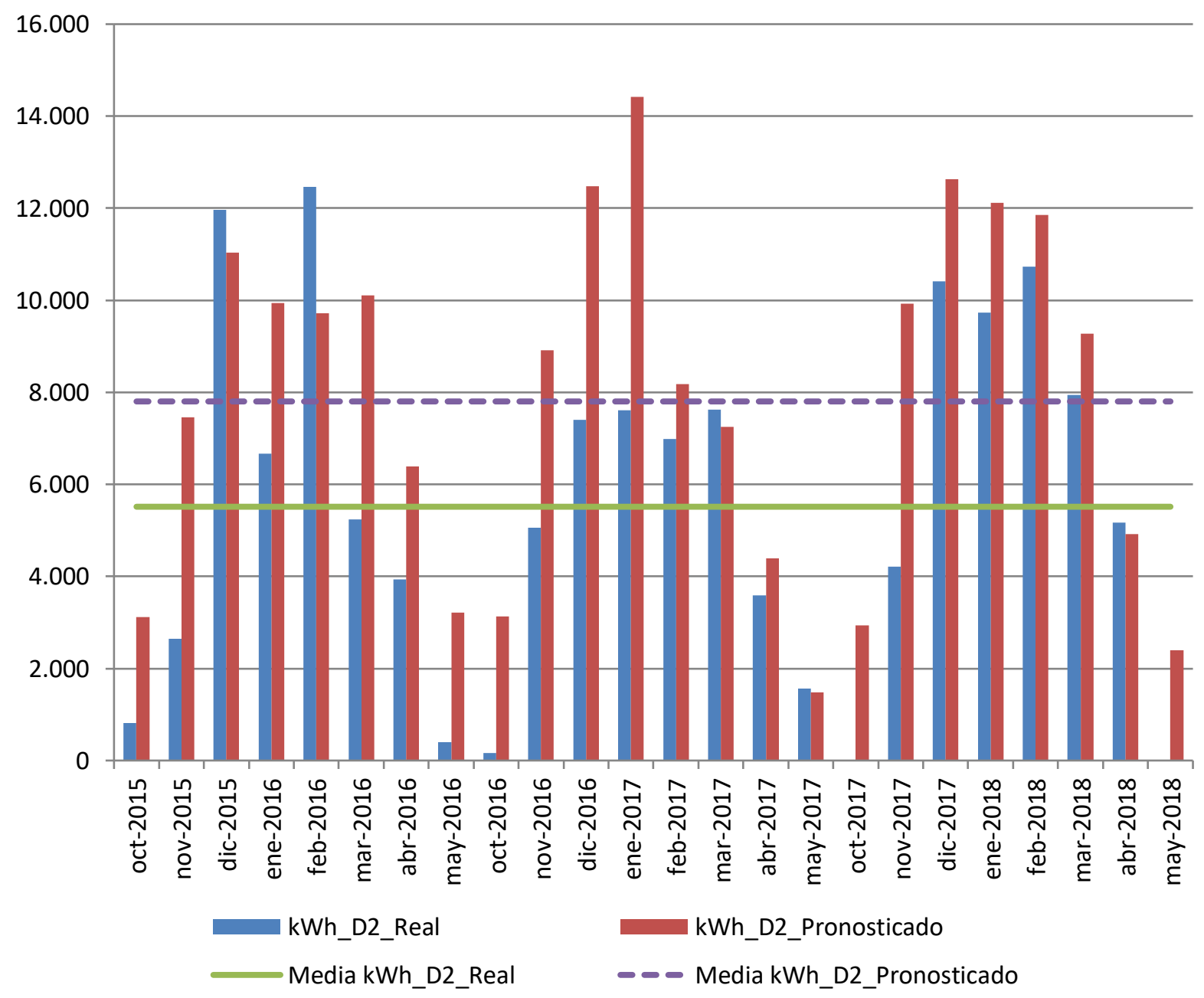

Figura 61. Consumos reales y pronosticados Octubre 2015-Mayo 2018. Edificio D2 
En la Figura 62, se observa el consumo real del Edificio D2, en comparación con el consumo pronosticado acumulado que hubiera tenido el Edificio de no haberse incorporado a la red de calor.

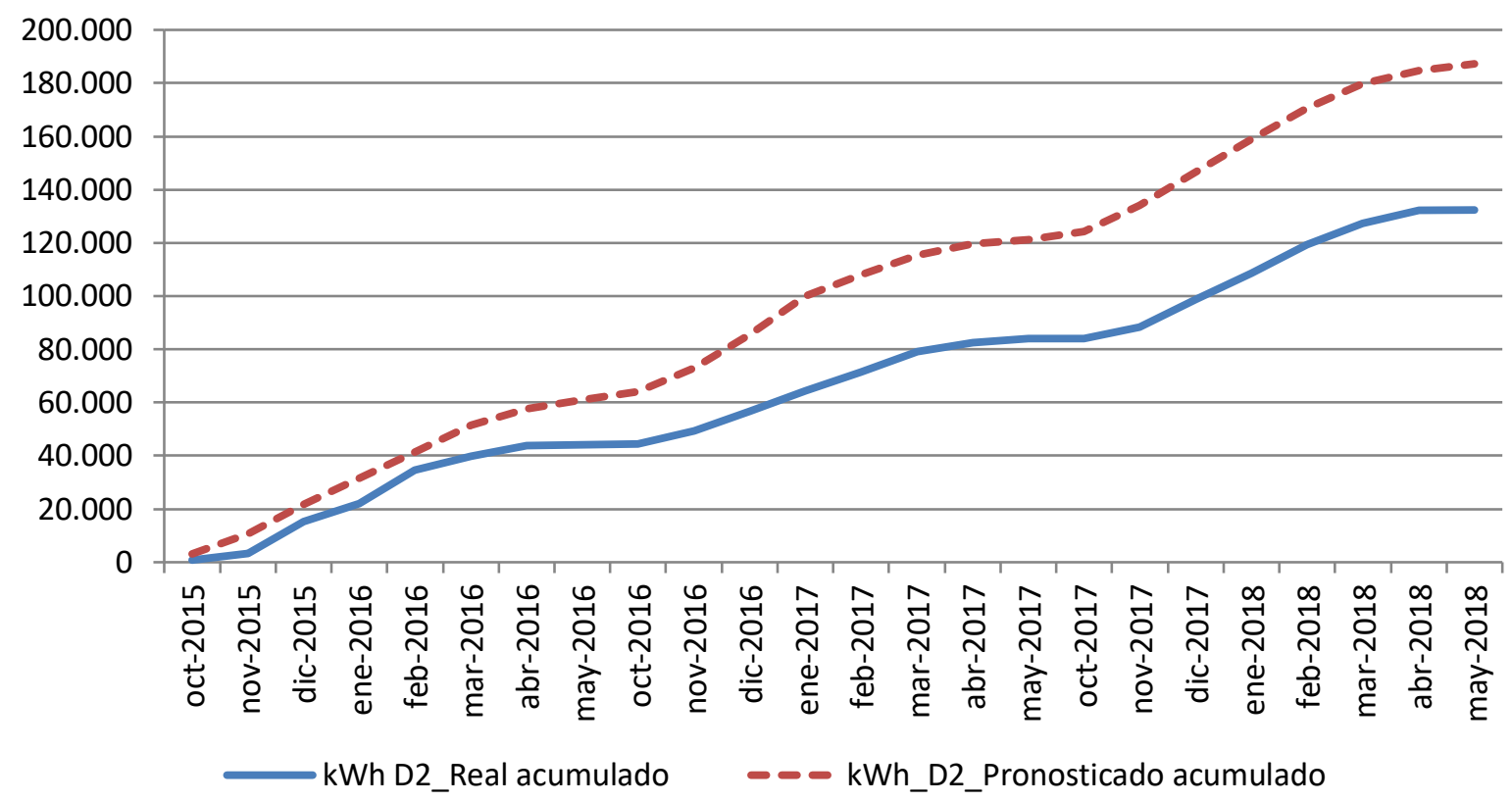

Figura 62. Consumo acumulado real y pronosticado. Octubre 2015-Mayo 2018. Edificio D2

Los resultados del ahorro de consumos, emisiones y precio máximo de la energía útil comprada a la red para un ahorro económico del 15\%, se exponen en la Tabla 32.

Tabla 32. Resumen de resultados. Edificio D2

\begin{tabular}{lcc}
\hline $\begin{array}{l}\text { Diferencia significativa encontrada entre las medias de los } \\
\text { consumos 2015-2018 }\end{array}$ & $41,5 \%$ & $2.288 \mathrm{kWh}$ \\
\hline $\begin{array}{l}\text { Ahorro de consumo térmico durante las tres temporadas } \\
\text { posteriores a la construcción de la red respecto a lo que se hubiera } \\
\text { consumido de no ser por la red }\end{array}$ & $29,3 \%$ & $\begin{array}{c}54.905 \\
\mathrm{kWh}\end{array}$ \\
\hline Ahorro de emisiones de $\mathrm{CO}_{2}$ & $87,5 \%$ & $41 \mathrm{t} \mathrm{CO}_{2}$ \\
\hline $\begin{array}{l}\text { Precio máximo de kWh útiles comprados a la red para obtener un } \\
\text { ahorro del 15\% }\end{array}$ & $\begin{array}{c}0,03961 \\
€ / \mathrm{kWh}\end{array}$ & $909 €$ \\
\hline
\end{tabular}




\subsection{Edificio D3. Centro de Transferencia de Tecnologías aplicadas. CTTA}

Edificio de tipo docente que empezó a funcionar en el año 2007, cuenta con una superficie construida de $5.487 \mathrm{~m}^{2}$. Inicialmente la calefacción era suministrada mediante tres calderas de gas natural de $116 \mathrm{~kW}$ cada una, lo que hace una potencia total de $348 \mathrm{~kW}$. La subestación de intercambio con la red de calor construida en el año 2015, cuenta con una potencia de $342 \mathrm{~kW}$. En la Figura 63 se marca la ubicación del edificio

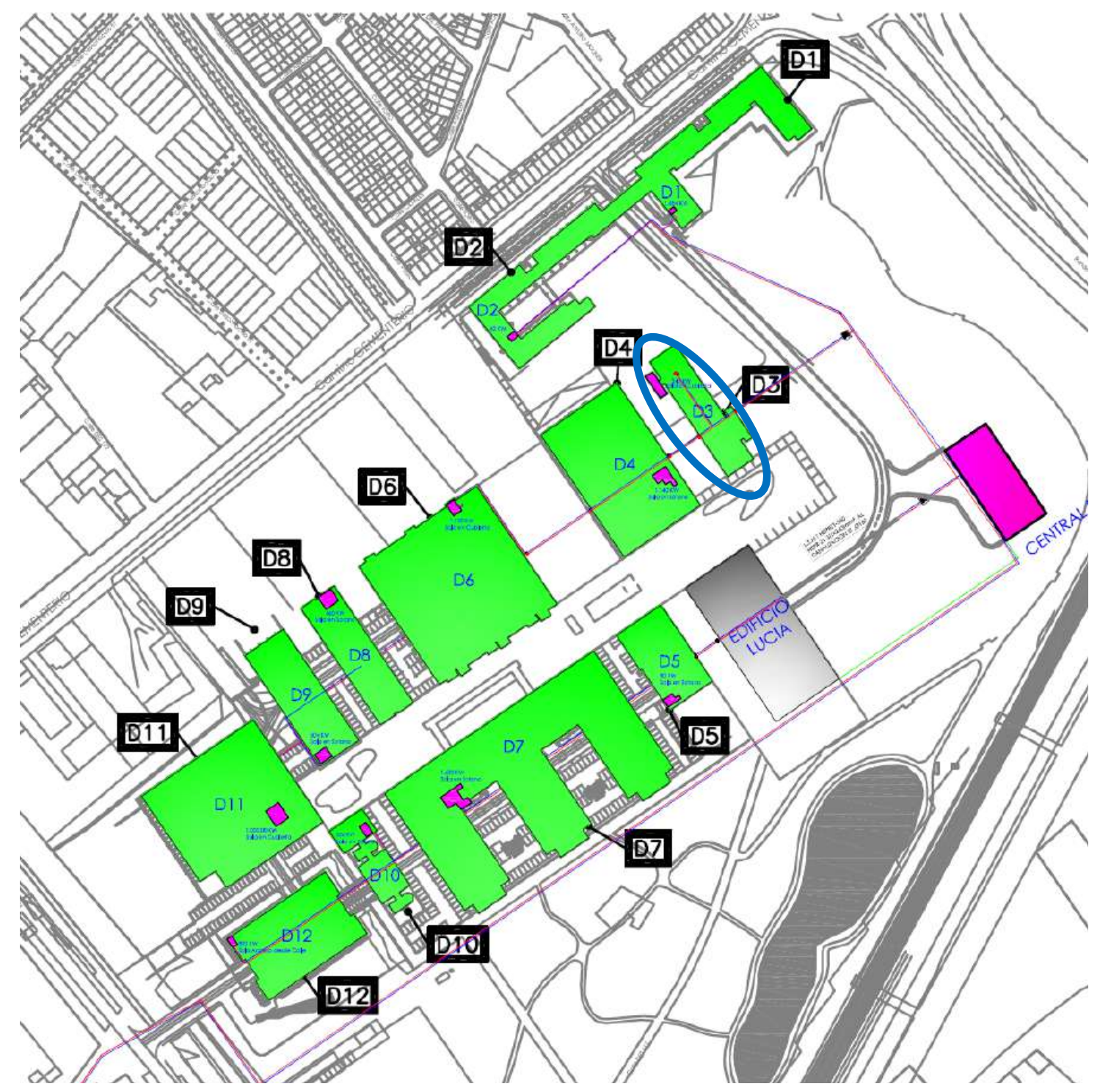

Figura 63. Ubicación del Edificio D3 en el croquis del campus Miguel Delibes 
El modelo encontrado para predecir el consumo térmico del Edificio, fue

$$
\text { kWh_D3_Pronosticado }=-6854,944+192,51 \times \text { GD15_30min }
$$

El resumen del modelo, con el coeficiente de correlación de Pearson ( $R$ ) y el coeficiente de determinación $\left(R^{2}\right)$ se muestra en la Tabla 33 y en la Tabla 34, el resultado de la verificación de los supuestos de la regresión lineal.

Tabla 33. Resumen de los modelos encontrados para el Edificio D3

\begin{tabular}{cccccr}
\hline & $\begin{array}{c}\text { Variable } \\
\text { independiente 1 }\end{array}$ & Constante & B & $R$ & $R^{2}$ \\
\hline D3 & GD15_30min & $-6.854,944$ & 192,510 & 0,921 & 0,848 \\
\hline
\end{tabular}

Tabla 34. Resumen del cumplimiento de los supuestos de regresión. Edificio D3

\begin{tabular}{ll}
\hline \multicolumn{1}{c}{ Cumplimiento de supuestos de la regresión lineal } & Modelo 1 \\
\hline 1. Linealidad de las variables & Cumple \\
\hline 2. Normalidad de variables & Cumple \\
\hline 3. Independencia de los errores o no autocorrelación de los residuos & Cumple \\
\hline 4. Homocedasticidad de la varianza, los errores son aleatorios & Cumple \\
\hline
\end{tabular}

En la Figura 64, se representan el consumo real y el pronosticado con el modelo de regresión obtenido, en kWh.

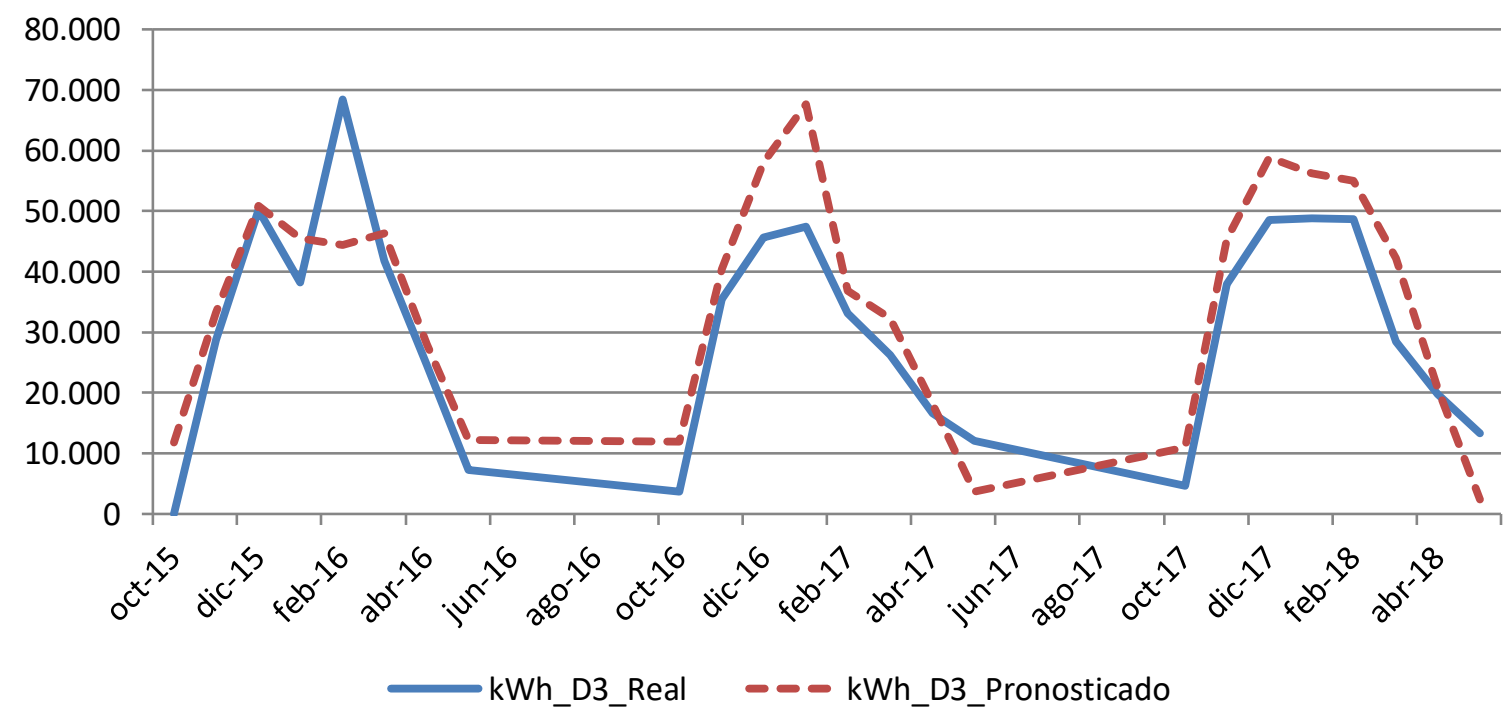

Figura 64. Representación de los consumos pronosticados para el Edificio D3. 2015-2018 
Los resultados de las diferencias entre las medias de los consumos, se exponen en las Tabla 35.

Tabla 35. Resultado de las diferencias significativas encontradas. Edificio D3

\begin{tabular}{cccccccccc}
\hline & $\begin{array}{c}\% \\
\text { Diferencia } \\
2015-2016\end{array}$ & Significativo & $\begin{array}{c}\% \\
\text { Diferencia } \\
2016-2017\end{array}$ & Significativo & $\begin{array}{c}\% \\
\text { Diferencia } \\
2017-2018\end{array}$ & Significativo & $\begin{array}{c}\% \\
\text { Diferencia } \\
2015-2018\end{array}$ & Significativo \\
\hline D3 & $5,1 \%$ & No & $22,1 \%$ & No & $16,7 \%$ & No & $14,2 \%$ & SI \\
\hline
\end{tabular}

En la Figura 65, se grafican los consumos reales y pronosticados para la temporada Octubre 2015 - Mayo 2018 para el Edificio D3, y las medias de dichos consumos. Según la prueba paramétrica realizada las diferencias encontradas son estadísticamente significativas, con un riesgo a estar equivocados del $5 \%$

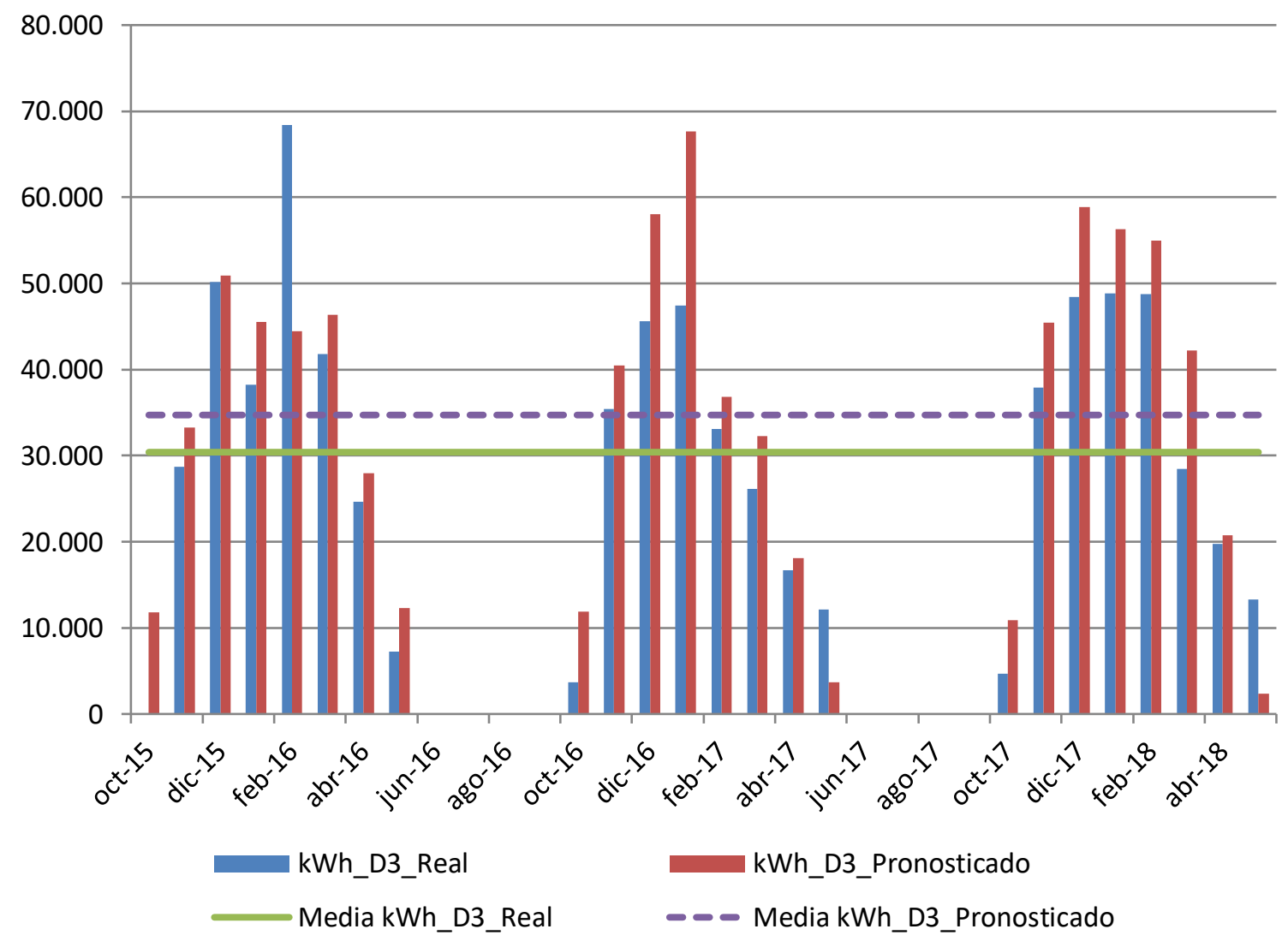

Figura 65. Consumos reales y pronosticados Octubre 2015-Mayo 2018. Edificio D3 
En la Figura 66, se observa el consumo real del Edificio D3, en comparación con el consumo pronosticado acumulado que hubiera tenido el Edificio de no haberse incorporado a la red de calor.

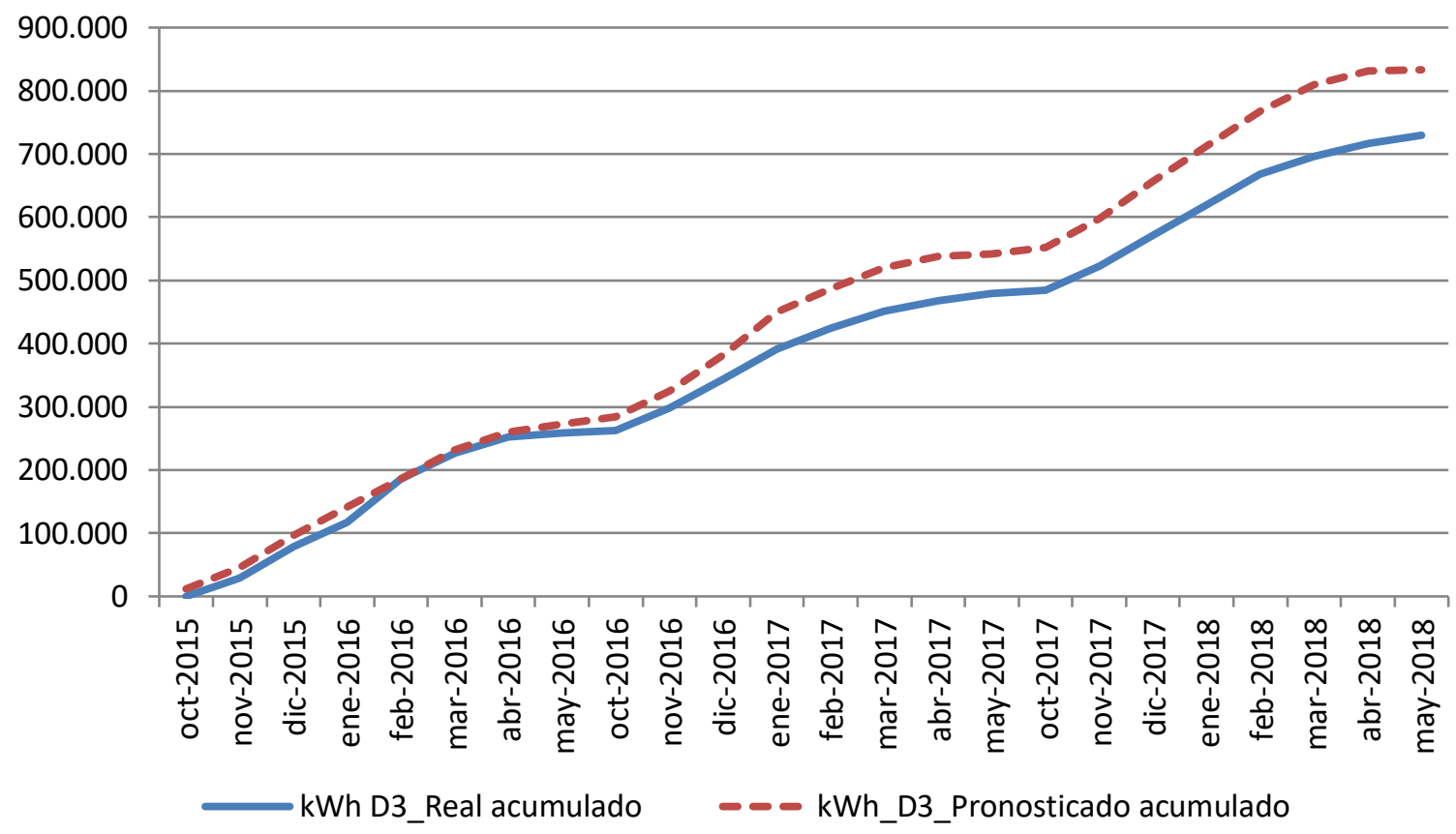

Figura 66. Consumo acumulado real y pronosticado. Octubre 2015-Mayo 2018. Edificio D3

Los resultados del ahorro de consumos, emisiones y precio máximo de la energía útil comprada a la red para un ahorro económico del 15\%, se exponen en las Tabla 36

Tabla 36. Resumen de resultados. Edificio D3

\begin{tabular}{lcc}
\hline $\begin{array}{l}\text { Diferencia significativa encontrada entre las medias de los } \\
\text { consumos 2015-2018 }\end{array}$ & $14,2 \%$ & $4.317 \mathrm{kWh}$ \\
\hline $\begin{array}{l}\text { Ahorro de consumo térmico durante las tres temporadas } \\
\text { posteriores a la construcción de la red respecto a lo que se hubiera } \\
\text { consumido de no ser por la red }\end{array}$ & $12,4 \%$ & $\begin{array}{c}103,598 \\
\mathrm{kWh}\end{array}$ \\
\hline Ahorro de emisiones de $\mathrm{CO}_{2}$ & $85,1 \%$ & $179 \mathrm{t} \mathrm{CO}_{2}$ \\
\hline $\begin{array}{l}\text { Precio máximo de kWh útiles comprados a la red para obtener un } \\
\text { ahorro del 15\% }\end{array}$ & $0,0314 € / \mathrm{kWh}$ & $26.890 €$ \\
\hline
\end{tabular}




\subsection{Edificio D4. Biblioteca aulario Miguel Delibes}

Edificio de tipo docente que empezó a funcionar en el año 2012, cuenta con una superficie construida de $14.541 \mathrm{~m}^{2}$. Inicialmente la calefacción era suministrada mediante dos calderas de gas natural de $570 \mathrm{~kW}$ cada una, lo que hace una potencia total de $1.140 \mathrm{~kW}$. La subestación de intercambio con la red de calor construida en el año 2015, cuenta con una potencia de $1.140 \mathrm{~kW}$. En la Figura 67 se marca la ubicación del edificio

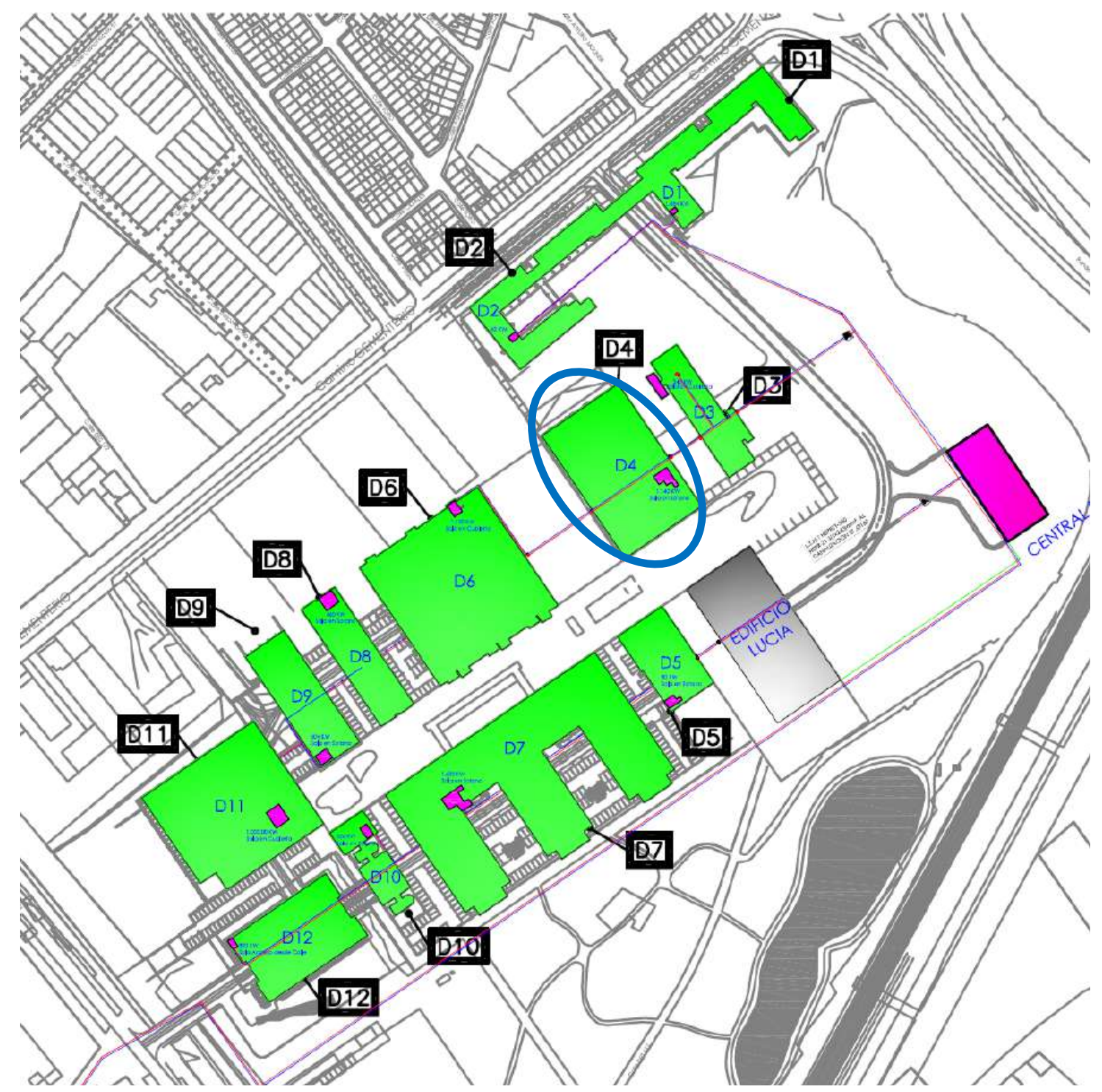

Figura 67. Ubicación del Edificio D4 en el croquis del campus Miguel Delibes 
El modelo encontrado para predecir el consumo térmico del Edificio, fue

$$
\text { kWh_D4_Pronosticado }=271.046,123-17.453,026 \times \text { T_med }
$$

El resumen del modelo, con el coeficiente de correlación de Pearson $(R)$ y el coeficiente de determinación $\left(R^{2}\right)$ se muestra en la Tabla 37 y en la Tabla 38 , el resultado de la verificación de los supuestos de la regresión lineal.

Tabla 37. Resumen de los modelos encontrados para el Edificio D4

\begin{tabular}{cccccr}
\hline & $\begin{array}{c}\text { Variable } \\
\text { independiente 1 }\end{array}$ & Constante & B & $R$ & $R^{2}$ \\
\hline D4 & Tmed & $271.046,123$ & $-17.453,026$ & $-0,940$ & 0,888 \\
\hline
\end{tabular}

Tabla 38. Resumen del cumplimiento de los supuestos de regresión. Edificio D4

\begin{tabular}{ll}
\hline \multicolumn{1}{c}{ Cumplimiento de supuestos de la regresión lineal } & Modelo 1 \\
\hline 1. Linealidad de las variables & Cumple \\
\hline 2. Normalidad de variables & Cumple \\
\hline 3. Independencia de los errores o no autocorrelación de los residuos & Cumple \\
\hline 4. Homocedasticidad de la varianza, los errores son aleatorios & Cumple \\
\hline
\end{tabular}

En la Figura 68, se representan el consumo real y el pronosticado con el modelo de regresión obtenido, en kWh.

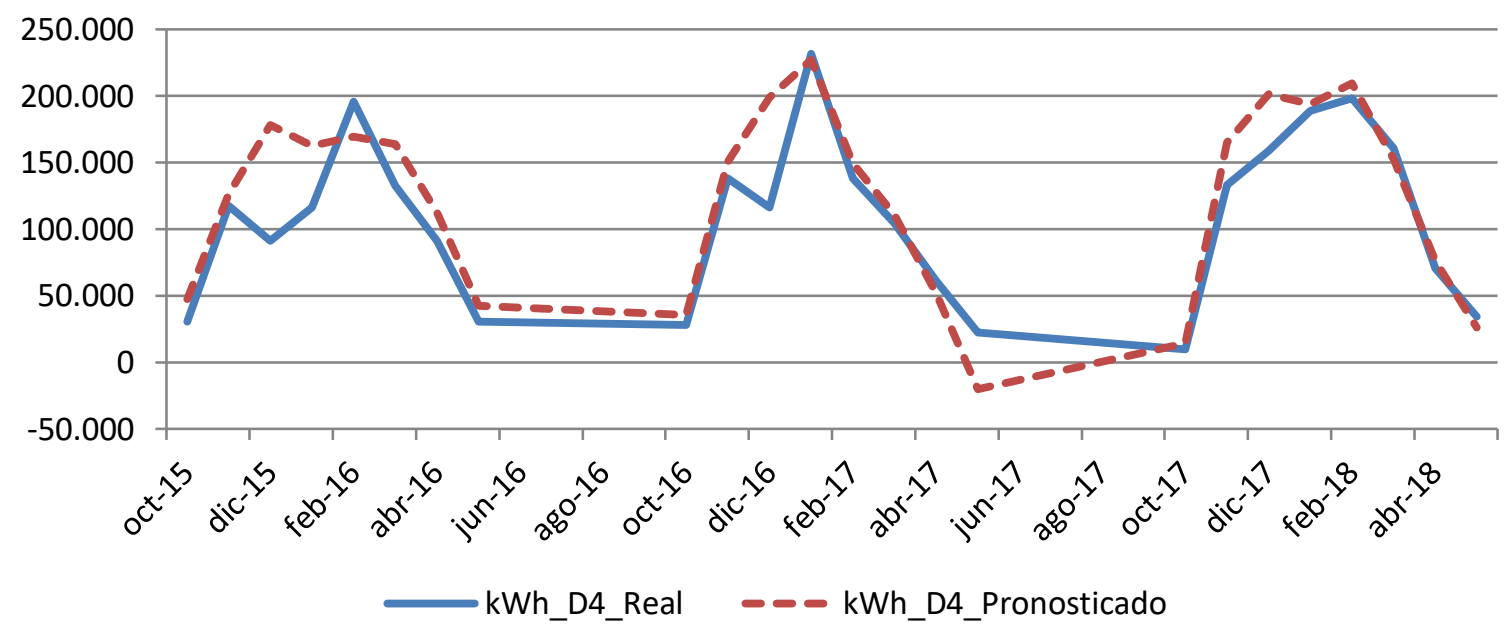

Figura 68. Representación de los consumos pronosticados para el Edificio D4. 2015-2018 
Los resultados de las diferencias entre las medias de los consumos, se exponen en las Tabla 39

Tabla 39. Resultado de las diferencias significativas encontradas. Edificio D4

\begin{tabular}{cccccccccc}
\hline & $\begin{array}{c}\% \\
\text { Diferencia } \\
2015-2016\end{array}$ & Significativo & $\begin{array}{c}\% \\
\text { Diferencia } \\
2016-2017\end{array}$ & Significativo & $\begin{array}{c}\% \\
\text { Diferencia } \\
2017-2018\end{array}$ & Significativo & $\begin{array}{c}\% \\
\text { Diferencia } \\
2015-2018\end{array}$ & Significativo \\
\hline D4 & $24,1 \%$ & No & $13,1 \%$ & No & $8,8 \%$ & No & $14,9 \%$ & SI \\
\hline
\end{tabular}

En la Figura 69, se grafican los consumos reales y pronosticados para la temporada Octubre 2015 - Mayo 2018 para el Edificio D4, y las medias de dichos consumos. Según la prueba paramétrica realizada las diferencias encontradas son estadísticamente significativas, con un riesgo a estar equivocados del $5 \%$

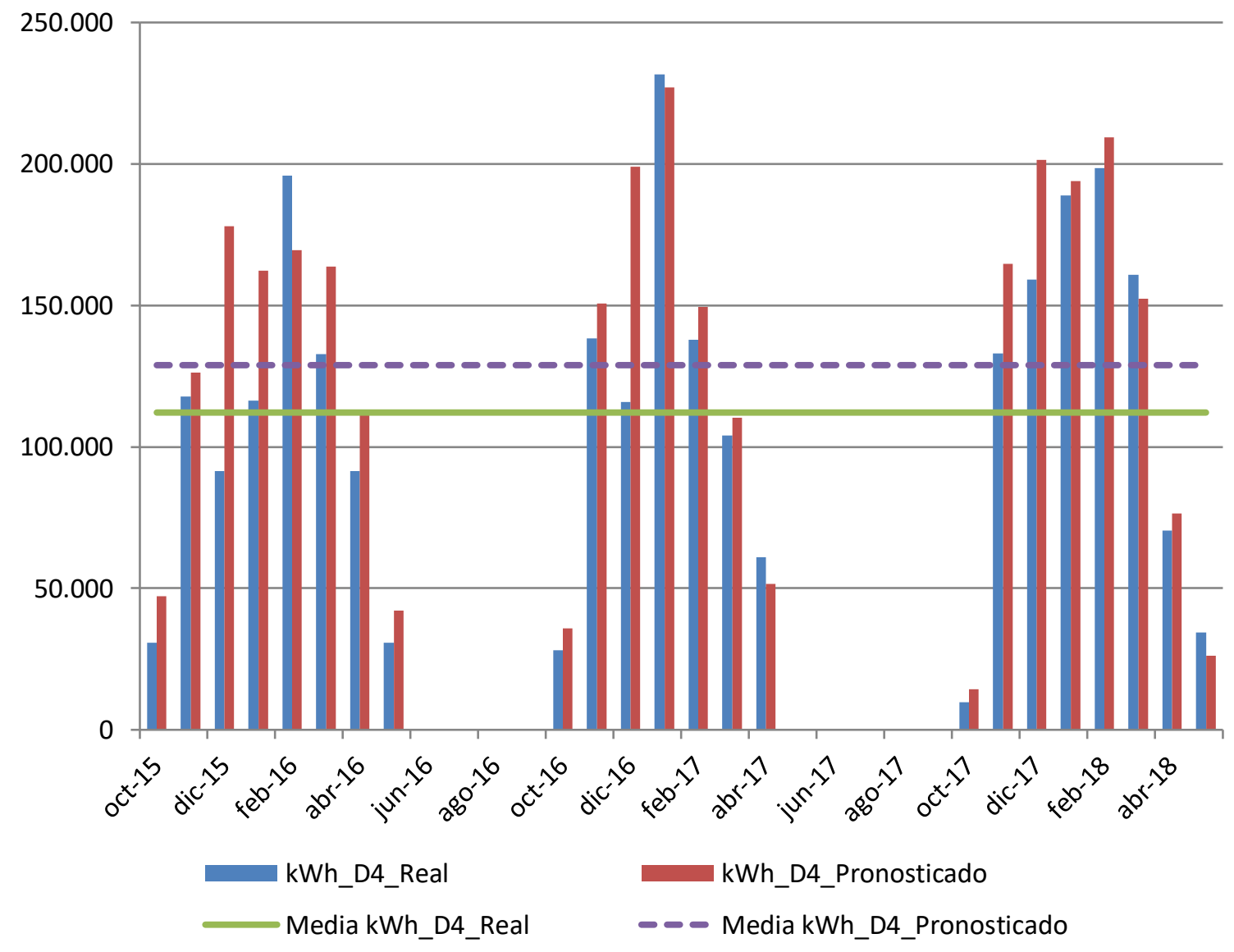

Figura 69. Consumos reales y pronosticados Octubre 2015-Mayo 2018. Edificio D4 
En la Figura 70, se observa el consumo real del Edificio D4, en comparación con el consumo pronosticado acumulado que hubiera tenido el Edificio de no haberse incorporado a la red de calor.

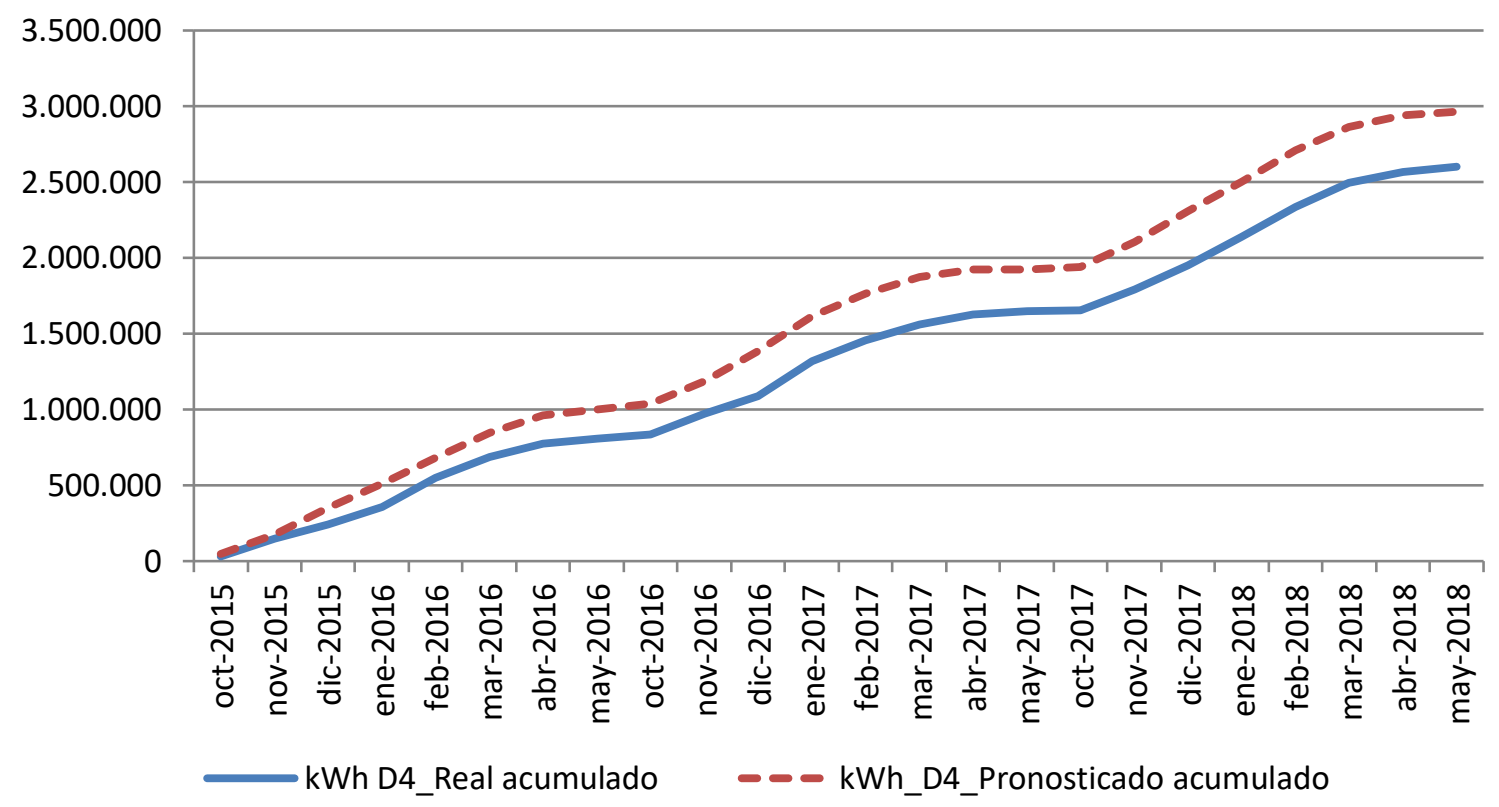

Figura 70. Consumo acumulado real y pronosticado. Octubre 2015-Mayo 2018. Edificio D4

Los resultados del ahorro de consumos, emisiones y precio máximo de la energía útil comprada a la red para un ahorro económico del 15\%, se exponen en las Tabla 40

Tabla 40. Resumen de resultados. Edificio D4

\begin{tabular}{lcc}
\hline $\begin{array}{l}\text { Diferencia significativa encontrada entre las medias de los } \\
\text { consumos 2015-2018 }\end{array}$ & $14,9 \%$ & $\begin{array}{c}16.751 \\
\mathrm{kWh}\end{array}$ \\
\hline $\begin{array}{l}\text { Ahorro de consumo térmico durante las tres temporadas } \\
\text { posteriores a la construcción de la red respecto a lo que se hubiera } \\
\text { consumido de no ser por la red }\end{array}$ & $13,0 \%$ & $\begin{array}{c}385.278 \\
\mathrm{kWh}\end{array}$ \\
\hline $\begin{array}{l}\text { Ahorro de emisiones de } \mathrm{CO}_{2} \\
\text { Precio máximo de kWh útiles comprados a la red para obtener un } \\
\text { ahorro del 15\% }\end{array}$ & $0,0313 € / \mathrm{kWh}$ & $14.400 €$ \\
\hline
\end{tabular}




\subsection{Edificio D5. Instituto Universitario de Oftalmología Aplicada. IOBA}

Edificio de tipo docente que empezó a funcionar en el año 2008, cuenta con una superficie construida de $4.146 \mathrm{~m}^{2}$. Inicialmente la calefacción era suministrada mediante dos calderas de gas natural de $41 \mathrm{~kW}$ cada una, lo que hace una potencia total de $81 \mathrm{~kW}$. La subestación de intercambio con la red de calor construida en el año 2015, cuenta con una potencia de $80 \mathrm{~kW}$. En la Figura 71 se marca la ubicación del edificio

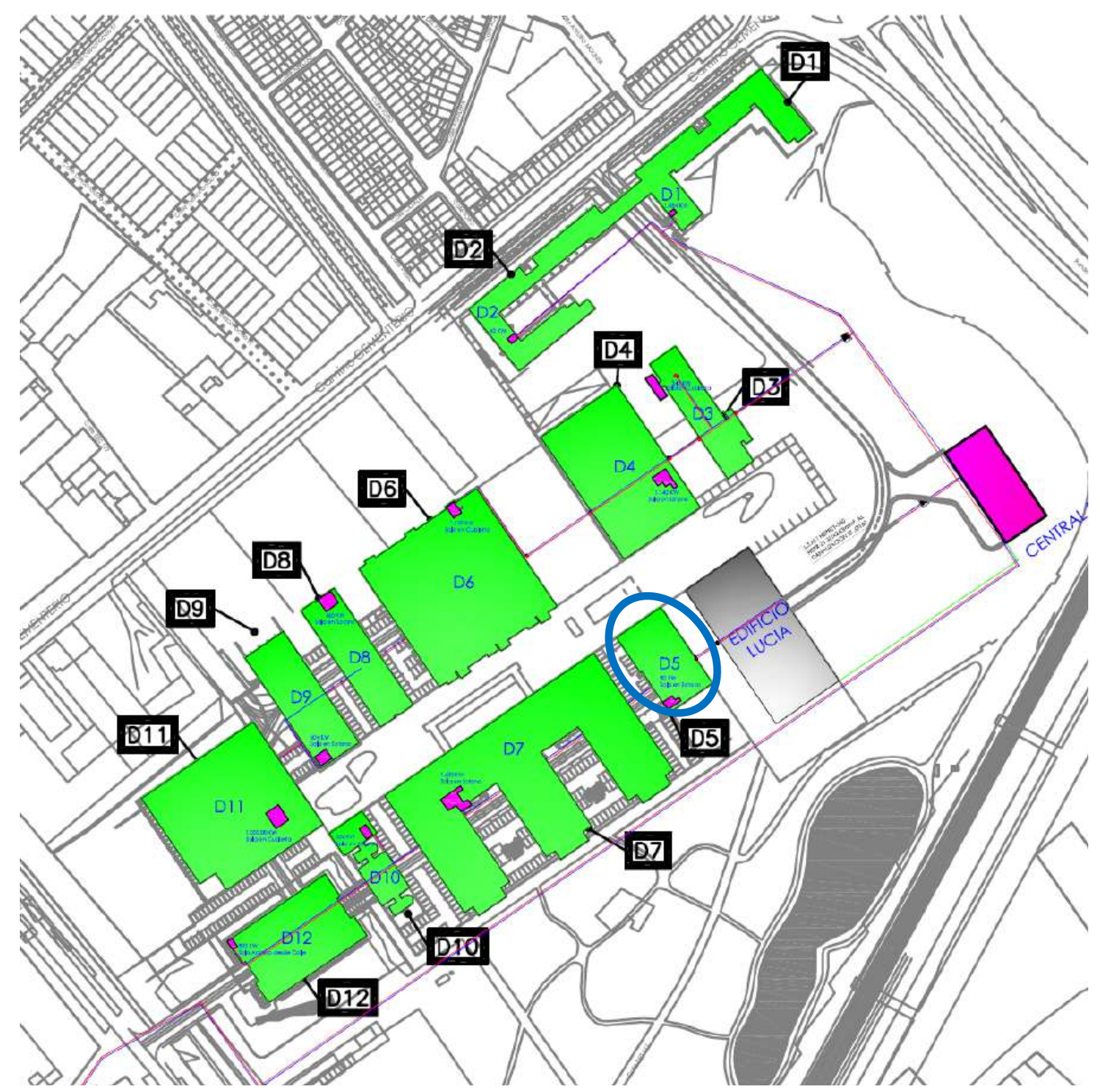

Figura 71. Ubicación del Edificio D5 en el croquis del campus Miguel Delibes 
El modelo encontrado para predecir el consumo térmico del Edificio, fue

$$
\text { kWh_D5_Pronosticado }=-653,894+56,535 \times \text { GD15_30min }
$$

El resumen del modelo, con el coeficiente de correlación de Pearson $(R$ ) y el coeficiente de determinación $\left(R^{2}\right)$ se muestra en la Tabla 41 y en la Tabla 42, el resultado de la verificación de los supuestos de la regresión lineal.

Tabla 41. Resumen de los modelos encontrados para el Edificio D5

\begin{tabular}{cccccr}
\hline & $\begin{array}{c}\text { Variable } \\
\text { independiente 1 }\end{array}$ & Constante & B & $R$ & $R^{2}$ \\
\hline D5 & GD15_30min & $-653,894$ & 56,535 & 0,993 & 0,986 \\
\hline
\end{tabular}

Tabla 42. Resumen del cumplimiento de los supuestos de regresión. Edificio D5

\begin{tabular}{ll}
\hline \multicolumn{1}{c}{ Cumplimiento de supuestos de la regresión lineal } & Modelo \\
\hline 1. Linealidad de las variables & Cumple \\
\hline 2. Normalidad de variables & Cumple \\
\hline 3. Independencia de los errores o no autocorrelación de los residuos & Cumple \\
\hline 4. Homocedasticidad de la varianza, los errores son aleatorios & Cumple \\
\hline
\end{tabular}

En la Figura 72, se representan el consumo real y el pronosticado con el modelo de regresión obtenido, en kWh.

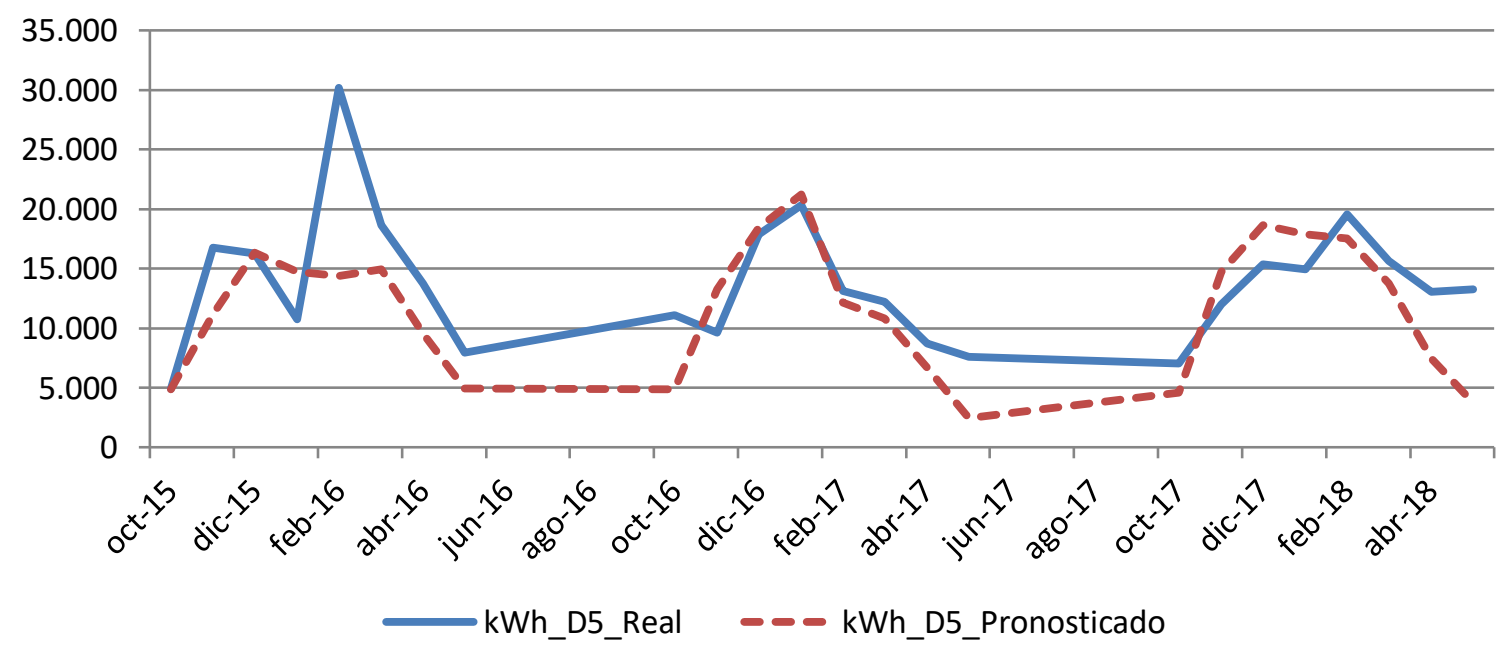

Figura 72. Representación de los consumos pronosticados para el Edificio D5. 2015-2018 
Los resultados de las diferencias entre las medias de los consumos, se exponen en las Tabla 43

Tabla 43. Resultado de las diferencias significativas encontradas. Edificio D5

\begin{tabular}{cccccccccc}
\hline & $\begin{array}{c}\% \\
\text { Diferencia } \\
2015-2016\end{array}$ & Significativo & $\begin{array}{c}\% \\
\text { Diferencia } \\
2016-2017\end{array}$ & Significativo & $\begin{array}{c}\% \\
\text { Diferencia } \\
2017-2018\end{array}$ & Significativo & $\begin{array}{c}\% \\
\text { Diferencia } \\
2015-2018\end{array}$ & Significativo \\
\hline D5 & $-23,7 \%$ & No & $-10,7 \%$ & No & $-11,3 \%$ & No & $-15,6 \%$ & SI \\
\hline
\end{tabular}

En la Figura 73, se grafican los consumos reales y pronosticados para la temporada Octubre 2015 - Mayo 2018 para el Edificio D5, y las medias de dichos consumos. Según la prueba paramétrica realizada las diferencias encontradas son estadísticamente significativas, con un riesgo a estar equivocados del $5 \%$

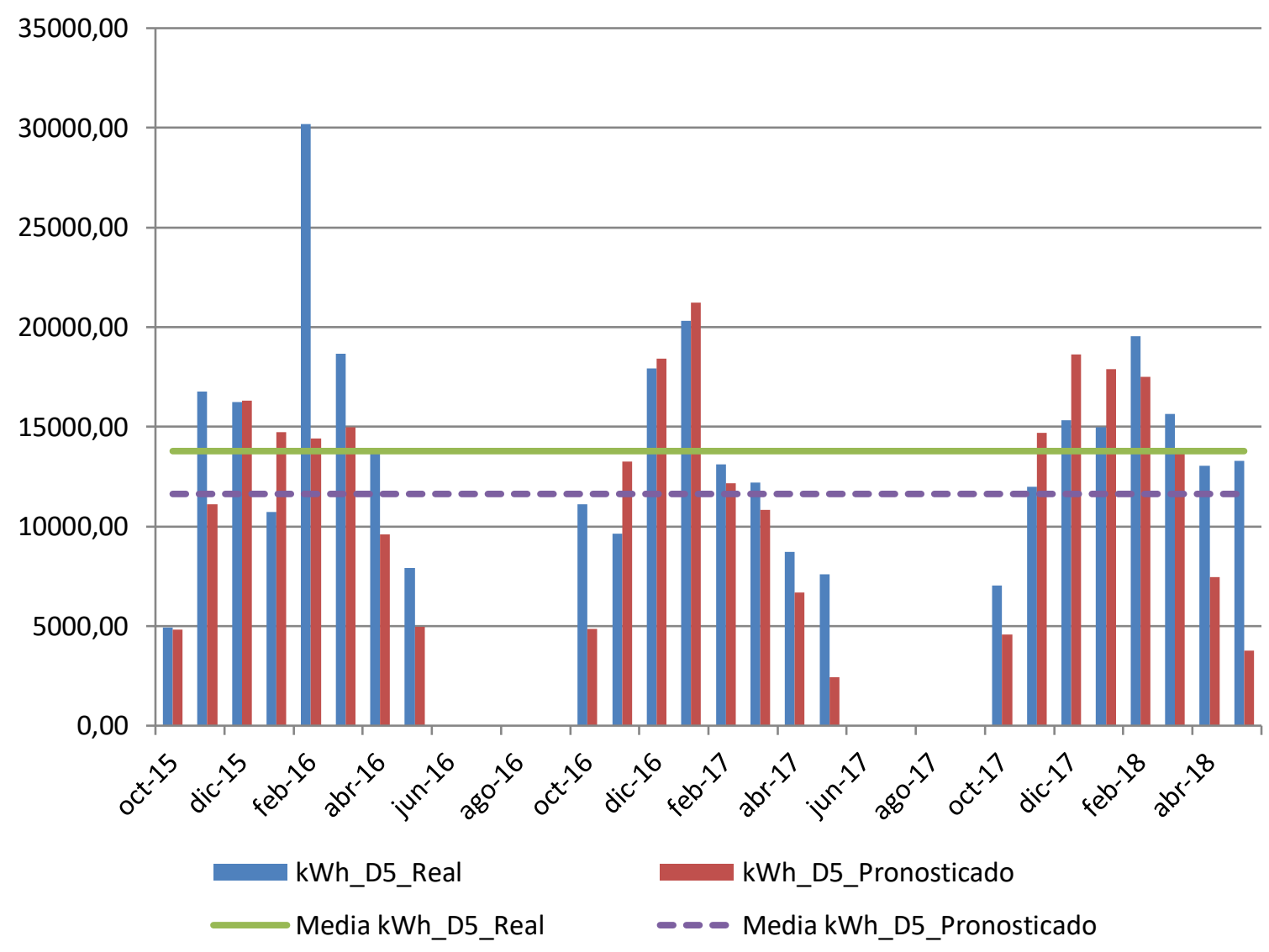

Figura 73. Consumos reales y pronosticados Octubre 2015-Mayo 2018. Edificio D5 
En la Figura 74, se observa el consumo real del Edificio D5, en comparación con el consumo pronosticado acumulado que hubiera tenido el Edificio de no haberse incorporado a la red de calor.

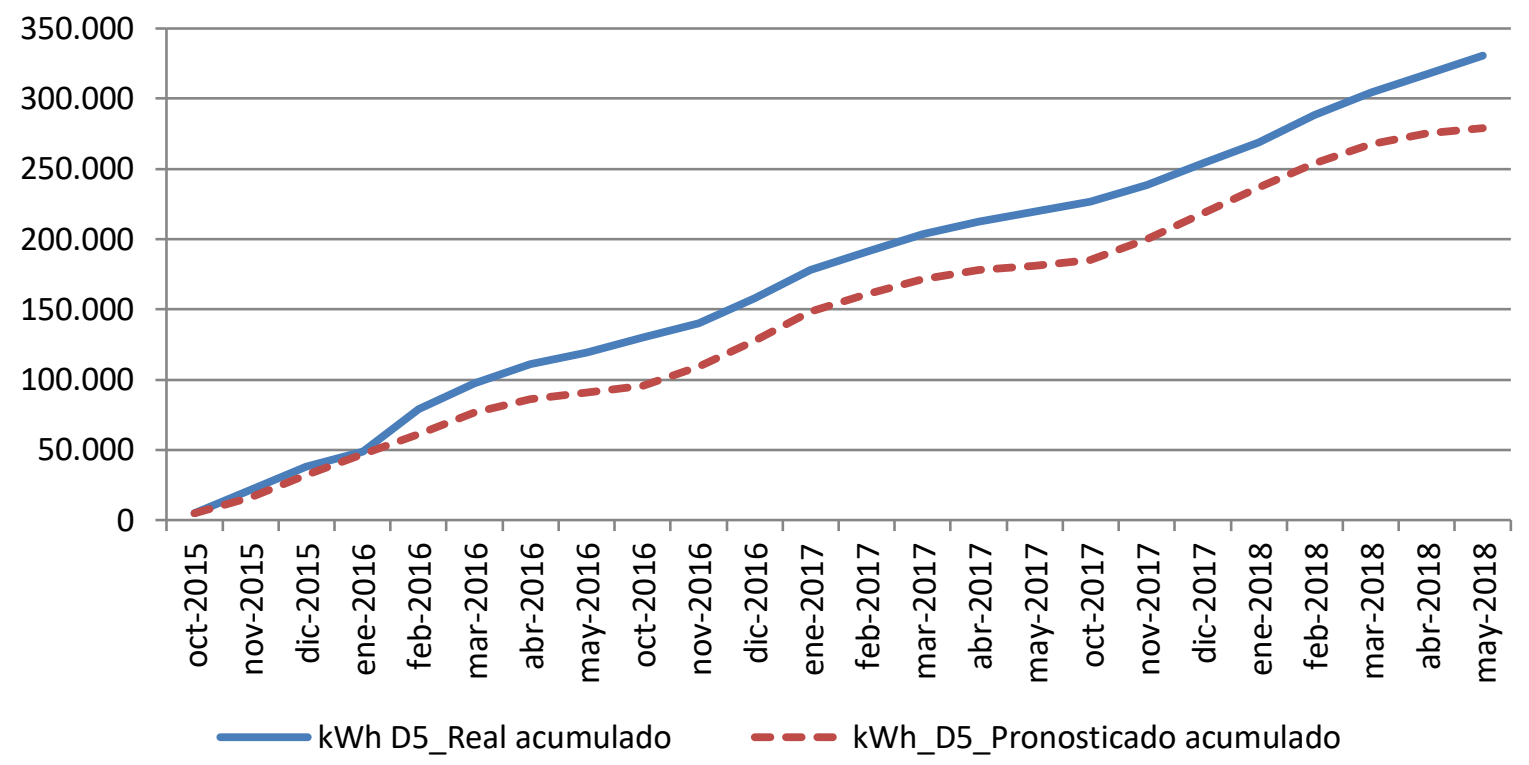

Figura 74. Consumo acumulado real y pronosticado. Octubre 2015-Mayo 2018. Edificio D5

Los resultados del ahorro de consumos, emisiones y precio máximo de la energía útil comprada a la red para un ahorro económico del 15\%, se exponen en las Tabla 44

Tabla 44. Resumen de resultados. Edificio D5

\begin{tabular}{lcc}
\hline $\begin{array}{l}\text { Diferencia significativa encontrada entre las medias de los } \\
\text { consumos 2015-2018 }\end{array}$ & $-15,6 \%$ & $-2.151 \mathrm{kWh}$ \\
\hline $\begin{array}{l}\text { Ahorro de consumo térmico durante las tres temporadas } \\
\text { posteriores a la construcción de la red respecto a lo que se hubiera } \\
\text { consumido de no ser por la red }\end{array}$ & $-18,5 \%$ & $\begin{array}{c}-51.614 \\
\mathrm{kWh}\end{array}$ \\
\hline \begin{tabular}{l} 
Ahorro de emisiones de $\mathrm{CO}_{2}$ \\
\hline $\begin{array}{l}\text { Precio máximo de kWh útiles comprados a la red para obtener un } \\
\text { ahorro del 15\% }\end{array}$
\end{tabular} & $0,02224 € / \mathrm{kWh}$ & $1.348 €$ \\
\hline
\end{tabular}




\subsection{Edificio D6. Facultad de Ciencias}

Edificio de tipo docente que empezó a funcionar en el año 2009, cuenta con una superficie construida de $19.137 \mathrm{~m}^{2}$. Inicialmente la calefacción era suministrada mediante dos calderas de gas natural de $581 \mathrm{~kW}$ cada una, lo que hace una potencia total de $1.162 \mathrm{~kW}$. La subestación de intercambio con la red de calor construida en el año 2015, cuenta con una potencia de $1.120 \mathrm{~kW}$. En la Figura 75 se marca la ubicación del edificio

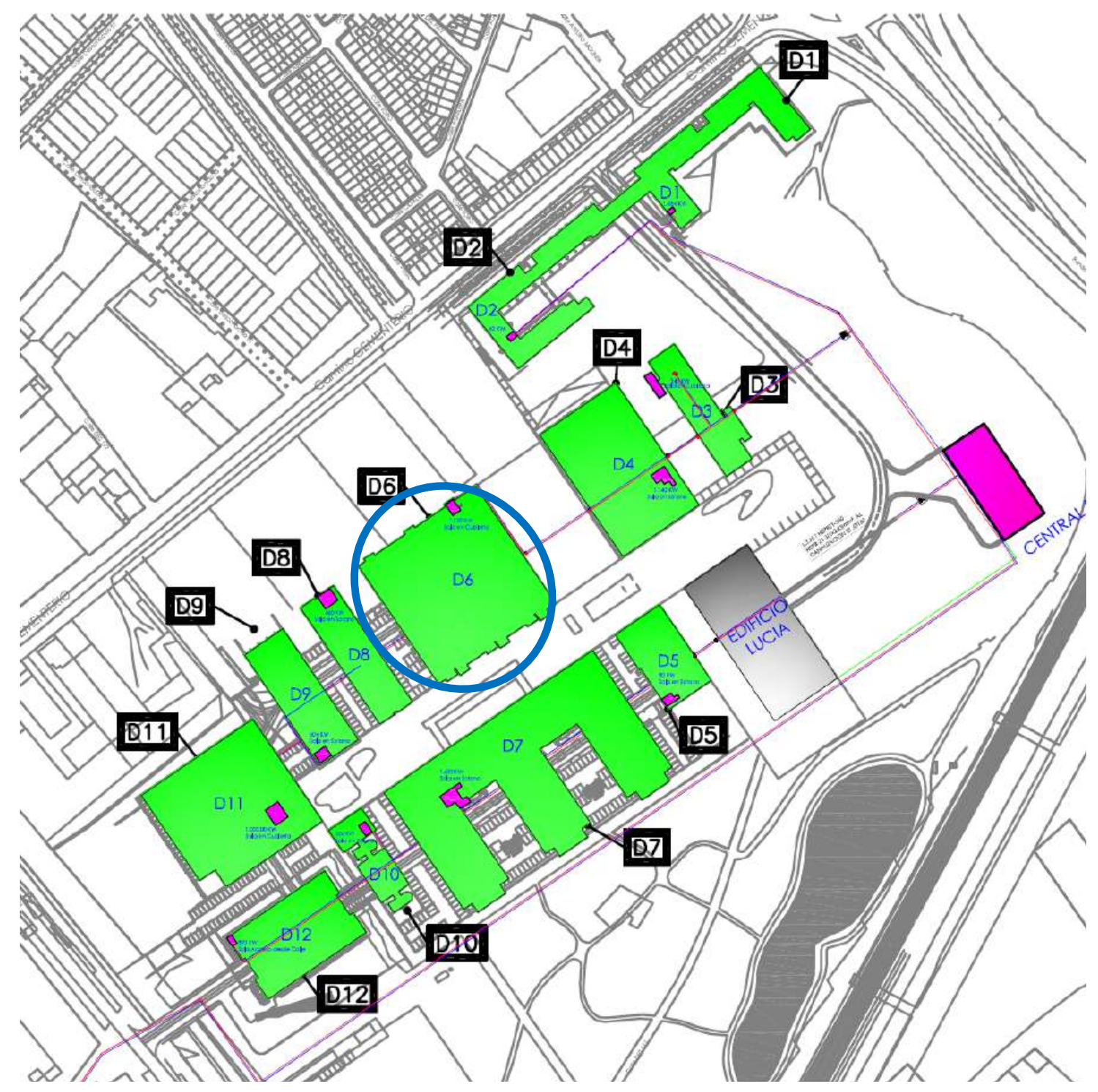

Figura 75. Ubicación del Edificio D6 en el croquis del campus Miguel Delibes 
El modelo encontrado para predecir el consumo térmico del Edificio, fue

$$
\text { kWh_D6_Pronosticado }=-6540,157+656,818 \times \text { GD15_30min }
$$

El resumen del modelo, con el coeficiente de correlación de Pearson $(R)$ y el coeficiente de determinación $\left(R^{2}\right)$ se muestra en la Tabla 45 y en la Tabla 46 , el resultado de la verificación de los supuestos de la regresión lineal.

Tabla 45. Resumen de los modelos encontrados para el Edificio D6

\begin{tabular}{cccccr}
\hline & $\begin{array}{c}\text { Variable } \\
\text { independiente 1 }\end{array}$ & Constante & B & $R$ & $R^{2}$ \\
\hline D6 & GD15_30min & $-6.540,157$ & 656,818 & 0,995 & 0,989 \\
\hline
\end{tabular}

Tabla 46. Resumen del cumplimiento de los supuestos de regresión. Edificio D6

\begin{tabular}{ll}
\hline \multicolumn{1}{c}{ Cumplimiento de supuestos de la regresión lineal } & Modelo \\
\hline 1. Linealidad de las variables & Cumple \\
\hline 2. Normalidad de variables & Cumple \\
\hline 3. Independencia de los errores o no autocorrelación de los residuos & Cumple \\
\hline 4. Homocedasticidad de la varianza, los errores son aleatorios & Cumple \\
\hline
\end{tabular}

En la Figura 76, se representan el consumo real y el pronosticado con el modelo de regresión obtenido, en kWh.

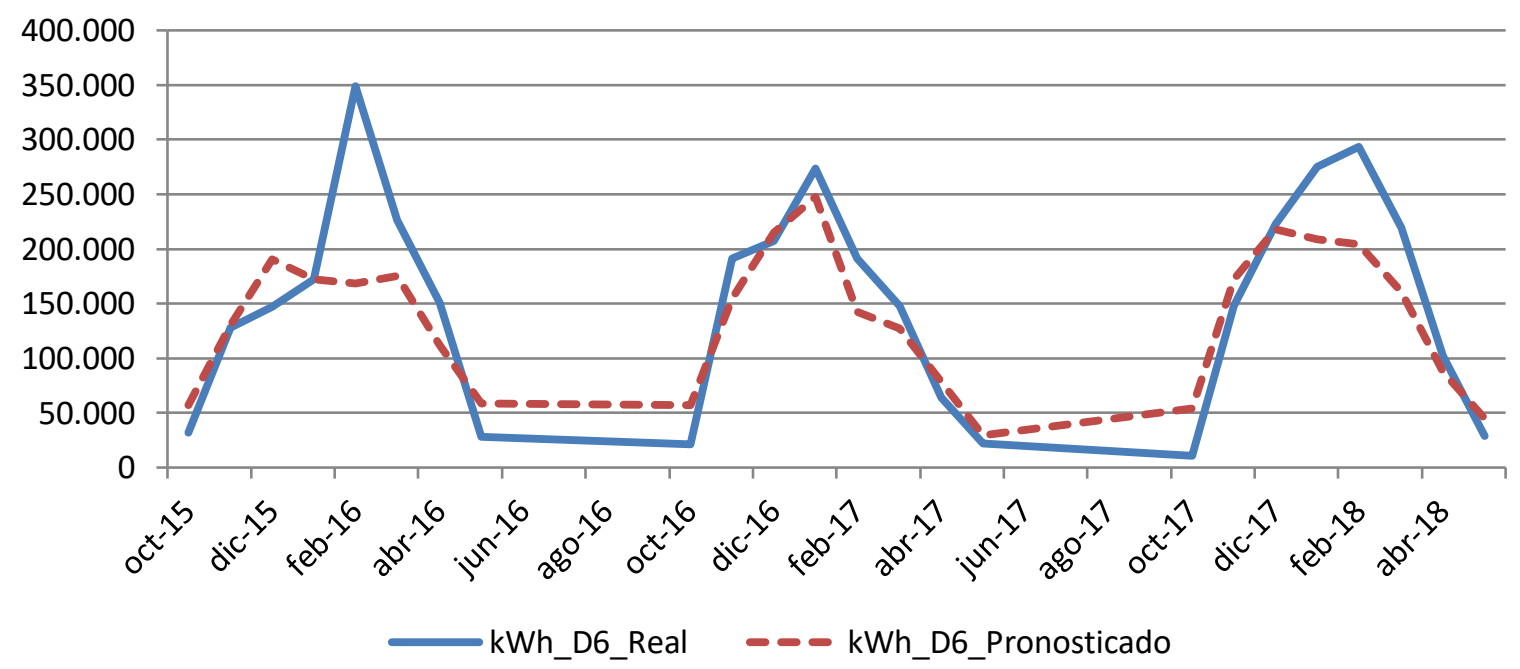

Figura 76. Representación de los consumos pronosticados para el Edificio D6. 2015-2018 
Los resultados de las diferencias entre las medias de los consumos, se exponen en las Tabla 47

Tabla 47. Resultado de las diferencias significativas encontradas. Edificio D6

\begin{tabular}{cccccccccc}
\hline & $\begin{array}{c}\% \\
\text { Diferencia } \\
2015-2016\end{array}$ & Significativo & $\begin{array}{c}\% \\
\text { Diferencia } \\
2016-2017\end{array}$ & Significativo & $\begin{array}{c}\% \\
\text { Diferencia } \\
2017-2018\end{array}$ & Significativo & $\begin{array}{c}\% \\
\text { Diferencia } \\
2015-2018\end{array}$ & Significativo \\
\hline D6 & $-13,8 \%$ & No & $-5,9 \%$ & No & $-11,5 \%$ & No & $-10,6 \%$ & No \\
\hline
\end{tabular}

En la Figura 77, se grafican los consumos reales y pronosticados para la temporada Octubre 2015 - Mayo 2018 para el Edificio D6, y las medias de dichos consumos. Según la prueba paramétrica realizada las diferencias encontradas no son estadísticamente significativas, con un riesgo a estar equivocados del $5 \%$

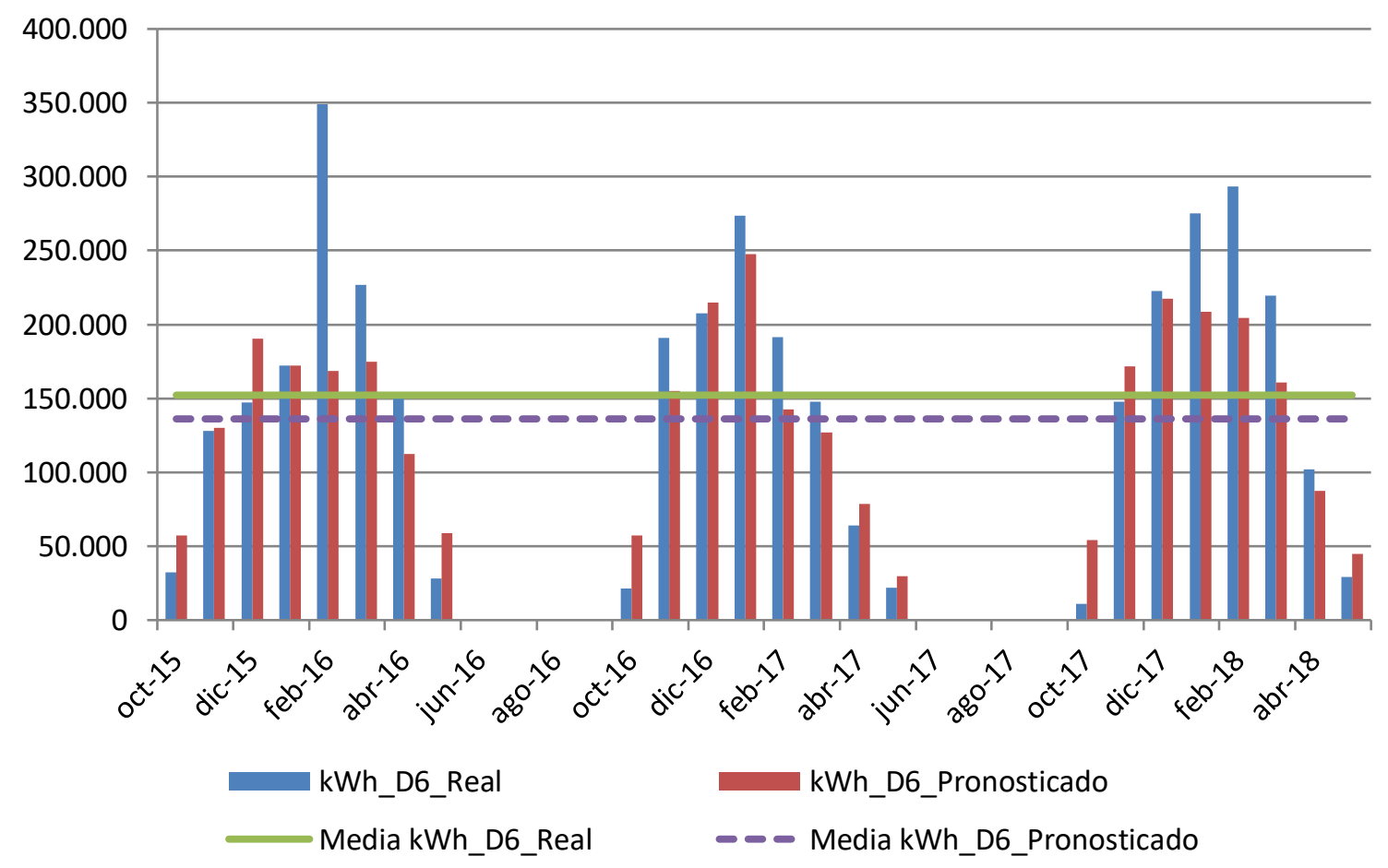

Figura 77. Consumos reales y pronosticados Octubre 2015-Mayo 2018. Edificio D6 
En la Figura 78, se observa el consumo real del Edificio D6, en comparación con el consumo pronosticado acumulado que hubiera tenido el Edificio de no haberse incorporado a la red de calor y de haberse encontrado diferencias significativas entre ambos consumos.

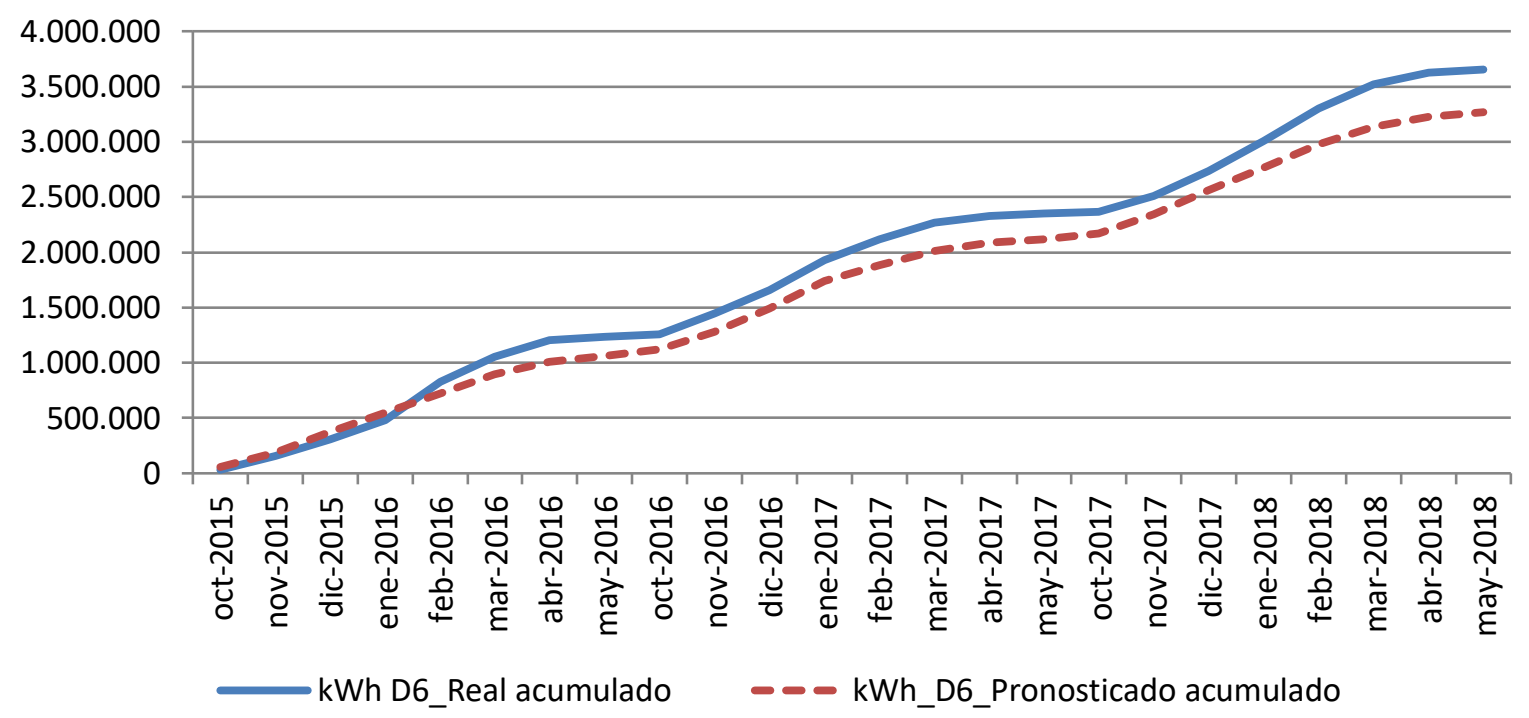

Figura 78. Consumo acumulado real y pronosticado. Octubre 2015-Mayo 2018. Edificio D6

Los resultados del ahorro de consumos, emisiones y precio máximo de la energía útil comprada a la red para un ahorro económico del 15\%, se exponen en las Tabla 48

Tabla 48. Resumen de resultados. Edificio D6

\begin{tabular}{llc}
\hline $\begin{array}{l}\text { Diferencia significativa encontrada entre las medias de los } \\
\text { consumos 2015-2018 }\end{array}$ & $0 \%$ & $0 \mathrm{kWh}$ \\
\hline $\begin{array}{l}\text { Ahorro de consumo térmico durante las tres temporadas } \\
\text { posteriores a la construcción de la red respecto a lo que se hubiera } \\
\text { consumido de no ser por la red }\end{array}$ & $0 \%$ & $0 \mathrm{kWh}$ \\
\hline Ahorro de emisiones de $\mathrm{CO}_{2}$ & $86,9 \%$ & $800 \mathrm{t} \mathrm{CO}$ \\
\hline $\begin{array}{l}\text { Precio máximo de kWh útiles comprados a la red para obtener un } \\
\text { ahorro del } 15 \%\end{array}$ & $0,02719 € / \mathrm{kWh}$ & $17.644 €$ \\
\hline
\end{tabular}




\subsection{Edificio D7. Telecomunicaciones e Informática}

Edificio de tipo docente que empezó a funcionar en el año 1997, cuenta con una superficie construida de $20.179 \mathrm{~m}^{2}$. Inicialmente la calefacción era suministrada mediante seis calderas de gas natural de $326 \mathrm{~kW}$ cada una, lo que hace una potencia total de $1.956 \mathrm{~kW}$. La subestación de intercambio con la red de calor construida en el año 2015, cuenta con una potencia de $1.620 \mathrm{~kW}$. En la Figura 79 se marca la ubicación del edificio

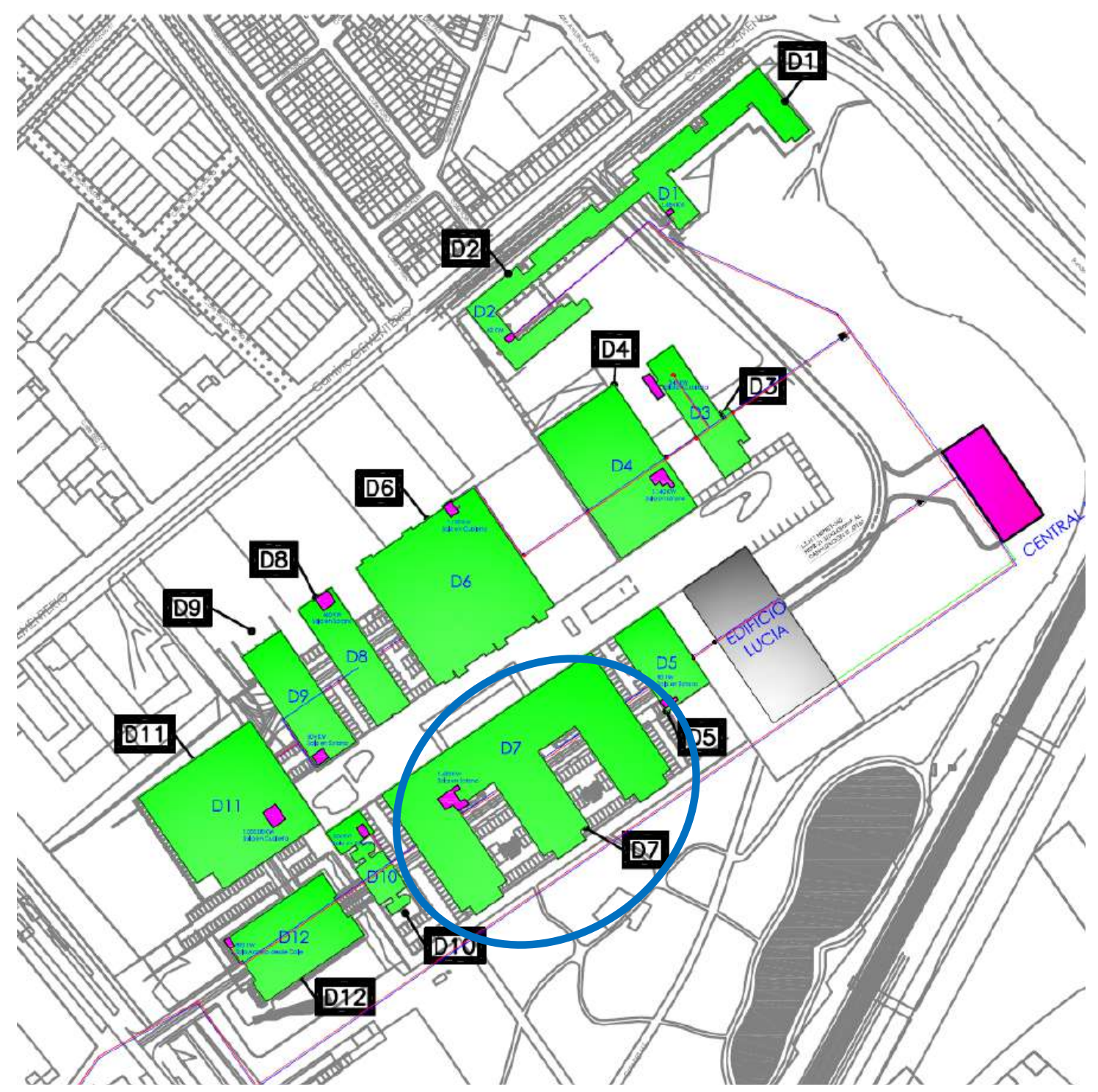

Figura 79. Ubicación del Edificio D7 en el croquis del campus Miguel Delibes 
El modelo encontrado para predecir el consumo térmico del Edificio, fue

$$
\text { kWh_D7_Pronosticado }=-6543,072+733,335 \times \text { GD15_30min }
$$

El resumen del modelo, con el coeficiente de correlación de Pearson ( $R$ ) y el coeficiente de determinación $\left(R^{2}\right)$ se muestra en la Tabla 49 y en la Tabla 50, el resultado de la verificación de los supuestos de la regresión lineal.

Tabla 49. Resumen de los modelos encontrados para el Edificio D7

\begin{tabular}{cccccr}
\hline & $\begin{array}{c}\text { Variable } \\
\text { independiente 1 }\end{array}$ & Constante & B & $R$ & $R^{2}$ \\
\hline D7 & GD15_30min & $-6.543,072$ & 733,335 & 0,996 & 0,991 \\
\hline
\end{tabular}

Tabla 50. Resumen del cumplimiento de los supuestos de regresión. Edificio D7

\begin{tabular}{ll}
\hline \multicolumn{1}{c}{ Cumplimiento de supuestos de la regresión lineal } & Modelo \\
\hline 1. Linealidad de las variables & Cumple \\
\hline 2. Normalidad de variables & Cumple \\
\hline 3. Independencia de los errores o no autocorrelación de los residuos & Cumple \\
\hline 4. Homocedasticidad de la varianza, los errores son aleatorios & Cumple \\
\hline
\end{tabular}

En la Figura 80, se representan el consumo real y el pronosticado con el modelo de regresión obtenido, en kWh.

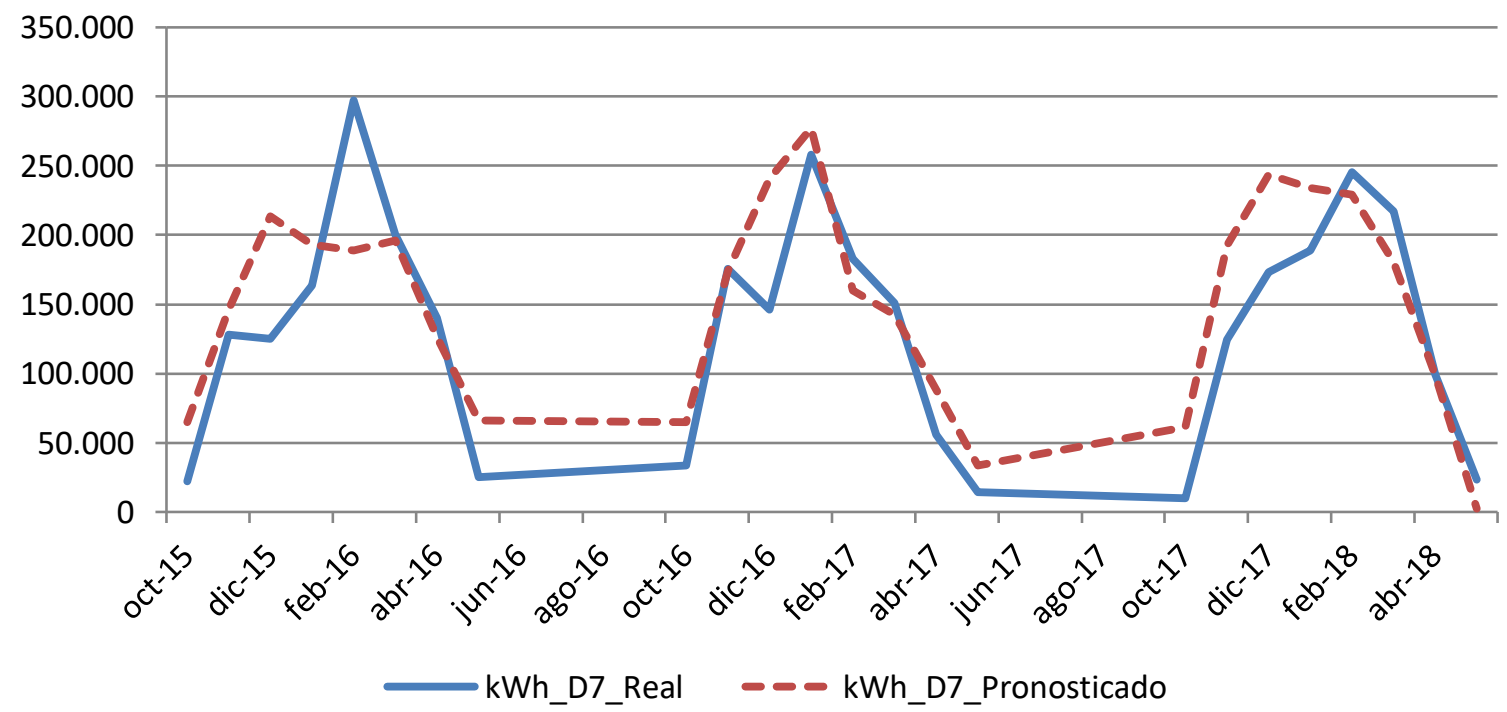

Figura 80. Representación de los consumos pronosticados para el Edificio D7. 2015-2018 
Los resultados de las diferencias entre las medias de los consumos, se exponen en las Tabla 51

Tabla 51. Resultado de las diferencias significativas encontradas. Edificio D7

\begin{tabular}{ccccccccc}
\hline & $\begin{array}{c}\% \\
\text { Diferencia } \\
2015-2016\end{array}$ & Significativo & $\begin{array}{c}\% \\
\text { Diferencia } \\
2016-2017\end{array}$ & Significativo & $\begin{array}{c}\% \\
\text { Diferencia } \\
2017-2018\end{array}$ & Significativo & $\begin{array}{c}\% \\
\text { Diferencia } \\
2015-2018\end{array}$ & Significativo \\
\hline D7 & $8,5 \%$ & No & $16,2 \%$ & No & $14,9 \%$ & No & $13,1 \%$ & No \\
\hline
\end{tabular}

En la Figura 81, se grafican los consumos reales y pronosticados para la temporada Octubre 2015 - Mayo 2018 para el Edificio D7, y las medias de dichos consumos. Según la prueba paramétrica realizada las diferencias encontradas no son estadísticamente significativas, con un riesgo a estar equivocados del $5 \%$

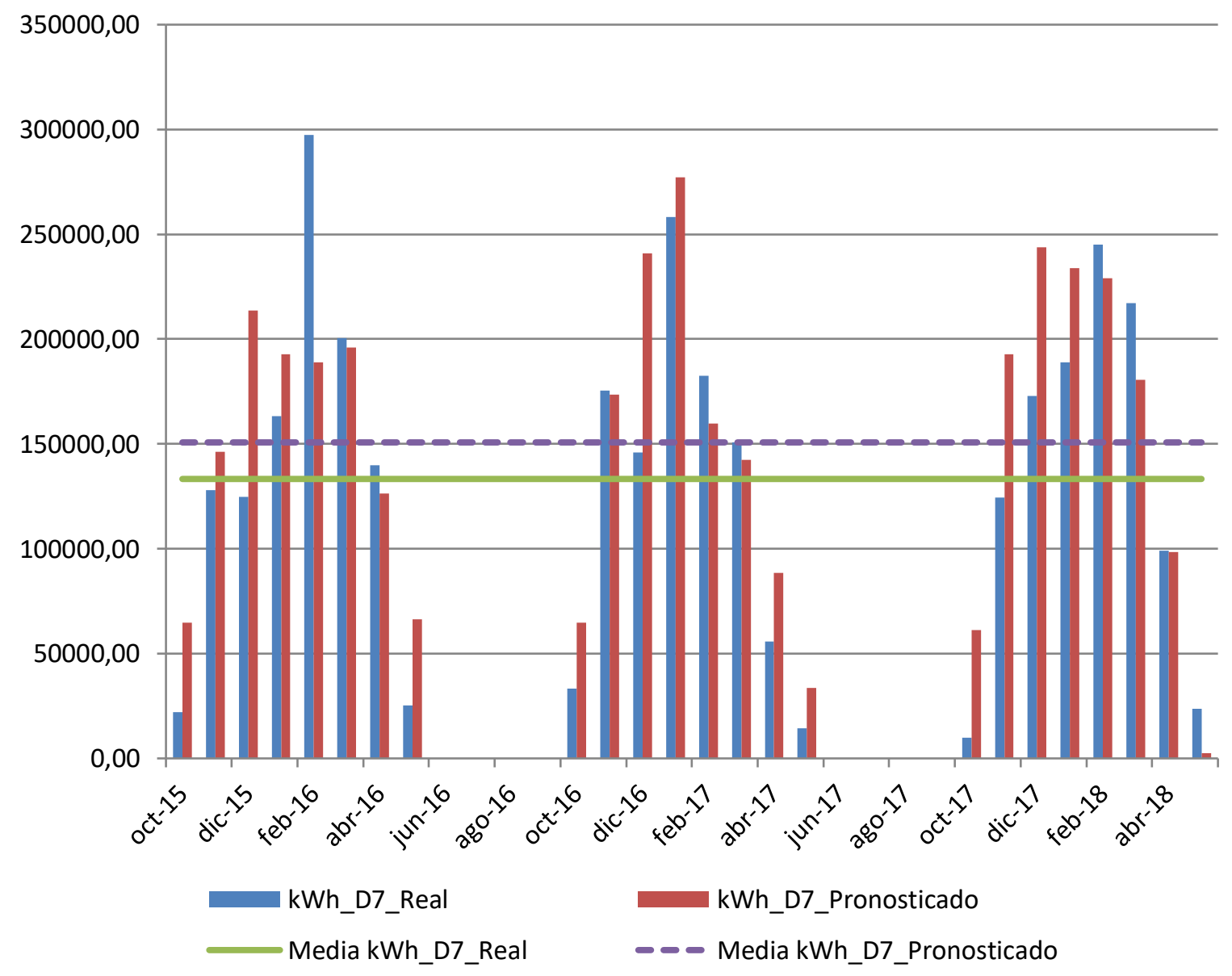

Figura 81. Consumos reales y pronosticados Octubre 2015-Mayo 2018. Edificio D7 
En la Figura 82, se observa el consumo real del Edificio D7, en comparación con el consumo pronosticado acumulado que hubiera tenido el Edificio de no haberse incorporado a la red de calor y de haberse encontrado diferencias significativas entre ambos consumos.

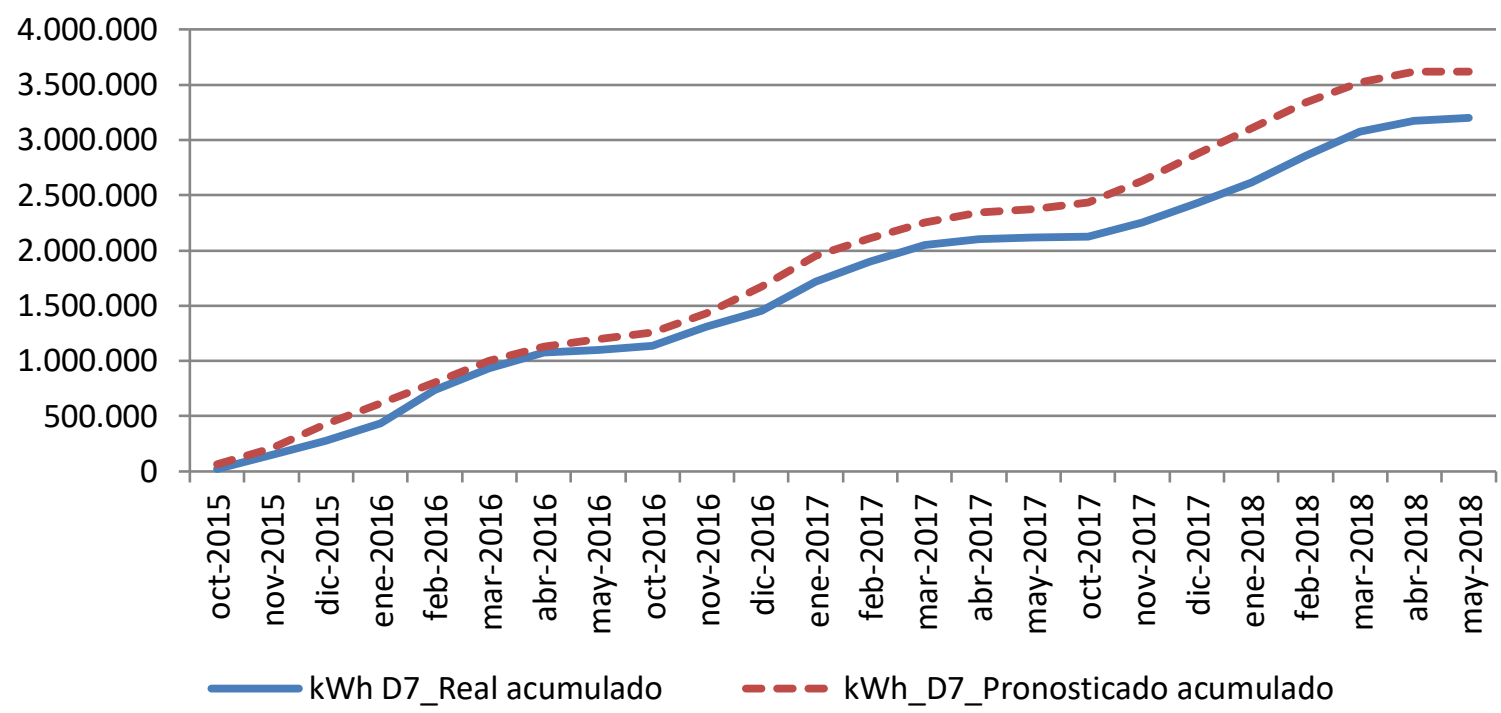

Figura 82. Consumo acumulado real y pronosticado. Octubre 2015-Mayo 2018. Edificio D7

Los resultados del ahorro de consumos, emisiones y precio máximo de la energía útil comprada a la red para un ahorro económico del 15\%, se exponen en la Tabla 52

Tabla 52. Resumen de resultados. Edificio D7

\begin{tabular}{llc}
\hline $\begin{array}{l}\text { Diferencia significativa encontrada entre las medias de los } \\
\text { consumos 2015-2018 }\end{array}$ & $0 \%$ & $0 \mathrm{kWh}$ \\
\hline $\begin{array}{l}\text { Ahorro de consumo térmico durante las tres temporadas } \\
\text { posteriores a la construcción de la red respecto a lo que se hubiera } \\
\text { consumido de no ser por la red }\end{array}$ & $0 \%$ & $0 \mathrm{kWh}$ \\
\hline Ahorro de emisiones de $\mathrm{CO}_{2}$ & $87,3 \%$ & $704 \mathrm{t} \mathrm{CO}_{2}$ \\
\hline $\begin{array}{l}\text { Precio máximo de kWh útiles comprados a la red para obtener un } \\
\text { ahorro del } 15 \%\end{array}$ & $0,02719 € / \mathrm{kWh}$ & $15.438 €$ \\
\hline
\end{tabular}




\subsection{Edificio D8. Edificio de Química Fina y Materiales Avanzados. QUIFIMA}

Edificio de tipo docente que empezó a funcionar en el año 2008, cuenta con una superficie construida de $5.610 \mathrm{~m}^{2}$. Inicialmente la calefacción era suministrada mediante dos calderas de gas natural de $233 \mathrm{~kW}$ cada una, lo que hace una potencia total de $466 \mathrm{~kW}$. La subestación de intercambio con la red de calor construida en el año 2015, cuenta con una potencia de $460 \mathrm{~kW}$. En la Figura 83 se marca la ubicación del edificio

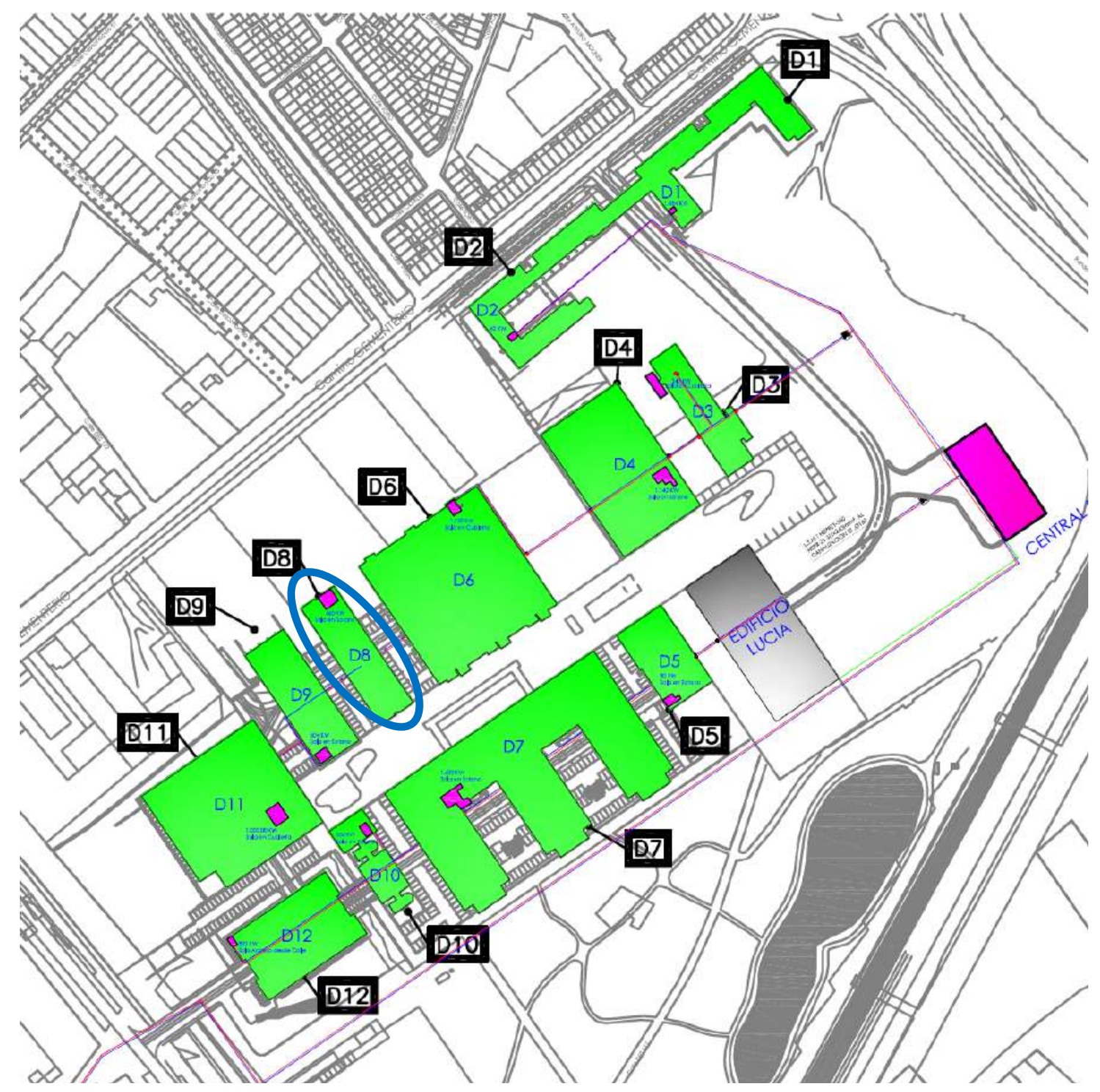

Figura 83. Ubicación del Edificio D8 en el croquis del campus Miguel Delibes 
El modelo encontrado para predecir el consumo térmico del Edificio, fue

Modelo 1: kWh_D8 $=91.484,519-5.414,103 \times$ T_med

Modelo 2: kWh_D8 $=63.357,055-4.991,184 \times$ T_med $+8.950,19 \times$ V_viento_diurna

El resumen de los modelos, con los coeficientes de correlación de Pearson (R) y el coeficiente de determinación $\left(R^{2}\right)$ se muestra en la Tabla 53 y en la Tabla 54 , el resultado de la verificación de los supuestos de la regresión lineal.

Tabla 53. Resumen de los modelos encontrados para el Edificio D8

\begin{tabular}{cccccc}
\hline & $\begin{array}{c}\text { Variables } \\
\text { independientes }\end{array}$ & Constante & B & $R^{2}$ \\
\hline D8_Modelo 1 & Tmed & $91.484,519$ & $-5.414,103$ & $-0,906$ & 0,821 \\
\hline D8_Modelo 2 & Tmed / V_diurna & 63357,055 & $-4991,184 / 8950,19$ & $-0,945$ & 0,894 \\
\hline
\end{tabular}

Tabla 54. Resumen del cumplimiento de los supuestos de regresión. Edificio D8

\begin{tabular}{llc}
\hline \multicolumn{1}{c}{ Cumplimiento de supuestos de la regresión lineal } & Modelo 1 & Modelo 2 \\
\hline 1. Linealidad de las variables & Cumple & Cumple \\
\hline 2. Normalidad de variables & Cumple & Cumple \\
\hline 3. Independencia de los errores o no autocorrelación de los residuos & Cumple & Cumple \\
\hline 4. Homocedasticidad de la varianza, los errores son aleatorios & Cumple & Cumple \\
\hline 5. Falta de multicolinealidad entre las variables independientes. & & Cumple \\
\hline
\end{tabular}

En la Figura 84, se representan los consumos reales y los pronosticados con los modelos de regresión obtenidos, en $\mathrm{kWh}$.

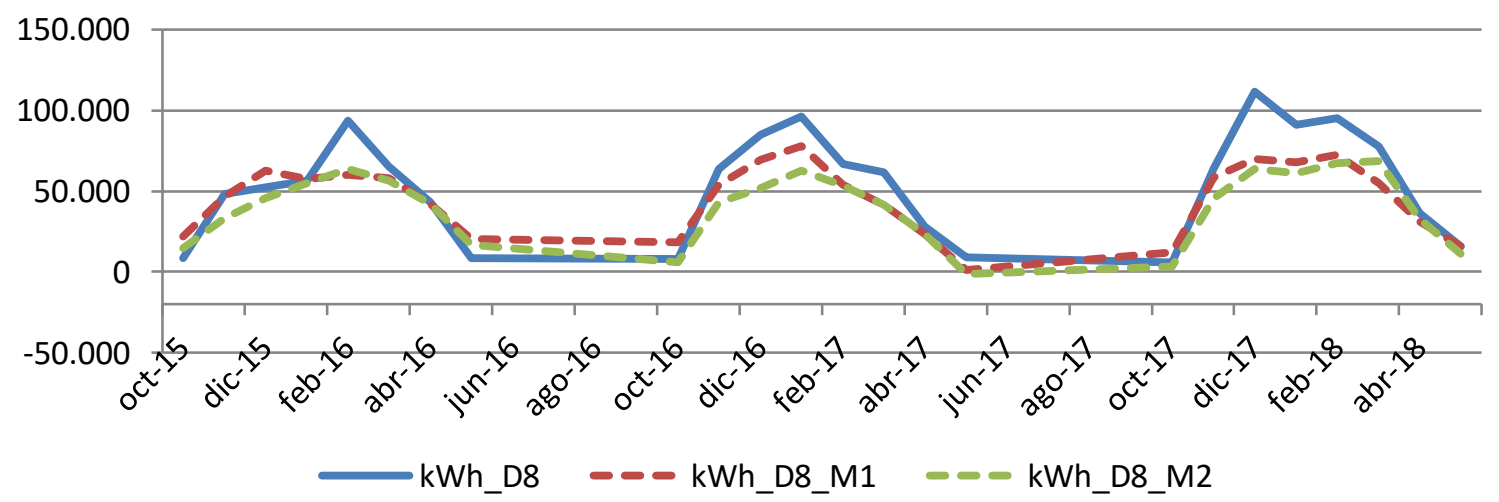

Figura 84. Representación de los consumos pronosticados para el Edificio D8. 2015-2018 
Los resultados de las diferencias entre las medias de los consumos, se exponen en las Tabla 55

Tabla 55. Resultado de las diferencias significativas encontradas. Edificio D8

\begin{tabular}{cccccccccc}
\hline & $\begin{array}{c}\% \\
\text { Diferencia } \\
2015-2016\end{array}$ & Significativo & $\begin{array}{c}\% \\
\text { Diferencia } \\
2016-2017\end{array}$ & Significativo & $\begin{array}{c}\% \\
\text { Diferencia } \\
2017-2018\end{array}$ & Significativo & $\begin{array}{c}\% \\
\text { Diferencia } \\
2015-2018\end{array}$ & Significativo \\
\hline D8_Modelo 1 & $-1,7 \%$ & No & $-18,8 \%$ & SI & $-23,4 \%$ & SI & $-15,6 \%$ & SI \\
\hline D8_Modelo 2 & $-13,0 \%$ & No & $-31,2 \%$ & SI & $-29,0 \%$ & SI & $-25,0 \%$ & SI \\
\hline
\end{tabular}

En la Figura 85 se grafican los consumos reales y pronosticados para el periodo Octubre 2015 - Mayo 2018 para el Edificio D8, y las medias de dichos consumos.

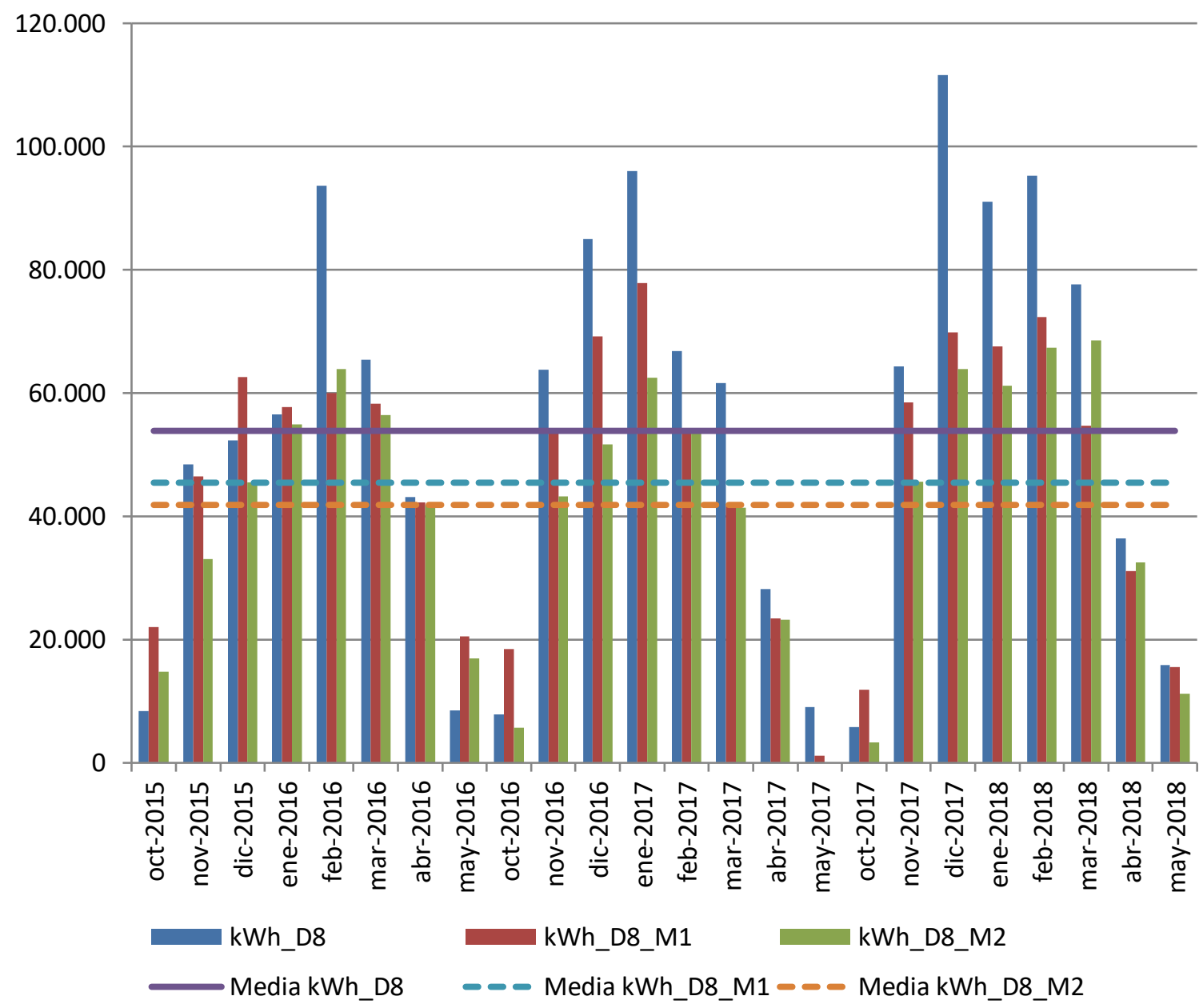

Figura 85. Consumos reales y pronosticados Octubre 2015-Mayo 2018. Edificio D8 
En la Figura 86, se observa el consumo real del Edificio D8, en comparación con el consumo pronosticado acumulado con el Modelo 1 y Modelo 2 que hubiera tenido el Edificio de no haberse incorporado a la red de calor.

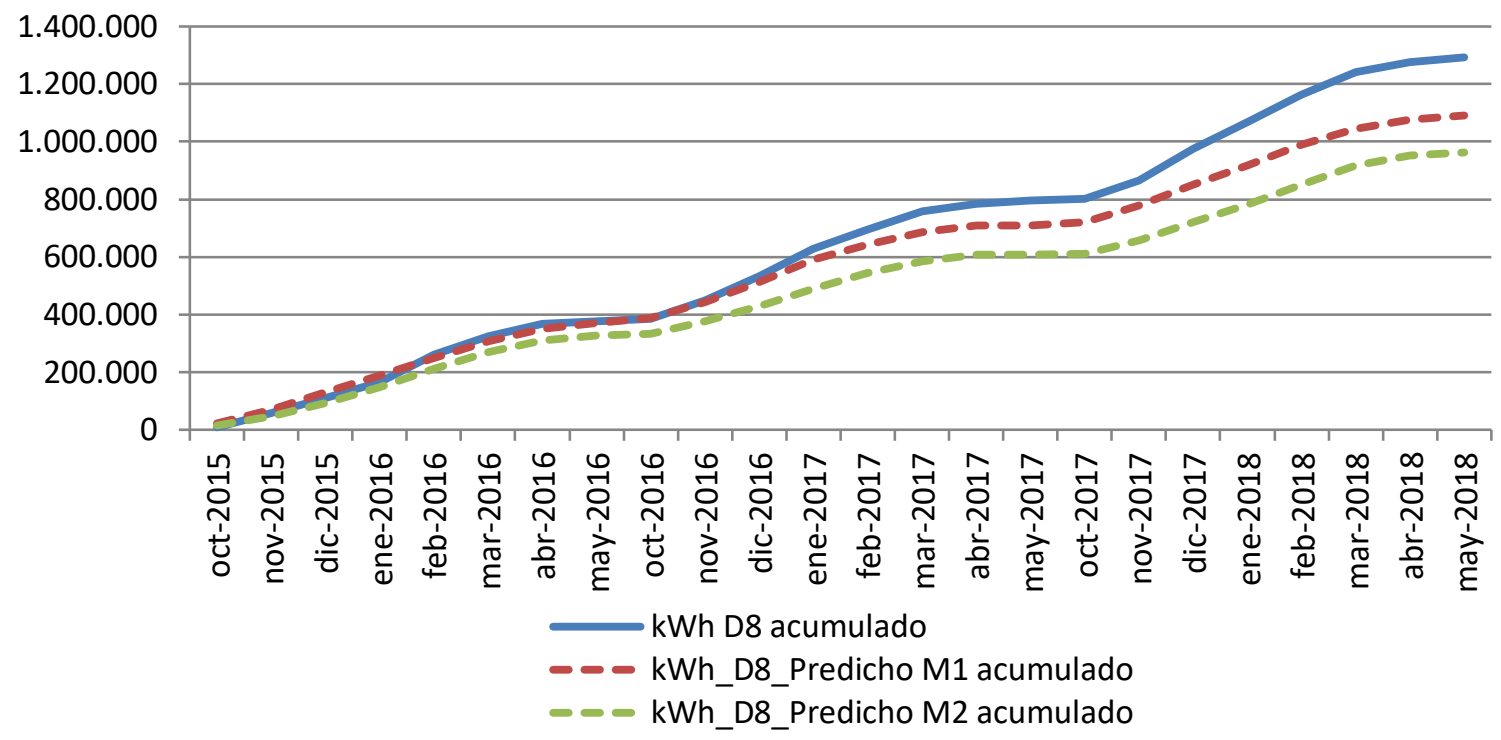

Figura 86. Consumo acumulado real y pronosticado. Octubre 2015-Mayo 2018. Edificio D8

Los resultados del ahorro de consumos, emisiones y precio máximo de la energía útil comprada a la red para un ahorro económico del 15\%, se exponen en la Tabla 56

Tabla 56. Resumen de resultados. Edificio D7

\begin{tabular}{lcc}
\hline $\begin{array}{l}\text { Diferencia significativa encontrada entre las medias de los } \\
\text { consumos 2015-2018. Utilizando el Modelo 2 (por ser el de } \\
\text { mayor coeficiente de correlación) }\end{array}$ & $-25 \%$ & $\begin{array}{c}-41.853 \\
\mathrm{kWh}\end{array}$ \\
\hline $\begin{array}{l}\text { Ahorro de consumo térmico durante las tres temporadas } \\
\text { posteriores a la construcción de la red respecto a lo que se hubiera } \\
\text { consumido de no ser por la red }\end{array}$ & $-33,4 \%$ & $\begin{array}{c}-321.233 \\
\mathrm{kWh}\end{array}$ \\
\hline $\begin{array}{l}\text { Ahorro de emisiones de } \mathrm{CO}_{2} \\
\begin{array}{l}\text { Precio máximo de kWh útiles comprados a la red para obtener un } \\
\text { ahorro del 15\% }\end{array}\end{array}$ & $\begin{array}{c}0,02015 \\
€ / \mathrm{kWh}\end{array}$ & $201 \mathrm{t} \mathrm{CO}_{2}$ \\
\hline
\end{tabular}




\subsection{Edificio D9. Gimnasio de la UVA}

Edificio de tipo deportivo que empezó a funcionar en el año 2001, cuenta con una superficie construida de $3.673 \mathrm{~m}^{2}$. Inicialmente la calefacción era suministrada mediante cuatro calderas de gas natural de $127 \mathrm{~kW}$ cada una, lo que hace una potencia total de 508 kW. La subestación de intercambio con la red de calor construida en el año 2015, cuenta con una potencia de 504 kW. En la Figura 87 se marca la ubicación del edificio

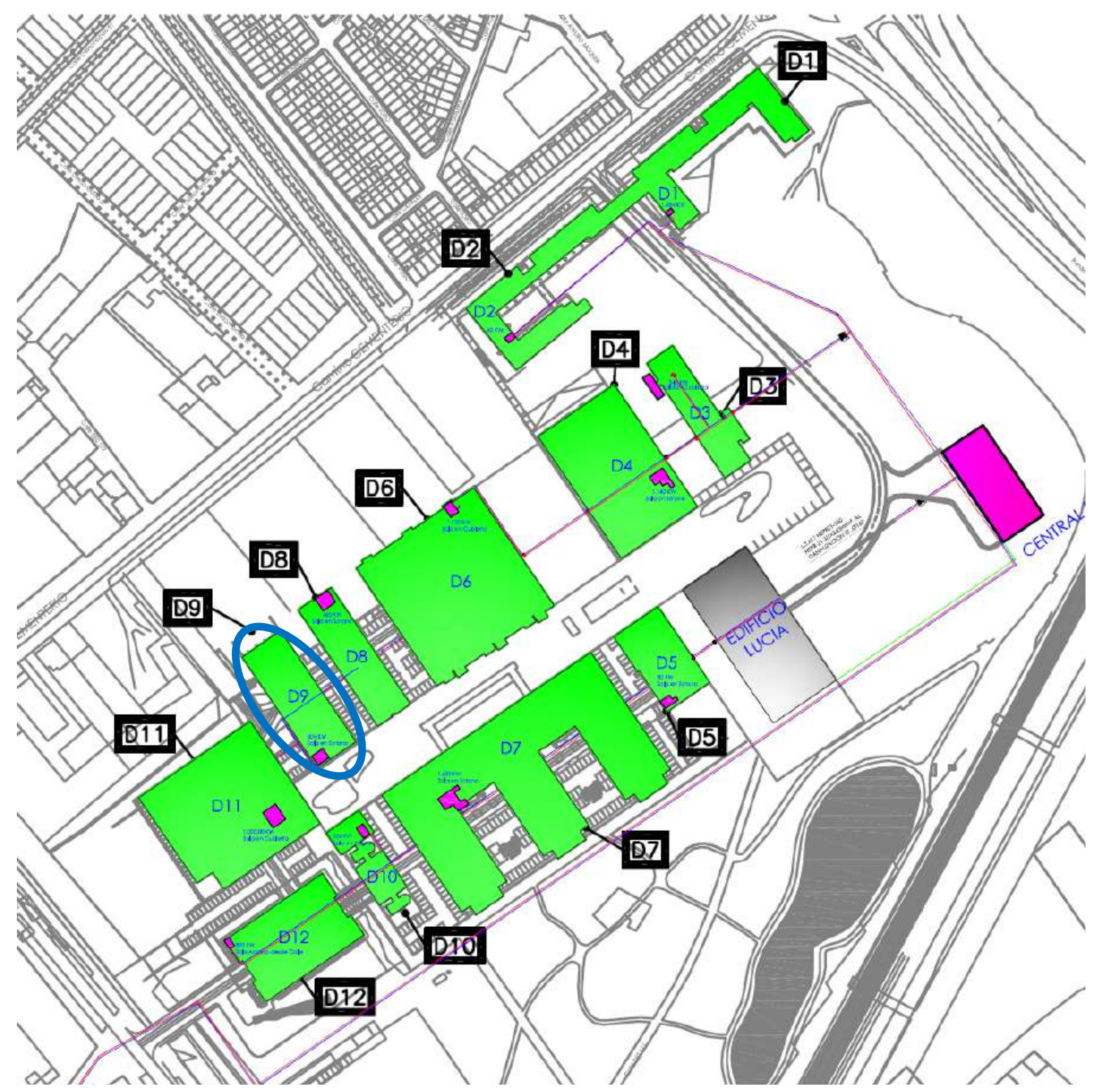

Figura 87. Ubicación del Edificio D9 en el croquis del campus Miguel Delibes 
El modelo encontrado para predecir el consumo térmico del Edificio, fue

$$
\text { kWh_D9_Pronosticado }=-654,602+139,864 \times \text { GD15_30min }
$$

El resumen del modelo, con el coeficiente de correlación de Pearson $(R)$ y el coeficiente de determinación $\left(R^{2}\right)$ se muestra en la Tabla 57 y en la Tabla 58, el resultado de la verificación de los supuestos de la regresión lineal.

Tabla 57. Resumen de los modelos encontrados para el Edificio D9

\begin{tabular}{cccccc}
\hline & $\begin{array}{c}\text { Variable } \\
\text { independiente 1 }\end{array}$ & Constante & B & $R$ & $R^{2}$ \\
\hline D9 & GD15_30min & $-654,602$ & 139,864 & 0,999 & 0,998 \\
\hline
\end{tabular}

Tabla 58. Resumen del cumplimiento de los supuestos de regresión. Edificio D9

\begin{tabular}{ll}
\hline \multicolumn{1}{c}{ Cumplimiento de supuestos de la regresión lineal } & Modelo \\
\hline 1. Linealidad de las variables & Cumple \\
\hline 2. Normalidad de variables & Cumple \\
\hline 3. Independencia de los errores o no autocorrelación de los residuos & Cumple \\
\hline 4. Homocedasticidad de la varianza, los errores son aleatorios & Cumple \\
\hline
\end{tabular}

En la Figura 88, se representan el consumo real y el pronosticado con el modelo de regresión obtenido, en kWh.

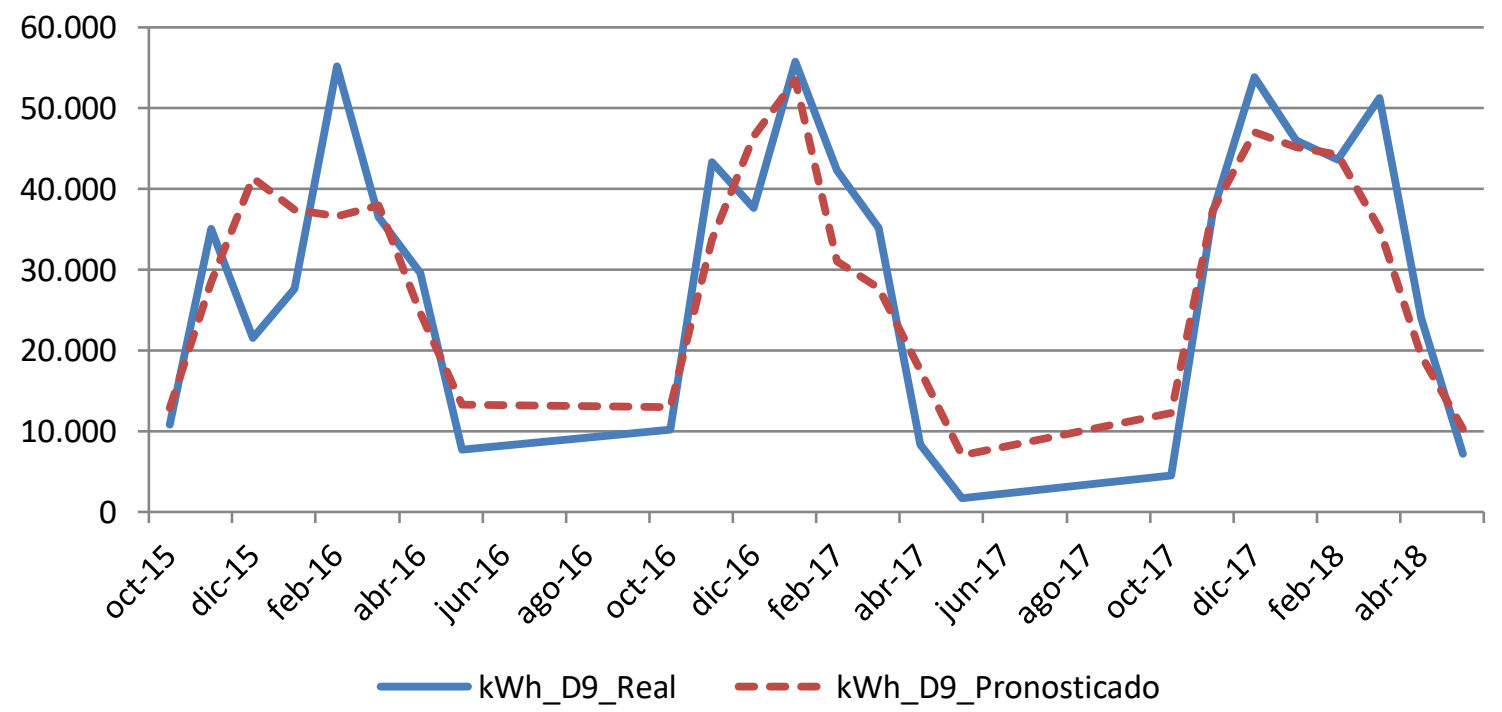

Figura 88. Representación de los consumos pronosticados para el Edificio D9. 2015-2018 
Los resultados de las diferencias entre las medias de los consumos, se exponen en la Tabla 59

Tabla 59. Resultado de las diferencias significativas encontradas. Edificio D7

\begin{tabular}{cccccccccc}
\hline & $\begin{array}{c}\% \\
\text { Diferencia } \\
2015-2016\end{array}$ & Significativo & $\begin{array}{c}\% \\
\text { Diferencia } \\
2016-2017\end{array}$ & Significativo & $\begin{array}{c}\% \\
\text { Diferencia } \\
2017-2018\end{array}$ & Significativo & $\begin{array}{c}\% \\
\text { Diferencia } \\
2015-2018\end{array}$ & Significativo \\
\hline D9 & $3,8 \%$ & No & $-1,8 \%$ & No & $-6,2 \%$ & No & $-1,7 \%$ & No \\
\hline
\end{tabular}

En la Figura 89, se grafican los consumos reales y pronosticados para la temporada Octubre 2015 - Mayo 2018 para el Edificio D9, y las medias de dichos consumos. Según la prueba paramétrica realizada las diferencias encontradas no son estadísticamente significativas, con un riesgo a estar equivocados del $5 \%$

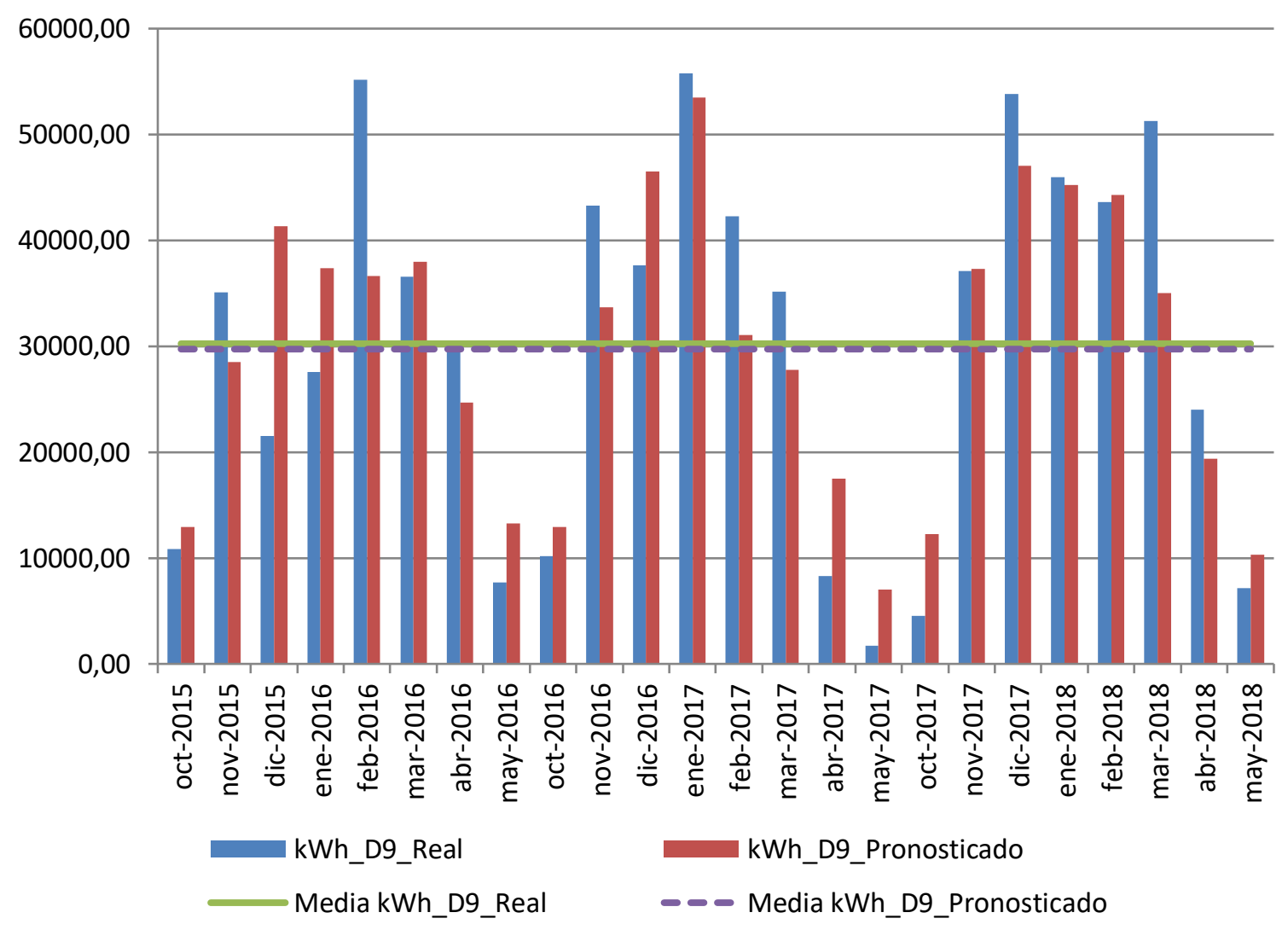

Figura 89. Consumos reales y pronosticados Octubre 2015-Mayo 2018. Edificio D9 
En la Figura 90, se observa el consumo real del Edificio D9, en comparación con el consumo pronosticado acumulado que hubiera tenido el Edificio de no haberse incorporado a la red de calor y de haberse encontrado diferencias significativas

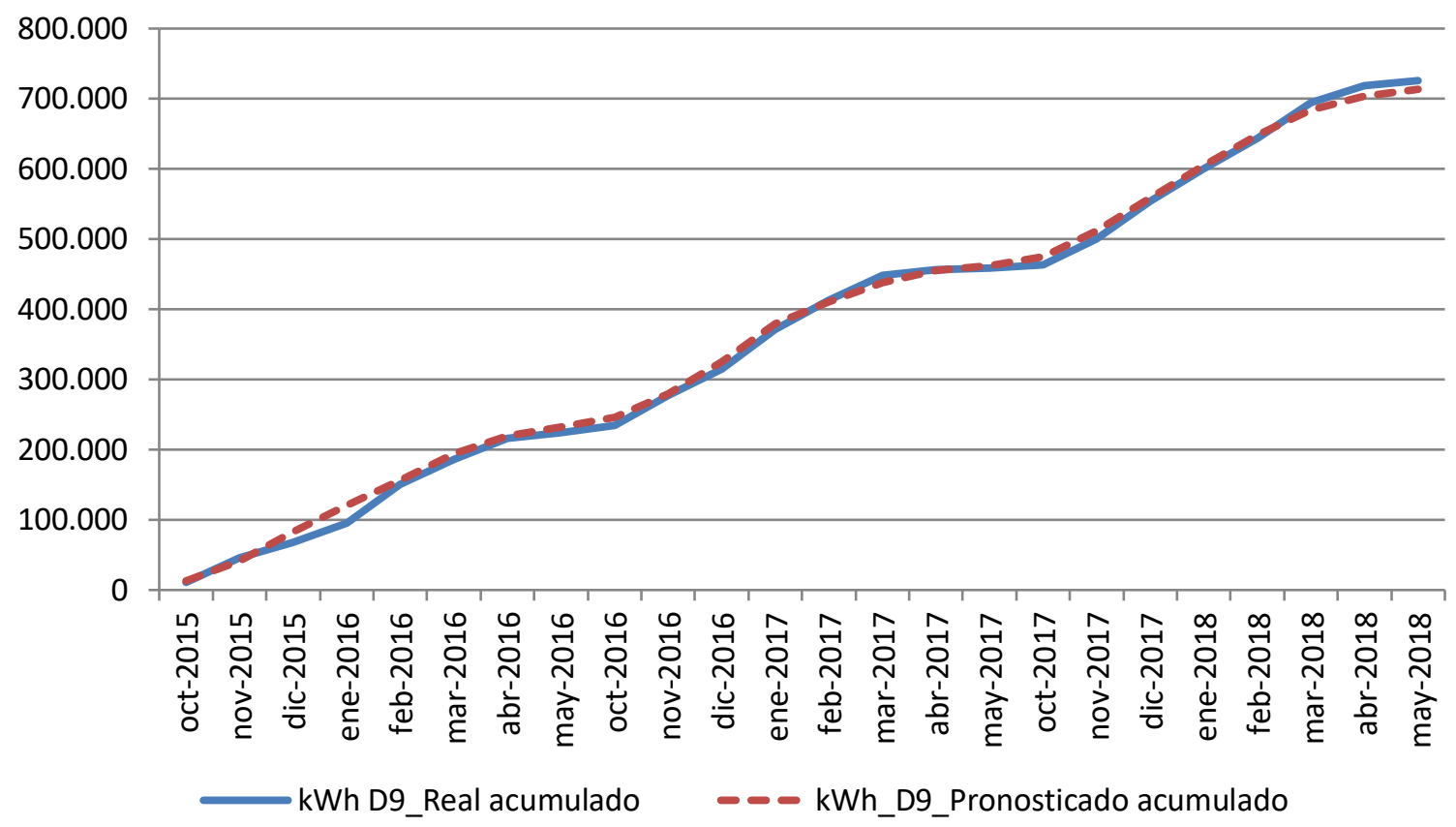

Figura 90. Consumo acumulado real y pronosticado. Octubre 2015-Mayo 2018. Edificio D9

Los resultados del ahorro de consumos, emisiones y precio máximo de la energía útil comprada a la red para un ahorro económico del 15\%, se exponen en la Tabla 60

Tabla 60. Resumen de resultados. Edificio D9

\begin{tabular}{lcc}
\hline $\begin{array}{l}\text { Diferencia significativa encontrada entre las medias de los } \\
\text { consumos 2015-2018 }\end{array}$ & $0 \%$ & $0 \mathrm{kWh}$ \\
\hline $\begin{array}{l}\text { Ahorro de consumo térmico durante las tres temporadas } \\
\text { posteriores a la construcción de la red respecto a lo que se hubiera } \\
\text { consumido de no ser por la red }\end{array}$ & $0 \%$ & $0 \mathrm{kWh}$ \\
\hline $\begin{array}{l}\text { Ahorro de emisiones de } \mathrm{CO}_{2} \\
\text { Precio máximo de kWh útiles comprados a la red para obtener un } \\
\text { ahorro del } 15 \%\end{array}$ & $0,02728 € / \mathrm{kWh}$ & $3.496 €$ \\
\hline
\end{tabular}




\subsection{Edificio D10. Centro de Idiomas}

Edificio de tipo docente que empezó a funcionar en el año 1996, cuenta con una superficie construida de $5.636 \mathrm{~m}^{2}$. Inicialmente la calefacción era suministrada mediante una caldera de gas natural de $326 \mathrm{~kW}$. La subestación de intercambio con la red de calor construida en el año 2015, cuenta con una potencia de 326 kW. En la Figura 91 se marca la ubicación del edificio.

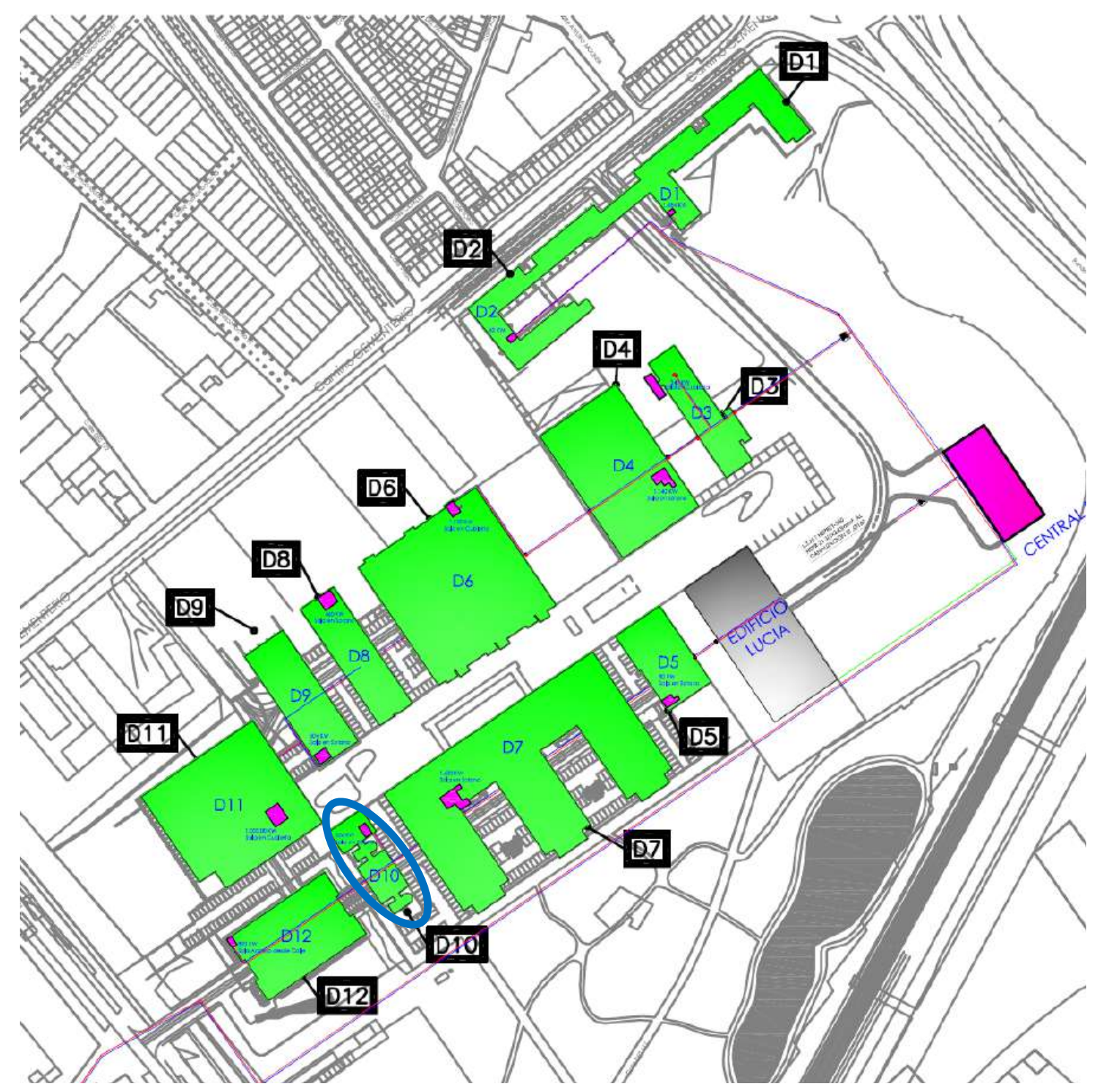

Figura 91. Ubicación del Edificio D10 en el croquis del campus Miguel Delibes 
El modelo encontrado para predecir el consumo térmico del Edificio, fue

$$
\text { kWh_D10_Pronosticado }=66791,063-4393,782 \times \text { T_med }
$$

El resumen del modelo, con el coeficiente de correlación de Pearson $(R)$ y el coeficiente de determinación $\left(R^{2}\right)$ se muestra en la Tabla 61 y en la Tabla 62, el resultado de la verificación de los supuestos de la regresión lineal.

Tabla 61. Resumen de los modelos encontrados para el Edificio D10

\begin{tabular}{cccccc}
\hline & $\begin{array}{c}\text { Variable } \\
\text { independiente 1 }\end{array}$ & Constante & $B$ & $R$ & $R^{2}$ \\
\hline D10 & T_med & $66.791,063$ & $-4.393,782$ & $-0,896$ & 0,802 \\
\hline
\end{tabular}

Tabla 62. Resumen del cumplimiento de los supuestos de regresión. Edificio D10

\begin{tabular}{ll}
\hline \multicolumn{1}{c}{ Cumplimiento de supuestos de la regresión lineal } & Modelo \\
\hline 1. Linealidad de las variables & Cumple \\
\hline 2. Normalidad de variables & Cumple \\
\hline 3. Independencia de los errores o no autocorrelación de los residuos & Cumple \\
\hline 4. Homocedasticidad de la varianza, los errores son aleatorios & Cumple \\
\hline
\end{tabular}

En la Figura 92, se representan el consumo real y el pronosticado con el modelo de regresión obtenido, en $\mathrm{kWh}$.

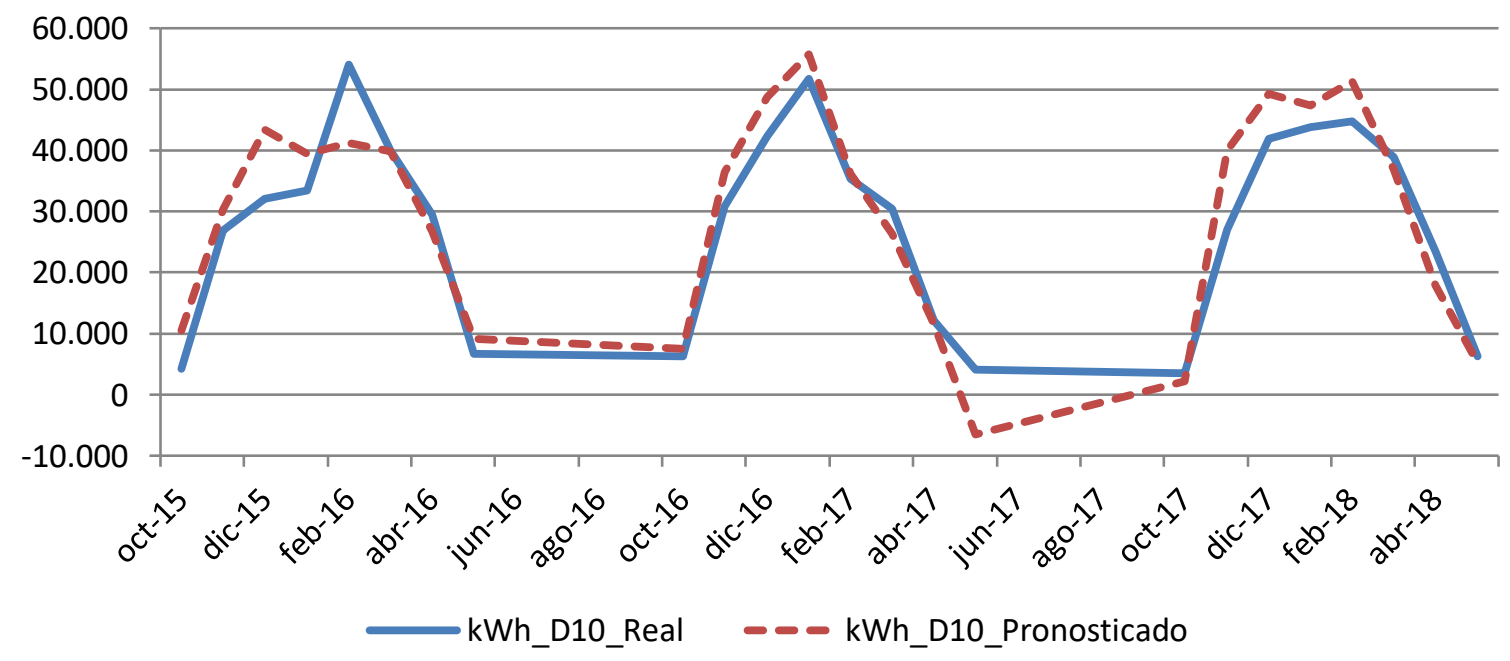

Figura 92. Representación de los consumos pronosticados para el Edificio D10. 2015-2018 
Los resultados de las diferencias entre las medias de los consumos, se exponen en la Tabla 63

Tabla 63. Resultado de las diferencias significativas encontradas. Edificio D10

\begin{tabular}{cccccccccc}
\hline & $\begin{array}{c}\% \\
\text { Diferencia } \\
2015-2016\end{array}$ & Significativo & $\begin{array}{c}\% \\
\text { Diferencia } \\
2016-2017\end{array}$ & Significativo & $\begin{array}{c}\% \\
\text { Diferencia } \\
2017-2018\end{array}$ & Significativo & $\begin{array}{c}\% \\
\text { Diferencia } \\
2015-2018\end{array}$ & Significativo \\
\hline D10 & $6,1 \%$ & No & $6,6 \%$ & No & $8,9 \%$ & No & $7,2 \%$ & No \\
\hline
\end{tabular}

En la Figura 93, se grafican los consumos reales y pronosticados para la temporada Octubre 2015 - Mayo 2018 para el Edificio D10, y las medias de dichos consumos. Según la prueba paramétrica realizada las diferencias encontradas no son estadísticamente significativas, con un riesgo a estar equivocados del $5 \%$

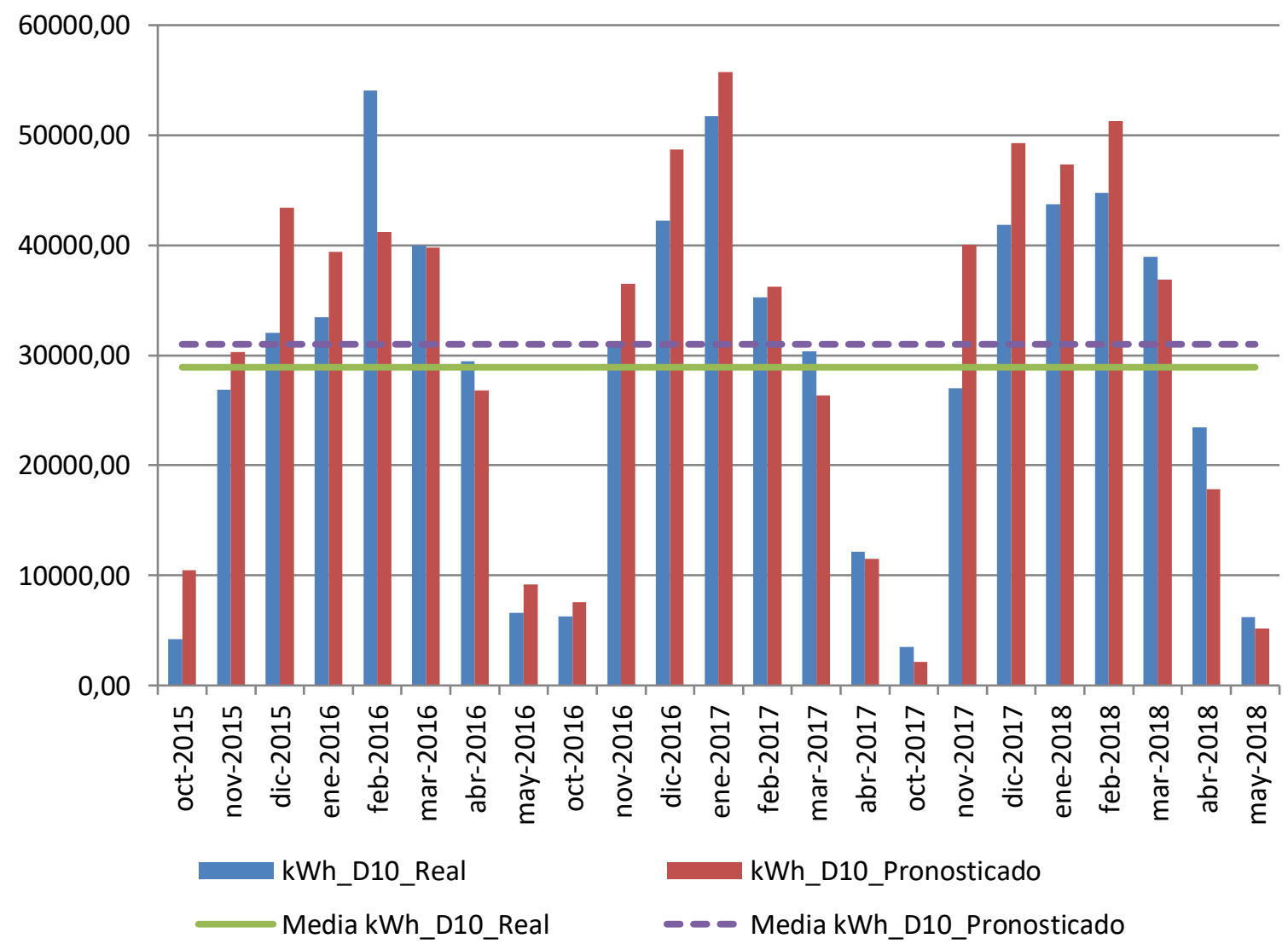

Figura 93. Consumos reales y pronosticados Octubre 2015-Mayo 2018. Edificio D10 
En la Figura 94, se observa el consumo real del Edificio D10, en comparación con el consumo pronosticado acumulado que hubiera tenido el Edificio de no haberse incorporado a la red de calor y de haberse encontrado diferencias significativas.

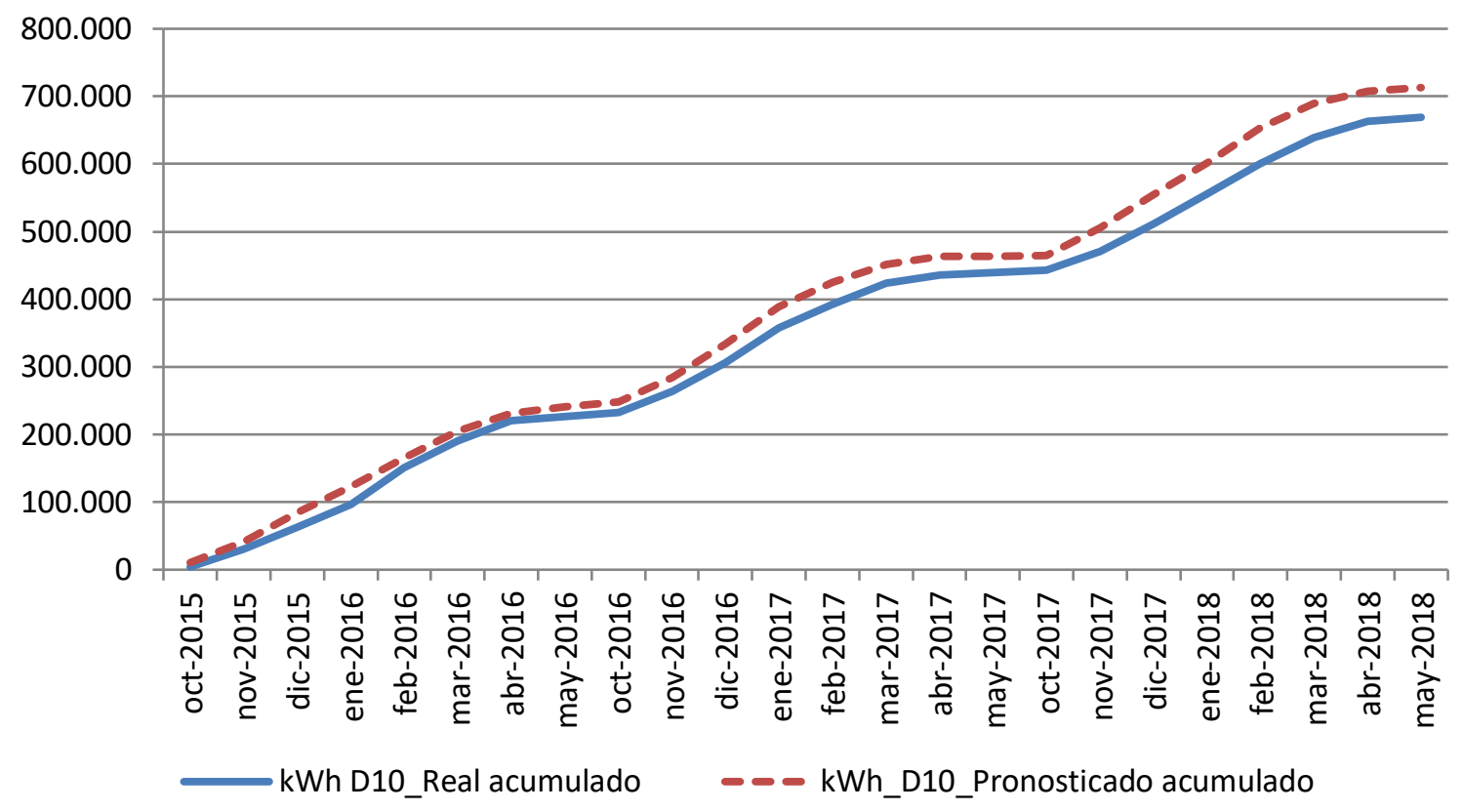

Figura 94. Consumo acumulado real y pronosticado. Octubre 2015-Mayo 2018. Edificio D10

Los resultados del ahorro de consumos, emisiones y precio máximo de la energía útil comprada a la red para un ahorro económico del 15\%, se exponen en la Tabla 64

Tabla 64. Resumen de resultados. Edificio D10

\begin{tabular}{llc}
\hline $\begin{array}{l}\text { Diferencia significativa encontrada entre las medias de los } \\
\text { consumos 2015-2018 }\end{array}$ & $0 \%$ & $0 \mathrm{kWh}$ \\
\hline $\begin{array}{l}\text { Ahorro de consumo térmico durante las tres temporadas } \\
\text { posteriores a la construcción de la red respecto a lo que se hubiera } \\
\text { consumido de no ser por la red }\end{array}$ & $0 \%$ & $0 \mathrm{kWh}$ \\
\hline $\begin{array}{l}\text { Ahorro de emisiones de } \mathrm{CO}_{2} \\
\text { Precio máximo de kWh útiles comprados a la red para obtener un } \\
\text { ahorro del 15\% }\end{array}$ & $0,02728 € / \mathrm{kWh}$ & $3.223 €$ \\
\hline
\end{tabular}




\subsection{Edificio D11. Facultad de Educación y Trabajo Social}

Edificio de tipo docente que empezó a funcionar en el año 2001, cuenta con una superficie construida de $14.943 \mathrm{~m}^{2}$. Inicialmente la calefacción era suministrada mediante dos calderas de gas natural de $500 \mathrm{~kW}$ cada una, lo que hace un total de $1.000 \mathrm{~kW}$. La subestación de intercambio con la red de calor construida en el año 2015, cuenta con una potencia de 1000 kW. En la Figura 95 se marca la ubicación del edificio.

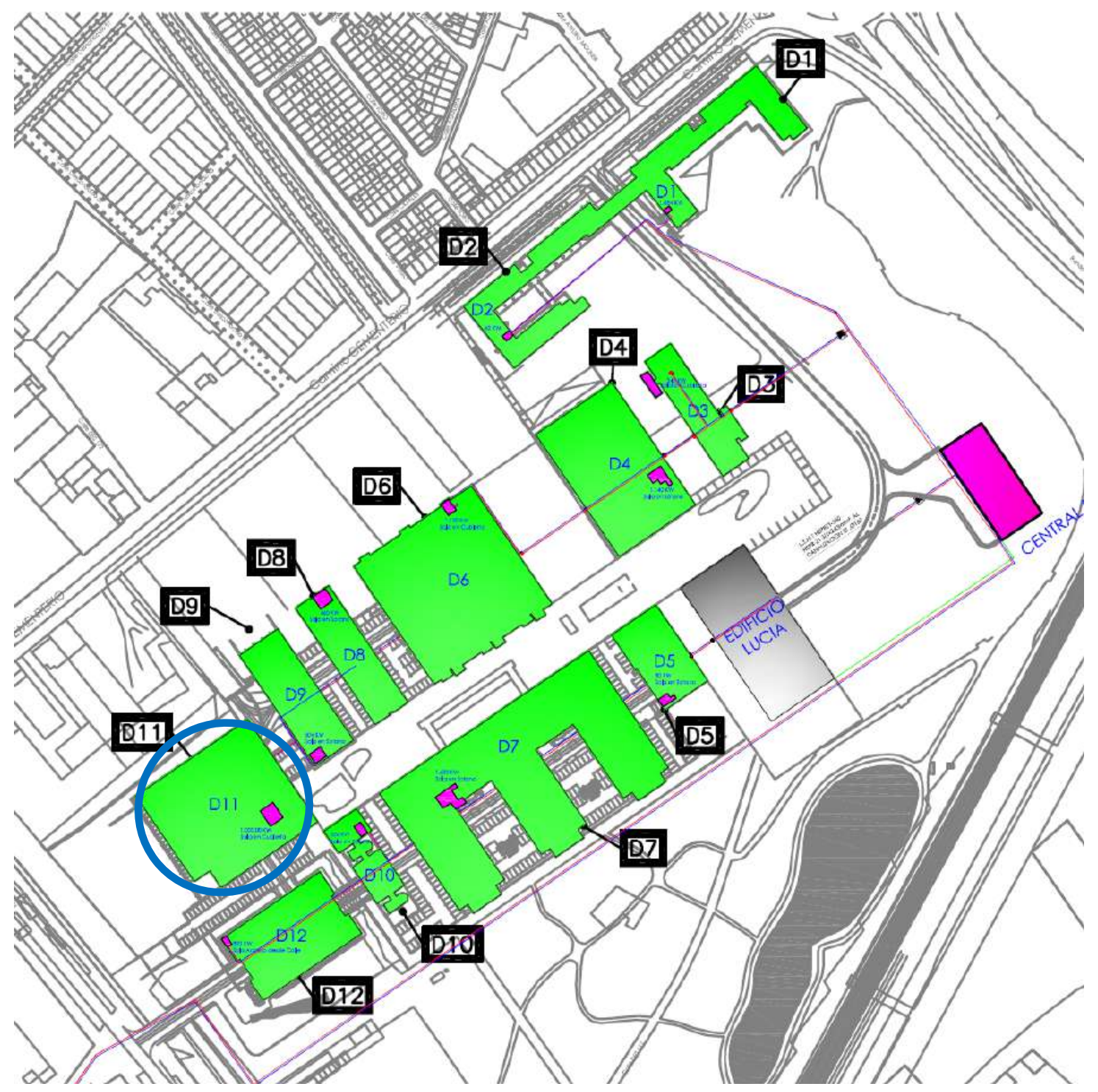

Figura 95. Ubicación del Edificio D11 en el croquis del campus Miguel Delibes 
Los modelos encontrados para predecir el consumo térmico del Edificio, fueron

Modelo 1: $\quad$ kWh_D11 $=187.840,052-12.648,948 \times$ T_med

Modelo 2: $\quad$ kWh_D11 $=630672,573-38572,601$ Tmed - 1044,773 GD15_30min

El resumen de los modelos, con los coeficientes de correlación de Pearson (R) y el coeficiente de determinación $\left(R^{2}\right)$ se muestra en la Tabla 65 y en la Tabla 66, el resultado de la verificación de los supuestos de la regresión lineal.

Tabla 65. Resumen de los modelos encontrados para el Edificio D11

\begin{tabular}{lccccc}
\hline & $\begin{array}{c}\text { Variables } \\
\text { independientes }\end{array}$ & Constante & B & R & $R^{2}$ \\
\hline D11_Modelo 1 & Tmed & $187.840,052$ & $-12.648,948$ & $-0,898$ & 0,807 \\
\hline D11_Modelo 2 & Tmed / GD15_30min & 630672,573 & $-38572,601 /-1044,773$ & $-0,931$ & 0,866 \\
\hline
\end{tabular}

Tabla 66. Resumen del cumplimiento de los supuestos de regresión. Edificio D11

Cumplimiento de supuestos de la regresión lineal Modelo 1
Modelo 2

1. Linealidad de las variables Cumple Cumple

2. Normalidad de variables Cumple Cumple

3. Independencia de los errores o no autocorrelación de los residuos Cumple

4. Homocedasticidad de la varianza, los errores son aleatorios Cumple Cumple $(*)$

5. Falta de multicolinealidad entre las variables independientes.

Cumple

$(*)$ Existe cierta correlación en los residuos

Se rechaza el modelo 2, al no cumplir todos los supuestos de la regresión lineal En la Figura 96, se representan los consumos reales y los pronosticados con los modelos de regresión obtenidos, en $\mathrm{kWh}$.

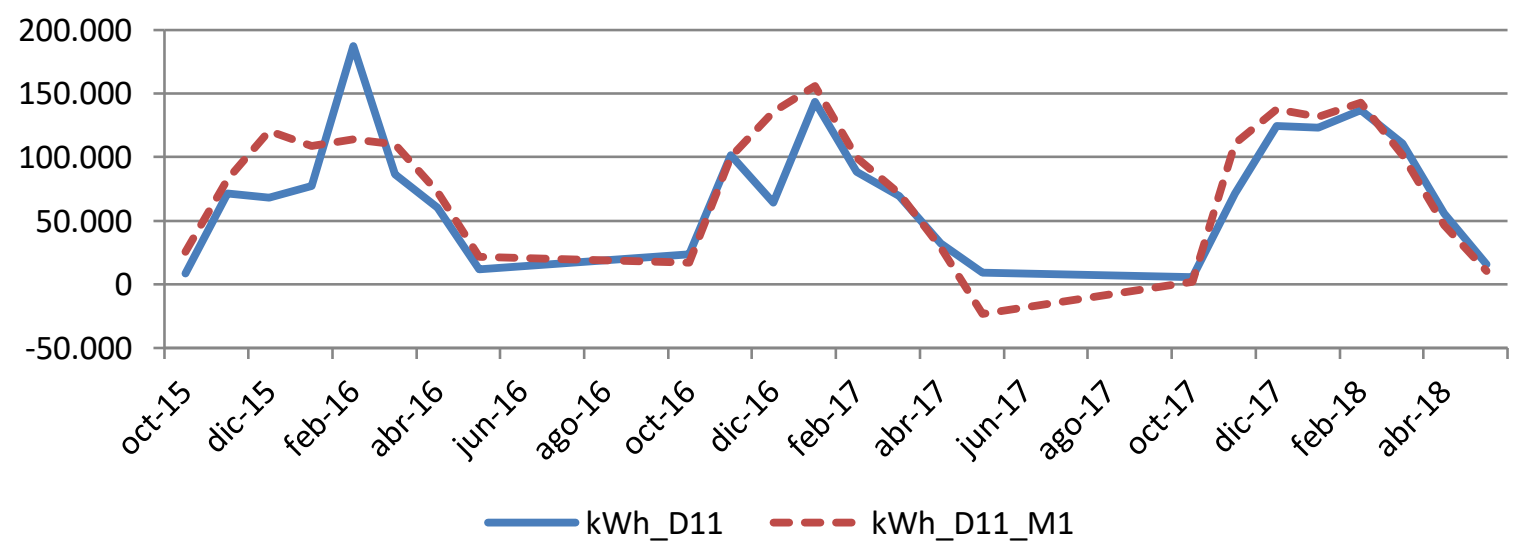

Figura 96. Representación de los consumos pronosticados para el Edificio D11. 2015-2018 
Los resultados de las diferencias entre las medias de los consumos, se exponen en la Tabla 67

Tabla 67. Resultado de las diferencias significativas encontradas. Edificio D11

\begin{tabular}{ccccccccc}
\hline & $\begin{array}{c}\% \\
\text { Diferencia } \\
2015-2016\end{array}$ & Significativo & $\begin{array}{c}\% \\
\text { Diferencia } \\
2016-2017\end{array}$ & Significativo & $\begin{array}{c}\% \\
\text { Diferencia } \\
2017-2018\end{array}$ & Significativo & $\begin{array}{c}\% \\
\text { Diferencia } \\
2015-2018\end{array}$ & Significativo \\
\hline D11 & $14,8 \%$ & No & $16,6 \%$ & No & $6,1 \%$ & No & $12,1 \%$ & No \\
\hline
\end{tabular}

En la Figura 97, se grafican los consumos reales y pronosticados para la temporada Octubre 2015 - Mayo 2018 para el Edificio D11, y las medias de dichos consumos. Según la prueba paramétrica realizada las diferencias encontradas no son estadísticamente significativas, con un riesgo a estar equivocados del $5 \%$

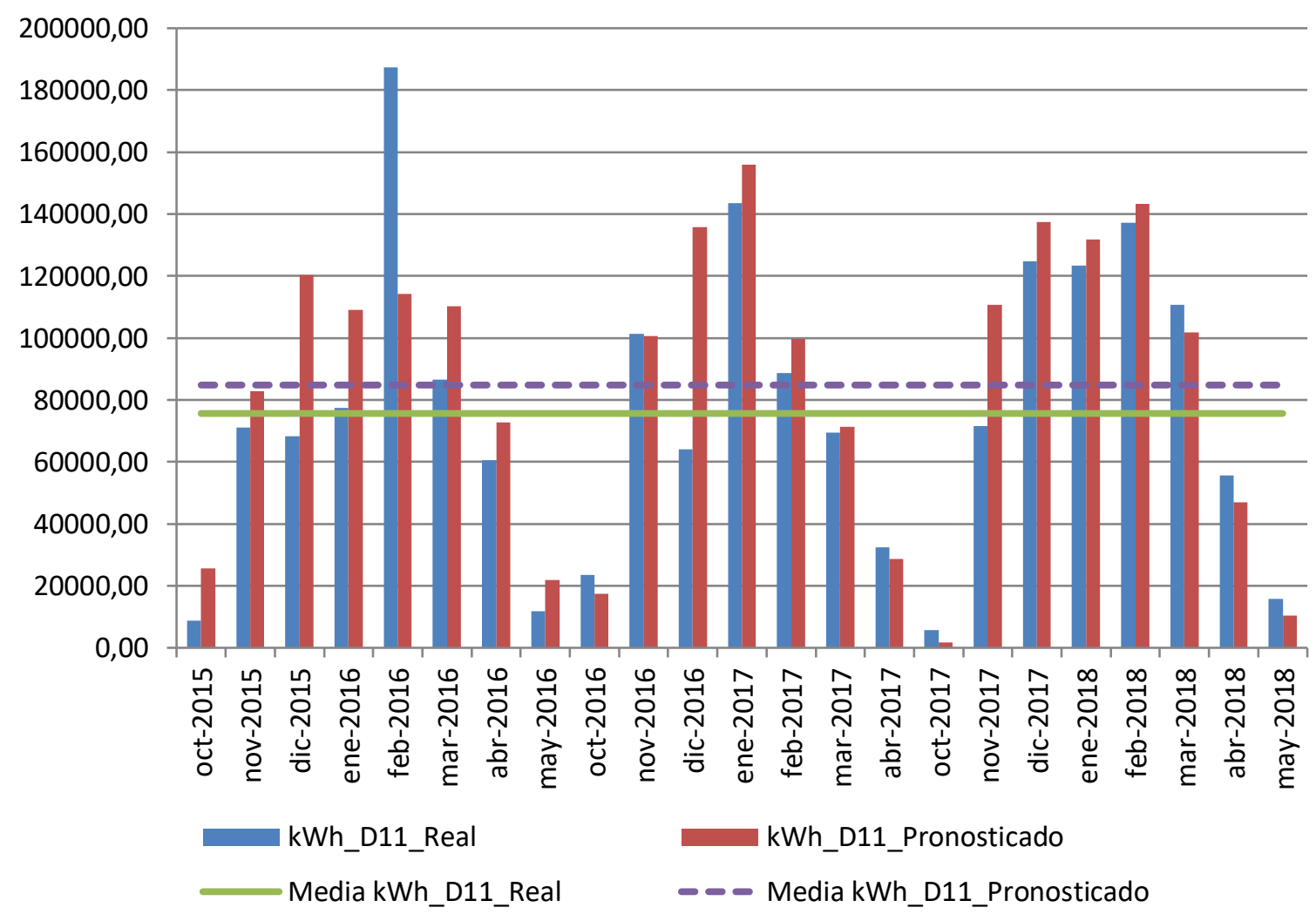

Figura 97. Consumos reales y pronosticados Octubre 2015-Mayo 2018. Edificio D11

En la Figura 98, se observa el consumo real del Edificio D11, en comparación con el consumo pronosticado acumulado que hubiera tenido el Edificio de no haberse incorporado a la red de calor y si se hubieran encontrado diferencias significativas. 


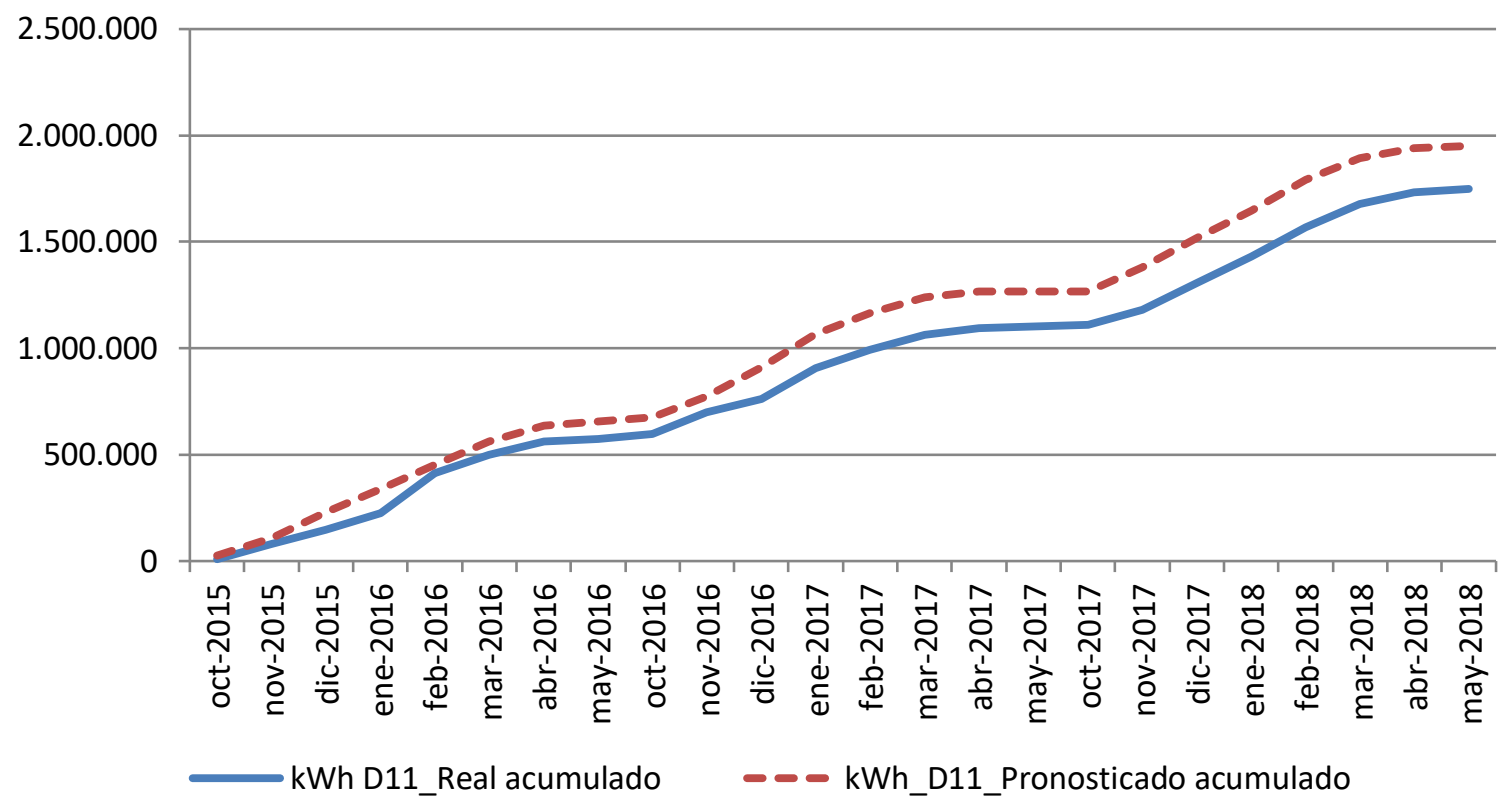

Figura 98. Consumo acumulado real y pronosticado. Octubre 2015-Mayo 2018. Edificio D11

Los resultados del ahorro de consumos, emisiones y precio máximo de la energía útil comprada a la red para un ahorro económico del 15\%, se exponen en la Tabla 68

Tabla 68. Resumen de resultados. Edificio D11

\begin{tabular}{lcc}
\hline $\begin{array}{l}\text { Diferencia significativa encontrada entre las medias de los } \\
\text { consumos 2015-2018 }\end{array}$ & $0 \%$ & $0 \mathrm{kWh}$ \\
\hline $\begin{array}{l}\text { Ahorro de consumo térmico durante las tres temporadas } \\
\text { posteriores a la construcción de la red respecto a lo que se hubiera } \\
\text { consumido de no ser por la red }\end{array}$ & $0 \%$ & $0 \mathrm{kWh}$ \\
\hline $\begin{array}{l}\text { Ahorro de emisiones de } \mathrm{CO}_{2} \\
\begin{array}{l}\text { Precio máximo de kWh útiles comprados a la red para obtener un } \\
\text { ahorro del 15\% }\end{array}\end{array}$ & $0,02710 € / \mathrm{kWh}$ & $8.445 €$ \\
\hline
\end{tabular}




\subsection{Edificio D12. Edificio de I+D}

Edificio de tipo docente que empezó a funcionar en el año 2007, cuenta con una superficie construida de $7.412 \mathrm{~m}^{2}$. Inicialmente la calefacción era suministrada mediante dos calderas de gas natural de una potencia de $401 \mathrm{~kW}$, lo que suma un total de $802 \mathrm{~kW}$. La subestación de intercambio con la red de calor construida en el año 2015, cuenta con una potencia de 802 kW. En la Figura 99 se marca la ubicación del edificio.

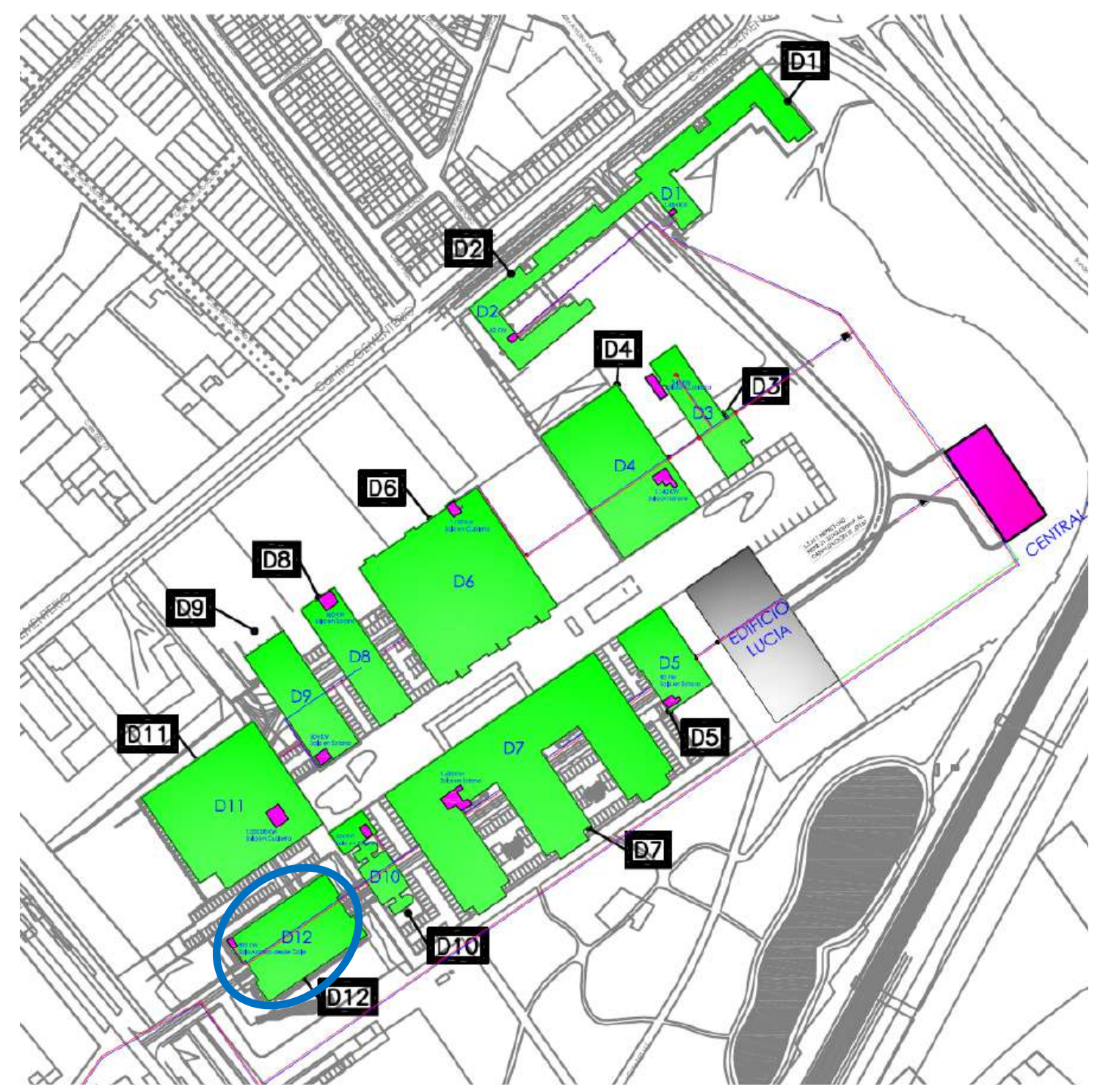

Figura 99. Ubicación del Edificio D12 en el croquis del campus Miguel Delibes 
El modelo encontrado para predecir el consumo térmico del Edificio, fue

$$
\text { kWh_D12_Pronosticado }=-663,549+173,214 \times \text { GD15_30min }
$$

El resumen del modelo, con el coeficiente de correlación de Pearson ${ }^{\circledR}$ y el coeficiente de determinación $\left(R^{2}\right)$ se muestra en la Tabla 69 y en la Tabla 70, el resultado de la verificación de los supuestos de la regresión lineal.

Tabla 69. Resumen de los modelos encontrados para el Edificio D12

\begin{tabular}{cccccc}
\hline & $\begin{array}{c}\text { Variable } \\
\text { independiente 1 }\end{array}$ & Constante & B & $R$ & $R^{2}$ \\
\hline D12 & GD15_30min & $-663,549$ & 173,214 & 0,999 & 0,998 \\
\hline
\end{tabular}

Tabla 70. Resumen del cumplimiento de los supuestos de regresión. Edificio D12

\begin{tabular}{ll}
\hline \multicolumn{1}{c}{ Cumplimiento de supuestos de la regresión lineal } & Modelo \\
\hline 1. Linealidad de las variables & Cumple \\
\hline 2. Normalidad de variables & Cumple \\
\hline 3. Independencia de los errores o no autocorrelación de los residuos & Cumple \\
\hline 4. Homocedasticidad de la varianza, los errores son aleatorios & Cumple \\
\hline
\end{tabular}

En la Figura 100, se representan el consumo real y el pronosticado con el modelo de regresión obtenido, en $\mathrm{kWh}$.

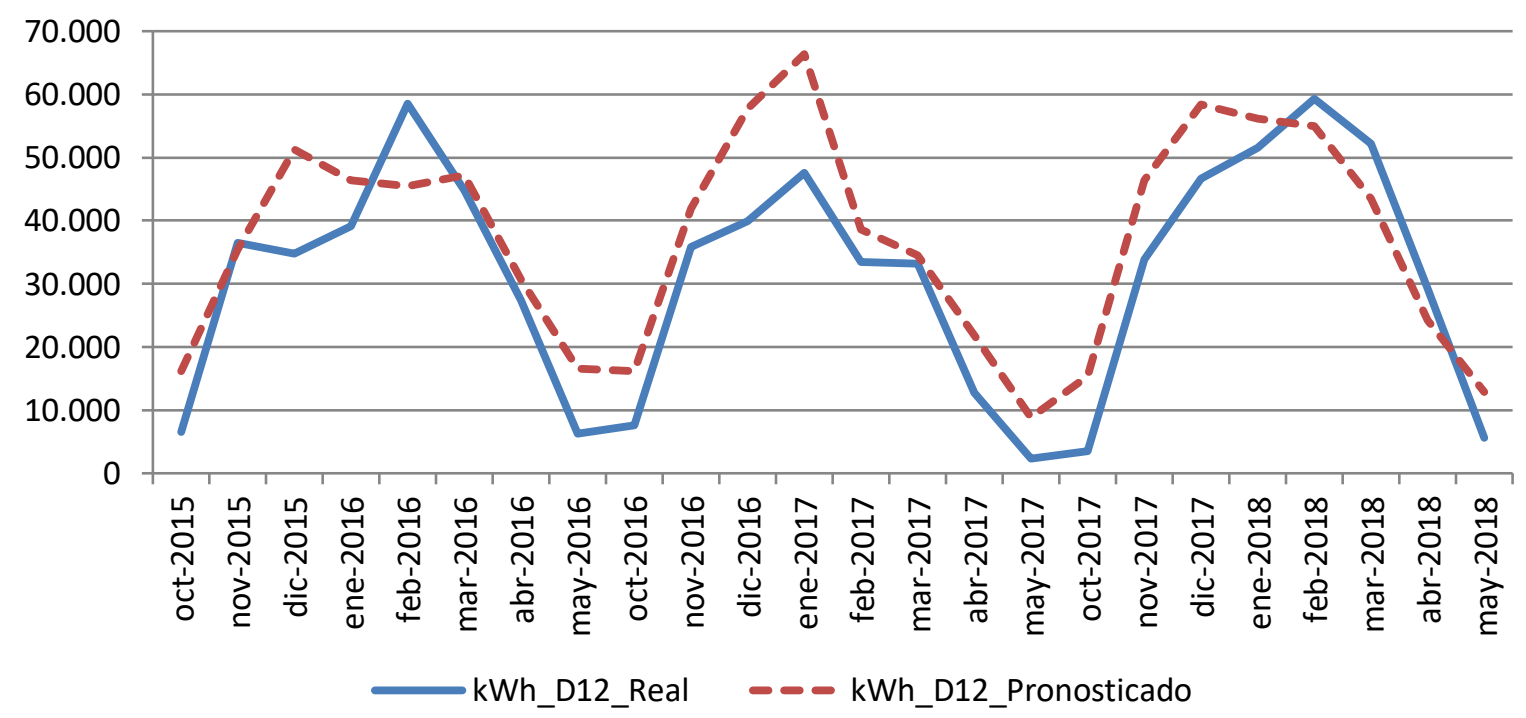

Figura 100. Representación de los consumos pronosticados para el Edificio D12. 2015-2018 
Los resultados de las diferencias entre las medias de los consumos, se exponen en la Tabla 71

Tabla 71. Resultado de las diferencias significativas encontradas. Edificio D12

\begin{tabular}{cccccccccc}
\hline & $\begin{array}{c}\% \\
\text { Diferencia } \\
2015-2016\end{array}$ & Significativo & $\begin{array}{c}\% \\
\text { Diferencia } \\
2016-2017\end{array}$ & Significativo & $\begin{array}{c}\% \\
\text { Diferencia } \\
2017-2018\end{array}$ & Significativo & $\begin{array}{c}\% \\
\text { Diferencia } \\
2015-2018\end{array}$ & Significativo \\
\hline D12 & $13,8 \%$ & No & $34,6 \%$ & SI & $10,6 \%$ & No & $18,5 \%$ & SI \\
\hline
\end{tabular}

En la Figura 101, se grafican los consumos reales y pronosticados para la temporada Octubre 2015 - Mayo 2018 para el Edificio D12, y las medias de dichos consumos. Según la prueba paramétrica realizada las diferencias encontradas son estadísticamente significativas, con un riesgo a estar equivocados del $5 \%$

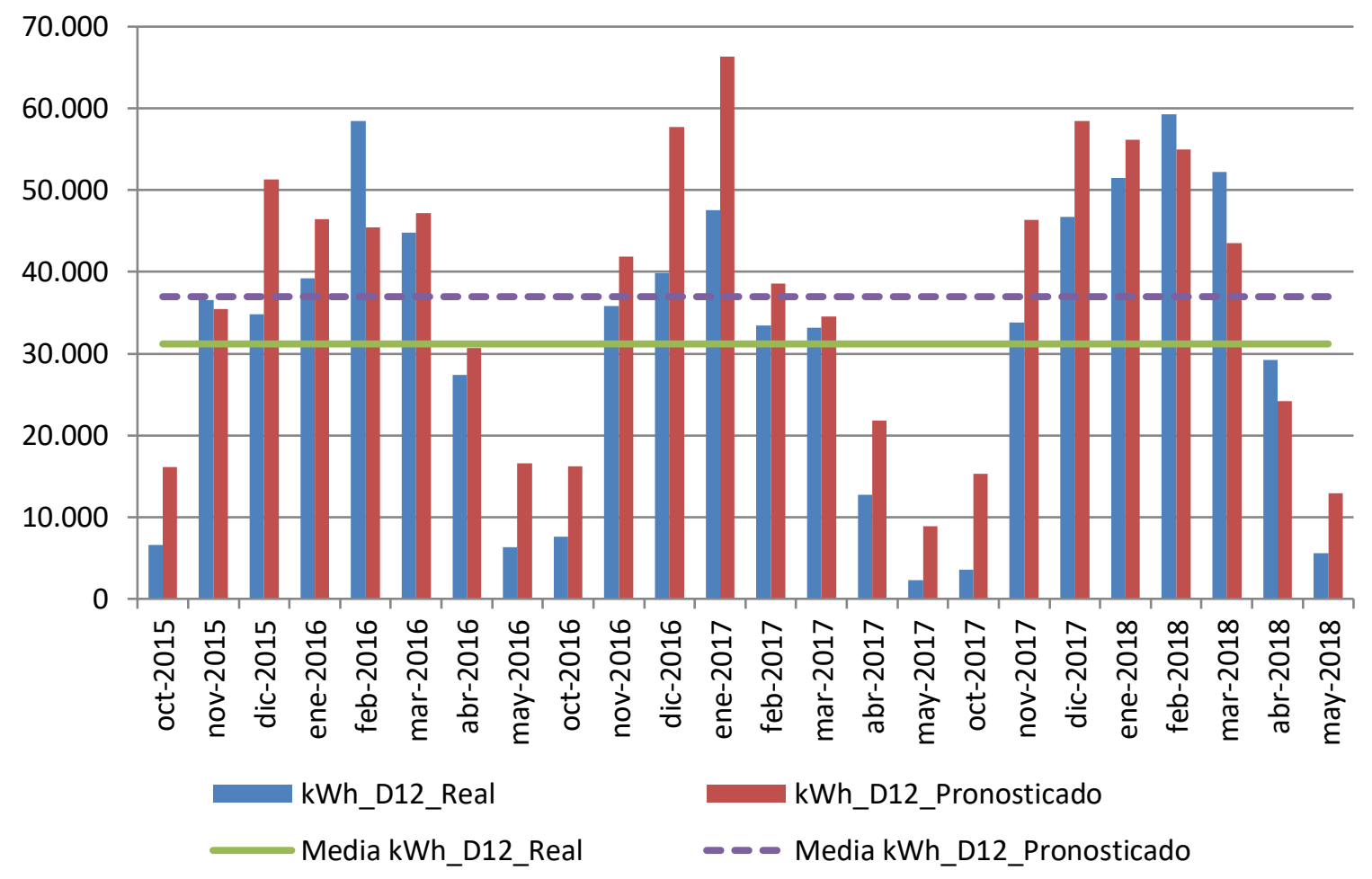

Figura 101. Consumos reales y pronosticados Octubre 2015-Mayo 2018. Edificio D12 
En la Figura 102, se observa el consumo real del Edificio D12, en comparación con el consumo pronosticado acumulado que hubiera tenido el Edificio de no haberse incorporado a la red de calor.

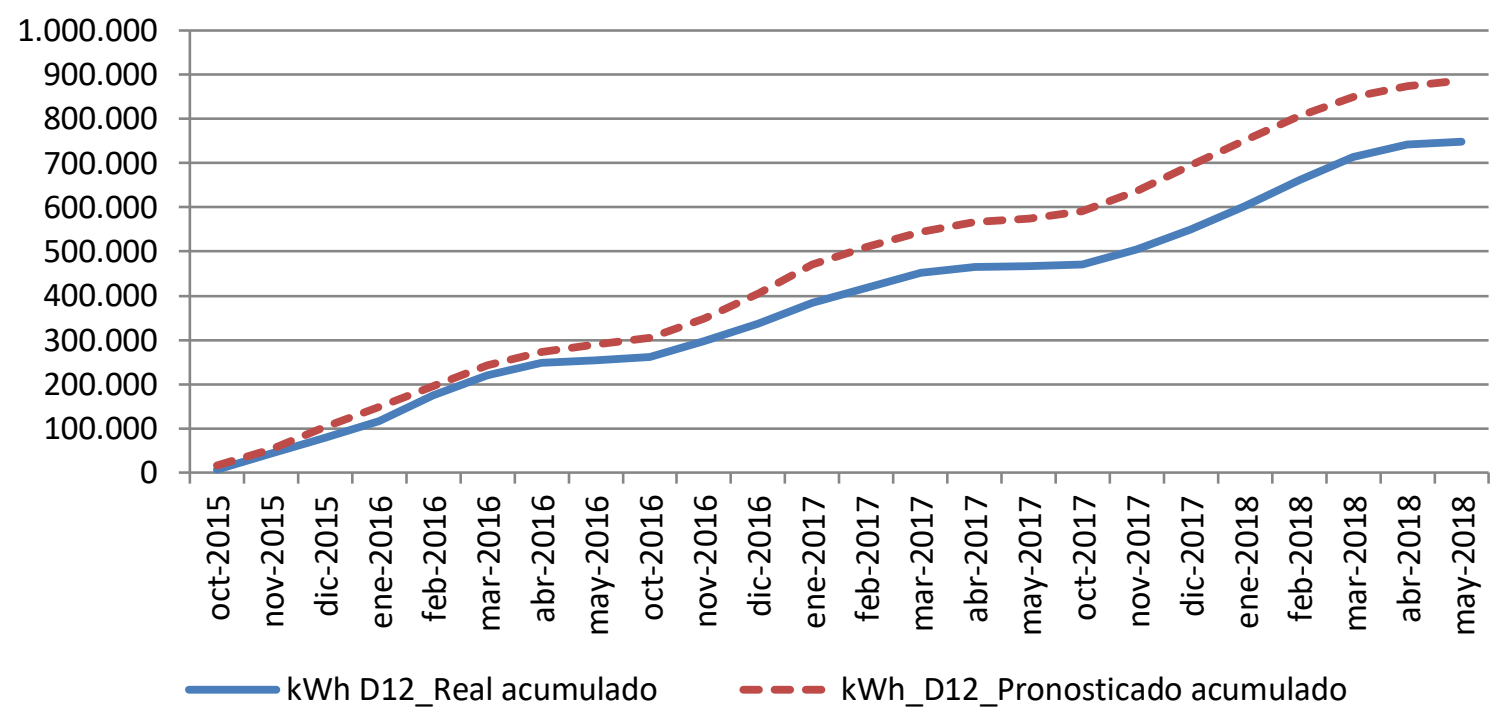

Figura 102. Consumo acumulado real y pronosticado. Octubre 2015-Mayo 2018. Edificio D12

Los resultados del ahorro de consumos, emisiones y precio máximo de la energía útil comprada a la red para un ahorro económico del 15\%, se exponen en la Tabla 72

Tabla 72. Resumen de resultados. Edificio D12

\begin{tabular}{lcc}
\hline $\begin{array}{l}\text { Diferencia significativa encontrada entre las medias de los } \\
\text { consumos 2015-2018 }\end{array}$ & $18,5 \%$ & $5.778 \mathrm{kWh}$ \\
\hline $\begin{array}{l}\text { Ahorro de consumo térmico durante las tres temporadas } \\
\text { posteriores a la construcción de la red respecto a lo que se hubiera } \\
\text { consumido de no ser por la red }\end{array}$ & $15,6 \%$ & $\begin{array}{c}138.666 \\
\mathrm{kWh}\end{array}$ \\
\hline $\begin{array}{l}\text { Ahorro de emisiones de } \mathrm{CO}_{2} \\
\text { Precio máximo de kWh útiles comprados a la red para obtener un } \\
\text { ahorro del 15\% }\end{array}$ & $0,03256 € / \mathrm{kWh}$ & $4.306 €$ \\
\hline
\end{tabular}




\subsection{Resultados y discusión}

En la Tabla 73, se muestran los modelos de línea base encontrados para los 12 edificios del Campus Miguel Delibes. Para todos los edificios se obtuvieron modelos válidos de regresión simple, dado que cumplieron todos los supuestos estadísticos de la regresión lineal y para dos de ellos, además se hallaron modelos de regresión multivariable, recopilados en la Tabla 74. La regresión múltiple encontrada para el Edificio D11, no resultó válida por existir multicolinealidad entre las dos variables independientes.

Cinco de los modelos de regresión simple $(41,6 \%)$, tuvieron como variable independiente la Temperatura media y los siete restantes (58,3\%), tuvieron a los Grados día Base 15 obtenidos con datos cada 30 minutos como variable independiente. El resto de las variables climáticas analizadas no mostraron influencias significativas en el consumo de los edificios de manera lineal.

Tabla 73. Resumen de modelos de regresión simple. Campus Miguel Delibes

\begin{tabular}{lrrrrr}
\hline Edificio & Variable independiente & \multicolumn{1}{c}{ Constante } & \multicolumn{1}{c}{$\mathrm{B}$} & \multicolumn{1}{c}{$\mathrm{R}$} & \multicolumn{1}{c}{$\mathrm{R}^{2}$} \\
\hline D1 & Tmed & $391.037,854$ & $-23.838,939$ & $-0,899$ & 0,808 \\
\hline D2 & GD15 & $-663,338$ & 38,971 & 0,985 & 0,970 \\
\hline D3 & GD15 & $-6.854,944$ & 192,510 & 0,921 & 0,848 \\
\hline D4 & Tmed & $271.046,123$ & $-17.453,026$ & $-0,940$ & 0,888 \\
\hline D5 & GD15 & $-653,894$ & 56,535 & 0,993 & 0,986 \\
\hline D6 & GD15 & $-6.540,157$ & 656,818 & 0,995 & 0,989 \\
\hline D7 & GD15 & $-6.543,072$ & 733,335 & 0,996 & 0,991 \\
\hline D8 & Tmed & $91.484,519$ & $-5.414,103$ & $-0,906$ & 0,821 \\
\hline D9 & GD15 & $-654,602$ & 139,864 & 0,999 & 0,998 \\
\hline D10 & Tmed & $66.791,063$ & $-4.393,782$ & $-0,896$ & 0,802 \\
\hline D11 & Tmed & $187.840,052$ & $-12.648,948$ & $-0,898$ & 0,807 \\
\hline D12 & GD15 & $-663,549$ & 173,214 & 0,999 & 0,998 \\
\hline
\end{tabular}

Tabla 74. Resumen de modelos de regresión múltiple. Campus Miguel Delibes

\begin{tabular}{lllrrrrr}
\hline & $\begin{array}{c}\text { Variable } \\
\text { independiente } \\
\end{array}$ & $\begin{array}{c}\text { Variable } \\
\text { independiente } \\
2\end{array}$ & Constante & B1 & B2 & R & $R^{2}$ \\
\hline D1 & Tmed & V_nocturna & $271.370,906$ & $-20.045,184$ & 50568,513 & $-0,931$ & 0,866 \\
\hline D8 & Tmed & V_diurna & 63357,055 & $-4991,184$ & 8950,19 & 0,945 & 0,894 \\
\hline D11 $\left(^{*}\right)$ & Tmed & GD15 & 630672,573 & $-38572,601$ & $-1044,773$ & $-0,931$ & 0,866 \\
\hline
\end{tabular}

$\left(^{*}\right)$ Modelo no válido. Multicolinealidad entre las variables 
Los dos modelos válidos encontrados de regresión múltiple correlacionaron como la Temperatura media y con la velocidad del viento, en el Edificio D1, con la velocidad del viento nocturna y el Edificio D8, con la velocidad del viento diurna. En estos modelos el resto de las variables climáticas tampoco mostraron correlaciones significativas. Los modelos de regresión múltiple presentan mejores coeficientes de correlación y determinación que los modelos de regresión simple para el mismo edificio.

Todos los modelos encontrados tienen un coeficiente de correlación superior a 0,896 en valor absoluto, siendo positivo para los modelos con los Grados día y negativo para los modelos con la Temperatura media. El coeficiente de determinación es superior a 0,802, por lo que con los modelos encontrados se puede predecir más del $80 \%$ de los consumos futuros con un error del $5 \%$.

En cuanto a las diferencias entre los consumos reales de las tres temporadas posteriores a la construcción de la red de calor y los consumos estimados o pronosticados que se hubieran obtenido en esas mismas temporadas si los edificios no se hubieran unido a la red de calor, como se muestra en la Tabla 75, se han obtenido diferencias significativas en 7 de los 12 edificios (58,3\%), en 5 de los cuales las diferencias fueron positivas (se obtuvo ahorros energéticos con la incorporación a la red) y en los otros dos las diferencias encontradas fueron negativas, se obtuvieron aumentos de consumo.

Los edificios que han obtenido ahorros significativos son:

- D1: Apartamentos Cardenal Mendoza, de tipo residencial, con $17.616 \mathrm{~m}^{2}$ construidos, una potencia inicial instalada de $1.554 \mathrm{~kW}$, con 19 años de antigüedad hasta el 2015, un ratio de $166 \mathrm{kWh} / \mathrm{m}^{2}$ en el total de octubre 2012 a mayo $2014 \mathrm{y}$ 1.878 horas de funcionamiento a carga nominal de las calderas durante ese periodo. Diferencia del $22,5 \%$ en las tres temporadas posteriores a la red de calor

- D2: Biblioteca de los Apartamentos Cardenal Mendoza, de tipo docente, con 464 $\mathrm{m}^{2}$ construidos, una potencia inicial instalada de $41 \mathrm{~kW}$, con 19 años de antigüedad hasta el 2015, de $275 \mathrm{kWh} / \mathrm{m}^{2}$ en el total de octubre 2012 a mayo 2014 y 3.111 horas de funcionamiento a carga nominal de las calderas durante ese periodo. Diferencia del $41,5 \%$ en las tres temporadas posteriores a la red de calor

- D3: Edificio CTTA (Centro de Transferencia de Tecnologías Aplicadas) de tipo docente, con $5.487 \mathrm{~m}^{2}$ construidos, una potencia inicial instalada de $348 \mathrm{~kW}$, con 8 años de antigüedad hasta el 2015, de $104 \mathrm{kWh} / \mathrm{m}^{2}$ en el total de octubre 2012 a mayo 2014 y 1.646 horas de funcionamiento a carga nominal de las calderas durante ese periodo. Diferencia del $14,2 \%$ en las tres temporadas posteriores a la red de calor. 
- D4. Biblioteca aulario Miguel Delibes, de tipo docente, con $14.541 \mathrm{~m}^{2}$ construidos, una potencia inicial instalada de $1.140 \mathrm{~kW}$, con 3 años de antigüedad hasta el 2015, de $142 \mathrm{kWh} / \mathrm{m}^{2}$ en el total de octubre 2012 a mayo 2014 y 1.807 horas de funcionamiento a carga nominal de las calderas durante ese periodo. Diferencia del $14,9 \%$ en las tres temporadas posteriores a la red de calor

- D12. Edificio I+D. de tipo docente, con $7.412 \mathrm{~m}^{2}$ construidos, una potencia inicial instalada de $1.000 \mathrm{~kW}$, con 8 años de antigüedad hasta el 2015, de $81 \mathrm{kWh} / \mathrm{m}^{2}$ en el total de octubre 2012 a mayo 2014 y 752 horas de funcionamiento a carga nominal de las calderas durante ese periodo. Diferencia del $18,5 \%$ en las tres temporadas posteriores a la red de calor

Los edificios que han obtenido aumentos significativos en su consumo térmico han sido:

- D5: Edificio IOBA (Instituto Universitario de Oftalmología aplicada), de tipo docente, con $4.146 \mathrm{~m}^{2}$ construidos, una potencia inicial instalada de $81 \mathrm{~kW}$, con 7 años de antigüedad hasta el 2015, un ratio de $46 \mathrm{kWh} / \mathrm{m}^{2}$ en el total de octubre 2012 a mayo 2014 y 2.345 horas de funcionamiento a carga nominal de las calderas durante ese periodo. Diferencia del $15,6 \%$ en las tres temporadas posteriores a la red de calor

- D8: Edificio QUIFIMA (Química Fina y Materiales Avanzados), de tipo docente, con $5.610 \mathrm{~m}^{2}$ construidos, una potencia inicial instalada de $466 \mathrm{~kW}$, con 7 años de antigüedad hasta el 2015, un ratio de $135 \mathrm{kWh} / \mathrm{m}^{2}$ en el total de octubre 2012 a mayo 2014 y 1.629 horas de funcionamiento a carga nominal de las calderas durante ese periodo. Diferencia del $15,6 \%$ en las tres temporadas posteriores a la red de calor

Un resumen de las características de los edificios, se muestra en la Tabla 77

Durante la primera temporada (octubre 2015-mayo 2016), ningún edificio del Campus mostró diferencias significativas en sus consumos. Durante la segunda temporada (octubre 2016 - mayo 2017), 3 edificios mostraron ahorros significativos y 1 aumento significativo en el consumo. Durante la tercera temporada (octubre 2017 - mayo 2018), 2 edificios mostraron ahorros significativos y 1 aumento significativos.

En el total de las tres temporadas, fueron 5 edificios los que presentaron ahorros y 2 los que presentaron aumentos de consumo 
En la Tabla 75 y Tabla 76, se muestran en verde los edificios que presentan ahorros significativos en los consumos y en naranja los que presentan aumentos significativos de los mismos.

Tabla 75. Resumen de diferencias significativas regresión simple. Campus Miguel Delibes

\begin{tabular}{ccccccccc}
\hline Edificio & $\begin{array}{c}\text { Variable } \\
\text { independiente }\end{array}$ & $\begin{array}{c}\% \\
\text { Diferencia } \\
2015- \\
2016\end{array}$ & Significativo & $\begin{array}{c}\% \\
\text { Diferencia } \\
2016- \\
2017\end{array}$ & Significativo & $\begin{array}{c}\% \\
\text { Diferencia } \\
2017- \\
2018\end{array}$ & $\begin{array}{c}\% \\
\text { Significativo }\end{array}$ & $\begin{array}{c}\text { Diferencia } \\
2015- \\
2018\end{array}$ \\
\hline Significativo
\end{tabular}

Los GD15 son los calculados a partir de datos cada 30 minutos

Tabla 76. Resumen de diferencias significativas regresión múltiple. Campus Miguel Delibes

\begin{tabular}{|c|c|c|c|c|c|c|c|c|c|}
\hline Edificio & $\begin{array}{c}\text { Variables } \\
\text { independientes }\end{array}$ & $\begin{array}{c}\% \\
\text { Diferencia } \\
2015- \\
2016 \\
\end{array}$ & Significativo & $\begin{array}{c}\% \\
\text { Diferencia } \\
2016- \\
2017 \\
\end{array}$ & Significativo & $\begin{array}{c}\% \\
\text { Diferencia } \\
2017- \\
2018 \\
\end{array}$ & Significativo & $\begin{array}{c}\% \\
\text { Diferencia } \\
2015- \\
2018 \\
\end{array}$ & Significativo \\
\hline D1 & $\begin{array}{c}\text { T med } \\
\text { V_nocturna }\end{array}$ & $10,2 \%$ & No & $11,8 \%$ & No & $12,4 \%$ & No & $11,5 \%$ & No Normal \\
\hline D8 & $\begin{array}{c}\text { GD15 } \\
\text { V_diurna }\end{array}$ & $-13,0 \%$ & No & $-31,2 \%$ & SI & $-29,0 \%$ & SI & $-25,0 \%$ & SI \\
\hline
\end{tabular}

Los GD15 son los calculados a partir de datos cada 30 minutos 
Capítulo 4. Resultados y Discusión. Campus Miguel Delibes

Tabla 77. Resumen de características de los edificios del Campus Miguel Delibes

\begin{tabular}{|c|c|c|c|c|c|c|c|c|}
\hline & Tipo & $\begin{array}{c}\text { kWh total } \\
\text { oct-12- } \\
\text { may-14 }\end{array}$ & $\mathrm{m}^{2}$ & $\mathrm{kWh} / \mathrm{m}^{2}$ & $\begin{array}{c}\text { kW } \\
\text { instalados } \\
\text { Gas } \\
\text { Natural }\end{array}$ & $\begin{array}{c}\text { kW } \\
\text { instalados } \\
\text { subestación }\end{array}$ & $\begin{array}{c}\mathrm{h} \\
\text { funcionamiento } \\
\text { a carga nominal } \\
\text { durante oct-12 } \\
\text { - may14 }\end{array}$ & $\begin{array}{c}\text { Años de } \\
\text { antigüed } \\
\text { ad hasta } \\
2015\end{array}$ \\
\hline D1 & Residencial & 2.917 .883 & 17.616 & 165,64 & 1.554 & 1.454 & $1.877,66$ & 19 \\
\hline D2 & Docente & 127.560 & 464 & 274,91 & 41 & 42 & $3.111,22$ & 19 \\
\hline D3 & Docente & 572.885 & 5.487 & 104,41 & 348 & 342 & $1.646,22$ & 8 \\
\hline D4 & Docente & 2.060 .198 & 14.541 & 141,68 & 1.140 & 1.140 & $1.807,19$ & 3 \\
\hline D5 & Docente & 189.987 & 4.146 & 45,82 & 81 & 80 & $2.345,52$ & 7 \\
\hline D6 & Docente & 2.224 .169 & 19.137 & 116,22 & 1.162 & 1.120 & $1.914,09$ & 6 \\
\hline D7 & Docente & 2.495 .431 & 20.179 & 123,66 & 1.953 & 1.620 & $1.275,78$ & 18 \\
\hline D8 & Docente & 757.645 & 5.610 & 135,05 & 466 & 460 & $1.625,85$ & 7 \\
\hline D9 & Deportivo & 485.432 & 3.673 & 132,16 & 508 & 504 & 955,57 & 14 \\
\hline D10 & Docente & 495.620 & 5.636 & 87,94 & 326 & 326 & $1.520,31$ & 19 \\
\hline D11 & Docente & 1.355 .765 & 14.943 & 90,73 & 1.000 & 1.000 & $1.355,77$ & 14 \\
\hline D12 & Docente & 603.534 & 7.412 & 81,43 & 802 & 802 & 752,54 & 8 \\
\hline DELIBES & & 14.286 .109 & 118.844 & 120,21 & 9.385 & 8.890 & $1.522,23$ & 19 \\
\hline
\end{tabular}

La Tabla 78 y Tabla 79, recopilan los consumos de los edificios del Campus Miguel Delibes, se muestran los consumos reales y los estimados o pronosticados con los modelos de regresión validados como línea base del consumo de cada edificio. 
Capítulo 4. Resultados y Discusión. Campus Miguel Delibes

Tabla 78. Consumo Real térmico de los edificios del Campus Miguel Delibes (kWh)

\begin{tabular}{|c|c|c|c|c|c|c|c|c|c|c|c|c|c|}
\hline REAL & D1 & D2 & D3 & D4 & D5 & D6 & D7 & D8 & D9 & D10 & D11 & D12 & TOTAL \\
\hline oct-12 & 52.823 & 2.973 & 15.679 & 38.678 & 5.298 & 65.093 & 75.227 & 28.190 & 16.335 & 9.525 & 15.176 & 20.755 & 345.753 \\
\hline nov-12 & 220.904 & 8.215 & 34.701 & 195.712 & 12.464 & 145.750 & 163.403 & 44.053 & 31.692 & 24.605 & 121.937 & 39.191 & 1.042 .627 \\
\hline dic-12 & 228.313 & 11.245 & 47.474 & 176.685 & 16.625 & 194.289 & 217.741 & 58.473 & 42.168 & 51.330 & 93.881 & 52.395 & 1.190 .619 \\
\hline ene-13 & 239.241 & 12.064 & 61.790 & 191.773 & 17.744 & 207.050 & 231.815 & 61.638 & 44.716 & 43.452 & 112.357 & 55.517 & 1.279 .157 \\
\hline feb-13 & 273.273 & 11.615 & 51.895 & 201.662 & 17.029 & 198.500 & 222.100 & 71.642 & 42.732 & 53.877 & 146.609 & 53.024 & 1.343 .958 \\
\hline mar-13 & 210.397 & 9.500 & 35.453 & 143.416 & 13.786 & 160.192 & 178.875 & 64.884 & 34.135 & 36.141 & 90.810 & 42.283 & 1.019 .870 \\
\hline$a b r-13$ & 219.730 & 6.534 & 33.758 & 118.693 & 9.765 & 114.486 & 128.571 & 45.407 & 25.105 & 23.334 & 67.242 & 31.248 & 823.873 \\
\hline may-13 & 135.157 & 5.196 & 16.401 & 57.071 & 7.775 & 91.192 & 102.436 & 20.377 & 20.021 & 5.546 & 35.376 & 24.925 & 521.472 \\
\hline oct-13 & 35.931 & 3.398 & 9.887 & 51.998 & 5.004 & 58.407 & 65.408 & 21.697 & 12.629 & 9.525 & 7.360 & 15.683 & 296.925 \\
\hline nov-13 & 0 & 8.280 & 32.104 & 103.055 & 12.654 & 149.340 & 168.407 & 32.562 & 33.422 & 24.605 & 86.849 & 41.737 & 693.017 \\
\hline dic-13 & 322.634 & 14.205 & 64.828 & 225.143 & 20.880 & 243.583 & 272.681 & 76.564 & 52.571 & 51.330 & 128.882 & 65.261 & 1.538 .561 \\
\hline ene-14 & 320.896 & 11.133 & 59.681 & 153.040 & 16.068 & 186.405 & 207.919 & 67.774 & 39.501 & 43.452 & 140.938 & 48.884 & 1.295 .691 \\
\hline feb-14 & 307.368 & 9.351 & 53.522 & 201.660 & 14.051 & 165.006 & 185.496 & 75.981 & 36.368 & 53.877 & 160.288 & 45.304 & 1.308 .271 \\
\hline mar-14 & 165.884 & 6.636 & 20.039 & 116.269 & 10.258 & 121.453 & 137.241 & 50.114 & 27.453 & 36.141 & 92.685 & 34.339 & 818.512 \\
\hline$a b r-14$ & 156.449 & 3.899 & 25.860 & 53.303 & 5.701 & 66.396 & 74.250 & 20.141 & 14.255 & 23.334 & 53.233 & 17.680 & 514.499 \\
\hline may-14 & 28.883 & 3.318 & 9.813 & 32.040 & 4.886 & 57.028 & 63.862 & 18.148 & 12.328 & 5.546 & 2.142 & 15.308 & 253.304 \\
\hline oct-15 & 34.650 & 810 & 0 & 30.770 & 4.908 & 32.180 & 22.220 & 8.364 & 10.847 & 4.183 & 8.810 & 6.590 & 164.332 \\
\hline nov-15 & 162.230 & 2.643 & 28.683 & 117.720 & 16.749 & 128.080 & 128.080 & 48.422 & 35.070 & 26.851 & 71.160 & 36.550 & 802.238 \\
\hline dic-15 & 192.680 & 11.959 & 50.191 & 91.520 & 16.244 & 147.210 & 124.770 & 52.355 & 21.527 & 32.026 & 68.390 & 34.820 & 843.692 \\
\hline ene-16 & 182.730 & 6.666 & 38.231 & 116.430 & 10.727 & 172.470 & 163.370 & 56.577 & 27.599 & 33.481 & 77.420 & 39.180 & 924.881 \\
\hline feb-16 & 292.080 & 12.459 & 68.430 & 195.806 & 30.176 & 348.935 & 297.336 & 93.692 & 55.163 & 54.047 & 187.398 & 58.477 & 1.693 .998 \\
\hline mar-16 & 195.399 & 5.239 & 41.775 & 132.677 & 18.666 & 226.654 & 200.359 & 65.365 & 36.551 & 39.987 & 86.570 & 44.763 & 1.094 .003 \\
\hline abr-16 & 140.815 & 3.941 & 24.655 & 91.374 & 13.772 & 150.969 & 139.890 & 43.085 & 29.596 & 29.457 & 60.654 & 27.410 & 755.618 \\
\hline may-16 & 50.295 & 405 & 7.268 & 30.726 & 7.926 & 28.051 & 25.190 & 8.549 & 7.715 & 6.620 & 11.790 & 6.310 & 190.845 \\
\hline oct-16 & 60.420 & 165 & 3.711 & 28.123 & 11.119 & 21.196 & 33.434 & 7.817 & 10.167 & 6.261 & 23.413 & 7.600 & 213.428 \\
\hline nov-16 & 185.097 & 5.063 & 35.452 & 138.294 & 9.643 & 190.925 & 175.576 & 63.818 & 43.277 & 30.783 & 101.456 & 35.820 & 1.015 .205 \\
\hline dic-16 & 232.890 & 7.397 & 45.615 & 115.985 & 17.910 & 207.496 & 145.836 & 84.992 & 37.629 & 42.246 & 64.092 & 39.872 & 1.041 .961 \\
\hline ene-17 & 245.060 & 7.617 & 47.454 & 231.678 & 20.318 & 273.478 & 258.264 & 96.064 & 55.750 & 51.733 & 143.509 & 47.548 & 1.478 .474 \\
\hline feb-17 & 181.458 & 6.987 & 33.104 & 137.936 & 13.128 & 191.313 & 182.550 & 66.871 & 42.290 & 35.287 & 88.654 & 33.393 & 1.012 .971 \\
\hline mar-17 & 144.074 & 7.621 & 26.179 & 104.060 & 12.215 & 147.550 & 150.896 & 61.592 & 35.130 & 30.375 & 69.390 & 33.195 & 822.277 \\
\hline abr-17 & 56.590 & 3.584 & 16.672 & 61.046 & 8.730 & 64.206 & 55.650 & 28.173 & 8.288 & 12.121 & 32.388 & 12.700 & 360.148 \\
\hline may-17 & 38.400 & 1.566 & 12.122 & 22.428 & 7.585 & 22.062 & 14.320 & 9.028 & 1.706 & 4.111 & 9.030 & 2.318 & 144.676 \\
\hline oct-17 & 43.056 & 10 & 4.697 & 9.706 & 7.020 & 10.750 & 9.884 & 5.806 & 4.566 & 3.499 & 5.700 & 3.530 & 108.223 \\
\hline nov-17 & 160.774 & 4.213 & 37.870 & 133.130 & 11.984 & 148.032 & 124.350 & 64.362 & 37.102 & 27.035 & 71.556 & 33.788 & 854.197 \\
\hline dic-17 & 251.172 & 10.407 & 48.468 & 159.080 & 15.343 & 222.510 & 173.018 & 111.550 & 53.819 & 41.851 & 124.822 & 46.710 & 1.258 .751 \\
\hline ene-18 & 242.664 & 9.738 & 48.828 & 188.850 & 14.960 & 275.251 & 188.888 & 91.069 & 45.982 & 43.756 & 123.410 & 51.528 & 1.324 .924 \\
\hline feb-18 & 246.178 & 10.737 & 48.728 & 198.442 & 19.556 & 293.190 & 245.226 & 95.311 & 43.599 & 44.761 & 137.100 & 59.290 & 1.442 .119 \\
\hline mar-18 & 208.040 & 7.939 & 28.432 & 160.912 & 15.655 & 219.610 & 217.314 & 77.654 & 51.291 & 38.923 & 110.644 & 52.218 & 1.188 .633 \\
\hline$a b r-18$ & 132.930 & 5.172 & 19.765 & 70.510 & 13.055 & 102.000 & 99.014 & 36.472 & 24.007 & 23.478 & 55.580 & 29.262 & 611.245 \\
\hline may-18 & 53.590 & 7 & 13.337 & 34.320 & 13.273 & 29.180 & 23.570 & 15.896 & 7.171 & 6.241 & 15.860 & 5.570 & 218.015 \\
\hline TOTAL & 6.651 .155 & 259.906 & 1.302 .553 & 4.661 .722 & 520.647 & 5.877 .468 & 5.694 .439 & 2.050 .529 & 1.211 .274 & 1.164 .732 & 3.104 .563 & 1.351 .976 & 33.850 .963 \\
\hline
\end{tabular}


Capítulo 4. Resultados y Discusión. Campus Miguel Delibes

Tabla 79. Consumo Pronosticado térmico de los edificios del Campus Miguel Delibes (kWh)

\begin{tabular}{|c|c|c|c|c|c|c|c|c|c|c|c|c|c|}
\hline PRONOST & D1 & D2 & D3 & D4 & D5 & D6 & D7 & D8 & D9 & D10 & D11 & D12 & TOTAL \\
\hline oct-12 & 52.823 & 2.973 & 15.679 & 38.678 & 5.298 & 65.093 & 75.227 & 28.190 & 16.335 & 9.525 & 15.176 & 20.755 & 345.752 \\
\hline nov-12 & 220.904 & 8.215 & 34.701 & 195.712 & 12.464 & 145.750 & 163.403 & 44.053 & 31.692 & 24.605 & 121.937 & 39.191 & 1.042 .627 \\
\hline dic-12 & 228.313 & 11.245 & 47.474 & 176.685 & 16.625 & 194.289 & 217.741 & 58.473 & 42.168 & 51.330 & 93.881 & 52.395 & 1.190 .619 \\
\hline ene-13 & 239.241 & 12.064 & 61.790 & 191.773 & 17.744 & 207.050 & 231.815 & 61.638 & 44.716 & 43.452 & 112.357 & 55.517 & 1.279 .157 \\
\hline feb-13 & 273.273 & 11.615 & 51.895 & 201.662 & 17.029 & 198.500 & 222.100 & 71.642 & 42.732 & 53.877 & 146.609 & 53.024 & 1.343 .958 \\
\hline mar-13 & 210.397 & 9.500 & 35.453 & 143.416 & 13.786 & 160.192 & 178.875 & 64.884 & 34.135 & 36.141 & 90.810 & 42.283 & 1.019 .872 \\
\hline$a b r-13$ & 219.730 & 6.534 & 33.758 & 118.693 & 9.765 & 114.486 & 128.571 & 45.407 & 25.105 & 23.334 & 67.242 & 31.248 & 823.873 \\
\hline may-13 & 135.157 & 5.196 & 16.401 & 57.071 & 7.775 & 91.192 & 102.436 & 20.377 & 20.021 & 5.546 & 35.376 & 24.925 & 521.473 \\
\hline oct-13 & 35.931 & 3.398 & 9.887 & 51.998 & 5.004 & 58.407 & 65.408 & 21.697 & 12.629 & 9.525 & 7.360 & 15.683 & 296.927 \\
\hline nov-13 & 0 & 8.280 & 32.104 & 103.055 & 12.654 & 149.340 & 168.407 & 32.562 & 33.422 & 24.605 & 86.849 & 41.737 & 693.015 \\
\hline dic-13 & 322.634 & 14.205 & 64.828 & 225.143 & 20.880 & 243.583 & 272.681 & 76.564 & 52.571 & 51.330 & 128.882 & 65.261 & 1.538 .562 \\
\hline ene-14 & 320.896 & 11.133 & 59.681 & 153.040 & 16.068 & 186.405 & 207.919 & 67.774 & 39.501 & 43.452 & 140.938 & 48.884 & 1.295 .691 \\
\hline feb-14 & 307.368 & 9.351 & 53.522 & 201.660 & 14.051 & 165.006 & 185.496 & 75.981 & 36.368 & 53.877 & 160.288 & 45.304 & 1.308 .272 \\
\hline mar-14 & 165.884 & 6.636 & 20.039 & 116.269 & 10.258 & 121.453 & 137.241 & 50.114 & 27.453 & 36.141 & 92.685 & 34.339 & 818.512 \\
\hline abr-14 & 156.449 & 3.899 & 25.860 & 53.303 & 5.701 & 66.396 & 74.250 & 20.141 & 14.255 & 23.334 & 53.233 & 17.680 & 514.501 \\
\hline may-14 & 28.883 & 3.318 & 9.813 & 32.040 & 4.886 & 57.028 & 63.862 & 18.148 & 12.328 & 5.546 & 2.142 & 15.308 & 253.302 \\
\hline oct-15 & 85.453 & 3.119 & 11.827 & 47.321 & 4.832 & 32.180 & 22.220 & 14.797 & 10.847 & 4.183 & 8.810 & 16.146 & 261. \\
\hline nov-15 & 193.119 & 7.457 & 33.257 & 126.145 & 11.126 & 128.080 & 128.080 & 33.062 & 35.070 & 26.851 & 71.160 & 35.428 & 828.834 \\
\hline dic-15 & 264.007 & 11.032 & 50.916 & 178.044 & 16.312 & 147.210 & 124.770 & 45.474 & 21.527 & 32.026 & 68.390 & 51.317 & 1.011 .025 \\
\hline ene-16 & 242.437 & 9.934 & 45.495 & 162.252 & 14.720 & 172.470 & 163.370 & 54.923 & 27.599 & 33.481 & 77.420 & 46.439 & 1.050 \\
\hline feb-16 & 252.386 & 9.717 & 44.423 & 169.536 & 14.405 & 348.935 & 297.336 & 63.891 & 55.163 & 54.047 & 187.398 & 45.474 & 1.542 .710 \\
\hline mar-16 & 244.598 & 10.106 & 46.343 & 163.834 & 14.969 & 226.654 & 200.359 & 56.470 & 36.551 & 39.987 & 86.570 & 47.202 & 1.173 .640 \\
\hline abr-16 & 174.088 & 6.392 & 27.998 & 112.212 & 9.581 & 150.969 & 139.890 & 41.822 & 29.596 & 29.457 & 60.654 & 30.696 & 813.354 \\
\hline may-16 & 78.409 & 3.208 & 12.268 & 42.164 & 4.962 & 28.051 & 25.190 & 16.960 & 7.715 & 6.620 & 11.790 & 16.543 & 253.880 \\
\hline oct-16 & 69.681 & 3.130 & 11.883 & 35.774 & 4.849 & 21.196 & 33.434 & 5.703 & 10.167 & 6.261 & 23.413 & 16.197 & 241.689 \\
\hline nov-16 & 226.509 & 8.911 & 40.443 & 150.591 & 13.236 & 190.925 & 175.576 & 43.290 & 43.277 & 30.783 & 101.456 & 41.893 & 1.066 .892 \\
\hline dic-16 & 292.775 & 12.480 & 58.069 & 199.106 & 18.413 & 207.496 & 145.836 & 51.688 & 37.629 & 42.246 & 64.092 & 57.753 & 1.187 .583 \\
\hline ene-17 & 331.056 & 14.418 & 67.643 & 227.132 & 21.224 & 273.478 & 258.264 & 62.541 & 55.750 & 51.733 & 143.509 & 66.368 & 1.573 .117 \\
\hline feb-17 & 225.127 & 8.174 & 36.799 & 149.579 & 12.166 & 191.313 & 182.550 & 53.578 & 42.290 & 35.287 & 88.654 & 38.614 & 1.064 .132 \\
\hline mar-17 & 171.497 & 7.254 & 32.257 & 110.315 & 10.832 & 147.550 & 150.896 & 41.441 & 35.130 & 30.375 & 69.390 & 34.528 & 841.466 \\
\hline abr-17 & 91.216 & 4.392 & 18.118 & 51.539 & 6.680 & 64.206 & 55.650 & 23.200 & 8.288 & 12.121 & 32.388 & 21.806 & 389.604 \\
\hline may-17 & & 1.475 & 3.706 & & 2.447 & 22.062 & 14.320 & & 1.706 & 4.111 & 9.030 & 8.839 & 67.695 \\
\hline oct-17 & 0.336 & 2.934 & 10.917 & 14.290 & 4.565 & 10.750 & 9.884 & 3.312 & 4.566 & 3.499 & 5.700 & 15.327 & 126.080 \\
\hline nov-17 & 245.851 & 9.921 & 45.431 & 164.751 & 14.701 & 148.032 & 124.350 & 45.665 & 37.102 & 27.035 & 71.556 & 46.382 & 980.778 \\
\hline dic-17 & 295.890 & 12.636 & 58.840 & 201.386 & 18.639 & 222.510 & 173.018 & 63.880 & 53.819 & 41.851 & 124.822 & 58.447 & 1.325 .738 \\
\hline ene-18 & 285.654 & 12.117 & 56.277 & 193.892 & 17.886 & 275.251 & 188.888 & 61.226 & 45.982 & 43.756 & 123.410 & 56.141 & 1.360 .481 \\
\hline feb-18 & 306.920 & 11.857 & 54.992 & 209.462 & 17.509 & 293.190 & 245.226 & 67.366 & 43.599 & 44.761 & 137.100 & 54.984 & 1.486 .966 \\
\hline mar-18 & 228.872 & 9.275 & 42.239 & 152.321 & 13.764 & 219.610 & 217.314 & 68.583 & 51.291 & 38.923 & 110.644 & 43.509 & 1.196 .345 \\
\hline abr-18 & 125.321 & 4.921 & 20.733 & 76.509 & 7.448 & 102.000 & 99.014 & 32.522 & 24.007 & 23.478 & 55.580 & 24.159 & 595.692 \\
\hline may-18 & 6.631 & 2.392 & 2.392 & 26.220 & 3.779 & 29.180 & 23.570 & 11.231 & 7.171 & 6.241 & 15.860 & 12.918 & 197.584 \\
\hline TOTAL & 7.445 .717 & 314.813 & 1.406 .150 & 5.024 .572 & 469.034 & 5.877 .469 & 5.694 .440 & 1.720 .268 & 1.211 .273 & 1.164 .732 & 3.104 .563 & 1.490 .642 & 34.923 .673 \\
\hline
\end{tabular}


La Tabla 80 y Figura 103, muestran el resumen del ahorro energético que se ha obtenido en cada uno de los edificios del Campus Miguel Delibes y en el conjunto del Campus, durante las tres temporadas de calefacción siguientes a la puesta en marcha de la red de calor, siendo este del 5,5\% lo que equivale a un ahorro de $1.142 .561 \mathrm{kWh}$.

Tabla 80. Resumen de ahorro de energía térmica del Campus Miguel Delibes (kWh)

\begin{tabular}{|c|c|c|c|c|c|c|c|c|c|c|c|c|c|}
\hline kWh térmicos & D1 & D2 & D3 & D4 & D5 & D6 & D7 & D8 & D9 & D10 & D11 & D12 & TOTAL \\
\hline TOTAL Pronost oct-15-may-18 & 4.527 .834 & 187.251 & 833.265 & 2.964 .374 & 279.046 & 3.653 .299 & 3.199 .008 & 962.623 & 725.842 & 669.112 & 1.748 .798 & 887.108 & 20.637 .560 \\
\hline TOTAL Real oct-15-may-18 & 3.694 .872 & 132.346 & 729.668 & 2.579 .096 & 330.660 & 3.653 .299 & 3.199 .008 & 1.283 .856 & 725.842 & 669.112 & 1.748 .798 & 748.442 & 19.494 .998 \\
\hline Ahorro (kWh) & 832.961 & 54.905 & 103.598 & 385.278 & -51.614 & 0 & 0 & -321.233 & 0 & 0 & 0 & 138.666 & 1.142 .561 \\
\hline Ahorro (\%) & $18,4 \%$ & $29,3 \%$ & $12,4 \%$ & $13,0 \%$ & $-18,5 \%$ & $0,0 \%$ & $0,0 \%$ & $-33,4 \%$ & $0,0 \%$ & $0,0 \%$ & $0,0 \%$ & $15,6 \%$ & $5,5 \%$ \\
\hline Diferencias en las medias & $22,5 \%$ & $41,5 \%$ & $14,2 \%$ & $14,9 \%$ & $-15,6 \%$ & $0,0 \%$ & $0,0 \%$ & $-25,0 \%$ & $0,0 \%$ & $0,0 \%$ & $0,0 \%$ & $18,5 \%$ & $5,9 \%$ \\
\hline
\end{tabular}

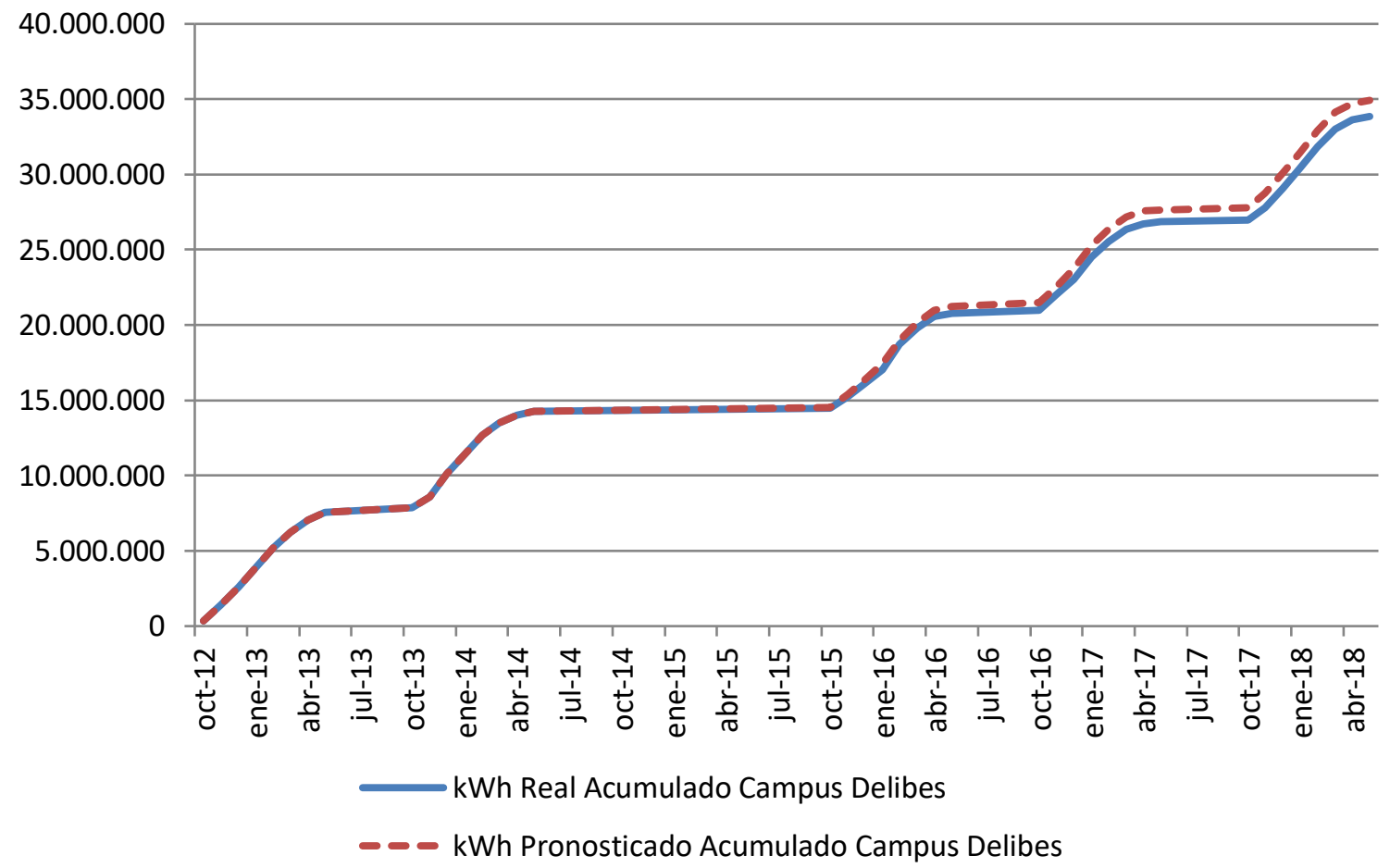

Figura 103. Consumo real acumulado y pronosticado (kWh). Campus Miguel Delibes 
Capítulo 4. Resultados y Discusión. Campus Miguel Delibes

La Tabla 81 y Figura 104, muestran el resumen del ahorro de emisiones de $\mathrm{CO}_{2}$, que se ha obtenido en cada uno de los edificios del Campus Miguel Delibes y en el conjunto del Campus, durante las tres temporadas de calefacción siguientes a la puesta en marcha de la red de calor, siendo este del $87,4 \%$ lo que equivale a un ahorro de 4.543 toneladas de $\mathrm{CO}_{2}$.

Tabla 81. Ahorro de emisiones CO2 del Campus Miguel Delibes (kg CO2)

\begin{tabular}{|c|c|c|c|c|c|c|c|c|c|c|c|c|c|}
\hline $\begin{array}{l}\text { Ahorro } \mathrm{CO}_{2} \\
\left(\mathrm{~kg} \mathrm{CO}_{2}\right)\end{array}$ & D1 & $\mathrm{D} 2$ & D3 & D4 & D5 & D6 & D7 & D8 & D9 & D10 & D11 & D12 & TOTAL \\
\hline oct-15 & 20.703 & 766 & 2.980 & 11.186 & 1.100 & 7.337 & 5.066 & 3.528 & 2.473 & 954 & 2.009 & 3.911 & 62.013 \\
\hline nov-15 & 44.772 & 1.816 & 7.692 & 28.963 & 2.402 & 29.202 & 29.202 & 7.169 & 7.996 & 6.122 & 16.224 & 8.051 & 189.612 \\
\hline dic-15 & 61.905 & 2.493 & 11.626 & 42.671 & 3.721 & 33.564 & 28.448 & 10.203 & 4.908 & 7.302 & 15.593 & 12.096 & 234.530 \\
\hline ene-16 & 56.709 & 2.343 & 10.547 & 38.093 & 3.452 & 39.323 & 37.248 & 12.483 & 6.293 & 7.634 & 17.652 & 10.762 & 242.539 \\
\hline feb-16 & 36.833 & 475 & 3.968 & 27.359 & -961 & 56.382 & 54.079 & 9.197 & 10.073 & 9.161 & 25.347 & 7.280 & 239.192 \\
\hline mar-16 & 54.145 & 2.415 & 10.524 & 34.883 & 2.499 & 48.199 & 39.583 & 11.849 & 8.023 & 8.998 & 18.361 & 10.184 & 249.663 \\
\hline abr-16 & 40.416 & 1.420 & 5.999 & 25.922 & 1.775 & 33.929 & 31.266 & 9.457 & 6.465 & 6.690 & 13.764 & 7.077 & 184.180 \\
\hline may-16 & 18.508 & 799 & 2.917 & 9.884 & 716 & 6.386 & 5.705 & 4.069 & 1.741 & 1.509 & 2.688 & 4.017 & 58.938 \\
\hline oct-16 & 10.763 & 748 & 2.214 & 5.688 & -395 & 4.455 & 7.107 & -533 & 1.559 & 1.231 & 2.485 & 3.489 & 38.811 \\
\hline nov-16 & 50.455 & 1.971 & 6.656 & 34.342 & 3.084 & 41.309 & 39.918 & 6.929 & 9.814 & 6.953 & 22.280 & 9.697 & 233.408 \\
\hline dic-16 & 67.625 & 2.794 & 11.061 & 46.072 & 4.206 & 47.187 & 33.128 & 10.635 & 8.543 & 9.628 & 14.104 & 13.580 & 268.565 \\
\hline ene-17 & 76.724 & 3.450 & 15.907 & 51.657 & 4.848 & 62.032 & 57.976 & 13.323 & 12.711 & 11.793 & 30.392 & 15.554 & 356.369 \\
\hline feb-17 & 52.357 & 1.759 & 7.711 & 34.353 & 2.495 & 42.308 & 41.448 & 11.822 & 9.642 & 8.044 & 20.199 & 8.915 & 241.052 \\
\hline mar-17 & 39.489 & 1.543 & 7.112 & 25.302 & 2.429 & 33.641 & 34.282 & 8.903 & 7.962 & 6.847 & 15.821 & 7.844 & 191.176 \\
\hline abr-17 & 21.546 & 1.021 & 3.888 & 11.401 & 1.472 & 14.617 & 12.688 & 5.137 & 1.890 & 2.764 & 7.255 & 5.190 & 88.869 \\
\hline may-17 & & -18 & 448 & -558 & 342 & 4.840 & 3.265 & & 389 & 930 & 2.059 & 2.088 & 13.784 \\
\hline oct-17 & 5.651 & 737 & 2.638 & 3.355 & -133 & 2.451 & 2.166 & 695 & 549 & 798 & 1.300 & 3.778 & 23.985 \\
\hline nov-17 & 57.972 & 2.390 & 10.540 & 38.076 & 3.408 & 32.996 & 28.124 & 9.928 & 8.426 & 6.164 & 16.220 & 10.857 & 225.101 \\
\hline dic-17 & 68.109 & 2.934 & 13.665 & 46.685 & 4.329 & 50.732 & 38.972 & 13.346 & 12.242 & 9.537 & 27.996 & 13.608 & 302.154 \\
\hline ene-18 & 65.918 & 2.820 & 13.010 & 44.329 & 4.148 & 62.739 & 42.910 & 13.201 & 10.484 & 9.954 & 28.010 & 12.909 & 310.432 \\
\hline feb-18 & 71.242 & 2.730 & 12.688 & 47.905 & 3.930 & 66.847 & 55.142 & 14.481 & 9.941 & 10.196 & 31.259 & 12.433 & 338.795 \\
\hline mar-18 & 52.683 & 2.147 & 9.962 & 34.315 & 3.074 & 50.071 & 48.566 & 15.074 & 11.552 & 8.812 & 24.647 & 9.509 & 270.412 \\
\hline abr-18 & 28.391 & 1.116 & 4.750 & 17.588 & 1.564 & 23.256 & 22.488 & 7.282 & 5.461 & 5.322 & 12.572 & 5.360 & 135.149 \\
\hline may-18 & 12.985 & 603 & 283 & 5.784 & 634 & 6.653 & 5.374 & 2.449 & 1.635 & 1.423 & 3.616 & 3.122 & 44.559 \\
\hline Ahorro kg CO2 & 1.015 .900 & 41.273 & 178.787 & 665.253 & 54.139 & 800.458 & 704.151 & 200.629 & 160.770 & 148.767 & 371.852 & 201.311 & 4.543 .289 \\
\hline kg CO2 antes & 1.141 .014 & 47.187 & 209.983 & 747.022 & 70.320 & 920.631 & 806.150 & 242.581 & 182.912 & 168.616 & 440.697 & 223.551 & 5.200 .665 \\
\hline \% Ahorro & $89,0 \%$ & $87,5 \%$ & $85,1 \%$ & $89,1 \%$ & $77,0 \%$ & $86,9 \%$ & $87,3 \%$ & $82,7 \%$ & $87,9 \%$ & $88,2 \%$ & $84,4 \%$ & $90,1 \%$ & $87,4 \%$ \\
\hline
\end{tabular}

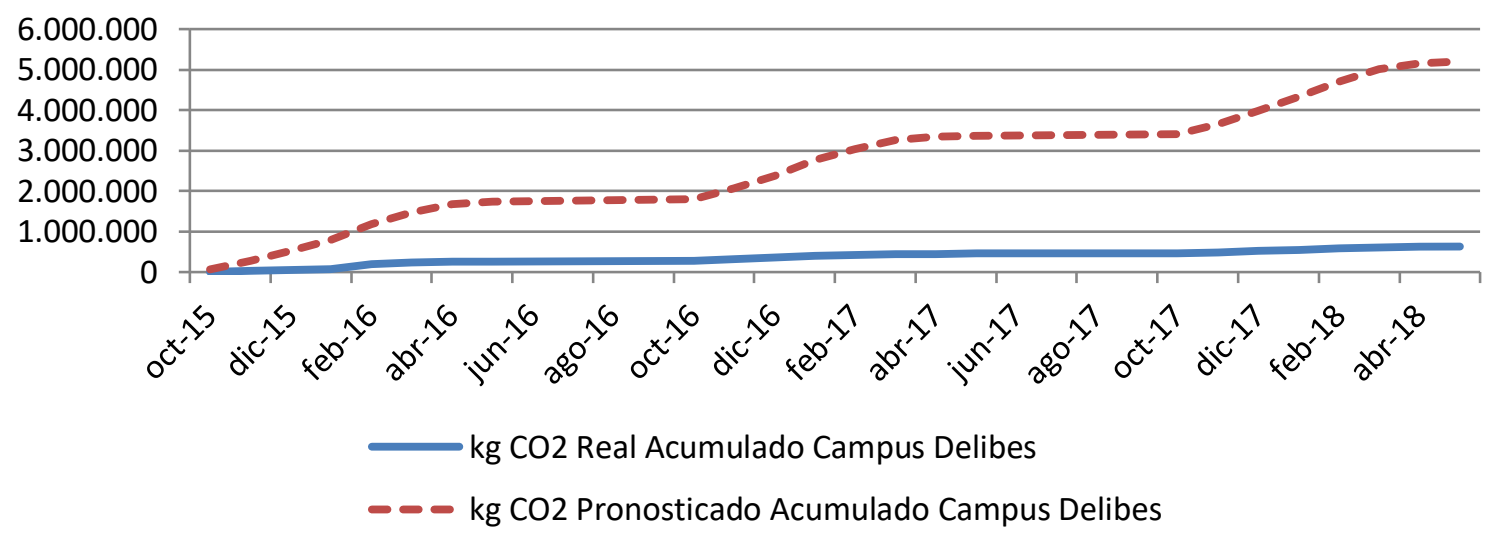

Figura 104. Emisiones reales acumuladas y pronosticadas (kg CO2). Campus Miguel Delibes 
En la Tabla 82 se muestran los precios que hubieran tenido que tener los kWh comprados a la red de calor, para obtener un ahorro económico del $0 \%$ y del $15 \%$, durante las tres temporadas siguientes a la ejecución de la red, con respecto a lo que hubiera pagado la Universidad por la compra de la energía al suministrador de gas natural de no haberse conectado a la red de calor.

Tabla 82. Precios máximos de compra de la energía a la red de calor

\begin{tabular}{ccc}
\hline & $\begin{array}{c}€ / \text { kWh max comprado para 0\% } \\
\text { ahorro económico }\end{array}$ & $\begin{array}{c}€ / \text { kWh max comprado para 15\% } \\
\text { ahorro económico }\end{array}$ \\
\hline D1 & 0,04000 & 0,03380 \\
\hline D2 & 0,04715 & 0,03961 \\
\hline D3 & 0,03740 & 0,03140 \\
\hline D4 & 0,03701 & 0,03130 \\
\hline D5 & 0,02681 & 0,02224 \\
\hline D6 & 0,03220 & 0,02719 \\
\hline D7 & 0,03220 & 0,02719 \\
\hline D8 & 0,02391 & 0,02015 \\
\hline D9 & 0,03225 & 0,02728 \\
\hline D10 & 0,03223 & 0,02728 \\
\hline D11 & 0,03228 & 0,02710 \\
\hline D12 & 0,03846 & 0,03256 \\
\hline DELIBES (min) & 0,02391 & 0,02015 \\
\hline
\end{tabular}

Se han estimado que los precios que se hubieran pagado por los combustibles fósiles son los que figuran en la Tabla 83

Tabla 83. Precios estimados para los combustibles

\begin{tabular}{cccccc}
\hline Precios $(€ /(\mathrm{kWh})$ & 2015 & 2016 & 2017 & 2018 & Promedio \\
\hline Gasóleo C & 0,0517 & 0,0437 & 0,0499 & 0,056 & 0,050325 \\
\hline Gas Natural & 0,0373 & 0,0306 & 0,0314 & 0,0336 & 0,033225 \\
\hline Astilla & 0,0277 & 0,0256 & 0,0254 & 0,0239 & 0,02565 \\
\hline
\end{tabular}




\section{CAPÍTULO 5. RESULTADOS Y DISCUSIÓN. CAMPUS RÍO ESGUEVA.}

\subsection{Introducción}

En este capítulo se irán analizando cada uno de los once edificios de la Universidad de Valladolid, pertenecientes al Campus Río Esgueva, que están conectados a la red de calor.

Para cada uno de ellos se irá aplicando la metodología descrita en el capítulo 3, al igual que se hizo en el capítulo anterior:

- Se irá obteniendo el modelo o modelos que pueda predecir su consumo térmico en función de la o las variables climáticas que más influencia tengan sobre el consumo.

- Se comprobará el cumplimiento de todos los supuestos de la regresión lineal simple o múltiple, en función de los modelos obtenidos.

- Se verificará la existencia de diferencias significativas entre las medias de los consumos reales obtenidos para cada una de las tres temporadas posteriores a la puesta en marcha de la red y para las tres temporadas en su conjunto.

- Se estimaran las emisiones de $\mathrm{CO}_{2}$ ahorradas en cada edificio, en las tres temporadas de funcionamiento de la red, por utilizar energía procedente de la red de calor.

- Se calculará el precio máximo de la energía térmica comprada a la red para que el ahorro económico que se experimente en las tres temporadas de funcionamiento de la red, llegue a ser del $15 \%$ con respecto al coste hubiera tenido la Universidad si el edificio no se hubiera conectado a la red de calor.

En este capítulo se mostrará únicamente el resumen de los resultados de cada edificio, recogiéndose el desarrollo de la metodología completa para cada edificio en el Anexo V. 


\subsection{Edificio E1. Edificio del Servicio de Mantenimiento}

Edificio de 1940, caracterizado por los horarios de funcionamiento como de tipo docente, que empezó a funcionar para la UVA en el año 1989, cuenta con una superficie construida de $1.681 \mathrm{~m}^{2}$. Inicialmente la calefacción era suministrada mediante una caldera de gasóleo de una potencia de $291 \mathrm{~kW}$. La subestación de intercambio con la red de calor construida en el año 2015, cuenta con una potencia de 291 kW. En la Figura 105 se marca la ubicación del edificio.

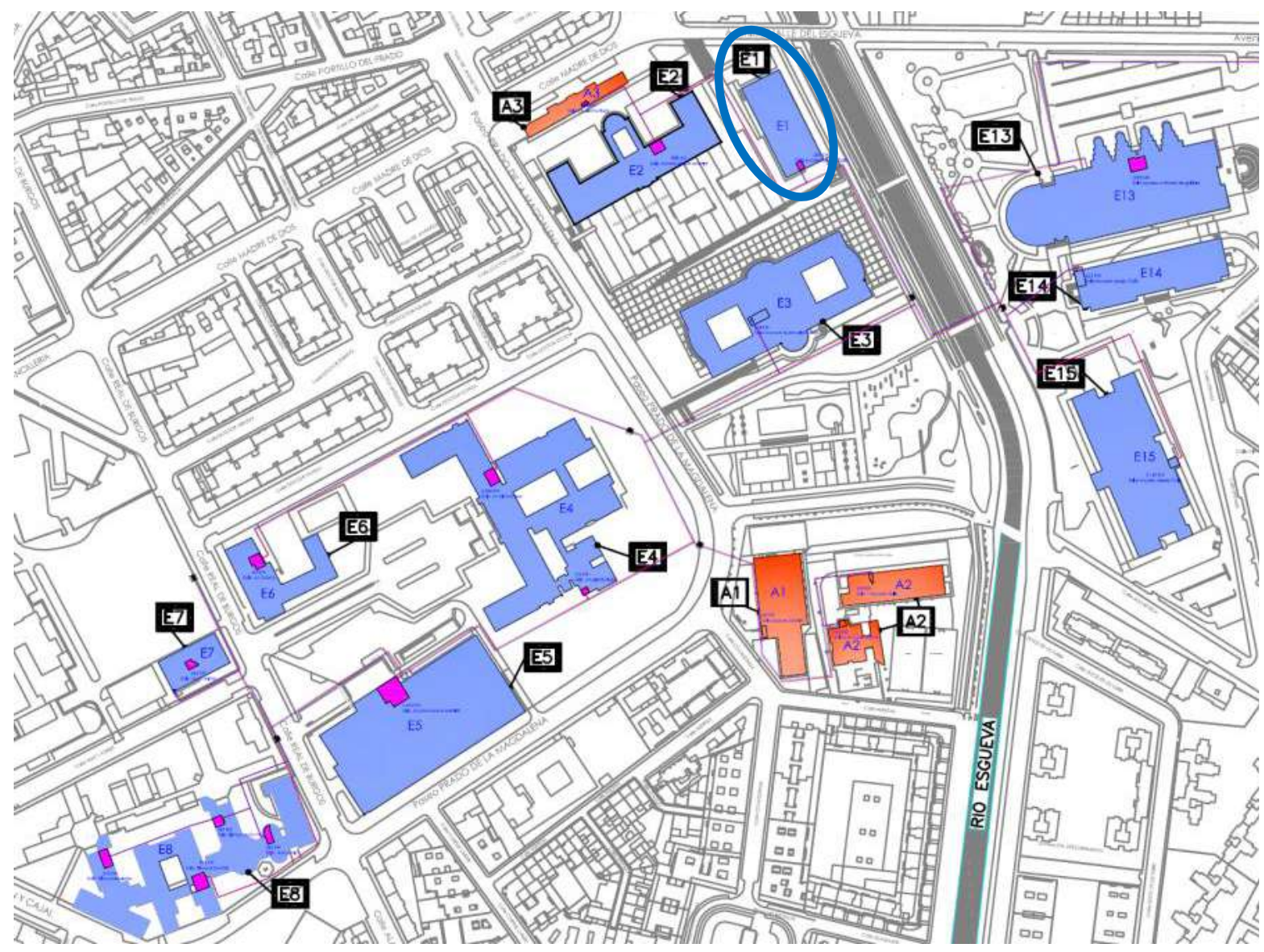

Figura 105. Ubicación del Edificio E1 en el croquis del campus Río Esgueva 
El modelo encontrado para predecir el consumo térmico del Edificio, fue

$$
\text { kWh_E1_Pronosticado }=-97,801+44,252 \times \text { GD20_24h }
$$

El resumen del modelo, con el coeficiente de correlación de Pearson $(R)$ y el coeficiente de determinación $\left(R^{2}\right)$ se muestra en la Tabla 84 y en la Tabla 85 , el resultado de la verificación de los supuestos de la regresión lineal.

Tabla 84. Resumen de los modelos encontrados para el Edificio E1

\begin{tabular}{cccccc}
\hline & $\begin{array}{c}\text { Variable } \\
\text { independiente 1 }\end{array}$ & Constante & B & $R$ & $R^{2}$ \\
\hline E1 & GD20_24h & $-97,801$ & 44,252 & 0,655 & 0,429 \\
\hline
\end{tabular}

Tabla 85. Resumen del cumplimiento de los supuestos de regresión. Edificio E1

\begin{tabular}{lc}
\hline \multicolumn{1}{c}{ Cumplimiento de supuestos de la regresión lineal } & Modelo \\
\hline 1. Linealidad de las variables & Cumple \\
\hline 2. Normalidad de variables & Cumple \\
\hline 3. Independencia de los errores o no autocorrelación de los residuos & Cumple $\left({ }^{*}\right)$ \\
\hline 4. Homocedasticidad de la varianza, los errores son aleatorios & Cumple \\
\hline
\end{tabular}

$(*)$ Existe cierta correlación en los residuos

En la Figura 106, se representan el consumo real y el pronosticado con el modelo de regresión obtenido, en kWh.

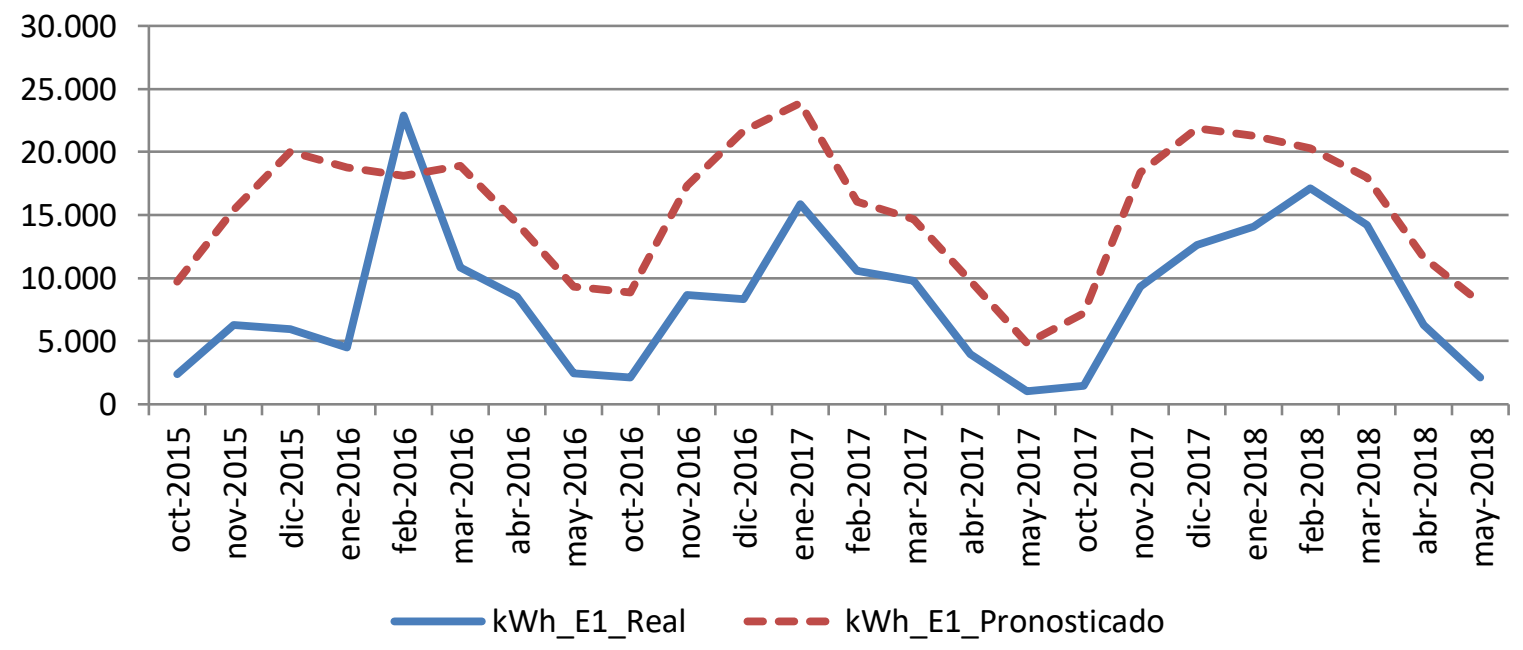

Figura 106. Representación de los consumos pronosticados para el Edificio E1. 2015-2018 
Los resultados de las diferencias entre las medias de los consumos, se exponen en la Tabla 86

Tabla 86. Resultado de las diferencias significativas encontradas. Edificio E1

\begin{tabular}{ccccccccc}
\hline & $\begin{array}{c}\% \\
\text { Diferencia } \\
2015-2016\end{array}$ & Significativo & $\begin{array}{c}\% \\
\text { Diferencia } \\
2016-2017\end{array}$ & Significativo & $\begin{array}{c}\% \\
\text { Diferencia } \\
2017-2018\end{array}$ & Significativo & $\begin{array}{c}\% \\
\text { Diferencia } \\
2015-2018\end{array}$ & Significativo \\
\hline E1 & kWh real & & & & & SI \\
no & $95,2 \%$ & $93,8 \%$ & SI & $64,0 \%$ & SI & $82,8 \%$ & SI \\
\hline
\end{tabular}

En la Figura 107, se grafican los consumos reales y pronosticados para la temporada Octubre 2015 - Mayo 2018 para el Edificio E1, y las medias de dichos consumos. Según la prueba paramétrica realizada las diferencias encontradas son estadísticamente significativas, con un riesgo a estar equivocados del $5 \%$

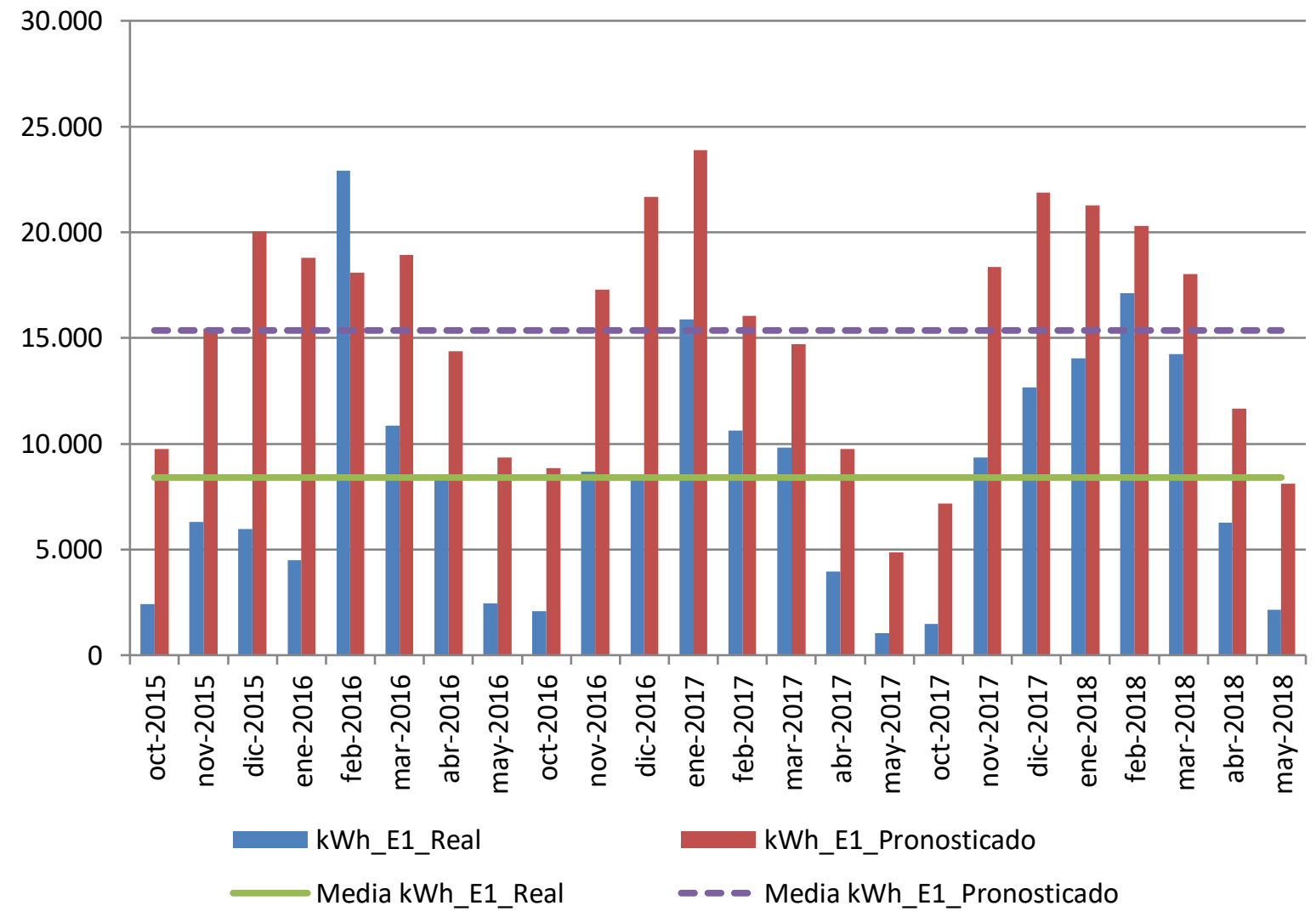

Figura 107. Consumos reales y pronosticados Octubre 2015-Mayo 2018. Edificio E1 
En la Figura 108, se observa el consumo real del Edificio E1, en comparación con el consumo pronosticado acumulado que hubiera tenido el Edificio de no haberse incorporado a la red de calor.

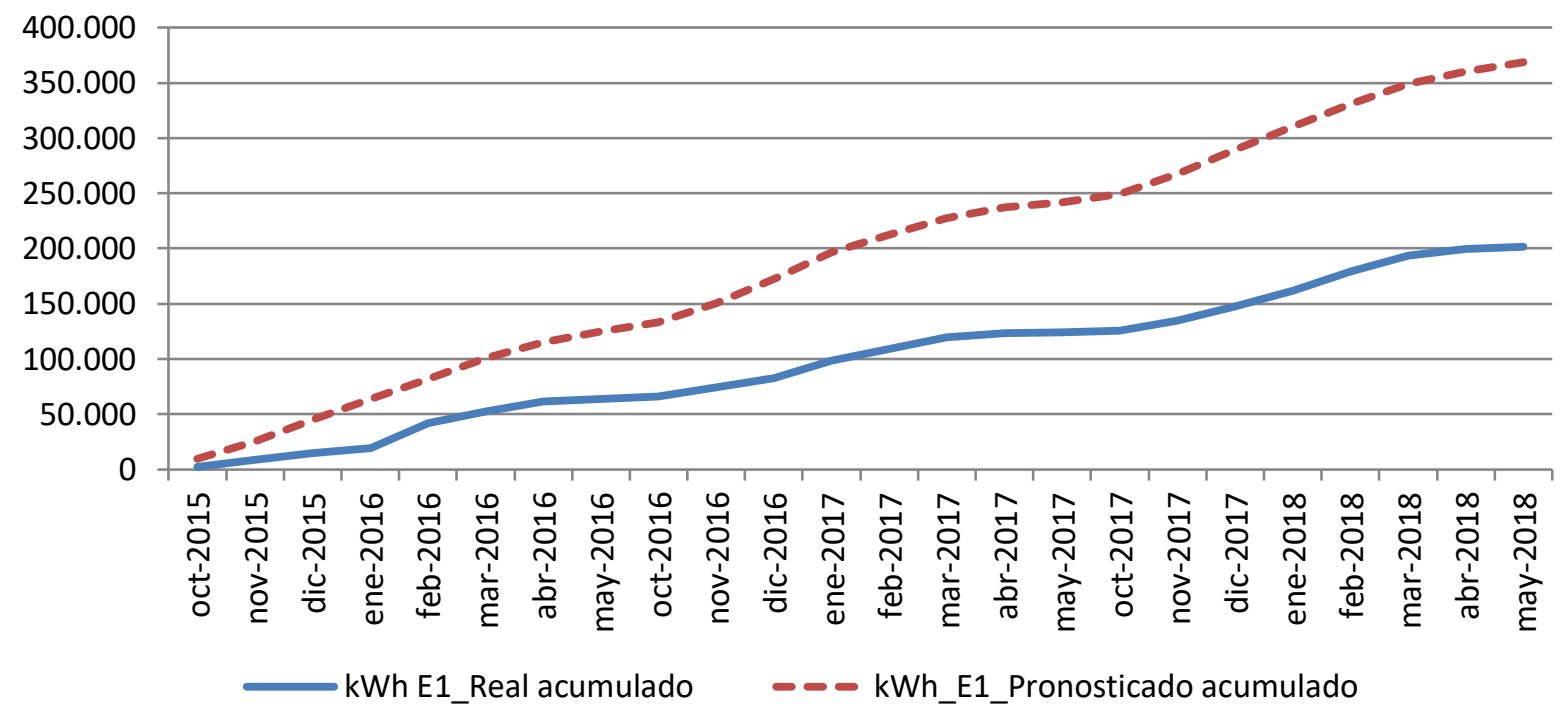

Figura 108. Consumo acumulado real y pronosticado. Octubre 2015-Mayo 2018. Edificio E1

Los resultados del ahorro de consumos, emisiones y precio máximo de la energía útil comprada a la red para un ahorro económico del 15\%, se exponen en la Tabla 87

Tabla 87. Resumen de resultados. Edificio E1

\begin{tabular}{lcc}
\hline $\begin{array}{l}\text { Diferencia significativa encontrada entre las medias de los } \\
\text { consumos 2015-2018 }\end{array}$ & $82,8 \%$ & $6.957 \mathrm{kWh}$ \\
\hline $\begin{array}{l}\text { Ahorro de consumo térmico durante las tres temporadas } \\
\text { posteriores a la construcción de la red respecto a lo que se hubiera } \\
\text { consumido de no ser por la red }\end{array}$ & $45,3 \%$ & $\begin{array}{c}166.959 \\
\mathrm{kWh}\end{array}$ \\
\hline $\begin{array}{l}\text { Ahorro de emisiones de } \mathrm{CO}_{2} \\
\text { Precio máximo de kWh útiles comprados a la red para obtener un } \\
\text { ahorro del 15\% }\end{array}$ & $0,0804 € / \mathrm{kWh}$ & $2.369 €$ \\
\hline
\end{tabular}




\subsection{Edificio E2. Facultad de Comercio}

Edificio de tipo docente que empezó a funcionar en el año 1994, cuenta con una superficie construida de $11.160 \mathrm{~m}^{2}$. Inicialmente la calefacción era suministrada mediante tres calderas de gasóleo de una potencia total de $989 \mathrm{~kW}$. La subestación de intercambio con la red de calor construida en el año 2015, cuenta con una potencia de 988 kW. En la Figura 109 se marca la ubicación del edificio.

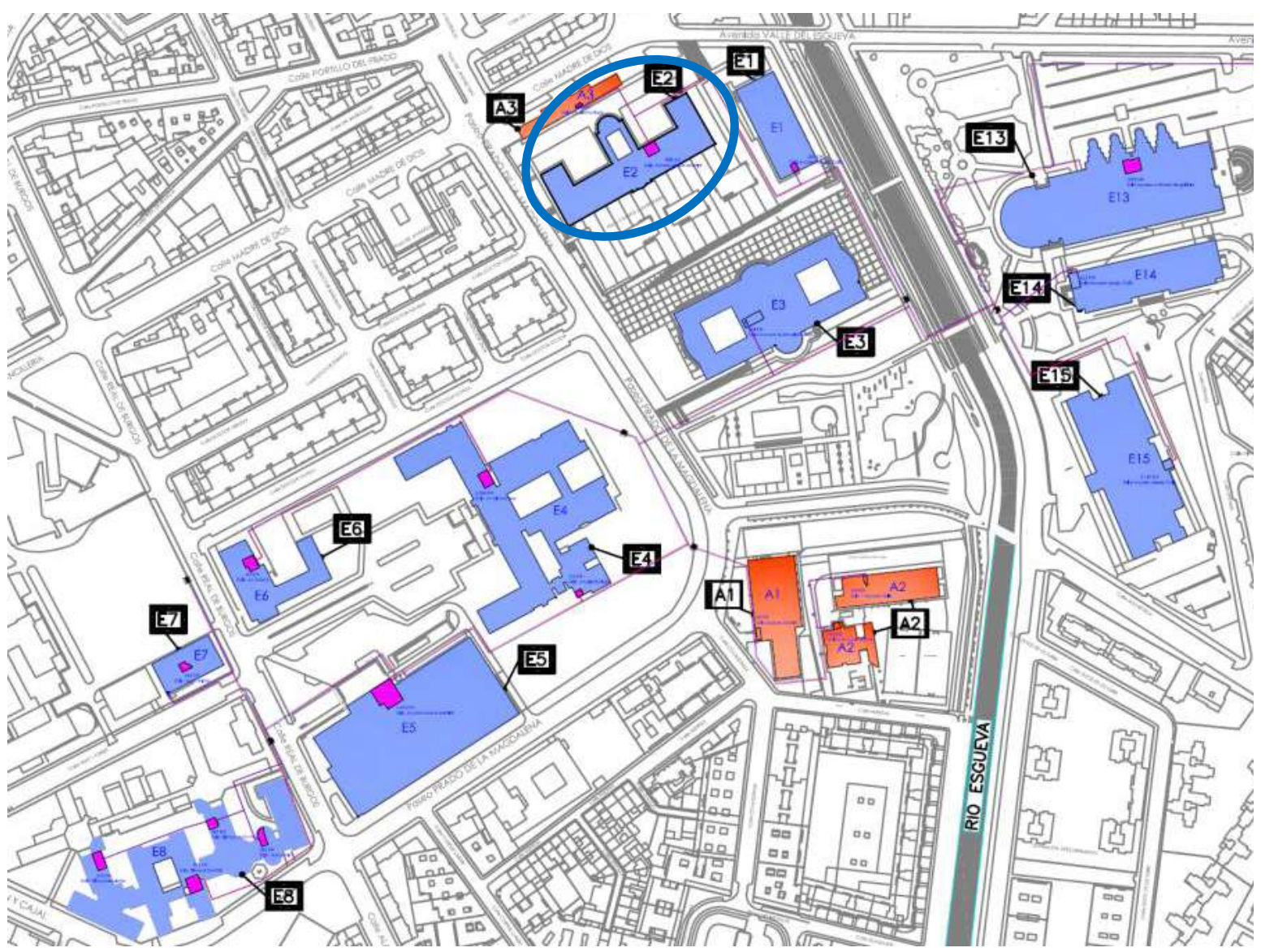

Figura 109. Ubicación del Edificio E2 en el croquis del campus Río Esgueva 
El modelo encontrado para predecir el consumo térmico del Edificio, fue

$$
\mathrm{kWh} \text { E2_Pronosticado }=83.663,793-7.896,58 \times \mathrm{T} \_\mathrm{min}
$$

El resumen del modelo, con el coeficiente de correlación de Pearson $(R$ ) y el coeficiente de determinación $\left(R^{2}\right)$ se muestra en la Tabla 88 y en la Tabla 89 , el resultado de la verificación de los supuestos de la regresión lineal.

Tabla 88. Resumen de los modelos encontrados para el Edificio E2

\begin{tabular}{cccccc}
\hline & $\begin{array}{c}\text { Variable } \\
\text { independiente 1 }\end{array}$ & Constante & B & $R$ & $R^{2}$ \\
\hline E2 & T_min & $83.663,793$ & $-7.896,580$ & $-0,819$ & 0,671 \\
\hline
\end{tabular}

Tabla 89. Resumen del cumplimiento de los supuestos de regresión. Edificio E1

\begin{tabular}{lc}
\hline \multicolumn{1}{c}{ Cumplimiento de supuestos de la regresión lineal } & Modelo \\
\hline 1. Linealidad de las variables & Cumple \\
\hline 2. Normalidad de variables & Cumple \\
\hline 3. Independencia de los errores o no autocorrelación de los residuos & Cumple $\left(^{*}\right)$ \\
\hline 4. Homocedasticidad de la varianza, los errores son aleatorios & Cumple \\
\hline
\end{tabular}

$\left({ }^{*}\right)$ Existe cierta correlación en los residuos

En la Figura 110, se representan el consumo real y el pronosticado con el modelo de regresión obtenido, en kWh.

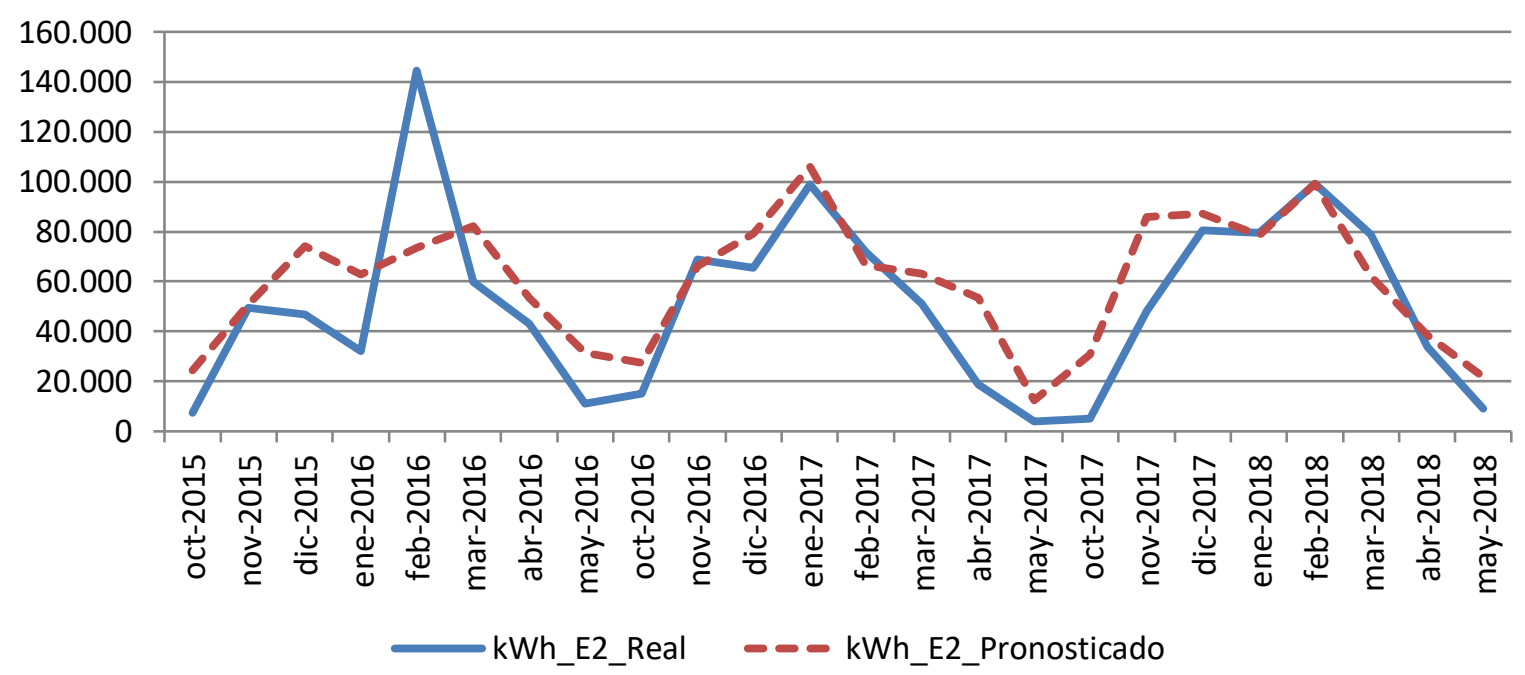

Figura 110. Representación de los consumos pronosticados para el Edificio E2. 2015-2018 
Los resultados de las diferencias entre las medias de los consumos, se exponen en la Tabla 90

Tabla 90. Resultado de las diferencias significativas encontradas. Edificio E2

\begin{tabular}{|c|c|c|c|c|c|c|c|c|}
\hline & $\begin{array}{c}\% \\
\text { Diferencia } \\
\text { 2015-2016 }\end{array}$ & Significativo & $\begin{array}{c}\% \\
\text { Diferencia } \\
\text { 2016-2017 }\end{array}$ & Significativo & $\begin{array}{c}\% \\
\text { Diferencia } \\
2017- \\
2018 \\
\end{array}$ & Significativo & $\begin{array}{c}\% \\
\text { Diferencia } \\
2015- \\
2018 \\
\end{array}$ & Significativo \\
\hline E2 & $14,7 \%$ & kWh real no normal & $20,5 \%$ & No & $16,0 \%$ & No & $17,0 \%$ & No \\
\hline
\end{tabular}

En la Figura 111, se grafican los consumos reales y pronosticados para la temporada Octubre 2015 - Mayo 2018 para el Edificio E2, y las medias de dichos consumos. Según la prueba paramétrica realizada las diferencias encontradas no son estadísticamente significativas, con un riesgo a estar equivocados del $5 \%$

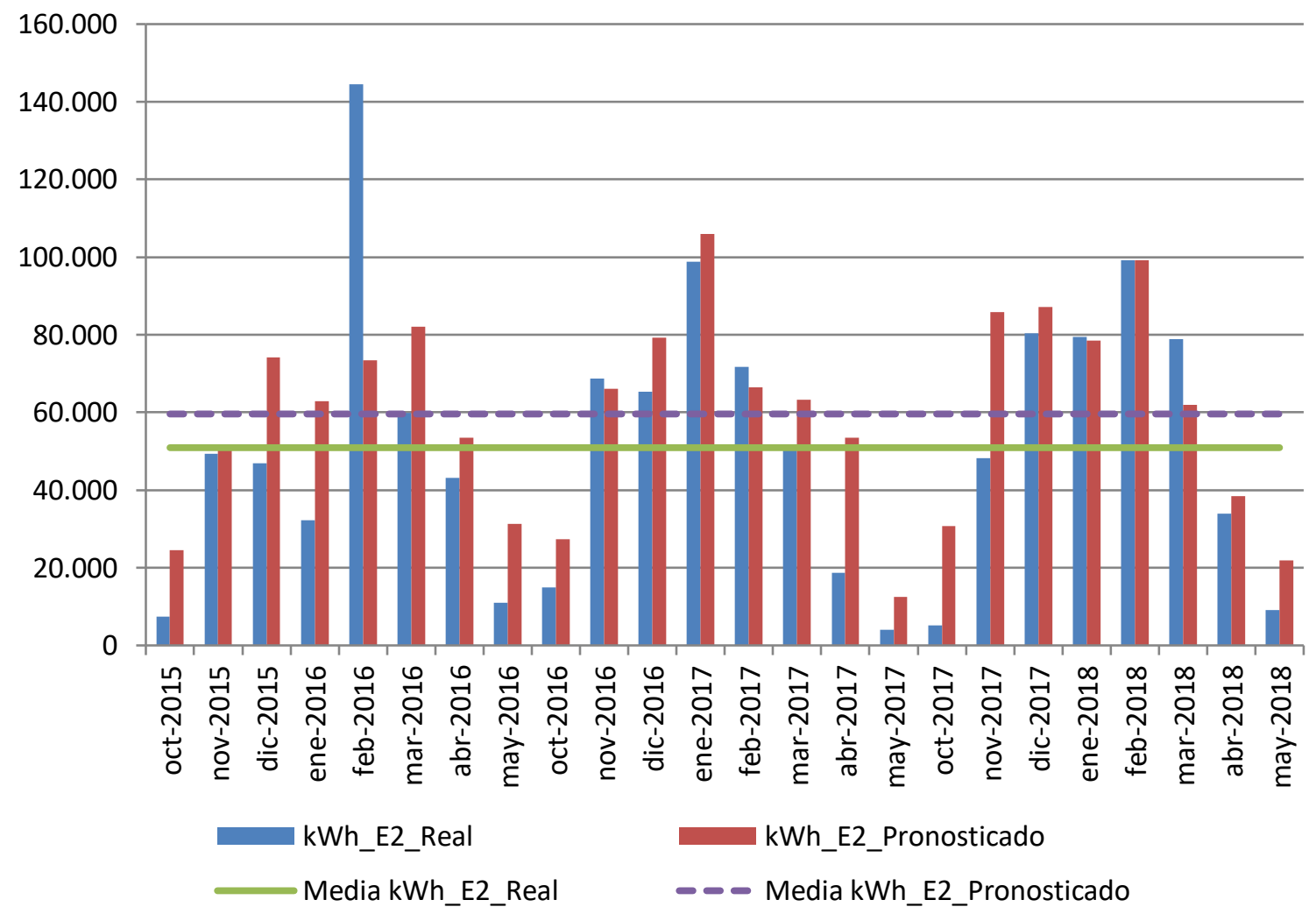

Figura 111. Consumos reales y pronosticados Octubre 2015-Mayo 2018. Edificio E2 
En la Figura 112, se observa el consumo real del Edificio E2, en comparación con el consumo pronosticado acumulado que hubiera tenido el Edificio de no haberse incorporado a la red de calor y de haberse encontrado diferencias significativas.

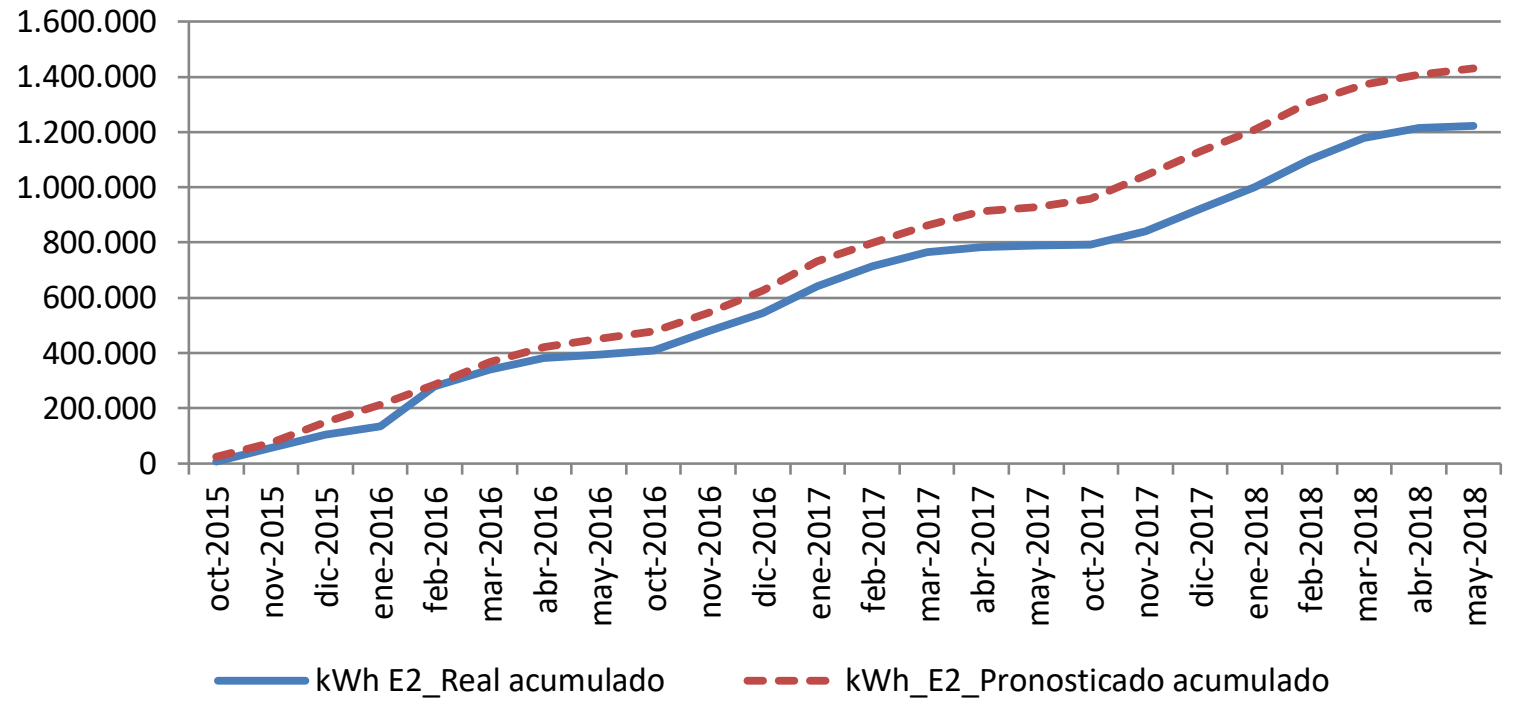

Figura 112. Consumo acumulado real y pronosticado. Octubre 2015-Mayo 2018. Edificio E2

Los resultados del ahorro de consumos, emisiones y precio máximo de la energía útil comprada a la red para un ahorro económico del 15\%, se exponen en la Tabla 91

Tabla 91. Resumen de resultados. Edificio E2

\begin{tabular}{lccc}
\hline $\begin{array}{l}\text { Diferencia significativa encontrada entre las medias de los } \\
\text { consumos 2015-2018 }\end{array}$ & $0 \%$ & $0 \mathrm{kWh}$ \\
\hline $\begin{array}{l}\text { Ahorro de consumo térmico durante las tres temporadas } \\
\text { posteriores a la construcción de la red respecto a lo que se hubiera } \\
\text { consumido de no ser por la red }\end{array}$ & $0 \%$ & $0 \mathrm{kWh}$ \\
\hline $\begin{array}{l}\text { Ahorro de emisiones de } \mathrm{CO}_{2} \\
\text { Precio máximo de } \mathrm{kWh} \text { útiles comprados a la red para obtener un } \\
\text { ahorro del } 15 \%\end{array}$ & $0,0428 € / \mathrm{kWh}$ & $7.853 €$ \\
\hline
\end{tabular}




\subsection{Edificio E3. Facultad de Filosofía y Letras}

Edificio de tipo docente que empezó a funcionar en el año 1997, cuenta con una superficie construida de $21.709 \mathrm{~m}^{2}$. Inicialmente la calefacción era suministrada mediante dos calderas de gas natural de una potencia total de $930 \mathrm{~kW}$. La subestación de intercambio con la red de calor construida en el año 2015, cuenta con una potencia de $929 \mathrm{~kW}$. En la Figura 113 se marca la ubicación del edificio.

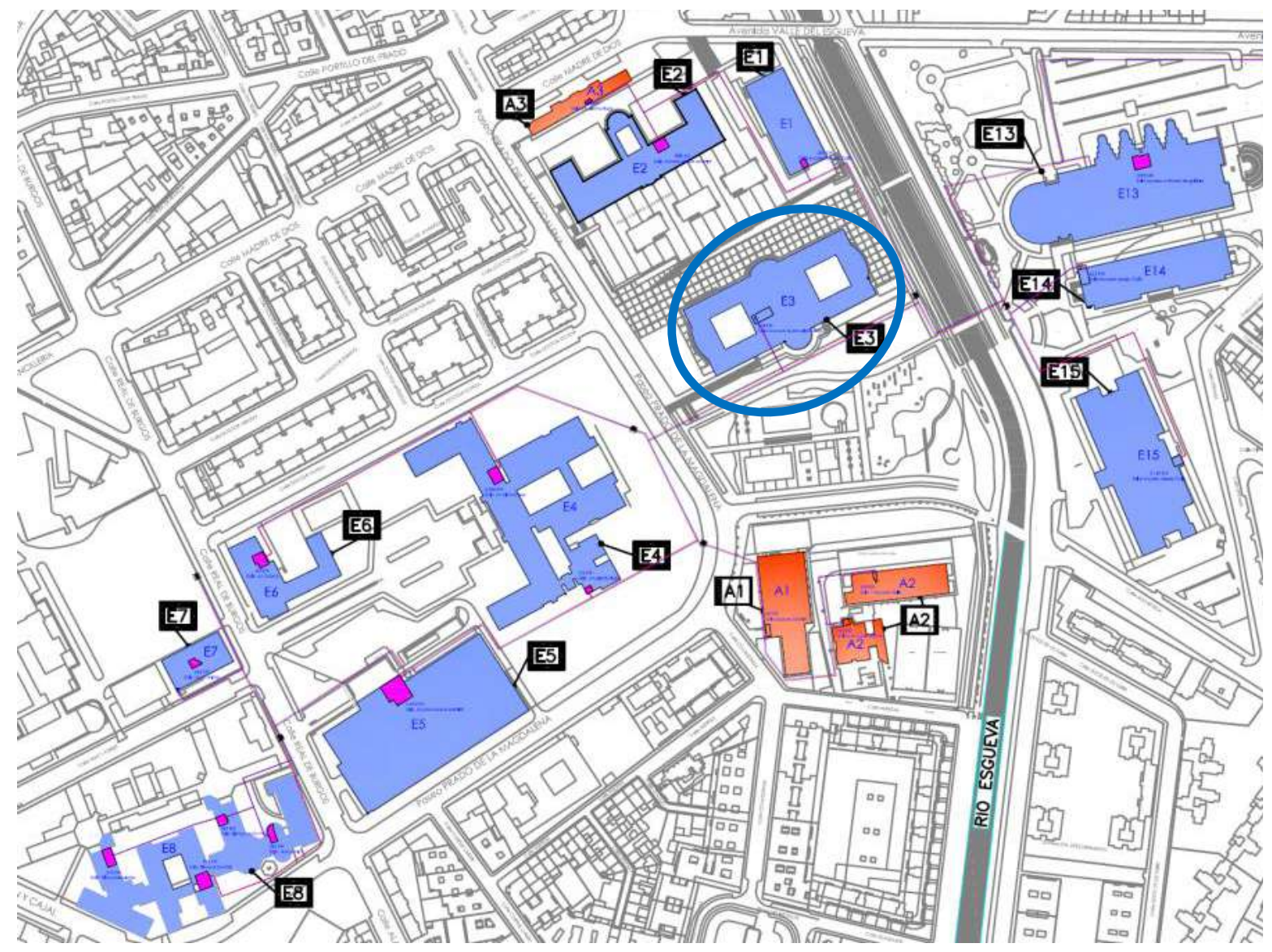

Figura 113. Ubicación del Edificio E3 en el croquis del campus Río Esgueva 
Los modelos encontrados para predecir el consumo térmico del Edificio, fue

Modelo 1: $\quad$ kWh_E3 $=219.817,236-26.412,48 \times$ T_min

Modelo 2: kWh_E3 = 130.691,591-24.484,085 x T_min + 30.147,142 x V_viento_diurna

El resumen de los modelos, con los coeficientes de correlación de Pearson (R) y el coeficiente de determinación $\left(R^{2}\right)$ se muestra en la Tabla 92 y en la Tabla 93, el resultado de la verificación de los supuestos de la regresión lineal.

Tabla 92. Resumen de los modelos encontrados para el Edificio E3

\begin{tabular}{ccccrr} 
& $\begin{array}{c}\text { Variables } \\
\text { independientes }\end{array}$ & Constante & B & $R^{2}$ \\
\hline E3_Modelo 1 & Tmin & $219.817,236$ & $-26.412,480$ & $-0,918$ & 0,843 \\
\hline E3_Modelo 2 & Tmin / V_diurna & $130.691,591$ & $-24.484,085 / 30147,142$ & $-0,950$ & 0,902 \\
\hline
\end{tabular}

Tabla 93. Resumen del cumplimiento de los supuestos de regresión. Edificio E3

\begin{tabular}{llc}
\hline \multicolumn{1}{c}{ Cumplimiento de supuestos de la regresión lineal } & Modelo 1 & Modelo 2 \\
\hline 1. Linealidad de las variables & Cumple & Cumple \\
\hline 2. Normalidad de variables & Cumple & Cumple \\
\hline 3. Independencia de los errores o no autocorrelación de los residuos & Cumple & Cumple \\
\hline 4. Homocedasticidad de la varianza, los errores son aleatorios & Cumple & Cumple \\
\hline 5. Falta de multicolinealidad entre las variables independientes. & & Cumple \\
\hline
\end{tabular}

En la Figura 114, se representan los consumos reales y los pronosticados con los modelos de regresión obtenidos, en kWh.

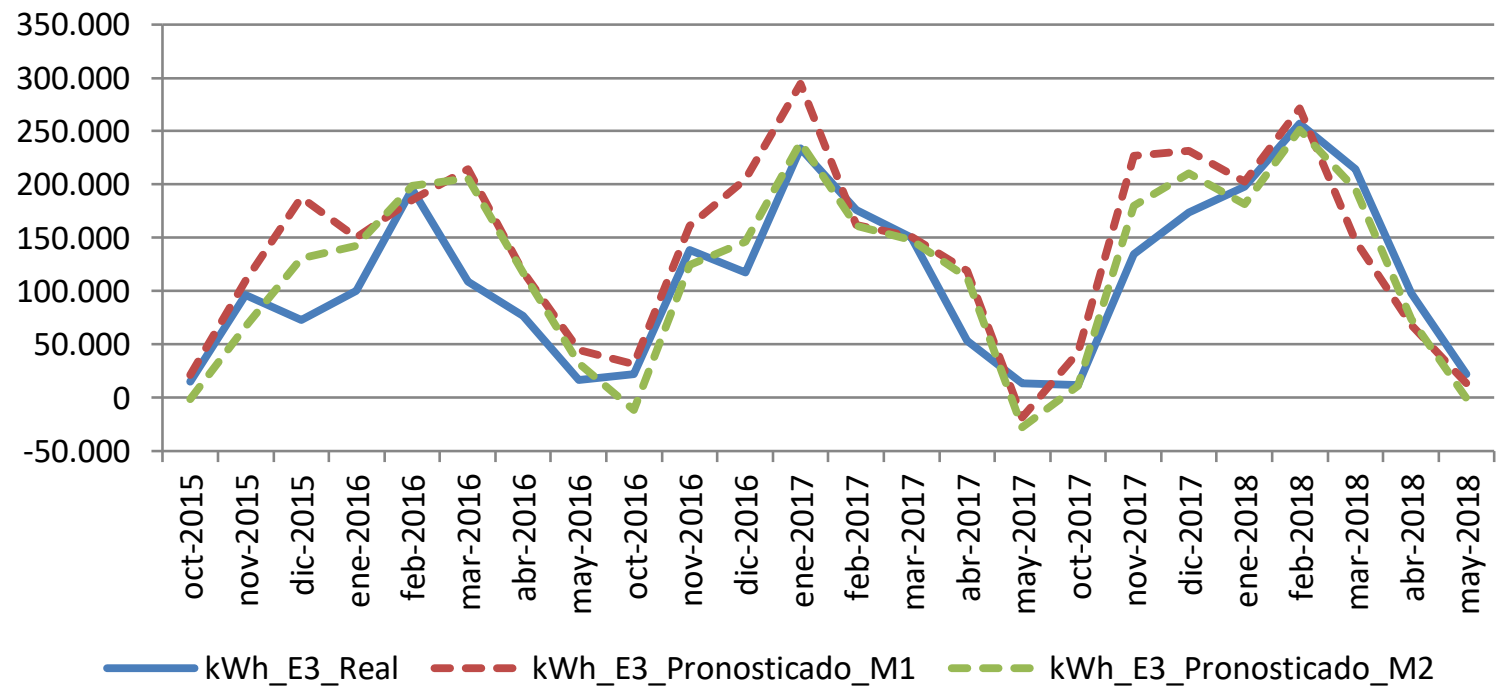

Figura 114. Representación de los consumos pronosticados para el Edificio E3. 2015-2018 
Los resultados de las diferencias entre las medias de los consumos, se exponen en la Tabla 94

Tabla 94. Resultado de las diferencias significativas encontradas. Edificio E3

\begin{tabular}{cccccccccc}
\hline & $\begin{array}{c}\text { \% Diferencia } \\
2015-2016\end{array}$ & Significativo & $\begin{array}{c}\% \\
\text { Diferencia } \\
2016-2017\end{array}$ & Significativo & $\begin{array}{c}\% \\
\text { Diferencia } \\
2017-2018\end{array}$ & Significativo & $\begin{array}{c}\% \\
\text { Diferencia } \\
2015-2018\end{array}$ & Significativo \\
\hline E3_Modelo 1 & $51,3 \%$ & SI & $25,8 \%$ & No & $8,5 \%$ & No & $29,9 \%$ & SI \\
\hline E3_Modelo 2 & $33,8 \%$ & No & $7,2 \%$ & No & $1,6 \%$ & No & $11,7 \%$ & No & \\
\hline
\end{tabular}

En la Figura 115 se grafican los consumos reales y pronosticados para el periodo Octubre 2015 - Mayo 2018 para el Edificio E3, y las medias de dichos consumos.

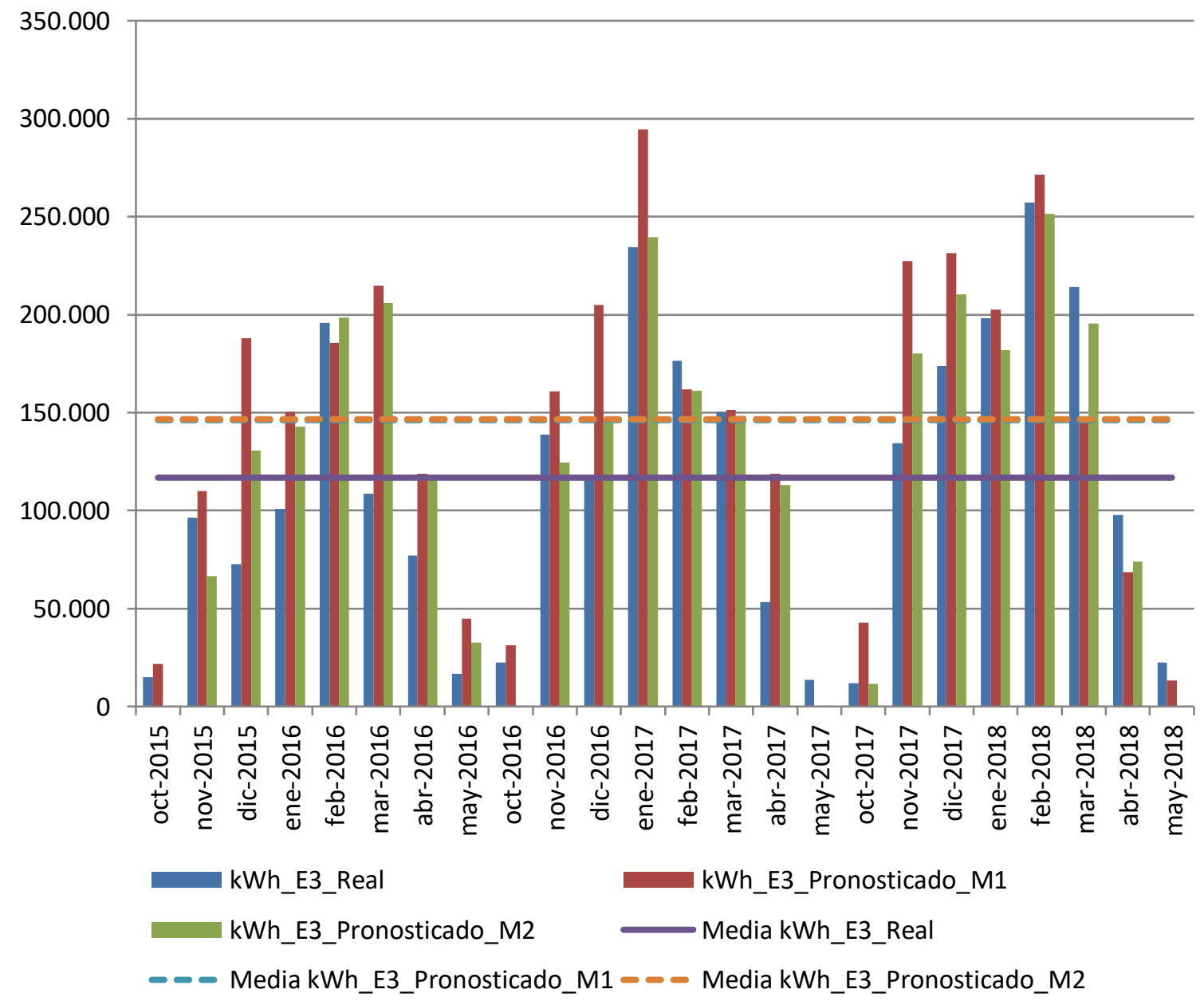

Figura 115. Consumos reales y pronosticados Octubre 2015-Mayo 2018. Edificio E3 
En la Figura 116, se observa el consumo real del Edificio E3, en comparación con el consumo pronosticado acumulado con el Modelo 1 que es con el que existen diferencias significativas, si el Edificio no se hubiera incorporado a la red de calor.

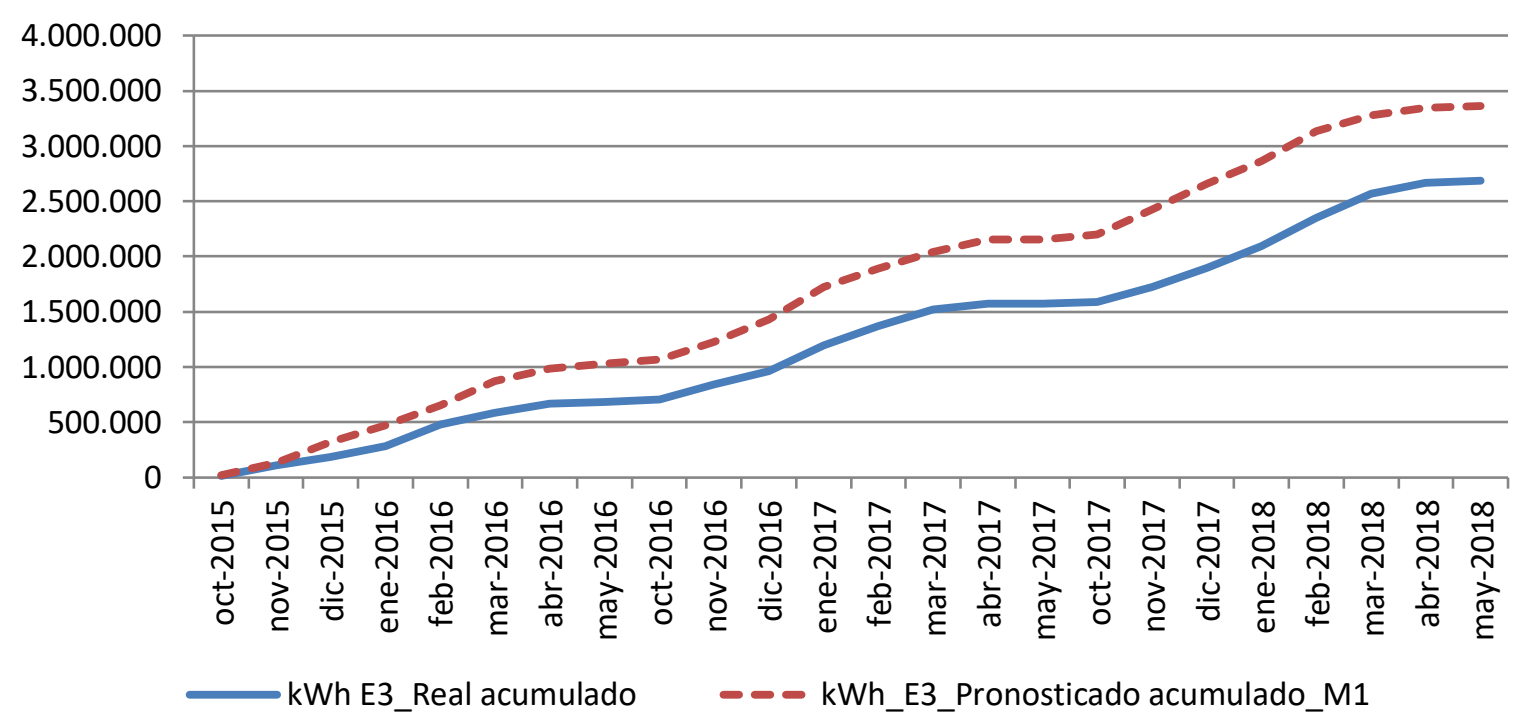

Figura 116. Consumo acumulado real y pronosticado. Octubre 2015-Mayo 2018. Edificio E3

Los resultados del ahorro de consumos, emisiones y precio máximo de la energía útil comprada a la red para un ahorro económico del 15\%, se exponen en la Tabla 95

Tabla 95. Resumen de resultados. Edificio E3

\begin{tabular}{|c|c|c|}
\hline $\begin{array}{l}\text { Diferencia significativa encontrada entre las medias de los } \\
\text { consumos 2015-2018. Utilizando el Modelo } 2 \text { (por ser el de } \\
\text { mayor coeficiente de correlación) }\end{array}$ & $29,9 \%$ & $\begin{array}{c}33.679 \\
\text { kWh }\end{array}$ \\
\hline $\begin{array}{l}\text { Ahorro de consumo térmico durante las tres temporadas } \\
\text { posteriores a la construcción de la red respecto a lo que se hubiera } \\
\text { consumido de no ser por la red }\end{array}$ & $20,1 \%$ & $\begin{array}{c}675.763 \\
k W h\end{array}$ \\
\hline Ahorro de emisiones de $\mathrm{CO}_{2}$ & $87,4 \%$ & $592 \mathrm{t} \mathrm{CO}_{2}$ \\
\hline $\begin{array}{l}\text { Precio máximo de kWh útiles comprados a la red para obtener un } \\
\text { ahorro del } 15 \%\end{array}$ & $\begin{array}{l}0,02778 \\
€ / k W h\end{array}$ & $11.280 €$ \\
\hline
\end{tabular}




\subsection{Edificio E4. Escuela de Ingenierías Industriales. Antigua Facultad de Ciencias}

Edificio de tipo docente que empezó a funcionar en el año 1968, cuenta con una superficie construida de $32.305 \mathrm{~m}^{2}$. Inicialmente la calefacción era suministrada mediante tres calderas de gasóleo de una potencia de $3.139 \mathrm{~kW}$. La subestación de intercambio con la red de calor construida en el año 2015, cuenta con una potencia de $2.384 \mathrm{~kW}$. En la Figura 117 se marca la ubicación del edificio.

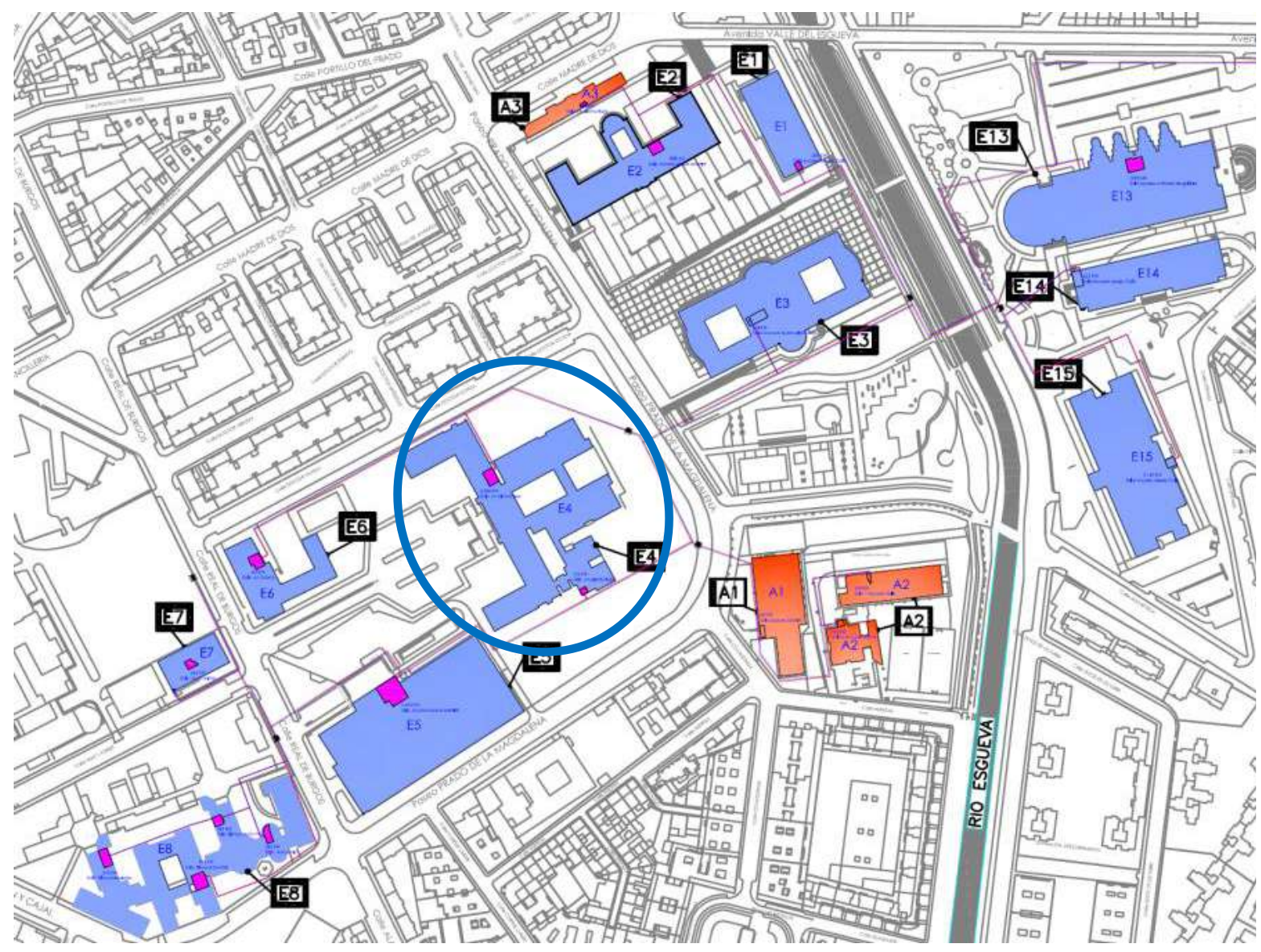

Figura 117. Ubicación del Edificio E4 en el croquis del campus Río Esgueva 
El modelo encontrado para predecir el consumo térmico del Edificio, fue

kWh_E4_Pronosticado $=234.879,945-16.850,392 \times$ T_med

El resumen del modelo, con el coeficiente de correlación de Pearson $(R)$ y el coeficiente de determinación $\left(R^{2}\right)$ se muestra en la Tabla 96 y en la Tabla 97, el resultado de la verificación de los supuestos de la regresión lineal.

Tabla 96.Resumen de los modelos encontrados para el Edificio E4

\begin{tabular}{cccccr}
\hline & $\begin{array}{c}\text { Variable } \\
\text { independiente 1 }\end{array}$ & Constante & B & $R$ & $R^{2}$ \\
\hline E4 & T_med & $234.879,945$ & $-16.850,392$ & $-0,909$ & 0,826 \\
\hline
\end{tabular}

Tabla 97. Resumen del cumplimiento de los supuestos de regresión. Edificio E4

\begin{tabular}{ll}
\hline \multicolumn{1}{c}{ Cumplimiento de supuestos de la regresión lineal } & Modelo \\
\hline 1. Linealidad de las variables & Cumple \\
\hline 2. Normalidad de variables & Cumple \\
\hline 3. Independencia de los errores o no autocorrelación de los residuos & Cumple \\
\hline 4. Homocedasticidad de la varianza, los errores son aleatorios & Cumple \\
\hline
\end{tabular}

En la Figura 118, se representan el consumo real y el pronosticado con el modelo de regresión obtenido, en kWh.

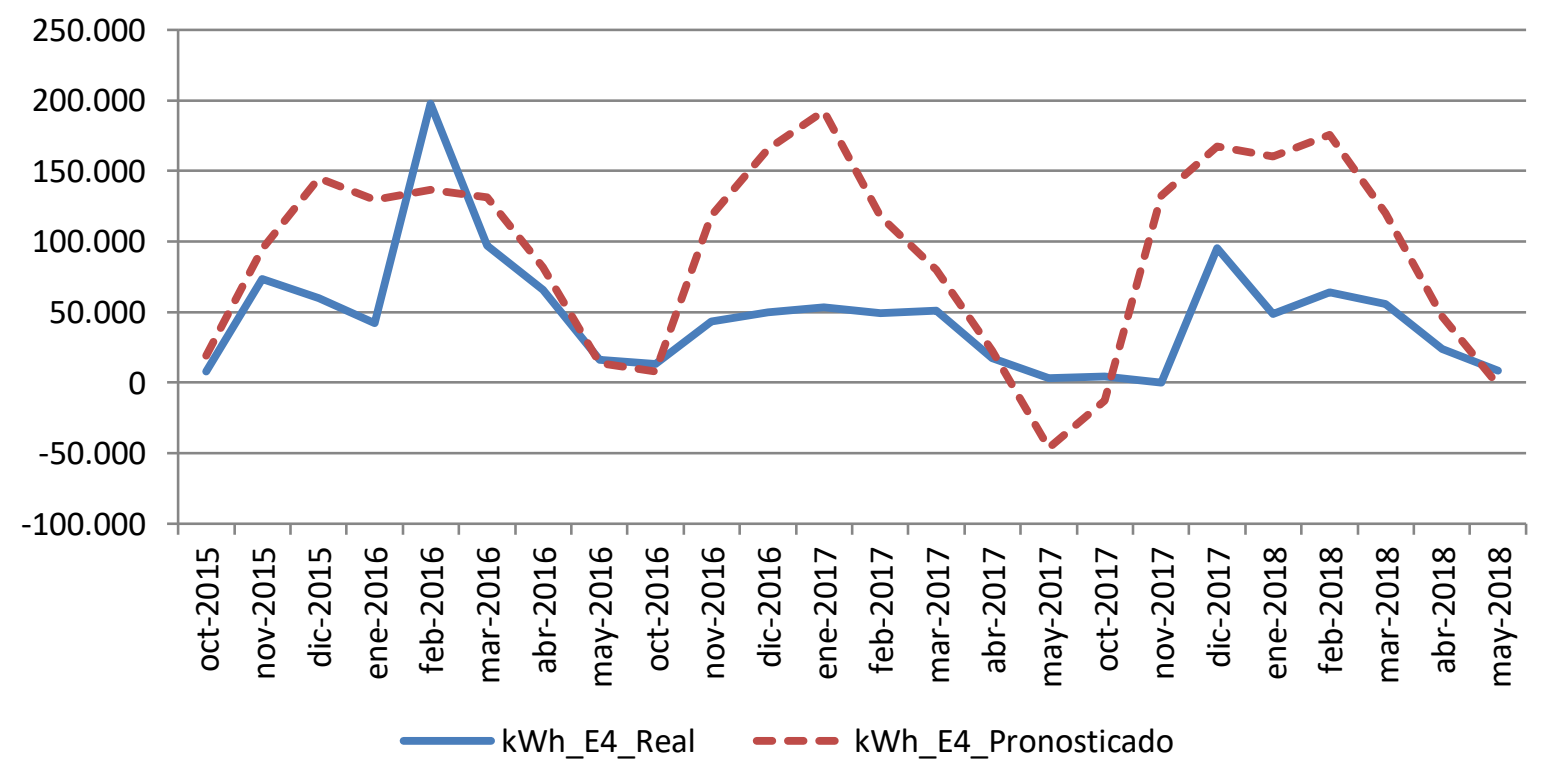

Figura 118. Representación de los consumos pronosticados para el Edificio E4. 2015-2018 
Los resultados de las diferencias entre las medias de los consumos, se exponen en la Tabla 98

Tabla 98. Resultado de las diferencias significativas encontradas. Edificio E4

\begin{tabular}{|c|c|c|c|c|c|c|c|c|}
\hline & $\begin{array}{c}\text { \% Diferencia } \\
2015-2016\end{array}$ & Significativo & $\begin{array}{c}\% \\
\text { Diferencia } \\
\text { 2016-2017 }\end{array}$ & Significativo & $\begin{array}{c}\% \\
\text { Diferencia } \\
\text { 2017-2018 } \\
\end{array}$ & Significativo & $\begin{array}{c}\% \\
\text { Diferencia } \\
\text { 2015-2018 }\end{array}$ & Significativo \\
\hline E4 & $34,4 \%$ & No & $154,0 \%$ & $\begin{array}{l}\text { kWh E4 } \\
\text { real no } \\
\text { normal }\end{array}$ & $179,3 \%$ & $\mathrm{SI}$ & $100,9 \%$ & $\begin{array}{c}\text { kWh E4 real } \\
\text { no normal }\end{array}$ \\
\hline
\end{tabular}

En la Figura 119, se grafican los consumos reales y pronosticados para la temporada Octubre 2015 - Mayo 2018 para el Edificio E4, y las medias de dichos consumos. No se ha podido llevar a cabo la prueba paramétrica dado que no se cumplía la hipótesis de normalidad de las muestras.

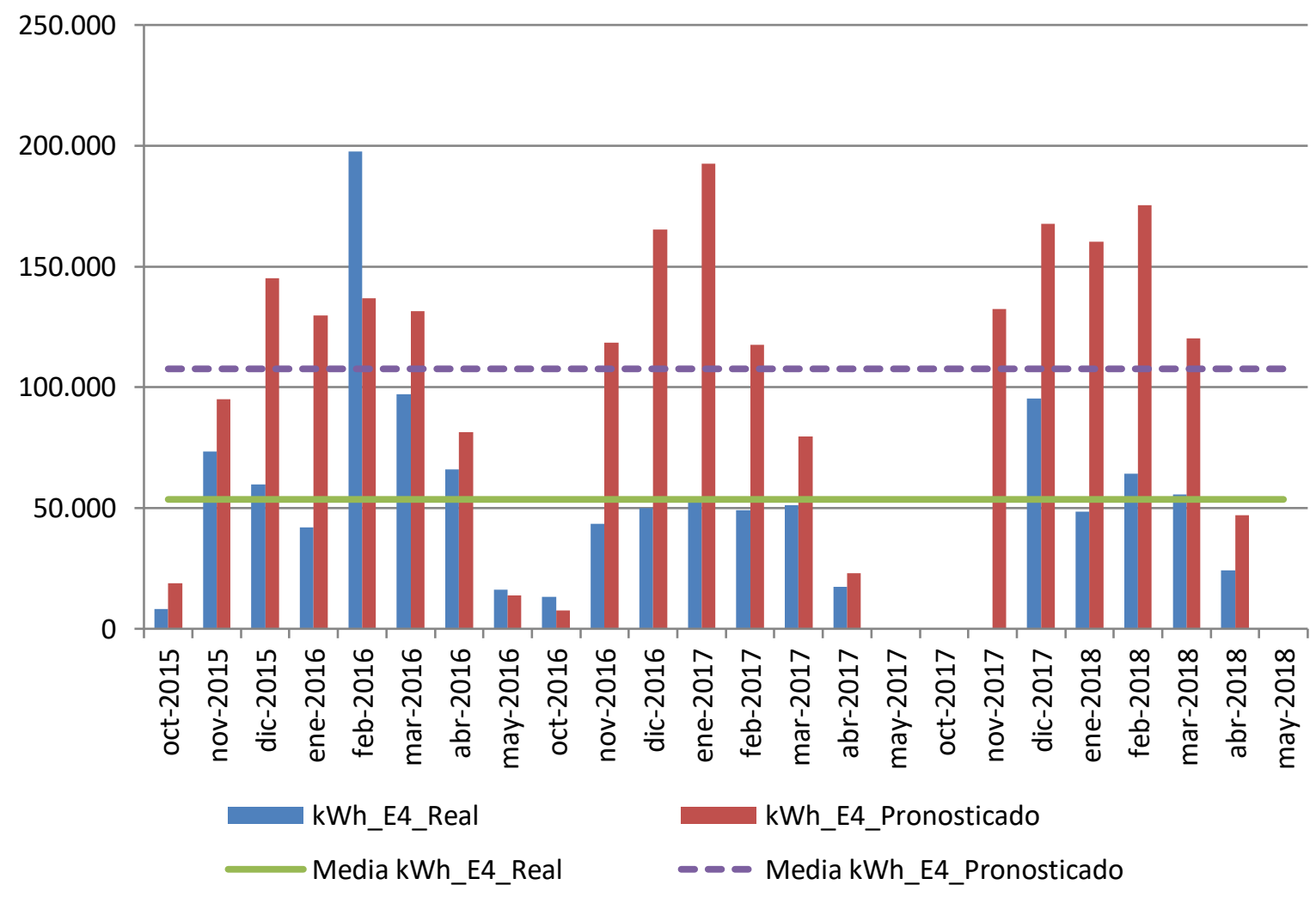

Figura 119. Consumos reales y pronosticados Octubre 2015-Mayo 2018. Edificio E4 
En la Figura 120, se observa el consumo real del Edificio E4, en comparación con el consumo pronosticado acumulado que hubiera tenido el Edificio de no haberse incorporado a la red de calor y de haberse detectado diferencias significativas entre ambos consumos.

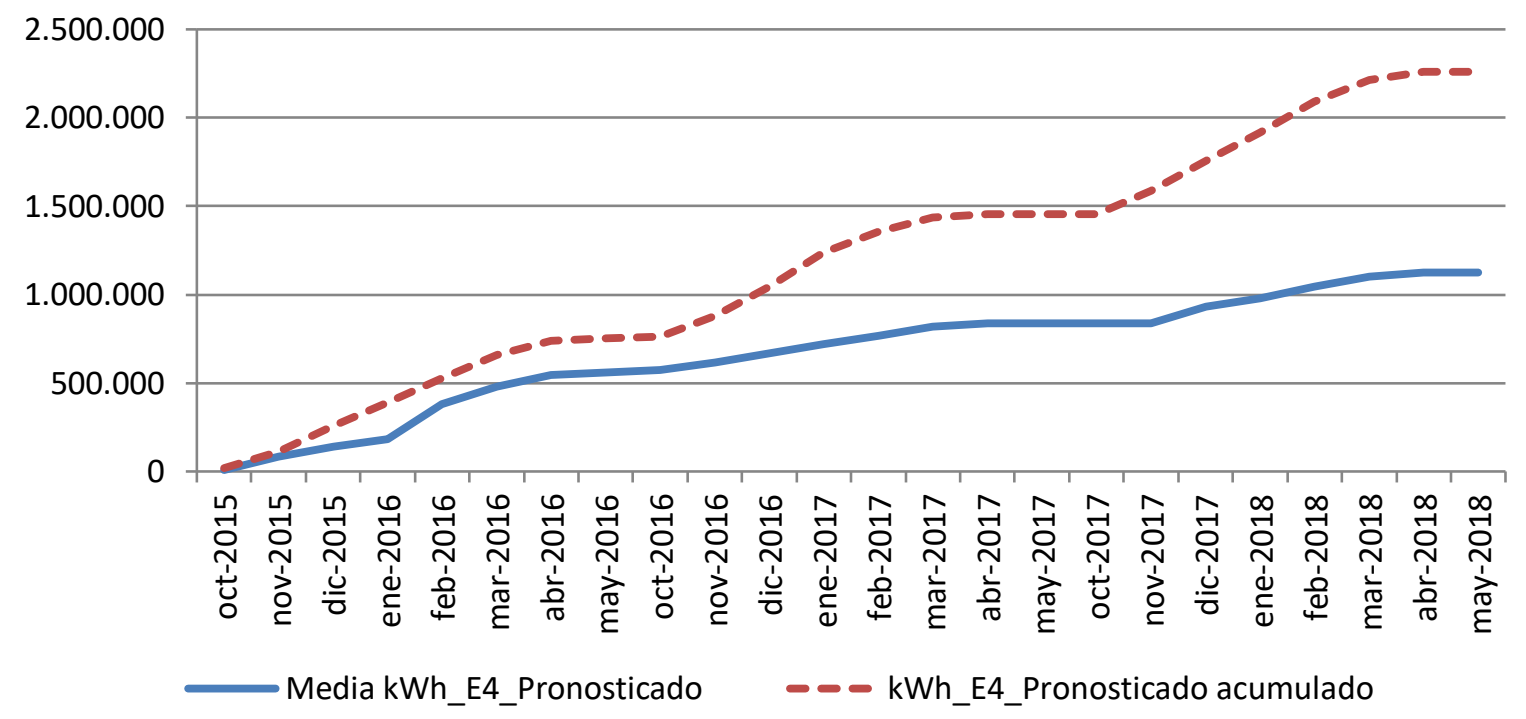

Figura 120. Consumo acumulado real y pronosticado. Octubre 2015-Mayo 2018. Edificio E4

Los resultados del ahorro de consumos, emisiones y precio máximo de la energía útil comprada a la red para un ahorro económico del 15\%, se exponen en la Tabla 99

Tabla 99. Resumen de resultados. Edificio E4

\begin{tabular}{lcc}
\hline $\begin{array}{l}\text { Diferencia significativa encontrada entre las medias de los } \\
\text { consumos 2015-2018 }\end{array}$ & - \\
\hline $\begin{array}{l}\text { Ahorro de consumo térmico durante las tres temporadas } \\
\text { posteriores a la construcción de la red respecto a lo que se hubiera } \\
\text { consumido de no ser por la red }\end{array}$ & - & - \\
\hline Ahorro de emisiones de $\mathrm{CO}_{2}$ & $78,5 \%$ & $275 \mathrm{t} \mathrm{CO}_{2}$ \\
\hline $\begin{array}{l}\text { Precio máximo de kWh útiles comprados a la red para obtener un } \\
\text { ahorro del } 15 \%\end{array}$ & $\begin{array}{c}0,040876 \\
£ / \mathrm{kWh}\end{array}$ & $7.084 €$ \\
\hline
\end{tabular}




\subsection{Edificio E5. Edificio Alfonso VIII}

Edificio de tipo residencial que empezó a funcionar en el año 1991, cuenta con una superficie construida de $20.016 \mathrm{~m}^{2}$. Inicialmente la calefacción era suministrada mediante tres calderas de gasóleo de una potencia de $4.943 \mathrm{~kW}$. La subestación de intercambio con la red de calor construida en el año 2015, cuenta con una potencia de $3.800 \mathrm{~kW}$. En la Figura 121 se marca la ubicación del edificio.

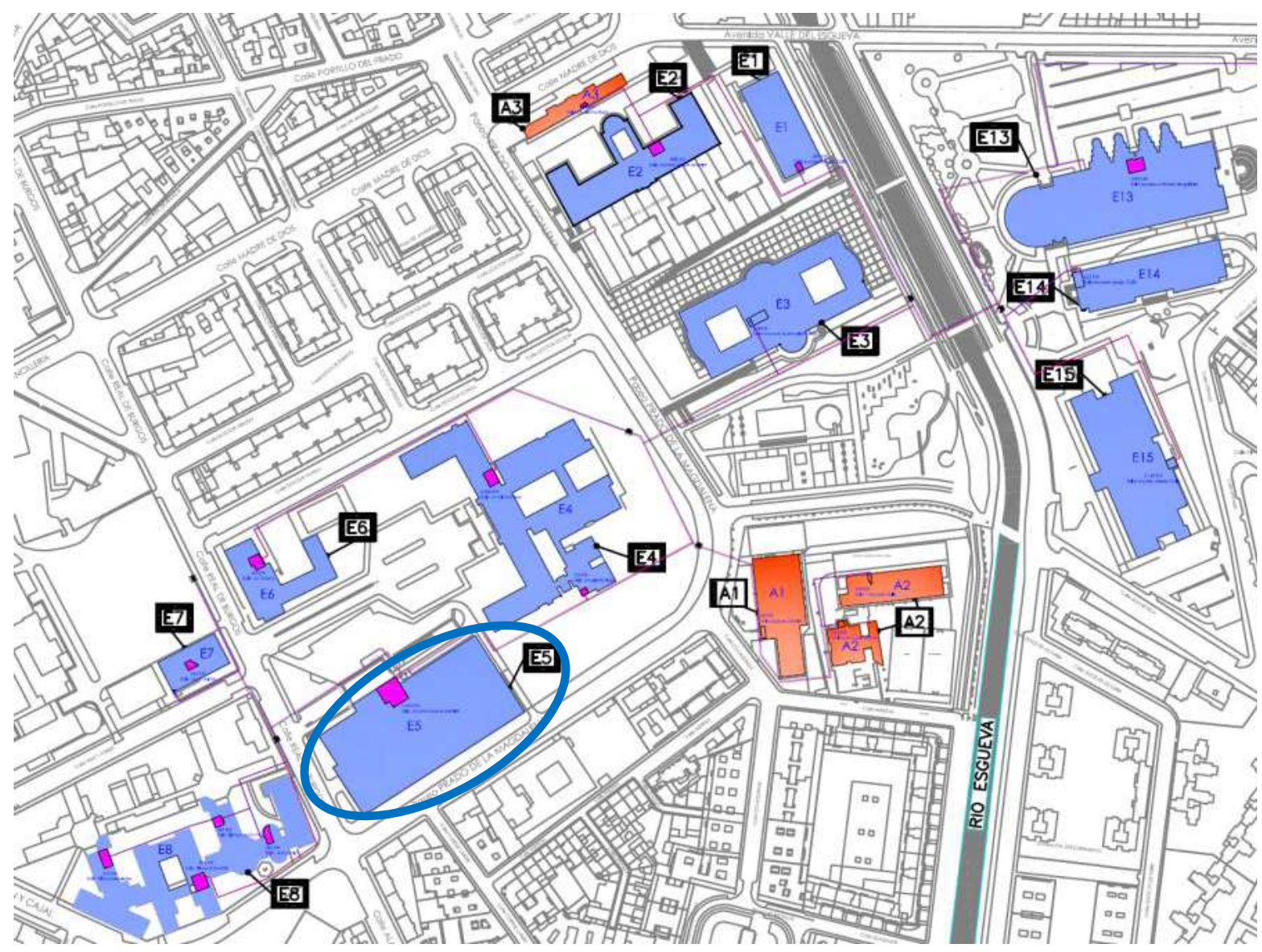

Figura 121. Ubicación del Edificio E5 en el croquis del campus Río Esgueva 
El modelo encontrado para predecir el consumo térmico del Edificio, fue

$$
\text { kWh_E5_Pronosticado }=29.320,001+816,043 \times \text { GD15_30min }
$$

El resumen del modelo, con el coeficiente de correlación de Pearson ( $R$ ) y el coeficiente de determinación $\left(\mathrm{R}^{2}\right)$ se muestra en la Tabla 100 y en la Tabla 101, el resultado de la verificación de los supuestos de la regresión lineal.

Tabla 100. Resumen de los modelos encontrados para el Edificio E5

\begin{tabular}{cccccc}
\hline & $\begin{array}{c}\text { Variable } \\
\text { independiente 1 }\end{array}$ & Constante & $\mathrm{B}$ & $\mathrm{R}$ & $\mathrm{R}^{2}$ \\
\hline E5 & GD15_30min & $29.320,001$ & 816,043 & 0,857 & 0,734 \\
\hline
\end{tabular}

Tabla 101. Resumen del cumplimiento de los supuestos de regresión. Edificio E5

\begin{tabular}{ll}
\hline \multicolumn{1}{c}{ Cumplimiento de supuestos de la regresión lineal } & Modelo \\
\hline 1. Linealidad de las variables & Cumple \\
\hline 2. Normalidad de variables & Cumple \\
\hline 3. Independencia de los errores o no autocorrelación de los residuos & Cumple \\
\hline 4. Homocedasticidad de la varianza, los errores son aleatorios & Cumple \\
\hline
\end{tabular}

En la Figura 122, se representan el consumo real y el pronosticado con el modelo de regresión obtenido, en kWh.

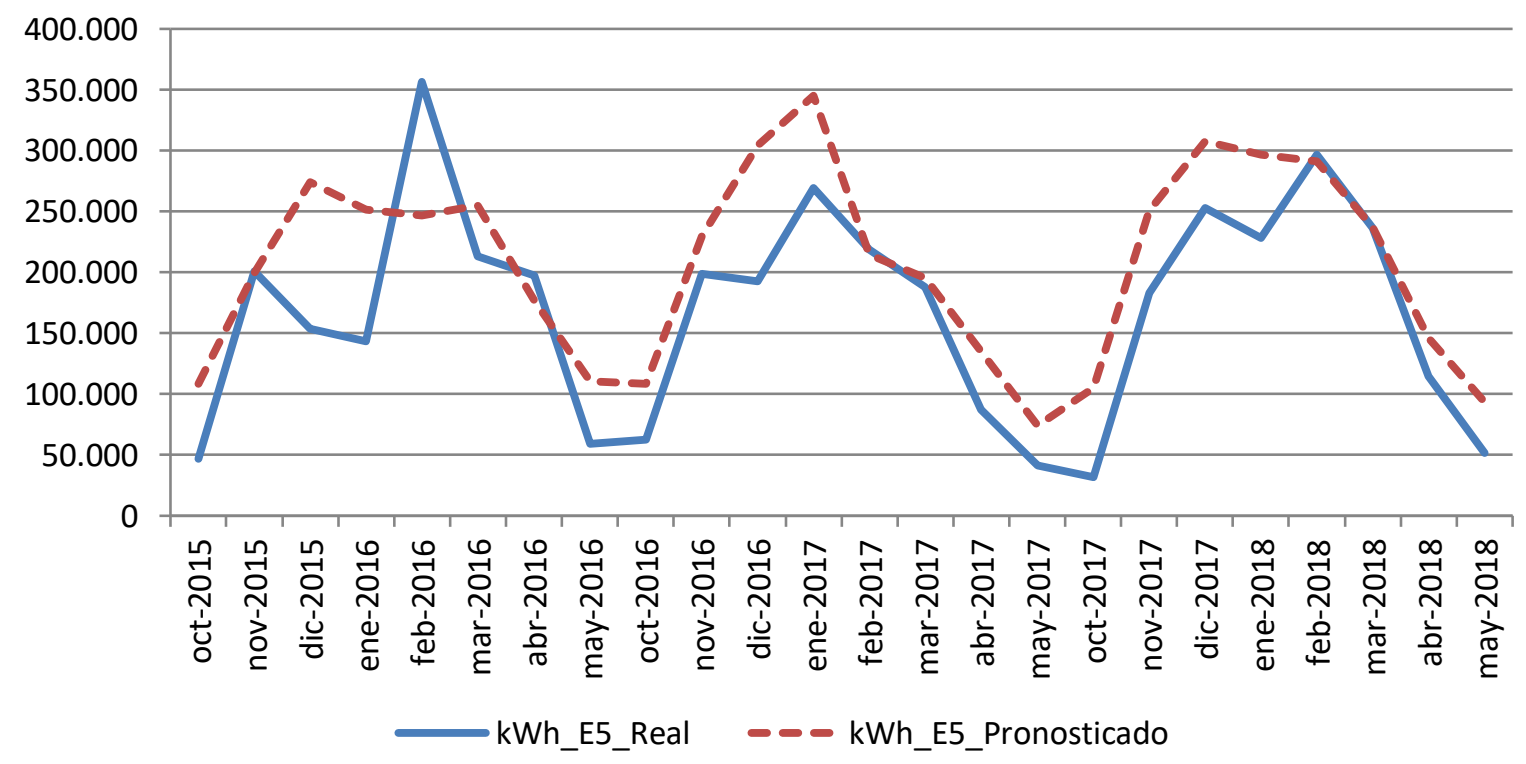

Figura 122. Representación de los consumos pronosticados para el Edificio E5. 2015-2018 
Los resultados de las diferencias entre las medias de los consumos, se exponen en la Tabla 102

Tabla 102. Resultado de las diferencias significativas encontradas. Edificio E5

\begin{tabular}{ccccccccc}
\hline & $\begin{array}{c}\% \\
\text { Diferencia } \\
2015-2016\end{array}$ & Significativo & $\begin{array}{c}\% \\
\text { Diferencia } \\
2016-2017\end{array}$ & Significativo & $\begin{array}{c}\% \\
\text { Diferencia } \\
2017-2018\end{array}$ & Significativo & $\begin{array}{c}\% \\
\text { Diferencia } \\
2015-2018\end{array}$ & Significativo \\
\hline E5 & $18,4 \%$ & No & $27,7 \%$ & SI & $23,9 \%$ & SI & $23,2 \%$ & SI \\
\hline
\end{tabular}

En la Figura 123, se grafican los consumos reales y pronosticados para la temporada Octubre 2015 - Mayo 2018 para el Edificio E5, y las medias de dichos consumos. Según la prueba paramétrica realizada las diferencias encontradas son estadísticamente significativas, con un riesgo a estar equivocados del $5 \%$

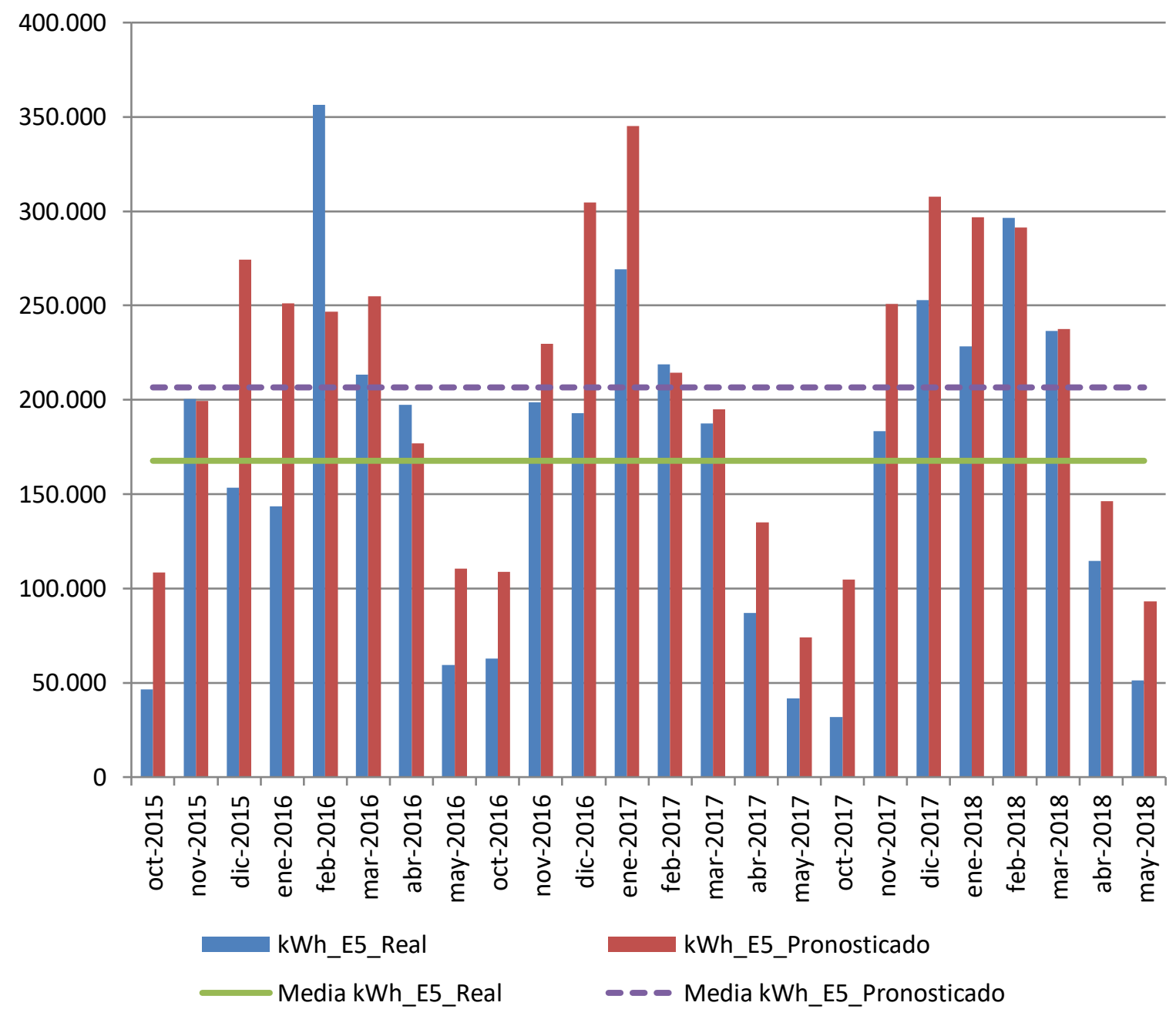

Figura 123. Consumos reales y pronosticados Octubre 2015-Mayo 2018. Edificio E5 
En la Figura 124, se observa el consumo real del Edificio E5, en comparación con el consumo pronosticado acumulado que hubiera tenido el Edificio de no haberse incorporado a la red de calor.

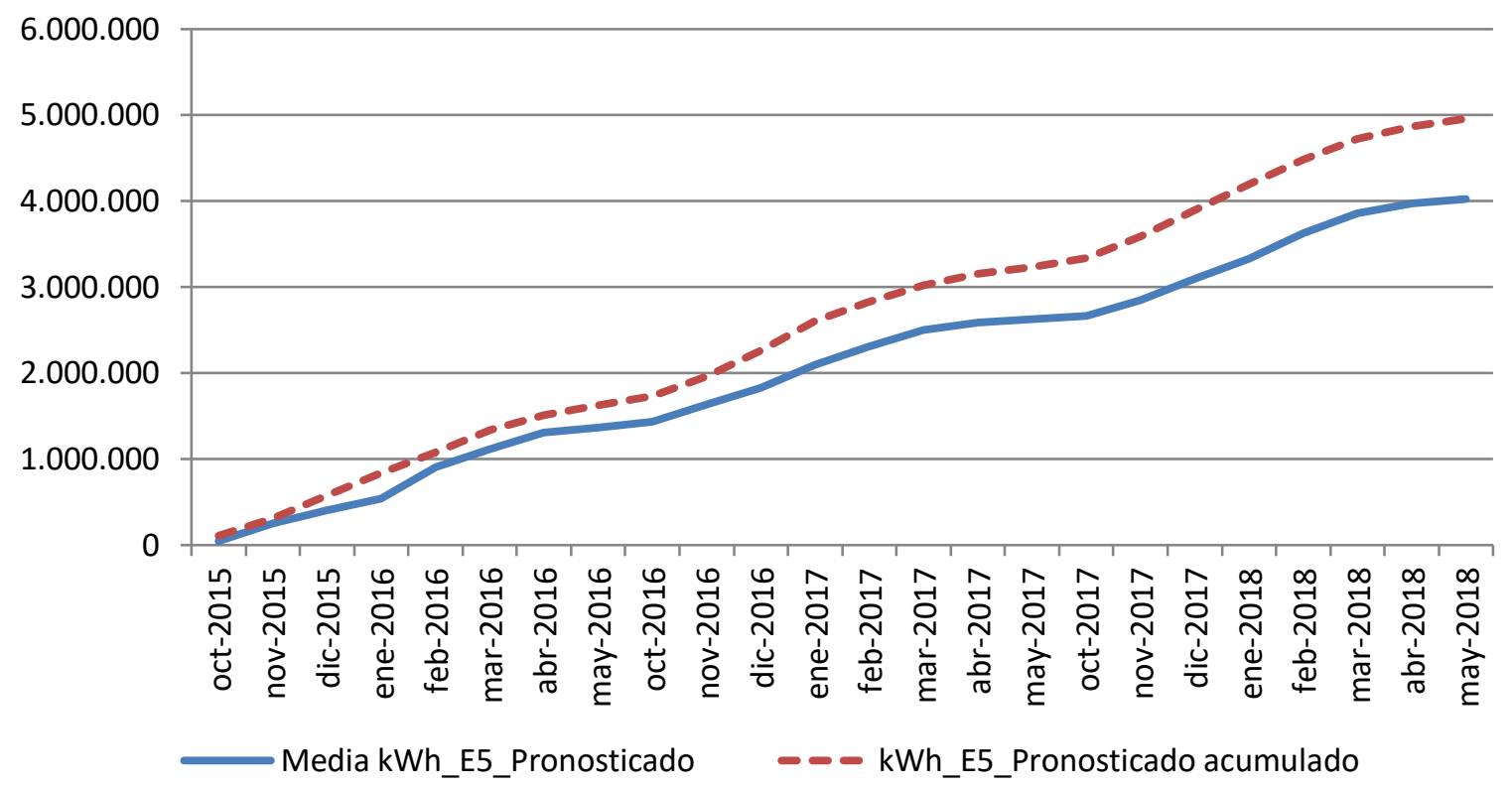

Figura 124. Consumo acumulado real y pronosticado. Octubre 2015-Mayo 2018. Edificio E5

Los resultados del ahorro de consumos, emisiones y precio máximo de la energía útil comprada a la red para un ahorro económico del 15\%, se exponen en la Tabla 103

Tabla 103. Resumen de resultados. Edificio E5

\begin{tabular}{lcc}
\hline $\begin{array}{l}\text { Diferencia significativa encontrada entre las medias de los } \\
\text { consumos 2015-2018 }\end{array}$ & $23,2 \%$ & $\begin{array}{c}38.903 \\
\mathrm{kWh}\end{array}$ \\
\hline $\begin{array}{l}\text { Ahorro de consumo térmico durante las tres temporadas } \\
\text { posteriores a la construcción de la red respecto a lo que se hubiera } \\
\text { consumido de no ser por la red }\end{array}$ & $18,8 \%$ & $\begin{array}{c}933.665 \\
\mathrm{kWh}\end{array}$ \\
\hline Ahorro de emisiones de $\mathrm{CO}_{2}$ & $90,9 \%$ & $1.402 \mathrm{t} \mathrm{CO}_{2}$ \\
\hline $\begin{array}{l}\text { Precio máximo de kWh útiles comprados a la red para obtener un } \\
\text { ahorro del 15\% }\end{array}$ & $\begin{array}{c}0,05317 \\
€ / \mathrm{kWh}\end{array}$ & $31.886 €$ \\
\hline
\end{tabular}




\subsection{Edificio E6. Colegio Mayor Femenino Santa Cruz}

Edificio de tipo residencial que empezó a funcionar en el año 1981, cuenta con una superficie construida de $6.660 \mathrm{~m}^{2}$. Inicialmente la calefacción era suministrada mediante dos calderas de gas natural de una potencia de $716 \mathrm{~kW}$. La subestación de intercambio con la red de calor construida en el año 2015, cuenta con una potencia de $560 \mathrm{~kW}$. En la Figura 125 se marca la ubicación del edificio.

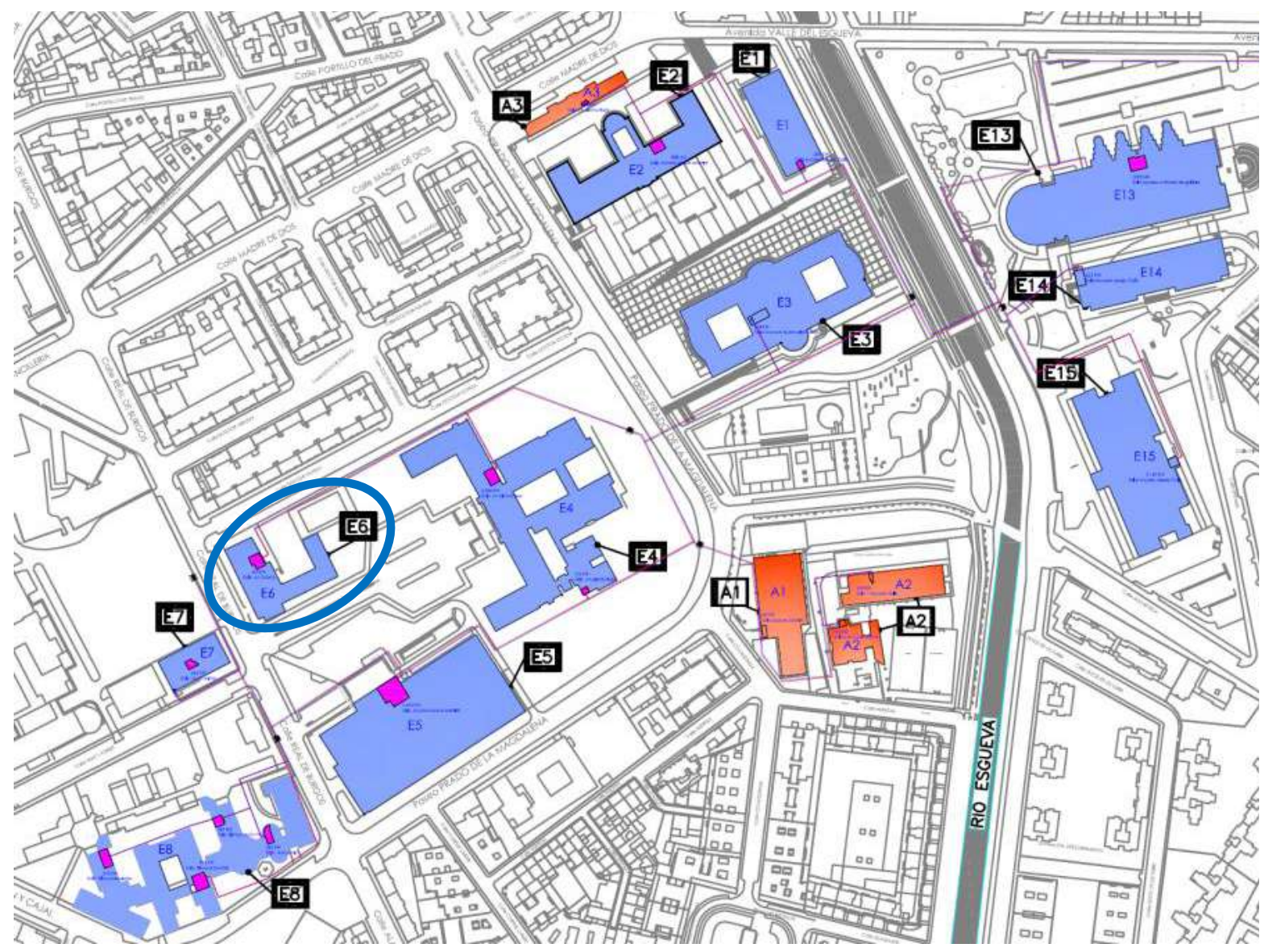

Figura 125. Ubicación del Edificio E6 en el croquis del campus Río Esgueva 
El modelo encontrado para predecir el consumo térmico del Edificio, fue

$$
\text { kWh_E6_Pronosticado }=99.745,107-5.510,824 \times \text { T_med }
$$

El resumen del modelo, con el coeficiente de correlación de Pearson $(R)$ y el coeficiente de determinación $\left(R^{2}\right)$ se muestra en la Tabla 104 y en la Tabla 105, el resultado de la verificación de los supuestos de la regresión lineal.

Tabla 104. Resumen de los modelos encontrados para el Edificio E6

\begin{tabular}{cccccc}
\hline & $\begin{array}{c}\text { Variable } \\
\text { independiente 1 }\end{array}$ & Constante & B & $R$ & $R^{2}$ \\
\hline E6 & T_med & $99.745,107$ & $-5.510,824$ & $-0,939$ & 0,883 \\
\hline
\end{tabular}

Tabla 105. Resumen del cumplimiento de los supuestos de regresión. Edificio E6

\begin{tabular}{ll}
\hline \multicolumn{1}{c}{ Cumplimiento de supuestos de la regresión lineal } & Modelo \\
\hline 1. Linealidad de las variables & Cumple \\
\hline 2. Normalidad de variables & Cumple \\
\hline 3. Independencia de los errores o no autocorrelación de los residuos & Cumple \\
\hline 4. Homocedasticidad de la varianza, los errores son aleatorios & Cumple \\
\hline
\end{tabular}

En la Figura 126, se representan el consumo real y el pronosticado con el modelo de regresión obtenido, en kWh.

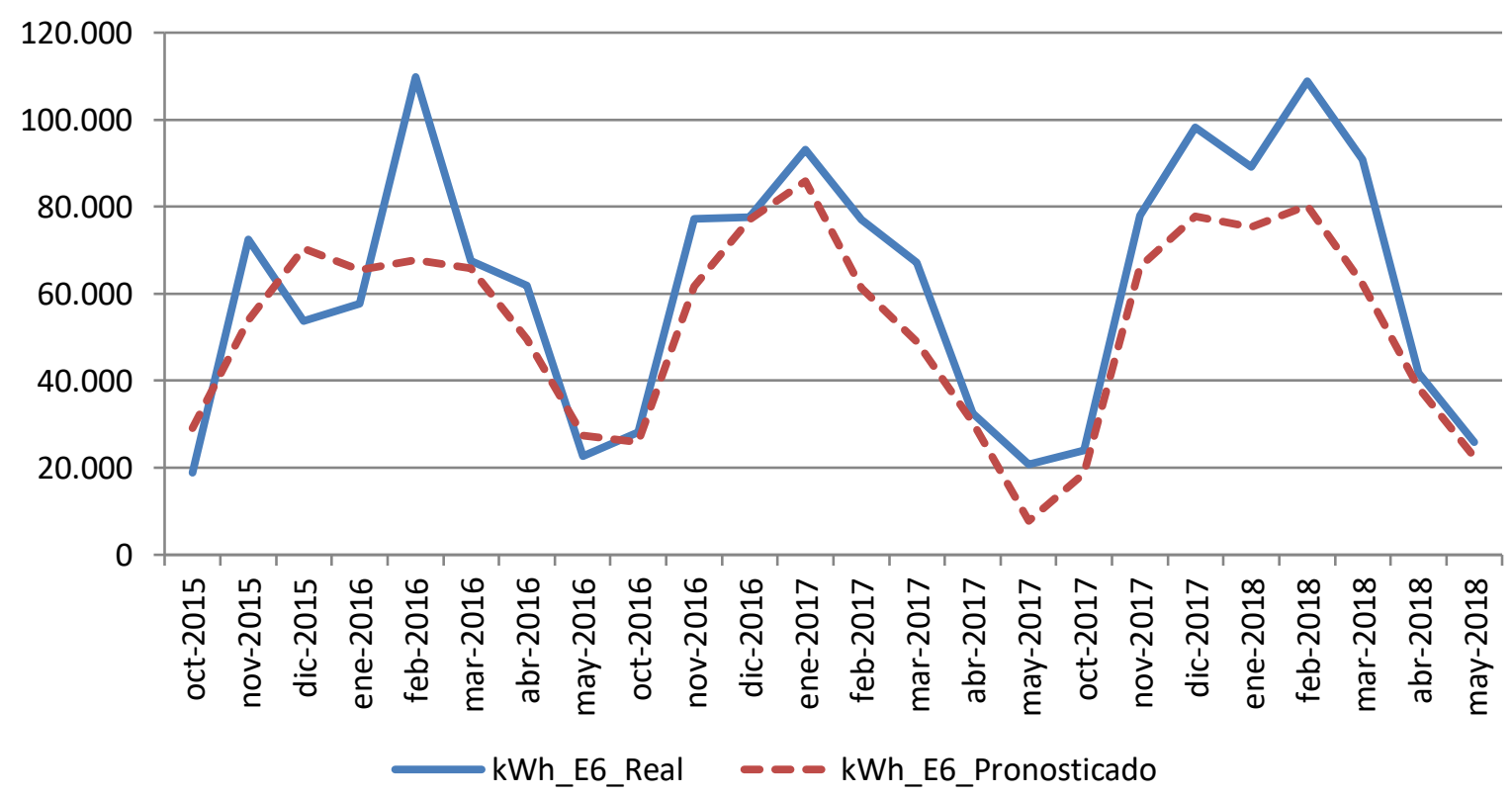

Figura 126. Representación de los consumos pronosticados para el Edificio E6. 2015-2018 
Los resultados de las diferencias entre las medias de los consumos, se exponen en la Tabla 106

Tabla 106. Resultado de las diferencias significativas encontradas. Edificio E6

\begin{tabular}{cccccccccc}
\hline & $\begin{array}{c}\% \\
\text { Diferencia } \\
2015-2016\end{array}$ & Significativo & $\begin{array}{c}\% \\
\text { Diferencia } \\
2016-2017\end{array}$ & Significativo & $\begin{array}{c}\% \\
\text { Diferencia } \\
2017-2018\end{array}$ & Significativo & $\begin{array}{c}\% \\
\text { Diferencia } \\
2015-2018\end{array}$ & Significativo \\
\hline E6 & $-7,5 \%$ & No & $-15,7 \%$ & SI & $-20,7 \%$ & SI & $-15,0 \%$ & SI \\
\hline
\end{tabular}

En la Figura 127, se grafican los consumos reales y pronosticados para la temporada Octubre 2015 - Mayo 2018 para el Edificio E6, y las medias de dichos consumos. Según la prueba paramétrica realizada las diferencias encontradas son estadísticamente significativas, con un riesgo a estar equivocados del $5 \%$

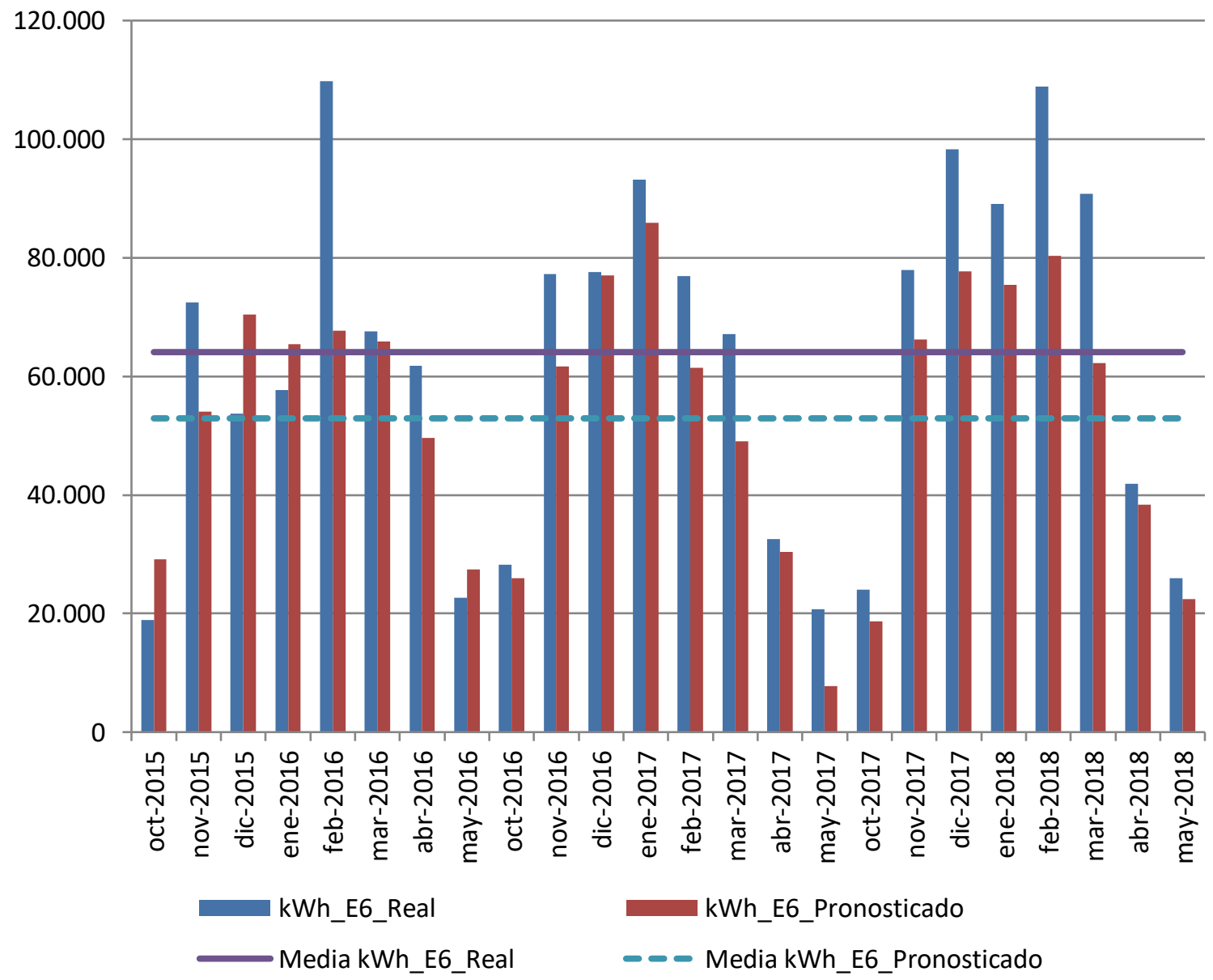

Figura 127. Consumos reales y pronosticados Octubre 2015-Mayo 2018. Edificio E6 
En la Figura 128, se observa el consumo real del Edificio E6, en comparación con el consumo pronosticado acumulado que hubiera tenido el Edificio de no haberse incorporado a la red de calor.

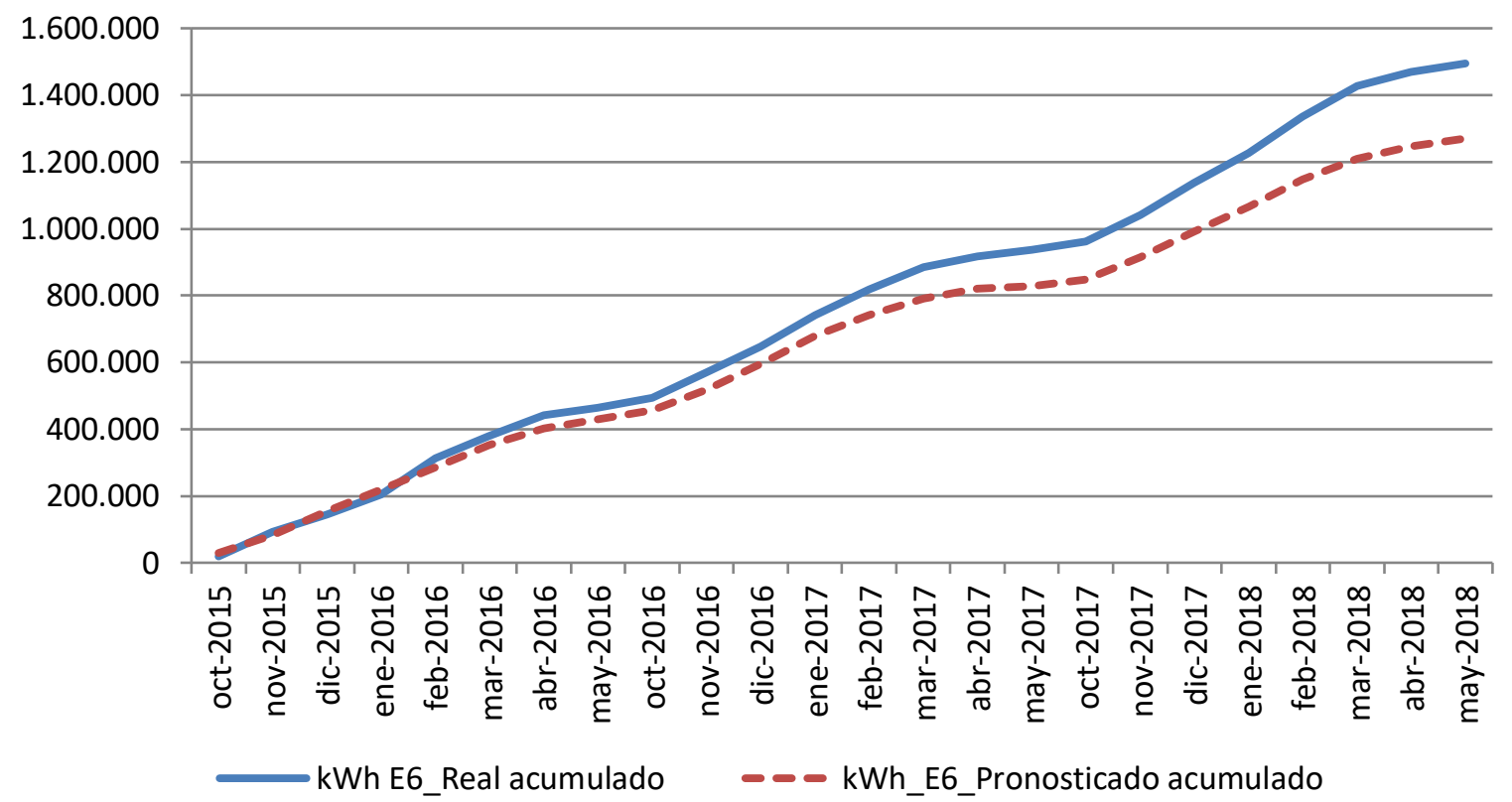

Figura 128. Consumo acumulado real y pronosticado. Octubre 2015-Mayo 2018. Edificio E6

Los resultados del ahorro de consumos, emisiones y precio máximo de la energía útil comprada a la red para un ahorro económico del 15\%, se exponen en la Tabla 107

Tabla 107. Resumen de resultados. Edificio E6

\begin{tabular}{lcc}
\hline $\begin{array}{l}\text { Diferencia significativa encontrada entre las medias de los } \\
\text { consumos 2015-2018 }\end{array}$ & $-15,0 \%$ & $-9.360 \mathrm{kWh}$ \\
\hline $\begin{array}{l}\text { Ahorro de consumo térmico durante las tres temporadas } \\
\text { posteriores a la construcción de la red respecto a lo que se hubiera } \\
\text { consumido de no ser por la red }\end{array}$ & $-17,7 \%$ & $\begin{array}{c}-224.650 \\
\mathrm{kWh}\end{array}$ \\
\hline $\begin{array}{l}\text { Ahorro de emisiones de } \mathrm{CO}_{2} \\
\begin{array}{l}\text { Precio máximo de kWh útiles comprados a la red para obtener un } \\
\text { ahorro del 15\% }\end{array}\end{array}$ & $0,0279 € / \mathrm{kWh}$ & $6.296 €$ \\
\hline
\end{tabular}




\subsection{Edificio E7. Instituto de Biología Genética y Molecular}

Edificio de tipo residencial que empezó a funcionar en el año 2005, cuenta con una superficie construida de $3.919 \mathrm{~m}^{2}$. Inicialmente la calefacción era suministrada mediante dos calderas de gas natural de una potencia de $466 \mathrm{~kW}$. La subestación de intercambio con la red de calor construida en el año 2015, cuenta con una potencia de $465 \mathrm{~kW}$. En la Figura 129 se marca la ubicación del edificio.

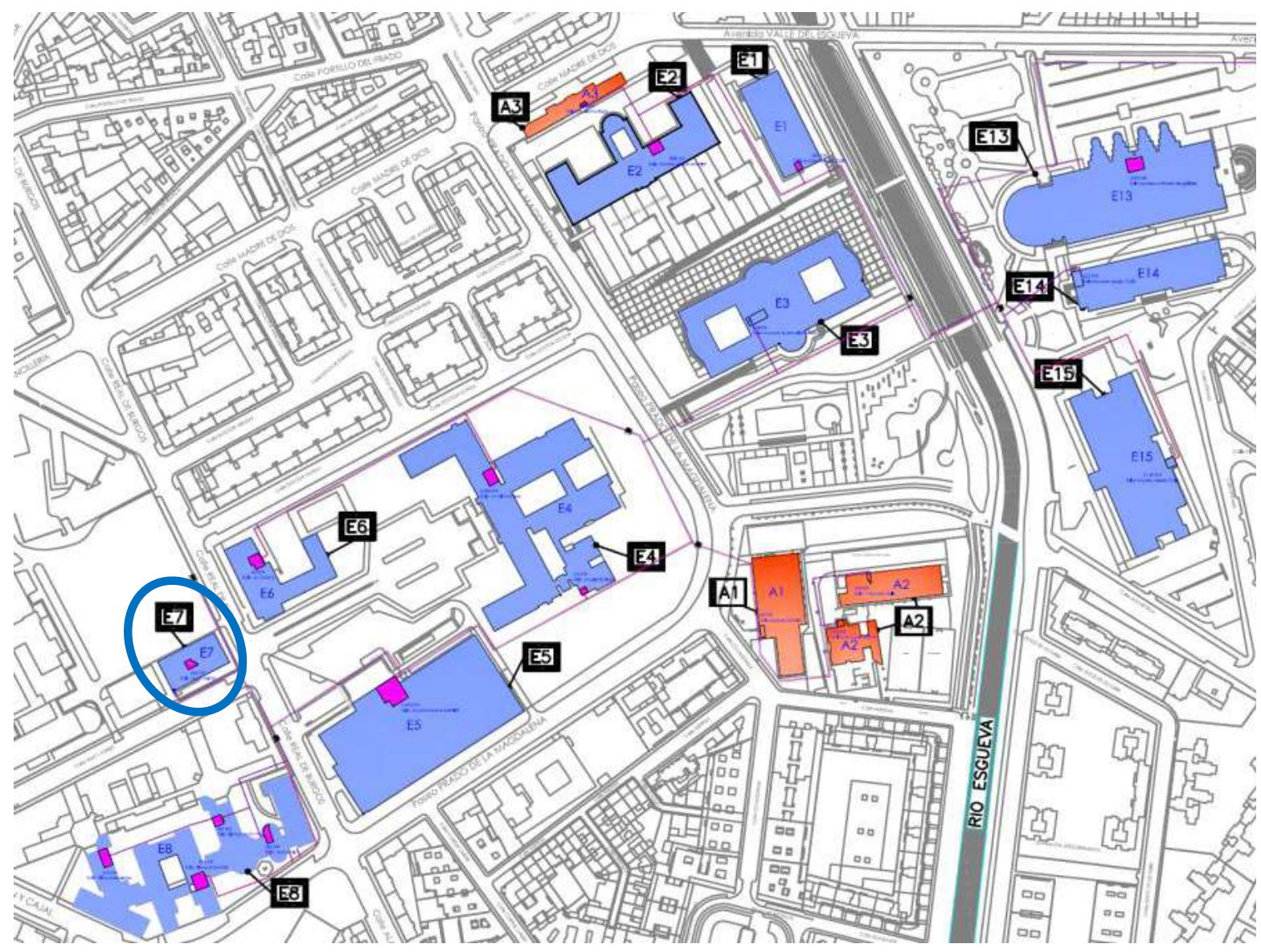

Figura 129. Ubicación del Edificio E7 en el croquis del campus Río Esgueva 
El modelo encontrado para predecir el consumo térmico del Edificio, fue

$$
\text { kWh_E7_Pronosticado }=-437,414+109,126 \times \text { GD15_30min }
$$

El resumen del modelo, con el coeficiente de correlación de Pearson $(R)$ y el coeficiente de determinación $\left(R^{2}\right)$ se muestra en la Tabla 108 y en la Tabla 109, el resultado de la verificación de los supuestos de la regresión lineal.

Tabla 108. Resumen de los modelos encontrados para el Edificio E7

\begin{tabular}{cccccr}
\hline & $\begin{array}{c}\text { Variable } \\
\text { independiente 1 }\end{array}$ & Constante & B & $R$ & $R^{2}$ \\
\hline E7 & $-437,414$ & 109,126 & 0,925 & 0,855 & $-437,414$ \\
\hline
\end{tabular}

Tabla 109. Resumen del cumplimiento de los supuestos de regresión. Edificio E7

\begin{tabular}{ll}
\hline \multicolumn{1}{c}{ Cumplimiento de supuestos de la regresión lineal } & Modelo \\
\hline 1. Linealidad de las variables & Cumple \\
\hline 2. Normalidad de variables & Cumple \\
\hline 3. Independencia de los errores o no autocorrelación de los residuos & Cumple \\
\hline 4. Homocedasticidad de la varianza, los errores son aleatorios & Cumple \\
\hline
\end{tabular}

En la Figura 130, se representan el consumo real y el pronosticado con el modelo de regresión obtenido, en kWh.

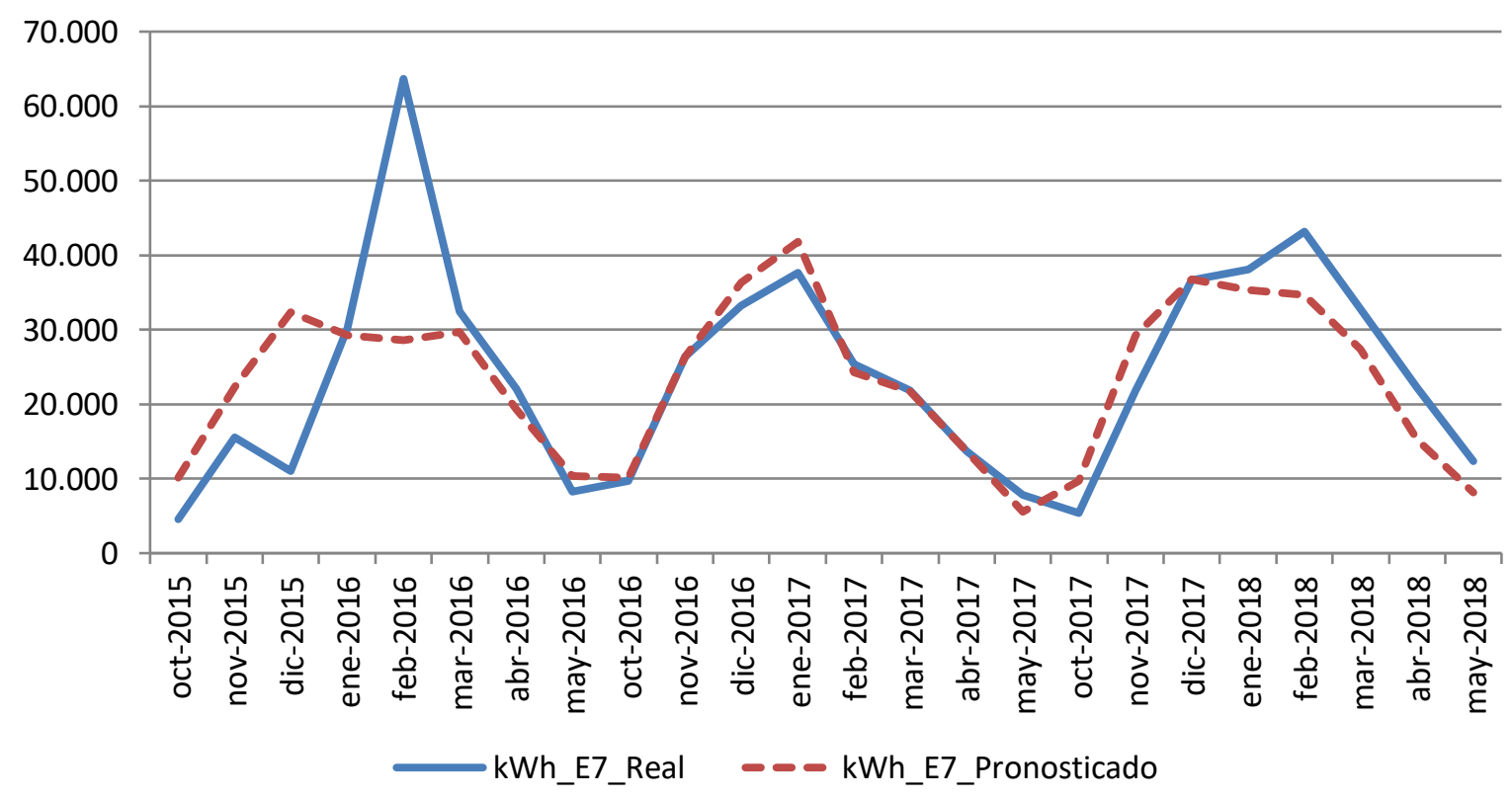

Figura 130. Representación de los consumos pronosticados para el Edificio E7. 2015-2018 
Los resultados de las diferencias entre las medias de los consumos, se exponen en la Tabla 110

Tabla 110. Resultado de las diferencias significativas encontradas. Edificio E6

\begin{tabular}{cccccccccc}
\hline & $\begin{array}{c}\% \\
\text { Diferencia } \\
2015-2016\end{array}$ & Significativo & $\begin{array}{c}\% \\
\text { Diferencia } \\
2016-2017\end{array}$ & Significativo & $\begin{array}{c}\% \\
\text { Diferencia } \\
2017-2018\end{array}$ & Significativo & $\begin{array}{c}\% \\
\text { Diferencia } \\
2015-2018\end{array}$ & Significativo \\
\hline E7 & $-3,0 \%$ & No & $2,5 \%$ & No & $-7,5 \%$ & No & $-3,0 \%$ & No & \\
\hline
\end{tabular}

En la Figura 131, se grafican los consumos reales y pronosticados para la temporada Octubre 2015 - Mayo 2018 para el Edificio E7, y las medias de dichos consumos. Según la prueba paramétrica realizada las diferencias encontradas no son estadísticamente significativas, con un riesgo a estar equivocados del $5 \%$

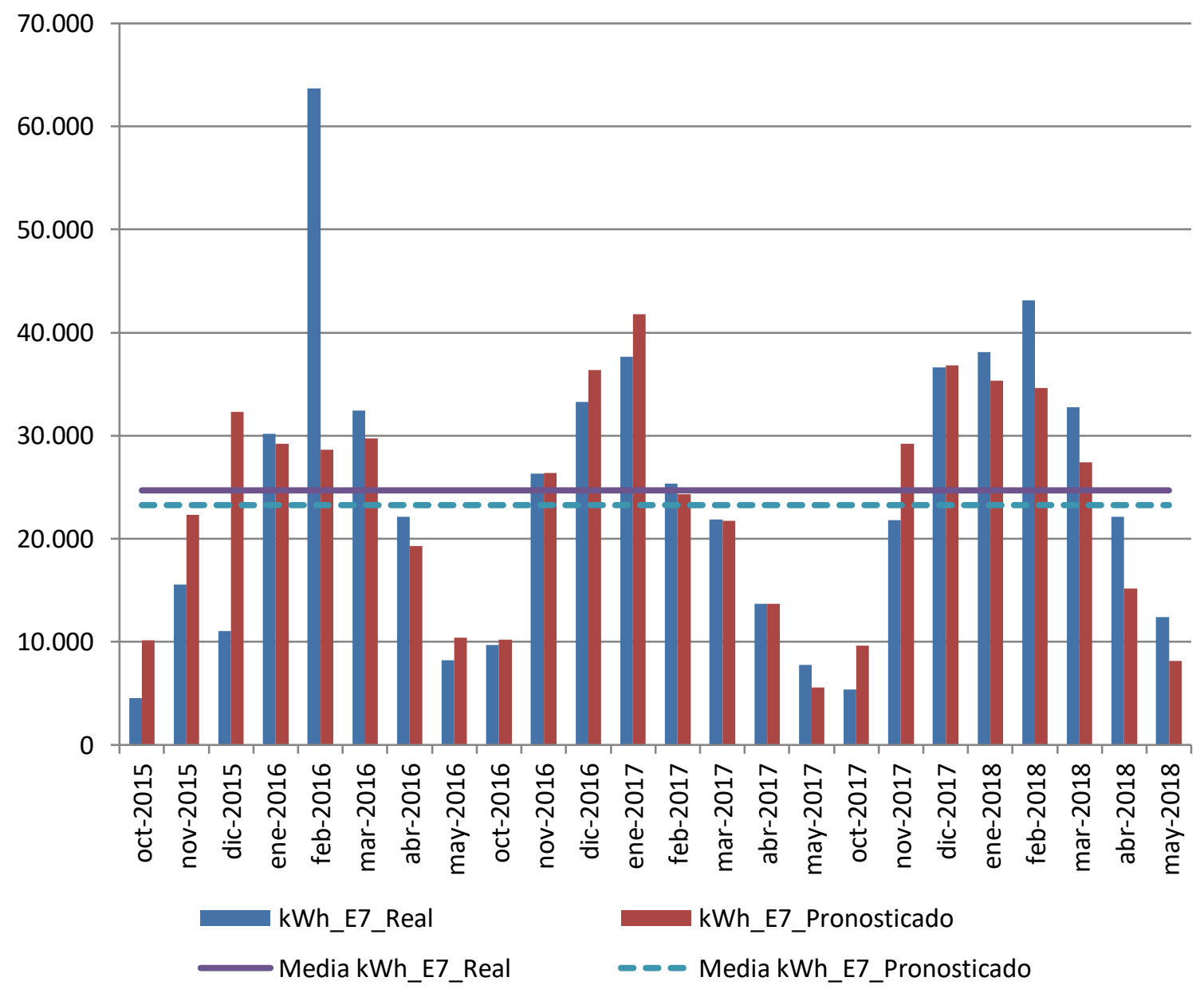

Figura 131. Consumos reales y pronosticados Octubre 2015-Mayo 2018. Edificio E7 
En la Figura 132, se observa el consumo real del Edificio E7, en comparación con el consumo pronosticado acumulado que hubiera tenido el Edificio de no haberse incorporado a la red de calor y de haberse producido diferencias significativas.

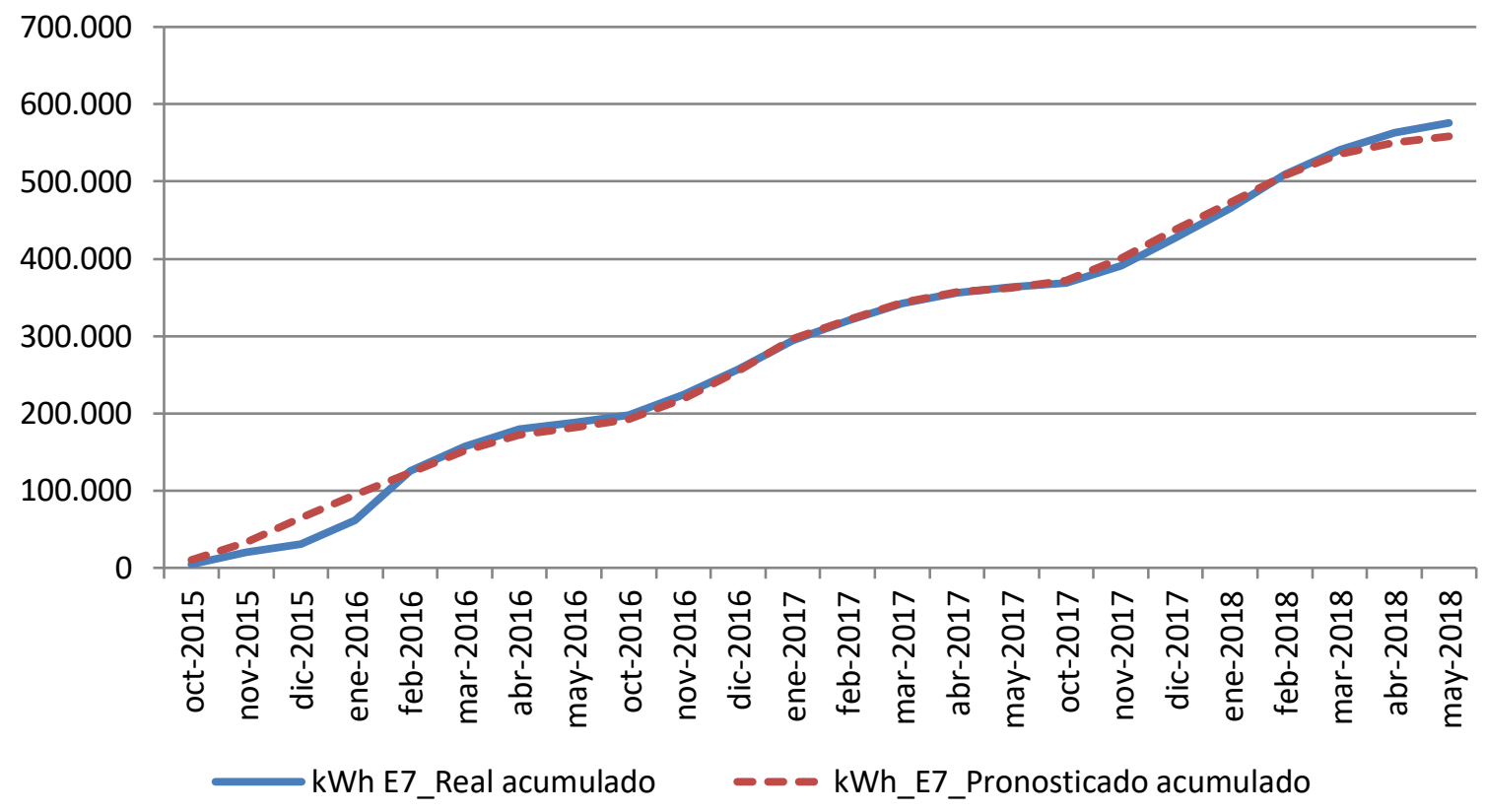

Figura 132. Consumo acumulado real y pronosticado. Octubre 2015-Mayo 2018. Edificio E7

Los resultados del ahorro de consumos, emisiones y precio máximo de la energía útil comprada a la red para un ahorro económico del 15\%, se exponen en la Tabla 111

Tabla 111. Resumen de resultados. Edificio E7

Diferencia significativa encontrada entre las medias de los consumos 2015-2018

Ahorro de consumo térmico durante las tres temporadas posteriores a la construcción de la red respecto a lo que se hubiera consumido de no ser por la red

\begin{tabular}{lcc}
\hline Ahorro de emisiones de $\mathrm{CO}_{2}$ & $84,1 \%$ & $122 \mathrm{t} \mathrm{CO}$ \\
\hline $\begin{array}{l}\text { Precio máximo de kWh útiles comprados a la red para obtener un } \\
\text { ahorro del } 15 \%\end{array}$ & $\begin{array}{c}0,02758 \\
€ / \mathrm{kWh}\end{array}$ & $2.401 €$ \\
\hline
\end{tabular}




\subsection{Edificio E8. Facultad de Ciencias de la Salud}

Edificio de tipo docente que empezó a funcionar en el año 1960, cuenta con una superficie construida de $29.802 \mathrm{~m}^{2}$. Inicialmente la calefacción era suministrada mediante ocho calderas de gas natural de una potencia total de $2.320 \mathrm{~kW}$. La subestación de intercambio con la red de calor construida en el año 2015, cuenta con una potencia de $2.172 \mathrm{~kW}$. En la Figura 133 se marca la ubicación del edificio.

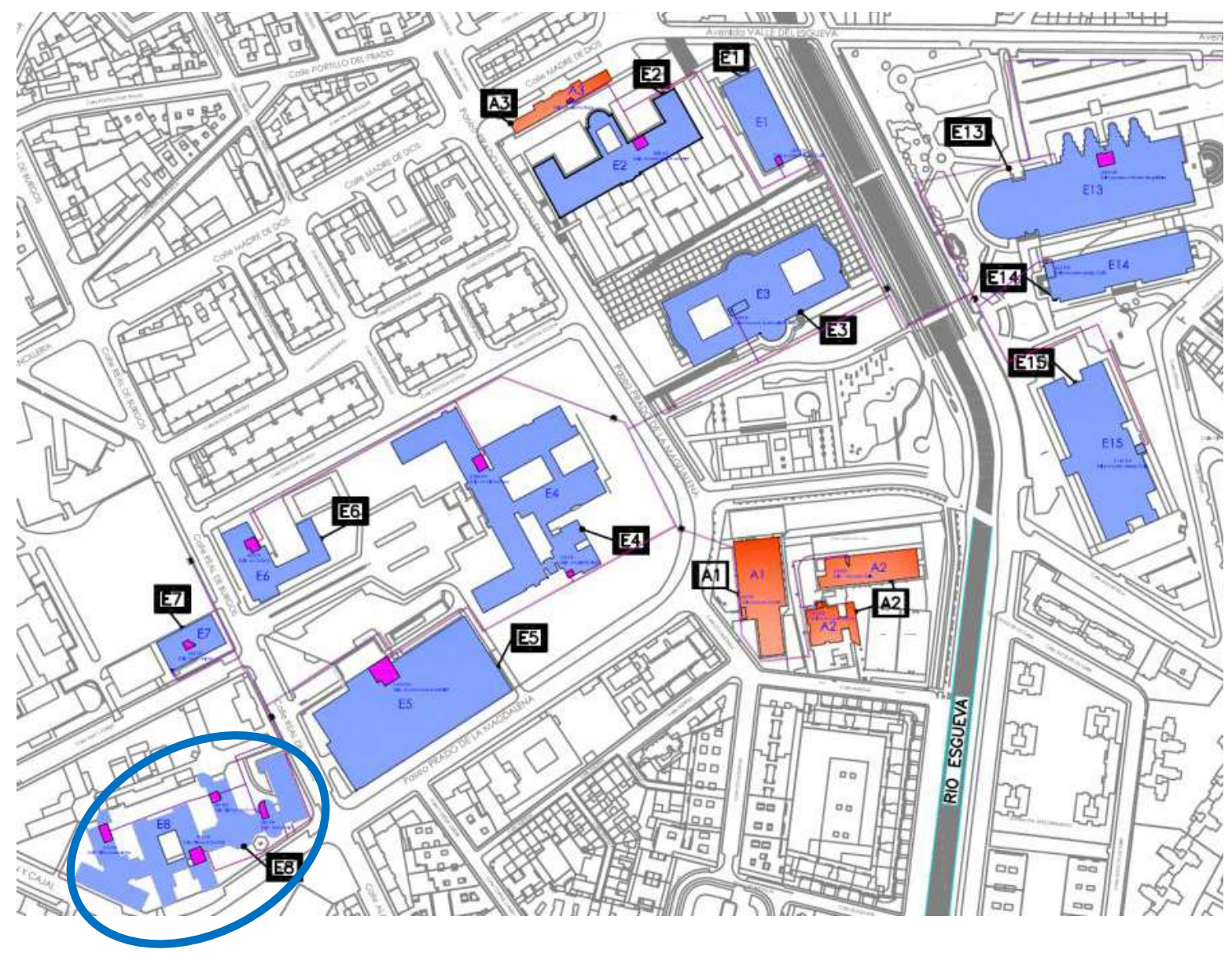

Figura 133. Ubicación del Edificio E8 en el croquis del campus Río Esgueva 
Los modelos encontrados para predecir el consumo térmico del Edificio, fueron:

Modelo 1:

$$
\text { kWh_E8 }=381.573,782-44.158,494 \times \text { T_min }
$$

Modelo 2:

$$
\text { kWh_E8 }=88.655,039-37.820,664 \times \text { T_min }+99.081,056 \times \text { V_viento_diurna }
$$

El resumen de los modelos, con los coeficientes de correlación de Pearson (R) y el coeficiente de determinación $\left(R^{2}\right)$ se muestra en la Tabla 112 y en la Tabla 113, el resultado de la verificación de los supuestos de la regresión lineal.

Tabla 112. Resumen de los modelos encontrados para el Edificio E8

\begin{tabular}{lccccc}
\hline & $\begin{array}{c}\text { Variables } \\
\text { independientes }\end{array}$ & Constante & B & $R^{2}$ \\
\hline E8_Modelo 1 & Tmin & $381.573,782$ & $-44.158,494$ & $-0,801$ & 0,641 \\
\hline E8_Modelo 2 & Tmin / V_diurna & $88.655,039$ & $-37.820,664 / 99.081,056$ & $-0,903$ & 0,816 \\
\hline
\end{tabular}

Tabla 113. Resumen del cumplimiento de los supuestos de regresión. Edificio E8

\begin{tabular}{lcc}
\hline Cumplimiento de supuestos de la regresión lineal & Modelo 1 & Modelo 2 \\
\hline 1. Linealidad de las variables & Cumple & Cumple \\
\hline 2. Normalidad de variables & Cumple & Cumple \\
\hline $\begin{array}{l}\text { 3. Independencia de los errores o no autocorrelación de } \\
\text { los residuos }\end{array}$ & Cumple & Cumple \\
\hline $\begin{array}{l}\text { 4. Homocedasticidad de la varianza, los errores son } \\
\text { aleatorios }\end{array}$ & Cumple & $\begin{array}{c}\text { No cumple. } \\
\text { Pequeña correlación en los } \\
\text { residuos y la velocidad del } \\
\text { viento diurna }\end{array}$ \\
\hline $\begin{array}{l}\text { 5. Falta de multicolinealidad entre las variables } \\
\text { independientes. }\end{array}$ & Cumple \\
\hline
\end{tabular}


En la Figura 134, se representan los consumos reales y los pronosticados con los modelos de regresión obtenidos, en $\mathrm{kWh}$.

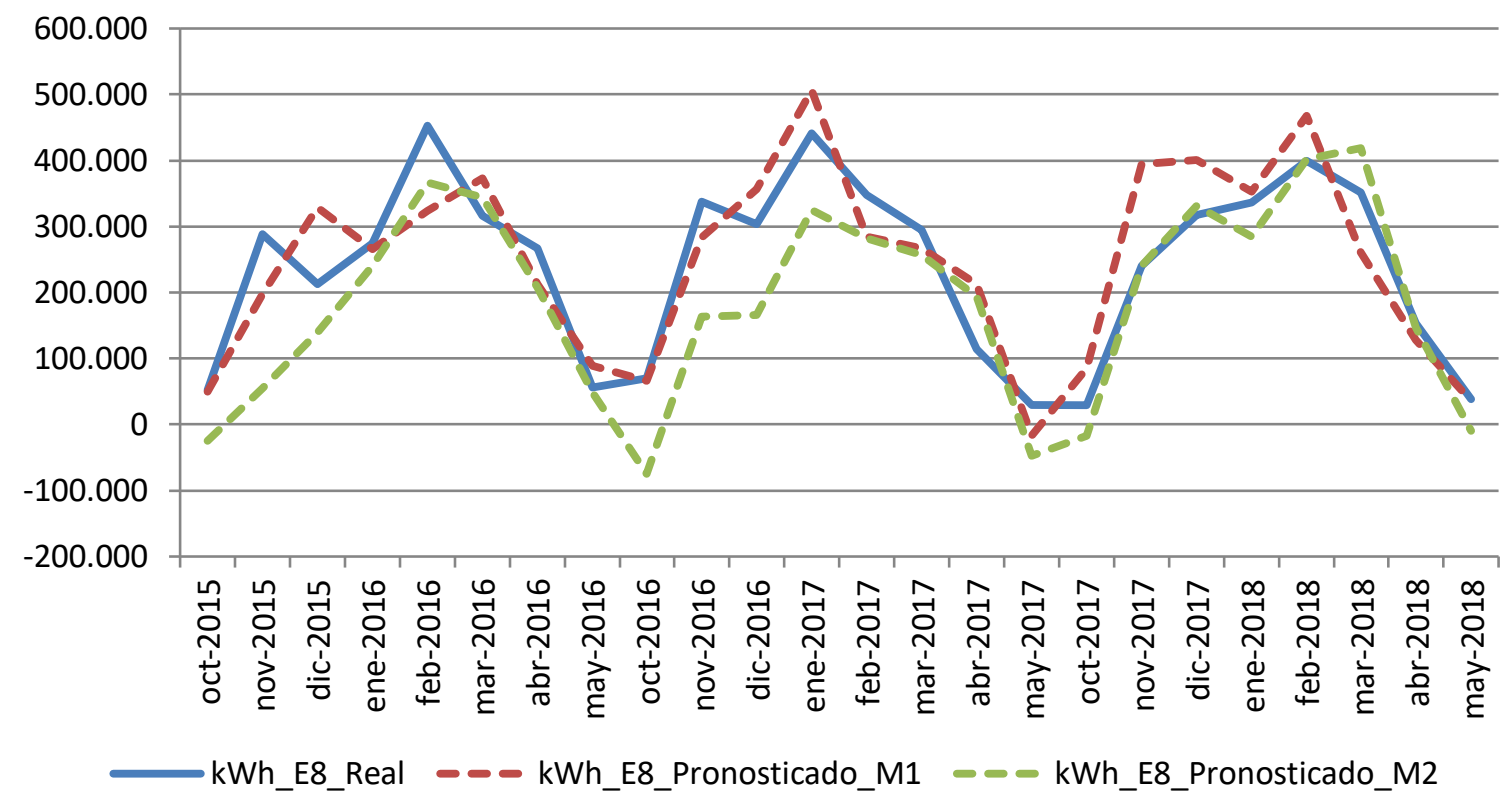

Figura 134. Representación de los consumos pronosticados para el Edificio E8. 2015-2018

Los resultados de las diferencias entre las medias de los consumos, se exponen en la Tabla 114

Tabla 114. Resultado de las diferencias significativas encontradas. Edificio E8

\begin{tabular}{ccccccccc}
\hline & $\begin{array}{c}\text { \% Diferencia } \\
2015-2016\end{array}$ & Significativo & $\begin{array}{c}\% \\
\text { Diferencia } \\
2016-2017\end{array}$ & Significativo & $\begin{array}{c}\% \\
\text { Diferencia } \\
2017-2018\end{array}$ & Significativo & $\begin{array}{c}\% \\
\text { Diferencia } \\
2015-2018\end{array}$ & Significativo \\
\hline E8_Modelo 1 & $-4,2 \%$ & No & $3,6 \%$ & No & $14,0 \%$ & No & $4,4 \%$ & No \\
\hline & & & & & & & Si, pero \\
modelo \\
E8_Modelo 2
\end{tabular}


En la Figura 135 se grafican los consumos reales y pronosticados para el periodo Octubre 2015 - Mayo 2018 para el Edificio E8, y las medias de dichos consumos.

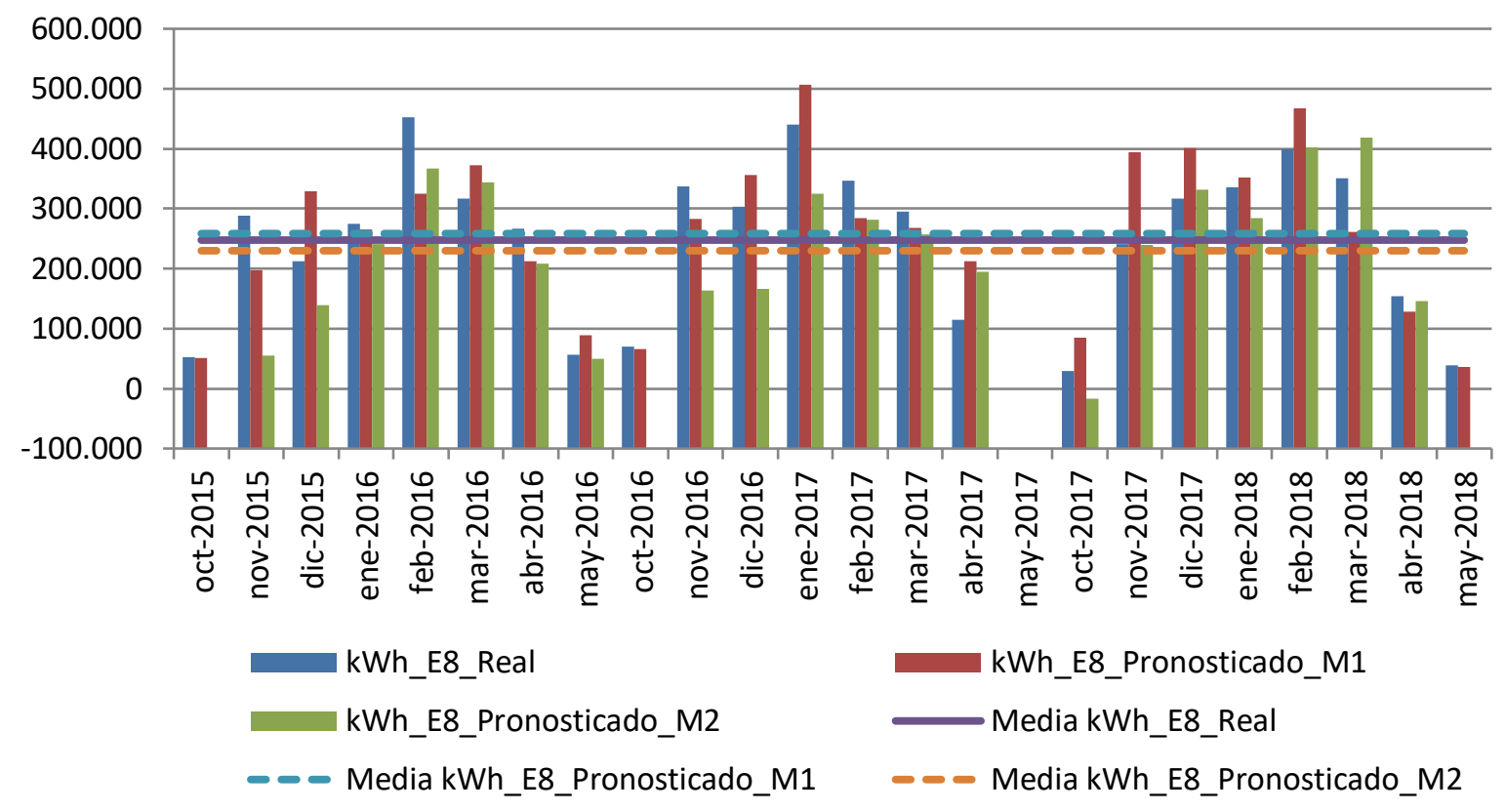

Figura 135. Consumos reales y pronosticados Octubre 2015-Mayo 2018. Edificio E8

En la Figura 136, se observa el consumo real del Edificio E8, en comparación con el consumo pronosticado acumulado con el Modelo 1 que es considerado válido, de haberse encontrado diferencias significaticvas y si el Edificio no se hubiera incorporado a la red de calor.

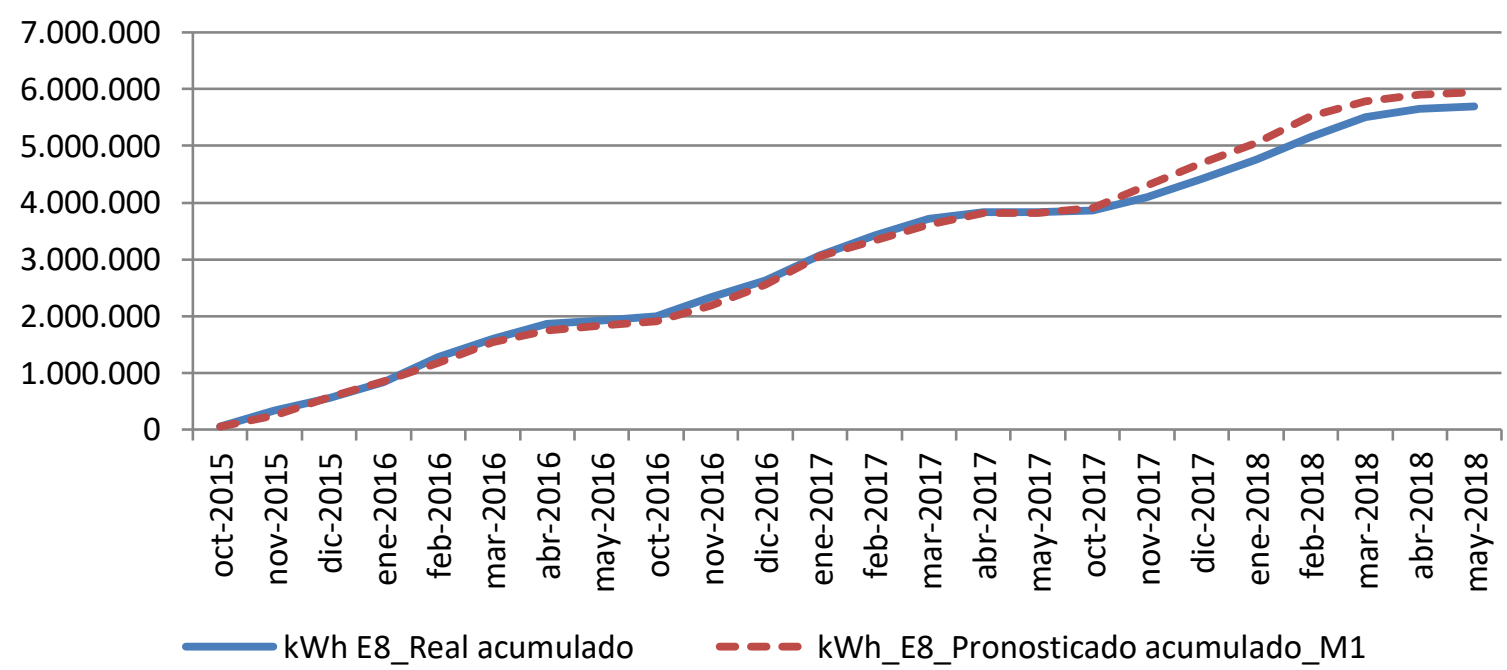

Figura 136. Consumo acumulado real y pronosticado. Octubre 2015-Mayo 2018. Edificio E8 
Los resultados del ahorro de consumos, emisiones y precio máximo de la energía útil comprada a la red para un ahorro económico del 15\%, se exponen en la Tabla 115

Tabla 115. Resumen de resultados. Edificio E8

Diferencia significativa encontrada entre las medias de los consumos 2015-2018.

Ahorro de consumo térmico durante las tres temporadas posteriores a la construcción de la red respecto a lo que se hubiera consumido de no ser por la red

Ahorro de emisiones de $\mathrm{CO}_{2}$ $88,6 \%$

$1.271 \mathrm{t} \mathrm{CO}_{2}$

Precio máximo de kWh útiles comprados a la red para obtener un

0,02778

$23.845 €$ ahorro del $15 \%$

$€ / \mathrm{kWh}$

$23.845 €$




\subsection{Edificio E13. Facultad de Económicas}

Edificio de tipo docente que empezó a funcionar en el año 1982, cuenta con una superficie construida de $17.776 \mathrm{~m}^{2}$. Inicialmente la calefacción era suministrada mediante dos calderas de gas natural de una potencia de $1.604 \mathrm{~kW}$. La subestación de intercambio con la red de calor construida en el año 2015, cuenta con una potencia de $1.624 \mathrm{~kW}$. En la Figura 137 se marca la ubicación del edificio.

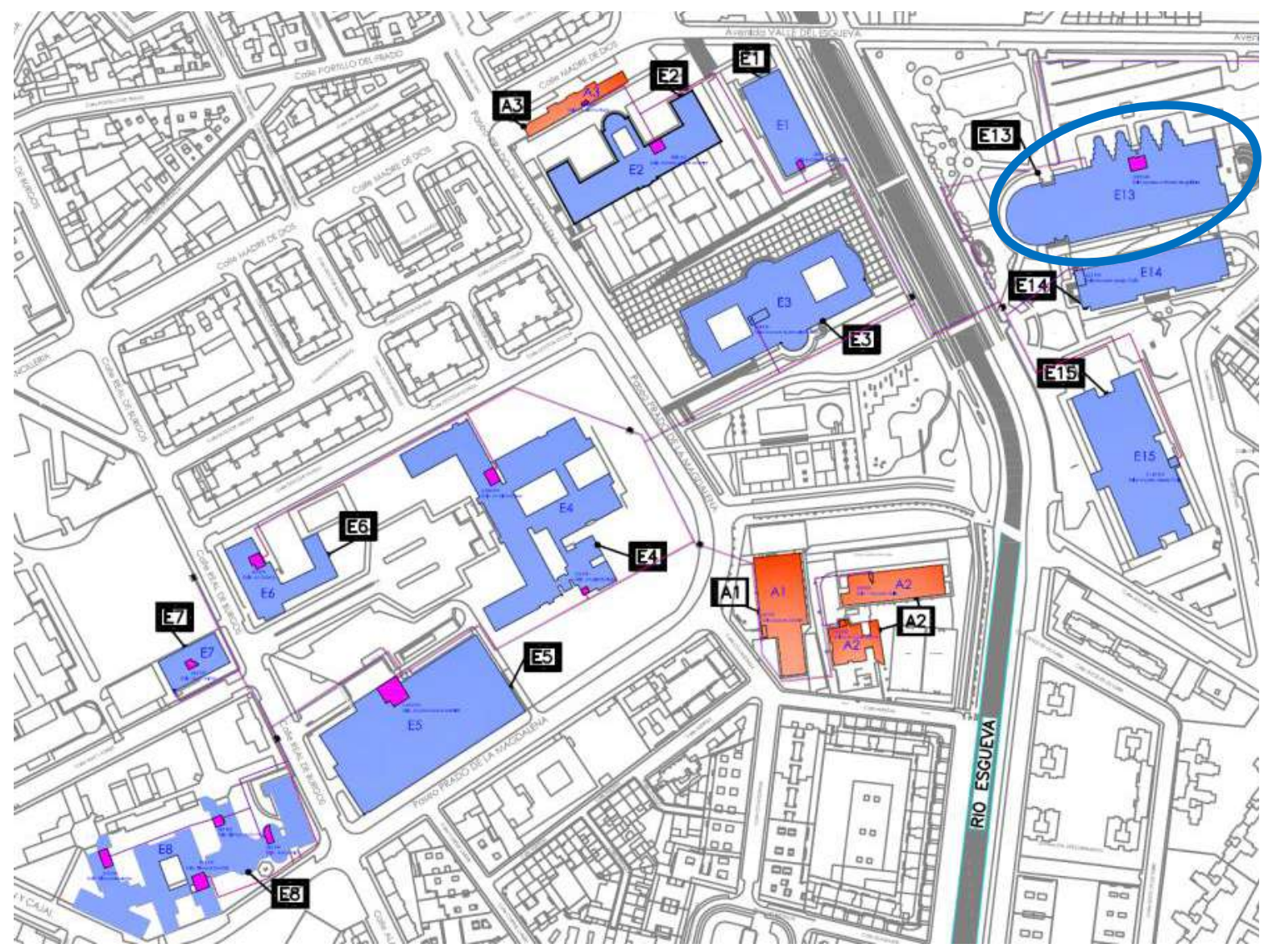

Figura 137. Ubicación del Edificio E13 en el croquis del campus Río Esgueva 
El modelo encontrado para predecir el consumo térmico del Edificio, fue

$$
\text { kWh_E13_Pronosticado }=461.136,517-21.706,507 \times \text { T_max }
$$

El resumen del modelo, con el coeficiente de correlación de Pearson $(R)$ y el coeficiente de determinación $\left(R^{2}\right)$ se muestra en la Tabla 116 y en la Tabla 117, el resultado de la verificación de los supuestos de la regresión lineal.

Tabla 116. Resumen de los modelos encontrados para el Edificio E13

\begin{tabular}{cccccr}
\hline & $\begin{array}{c}\text { Variable } \\
\text { independiente 1 }\end{array}$ & Constante & B & $R$ & $R^{2}$ \\
\hline E13 & $461.136,517$ & $-21.706,507$ & $-0,920$ & 0,847 & $461.136,517$ \\
\hline
\end{tabular}

Tabla 117. Resumen del cumplimiento de los supuestos de regresión. Edificio E13

\begin{tabular}{lc}
\hline \multicolumn{1}{c}{ Cumplimiento de supuestos de la regresión lineal } & Modelo \\
\hline 1. Linealidad de las variables & Cumple \\
\hline 2. Normalidad de variables & Cumple \\
\hline 3. Independencia de los errores o no autocorrelación de los residuos & Cumple $\left(^{*}\right)$ \\
\hline 4. Homocedasticidad de la varianza, los errores son aleatorios & Cumple \\
\hline
\end{tabular}

$\left({ }^{*}\right)$ Existe cierta correlación en los residuos

En la Figura 138, se representan el consumo real y el pronosticado con el modelo de regresión obtenido, en kWh.

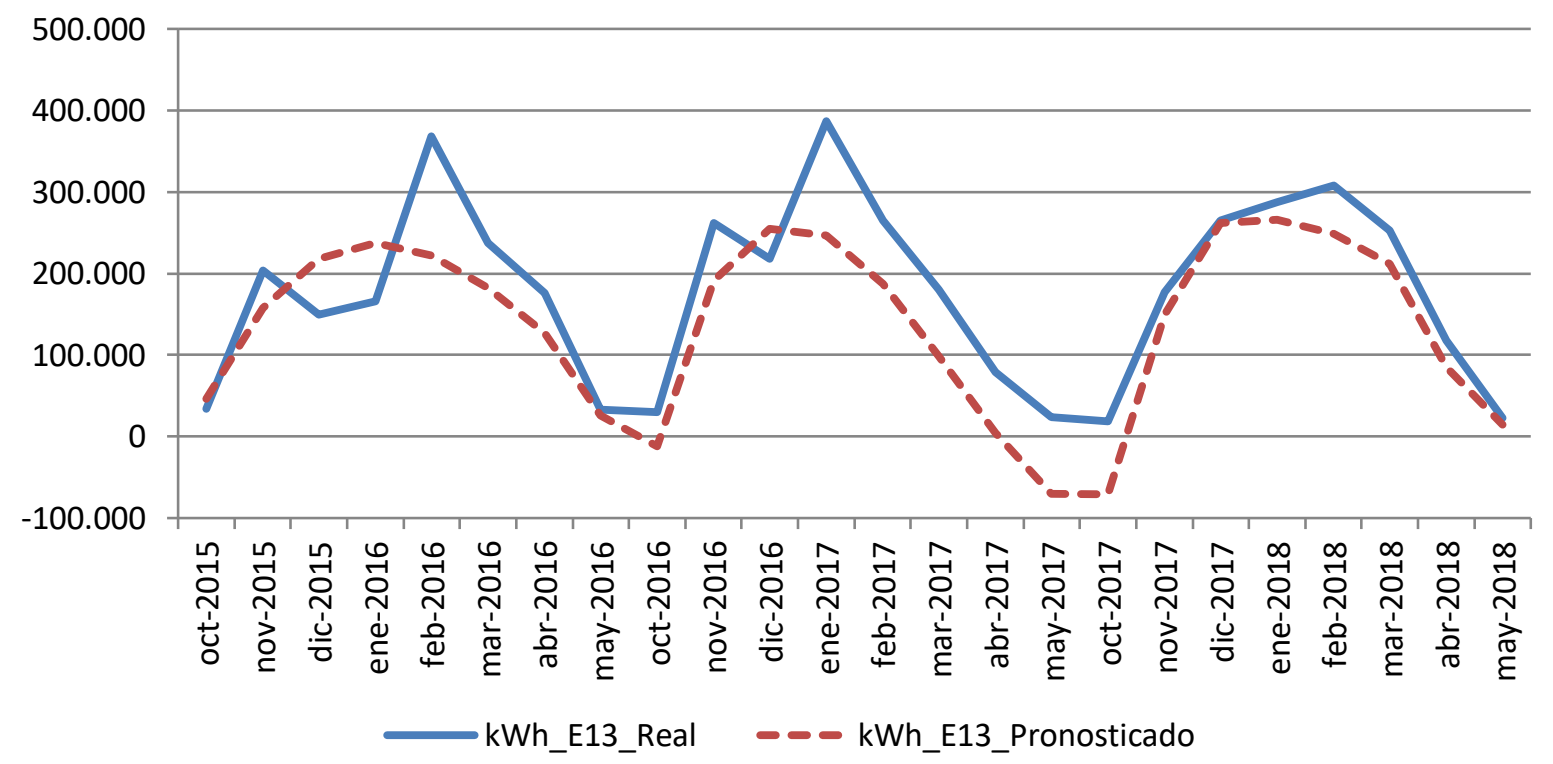

Figura 138. Representación de los consumos pronosticados para el Edificio E13. 2015-2018 
Los resultados de las diferencias entre las medias de los consumos, se exponen en la Tabla 118

Tabla 118. Resultado de las diferencias significativas encontradas. Edificio E6

\begin{tabular}{ccccccccc}
\hline & $\begin{array}{c}\% \\
\text { Diferencia } \\
2015-2016\end{array}$ & Significativo & $\begin{array}{c}\% \\
\text { Diferencia } \\
2016-2017\end{array}$ & Significativo & $\begin{array}{c}\% \\
\text { Diferencia } \\
2017-2018\end{array}$ & Significativo & $\begin{array}{c}\% \\
\text { Diferencia } \\
2015-2018\end{array}$ & Significativo \\
\hline E13 & $-11,0 \%$ & No & $-29,4 \%$ & SI & $-13,6 \%$ & SI & $-18,0 \%$ & $\begin{array}{c}\text { Pronosticos } \\
\text { no normal }\end{array}$ \\
\hline
\end{tabular}

En la Figura 139, se grafican los consumos reales y pronosticados para la temporada Octubre 2015 - Mayo 2018 para el Edificio E13, y las medias de dichos consumos. Según la prueba paramétrica realizada las diferencias encontradas no son estadísticamente significativas, por no haberse cumplido la hipótesis de normalidad de los pronósticos, con un riesgo a estar equivocados del $5 \%$

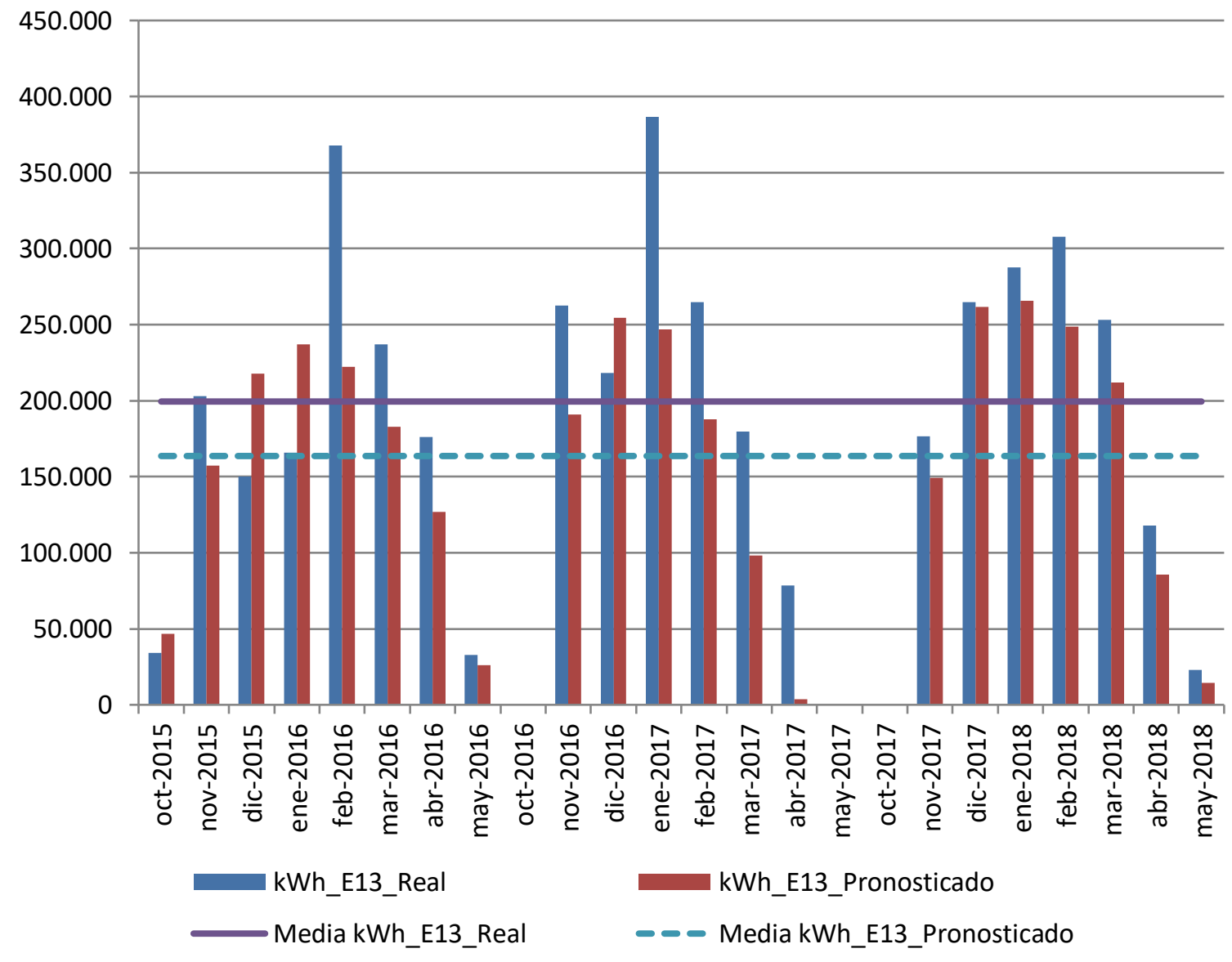

Figura 139. Consumos reales y pronosticados Octubre 2015-Mayo 2018. Edificio E13 
En la Figura 140, se observa el consumo real del Edificio E13, en comparación con el consumo pronosticado acumulado que hubiera tenido el Edificio de no haberse incorporado a la red de calor y de haberse producido diferencias significativas.

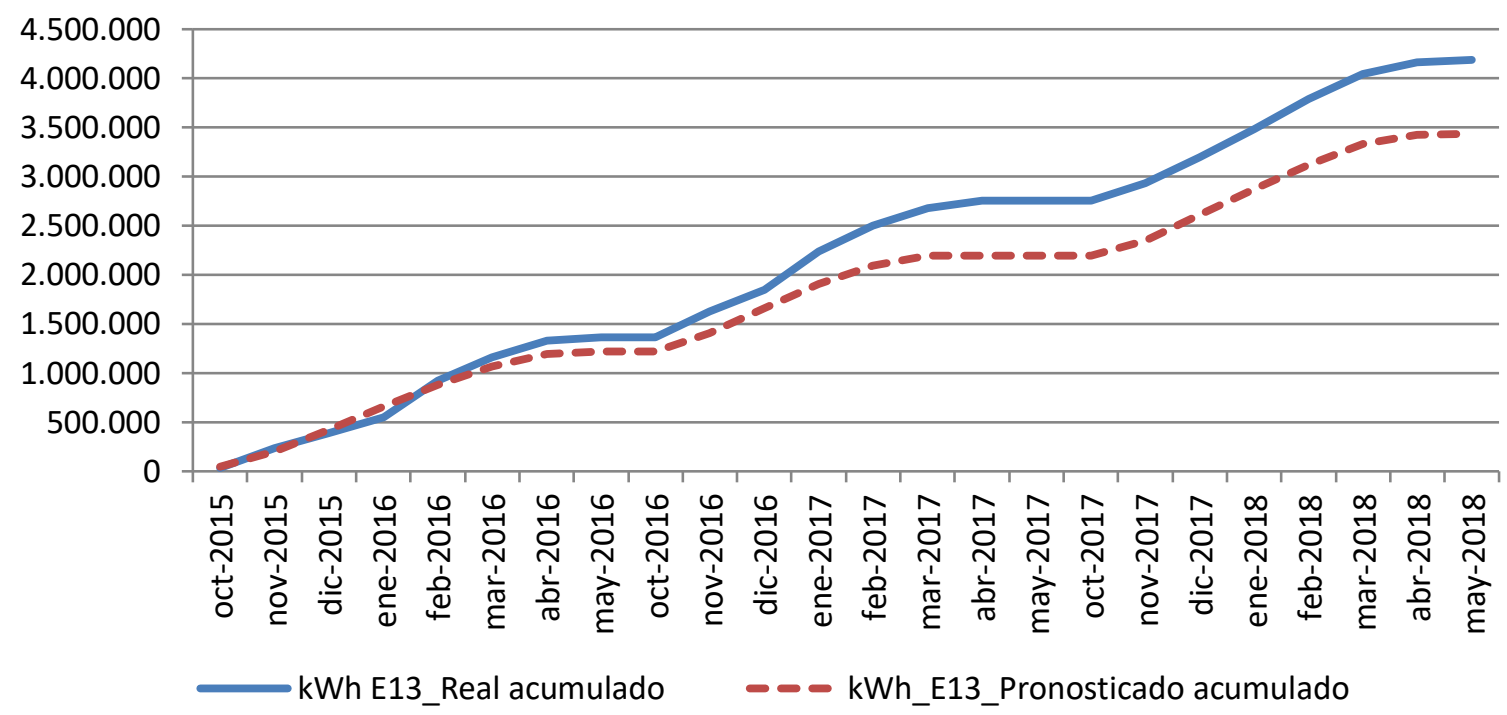

Figura 140. Consumo acumulado real y pronosticado. Octubre 2015-Mayo 2018. Edificio E13

Los resultados del ahorro de consumos, emisiones y precio máximo de la energía útil comprada a la red para un ahorro económico del 15\%, se exponen en la Tabla 119

Tabla 119. Resumen de resultados. Edificio E13

\begin{tabular}{lll}
\hline $\begin{array}{l}\text { Diferencia significativa encontrada entre las medias de los } \\
\text { consumos 2015-2018 }\end{array}$ & - \\
\hline $\begin{array}{l}\text { Ahorro de consumo térmico durante las tres temporadas } \\
\text { posteriores a la construcción de la red respecto a lo que se hubiera } \\
\text { consumido de no ser por la red }\end{array}$ & - & \\
\hline Ahorro de emisiones de $\mathrm{CO}_{2}$ & $87,2 \%$ & $920 \mathrm{t} \mathrm{CO}_{2}$ \\
\hline $\begin{array}{l}\text { Precio máximo de kWh útiles comprados a la red para obtener un } \\
\text { ahorro del } 15 \%\end{array}$ & $\begin{array}{c}0,02740 \\
£ / \mathrm{kWh}\end{array}$ & $17.590 €$ \\
\hline
\end{tabular}




\subsection{Edificio E14. Aulario del Campus Esgueva}

Edificio de tipo docente que empezó a funcionar en el año 1986, cuenta con una superficie construida de $7.569 \mathrm{~m}^{2}$. Inicialmente la calefacción era suministrada mediante dos calderas de gasóleo de una potencia de $407 \mathrm{~kW}$. La subestación de intercambio con la red de calor construida en el año 2015, cuenta con una potencia de 425 kW. En la Figura 141 se marca la ubicación del edificio.

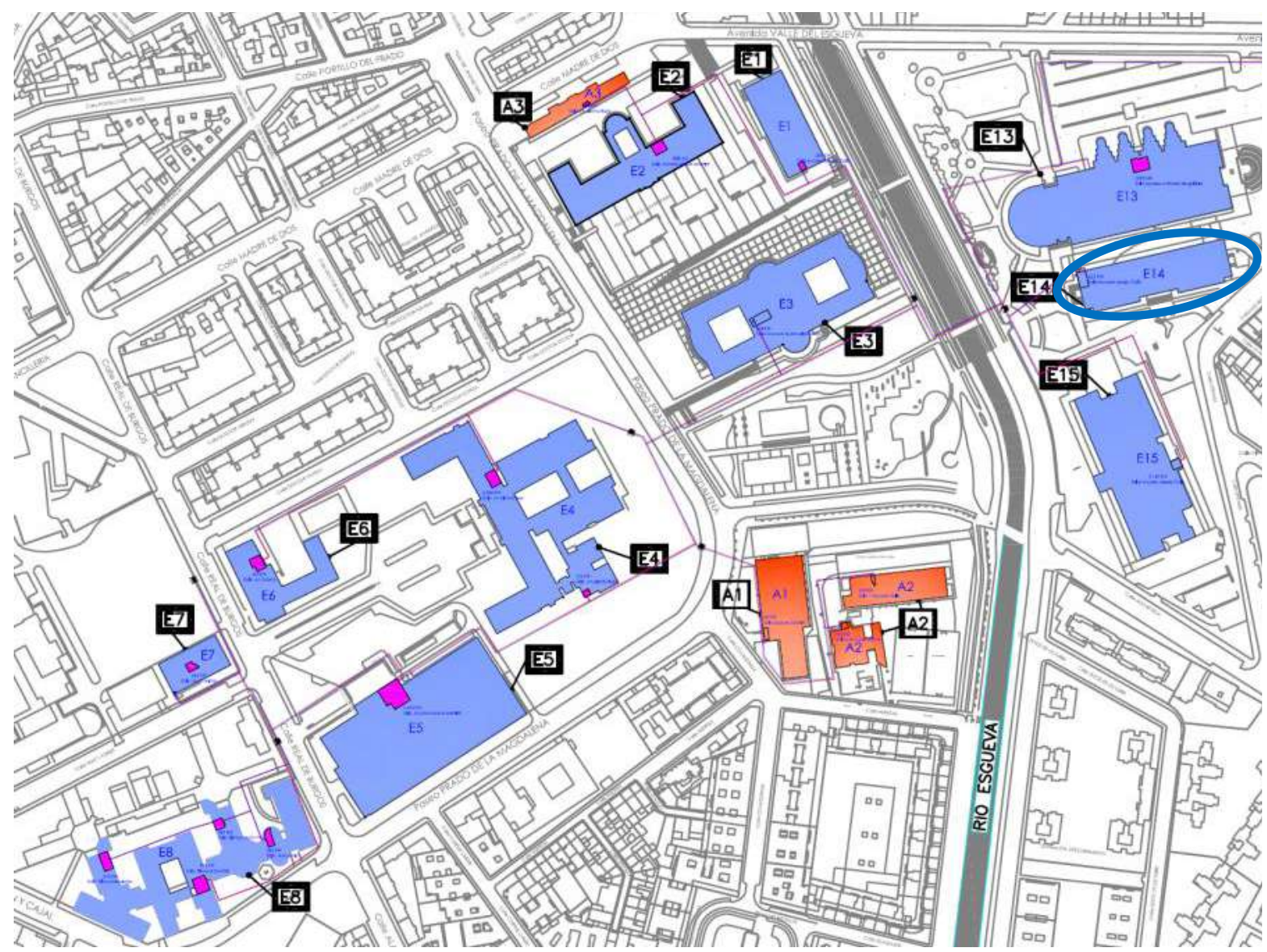

Figura 141. Ubicación del Edificio E14 en el croquis del campus Río Esgueva 
El modelo encontrado para predecir el consumo térmico del Edificio, fue

$\mathrm{kWh}$ _E14_Pronosticado $=-24.047,456+184,862 \times$ GD20_24h

El resumen del modelo, con el coeficiente de correlación de Pearson $(R)$ y el coeficiente de determinación $\left(R^{2}\right)$ se muestra en la Tabla 120 y en la Tabla 121 , el resultado de la verificación de los supuestos de la regresión lineal.

Tabla 120. Resumen de los modelos encontrados para el Edificio E14

\begin{tabular}{cccccc}
\hline & $\begin{array}{c}\text { Variable } \\
\text { independiente 1 }\end{array}$ & Constante & B & $\mathrm{R}$ & $\mathrm{R}^{2}$ \\
\hline E14 & GD20_24h & $-24.047,456$ & 184,862 & 0,923 & 0,853 \\
\hline
\end{tabular}

Tabla 121. Resumen del cumplimiento de los supuestos de regresión. Edificio E14

\begin{tabular}{ll}
\hline \multicolumn{1}{c}{ Cumplimiento de supuestos de la regresión lineal } & Modelo \\
\hline 1. Linealidad de las variables & Cumple \\
\hline 2. Normalidad de variables & Cumple \\
\hline 3. Independencia de los errores o no autocorrelación de los residuos & Cumple \\
\hline 4. Homocedasticidad de la varianza, los errores son aleatorios & Cumple \\
\hline
\end{tabular}

En la Figura 142, se representan el consumo real y el pronosticado con el modelo de regresión obtenido, en kWh.

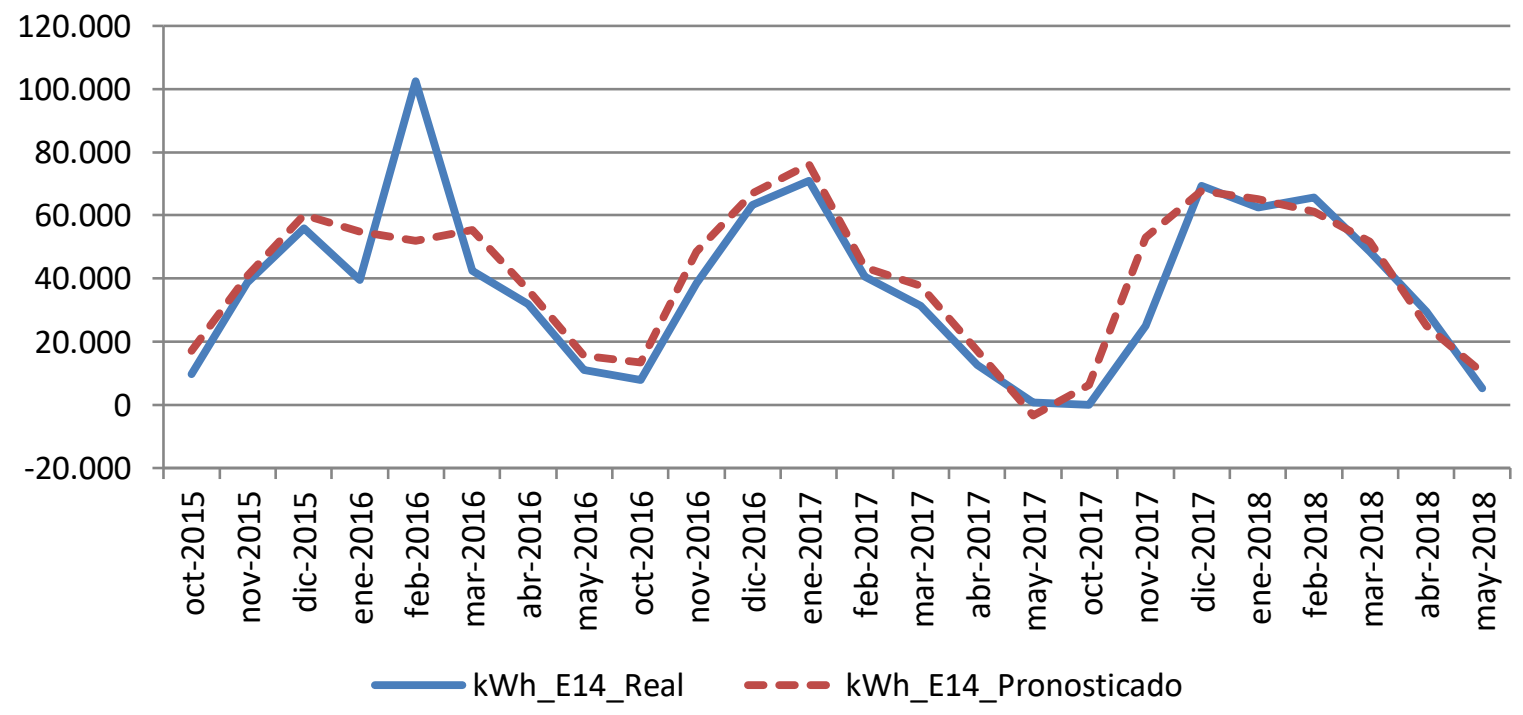

Figura 142. Representación de los consumos pronosticados para el Edificio E14. 2015-2018 
Los resultados de las diferencias entre las medias de los consumos, se exponen en la Tabla 122

Tabla 122. Resultado de las diferencias significativas encontradas. Edificio E14

\begin{tabular}{cccccccccc}
\hline & $\begin{array}{c}\% \\
\text { Diferencia } \\
2015-2016\end{array}$ & Significativo & $\begin{array}{c}\% \\
\text { Diferencia } \\
2016-2017\end{array}$ & Significativo & $\begin{array}{c}\% \\
\text { Diferencia } \\
2017-2018\end{array}$ & Significativo & $\begin{array}{c}\% \\
\text { Diferencia } \\
2015-2018\end{array}$ & Significativo \\
\hline E14 & $0,1 \%$ & No & $14,4 \%$ & SI & $11,4 \%$ & No & $8,1 \%$ & No \\
\hline
\end{tabular}

En la Figura 143, se grafican los consumos reales y pronosticados para la temporada Octubre 2015 - Mayo 2018 para el Edificio E14, y las medias de dichos consumos. Según la prueba paramétrica realizada las diferencias encontradas no son estadísticamente significativas, con un riesgo a estar equivocados del $5 \%$

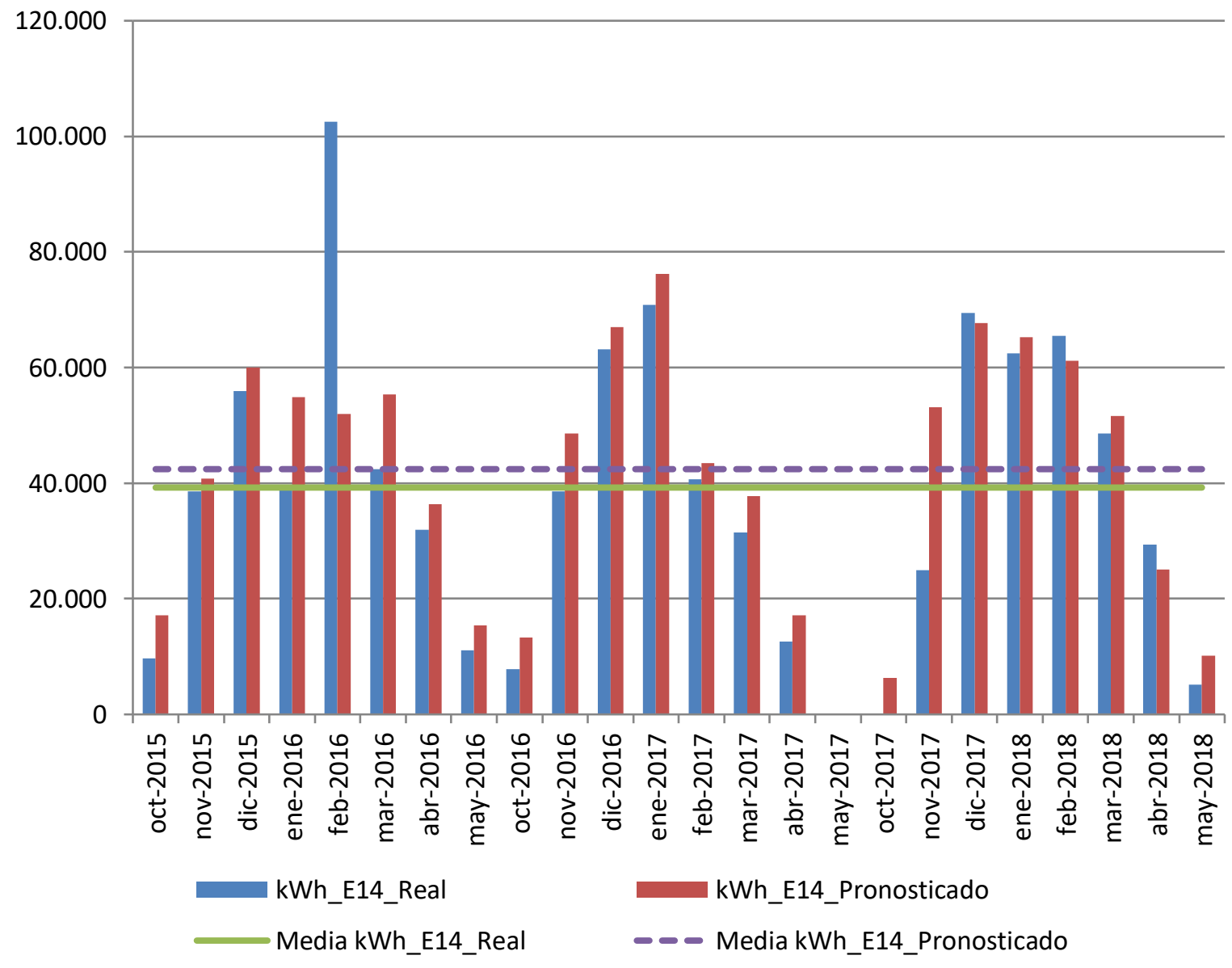

Figura 143. Consumos reales y pronosticados Octubre 2015-Mayo 2018. Edificio E14 
En la Figura 144, se observa el consumo real del Edificio E14, en comparación con el consumo pronosticado acumulado que hubiera tenido el Edificio de no haberse incorporado a la red de calor y de haberse detectado diferencias significativas.

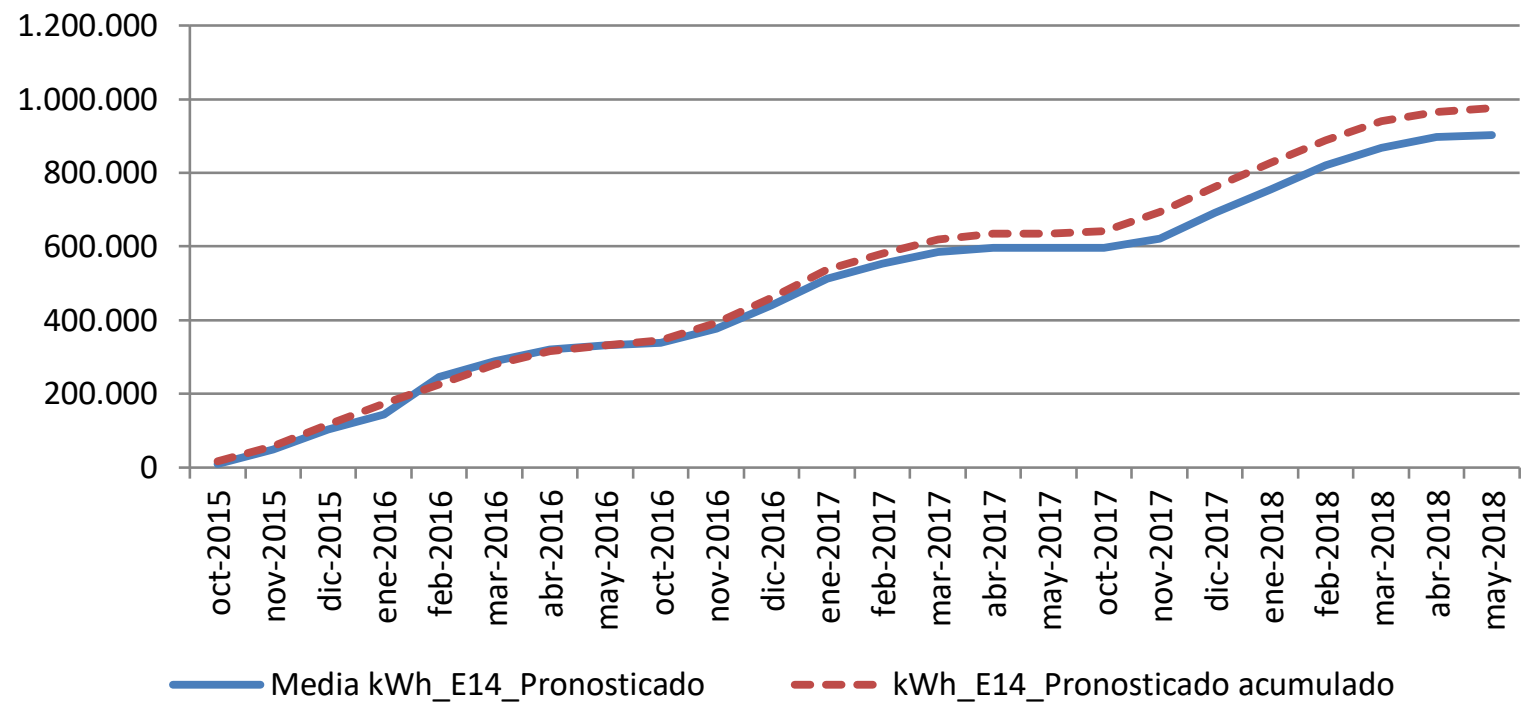

Figura 144. Consumo acumulado real y pronosticado. Octubre 2015-Mayo 2018. Edificio E14

Los resultados del ahorro de consumos, emisiones y precio máximo de la energía útil comprada a la red para un ahorro económico del 15\%, se exponen en la Tabla 123

Tabla 123. Resumen de resultados. Edificio E14

Diferencia significativa encontrada entre las medias de los consumos 2015-2018

Ahorro de consumo térmico durante las tres temporadas posteriores a la construcción de la red respecto a lo que se hubiera consumido de no ser por la red

Ahorro de emisiones de $\mathrm{CO}_{2}$ $86,8 \%$ $244 \mathrm{t} \mathrm{CO}_{2}$ Precio máximo de kWh útiles comprados a la red para obtener un ahorro del $15 \%$

$0,0427 € / k W h \quad 5.793 €$




\subsection{Edificio E15. Escuela de Ingenierías Industriales (sede Paseo del Cauce)}

Edificio de tipo docente que empezó a funcionar en el año 1985, cuenta con una superficie construida de $18.512 \mathrm{~m}^{2}$. Inicialmente la calefacción era suministrada mediante cuatro calderas de gas natural de una potencia total de $2.324 \mathrm{~kW}$. La subestación de intercambio con la red de calor construida en el año 2015, cuenta con una potencia de $2.160 \mathrm{~kW}$. En la Figura 145 se marca la ubicación del edificio.

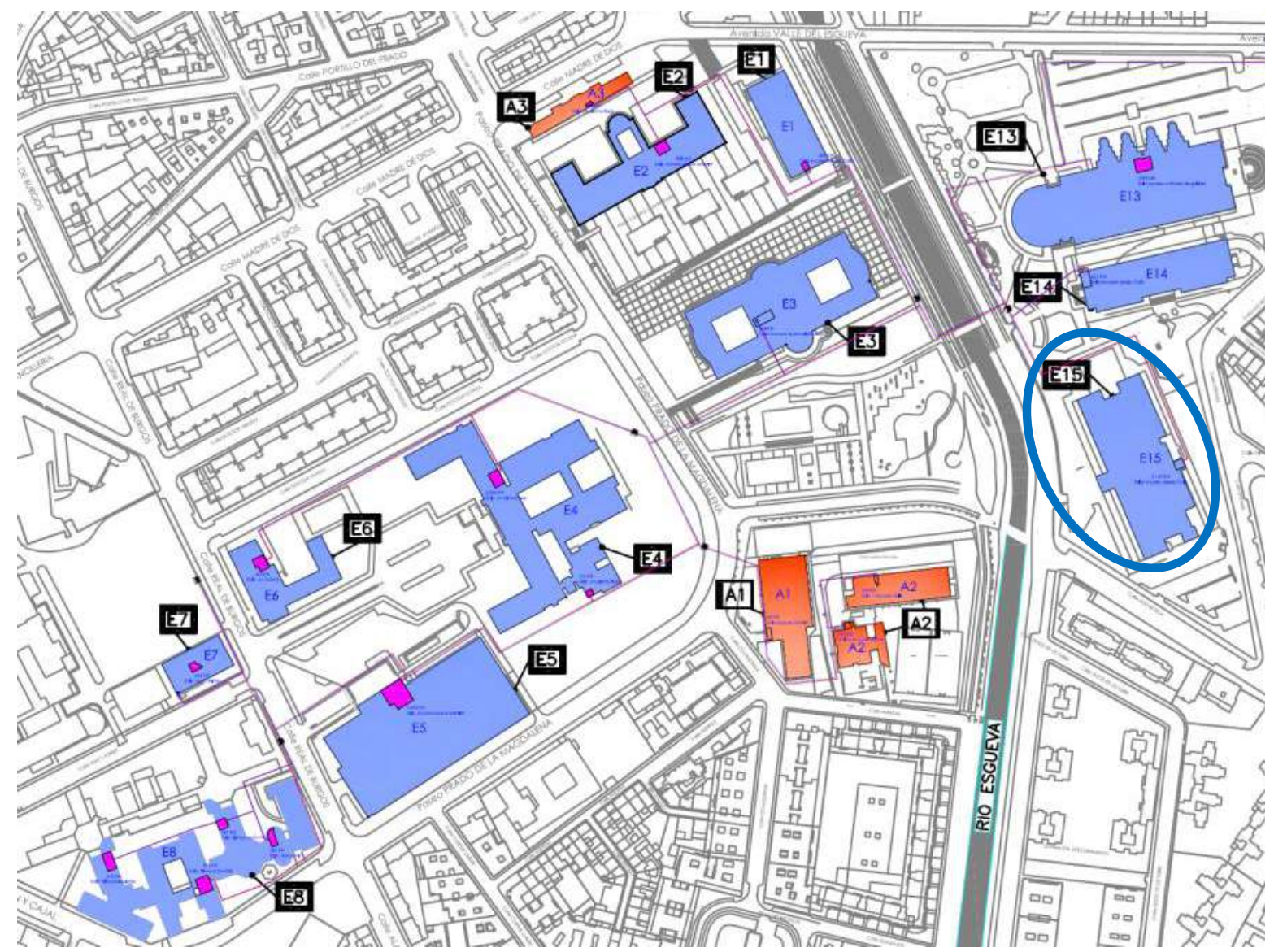

Figura 145. Ubicación del Edificio E15 en el croquis del campus Río Esgueva 
Los modelos encontrados para predecir el consumo térmico del Edificio, fueron:

Modelo 1: $\quad$ kWh_E15 $=417.713,362-29.001,808 \times$ T_med (No aceptado)

Modelo 2: kWh_E15 $=299.729,447-28.070,125$ x T_med $+15.392,005$ x V_viento_max

El resumen de los modelos, con los coeficientes de correlación de Pearson (R) y el coeficiente de determinación $\left(R^{2}\right)$ se muestra en la Tabla 124 y en la Tabla 125, el resultado de la verificación de los supuestos de la regresión lineal.

Tabla 124. Resumen de los modelos encontrados para el Edificio E15

\begin{tabular}{lccrrr} 
& $\begin{array}{c}\text { Variables } \\
\text { independientes }\end{array}$ & Constante & B & $R^{2}$ \\
\hline E15_Modelo 1 & Tmed & $417.713,362$ & $-29.001,808$ & $-0,947$ & 0,896 \\
\hline E15_Modelo 2 & Tmed / V_max & $299.729,447$ & $-28.070,125 / 15.392,005$ & $-0,962$ & 0,925 \\
\hline
\end{tabular}

Tabla 125. Resumen del cumplimiento de los supuestos de regresión. Edificio E15

\begin{tabular}{lcc}
\hline \multicolumn{1}{c}{ Cumplimiento de supuestos de la regresión lineal } & Modelo 1 & Modelo 2 \\
\hline 1. Linealidad de las variables & Cumple & Cumple \\
\hline 2. Normalidad de variables & Cumple & Cumple \\
\hline 3. Independencia de los errores o no autocorrelación de los residuos & No Cumple & Cumple \\
\hline 4. Homocedasticidad de la varianza, los errores son aleatorios & Cumple & Cumple \\
\hline 5. Falta de multicolinealidad entre las variables independientes. & & Cumple \\
\hline
\end{tabular}

En la Figura 146, se representan los consumos reales y los pronosticados con los modelos de regresión obtenidos, en $\mathrm{kWh}$, aunque el Modelo 1 ha sido rechazado, por no cumplir todos los supuestos de la regresión lineal.

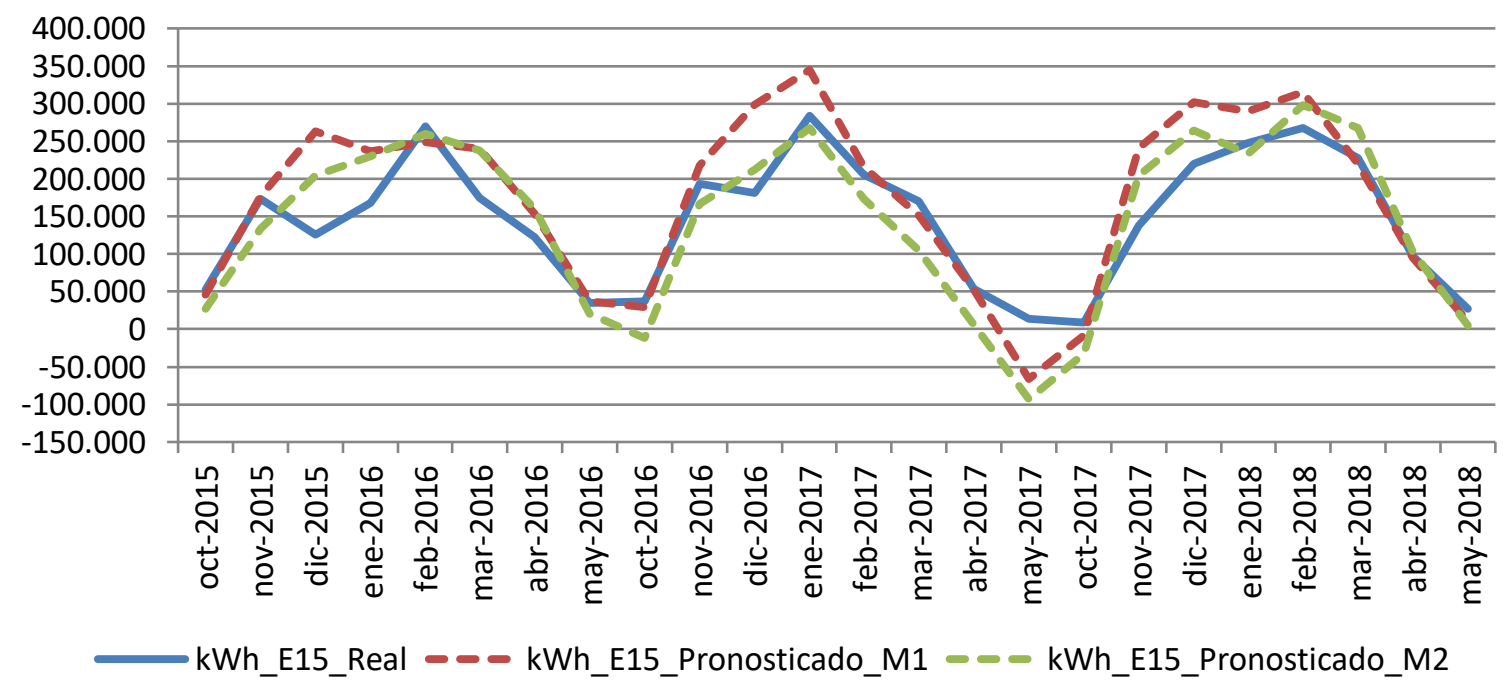

Figura 146. Representación de los consumos pronosticados para el Edificio E15. 2015-2018 
Los resultados de las diferencias entre las medias de los consumos, se exponen en la Tabla 126

Tabla 126. Resultado de las diferencias significativas encontradas. Edificio E15

\begin{tabular}{ccccccccc}
\hline & $\begin{array}{c}\text { \% Diferencia } \\
2015-2016\end{array}$ & Significativo & $\begin{array}{c}\% \\
\text { Diferencia } \\
2016-2017\end{array}$ & Significativo & $\begin{array}{c}\% \\
\text { Diferencia } \\
2017-2018\end{array}$ & Significativo & $\begin{array}{c}\% \\
\text { Diferencia } \\
2015-2018\end{array}$ & Significativo \\
\hline $\begin{array}{c}\text { E15_Modelo } \\
2\end{array}$ & $4,2 \%$ & No & $-14,4 \%$ & No & $12,4 \%$ & No & $4,2 \%$ & $\begin{array}{c}\text { Pronosticos } \\
\text { no normal }\end{array}$ \\
\hline
\end{tabular}

En la Figura 147 se grafican los consumos reales y pronosticados para el periodo Octubre 2015 - Mayo 2018 para el Edificio E15, y las medias de dichos consumos.

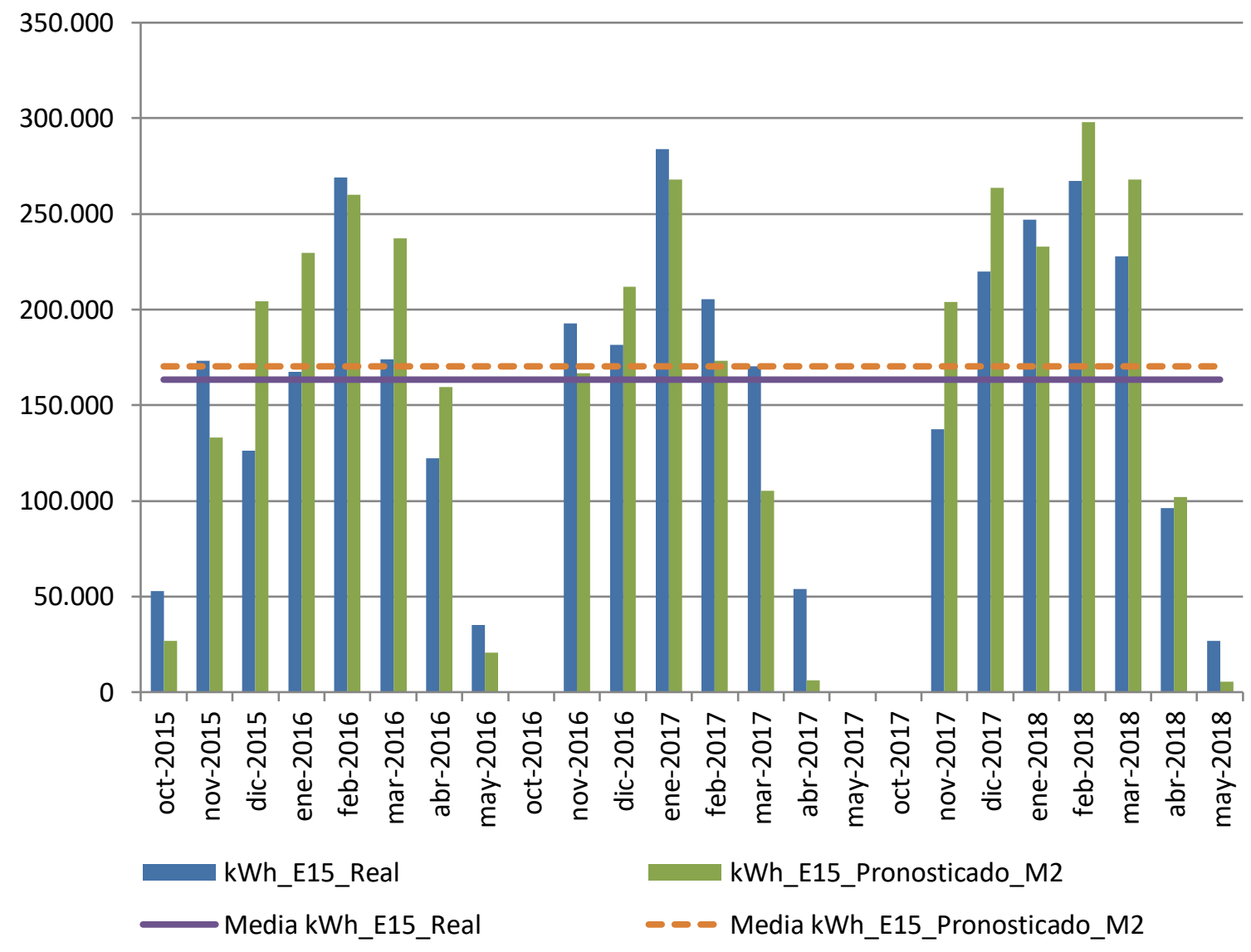

Figura 147. Consumos reales y pronosticados Octubre 2015-Mayo 2018. Edificio E15 
En la Figura 148, se observa el consumo real del Edificio E15, en comparación con el consumo pronosticado acumulado con el Modelo 2, si se hubieran detectado diferencias y si el Edificio no se hubiera incorporado a la red de calor.

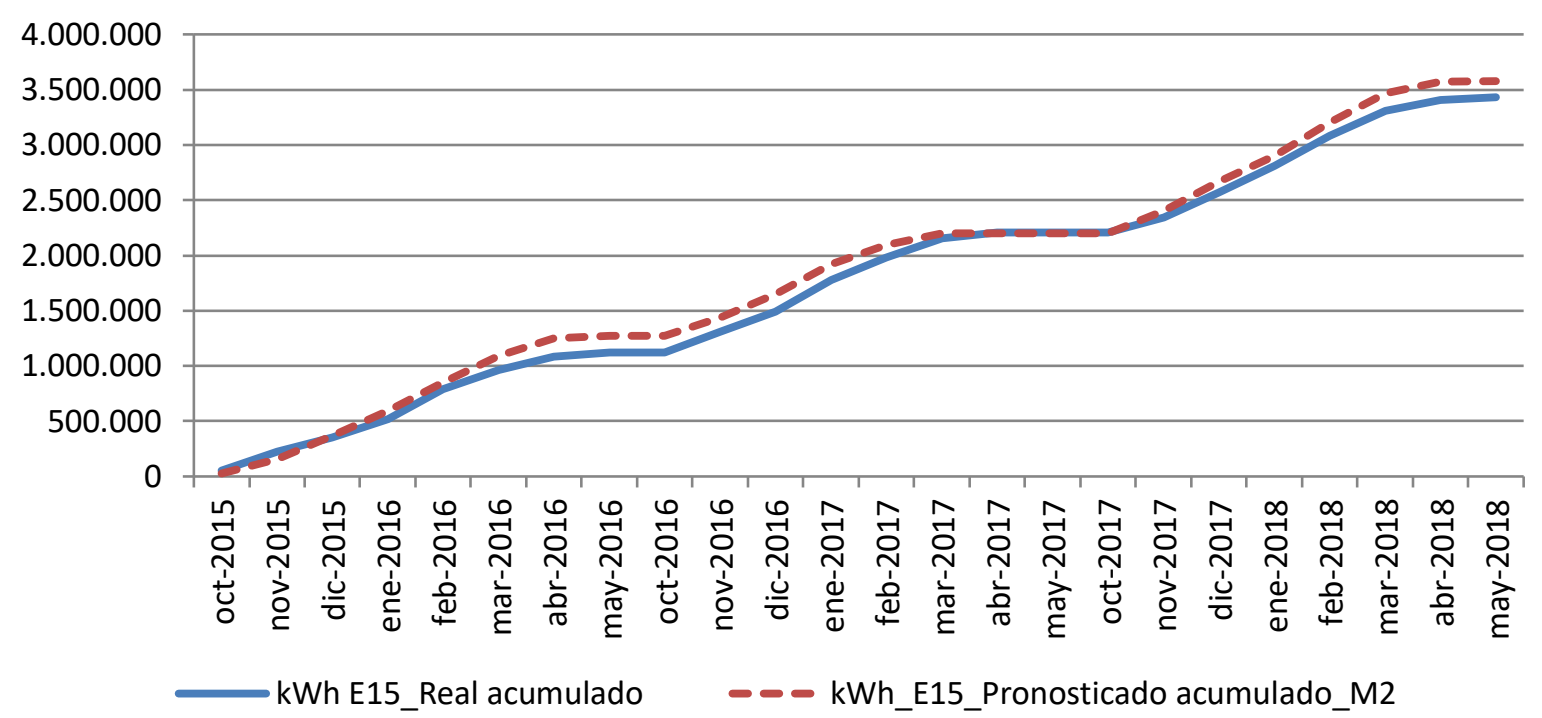

Figura 148. Consumo acumulado real y pronosticado. Octubre 2015-Mayo 2018. Edificio E15

Los resultados del ahorro de consumos, emisiones y precio máximo de la energía útil comprada a la red para un ahorro económico del 15\%, se exponen en la Tabla 127

Tabla 127. Resumen de resultados. Edificio E15

Diferencia significativa encontrada entre las medias de los consumos 2015-2018. Utilizando el Modelo 2 (por ser el de mayor coeficiente de correlación)

Ahorro de consumo térmico durante las tres temporadas posteriores a la construcción de la red respecto a lo que se hubiera consumido de no ser por la red

\begin{tabular}{lcc}
\hline Ahorro de emisiones de $\mathrm{CO}_{2}$ & $88,0 \%$ & $761 \mathrm{t} \mathrm{CO} 2$ \\
\hline $\begin{array}{l}\text { Precio máximo de kWh útiles comprados a la red para obtener un } \\
\text { ahorro del } 15 \%\end{array}$ & $\begin{array}{c}0,02753 \\
€ / \mathrm{kWh}\end{array}$ & $14.424 €$ \\
\hline
\end{tabular}




\subsection{Resultados y discusión}

En la Tabla 128 se muestran los modelos de línea base encontrados para los 11 edificios del Campus Río Esgueva. Para todos los edificios, excepto para el E15, se obtuvieron modelos válidos de regresión simple y para tres de ellos, además se hallaron modelos de regresión multivariable, recopilados en la Tabla 129. La regresión múltiple encontrada para el Edificio E8, no resultó válida por existir correlación entre los residuos y la variable independiente V_diurna.

Seis de los modelos de regresión simple (54,5\%), tuvieron como variable independiente la Temperatura (tres, la temperatura mínima, dos la temperatura media y uno la temperatura máxima), los cuatro restantes $(36,4 \%)$, tuvieron a los Grados día como varibale independiente (dos en Base 15 obtenidos con datos cada 30 minutos, y dos en Base 20 obtenidos con datos diarios). El resto de las variables climáticas analizadas no mostraron influencias significativas en el consumo de los edificios de manera lineal.

Tabla 128. Resumen de modelos de regresión simple. Campus Río Esgueva

\begin{tabular}{clrrrr}
\hline Edificio & Variable independiente & \multicolumn{1}{c}{ Constante } & \multicolumn{1}{c}{ B } & \multicolumn{1}{c}{$\mathrm{R}$} & \multicolumn{1}{c}{$\mathrm{R}^{2}$} \\
\hline E1 & GD20_24h & $-97,801$ & 44,252 & 0,655 & 0,429 \\
\hline E2 & T_min & $83.663,793$ & $-7.896,580$ & $-0,819$ & 0,671 \\
\hline E3 & T_min & $219.817,236$ & $-26.412,480$ & $-0,918$ & 0,843 \\
\hline E4 & T_med & $234.879,945$ & $-16.850,392$ & $-0,909$ & 0,826 \\
\hline E5 & GD15_30min & $29.320,001$ & 816,043 & 0,857 & 0,734 \\
\hline E6 & T_med & $99.745,107$ & $-5.510,824$ & $-0,939$ & 0,883 \\
\hline E7 & GD15_30min & $-437,414$ & 109,126 & 0,925 & 0,855 \\
\hline E8 & T_min & $381.573,782$ & $-44.158,494$ & $-0,801$ & 0,641 \\
\hline E13 & T_max & $461.136,517$ & $-21.706,507$ & $-0,920$ & 0,847 \\
\hline E14 & GD20_24h & $-24.047,456$ & 184,862 & 0,923 & 0,853 \\
\hline E15 (*) & T_med & $417.713,362$ & $-29.001,808$ & $-0,947$ & 0,896 \\
\hline
\end{tabular}

$(*)$. Modelo no válido por existir autocorrelación en los residuos. Los residuos no son independientes

Tabla 129. Resumen de modelos de regresión múltiple. Campus Río Esgueva

\begin{tabular}{cccccccc}
\hline & $\begin{array}{c}\text { Variable } \\
\text { independiente } \\
1\end{array}$ & $\begin{array}{c}\text { Variable } \\
\text { independiente } \\
2\end{array}$ & Constante & B1 & B2 & $R$ & $R^{2}$ \\
\hline E3 & T_min & V_diurna & $130.691,591$ & $-24.484,085$ & $30.147,142$ & $-0,950$ & 0,902 \\
\hline E8 $\left(^{* *}\right)$ & T_min & V_diurna & $88.655,039$ & $-37.820,664$ & $99.081,056$ & $-0,903$ & 0,816 \\
\hline E15 & T_med & V_max & $299.729,447$ & $-28.070,125$ & $15.392,005$ & $-0,962$ & 0,925 \\
\hline
\end{tabular}

$(* *)$ Modelo no válido. No hay homocedasticidad de la varianza. Existe correlación entre los residuos y V_durna. 
Los dos modelos válidos encontrados de regresión múltiple correlacionaron con la Temperatura (mínima en un caso y media en el otro) y con la velocidad del viento, en el Edificio E3, con la velocidad del viento diurna y en el Edificio E15, con la velocidad del viento máxima. En estos modelos el resto de las variables climáticas tampoco mostraron correlaciones significativas. Los modelos de regresión múltiple presentan mejores coeficientes de correlación y determinación que los modelos de regresión simple para el mismo edificio.

Con excepción del Edificio E1, donde el coeficiente de correlación es de 0,655 y el coeficiente de determinación de 0,429 , los modelos encontrados tienen un coeficiente de correlación superior a 0,80 en valor absoluto, siendo positivo para los modelos con los Grados día y negativo para los modelos con la Temperatura. El coeficiente de determinación es superior a 0,64, por lo que con los modelos encontrados se puede predecir más del $64 \%$ de los consumos futuros con un error del $5 \%$.

En cuanto a las diferencias entre los consumos reales de las tres temporadas posteriores a la construcción de la red de calor y los consumos estimados o pronosticados que se hubieran obtenido en esas mismas temporadas si los edificios no se hubieran unido a la red de calor, como se muestra en la Tabla 130, se han obtenido diferencias significativas en 4 de los 11 edificios (36,4\%), en 3 de los cuales las diferencias fueron positivas (se obtuvo ahorros energéticos con la incorporación a la red) y en el otro las diferencias encontradas fueron negativas, se obtuvo aumentos de consumo.

Los edificios que han obtenido ahorros significativos son:

- E1: Edificio del Servicio de Mantenimiento, cuyo horario de funcionamiento se identifica a los edificios de tipo docente, con $1.681 \mathrm{~m}^{2}$ construidos, una potencia inicial instalada de $291 \mathrm{~kW}$, en caldera de gasóleo, con 75 años de antigüedad hasta el 2015, un ratio de $150 \mathrm{kWh} / \mathrm{m}^{2}$ en el total de octubre 2012 a mayo $2014 \mathrm{y}$ 868 horas de funcionamiento a carga nominal de las calderas durante ese periodo. Diferencia del $82,8 \%$ en las tres temporadas posteriores a la red de calor

- E3: Faculdad de Filosofía y Letras, de tipo docente, con $21.709 \mathrm{~m}^{2}$ construidos, una potencia inicial instalada de $930 \mathrm{~kW}$, en calderas de gas natural, con 18 años de antigüedad hasta el 2015, de $101 \mathrm{kWh} / \mathrm{m}^{2}$ en el total de octubre 2012 a mayo 2014 y 2.369 horas de funcionamiento a carga nominal de las calderas durante ese periodo. Diferencia del $29,9 \%$ en las tres temporadas posteriores a la red de calor

- E5: Edificio Alfonso VIII, de tipo residencial, con $20.016 \mathrm{~m}^{2}$ construidos, una potencia inicial instalada de $4.943 \mathrm{~kW}$, con calderas de gasóleo, con 24 años de antigüedad hasta el 2015, de $168 \mathrm{kWh} / \mathrm{m}^{2}$ en el total de octubre 2012 a mayo 2014 y 680 horas de funcionamiento a carga nominal de las calderas durante ese periodo. Diferencia del $23,2 \%$ en las tres temporadas posteriores a la red de calor. 
El edificio que ha obtenido un aumento significativo en su consumo térmico ha sido:

- E6: Edificio Colegio Mayor Femenino Santa Cruz, de tipo residencial, con $6.660 \mathrm{~m}^{2}$ construidos, una potencia inicial instalada de $716 \mathrm{~kW}$, en calderas de gas natural, con 34 años de antigüedad hasta el 2015, un ratio de $132 \mathrm{kWh} / \mathrm{m}^{2}$ en el total de octubre 2012 a mayo 2014 y 1.225 horas de funcionamiento a carga nominal de las calderas durante ese periodo. Diferencia del $15,0 \%$ en las tres temporadas posteriores a la red de calor

En la Tabla 130 y Tabla 131, se muestran en verde los edificios que presentan ahorros significativos en los consumos y en naranja el que presentó aumento significativo.

Tabla 130. Resumen de diferencias significativas regresión simple. Campus Río Esgueva

\begin{tabular}{|c|c|c|c|c|c|c|c|c|c|}
\hline Edificio & $\begin{array}{c}\text { Variable } \\
\text { independiente }\end{array}$ & $\begin{array}{c}\% \\
\text { Diferencia } \\
\text { 2015-2016 }\end{array}$ & Significativo & $\begin{array}{c}\text { \% Diferencia } \\
\text { 2016-2017 }\end{array}$ & Significativo & $\begin{array}{c}\text { \% Diferencia } \\
\text { 2017-2018 }\end{array}$ & Significativo & $\begin{array}{c}\% \\
\text { Diferencia } \\
\text { 2015-2018 }\end{array}$ & Significativo \\
\hline E1 & GD20_24h & $95,2 \%$ & $\begin{array}{c}\text { kWh E1 real } \\
\text { no normal }\end{array}$ & $93,8 \%$ & SI & $64,0 \%$ & SI & $82,8 \%$ & SI \\
\hline E2 & T_min & $14,7 \%$ & $\begin{array}{c}\text { kWh E2 real } \\
\text { no normal }\end{array}$ & $20,5 \%$ & No & $16,0 \%$ & No & $17,0 \%$ & No \\
\hline E3 & T_min & $51,3 \%$ & SI & $25,8 \%$ & No & $8,5 \%$ & No & $29,9 \%$ & SI \\
\hline E4 & T_med & $34,4 \%$ & No & $154,0 \%$ & $\begin{array}{c}\text { kWh E4 real no } \\
\text { normal }\end{array}$ & $179,3 \%$ & SI & $100,9 \%$ & $\begin{array}{c}\text { kWh E4 real } \\
\text { no normal }\end{array}$ \\
\hline E5 & $\begin{array}{c}\text { GD15_30mi } \\
\mathrm{n}\end{array}$ & $18,4 \%$ & No & $27,7 \%$ & SI & $23,9 \%$ & $\mathrm{SI}$ & $23,2 \%$ & SI \\
\hline E6 & T_med & $-7,5 \%$ & No & $-15,7 \%$ & SI & $-20,7 \%$ & SI & $-15,0 \%$ & SI \\
\hline E7 & $\begin{array}{c}\text { GD15_30mi } \\
\mathrm{n}\end{array}$ & $-3,0 \%$ & No & $2,5 \%$ & No & $-7,5 \%$ & No & $-3,0 \%$ & No \\
\hline E8 & T_min & $-4,2 \%$ & No & $3,6 \%$ & No & $14,0 \%$ & No & $4,4 \%$ & No \\
\hline E13 & T_max & $-11,0 \%$ & No & $-29,4 \%$ & SI & $-13,6 \%$ & $\mathrm{SI}$ & $-18,0 \%$ & $\begin{array}{c}\text { Pronosticos no } \\
\text { normal }\end{array}$ \\
\hline E14 & GD20_24h & $0,1 \%$ & No & $14,4 \%$ & SI & $11,4 \%$ & No & $8,1 \%$ & No \\
\hline E15 & T_med & - & - & - & - & - & - & - & - \\
\hline
\end{tabular}

Tabla 131. Resumen de diferencias significativas regresión múltiple. Campus Río Esgueva

\begin{tabular}{|c|c|c|c|c|c|c|c|c|c|}
\hline Edificio & $\begin{array}{c}\text { Variables } \\
\text { independientes }\end{array}$ & $\begin{array}{c}\% \\
\text { Diferencia } \\
\text { 2015-2016 }\end{array}$ & Significativo & $\begin{array}{c}\% \\
\text { Diferencia } \\
\text { 2016-2017 }\end{array}$ & Significativo & $\begin{array}{c}\% \\
\text { Diferencia } \\
\text { 2017-2018 }\end{array}$ & Significativo & $\begin{array}{c}\% \\
\text { Diferencia } \\
\text { 2015-2018 }\end{array}$ & Significativo \\
\hline E3 & $\begin{array}{c}\text { T min } \\
\text { V_diurna }\end{array}$ & $33,8 \%$ & No & $7,2 \%$ & No & $1,6 \%$ & No & $11,7 \%$ & No \\
\hline E15 & $\begin{array}{l}\text { T_med } \\
\text { V_max }\end{array}$ & $4,2 \%$ & No & $-14,4 \%$ & No & $12,4 \%$ & No & $4,2 \%$ & $\begin{array}{c}\text { Pronosticos no } \\
\text { normal }\end{array}$ \\
\hline
\end{tabular}


Un resumen de las características de los edificios, se muestra en la Tabla 132

Durante la primera temporada (octubre 2015-mayo 2016), sólo el edificio E3 mostró diferencias significativas en sus consumos. Durante la segunda temporada (octubre 2016 mayo 2017), 3 edificios mostraron ahorros significativos y 1 aumento significativo en el consumo. Durante la tercera temporada (octubre 2017 - mayo 2018), 2 edificios mostraron ahorros significativos y 1 aumento significativos.

En el total de las tres temporadas, fueron 5 edificios los que presentaron ahorros y 2 los que presentaron aumentos de consumo

Tabla 132. Resumen de características de los edificios del Campus Río Esgueva

\begin{tabular}{|c|c|c|c|c|c|c|c|c|c|}
\hline & Tipo & $\begin{array}{c}\text { Combustble } \\
\text { inicial }\end{array}$ & $\begin{array}{l}\text { kWh total } \\
\text { oct-12 - } \\
\text { may-14 }\end{array}$ & $\mathrm{m}^{2}$ & $\mathrm{kWh} / \mathrm{m}^{2}$ & $\begin{array}{c}\text { kW } \\
\text { instalados } \\
\text { Gas } \\
\text { Natural }\end{array}$ & $\begin{array}{l}\text { kW instalados } \\
\text { subestación }\end{array}$ & $\begin{array}{c}\mathrm{h} \\
\text { funcionamiento } \\
\text { a carga nominal } \\
\text { durante oct-12 } \\
\text { - may14 }\end{array}$ & $\begin{array}{c}\text { Años de } \\
\text { antigüedad } \\
\text { hasta } 2015\end{array}$ \\
\hline E1 & Docente & Gasóleo & 252.500 & 1.681 & 150,21 & 291 & 291 & 867,70 & 75 \\
\hline E2 & Docente & Gasóleo & 945.845 & 11.160 & 84,75 & 989 & 988 & 956,36 & 21 \\
\hline E3 & Docente & Gas Natural & 2.203 .319 & 21.709 & 101,49 & 930 & 929 & $2.369,16$ & 18 \\
\hline E4 & Docente & Gasóleo & 1.560 .450 & 32.305 & 48,30 & 3.139 & 2.384 & 497,12 & 47 \\
\hline E5 & Residencial & Gasóleo & 3.362 .492 & 20.016 & 167,99 & 4.943 & 3.800 & 680,25 & 24 \\
\hline E6 & Residencial & Gas Natural & 877.200 & 6.660 & 131,71 & 716 & 560 & $1.225,14$ & 34 \\
\hline E7 & Docente & Gas Natural & 379.919 & 3.919 & 96,94 & 466 & 465 & 815,28 & 10 \\
\hline E8 & Docente & Gas Natural & 3.908 .737 & 29.802 & 131,16 & 2.320 & 2.172 & $1.684,80$ & 55 \\
\hline E13 & Docente & Gas Natural & 2.583 .651 & 17.776 & 145,34 & 1.604 & 1.624 & $1.610,75$ & 33 \\
\hline E14 & Docente & Gasóleo & 676.599 & 7.569 & 89,39 & 407 & 425 & $1.662,41$ & 29 \\
\hline E15 & Docente & Gas Natural & 2.900 .998 & 18.512 & 156,71 & 2.324 & 2.160 & $1.248,28$ & 30 \\
\hline $\begin{array}{c}\text { RIO } \\
\text { ESGUEVA }\end{array}$ & & & 19.651 .710 & 171.109 & 114,85 & 18.129 & 15.798 & $1.083,99$ & \\
\hline
\end{tabular}

La Tabla 133 y Tabla 134, recopilan los consumos de los edificios del Campus Río Esgueva, se muestran los consumos reales y los estimados o pronosticados con los modelos de regresión validados como línea base del consumo de cada edificio. 
Capítulo 5. Resultados y Discusión. Campus Río Esgueva

Tabla 133. Consumo Real térmico de los edificios del Campus Río Esgueva (kWh)

\begin{tabular}{|c|c|c|c|c|c|c|c|c|c|c|c|c|}
\hline REAL & E1 & E2 & E3 & E4 & E5 & E6 & E7 & E8 & E13 & E14 & E15 & TOTAL \\
\hline oct-12 & 8.417 & 36.834 & 7.828 & 14.142 & 117.869 & 26.717 & 7.328 & 44.728 & 26.441 & 25.019 & 14.487 & 349.810 \\
\hline nov-12 & .083 & 4.166 & 158.718 & 111.738 & 205.331 & 70.411 & 29.013 & 187.155 & 233.547 & 65.981 & 211.446 & 1.369 .590 \\
\hline dic-12 & & & & & & & & & & & & 1.587 .597 \\
\hline ene-13 & & & & & & & 30.880 & 342.443 & 231.986 & & & 1.744 .852 \\
\hline feb-13 & 5.595 & 84.570 & 41.484 & 239.369 & 296.940 & 77.600 & 32.427 & 348.845 & 231.133 & 54.283 & 314.998 & .244 \\
\hline mar-13 & 21.438 & 66.955 & 169.961 & 118.256 & 303.000 & 62.022 & 23.298 & 381.056 & 192.983 & 40.277 & 236.366 & 1.615 .611 \\
\hline$a b r-13$ & & & & & & & & & 106.846 & & & \\
\hline may-13 & .902 & 30.436 & 6.794 & 11.169 & .000 & 31.816 & .021 & 2.781 & 53.047 & .487 & 082 & .534 \\
\hline oct-13 & 409 & 18.951 & 8.427 & 25.730 & .374 & 20.432 & 12.346 & 39.057 & 22 & 1.616 & .235 & .600 \\
\hline nov-13 & & 51.613 & & & & & 26.338 & & 143.684 & 55.254 & & 1.240 .614 \\
\hline dic-13 & 2 & 120. & & & & & & & & & & \\
\hline ene-14 & .990 & 88.737 & 192.743 & 114.800 & 298.152 & 67.999 & 36.151 & 349.596 & 336.166 & 51.061 & 258.821 & .216 \\
\hline feb-14 & & 84.512 & 242.403 & & & 79.509 & 29.124 & 496.930 & 259.725 & 53.630 & & \\
\hline mar-14 & & & & & & & & & & & & \\
\hline abr-14 & 472 & 39.045 & 0.428 & 30.084 & 163.647 & 41.877 & 15.668 & 219.679 & 86.292 & 17.641 & 116.325 & 158 \\
\hline may-14 & 01 & 3.971 & 1.239 & 14.875 & 142.383 & 22.289 & 11.334 & 11.049 & 13.279 & 8.218 & 18.881 & 280 \\
\hline oct-15 & & & & & & & & & & & & \\
\hline nov-15 & 295 & 49.410 & 6.450 & 73.400 & 200.500 & 72.507 & 15.559 & 288.652 & 203.190 & 38.632 & 173.200 & .795 \\
\hline dic-15 & 973 & 46.960 & 2.750 & 59.700 & 153.300 & 53.670 & 11.035 & 212.113 & 149.940 & 55.921 & 126.100 & 462 \\
\hline ene-16 & & 3 & & & & & & 332 & 165.700 & & 167.500 & \\
\hline feb-16 & 22.898 & 144.460 & 195.869 & 197.706 & 356.509 & 109.816 & 63.667 & 452.764 & 367.886 & 102.472 & 269.211 & 2.283 .258 \\
\hline mar-16 & 10.846 & 9.975 & 108.608 & .973 & 213.337 & 67.548 & 32.434 & 316.817 & 236.912 & 42.448 & 174. & 59.901 \\
\hline$a b r-16$ & 541 & & 55 & & 136 & & & 266. & 175.949 & 91 & 122 & \\
\hline may-16 & & 10.969 & 6.782 & & 59.265 & 22.683 & 8.218 & & 32.710 & 11.087 & & 271.866 \\
\hline oct-16 & & 15.025 & .329 & & 2.832 & 28.182 & 9.706 & & & 7.812 & & \\
\hline nov-16 & 681 & 68.720 & 88.878 & 43.359 & 198.634 & 77.281 & 26.341 & 337.657 & 262.380 & 38.585 & 192.797 & 314 \\
\hline dic-16 & & & 117.308 & & 192.899 & 77.584 & 33.256 & 303.434 & 218.390 & 63.199 & 181.536 & 1.311 .308 \\
\hline ene-17 & 5.891 & 98.867 & 234.302 & & 269.378 & 93.129 & 37.659 & 440.599 & 386.780 & 70.886 & 283.796 & 1.984 .427 \\
\hline feb-17 & 10.605 & 71.759 & 176.446 & 49.191 & 218.934 & 76.931 & 25.322 & 347.129 & 264.570 & 40.723 & 205.600 & 1.487 .209 \\
\hline mar-17 & 9.821 & 51.050 & 150.460 & 51.117 & 187.634 & 67.113 & 21.876 & 295.002 & 179.680 & 31.425 & 170.464 & 1.215 .642 \\
\hline abr-17 & & & & & & & 13.691 & 114.519 & & 12.601 & & \\
\hline may-17 & 1.035 & 3.965 & 13.640 & 3.184 & 41.591 & 20.749 & 7.778 & 29.943 & 23.570 & 769 & 13.800 & 160.024 \\
\hline oct-17 & 1.462 & 5.110 & 11.920 & 4.400 & 31.700 & 23.998 & 5.393 & 29.261 & 18.590 & 1 & 8.772 & 140.608 \\
\hline nov-17 & 9.358 & 48.158 & 134.498 & 0 & 183.300 & 77.893 & 21.837 & 240.790 & 176.720 & 24.942 & 137.564 & 1.055 .061 \\
\hline dic-17 & 12.659 & 80.392 & 173.668 & 95.300 & 252.700 & 98.278 & 36.608 & 316.883 & 264.900 & 69.441 & 220.020 & 1.620 .849 \\
\hline ene-18 & 14.052 & 79.450 & 198.228 & 48.500 & 228.300 & 89.052 & 38.115 & 335.954 & 287.620 & 62.464 & 247.100 & 1.628 .835 \\
\hline feb-18 & 17.125 & 99.180 & 257.218 & 64.100 & 296.600 & 108.817 & 43.138 & 399.029 & 307.970 & 65.539 & 267.216 & 1.925 .932 \\
\hline mar-18 & 14.234 & 78.870 & 214.196 & 55.500 & 236.500 & 90.765 & 32.745 & 351.334 & 253.030 & 48.603 & 227.864 & 1.603 .642 \\
\hline abr-18 & 6.280 & 33.930 & 97.846 & 24.100 & 114.600 & 41.843 & 22.137 & 153.387 & 118.064 & 29.414 & 96.348 & 737.949 \\
\hline may-18 & 2.132 & 9.060 & 22.440 & 8.600 & 51.300 & 25.939 & 12.372 & 38.661 & 22.920 & 5.144 & 26.700 & 225.268 \\
\hline TOTAL & 454.110 & 2.168 .001 & 4.903 .162 & 2.701 .502 & 7.386 .863 & 2.371 .843 & 955.683 & 9.633 .856 & 6.843 .774 & 1.579 .922 & 6.391 .820 & 45.390 .537 \\
\hline
\end{tabular}


Capítulo 5. Resultados y Discusión. Campus Río Esgueva

Tabla 134. Consumo Pronosticado térmico de los edificios del Campus Río Esgueva (kWh)

\begin{tabular}{|c|c|c|c|c|c|c|c|c|c|c|c|c|}
\hline PRONOST & E1 & E2 & E3 & E4 & E5 & E6 & E7 & E8 & E13 & E14 & E15 & TOTAL \\
\hline oct-12 & 18.417 & 36.834 & 17.828 & 14.142 & 117.869 & 26.717 & 7.328 & 44.728 & 26.441 & 25.019 & 14.487 & 349.810 \\
\hline nov-12 & 32.083 & 64.166 & 158.718 & 111.738 & 205.331 & 70.411 & 29.013 & 187.155 & 233.547 & 65.981 & 211.446 & 1.369 .590 \\
\hline dic-12 & 16.491 & 47.219 & 168.403 & 153.434 & 303.000 & 69.423 & 34.243 & 192.809 & 246.803 & 70.700 & 285.072 & 1.587 .597 \\
\hline ene-13 & 17.414 & 49.862 & 195.511 & 181.744 & 323.200 & 60.486 & 30.880 & 342.443 & 231.986 & 56.717 & 254.609 & 1.744 .852 \\
\hline feb-13 & 16.595 & 84.570 & 241.484 & 239.369 & 296.940 & 77.600 & 32.427 & 348.845 & 231.133 & 54.283 & 314.998 & 1.938 .244 \\
\hline mar-13 & 21.438 & 66.955 & 169.961 & 118.256 & 303.000 & 62.022 & 23.298 & 381.056 & 192.983 & 40.277 & 236.366 & 1.615 .611 \\
\hline abr-13 & 16.161 & 50.475 & 122.600 & 79.149 & 195.940 & 47.899 & 18.563 & 183.948 & 106.846 & 32.185 & 146.559 & 1.000 .325 \\
\hline may-13 & 12.902 & 30.436 & 66.794 & 11.169 & 101.000 & 31.816 & 7.021 & 62.781 & 53.047 & 28.487 & 50.082 & 455.534 \\
\hline oct-13 & 6.409 & 18.951 & 8.427 & 25.730 & 81.374 & 20.432 & 12.346 & 39.057 & 22 & 1.616 & 2.235 & 216.600 \\
\hline nov-13 & 17.455 & 51.613 & 111.525 & 127.313 & 221.626 & 61.042 & 26.338 & 237.231 & 143.684 & 55.254 & 187.533 & 1.240 .614 \\
\hline dic-13 & 26.636 & 120.015 & 235.091 & 148.502 & 303.000 & 86.228 & 41.230 & 443.980 & 273.337 & 69.059 & 318.094 & 2.065 .172 \\
\hline ene-14 & 14.990 & 88.737 & 192.743 & 114.800 & 298.152 & 67.999 & 36.151 & 349.596 & 336.166 & 51.061 & 258.821 & 1.809 .216 \\
\hline feb-14 & 14.276 & 84.512 & 242.403 & 109.572 & 204.363 & 79.509 & 29.124 & 496.930 & 259.725 & 53.630 & 276.638 & 1.850 .682 \\
\hline mar-14 & 11.000 & 78.485 & 160.164 & 80.574 & 101.667 & 51.450 & 24.955 & 367.450 & 148.360 & 46.470 & 208.852 & 1.279 .427 \\
\hline abr-14 & 5.472 & 39.045 & 100.428 & 30.084 & 163.647 & 41.877 & 15.668 & 219.679 & 86.292 & 17.641 & 116.325 & 836.158 \\
\hline may-14 & 4.761 & 33.971 & 11.239 & 14.875 & 142.383 & 22.289 & 11.334 & 11.049 & 13.279 & 8.218 & 18.881 & 292.280 \\
\hline oct-15 & 9.754 & 7.380 & 21.724 & 8.100 & 108.511 & 29.104 & 4.549 & 52.860 & 34.000 & 9.687 & 53.000 & 338.669 \\
\hline nov-15 & 15.432 & 49.410 & 110.038 & 73.400 & 199.353 & 53.993 & 15.559 & 288.652 & 203.190 & 38.632 & 173.200 & 1.220 .859 \\
\hline dic-15 & 20.028 & 46.960 & 188.046 & 59.700 & 274.210 & 70.376 & 11.035 & 212.113 & 149.940 & 55.921 & 126.100 & 1.214 .429 \\
\hline ene-16 & 18.787 & 32.190 & 150.472 & 42.100 & 251.229 & 65.389 & 30.213 & 274.832 & 165.700 & 39.537 & 167.500 & 1.237 .949 \\
\hline feb-16 & 18.104 & 144.460 & 185.536 & 197.706 & 246.684 & 67.698 & 63.667 & 452.764 & 367.886 & 102.472 & 269.211 & 2.116 .188 \\
\hline mar-16 & 18.912 & 59.975 & 214.628 & 96.973 & 254.823 & 65.889 & 32.434 & 316.817 & 236.912 & 42.448 & 174.003 & 1.513 .815 \\
\hline$a b r-16$ & 14.372 & 43.230 & 118.649 & 65.845 & 177.058 & 49.593 & 22.115 & 266.496 & 175.949 & 31.991 & 122.200 & 1.087 .498 \\
\hline may-16 & 9.348 & 10.969 & 44.745 & 16.189 & 110.382 & 27.474 & 8.218 & 56.485 & 32.710 & 11.087 & 35.033 & 362.641 \\
\hline oct-16 & 8.846 & 15.025 & 31.276 & 13.250 & 108.751 & 25.926 & 9.706 & 70.515 & 29.981 & 7.812 & 37.197 & 358.287 \\
\hline nov-16 & 17.291 & 68.720 & 160.970 & 43.359 & 229.814 & 61.716 & 26.341 & 337.657 & 262.380 & 38.585 & 192.797 & 1.439 .631 \\
\hline dic-16 & 21.684 & 65.329 & 204.813 & 50.061 & 304.532 & 77.035 & 33.256 & 303.434 & 218.390 & 63.199 & 181.536 & 1.523 .270 \\
\hline ene-17 & 23.887 & 98.867 & 294.505 & 53.139 & 345.116 & 85.876 & 37.659 & 440.599 & 386.780 & 70.886 & 283.796 & 2.121.111 \\
\hline feb-17 & 16.060 & 71.759 & 161.993 & 49.191 & 214.366 & 61.395 & 25.322 & 347.129 & 264.570 & 40.723 & 205.600 & 1.458 .107 \\
\hline mar-17 & 14.705 & 51.050 & 151.486 & 51.117 & 195.114 & 48.993 & 21.876 & 295.002 & 179.680 & 31.425 & 170.464 & 1.210 .913 \\
\hline abr-17 & 9.757 & 18.717 & 118.701 & 17.237 & 135.178 & 30.440 & 13.691 & 114.519 & 78.670 & 12.601 & 53.800 & 603.313 \\
\hline may-17 & 4.849 & 3.965 & 0 & 3.184 & 74.086 & 7.785 & 7.778 & 29.943 & 23.570 & 769 & 13.800 & 169.729 \\
\hline oct-17 & 7.180 & 5.110 & 42.709 & 4.400 & 104.653 & 18.676 & 5.393 & 29.261 & 18.590 & 1 & 8.772 & 244.746 \\
\hline nov-17 & 18.368 & 48.158 & 227.204 & 0 & 250.958 & 66.180 & 21.837 & 240.790 & 176.720 & 24.942 & 137.564 & 1.212 .722 \\
\hline dic-17 & 21.863 & 80.392 & 231.336 & 95.300 & 307.800 & 77.747 & 36.608 & 316.883 & 264.900 & 69.441 & 220.020 & 1.722 .291 \\
\hline ene-18 & 21.274 & 79.450 & 202.496 & 48.500 & 296.935 & 75.381 & 38.115 & 335.954 & 287.620 & 62.464 & 247.100 & 1.695 .289 \\
\hline feb-18 & 20.311 & 99.180 & 271.463 & 64.100 & 291.486 & 80.304 & 43.138 & 399.029 & 307.970 & 65.539 & 267.216 & 1.909 .736 \\
\hline mar-18 & 18.007 & 78.870 & 147.456 & 55.500 & 237.427 & 62.257 & 32.745 & 351.334 & 253.030 & 48.603 & 227.864 & 1.513 .093 \\
\hline$a b r-18$ & 11.656 & 33.930 & 68.518 & 24.100 & 146.264 & 38.320 & 22.137 & 153.387 & 118.064 & 29.414 & 96.348 & 742.138 \\
\hline may-18 & 8.095 & 9.060 & 13.203 & 8.600 & 93.303 & 22.443 & 12.372 & 38.661 & 22.920 & 5.144 & 26.700 & 260.502 \\
\hline TOTAL & 621.069 & 2.168 .001 & 5.565 .285 & 2.701 .502 & 8.320 .528 & 2.147 .192 & 955.683 & 9.633 .856 & 6.843 .774 & 1.579 .922 & 6.391 .820 & 46.928 .634 \\
\hline
\end{tabular}


La Tabla 135 y Figura 149, muestran el resumen del ahorro energético que se ha obtenido en cada uno de los edificios del Campus Río Esgueva y en el conjunto del Campus, durante las tres temporadas de calefacción siguientes a la puesta en marcha de la red de calor, siendo este del 5,5\% lo que equivale a un ahorro de $1.142 .561 \mathrm{kWh}$.

Tabla 135. Resumen de ahorro de energía térmica del Campus Río Esgueva (kWh)

\begin{tabular}{|c|c|c|c|c|c|c|c|c|c|c|c|c|}
\hline kWh térmicos & E1 & E2 & E3 & E4 & E5 & E6 & E7 & E8 & E13 & E14 & E15 & TOTAL \\
\hline TOTAL Pronost oct-15-may-18 & 368.569 & 1.222 .156 & 3.361 .966 & 1.141 .052 & 4.958 .036 & 1.269 .992 & 575.765 & 5.725 .119 & 4.260 .123 & 903.323 & 3.490 .822 & 27.276 .924 \\
\hline TOTAL Real oct-15-may-18 & 201.610 & 1.222 .156 & 2.686 .203 & 1.141 .052 & 4.024 .371 & 1.494 .643 & 575.765 & 5.725 .119 & 4.260 .123 & 903.323 & 3.490 .822 & 25.725 .187 \\
\hline Ahorro (kWh) & 166.959 & 0 & 675.763 & 0 & 933.665 & -224.650 & 0 & 0 & 0 & 0 & 0 & 1.551 .737 \\
\hline Ahorro (\%) & $45,3 \%$ & $0,0 \%$ & $20,1 \%$ & $0,0 \%$ & $18,8 \%$ & $-17,7 \%$ & $0,0 \%$ & $0,0 \%$ & $0,0 \%$ & $0,0 \%$ & $0,0 \%$ & $5,7 \%$ \\
\hline Diferencias en las medias & $82,8 \%$ & $0,0 \%$ & $25,2 \%$ & $0,0 \%$ & $23,2 \%$ & $-15,0 \%$ & $0,0 \%$ & $0,0 \%$ & $0,0 \%$ & $0,0 \%$ & $0,0 \%$ & $6.0 \%$ \\
\hline
\end{tabular}

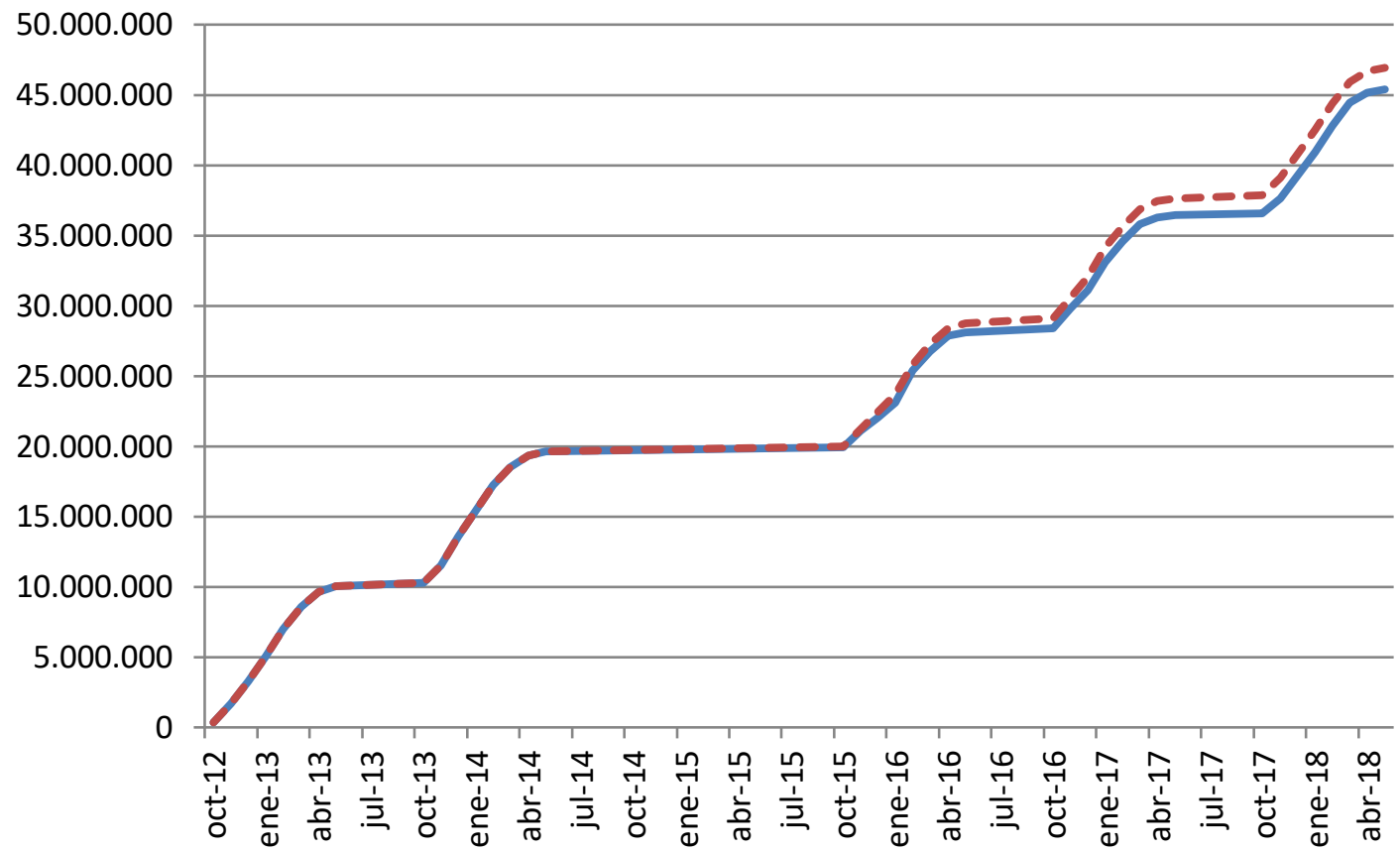

kWh Real Acumulado Río Esgueva - - kWh Pronosticado Acumulado Río Esgueva

Figura 149. Consumo real acumulado y pronosticado (kWh). Campus Río Esgueva 
Capítulo 5. Resultados y Discusión. Campus Río Esgueva

La Tabla 136 y Figura 150, muestran el resumen del ahorro de emisiones de $\mathrm{CO}_{2}$, que se ha obtenido en cada uno de los edificios del Campus Río Esgueva y en el conjunto del Campus, durante las tres temporadas de calefacción siguientes a la puesta en marcha de la red de calor, siendo este del $87,9 \%$ lo que equivale a un ahorro de 6.346 toneladas de $\mathrm{CO}_{2}$.

Tabla 136. Ahorro de emisiones CO2 del Campus Río Esgueva (kg CO2)

\begin{tabular}{|c|c|c|c|c|c|c|c|c|c|c|c|c|}
\hline $\begin{array}{l}\text { Ahorro } \mathrm{CO}_{2} \\
\left(\mathrm{~kg} \mathrm{CO}_{2}\right)\end{array}$ & E1 & E2 & E3 & E4 & E5 & E6 & E7 & E8 & E13 & E14 & E15 & TOTAL \\
\hline oct-15 & 2.976 & 2.118 & 3.420 & 2.325 & 32.629 & 4.302 & 1.037 & 12.052 & 7.752 & 2.780 & 12.084 & 83.474 \\
\hline nov-15 & 4.648 & 14.181 & 21.991 & 21.066 & 57.187 & 16.532 & 3.547 & 65.813 & 46.327 & 11.087 & 39.490 & 301.868 \\
\hline dic-15 & 6.085 & 13.478 & 16.587 & 17.134 & 81.600 & 12.237 & 2.516 & 48.362 & 34.186 & 16.049 & 28.751 & 276.985 \\
\hline ene-16 & 5.735 & 9.239 & 22.946 & 12.083 & 74.686 & 13.153 & 6.889 & 62.662 & 37.780 & 11.347 & 38.190 & 294.708 \\
\hline feb-16 & 2.149 & 22.725 & 29.806 & 26.892 & 41.168 & 19.182 & 7.510 & 87.396 & 61.254 & 18.542 & 51.163 & 367.787 \\
\hline mar-16 & 5.592 & 15.880 & 24.289 & 23.706 & 71.522 & 14.353 & 7.226 & 70.804 & 47.802 & 11.474 & 37.552 & 330.200 \\
\hline abr-16 & 4.243 & 11.867 & 17.554 & 16.503 & 49.627 & 13.749 & 5.026 & 60.641 & 39.378 & 8.768 & 27.862 & 255.217 \\
\hline may-16 & 2.846 & 3.131 & 3.819 & 3.875 & 32.744 & 4.524 & 1.868 & 12.879 & 7.458 & 2.316 & 5.335 & 80.795 \\
\hline oct-16 & 2.592 & 2.965 & 3.684 & 2.353 & 25.474 & 4.222 & 1.259 & 12.768 & -1.878 & 1.465 & -2.830 & 52.076 \\
\hline nov-16 & 5.094 & 18.641 & 31.133 & 11.738 & 65.375 & 17.443 & 5.931 & 76.032 & 59.102 & 10.757 & 42.431 & 343.678 \\
\hline dic-16 & 6.544 & 18.440 & 26.544 & 10.562 & 89.219 & 17.686 & 7.571 & 69.086 & 49.766 & 17.038 & 40.447 & 352.903 \\
\hline ene-17 & 7.041 & 27.454 & 52.803 & 14.207 & 98.835 & 20.989 & 8.586 & 99.603 & 88.168 & 20.329 & 64.592 & 502.606 \\
\hline feb-17 & 4.729 & 19.869 & 39.998 & 12.398 & & 17.531 & 5.773 & 78.392 & 60.185 & 11.679 & 46.877 & 358.491 \\
\hline mar-17 & 4.322 & 14.651 & 34.250 & 14.407 & 55.823 & 15.294 & 4.988 & 67.003 & 40.821 & 9.019 & 38.714 & 299.294 \\
\hline abr-17 & 2.939 & 5.350 & 11.854 & 4.133 & 39.804 & 7.404 & 3.122 & 26.005 & 17.937 & 3.444 & 12.266 & 134.256 \\
\hline may-17 & 1.461 & 1.036 & -327 & -990 & 21.270 & 4.720 & 1.660 & -770 & -566 & -27 & -331 & 27.136 \\
\hline oct-17 & 2.198 & 1.467 & 2.700 & -106 & 31.786 & 2.921 & 535 & 6.259 & -446 & 0 & -364 & 46.950 \\
\hline nov-17 & 5.488 & 13.821 & 30.117 & 0 & 73.649 & 17.727 & 4.973 & 54.451 & 40.292 & 7.158 & 31.259 & 278.935 \\
\hline dic-17 & 6.496 & 23.073 & 39.503 & 27.351 & 89.661 & 22.384 & 8.347 & 71.781 & 60.397 & 19.930 & 50.092 & 419.013 \\
\hline ene-18 & 6.279 & 22.802 & 45.003 & 13.920 & 86.868 & 20.244 & 8.665 & 75.926 & 65.577 & 17.927 & 56.339 & 419.549 \\
\hline feb-18 & 5.906 & 28.465 & 58.370 & 18.397 & 83.534 & 24.794 & 9.806 & 90.763 & 70.217 & 18.810 & 60.922 & 469.983 \\
\hline mar-18 & 5.258 & 22.636 & 48.459 & 15.929 & 68.164 & 20.472 & 7.428 & 79.770 & 56.751 & 13.949 & 51.756 & 390.572 \\
\hline abr-18 & 3.474 & 9.738 & 22.287 & 6.917 & 42.738 & 9.540 & 4.951 & 34.908 & 26.703 & 8.442 & 21.956 & 191.654 \\
\hline may-18 & 2.466 & 2.600 & 5.116 & -206 & 27.786 & 5.914 & 2.821 & 8.815 & 5.226 & 1.476 & 6.088 & 68.102 \\
\hline Ahorro kg CO2 & 106.562 & 325.624 & 591.905 & 274.591 & 1.402 .208 & 327.315 & 122.035 & 1.271 .401 & 920.191 & 243.760 & 760.640 & 6.346 .232 \\
\hline kg CO2 antes & 114.625 & 380.091 & 676.923 & 349.834 & 1.541 .949 & 376.650 & 145.093 & 1.435 .184 & 1.055 .372 & 280.694 & 864.625 & 7.221 .040 \\
\hline \% Ahorro & $93,0 \%$ & $85,7 \%$ & $87,4 \%$ & $78,5 \%$ & $90,9 \%$ & $86,9 \%$ & $84,1 \%$ & $88,6 \%$ & $87,2 \%$ & $86,8 \%$ & $88,0 \%$ & $87,9 \%$ \\
\hline
\end{tabular}

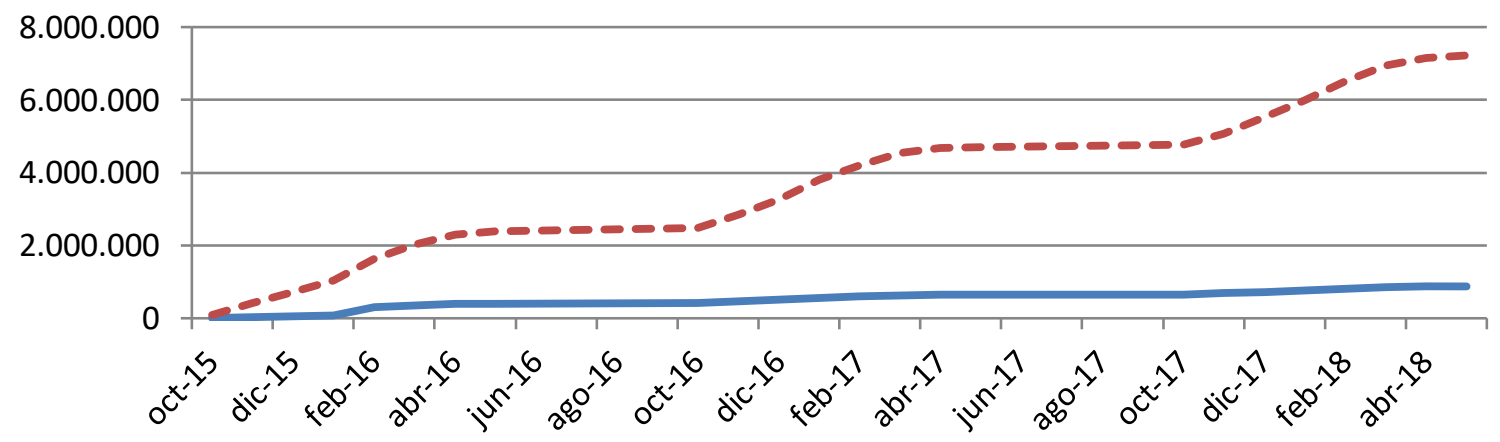

kg CO2 Real Acumulado Río Esgueva - - kg CO2 Pronosticado Acumulado Río Esgueva

Figura 150. Emisiones reales acumuladas y pronosticadas (kg CO2). Campus Río Esgueva 
En la Tabla 137 se muestran los precios que hubieran tenido que tener los $\mathrm{kWh}$ comprados a la red de calor, para obtener un ahorro económico del $0 \%$ y del $15 \%$, durante las tres temporadas siguientes a la ejecución de la red, con respecto a lo que hubiera pagado la Universidad por la compra de la energía al suministrador de gas natural o gasóleo de no haberse conectado a la red de calor.

Tabla 137. Precios máximos de compra de la energía a la red de calor

\begin{tabular}{ccc}
\hline & $\begin{array}{c}€ / \text { kWh max comprado para 0\% } \\
\text { ahorro económico }\end{array}$ & $\begin{array}{c}€ / \text { kWh max comprado para 15\% } \\
\text { ahorro económico }\end{array}$ \\
\hline E1 & 0,09280 & 0,08040 \\
\hline E2 & 0,04970 & 0,04280 \\
\hline E3 & 0,03210 & 0,02778 \\
\hline E4 & 0,04815 & 0,04088 \\
\hline E5 & 0,06140 & 0,05317 \\
\hline E6 & 0,03230 & 0,02790 \\
\hline E7 & 0,03208 & 0,02758 \\
\hline E8 & 0,03208 & 0,02778 \\
\hline E13 & 0,03166 & 0,02740 \\
\hline E14 & 0,04952 & 0,04270 \\
\hline E15 & 0,03176 & 0,02753 \\
\hline Río ESGUEVA (min) & 0,03166 & 0,02740 \\
\hline
\end{tabular}

Se han estimado que los precios que se hubieran pagado por los combustibles fósiles son los que figuran en la Tabla 138

Tabla 138. Precios estimados para los combustibles

\begin{tabular}{cccccc}
\hline Precios $(€ /(\mathrm{kWh})$ & 2015 & 2016 & 2017 & 2018 & Promedio \\
\hline Gasóleo C & 0,0517 & 0,0437 & 0,0499 & 0,056 & 0,050325 \\
\hline Gas Natural & 0,0373 & 0,0306 & 0,0314 & 0,0336 & 0,033225 \\
\hline Astilla & 0,0277 & 0,0256 & 0,0254 & 0,0239 & 0,02565 \\
\hline
\end{tabular}




\section{CAPÍTULO 6. CONCLUSIONES}

\subsection{Conclusiones sobre la metodología}

La metodología propuesta para la verificación de la existencia de diferencias significativas entre los consumos anteriores y posteriores a la construcción de la red, se ha podido llevar a cabo en todos los edificios estudiados, obteniéndose primero los modelos de las líneas base de los consumos de los edificios, mediante el tratamiento de los datos de los consumos de las dos temporadas anteriores a la red con las variables climáticas.

En la Tabla 139 se muestran los modelos de línea base encontrados para los 23 edificios de la UVA.

Tabla 139. Resumen de modelos de regresión simple. UVA

\begin{tabular}{|c|c|c|c|c|c|}
\hline Edificio & Variable independiente & Constante & $B$ & $\mathrm{R}$ & $\mathrm{R}^{2}$ \\
\hline D1 & T_med & $391.037,854$ & $-23.838,939$ & $-0,899$ & 0,808 \\
\hline D2 & GD15_30min & $-663,338$ & 38,971 & 0,985 & 0,970 \\
\hline D3 & GD15_30min & $-6.854,944$ & 192,510 & 0,921 & 0,848 \\
\hline D4 & T_med & $271.046,123$ & $-17.453,026$ & $-0,940$ & 0,888 \\
\hline D5 & GD15_30min & $-653,894$ & 56,535 & 0,993 & 0,986 \\
\hline D6 & GD15_30min & $-6.540,157$ & 656,818 & 0,995 & 0,989 \\
\hline D7 & GD15_30min & $-6.543,072$ & 733,335 & 0,996 & 0,991 \\
\hline D8 & T_med & $91.484,519$ & $-5.414,103$ & $-0,906$ & 0,821 \\
\hline D9 & GD15_30min & $-654,602$ & 139,864 & 0,999 & 0,998 \\
\hline D10 & T_med & $66.791,063$ & $-4.393,782$ & $-0,896$ & 0,802 \\
\hline $\mathrm{D} 11$ & T_med & $187.840,052$ & $-12.648,948$ & $-0,898$ & 0,807 \\
\hline D12 & GD15_30min & $-663,549$ & 173,214 & 0,999 & 0,998 \\
\hline E1 & GD20_24h & $-97,801$ & 44,252 & 0,655 & 0,429 \\
\hline E2 & T_min & $83.663,793$ & $-7.896,580$ & $-0,819$ & 0,671 \\
\hline E3 & T_min & $219.817,236$ & $-26.412,480$ & $-0,918$ & 0,843 \\
\hline E4 & T_med & $234.879,945$ & $-16.850,392$ & $-0,909$ & 0,826 \\
\hline E5 & GD15_30min & $29.320,001$ & 816,043 & 0,857 & 0,734 \\
\hline E6 & T_med & $99.745,107$ & $-5.510,824$ & $-0,939$ & 0,883 \\
\hline E7 & GD15_30min & $-437,414$ & 109,126 & 0,925 & 0,855 \\
\hline E8 & T_min & $381.573,782$ & $-44.158,494$ & $-0,801$ & 0,641 \\
\hline E13 & T_max & $461.136,517$ & $-21.706,507$ & $-0,920$ & 0,847 \\
\hline E14 & GD20_24h & $-24.047,456$ & 184,862 & 0,923 & 0,853 \\
\hline$E 15\left(^{*}\right)$ & T_med & $417.713,362$ & $-29.001,808$ & $-0,947$ & 0,896 \\
\hline
\end{tabular}

$\left({ }^{*}\right)$. Modelo no válido por existir autocorrelación en los residuos. Los residuos no son independientes 
Para todos los edificios, excepto para el E15, se obtuvieron modelos válidos de regresión simple. Once de los modelos de regresión simple (un 47,8\%) tuvieron como variable independiente los grados día (nueve en Base 15 obtenidos con datos cada 30 minutos y dos en Base 20 obtenidos con datos diarios); el resto de los modelos correlacionaron con la Temperatura (siete de ellos, sin contar el edificio E15, con la Temperatura media, tres con la temperatura mínima y uno con la temperatura máxima). El resto de las variables climáticas analizadas no mostraron influencias significativas en el consumo de los edificios de manera lineal.

Como se refleja en la Tabla 140, para cuatro de los 23 edificios (un 17,4\%) se encontraron modelos de regresión multivariable válidos. Por lo que se afirma que para el $100 \%$ de los edificios analizados se encontraron modelos de regresión que podrán ser utilizados para predecir el consumo del edificio. Los modelos de regresión múltiple correlacionaron como la Temperatura y con la velocidad del viento, en tres de los cuatro se trató de la temperatua media y en uno de ellos de la Temperatura mínina; en cuanto a la velocidad, en dos de ellos fue la velocidad del viento diurna, en otro la velocidad del viento nocturna y en el otro de la velocidad del viento máxima. En estos modelos el resto de las variables climáticas tampoco mostraron correlaciones significativas.

Tabla 140. Resumen de modelos de regresión múltiple UVA

\begin{tabular}{|c|c|c|c|c|c|c|c|}
\hline & $\begin{array}{c}\text { Variable } \\
\text { independiente } \\
1\end{array}$ & $\begin{array}{c}\text { Variable } \\
\text { independiente } \\
2\end{array}$ & Constante & B1 & B2 & $\mathrm{R}$ & $\mathrm{R}^{2}$ \\
\hline D1 & T_med & V_nocturna & $271.370,906$ & $-20.045,184$ & 50568,513 & $-0,931$ & 0,866 \\
\hline D8 & T_med & V_diurna & 63357,055 & $-4991,184$ & 8950,19 & 0,945 & 0,894 \\
\hline B11(*) & Imed & GD15 & 630672,573 & $-38572,601$ & $-1044,773$ & $-0,931$ & 0,866 \\
\hline E3 & T_min & V_diurna & $130.691,591$ & $-24.484,085$ & $30.147,142$ & $-0,950$ & 0,902 \\
\hline$E 8(* *)$ & $I_{-\min }$ & $\forall$ _diurna & $88.655,039$ & $37.820,664$ & $99.081,056$ & 0,903 & 0,816 \\
\hline E15 & T_med & V_max & 299.729,447 & $-28.070,125$ & $15.392,005$ & $-0,962$ & 0,925 \\
\hline
\end{tabular}

$(*)$ Modelo no válido. Multicolinealidad entre las variables

$\left({ }^{* *}\right)$ Modelo no válido. No hay homocedasticidad de la varianza. Existe correlación entre los residuos y V_durna.

Los modelos de regresión múltiple presentan mejores coeficientes de correlación y determinación que los modelos de regresión simple para el mismo edificio. 
Aunque es común la práctica de utilizar los grados día para desglosar el consumo de un edificio por meses, de hecho se considera la forma más conveniente de hacerlo cuando no se dispone de contadores de energía que puedan efectuar de una manera directa ese desglose, tal como se recoge en numerosos estudios (Euronet) [122], (Bromley, 2009) [123], (Federación Española de Municipios y Provincias (FEMP), 2011) [124], (Agencia Chilena de Eficiencia Energética. AchEE, 2014) [125]; ningún modelo de correlación múltiple encontrado ha correlacionado con esta variable.

Con excepción del Edificio E1, donde el coeficiente de correlación es de 0,655 y el coeficiente de determinación de 0,429 , los modelos encontrados tienen un coeficiente de correlación superior a 0,80 en valor absoluto, siendo positivo para los modelos con los Grados día y negativo para los modelos con la Temperatura. El coeficiente de determinación es superior a 0,64, por lo que con los modelos encontrados se puede predecir más del $64 \%$ de los consumos futuros con un error del $5 \%$.

En cuanto a las diferencias entre los consumos reales de las tres temporadas posteriores a la construcción de la red de calor y los consumos estimados o pronosticados que se hubieran obtenido en esas mismas temporadas si los edificios no se hubieran unido a la red de calor, como se muestra en la Tabla 141 y Tabla 142, se han obtenido diferencias significativas en 11 de los 23 edificios (47,8\%), en 8 de los cuales las diferencias fueron positivas (se obtuvo ahorros energéticos con la incorporación a la red) y en tres las diferencias encontradas fueron negativas, se obtuvo aumentos de consumo. En dichas tablas se muestran en verde los edificios que presentan ahorros significativos en los consumos y en naranja los que presentaron aumentos significativos.

Durante la primera temporada (octubre 2015-mayo 2016), sólo dos edificios (D1 y E3) mostraron diferencias significativas en sus consumos. Durante la segunda temporada (octubre 2016 - mayo 2017), 5 edificios mostraron ahorros significativos y 2 aumento significativo en el consumo. Durante la tercera temporada (octubre 2017 - mayo 2018), 4 edificios mostraron ahorros significativos y 2 aumento significativos.

En el total de las tres temporadas, fueron 8 edificios los que presentaron ahorros y 3 los que presentaron aumentos de consumo 
Capítulo 6. Conclusiones

Tabla 141. Resumen de diferencias significativas regresión simple UVA

\begin{tabular}{|c|c|c|c|c|c|c|c|c|c|}
\hline Edificio & $\begin{array}{c}\text { Variable } \\
\text { independiente }\end{array}$ & $\begin{array}{c}\text { \% Diferencia } \\
\text { 2015-2016 }\end{array}$ & Significativo & $\begin{array}{l}\text { \% Diferencia } \\
\text { 2016-2017 }\end{array}$ & Significativo & $\begin{array}{c}\% \\
\text { Diferencia } \\
2017-2018 \\
\end{array}$ & Significativo & $\begin{array}{c}\% \\
\text { Diferencia } \\
\text { 2015-2018 } \\
\end{array}$ & Significativo \\
\hline D1 & T_med & $22,7 \%$ & SI & $27,3 \%$ & SI & $18,5 \%$ & SI & $22,5 \%$ & SI \\
\hline D2 & GD15_30min & $38,2 \%$ & No & $50,6 \%$ & SI & $37,0 \%$ & SI & $41,5 \%$ & SI \\
\hline D3 & GD15_30min & $5,1 \%$ & No & $22,1 \%$ & No & $16,7 \%$ & No & $14,2 \%$ & SI \\
\hline D4 & T_med & $24,1 \%$ & No & $13,1 \%$ & No & $8,8 \%$ & No & $14,9 \%$ & SI \\
\hline D5 & GD15_30min & $-23,7 \%$ & No & $-10,7 \%$ & No & $-11,3 \%$ & No & $-15,6 \%$ & SI \\
\hline D6 & GD15_30min & $-13,8 \%$ & No & $-5,9 \%$ & No & $-11,5 \%$ & No & $-10,6 \%$ & No \\
\hline D7 & GD15_30min & $8,5 \%$ & No & $16,2 \%$ & No & $14,9 \%$ & No & $13,1 \%$ & No \\
\hline D8 & T_med & $-1,7 \%$ & No & $-18,8 \%$ & SI & $-23,4 \%$ & SI & $-15,6 \%$ & SI \\
\hline D9 & GD15_30min & $3,8 \%$ & No & $-1,8 \%$ & No & $-6,2 \%$ & No & $-1,7 \%$ & No \\
\hline D10 & T_med & $6,1 \%$ & No & $6,6 \%$ & No & $8,9 \%$ & No & $7,2 \%$ & No \\
\hline D11 & T_med & $14,8 \%$ & No & $16,6 \%$ & No & $6,1 \%$ & No & $12,1 \%$ & No \\
\hline D12 & GD15_30min & $13,8 \%$ & No & $34,6 \%$ & SI & $10,6 \%$ & No & $18,5 \%$ & SI \\
\hline E1 & GD20_24h & $95,2 \%$ & $\begin{array}{l}\text { kWh E1 real } \\
\text { no normal }\end{array}$ & $93,8 \%$ & SI & $64,0 \%$ & SI & $82,8 \%$ & SI \\
\hline E2 & T_min & $14,7 \%$ & $\begin{array}{c}\text { kWh E2 real } \\
\text { no normal }\end{array}$ & $20,5 \%$ & No & $16,0 \%$ & No & $17,0 \%$ & No \\
\hline E3 & T_min & $51,3 \%$ & $\mathrm{SI}$ & $25,8 \%$ & No & $8,5 \%$ & No & $29,9 \%$ & SI \\
\hline E4 & T_med & $34,4 \%$ & No & $154,0 \%$ & $\begin{array}{c}\text { kWh E4 real } \\
\text { no normal }\end{array}$ & $179,3 \%$ & SI & $100,9 \%$ & $\begin{array}{l}\text { kWh E4 real } \\
\text { no normal }\end{array}$ \\
\hline E5 & GD15_30min & $18,4 \%$ & No & $27,7 \%$ & SI & $23,9 \%$ & SI & $23,2 \%$ & SI \\
\hline E6 & T_med & $-7,5 \%$ & No & $-15,7 \%$ & SI & $-20,7 \%$ & $\mathrm{SI}$ & $-15,0 \%$ & SI \\
\hline E7 & GD15_30min & $-3,0 \%$ & No & $2,5 \%$ & No & $-7,5 \%$ & No & $-3,0 \%$ & No \\
\hline E8 & T_min & $-4,2 \%$ & No & $3,6 \%$ & No & $14,0 \%$ & No & $4,4 \%$ & No \\
\hline E13 & T_max & $-11,0 \%$ & No & $-29,4 \%$ & SI & $-13,6 \%$ & SI & $-18,0 \%$ & $\begin{array}{c}\text { Pronosticos } \\
\text { no normal }\end{array}$ \\
\hline E14 & GD20_24h & $0,1 \%$ & No & $14,4 \%$ & $\mathrm{SI}$ & $11,4 \%$ & No & $8,1 \%$ & No \\
\hline E15 & T_med & - & - & - & - & - & - & - & - \\
\hline
\end{tabular}

Tabla 142. Resumen de diferencias significativas regresión múltiple UVA

\begin{tabular}{|c|c|c|c|c|c|c|c|c|c|}
\hline Edificio & $\begin{array}{c}\text { Variables } \\
\text { independientes }\end{array}$ & $\begin{array}{c}\text { \% Diferencia } \\
2015-2016\end{array}$ & Significativo & $\begin{array}{c}\% \\
\text { Diferencia } \\
2016- \\
2017 \\
\end{array}$ & Significativo & $\begin{array}{c}\% \\
\text { Diferencia } \\
2017- \\
2018 \\
\end{array}$ & Significativo & $\begin{array}{c}\text { \% Diferencia } \\
2015-2018\end{array}$ & Significativo \\
\hline D1 & $\begin{array}{c}\text { T med } \\
\mathrm{V} \_ \text {nocturna }\end{array}$ & $10,2 \%$ & No & $11,8 \%$ & No & $12,4 \%$ & No & $11,5 \%$ & No Normal \\
\hline D8 & $\begin{array}{c}\text { GD15 } \\
\text { V_diurna }\end{array}$ & $-13,0 \%$ & No & $-31,2 \%$ & SI & $-29,0 \%$ & SI & $-25,0 \%$ & SI \\
\hline E3 & $\begin{array}{c}T \text { min } \\
V_{-} \text {diurna }\end{array}$ & $33,8 \%$ & No & $7,2 \%$ & No & $1,6 \%$ & No & $11,7 \%$ & No \\
\hline E15 & $\begin{array}{l}\text { T_med } \\
\text { V_max }\end{array}$ & $4,2 \%$ & No & $-14,4 \%$ & No & $12,4 \%$ & No & $4,2 \%$ & $\begin{array}{c}\text { Pronosticos } \\
\text { no normal }\end{array}$ \\
\hline
\end{tabular}


Capítulo 6. Conclusiones

Un resumen de las características de los edificios, se muestra en la Tabla 143

Tabla 143. Resumen de características de los edificios de la UVA

\begin{tabular}{|c|c|c|c|c|c|c|c|c|c|}
\hline & Tipo & $\begin{array}{c}\text { Tipo de } \\
\text { combustible }\end{array}$ & $\begin{array}{l}\text { kWh total } \\
\text { oct-12 - } \\
\text { may-14 }\end{array}$ & $\mathrm{m}^{2}$ & $\mathrm{kWh} / \mathrm{m}^{2}$ & $\begin{array}{c}\text { kW } \\
\text { instala } \\
\text { dos } \\
\text { Gas } \\
\text { Natural }\end{array}$ & $\begin{array}{l}\text { kW instalados } \\
\text { subestación }\end{array}$ & $\begin{array}{c}\mathrm{h} \\
\text { funcionamiento } \\
\text { a carga nominal } \\
\text { durante oct-12 } \\
\text { - may14 }\end{array}$ & $\begin{array}{c}\text { Años de } \\
\text { hasta } \\
2015\end{array}$ \\
\hline D1 & Residencial & Gas Natural & 2.917 .883 & 17.616 & 165,64 & 1.554 & 1.454 & $1.877,66$ & 19 \\
\hline D2 & Docente & Gas Natural & 127.560 & 464 & 274,91 & 41 & 42 & $3.111,22$ & 19 \\
\hline D3 & Docente & Gas Natural & 572.885 & 5.487 & 104,41 & 348 & 342 & $1.646,22$ & 8 \\
\hline D4 & Docente & Gas Natural & 2.060 .198 & 14.541 & 141,68 & 1.140 & 1.140 & $1.807,19$ & 3 \\
\hline D5 & Docente & Gas Natural & 189.987 & 4.146 & 45,82 & 81 & 80 & $2.345,52$ & 7 \\
\hline D6 & Docente & Gas Natural & 2.224 .169 & 19.137 & 116,22 & 1.162 & 1.120 & $1.914,09$ & 6 \\
\hline D7 & Docente & Gas Natural & 2.495 .431 & 20.179 & 123,66 & 1.956 & 1.620 & $1.275,78$ & 18 \\
\hline D8 & Docente & Gas Natural & 757.645 & 5.610 & 135,05 & 466 & 460 & $1.625,85$ & 7 \\
\hline D9 & Deportivo & Gas Natural & 485.432 & 3.673 & 132,16 & 508 & 504 & 955,57 & 14 \\
\hline D10 & Docente & Gas Natural & 495.620 & 5.636 & 87,94 & 326 & 326 & $1.520,31$ & 19 \\
\hline D11 & Docente & Gas Natural & 1.355 .765 & 14.943 & 90,73 & 1.000 & 1.000 & $1.355,77$ & 14 \\
\hline D12 & Docente & Gas Natural & 603.534 & 7.412 & 81,43 & 802 & 802 & 752,54 & 8 \\
\hline DELIBES & & & 14.286 .109 & 118.844 & 120,21 & 9.385 & 8.890 & $1.522,23$ & \\
\hline E1 & Docente & Gasóleo & 252.500 & 1.681 & 150,21 & 291 & 291 & 867,70 & 75 \\
\hline E2 & Docente & Gasóleo & 945.845 & 11.160 & 84,75 & 989 & 988 & 956,36 & 21 \\
\hline E3 & Docente & Gas Natural & 2.203.319 & 21.709 & 101,49 & 930 & 929 & $2.369,16$ & 18 \\
\hline E4 & Docente & Gasóleo & 1.560 .450 & 32.305 & 48,30 & 3.139 & 2.384 & 497,12 & 47 \\
\hline E5 & Residencial & Gasóleo & 3.362 .492 & 20.016 & 167,99 & 4.943 & 3.800 & 680,25 & 24 \\
\hline E6 & Residencial & Gas Natural & 877.200 & 6.660 & 131,71 & 716 & 560 & $1.225,14$ & 34 \\
\hline E7 & Docente & Gas Natural & 379.919 & 3.919 & 96,94 & 466 & 465 & 815,28 & 10 \\
\hline E8 & Docente & Gas Natural & 3.908 .737 & 29.802 & 131,16 & 2.320 & 2.172 & $1.684,80$ & 55 \\
\hline E13 & Docente & Gas Natural & 2.583 .651 & 17.776 & 145,34 & 1.604 & 1.624 & $1.610,75$ & 33 \\
\hline E14 & Docente & Gasóleo & 676.599 & 7.569 & 89,39 & 407 & 425 & $1.662,41$ & 29 \\
\hline E15 & Docente & Gas Natural & 2.900 .998 & 18.512 & 156,71 & 2.326 & 2.160 & $1.247,20$ & 30 \\
\hline RÍO ESGUEVA & & & 19.651 .710 & 171.109 & 114,85 & 18.129 & 15.798 & $1.083,99$ & \\
\hline UVA & & & 33.937 .819 & 289.953 & 117,05 & 27.514 & 24.688 & $1.233,65$ & \\
\hline
\end{tabular}

El 42,1\% de la energía consumida por los edificios de la UVA (14.286 MWh), durante las dos temporadas anteriores a la construcción de red, fue en los doce edificios del campus Miguel Delibes, en el Campus Río Esgueva, se consumió el 57,9\% de la energía restante (19.652 MWh).

El ratio de $\mathrm{kWh} / \mathrm{m}^{2}$ durante esas dos temporadas de calefacción en los edificios de la UVA, fue de 117, siendo mayor el ratio en los edificios del Campus Miguel Delibes (120), que los edificios del Campus del Río Esgueva (115)

Tan sólo 5 de los 23 edificios de la UVA (21,7\%) consumieron Gasóleo C para satisfacer sus necesidades térmicas, el resto de los 18 edficios (78,3\%), consumieron Gas Natural.

Con la red de calor, la potencia en las subestaciones se redujo en $2.826 \mathrm{~kW}$, lo que representa una reducción del 10,3 \% de la potencia inicialmente instalada en las salas de calderas de los edificios de la UVA 
Capítulo 6. Conclusiones

En la Tabla 144, se muestran los consumos reales y pronosticados con los modelos de regresión encontrados para los edificios del Campus Miguel Delibes y los edificios del Campus Río Esgueva y para el conjunto total de los edificios de la UVA, conectadados a red.

Tabla 144. Consumo Real térmico y pronosticado de los edificios de la UVA (kWh)

\begin{tabular}{|c|c|c|c|c|c|c|c|c|}
\hline \multirow{3}{*}{ REAL } & \multicolumn{4}{|c|}{ CONSUMOS REALES } & \multicolumn{4}{|c|}{ CONSUMOS PRONOSTICADOS } \\
\hline & DELIBES & RíO & TOTAL & TOTAL & DELIBES & RÍO & TOTAL & TOTAL \\
\hline & & ESGUEVA & & ACUMULADO & & ESGUEVA & & ACUMULADO \\
\hline oct-12 & 345.753 & 349.810 & 695.563 & 695.563 & 345.752 & 349.810 & 695.562 & 695.562 \\
\hline nov-12 & 1.042 .627 & 1.369 .590 & 2.412 .217 & 3.107 .780 & 1.042 .627 & 1.369 .590 & 2.412 .218 & 3.107 .779 \\
\hline dic-12 & 1.190 .619 & 1.587 .597 & 2.778 .216 & 5.885 .996 & 1.190 .619 & 1.587 .597 & 2.778 .216 & 5.885 .995 \\
\hline ene-13 & 1.279 .157 & 1.744 .852 & 3.024 .008 & 8.910 .005 & 1.279 .157 & 1.744 .852 & 3.024 .008 & 8.910 .004 \\
\hline feb-13 & 1.343 .958 & 1.938 .244 & 3.282 .202 & 12.192.207 & 1.343 .958 & 1.938 .244 & 3.282 .202 & 12.192 .206 \\
\hline mar-13 & 1.019 .870 & 1.615 .611 & 2.635 .481 & 14.827 .688 & 1.019 .872 & 1.615 .611 & 2.635 .483 & 14.827 .689 \\
\hline abr-13 & 823.873 & 1.000 .325 & 1.824 .198 & 16.651 .885 & 823.873 & 1.000 .325 & 1.824 .198 & 16.651 .886 \\
\hline may-13 & 521.472 & 455.534 & 977.007 & 17.628 .892 & 521.473 & 455.534 & 977.007 & 17.628 .893 \\
\hline oct-13 & 296.925 & 216.600 & 513.525 & 18.142 .417 & 296.927 & 216.600 & 513.526 & 18.142 .420 \\
\hline nov-13 & 693.017 & 1.240 .614 & 1.933 .631 & 20.076 .048 & 693.015 & 1.240 .614 & 1.933 .630 & 20.076 .049 \\
\hline dic-13 & 1.538 .561 & 2.065 .172 & 3.603 .733 & 23.679 .781 & 1.538 .562 & 2.065 .172 & 3.603 .734 & 23.679 .783 \\
\hline ene-14 & 1.295 .691 & 1.809 .216 & 3.104 .907 & 26.784 .688 & 1.295 .691 & 1.809 .216 & 3.104 .906 & 26.784 .690 \\
\hline feb-14 & 1.308 .271 & 1.850 .682 & 3.158 .953 & 29.943 .640 & 1.308 .272 & 1.850 .682 & 3.158 .954 & 29.943 .644 \\
\hline mar-14 & 818.512 & 1.279 .427 & 2.097 .939 & 32.041 .579 & 818.512 & 1.279 .427 & 2.097 .939 & 32.041 .582 \\
\hline abr-14 & 514.499 & 836.158 & 1.350 .656 & 33.392 .235 & 514.501 & 836.158 & 1.350 .658 & 33.392 .240 \\
\hline may-14 & 253.304 & 292.280 & 545.583 & 33.937 .819 & 253.302 & 292.280 & 545.582 & 33.937 .823 \\
\hline oct-15 & 164.332 & 252.453 & 416.785 & 34.354 .604 & 261.734 & 338.669 & 600.403 & 34.538 .225 \\
\hline nov-15 & 802.238 & 1.217 .795 & 2.020 .033 & 36.374 .637 & 828.834 & 1.220 .859 & 2.049 .693 & 36.587 .918 \\
\hline dic-15 & 843.692 & 947.462 & 1.791 .154 & 38.165 .791 & 1.011 .025 & 1.214 .429 & 2.225 .454 & 38.813 .373 \\
\hline ene-16 & 924.881 & 1.058 .501 & 1.983 .382 & 40.149 .173 & 1.050 .539 & 1.237 .949 & 2.288 .489 & 41.101 .861 \\
\hline feb-16 & 1.693 .998 & 2.283 .258 & 3.977 .256 & 44.126 .428 & 1.542 .710 & 2.116 .188 & 3.658 .898 & 44.760 .759 \\
\hline mar-16 & 1.094 .003 & 1.359 .901 & 2.453 .904 & 46.580 .332 & 1.173 .640 & 1.513 .815 & 2.687 .455 & 47.448 .214 \\
\hline$a b r-16$ & 755.618 & 1.072 .663 & 1.828 .281 & 48.408 .613 & 813.354 & 1.087 .498 & 1.900 .852 & 49.349 .066 \\
\hline may-16 & 190.845 & 271.866 & 462.712 & 48.871 .325 & 253.880 & 362.641 & 616.521 & 49.965 .587 \\
\hline oct-16 & 213.428 & 298.923 & 512.351 & 49.383 .675 & 241.689 & 358.287 & 599.976 & 50.565 .563 \\
\hline nov-16 & 1.015 .205 & 1.393 .314 & 2.408 .519 & 51.792 .194 & 1.066 .892 & 1.439 .631 & 2.506 .522 & 53.072 .085 \\
\hline dic-16 & 1.041.961 & 1.311 .308 & 2.353 .269 & 54.145 .463 & 1.187 .583 & 1.523 .270 & 2.710 .853 & 55.782 .938 \\
\hline ene-17 & 1.478 .474 & 1.984 .427 & 3.462 .901 & 57.608 .364 & 1.573 .117 & 2.121 .111 & 3.694 .228 & 59.477 .166 \\
\hline feb-17 & 1.012 .971 & 1.487 .209 & 2.500 .181 & 60.108 .545 & 1.064 .132 & 1.458 .107 & 2.522 .239 & 61.999 .405 \\
\hline mar-17 & 822.277 & 1.215 .642 & 2.037 .920 & 62.146 .464 & 841.466 & 1.210 .913 & 2.052 .379 & 64.051 .784 \\
\hline abr-17 & 360.148 & 485.936 & 846.085 & 62.992 .549 & 389.604 & 603.313 & 992.916 & 65.044 .700 \\
\hline may-17 & 144.676 & 160.024 & 304.700 & 63.297 .249 & 67.695 & 169.729 & 237.424 & 65.282 .125 \\
\hline oct-17 & 108.223 & 140.608 & 248.831 & 63.546 .080 & 126.080 & 244.746 & 370.826 & 65.652 .951 \\
\hline nov-17 & 854.197 & 1.055 .061 & 1.909 .257 & 65.455 .337 & 980.778 & 1.212 .722 & 2.193 .499 & 67.846 .450 \\
\hline dic-17 & 1.258 .751 & 1.620 .849 & 2.879 .600 & 68.334 .937 & 1.325 .738 & 1.722 .291 & 3.048 .029 & 70.894 .479 \\
\hline ene- 18 & 1.324 .924 & 1.628 .835 & 2.953 .760 & 71.288 .697 & 1.360 .481 & 1.695 .289 & 3.055 .770 & 73.950 .250 \\
\hline feb-18 & 1.442 .119 & 1.925 .932 & 3.368 .051 & 74.656 .748 & 1.486 .966 & 1.909 .736 & 3.396 .702 & 77.346 .952 \\
\hline mar-18 & 1.188 .633 & 1.603 .642 & 2.792 .275 & 77.449 .023 & 1.196 .345 & 1.513 .093 & 2.709 .438 & 80.056 .390 \\
\hline abr-18 & 611.245 & 737.949 & 1.349.194 & 78.798 .217 & 595.692 & 742.138 & 1.337 .830 & 81.394 .220 \\
\hline may-18 & 218.015 & 225.268 & 443.283 & 79.241 .500 & 197.584 & 260.502 & 458.086 & 81.852 .306 \\
\hline TOTAL & 33.850 .963 & 45.390 .537 & 79.241 .500 & & 34.923 .673 & 46.928 .634 & 81.852 .306 & \\
\hline Total pronosticado oct-15-may18 & & & & & 20.637 .560 & 27.276 .924 & 47.914 .484 & \\
\hline Total real oct-15-may18 & & & & & 19.494 .998 & 25.725 .187 & 45.220 .186 & \\
\hline Ahorro (kWh) & & & & & 1.142 .561 & 1.551 .737 & 2.694 .298 & \\
\hline Ahorro (\%) & & & & & $5,5 \%$ & $5,7 \%$ & $5,6 \%$ & \\
\hline Diferencias en las medias & & & & & $5,9 \%$ & $6,0 \%$ & $6,0 \%$ & \\
\hline
\end{tabular}


La Figura 151, muestran el resumen del ahorro energético que se ha obtenido en cada Campus y en el total de los edificios de la UVA, durante las tres temporadas de calefacción siguientes a la puesta en marcha de la red de calor, siendo el ahorro conseguido del este del $5,6 \%$ lo que equivale a un ahorro de $2.694 \mathrm{MWh}$.

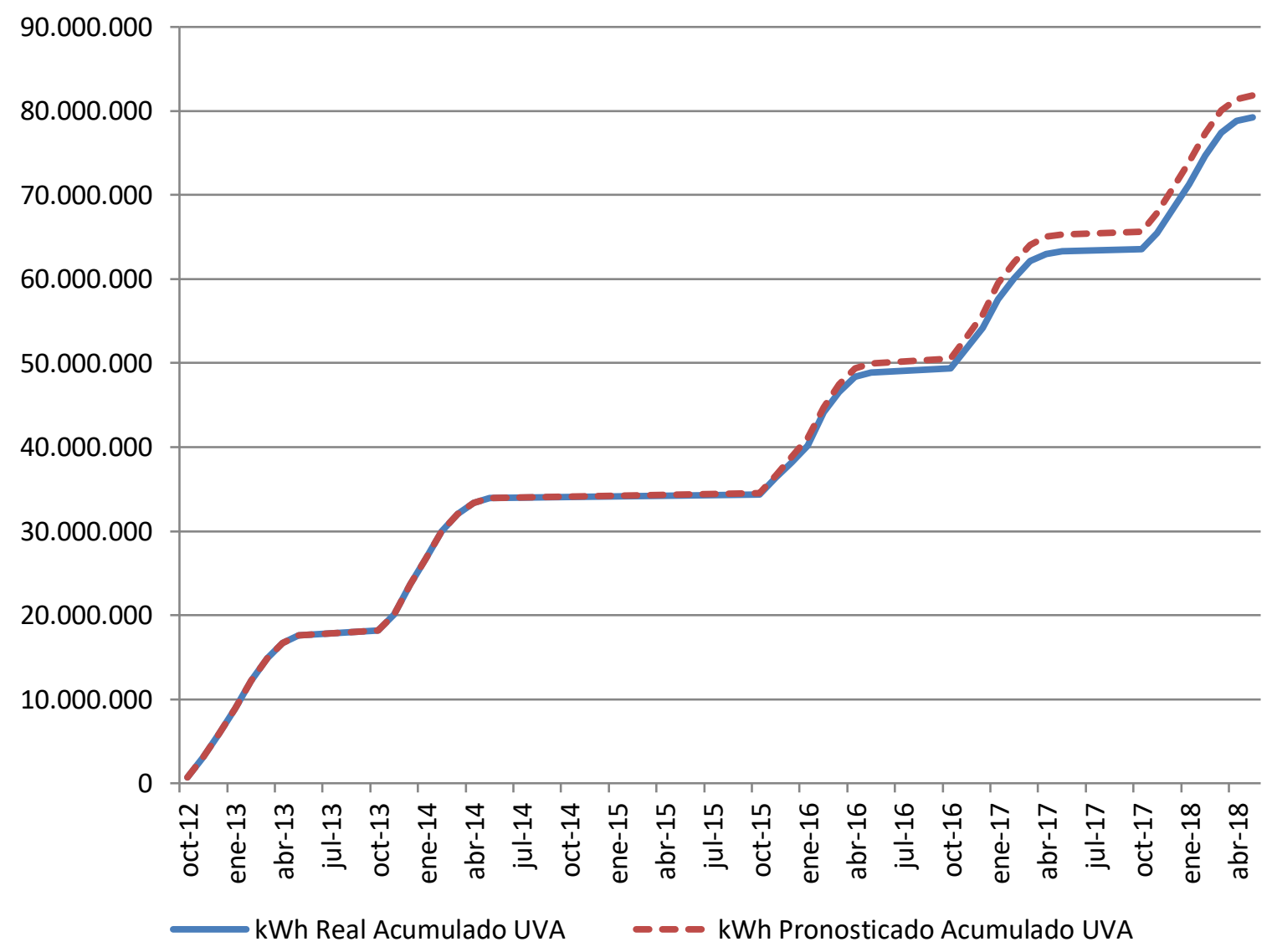

Figura 151. Consumo real acumulado y pronosticado (kWh). Campus Río Esgueva

En la Tabla 145 se muestran los precios que hubieran tenido que tener los $\mathrm{kWh}$ comprados a la red de calor, para obtener un ahorro económico del $0 \%$ y del $15 \%$, durante las tres temporadas siguientes a la ejecución de la red, con respecto a lo que hubiera pagado la Universidad por la compra de la energía al suministrador de gas natural o gasóleo de no haberse conectado a la red de calor. 
Capítulo 6. Conclusiones

Tabla 145. Precios máximos de compra de la energía a la red de calor

\begin{tabular}{crr}
\hline & $\begin{array}{c}\text { E/kWh max comprado para 0\% } \\
\text { ahorro económico }\end{array}$ & $\begin{array}{c}\text { E/kWh max comprado para 15\% } \\
\text { ahorro económico }\end{array}$ \\
\hline D1 & 0,04000 & 0,03380 \\
\hline D2 & 0,04715 & 0,03961 \\
\hline D3 & 0,03740 & 0,03140 \\
\hline D4 & 0,03701 & 0,03130 \\
\hline D5 & 0,02681 & 0,02224 \\
\hline D6 & 0,03220 & 0,02719 \\
\hline D7 & 0,03220 & 0,02719 \\
\hline D8 & 0,02391 & 0,02015 \\
\hline D9 & 0,03225 & 0,02728 \\
\hline D10 & 0,03223 & 0,02728 \\
\hline D11 & 0,03228 & 0,02710 \\
\hline D12 & 0,03846 & 0,03256 \\
\hline E1 & 0,09280 & 0,08040 \\
\hline E2 & 0,04970 & 0,04280 \\
\hline E3 & 0,03210 & 0,02778 \\
\hline E4 & 0,04815 & 0,04088 \\
\hline E5 & 0,06140 & 0,05317 \\
\hline E6 & 0,03230 & 0,02790 \\
\hline E7 & 0,03208 & 0,02758 \\
\hline E8 & 0,03208 & 0,02778 \\
\hline E13 & 0,03166 & 0,02740 \\
\hline E14 & 0,04952 & 0,04270 \\
\hline E15 & 0,03176 & 0,02753 \\
\hline TOTAL UVA & 0,02391 & 0,02015 \\
\hline
\end{tabular}

Se han estimado que los precios que se hubieran pagado por los combustibles fósiles son los que figuran en la Tabla 146, luego el precio que tenía que haber pagado la UVA por la energía suminstrada de la red de calor, tendría que haber sido muy semejante al precio de la astilla para haber podido obtener un ahorro económico en todos los edificios. Cabe recordar que en todos los edificios por haber mantenido y utilizado de forma puntual los suministros de gas natural y gasóleo, la UVA ha tenido que seguir pagando los costes fijos asociados al suminsitro de combustibles fósiles, lo que emperora la eficiencia económica obtenida con la incorporación de los edificios a la red.

Tabla 146. Precios estimados para los combustibles

\begin{tabular}{cccccc}
\hline Precios $(€ /(\mathrm{kWh})$ & 2015 & 2016 & 2017 & 2018 & Promedio \\
\hline Gasóleo C & 0,0517 & 0,0437 & 0,0499 & 0,056 & 0,050325 \\
\hline Gas Natural & 0,0373 & 0,0306 & 0,0314 & 0,0336 & 0,033225 \\
\hline Astilla & 0,0277 & 0,0256 & 0,0254 & 0,0239 & 0,02565 \\
\hline
\end{tabular}




\subsection{Conclusiones sobre la eficiencia energética}

Como se ha expuesto en el apartado anterior el ahorro energético obtenido en el consjunto de los edificios de la UVA, ha sido del 5,6\% lo que equivale a un ahorro de $2.694 \mathrm{MWh}$

Tal como se define en la Directiva 2012/27/CEE, relativa a la Eficiencia Energética (EI Parlamento Europeo y el Consejo de la Unión Europea, 2012) [27], un sistema Urbano Eficiente de Calefacción y Refrigeración, sería todo aquél que utilice al menos un $50 \%$ de energía renovable. Así pues atendiendo a esta definición la red de calor a la que están conectados los 23 edificios de la UVA, se puede considerar un Sistema Urbano Eficiente, dado que utiliza más del $95 \%$ de la energía a partir de la biomasa, concretamente en las tres temporadas posteriores a la ejecución de la red, el porcentaje de energía proveniente de Biomasa y de combustibles fósiles se muestra en la Tabla 147.

Tabla 147. Porcentaje de energía proveniente de Biomasa y de combustibles fósiles. UVA

\begin{tabular}{|c|c|c|c|c|c|c|}
\hline $\begin{array}{c}\text { Octubre 2015- } \\
\text { Mayo } 2018\end{array}$ & $\begin{array}{c}\text { Tipo de } \\
\text { combustible }\end{array}$ & kWh Combustible & kWh Biomasa & kWh TOTAL & \% Combustible fósil & \% Biomasa \\
\hline D1 & Gas Natural & 160.372 & 3.572 .900 & 3.733 .272 & $4,3 \%$ & $95,7 \%$ \\
\hline $\mathrm{D} 2$ & Gas Natural & 12.010 & 120.336 & 132.346 & $9,1 \%$ & $90,9 \%$ \\
\hline D3 & Gas Natural & 60.015 & 669.653 & 729.668 & $8,2 \%$ & $91,8 \%$ \\
\hline D4 & Gas Natural & 84.794 & 2.516 .730 & 2.601 .524 & $3,3 \%$ & $96,7 \%$ \\
\hline D5 & Gas Natural & 36.161 & 294.499 & 330.660 & $10,9 \%$ & $89,1 \%$ \\
\hline D6 & Gas Natural & 142.519 & 3.510 .780 & 3.653 .299 & $3,9 \%$ & $96,1 \%$ \\
\hline D7 & Gas Natural & 110.628 & 3.088 .380 & 3.199 .008 & $3,5 \%$ & $96,5 \%$ \\
\hline D8 & Gas Natural & 48.858 & 1.244 .026 & 1.292 .884 & $3,8 \%$ & $96,2 \%$ \\
\hline D9 & Gas Natural & 20.711 & 705.131 & 725.842 & $2,9 \%$ & $97,1 \%$ \\
\hline D10 & Gas Natural & 16.627 & 652.485 & 669.112 & $2,5 \%$ & $97,5 \%$ \\
\hline D11 & Gas Natural & 117.868 & 1.630 .930 & 1.748 .798 & $6,7 \%$ & $93,3 \%$ \\
\hline D12 & Gas Natural & 18.762 & 729.680 & 748.442 & $2,5 \%$ & $97,5 \%$ \\
\hline E1 & Gasoleo C & 11.235 & 190.375 & 201.610 & $5,6 \%$ & $94,4 \%$ \\
\hline E2 & Gasoleo C & 87.576 & 1.134 .580 & 1.222 .156 & $7,2 \%$ & $92,8 \%$ \\
\hline E3 & Gas Natural & 88.693 & 2.611 .150 & 2.699 .843 & $3,3 \%$ & $96,7 \%$ \\
\hline E4 & Gasoleo C & 166.752 & 974.300 & 1.141 .052 & $14,6 \%$ & $85,4 \%$ \\
\hline E5 & Gas Natural & 150.371 & 3.874 .000 & 4.024 .371 & $3,7 \%$ & $96,3 \%$ \\
\hline E6 & Gas Natural & 59.050 & 1.435 .593 & 1.494 .643 & $4,0 \%$ & $96,0 \%$ \\
\hline E7 & Gas Natural & 40.524 & 535.241 & 575.765 & $7,0 \%$ & $93,0 \%$ \\
\hline E8 & Gas Natural & 115.704 & 5.609 .415 & 5.725 .119 & $2,0 \%$ & $98,0 \%$ \\
\hline E13 & Gas Natural & 144.463 & 4.115 .660 & 4.260 .123 & $3,4 \%$ & $96,6 \%$ \\
\hline E14 & Gasoleo C & 53.153 & 850.170 & 903.323 & $5,9 \%$ & $94,1 \%$ \\
\hline E15 & Gas Natural & 88.622 & 3.402 .200 & 3.490 .822 & $2,5 \%$ & $97,5 \%$ \\
\hline TOTAL UVA & & 1.835 .468 & 43.468 .214 & 45.303 .682 & $4,1 \%$ & $95,9 \%$ \\
\hline
\end{tabular}


Es por la definición que considera la Directiva, que el factor clave en la eficiencia energética de los sistemas de climatización de distrito sea la incorporación de energías renovables, o energías residuales que de otro modo serían desechadas a nivel de climatización de edificios de forma individual. Según (Federación Española de Municipios y Provincias. FEMP, 2011) [126], una aproximación habitual para la medida de la eficiencia energética es el "Factor de recurso primario" (PRF, por sus siglas en inglés "Primary Resorce Factor"), que establece la relación entre la energía no renovable consumida por el edificio sobre la energía final suministrada en el mismo, el factor representaría el suministro energético excluyendo el componente renovable. La idea es poder comparar el suministro energético a través de un sistema de redes de calor frente a los sistemas convencionales.

En el caso en estudio el PRF de los edificios antes de ser conectados a la red era del $100 \%$, frente al $4,1 \%$ que se ha obtenido tras la conexión de los edificios a la red de calor. 


\subsection{Conclusiones sobre la mejora medioambiental}

La Tabla 148 y Figura 152, muestran el resumen del ahorro de emisiones de $\mathrm{CO}_{2}$, que se ha obtenido en cada uno de los Campus y en el conjunto de los edificios de la UVA, durante las tres temporadas de calefacción siguientes a la puesta en marcha de la red de calor, siendo este del $87,7 \%$ lo que equivale a un ahorro de 10.890 toneladas de $\mathrm{CO}_{2}$. Unas 3.630 toneladas de $\mathrm{CO}_{2}$ /año.

Tabla 148. Ahorro de emisiones $\mathrm{CO}_{2}$ de la UVA (kg CO2)

\begin{tabular}{lrrrr}
\hline Ahorro $\mathrm{CO}_{2}\left(\mathrm{~kg} \mathrm{CO}_{2}\right)$ & \multicolumn{1}{c}{ DELIBES } & RíO ESGUEVA & TOTAL UVA & TOTAL ACUMULADO \\
\hline oct-15 & 62.013 & 83.474 & 145.487 & 145.487 \\
\hline nov-15 & 189.612 & 301.868 & 491.480 & 636.967 \\
\hline dic-15 & 234.530 & 276.985 & 511.515 & 1.148 .482 \\
\hline ene-16 & 242.539 & 294.708 & 537.247 & 1.685 .729 \\
\hline feb-16 & 239.192 & 367.787 & 606.979 & 2.292 .707 \\
\hline mar-16 & 249.663 & 330.200 & 579.863 & 2.872 .570 \\
\hline abr-16 & 184.180 & 255.217 & 439.397 & 3.311 .967 \\
\hline may-16 & 58.938 & 80.795 & 139.733 & 3.451 .700 \\
\hline oct-16 & 38.811 & 52.076 & 90.887 & 3.542 .588 \\
\hline nov-16 & 233.408 & 343.678 & 577.086 & 4.119 .673 \\
\hline dic-16 & 268.565 & 352.903 & 621.468 & 4.741 .141 \\
\hline ene-17 & 356.369 & 502.606 & 858.975 & 5.600 .116 \\
\hline feb-17 & 241.052 & 358.491 & 599.543 & 6.199 .658 \\
\hline mar-17 & 191.176 & 299.294 & 490.471 & 6.690 .129 \\
\hline abr-17 & 88.869 & 134.256 & 223.125 & 6.913 .254 \\
\hline may-17 & 13.784 & 27.136 & 40.920 & 6.954 .174 \\
\hline oct-17 & 23.985 & 46.950 & 70.935 & 7.025 .109 \\
\hline nov-17 & 225.101 & 278.935 & 504.037 & 7.529 .146 \\
\hline dic-17 & 302.154 & 419.013 & 721.167 & 8.250 .313 \\
\hline ene-18 & 310.432 & 419.549 & 729.981 & 8.980 .293 \\
\hline feb-18 & 338.795 & 469.983 & 808.778 & 9.789 .071 \\
\hline mar-18 & 270.412 & 390.572 & 660.984 & 10.450 .056 \\
\hline abr-18 & 135.149 & 191.654 & 326.803 & 10.776 .859 \\
\hline may-18 & 44.559 & 68.102 & 112.661 & 10.889 .520 \\
\hline Ahorro kg CO2 & $\mathbf{4 . 5 4 3 . 2 8 9}$ & $\mathbf{6 . 3 4 6 . 2 3 2}$ & $\mathbf{1 0 . 8 8 9 . 5 2 0}$ & \\
\hline kg CO2 antes & 5.200 .665 & 7.221 .040 & 12.421 .705 & \\
\hline$\%$ Ahorro & $\mathbf{8 7 , 4 \%}$ & $\mathbf{8 7 , 9 \%}$ & $\mathbf{8 7 , 7 \%}$ & \\
\hline & & & & \\
\hline
\end{tabular}

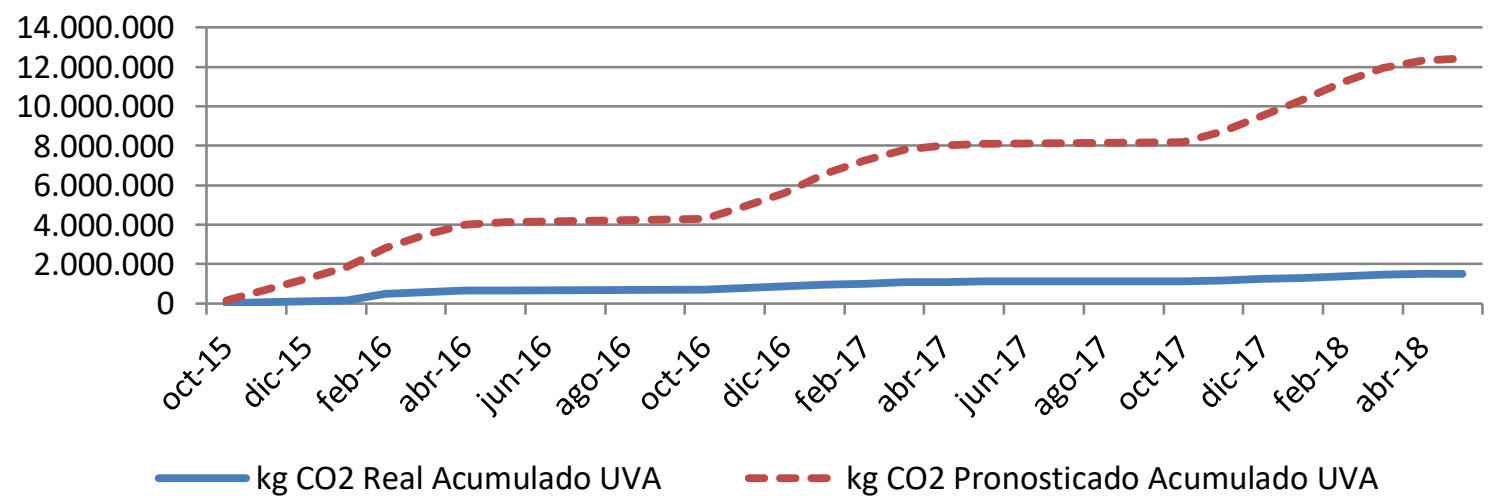

Figura 152. Emisiones reales acumuladas y pronosticadas (kg CO2). UVA 


\subsection{Futuro de la red. Nuevas líneas de investigación}

Sólo 4 de los 23 edificios estudiados (17,4\%), utilizaban calderas de gasóleo como sistema inicial y sólo en uno de los cuatro (E1) se han obtenido diferencias significativas estadísticamente significativas entre los consumos de antes y después de la red de calor. Aunque en este análisis no se haya podido probar la existencia de un importante ahorro energético en todos los edificios, dado que sólo en 8 de los mismos (34,7\%) se han obtenidos ahorros significativos, en 3 de los edificios $(13,0 \%)$, se obtuvieron aumentos significativos del consumo y en los 12 restantes (52,2\%), las diferencias encontraas no resultaron ser significativas, lo que es innegable es el ahorro de emisiones conseguido al sustituir más del 95\% de la energía suministrada provenientes de combustibles fósiles por energía proveniente de la astilla.

El estudio ha analiza la viabilidad de las redes de calor en función de la predicción de la demanda esperada de calor, utilizando únicamente como variables independientes los datos climatológicos del momento y con un riesgo de error igual o inferior al $5 \%$, esto permitiría realizar un estudio de los consumos de acuerdo a la evolución esperada de los datos climáticos medios de la zona como hizo (Andric, y otros, 2017) [127], que tuvo en cuenta, además, el aumento de las temperaturas futuras por el efecto del cambio climático, obteniendo errores en las predicciones del 20 al $60 \%$.

Los resultados sobre las dos temporadas de calefacción tenidas en cuenta para la obtención de los modelos de las líneas base (16 meses) indican que la regresión utiliza de forma muy semejante los grados día $(47,8 \%)$ y la temperatura $(52,2 \%)$ para establecer su modelo, sin tener en consideración el resto de las variables como: las humedades relativas, la radiación, las precipitaciones o las velocidades del viento. Conforme a (Granderson \& Price, 2014) [128] un periodo de referencia mayor a 12 meses, no garantizaría un error menor, y la utilización de datos mensuales, predice con un error menor el ahorro de energía que el uso de datos diarios o semanales.

Los modelos de línea base de consumos obtenidos permiten evaluar cualquier implantación que intente alcanzar una mejora en la eficiencia energética de la red de calor, de forma objetiva y contrastada. Esta herramienta será muy importante durante toda la vida útil de la red de la Universidad de Valladolid, aproximadamente la vida útil de una red de calor convencional es de 30 años (Kim \& Weidlich, 2017) [129], las mejoras que se realicen permitirán convertir a la actual red de calor de la UVA de tercera generación en red inteligente de calor de cuarta generación, en la que, como en cualquier sistema de calefacción, el control (Vanhoudt, Claessens, Desmedt, \& Johansson, 2017) [130], monitorización y regulación de la demanda será fundamental para aumentar la eficiencia energética (Abghari, García-Martín, Johansson, Lavesson, \& Grahn, 2017) [131]. 
En la actualidad, también se investiga sobre la conveniencia de utilizar redes de calor, en función del sistema inicial que se tuviera para satisfacer la demanda, información que, como recoge el trabajo de (Ulseth, Byskov, Georges, Justo, \& Utne, 2017) [132], es importante conocer para poder planificar una red de calor y realizar sin excesivos errores el estudio de su viabilidad económica. En Noruega se cuestionó la utilización de redes de calor para calefactar casas que poseían bombas de calor que eran también utilizadas para satisfacer la demanda de ACS, incluso otros estudios, han analizado la viabilidad del uso de electricidad como fuente para un sistema de calefacción de distrito municipal con bajas emisiones locales, aunque evidentemente no resulte viable económicamente con los actuales precios de la electricidad (Khabdullin, Khabdullina, Khabdullina, Lauka, \& Blumberga, 2017) [133].

El siguiente paso que se está dando en la red de la UVA, es el uso de energía solar térmica para ACS, como se está realizando en otras muchas redes de tercera generación (Winterscheid, Dalenbäck, \& Holler, 2017) [134] y (Winterscheid, C, Holler, \& Dalenbäck, 2017) [135]. El uso de energías renovables permitirá aumentar la eficiencia energética de la red, siendo, además, el paso lógico para su conversión paulatina a una red de cuarta generación, como expone (Pavicevic, Novosel, Puksec, \& Duic, 2017) [136] en su trabajo sobre un district heating en Zagreb.

Por la disposición de los edificios de la Universidad y de la administración regional próximos a la red, no conectados todavía, que disponen de sistemas de calefacción de distintos saltos térmicos, no sería posible que al igual que la propuesta realizada por (Mertz, Serra, Reneaume, \& J.M, 2017) [137] se conectaran nuevos edificios en cascada, en lugar de en paralelo. Este tipo de conexión hubiera permitido que edificios que requieran menores temperaturas (edificios con sistema todo aire) hubieran podido conectarse a la salida de los edificios que necesitan mayores temperaturas (edificios sanitarios como hospitales o clínicas). 


\section{ANEXO I. PROTOCOLOS DE MEDIDA Y VERIFICACIÓN}

Cuando se desea evaluar el ahorro conseguido al aplicar una mejora energética, hay que estudiar cómo será la medida y la verificación de ese ahorro.

El ahorro no se puede medir de forma directa, al ser una ausencia del consumo de energía, por lo que se tiene que determinar por comparación entre el consumo antes y después de la aplicación de la medida, una vez se hayan realizado los ajustes necesarios en función de la variación de las condiciones iniciales.

Existen muchos protocolos que se aplican internacionalmente para medir y verificar los ahorros energéticos obtenidos con la implantación de una medida de ahorro.

Principalmente los protocolos de medida son demandados por empresas de servicios energéticos, empresas comercializadoras y distribuidoras de energía, la industria en general, entidades financieras y la Administración pública. Todos ellos pueden utilizar la Medida y Verificación para cuantificar, valorar y mejorar la eficiencia de sus instalaciones e inversiones. (Centro Tecnológico de Eficiencia y Sostenibilidad Energética (ENERGYLAB), 2014) [138]

La utilización de estos protocolos entre las empresas o entidades que consumen energía y en las que suministran energía, como las Empresas de Servicios Energéticos (ESEs) es especialmente ventajoso, puesto que sirve como garantía tanto para el cliente como para el proveedor, evita posibles conflictos derivados de la medida o justificación de los ahorros y los contratos basados en ahorros demostrados de energía pueden basar sus estimaciones en los métodos aceptados internacionalmente en esos protocolos, que además deberán ser aceptados por todas las partes. Los protocolos utilizan procesos de Medida y Verificación (M\&V) fiables, objetivos y técnicamente rigurosos.

Entre los protocolos aceptados internacionalmente se encuentran: (Asociación de Empresas de Eficiencia Energética. A3e, 2015) [139] 
IPMVP (Protocolo Internacional de Verificación y Medida).

Desarrollado por EVO (Efficency Valuation Organization), organización de Estados Unidos, sin ánimo de lucro.

El IPMVP es el estándar líder internacional en protocolos de medida y verificación.

Aporta soluciones para la verificación de los resultados de eficiencia energética, eficiencia en el uso del agua y proyectos de energías renovables.

Según cita este protocolo, en su Capítulo 2:

La Medida y Verificación (M\&V) es un proceso que consiste en utilizar la medida para establecer de forma fiable el ahorro real generado en una instalación dentro de un programa de gestión de energía. (Efficiency Valuation Organization (EVO), 2010) [140]

\section{FEMP (Federal Energy Management Program)}

Ha sido desarrollado por el Departamento de Energía de los Estados Unidos (DOE). Aporta métodos y guías para la medida y verificación en contratos federales de EEUU de ahorro de energía, supone una aplicación específica del IPMVP para aplicaciones concretas como: eficiencia y control en la iluminación, motores de velocidad constante y variable, sistemas de enfriamiento, agua, bombas de calor geotérmicas y energías renovables

\section{ASHRAE Guideline 14-2014}

Desarrollado por ASHRAE (American Society of Heating, Refrigerating and Air-Conditioning Engineers), tiene una estrecha relación con el protocolo IPMVP, dado que son documentos complementarios, el IPMVP es un marco de definiciones y aproximaciones, mientras que la Guía 14 contiene más detalles técnicos para su aplicación. (ASHRAE, 2014) [141]

Otra diferencia es que mientras el IPMVP incluye cuatro opciones de verificación, de las cuales la Opción A, permite realizar estimaciones sin la necesidad de mediciones, la Guía 14 , requiere mediciones para todas las opciones que propone.

\section{Australian Best Practice Guide}

Se trata de una guía elaborada por The Australasian Energy Performance Contracting Association for the Innovation Access Program of AusIndustry in Australian Department of Industry Tourism and Resources. Se basa principalmente en la edición 2002 del IPMVP, en la Guía 14 de ASHRAE y en la Guía FEMP. Fue generada para la aplicación en los contratos de rendimientos o contratos para la mejora de la eficiencia energética. 


\section{California Energy Efficiency Evaluations Protocol}

Creado por la CPUC (California Public Utilities Commission), que regula las compañías privadas de electricidad, telecomunicaciones, agua y transporte público del Estado de California. También contiene aspectos del IPMVP, haciendo una reseña especial sobre la Opción D. de simulación calibrada, exigiendo que los programas informáticos que se empleen cumplan con el Standard 140 de la ASHRAE, empleado para hacer pruebas y evaluar los programas de simulación energética.

El IPMVP del 2010 está compuesto de tres documentos:

- Volumen 1. Conceptos y Opciones para determinar el Ahorro de Energía y Agua

- Volumen 2. Conceptos y prácticas para la mejora de la calidad del Aire interior

- Volumen 3. Conceptos y prácticas para determinar los ahorros de energía:

- Parte I. En edificios de nueva construcción

- Parte II. En Aplicaciones de Energías Renovables.

En el 2014, se actualizó este protocolo, reorganizando los documentos, definiendo la terminología utilizada y los principios rectores para aplicar las M\&V. (EVO, 2014) [142] (Efficiency Valuation Organization (EVO), 2014) [143]

El protocolo IPMVP, es una guía respecto a las prácticas más comunes relacionadas con la medida, el cálculo y la elaboración de los informes demostrativos de ahorros. No es una norma, ni está sujeta a ninguna obligación legal de su cumplimiento.

El protocolo ofrece cuatro opciones para determinar el ahorro:

- Opción A. Verificación aislada de la Medida de Mejora de la Eficiencia Energética (MMEE), con medición del parámetro clave y estimación de los demás.

- Opción B. Verificación aislada de la MMEE con medición de todos los parámetros. La dificultad y coste de su implementación crece con la complejidad de la medida realizada.

- Opción C. Verificación de toda la instalación.

- Opción D. Simulación calibrada con un programa de simulación para predecir el consumo de la instalación en el periodo de referencia, demostrativo o ambos. El modelo de simulación debe ser calibrado para que pueda predecir un patrón de consumo que coincida de forma fiable con los datos registrados realmente por el equipo de medida. 
La opción C implica el uso del equipo de medida de la empresa de suministro como los contadores de facturación o de equipos y contadores propios que midan toda la instalación o el empleo de facturas del suministro energético. Dado que la medida es relativa a toda la instalación, el ahorro que refleja la opción $\mathrm{C}$ incluye todos los efectos positivos o negativos de cualquier modificación que ocurra dentro de la instalación y que no sean atribuibles a las MMEE implementadas.

Esta opción está pensada para proyectos donde el ahorro estimado es superior al $10 \%$ de la energía de referencia, cuando el periodo demostrativo de ahorro es inferior a dos años, en caso de no ser así, el protocolo recomienda la opción D.

Las fases que establece el protocolo IPMVP para un Plan de Medida y Verificación (M\&V) son:

1. Diseño del Plan de $M \& V$

2. Establecimiento del Periodo de Referencia, deberá abarcar un ciclo operativo completo

a. Medición del consumo

b. Obtención del patrón de consumo y definición de las variables que le influyen

3. Implementación de la MMEE

4. Establecimiento del Periodo de demostración del ahorro, deberá abarcar al menos un ciclo operativo normal de los equipos o de la instalación, para conseguir una completa caracterización de la efectividad del ahorro en todas las condiciones normales de operación.

a. Medición del consumo

b. Obtención de ahorros ajustados a partir del patrón de consumo y del consumo medido en este periodo

c. Elaboración de informes

Los ajustes aseguran que las condiciones del periodo de referencia son las mismas que las del periodo demostrativo de ahorro y pueden clasificarse en dos tipos:

- Ajustes Rutinarios que son los ocasionados por variables que influyen en la energía y que experimentan variaciones durante el periodo demostrativo de ahorro (climatología, nivel de producción o carga de trabajo de las máquinas o instalaciones, ...)

- Ajustes no Rutinarios, debidos a parámetros que influyen en la energía y que no se prevé que cambien con el tiempo: tamaño de la instalación, diseño y funcionamiento de los equipos existentes, número de turnos de trabajo, tipo de ocupantes, consignas interiores, horarios de encendido / apagado. .... 


\section{ANEXO II. TRATAMIENTO ESTADÍSTICO DE LOS DATOS}

\section{All.1.Nomenclatura.}

\begin{tabular}{ll}
\hline & Estadístico \\
& Valor obtenido a partir de datos de la muestra \\
\hline $\boldsymbol{\alpha}$ & Nivel de significación. \\
& Es un umbral que permite determinar si el resultado es significativo. \\
& Indica la probabilidad de rechazar la hipótesis nula cuando ésta es verdadera. \\
& $\alpha=$ P(Rechazar Ho / Ho es cierta) \\
& Es el error de tipo I o “falso positivo" \\
& Un nivel de 0,05 indica un riesgo del $5 \%$ de estar equivocados \\
& Nivel de confianza \\
Indica la probabilidad de que el estadístico se encuentre en el intervalo de \\
confianza \\
Un nivel de 0,95 indica que en el $95 \%$ de las veces el estadístico se encontrará en \\
el intervalo de confianza definido \\
Valor de $\mathbf{p}$ \\
Probabilidad que presenta el estadístico de ser posible bajo la hipótesis nula. \\
Oscila entre 0 y 1 \\
Si esta probabilidad es menor o igual al nivel de significancia, la hipótesis nula es \\
rechazada \\
p-valor $\leq \alpha \rightarrow$ Rechazo Ho \\
p-valor $>\alpha \rightarrow$ No Rechazo Ho \\
(No implica certeza de Ho, indica que hay más probabilidad de que \\
$\quad$ Ho sea cierta que incierta) \\
\hline
\end{tabular}


$\boldsymbol{\beta} \quad$ Indica la probabilidad de aceptar la hipótesis nula cuando ésta es falsa.

$\beta=P$ (Aceptar Ho / Ho es falsa)

Es el error de tipo II

\section{1- $\beta \quad$ Potencia de la prueba}

Indica la probabilidad de rechazar la hipótesis nula cuando ésta es falsa

$1-\beta=P($ Rechazar Ho / Ho es falsa)

$\boldsymbol{\mu} \quad$ Media de una población de $\mathrm{N}$ elementos donde Xi es cada elemento

$$
\mu=\frac{1}{N} \sum_{i=1}^{N} x_{i}=\bar{x}_{\imath}
$$

\section{$\sigma \quad$ Desviación típica o estándar}

Indica la dispersión de los valores alrededor de la media

Representa el error estándar de la estimación

Es la raíz cuadrada de la diferencia entre el promedio de los cuadrados de los valores y el cuadrado del valor promedio.

$$
\sigma=\sqrt{\frac{1}{N} \sum_{i=1}^{N}\left(x_{i}-\mu\right)^{2}}
$$

\section{$\sigma^{2} \quad$ Varianza}

Establece la variabilidad de la variable, mide la dispersión de los datos.

A mayor dispersión mayor variabilidad y menor homogeneidad.

Es la media del cuadrado de la desviación de dicha variable respecto a su media

$$
\sigma^{2}=\frac{1}{N} \sum_{i=1}^{N}\left(x_{i}-\mu\right)^{2}
$$

R Coeficiente de correlación o coeficiente de correlación de Pearson

Indicará el grado de dependencia entre las variables independientes y la variable dependiente

El valor del coeficiente de correlación puede variar entre 1 y -1

- $\mathrm{R}=-1$ la corrección es perfecta e inversa

- $\mathrm{R}=0$ no existe ninguna correlación entre las variables

- $\mathrm{R}=1$ la correlación es perfecta y directa 


\section{$\mathbf{R}^{\mathbf{2}} \quad$ Coeficiente de determinación}

Indica qué proporción de la variación de la variable dependiente (Y) puede ser explicada por la variación de la(s) variable(s) independiente(s) (X).

Puede tomar valores entre 0 y 1

$\mathrm{R}^{2}=1$, indica ajuste lineal perfecto

\section{$\mathbf{R}^{\mathbf{2}}$ corregido Coeficiente de determinación lineal corregido}

Tiene en cuenta el número de variables independientes ( $k$ incluidas en el modelo y el tamaño de la muestra $(n)$, reduce el coeficiente para muestras muy pequeñas con muchas variables independientes

$$
R_{\text {corregido }}^{2}=1-\frac{(n-1)\left(1-R^{2}\right)}{n-k-1}
$$

\section{e $\quad$ Error o residuo del modelo}

Diferencia entre el valor real $\left(Y_{i}\right)$ y el valor pronosticado o predicho por el modelo $\left(\hat{\mathrm{Y}}_{\mathrm{i}}\right)$

$$
\mathrm{e}_{\mathrm{i}}=\text { residuos del modelo }=\mathrm{Y}_{\mathrm{i}}-\hat{\mathrm{Y}}_{\mathrm{i}}
$$

\section{Error típico de la estimación o de la recta de regresión}

Indica la magnitud de los errores, describe la variación de la variable respuesta $Y$ respecto a la recta de regresión.

Es la desviación típica de los residuos, es decir es la raíz cuadrada de la media cuadrática residual.

Representa una medida de la parte de variabilidad de la variable dependiente que no se explica por el modelo de regresión.

$\mathrm{n}=$ número de observaciones de la muestra

$$
S e=\sqrt{\frac{\sum_{i=1}^{n}\left(Y_{i}-\widehat{Y}_{l}\right)^{2}}{n-2}}
$$

Para regresión lineal múltiple

$\mathrm{k}$ = número de variables independientes del modelo

$$
S e=\sqrt{\frac{\sum_{i=1}^{n}\left(Y_{i}-\widehat{Y}_{l}\right)^{2}}{n-k-1}}
$$




\section{All.2.Intervalo de confianza.}

Para poder cuantificar una característica, en este caso la eficiencia energética de un sistema, es necesario la obtención, estudio, tratamiento y análisis de una realidad, es decir es necesario realizar una investigación sobre esa realidad.

Si la realidad investigada además de poder ser descrita (investigación descriptiva), puede ser medida, se dispondrá de una información no sólo nominal sino también numérica, que podrá ser tratada con operaciones lógicas y de cálculo numérico, de manera que se puedan establecer correlaciones entre los datos disponibles (investigación correlacional), estas correlaciones podrán ser tratadas y procesadas de manera que puedan dar respuesta a preguntas sobre la causa y el efecto de las variables analizadas, llegando con ello a la investigación experimental.

Cuando se dispone de una serie de datos y se desea llegar a conclusiones fiables, la única forma es recurrir a la estadística, la estadística nos permite generalizar los hallazgos encontrados en una muestra reducida de la realidad a la globalidad de la misma.

La estimación de un valor estadístico a partir de los datos de una muestra, no se hace como valor absoluto, pues si se volviera a repetir el cálculo del valor para otra muestra de la misma población, se obtendrían valores diferentes, por lo tanto la estimación de los valores se hace mediante intervalos de confianza, intervalos que estarán formados por un grupo de valores que en muchas ocasiones sigue la expresión:

\section{Estimación \pm margen de error.}

Por lo tanto para estimar un valor estadístico a partir de una muestra se debe aceptar un riesgo a cometer un error si se considera como buena la conclusión final obtenida. Este riesgo está relacionado con el intervalo de confianza que como se ha indicado, representa entre qué valores se estima, que estará el resultado con una determinada probabilidad de acierto, esa probabilidad de éxito es el llamado "nivel de confianza"; ambos conceptos están directamente relacionados, de forma que un intervalo de confianza más amplío tendrá una mayor probabilidad de acierto, pero al aumentar esa amplitud y probabilidad se perderá precisión.

El error aleatorio cometido se denomina "nivel de significación", se representa por a e indica las posibilidades de fallar en la estimación. El nivel de confianza en estadística se representa con 1- $\alpha$ y como se ha señalado indica la probabilidad de que el estadístico se encuentre en el intervalo de confianza. Los niveles de confianza más utilizados son el $90 \%$, $95 \%$ y $99 \%$, lo que arroja unas posibilidades de fallo del $10 \%, 5 \%$ y $1 \%$. 
El nivel más preciso será el del $90 \%$, por ser el que tiene el intervalo de confianza más estrecho, pero también es el que tendrá más posibilidades de fallo (10\%), por el contrario el nivel cuyo intervalo de confianza es más amplio será el del $99 \%$, pero no se podrá afinar tanto en los resultados. Esto se puede apreciar en la Figura 153

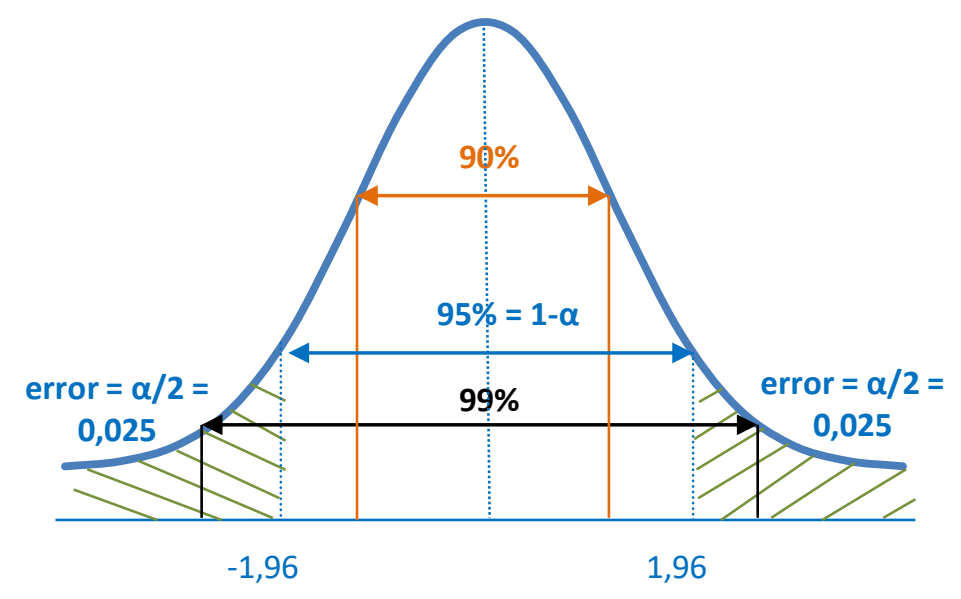

Figura 153. Intervalos de confianza en una distribución normal.

Para definir un intervalo de confianza es necesario saber la distribución que sigue la variable que estamos estudiando, lo habitual es partir de una distribución normal o gaussiana, puesto que por su forma se puede determinar exactamente el porcentaje de valores que está dentro de cualquier intervalo específico

El intervalo de confianza, que tiene asociado un nivel de confianza de (1- $\alpha)$, para la media $\mu$ de la población se puede obtener a partir de la Ecuación 14.

$$
\bar{x} \pm Z_{\alpha / 2} \frac{\sigma}{\sqrt{n}}
$$

Siendo:

$\bar{x}:$ Media de los valores

$Z_{\alpha / 2}$ : Valor de la curva normal obtenido para $\alpha / 2$

$\sigma$ : Desviación estándar

$n$ : Número de valores de la muestra

El valor $Z_{0,025}=1,96$, luego el intervalo de confianza para la media de una población con un nivel de confianza del $95 \%$ es $[\bar{x}-1,96 \sigma, \bar{x}+1,96 \sigma]$ y menos del $5 \%$ de las observaciones estarán fuera de ese rango. (Poquet, Sastre, \& Crespo, 2014) [144]. 
Si se toman muestras aleatorias del mismo tamaño, lo único que varía en este intervalo es la media de los valores, es decir el centro de los intervalos obtenidos, pero el margen de error sería el mismo para todas las muestras.

Tomando una única muestra, para un nivel de confianza del $95 \%$, se sabe que existe una probabilidad del $95 \%$ de que la media de la población se encuentre en el intervalo seleccionado y un $5 \%$ de las veces se obtendrán intervalos erróneos.

En una distribución Normal, se sabe que:

- el $68,26 \%$ de las observaciones está dentro del intervalo que tiene su centro en la media y su amplitud en una desviación de la media $[\bar{x}-\sigma, \bar{x}+\sigma]$

- el 95,44\% de las observaciones está dentro del intervalo que tiene su centro en la media y su amplitud en dos desviaciones estándar de la media $[\bar{x}-2 \sigma, \bar{x}+2 \sigma]$

- el 99,74\% de las observaciones está dentro de tres desviaciones estándar de la media $[\bar{x}-3 \sigma, \bar{x}+3 \sigma]$

Si se fija el nivel de confianza, al aumentar el tamaño de la muestra, se reduce el margen de error. Si fijamos el tamaño de la muestra, al incrementar el nivel de confianza se aumenta el margen de error.

\section{All.3.Contraste de hipótesis y zonas de rechazo.}

Cuando lo que se desea es comprobar que una característica observada en una muestra se puede extrapolar al resto de la realidad, se recurre al contraste de hipótesis, de manera que se establece una hipótesis estadística o afirmación que puede ser cierta o no y con la información extraída de la muestra se contrasta para aceptarla o rechazarla.

La hipótesis que se formula con la intención de rechazarla se llama hipótesis nula $\left(\mathrm{H}_{0}\right)$, se considera como la hipótesis neutra o que no supone cambios y el rechazarla implica la aceptación de la hipótesis alternativa $\left(\mathrm{H}_{1}\right)$ que es la afirmación contraria. La hipótesis nula nunca se considera probada mediante muestreo porque siempre cabe la posibilidad de que exista una pequeña desviación en la muestra tomada que no pueda ser detectada: pero puede ser rechazada por los datos analizados cuando existan diferencias suficientemente grandes. Por eso un resultado con base en un rechazo de la hipótesis nula es más significativa que una que termine en una decisión de no rechazo, el no rechazo no implica que sea aceptada por ser cierta, sino que existe más probabilidad de que la hipótesis sea cierta que incierta. (Trejo) [145]. 
Tanto si se acepta como si se rechazan las hipótesis estadísticas formuladas se comete un error. Se habla de dos tipos de errores:

- Error cometido por rechazar la hipótesis nula siendo cierta (error tipo I) ( $\alpha$ )

- Error cometido por aceptar la hipótesis nula siendo falsa (error tipo II) ( $\beta$ )

El valor $\mathrm{p}$ o " $p$-valor" se define como la probabilidad de observar unos datos que van en contra de Ho. Cuanto menor es el valor p, más evidencias hay en contra de Ho y más evidencias hay a favor de $\mathrm{H}_{1}$.

Al rechazar Ho se comete un error que viene dado por el nivel de significación $\alpha$ y que indica la probabilidad que existe de rechazar Ho siendo cierta.

Cuando se acepta Ho también se comete un error, que viene dado por $\beta$, e indica la probabilidad que existe de aceptar Ho siendo falsa.

Lo ideal sería que $\alpha$ y $\beta$, permanecieran en valores muy bajos, pero estos valores están relacionados cuando $\alpha$ es muy bajo, $\beta$ es muy elevado, aunque no se puede probar que $\alpha+\beta=1$.

Como el contraste de hipótesis se plantea para rechazar la hipótesis nula, lo habitual es fijar un nivel de aceptación para el error tipo l, es decir fijar un nivel de significación " $\alpha$ " $y$ limitar el error tipo II ( $\beta$ ) incrementando el número de observaciones de la muestra. Por lo tanto el aceptar la hipótesis nula debe interpretarse que con la información disponible en la muestra no se puede detectar que la hipótesis sea falsa. (Cruz Ramírez) [146].

Para un nivel de significación de $\alpha=0,05$, se rechazará Ho cuando el $p$-valor se encuentre por debajo de ese umbral es decir cuando $p$-valor $\leq 0,05$, lo que implica que aceptamos una probabilidad " $\mathrm{p}$ " de cometer el error de rechazar la hipótesis nula siendo cierta del $5 \%$. Es decir si se rechaza $\mathrm{H}_{0}$, la prueba resultará ser significativa, con un riesgo del $5 \%$ de estar equivocados.

Cuando la prueba divide a la región de rechazo en dos colas se llama prueba bilateral (se produce cuando la hipótesis nula afirma un valor y la alternativa asigna cualquier valor distinto al de la hipótesis nula. La hipótesis nula será rechazada cuando el estadístico de contraste sea menor de $-1,96$ o mayor de 1,96, para un nivel de confianza del $95 \%$ y sólo el $5 \%$ de todas las muestras podrían producir un valor del estadístico que caiga en las zonas de rechazo, como se aprecia en la Figura 154. 


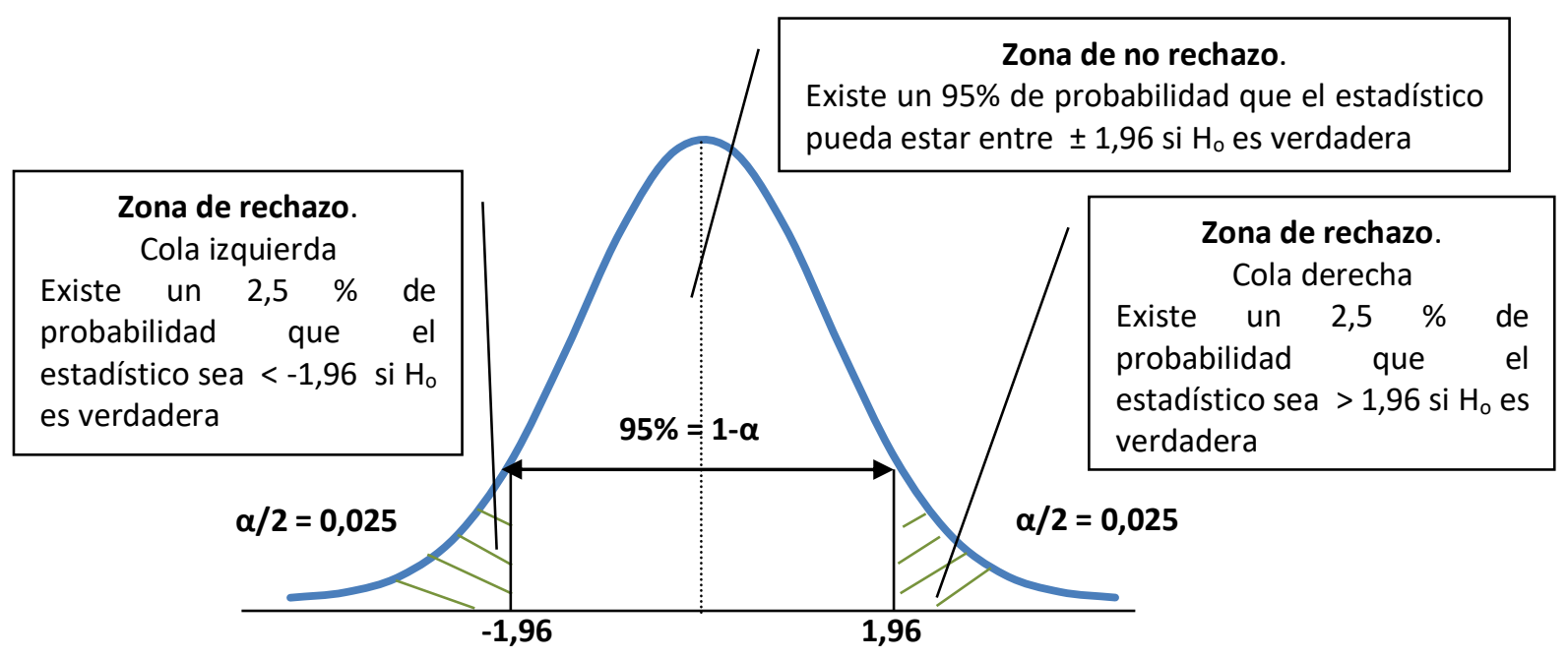

Figura 154. Zonas de rechazo en pruebas bilaterales

En pruebas unilaterales, la hipótesis nula afirma que es igual o menor a un valor, y la alternativa afirma que el valor es superior (cola derecha, zona de rechazo a la derecha) o la hipótesis nula afirma que es igual o mayor a un valor y la alternativa que el valor es inferior (cola izquierda, zona de rechazo a la izquierda)

\section{All.4.Regresión.}

En la investigación experimental, se tiene una variable dependiente, que es la variable que se mide en el experimento, una o varias variables independientes que son las que influyen en lo que se ha medido y una o varias variables extrañas o espúreas que son las que no tienen influencia en lo medido y hay que eliminar del modelo de la investigación.

Cuando las variables numéricas se distribuyen según una Normal y se desea saber por una parte, cuáles son las variables independientes que influyen en la variable dependiente y con qué peso lo hacen y por otra parte cuales son las variables espúreas que no influyen en la variable dependiente, se recurre a la regresión estadística.

Con el análisis de regresión se identifica y se entiende cómo cambia el valor de la variable dependiente al cambiar las independientes, estimando cuál es el valor promedio que tomaría la variable dependiente cuando se fijan las independientes. Esta relación se establece en la función o ecuación de regresión que representa la variable respuesta, predicha, regresora o dependiente $(\mathrm{Y})$ en función de la(s) variable(s) dependiente(s), predictora(s) o explicativa(s) (X). 
Cuando la dependencia es de tipo lineal, la regresión sólo relaciona una variable independiente con la dependiente, se habla entonces de regresión lineal simple (Ecuación 15), en caso de existir más variables independientes se hablaría de regresión lineal múltiple. (Ecuación 16)

Cuando la regresión se analiza a partir de datos numéricos, se habla de regresión paramétrica y a la correlación que se obtiene entre las variables se le puede asignar un peso para intentar explicar la relación causa - efecto; pero esta causalidad deberá ser explicada mediante el conocimiento de la naturaleza del sistema modelado. Si el análisis de regresión se realiza con variables no numéricas o nominales, se habla de regresión no paramétrica y la correlación que se pueda establecer entre ellas tampoco implicará causalidad. (Scott Armstrong, 2012) [147]

La forma de regresión que se emplea en esta investigación es la basada en el método de mínimos cuadrados, que busca minimizar la suma de cuadrados de las diferencias en la variable dependiente $\left(Y_{i}\right)$ y los valores estimados o predichos para la variable dependiente a partir de la ecuación elegida $\left(\hat{Y}_{i}\right)$, es decir se intenta minimizar la suma de los cuadrados de los residuos o errores $=\Sigma\left(Y_{i}-\hat{Y}_{i}\right)^{2}$. (Universidad de Cádiz (UCA)) [148]

Para el caso las regresiones lineales simples de este estudio, las expresiones empleadas son las dadas en las siguientes ecuaciones 15 y 16 que son equivalentes

$$
\begin{aligned}
& \hat{Y}=\beta X+\beta o \\
& Y_{i}=\beta X_{i}+\beta o+e_{i}
\end{aligned}
$$

Donde:

$$
\begin{aligned}
& \hat{Y}=\text { Variable dependiente pronosticada o consumo de los edificios en } \mathrm{kWh} \\
& Y_{i}=\text { Valores reales de la variable dependiente } \\
& \beta=\text { Pendiente de la variable independiente } \\
& X=\text { Variable independiente } \\
& \beta o=\text { Valor numérico fijo } \\
& e_{i}=\text { residuos del modelo }=Y_{i}-\hat{Y}_{i}
\end{aligned}
$$

Cuando se disponen de " $n$ " datos de la variable independiente $\left(X_{i}\right)$ y " $n$ " datos de la variable dependiente $\left(\mathrm{Y}_{\mathrm{i}}\right)$, la expresión que logra hacer mínima la suma de los cuadrados de los errores viene dada en la Ecuación 17. 


$$
\begin{gathered}
Y=\frac{n\left(\sum_{i=1}^{n} X_{i} Y_{i}\right)-\left(\sum_{i=1}^{n} X_{i}\right)\left(\sum_{i=1}^{n} Y_{i}\right)}{n\left(\sum_{i=1}^{n} X_{i}^{2}\right)-\left(\sum_{i=1}^{n} X_{i}\right)^{2}} X \\
+\frac{\left(\sum_{i=1}^{n} Y_{i}\right)-\left(\sum_{i=1}^{n} X_{i}\right) \frac{n\left(\sum_{i=1}^{n} X_{i} Y_{i}\right)-\left(\sum_{i=1}^{n} X_{i}\right)\left(\sum_{i=1}^{n} Y_{i}\right)}{n\left(\sum_{i=1}^{n} X_{i}^{2}\right)-\left(\sum_{i=1}^{n} X_{i}\right)^{2}}}{n}
\end{gathered}
$$

(Ecuación 17)

Para el caso las regresiones lineales múltiples de este estudio, se utilizará la expresión de la Ecuación 18:

$$
\hat{Y}=\beta_{1} X_{1}+\beta_{2} X_{2}+\beta_{3} X_{3}+\ldots \ldots \ldots+\beta o \quad \text { (Ecuación 18) }
$$

Donde:

$\hat{Y}=$ Variable dependiente pronosticada o consumo de los edificios en kWh

$\beta_{\mathrm{i}}=$ Cada una de las pendientes de las variables independientes

$X_{i}=$ Variables independientes

$\beta o=$ Valor numérico fijo.

En ambas expresiones, se está aceptando que todos los factores o causas que influyen en la variable independiente $Y$, se clasifican en dos tipos: los explicados por la(s) variable(s) dependiente(s) (X) y los factores no controlados o aleatorios que son los llamados perturbaciones, errores aleatorios o residuos, que provocan que la dependencia entre las variables dependiente $\mathrm{e}$ independientes no sea perfecta, sino que tenga una cierta incertidumbre. (Universidad de Jaén) [149].

Una vez obtenida la ecuación de regresión, se puede comprobar la bondad de la misma, analizando el coeficiente de de correlación o coeficiente de correlación de Pearson (R), que indicará el grado de dependencia entre las variables independientes y la variable dependiente, viene dado por la Ecuación 19.

$$
R=\frac{n\left(\sum_{i=1}^{n} X_{i} Y_{i}\right)-\left(\sum_{i=1}^{n} X_{i}\right)\left(\sum_{i=1}^{n} Y_{i}\right)}{\sqrt{\left(n\left(\sum_{i=1}^{n} X_{i}^{2}\right)-\left(\sum_{i=1}^{n} X_{i}\right)^{2}\right)\left(n\left(\sum_{i=1}^{n} Y_{i}^{2}\right)-\left(\sum_{i=1}^{n} Y_{i}\right)^{2}\right)}}
$$

El valor del coeficiente de correlación puede variar entre 1 y -1 
- $\quad \mathrm{Si}$ R =-1 la corrección es perfecta e inversa (al aumentar la variable independiente, la variable dependiente disminuye)

- $\mathrm{Si} R=0$ no existe ninguna correlación entre las variables, hay ausencia de linealidad $(\beta=0)$

- Si R = 1 la correlación es perfecta y directa (al aumentar la variable independiente lo hace la dependiente)

Otro de los coeficientes que ponderan la bondad de un ajuste es el coeficiente de deteminación $\mathbf{R}^{\mathbf{2}}$, que indica qué proporción de la variación de la variable dependiente (Y) puede ser explicada por la variación de la(s) variable(s) independiente(s) (X). Viene definido por la Ecuación 20 y en los modelos de regresión lineal coincide con el cuadrado del coeficiente de correlación lineal $\left(R^{2}=r^{2}\right)$

$$
R^{2}=\frac{\sum_{i=1}^{n}\left(\widehat{Y}_{l}-\bar{Y}\right)^{2}}{\sum_{i=1}^{n}\left(Y_{i}-\bar{Y}\right)^{2}}
$$

Donde:

- $\quad \bar{Y}_{i}=$ Valor medio de la variable dependiente

- $\widehat{Y}_{l}=$ Cada uno de los valores pronosticados de la variable dependiente

- $Y_{i}=$ Cada uno de los valores de la variable dependiente

- $\mathrm{n}=$ número de datos.

- $\quad \sum_{i=1}^{n}\left(\widehat{Y}_{l}-\bar{Y}\right)^{2}=$ Suma de cuadrados explicada por el modelo.

Si las estimaciones están muy alejadas de la media de los valores observados, es la parte de la variación total de $Y$ que consigue explicar el modelo de regresión utilizado

- $\sum_{i=1}^{n}\left(Y_{i}-\bar{Y}\right)^{2}=$ Suma de cuadrados total.

Es una medida de la variación total de los datos de la variable respuesta $Y$.

- $\quad \sum_{i=1}^{n}\left(Y_{i}-\widehat{Y}_{l}\right)^{2}=$ Suma de cuadrados no explicada por el modelo

El coeficiente de determinación puede tomar valores entre 0 y 1 , cuanto más se aproxime a la unidad mejor será el ajuste, (coeficiente de determinación $=1$, indica ajuste lineal perfecto) y mayor fiabilidad se tendrá en los pronósticos realizados con el modelo. 
Si se desea comparar la bondad de varias regresiones con igual tamaño de muestra, pero diferentes números de variables dependientes, se puede analizar el coeficiente de determinación lineal corregido ( $R^{2}$ corregido), que tiene en cuenta el número de variables independientes incluidas en el modelo y el tamaño de la muestra, reduciendo el coeficiente para muestras muy pequeñas con muchas variables independientes. Su expresión viene dada en la Ecuación 21

$$
R_{\text {corregido }}^{2}=1-\frac{(n-1)\left(1-R^{2}\right)}{n-k-1}
$$

Donde:

- $\mathrm{n}=$ Tamaño de la muestra

- $\mathrm{k}$ = número de regresores o variables independientes.

Otro de los valores a estudiar en una regresión es el error típico de la estimación (Se), que es la desviación típica de los residuos, por lo que representa una medida de la parte de variabilidad de la variable dependiente que no se explica por el modelo de regresión.

En general cuanto mejor es el ajuste, más pequeño es este error típico. El error típico es la raíz cuadrada de la media cuadrática residual y viene dado por la Ecuación 22. (Capítulo 18. Análisis de regresión lineal. El procedimiento de Regresión lineal. Guia SPSS) [150]

$$
S e=\sqrt{\frac{\sum_{i=1}^{n}\left(Y_{i}-\widehat{Y}_{\imath}\right)^{2}}{n-2}}
$$

Donde:

- $\widehat{Y}_{l}==$ Cada uno de los valores pronosticados de la variable dependiente

- $Y_{i}=$ Cada uno de los valores de la variable dependiente

- $\mathrm{n}=$ número de datos.

Para los modelos de regresión lineal múltiple, el error típico se obtiene de la Ecuación 23.

$$
S e=\sqrt{\frac{\sum_{i=1}^{n}\left(Y_{i}-\widehat{Y}_{l}\right)^{2}}{n-k-1}}
$$

Donde:

- $\quad \mathrm{k}$ = número de las variables independientes del modelo. 
En regresión lineal, otro de los análisis que se pueden realizar es el Análisis de la Varianza (ANOVA), lo que permite decidir si existen relaciones significativas entre las variables. Este análisis basa sus decisiones en el estadístico $\mathrm{F}$ de Snedecor, que permite contrastar la hipótesis nula de ser el valor del coeficiente correlación cero $(R=0)$, lo que equivale, en el modelo de regresión simple, a contrastar la hipótesis nula de las pendientes en la recta de regresión $(\beta=0)$.

Si el valor de significación es $\leq 0,05$, será improbable que $R=0$, por lo que existe una relación lineal significativa entre la variable dependiente y el conjunto de las variables independientes tomadas juntas.

El análisis de ANOVA ofrece información sobre la varianza y da una pista más sobre la adecuación del modelo de regresión para estimar los valores de la variable dependiente.

La varianza se descompone en varianza explicada por el modelo y por la varianza residual, es decir, aquella que el modelo no es capaz de explicar a partir de las variables introducidas.

Otra información que se puede obtener en un análisis de regresión son los coeficientes de correlaciones parciales, un coeficiente de correlación parcial indica el grado de relación que existe entre dos variables después de eliminar el efecto de terceras variables, es decir expresan el grado de relación que hay entre cada variable independiente y la variable dependiente tras desaparecer el efecto del resto de las variables independientes incluidas en el modelo.

Una vez obtenido el modelo de regresión para predecir los consumos se debe comprobar que se verifican las hipótesis del modelo:

- Linealidad de las variables.

- Normalidad de las variables y los residuos,

- Independencia (no autocorrelación) de los residuos.

- Homocedasticidad de los residuos (homogeneidad de la varianza), comprobando la no existencia de correlación entre los residuos, los pronósticos y las variables independientes para demostrar la aleatoriedad de los residuos.

En los modelos de regresión lineal múltiple, se comprueba también:

- Falta de multicolinealidad en las variables independientes, analizando los índices de condición, según los diagnósticos de colinealidad. 


\section{All.5.Pruebas paramétricas. T-Student.}

Para poder tomar decisiones en los contrastes de hipótesis, la estadística posee dos tipos de pruebas las paramétricas y las no paramétricas.

Las pruebas paramétricas consideran valores calculados con los datos de la población y para puedan ser utilizadas deben cumplirse una serie de hipótesis que, en caso, de no cumplirse impiden su utilización.

Para poder aplicar las pruebas paramétricas los datos deben ser valores numéricos, independientes unos de otros, las varianzas poblacionales de las variables en estudio deben ser similares (homocedasticidad), la relación entre las variables debe ser de tipo lineal y la distribución de las variables en la población debe seguir una distribución normal. (Ramalle Gómara \& Andrés de Llano, 2003) [151].

Las pruebas no paramétricas pueden ser utilizadas sin cumplir esas hipótesis previas, pueden emplearse con datos nominales y ordinales, la distribución poblacional puede ser cualquiera y tampoco es necesario conocer ni suponer nada acerca de las varianzas poblacionales. Pero, las pruebas paramétricas tienen más potencia que las no paramétricas, es decir tienen más probabilidad de elegir la hipótesis alternativa cuando es cierta, lo que implica que tienen más capacidad de encontrar diferencias significativas cuando es cierto que existen.

Es por ello que en esta investigación se ha utilizado la prueba paramétrica t-Student, prueba $t$ de estudiante o Test $-\mathrm{T}$, para valorar la existencia de diferencias significativas entre los consumos pronosticados en caso de haber existido la red de calor y los consumos que realmente se han obtenido tras la construcción de la red de calor.

Esta prueba utiliza como estadístico un parámetro que tiene una distribución t de Student si la hipótesis nula es cierta, se utiliza cuando las observaciones se distribuyen según una Normal pero el tamaño de la muestra es demasiado pequeño como para que el estadístico en el que está basada la decisión de aceptar o rechazar la hipótesis nula se distribuya según una normal.

En la investigación se ha utilizado el contraste de hipótesis para la comparación de medias con varianzas desconocidas e iguales, es decir la prueba paramétrica " $\mathrm{t}$ " de Student para muestras relacionadas, especialmente indicada para la comparación de las medias de dos grupos cuando existe algún tipo de relación entre los individuos de ambos grupos.

En el estudio: la relación existente es que se trababa de los consumos asociados a la misma instalación, pero en diversos periodos de tiempo. 
La hipótesis nula que se plantea es la igualdad de medias es decir la no existencia de diferencias significativas entre las medias aritméticas de las dos poblaciones. De este modo, si las variables se distribuyen según una normal y la significación estadística resulta $\leq 0,05$, se rechaza $\mathrm{H}_{0}$ y se puede afirmar que existen diferencias significativas. En caso contrario no se rechaza la hipótesis nula de igualdad de medias, concluyendo que las diferencias encontradas no son estadísticamente significativas y no van más allá de lo que sería esperable por azar (Navidi, 2006) [152], todo ello con la aceptación de un riesgo de error del $5 \%$, o lo que es lo mismo un nivel de confianza del $95 \%$. 
Anexo II. Tratamiento estadístico de los datos 


\section{ANEXO III. DESCRIPCIÓN DE LOS EDIFICIOS DE LA RED DE CALOR DE LA UVA}

\section{Alll.1.Edificios del Campus Miguel Delibes.}

Todos los edificios conectados a la red que pertenecen a este Campus, originalmente contaban con calderas de gas natural.

\section{D1. Apartamentos Cardenal Mendoza}

Situados en Camino Cementerio, 22. 47011 Valladolid. (Figuras 155 y 156)

La superficie total construida es de $17.616 \mathrm{~m}^{2}$. Fueron inaugurados en 1996 y el complejo consta de 201 apartamentos con 2 habitaciones individuales cada uno de ellos, baño, salón y cocina. Además los apartamentos cuentan con servicios comunes de conserjería, garaje, restaurante y salones. (Universidad de Valladolid) [153].

Inicialmente contaban con dos calderas de 479 kW y 596 kW para calefacción y una tercera de $479 \mathrm{~kW}$ para ACS. La potencia total instalada inicialmente era de $1.554 \mathrm{~kW}$.
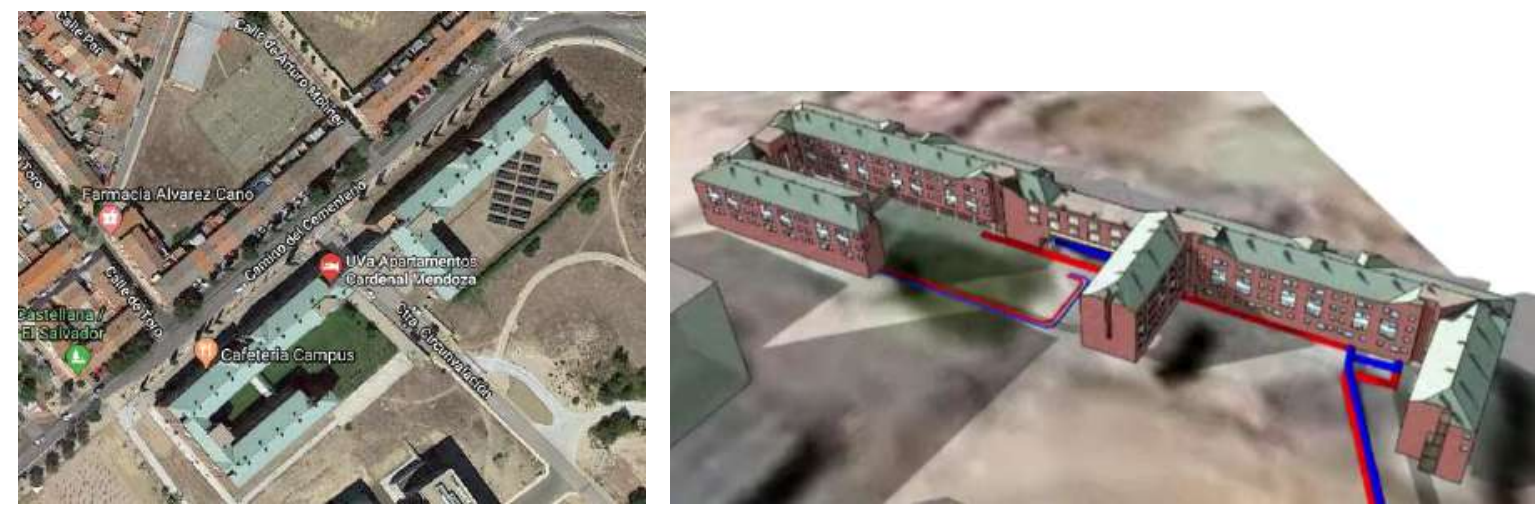

Figura 155. Ubicación Apartamentos Cardenal Mendoza (D1). 

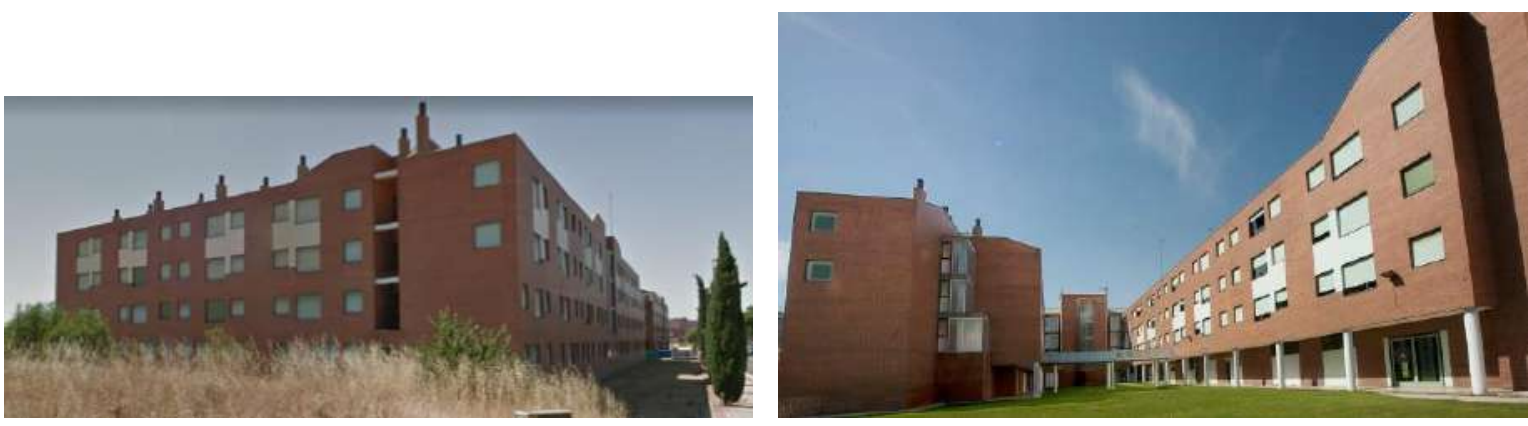

Figura 156. Fotografía de los Apartamentos Cardenal Mendoza (D1).

\section{D2. Biblioteca de los Apartamentos Cardenal Mendoza.}

Ubicada en el mismo complejo que los Apartamentos, cuenta con una superficie construida de $464 \mathrm{~m}^{2}$ y una sala de calderas con una caldera de 40,9 kW para calefacción. (Figura 157). (Fundación General de la Universidad de Valladolid. (FUNGE)) [154].

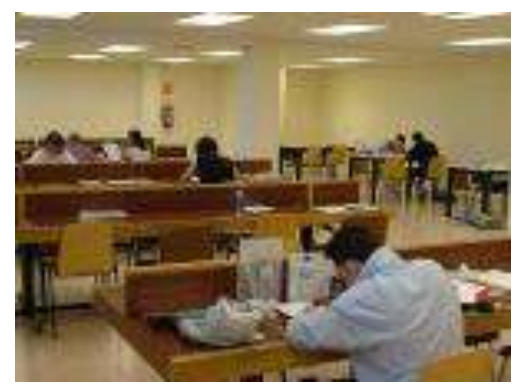

Figura 157. Biblioteca de los Apartamentos Cardenal Mendoza (D2)

\section{D3. Centro de Transferencia de Tecnologías Aplicadas (CTTA)}

Situado en Paseo de Belén, 9A. 47011 Valladolid. (Figuras 158 y 159)

La superficie total construida es de $5.487 \mathrm{~m}^{2}$. Forma parte del la Fundación del Parque Científico UVa, que inicia su actividad en el 2007.

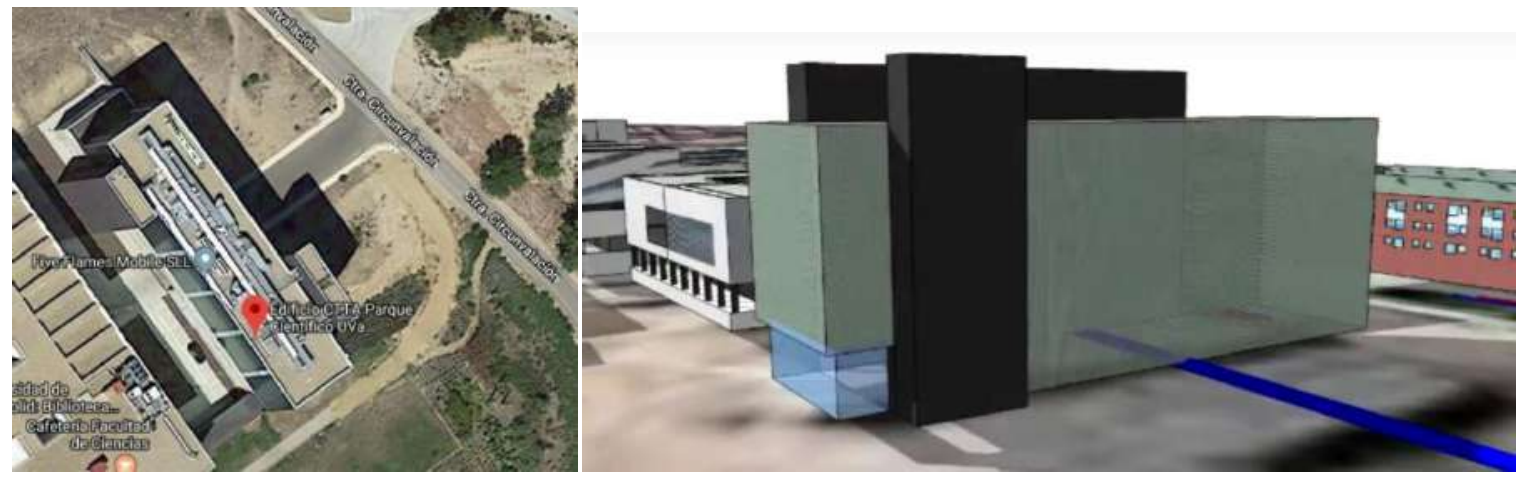

Figura 158. Centro de Transferencia de Tecnologías Aplicadas. CTTA. (D3) 

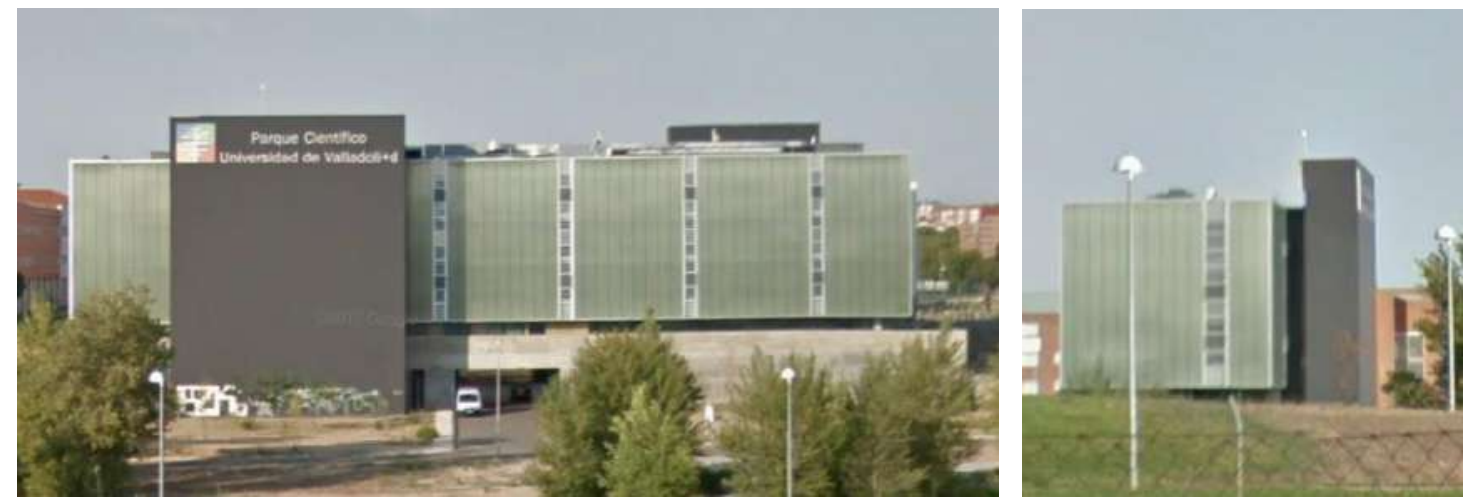

Figura 159. Fotografías del Centro de Transferencia de Tecnologías Aplicadas. CTTA. (D3)

Inicialmente contaba con tres calderas de $116 \mathrm{~kW}$ para calefacción, lo que hace una potencia total de $348 \mathrm{~kW}$ instalada.

\section{D4. Biblioteca - Aulario Miguel Delibes}

Situado en Paseo de Belén, 9. 47011 Valladolid. (Figuras 160 y 161)

La superficie total construida es de $14.541 \mathrm{~m}^{2}$. Se encuentra en servicio desde el curso 2012-2013. Inicialmente contaba con dos calderas de $570 \mathrm{~kW}$ para calefacción, lo que hace una potencia total $1.140 \mathrm{~kW}$ instalada.
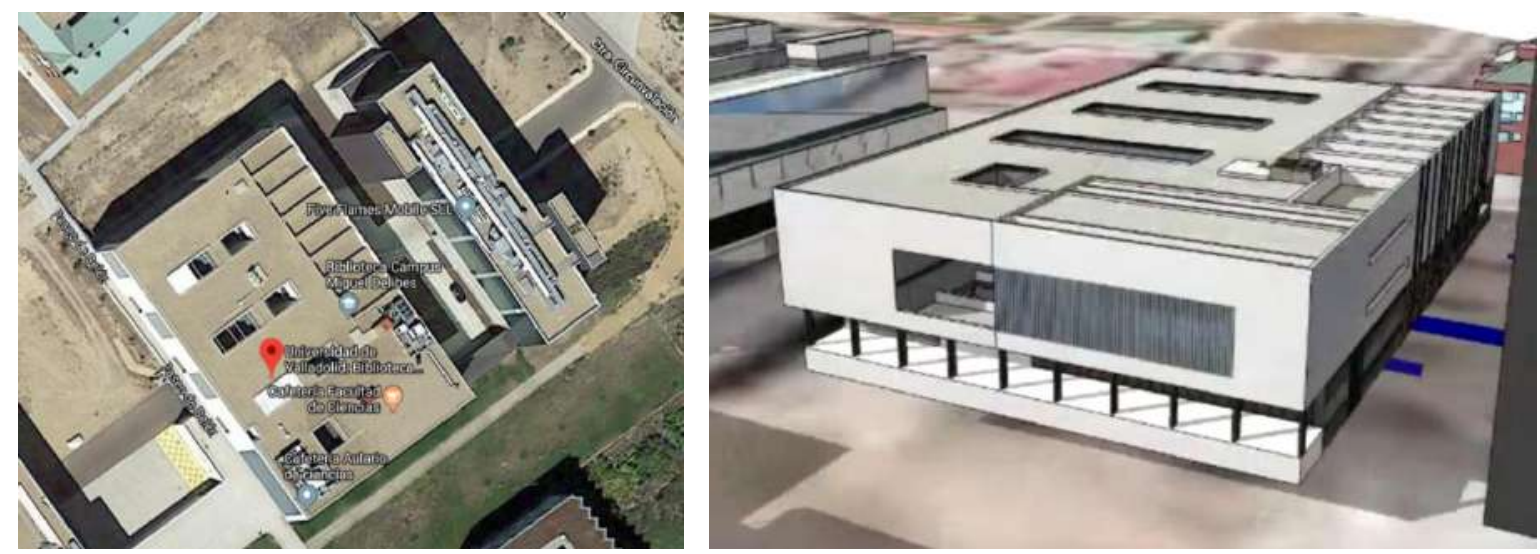

Figura 160. Biblioteca - Aulario Miguel Delibes (D4)
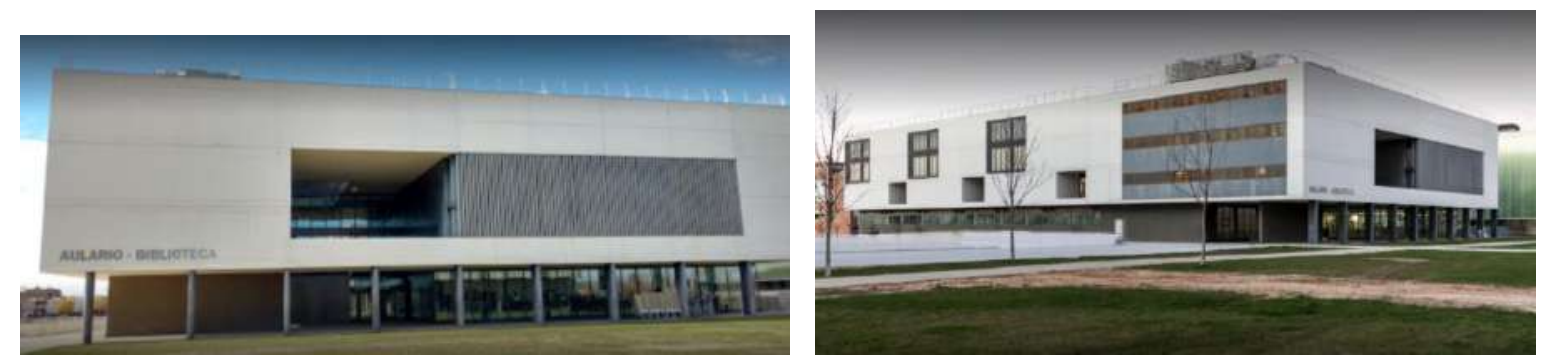

Figura 161. Fotografías de la Biblioteca - Aulario Miguel Delibes (D4) 


\section{D5. Edificio del Instituto Universitario de Oftalmología Aplicada (IOBA)}

Situado en Paseo de Belén, 17. 47011 Valladolid. (Figuras 162 y 163)

La superficie total construida es de $4.146 \mathrm{~m}^{2}$. El edificio empezó a funcionar en el año 2008. Inicialmente contaba con dos calderas de 40,7 kW para calefacción, lo que hace una potencia total $81 \mathrm{~kW}$ instalada.
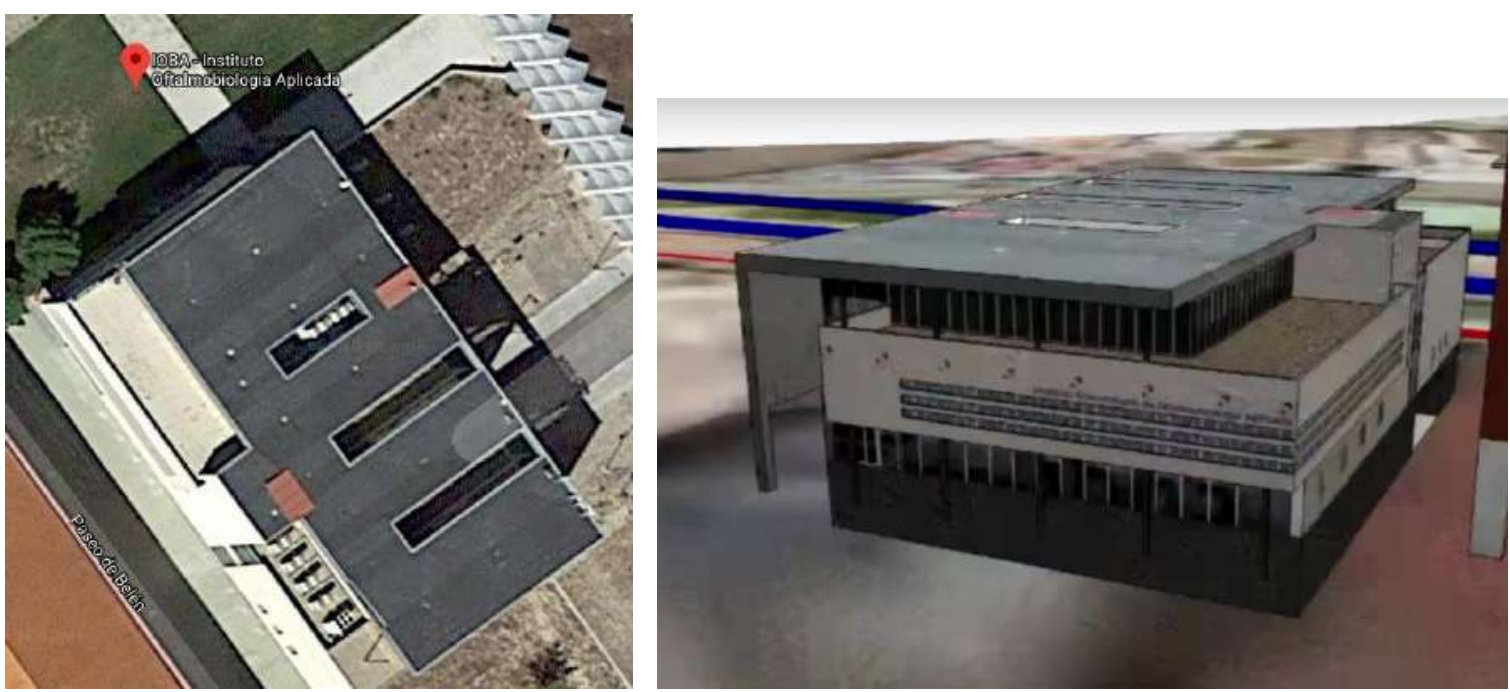

Figura 162. Instituto Universitario de Oftalmología Aplicada. IOBA. (D5)
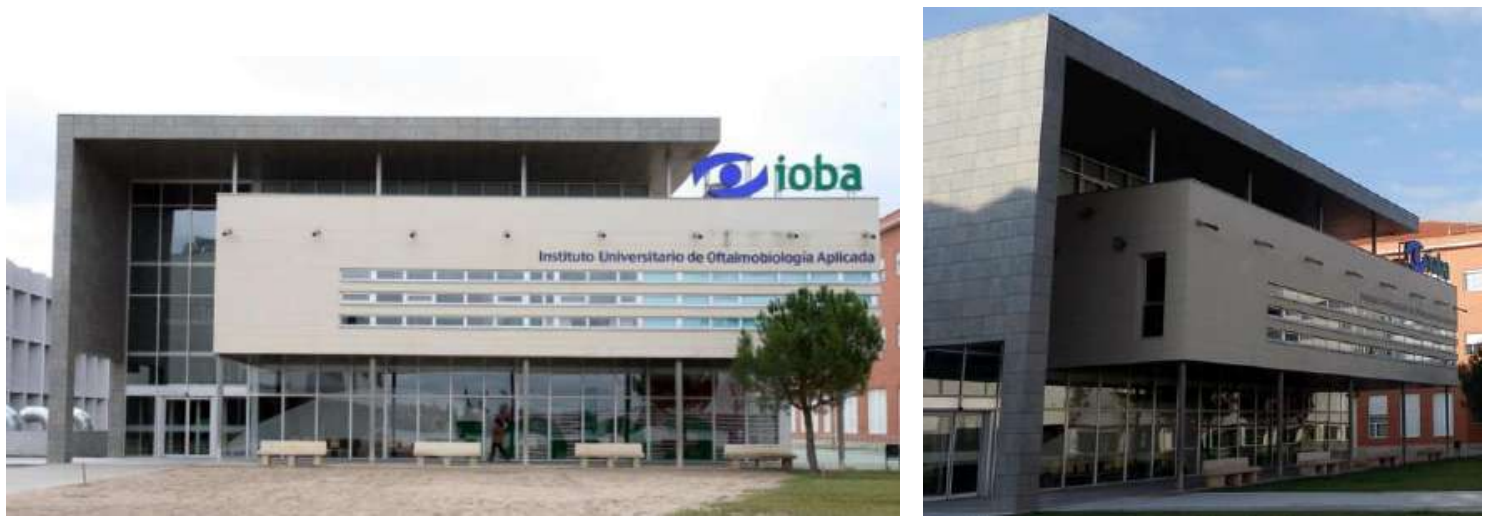

Figura 163. Fotografías del Instituto Universitario de Oftalmología Aplicada. IOBA. (D5)

\section{D6. Nueva Facultad de Ciencias}

Situado en Paseo de Belén, 7. 47011 Valladolid. (Figuras 164 y 165)

La superficie total construida es de $19.134 \mathrm{~m}^{2}$. El edificio se empezó a utilizar como Facultad de Ciencias en el curso 2009 - 2010. Inicialmente contaba con dos calderas de $581 \mathrm{~kW}$ para calefacción, lo que hace una potencia total 1.162 kW instalada. 

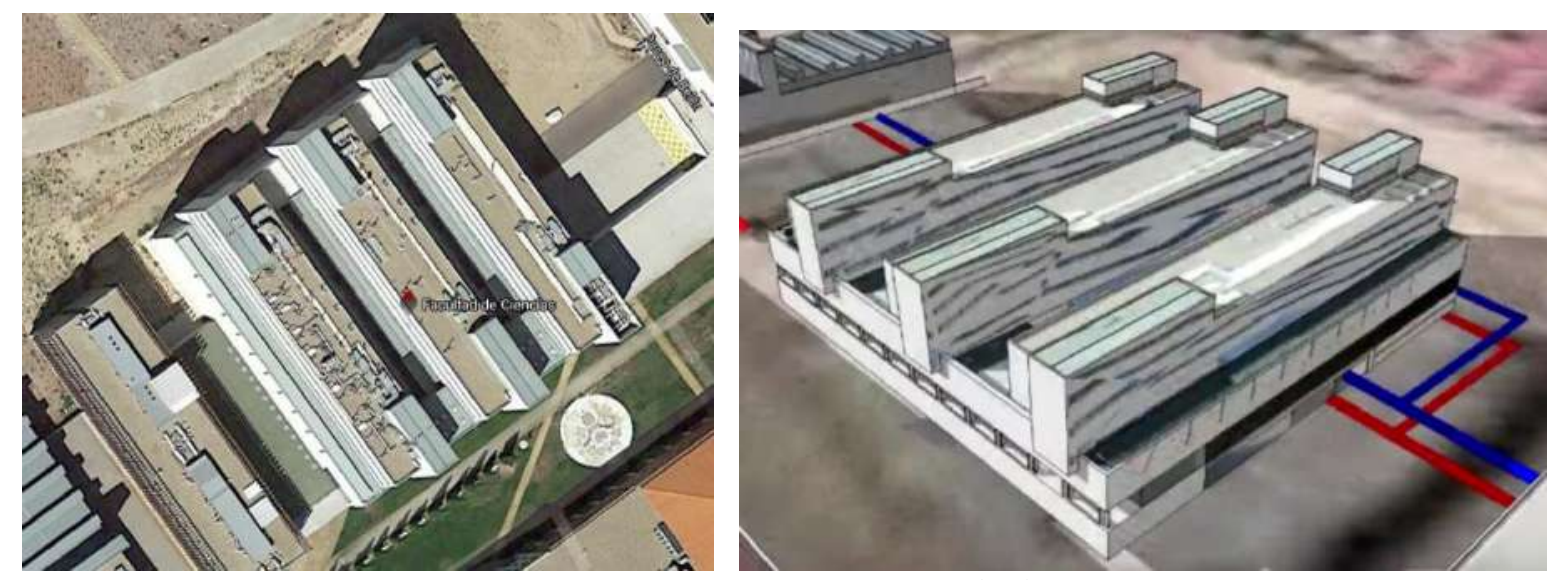

Figura 164. Facultad de Ciencias (D6)
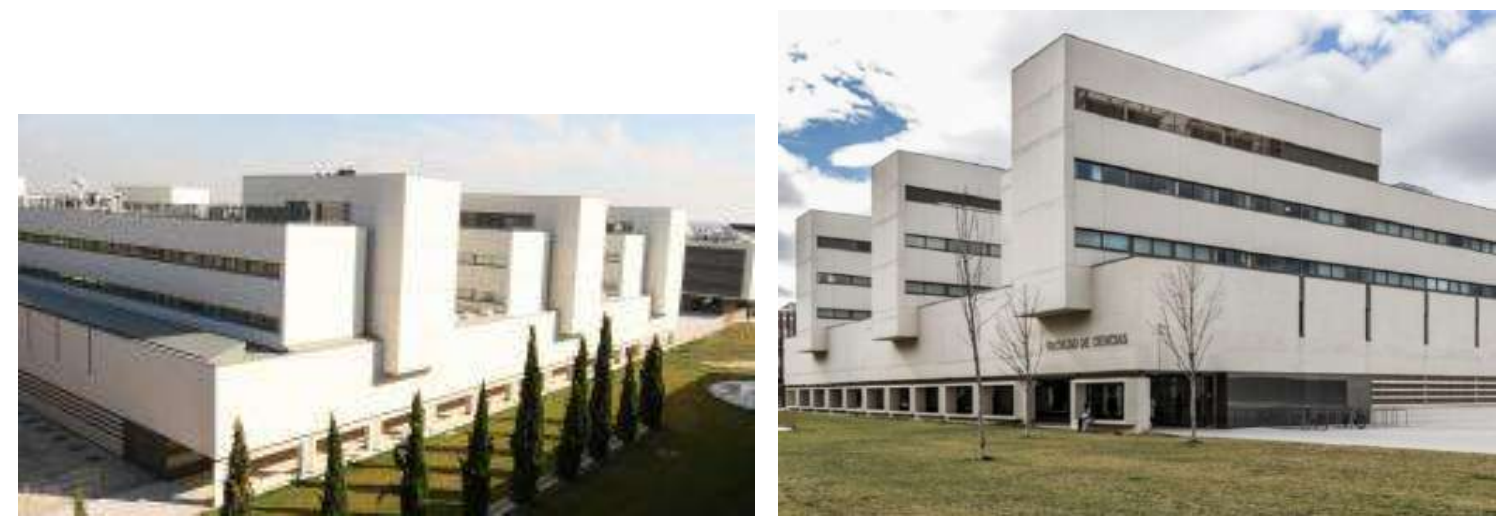

Figura 165, Fotografías de Facultad de Ciencias (D6)

\section{D7. Telecomunicaciones e Informática}

Situado en Paseo de Belén, 15. 47011 Valladolid. (Figuras 166 y 167) La superficie total construida es de $20.179 \mathrm{~m}^{2}$. En funcionamiento desde 1997. (Encinas, A.G, 2017) [155]. Inicialmente contaba con seis calderas de $326 \mathrm{~kW}$ para calefacción, lo que hace una potencia total $1.956 \mathrm{~kW}$ instalada.
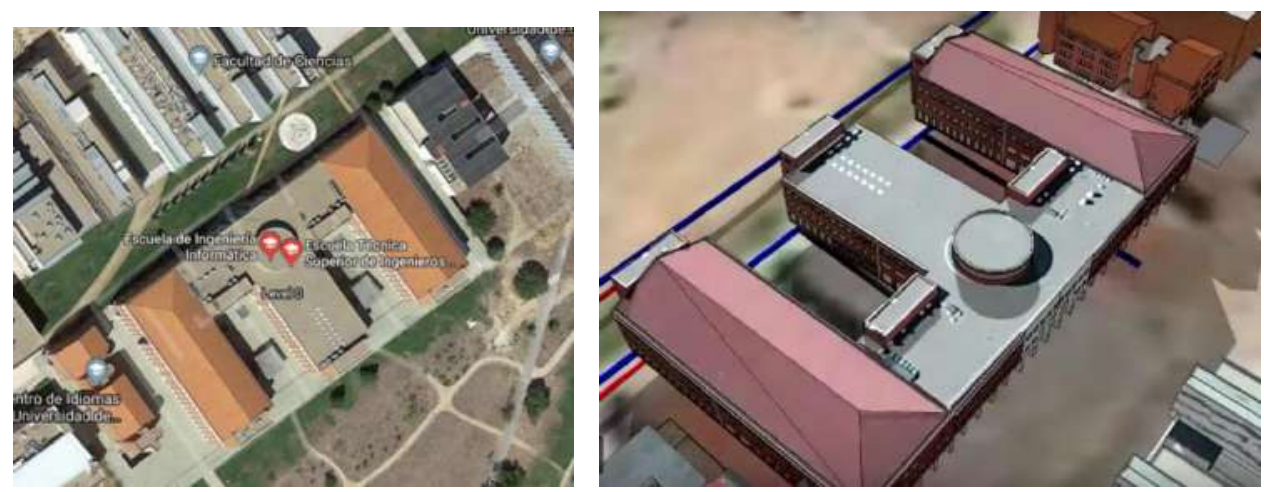

Figura 166. Telecomunicaciones e Informática (D7) 


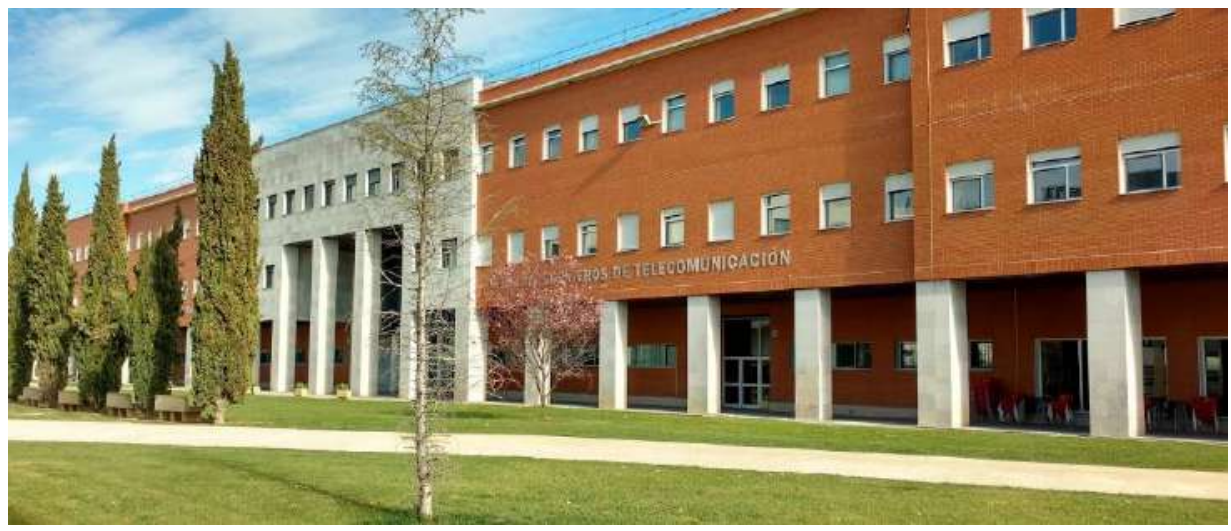

Figura 167. Fotografía de Telecomunicaciones e Informática (D7)

\section{D8. Edificio de Química Fina y Materiales Avanzados (QUIFIMA)}

Situado en Paseo de Belén, 15. 47011 Valladolid. (Figuras 168 y 169) La superficie total construida es de $5.610 \mathrm{~m}^{2}$. Se construyó en el 2004 y fue inaugurado en el 2008). Inicialmente contaba con dos calderas de $233 \mathrm{~kW}$ cada una para calefacción, lo que hace una potencia total $466 \mathrm{~kW}$ instalada.
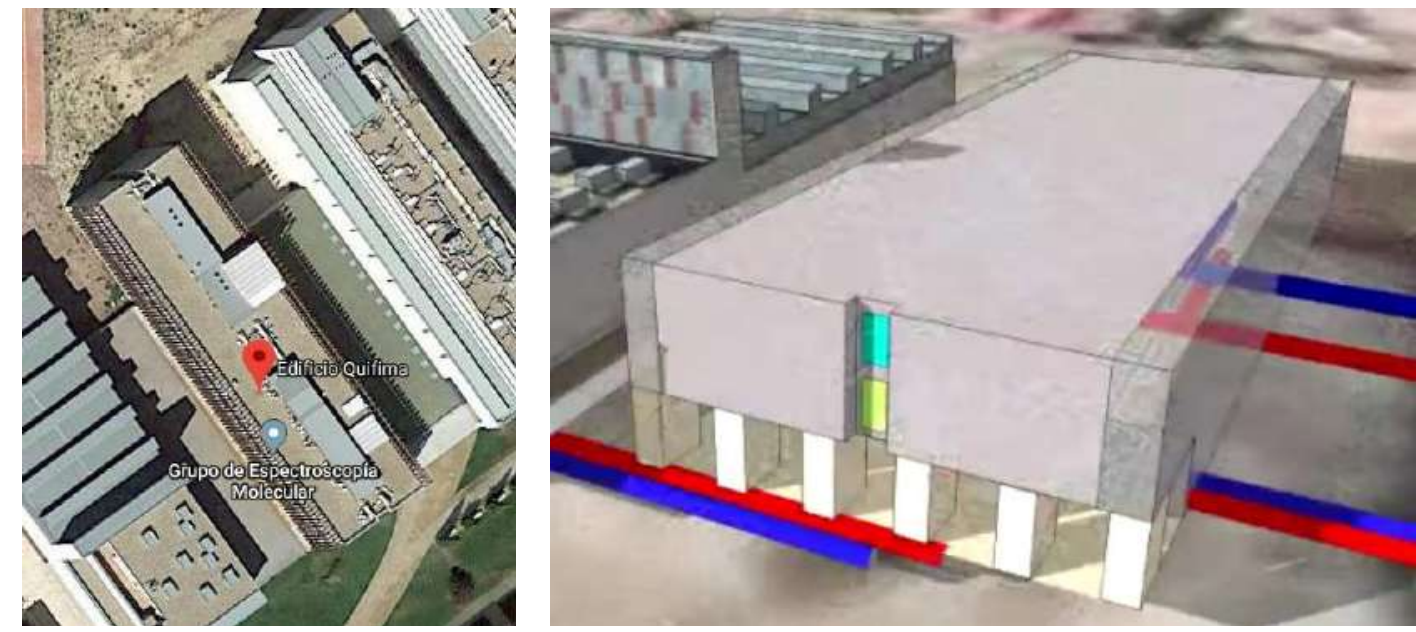

Figura 168. Edificio Química Fina y Materiales Avanzados (QUIFIMA) (D8)
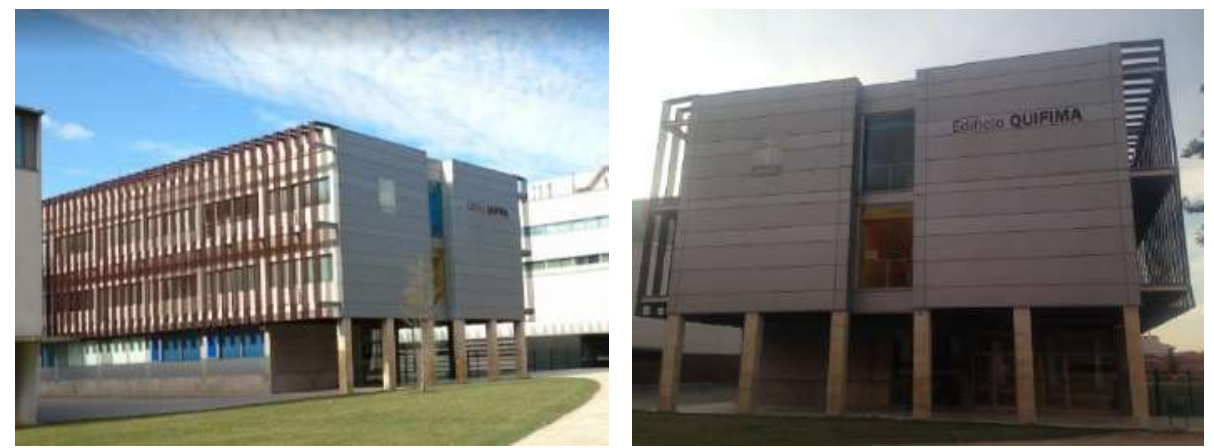

Figura 169. Fotografías del Edificio Química Fina y Materiales Avanzados (QUIFIMA) (D8) 


\section{D9. Gimnasio de la Facultad de Educación}

Situado en Paseo de Belén, 1. 47011 Valladolid. (Figuras 170 y 171)

La superficie total construida es de $3.673 \mathrm{~m}^{2}$. Se podría fechar en el mismo año que la Facultad de Educación: 2001. Inicialmente contaba con cuatro calderas de 127 kW cada una, lo que hace una potencia total de $508 \mathrm{~kW}$ instalada.

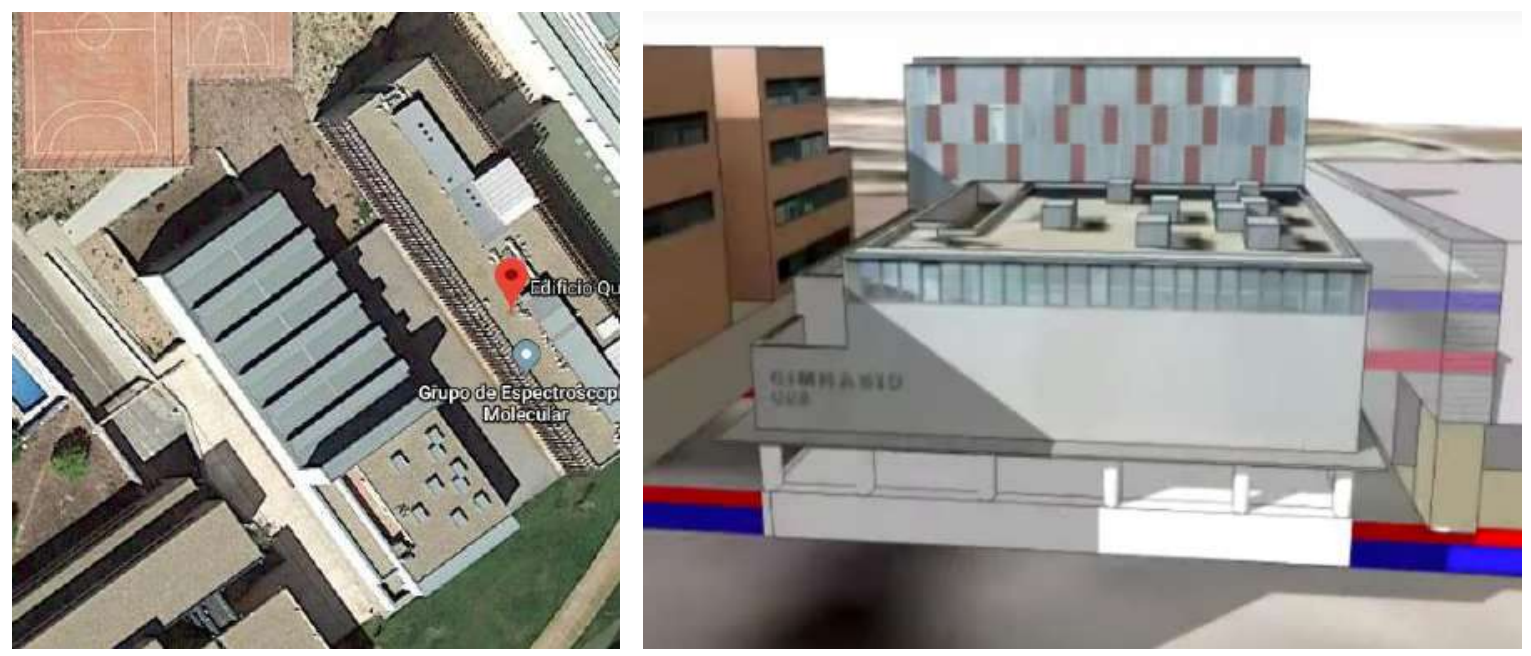

Figura 170. Gimnasio de la UVA. (D9)

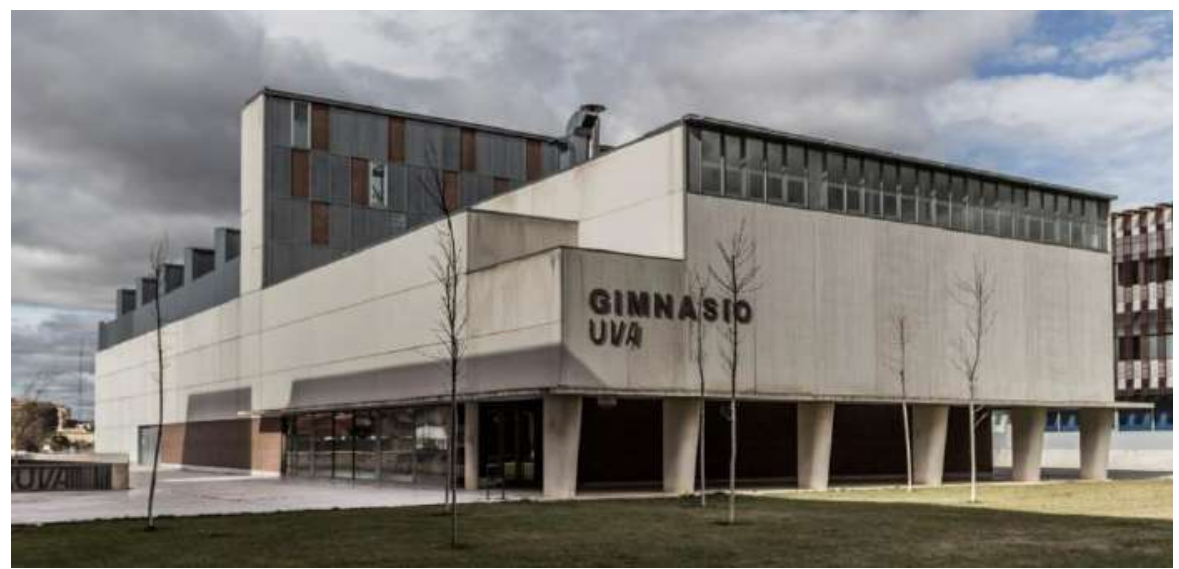

Figura 171. Fotografía del Gimnasio de la UVA (D9)

\section{D10. Centro de Idiomas}

Situado en Paseo de Belén, 13. 47011 Valladolid. (Figuras 172 y 173)

La superficie total construida es de $5.636 \mathrm{~m}^{2}$. Puesto en funcionamiento en 1996. Inicialmente contaba con una caldera de $326 \mathrm{~kW}$ para calefacción. 

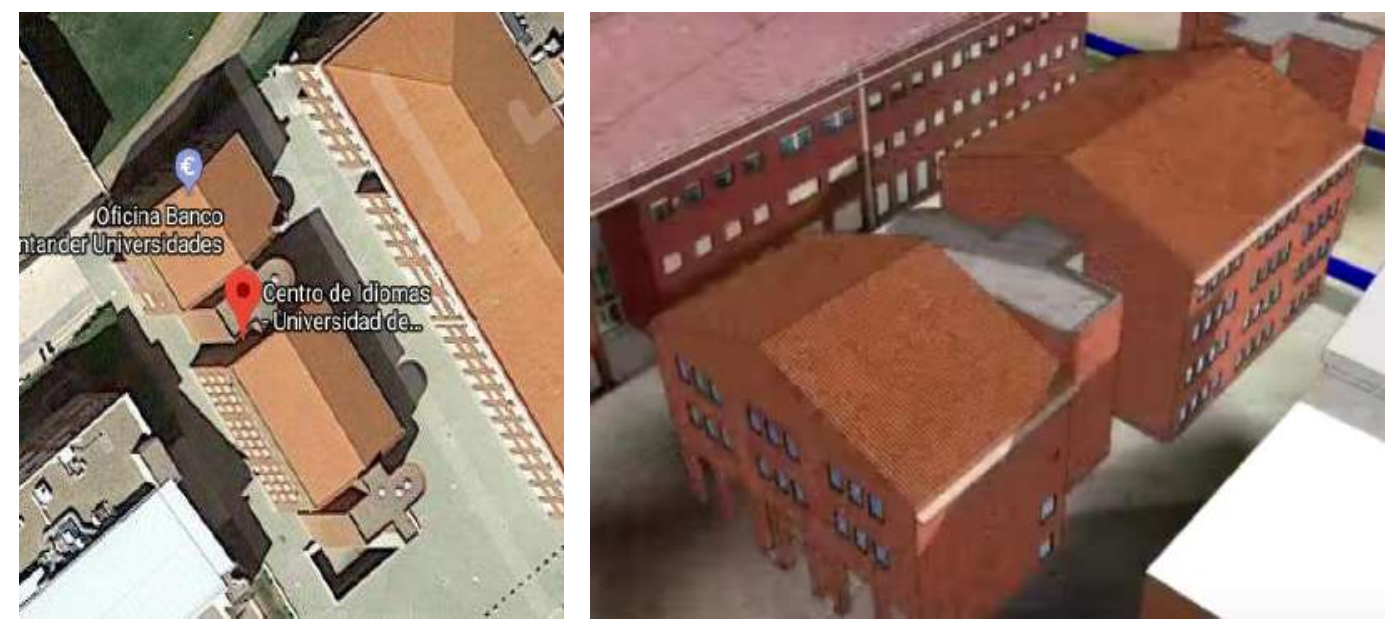

Figura 172. Centro de Idiomas (D10)

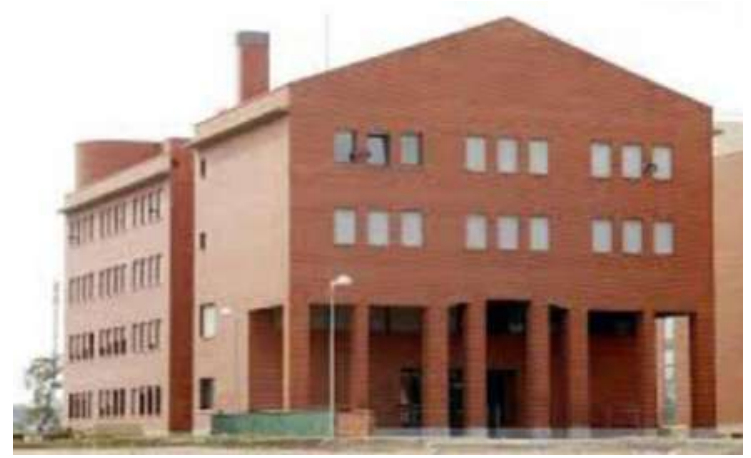

Figura 173. Fotografía del Centro de Idiomas (D10)

\section{D11. Facultad de Educación y Trabajo Social}

Situado en Paseo de Belén, 1. 47011 Valladolid. (Figuras 174 y 175)

La superficie total construida es de $14.943 \mathrm{~m}^{2}$. Se puso en funcionamiento en 2001. Inicialmente contaba con dos calderas de $500 \mathrm{~kW}$ cada una para calefacción, lo que hace una potencia total instalada de $1.000 \mathrm{~kW}$.
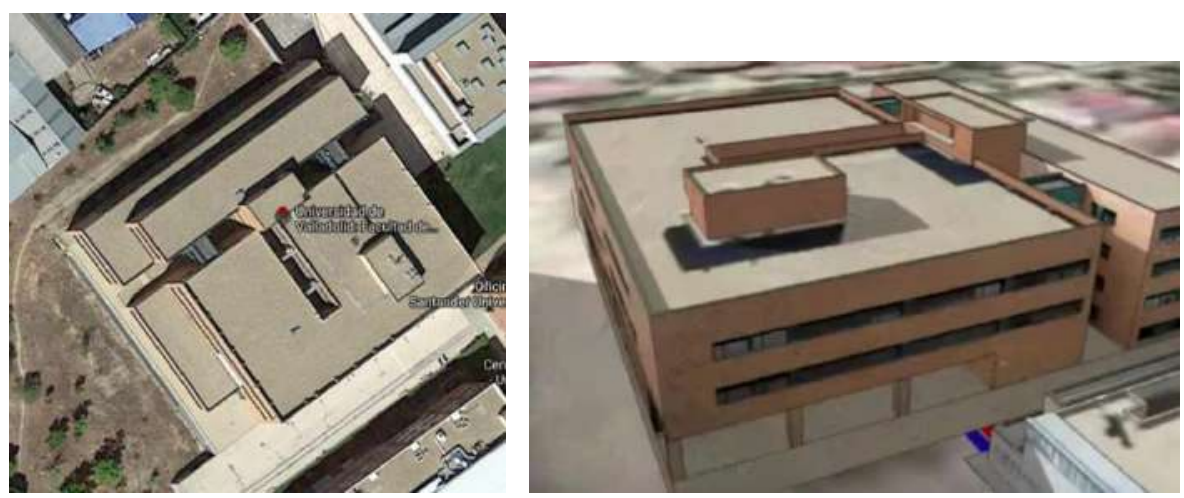

Figura 174. Facultad de Educación y Trabajo Social (D11) 


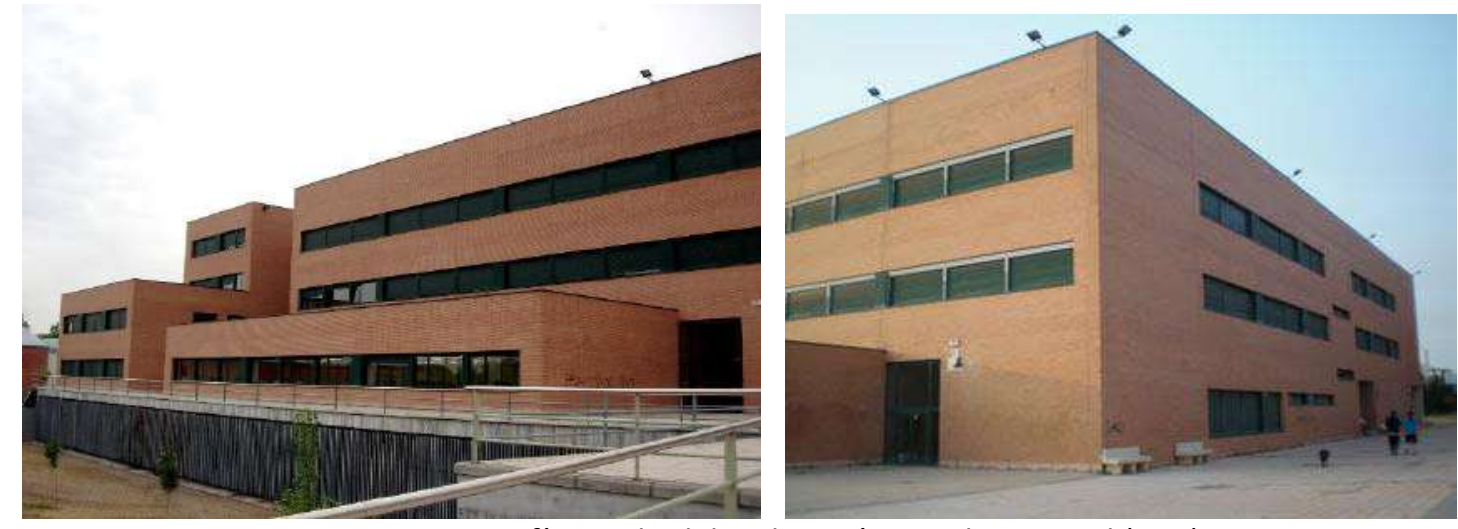

Figura 175. Fotografía Facultad de Educación y Trabajo Social (D11)

\section{D12. Edificio de I+D}

Situado en Paseo de Belén, 11. 47011 Valladolid. (Figuras 176 y 177) La superficie total construida es de $7.412 \mathrm{~m}^{2}$. Se puso en funcionamiento en el 2007. Inicialmente contaba con dos calderas de $401 \mathrm{~kW}$ cada una para calefacción, lo que hace una potencia total instalada de $802 \mathrm{~kW}$.
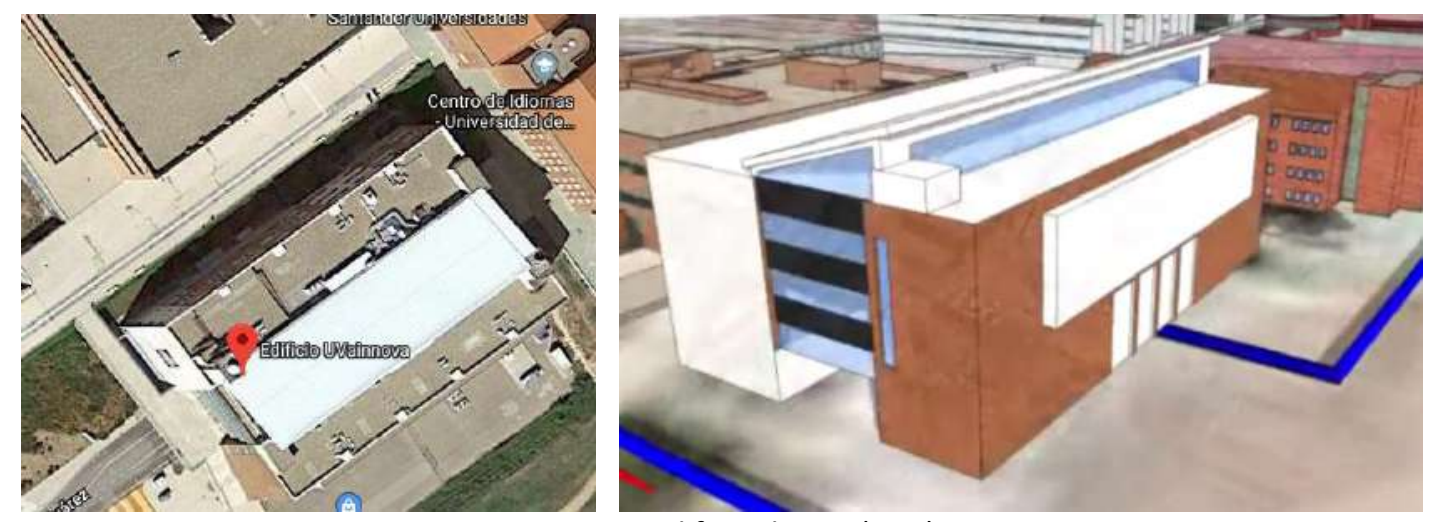

Figura 176. Edificio de I+D (D12)
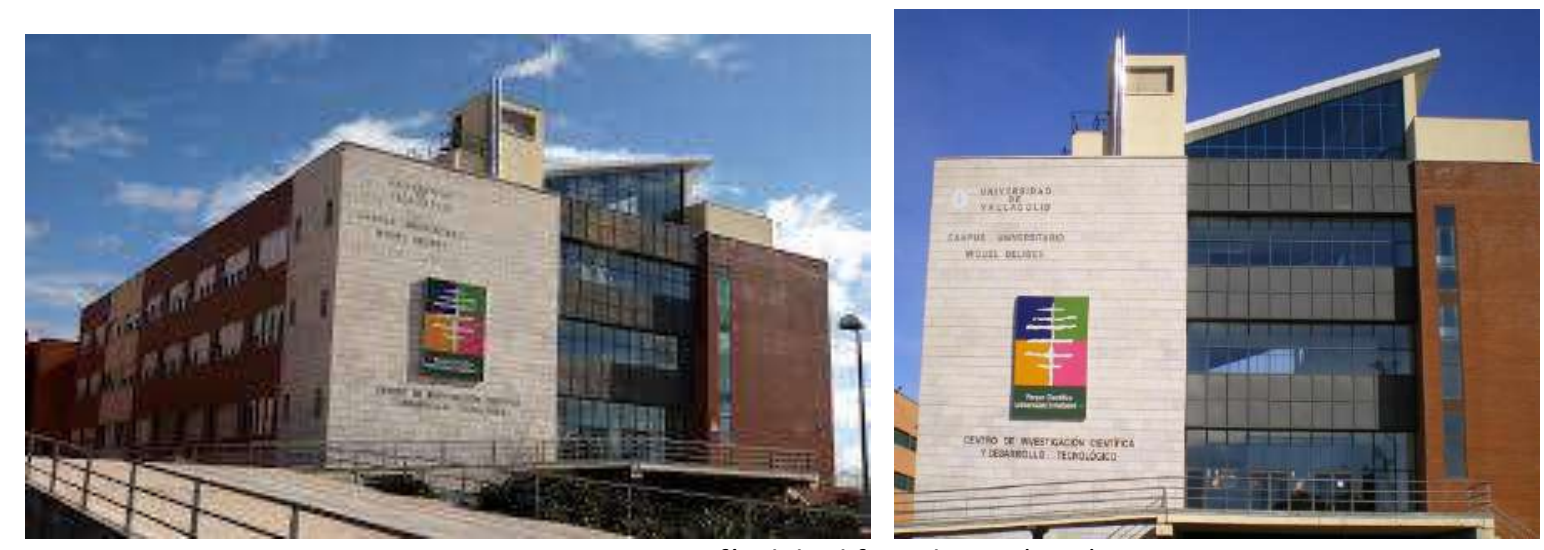

Figura 177. Fotografía del Edificio de I+D (D12) 


\section{Alll.2.Edificios del Campus Río Esgueva.}

\section{E1. Edificio del Servicio de Mantenimiento}

Situado en Avenida Valle Esgueva, 2. 47011 Valladolid. (Figuras 178 y 179)

La superficie total construida es de $1.681 \mathrm{~m}^{2}$. Edificio de 1940 que se puso al servicio de la UVA en 1989. (Anta, 2017) [156]. Inicialmente contaba con una sala de calderas con una caldera de 291 kW para calefacción de gasóleo.
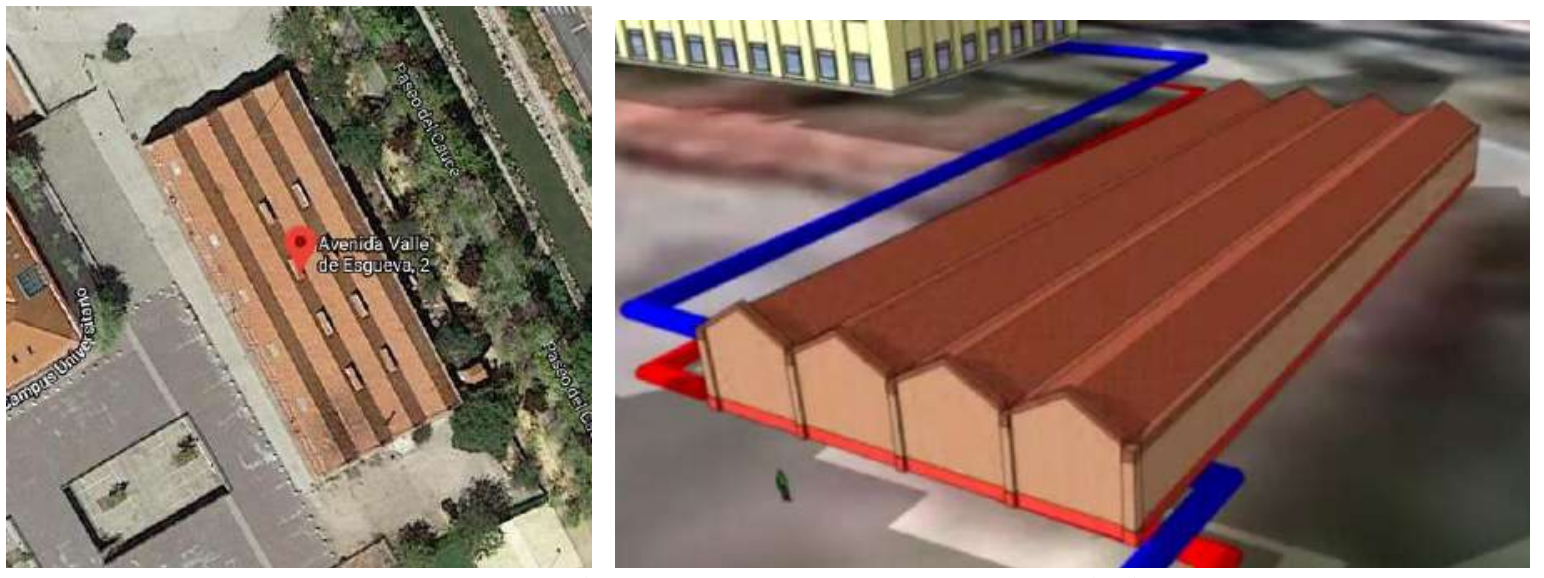

Figura 178. Edificio del Servicio de Mantenimiento (E1)

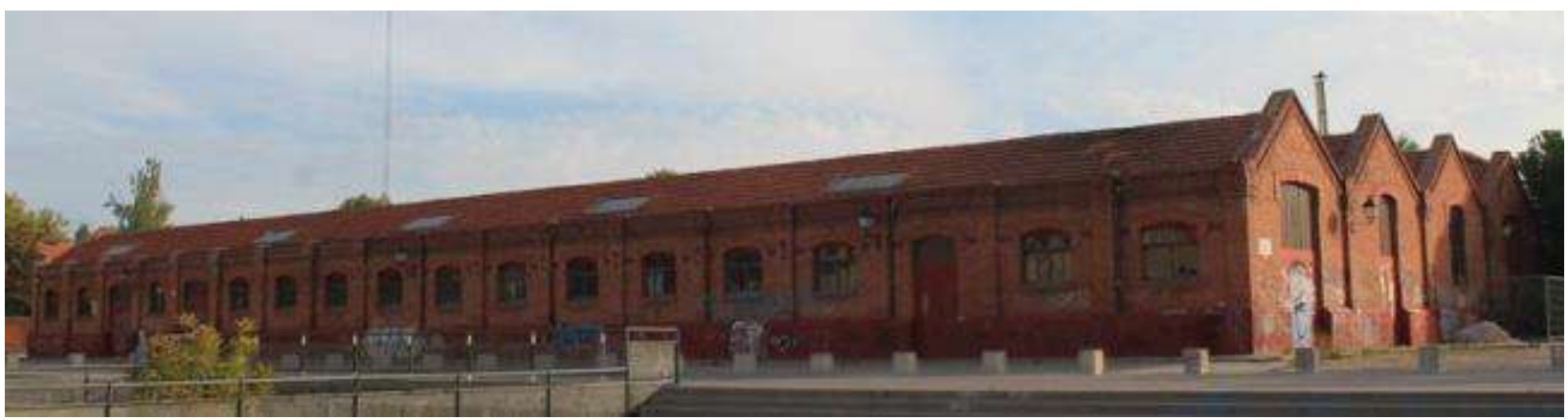

Figura 179. Fotografía de edificio del servicio de mantenimiento (E1)

\section{E2. Escuela Universitaria de Empresariales. Facultad de Comercio}

Situado en Plaza del Campus, 1. 47005 Valladolid. (Figuras 180 y 181)

La superficie total construida es de $11.160 \mathrm{~m}^{2}$. Se puso en funcionamiento en 1994. (Universidad de Valladolid (UVA), 2018) [157]. Inicialmente contaba con una sala de calderas con tres calderas de gasóleo de 407 kW, 291 kW y 291 kW para calefacción, lo que suma un total de $989 \mathrm{~kW}$ de potencia instalada. 

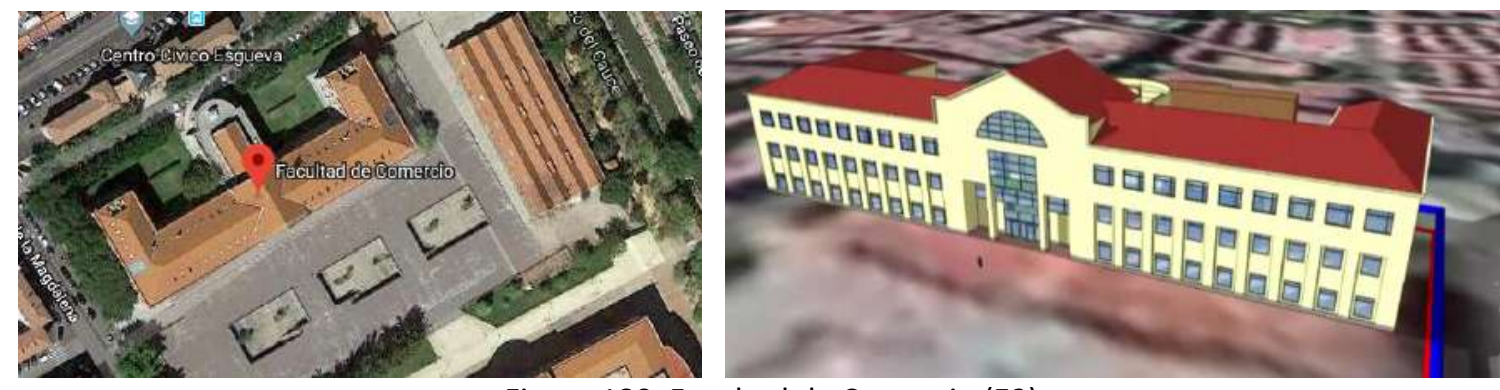

Figura 180. Facultad de Comercio (E2)
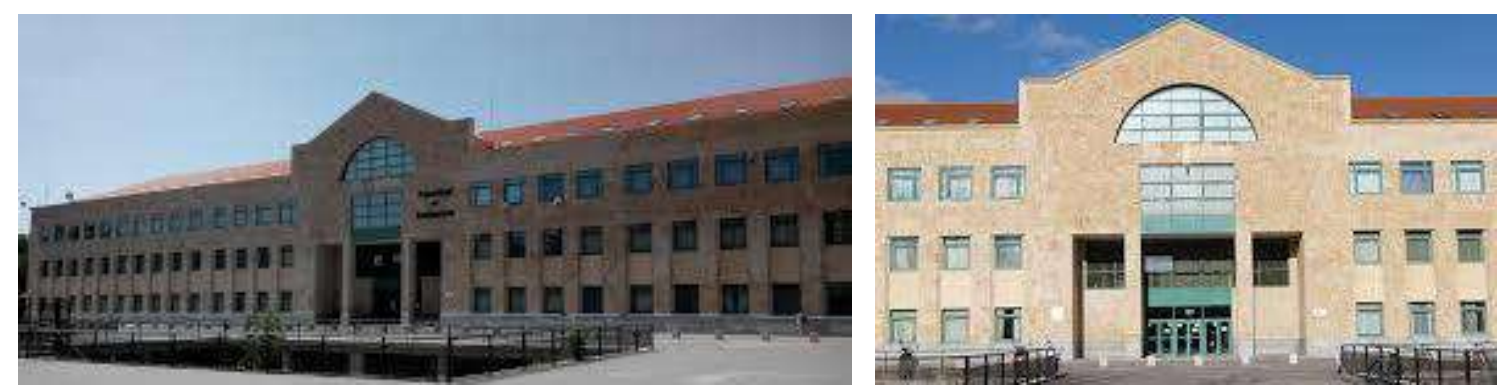

Figura 181. Fotografías de la Facultad de Comercio (E2)

\section{E3. Facultad de Filosofía y Letras}

Situado en Plaza del Campus, s/n. 47011 Valladolid. (Figuras 182 y 183) La superficie total construida es de $21.709 \mathrm{~m}^{2}$. El edificio se puso en funcionamiento en 1997. Inicialmente contaba con una sala de calderas con dos calderas de gas de $465 \mathrm{~kW}$, para calefacción, lo que suma un total de $930 \mathrm{~kW}$ de potencia instalada.

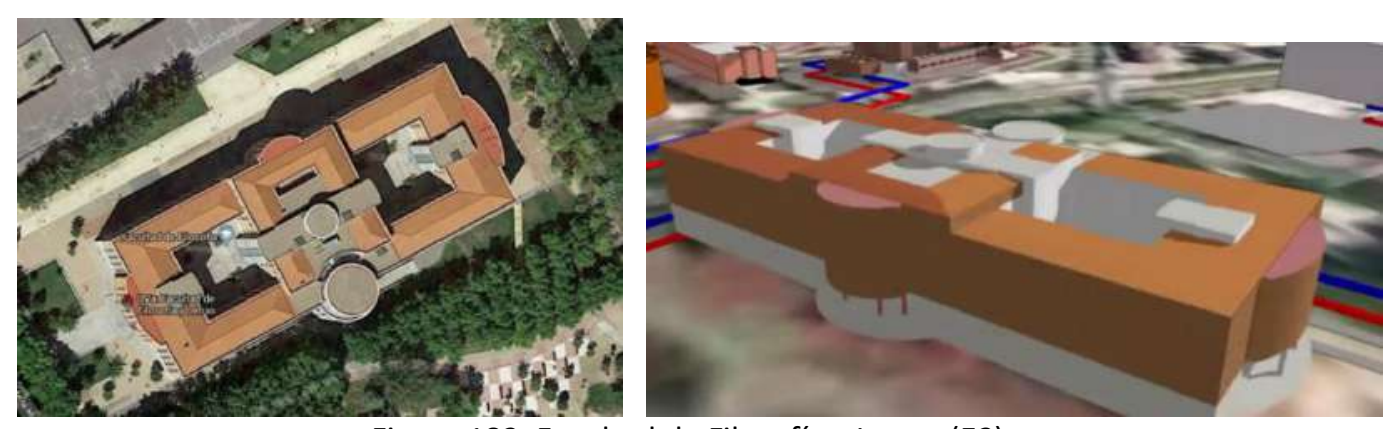

Figura 182. Facultad de Filosofía y Letras (E3) 

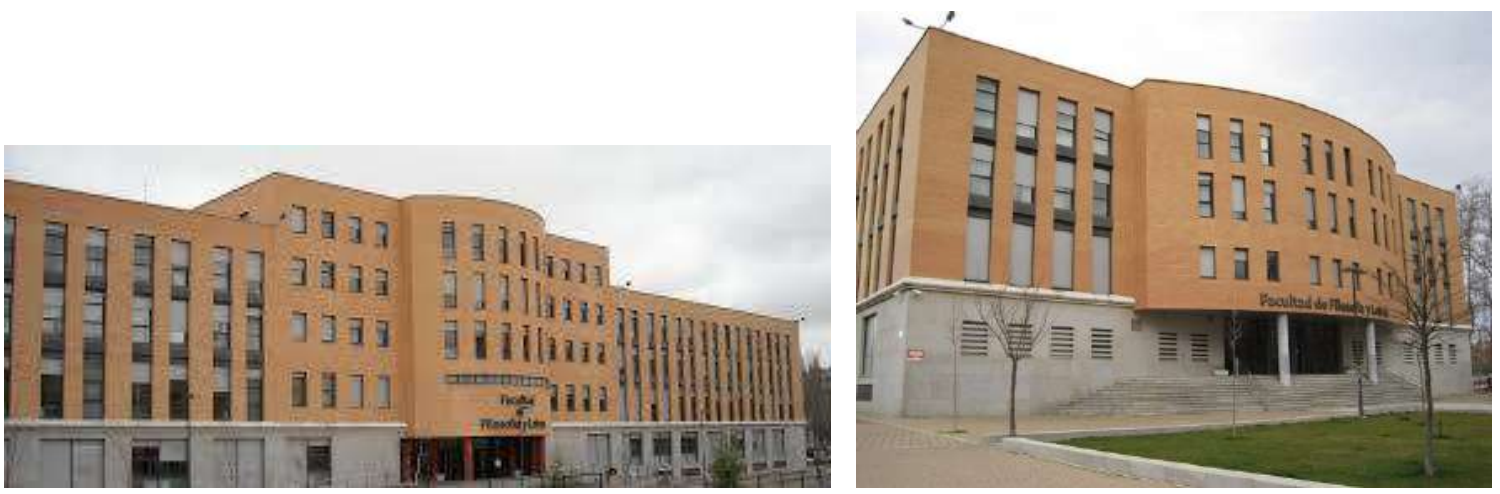

Figura 183. Fotografías de la Facultad de Filosofía y Letras (E3)

\section{E4. Antigua Facultad de Ciencias. Escuela de Ingenierías Industriales.}

Situado en C/ Doctor Mergelina s/n. 47011 Valladolid. (Figuras 184 y 185) La superficie total construida es de $32.305 \mathrm{~m}^{2}$. El edificio se puso en funcionamiento en 1968. Inicialmente contaba con dos salas de calderas una de ellas con dos calderas de gasóleo de $1.453 \mathrm{~kW}, 930 \mathrm{~kW}$ y en la segunda sala de calderas una caldera de gasóleo de $756 \mathrm{~kW}$, para calefacción, lo que suma un total de $3.139 \mathrm{~kW}$ de potencia instalada.
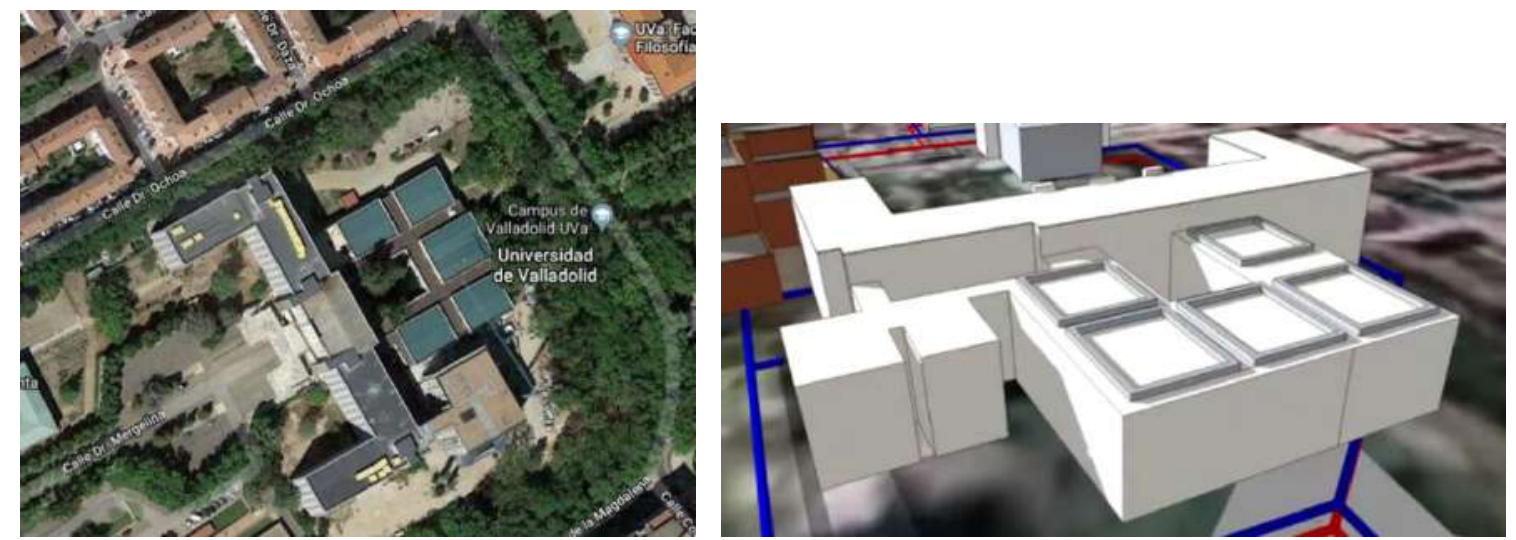

Figura 184. Antigua Facultad de Ciencias. Escuela de Ingenierías Industriales (E4)

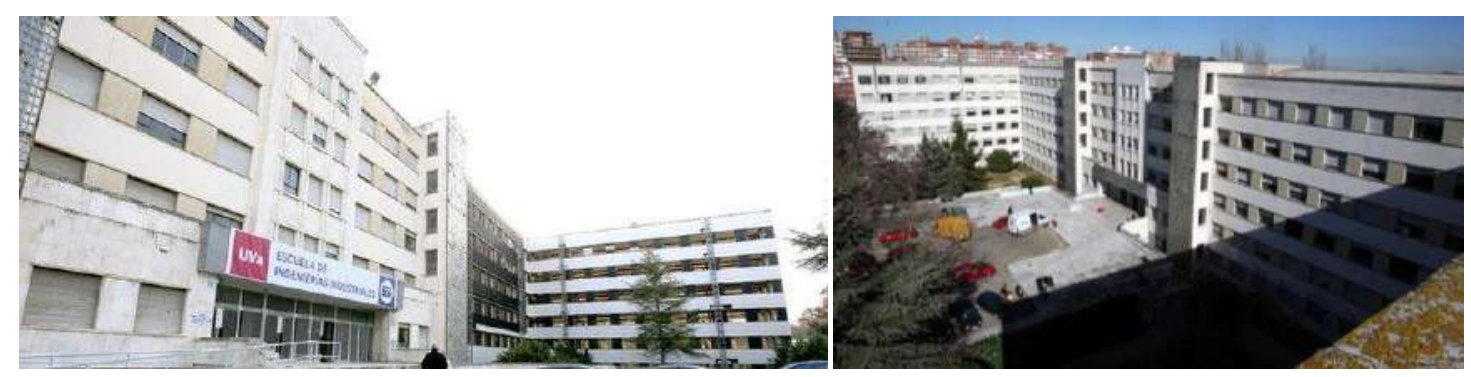

Figura 185. Fotografías Antigua Facultad de Ciencias. Escuela de Ingenierías Industriales (E4) 


\section{E5. Edificio Alfonso VIII.}

Situado en C/ Real de Burgos, 2. 47011 Valladolid. (Figuras 186 y 187) La superficie total construida es de $20.016 \mathrm{~m}^{2}$. La residencia se puso en funcionamiento en 1991. Inicialmente contaba con una sala de calderas con tres calderas de gasóleo, dos de 2.326 kW cada una para calefacción y una de 291 kW para Agua Caliente Sanitaria, lo que suma un total de $4.943 \mathrm{~kW}$ de potencia instalada.
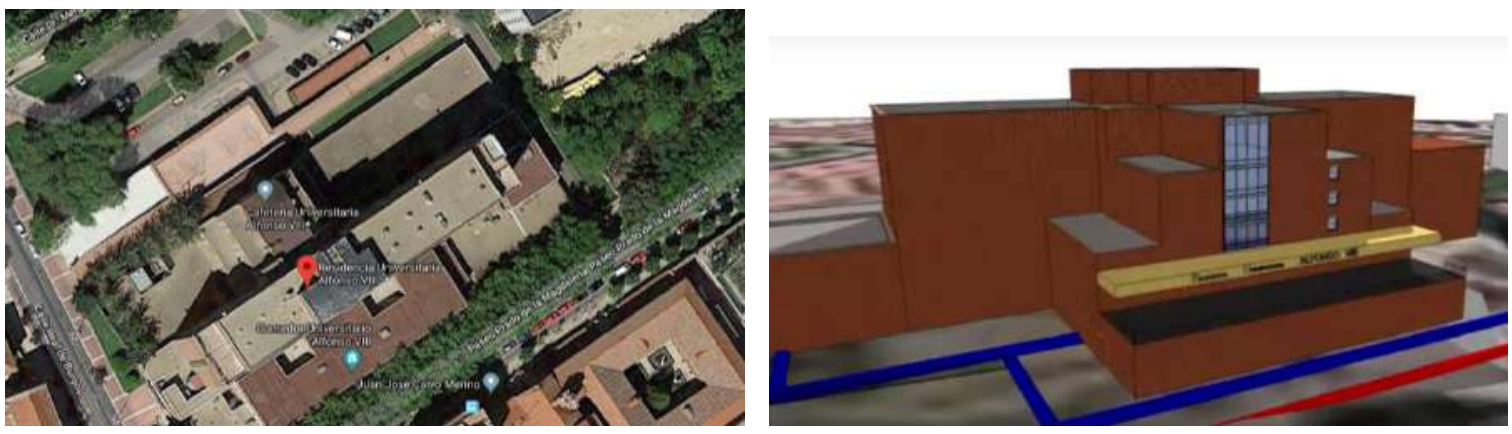

Figura 186. Edificio Alfonso VIII (E5)
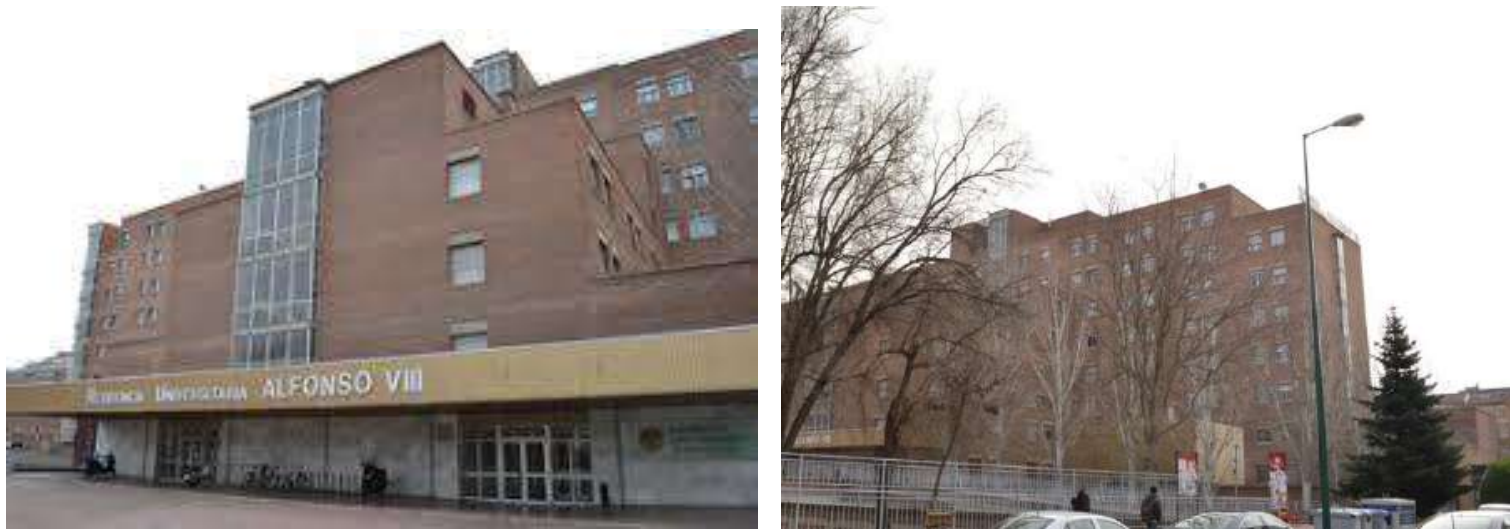

Figura 187. Fotografías Edificio Alfonso VIII (E5)

\section{E6. Edificio Colegio Mayor Femenino Santa Cruz.}

Situado en C/ Real de Burgos, s/n. 47011 Valladolid. (Figuras 188 y 189) La superficie total construida es de $6.660 \mathrm{~m}^{2}$. La residencia se inauguró en 1981, situada en el edificio que albergó la Escuela Universitaria de Enfermería. Inicialmente contaba con una sala de calderas con dos calderas de gas, de 358 kW cada una para calefacción y Agua Caliente Sanitaria, lo que suma un total de $716 \mathrm{~kW}$ de potencia instalada. 

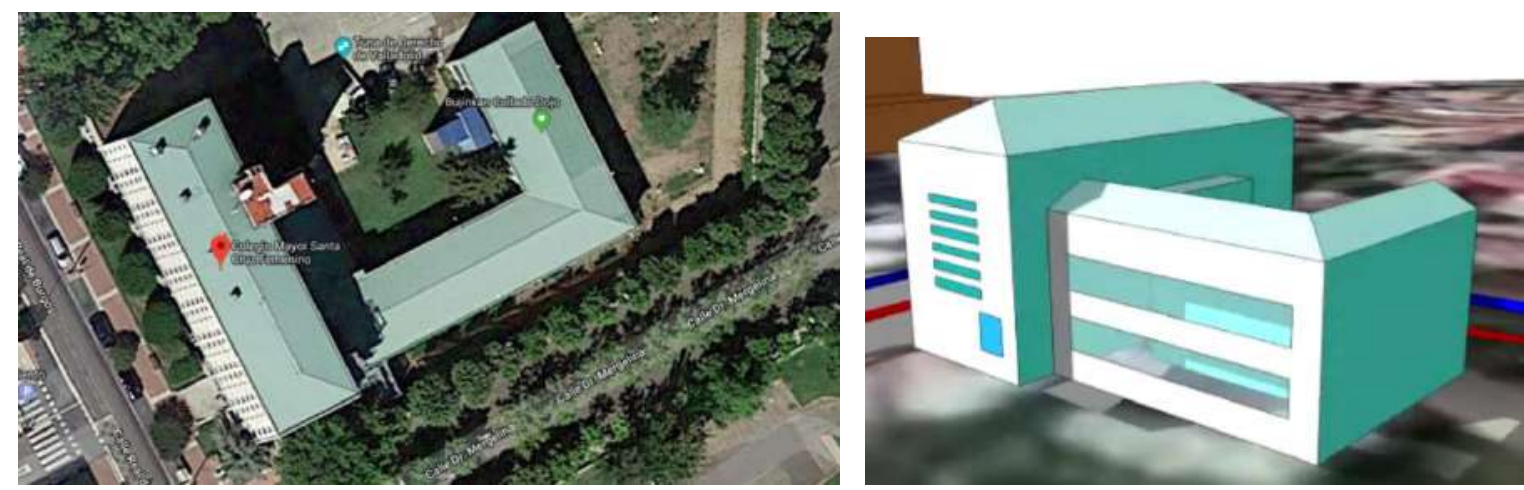

Figura 188. Colegio Mayor Femenino Santa Cruz (E6)
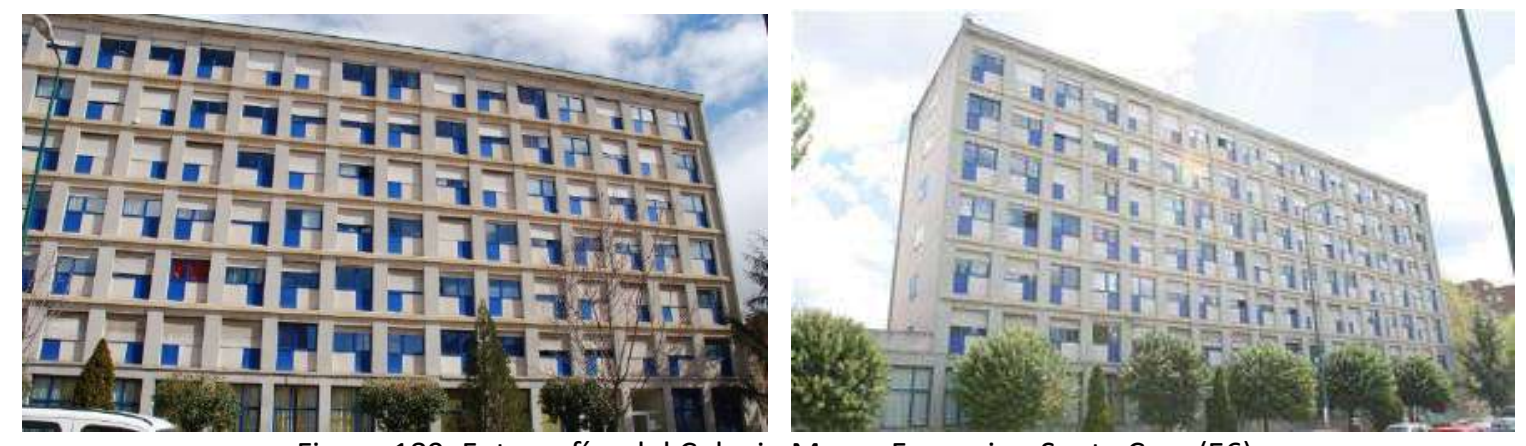

Figura 189. Fotografías del Colegio Mayor Femenino Santa Cruz (E6)

\section{E7. Instituto de Biología y Genética Molecular (IBGM)}

Situado en C/ Sanz y Forés, 3. 47003 Valladolid. (Figuras 190 y 191)

La superficie total construida es de $3.919 \mathrm{~m}^{2}$. Se inauguró en el 2005. (Europa Press, 2011) [158]. Inicialmente contaba con una sala de calderas con dos calderas de gas, de $233 \mathrm{~kW}$ cada una para calefacción y Agua Caliente Sanitaria, lo que suma un total de 466 kW de potencia instalada.
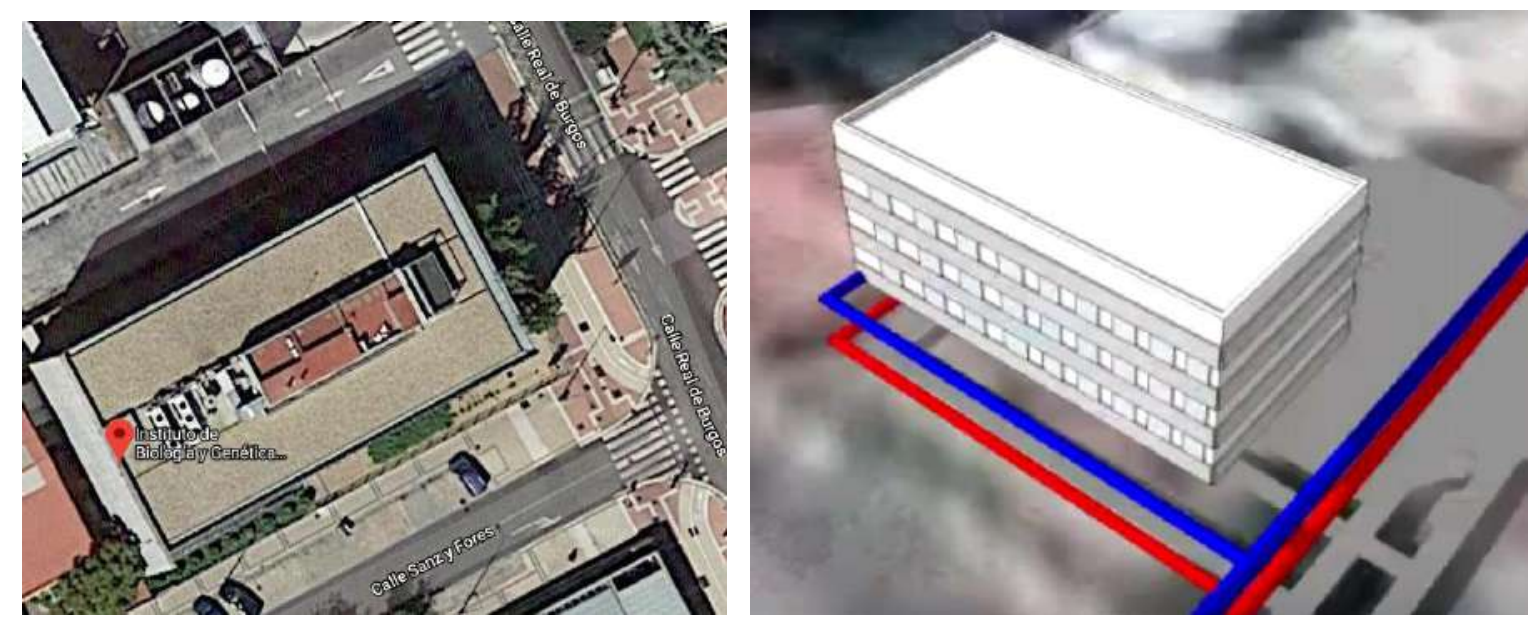

Figura 190. Instituto de Biología Genética y Molecular. (IBGM) (E7) 

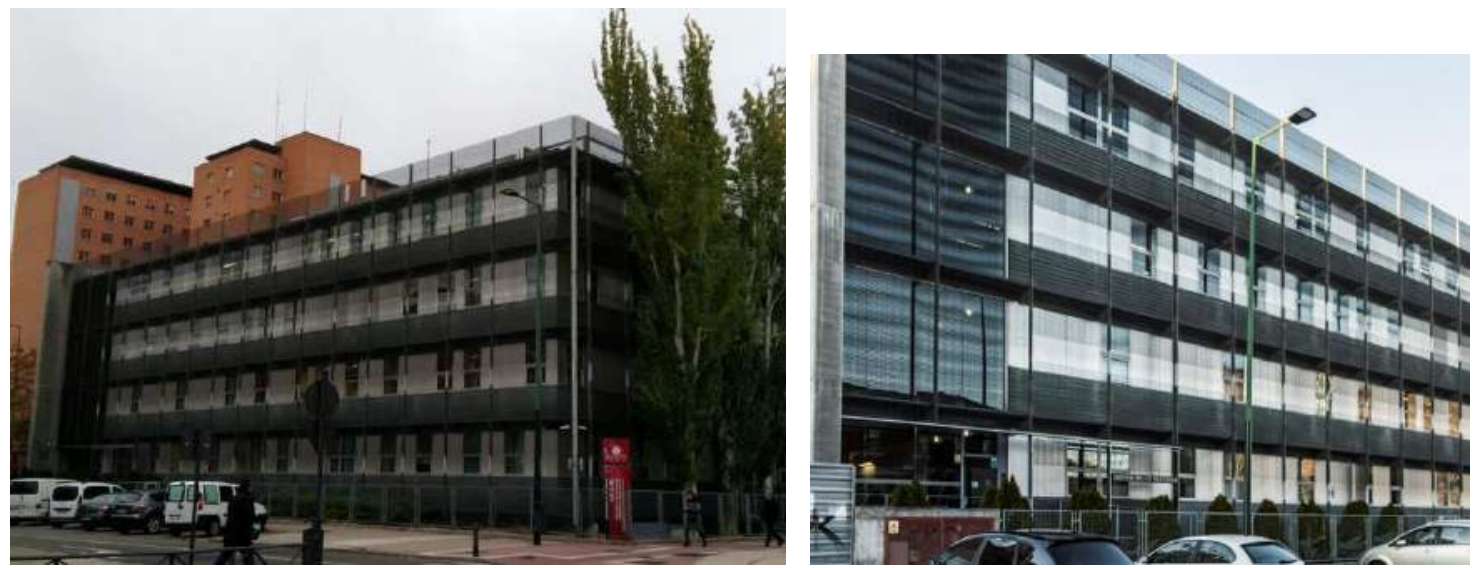

Figura 191. Fotografías del Instituto de Biología Genética y Molecular. (IBGM) (E7)

\section{E8. Facultad de Ciencias de la Salud}

Situado en Avenida Ramón y Cajal, 7. 47005 Valladolid. (Figuras 192 y 193)

La superficie total construida es de $29.802 \mathrm{~m}^{2}$. En 1889, se inauguró la Facultad en su actual emplazamiento y en 1960 se anexó el edificio del bloque central.

Cuenta con 4 salas de calderas, con una potencia total instalada de $2.320 \mathrm{~kW}$.

- Una sala en Anatomía con dos calderas de gas natural de 265 kW y 75 kW para Calefacción y ACS, lo que hace una potencia de $340 \mathrm{~kW}$

- Un sala en el cuerpo central con dos calderas de gas natural de 265 kW y 705 kW para Calefacción, lo que hace una potencia de $970 \mathrm{~kW}$

- Una sala en el ala derecha, con dos calderas de gas natural de $285 \mathrm{~kW}$ cada una, para Calefacción, lo que hace una potencia de $570 \mathrm{~kW}$

- Una última sala en el ala izquierda, con dos calderas de gas natural de $265 \mathrm{~kW}$ y 175 kW para Calefacción y ACS, lo que hace una potencia de 440 kW
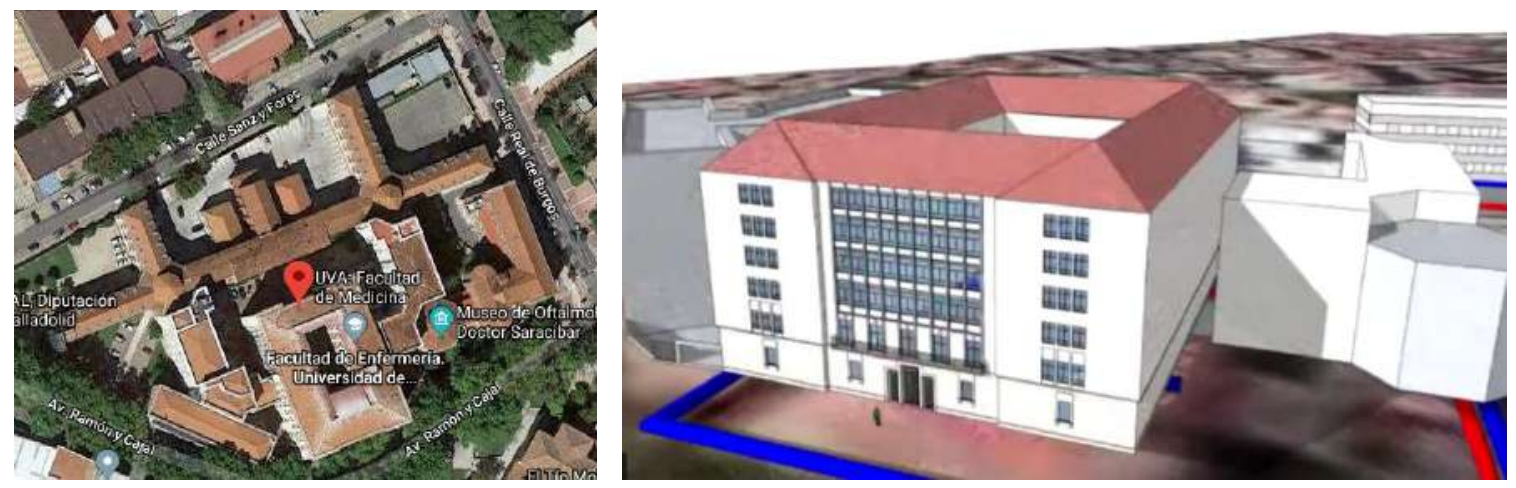

Figura 192. Facultad de Ciencias de la Salud (E8) 


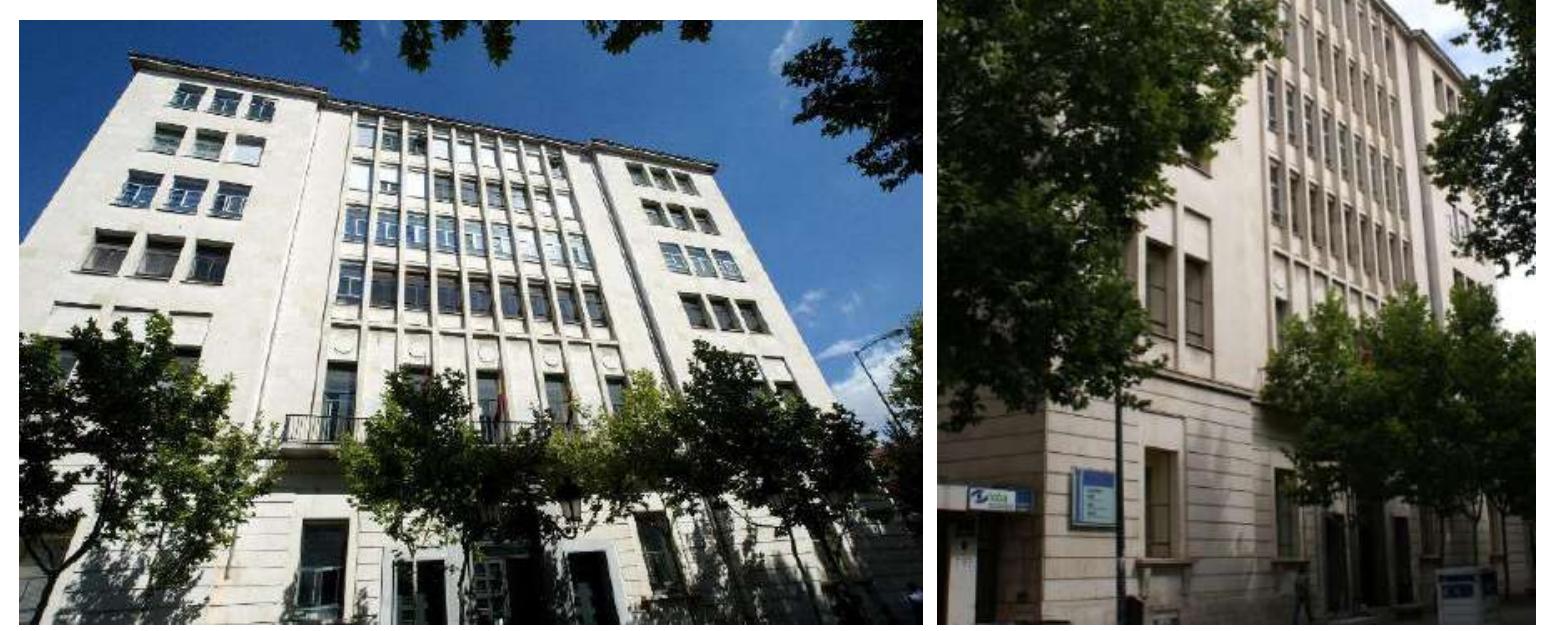

Figura 193. Fotografías Facultad de Ciencias de la Salud (E8)

\section{E13. Facultad de Económicas}

Situado en Avenida Valle Esgueva, 6. 47011 Valladolid. (Figuras 194 y 195)

La superficie total construida es de $17.776 \mathrm{~m}^{2}$. Se puso en funcionamiento en 1982 (Anta, 2017) [156]. Inicialmente contaba con una sala de calderas con dos calderas de gas, de 802 kW cada una para calefacción, lo que suma un total de 1.604 kW de potencia instalada.
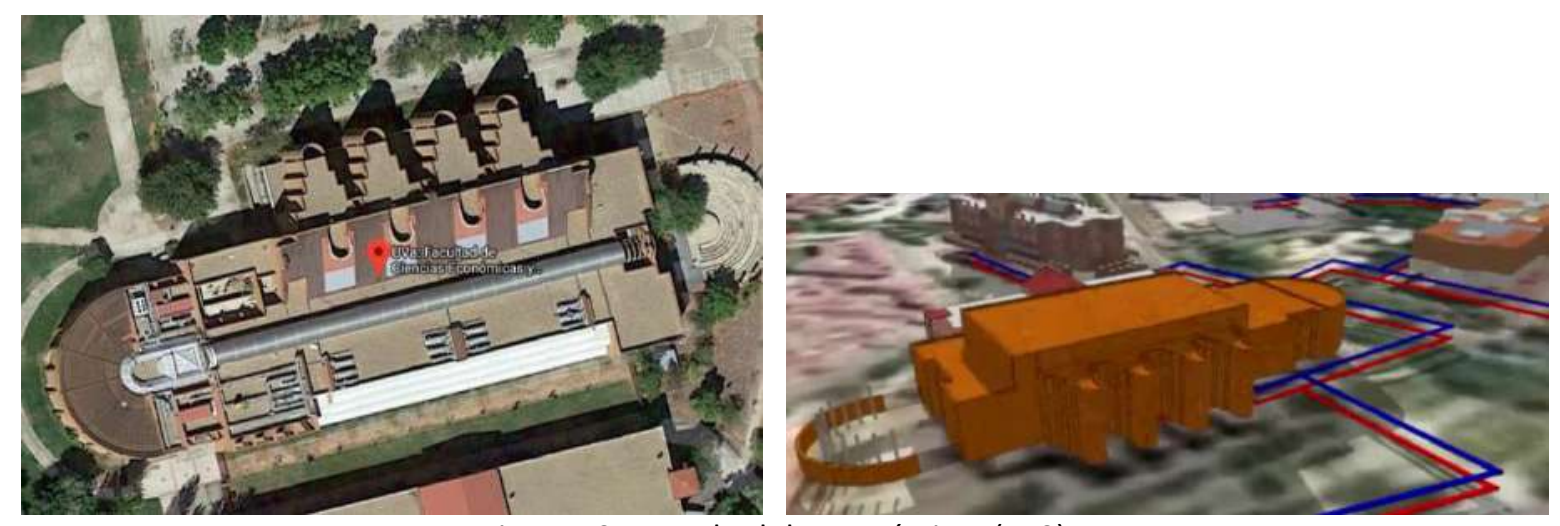

Figura 194. Facultad de Económicas (E13) 

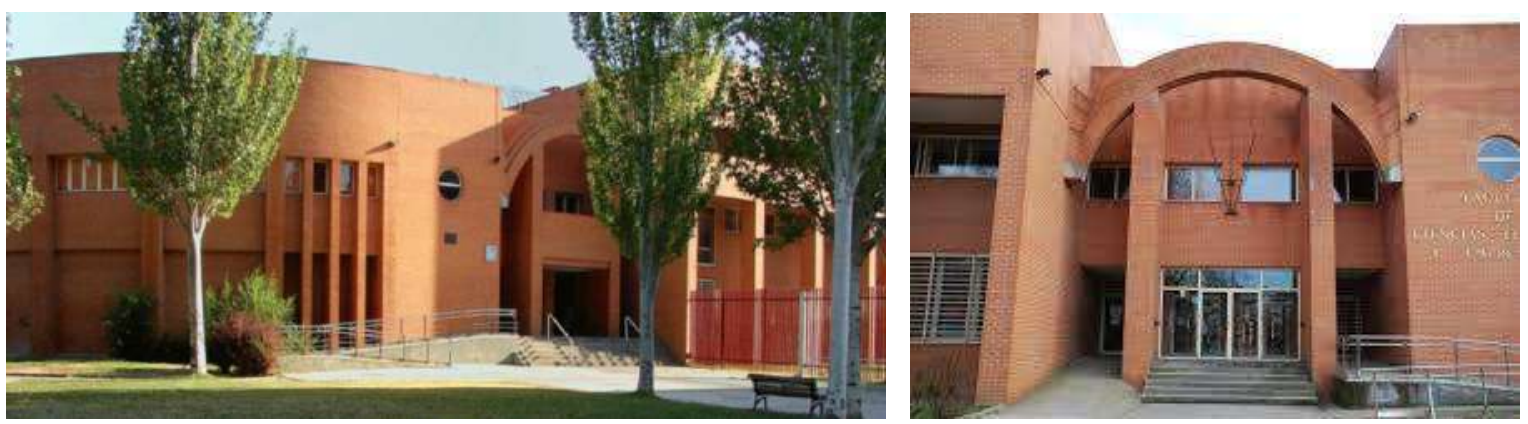

Figura 195. Fotografías de la Facultad de Económicas (E13)

\section{E14. Aulario del Campus Esgueva}

Situado en Calle Reyes Magos, s/n. 47011 Valladolid. (Figuras 196 y 197) La superficie total construida es de $7.569 \mathrm{~m}^{2}$. Se construyó en 1986. (Sede Electrónica del Catastro) [159]. Inicialmente contaba con una sala de calderas con dos calderas de gasóleo de 233 kW y 174 kW para calefacción, lo que suma un total de 407 kW de potencia instalada.

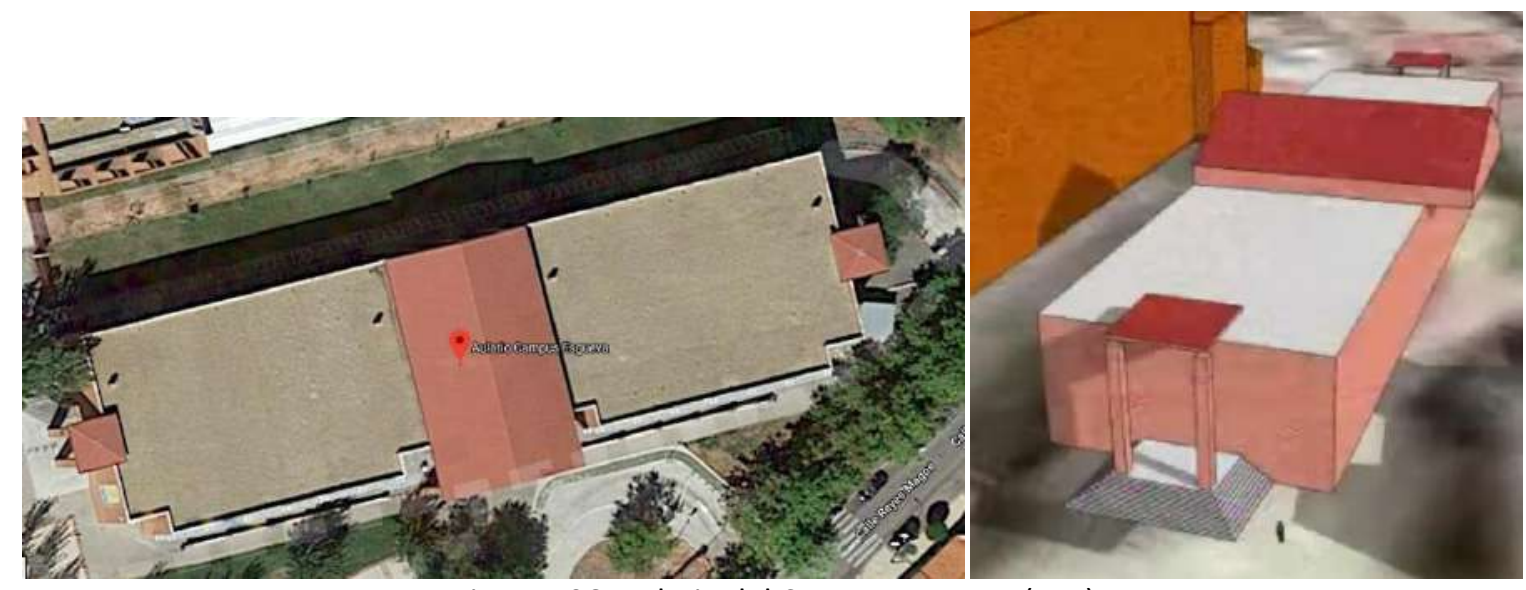

Figura 196. Aulario del Campus Esgueva (E14)

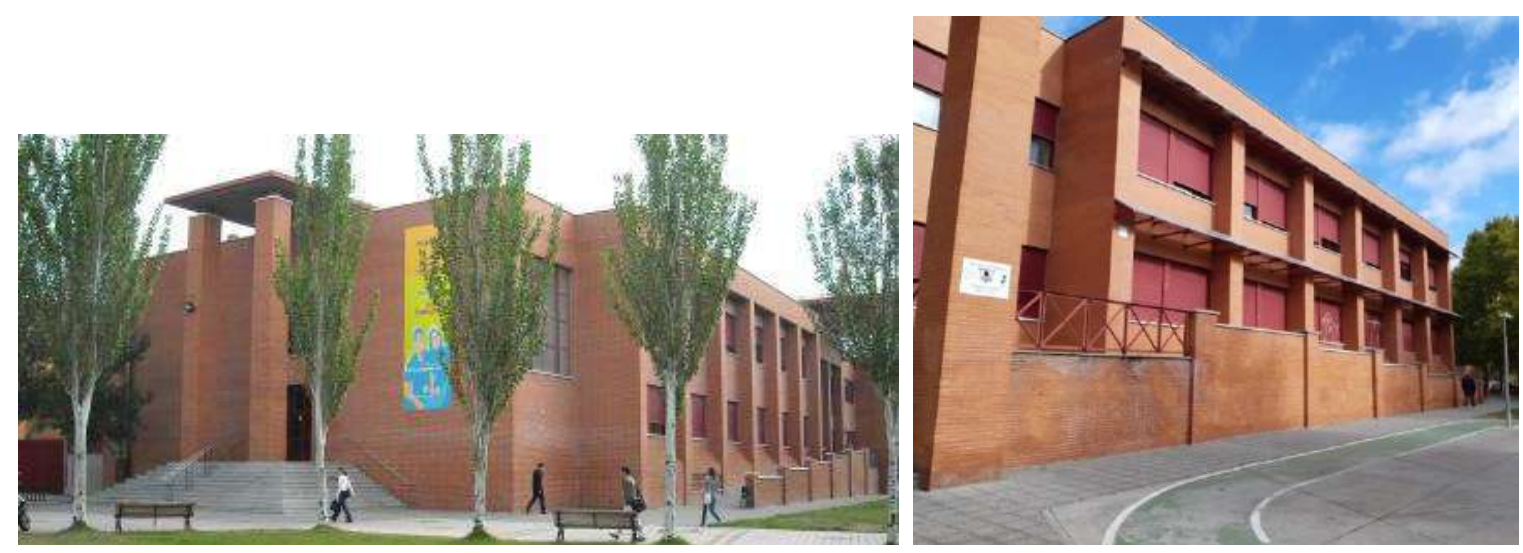

Figura 197. Fotografías del Aulario del Campus Esgueva (E14) 


\section{E15. Escuela de Ingenierías Industriales (Sede Paseo del Cauce)}

Situado en Paseo del Cauce, 59. 47011 Valladolid. (Figuras 198 y 199) La superficie total construida es de $18.512 \mathrm{~m}^{2}$. Se puso en funcionamiento en 1985. (Anta, 2017) [156]. Inicialmente contaba con cuatro calderas de gas natural de $581 \mathrm{~kW}$ cada una, para calefacción, lo que suma un total de $2.326 \mathrm{~kW}$ de potencia instalada.
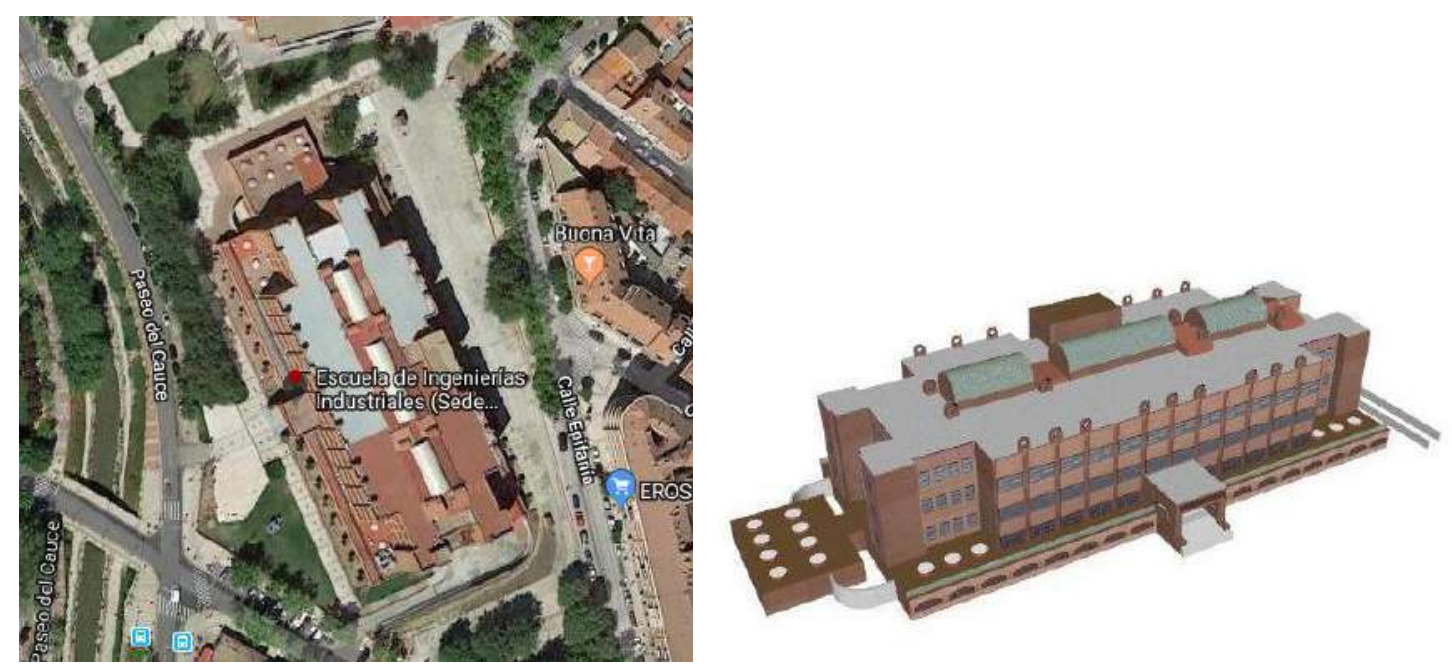

Figura 198. Escuela de Ingenierías Industriales (sede Paseo del Cauce) (E15)
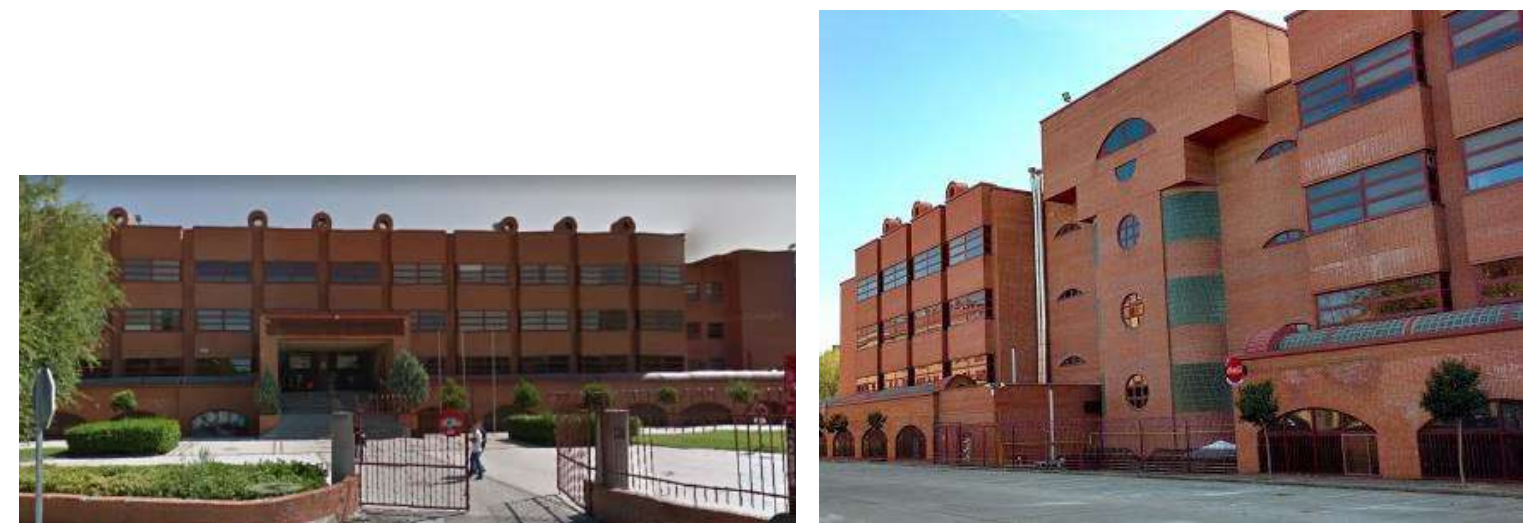

Figura 199. Fotografías de la Escuela de Ingenierías Industriales (sede Paseo del Cauce) (E15) 


\section{ANEXO IV. \\ DESARROLLO DEL ANÁLISIS DE LOS EDIFICIOS \\ DEL CAMPUS MIGUEL DELIBES}

\section{AIV.1.Edificio D1. Apartamentos Cardenal Mendoza}

\section{AIV.1.1. Obtención de la línea base de referencia energética}

Tal como se ha expuesto en el capítulo anterior los datos de partida para la obtención de la línea base de referencia parte de los datos de consumo térmico de las temporadas: octubre de 2012 a mayo de 2013 y de octubre de 2013 a mayo de 2014, junto con los datos climáticos de dichas temporadas. Los datos de consumo se muestran en la Tabla 149.

Tabla 149. Consumos térmicos del edificio D1

\begin{tabular}{lr}
\hline & Consumos térmicos $(\mathrm{kWh})$. D1 \\
\hline oct-12 & 52.823 \\
\hline nov-12 & 220.904 \\
\hline dic-12 & 228.313 \\
\hline ene-13 & 239.241 \\
\hline feb-13 & 273.273 \\
\hline mar-13 & 210.397 \\
\hline abr-13 & 219.730 \\
\hline may-13 & 135.157 \\
\hline oct-13 & 35.931 \\
\hline nov-13 & 0 \\
\hline dic-13 & 322.634 \\
\hline ene-14 & 320.896 \\
\hline feb-14 & 307.368 \\
\hline mar-14 & 165.884 \\
\hline abr-14 & 156.449 \\
\hline may-14 & 28.883 \\
\hline Promedio & 194.526 \\
\hline Total (oct-12-may-13) & 1.579 .838 \\
\hline Total (oct-13-may-14) & 1.338 .045 \\
\hline Total (oct-12-may-13) & 2.917 .883 \\
\hline
\end{tabular}


Se disponen de 15 datos para establecer el modelo de regresión con las variables climáticas, no se ha tenido en cuenta el consumo del mes de noviembre de 2013, por no estar registrado.

Utilizando el programa SPSS V.20, se obtiene el modelo de regresión mediante el método de pasos sucesivos. Como se puede ver en la Tabla 150 para el edificio D1, el método ofrece dos modelos de regresión, uno con una sola variable (Temperatura media) y otro con dos variables (Temperatura media y velocidad del viento nocturna).

El primer modelo (modelo de regresión lineal simple) fue construido con un solo paso, incluyendo la Temperatura media por ser la variable más significativa (variable con menor valor de Sig $=0,000$ ) que indica la probabilidad de cometer un error al rechazar que la pendiente de la variable "Temperatura media" es igual a cero, por lo que se acepta que esa variable forma parte del modelo con una pendiente $(B=-23838,939)$.

El segundo modelo (modelo de regresión lineal múltiple) se construyó en dos pasos, primero entró la Temperatura media y luego entró la siguiente variable que rechazase la Hipótesis nula, (las variables que rechazan la hipótesis nula son las que presentan una pendiente estadísticamente significativa y su probabilidad de cometer el error de rechazar Ho es $\leq 0,05$, para un nivel de confianza del $95 \%$ ), esta variable fue la "velocidad de viento nocturna", por presentar un valor de Sig $=0,042$, el resto de las variables como se observa en la Tabla 151 fueron excluidas del modelo al tener valores de sig >0,05.

Tabla 150. Modelos de regresión del Edificio D1

\begin{tabular}{|c|c|c|c|c|c|c|c|}
\hline & \multirow{2}{*}{ Modelo } & \multicolumn{2}{|c|}{$\begin{array}{l}\text { Coeficientes no } \\
\text { estandarizados }\end{array}$} & & \multirow{2}{*}{ Sig. } & \multicolumn{2}{|c|}{$\begin{array}{c}\text { Intervalo de confianza de } \\
95,0 \% \text { para B }\end{array}$} \\
\hline & & B & Error típ. & & & $\begin{array}{l}\text { Límite } \\
\text { inferior }\end{array}$ & $\begin{array}{l}\text { Límite } \\
\text { superior }\end{array}$ \\
\hline \multirow[t]{2}{*}{1} & (Constante) & 391037,854 & 28911,845 & 13,525 &, 000 & 328577,609 & 453498,099 \\
\hline & T_med & $-23838,939$ & 3218,214 & $-7,408$ & ,000 & $-30791,468$ & $-16886,410$ \\
\hline \multirow[t]{3}{*}{2} & (Constante) & 271370,906 & 58247,979 & 4,659 & ,001 & 144459,462 & 398282,350 \\
\hline & T_med & $-20045,184$ & 3257,020 & $-6,154$ & ,000 & $-27141,621$ & $-12948,747$ \\
\hline & V_viento_nocturna_m/s & 50568,513 & 22202,726 & 2,278 &, 042 & 2192,929 & 98944,097 \\
\hline
\end{tabular}

En la Figura 200 se representa el modelo 1 de regresión con sus límites inferior y superior para un nivel de confianza del $95 \%$ 
Anexo IV. Desarrollo del análisis de los edificios del Campus Miguel Delibes

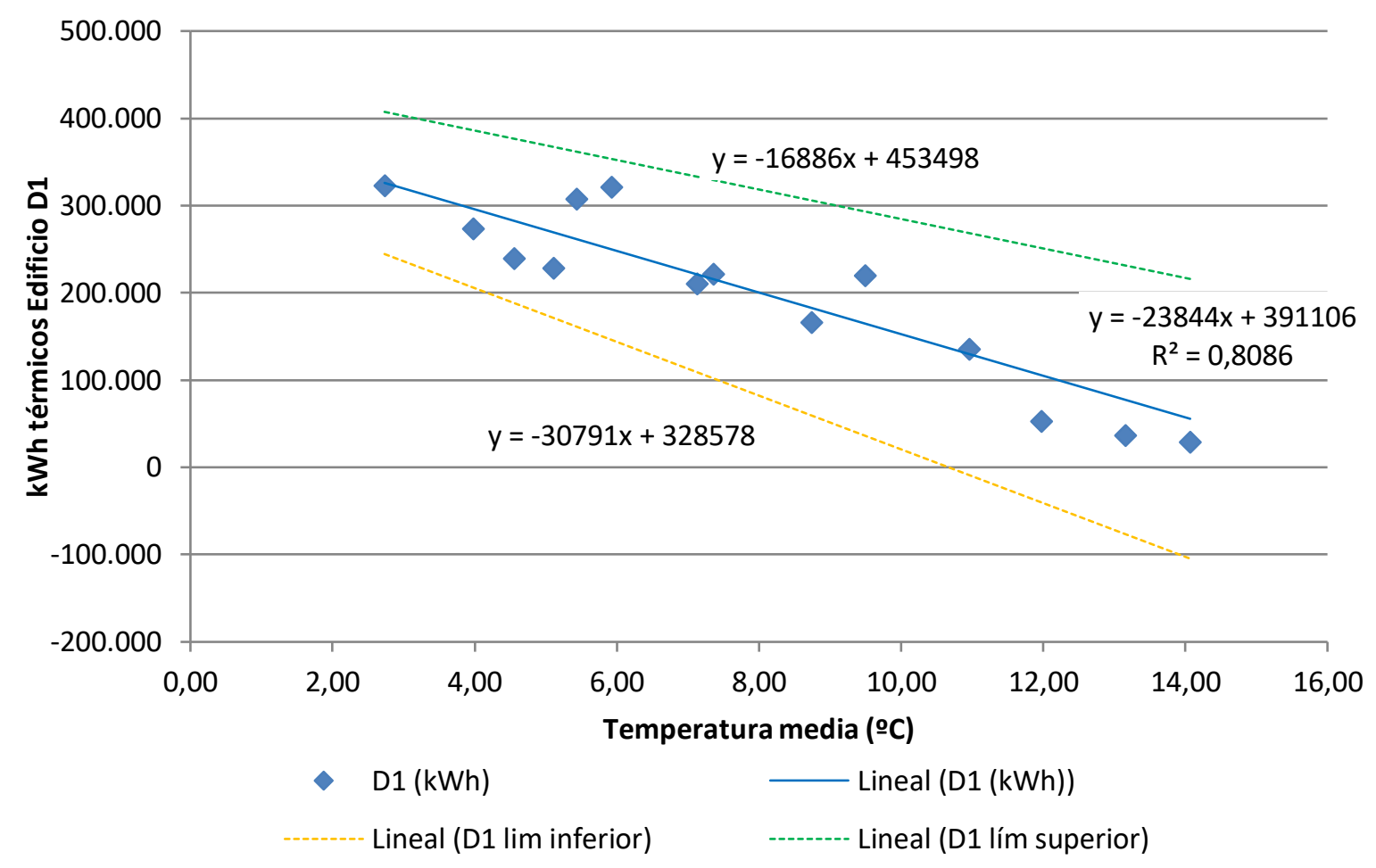

Figura 200. Representación del modelo de regresión lineal simple para el Edificio D1

En la Figura 201 se representa el modelo 2 de regresión lineal múltiple para el edificio D1

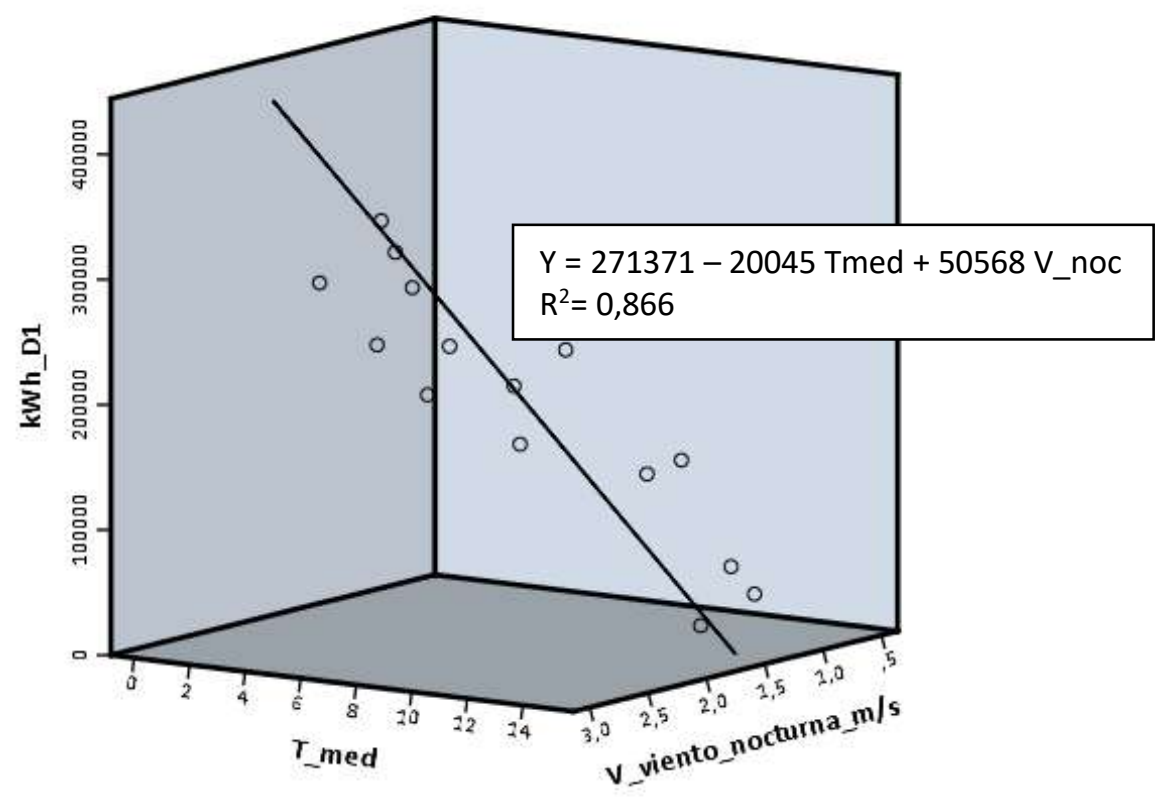

Figura 201. Representación del modelo de regresión lineal múltiple para el Edificio D1 
Los valores de la columna $\mathrm{t}$ se obtienen dividiendo el valor de los coeficientes no estandarizados entre sus errores típicos, este estadístico tiende a ser mayor en valor absoluto cuando la hipótesis alternativa es verdadera, es decir cuando la variable posee una pendiente significativa en el modelo de regresión.

En las tablas 26 y 27, el estadístico t y su nivel crítico (Sig), permiten contrastar la hipótesis nula consistente en que el coeficiente de regresión vale cero en el modelo; a mayor valor de $t$, mayor peso en el modelo.

El valor "Sig" corresponde a los valores de probabilidad de los valores de $t$, es la probabilidad de obtener el valor de t si la hipótesis nula fuera cierta, cuando son $\leq 0,05$ se rechaza la hipótesis nula y se concluye que las pendientes son distintas de cero, luego si Sig $>0,05$ se acepta la hipótesis nula de que la pendiente de la variable independiente en el modelo de regresión es igual a cero, no cumpliendo el criterio de entrada en el modelo.

La correlación parcial, que aparece en la Tabla 151 estudia la relación existente entre dos variables cuantitativas cuando se controla o elimina el efecto de terceras variables, en el modelo de regresión lineal, a mayor valor absoluto, mayor relación entre la variable dependiente y la independiente.

Tabla 151. Variables excluidas del modelo de región del Edificio D1

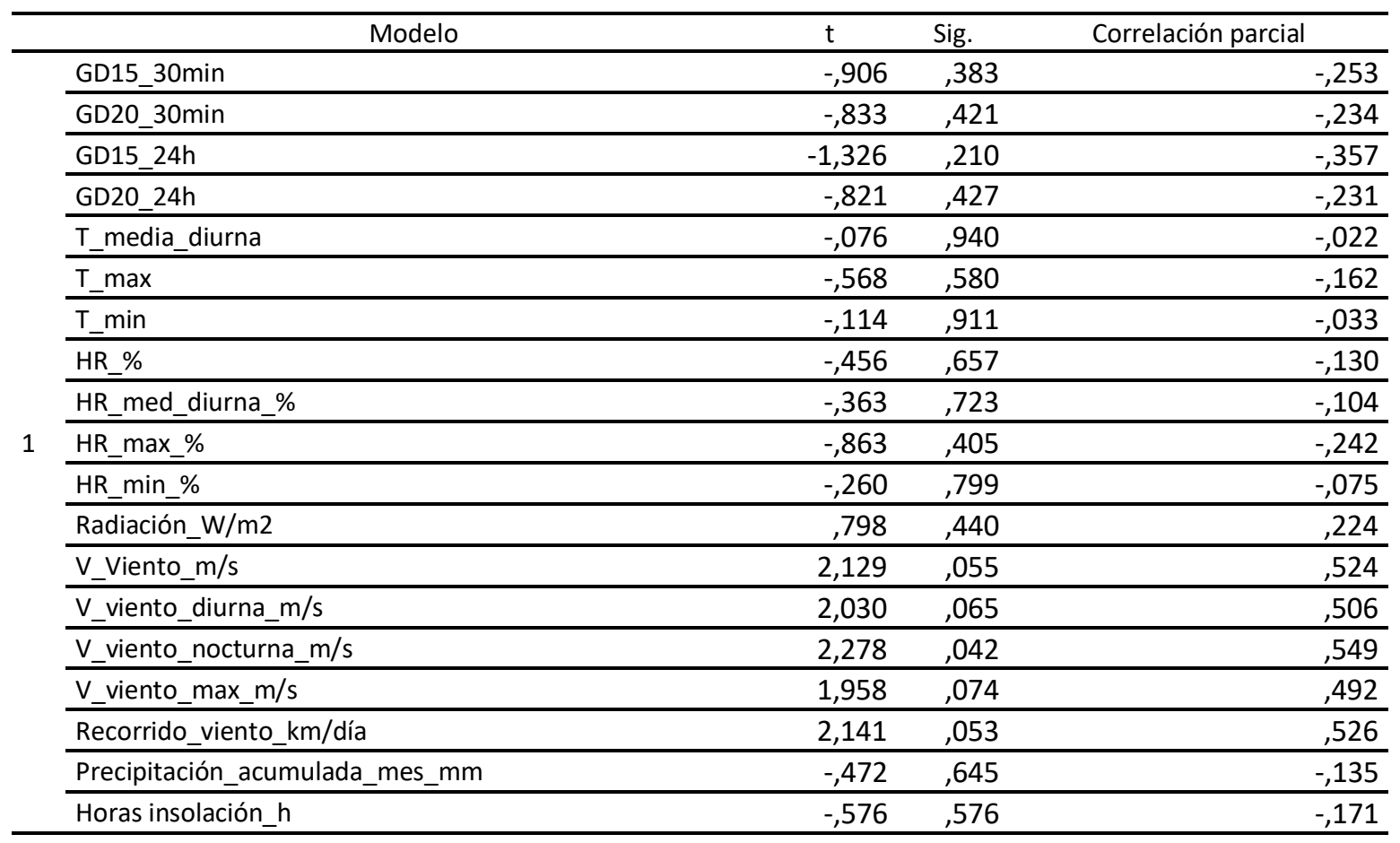




\begin{tabular}{|c|c|c|c|c|}
\hline & Modelo & $T$ & Sig. & Correlación parcial \\
\hline \multirow{18}{*}{2} & GD15_30min &,- 563 &, 585 &,- 167 \\
\hline & GD20_30min &,- 880 & ,398 &,- 256 \\
\hline & GD15_24h &,- 504 & 624 &,- 150 \\
\hline & GD20_24h &,- 125 & ,903 &,- 038 \\
\hline & T_media_diurna &,- 285 & 781 &,- 086 \\
\hline & T_max & ,062 & ,952 & ,019 \\
\hline & T_min & ,368 & ,720 & 110 \\
\hline & HR_\% & ,282 & ,783 & 085 \\
\hline & HR_med_diurna_\% & ,346 & ,736 & 104 \\
\hline & HR_max_\% & ,249 & ,808 & 075 \\
\hline & HR_min_\% &,- 006 & ,995 &,- 002 \\
\hline & Radiación_W/m2 &,- 463 & 652 &,- 138 \\
\hline & V_Viento_m/s &,- 352 & ,731 &,- 106 \\
\hline & V_viento_diurna_m/s &,- 278 & ,786 &,- 084 \\
\hline & V_viento_max_m/s &,- 414 & ,687 &,- 124 \\
\hline & Recorrido_viento_km/día &,- 830 & ,424 &,- 243 \\
\hline & Precipitación_acumulada_mes_mm &,- 187 & 855 &,- 056 \\
\hline & Horas insolación_h &,- 576 & ,576 &,- 171 \\
\hline
\end{tabular}

La bondad de los modelos de regresión obtenidos para el edificio D1, se resumen en la Tabla 152

Tabla 152. Resumen de la bondad de los modelos de regresión para el Edificio D1

\begin{tabular}{ccccc}
\hline Modelo & $\mathrm{R}$ & R cuadrado & R cuadrado corregida & $\begin{array}{c}\text { Error típ. de la } \\
\text { estimación }\end{array}$ \\
\hline 1 & $-0,899$ &, 808 &, 794 & 44516,90807 \\
\hline 2 & $-0,931$ &, 866 &, 844 & 38716,12419 \\
\hline
\end{tabular}

Se observa como el modelo 1 de regresión lineal simple presenta un Coeficiente de Correlación de Pearson ( $\mathrm{R}$ ) inferior en valor absoluto al modelo 2 de regresión lineal múltiple, este coeficiente indica que las variables de los modelos están correlacionadas de manera muy fuerte (en la correlación perfecta $\mathrm{R}= \pm 1$ ). La correlación que se produce en ambos modelos es inversa, al aumentar el valor de las variables independientes disminuye el valor de la variable dependiente que es el consumo térmico.

El coeficiente de determinación $\left(R^{2}\right)$, nos indica que con el modelo 1 se podría explicar el $80,8 \%$ de los datos reales obtenidos y el modelo 2 , el porcentaje de aciertos o de explicación asciende al 86,6\%, ambos aceptando un error del 5\%.

El coeficiente de determinación corregido $\left(R^{2}\right.$ corregido) que tiene en cuenta el número de variables independientes incluidas en el modelo y el tamaño de la muestra, reduce el coeficiente de determinación al 79,4\% en el modelo 1 y al 84,4 \% en el modelo 2. 
El error típico de la estimación que nos indica la magnitud de los errores, es decir la parte de la variable dependiente que dejamos sin explicar con el modelo y que describe la variación de la variable respuesta (el Consumo) respecto a la recta de regresión, es de $44.517 \mathrm{kWh}$ para el modelo 1 y de $38.716 \mathrm{kWh}$ para el modelo 2, lo que representa un $22,9 \%$ del promedio de los consumos que fue de $194.526 \mathrm{kWh}$ para el modelo 1 y del 19,9\% para el modelo 2.

Por tanto aunque el modelo 2 es más preciso, también es aceptado el modelo 1 para la representación de la línea base de los consumos térmicos del edificio D1.

\section{AIV.1.2. Verificación del cumplimiento de los supuestos estadísticos}

Las condiciones que se deben cumplir en un modelo de regresión son:

- Linealidad de las variables, las variables se encuentran relacionadas de forma lineal.

Como se observa en la Tabla 150, la pendiente (B), para el modelo 1, obtuvo un valor de Sig $=0,000$, que al ser $\leq 0,05$, nos indica que podemos rechazar la hipótesis nula de pendiente igual a cero y nos da la evidencia de linealidad entre la variable dependiente (kWh del edificio D1) y la independiente (Temperatura media). Al ser el valor de la pendiente negativa, indica una relación inversa entre el consumo y la Temperatura media.

Para el modelo 2, según la misma Tabla 150, las pendientes de las dos variables introducidas en el modelo obtuvieron unos valores de Sig $=0,000$ para la Temperatura media y de 0,042 para la Velocidad del viento nocturna, ambos $\leq 0,05$, lo que nos indica que podemos rechazar la hipótesis nula de pendiente igual a cero y nos da la evidencia de linealidad entre la variable dependiente ( $\mathrm{kWh}$ del edificio D1) y las independientes (Temperatura media y velocidad del viento nocturna). Al ser el valor de la primera pendiente negativa, indica una relación inversa entre el consumo y la Temperatura media y de la segunda pendiente positiva, indica relación directa entre el consumo y la velocidad del viento nocturna. 
- Normalidad. Todos los valores obtenidos para la variable dependiente (Y), deben estar distribuidos normalmente en cada valor de las variables independientes $(X)$.

Se comprueba la normalidad de las variables y de los residuos mediante el Test de Shapiro - Wilk para muestras pequeñas (menores a 30 observaciones), siendo la hipótesis nula el que la distribución es Normal, luego si la probabilidad del estadístico del test es $\leq$ al nivel de significación 0,05, la hipótesis nula es rechazada y sólo aceptaremos que las variables se distribuyen según una Normal cuando el valor de la significación sea mayor que 0,05 (valor de la significación >0,05) en el Test de Shapiro Wilk.

La Tabla 153, muestra la prueba de normalidad de Shapiro-Wilk y cómo tanto la variable dependiente (consumos del Edificio D1), como las variables independientes: Temperatura media y velocidad de viento nocturna poseen una Sig $>0,05$, por lo que aceptamos la hipótesis nula de Normalidad de las variables

Tabla 153. Prueba de normalidad para el edificio D1

\begin{tabular}{lcccccc}
\hline & \multicolumn{3}{c}{ Kolmogorov-Smirnov } & \multicolumn{3}{c}{ Shapiro-Wilk } \\
\cline { 2 - 7 } & Estadístico & gl & Sig. & Estadístico & gl & Sig. \\
\hline kWh_D1 &, 164 & 15 &, $200^{*}$ &, 922 & 15 &, $\mathbf{2 0 3}$ \\
\hline T_med &, 134 & 15 &, $200^{*}$ &, 939 & 15 &, $\mathbf{3 7 5}$ \\
\hline V_viento_nocturna_m/s &, 135 & 15 &, $200^{*}$ &, 973 & 15 &, $\mathbf{9 0 3}$ \\
\hline
\end{tabular}

- Independencia de los errores. Los errores asociados a los valores de la variable respuesta $(Y)$ deberán ser independientes unos de otros.

Para la comprobación se utiliza el estadístico de Durbin -Watson.

Se comprueba que el Estadístico de Durbin Watson para el nivel de significancia del 5\%, y para el tamaño de la muestra " $n$ " y el número de variables independientes del modelo " $k$ ", se encuentra en el intervalo [dU, 4-dU], de la Tabla 3, intervalo centrado en el 2, que indica la ausencia de autocorrelación.

El valor del Estadístico Durbin-Watson facilitado por el programa SPSS, es:

- para el modelo 1 de 1,782 (Regresión lineal simple)

- para el modelo 2 de 2,440 (Regresión lineal múltiple)

En el modelo $1, \mathrm{n}=15$ y $\mathrm{k}=1$, según la Tabla 3 , el valor $\mathrm{dU}=1,361$, luego el intervalo que marca la ausencia de correlación es [1,361, 2,639], como el valor del estadístico 1,782 está dentro del intervalo, se acepta la ausencia de autocorrelación

En el modelo $2, \mathrm{n}=15$ y $\mathrm{k}=2$, según la Tabla 3 , el valor $\mathrm{dU}=1,543$, luego el intervalo que marca la ausencia de correlación es [1,543,2,457], como el valor del estadístico 2,440 está dentro del intervalo, se acepta la ausencia de autocorrelación 
- Homocedasticidad de la varianza. Se pretende comprobar que la varianza de los errores $\left(\sigma^{2}\right)$ es constante para cualquier valor de la(s) variable(s) independiente(s) (X), es decir que el valor medio del cuadrado de la desviación de los errores respecto a su media es constante.

Esta condición indica que el error es una variable aleatoria que tomará un valor distinto cada vez que se ejecute el modelo y que no existe correlación entre los residuos y los pronósticos.

La forma de comprobar la homocedasticidad es verificando si el coeficiente de determinación $\mathrm{R}^{2}$, que indica la proporción de la variable dependiente ( $\mathrm{Y}$ o consumo del edificio) que puede ser explicada por la variación de las variables independientes (las variables climatológicas), en las relaciones: residuos y predicciones y entre residuos y variables independientes es nulo o muy próximo a cero, lo que indicará que no existe ningún tipo de correlación en los residuos y que éstos son aleatorios.

Se grafican los diagramas de dispersión de esas relaciones, comprobando que se corresponden a nubes de puntos totalmente aleatorias, sin tendencias ni patrones en sus representaciones gráficas.

Para el modelo 1. Regresión lineal simple, las Figura 202 y Figura 203, muestran que la relación entre los pronósticos y los residuos, posee un coeficiente de determinación = $1,11 \times 10^{-16}$, cercano a cero y entre la variable independiente (Temperatura media) y los residuos un coeficiente de determinación de $-2,22 \times 10^{-16}$, también prácticamente nulo; por lo que se concluye que no existe ningún tipo de correlación en los residuos y que éstos son aleatorios, siendo la varianza de los residuos constante

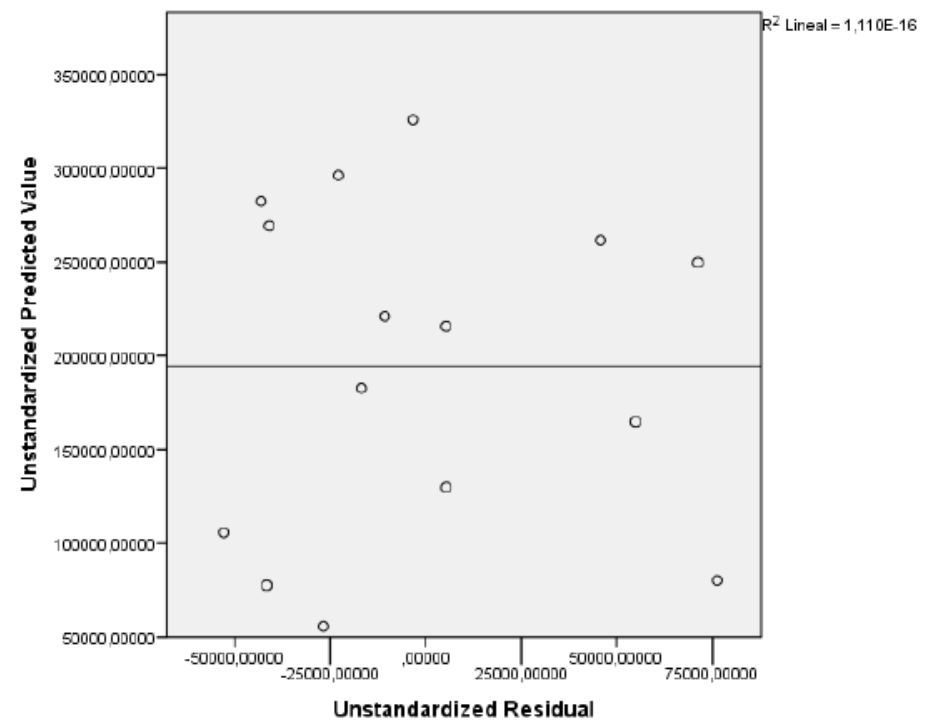

Figura 202. Relación entre los pronósticos y los residuos en el Edificio D1. Modelo 1 


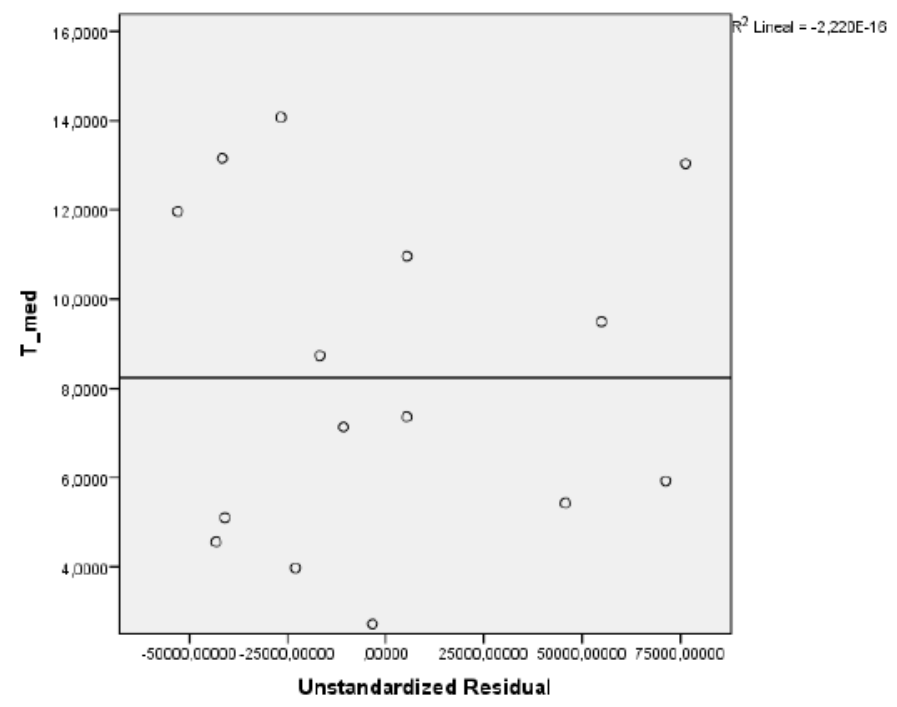

Figura 203. Relación entre la Temperatura media y los residuos en el Edificio D1. Modelo 1

Para el modelo 2. Regresión lineal múltiple, las Figura 204, Figura 205 y Figura 206, muestran que la relación entre los pronósticos y los residuos, posee un coeficiente de determinación

$=-2,22 \times 10^{-16}$, cercano a cero, entre la variable independiente (Temperatura media) y los residuos un coeficiente de determinación de $-2,22 \times 10^{-16}$, también prácticamente nulo y entre la variable independiente (velocidad del viento nocturna) y los residuos de 0; por lo que se concluye que no existe ningún tipo de correlación en los residuos y que éstos son aleatorios, siendo la varianza de los residuos constante

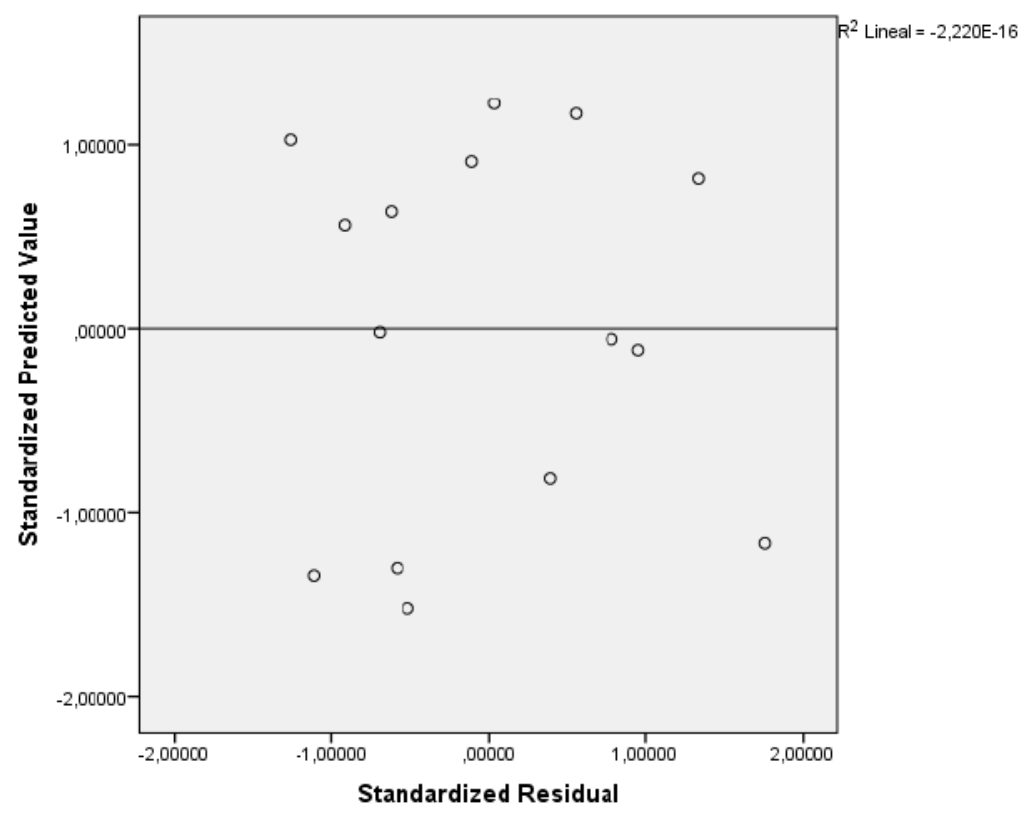


Figura 204. Relación entre los pronósticos y los residuos en el Edificio D1. Modelo 2

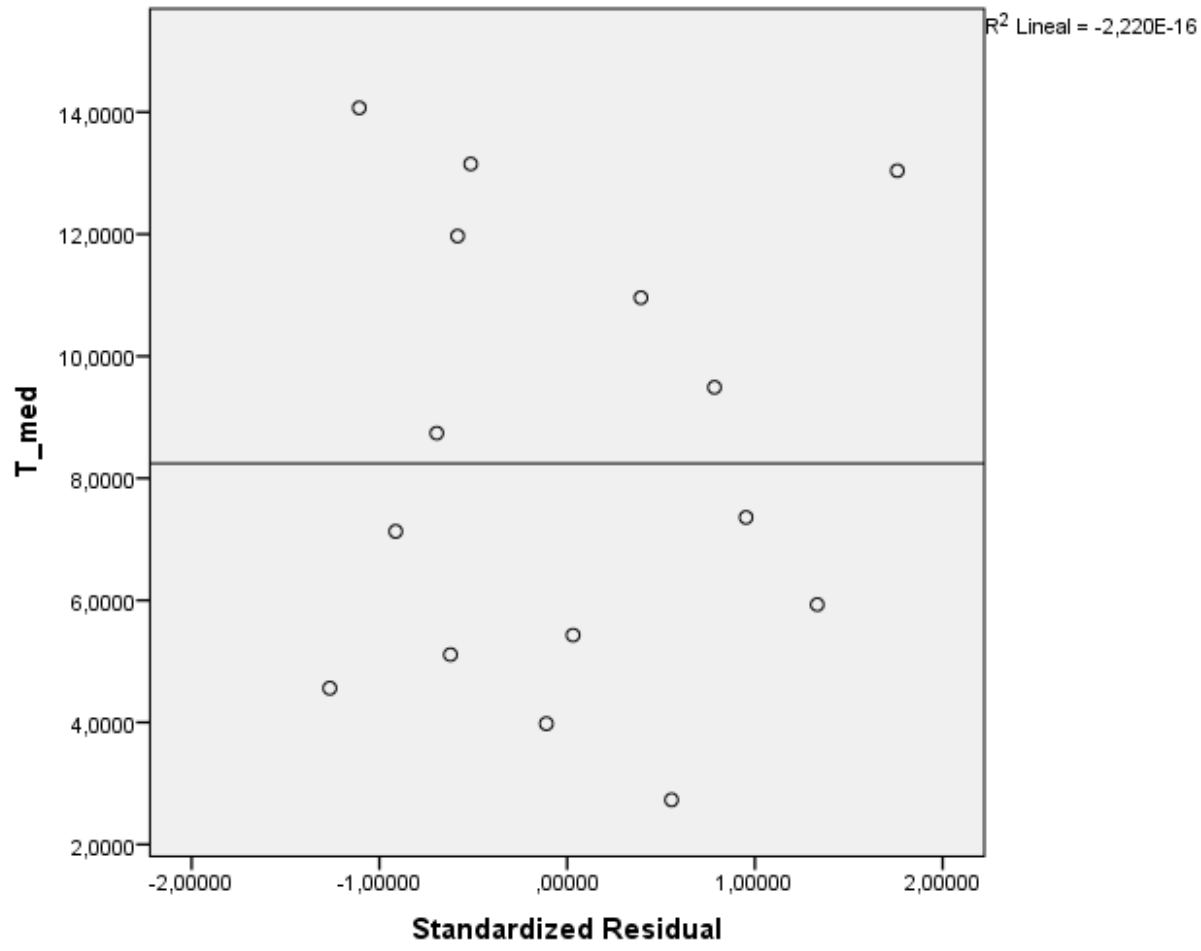

Figura 205. Relación entre la Temperatura media y los residuos en el Edificio D1. Modelo 2

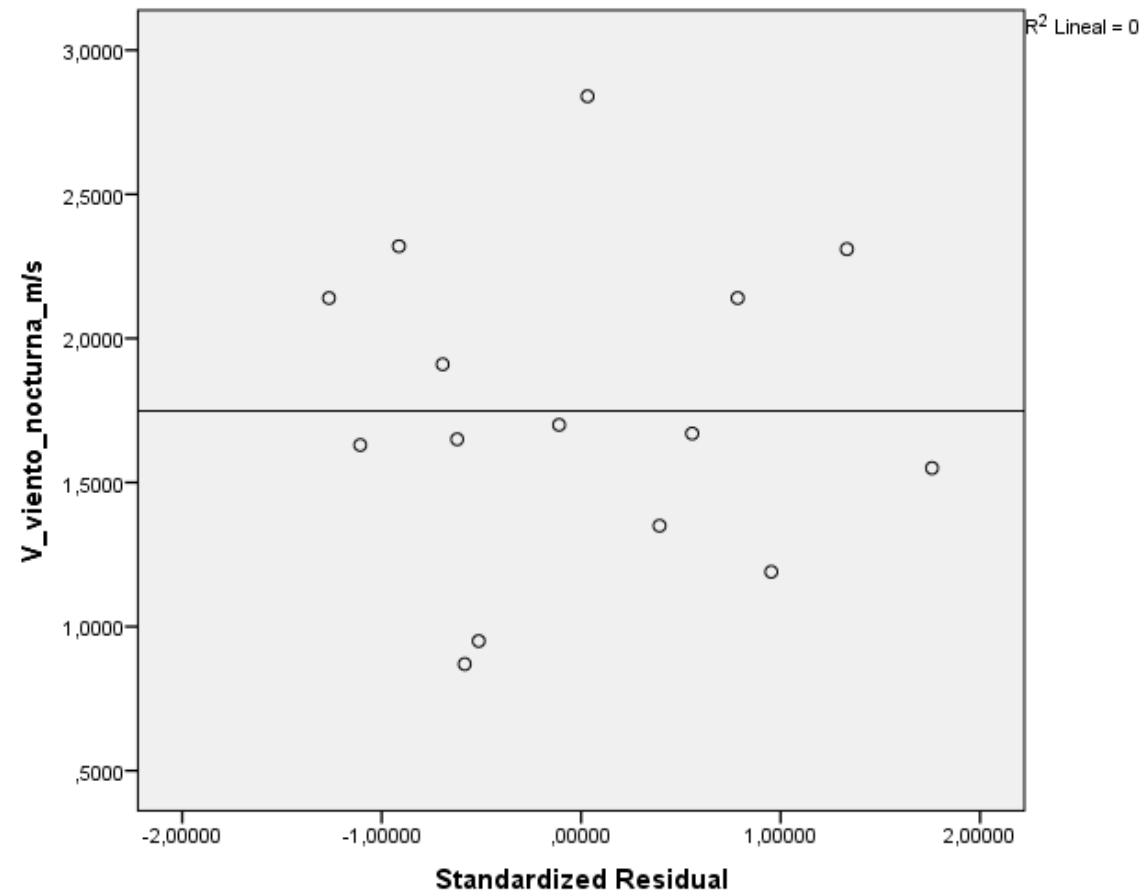

Figura 206. Relación entre la velocidad nocturna y los residuos. Edificio D1. Modelo 2 
- Cuando la regresión es lineal múltiple, se comprueba la falta de multicolinealidad o No-Colinealidad entre las variables independientes, es decir que las variables que forman parte del modelo no están correlacionadas entre ellas.

El problema de la multicolinealidad es moderado cuando el índice de condición toma un valor entre 20 y 30 y es grave cuando el índice de condición toma un valor superior a 30. El número de condición mide la sensibilidad de las estimaciones mínimo-cuadráticas ante pequeños cambios en los datos a mayor valor más correlación entre las variables.

La Tabla 154, muestra los índices de condición de las variables del modelo de regresión múltiple, ninguno de ellos supera el valor 20, por lo que no existen evidencias de correlación entre las variables independientes del modelo

Tabla 154. Índice de condición de las variables independientes del Modelo 2 en el EdificioD1

\begin{tabular}{llr}
\hline Modelo & Dimensión & Índice de condición \\
\hline \multirow{2}{*}{2} & 1 & 1,000 \\
\cline { 2 - 4 } & 2 & 3,915 \\
\cline { 2 - 3 } & 3 & 12,192 \\
\hline
\end{tabular}

En cuanto a los índices estadísticos de colinealidad como son los niveles Tolerancia y su inverso que son los Factores de Inflación de la Varianza (FIV). El nivel de tolerancia se obtiene restando a 1 el coeficiente de determinación $\left(R^{2}\right)$. Como se observa en la Figura 207, el coeficiente de determinación entre las dos variables independientes es $R^{2}=0,262$, luego la Tolerancia es $T=1-R^{2}=1-0,262=0,738$ y FIV $=1 / T=1,354$

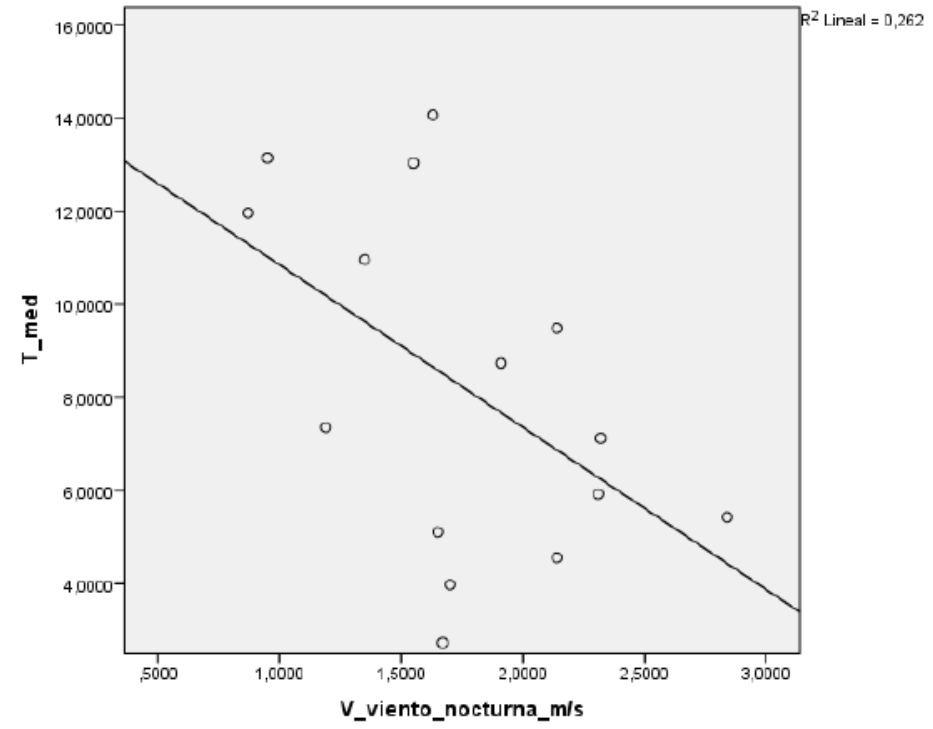

Figura 207. Gráfico de la temperatura media y la velocidad del viento nocturno. 
Si la Tolerancia toma un valor próximo a la unidad no existirá colinealidad (a mayor tolerancia menor colinealidad), por lo que se podrá deducir que no existe multicolinealidad entre las variables independientes. Pueden existir problemas de colinealidad si algún FIV es superior a 10 , que corresponde con un $R^{2}$ de 0,9 y una Tolerancia menor a 0,1

La Tabla 155, muestra los estadísticos de colinealidad y se observa como la Tolerancia toma valores de 0,738 , próxima a 1 y los valores de FV permanecen por debajo de 10, por lo que no existen problemas de colinealidad entre la temperatura media y la velocidad del viento nocturna.

Tabla 155. Estadísticos de colinealidad para los modelos del Edificio D1

\begin{tabular}{|c|c|c|c|}
\hline Modelo & & Tolerancia & FIV \\
\hline 1 & T_med & 1,000 & 1,000 \\
\hline \multirow{2}{*}{2} & T_med & ,738 & 1,354 \\
\hline & V_viento_nocturna_m/s & ,738 & 1,354 \\
\hline
\end{tabular}

\section{AIV.1.3. Obtención de los consumos térmicos previstos}

Una vez comprobado el cumplimiento de los supuestos estadísticos se aceptan los modelos de línea base encontrados para modelizar el consumo del Edificio D1.

Modelo 1:

$$
\text { kWh_D1 }=391.037,854-23.838,939 \times \text { T_med }
$$

Modelo 2:

kWh_D1 $=271.370,906-20.045,184$ x T_med $+50.568,513 \times$ V_viento_nocturna

Con estos modelos se procede a predecir los consumos previstos para las temporadas: octubre 2015-mayo 2016, octubre 2016 - mayo 2017 y octubre 2017-mayo 2018, estos consumos se muestran en la Tabla 156, donde "KWh_D1", representa el consumo real, "kWh_D1_M1", el consumo pronosticado con el Modelo 1 y "kWh_D1_M2", el consumo pronosticado con el Modelo 2. 
Anexo IV. Desarrollo del análisis de los edificios del Campus Miguel Delibes

Tabla 156. Consumos previstos octubre 2014 - mayo 2017 para el edificio D1.

\begin{tabular}{|c|c|c|c|c|c|c|}
\hline & T_media & V_viento_nocturna & kWh_D1 & kWh_D1_M1 & kWh_D1_M2 & $\begin{array}{l}\text { kWh_D1_M1 - } \\
\text { kWh_D1_M2 }\end{array}$ \\
\hline oct-15 & 12,82 & 1,11 & 34.650 & 85.453 & 70.296 & 15.158 \\
\hline nov-15 & 8,30 & 1,12 & 162.230 & 193.119 & 161.642 & 31.477 \\
\hline dic-15 & 5,33 & 0,67 & 192.680 & 264.007 & 198.208 & 65.799 \\
\hline ene-16 & 6,23 & 1,89 & 182.730 & 242.437 & 242.091 & 346 \\
\hline feb-16 & 5,82 & 2,41 & 292.080 & 252.386 & 276.480 & -24.094 \\
\hline mar-16 & 6,14 & 1,44 & 195.399 & 244.598 & 220.907 & 23.690 \\
\hline$a b r-16$ & 9,10 & 1,18 & 140.815 & 174.088 & 148.786 & 25.302 \\
\hline may-16 & 13,11 & 1,02 & 50.295 & 78.409 & 60.189 & 18.221 \\
\hline oct-16 & 13,48 & 0,67 & 60.420 & 69.681 & 34.978 & 34.703 \\
\hline nov-16 & 6,90 & 1,24 & 185.097 & 226.509 & 195.528 & 30.981 \\
\hline dic-16 & 4,12 & 0,77 & 232.890 & 292.775 & 227.472 & 65.304 \\
\hline ene-17 & 2,52 & 0,74 & 245.060 & 331.056 & 258.111 & 72.945 \\
\hline feb-17 & 6,96 & 2,27 & 181.458 & 225.127 & 246.474 & -21.346 \\
\hline mar-17 & 9,21 & 1,62 & 144.074 & 171.497 & 168.868 & 2.628 \\
\hline$a b r-17$ & 12,58 & 1,69 & 56.590 & 91.216 & 104.909 & -13.693 \\
\hline may-17 & 16,69 & 1,16 & 38.400 & -6.757 & -4.524 & -2.233 \\
\hline oct-17 & 14,71 & 1,21 & 43.056 & 40.336 & 37.640 & 2.696 \\
\hline nov-17 & 6,09 & 0,69 & 160.774 & 245.851 & 183.974 & 61.876 \\
\hline dic-17 & 3,99 & 1,66 & 251.172 & 295.890 & 275.374 & 20.516 \\
\hline ene-18 & 4,42 & 1,58 & 242.664 & 285.654 & 262.608 & 23.047 \\
\hline feb-18 & 3,53 & 1,37 & 246.178 & 306.920 & 269.847 & 37.074 \\
\hline mar-18 & 6,80 & 2,99 & 208.040 & 228.872 & 286.359 & -57.487 \\
\hline$a b r-18$ & 11,15 & 1,63 & 132.930 & 125.321 & 130.131 & -4.810 \\
\hline may-18 & 14,03 & 1,35 & 53.590 & 56.631 & 58.417 & -1.786 \\
\hline
\end{tabular}

El dato del consumo de mayo de 2017, no será tenido en cuenta puesto que la estimación arroja valores negativos para ambos modelos.

\section{AIV.1.4. Estudio de la existencia de diferencias significativas}

Utilizando el contraste de hipótesis para la comparación de medias para muestras relacionadas, es decir la prueba paramétrica " $\mathrm{t}$ " de Student para muestras relacionadas, podemos concluir que si las variables se distribuyen según una normal y la significación estadística resulta $\leq 0,05$, existen diferencias significativas. En caso contrario no se rechaza la hipótesis nula de igualdad de medias, concluyendo que las diferencias encontradas no son estadísticamente significativas y no van más allá de lo que sería esperable por azar, todo ello con la aceptación de un riesgo de error del 5\%, o lo que es lo mismo un nivel de confianza del $95 \%$

A continuación se muestra la comparación de medias realizada para cada uno de los tres periodos posteriores a la construcción de la red y para el periodo total hasta mayo de 2018. 
Para la temporada Octubre 2015 - Mayo 2016, se comprueba mediante el Test de Shapiro -Wilk que tanto los valores reales como los pronosticados con los dos modelos se distribuyen según una Normal puesto que en todos los casos los valores de Sig >0,05, como se observa en la Tabla 157

Tabla 157. Prueba de Normalidad temporada Octubre 2015-Mayo 2016. Edificio D1

\begin{tabular}{ccccccc}
\hline & \multicolumn{3}{c}{ Kolmogorov-Smirnov $^{\mathrm{a}}$} & \multicolumn{3}{c}{ Shapiro-Wilk } \\
\cline { 2 - 7 } & Estadístico & gl & Sig. & Estadístico & gl & Sig. \\
\hline kWh_real &, 194 & 8 &, $200^{*}$ &, 930 & 8 &, 513 \\
\hline kWh_pronost_M1 &, 252 & 8 &, 144 &, 839 & 8 &, 073 \\
\hline kWh_pronost_M2 &, 155 & 8 &, $200^{*}$ &, 943 & 8 &, 636 \\
\hline
\end{tabular}

En la Tabla 158, se observa como las medias tanto de los consumos pronosticados con el Modelo 1, como de los consumos pronosticados con el Modelo 2, son superiores a las medias de los consumos reales del Edificio D1, un 22,7 \% superiores con la estimación del Modelo 1 y un 10,2 \% superior con la estimación del Modelo 2

Tabla 158. Estadísticos de muestras relacionadas. Octubre 2015-Mayo 2016. Edificio D1

\begin{tabular}{cllcccc}
\hline & & Media & $\begin{array}{c}\text { \% Diferencia } \\
\text { entre medias }\end{array}$ & $\mathrm{N}$ & $\begin{array}{c}\text { Desviación } \\
\text { típ. }\end{array}$ & $\begin{array}{c}\text { Error típ. de } \\
\text { la media }\end{array}$ \\
\hline Par & kWh_real & 156359,8750 & & 8 & 83064,25522 & 29367,64907 \\
\cline { 2 - 7 } 1 & kWh_pronost_M1 & 191812,1250 & $22,7 \%$ & 8 & 74372,52338 & 26294,65781 \\
\hline Par & kWh_real & 156359,8750 & & 8 & 83064,25522 & 29367,64907 \\
\cline { 2 - 7 } 2 & kWh_pronost_M2 & 172324,8750 & $10,2 \%$ & 8 & 77826,09693 & 27515,68045 \\
\hline
\end{tabular}

La Tabla 159 muestra que las diferencias entre las medias son significativas entre los consumos reales y los pronosticados con el Modelo 1 (Regresión lineal simple) (sig $\leq 0,05)$, pero no son significativas entre los consumos reales y los pronosticados con el Modelo 2 (Regresión lineal múltiple) (sig >0,05)

Tabla 159. Prueba de muestras relacionadas. Octubre 2015-Mayo 2016. Edificio D1

\begin{tabular}{|c|c|c|c|c|c|c|c|c|c|}
\hline & & \multicolumn{5}{|c|}{ Diferencias relacionadas } & \multirow{3}{*}{$\mathrm{t}$} & \multirow{3}{*}{ gl } & \multirow{3}{*}{$\begin{array}{c}\text { Sig. } \\
\text { (bilateral) }\end{array}$} \\
\hline & & \multirow{2}{*}{ Media } & \multirow{2}{*}{$\begin{array}{l}\text { Desviación } \\
\text { típ. }\end{array}$} & \multirow{2}{*}{$\begin{array}{c}\text { Error típ. } \\
\text { de la media }\end{array}$} & \multicolumn{2}{|c|}{$\begin{array}{c}\text { 95\% Intervalo de confianza } \\
\text { para la diferencia }\end{array}$} & & & \\
\hline & & & & & Inferior & Superior & & & \\
\hline Par 1 & $\begin{array}{c}\text { kWh_real - } \\
\text { kWh_pronost_M1 }\end{array}$ & $-35452,25$ & 33861,67 & 11971,91 & $-63761,32$ & $-7143,18$ & $-2,961$ & 7 & ,021 \\
\hline Par 2 & $\begin{array}{c}\text { kWh_real - } \\
\text { kWh_pronost_M2 }\end{array}$ & $-15965,00$ & 23426,68 & 8282,58 & $-35550,20$ & 3620,20 & $-1,928$ & 7 & ,095 \\
\hline
\end{tabular}


En la Figura 208, se grafican los consumos reales y pronosticados para la temporada Octubre 2015 - Mayo 2016 para el Edificio D1, y las medias de dichos consumos. Según la prueba paramétrica realizada únicamente es estadísticamente significativa la diferencia encontrada entre el consumo real y el pronosticado por el modelo 1, esta diferencia implica que utilizando la línea base establecida en el Modelo 1, se ha logrado un ahorro del $22,7 \%$ con la implantación de la red de calor, durante la temporada octubre 2015 mayo 2016, para un nivel de confianza del $95 \%$.

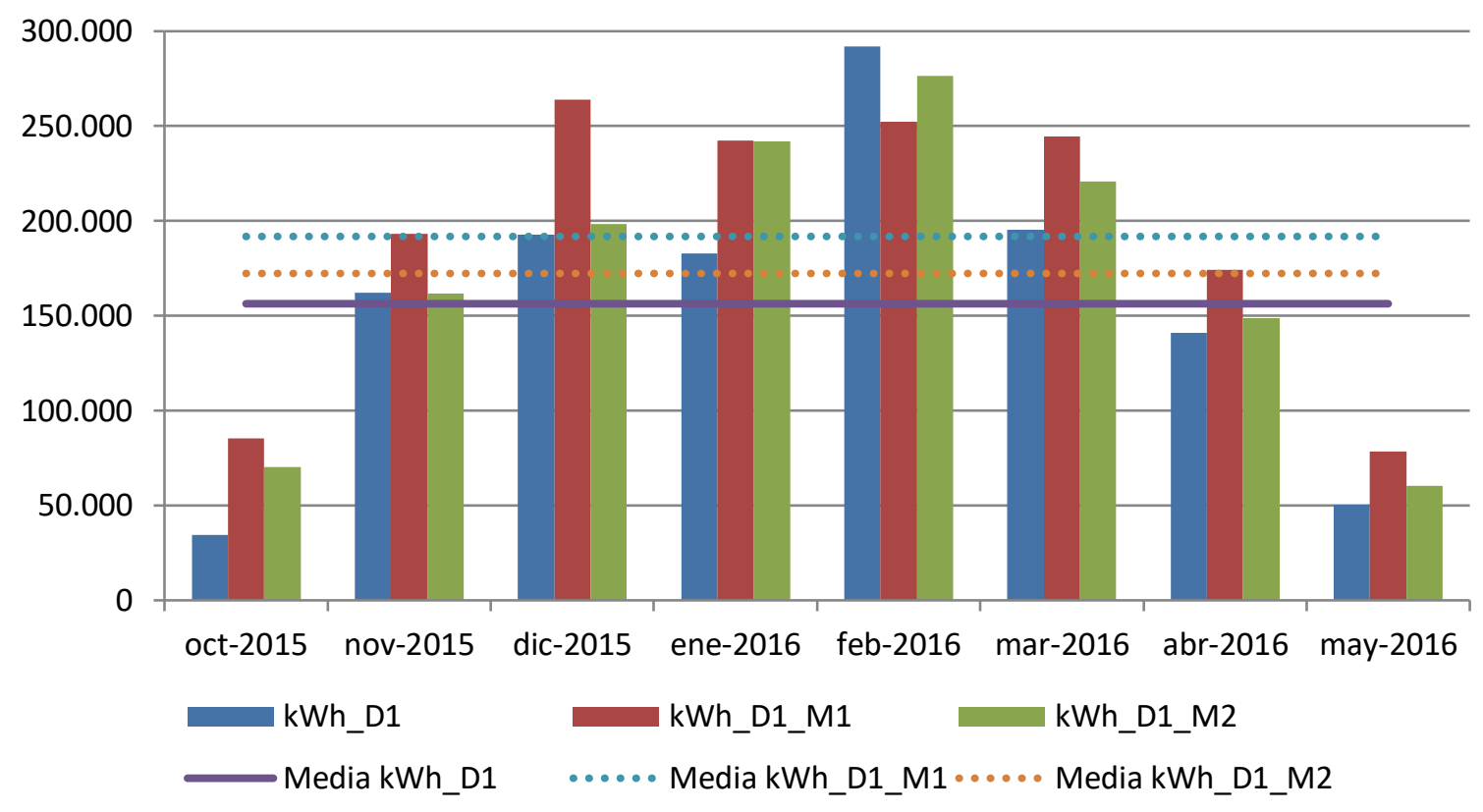

Figura 208. Consumos reales y pronosticados Octubre 2015-Mayo 2016. Edificio D1

Para la temporada Octubre 2016 - Abril 2017, se comprueba mediante el Test de Shapiro -Wilk que tanto los valores reales como los pronosticados con los dos modelos se distribuyen según una Normal puesto que en todos los casos los valores de Sig >0,05, como se observa en la Tabla 160

Tabla 160. Prueba de Normalidad temporada Octubre 2016-Abril 2017. Edificio D1

\begin{tabular}{|c|c|c|c|c|c|c|}
\hline & \multicolumn{3}{|c|}{ Kolmogorov-Smirnov ${ }^{a}$} & \multicolumn{3}{|c|}{ Shapiro-Wilk } \\
\hline & Estadístico & gl & Sig. & Estadístico & $\mathrm{gl}$ & Sig. \\
\hline kWh_real & 193 & 7 & ,200* & ,893 & 7 & ,293 \\
\hline kWh_pronost_M1 & 169 & 7 & $200^{*}$ & ,946 & 7 & ,695 \\
\hline kWh_pronost_M2 & 176 & 7 & ,200* & ,911 & 7 & ,400 \\
\hline
\end{tabular}


En la Tabla 161, se observa como las medias tanto de los consumos pronosticados con el Modelo 1, como de los consumos pronosticados con el Modelo 2, son superiores a las medias de los consumos reales del Edificio D1, un 27,3 \% superiores con la estimación del Modelo 1 y un $11,8 \%$ superior con la estimación del Modelo 2

Tabla 161. Estadísticos de muestras relacionadas. Octubre 2016-Abril 2017. Edificio D1

\begin{tabular}{clccccc}
\hline & & Media & $\begin{array}{c}\text { \% Diferencia } \\
\text { entre medias }\end{array}$ & N & $\begin{array}{c}\text { Desviación } \\
\text { típ. }\end{array}$ & $\begin{array}{c}\text { Error típ. de } \\
\text { la media }\end{array}$ \\
\hline Par & kWh_real & 157941,2857 & & 7 & 75798,23516 & 28649,04001 \\
\cline { 2 - 7 } 1 & kWh_pronost_M1 & 201123,0000 & $27,3 \%$ & 7 & 97243,30525 & 36754,51462 \\
\hline Par & kWh_real & 157941,2857 & & 7 & 75798,23516 & 28649,04001 \\
\cline { 2 - 7 } 2 & kWh_pronost_M2 & 176620,0000 & $11,8 \%$ & 7 & 81372,41543 & 30755,88211 \\
\hline
\end{tabular}

La Tabla 162, muestra que las diferencias entre las medias son significativas entre los consumos reales y los pronosticados con el Modelo 1 (Regresión lineal simple) (sig $\leq 0,05$ ), pero no son significativas entre los consumos reales y los pronosticados con el Modelo 2 (Regresión lineal múltiple) (sig >0,05)

Tabla 162. Prueba de muestras relacionadas. Octubre 2016-Abril 2017. Edificio D1

\begin{tabular}{|c|c|c|c|c|c|c|c|c|c|}
\hline & & \multicolumn{5}{|c|}{ Diferencias relacionadas } & \multirow{3}{*}{$\mathrm{t}$} & \multirow{3}{*}{$\mathrm{gl}$} & \multirow{3}{*}{$\begin{array}{c}\text { Sig. } \\
\text { (bilateral) }\end{array}$} \\
\hline & & \multirow{2}{*}{ Media } & \multirow{2}{*}{$\begin{array}{l}\text { Desviación } \\
\text { típ. }\end{array}$} & \multirow{2}{*}{$\begin{array}{l}\text { Error típ. } \\
\text { de la media }\end{array}$} & \multicolumn{2}{|c|}{$\begin{array}{c}\text { 95\% Intervalo de confianza } \\
\text { para la diferencia }\end{array}$} & & & \\
\hline & & & & & Inferior & Superior & & & \\
\hline Par 1 & $\begin{array}{c}\text { kWh_real - } \\
\text { kWh_pronost_M1 }\end{array}$ & $-43181,71$ & 24452,62 & 9242,22 & $-65796,62$ & $-20566,81$ & $-4,672$ & 6 & ,003 \\
\hline Par 2 & $\begin{array}{c}\text { kWh_real - } \\
\text { kWh_pronost_M2 }\end{array}$ & $-18678,71$ & 30795,22 & 11639,50 & $-47159,54$ & 9802,11 & $-1,605$ & 6 & 160 \\
\hline
\end{tabular}

En la Figura 209, se grafican los consumos reales y pronosticados para la temporada Octubre 2016 - Abril 2017 para el Edificio D1, y las medias de dichos consumos. Según la prueba paramétrica realizada únicamente es estadísticamente significativa la diferencia encontrada entre el consumo real y el pronosticado por el modelo 1, esta diferencia implica que utilizando la línea base establecida en el Modelo 1, se ha logrado un ahorro del 27,3 \% con la implantación de la red de calor, durante la temporada octubre 2016 abril 2017, para un nivel de confianza del $95 \%$. 


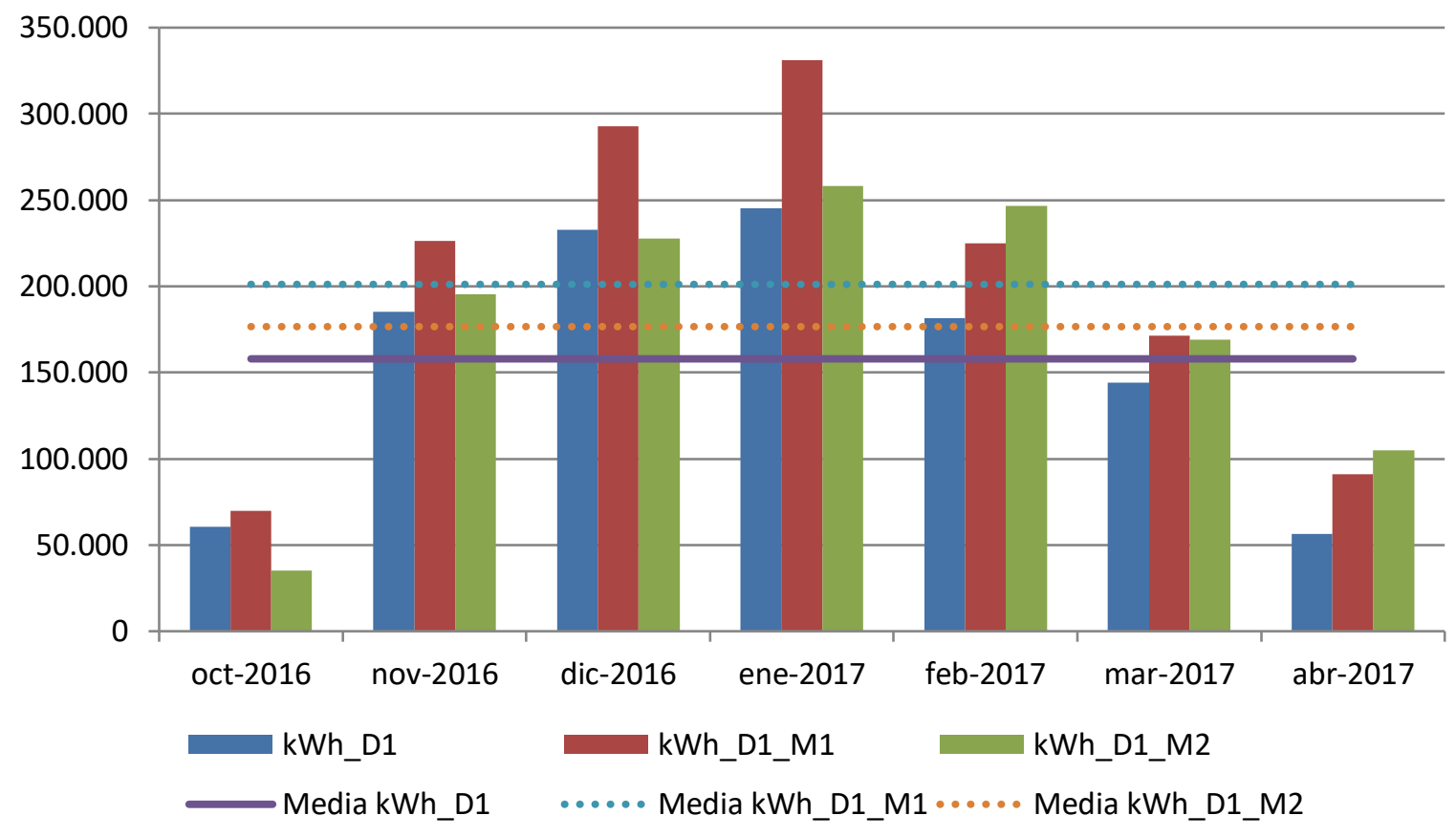

Figura 209. Consumos reales y pronosticados Octubre 2016-Abril 2017. Edificio D1

Para la temporada Octubre 2017 - Mayo 2018, se comprueba mediante el Test de Shapiro -Wilk que tanto los valores reales como los pronosticados con los dos modelos se distribuyen según una Normal puesto que en todos los casos los valores de Sig >0,05, como se observa en la Tabla 163

Tabla 163. Prueba de Normalidad temporada Octubre 2017-Mayo 2018. Edificio D1

\begin{tabular}{|c|c|c|c|c|c|c|}
\hline & \multicolumn{3}{|c|}{ Kolmogorov-Smirnov ${ }^{a}$} & \multicolumn{3}{|c|}{ Shapiro-Wilk } \\
\hline & Estadístico & $\mathrm{gl}$ & Sig. & Estadístico & gl & Sig. \\
\hline kWh_real & 188 & 8 & ,200* & ,868 & 8 & , 144 \\
\hline kWh_pronost_M1 & ,236 & 8 &, $200^{*}$ & 858 & 8 & 114 \\
\hline kWh_pronost_M2 & ,268 & 8 & ,093 & 850 & 8 & ,096 \\
\hline
\end{tabular}

En la Tabla 164 se observa como las medias tanto de los consumos pronosticados con el Modelo 1, como de los consumos pronosticados con el Modelo 2, son superiores a las medias de los consumos reales del Edificio D1, un 18,5\% superiores con la estimación del Modelo 1 y un 12,4 \% superior con la estimación del Modelo 2 
Anexo IV. Desarrollo del análisis de los edificios del Campus Miguel Delibes

Tabla 164. Estadísticos de muestras relacionadas. Octubre 2017-Mayo 2018. Edificio D1

\begin{tabular}{clllrrr}
\hline & & Media & $\begin{array}{c}\text { \% Diferencia } \\
\text { entre medias }\end{array}$ & N & \multicolumn{1}{c}{$\begin{array}{c}\text { Desviación } \\
\text { típ. }\end{array}$} & \multicolumn{1}{c}{$\begin{array}{c}\text { Error típ. de } \\
\text { la media }\end{array}$} \\
\hline Par & kWh_real & 167300,5000 & & 8 & 84672,60695 & 29936,28728 \\
\cline { 2 - 7 } 1 & kWh_pronost_M1 & 198184,3750 & $18,5 \%$ & 8 & 108560,14590 & 38381,80767 \\
\hline Par & kWh_real & 167300,5000 & & 8 & 84672,60695 & 29936,28728 \\
\cline { 2 - 7 } 2 & kWh_pronost_M2 & 188043,7500 & $12,4 \%$ & 8 & 101656,91027 & 35941,14530 \\
\hline
\end{tabular}

La Tabla 165 muestra que las diferencias entre las medias son significativas entre los consumos reales y los pronosticados con el Modelo 1 (Regresión lineal simple) (sig $\leq 0,05)$, pero no son significativas entre los consumos reales y los pronosticados con el Modelo 2 (Regresión lineal múltiple) (sig >0,05)

Tabla 165. Prueba de muestras relacionadas. Octubre 2017-Mayo 2018. Edificio D1

\begin{tabular}{|c|c|c|c|c|c|c|c|c|c|}
\hline & & \multicolumn{5}{|c|}{ Diferencias relacionadas } & \multirow{3}{*}{$\mathrm{t}$} & \multirow{3}{*}{ gl } & \multirow{3}{*}{$\begin{array}{c}\text { Sig. } \\
\text { (bilateral }\end{array}$} \\
\hline & & \multirow[t]{2}{*}{ Media } & \multirow{2}{*}{$\begin{array}{c}\text { Desviación } \\
\text { típ. }\end{array}$} & \multirow{2}{*}{$\begin{array}{l}\text { Error típ. } \\
\text { de la media }\end{array}$} & \multicolumn{2}{|c|}{$\begin{array}{c}\text { 95\% Intervalo de confianza } \\
\text { para la diferencia }\end{array}$} & & & \\
\hline & & & & & Inferior & Superior & & & \\
\hline Par 1 & $\begin{array}{c}\text { kWh_real - } \\
\text { kWh_pronost_M1 }\end{array}$ & $-30883,87$ & 33066,02 & 11690,60 & $-58527,76$ & $-3239,99$ & $-2,642$ & 7 & ,033 \\
\hline Par 2 & $\begin{array}{c}\text { kWh_real - } \\
\text { kWh_pronost_M2 }\end{array}$ & $-20743,25$ & 26278,82 & 9290,97 & $-42712,90$ & 1226,39 & $-2,233$ & 7 & ,061 \\
\hline
\end{tabular}

En la Figura 210 se grafican los consumos reales y pronosticados para la temporada Octubre 2017 - Mayo 2018 para el Edificio D1, y las medias de dichos consumos. Según la prueba paramétrica realizada únicamente es estadísticamente significativa la diferencia encontrada entre el consumo real y el pronosticado por el modelo 1, para un nivel de confianza del $95 \%$.

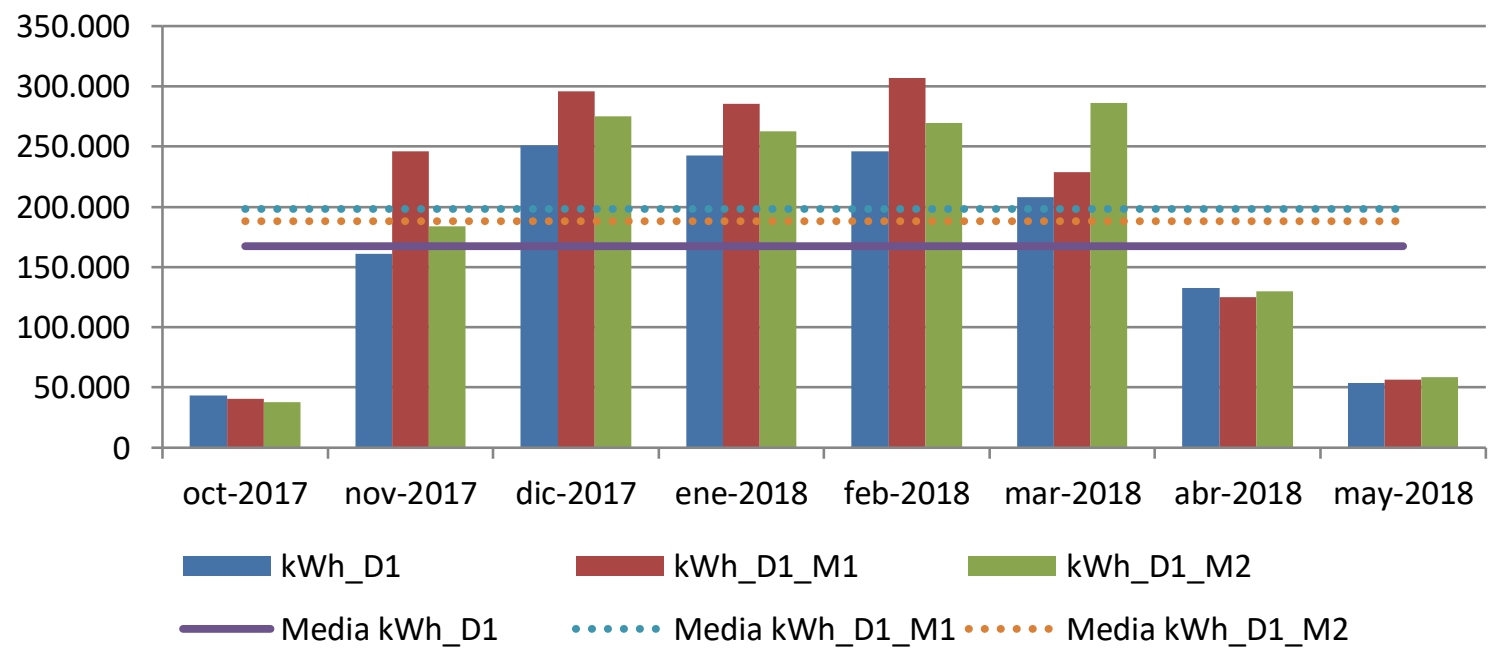

Figura 210. Consumos reales y pronosticados Octubre 2017-Mayo 2018. Edificio D1 
Para el total de las tres temporadas Octubre 2015 - Mayo 2018, se comprueba mediante el Test de Shapiro -Wilk, los valores reales como los pronosticados con el Modelo M1 se distribuyen según una Normal puesto que en esos casos los valores de Sig $>0,05$, sin embargo, los valores de los consumos pronosticados con el Modelo 2, rechazan la hipótesis nula de normalidad, (Sig $\leq 0,05$ ), como se observa en la Tabla 166

Tabla 166.Prueba de Normalidad temporada Octubre 2015-Mayo 2018. Edificio D1

\begin{tabular}{ccccccc}
\hline & \multicolumn{3}{c}{ Kolmogorov-Smirnov $^{\text {a }}$} & \multicolumn{3}{c}{ Shapiro-Wilk } \\
\cline { 2 - 7 } & Estadístico & gl & Sig. & Estadístico & gl & Sig. \\
\hline kWh_real &, 162 & 23 &, 122 &, 923 & 23 &, 076 \\
\hline kWh_pronost_M1 &, 188 & 23 &, 033 &, 920 & 23 &, 065 \\
\hline kWh_pronost_M2 &, 125 & 23 &, 200 &, 911 & 23 &, 042 \\
\hline
\end{tabular}

En la Tabla 167, se observa como las medias tanto de los consumos pronosticados con el Modelo 1, como de los consumos pronosticados con el Modelo 2, son superiores a las medias de los consumos reales del Edificio D1, un 22,5\% superiores con la estimación del Modelo 1 y un 11,5 \% superior con la estimación del Modelo 2

Tabla 167. Estadísticos de muestras relacionadas. Octubre 2015-Mayo 2018. Edificio D1

\begin{tabular}{cllcccc}
\hline & & Media & $\begin{array}{c}\text { \% Diferencia } \\
\text { entre medias }\end{array}$ & N & $\begin{array}{c}\text { Desviación } \\
\text { típ. }\end{array}$ & $\begin{array}{c}\text { Error típ. de } \\
\text { la media }\end{array}$ \\
\hline Par & kWh_real & 160646,6087 & & 23 & 77901,01966 & 16243,48547 \\
\cline { 2 - 7 } 1 & kWh_pronost_M1 & 196862,3043 & $22,5 \%$ & 23 & 90024,92009 & 18771,49346 \\
\hline Par & kWh_real & 160646,6087 & & 23 & 77901,01966 & 16243,48547 \\
\cline { 2 - 7 } 2 & kWh_pronost_M2 & 179099,5217 & $11,5 \%$ & 23 & 84076,86364 & 17531,23796 \\
\hline
\end{tabular}

La Tabla 168 muestra que las diferencias entre las medias son significativas entre los consumos reales y los pronosticados con el Modelo 1 (Regresión lineal simple) (sig $\leq 0,05)$, y también lo serían entre los consumos reales y los pronosticados con el Modelo 2 (Regresión lineal múltiple) si el supuesto de Normalidad en estas variables se hubiera cumplido, al no cumplirse, la prueba paramétrica no resulta válida para este Modelo.

Tabla 168. Prueba de muestras relacionadas. Octubre 2015-Mayo 2018. Edificio D1

\begin{tabular}{|c|c|c|c|c|c|c|c|c|c|}
\hline & & \multicolumn{5}{|c|}{ Diferencias relacionadas } & \multirow{3}{*}{$\mathrm{t}$} & \multirow{3}{*}{$\mathrm{gl}$} & \multirow{3}{*}{$\begin{array}{c}\text { Sig. } \\
\text { (bilateral) }\end{array}$} \\
\hline & & \multirow[t]{2}{*}{ Media } & \multirow{2}{*}{$\begin{array}{l}\text { Desviación } \\
\text { típ. }\end{array}$} & \multirow{2}{*}{$\begin{array}{c}\text { Error típ. } \\
\text { de la media }\end{array}$} & \multicolumn{2}{|c|}{$\begin{array}{l}\text { 95\% Intervalo de confianza } \\
\text { para la diferencia }\end{array}$} & & & \\
\hline & & & & & Inferior & Superior & & & \\
\hline Par 1 & $\begin{array}{c}\text { kWh_real - } \\
\text { kWh_pronost_M1 }\end{array}$ & $-36215,69$ & 30029,66 & 6261,62 & $-49201,49$ & $-23229,89$ & $-5,784$ & 22 & ,000 \\
\hline Par 2 & $\begin{array}{c}\text { kWh_real - } \\
\text { kWh_pronost_M2 }\end{array}$ & $-18452,91$ & 25635,21 & 5345,31 & $-29538,41$ & $-7367,41$ & $-3,452$ & 22 & ,002 \\
\hline
\end{tabular}




\section{AIV.1.5. Estimación de las emisiones de $\mathrm{CO}_{2}$ evitadas.}

Teniendo en cuenta que el consumir Gas natural se producen $0,252 \mathrm{~kg} \mathrm{CO}_{2} / \mathrm{kWh}$ E. final y que al consumir la energía suministrada por red a partir de Biomasa se producen 0,024 kg $\mathrm{CO}_{2} / \mathrm{kWh}$. final, en la Tabla 169, se muestra las emisiones de $\mathrm{CO}_{2}$ reales para las temporadas octubre 2015 - mayo 2018 y utilizando el Modelo 1, las emisiones de $\mathrm{CO}_{2}$ que se hubieran tenido de haber seguido utilizando las calderas de gas natural originales sin el apoyo de la red de calor.

Tabla 169. Estimación del ahorro de emisiones de CO2 para el Edificio D1.

\begin{tabular}{|c|c|c|c|c|c|c|c|c|c|c|}
\hline & $\begin{array}{l}\text { kWh_D1 } \\
\text { Gas } \\
\text { Natural }\end{array}$ & $\begin{array}{l}\text { kWh_D1 } \\
\text { Biomasa }\end{array}$ & $\begin{array}{l}\text { kWh_D1 } \\
\text { Real Total }\end{array}$ & $\begin{array}{c}\text { kWh_D1_- } \\
\text { M1 } \\
\text { Predicho }\end{array}$ & $\begin{array}{l}\text { kg CO2 Real } \\
\text { debido al } \\
\text { consumo de } \\
\text { Gas Natural }\end{array}$ & $\begin{array}{l}\text { kg CO2 } \\
\text { Real } \\
\text { debido a } \\
\text { Biomasa }\end{array}$ & $\begin{array}{l}\text { kg CO2 } \\
\text { Real } \\
\text { debido al } \\
\text { consumo } \\
\text { TOTAL }\end{array}$ & $\begin{array}{c}\text { kg CO2 } \\
\text { que se } \\
\text { hubiera } \\
\text { tenido } \\
\text { debido a } \\
\text { Gas } \\
\text { Natural }\end{array}$ & $\begin{array}{l}\text { Ahorro de } \\
\text { kg CO2 }\end{array}$ & $\begin{array}{l}\text { Ahorro de kg } \\
\text { CO2 } \\
\text { acumulado }\end{array}$ \\
\hline oct-2015 & 0 & 34.650 & 34.650 & 85.453 & 0 & 832 & 832 & 21.534 & 20.703 & 20.703 \\
\hline nov-2015 & 0 & 162.230 & 162.230 & 193.119 & 0 & 3.894 & 3.894 & 48.666 & 44.772 & 65.475 \\
\hline dic-2015 & 0 & 192.680 & 192.680 & 264.007 & 0 & 4.624 & 4.624 & 66.530 & 61.905 & 127.381 \\
\hline ene-2016 & 0 & 182.730 & 182.730 & 242.437 & 0 & 4.386 & 4.386 & 61.094 & 56.709 & 184.089 \\
\hline feb-2016 & 86.660 & 205.420 & 292.080 & 252.386 & 21.838 & 4.930 & 26.768 & 63.601 & 36.833 & 220.922 \\
\hline mar-2016 & 12.299 & 183.100 & 195.399 & 244.598 & 3.099 & 4.394 & 7.494 & 61.639 & 54.145 & 275.067 \\
\hline abr-2016 & 325 & 140.490 & 140.815 & 174.088 & 82 & 3.372 & 3.454 & 43.870 & 40.416 & 315.483 \\
\hline may-2016 & 195 & 50.100 & 50.295 & 78.409 & 49 & 1.202 & 1.251 & 19.759 & 18.508 & 333.991 \\
\hline oct-2016 & 23.450 & 36.970 & 60.420 & 69.681 & 5.910 & 887 & 6.797 & 17.560 & 10.763 & 344.754 \\
\hline nov-2016 & 9.577 & 175.520 & 185.097 & 226.509 & 2.413 & 4.212 & 6.626 & 57.080 & 50.455 & 395.208 \\
\hline dic-2016 & 2.480 & 230.410 & 232.890 & 292.775 & 625 & 5.530 & 6.155 & 73.779 & 67.625 & 462.833 \\
\hline ene-2017 & 3.600 & 241.460 & 245.060 & 331.056 & 907 & 5.795 & 6.702 & 83.426 & 76.724 & 539.557 \\
\hline feb-2017 & 88 & 181.370 & 181.458 & 225.127 & 22 & 4.353 & 4.375 & 56.732 & 52.357 & 591.914 \\
\hline mar-2017 & 1.184 & 142.890 & 144.074 & 171.497 & 298 & 3.429 & 3.728 & 43.217 & 39.489 & 631.403 \\
\hline abr-2017 & 360 & 56.230 & 56.590 & 91.216 & 91 & 1.350 & 1.440 & 22.986 & 21.546 & 652.949 \\
\hline oct-2017 & 15.266 & 27.790 & 43.056 & 40.336 & 3.847 & 667 & 4.514 & 10.165 & 5.651 & 658.600 \\
\hline nov-2017 & 544 & 160.230 & 160.774 & 245.851 & 137 & 3.846 & 3.983 & 61.954 & 57.972 & 716.572 \\
\hline dic-2017 & 1.872 & 249.300 & 251.172 & 295.890 & 472 & 5.983 & 6.455 & 74.564 & 68.109 & 784.681 \\
\hline ene-2018 & 1.064 & 241.600 & 242.664 & 285.654 & 268 & 5.798 & 6.067 & 71.985 & 65.918 & 850.599 \\
\hline feb-2018 & 848 & 245.330 & 246.178 & 306.920 & 214 & 5.888 & 6.102 & 77.344 & 71.242 & 921.842 \\
\hline mar-2018 & 0 & 208.040 & 208.040 & 228.872 & 0 & 4.993 & 4.993 & 57.676 & 52.683 & 974.524 \\
\hline$a b r-2018$ & 0 & 132.930 & 132.930 & 125.321 & 0 & 3.190 & 3.190 & 31.581 & 28.391 & 1.002 .915 \\
\hline may-2018 & 0 & 53.590 & 53.590 & 56.631 & 0 & 1.286 & 1.286 & 14.271 & 12.985 & 1.015 .900 \\
\hline
\end{tabular}

Como se observa durante estas tres temporadas se ha obtenido un ahorro total de 1.016 Toneladas de $\mathrm{CO}_{2}$, debido al consumo térmico del edificio D1. 


\section{AIV.1.6. Estimación del precio máximo de compra a la red.}

Tomando como referencia los precios del gas natural de la Tabla 170 para cada temporada, obtenidos a partir de los datos establecidos en el Capítulo 3, donde se tiene en cuenta el precio por el termino variable y fijo; se puede realizar la estimación del precio máximo de compra de la energía útil a la red de calor para obtener un $0 \%$ de ahorro y un $15 \%$ de ahorro. La Tabla 171, muestra el precio que se pagaría para un ahorro del $15 \%$

Tabla 170. Precios de referencia para Gas natural y Astilla

\begin{tabular}{|c|c|c|c|c|}
\hline Precios (€/(kWh) & 2015 & 2016 & 2017 & 2018 \\
\hline Gas Natural & 0,0373 & 0,0306 & 0,0314 & 0,0336 \\
\hline Astilla & 0,0277 & 0,0256 & 0,0254 & 0,0239 \\
\hline $\begin{array}{l}€ / \text { kWh útiles máximos de compra a la red para } \\
\text { un ahorro del } 0,0 \%\end{array}$ & \multicolumn{4}{|c|}{0,0400} \\
\hline $\begin{array}{l}€ / \text { kWh útiles máximos de compra a la red para } \\
\text { un ahorro del } 15,0 \%\end{array}$ & \multicolumn{4}{|c|}{0,0338} \\
\hline
\end{tabular}

Tabla 171. Ahorro Económico por el consumo térmico en el Edificio D1

\begin{tabular}{|c|c|c|c|c|c|c|c|c|c|c|}
\hline & $\begin{array}{c}\text { kWh_D1 } \\
\text { Gas } \\
\text { Natural }\end{array}$ & $\begin{array}{l}\text { kWh_D1 } \\
\text { Biomasa }\end{array}$ & kWh_D1 & $\begin{array}{c}\text { kWh_D1 } \\
\text { M1 }\end{array}$ & $\begin{array}{c}€ \text { Real Gas } \\
\text { Natural }\end{array}$ & $\begin{array}{c}€ \text { Real } \\
\text { Biomasa }\end{array}$ & $\begin{array}{l}€ \text { Real } \\
\text { Total }\end{array}$ & $\begin{array}{c}\text { € predicho } \\
\text { Gas } \\
\text { natural }\end{array}$ & $\begin{array}{c}€ \\
\text { Ahorro }\end{array}$ & $€$ Acumulado \\
\hline oct-2015 & 0 & 34.650 & 34.650 & 85.453 & 0 & 1.171 & 1.171 & 3.187 & 2.016 & 2.016 \\
\hline nov-2015 & 0 & 162.230 & 162.230 & 193.119 & 0 & 5.483 & 5.483 & 7.203 & 1.720 & 3.736 \\
\hline dic-2015 & 0 & 192.680 & 192.680 & 264.007 & 0 & 6.513 & 6.513 & 9.847 & 3.335 & 7.071 \\
\hline ene-2016 & 0 & 182.730 & 182.730 & 242.437 & 0 & 6.176 & 6.176 & 7.419 & 1.242 & 8.313 \\
\hline feb-2016 & 86.660 & 205.420 & 292.080 & 252.386 & 2.652 & 6.943 & 9.595 & 7.723 & -1.872 & 6.441 \\
\hline mar-2016 & 12.299 & 183.100 & 195.399 & 244.598 & 376 & 6.189 & 6.565 & 7.485 & 920 & 7.361 \\
\hline$a b r-2016$ & 325 & 140.490 & 140.815 & 174.088 & 10 & 4.749 & 4.758 & 5.327 & 569 & 7.930 \\
\hline may-2016 & 195 & 50.100 & 50.295 & 78.409 & 6 & 1.693 & 1.699 & 2.399 & 700 & 8.630 \\
\hline oct-2016 & 23.450 & 36.970 & 60.420 & 69.681 & 718 & 1.250 & 1.967 & 2.132 & 165 & 8.795 \\
\hline nov-2016 & 9.577 & 175.520 & 185.097 & 226.509 & 293 & 5.933 & 6.226 & 6.931 & 706 & 9.500 \\
\hline dic-2016 & 2.480 & 230.410 & 232.890 & 292.775 & 76 & 7.788 & 7.864 & 8.959 & 1.095 & 10.595 \\
\hline ene-2017 & 3.600 & 241.460 & 245.060 & 331.056 & 113 & 8.161 & 8.274 & 10.395 & 2.121 & 12.716 \\
\hline feb-2017 & 88 & 181.370 & 181.458 & 225.127 & 3 & 6.130 & 6.133 & 7.069 & 936 & 13.652 \\
\hline mar-2017 & 1.184 & 142.890 & 144.074 & 171.497 & 37 & 4.830 & 4.867 & 5.385 & 518 & 14.170 \\
\hline abr-2017 & 360 & 56.230 & 56.590 & 91.216 & 11 & 1.901 & 1.912 & 2.864 & 952 & 15.122 \\
\hline oct-2017 & 15.266 & 27.790 & 43.056 & 40.336 & 479 & 939 & 1.419 & 1.267 & -152 & 14.970 \\
\hline nov-2017 & 544 & 160.230 & 160.774 & 245.851 & 17 & 5.416 & 5.433 & 7.720 & 2.287 & 17.257 \\
\hline dic-2017 & 1.872 & 249.300 & 251.172 & 295.890 & 59 & 8.426 & 8.485 & 9.291 & 806 & 18.063 \\
\hline ene-2018 & 1.064 & 241.600 & 242.664 & 285.654 & 36 & 8.166 & 8.202 & 9.598 & 1.396 & 19.459 \\
\hline feb-2018 & 848 & 245.330 & 246.178 & 306.920 & 28 & 8.292 & 8.321 & 10.313 & 1.992 & 21.451 \\
\hline mar-2018 & 0 & 208.040 & 208.040 & 228.872 & 0 & 7.032 & 7.032 & 7.690 & 658 & 22.109 \\
\hline abr-2018 & 0 & 132.930 & 132.930 & 125.321 & 0 & 4.493 & 4.493 & 4.211 & -282 & 21.827 \\
\hline may-2018 & 0 & 53.590 & 53.590 & 56.631 & 0 & 1.811 & 1.811 & 1.903 & 91 & 21.919 \\
\hline$€$ Total & & & & & & & 124.399 & 146.318 & & \\
\hline Ahorro (\%) & & & & & & & & & & $15,0 \%$ \\
\hline
\end{tabular}




\section{AIV.2.Edificio D2. Biblioteca de los Apartamentos Cardenal Mendoza.}

\section{AIV.2.1. Obtención de la línea base de referencia energética}

Los datos de partida para la obtención de la línea base de referencia se muestran en la Tabla 172.

Tabla 172. Consumos térmicos del edificio D2

\begin{tabular}{lr}
\hline & Consumos térmicos (kWh). D2 \\
\hline oct-12 & 2.973 \\
\hline nov-12 & 8.215 \\
\hline dic-12 & 11.245 \\
\hline ene-13 & 12.064 \\
\hline feb-13 & 11.615 \\
\hline mar-13 & 9.500 \\
\hline abr-13 & 6.534 \\
\hline may-13 & 5.196 \\
\hline oct-13 & 3.398 \\
\hline nov-13 & 8.280 \\
\hline dic-13 & 14.205 \\
\hline ene-14 & 11.133 \\
\hline feb-14 & 9.351 \\
\hline mar-14 & 6.636 \\
\hline abr-14 & 3.899 \\
\hline may-14 & 3.318 \\
\hline Promedio & 7.973 \\
\hline Total (oct-12-may-13) & 67.342 \\
\hline Total (oct-13-may-14) & 60.220 \\
\hline Total (oct-12-may-13) & 127.562 \\
\hline
\end{tabular}

Se disponen de 16 datos para establecer el modelo de regresión, mediante el método de pasos sucesivos. Como se puede ver en la Tabla 173 para el edificio, el método ofrece un modelo de regresión, con una sola variable (Grados Día en base 15, obtenidos con datos cada 30 minutos). El modelo fue construido con un solo paso, incluyendo los Grados día base 15 por ser la variable más significativa (variable con menor valor de Sig $=0,000$ ). El resto de las variables como se observa en la Tabla 174 fueron excluidas del modelo al tener valores de sig $>0,05$. 
Tabla 173. Modelos de regresión del Edificio D2

\begin{tabular}{|c|c|c|c|c|c|c|c|}
\hline \multirow{2}{*}{\multicolumn{2}{|c|}{ Modelo }} & \multicolumn{2}{|c|}{$\begin{array}{l}\text { Coeficientes no } \\
\text { estandarizados }\end{array}$} & \multirow{2}{*}{$\mathrm{t}$} & \multirow{2}{*}{ Sig. } & \multicolumn{2}{|c|}{$\begin{array}{c}\text { Intervalo de confianza de } \\
95,0 \% \text { para B } \\
\end{array}$} \\
\hline & & $B$ & Error típ. & & & $\begin{array}{l}\text { Límite } \\
\text { inferior }\end{array}$ & $\begin{array}{l}\text { Límite } \\
\text { superior }\end{array}$ \\
\hline & (Constante) & $-663,338$ & 436,194 & $-1,521$ & ,151 & $-1598,880$ & 272,204 \\
\hline & GD15_30min & 38,971 & 1,832 & 21,270 & ,000 & 35,041 & 42,900 \\
\hline
\end{tabular}

En la Figura 211 se representa el modelo de regresión con sus límites inferior y superior para un nivel de confianza del $95 \%$

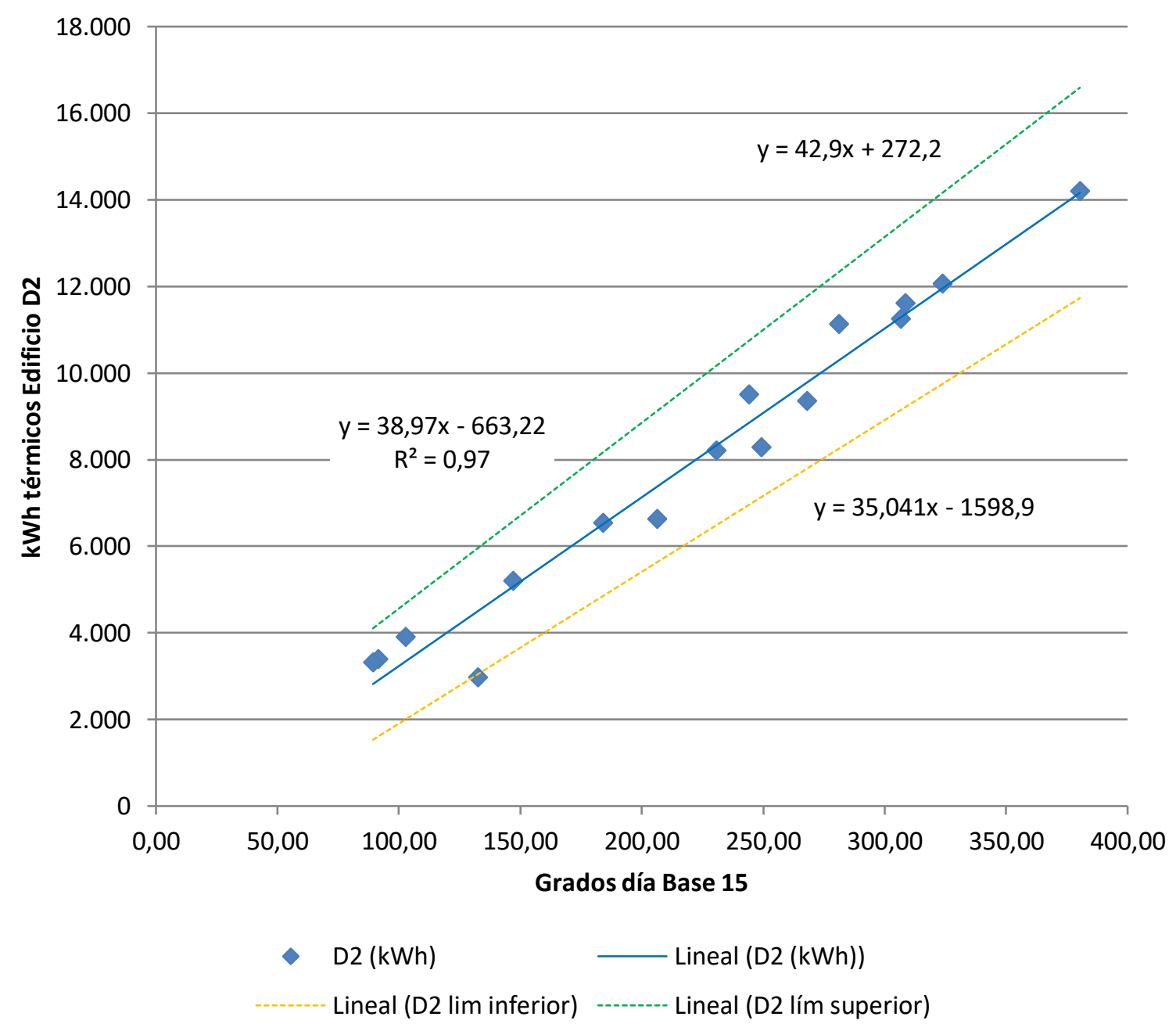

Figura 211. Representación del modelo de regresión lineal simple para el Edificio D2 
Tabla 174. Variables excluidas del modelo de región del Edificio D2

\begin{tabular}{|c|c|c|c|c|}
\hline & Modelo & $\mathrm{t}$ & Sig. & Correlación parcial \\
\hline & GD20_30min &, 040 & ,969 & 011 \\
\hline & GD15_24h &,- 573 & ,576 &,- 157 \\
\hline & GD20_24h &,- 042 & 967 &,- 012 \\
\hline & T_med_30min_C & ,405 & ,692 & 112 \\
\hline & T_media_diurna_C & ,093 & 928 &, 026 \\
\hline & T_max_C &,- 299 & ,770 &,- 083 \\
\hline & T_min_C & 800 & ,438 &, 217 \\
\hline & HR_\% & ,199 & ,846 &, 055 \\
\hline & HR_med_diurna_\% & ,144 & 888 &, 040 \\
\hline \multirow[t]{10}{*}{1} & HR_max_\% & ,340 & ,739 & ,094 \\
\hline & HR_min_\% & ,315 & ,758 & 087 \\
\hline & Radiación_W/m2 & ,643 & ,531 & ,176 \\
\hline & V_Viento_m/s & 838 & ,417 & ,226 \\
\hline & V_viento_diurna_m/s & ,731 & ,478 & ,199 \\
\hline & V_viento_nocturna_m/s & ,973 & ,348 & ,261 \\
\hline & V_viento_max_m/s & 619 & ,547 & , 169 \\
\hline & Recorrido_viento_km/día & 839 & ,417 & 227 \\
\hline & Precipitación_acumulada_mes_mm &,- 054 & ,958 &,- 015 \\
\hline & Horas insolación_h &, 420 & ,681 & 116 \\
\hline
\end{tabular}

La bondad de los modelos de regresión obtenidos para el edificio D2, se resumen en la Tabla 175

Tabla 175. Resumen de la bondad de los modelos de regresión para el Edificio D2

\begin{tabular}{ccccc}
\hline Modelo & $\mathrm{R}$ & $\mathrm{R}$ cuadrado & $\mathrm{R}$ cuadrado corregida & $\begin{array}{c}\text { Error típ. de la } \\
\text { estimación }\end{array}$ \\
\hline 1 &, $985^{\mathrm{a}}$ & 970 &, 968 & 637,71116 \\
\hline
\end{tabular}

Se observa como el modelo de regresión lineal simple presenta un Coeficiente de Correlación de Pearson (R) de 0,985, lo que indica que las variables están correlacionadas de manera muy fuerte (en la correlación perfecta $R= \pm 1$ ). La correlación que se produce es directa, al aumentar el valor de los Grados día, aumenta el consumo térmico.

El coeficiente de determinación $\left(R^{2}\right)$, nos indica que con el modelo se podría explicar el $97,0 \%$ de los datos reales obtenidos aceptando un error del $5 \%$.

El error típico de la estimación que nos indica la magnitud de los errores, es decir la parte de la variable dependiente que dejamos sin explicar con el modelo y que describe la variación de la variable respuesta (el Consumo) respecto a la recta de regresión, es de 638 $\mathrm{kWh}$, lo que representa un $8,0 \%$ del promedio de los consumos que fue de $7.973 \mathrm{kWh}$. 


\section{AIV.2.2. Verificación del cumplimiento de los supuestos estadísticos}

Las condiciones que se deben cumplir en un modelo de regresión son:

- Linealidad de las variables, las variables se encuentran relacionadas de forma lineal.

Como se observa en la Tabla 173, la pendiente (B), obtuvo un valor de Sig $=0,000$, que al ser $\leq 0,05$, nos indica que podemos rechazar la hipótesis nula de pendiente igual a cero y nos da la evidencia de linealidad entre la variable dependiente ( $k$ Wh del edificio D2) y la independiente (GD15_30min). Al ser el valor de la pendiente positiva, indica una relación directa entre el consumo y los Grados día base 15.

- Normalidad. Todos los valores obtenidos para la variable dependiente (Y), deben estar distribuidos normalmente en cada valor de la variable independiente $(X)$.

Se comprueba la normalidad de las variables y de los residuos mediante el Test de Shapiro - Wilk para muestras pequeñas (menores a 30 observaciones), siendo la hipótesis nula el que la distribución es Normal.

La Tabla 176, muestra la prueba de normalidad de Shapiro-Wilk y cómo tanto la variable dependiente (consumos del Edificio), como la variable independientes: GD15 poseen una Sig $>0,05$, por lo que aceptamos la hipótesis nula de Normalidad de las variables

Tabla 176. Prueba de normalidad para el edificio D2

\begin{tabular}{lcccccc}
\hline & \multicolumn{3}{c}{ Kolmogorov-Smirnov } & \multicolumn{3}{c}{ Shapiro-Wilk } \\
\cline { 2 - 7 } & Estadístico & $\mathrm{gl}$ & Sig. & Estadístico & $\mathrm{gl}$ & Sig. \\
\hline kWh_D2 &, 125 & 16 &, $200^{*}$ &, 943 & 16 &, 383 \\
\hline GD15_30min &, 109 & 16 &, $200^{*}$ &, 953 & 16 &, 541 \\
\hline
\end{tabular}

- Independencia de los errores. Los errores asociados a los valores de la variable respuesta $(\mathrm{Y})$ deberán ser independientes unos de otros.

Para la comprobación se utiliza el estadístico de Durbin -Watson.

Se comprueba que el Estadístico de Durbin Watson para el nivel de significancia del 5\%, y para el tamaño de la muestra " $n$ " y el número de variables independientes del modelo " $k$ ", se encuentra en el intervalo [dU, 4-dU], de la Tabla 3, intervalo centrado en el 2, que indica la ausencia de autocorrelación. 
El valor del Estadístico Durbin-Watson facilitado por el programa SPSS, es 1,583.

En el modelo, $n=16$ y $k=1$, según la Tabla 3 el valor $d U=1,371$, luego el intervalo que marca la ausencia de correlación es [1,371, 2,629], como el valor del estadístico 1,583 está dentro del intervalo, se acepta la ausencia de autocorrelación

- Homocedasticidad de la varianza. Se pretende comprobar que la varianza de los errores $\left(\sigma^{2}\right)$ es constante para cualquier valor de la variable independiente (X), es decir que el valor medio del cuadrado de la desviación de los errores respecto a su media es constante.

Esta condición indica que no existe correlación entre los residuos y los pronósticos. Se comprueba que el coeficiente de determinación $R^{2}$, en las relaciones: residuos $y$ predicciones y entre residuos y variable independiente es nulo o muy próximo a cero, lo que indicará que no existe ningún tipo de correlación en los residuos y que éstos son aleatorios.

Se grafican los diagramas de dispersión de esas relaciones, comprobando que se corresponden a nubes de puntos totalmente aleatorias, sin tendencias ni patrones en sus representaciones gráficas.

Las Figura 212 y Figura 213, muestran que la relación entre los pronósticos y los residuos, posee un coeficiente de determinación $=3,33 \times 10^{-16}$, cercano a cero y entre la variable independiente (Grados día base 15) y los residuos un coeficiente de determinación de $1,11 \times 10^{-16}$, también prácticamente nulo; por lo que se concluye que no existe ningún tipo de correlación en los residuos y que éstos son aleatorios, siendo la varianza de los residuos constante

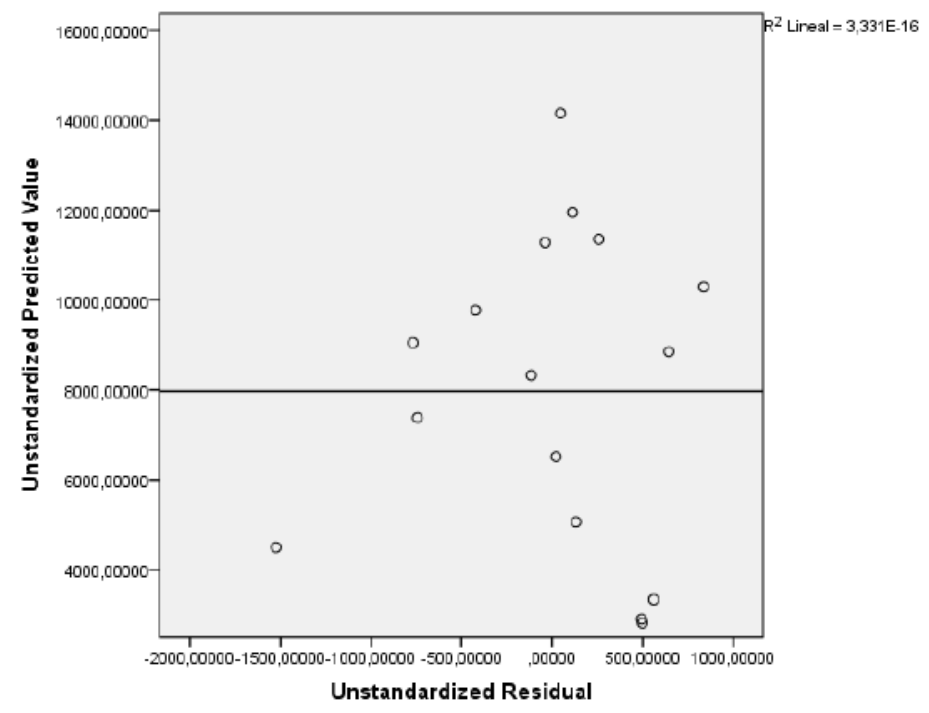

Figura 212. Relación entre los pronósticos y los residuos en el Edificio D2 


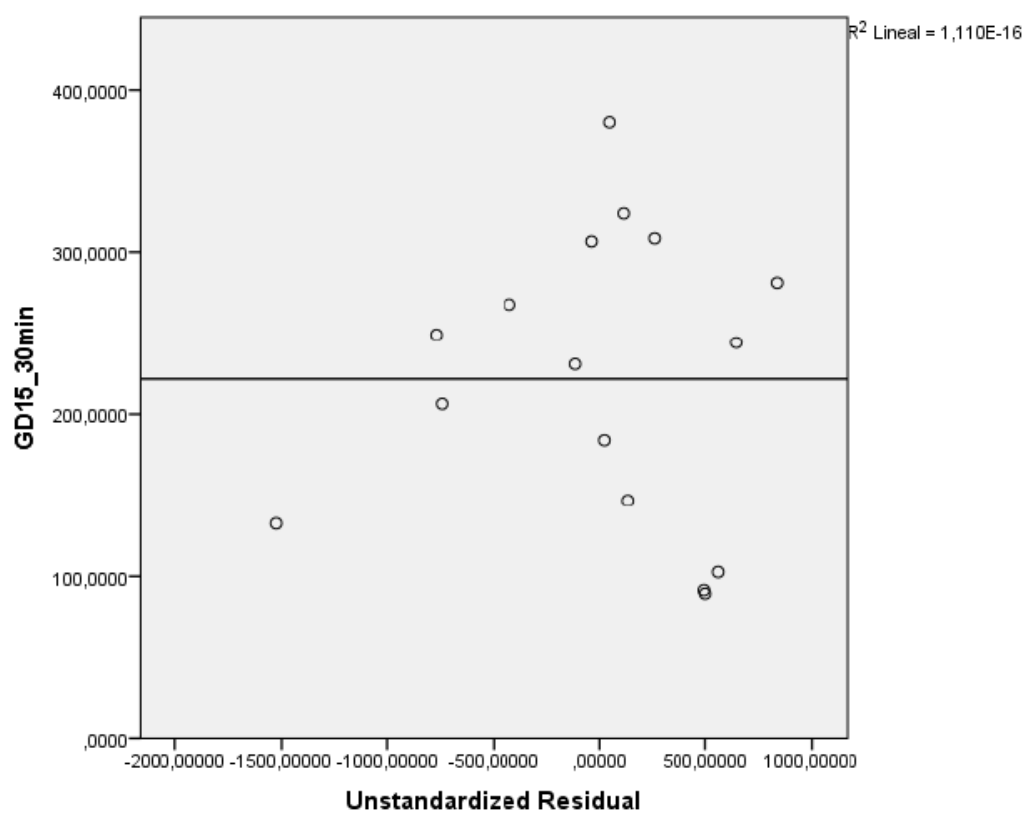

Figura 213. Relación entre GD15 y los residuos en el Edificio D2

\section{AIV.2.3. Obtención de los consumos térmicos previstos}

Una vez comprobado el cumplimiento de los supuestos estadísticos se acepta el modelo de línea base encontrado para modelizar el consumo del Edificio D2.

$$
\text { kWh_D2_Pronosticado }=-663,338+38,971 \times \text { GD15_30min }
$$

Con este modelo se procede a predecir los consumos previstos para las temporadas: octubre 2015-mayo 2016, octubre 2016 - mayo 2017 y octubre 2017-mayo 2018, estos consumos se muestran en la Tabla 177, donde "KWh_D2_Real", representa el consumo real, "kWh_D2_Pronosticado", el consumo pronosticado con el Modelo. 
Tabla 177. Consumos previstos octubre 2014 - mayo 2017 para el edificio D2.

\begin{tabular}{rrrr}
\hline & GD15 & kWh_D2_Real & kWh_D2_Pronosticado \\
\hline oct-15 & 97,04 & 810 & 3.119 \\
\hline nov-15 & 208,36 & 2.643 & 7.457 \\
\hline dic-15 & 300,09 & 11.959 & 11.032 \\
\hline ene-16 & 271,93 & 6.666 & 9.934 \\
\hline feb-16 & 266,36 & 12.459 & 9.717 \\
\hline mar-16 & 276,34 & 5.239 & 10.106 \\
\hline abr-16 & 181,04 & 3.941 & 6.392 \\
\hline may-16 & 99,34 & 405 & 3.208 \\
\hline oct-16 & 97,34 & 165 & 3.130 \\
\hline nov-16 & 245,69 & 5.063 & 8.911 \\
\hline dic-16 & 337,25 & 7.397 & 12.480 \\
\hline ene-17 & 386,98 & 7.617 & 14.418 \\
\hline feb-17 & 226,76 & 6.987 & 8.174 \\
\hline mar-17 & 203,17 & 7.621 & 7.254 \\
\hline abr-17 & 129,72 & 3.584 & 4.392 \\
\hline may-17 & 54,86 & 1.566 & 1.475 \\
\hline oct-17 & 92,31 & 10 & 2.934 \\
\hline nov-17 & 271,60 & 4.213 & 9.921 \\
\hline dic-17 & 341,26 & 10.407 & 12.636 \\
\hline ene-18 & 327,94 & 9.738 & 12.117 \\
\hline feb-18 & 321,27 & 10.737 & 11.857 \\
\hline mar-18 & 255,02 & 7.939 & 9.275 \\
\hline abr-18 & 143,31 & 5.172 & 4.921 \\
\hline may-18 & 78,41 & 7 & 2.392 \\
\hline & & &
\end{tabular}

\section{AIV.2.4. Estudio de la existencia de diferencias significativas}

Utilizando la prueba " $\mathrm{t}$ " de Student para muestras relacionadas, podemos concluir que si las variables se distribuyen según una normal y la significación estadística resulta $\leq 0,05$, existen diferencias significativas, con un nivel de confianza del $95 \%$

A continuación se muestra la comparación de medias realizada para cada uno de los tres periodos posteriores a la construcción de la red y para el periodo total hasta mayo de 2018.

Para la temporada Octubre 2015 - Mayo 2016, se comprueba mediante el Test de Shapiro -Wilk que tanto los valores reales como los pronosticados se distribuyen según una Normal puesto que en todos los casos los valores de Sig $>0,05$, como se observa en la Tabla 178 
Anexo IV. Desarrollo del análisis de los edificios del Campus Miguel Delibes

Tabla 178. Prueba de Normalidad temporada Octubre 2015-Mayo 2016. Edificio D2

\begin{tabular}{ccccrrrr}
\hline & \multicolumn{3}{c}{ Kolmogorov-Smirnov $^{\mathrm{a}}$} & \multicolumn{3}{c}{ Shapiro-Wilk } \\
\cline { 2 - 9 } & Estadístico & gl & \multicolumn{1}{c}{ Sig. } & Estadístico & gl & Sig. \\
\hline kWh_real &, 168 & 8 &, 200 &, 896 & 8 &, 266 \\
\hline kWh_pronosticado &, 248 & 8 &, 159 &, 865 & 8 &, 136 \\
\hline
\end{tabular}

En la Tabla 179, se observa como las medias de los consumos pronosticados, son superiores a las medias de los consumos reales del Edificio D2, en un 38,2\%

Tabla 179. Estadísticos de muestras relacionadas. Octubre 2015-Mayo 2016. Edificio D2

\begin{tabular}{lccccc}
\hline & Media & $\begin{array}{c}\text { \% Diferencia } \\
\text { entre medias }\end{array}$ & $\mathrm{N}$ & $\begin{array}{c}\text { Desviación } \\
\text { típ. }\end{array}$ & $\begin{array}{c}\text { Error típ. de } \\
\text { la media }\end{array}$ \\
\hline kWh_real & 5515,2500 & & 8 & 4630,95537 & 1637,28997 \\
\hline kWh_pronosticado & 7620,6250 & $38,2 \%$ & 8 & 3135,81249 & 1108,67714 \\
\hline
\end{tabular}

La Tabla 180 muestra que las diferencias entre las medias no son significativas entre los consumos reales y los pronosticados (sig $>0,05$ ), a pesar de existir ese $38 \%$ de diferencia

Tabla 180. Prueba de muestras relacionadas. Octubre 2015-Mayo 2016. Edificio D2

\begin{tabular}{|c|c|c|c|c|c|c|c|c|c|}
\hline & & \multicolumn{5}{|c|}{ Diferencias relacionadas } & \multirow{3}{*}{$\mathrm{t}$} & \multirow{3}{*}{ gl } & \multirow{3}{*}{$\begin{array}{c}\text { Sig. } \\
\text { (bilateral) }\end{array}$} \\
\hline & & \multirow[t]{2}{*}{ Media } & \multirow{2}{*}{$\begin{array}{l}\text { Desviación } \\
\text { típ. }\end{array}$} & \multirow{2}{*}{$\begin{array}{c}\text { Error típ. } \\
\text { de la media }\end{array}$} & \multicolumn{2}{|c|}{$\begin{array}{l}\text { 95\% Intervalo de confianza } \\
\text { para la diferencia }\end{array}$} & & & \\
\hline & & & & & Inferior & Superior & & & \\
\hline Par 1 & $\begin{array}{c}\text { kWh_real - } \\
\text { kWh_pronosticado }\end{array}$ & $-2105,375$ & 2663,372 & 941,644 & $-4332,010$ & 121,260 & $-2,236$ & 7 & ,060 \\
\hline
\end{tabular}

En la Figura 214, se grafican los consumos reales y pronosticados para la temporada Octubre 2015 - Mayo 2016 para el Edificio D2, y las medias de dichos consumos. Según la prueba paramétrica realizada las diferencias encontradas no son estadísticamente significativas, por lo que no se puede afirmar la existencia de ahorros en el consumo térmico entre la situación anterior y posterior a la red de calor, con un riesgo a estar equivocados del $5 \%$ 


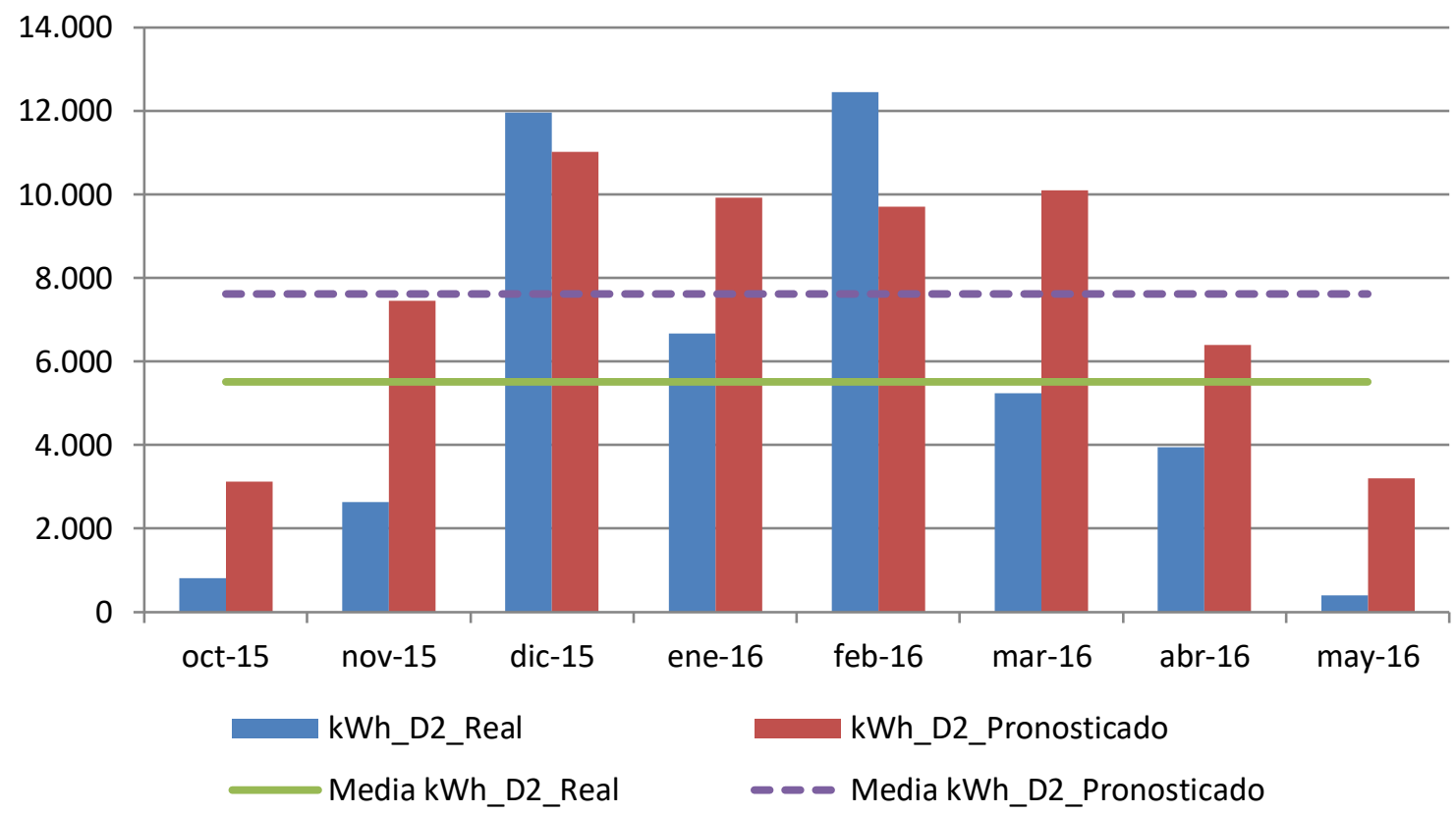

Figura 214. Consumos reales y pronosticados Octubre 2015-Mayo 2016. Edificio D2

Para la temporada Octubre 2016 - Mayo 2017, se comprueba mediante el Test de Shapiro -Wilk que tanto los valores reales como los pronosticados con los dos modelos se distribuyen según una Normal puesto que en todos los casos los valores de Sig >0,05, como se observa en la Tabla 181

Tabla 181. Prueba de Normalidad temporada Octubre 2016-Mayo 2017. Edificio D2

\begin{tabular}{ccccccrr}
\hline & \multicolumn{3}{c}{ Kolmogorov-Smirnov $^{\mathrm{a}}$} & \multicolumn{3}{c}{ Shapiro-Wilk } \\
\cline { 2 - 8 } & Estadístico & gl & \multicolumn{1}{c}{ Sig. } & Estadístico & gl & \multicolumn{1}{c}{ Sig. } \\
\hline kWh_real &, 250 & 8 &, 149 &, 856 & 8 &, 109 \\
\hline kWh_pronosticado &, 133 & 8 &, $200^{*}$ &, 965 & 8 &, 856 \\
\hline
\end{tabular}

En la Tabla 182, se observa como las medias de los consumos pronosticados, son superiores a las medias de los consumos reales del Edificio D2, en un 50,6\%

Tabla 182. Estadísticos de muestras relacionadas. Octubre 2016-Mayo 2017. Edificio D2

\begin{tabular}{lccccc}
\hline & Media & $\begin{array}{c}\text { \% Diferencia } \\
\text { entre medias }\end{array}$ & $\mathrm{N}$ & $\begin{array}{c}\text { Desviación } \\
\text { típ. }\end{array}$ & $\begin{array}{c}\text { Error típ. de } \\
\text { la media }\end{array}$ \\
\hline kWh_real & 5000,0000 & & 8 & 2942,07687 & 1040,18125 \\
\hline kWh_pronosticado & 7529,2500 & $50,6 \%$ & 8 & 4475,57150 & 1582,35348 \\
\hline
\end{tabular}

La Tabla 183 muestra que las diferencias entre las medias son significativas entre los consumos reales y los pronosticados (sig $\leq 0,05$ ) 
Tabla 183. Prueba de muestras relacionadas. Octubre 2016-Mayo 2017. Edificio D2

\begin{tabular}{|c|c|c|c|c|c|c|c|c|c|}
\hline & & \multicolumn{5}{|c|}{ Diferencias relacionadas } & \multirow{3}{*}{$\mathrm{t}$} & \multirow{3}{*}{$\mathrm{gl}$} & \multirow{3}{*}{$\begin{array}{c}\text { Sig. } \\
\text { (bilateral) }\end{array}$} \\
\hline & & \multirow[t]{2}{*}{ Media } & \multirow{2}{*}{$\begin{array}{l}\text { Desviación } \\
\text { típ. }\end{array}$} & \multirow{2}{*}{$\begin{array}{c}\text { Error típ. } \\
\text { de la media }\end{array}$} & \multicolumn{2}{|c|}{$\begin{array}{l}\text { 95\% Intervalo de confianza } \\
\text { para la diferencia }\end{array}$} & & & \\
\hline & & & & & Inferior & Superior & & & \\
\hline Par 1 & $\begin{array}{c}\text { kWh_real - } \\
\text { kWh_pronosticado }\end{array}$ & $-2529,250$ & 2583,375 & 913,361 & $-4689,005$ & $-369,495$ & $-2,769$ & 7 & ,028 \\
\hline
\end{tabular}

En la Figura 215, se grafican los consumos reales y pronosticados para la temporada Octubre 2016 - Mayo 2017 para el Edificio D2, y las medias de dichos consumos. Según la prueba paramétrica realizada las diferencias encontradas son estadísticamente significativas, con un riesgo a estar equivocados del $5 \%$

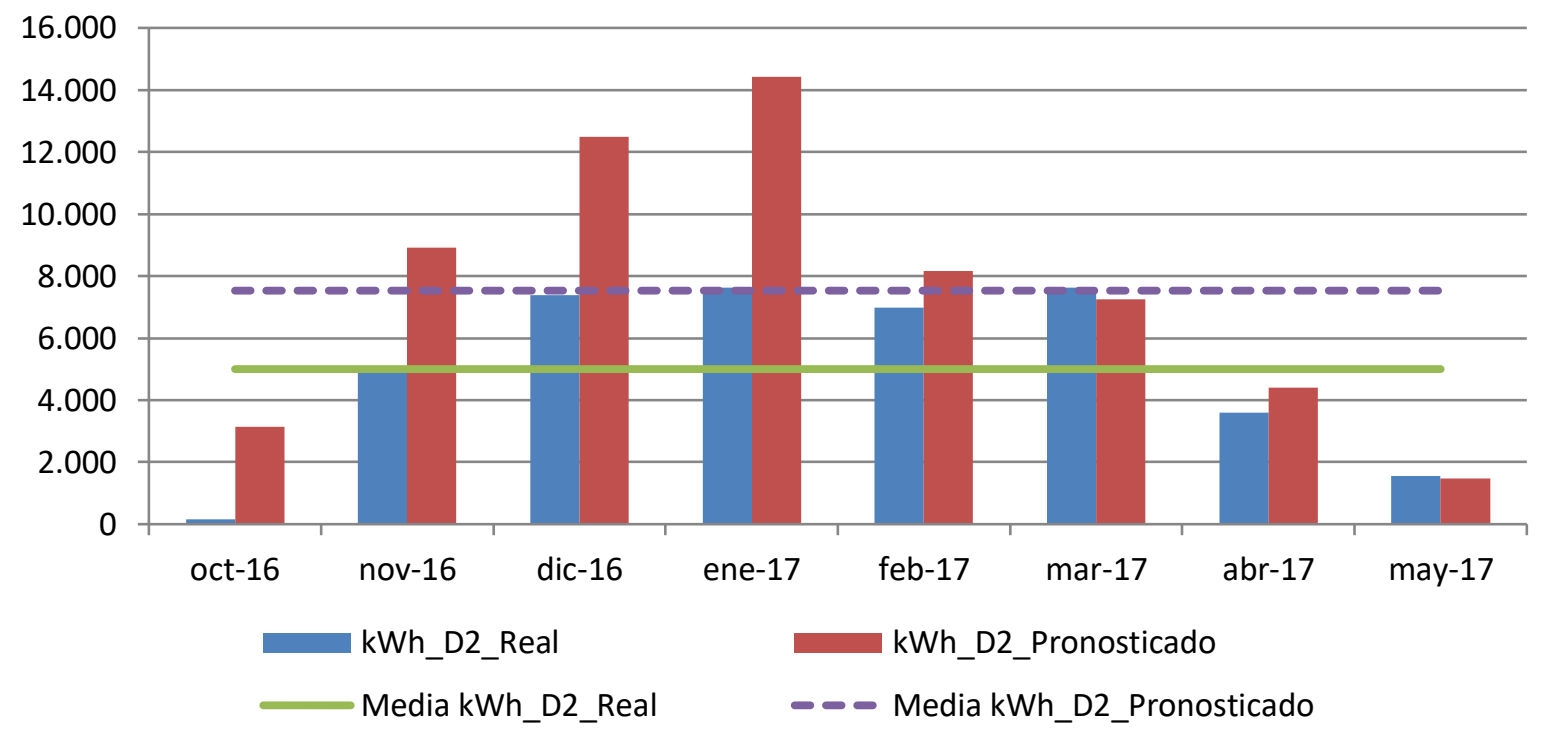

Figura 215. Consumos reales y pronosticados Octubre 2016-Mayo 2017. Edificio D2

Para la temporada Octubre 2017 - Mayo 2018, se comprueba mediante el Test de Shapiro -Wilk que tanto los valores reales como los pronosticados se distribuyen según una Normal puesto que en todos los casos los valores de Sig $>0,05$, como se observa en la Tabla 184

Tabla 184. Prueba de Normalidad temporada Octubre 2017-Mayo 2018. Edificio D2

\begin{tabular}{cccccccr}
\hline & \multicolumn{3}{c}{ Kolmogorov-Smirnov $^{\mathrm{a}}$} & \multicolumn{3}{c}{ Shapiro-Wilk } \\
\cline { 2 - 9 } & Estadístico & gl & Sig. & Estadístico & gl & Sig. \\
\hline kWh_real &, 176 & 8 &, 200 &, 879 & 8 &, 185 \\
\hline kWh_pronosticado &, 220 & 8 &, $200^{*}$ &, 860 & 8 &, 119 \\
\hline
\end{tabular}


En la Tabla 185, se observa como las medias de los consumos pronosticados, son superiores a las medias de los consumos reales del Edificio D2, en un 37,0\%

Tabla 185. Estadísticos de muestras relacionadas. Octubre 2017-Mayo 2018. Edificio D2

\begin{tabular}{lccccc}
\hline & Media & $\begin{array}{c}\text { \% Diferencia } \\
\text { entre medias }\end{array}$ & $\mathrm{N}$ & $\begin{array}{c}\text { Desviación } \\
\text { típ. }\end{array}$ & $\begin{array}{c}\text { Error típ. de } \\
\text { la media }\end{array}$ \\
\hline $\mathrm{kWh}$ real & 6027,8750 & & 8 & 4395,81081 & 1554,15382 \\
\hline $\mathrm{kWh}$ pronosticado & 8256,6250 & $37,0 \%$ & 8 & 4220,72962 & 1492,25327 \\
\hline
\end{tabular}

La Tabla 186 muestra que las diferencias entre las medias son significativas entre los consumos reales y los pronosticados (sig $\leq 0,05)$

Tabla 186. Prueba de muestras relacionadas. Octubre 2017-Mayo 2018. Edificio D2

\begin{tabular}{|c|c|c|c|c|c|c|c|c|c|}
\hline & & \multicolumn{5}{|c|}{ Diferencias relacionadas } & \multirow{3}{*}{$\mathrm{t}$} & \multirow{3}{*}{$\mathrm{gl}$} & \multirow{3}{*}{$\begin{array}{c}\text { Sig. } \\
\text { (bilateral) }\end{array}$} \\
\hline & & \multirow{2}{*}{ Media } & \multirow{2}{*}{$\begin{array}{l}\text { Desviación } \\
\text { típ. }\end{array}$} & \multirow{2}{*}{$\begin{array}{c}\text { Error típ. } \\
\text { de la media }\end{array}$} & \multicolumn{2}{|c|}{$\begin{array}{c}\text { 95\% Intervalo de confianza } \\
\text { para la diferencia }\end{array}$} & & & \\
\hline & & & & & Inferior & Superior & & & \\
\hline Par 1 & $\begin{array}{c}\text { kWh_real - } \\
\text { kWh_pronosticado }\end{array}$ & $-2228,750$ & 1724,240 & 609,611 & $-3670,251$ & $-787,249$ & $-3,656$ & 7 & ,008 \\
\hline
\end{tabular}

En la Figura 216, se grafican los consumos reales y pronosticados para la temporada Octubre 2017 - Mayo 2018 para el Edificio D2, y las medias de dichos consumos. Según la prueba paramétrica realizada las diferencias encontradas son estadísticamente significativas, con un riesgo a estar equivocados del $5 \%$

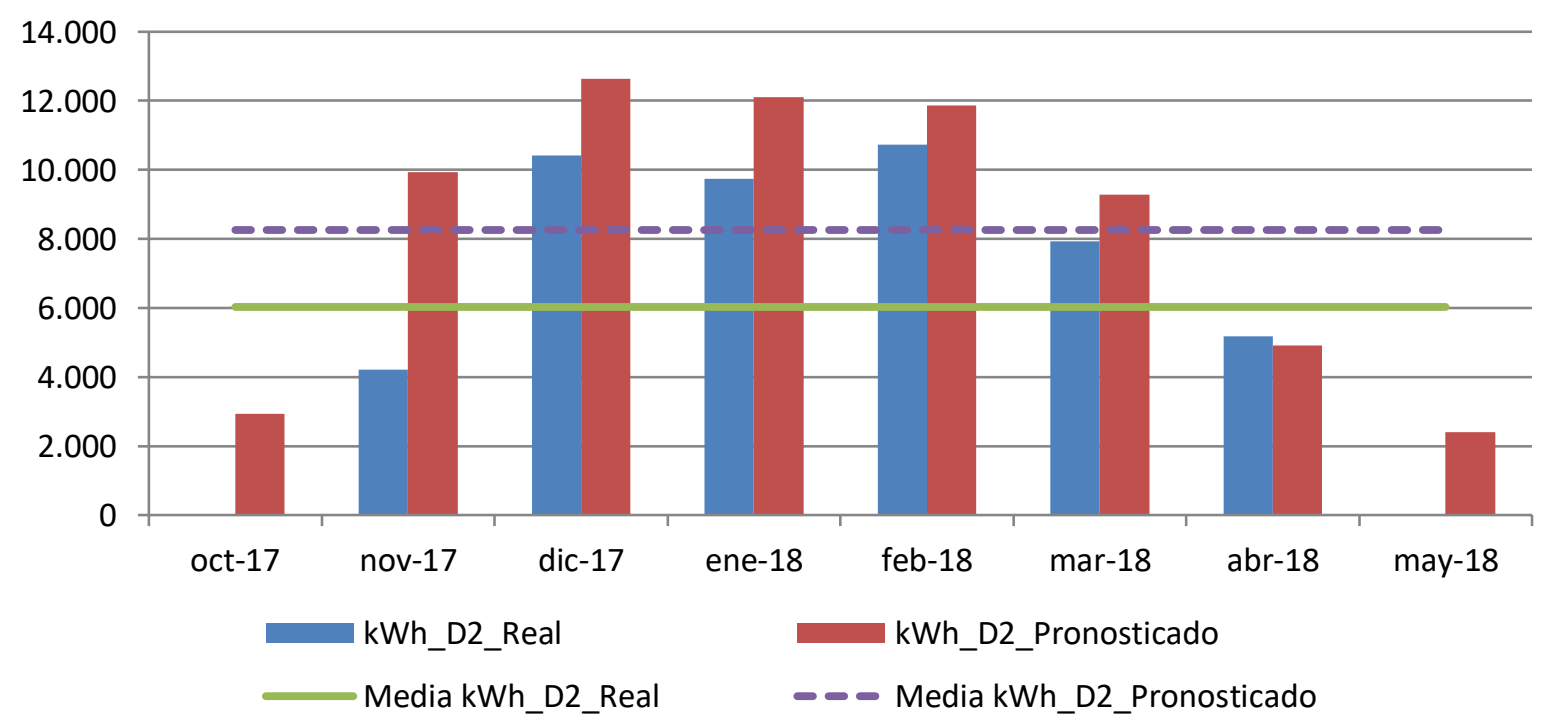

Figura 216. Consumos reales y pronosticados Octubre 2017-Mayo 2018. Edificio D2 
Para el total de las tres temporadas Octubre 2015 - Mayo 2018, se comprueba mediante el Test de Shapiro -Wilk, que los valores reales y los pronosticados se distribuyen según una Normal puesto que en esos casos los valores de Sig $>0,05$, como se observa en la Tabla 187

Tabla 187. Prueba de Normalidad temporada Octubre 2015-Mayo 2018. Edificio D2

\begin{tabular}{ccccccrr}
\hline & \multicolumn{3}{c}{ Kolmogorov-Smirnov $^{\mathrm{a}}$} & \multicolumn{4}{c}{ Shapiro-Wilk } \\
\cline { 2 - 8 } & Estadístico & gl & Sig. & Estadístico & gl & \multicolumn{1}{c}{ Sig. } \\
\hline kWh_real &, 094 & 24 &, 200 &, 947 & 24 &, 239 \\
\hline kWh_pronosticado &, 135 & 24 &, 200 &, 942 & 24 &, 183 \\
\hline
\end{tabular}

En la Tabla 188 se observa como las medias de los consumos pronosticados, son superiores a las medias de los consumos reales del Edificio D2, en un 41,5\%

Tabla 188. Estadísticos de muestras relacionadas. Octubre 2015-Mayo 2018. Edificio D2

\begin{tabular}{lccccc}
\hline & Media & $\begin{array}{c}\text { \% Diferencia } \\
\text { entre medias }\end{array}$ & $\mathrm{N}$ & $\begin{array}{c}\text { Desviación } \\
\text { típ. }\end{array}$ & $\begin{array}{c}\text { Error típ. de } \\
\text { la media }\end{array}$ \\
\hline kWh_real & 5514,3750 & & 24 & 3902,05706 & 796,50406 \\
\hline kWh_pronosticado & 7802,1667 & $41,5 \%$ & 24 & 3823,62290 & 780,49376 \\
\hline
\end{tabular}

La Tabla 189 muestra que las diferencias entre las medias son significativas entre los consumos reales y los pronosticados (sig $\leq 0,05)$

Tabla 189. Prueba de muestras relacionadas. Octubre 2015-Mayo 2018. Edificio D2

\begin{tabular}{|c|c|c|c|c|c|c|c|c|}
\hline & \multicolumn{5}{|c|}{ Diferencias relacionadas } & \multirow{3}{*}{$\mathrm{t}$} & \multirow{3}{*}{$\mathrm{gl}$} & \multirow{3}{*}{$\begin{array}{c}\text { Sig. } \\
\text { (bilateral) }\end{array}$} \\
\hline & \multirow[t]{2}{*}{ Media } & \multirow{2}{*}{$\begin{array}{l}\text { Desviación } \\
\text { típ. }\end{array}$} & \multirow{2}{*}{$\begin{array}{l}\text { Error típ. de } \\
\text { la media }\end{array}$} & \multicolumn{2}{|c|}{$\begin{array}{l}\text { 95\% Intervalo de confianza } \\
\text { para la diferencia }\end{array}$} & & & \\
\hline & & & & Inferior & Superior & & & \\
\hline $\begin{array}{c}\text { kWh_real - } \\
\text { kWh_pronosticado }\end{array}$ & $-2287,792$ & 2264,501 & 462,239 & $-3244,006$ & $-1331,577$ & $-4,949$ & 23 & ,000 \\
\hline
\end{tabular}




\section{AIV.2.5. Estimación de las emisiones de $\mathrm{CO} 2$ evitadas.}

Teniendo en cuenta que el consumir Gas natural se producen 0,252 $\mathrm{kg} \mathrm{CO}_{2} / \mathrm{kWh} \mathrm{E}$. final y que al consumir la energía suministrada por red a partir de Biomasa se producen 0,024 kg $\mathrm{CO}_{2} / \mathrm{kWh}$. final, en la Tabla 190, se muestra las emisiones de $\mathrm{CO}_{2}$ reales para las temporadas octubre 2015 - mayo 2018 y utilizando el Modelo de regresión, las emisiones de $\mathrm{CO}_{2}$ que se hubieran tenido de haber seguido utilizando las calderas de gas natural originales sin el apoyo de la red de calor.

Tabla 190. Estimación del ahorro de emisiones de CO2 para el Edificio D2.

\begin{tabular}{|c|c|c|c|c|c|c|c|c|c|c|}
\hline & $\begin{array}{c}\text { kWh_D2 } \\
\text { Gas } \\
\text { Natural }\end{array}$ & $\begin{array}{l}\text { kWh_D2 } \\
\text { Biomasa }\end{array}$ & $\begin{array}{l}\text { kWh_D2 } \\
\text { Real Total }\end{array}$ & $\begin{array}{l}\text { kWh_D2 } \\
\text { Predicho }\end{array}$ & $\begin{array}{l}\text { kg CO2 Real } \\
\text { debido al } \\
\text { consumo de } \\
\text { Gas Natural }\end{array}$ & $\begin{array}{l}\text { kg CO2 } \\
\text { Real } \\
\text { debido a } \\
\text { Biomasa }\end{array}$ & $\begin{array}{l}\text { kg CO2 } \\
\text { Real } \\
\text { debido al } \\
\text { consumo } \\
\text { TOTAL }\end{array}$ & $\begin{array}{c}\text { kg CO2 } \\
\text { que se } \\
\text { hubiera } \\
\text { tenido } \\
\text { debido a } \\
\text { Gas } \\
\text { Natural }\end{array}$ & $\begin{array}{l}\text { Ahorro de } \\
\text { kg CO2 }\end{array}$ & $\begin{array}{l}\text { Ahorro de kg } \\
\text { CO2 } \\
\text { acumulado }\end{array}$ \\
\hline oct-2015 & 0 & 810 & 810 & 3.119 & 0 & 19 & 19 & 786 & 766 & 766 \\
\hline nov-2015 & 0 & 2.643 & 2.643 & 7.457 & 0 & 63 & 63 & 1.879 & 1.816 & 2.582 \\
\hline dic-2015 & 0 & 11.959 & 11.959 & 11.032 & 0 & 287 & 287 & 2.780 & 2.493 & 5.075 \\
\hline ene-2016 & 0 & 6.666 & 6.666 & 9.934 & 0 & 160 & 160 & 2.503 & 2.343 & 7.418 \\
\hline feb-2016 & 7.347 & 5.112 & 12.459 & 9.717 & 1.851 & 123 & 1.974 & 2.449 & 475 & 7.893 \\
\hline mar-2016 & 24 & 5.215 & 5.239 & 10.106 & 6 & 125 & 131 & 2.547 & 2.415 & 10.308 \\
\hline abr-2016 & 422 & 3.519 & 3.941 & 6.392 & 106 & 84 & 191 & 1.611 & 1.420 & 11.728 \\
\hline may-2016 & 0 & 405 & 405 & 3.208 & 0 & 10 & 10 & 808 & 799 & 12.527 \\
\hline oct-2016 & 160 & 5 & 165 & 3.130 & 40 & 0 & 40 & 789 & 748 & 13.275 \\
\hline nov-2016 & 672 & 4.391 & 5.063 & 8.911 & 169 & 105 & 275 & 2.246 & 1.971 & 15.246 \\
\hline dic-2016 & 760 & 6.637 & 7.397 & 12.480 & 192 & 159 & 351 & 3.145 & 2.794 & 18.040 \\
\hline ene-2017 & 0 & 7.617 & 7.617 & 14.418 & 0 & 183 & 183 & 3.633 & 3.450 & 21.491 \\
\hline feb-2017 & 584 & 6.403 & 6.987 & 8.174 & 147 & 154 & 301 & 2.060 & 1.759 & 23.250 \\
\hline mar-2017 & 448 & 7.173 & 7.621 & 7.254 & 113 & 172 & 285 & 1.828 & 1.543 & 24.793 \\
\hline abr-2017 & 0 & 3.584 & 3.584 & 4.392 & 0 & 86 & 86 & 1.107 & 1.021 & 25.814 \\
\hline may-2017 & 1.544 & 22 & 1.566 & 1.475 & 389 & 1 & 390 & 372 & -18 & 25.796 \\
\hline oct-2017 & 8 & 2 & 10 & 2.934 & 2 & 0 & 2 & 739 & 737 & 26.533 \\
\hline nov-2017 & 40 & 4.173 & 4.213 & 9.921 & 10 & 100 & 110 & 2.500 & 2.390 & 28.923 \\
\hline dic-2017 & 0 & 10.407 & 10.407 & 12.636 & 0 & 250 & 250 & 3.184 & 2.934 & 31.857 \\
\hline ene-2018 & 0 & 9.738 & 9.738 & 12.117 & 0 & 234 & 234 & 3.053 & 2.820 & 34.677 \\
\hline feb-2018 & 0 & 10.737 & 10.737 & 11.857 & 0 & 258 & 258 & 2.988 & 2.730 & 37.407 \\
\hline mar-2018 & 0 & 7.939 & 7.939 & 9.275 & 0 & 191 & 191 & 2.337 & 2.147 & 39.554 \\
\hline abr-2018 & 0 & 5.172 & 5.172 & 4.921 & 0 & 124 & 124 & 1.240 & 1.116 & 40.670 \\
\hline may-2018 & 0 & 7 & 7 & 2.392 & 0 & 0 & 0 & 603 & 603 & 41.273 \\
\hline
\end{tabular}

Como se observa durante estas tres temporadas se ha obtenido un ahorro total de 41 Toneladas de $\mathrm{CO}_{2}$, debido al consumo térmico del edificio D2. 
Anexo IV. Desarrollo del análisis de los edificios del Campus Miguel Delibes

\section{AIV.2.6. Estimación del precio máximo de compra a la red.}

Tomando como referencia los precios del gas natural de la Tabla 191 para cada temporada, obtenidos a partir de los datos establecidos en el Capítulo 3, donde se tiene en cuenta el precio por el termino variable y fijo; se puede realizar la estimación del precio máximo de compra de la energía útil a la red de calor para obtener un $0 \%$ de ahorro y un $15 \%$ de ahorro. La Tabla 192, muestra el precio que se pagaría para un ahorro del $15 \%$

Tabla 191. Precios de referencia para Gas natural y Astilla

\begin{tabular}{|c|c|c|c|c|}
\hline Precios (€/(kWh) & 2015 & 2016 & 2017 & 2018 \\
\hline Gas Natural & 0,0373 & 0,0306 & 0,0314 & 0,0336 \\
\hline Astilla & 0,0277 & 0,0256 & 0,0254 & 0,0239 \\
\hline $\begin{array}{l}€ / \text { kWh útiles máximos de compra a la red para } \\
\text { un ahorro del } 0,0 \%\end{array}$ & \multicolumn{4}{|c|}{0,04715} \\
\hline $\begin{array}{l}€ / \text { kWh útiles máximos de compra a la red para } \\
\text { un ahorro del } 15,0 \%\end{array}$ & \multicolumn{4}{|c|}{0,03961} \\
\hline
\end{tabular}

Tabla 192. Ahorro Económico por el consumo térmico en el Edificio D2

\begin{tabular}{|c|c|c|c|c|c|c|c|c|c|c|}
\hline & $\begin{array}{c}\text { kWh_D2 } \\
\text { _Gas } \\
\text { Natural }\end{array}$ & $\begin{array}{c}\text { kWh_D2_- } \\
\text { Biomasa }\end{array}$ & $\begin{array}{c}\text { kWh_D2 } \\
\text { Real }\end{array}$ & $\begin{array}{c}\text { kWh_D2 } \\
\text { Pronosticado }\end{array}$ & $\begin{array}{c}€ \text { Real } \\
\text { Gas } \\
\text { Natural } \\
\end{array}$ & $\begin{array}{l}€ \text { Real } \\
\text { Biomasa }\end{array}$ & $\begin{array}{l}€ \text { Real } \\
\text { Total }\end{array}$ & $\begin{array}{c}\text { € predicho } \\
\text { Gas } \\
\text { natural }\end{array}$ & $\begin{array}{c}€ \\
\text { Ahorro }\end{array}$ & $€$ Acumulado \\
\hline oct-2015 & 0 & 810 & 810 & 3.119 & 0 & 32 & 32 & 116 & 84 & 84 \\
\hline nov-2015 & 0 & 2.643 & 2.643 & 7.457 & 0 & 105 & 105 & 278 & 173 & 258 \\
\hline dic-2015 & 0 & 11.959 & 11.959 & 11.032 & 0 & 474 & 474 & 411 & -62 & 195 \\
\hline ene-2016 & 0 & 6.666 & 6.666 & 9.934 & 0 & 264 & 264 & 304 & 40 & 235 \\
\hline feb-2016 & 7.347 & 5.112 & 12.459 & 9.717 & 225 & 202 & 427 & 297 & -130 & 105 \\
\hline mar-2016 & 24 & 5.215 & 5.239 & 10.106 & 1 & 207 & 207 & 309 & 102 & 207 \\
\hline abr-2016 & 422 & 3.519 & 3.941 & 6.392 & 13 & 139 & 152 & 196 & 43 & 251 \\
\hline may-2016 & 0 & 405 & 405 & 3.208 & 0 & 16 & 16 & 98 & 82 & 333 \\
\hline oct-2016 & 160 & 5 & 165 & 3.130 & 5 & 0 & 5 & 96 & 91 & 423 \\
\hline nov-2016 & 672 & 4.391 & 5.063 & 8.911 & 21 & 174 & 194 & 273 & 78 & 502 \\
\hline dic-2016 & 760 & 6.637 & 7.397 & 12.480 & 23 & 263 & 286 & 382 & 96 & 597 \\
\hline ene-2017 & 0 & 7.617 & 7.617 & 14.418 & 0 & 302 & 302 & 453 & 151 & 748 \\
\hline feb-2017 & 584 & 6.403 & 6.987 & 8.174 & 18 & 254 & 272 & 257 & -15 & 733 \\
\hline mar-2017 & 448 & 7.173 & 7.621 & 7.254 & 14 & 284 & 298 & 228 & -70 & 663 \\
\hline abr-2017 & 0 & 3.584 & 3.584 & 4.392 & 0 & 142 & 142 & 138 & -4 & 659 \\
\hline may-2017 & 1.544 & 22 & 1.566 & 1.475 & 48 & 1 & 49 & 46 & -3 & 656 \\
\hline oct-2017 & 8 & 2 & 10 & 2.934 & 0 & 0 & 0 & 92 & 92 & 747 \\
\hline nov-2017 & 40 & 4.173 & 4.213 & 9.921 & 1 & 165 & 167 & 312 & 145 & 892 \\
\hline dic-2017 & 0 & 10.407 & 10.407 & 12.636 & 0 & 412 & 412 & 397 & -15 & 877 \\
\hline ene-2018 & 0 & 9.738 & 9.738 & 12.117 & 0 & 386 & 386 & 407 & 21 & 898 \\
\hline feb-2018 & 0 & 10.737 & 10.737 & 11.857 & 0 & 425 & 425 & 398 & -27 & 871 \\
\hline mar-2018 & 0 & 7.939 & 7.939 & 9.275 & 0 & 314 & 314 & 312 & -3 & 869 \\
\hline abr-2018 & 0 & 5.172 & 5.172 & 4.921 & 0 & 205 & 205 & 165 & -40 & 829 \\
\hline may-2018 & 0 & 7 & 7 & 2.392 & 0 & 0 & 0 & 80 & 80 & 909 \\
\hline$€$ Total & & & & & & & 5.136 & 6.045 & & \\
\hline Ahorro (\%) & & & & & & & & & & $15,0 \%$ \\
\hline
\end{tabular}




\section{AIV.3.Edificio D3. Centro de Transferencia de Tecnologías aplicadas. CTTA.}

\section{AIV.3.1.Obtención de la línea base de referencia energética}

Los datos de partida para la obtención de la línea base de referencia se muestran en la Tabla 193

\section{Tabla 193. Consumos térmicos del edificio D3}

\begin{tabular}{lr}
\hline & Consumos térmicos (kWh). D3 \\
\hline oct-12 & 15.679 \\
\hline nov-12 & 34.701 \\
\hline dic-12 & 47.474 \\
\hline ene-13 & 61.790 \\
\hline feb-13 & 51.895 \\
\hline mar-13 & 35.453 \\
\hline abr-13 & 33.758 \\
\hline may-13 & 16.401 \\
\hline oct-13 & 9.887 \\
\hline nov-13 & 32.104 \\
\hline dic-13 & 64.828 \\
\hline ene-14 & 59.681 \\
\hline feb-14 & 53.522 \\
\hline mar-14 & 20.039 \\
\hline abr-14 & 25.860 \\
\hline may-14 & 9.813 \\
\hline Promedio & 35.805 \\
\hline Total (oct-12-may-13) & 297.151 \\
\hline Total (oct-13-may-14) & 275.734 \\
\hline Total (oct-12-may-13) & 572.885 \\
\hline
\end{tabular}

Se disponen de 16 datos para establecer el modelo de regresión, mediante el método de pasos sucesivos. Como se puede ver en la Tabla 194 para el edificio, el método ofrece un modelo de regresión, con una sola variable (Grados Día en base 15, obtenidos con datos cada 30 minutos). El modelo fue construido con un solo paso, incluyendo los Grados día base 15 por ser la variable más significativa (variable con menor valor de Sig =0,000). El resto de las variables como se observa en la Tabla 195 fueron excluidas del modelo al tener valores de sig $>0,05$.

Tabla 194. Modelos de regresión del Edificio D3

\begin{tabular}{|c|c|c|c|c|c|c|c|}
\hline & \multirow{2}{*}{ Modelo } & \multicolumn{2}{|c|}{$\begin{array}{l}\text { Coeficientes no } \\
\text { estandarizados }\end{array}$} & \multirow{2}{*}{$\mathrm{t}$} & \multirow{2}{*}{ Sig. } & \multicolumn{2}{|c|}{$\begin{array}{c}\text { Intervalo de confianza de } \\
95,0 \% \text { para B } \\
\end{array}$} \\
\hline & & B & Error típ. & & & $\begin{array}{l}\text { Límite } \\
\text { inferior }\end{array}$ & $\begin{array}{l}\text { Límite } \\
\text { superior }\end{array}$ \\
\hline \multirow[t]{2}{*}{1} & (Constante) & $-6854,944$ & 5178,244 & $-1,324$ & 207 & $-17961,172$ & 4251,284 \\
\hline & GD15_30min & 192,510 & 21,751 & 8,851 & ,000 & 145,859 & 239,161 \\
\hline
\end{tabular}


En la Figura 217 se representa el modelo de regresión con sus límites inferior y superior para un nivel de confianza del $95 \%$

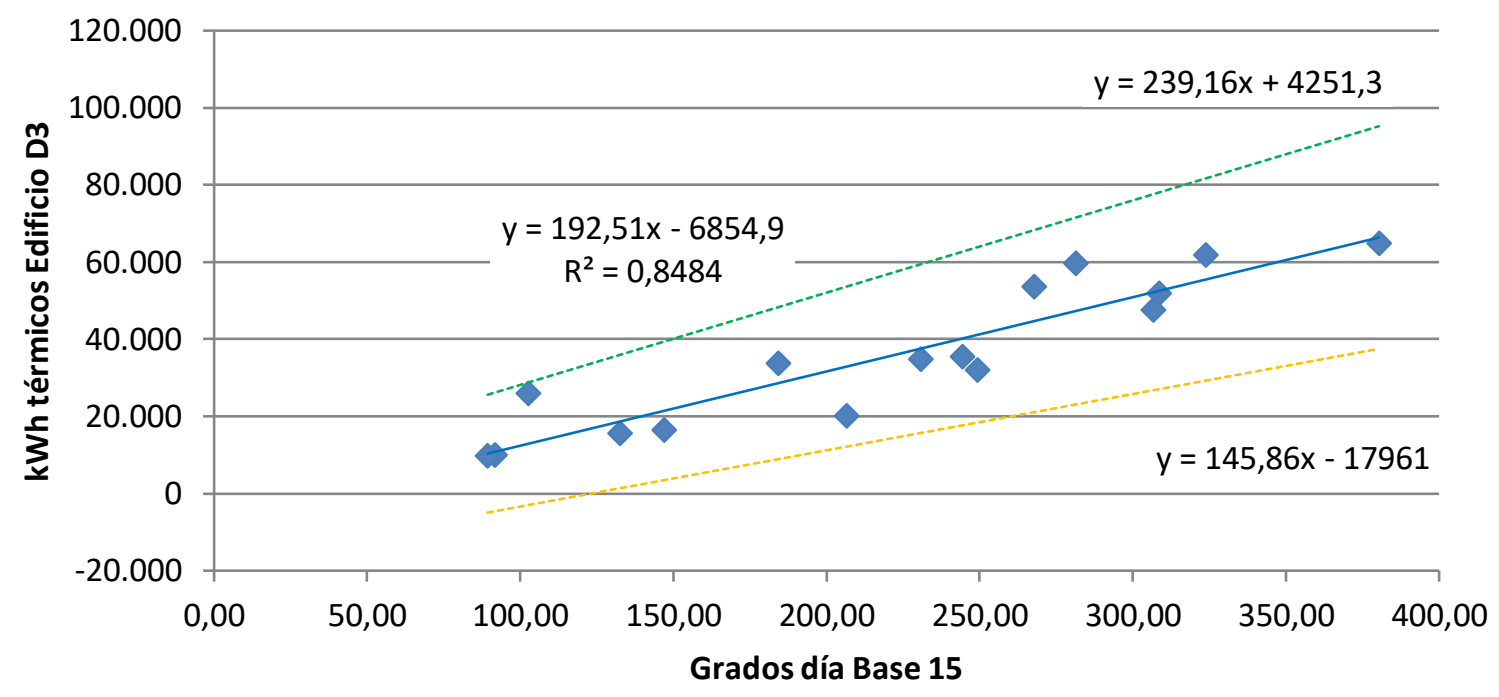

$\bullet \quad$ D3 $(k W h) \quad$ Lineal $(\mathrm{D} 3(\mathrm{kWh}))$

Lineal (D3 lim inferior) -----.--- Lineal (D3 lím superior)

Figura 217. Representación del modelo de regresión lineal simple para el Edificio D3

Tabla 195. Variables excluidas del modelo de región del Edificio D3

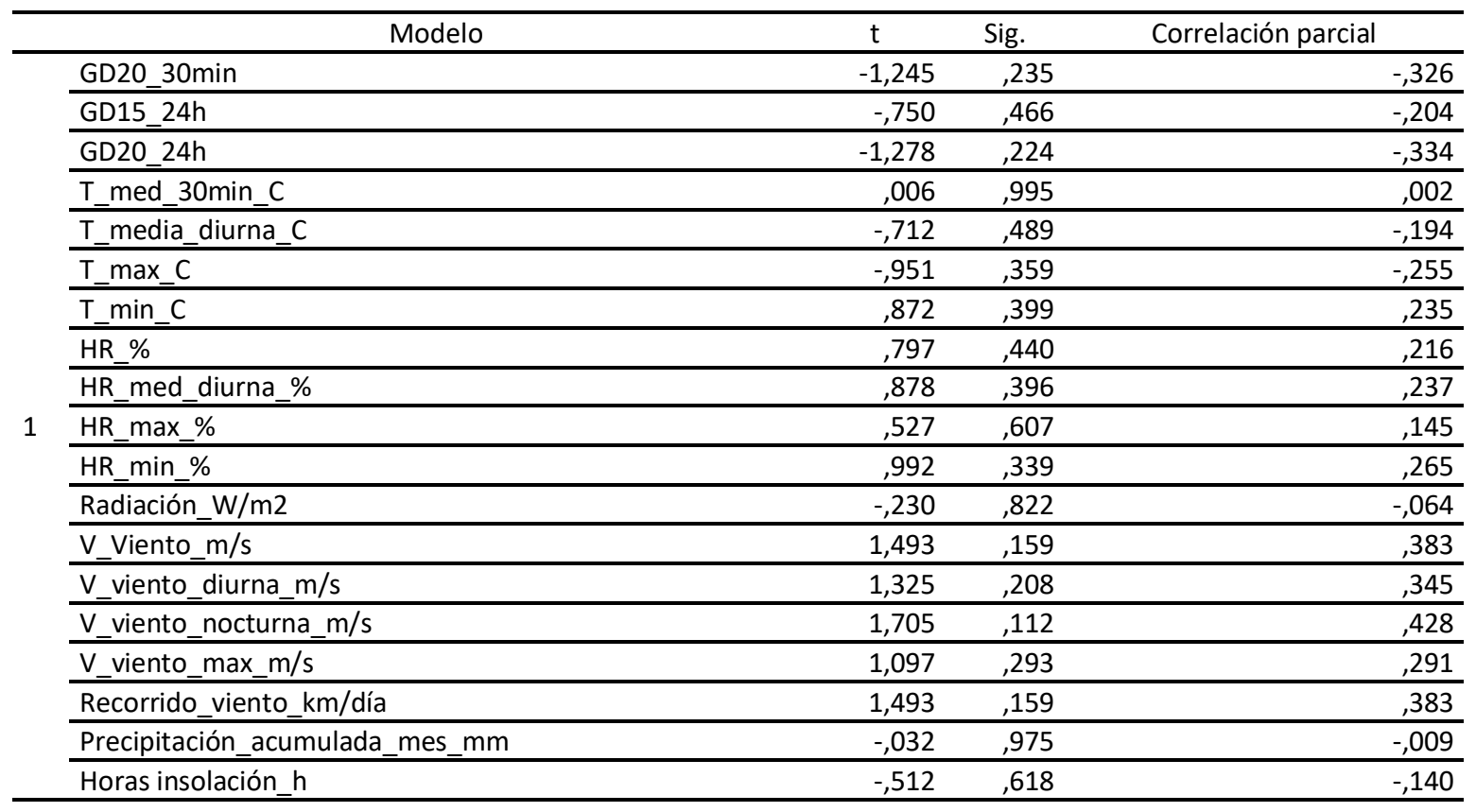


La bondad de los modelos de regresión obtenidos para el edificio D3, se resumen en la Tabla 196

Tabla 196. Resumen de la bondad de los modelos de regresión para el Edificio D3

\begin{tabular}{ccccc}
\hline Modelo & $\mathrm{R}$ & $\mathrm{R}$ cuadrado & $\mathrm{R}$ cuadrado corregida & $\begin{array}{c}\text { Error típ. de la } \\
\text { estimación }\end{array}$ \\
\hline 1 &, 921 &, 848 &, 838 & 7570,62826 \\
\hline
\end{tabular}

Se observa como el modelo de regresión lineal simple presenta un Coeficiente de Correlación de Pearson $(\mathrm{R})$ de 0,921 , lo que indica que las variables están correlacionadas de manera muy fuerte (en la correlación perfecta $R= \pm 1$ ). La correlación que se produce es directa, al aumentar el valor de los Grados día, aumenta el consumo térmico.

El coeficiente de determinación $\left(R^{2}\right)$, nos indica que con el modelo se podría explicar el $84,8 \%$ de los datos reales obtenidos aceptando un error del $5 \%$.

El error típico de la estimación que nos indica la magnitud de los errores, es decir la parte de la variable dependiente que dejamos sin explicar con el modelo y que describe la variación de la variable respuesta (el Consumo) respecto a la recta de regresión, es de $7.570 \mathrm{kWh}$, lo que representa un 21,1\% del promedio de los consumos que fue de 35.805 kWh.

\section{AIV.3.2. Verificación del cumplimiento de los supuestos estadísticos}

Las condiciones que se deben cumplir en un modelo de regresión son:

\section{- Linealidad de las variables, las variables se encuentran relacionadas de forma lineal.}

Como se observa en la Tabla 194, la pendiente (B), obtuvo un valor de Sig $=0,000$, que al ser $\leq 0,05$, nos indica que podemos rechazar la hipótesis nula de pendiente igual a cero y nos da la evidencia de linealidad entre la variable dependiente ( $\mathrm{kWh}$ del edificio D3) y la independiente (GD15_30min). Al ser el valor de la pendiente positiva, indica una relación directa entre el consumo y los Grados día base 15 . 
- Normalidad. Todos los valores obtenidos para la variable dependiente (Y), deben estar distribuidos normalmente en cada valor de la variable independiente $(X)$.

Se comprueba la normalidad de las variables y de los residuos mediante el Test de Shapiro - Wilk para muestras pequeñas (menores a 30 observaciones), siendo la hipótesis nula el que la distribución es Normal.

La Tabla 197, muestra la prueba de normalidad de Shapiro-Wilk y cómo tanto la variable dependiente (consumos del Edificio), como la variable independientes: GD15 poseen una Sig $>0,05$, por lo que aceptamos la hipótesis nula de Normalidad de las variables

Tabla 197. Prueba de normalidad para el edificio D3

\begin{tabular}{lcccccr}
\hline & \multicolumn{3}{c}{ Kolmogorov-Smirnov } & \multicolumn{3}{c}{ Shapiro-Wilk } \\
\cline { 2 - 7 } & Estadístico & gl & Sig. & Estadístico & gl & Sig. \\
\hline kWh_D3 &, 132 & 16 &, $200^{*}$ &, 931 & 16 &, 251 \\
\hline GD15_30min &, 109 & 16 &, $200^{*}$ &, 953 & 16 &, 541 \\
\hline
\end{tabular}

- Independencia de los errores. Los errores asociados a los valores de la variable respuesta $(Y)$ deberán ser independientes unos de otros.

Para la comprobación se utiliza el estadístico de Durbin -Watson.

Se comprueba que el Estadístico de Durbin Watson para el nivel de significancia del 5\%, y para el tamaño de la muestra " $n$ " y el número de variables independientes del modelo " $k$ ", se encuentra en el intervalo [dU, 4-dU], de la Tabla 3, intervalo centrado en el 2, que indica la ausencia de autocorrelación.

El valor del Estadístico Durbin-Watson facilitado por el programa SPSS, es 2,559.

En el modelo, $n=16$ y $k=1$, según la Tabla 3 el valor $d U=1,371$, luego el intervalo que marca la ausencia de correlación es [1,371, 2,629], como el valor del estadístico 2,559 está dentro del intervalo, se acepta la ausencia de autocorrelación

- Homocedasticidad de la varianza. Se pretende comprobar que la varianza de los errores $\left(\sigma^{2}\right)$ es constante para cualquier valor de la variable independiente $(X)$, es decir que el valor medio del cuadrado de la desviación de los errores respecto a su media es constante.

Esta condición indica que no existe correlación entre los residuos y los pronósticos. Se comprueba que el coeficiente de determinación $\mathrm{R}^{2}$, en las relaciones: residuos $\mathrm{y}$ predicciones y entre residuos y variable independiente es nulo o muy próximo a cero, lo que indicará que no existe ningún tipo de correlación en los residuos y que éstos son aleatorios. 
Se grafican los diagramas de dispersión de esas relaciones, comprobando que se corresponden a nubes de puntos totalmente aleatorias, sin tendencias ni patrones en sus representaciones gráficas.

Las Figura 218 y Figura 219, muestran que la relación entre los pronósticos y los residuos, posee un coeficiente de determinación $=0$ y entre la variable independiente (Grados Día

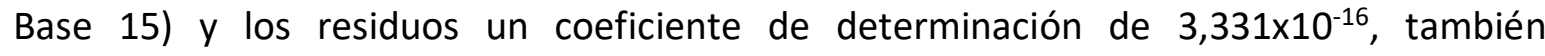
prácticamente nulo; por lo que se concluye que no existe ningún tipo de correlación en los residuos y que éstos son aleatorios, siendo la varianza de los residuos constante

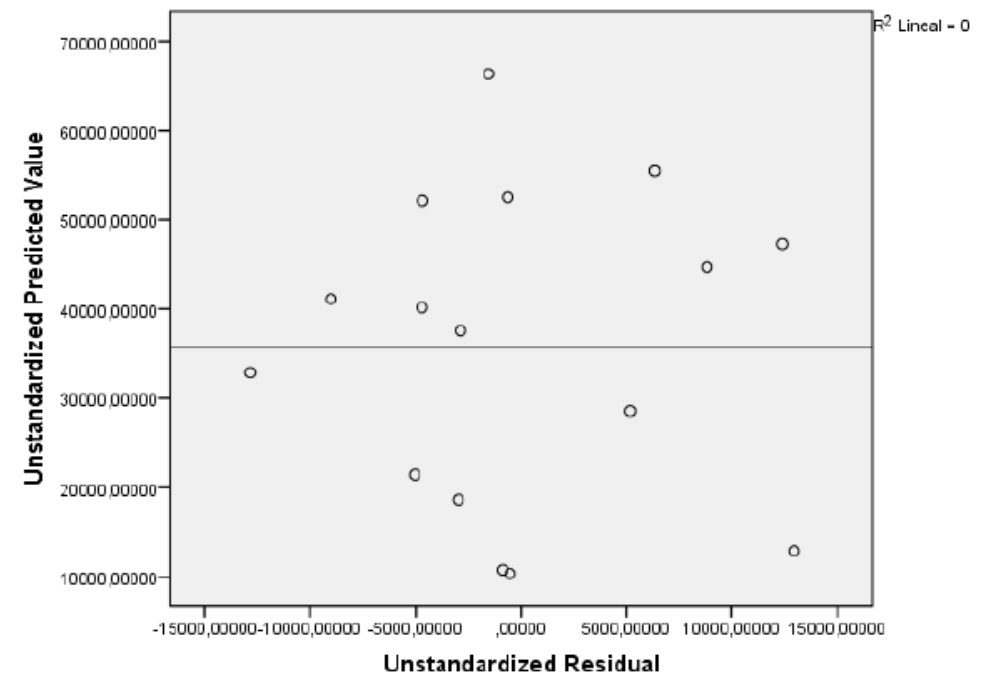

Figura 218. Relación entre los pronósticos y los residuos en el Edificio D3

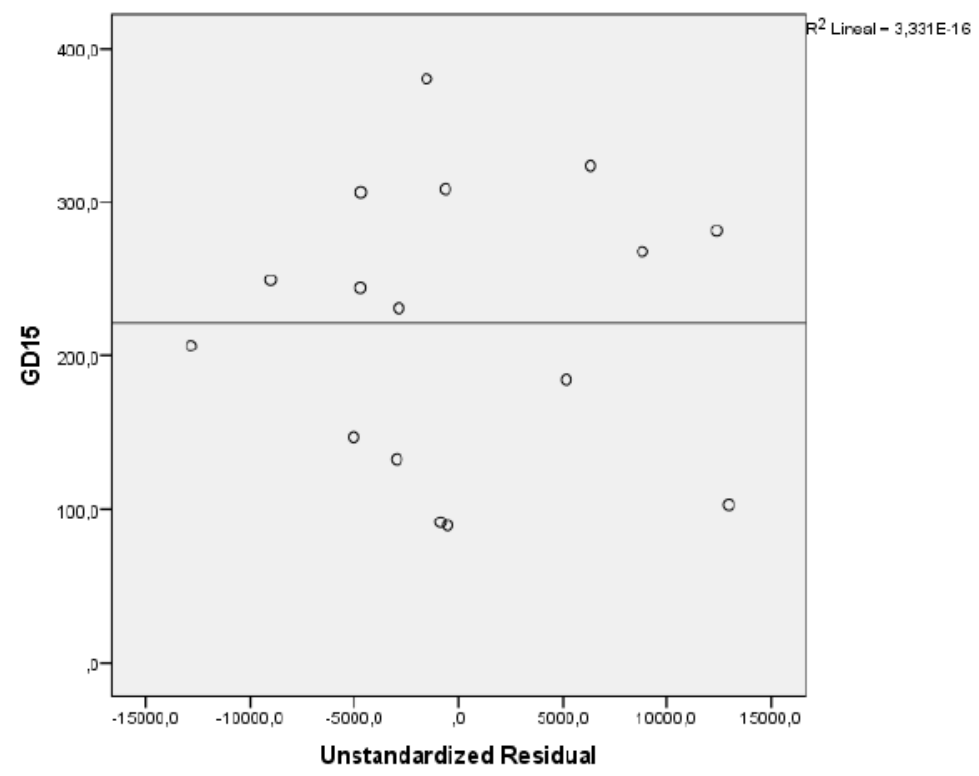

Figura 219. Relación entre GD15 y los residuos en el Edificio D3 


\section{AIV.3.3. Obtención de los consumos térmicos previstos}

Una vez comprobado el cumplimiento de los supuestos estadísticos se acepta el modelo de línea base encontrado para modelizar el consumo del Edificio D3.

$$
\text { kWh_D3_Pronosticado }=-6854,944+192,51 \times \text { GD15_30min }
$$

Con este modelo se procede a predecir los consumos previstos para las temporadas: octubre 2015-mayo 2016, octubre 2016 - mayo 2017 y octubre 2017-mayo 2018, estos consumos se muestran en la Tabla 198, donde "KWh_D3_Real", representa el consumo real, "kWh_D3_Pronosticado", el consumo pronosticado con el Modelo.

Tabla 198. Consumos previstos octubre 2014 - mayo 2017 para el edificio D3.

\begin{tabular}{rrrr}
\hline & GD15 & kWh_D3_Real & kWh_D3_Pronosticado \\
\hline oct-15 & 97,04 & 0 & 11.827 \\
\hline nov-15 & 208,36 & 28.683 & 33.257 \\
\hline dic-15 & 300,09 & 50.191 & 50.916 \\
\hline ene-16 & 271,93 & 38.231 & 45.495 \\
\hline feb-16 & 266,36 & 68.430 & 44.423 \\
\hline mar-16 & 276,34 & 41.775 & 46.343 \\
\hline abr-16 & 181,04 & 24.655 & 27.998 \\
\hline may-16 & 99,34 & 7.268 & 12.268 \\
\hline oct-16 & 97,34 & 3.711 & 11.883 \\
\hline nov-16 & 245,69 & 35.452 & 40.443 \\
\hline dic-16 & 337,25 & 45.615 & 58.069 \\
\hline ene-17 & 386,98 & 47.454 & 67.643 \\
\hline feb-17 & 226,76 & 33.104 & 36.799 \\
\hline mar-17 & 203,17 & 26.179 & 32.257 \\
\hline abr-17 & 129,72 & 16.672 & 18.118 \\
\hline may-17 & 54,86 & 12.122 & 3.706 \\
\hline oct-17 & 92,31 & 4.697 & 10.917 \\
\hline nov-17 & 271,60 & 37.870 & 45.431 \\
\hline dic-17 & 341,26 & 48.468 & 58.840 \\
\hline ene-18 & 327,94 & 48.828 & 56.277 \\
\hline feb-18 & 321,27 & 48.728 & 54.992 \\
\hline mar-18 & 255,02 & 28.432 & 42.239 \\
\hline abr-18 & 143,31 & 19.765 & 20.733 \\
\hline may-18 & 78,41 & 13.337 & 2.392 \\
\hline & & &
\end{tabular}




\section{AIV.3.4. Estudio de la existencia de diferencias significativas}

Utilizando la prueba " $\mathrm{t}$ " de Student para muestras relacionadas, podemos concluir que si las variables se distribuyen según una normal y la significación estadística resulta $\leq 0,05$, existen diferencias significativas, con un nivel de confianza del 95\%

A continuación se muestra la comparación de medias realizada para cada uno de los tres periodos posteriores a la construcción de la red y para el periodo total hasta mayo de 2018.

Para la temporada Octubre 2015 - Mayo 2016, se comprueba mediante el Test de Shapiro -Wilk que tanto los valores reales como los pronosticados se distribuyen según una Normal puesto que en todos los casos los valores de Sig $>0,05$, como se observa en la Tabla 199

Tabla 199. Prueba de Normalidad temporada Octubre 2015-Mayo 2016. Edificio D3

\begin{tabular}{ccccrrrr}
\hline & \multicolumn{3}{c}{ Kolmogorov-Smirnov $^{\mathrm{a}}$} & \multicolumn{3}{c}{ Shapiro-Wilk } \\
\cline { 2 - 9 } & Estadístico & gl & \multicolumn{1}{c}{ Sig. } & Estadístico & gl & Sig. \\
\hline kWh_real &, 120 & 8 &, 200 &, 981 & 8 &, 966 \\
\hline kWh_pronosticado &, 248 & 8 &, 159 &, 865 & 8 &, 135 \\
\hline
\end{tabular}

En la Tabla 200, se observa como las medias de los consumos pronosticados, son superiores a las medias de los consumos reales del Edificio D3, en un 5,1\%

Tabla 200. Estadísticos de muestras relacionadas. Octubre 2015-Mayo 2016. Edificio D3

\begin{tabular}{lccccc}
\hline & Media & $\begin{array}{c}\text { \% Diferencia } \\
\text { entre medias }\end{array}$ & $\mathrm{N}$ & $\begin{array}{c}\text { Desviación } \\
\text { típ. }\end{array}$ & $\begin{array}{c}\text { Error típ. de } \\
\text { la media }\end{array}$ \\
\hline kWh_real & 32404,1250 & & 8 & 22334,31111 & 7896,37142 \\
\hline kWh_pronosticado & 34065,8750 & $5,1 \%$ & 8 & 15490,72418 & 5476,79806 \\
\hline
\end{tabular}

La Tabla 201 muestra que las diferencias entre las medias no son significativas entre los consumos reales y los pronosticados ( $\operatorname{sig}>0,05$ ), a pesar de existir ese $5,1 \%$ de diferencia

Tabla 201. Prueba de muestras relacionadas. Octubre 2015-Mayo 2016. Edificio D3

\begin{tabular}{|c|c|c|c|c|c|c|c|c|c|}
\hline & & \multicolumn{5}{|c|}{ Diferencias relacionadas } & \multirow{3}{*}{$\mathrm{t}$} & \multirow{3}{*}{ gl } & \multirow{3}{*}{$\begin{array}{c}\text { Sig. } \\
\text { (bilateral) }\end{array}$} \\
\hline & & \multirow[t]{2}{*}{ Media } & \multirow{2}{*}{$\begin{array}{l}\text { Desviación } \\
\text { típ. }\end{array}$} & \multirow{2}{*}{$\begin{array}{l}\text { Error típ. } \\
\text { de la media }\end{array}$} & \multicolumn{2}{|c|}{$\begin{array}{l}\text { 95\% Intervalo de confianza } \\
\text { para la diferencia }\end{array}$} & & & \\
\hline & & & & & Inferior & Superior & & & \\
\hline Par 1 & $\begin{array}{c}\text { kWh_real - } \\
\text { kWh_pronosticado }\end{array}$ & $-1661,750$ & 10858,688 & 3839,126 & $-10739,840$ & 7416,340 &,- 433 & 7 & 678 \\
\hline
\end{tabular}


En la Figura 220, se grafican los consumos reales y pronosticados para la temporada Octubre 2015 - Mayo 2016 para el Edificio D3, y las medias de dichos consumos. Según la prueba paramétrica realizada las diferencias encontradas no son estadísticamente significativas, por lo que no se puede afirmar la existencia de ahorros en el consumo térmico entre la situación anterior y posterior a la red de calor, con un riesgo a estar equivocados del $5 \%$

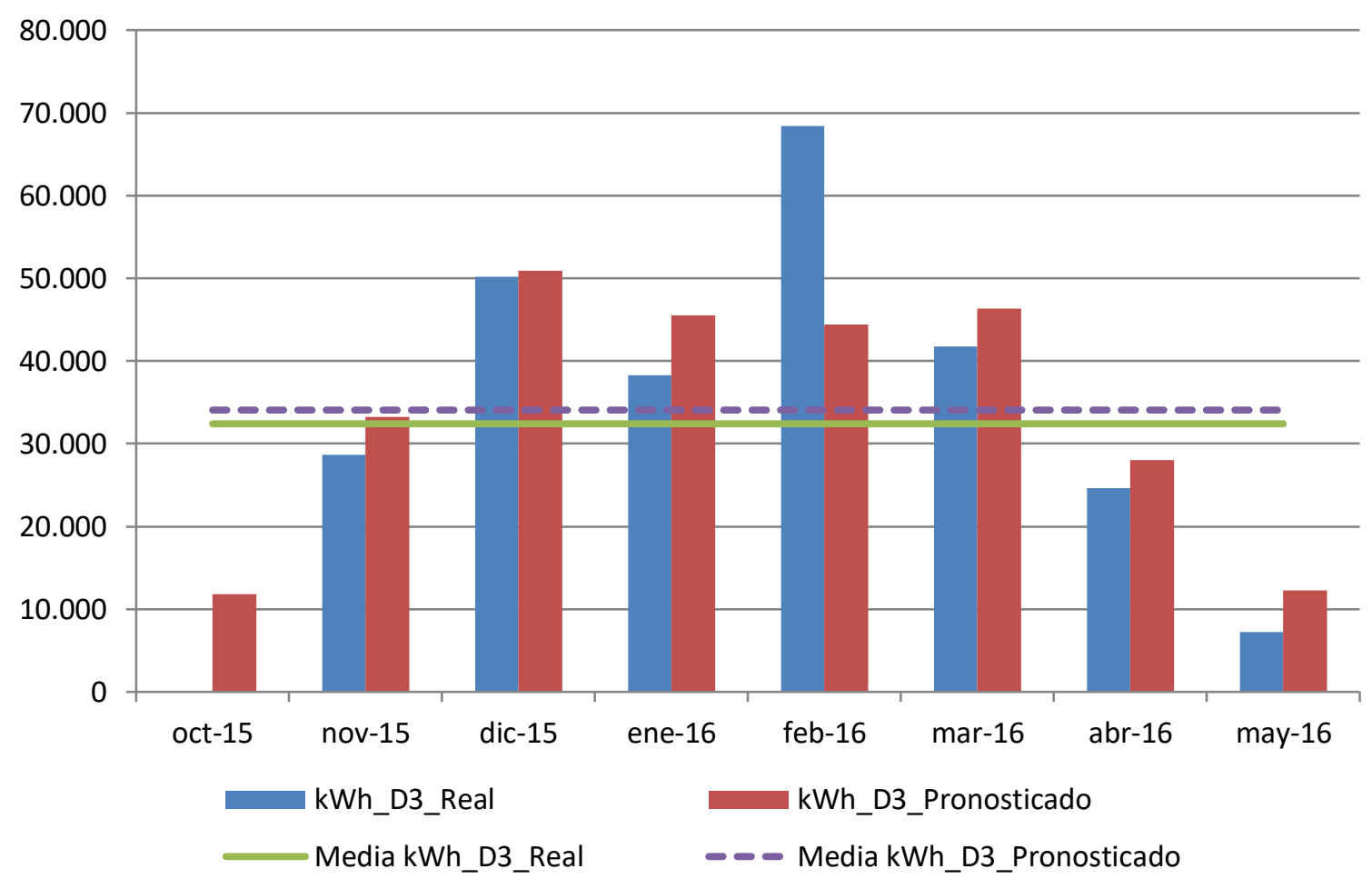

Figura 220. Consumos reales y pronosticados Octubre 2015-Mayo 2016. Edificio D3

Para la temporada Octubre 2016 - Mayo 2017, se comprueba mediante el Test de Shapiro -Wilk que tanto los valores reales como los pronosticados con los dos modelos se distribuyen según una Normal puesto que en todos los casos los valores de Sig >0,05, como se observa en la Tabla 202

Tabla 202. Prueba de Normalidad temporada Octubre 2016-Mayo 2017. Edificio D3

\begin{tabular}{cccccccr}
\hline & \multicolumn{3}{c}{ Kolmogorov-Smirnov $^{\text {a }}$} & \multicolumn{3}{c}{ Shapiro-Wilk } \\
\cline { 2 - 8 } & Estadístico & gl & \multicolumn{1}{c}{ Sig. } & Estadístico & gl & \multicolumn{1}{c}{ Sig. } \\
\hline kWh_real &, 138 & 8 &, 200 &, 953 & 8 &, 738 \\
\hline kWh_pronosticado &, 133 & 8 &, 200 &, 965 & 8 &, 856 \\
\hline
\end{tabular}


En la Tabla 203, se observa como las medias de los consumos pronosticados, son superiores a las medias de los consumos reales del Edificio D3, en un 22,1\%

Tabla 203. Estadísticos de muestras relacionadas. Octubre 2016-Mayo 2017. Edificio D3

\begin{tabular}{lccccc}
\hline & Media & $\begin{array}{c}\text { \% Diferencia } \\
\text { entre medias }\end{array}$ & N & $\begin{array}{c}\text { Desviación } \\
\text { típ. }\end{array}$ & $\begin{array}{c}\text { Error típ. de } \\
\text { la media }\end{array}$ \\
\hline kWh_real & 27538,6250 & & 8 & 15776,71230 & 5577,91012 \\
\hline kWh_pronosticado & 33614,7500 & $22,1 \%$ & 8 & 22108,47161 & 7816,52510 \\
\hline
\end{tabular}

La Tabla 204 muestra que las diferencias entre las medias no son significativas entre los consumos reales y los pronosticados (sig >0,05), a pesar de existir ese $22,1 \%$ de diferencia

Tabla 204. Prueba de muestras relacionadas. Octubre 2016-Mayo 2017. Edificio D3

\begin{tabular}{|c|c|c|c|c|c|c|c|c|c|}
\hline & & \multicolumn{5}{|c|}{ Diferencias relacionadas } & \multirow{3}{*}{$\mathrm{t}$} & \multirow{3}{*}{ gl } & \multirow{3}{*}{$\begin{array}{l}\text { Sig. } \\
\text { (bilateral) }\end{array}$} \\
\hline & & \multirow[t]{2}{*}{ Media } & \multirow{2}{*}{$\begin{array}{l}\text { Desviación } \\
\text { típ. }\end{array}$} & \multirow{2}{*}{$\begin{array}{l}\text { Error típ. } \\
\text { de la media }\end{array}$} & \multicolumn{2}{|c|}{$\begin{array}{l}\text { 95\% Intervalo de confianza } \\
\text { para la diferencia }\end{array}$} & & & \\
\hline & & & & & Inferior & Superior & & & \\
\hline Par 1 & $\begin{array}{c}\text { kWh_real - } \\
\text { kWh_pronosticado }\end{array}$ & $-6076,125$ & 8302,755 & 2935,467 & $-13017,402$ & 865,152 & $-2,070$ & 7 & 077 \\
\hline
\end{tabular}

En la Figura 221, se grafican los consumos reales y pronosticados para la temporada Octubre 2016 - Mayo 2017 para el Edificio D3, y las medias de dichos consumos. Según la prueba paramétrica realizada las diferencias encontradas no son estadísticamente significativas, con un riesgo a estar equivocados del $5 \%$

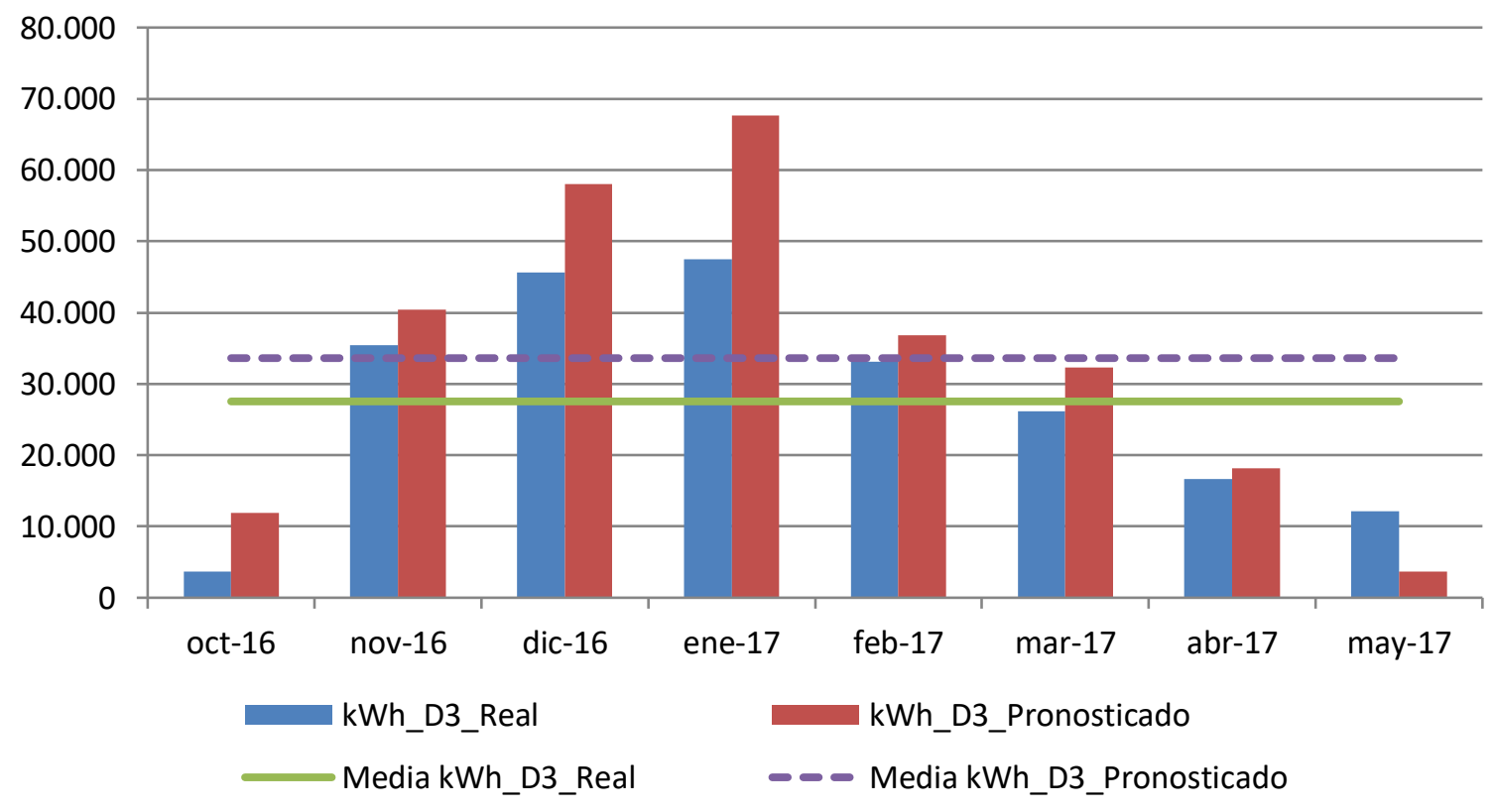

Figura 221. Consumos reales y pronosticados Octubre 2016-Mayo 2017. Edificio D3 
Para la temporada Octubre 2017 - Mayo 2018, se comprueba mediante el Test de Shapiro -Wilk que tanto los valores reales como los pronosticados se distribuyen según una Normal puesto que en todos los casos los valores de Sig $>0,05$, como se observa en la Tabla 205

Tabla 205. Prueba de Normalidad temporada Octubre 2017-Mayo 2018. Edificio D3

\begin{tabular}{cccccccr}
\hline & \multicolumn{3}{c}{ Kolmogorov-Smirnov $^{\mathrm{a}}$} & \multicolumn{3}{c}{ Shapiro-Wilk } \\
\cline { 2 - 8 } & \multicolumn{1}{c}{ Estadístico } & gl & \multicolumn{1}{c}{ Sig. } & Estadístico & gl & Sig. \\
\hline kWh_real &, 214 & 8 &, 200 &, 891 & 8 &, 237 \\
\hline kWh_pronosticado &, 228 & 8 &, $200^{*}$ &, 877 & 8 &, 174 \\
\hline
\end{tabular}

En la Tabla 206, se observa como las medias de los consumos pronosticados, son superiores a las medias de los consumos reales del Edificio D3, en un 16,7\%

Tabla 206. Estadísticos de muestras relacionadas. Octubre 2017-Mayo 2018. Edificio D3

\begin{tabular}{lccccc}
\hline & Media & $\begin{array}{c}\text { \% Diferencia } \\
\text { entre medias }\end{array}$ & $\mathrm{N}$ & $\begin{array}{c}\text { Desviación } \\
\text { típ. }\end{array}$ & $\begin{array}{c}\text { Error típ. de } \\
\text { la media }\end{array}$ \\
\hline kWh_real & 31265,6250 & & 8 & 17404,97575 & 6153,58819 \\
\hline kWh_pronosticado & 36477,6250 & $16,7 \%$ & 8 & 22075,51362 & 7804,87269 \\
\hline
\end{tabular}

La Tabla 207 muestra que las diferencias entre las medias no son significativas entre los consumos reales y los pronosticados (sig $>0,05$ ), a pesar de existir ese $16,7 \%$ de diferencia

Tabla 207. Prueba de muestras relacionadas. Octubre 2017-Mayo 2018. Edificio D3

\begin{tabular}{|c|c|c|c|c|c|c|c|c|c|}
\hline & & \multicolumn{5}{|c|}{ Diferencias relacionadas } & \multirow{3}{*}{$\mathrm{t}$} & \multirow{3}{*}{ gl } & \multirow{3}{*}{$\begin{array}{c}\text { Sig. } \\
\text { (bilateral) }\end{array}$} \\
\hline & & \multirow[t]{2}{*}{ Media } & \multirow{2}{*}{$\begin{array}{l}\text { Desviación } \\
\text { típ. }\end{array}$} & \multirow{2}{*}{$\begin{array}{c}\text { Error típ. } \\
\text { de la media }\end{array}$} & \multicolumn{2}{|c|}{$\begin{array}{c}\text { 95\% Intervalo de confianza } \\
\text { para la diferencia }\end{array}$} & & & \\
\hline & & & & & Inferior & Superior & & & \\
\hline Par 1 & $\begin{array}{c}\text { kWh_real - } \\
\text { kWh_pronosticado }\end{array}$ & $-5212,000$ & 7485,267 & 2646,441 & $-11469,840$ & 1045,840 & $-1,969$ & 7 & 090 \\
\hline
\end{tabular}

En la Figura 222, se grafican los consumos reales y pronosticados para la temporada Octubre 2017 - Mayo 2018 para el Edificio D3, y las medias de dichos consumos. Según la prueba paramétrica realizada las diferencias encontradas no son estadísticamente significativas, con un riesgo a estar equivocados del $5 \%$ 
Anexo IV. Desarrollo del análisis de los edificios del Campus Miguel Delibes

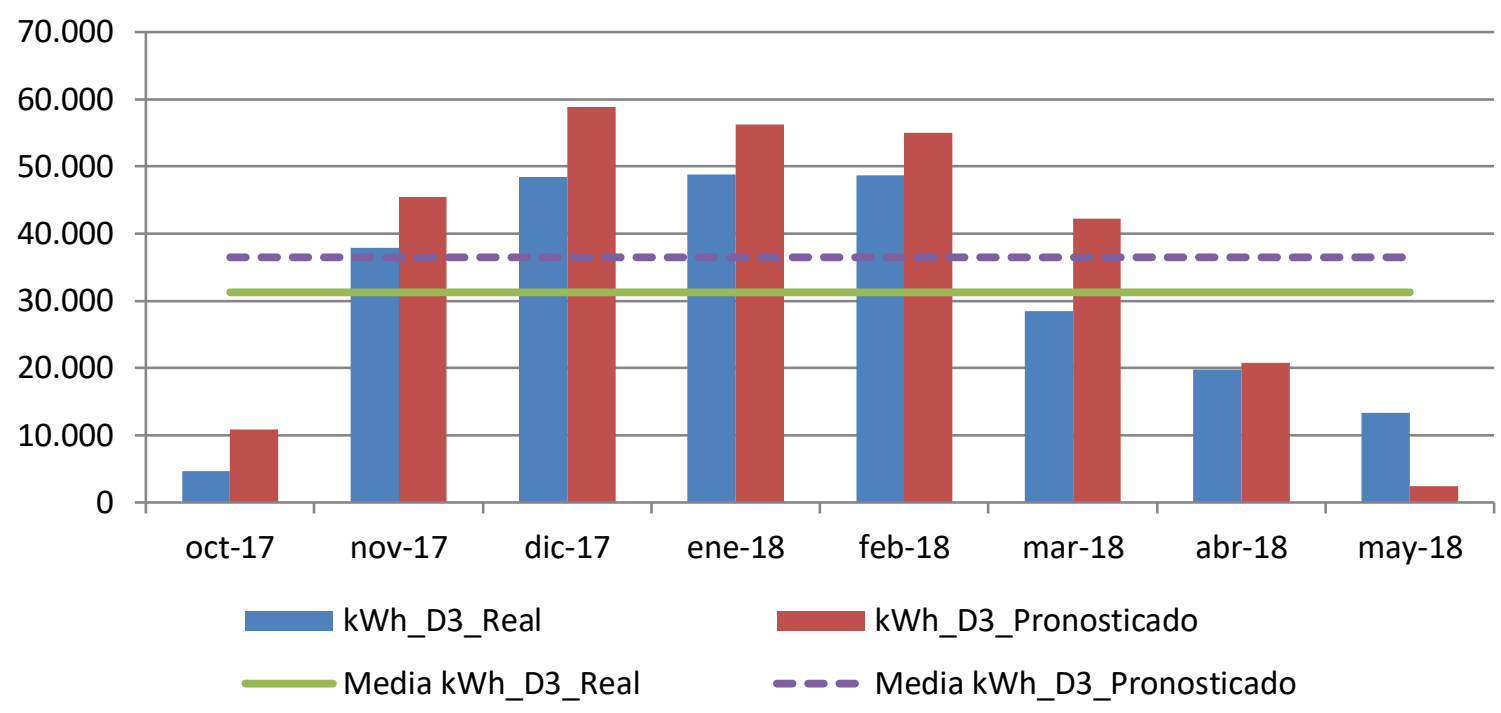

Figura 222. Consumos reales y pronosticados Octubre 2017-Mayo 2018. Edificio D3

Para el total de las tres temporadas Octubre 2015 - Mayo 2018, se comprueba mediante el Test de Shapiro -Wilk, que los valores reales y los pronosticados se distribuyen según una Normal puesto que en esos casos los valores de Sig $>0,05$, como se observa en la Tabla 208

Tabla 208. Prueba de Normalidad temporada Octubre 2015-Mayo 2018. Edificio D3

\begin{tabular}{cccrrrr}
\hline & \multicolumn{3}{c}{ Kolmogorov-Smirnov $^{\text {a }}$} & \multicolumn{3}{c}{ Shapiro-Wilk } \\
\cline { 2 - 8 } & Estadístico & gl & Sig. & Estadístico & gl & Sig. \\
\hline kWh_real &, 094 & 24 &, 200 &, 963 & 24 &, 513 \\
\hline kWh_pronosticado &, 128 & 24 &, 200 &, 946 & 24 &, 221 \\
\hline
\end{tabular}

En la Tabla 209 se observa como las medias de los consumos pronosticados, son superiores a las medias de los consumos reales del Edificio D3, en un 14,2\%

Tabla 209. Estadísticos de muestras relacionadas. Octubre 2015-Mayo 2018. Edificio D3

\begin{tabular}{lccccc}
\hline & Media & $\begin{array}{c}\text { \% Diferencia } \\
\text { entre medias }\end{array}$ & $\mathrm{N}$ & $\begin{array}{c}\text { Desviación } \\
\text { típ. }\end{array}$ & $\begin{array}{c}\text { Error típ. de } \\
\text { la media }\end{array}$ \\
\hline kWh_real & 30402,7917 & & 24 & 18007,53602 & 3675,77290 \\
\hline kWh_pronosticado & 34719,4167 & $14,2 \%$ & 24 & 19281,03043 & 3935,72386 \\
\hline
\end{tabular}


La Tabla 210 muestra que las diferencias entre las medias son significativas entre los consumos reales y los pronosticados (sig $\leq 0,05$ ), a pesar de no haber resultado significativas analizando los datos de manera individual en cada temporada.

Tabla 210. Prueba de muestras relacionadas. Octubre 2015-Mayo 2018. Edificio D3

\begin{tabular}{|c|c|c|c|c|c|c|c|c|}
\hline & \multicolumn{5}{|c|}{ Diferencias relacionadas } & \multirow{3}{*}{$\mathrm{t}$} & \multirow{3}{*}{ gl } & \multirow{3}{*}{$\begin{array}{c}\text { Sig. } \\
\text { (bilateral) }\end{array}$} \\
\hline & \multirow[t]{2}{*}{ Media } & \multirow{2}{*}{$\begin{array}{l}\text { Desviación } \\
\text { típ. }\end{array}$} & \multirow{2}{*}{$\begin{array}{l}\text { Error típ. de } \\
\text { la media }\end{array}$} & \multicolumn{2}{|c|}{$\begin{array}{l}\text { 95\% Intervalo de confianza } \\
\text { para la diferencia }\end{array}$} & & & \\
\hline & & & & Inferior & Superior & & & \\
\hline $\begin{array}{c}\text { kWh_real - } \\
\text { kWh_pronosticado }\end{array}$ & $-4316,625$ & 8816,239 & 1799,607 & $-8039,396$ & $-593,854$ & $-2,399$ & 23 &, 025 \\
\hline
\end{tabular}




\section{AIV.3.5. Estimación de las emisiones de $\mathrm{CO} 2$ evitadas.}

Teniendo en cuenta que el consumir Gas natural se producen 0,252 $\mathrm{kg} \mathrm{CO}_{2} / \mathrm{kWh} \mathrm{E}$. final y que al consumir la energía suministrada por red a partir de Biomasa se producen 0,024 $\mathrm{kg}$ $\mathrm{CO}_{2} / \mathrm{kWh}$. final, en la Tabla 211, se muestra las emisiones de $\mathrm{CO}_{2}$ reales para las temporadas octubre 2015 - mayo 2018 y utilizando el Modelo de regresión, las emisiones de $\mathrm{CO}_{2}$ que se hubieran tenido de haber seguido utilizando las calderas de gas natural originales sin el apoyo de la red de calor.

Tabla 211. Estimación del ahorro de emisiones de CO2 para el Edificio D3.

\begin{tabular}{|c|c|c|c|c|c|c|c|c|c|c|}
\hline & $\begin{array}{l}\text { kWh_D3 } \\
\text { Gas } \\
\text { Natural }\end{array}$ & $\begin{array}{l}\text { kWh_D3 } \\
\text { Biomasa }\end{array}$ & $\begin{array}{l}\text { kWh_D3 } \\
\text { Real Total }\end{array}$ & $\begin{array}{l}\text { kWh_D3 } \\
\text { Predicho }\end{array}$ & $\begin{array}{l}\text { kg CO2 Real } \\
\text { debido al } \\
\text { consumo de } \\
\text { Gas Natural }\end{array}$ & $\begin{array}{l}\text { kg CO2 } \\
\text { Real } \\
\text { debido a } \\
\text { Biomasa }\end{array}$ & $\begin{array}{l}\text { kg CO2 } \\
\text { Real } \\
\text { debido al } \\
\text { consumo } \\
\text { TOTAL }\end{array}$ & $\begin{array}{c}\text { kg CO2 } \\
\text { que se } \\
\text { hubiera } \\
\text { tenido } \\
\text { debido a } \\
\text { Gas } \\
\text { Natural }\end{array}$ & $\begin{array}{l}\text { Ahorro de } \\
\text { kg CO2 }\end{array}$ & $\begin{array}{l}\text { Ahorro de kg } \\
\text { CO2 } \\
\text { acumulado }\end{array}$ \\
\hline oct-2015 & 0 & 0 & 0 & 11.827 & 0 & 0 & 0 & 2.980 & 2.980 & 2.980 \\
\hline nov-2015 & 0 & 28.683 & 28.683 & 33.257 & 0 & 688 & 688 & 8.381 & 7.692 & 10.673 \\
\hline dic-2015 & 0 & 50.191 & 50.191 & 50.916 & 0 & 1.205 & 1.205 & 12.831 & 11.626 & 22.299 \\
\hline ene-2016 & 0 & 38.231 & 38.231 & 45.495 & 0 & 918 & 918 & 11.465 & 10.547 & 32.846 \\
\hline feb-2016 & 24.492 & 43.938 & 68.430 & 44.423 & 6.172 & 1.055 & 7.226 & 11.195 & 3.968 & 36.814 \\
\hline mar-2016 & 666 & 41.109 & 41.775 & 46.343 & 168 & 987 & 1.154 & 11.678 & 10.524 & 47.338 \\
\hline abr-2016 & 2.038 & 22.617 & 24.655 & 27.998 & 513 & 543 & 1.056 & 7.055 & 5.999 & 53.337 \\
\hline may-2016 & 0 & 7.268 & 7.268 & 12.268 & 0 & 174 & 174 & 3.092 & 2.917 & 56.254 \\
\hline oct-2016 & 3.032 & 679 & 3.711 & 11.883 & 764 & 16 & 780 & 2.995 & 2.214 & 58.469 \\
\hline nov-2016 & 11.777 & 23.675 & 35.452 & 40.443 & 2.968 & 568 & 3.536 & 10.192 & 6.656 & 65.124 \\
\hline dic-2016 & 10.865 & 34.750 & 45.615 & 58.069 & 2.738 & 834 & 3.572 & 14.633 & 11.061 & 76.186 \\
\hline ene-2017 & 0 & 47.454 & 47.454 & 67.643 & 0 & 1.139 & 1.139 & 17.046 & 15.907 & 92.093 \\
\hline feb-2017 & 3.368 & 29.736 & 33.104 & 36.799 & 849 & 714 & 1.562 & 9.273 & 7.711 & 99.804 \\
\hline mar-2017 & 1.704 & 24.475 & 26.179 & 32.257 & 429 & 587 & 1.017 & 8.129 & 7.112 & 106.916 \\
\hline abr-2017 & 1.216 & 15.456 & 16.672 & 18.118 & 306 & 371 & 677 & 4.566 & 3.888 & 110.804 \\
\hline may-2017 & 856 & 11.266 & 12.122 & 3.706 & 216 & 270 & 486 & 934 & 448 & 111.252 \\
\hline oct-2017 & 0 & 4.697 & 4.697 & 10.917 & 0 & 113 & 113 & 2.751 & 2.638 & 113.890 \\
\hline nov-2017 & 0 & 37.870 & 37.870 & 45.431 & 0 & 909 & 909 & 11.449 & 10.540 & 124.430 \\
\hline dic-2017 & 0 & 48.468 & 48.468 & 58.840 & 0 & 1.163 & 1.163 & 14.828 & 13.665 & 138.094 \\
\hline ene-2018 & 0 & 48.828 & 48.828 & 56.277 & 0 & 1.172 & 1.172 & 14.182 & 13.010 & 151.104 \\
\hline feb-2018 & 0 & 48.728 & 48.728 & 54.992 & 0 & 1.169 & 1.169 & 13.858 & 12.688 & 163.793 \\
\hline mar-2018 & 0 & 28.432 & 28.432 & 42.239 & 0 & 682 & 682 & 10.644 & 9.962 & 173.754 \\
\hline abr-2018 & 0 & 19.765 & 19.765 & 20.733 & 0 & 474 & 474 & 5.225 & 4.750 & 178.505 \\
\hline may-2018 & 0 & 13.337 & 13.337 & 2.392 & 0 & 320 & 320 & 603 & 283 & 178.787 \\
\hline
\end{tabular}

En estas tres temporadas se ha obtenido un ahorro total de 179 Toneladas de $\mathrm{CO}_{2}$ 
Anexo IV. Desarrollo del análisis de los edificios del Campus Miguel Delibes

AIV.3.6. Estimación del ahorro económico previsible.

Tomando como referencia los precios del gas natural de la Tabla 212 para cada temporada, obtenidos a partir de los datos establecidos en el Capítulo 3, donde se tiene en cuenta el precio por el termino variable y fijo; se puede realizar la estimación del precio máximo de compra de la energía útil a la red de calor para obtener un $0 \%$ de ahorro y un $15 \%$ de ahorro. La Tabla 213, muestral el precio que se pagaría para un ahorro del $15 \%$

Tabla 212. Precios de referencia para Gas natural y Astilla

\begin{tabular}{|c|c|c|c|c|}
\hline Precios (€/(kWh) & 2015 & 2016 & 2017 & 2018 \\
\hline Gas Natural & 0,0373 & 0,0306 & 0,0314 & 0,0336 \\
\hline Astilla & 0,0277 & 0,0256 & 0,0254 & 0,0239 \\
\hline $\begin{array}{l}€ / \text { kWh útiles máximos de compra a la red para } \\
\text { un ahorro del } 0,0 \%\end{array}$ & \multicolumn{4}{|c|}{0,0374} \\
\hline $\begin{array}{l}€ / \text { kWh útiles máximos de compra a la red para } \\
\text { un ahorro del } 15,0 \%\end{array}$ & \multicolumn{4}{|c|}{0,0314} \\
\hline
\end{tabular}

Tabla 213. Ahorro Económico por el consumo térmico en el Edificio D3

\begin{tabular}{|c|c|c|c|c|c|c|c|c|c|c|}
\hline & $\begin{array}{c}\text { kWh_D3 } \\
\text { _Gas } \\
\text { Natural }\end{array}$ & $\begin{array}{l}\text { kWh_D3_- } \\
\text { Biomasa }\end{array}$ & $\begin{array}{c}\text { kWh_D3 } \\
\text { Real }\end{array}$ & $\begin{array}{c}\text { kWh_D3 } \\
\text { Pronosticado }\end{array}$ & $\begin{array}{c}\text { Real } \\
\text { Gas } \\
\text { Natural }\end{array}$ & $\begin{array}{c}€ \text { Real } \\
\text { Biomasa }\end{array}$ & $\begin{array}{l}€ \text { Real } \\
\text { Total }\end{array}$ & $\begin{array}{c}\text { € predicho } \\
\text { Gas } \\
\text { natural }\end{array}$ & $\begin{array}{c}€ \\
\text { Ahorro }\end{array}$ & $€$ Acumulado \\
\hline oct-2015 & 0 & 0 & 0 & 11.827 & 0 & 0 & 0 & 441 & 441 & 441 \\
\hline nov-2015 & 0 & 28.683 & 28.683 & 33.257 & 0 & 901 & 901 & 1.240 & 340 & 781 \\
\hline dic-2015 & 0 & 50.191 & 50.191 & 50.916 & 0 & 1.576 & 1.576 & 1.899 & 323 & 1.104 \\
\hline ene-2016 & 0 & 38.231 & 38.231 & 45.495 & 0 & 1.200 & 1.200 & 1.392 & 192 & 1.296 \\
\hline feb-2016 & 24.492 & 43.938 & 68.430 & 44.423 & 749 & 1.380 & 2.129 & 1.359 & -770 & 526 \\
\hline mar-2016 & 666 & 41.109 & 41.775 & 46.343 & 20 & 1.291 & 1.311 & 1.418 & 107 & 633 \\
\hline abr-2016 & 2.038 & 22.617 & 24.655 & 27.998 & 62 & 710 & 773 & 857 & 84 & 717 \\
\hline may-2016 & 0 & 7.268 & 7.268 & 12.268 & 0 & 228 & 228 & 375 & 147 & 864 \\
\hline oct-2016 & 3.032 & 679 & 3.711 & 11.883 & 93 & 21 & 114 & 364 & 250 & 1.114 \\
\hline nov-2016 & 11.777 & 23.675 & 35.452 & 40.443 & 360 & 743 & 1.104 & 1.238 & 134 & 1.248 \\
\hline dic-2016 & 10.865 & 34.750 & 45.615 & 58.069 & 332 & 1.091 & 1.424 & 1.777 & 353 & 1.601 \\
\hline ene-2017 & 0 & 47.454 & 47.454 & 67.643 & 0 & 1.490 & 1.490 & 2.124 & 634 & 2.235 \\
\hline feb-2017 & 3.368 & 29.736 & 33.104 & 36.799 & 106 & 934 & 1.039 & 1.155 & 116 & 2.351 \\
\hline mar-2017 & 1.704 & 24.475 & 26.179 & 32.257 & 54 & 769 & 822 & 1.013 & 191 & 2.542 \\
\hline abr-2017 & 1.216 & 15.456 & 16.672 & 18.118 & 38 & 485 & 524 & 569 & 45 & 2.587 \\
\hline may-2017 & 856 & 11.266 & 12.122 & 3.706 & 27 & 354 & 381 & 116 & -264 & 2.323 \\
\hline oct-2017 & 0 & 4.697 & 4.697 & 10.917 & 0 & 147 & 147 & 343 & 195 & 2.518 \\
\hline nov-2017 & 0 & 37.870 & 37.870 & 45.431 & 0 & 1.189 & 1.189 & 1.427 & 237 & 2.756 \\
\hline dic-2017 & 0 & 48.468 & 48.468 & 58.840 & 0 & 1.522 & 1.522 & 1.848 & 326 & 3.081 \\
\hline ene-2018 & 0 & 48.828 & 48.828 & 56.277 & 0 & 1.533 & 1.533 & 1.891 & 358 & 3.439 \\
\hline feb-2018 & 0 & 48.728 & 48.728 & 54.992 & 0 & 1.530 & 1.530 & 1.848 & 318 & 3.757 \\
\hline mar-2018 & 0 & 28.432 & 28.432 & 42.239 & 0 & 893 & 893 & 1.419 & 526 & 4.283 \\
\hline abr-2018 & 0 & 19.765 & 19.765 & 20.733 & 0 & 621 & 621 & 697 & 76 & 4.359 \\
\hline may-2018 & 0 & 13.337 & 13.337 & 2.392 & 0 & 419 & 419 & 80 & -338 & 4.021 \\
\hline$€$ Total & & & & & & & 22.869 & 26.890 & & \\
\hline Ahorro (\%) & & & & & & & & & & $15,0 \%$ \\
\hline
\end{tabular}




\section{AIV.4.Edificio D4. Biblioteca Aulario Miguel Delibes.}

\section{AIV.4.1.Obtención de la línea base de referencia energética}

Los datos de partida para la obtención de la línea base de referencia se muestran en la Tabla 214

Tabla 214. Consumos térmicos del edificio D4

\begin{tabular}{lr}
\hline & Consumos térmicos (kWh). D4 \\
\hline oct-12 & 38.678 \\
\hline nov-12 & 195.712 \\
\hline dic-12 & 176.685 \\
\hline ene-13 & 191.773 \\
\hline feb-13 & 201.662 \\
\hline mar-13 & 143.416 \\
\hline abr-13 & 118.693 \\
\hline may-13 & 57.071 \\
\hline oct-13 & 51.998 \\
\hline nov-13 & 103.055 \\
\hline dic-13 & 225.143 \\
\hline ene-14 & 153.040 \\
\hline feb-14 & 201.660 \\
\hline mar-14 & 116.269 \\
\hline abr-14 & 53.303 \\
\hline may-14 & 32.040 \\
\hline Promedio & 128.762 \\
\hline Total (oct-12-may-13) & 1.123 .690 \\
\hline Total (oct-13-may-14) & 936.508 \\
\hline Total (oct-12-may-13) & 2.060 .198 \\
\hline
\end{tabular}

Se disponen de 16 datos para establecer el modelo de regresión, mediante el método de pasos sucesivos. Como se puede ver en la Tabla 215 para el edificio, el método ofrece un modelo de regresión, con una sola variable (Temperatura media). El modelo fue construido con un solo paso, incluyendo la temperatura media por ser la variable más significativa (variable con menor valor de Sig $=0,000$ ). El resto de las variables como se observa en la Tabla 216 fueron excluidas del modelo al tener valores de sig >0,05.

Tabla 215. Modelos de regresión del Edificio D4

\begin{tabular}{|c|c|c|c|c|c|c|c|}
\hline & \multirow{2}{*}{ Modelo } & \multicolumn{2}{|c|}{$\begin{array}{l}\text { Coeficientes no } \\
\text { estandarizados }\end{array}$} & \multirow{2}{*}{$\mathrm{t}$} & \multirow{2}{*}{ Sig. } & \multicolumn{2}{|c|}{$\begin{array}{c}\text { Intervalo de confianza de } \\
95,0 \% \text { para B } \\
\end{array}$} \\
\hline & & B & Error típ. & & & $\begin{array}{l}\text { Límite } \\
\text { inferior }\end{array}$ & $\begin{array}{c}\text { Límite } \\
\text { superior }\end{array}$ \\
\hline \multirow[t]{2}{*}{1} & (Constante) & 271046,123 & 14946,471 & 18,134 &, 000 & 238989,131 & 303103,116 \\
\hline & T_med & $-17453,026$ & 1686,482 & $-10,349$ & ,000 & $-21070,171$ & $-13835,881$ \\
\hline
\end{tabular}


En la Figura 223 se representa el modelo de regresión con sus límites inferior y superior para un nivel de confianza del $95 \%$

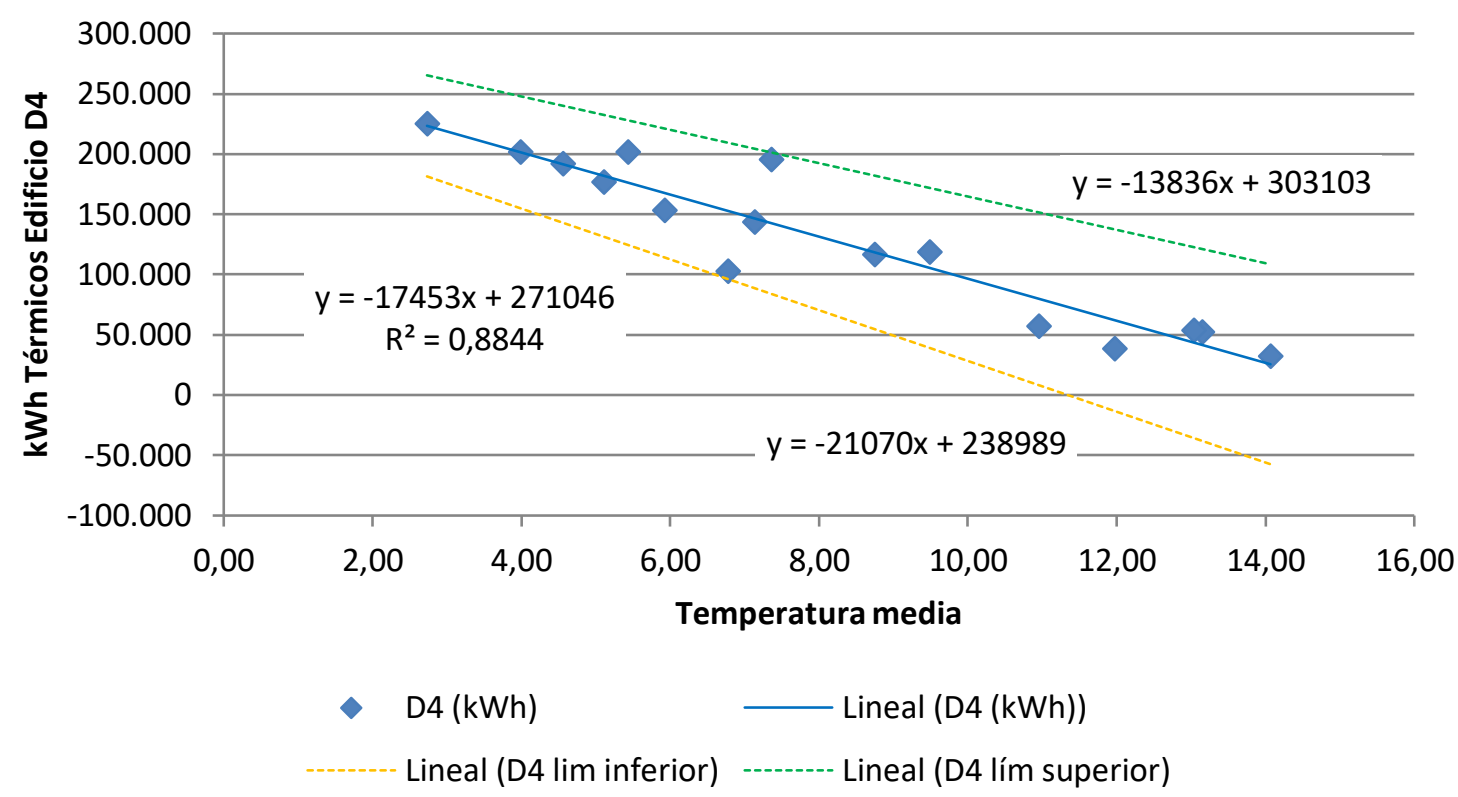

Figura 223. Representación del modelo de regresión lineal simple para el Edificio D4

Tabla 216. Variables excluidas del modelo de región del Edificio D4

\begin{tabular}{|c|c|c|c|c|}
\hline & Modelo & $\mathrm{t}$ & Sig. & Correlación parcial \\
\hline & GD15_30min &,- 783 & , 448 &,- 212 \\
\hline & GD20_30min &,- 996 & ,338 &,- 266 \\
\hline & GD15_24h &,- 910 & ,380 &,- 245 \\
\hline & GD20_24h & $-1,028$ & ,322 &,- 274 \\
\hline & T_media_diurna &,- 302 & ,767 &,- 083 \\
\hline & T_max &,- 250 & 807 &,- 069 \\
\hline & T_min &, 250 & 807 & 069 \\
\hline & HR_\% & ,241 & ,813 & ,067 \\
\hline & HR_med_diurna_\% & ,306 & ,765 & ,084 \\
\hline \multirow[t]{10}{*}{1} & HR_max_\% & 019 & ,985 &, 005 \\
\hline & HR_min_\% & 150 & ,883 & ,041 \\
\hline & Radiación_W/m2 & 007 & ,994 &, 002 \\
\hline & V_Viento_m/s & ,439 & ,668 & ,121 \\
\hline & V_viento_diurna_m/s & ,491 & 632 & ,135 \\
\hline & V_viento_nocturna_m/s & ,315 & ,758 & ,087 \\
\hline & V_viento_max_m/s & ,463 & ,651 & ,127 \\
\hline & Recorrido_viento_km/día & ,438 & ,668 & ,121 \\
\hline & Precipitación_acumulada_mes_mm & ,775 & ,452 & ,210 \\
\hline & Horas insolación_h &,- 066 & ,948 &,- 018 \\
\hline
\end{tabular}


La bondad de los modelos de regresión obtenidos para el edificio D4, se resumen en la Tabla 217

Tabla 217. Resumen de la bondad de los modelos de regresión para el Edificio D4

\begin{tabular}{ccccc}
\hline Modelo & $\mathrm{R}$ & $\mathrm{R}$ cuadrado & $\mathrm{R}$ cuadrado corregida & $\begin{array}{c}\text { Error típ. de la } \\
\text { estimación }\end{array}$ \\
\hline 1 &,- 940 &, 888 &, 876 & 23449,05332 \\
\hline
\end{tabular}

Se observa como el modelo de regresión lineal simple presenta un Coeficiente de Correlación de Pearson ( $R$ ) de -0,94, lo que indica que las variables están correlacionadas de manera muy fuerte (en la correlación perfecta $R= \pm 1$ ). La correlación que se produce es inversa, al aumentar el valor de la Temperatura media, disminuye el consumo térmico.

El coeficiente de determinación $\left(R^{2}\right)$, nos indica que con el modelo se podría explicar el $88,8 \%$ de los datos reales obtenidos aceptando un error del $5 \%$.

El error típico de la estimación que nos indica la magnitud de los errores, es decir la parte de la variable dependiente que dejamos sin explicar con el modelo y que describe la variación de la variable respuesta (el Consumo) respecto a la recta de regresión, es de $23.449 \mathrm{kWh}$, lo que representa un $18,2 \%$ del promedio de los consumos que fue de $128.762 \mathrm{kWh}$.

\section{AIV.4.2. Verificación del cumplimiento de los supuestos estadísticos}

Las condiciones que se deben cumplir en un modelo de regresión son:

\section{- Linealidad de las variables, las variables se encuentran relacionadas de forma lineal.}

Como se observa en la Tabla 215, la pendiente (B), obtuvo un valor de Sig =0,000, que al ser $\leq 0,05$, nos indica que podemos rechazar la hipótesis nula de pendiente igual a cero y nos da la evidencia de linealidad entre la variable dependiente ( $k W h$ del edificio $\mathrm{D} 4$ ) y la independiente (Temperatura media). Al ser el valor de la pendiente negativa, indica una relación inversa entre el consumo y la Temperatura media.

- Normalidad. Todos los valores obtenidos para la variable dependiente (Y), deben estar distribuidos normalmente en cada valor de la variable independiente $(X)$.

Se comprueba la normalidad de las variables y de los residuos mediante el Test de Shapiro - Wilk para muestras pequeñas, siendo la hipótesis nula el que la distribución es Normal. 
La Tabla 218, muestra la prueba de normalidad de Shapiro-Wilk y cómo tanto la variable dependiente (consumos del Edificio), como la variable independientes: Temperatura media poseen una Sig $>0,05$, por lo que aceptamos la hipótesis nula de Normalidad de las variables

Tabla 218. Prueba de normalidad para el edificio D4

\begin{tabular}{lccccccr}
\hline & \multicolumn{3}{c}{ Kolmogorov-Smirnov } & \multicolumn{3}{c}{ Shapiro-Wilk } \\
\cline { 2 - 8 } & Estadístico & gl & Sig. & Estadístico & gl & Sig. \\
\hline kWh_D4 &, 172 & 16 &, 200 &, 910 & 16 &, 116 \\
\hline T_med &, 150 & 16 &, 200 &, 942 & 16 &, 375 \\
\hline
\end{tabular}

- Independencia de los errores. Los errores asociados a los valores de la variable respuesta $(\mathrm{Y})$ deberán ser independientes unos de otros.

Para la comprobación se utiliza el estadístico de Durbin -Watson.

Se comprueba que el Estadístico de Durbin Watson para el nivel de significancia del 5\%, y para el tamaño de la muestra " $n$ " y el número de variables independientes del modelo " $k$ ", se encuentra en el intervalo [dU, 4-dU], de la Tabla 3, intervalo centrado en el 2, que indica la ausencia de autocorrelación.

El valor del Estadístico Durbin-Watson facilitado por el programa SPSS, es 2,735.

En el modelo, $n=16$ y $\mathrm{k}=1$, según la Tabla 3 el valor $\mathrm{dU}=1,371$ y dL =1,106, luego el intervalo que marca la ausencia de correlación es [1,371, 2,629].

Los intervalos $[0,1,106]$ y $[2,896,4]$ indican correlación positiva o negativa respectivamente y las zonas $[1,106,1,371]$ y $[2,629,2,896]$ son zonas no concluyentes; como el valor del estadístico 2,735 está dentro del último intervalo no concluyente, se comprueba la ausencia de autocorrelación, mediante el gráfico de residuos frente al tiempo.

La Figura 224, muestra que la relación entre los residuos y el tiempo, posee un coeficiente de determinación $=0,002$, también prácticamente nulo; por lo que se concluye que no existe autocorrelación en los residuos. 


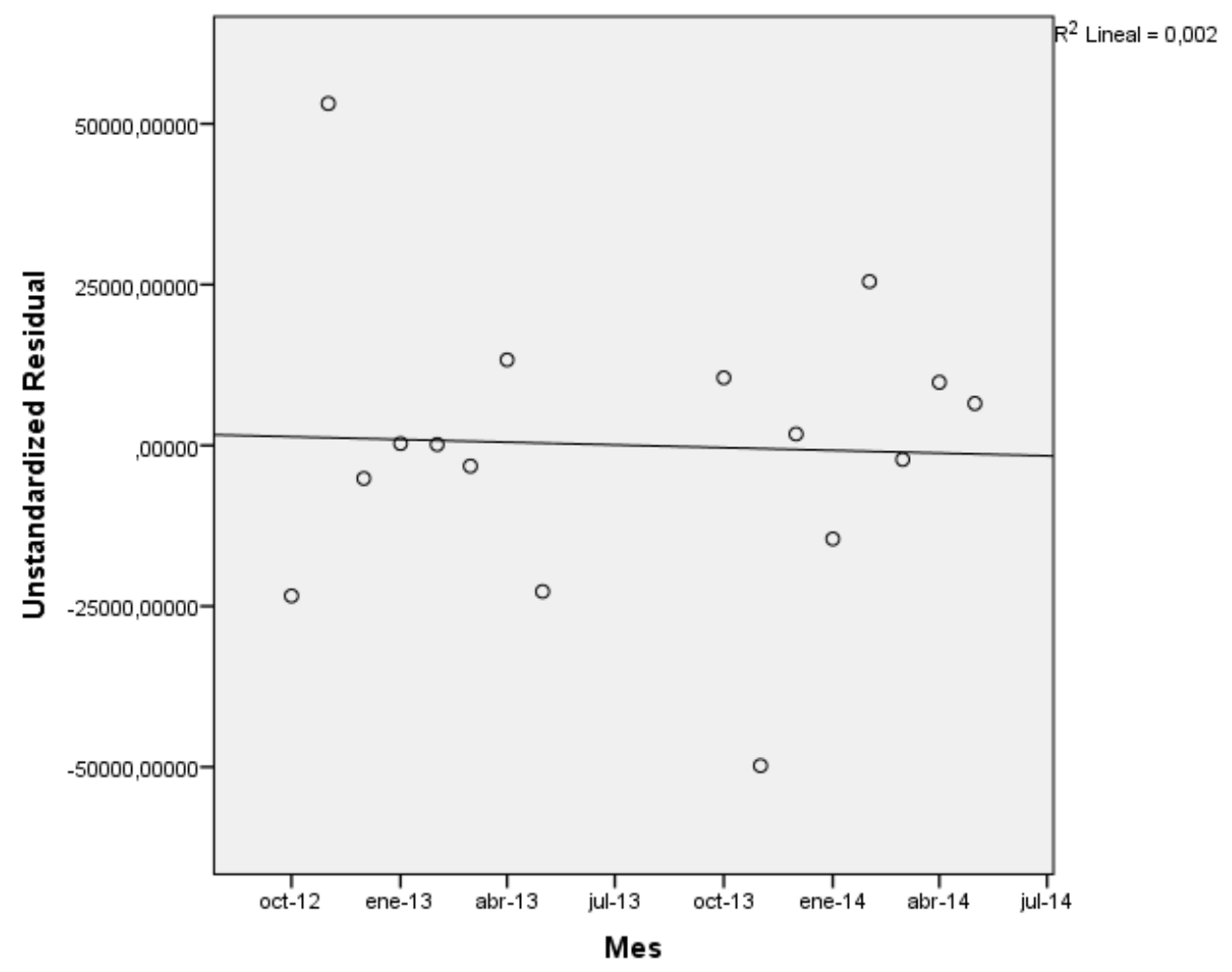

Figura 224. Relación entre los residuos y el tiempo en el Edificio D4

- Homocedasticidad de la varianza. Se pretende comprobar que la varianza de los errores $\left(\sigma^{2}\right)$ es constante para cualquier valor de la variable independiente $(X)$, es decir que el valor medio del cuadrado de la desviación de los errores respecto a su media es constante.

Esta condición indica que no existe correlación entre los residuos y los pronósticos. Se comprueba que el coeficiente de determinación $\mathrm{R}^{2}$, en las relaciones: residuos $\mathrm{y}$ predicciones y entre residuos y variable independiente es nulo o muy próximo a cero, lo que indicará que no existe ningún tipo de correlación en los residuos y que éstos son aleatorios.

Se grafican los diagramas de dispersión de esas relaciones, comprobando que se corresponden a nubes de puntos totalmente aleatorias, sin tendencias ni patrones en sus representaciones gráficas.

Las Figura 225 y Figura 226, muestran que la relación entre los pronósticos y los residuos, posee un coeficiente de determinación $=0 \mathrm{y}$ entre la variable independiente (Temperatura media) y los residuos un coeficiente de determinación, también de 0; por lo que se concluye que no existe ningún tipo de correlación en los residuos y que éstos son aleatorios, siendo la varianza de los residuos constante 


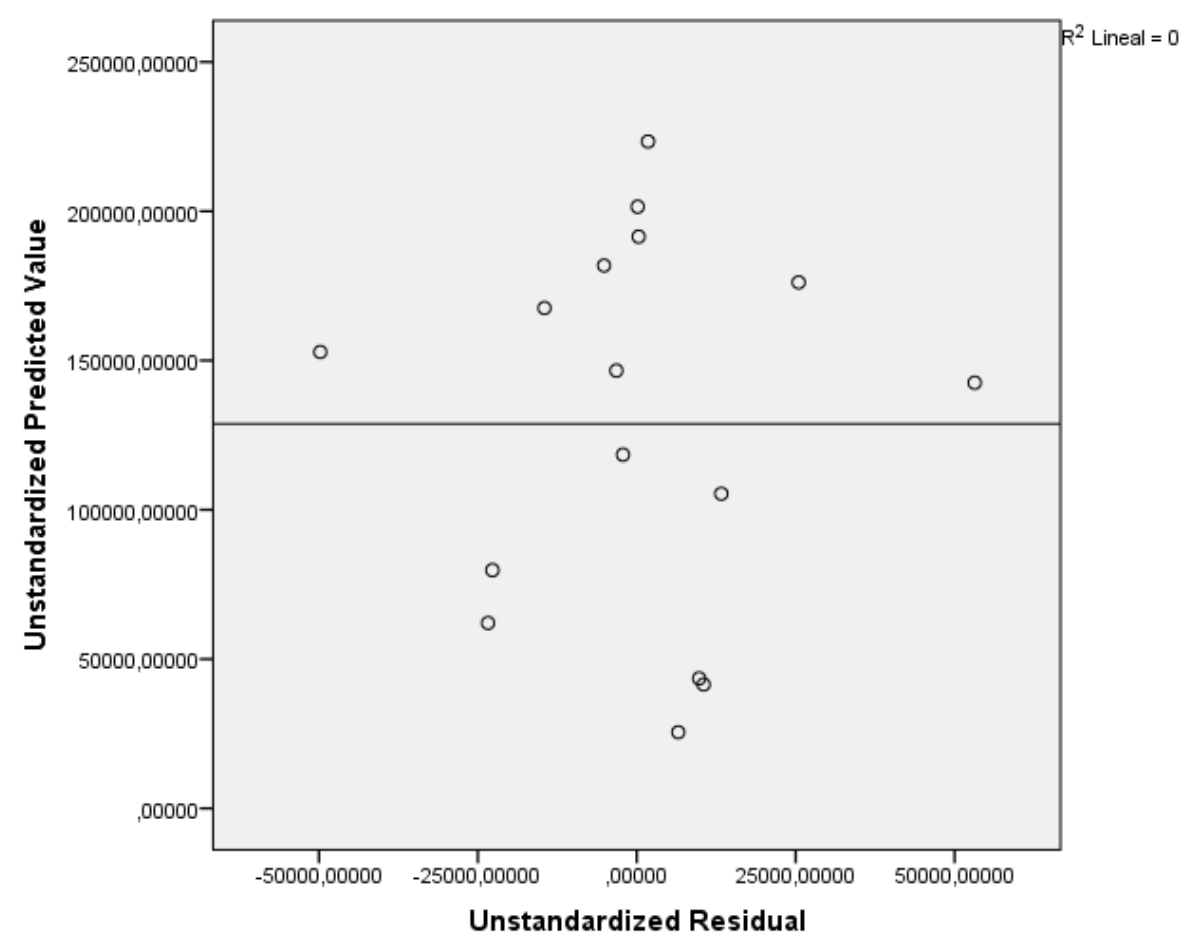

Figura 225. Relación entre los pronósticos y los residuos en el Edificio D4

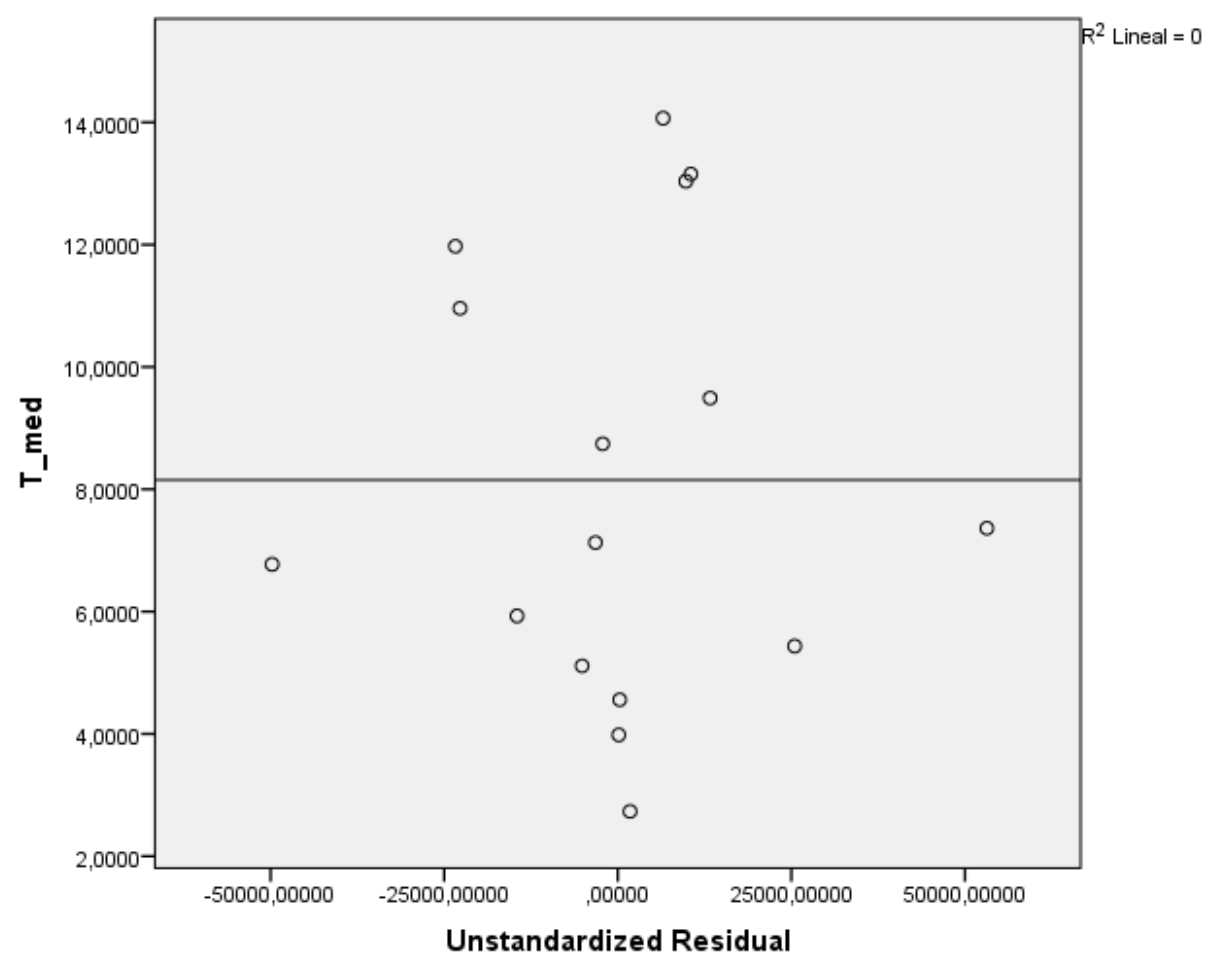

Figura 226. Relación entre Temperatura media y los residuos en el Edificio D4 


\section{AIV.4.3. Obtención de los consumos térmicos previstos}

Una vez comprobado el cumplimiento de los supuestos estadísticos se acepta el modelo de línea base encontrado para modelizar el consumo del Edificio D4.

$$
\text { kWh_D4_Pronosticado }=271.046,123-17.453,026 \times \text { T_med }
$$

Con este modelo se procede a predecir los consumos previstos para las temporadas: octubre 2015-mayo 2016, octubre 2016 - mayo 2017 y octubre 2017-mayo 2018, estos consumos se muestran en la Tabla 219, donde "KWh_D4_Real", representa el consumo real, "kWh_D4_Pronosticado", el consumo pronosticado con el Modelo. Se prescinde del valor pronosticado para mayo de 2017, por ser un valor imposible, en el estudio de diferencias significativas

Tabla 219. Consumos previstos octubre 2014 - mayo 2017 para el edificio D4.

\begin{tabular}{rrrr}
\hline & T_med & kWh_D4_Real & kWh_D4_Pronosticado \\
\hline oct-15 & 12,82 & 30.770 & 47.321 \\
\hline nov-15 & 8,30 & 117.720 & 126.145 \\
\hline dic-15 & 5,33 & 91.520 & 178.044 \\
\hline ene-16 & 6,23 & 116.430 & 162.252 \\
\hline feb-16 & 5,82 & 195.806 & 169.536 \\
\hline mar-16 & 6,14 & 132.677 & 163.834 \\
\hline abr-16 & 9,10 & 91.374 & 112.212 \\
\hline may-16 & 13,11 & 30.726 & 42.164 \\
\hline oct-16 & 13,48 & 28.123 & 35.774 \\
\hline nov-16 & 6,90 & 138.294 & 150.591 \\
\hline dic-16 & 4,12 & 115.985 & 199.106 \\
\hline ene-17 & 2,52 & 231.678 & 227.132 \\
\hline feb-17 & 6,96 & 137.936 & 149.579 \\
\hline mar-17 & 9,21 & 104.060 & 110.315 \\
\hline abr-17 & 12,58 & 61.046 & 51.539 \\
\hline may-17 & 16,69 & 22.428 & -20.189 \\
\hline oct-17 & 14,71 & 9.706 & 14.290 \\
\hline nov-17 & 6,09 & 133.130 & 164.751 \\
\hline dic-17 & 3,99 & 159.080 & 201.386 \\
\hline ene-18 & 4,42 & 188.850 & 193.892 \\
\hline feb-18 & 3,53 & 198.442 & 209.462 \\
\hline mar-18 & 6,80 & 160.912 & 152.321 \\
\hline abr-18 & 11,15 & 70.510 & 76.509 \\
\hline may-18 & 14,03 & 34.320 & 26.220 \\
\hline & & &
\end{tabular}




\section{AIV.4.4. Estudio de la existencia de diferencias significativas}

Utilizando la prueba " $\mathrm{t}$ " de Student para muestras relacionadas, podemos concluir que si las variables se distribuyen según una normal y la significación estadística resulta $\leq 0,05$, existen diferencias significativas, con un nivel de confianza del 95\%

A continuación se muestra la comparación de medias realizada para cada uno de los tres periodos posteriores a la construcción de la red y para el periodo total hasta mayo de 2018.

Para la temporada Octubre 2015 - Mayo 2016, se comprueba mediante el Test de Shapiro -Wilk que tanto los valores reales como los pronosticados se distribuyen según una Normal puesto que en todos los casos los valores de Sig $>0,05$, como se observa en la Tabla 220

Tabla 220. Prueba de Normalidad temporada Octubre 2015-Mayo 2016. Edificio D4

\begin{tabular}{ccccrrrr}
\hline & \multicolumn{3}{c}{ Kolmogorov-Smirnov $^{\mathrm{a}}$} & \multicolumn{3}{c}{ Shapiro-Wilk } \\
\cline { 2 - 9 } & Estadístico & gl & \multicolumn{1}{c}{ Sig. } & Estadístico & gl & Sig. \\
\hline kWh_real &, 180 & 8 &, 200 &, 928 & 8 &, 498 \\
\hline kWh_pronosticado &, 252 & 8 &, 144 &, 839 & 8 &, 073 \\
\hline
\end{tabular}

En la Tabla 221, se observa como las medias de los consumos pronosticados, son superiores a las medias de los consumos reales del Edificio D4, en un $24,1 \%$

Tabla 221. Estadísticos de muestras relacionadas. Octubre 2015-Mayo 2016. Edificio D4

\begin{tabular}{lccccc}
\hline & Media & $\begin{array}{c}\text { \% Diferencia } \\
\text { entre medias }\end{array}$ & $\mathrm{N}$ & $\begin{array}{c}\text { Desviación } \\
\text { típ. }\end{array}$ & $\begin{array}{c}\text { Error típ. de } \\
\text { la media }\end{array}$ \\
\hline kWh_real & 100877,8750 & & 8 & 54198,51369 & 19162,06828 \\
\hline kWh_pronosticado & 125188,5000 & $24,1 \%$ & 8 & 54449,58604 & 19250,83576 \\
\hline
\end{tabular}

La Tabla 222 muestra que las diferencias entre las medias no son significativas entre los consumos reales y los pronosticados (sig $>0,05$ ), a pesar de existir ese $24,1 \%$ de diferencia

Tabla 222. Prueba de muestras relacionadas. Octubre 2015-Mayo 2016. Edificio D4

\begin{tabular}{|c|c|c|c|c|c|c|c|c|c|}
\hline & & \multicolumn{5}{|c|}{ Diferencias relacionadas } & \multirow{3}{*}{$\mathrm{t}$} & \multirow{3}{*}{ gl } & \multirow{3}{*}{$\begin{array}{c}\text { Sig. } \\
\text { (bilateral) }\end{array}$} \\
\hline & & \multirow[t]{2}{*}{ Media } & \multirow{2}{*}{$\begin{array}{l}\text { Desviación } \\
\text { típ. }\end{array}$} & \multirow{2}{*}{$\begin{array}{l}\text { Error típ. } \\
\text { de la media }\end{array}$} & \multicolumn{2}{|c|}{$\begin{array}{l}\text { 95\% Intervalo de confianza } \\
\text { para la diferencia }\end{array}$} & & & \\
\hline & & & & & Inferior & Superior & & & \\
\hline Par 1 & $\begin{array}{c}\text { kWh_real - } \\
\text { kWh_pronosticado }\end{array}$ & $-24310,625$ & 32577,039 & 11517,722 & $-51545,711$ & 2924,461 & $-2,111$ & 7 & ,073 \\
\hline
\end{tabular}


En la Figura 227, se grafican los consumos reales y pronosticados para la temporada Octubre 2015 - Mayo 2016 para el Edificio D4, y las medias de dichos consumos. Según la prueba paramétrica realizada las diferencias encontradas no son estadísticamente significativas, por lo que no se puede afirmar la existencia de ahorros en el consumo térmico entre la situación anterior y posterior a la red de calor, con un riesgo a estar equivocados del $5 \%$

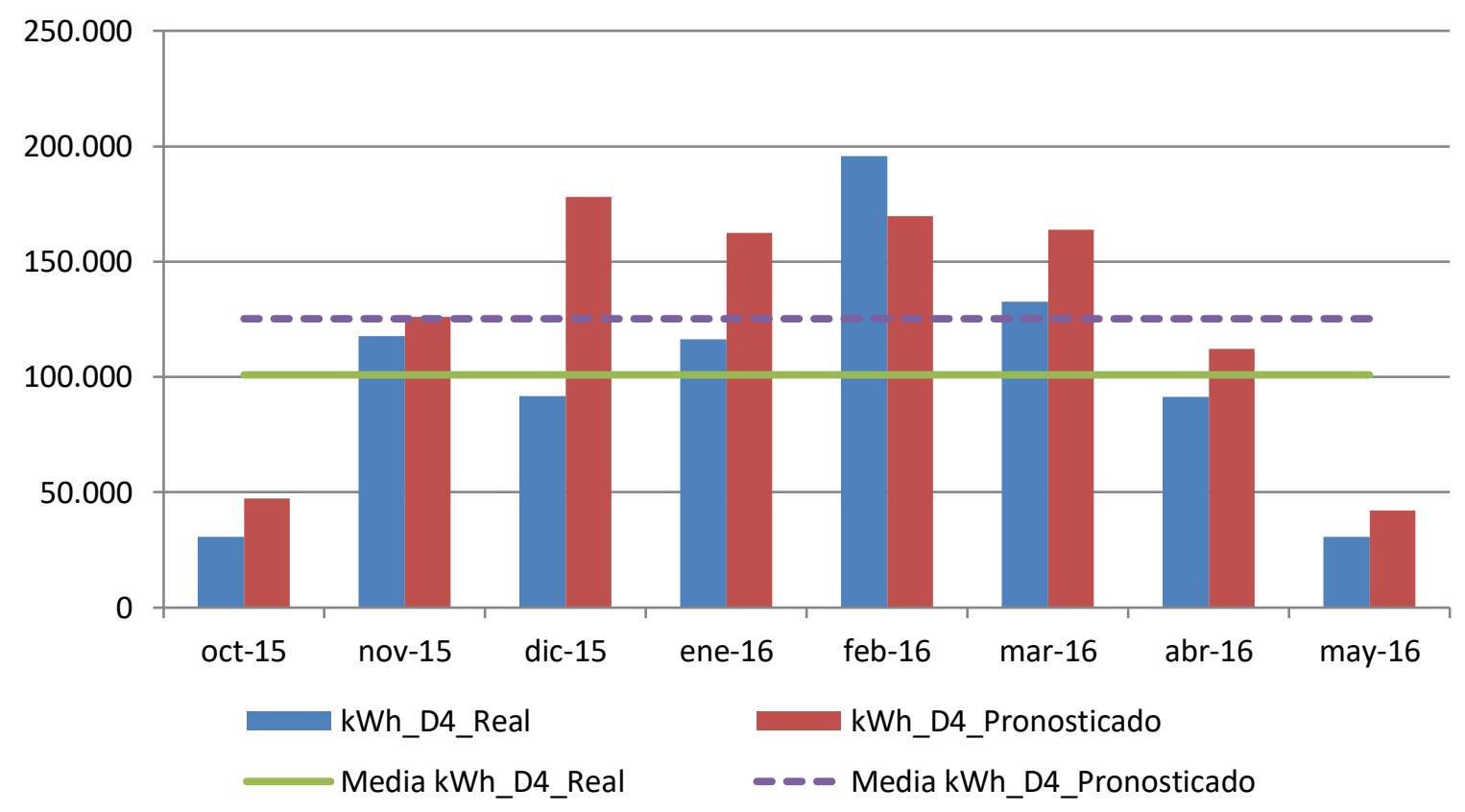

Figura 227. Consumos reales y pronosticados Octubre 2015-Mayo 2016. Edificio D4

Para la temporada Octubre 2016 - Abril 2017, se comprueba mediante el Test de Shapiro -Wilk que tanto los valores reales como los pronosticados con los dos modelos se distribuyen según una Normal puesto que en todos los casos los valores de Sig >0,05, como se observa en la Tabla 223. El número de datos disponibles son 7 , dado que el pronóstico para mayo de 2017 , resultó un dato negativo.

Tabla 223. Prueba de Normalidad temporada Octubre 2016-Abril 2017. Edificio D4

\begin{tabular}{cccccrrr}
\hline & \multicolumn{3}{c}{ Kolmogorov-Smirnov $^{\mathrm{a}}$} & \multicolumn{4}{c}{ Shapiro-Wilk } \\
\cline { 2 - 8 } & Estadístico & gl & Sig. & Estadístico & gl & \multicolumn{1}{c}{ Sig. } \\
\hline kWh_real &, 227 & 7 &, 200 &, 952 & 7 &, 749 \\
\hline kWh_pronosticado &, 169 & 7 &, 200 &, 946 & 7 &, 695 \\
\hline
\end{tabular}

En la Tabla 224, se observa como las medias de los consumos pronosticados, son superiores a las medias de los consumos reales del Edificio D4, en un 13,1\% 
Anexo IV. Desarrollo del análisis de los edificios del Campus Miguel Delibes

Tabla 224. Estadísticos de muestras relacionadas. Octubre 2016-Abril 2017. Edificio D4

\begin{tabular}{lccrcc}
\hline & Media & $\begin{array}{c}\text { \% Diferencia } \\
\text { entre medias }\end{array}$ & $\mathrm{N}$ & $\begin{array}{c}\text { Desviación } \\
\text { típ. }\end{array}$ & $\begin{array}{c}\text { Error típ. de } \\
\text { la media }\end{array}$ \\
\hline kWh_real & 116731,7143 & & 7 & 64859,76596 & 24514,68726 \\
\hline kWh_pronosticado & 132005,1429 & $13,1 \%$ & 7 & 71194,11705 & 26908,84693 \\
\hline
\end{tabular}

La Tabla 225 muestra que las diferencias entre las medias no son significativas entre los consumos reales y los pronosticados (sig $>0,05$ ), a pesar de existir ese $13,1 \%$ de diferencia

Tabla 225. Prueba de muestras relacionadas. Octubre 2016-Abril 2017. Edificio D4

\begin{tabular}{|c|c|c|c|c|c|c|c|c|c|}
\hline & & \multicolumn{5}{|c|}{ Diferencias relacionadas } & \multirow{3}{*}{$\mathrm{t}$} & \multirow{3}{*}{ gl } & \multirow{3}{*}{$\begin{array}{c}\text { Sig. } \\
\text { (bilateral) }\end{array}$} \\
\hline & & \multirow{2}{*}{ Media } & \multirow{2}{*}{$\begin{array}{l}\text { Desviación } \\
\text { típ. }\end{array}$} & \multirow{2}{*}{$\begin{array}{c}\text { Error típ. } \\
\text { de la media }\end{array}$} & \multicolumn{2}{|c|}{$\begin{array}{l}\text { 95\% Intervalo de confianza } \\
\text { para la diferencia }\end{array}$} & & & \\
\hline & & & & & Inferior & Superior & & & \\
\hline Par 1 & $\begin{array}{c}\text { kWh_real - } \\
\text { kWh_pronosticado }\end{array}$ & $-15273,428$ & 31015,171 & 11722,633 & $-43957,677$ & 13410,820 & $-1,303$ & 6 & ,240 \\
\hline
\end{tabular}

En la Figura 228, se grafican los consumos reales y pronosticados para la temporada Octubre 2016 - Abril 2017 para el Edificio D4, y las medias de dichos consumos. Según la prueba paramétrica realizada las diferencias encontradas no son estadísticamente significativas, con un riesgo a estar equivocados del $5 \%$

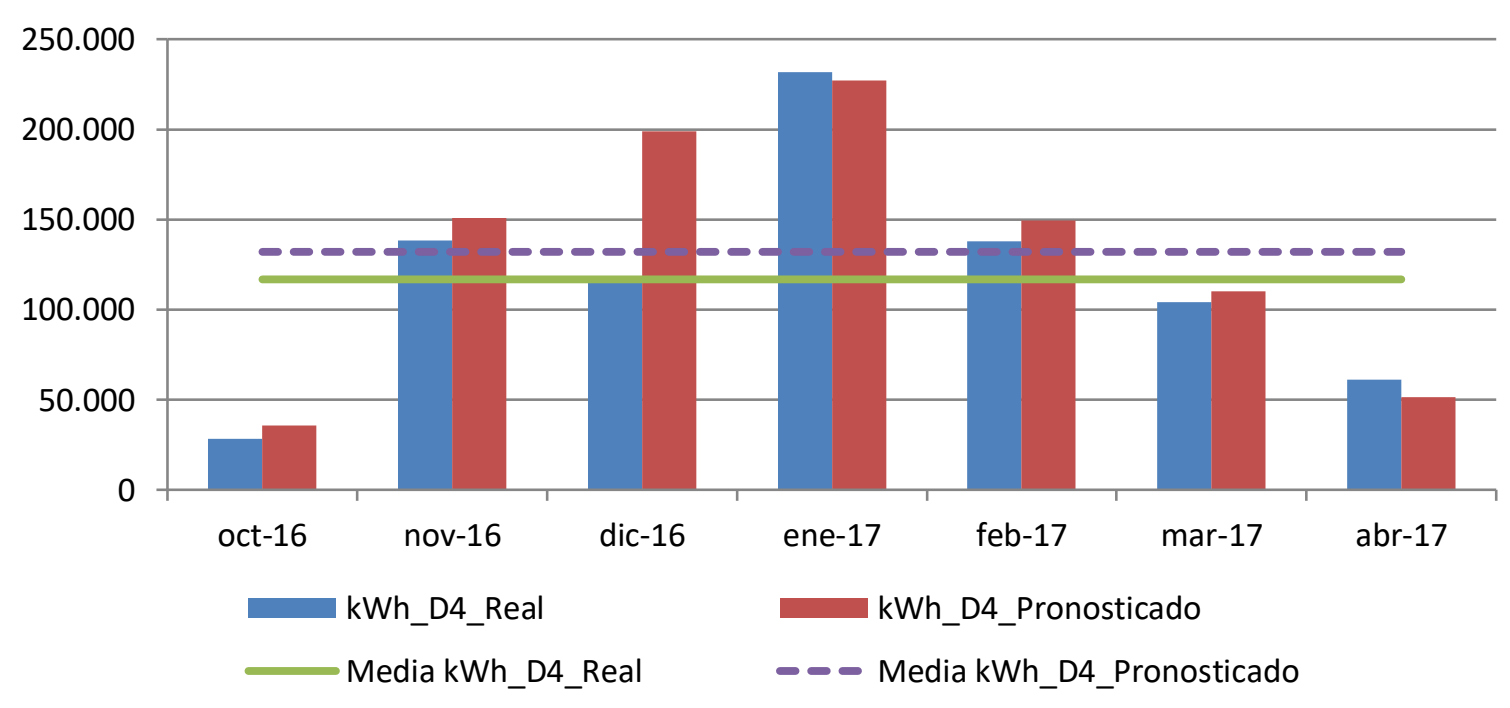

Figura 228. Consumos reales y pronosticados Octubre 2016-Abril 2017. Edificio D4

Para la temporada Octubre 2017 - Mayo 2018, se comprueba mediante el Test de Shapiro -Wilk que tanto los valores reales como los pronosticados se distribuyen según una Normal puesto que en todos los casos los valores de Sig > 0,05, como se observa en la Tabla 226 
Anexo IV. Desarrollo del análisis de los edificios del Campus Miguel Delibes

Tabla 226. Prueba de Normalidad temporada Octubre 2017-Mayo 2018. Edificio D4

\begin{tabular}{cccccrrr}
\hline & \multicolumn{3}{c}{ Kolmogorov-Smirnov $^{\mathrm{a}}$} & \multicolumn{3}{c}{ Shapiro-Wilk } \\
\cline { 2 - 8 } & Estadístico & gl & \multicolumn{1}{c}{ Sig. } & Estadístico & gl & Sig. \\
\hline kWh_real &, 210 & 8 &, 200 &, 898 & 8 &, 279 \\
\hline kWh_pronosticado &, 236 & 8 &, 200 &, 858 & 8 &, 114 \\
\hline
\end{tabular}

En la Tabla 227, se observa como las medias de los consumos pronosticados, son superiores a las medias de los consumos reales del Edificio D4, en un 8,8 \%

Tabla 227. Estadísticos de muestras relacionadas. Octubre 2017-Mayo 2018. Edificio D4

\begin{tabular}{lccccc}
\hline & Media & $\begin{array}{c}\text { \% Diferencia } \\
\text { entre medias }\end{array}$ & $\mathrm{N}$ & $\begin{array}{c}\text { Desviación } \\
\text { típ. }\end{array}$ & $\begin{array}{c}\text { Error típ. de } \\
\text { la media }\end{array}$ \\
\hline kWh_real & 119368,7500 & & 8 & 71931,32244 & 25431,56294 \\
\hline kWh_pronosticado & 129853,8750 & $8,8 \%$ & 8 & 79479,04118 & 28100,08449 \\
\hline
\end{tabular}

La Tabla 228 muestra que las diferencias entre las medias no son significativas entre los consumos reales y los pronosticados (sig $>0,05$ ), a pesar de existir ese $8,8 \%$ de diferencia

Tabla 228. Prueba de muestras relacionadas. Octubre 2017-Mayo 2018. Edificio D4

\begin{tabular}{|c|c|c|c|c|c|c|c|c|c|}
\hline & & \multicolumn{5}{|c|}{ Diferencias relacionadas } & \multirow{3}{*}{$\mathrm{t}$} & \multirow{3}{*}{ gl } & \multirow{3}{*}{$\begin{array}{l}\text { Sig. } \\
\text { (bilateral) }\end{array}$} \\
\hline & & \multirow[t]{2}{*}{ Media } & \multirow{2}{*}{$\begin{array}{l}\text { Desviación } \\
\text { típ. }\end{array}$} & \multirow{2}{*}{$\begin{array}{l}\text { Error típ. } \\
\text { de la media }\end{array}$} & \multicolumn{2}{|c|}{$\begin{array}{c}\text { 95\% Intervalo de confianza } \\
\text { para la diferencia } \\
\end{array}$} & & & \\
\hline & & & & & Inferior & Superior & & & \\
\hline Par 1 & $\begin{array}{c}\text { kWh_real - } \\
\text { kWh_pronosticado }\end{array}$ & $-10485,125$ & 17942,213 & 6343,530 & $-25485,190$ & 4514,940 & $-1,653$ & 7 & 142 \\
\hline
\end{tabular}

En la Figura 229 se grafican los consumos reales y pronosticados para la temporada Octubre 2017 - Mayo 2018 para el Edificio D4, y las medias de dichos consumos. Según la prueba paramétrica realizada las diferencias encontradas no son estadísticamente significativas, con un riesgo a estar equivocados del $5 \%$

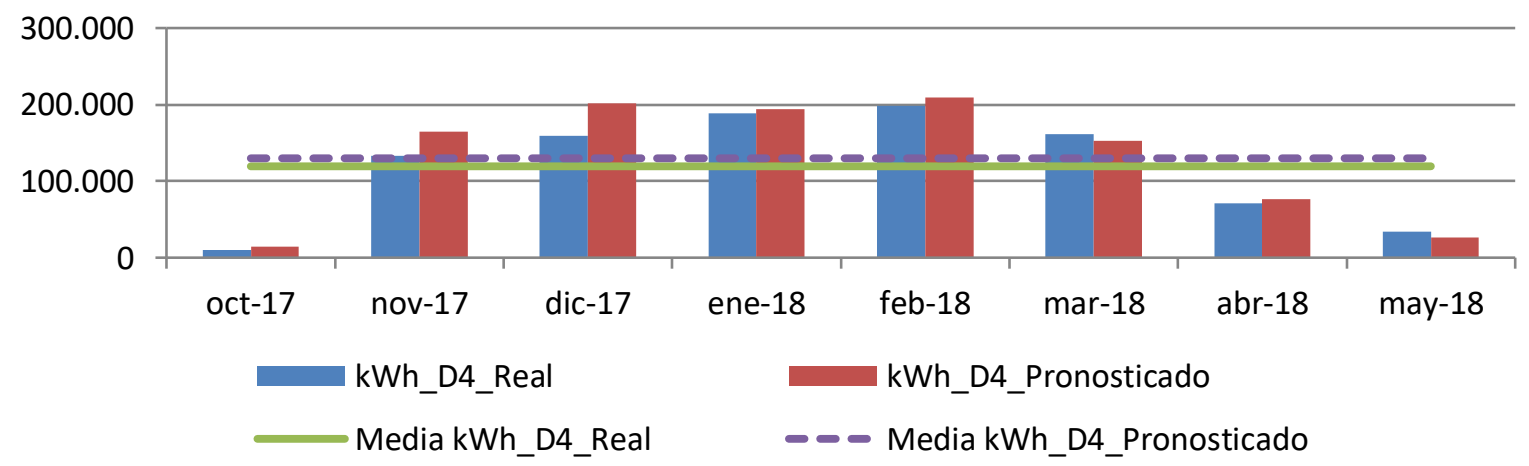

Figura 229. Consumos reales y pronosticados Octubre 2017-Mayo 2018. Edificio D4 
Para el total de las tres temporadas Octubre 2015 - Mayo 2018, se comprueba mediante el Test de Shapiro -Wilk, que los valores reales y los pronosticados se distribuyen según una Normal puesto que en esos casos los valores de Sig $>0,05$, como se observa en la Tabla 229

Tabla 229. Prueba de Normalidad temporada Octubre 2015-Mayo 2018. Edificio D4

\begin{tabular}{ccccrrrr}
\hline & \multicolumn{3}{c}{ Kolmogorov-Smirnov $^{\mathrm{a}}$} & \multicolumn{3}{c}{ Shapiro-Wilk } \\
\cline { 2 - 8 } & Estadístico & gl & Sig. & Estadístico & gl & \multicolumn{1}{c}{ Sig. } \\
\hline kWh_real &, 114 & 23 &, $200^{*}$ &, 965 & 23 &, 570 \\
\hline kWh_pronosticado &, 188 & 23 &, 033 &, 920 & 23 &, 065 \\
\hline
\end{tabular}

En la Tabla 230 se observa como las medias de los consumos pronosticados, son superiores a las medias de los consumos reales del Edificio D4, en un 14,9\%

Tabla 230. Estadísticos de muestras relacionadas. Octubre 2015-Mayo 2018. Edificio D4

\begin{tabular}{lccrcc}
\hline & Media & $\begin{array}{c}\text { \% Diferencia } \\
\text { entre medias }\end{array}$ & $\mathrm{N}$ & $\begin{array}{c}\text { Desviación } \\
\text { típ. }\end{array}$ & $\begin{array}{c}\text { Error típ. de } \\
\text { la media }\end{array}$ \\
\hline kWh_real & 112134,6126 & & 23 & 61644,92974 & 12853,85640 \\
\hline kWh_pronosticado & 128885,8313 & $14,9 \%$ & 23 & 65909,23020 & 13743,02452 \\
\hline
\end{tabular}

La Tabla 231 muestra que las diferencias entre las medias son significativas entre los consumos reales y los pronosticados (sig $\leq 0,05$ ), a pesar de no haber resultado significativas analizando los datos de manera individual en cada temporada.

Tabla 231. Prueba de muestras relacionadas. Octubre 2015-Mayo 2018. Edificio D4

\begin{tabular}{|c|c|c|c|c|c|c|c|c|}
\hline & \multicolumn{5}{|c|}{ Diferencias relacionadas } & \multirow{3}{*}{$\mathrm{t}$} & \multirow{3}{*}{ gl } & \multirow{3}{*}{$\begin{array}{c}\text { Sig. } \\
\text { (bilateral) }\end{array}$} \\
\hline & \multirow{2}{*}{ Media } & \multirow{2}{*}{$\begin{array}{l}\text { Desviación } \\
\text { típ. }\end{array}$} & \multirow{2}{*}{$\begin{array}{l}\text { Error típ. de } \\
\text { la media }\end{array}$} & \multicolumn{2}{|c|}{$\begin{array}{c}\text { 95\% Intervalo de confianza } \\
\text { para la diferencia }\end{array}$} & & & \\
\hline & & & & Inferior & Superior & & & \\
\hline $\begin{array}{c}\text { kWh_real - } \\
\text { kWh_pronosticado }\end{array}$ & $-16751,219$ & 27169,990 & 5665,334 & $-28500,403$ & $-5002,034$ & $-2,957$ & 22 & ,007 \\
\hline
\end{tabular}




\section{AIV.4.5. Estimación de las emisiones de $\mathrm{CO} 2$ evitadas.}

Teniendo en cuenta que el consumir Gas natural se producen 0,252 $\mathrm{kg} \mathrm{CO}_{2} / \mathrm{kWh} \mathrm{E}$. final y que al consumir la energía suministrada por red a partir de Biomasa se producen 0,024 $\mathrm{kg}$ $\mathrm{CO}_{2} / \mathrm{kWh}$. final, en la Tabla 232, se muestra las emisiones de $\mathrm{CO}_{2}$ reales para las temporadas octubre 2015 - mayo 2018 y utilizando el Modelo de regresión, las emisiones de $\mathrm{CO}_{2}$ que se hubieran tenido de haber seguido utilizando las calderas de gas natural originales sin el apoyo de la red de calor.

Tabla 232. Estimación del ahorro de emisiones de CO2 para el Edificio D4.

\begin{tabular}{|c|c|c|c|c|c|c|c|c|c|c|}
\hline & $\begin{array}{l}\text { kWh_D4 } \\
\text { Gas } \\
\text { Natural }\end{array}$ & $\begin{array}{l}\text { kWh_D4 } \\
\text { Biomasa }\end{array}$ & $\begin{array}{l}\text { kWh_D4 } \\
\text { Real Total }\end{array}$ & $\begin{array}{l}\text { kWh_D4 } \\
\text { Predicho }\end{array}$ & $\begin{array}{l}\text { kg CO2 Real } \\
\text { debido al } \\
\text { consumo de } \\
\text { Gas Natural }\end{array}$ & $\begin{array}{l}\text { kg CO2 } \\
\text { Real } \\
\text { debido a } \\
\text { Biomasa }\end{array}$ & $\begin{array}{l}\text { kg CO2 } \\
\text { Real } \\
\text { debido al } \\
\text { consumo } \\
\text { TOTAL }\end{array}$ & $\begin{array}{c}\text { kg CO2 } \\
\text { que se } \\
\text { hubiera } \\
\text { tenido } \\
\text { debido a } \\
\text { Gas } \\
\text { Natural }\end{array}$ & $\begin{array}{l}\text { Ahorro de } \\
\text { kg CO2 }\end{array}$ & $\begin{array}{l}\text { Ahorro de kg } \\
\text { CO2 } \\
\text { acumulado }\end{array}$ \\
\hline oct-2015 & 0 & 30.770 & 30.770 & 47.321 & 0 & 738 & 738 & 11.925 & 11.186 & 11.186 \\
\hline nov-2015 & 0 & 117.720 & 117.720 & 126.145 & 0 & 2.825 & 2.825 & 31.789 & 28.963 & 40.150 \\
\hline dic-2015 & 0 & 91.520 & 91.520 & 178.044 & 0 & 2.196 & 2.196 & 44.867 & 42.671 & 82.820 \\
\hline ene-2016 & 0 & 116.430 & 116.430 & 162.252 & 0 & 2.794 & 2.794 & 40.887 & 38.093 & 120.913 \\
\hline feb-2016 & 46.776 & 149.030 & 195.806 & 169.536 & 11.788 & 3.577 & 15.364 & 42.723 & 27.359 & 148.272 \\
\hline mar-2016 & 14.117 & 118.560 & 132.677 & 163.834 & 3.558 & 2.845 & 6.403 & 41.286 & 34.883 & 183.155 \\
\hline abr-2016 & 714 & 90.660 & 91.374 & 112.212 & 180 & 2.176 & 2.356 & 28.277 & 25.922 & 209.077 \\
\hline may-2016 & 16 & 30.710 & 30.726 & 42.164 & 4 & 737 & 741 & 10.625 & 9.884 & 218.961 \\
\hline oct-2016 & 11.633 & 16.490 & 28.123 & 35.774 & 2.932 & 396 & 3.327 & 9.015 & 5.688 & 224.649 \\
\hline nov-2016 & 1.264 & 137.030 & 138.294 & 150.591 & 319 & 3.289 & 3.607 & 37.949 & 34.342 & 258.990 \\
\hline dic-2016 & 5.785 & 110.200 & 115.985 & 199.106 & 1.458 & 2.645 & 4.103 & 50.175 & 46.072 & 305.063 \\
\hline ene-2017 & 88 & 231.590 & 231.678 & 227.132 & 22 & 5.558 & 5.580 & 57.237 & 51.657 & 356.719 \\
\hline feb-2017 & 136 & 137.800 & 137.936 & 149.579 & 34 & 3.307 & 3.341 & 37.694 & 34.353 & 391.072 \\
\hline mar-2017 & 0 & 104.060 & 104.060 & 110.315 & 0 & 2.497 & 2.497 & 27.799 & 25.302 & 416.374 \\
\hline abr-2017 & 536 & 60.510 & 61.046 & 51.539 & 135 & 1.452 & 1.587 & 12.988 & 11.401 & 427.775 \\
\hline may-2017 & 88 & 22.340 & 22.428 & 0 & 22 & 536 & 558 & 0 & -558 & 427.216 \\
\hline oct-2017 & 56 & 9.650 & 9.706 & 14.290 & 14 & 232 & 246 & 3.601 & 3.355 & 430.571 \\
\hline nov-2017 & 1.080 & 132.050 & 133.130 & 164.751 & 272 & 3.169 & 3.441 & 41.517 & 38.076 & 468.647 \\
\hline dic-2017 & 1.080 & 158.000 & 159.080 & 201.386 & 272 & 3.792 & 4.064 & 50.749 & 46.685 & 515.333 \\
\hline ene-2018 & 0 & 188.850 & 188.850 & 193.892 & 0 & 4.532 & 4.532 & 48.861 & 44.329 & 559.661 \\
\hline feb-2018 & 512 & 197.930 & 198.442 & 209.462 & 129 & 4.750 & 4.879 & 52.784 & 47.905 & 607.566 \\
\hline mar-2018 & 912 & 160.000 & 160.912 & 152.321 & 230 & 3.840 & 4.070 & 38.385 & 34.315 & 641.881 \\
\hline abr-2018 & 0 & 70.510 & 70.510 & 76.509 & 0 & 1.692 & 1.692 & 19.280 & 17.588 & 659.469 \\
\hline may-2018 & 0 & 34.320 & 34.320 & 26.220 & 0 & 824 & 824 & 6.607 & 5.784 & 665.253 \\
\hline
\end{tabular}

Como se observa durante estas tres temporadas se ha obtenido un ahorro total de 665 Toneladas de $\mathrm{CO}_{2}$, debido al consumo térmico del edificio D4. 


\section{AIV.4.6. Estimación del precio máximo de compra a la red.}

Tomando como referencia los precios del gas natural de la Tabla 233 para cada temporada, obtenidos a partir de los datos establecidos en el Capítulo 3, donde se tiene en cuenta el precio por el termino variable y fijo; se puede realizar la estimación del precio máximo de compra de la energía útil a la red de calor para obtener un $0 \%$ de ahorro y un $15 \%$ de ahorro. La Tabla 234, muestral el precio que se pagaría para un ahorro del $15 \%$

Tabla 233. Precios de referencia para Gas natural y Astilla

\begin{tabular}{|c|c|c|c|c|}
\hline Precios (€/(kWh) & 2015 & 2016 & 2017 & 2018 \\
\hline Gas Natural & 0,0373 & 0,0306 & 0,0314 & 0,0336 \\
\hline Astilla & 0,0277 & 0,0256 & 0,0254 & 0,0239 \\
\hline $\begin{array}{l}€ / \text { kWh útiles máximos de compra a la red para } \\
\text { un ahorro del } 0,0 \%\end{array}$ & \multicolumn{4}{|c|}{0,03701} \\
\hline $\begin{array}{l}€ / \text { kWh útiles máximos de compra a la red para } \\
\text { un ahorro del } 15,0 \%\end{array}$ & \multicolumn{4}{|c|}{0,03130} \\
\hline
\end{tabular}

Tabla 234. Ahorro Económico por el consumo térmico en el Edificio D4

\begin{tabular}{|c|c|c|c|c|c|c|c|c|c|c|}
\hline & $\begin{array}{c}\text { kWh_D4 } \\
\text { _Gas } \\
\text { Natural }\end{array}$ & $\begin{array}{c}\text { kWh_D4_ } \\
\text { Biomasa }\end{array}$ & $\begin{array}{c}\text { kWh_D4 } \\
\text { Real }\end{array}$ & $\begin{array}{c}\text { kWh_D4 } \\
\text { Pronosticado }\end{array}$ & $\begin{array}{l}\text { € Real } \\
\text { Gas } \\
\text { Natural }\end{array}$ & $\begin{array}{c}€ \text { Real } \\
\text { Biomasa }\end{array}$ & $\begin{array}{l}€ \text { Real } \\
\text { Total }\end{array}$ & $\begin{array}{c}\text { € predicho } \\
\text { Gas } \\
\text { natural }\end{array}$ & $\begin{array}{c}€ \\
\text { Ahorro }\end{array}$ & $€$ Acumulado \\
\hline oct-2015 & 0 & 30.770 & 30.770 & 47.321 & 0 & 963 & 963 & 1.765 & 802 & 802 \\
\hline nov-2015 & 0 & 117.720 & 117.720 & 126.145 & 0 & 3.685 & 3.685 & 4.705 & 1.021 & 1.823 \\
\hline dic-2015 & 0 & 91.520 & 91.520 & 178.044 & 0 & 2.865 & 2.865 & 6.641 & 3.776 & 5.599 \\
\hline ene-2016 & 0 & 116.430 & 116.430 & 162.252 & 0 & 3.644 & 3.644 & 4.965 & 1.321 & 6.920 \\
\hline feb-2016 & 46.776 & 149.030 & 195.806 & 169.536 & 1.431 & 4.665 & 6.096 & 5.188 & -908 & 6.011 \\
\hline mar-2016 & 14.117 & 118.560 & 132.677 & 163.834 & 432 & 3.711 & 4.143 & 5.013 & 870 & 6.882 \\
\hline abr-2016 & 714 & 90.660 & 91.374 & 112.212 & 22 & 2.838 & 2.860 & 3.434 & 574 & 7.456 \\
\hline may-2016 & 16 & 30.710 & 30.726 & 42.164 & 0 & 961 & 962 & 1.290 & 328 & 7.785 \\
\hline oct-2016 & 11.633 & 16.490 & 28.123 & 35.774 & 356 & 516 & 872 & 1.095 & 223 & 8.007 \\
\hline nov-2016 & 1.264 & 137.030 & 138.294 & 150.591 & 39 & 4.289 & 4.328 & 4.608 & 280 & 8.287 \\
\hline dic-2016 & 5.785 & 110.200 & 115.985 & 199.106 & 177 & 3.449 & 3.626 & 6.093 & 2.466 & 10.754 \\
\hline ene-2017 & 88 & 231.590 & 231.678 & 227.132 & 3 & 7.249 & 7.252 & 7.132 & -120 & 10.634 \\
\hline feb-2017 & 136 & 137.800 & 137.936 & 149.579 & 4 & 4.313 & 4.317 & 4.697 & 379 & 11.014 \\
\hline mar-2017 & 0 & 104.060 & 104.060 & 110.315 & 0 & 3.257 & 3.257 & 3.464 & 207 & 11.220 \\
\hline abr-2017 & 536 & 60.510 & 61.046 & 51.539 & 17 & 1.894 & 1.911 & 1.618 & -292 & 10.928 \\
\hline may-2017 & 88 & 22.340 & 22.428 & 0 & 3 & 699 & 702 & 0 & -702 & 10.226 \\
\hline oct-2017 & 56 & 9.650 & 9.706 & 14.290 & 2 & 302 & 304 & 449 & 145 & 10.371 \\
\hline nov-2017 & 1.080 & 132.050 & 133.130 & 164.751 & 34 & 4.133 & 4.167 & 5.173 & 1.006 & 11.377 \\
\hline dic-2017 & 1.080 & 158.000 & 159.080 & 201.386 & 34 & 4.945 & 4.979 & 6.324 & 1.344 & 12.721 \\
\hline ene-2018 & 0 & 188.850 & 188.850 & 193.892 & 0 & 5.911 & 5.911 & 6.515 & 604 & 13.325 \\
\hline feb-2018 & 512 & 197.930 & 198.442 & 209.462 & 17 & 6.195 & 6.212 & 7.038 & 826 & 14.150 \\
\hline mar-2018 & 912 & 160.000 & 160.912 & 152.321 & 31 & 5.008 & 5.039 & 5.118 & 79 & 14.230 \\
\hline abr-2018 & 0 & 70.510 & 70.510 & 76.509 & 0 & 2.207 & 2.207 & 2.571 & 364 & 14.594 \\
\hline may-2018 & 0 & 34.320 & 34.320 & 26.220 & 0 & 1.074 & 1.074 & 881 & -193 & 14.400 \\
\hline$€$ Total & & & & & & & 81.375 & 95.775 & & \\
\hline Ahorro (\%) & & & & & & & & & & $15,0 \%$ \\
\hline
\end{tabular}




\section{AIV.5.Edificio D5. Instituto Universitario de Oftalmología Aplicada. IOBA.}

\section{AIV.5.1. Obtención de la línea base de referencia energética}

Los datos de partida para la obtención de la línea base de referencia se muestran en la Tabla 235

Tabla 235. Consumos térmicos del edificio D5

\begin{tabular}{lr}
\hline & Consumos térmicos (kWh). D5 \\
\hline oct-12 & 5.298 \\
\hline nov-12 & 12.464 \\
\hline dic-12 & 16.625 \\
\hline ene-13 & 17.744 \\
\hline feb-13 & 17.029 \\
\hline mar-13 & 13.786 \\
\hline abr-13 & 9.765 \\
\hline may-13 & 7.775 \\
\hline oct-13 & 5.004 \\
\hline nov-13 & 12.654 \\
\hline dic-13 & 20.880 \\
\hline ene-14 & 16.068 \\
\hline feb-14 & 14.051 \\
\hline mar-14 & 10.258 \\
\hline abr-14 & 5.701 \\
\hline may-14 & 4.886 \\
\hline Promedio & 11.874 \\
\hline Total (oct-12-may-13) & 100.486 \\
\hline Total (oct-13-may-14) & 89.502 \\
\hline Total (oct-12-may-13) & 189.988 \\
\hline
\end{tabular}

Se disponen de 16 datos para establecer el modelo de regresión, mediante el método de pasos sucesivos. Como se puede ver en la Tabla 236 para el edificio, el método ofrece un modelo de regresión, con una sola variable (Grados Día en base 15, obtenidos con datos cada 30 minutos). El modelo fue construido con un solo paso, incluyendo los Grados día base 15 por ser la variable más significativa (variable con menor valor de Sig =0,000). El resto de las variables como se observa en la Tabla 237 fueron excluidas del modelo al tener valores de sig >0,05.

Tabla 236. Modelos de regresión del Edificio D5

\begin{tabular}{|c|c|c|c|c|c|c|c|}
\hline & \multirow[t]{2}{*}{ Modelo } & \multicolumn{2}{|c|}{$\begin{array}{l}\text { Coeficientes no } \\
\text { estandarizados }\end{array}$} & \multirow[t]{2}{*}{$\mathrm{t}$} & \multirow[t]{2}{*}{ Sig. } & \multicolumn{2}{|c|}{$\begin{array}{c}\text { Intervalo de confianza de } 95,0 \% \\
\text { para B }\end{array}$} \\
\hline & & B & Error típ. & & & Límite inferior & Límite superior \\
\hline \multirow[t]{2}{*}{1} & (Constante) & $-653,894$ & 435,857 & $-1,500$ & 156 & $-1588,716$ & 280,927 \\
\hline & GD15 30min & 56,535 & 1,831 & 30,880 & ,000 & 52,608 & 60,462 \\
\hline
\end{tabular}


En la Figura 230 se representa el modelo de regresión con sus límites inferior y superior para un nivel de confianza del $95 \%$

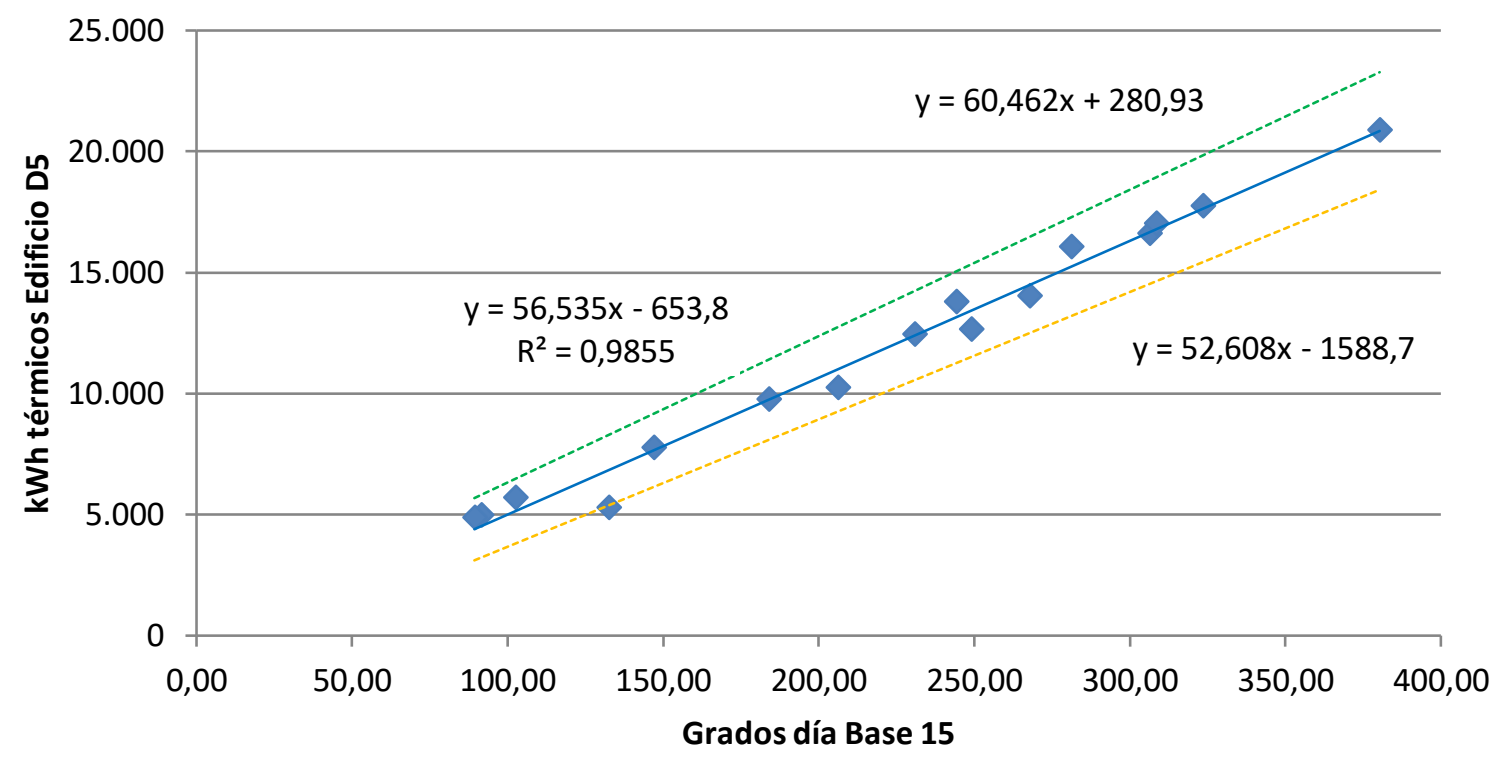

$$
\begin{aligned}
& \text { - D5 (kWh) Lineal (D5 (kWh)) } \\
& \text { Lineal (D5 lim inferior) -------- Lineal (D5 lím superior) }
\end{aligned}
$$

Figura 230. Representación del modelo de regresión lineal simple para el Edificio D5

\begin{tabular}{|c|c|c|c|c|}
\hline & Modelo & $\mathrm{t}$ & Sig. & Correlación parcial \\
\hline & GD20_30min &, 120 & ,906 & ,033 \\
\hline & GD15_24h &,- 472 & ,645 &,- 130 \\
\hline & GD20_24h &, 036 & 972 &, 010 \\
\hline & T_med_30min_C & 328 & ,748 & 091 \\
\hline & T_media_diurna_C & 000 & 1,000 &, 000 \\
\hline & T_max_C &,- 379 & ,710 &,- 105 \\
\hline & T_min_C &, 825 & ,424 &, 223 \\
\hline & HR_\% & 279 & ,784 & 077 \\
\hline & HR_med_diurna_\% & 229 & 822 &, 063 \\
\hline \multirow[t]{10}{*}{1} & HR_max_\% & ,415 & ,685 & ,114 \\
\hline & HR_min_\% & 399 & ,697 & ,110 \\
\hline & Radiación_W/m2 & ,557 & ,587 & ,153 \\
\hline & V_Viento_m/s & ,739 & ,473 & 201 \\
\hline & V_viento_diurna_m/s & 640 & ,533 & 175 \\
\hline & V_viento_nocturna_m/s & ,861 & ,405 &, 232 \\
\hline & V_viento_max_m/s & ,543 & ,596 & ,149 \\
\hline & Recorrido_viento_km/día & 740 & ,472 & 201 \\
\hline & Precipitación_acumulada_mes_mm & ,016 & 987 & 004 \\
\hline & Horas insolación_h & 339 & 740 & 094 \\
\hline
\end{tabular}

Tabla 237. Variables excluidas del modelo de región del Edificio D5 
La bondad de los modelos de regresión obtenidos para el edificio D5, se resumen en la Tabla 238

Tabla 238. Resumen de la bondad de los modelos de regresión para el Edificio D5

\begin{tabular}{ccccc}
\hline Modelo & $\mathrm{R}$ & $\mathrm{R}$ cuadrado & $\mathrm{R}$ cuadrado corregida & $\begin{array}{c}\text { Error típ. de la } \\
\text { estimación }\end{array}$ \\
\hline 1 &, 993 & 986 &, 984 & 637,22267 \\
\hline
\end{tabular}

Se observa como el modelo de regresión lineal simple presenta un Coeficiente de Correlación de Pearson (R) de 0,993, lo que indica que las variables están correlacionadas de manera muy fuerte (en la correlación perfecta $R= \pm 1$ ). La correlación que se produce es directa, al aumentar el valor de los Grados día, aumenta el consumo térmico.

El coeficiente de determinación $\left(R^{2}\right)$, nos indica que con el modelo se podría explicar el $98,6 \%$ de los datos reales obtenidos aceptando un error del $5 \%$.

El error típico de la estimación que nos indica la magnitud de los errores, es decir la parte de la variable dependiente que dejamos sin explicar con el modelo y que describe la variación de la variable respuesta (el Consumo) respecto a la recta de regresión, es de 637 $\mathrm{kWh}$, lo que representa un 5,4\% del promedio de los consumos que fue de $11.874 \mathrm{kWh}$.

\section{AIV.5.2. Verificación del cumplimiento de los supuestos estadísticos}

Las condiciones que se deben cumplir en un modelo de regresión son:

\section{- Linealidad de las variables, las variables se encuentran relacionadas de forma lineal.}

Como se observa en la Tabla 236, la pendiente (B), obtuvo un valor de Sig =0,000, que al ser $\leq 0,05$, nos indica que podemos rechazar la hipótesis nula de pendiente igual a cero y nos da la evidencia de linealidad entre la variable dependiente ( $\mathrm{kWh}$ del edificio D5) y la independiente (GD15_30min). Al ser el valor de la pendiente positiva, indica una relación directa entre el consumo y los Grados día base 15 calculado a partir de datos cada 30 minutos.

- Normalidad. Todos los valores obtenidos para la variable dependiente (Y), deben estar distribuidos normalmente en cada valor de la variable independiente (X).

Se comprueba la normalidad de las variables y de los residuos mediante el Test de Shapiro - Wilk para muestras pequeñas (menores a 30 observaciones), siendo la hipótesis nula el que la distribución es Normal. 
La Tabla 239, muestra la prueba de normalidad de Shapiro-Wilk y cómo tanto la variable dependiente (consumos del Edificio), como la variable independientes: GD15 poseen una Sig $>0,05$, por lo que aceptamos la hipótesis nula de Normalidad de las variables

Tabla 239. Prueba de normalidad para el edificio D5

\begin{tabular}{lrrrrrr}
\hline & \multicolumn{2}{c}{ Kolmogorov-Smirnov } & \multicolumn{3}{c}{ Shapiro-Wilk } \\
\cline { 2 - 7 } & Estadístico & gl & \multicolumn{1}{c}{ Sig. } & Estadístico & gl & Sig. \\
\hline kWh_D5 &, 136 & 16 &, 200 &, 938 & 16 &, 325 \\
\hline GD15_30min &, 109 & 16 &, 200 &, 953 & 16 &, 541 \\
\hline
\end{tabular}

- Independencia de los errores. Los errores asociados a los valores de la variable respuesta $(\mathrm{Y})$ deberán ser independientes unos de otros.

Para la comprobación se utiliza el estadístico de Durbin -Watson.

Se comprueba que el Estadístico de Durbin Watson para el nivel de significancia del 5\%, y para el tamaño de la muestra " $n$ " y el número de variables independientes del modelo " $k$ ", se encuentra en el intervalo [dU, 4-dU], de la Tabla 3, intervalo centrado en el 2, que indica la ausencia de autocorrelación.

El valor del Estadístico Durbin-Watson facilitado por el programa SPSS, es 1,693.

En el modelo, $n=16$ y $k=1$, según la Tabla 3 el valor $d U=1,371$, luego el intervalo que marca la ausencia de correlación es [1,371, 2,629], como el valor del estadístico 1,693 está dentro del intervalo, se acepta la ausencia de autocorrelación

- Homocedasticidad de la varianza. Se pretende comprobar que la varianza de los errores $\left(\sigma^{2}\right)$ es constante para cualquier valor de la variable independiente $(X)$, es decir que el valor medio del cuadrado de la desviación de los errores respecto a su media es constante.

Esta condición indica que no existe correlación entre los residuos y los pronósticos. Se comprueba que el coeficiente de determinación $R^{2}$, en las relaciones: residuos $y$ predicciones y entre residuos y variable independiente es nulo o muy próximo a cero, lo que indicará que no existe ningún tipo de correlación en los residuos y que éstos son aleatorios. Se grafican los diagramas de dispersión de esas relaciones, comprobando que se corresponden a nubes de puntos totalmente aleatorias, sin tendencias ni patrones en sus representaciones gráficas. Las Figura 231 y Figura 232, muestran que la relación entre los pronósticos y los residuos, posee un coeficiente de determinación $=0 \mathrm{y}$ entre la variable independiente (Grados Día Base 15) y los residuos un coeficiente de determinación también de 0 ; por lo que se concluye que no existe ningún tipo de correlación en los residuos y que éstos son aleatorios, siendo la varianza de los residuos constante 


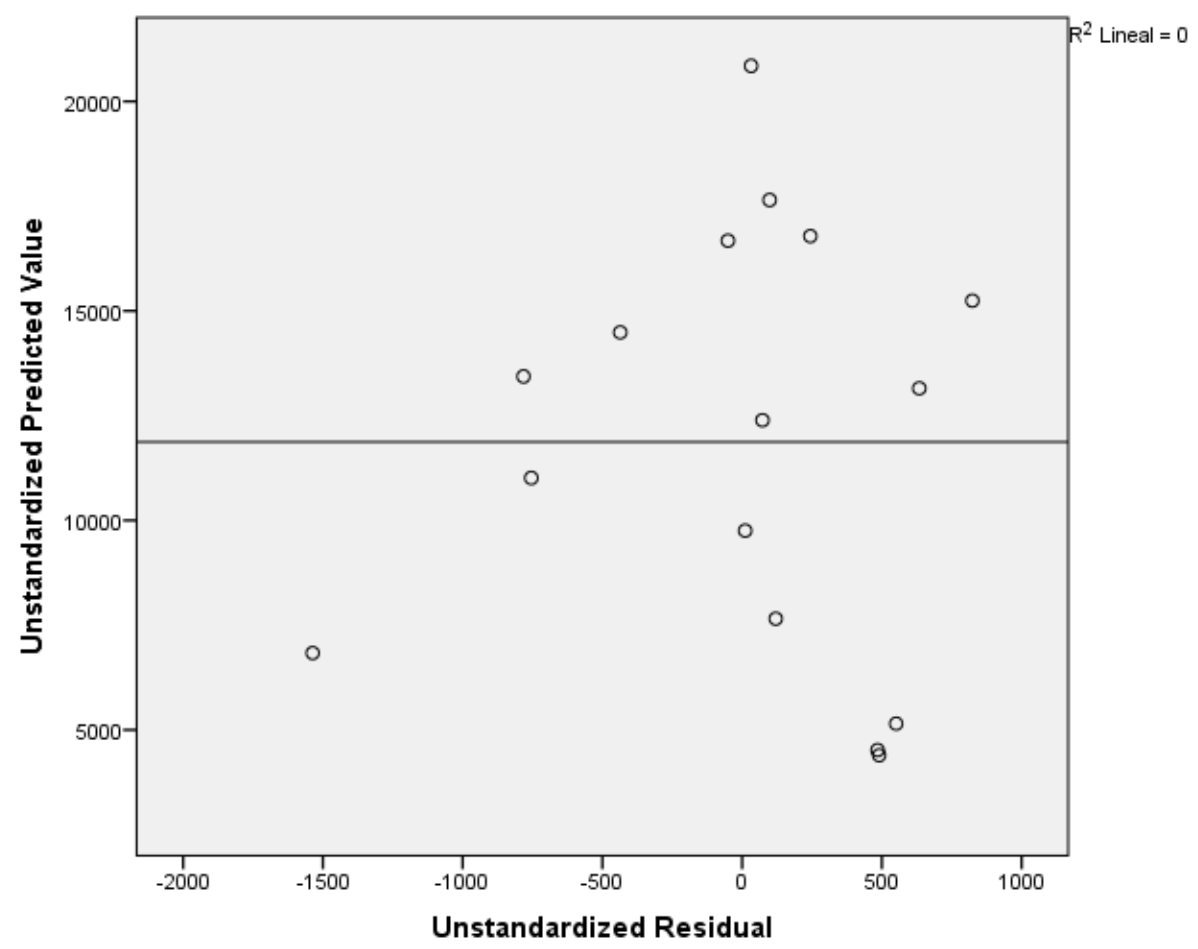

Figura 231. Relación entre los pronósticos y los residuos en el Edificio D5

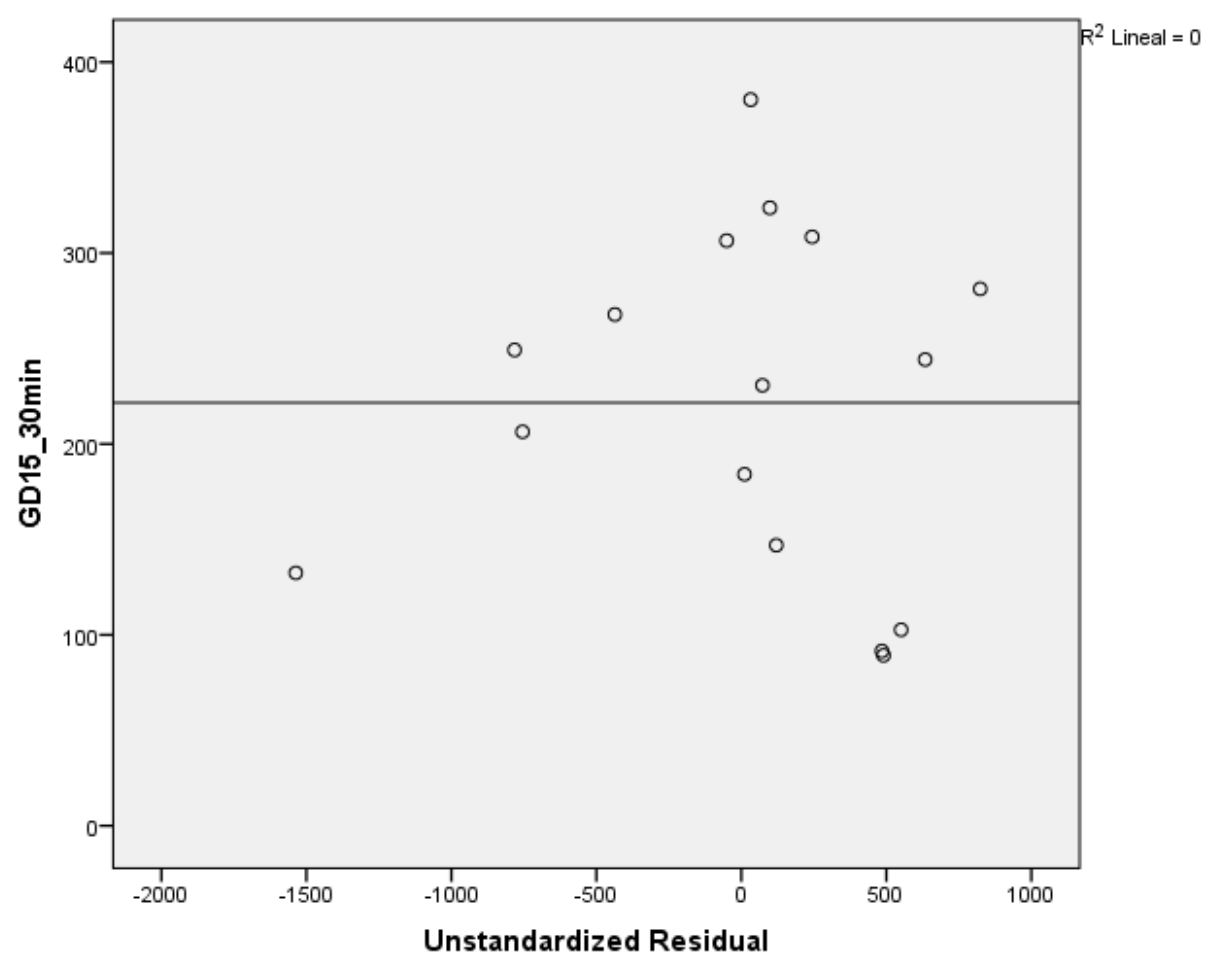

Figura 232. Relación entre GD15 y los residuos en el Edificio D5 


\section{AIV.5.3.Obtención de los consumos térmicos previstos}

Una vez comprobado el cumplimiento de los supuestos estadísticos se acepta el modelo de línea base encontrado para modelizar el consumo del Edificio D5.

$$
\text { kWh_D5_Pronosticado }=-653,894+56,535 \times \text { GD15_30min }
$$

Con este modelo se procede a predecir los consumos previstos para las temporadas: octubre 2015-mayo 2016, octubre 2016 - mayo 2017 y octubre 2017-mayo 2018, estos consumos se muestran en la Tabla 240, donde "KWh_D5_Real", representa el consumo real, "kWh_D5_Pronosticado", el consumo pronosticado con el Modelo.

Tabla 240. Consumos previstos octubre 2014 - mayo 2017 para el edificio D5.

\begin{tabular}{rrrr}
\hline & GD15 & kWh_D5_Real & kWh_D5_Pronosticado \\
\hline oct-15 & 97,04 & 4.908 & 4.832 \\
\hline nov-15 & 208,36 & 16.749 & 11.126 \\
\hline dic-15 & 300,09 & 16.244 & 16.312 \\
\hline ene-16 & 271,93 & 10.727 & 14.720 \\
\hline feb-16 & 266,36 & 30.176 & 14.405 \\
\hline mar-16 & 276,34 & 18.666 & 14.969 \\
\hline abr-16 & 181,04 & 13.772 & 9.581 \\
\hline may-16 & 99,34 & 7.926 & 4.962 \\
\hline oct-16 & 97,34 & 11.119 & 4.849 \\
\hline nov-16 & 245,69 & 9.643 & 13.236 \\
\hline dic-16 & 337,25 & 17.910 & 18.413 \\
\hline ene-17 & 386,98 & 20.318 & 21.224 \\
\hline feb-17 & 226,76 & 13.128 & 12.166 \\
\hline mar-17 & 203,17 & 12.215 & 10.832 \\
\hline abr-17 & 129,72 & 8.730 & 6.680 \\
\hline may-17 & 54,86 & 7.585 & 2.447 \\
\hline oct-17 & 92,31 & 7.020 & 4.565 \\
\hline nov-17 & 271,60 & 11.984 & 14.701 \\
\hline dic-17 & 341,26 & 15.343 & 18.639 \\
\hline ene-18 & 327,94 & 14.960 & 17.886 \\
\hline feb-18 & 321,27 & 19.556 & 17.509 \\
\hline mar-18 & 255,02 & 15.655 & 13.764 \\
\hline abr-18 & 143,31 & 13.055 & 7.448 \\
\hline may-18 & 78,41 & 13.273 & 3.779 \\
\hline & & &
\end{tabular}




\section{AIV.5.4. Estudio de la existencia de diferencias significativas}

Utilizando la prueba " $\mathrm{t}$ " de Student para muestras relacionadas, podemos concluir que si las variables se distribuyen según una normal y la significación estadística resulta $\leq 0,05$, existen diferencias significativas, con un nivel de confianza del 95\%

A continuación se muestra la comparación de medias realizada para cada uno de los tres periodos posteriores a la construcción de la red y para el periodo total hasta mayo de 2018.

Para la temporada Octubre 2015 - Mayo 2016, se comprueba mediante el Test de Shapiro -Wilk que tanto los valores reales como los pronosticados se distribuyen según una Normal puesto que en todos los casos los valores de Sig $>0,05$, como se observa en la Tabla 241

Tabla 241. Prueba de Normalidad temporada Octubre 2015-Mayo 2016. Edificio D5

\begin{tabular}{ccccrrrr}
\hline & \multicolumn{3}{c}{ Kolmogorov-Smirnov $^{\mathrm{a}}$} & \multicolumn{3}{c}{ Shapiro-Wilk } \\
\cline { 2 - 9 } & Estadístico & gl & Sig. & Estadístico & gl & \multicolumn{1}{c}{ Sig. } \\
\hline kWh_real &, 186 & 8 &, $200^{*}$ &, 948 & 8 &, 687 \\
\hline kWh_pronosticado &, 248 & 8 &, 159 &, 865 & 8 &, 135 \\
\hline
\end{tabular}

En la Tabla 242, se observa como las medias de los consumos pronosticados, son inferiores a las medias de los consumos reales del Edificio D5, en un $23,7 \%$

Tabla 242. Estadísticos de muestras relacionadas. Octubre 2015-Mayo 2016. Edificio D5

\begin{tabular}{lccrrc}
\hline & Media & $\begin{array}{c}\text { \% Diferencia } \\
\text { entre medias }\end{array}$ & $\mathrm{N}$ & $\begin{array}{c}\text { Desviación } \\
\text { típ. }\end{array}$ & $\begin{array}{c}\text { Error típ. de } \\
\text { la media }\end{array}$ \\
\hline $\mathrm{kWh}$ real & 13646,0000 & & 8 & 5369,58357 & 1898,43448 \\
\hline $\mathrm{kWh}$ _pronosticado & 11363,3750 & $-23,7 \%$ & 8 & 4549,37207 & 1608,44592 \\
\hline
\end{tabular}

La Tabla 243 muestra que las diferencias entre las medias no son significativas entre los consumos reales y los pronosticados (sig $>0,05$ ), a pesar de existir ese $-23,7 \%$ de diferencia

Tabla 243. Prueba de muestras relacionadas. Octubre 2015-Mayo 2016. Edificio D5

\begin{tabular}{|c|c|c|c|c|c|c|c|c|c|}
\hline & & \multicolumn{5}{|c|}{ Diferencias relacionadas } & \multirow{3}{*}{$\mathrm{t}$} & \multirow{3}{*}{ gl } & \multirow{3}{*}{$\begin{array}{c}\text { Sig. } \\
\text { (bilateral) }\end{array}$} \\
\hline & & \multirow[t]{2}{*}{ Media } & \multirow{2}{*}{$\begin{array}{l}\text { Desviación } \\
\text { típ. }\end{array}$} & \multirow{2}{*}{$\begin{array}{l}\text { Error típ. } \\
\text { de la media }\end{array}$} & \multicolumn{2}{|c|}{$\begin{array}{c}\text { 95\% Intervalo de confianza } \\
\text { para la diferencia }\end{array}$} & & & \\
\hline & & & & & Inferior & Superior & & & \\
\hline Par 1 & $\begin{array}{c}\text { kWh_real - } \\
\text { kWh_pronosticado }\end{array}$ & 2282,625 & 3363,917 & 1189,324 & $-529,680$ & 5094,930 & 1,919 & 7 & ,096 \\
\hline
\end{tabular}


En la Figura 233, se grafican los consumos reales y pronosticados para la temporada Octubre 2015 - Mayo 2016 para el Edificio D5, y las medias de dichos consumos. Según la prueba paramétrica realizada las diferencias encontradas no son estadísticamente significativas, por lo que no se puede afirmar la existencia de ahorros en el consumo térmico entre la situación anterior y posterior a la red de calor, con un riesgo a estar equivocados del $5 \%$

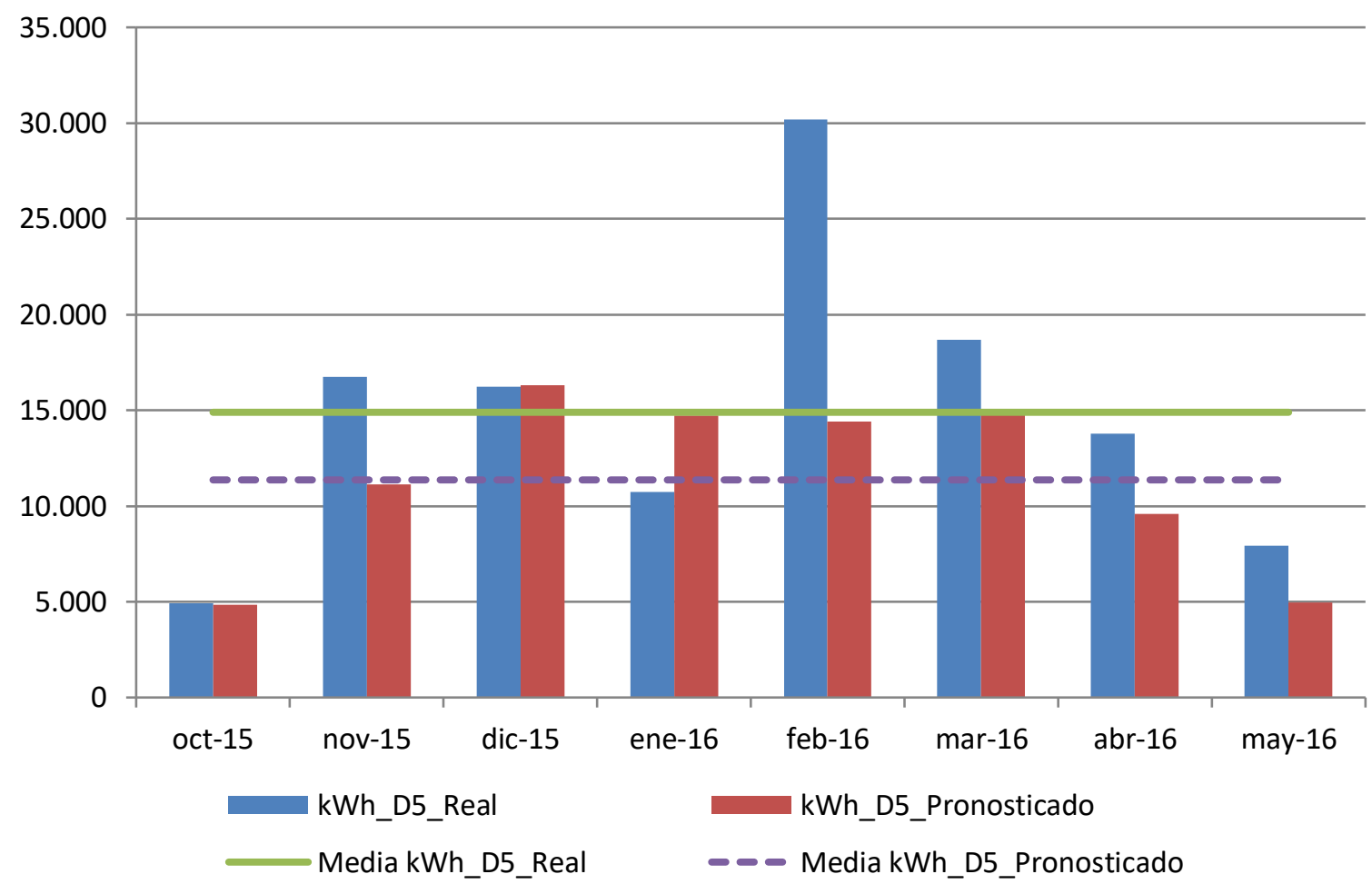

Figura 233. Consumos reales y pronosticados Octubre 2015-Mayo 2016. Edificio D5

Para la temporada Octubre 2016 - Mayo 2017, se comprueba mediante el Test de Shapiro -Wilk que tanto los valores reales como los pronosticados con los dos modelos se distribuyen según una Normal puesto que en todos los casos los valores de Sig >0,05, como se observa en la Tabla 244

Tabla 244. Prueba de Normalidad temporada Octubre 2016-Mayo 2017. Edificio D5

\begin{tabular}{cccccccr}
\hline & \multicolumn{3}{c}{ Kolmogorov-Smirnov $^{\mathrm{a}}$} & \multicolumn{3}{c}{ Shapiro-Wilk } \\
\cline { 2 - 8 } & Estadístico & gl & \multicolumn{1}{c}{ Sig. } & Estadístico & gl & \multicolumn{1}{c}{ Sig. } \\
\hline kWh_real &, 201 & 8 &, 200 &, 914 & 8 &, 381 \\
\hline kWh_pronosticado &, 133 & 8 &, 200 &, 965 & 8 &, 856 \\
\hline
\end{tabular}

En la Tabla 245, se observa como las medias de los consumos pronosticados, son inferiores a las medias de los consumos reales del Edificio D5, en un 10,7\% 
Anexo IV. Desarrollo del análisis de los edificios del Campus Miguel Delibes

Tabla 245. Estadísticos de muestras relacionadas. Octubre 2016-Mayo 2017. Edificio D5

\begin{tabular}{lccrcc}
\hline & Media & $\begin{array}{c}\text { \% Diferencia } \\
\text { entre medias }\end{array}$ & $\mathrm{N}$ & $\begin{array}{c}\text { Desviación } \\
\text { típ. }\end{array}$ & $\begin{array}{c}\text { Error típ. de } \\
\text { la media }\end{array}$ \\
\hline $\mathrm{kWh}$ real & 12581,0000 & & 8 & 4460,17424 & 1576,90973 \\
\hline $\mathrm{kWh}$ pronosticado & 11230,8750 & $-10,7 \%$ & 8 & 6492,79606 & 2295,55006 \\
\hline
\end{tabular}

La Tabla 246 muestra que las diferencias entre las medias no son significativas entre los consumos reales y los pronosticados (sig $>0,05$ ), a pesar de existir ese $-10,7 \%$ de diferencia

Tabla 246. Prueba de muestras relacionadas. Octubre 2016-Mayo 2017. Edificio D5

\begin{tabular}{|c|c|c|c|c|c|c|c|c|c|}
\hline & & \multicolumn{5}{|c|}{ Diferencias relacionadas } & \multirow{3}{*}{$\mathrm{t}$} & \multirow{3}{*}{$\mathrm{gl}$} & \multirow{3}{*}{$\begin{array}{c}\text { Sig. } \\
\text { (bilateral) }\end{array}$} \\
\hline & & \multirow{2}{*}{ Media } & \multirow{2}{*}{$\begin{array}{l}\text { Desviación } \\
\text { típ. }\end{array}$} & \multirow{2}{*}{$\begin{array}{c}\text { Error típ. } \\
\text { de la media }\end{array}$} & \multicolumn{2}{|c|}{$\begin{array}{l}\text { 95\% Intervalo de confianza } \\
\text { para la diferencia }\end{array}$} & & & \\
\hline & & & & & Inferior & Superior & & & \\
\hline Par 1 & $\begin{array}{c}\text { kWh_real - } \\
\text { kWh_pronosticado }\end{array}$ & 1350,125 & 3210,549 & 1135,100 & $-1333,961$ & 4034,211 & 1,189 & 7 & 273 \\
\hline
\end{tabular}

En la Figura 234, se grafican los consumos reales y pronosticados para la temporada Octubre 2016 - Mayo 2017 para el Edificio D5, y las medias de dichos consumos. Según la prueba paramétrica realizada las diferencias encontradas no son estadísticamente significativas, con un riesgo a estar equivocados del $5 \%$

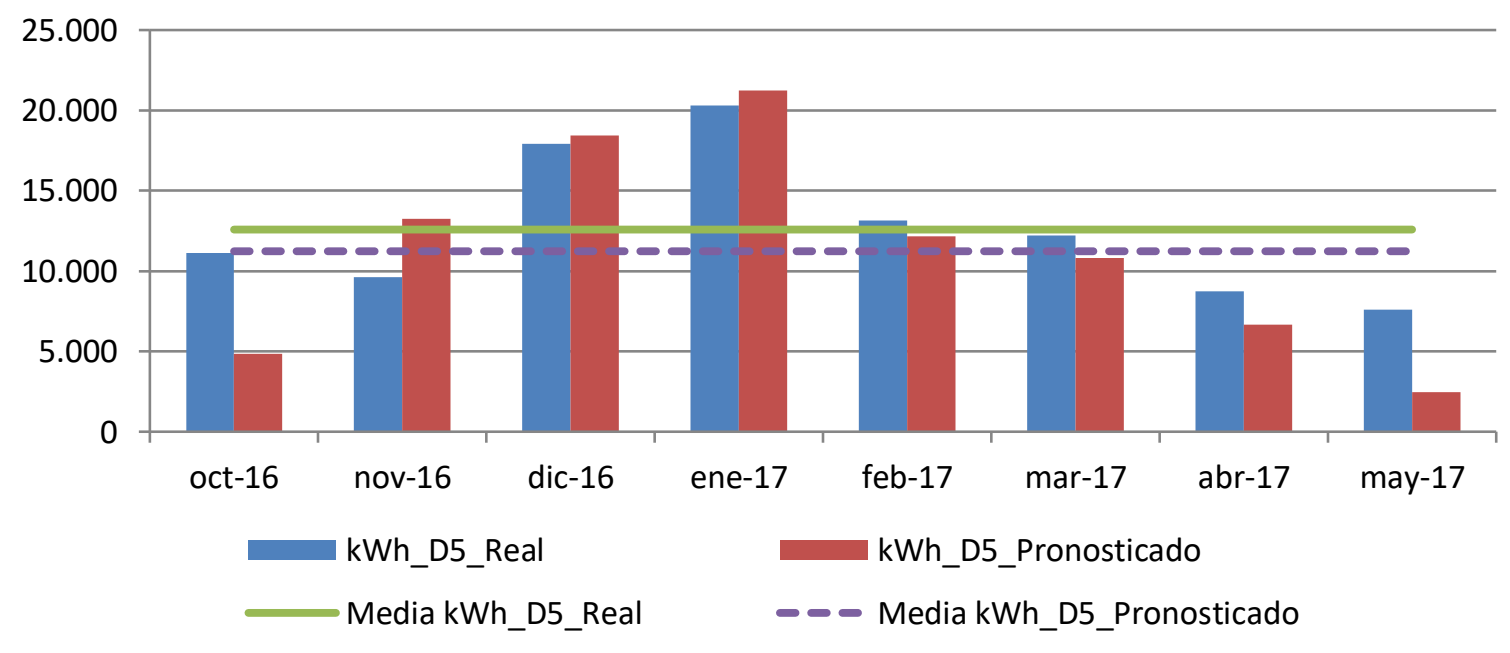

Figura 234. Consumos reales y pronosticados Octubre 2016-Mayo 2017. Edificio D5

Para la temporada Octubre 2017 - Mayo 2018, se comprueba mediante el Test de Shapiro -Wilk que tanto los valores reales como los pronosticados se distribuyen según una Normal puesto que en todos los casos los valores de Sig $>0,05$, como se observa en la Tabla 247 
Anexo IV. Desarrollo del análisis de los edificios del Campus Miguel Delibes

Tabla 247. Prueba de Normalidad temporada Octubre 2017-Mayo 2018. Edificio D5

\begin{tabular}{cccccrrr}
\hline & \multicolumn{3}{c}{ Kolmogorov-Smirnov $^{\mathrm{a}}$} & \multicolumn{3}{c}{ Shapiro-Wilk } \\
\cline { 2 - 8 } & Estadístico & gl & \multicolumn{1}{c}{ Sig. } & Estadístico & gl & Sig. \\
\hline kWh_real &, 183 & 8 &, 200 &, 945 & 8 &, 662 \\
\hline kWh_pronosticado &, 220 & 8 &, 200 &, 860 & 8 &, 119 \\
\hline
\end{tabular}

En la Tabla 248, se observa como las medias de los consumos pronosticados, son inferiores a las medias de los consumos reales del Edificio D5, en un 11,3\%

Tabla 248. Estadísticos de muestras relacionadas. Octubre 2017-Mayo 2018. Edificio D5

\begin{tabular}{lccccc}
\hline & Media & $\begin{array}{c}\text { \% Diferencia } \\
\text { entre medias }\end{array}$ & $\mathrm{N}$ & $\begin{array}{c}\text { Desviación } \\
\text { típ. }\end{array}$ & $\begin{array}{c}\text { Error típ. de } \\
\text { la media }\end{array}$ \\
\hline $\mathrm{kWh}$ _real & 13855,7500 & & 8 & 3593,11157 & 1270,35678 \\
\hline $\mathrm{kWh}$ _pronosticado & 12286,3750 & $-11,3 \%$ & 8 & 6122,62992 & 2164,67657 \\
\hline
\end{tabular}

La Tabla 249 muestra que las diferencias entre las medias no son significativas entre los consumos reales y los pronosticados (sig $>0,05$ ), a pesar de existir ese $-11,3 \%$ de diferencia

Tabla 249. Prueba de muestras relacionadas. Octubre 2017-Mayo 2018. Edificio D5

\begin{tabular}{|c|c|c|c|c|c|c|c|c|c|}
\hline & & \multicolumn{5}{|c|}{ Diferencias relacionadas } & \multirow{3}{*}{$\mathrm{t}$} & \multirow{3}{*}{ gl } & \multirow{3}{*}{$\begin{array}{c}\text { Sig. } \\
\text { (bilateral) }\end{array}$} \\
\hline & & \multirow{2}{*}{ Media } & \multirow{2}{*}{$\begin{array}{c}\text { Desviación } \\
\text { típ. }\end{array}$} & \multirow{2}{*}{$\begin{array}{c}\text { Error típ. } \\
\text { de la media }\end{array}$} & \multicolumn{2}{|c|}{$\begin{array}{l}\text { 95\% Intervalo de confianza } \\
\text { para la diferencia }\end{array}$} & & & \\
\hline & & & & & Inferior & Superior & & & \\
\hline Par 1 & $\begin{array}{c}\text { kWh_real - } \\
\text { kWh_pronosticado }\end{array}$ & 1569,375 & 4511,434 & 1595,031 & $-2202,278$ & 5341,028 & 984 & 7 & ,358 \\
\hline
\end{tabular}

En la Figura 235, se grafican los consumos reales y pronosticados para la temporada Octubre 2017 - Mayo 2018 para el Edificio D5, y las medias de dichos consumos. Según la prueba paramétrica realizada las diferencias encontradas no son estadísticamente significativas, con un riesgo a estar equivocados del $5 \%$

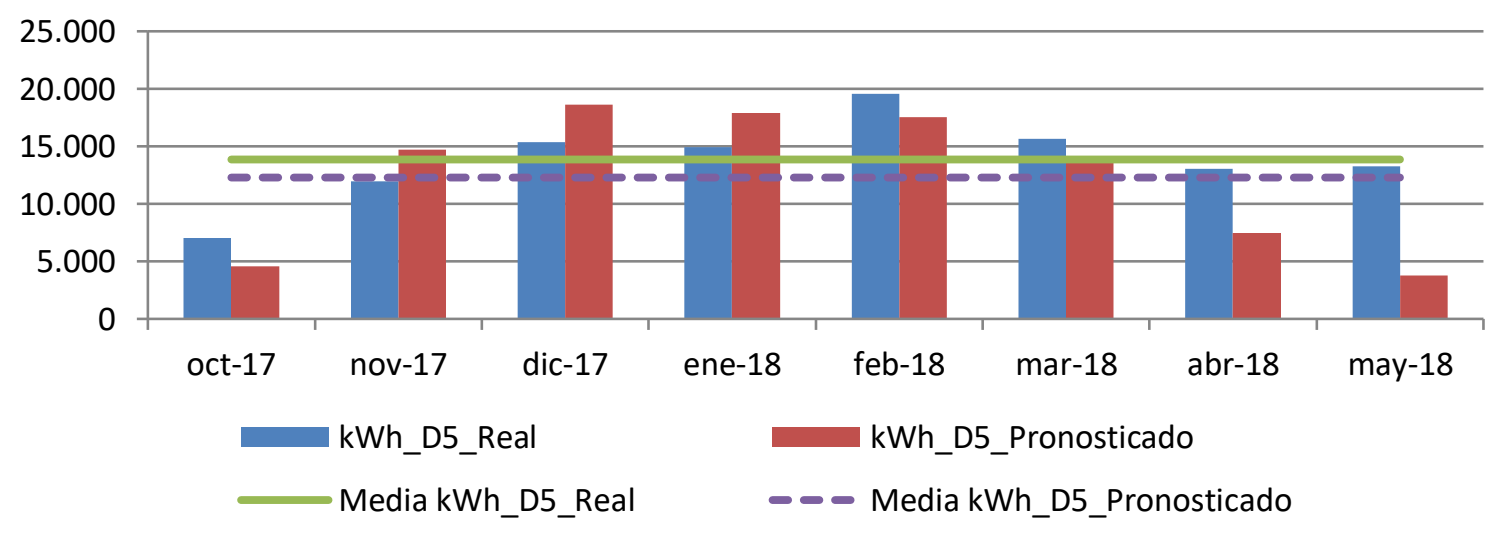

Figura 235. Consumos reales y pronosticados Octubre 2017-Mayo 2018. Edificio D5 
Para el total de las tres temporadas Octubre 2015 - Mayo 2018, se comprueba mediante el Test de Shapiro -Wilk, que los valores reales y los pronosticados se distribuyen según una Normal puesto que en esos casos los valores de Sig $>0,05$, como se observa en la Tabla 250

Tabla 250. Prueba de Normalidad temporada Octubre 2015-Mayo 2018. Edificio D5

\begin{tabular}{cccrrrrr}
\hline & \multicolumn{3}{c}{ Kolmogorov-Smirnov $^{\mathrm{a}}$} & \multicolumn{3}{c}{ Shapiro-Wilk } \\
\cline { 2 - 8 } & Estadístico & gl & \multicolumn{1}{c}{ Sig. } & Estadístico & gl & Sig. \\
\hline kWh_real &, 084 & 24 &, 200 &, 941 & 24 &, 169 \\
\hline kWh_pronosticado &, 135 & 24 &, 200 &, 942 & 24 &, 183 \\
\hline
\end{tabular}

En la Tabla 251 se observa como las medias de los consumos pronosticados, son inferiores a las medias de los consumos reales del Edificio D5, en un 15,6\%

Tabla 251. Estadísticos de muestras relacionadas. Octubre 2015-Mayo 2018. Edificio D5

\begin{tabular}{lccccc}
\hline & Media & $\begin{array}{c}\text { \% Diferencia } \\
\text { entre medias }\end{array}$ & $\mathrm{N}$ & $\begin{array}{c}\text { Desviación } \\
\text { típ. }\end{array}$ & $\begin{array}{c}\text { Error típ. de } \\
\text { la media }\end{array}$ \\
\hline $\mathrm{kWh}$ _real & 13777,5108 & & 24 & 5401,51747 & 1102,58014 \\
\hline $\mathrm{kWh}$ _pronosticado & 11626,9142 & $-15,6 \%$ & 24 & 5546,85045 & 1132,24611 \\
\hline
\end{tabular}

La Tabla 252 muestra que las diferencias entre las medias son significativas entre los consumos reales y los pronosticados (sig $\leq 0,05$ ), a pesar de no haber resultado significativas analizando los datos de manera individual en cada temporada.

Tabla 252. Prueba de muestras relacionadas. Octubre 2015-Mayo 2018. Edificio D5

\begin{tabular}{|c|c|c|c|c|c|c|c|c|}
\hline & \multicolumn{5}{|c|}{ Diferencias relacionadas } & \multirow{3}{*}{$\mathrm{t}$} & \multirow{3}{*}{$\mathrm{gl}$} & \multirow{3}{*}{$\begin{array}{c}\text { Sig. } \\
\text { (bilateral) }\end{array}$} \\
\hline & \multirow[t]{2}{*}{ Media } & \multirow{2}{*}{$\begin{array}{l}\text { Desviación } \\
\text { típ. }\end{array}$} & \multirow{2}{*}{$\begin{array}{l}\text { Error típ. de } \\
\text { la media }\end{array}$} & \multicolumn{2}{|c|}{$\begin{array}{c}\text { 95\% Intervalo de confianza } \\
\text { para la diferencia }\end{array}$} & & & \\
\hline & & & & Inferior & Superior & & & \\
\hline $\begin{array}{c}\text { kWh_real - } \\
\text { kWh_pronosticado }\end{array}$ & 2150,597 & 4540,661 & 926,859 & 233,243 & 4067,950 & 2,320 & 23 & ,030 \\
\hline
\end{tabular}




\section{AIV.5.5. Estimación de las emisiones de $\mathrm{CO} 2$ evitadas.}

Teniendo en cuenta que el consumir Gas natural se producen 0,252 $\mathrm{kg} \mathrm{CO}_{2} / \mathrm{kWh}$. final y que al consumir la energía suministrada por red a partir de Biomasa se producen 0,024 kg $\mathrm{CO}_{2}$ / kWh E. final, en la Tabla 253, se muestra las emisiones de $\mathrm{CO}_{2}$ reales para las temporadas octubre 2015 - mayo 2018 y utilizando el Modelo de regresión, las emisiones de $\mathrm{CO}_{2}$ que se hubieran tenido de haber seguido utilizando las calderas de gas natural originales sin el apoyo de la red de calor.

Tabla 253. Estimación del ahorro de emisiones de CO2 para el Edificio D5.

\begin{tabular}{|c|c|c|c|c|c|c|c|c|c|c|}
\hline & $\begin{array}{c}\text { kWh_D5 } \\
\text { Gas } \\
\text { Natural }\end{array}$ & $\begin{array}{l}\text { kWh_D5 } \\
\text { Biomasa }\end{array}$ & $\begin{array}{l}\text { kWh_D5 } \\
\text { Real Total }\end{array}$ & $\begin{array}{l}\text { kWh_D5 } \\
\text { Predicho }\end{array}$ & $\begin{array}{l}\text { kg CO2 Real } \\
\text { debido al } \\
\text { consumo de } \\
\text { Gas Natural }\end{array}$ & $\begin{array}{l}\text { kg CO2 } \\
\text { Real } \\
\text { debido a } \\
\text { Biomasa }\end{array}$ & $\begin{array}{l}\text { kg CO2 } \\
\text { Real } \\
\text { debido al } \\
\text { consumo } \\
\text { TOTAL }\end{array}$ & $\begin{array}{c}\text { kg CO2 } \\
\text { que se } \\
\text { hubiera } \\
\text { tenido } \\
\text { debido a } \\
\text { Gas } \\
\text { Natural }\end{array}$ & $\begin{array}{l}\text { Ahorro de } \\
\text { kg CO2 }\end{array}$ & $\begin{array}{l}\text { Ahorro de kg } \\
\text { CO2 } \\
\text { acumulado }\end{array}$ \\
\hline oct-2015 & 0 & 4.908 & 4.908 & 4.832 & 0 & 118 & 118 & 1.218 & 1.100 & 1.100 \\
\hline nov-2015 & 0 & 16.749 & 16.749 & 11.126 & 0 & 402 & 402 & 2.804 & 2.402 & 3.502 \\
\hline dic-2015 & 0 & 16.244 & 16.244 & 16.312 & 0 & 390 & 390 & 4.111 & 3.721 & 7.222 \\
\hline ene-2016 & 0 & 10.727 & 10.727 & 14.720 & 0 & 257 & 257 & 3.709 & 3.452 & 10.674 \\
\hline feb-2016 & 16.962 & 13.214 & 30.176 & 14.405 & 4.274 & 317 & 4.591 & 3.630 & -961 & 9.713 \\
\hline mar-2016 & 3.621 & 15.045 & 18.666 & 14.969 & 912 & 361 & 1.273 & 3.772 & 2.499 & 12.212 \\
\hline abr-2016 & 1.356 & 12.416 & 13.772 & 9.581 & 342 & 298 & 640 & 2.414 & 1.775 & 13.987 \\
\hline may-2016 & 1.510 & 6.416 & 7.926 & 4.962 & 381 & 154 & 534 & 1.250 & 716 & 14.702 \\
\hline oct-2016 & 5.921 & 5.198 & 11.119 & 4.849 & 1.492 & 125 & 1.617 & 1.222 & -395 & 14.308 \\
\hline nov-2016 & 88 & 9.555 & 9.643 & 13.236 & 22 & 229 & 251 & 3.336 & 3.084 & 17.392 \\
\hline dic-2016 & 16 & 17.894 & 17.910 & 18.413 & 4 & 429 & 433 & 4.640 & 4.206 & 21.598 \\
\hline ene-2017 & 56 & 20.262 & 20.318 & 21.224 & 14 & 486 & 500 & 5.349 & 4.848 & 26.446 \\
\hline feb-2017 & 1.120 & 12.008 & 13.128 & 12.166 & 282 & 288 & 570 & 3.066 & 2.495 & 28.942 \\
\hline mar-2017 & 32 & 12.183 & 12.215 & 10.832 & 8 & 292 & 300 & 2.730 & 2.429 & 31.371 \\
\hline abr-2017 & 8 & 8.722 & 8.730 & 6.680 & 2 & 209 & 211 & 1.683 & 1.472 & 32.843 \\
\hline may-2017 & 408 & 7.177 & 7.585 & 2.447 & 103 & 172 & 275 & 617 & 342 & 33.185 \\
\hline oct-2017 & 4.889 & 2.131 & 7.020 & 4.565 & 1.232 & 51 & 1.283 & 1.150 & -133 & 33.052 \\
\hline nov-2017 & 40 & 11.944 & 11.984 & 14.701 & 10 & 287 & 297 & 3.705 & 3.408 & 36.460 \\
\hline dic-2017 & 0 & 15.343 & 15.343 & 18.639 & 0 & 368 & 368 & 4.697 & 4.329 & 40.789 \\
\hline ene-2018 & 0 & 14.960 & 14.960 & 17.886 & 0 & 359 & 359 & 4.507 & 4.148 & 44.937 \\
\hline feb-2018 & 56 & 19.500 & 19.556 & 17.509 & 14 & 468 & 482 & 4.412 & 3.930 & 48.867 \\
\hline mar-2018 & 80 & 15.575 & 15.655 & 13.764 & 20 & 374 & 394 & 3.468 & 3.074 & 51.942 \\
\hline abr-2018 & 0 & 13.055 & 13.055 & 7.448 & 0 & 313 & 313 & 1.877 & 1.564 & 53.505 \\
\hline may-2018 & 0 & 13.273 & 13.273 & 3.779 & 0 & 319 & 319 & 952 & 634 & 54.139 \\
\hline
\end{tabular}

Como se observa durante estas tres temporadas se ha obtenido un ahorro total de 54 Toneladas de $\mathrm{CO}_{2}$, debido al consumo térmico del edificio D5. 
Anexo IV. Desarrollo del análisis de los edificios del Campus Miguel Delibes

\section{AIV.5.6. Estimación del precio máximo de compra a la red.}

Tomando como referencia los precios del gas natural de la Tabla 254 para cada temporada, obtenidos a partir de los datos establecidos en el Capítulo 3, donde se tiene en cuenta el precio por el termino variable y fijo; se puede realizar la estimación del precio máximo de compra de la energía útil a la red de calor para obtener un $0 \%$ de ahorro y un $15 \%$ de ahorro. La Tabla 255, muestral el precio que se pagaría para un ahorro del $15 \%$

Tabla 254. Precios de referencia para Gas natural y Astilla

\begin{tabular}{ccccc}
\hline Precios (€/(kWh) & 2015 & 2016 & 2017 & 2018 \\
\hline Gas Natural & 0,0373 & 0,0306 & 0,0314 & 0,0336 \\
\hline Astilla & 0,0277 & 0,0256 & 0,0254 & 0,0239 \\
\hline $\begin{array}{c}€ / \text { kWh útiles máximos de compra a la red para } \\
\text { un ahorro del 0,0\% }\end{array}$ & 0,02681 & \\
\hline $\begin{array}{c}€ / \text { kWh útiles máximos de compra a la red para } \\
\text { un ahorro del 15,0\% }\end{array}$ & 0,02224 & \\
\hline \begin{tabular}{l} 
un \\
\hline
\end{tabular} & & & \\
\hline
\end{tabular}

Tabla 255. Ahorro Económico por el consumo térmico en el Edificio D5

\begin{tabular}{|c|c|c|c|c|c|c|c|c|c|c|}
\hline & $\begin{array}{c}\text { kWh_D5 } \\
\text { _Gas } \\
\text { Natural }\end{array}$ & $\begin{array}{c}\text { kWh_D5_ } \\
\text { Biomasa }\end{array}$ & $\begin{array}{c}\text { kWh_D5 } \\
\text { Real }\end{array}$ & $\begin{array}{c}\text { kWh_D5 } \\
\text { Pronosticado }\end{array}$ & $\begin{array}{c}€ \text { Real } \\
\text { Gas } \\
\text { Natural }\end{array}$ & $\begin{array}{c}€ \text { Real } \\
\text { Biomasa }\end{array}$ & $\begin{array}{l}€ \text { Real } \\
\text { Total }\end{array}$ & $\begin{array}{c}\text { € predicho } \\
\text { Gas } \\
\text { natural }\end{array}$ & $\begin{array}{c}€ \\
\text { Ahorro }\end{array}$ & $€$ Acumulado \\
\hline oct-2015 & 0 & 4.908 & 4.908 & 4.832 & 0 & 109 & 109 & 180 & 71 & 71 \\
\hline nov-2015 & 0 & 16.749 & 16.749 & 11.126 & 0 & 372 & 372 & 415 & 42 & 114 \\
\hline dic-2015 & 0 & 16.244 & 16.244 & 16.312 & 0 & 361 & 361 & 608 & 247 & 361 \\
\hline ene-2016 & 0 & 10.727 & 10.727 & 14.720 & 0 & 239 & 239 & 450 & 212 & 573 \\
\hline feb-2016 & 16.962 & 13.214 & 30.176 & 14.405 & 519 & 294 & 813 & 441 & -372 & 201 \\
\hline mar-2016 & 3.621 & 15.045 & 18.666 & 14.969 & 111 & 335 & 445 & 458 & 13 & 213 \\
\hline abr-2016 & 1.356 & 12.416 & 13.772 & 9.581 & 41 & 276 & 318 & 293 & -24 & 189 \\
\hline may-2016 & 1.510 & 6.416 & 7.926 & 4.962 & 46 & 143 & 189 & 152 & -37 & 152 \\
\hline oct-2016 & 5.921 & 5.198 & 11.119 & 4.849 & 181 & 116 & 297 & 148 & -148 & 3 \\
\hline nov-2016 & 88 & 9.555 & 9.643 & 13.236 & 3 & 213 & 215 & 405 & 190 & 193 \\
\hline dic-2016 & 16 & 17.894 & 17.910 & 18.413 & 0 & 398 & 398 & 563 & 165 & 358 \\
\hline ene-2017 & 56 & 20.262 & 20.318 & 21.224 & 2 & 451 & 452 & 666 & 214 & 572 \\
\hline feb-2017 & 1.120 & 12.008 & 13.128 & 12.166 & 35 & 267 & 302 & 382 & 80 & 652 \\
\hline mar-2017 & 32 & 12.183 & 12.215 & 10.832 & 1 & 271 & 272 & 340 & 68 & 720 \\
\hline abr-2017 & 8 & 8.722 & 8.730 & 6.680 & 0 & 194 & 194 & 210 & 16 & 736 \\
\hline may-2017 & 408 & 7.177 & 7.585 & 2.447 & 13 & 160 & 172 & 77 & -96 & 640 \\
\hline oct-2017 & 4.889 & 2.131 & 7.020 & 4.565 & 153 & 47 & 201 & 143 & -58 & 583 \\
\hline nov-2017 & 40 & 11.944 & 11.984 & 14.701 & 1 & 266 & 267 & 462 & 195 & 777 \\
\hline dic-2017 & 0 & 15.343 & 15.343 & 18.639 & 0 & 341 & 341 & 585 & 244 & 1.021 \\
\hline ene-2018 & 0 & 14.960 & 14.960 & 17.886 & 0 & 333 & 333 & 601 & 268 & 1.290 \\
\hline feb-2018 & 56 & 19.500 & 19.556 & 17.509 & 2 & 434 & 435 & 588 & 153 & 1.442 \\
\hline mar-2018 & 80 & 15.575 & 15.655 & 13.764 & 3 & 346 & 349 & 462 & 114 & 1.556 \\
\hline abr-2018 & 0 & 13.055 & 13.055 & 7.448 & 0 & 290 & 290 & 250 & -40 & 1.516 \\
\hline may-2018 & 0 & 13.273 & 13.273 & 3.779 & 0 & 295 & 295 & 127 & -168 & 1.348 \\
\hline$€$ Total & & & & & & & 7.662 & 9.009 & & \\
\hline Ahorro (\%) & & & & & & & & & & $15,0 \%$ \\
\hline
\end{tabular}




\section{AIV.6.Edificio D6. Facultad de Ciencias.}

\section{AIV.6.1.Obtención de la línea base de referencia energética}

Los datos de partida para la obtención de la línea base de referencia se muestran en la Tabla 256

Tabla 256. Consumos térmicos del edificio D6

\begin{tabular}{lr}
\hline & Consumos térmicos $(\mathrm{kWh})$. D6 \\
\hline oct-12 & 65.093 \\
\hline nov-12 & 145.750 \\
\hline dic-12 & 194.289 \\
\hline ene-13 & 207.050 \\
\hline feb-13 & 198.500 \\
\hline mar-13 & 160.192 \\
\hline abr-13 & 114.486 \\
\hline may-13 & 91.192 \\
\hline oct-13 & 58.407 \\
\hline nov-13 & 149.340 \\
\hline dic-13 & 243.583 \\
\hline ene-14 & 186.405 \\
\hline feb-14 & 165.006 \\
\hline mar-14 & 121.453 \\
\hline abr-14 & 66.396 \\
\hline may-14 & 57.028 \\
\hline Promedio & 139.011 \\
\hline Total (oct-12-may-13) & 1.176 .552 \\
\hline Total (oct-13-may-14) & 1.047 .618 \\
\hline Total (oct-12-may-13) & 2.224 .170 \\
\hline
\end{tabular}

Se disponen de 16 datos para establecer el modelo de regresión, mediante el método de pasos sucesivos. Como se puede ver en la Tabla 257 para el edificio, el método ofrece un modelo de regresión, con una sola variable (Grados Día en base 15, obtenidos con datos cada 30 minutos). El modelo fue construido con un solo paso, incluyendo los Grados día base 15 por ser la variable más significativa (variable con menor valor de Sig $=0,000$ ). El resto de las variables como se observa en la Tabla 258 fueron excluidas del modelo al tener valores de sig $>0,05$.

Tabla 257. Modelos de regresión del Edificio D6

\begin{tabular}{|c|c|c|c|c|c|c|c|}
\hline & \multirow{2}{*}{ Modelo } & \multicolumn{2}{|c|}{$\begin{array}{l}\text { Coeficientes no } \\
\text { estandarizados }\end{array}$} & \multirow{2}{*}{$\mathrm{t}$} & \multirow{2}{*}{ Sig. } & \multicolumn{2}{|c|}{$\begin{array}{c}\text { Intervalo de confianza de } \\
95,0 \% \text { para B }\end{array}$} \\
\hline & & B & Error típ. & & & $\begin{array}{l}\text { Límite } \\
\text { inferior }\end{array}$ & $\begin{array}{l}\text { Límite } \\
\text { superior }\end{array}$ \\
\hline \multirow[t]{2}{*}{1} & (Constante) & $-6540,157$ & 4358,501 & $-1,501$ & ,156 & $-15888,212$ & 2807,898 \\
\hline & GD15_30min & 656,818 & 18,307 & 35,877 & ,000 & 617,552 & 696,084 \\
\hline
\end{tabular}


En la Figura 236 se representa el modelo de regresión con sus límites inferior y superior para un nivel de confianza del $95 \%$

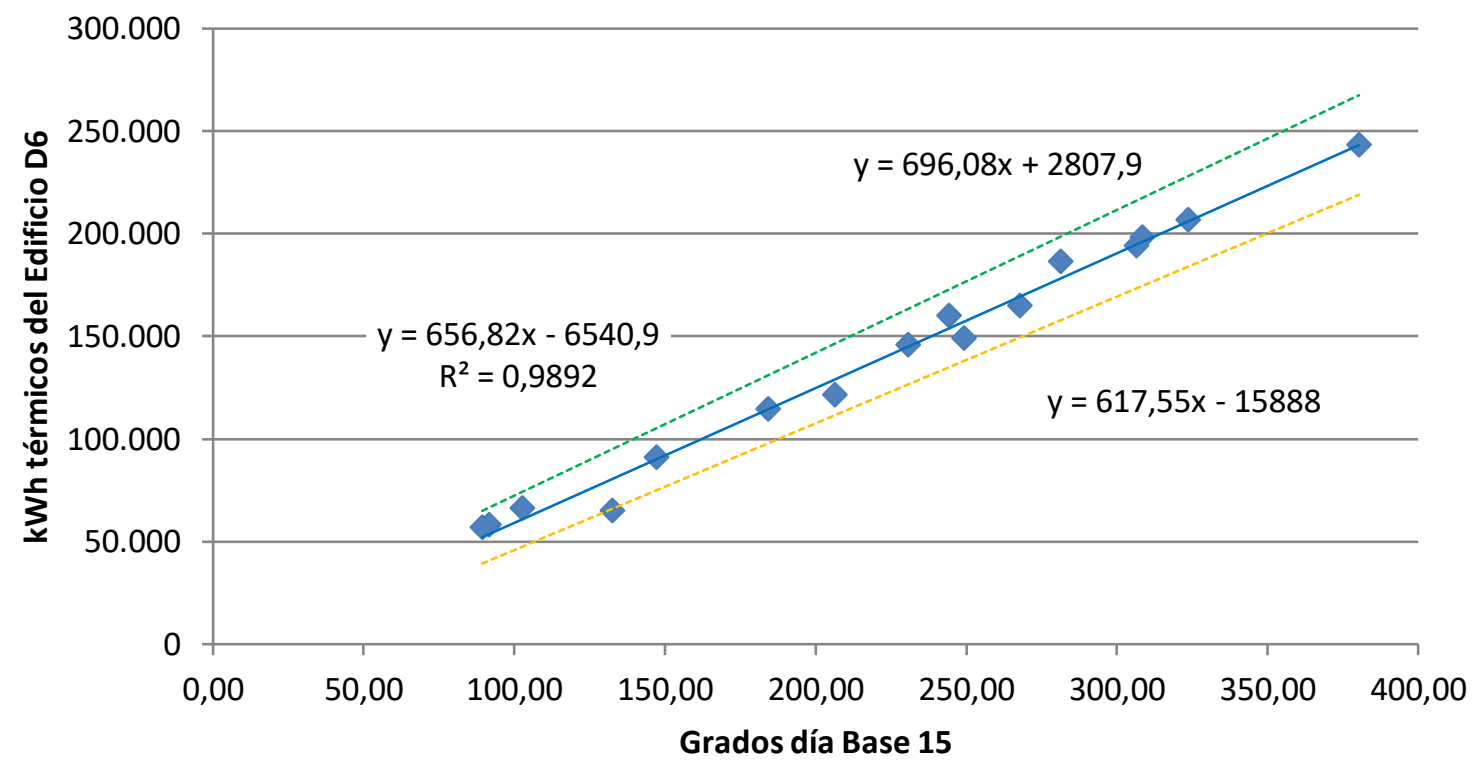

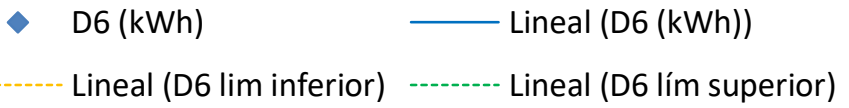

Figura 236. Representación del modelo de regresión lineal simple para el Edificio D6

Tabla 258. Variables excluidas del modelo de región del Edificio D6

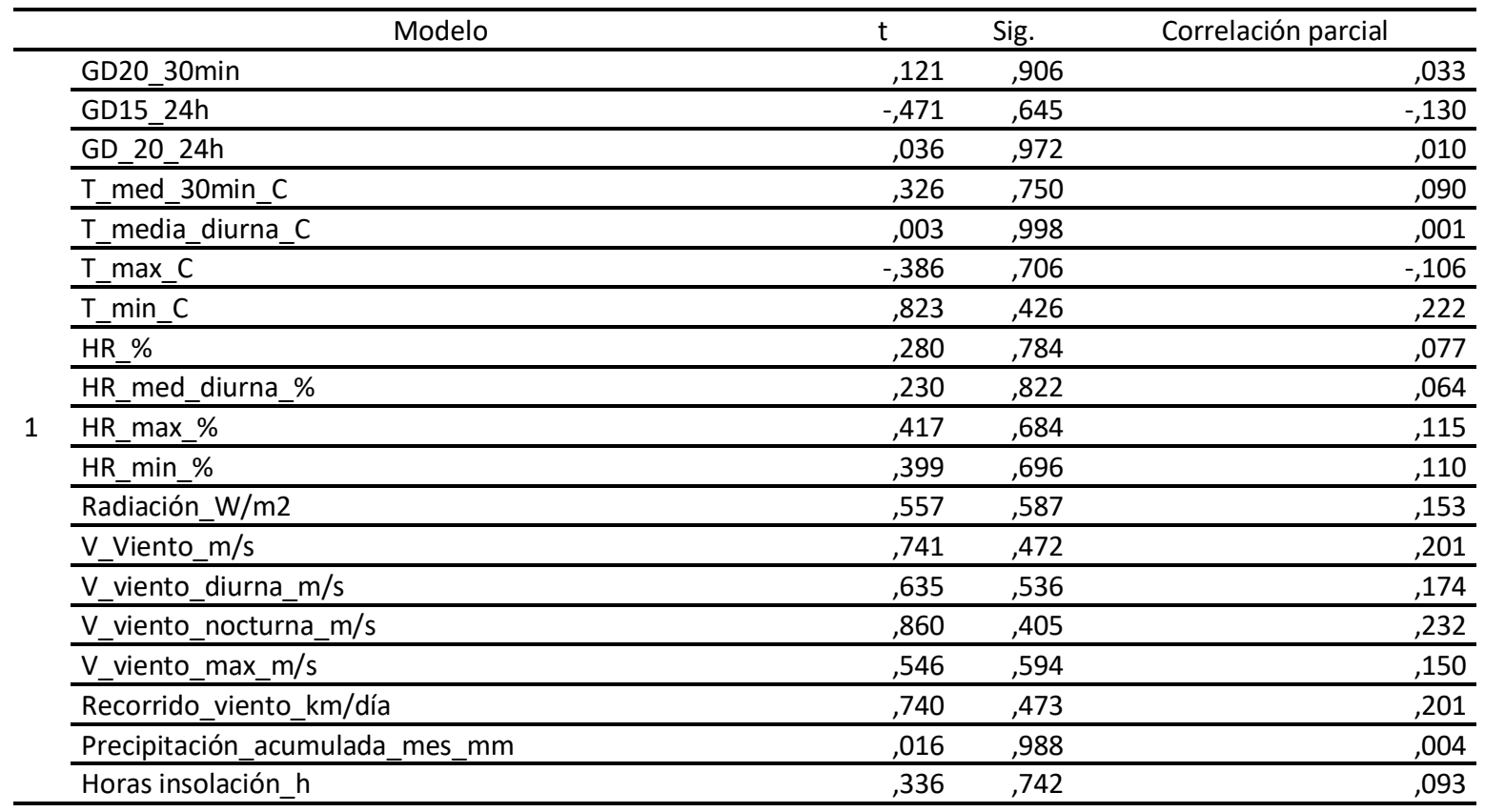


La bondad de los modelos de regresión obtenidos para el edificio D6, se resumen en la Tabla 259

Tabla 259. Resumen de la bondad de los modelos de regresión para el Edificio D6

\begin{tabular}{ccccc}
\hline Modelo & $\mathrm{R}$ & R cuadrado & R cuadrado corregida & $\begin{array}{c}\text { Error típ. de la } \\
\text { estimación }\end{array}$ \\
\hline 1 &, 995 &, 989 &, 988 & 6372,18709 \\
\hline
\end{tabular}

Se observa como el modelo de regresión lineal simple presenta un Coeficiente de Correlación de Pearson (R) de 0,995, lo que indica que las variables están correlacionadas de manera muy fuerte (en la correlación perfecta $R= \pm 1$ ). La correlación que se produce es directa, al aumentar el valor de los Grados día, aumenta el consumo térmico.

El coeficiente de determinación $\left(R^{2}\right)$, nos indica que con el modelo se podría explicar el $98,9 \%$ de los datos reales obtenidos aceptando un error del $5 \%$.

El error típico de la estimación que nos indica la magnitud de los errores, es decir la parte de la variable dependiente que dejamos sin explicar con el modelo y que describe la variación de la variable respuesta respecto a la recta de regresión, es de 6.372 kWh, lo que representa un 4,6\% del promedio de los consumos que fue de $139.011 \mathrm{kWh}$.

\section{AIV.6.2. Verificación del cumplimiento de los supuestos estadísticos}

Las condiciones que se deben cumplir en un modelo de regresión son:

\section{- Linealidad de las variables, las variables se encuentran relacionadas de forma lineal.}

Como se observa en la Tabla 257, la pendiente (B), obtuvo un valor de Sig =0,000, que al ser $\leq 0,05$, nos indica que podemos rechazar la hipótesis nula de pendiente igual a cero y nos da la evidencia de linealidad entre la variable dependiente ( $\mathrm{kWh}$ del edificio D6) y la independiente (GD15). Al ser el valor de la pendiente positiva, indica una relación directa entre el consumo y los Grados día base 15 calculado con datos cada 30 minutos.

- Normalidad. Todos los valores obtenidos para la variable dependiente (Y), deben estar distribuidos normalmente en cada valor de la variable independiente (X).

Se comprueba la normalidad de las variables y de los residuos mediante el Test de Shapiro - Wilk para muestras pequeñas (menores a 30 observaciones), siendo la hipótesis nula el que la distribución es Normal. 
La Tabla 260, muestra la prueba de normalidad de Shapiro-Wilk y cómo tanto la variable dependiente (consumos del Edificio), como la variable independientes: GD15 poseen una Sig $>0,05$, por lo que aceptamos la hipótesis nula de Normalidad de las variables

Tabla 260. Prueba de normalidad para el edificio D6

\begin{tabular}{lrrrrrr}
\hline & \multicolumn{2}{c}{ Kolmogorov-Smirnov } & \multicolumn{3}{c}{ Shapiro-Wilk } \\
\cline { 2 - 7 } & Estadístico & gl & \multicolumn{1}{c}{ Sig. } & Estadístico & gl & Sig. \\
\hline kWh_D6 &, 136 & 16 &, 200 &, 940 & 16 &, 325 \\
\hline GD15_30min &, 109 & 16 &, 200 &, 953 & 16 &, 541 \\
\hline
\end{tabular}

- Independencia de los errores. Los errores asociados a los valores de la variable respuesta $(\mathrm{Y})$ deberán ser independientes unos de otros.

Para la comprobación se utiliza el estadístico de Durbin -Watson.

Se comprueba que el Estadístico de Durbin Watson para el nivel de significancia del 5\%, y para el tamaño de la muestra " $n$ " y el número de variables independientes del modelo " $k$ ", se encuentra en el intervalo [dU, 4-dU], de la Tabla 3, intervalo centrado en el 2, que indica la ausencia de autocorrelación.

El valor del Estadístico Durbin-Watson facilitado por el programa SPSS, es 1,693.

En el modelo, $n=16$ y $k=1$, según la Tabla 3 el valor $d U=1,371$, luego el intervalo que marca la ausencia de correlación es [1,371, 2,629], como el valor del estadístico 1,693 está dentro del intervalo, se acepta la ausencia de autocorrelación

- Homocedasticidad de la varianza. Se pretende comprobar que la varianza de los errores $\left(\sigma^{2}\right)$ es constante para cualquier valor de la variable independiente $(X)$, es decir que el valor medio del cuadrado de la desviación de los errores respecto a su media es constante.

Esta condición indica que no existe correlación entre los residuos y los pronósticos. Se comprueba que el coeficiente de determinación $\mathrm{R}^{2}$, en las relaciones: residuos $\mathrm{y}$ predicciones y entre residuos y variable independiente es nulo o muy próximo a cero, lo que indicará que no existe ningún tipo de correlación en los residuos y que éstos son aleatorios. Se grafican los diagramas de dispersión de esas relaciones, comprobando que se corresponden a nubes de puntos totalmente aleatorias, sin tendencias ni patrones en sus representaciones gráficas. Las Figura 237 y Figura 238, muestran que la relación entre los pronósticos y los residuos, posee un coeficiente de determinación $=-2,22 \times 10^{-16}$ y entre la variable independiente (Grados Día Base 15) y los residuos un coeficiente de determinación de $1,11 \times 10^{-16}$; ambos prácticamente 0 , por lo que se concluye que no existe ningún tipo de correlación en los residuos y que éstos son aleatorios, siendo la varianza de los residuos constante. 
Anexo IV. Desarrollo del análisis de los edificios del Campus Miguel Delibes

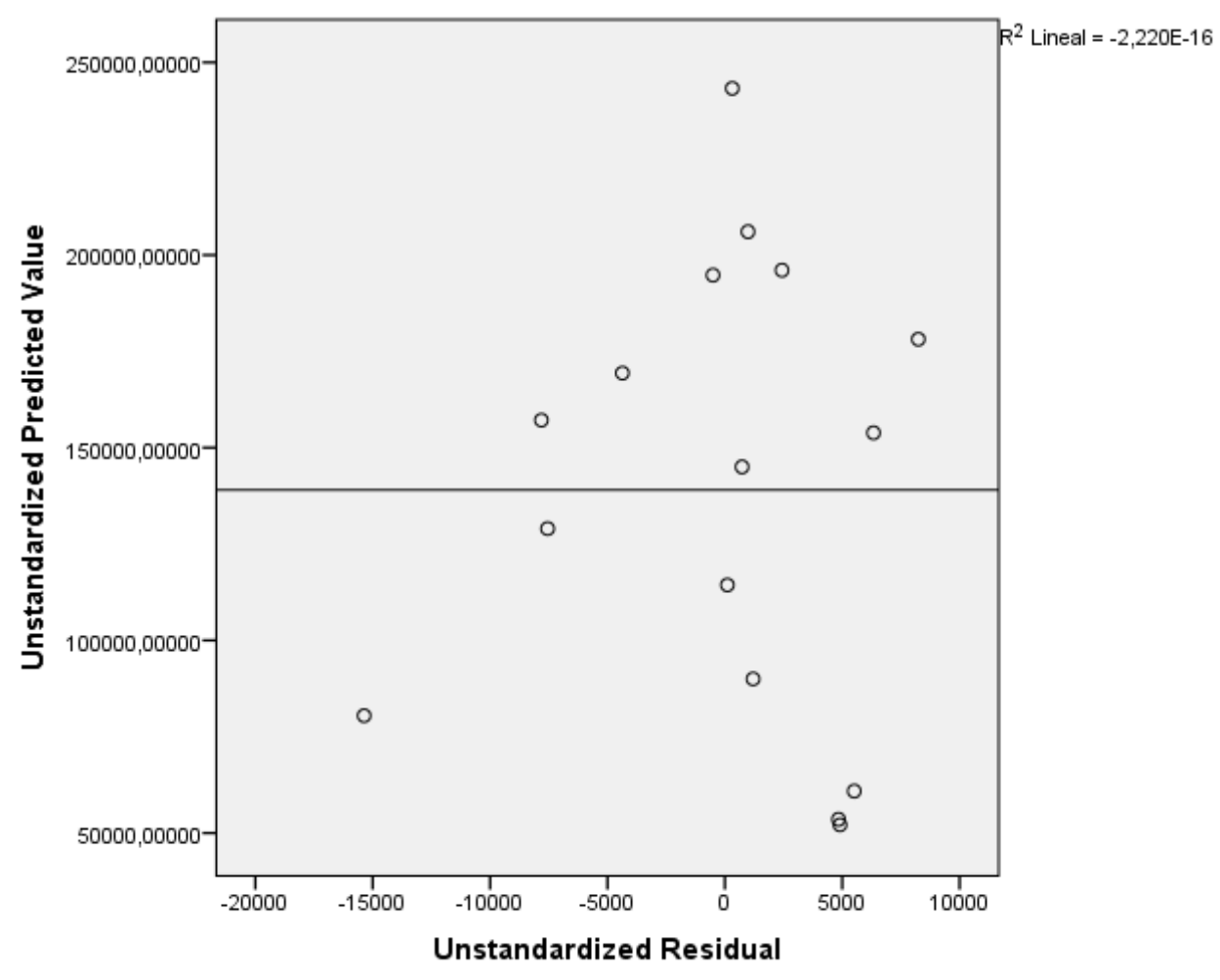

Figura 237. Relación entre los pronósticos y los residuos en el Edificio D6

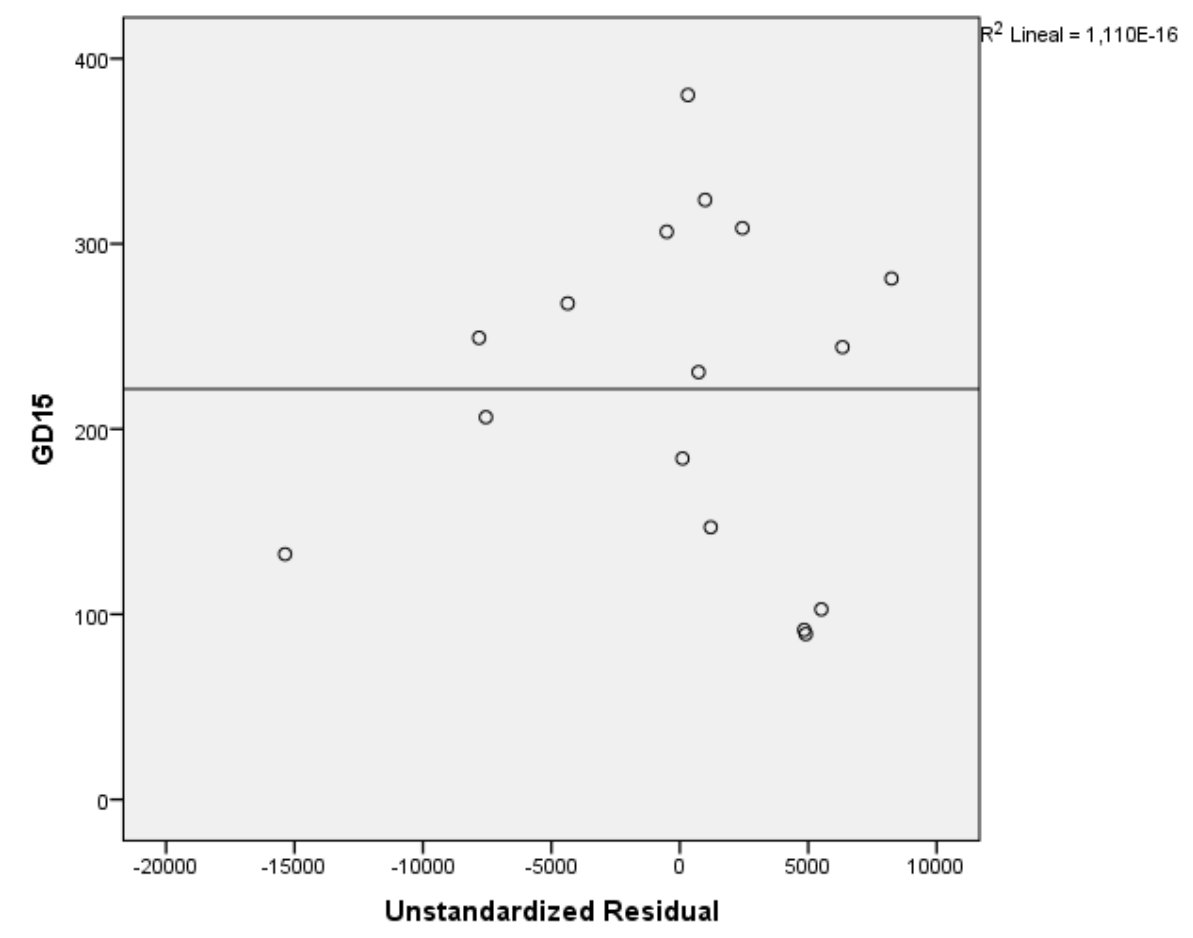

Figura 238. Relación entre GD15 y los residuos en el Edificio D6 


\section{AIV.6.3. Obtención de los consumos térmicos previstos}

Una vez comprobado el cumplimiento de los supuestos estadísticos se acepta el modelo de línea base encontrado para modelizar el consumo del Edificio D6.

$$
\text { kWh_D6_Pronosticado }=-6540,157+656,818 \times \text { GD15_30min }
$$

Con este modelo se procede a predecir los consumos previstos para las temporadas: octubre 2015-mayo 2016, octubre 2016 - mayo 2017 y octubre 2017-mayo 2018, estos consumos se muestran en la Tabla 261, donde "KWh_D6_Real", representa el consumo real, "kWh_D6_Pronosticado", el consumo pronosticado con el Modelo.

Tabla 261. Consumos previstos octubre 2014 - mayo 2017 para el edificio D6.

\begin{tabular}{rrrr}
\hline & \multicolumn{1}{c}{ GD15 } & kWh_D6_Real & kWh_D6_Pronosticado \\
\hline oct-15 & 97,04 & 32.180 & 57.199 \\
\hline nov-15 & 208,36 & 128.080 & 130.316 \\
\hline dic-15 & 300,09 & 147.210 & 190.568 \\
\hline ene-16 & 271,93 & 172.470 & 172.071 \\
\hline feb-16 & 266,36 & 348.935 & 168.412 \\
\hline mar-16 & 276,34 & 226.654 & 174.963 \\
\hline abr-16 & 181,04 & 150.969 & 112.372 \\
\hline may-16 & 99,34 & 28.051 & 58.705 \\
\hline oct-16 & 97,34 & 21.196 & 57.393 \\
\hline nov-16 & 245,69 & 190.925 & 154.834 \\
\hline dic-16 & 337,25 & 207.496 & 214.973 \\
\hline ene-17 & 386,98 & 273.478 & 247.638 \\
\hline feb-17 & 226,76 & 191.313 & 142.400 \\
\hline mar-17 & 203,17 & 147.550 & 126.905 \\
\hline abr-17 & 129,72 & 64.206 & 78.663 \\
\hline may-17 & 54,86 & 22.062 & 29.492 \\
\hline oct-17 & 92,31 & 10.750 & 54.094 \\
\hline nov-17 & 271,60 & 148.032 & 171.852 \\
\hline dic-17 & 341,26 & 222.510 & 217.603 \\
\hline ene-18 & 327,94 & 275.251 & 208.859 \\
\hline feb-18 & 321,27 & 293.190 & 204.472 \\
\hline mar-18 & 255,02 & 219.610 & 160.962 \\
\hline abr-18 & 143,31 & 102.000 & 87.586 \\
\hline may-18 & 78,41 & 29.180 & 44.959 \\
\hline & & &
\end{tabular}




\section{AIV.6.4. Estudio de la existencia de diferencias significativas}

Utilizando la prueba " $\mathrm{t}$ " de Student para muestras relacionadas, podemos concluir que si las variables se distribuyen según una normal y la significación estadística resulta $\leq 0,05$, existen diferencias significativas, con un nivel de confianza del $95 \%$

A continuación se muestra la comparación de medias realizada para cada uno de los tres periodos posteriores a la construcción de la red y para el periodo total hasta mayo de 2018.

Para la temporada Octubre 2015 - Mayo 2016, se comprueba mediante el Test de Shapiro -Wilk que tanto los valores reales como los pronosticados se distribuyen según una Normal puesto que en todos los casos los valores de Sig $>0,05$, como se observa en la Tabla 262

Tabla 262. Prueba de Normalidad temporada Octubre 2015-Mayo 2016. Edificio D6

\begin{tabular}{cccrrrrr}
\hline & \multicolumn{3}{c}{ Kolmogorov-Smirnov $^{\mathrm{a}}$} & \multicolumn{3}{c}{ Shapiro-Wilk } \\
\cline { 2 - 8 } & Estadístico & gl & Sig. & Estadístico & gl & \multicolumn{1}{c}{ Sig. } \\
\hline kWh_real &, 180 & 8 &, 200 &, 926 & 8 &, 482 \\
\hline kWh_pronosticado &, 248 & 8 &, 159 &, 865 & 8 &, 135 \\
\hline
\end{tabular}

En la Tabla 263, se observa como las medias de los consumos pronosticados, son inferiores a las medias de los consumos reales del Edificio D6, en un 13,8\%

Tabla 263. Estadísticos de muestras relacionadas. Octubre 2015-Mayo 2016. Edificio D6

\begin{tabular}{lccrrr}
\hline & Media & $\begin{array}{c}\text { \% Diferencia } \\
\text { entre medias }\end{array}$ & $\mathrm{N}$ & $\begin{array}{c}\text { Desviación } \\
\text { típ. }\end{array}$ & $\begin{array}{c}\text { Error típ. de } \\
\text { la media }\end{array}$ \\
\hline $\mathrm{kWh}$ _real & 154318,6250 & & 8 & 103543,63271 & 36608,20242 \\
\hline $\mathrm{kWh}$ _pronosticado & 133075,7500 & $-13,8 \%$ & 8 & 52852,53304 & 18686,19226 \\
\hline
\end{tabular}

La Tabla 264 muestra que las diferencias entre las medias no son significativas entre los consumos reales y los pronosticados (sig $>0,05$ ), a pesar de existir ese $-13,8 \%$ de diferencia

Tabla 264. Prueba de muestras relacionadas. Octubre 2015-Mayo 2016. Edificio D6

\begin{tabular}{|c|c|c|c|c|c|c|c|c|c|}
\hline & & \multicolumn{5}{|c|}{ Diferencias relacionadas } & \multirow{3}{*}{$\mathrm{t}$} & \multirow{3}{*}{ gl } & \multirow{3}{*}{$\begin{array}{c}\text { Sig. } \\
\text { (bilateral) }\end{array}$} \\
\hline & & \multirow[t]{2}{*}{ Media } & \multirow{2}{*}{$\begin{array}{l}\text { Desviación } \\
\text { típ. }\end{array}$} & \multirow{2}{*}{$\begin{array}{c}\text { Error típ. } \\
\text { de la media }\end{array}$} & \multicolumn{2}{|c|}{$\begin{array}{l}\text { 95\% Intervalo de confianza } \\
\text { para la diferencia }\end{array}$} & & & \\
\hline & & & & & Inferior & Superior & & & \\
\hline Par 1 & $\begin{array}{c}\text { kWh_real - } \\
\text { kWh_pronosticado }\end{array}$ & 21242,875 & 72299,829 & 25561,849 & $-39201,294$ & 81687,044 & ,831 & 7 & ,433 \\
\hline
\end{tabular}


En la Figura 239, se grafican los consumos reales y pronosticados para la temporada Octubre 2015 - Mayo 2016 para el Edificio D6, y las medias de dichos consumos. Según la prueba paramétrica realizada las diferencias encontradas no son estadísticamente significativas, por lo que no se puede afirmar la existencia de ahorros en el consumo térmico entre la situación anterior y posterior a la red de calor, con un riesgo a estar equivocados del $5 \%$

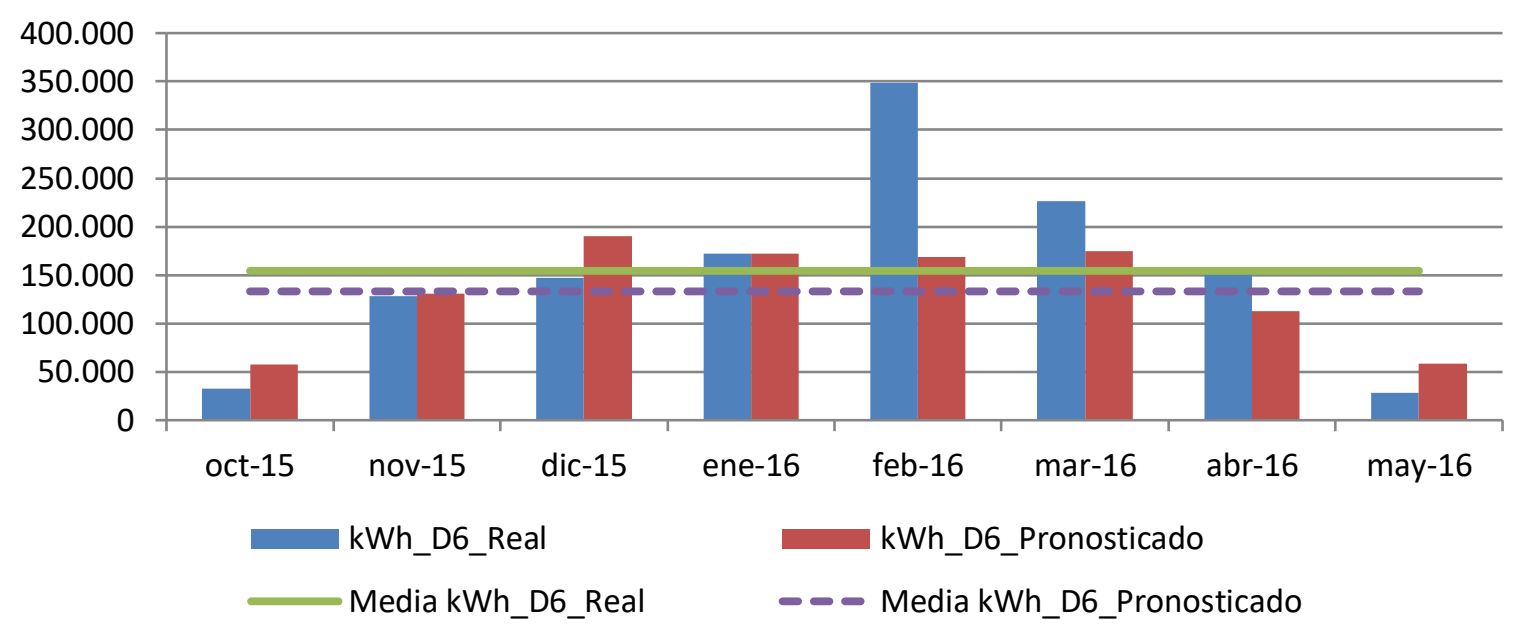

Figura 239. Consumos reales y pronosticados Octubre 2015-Mayo 2016. Edificio D6

Para la temporada Octubre 2016 - Mayo 2017, se comprueba mediante el Test de Shapiro -Wilk que tanto los valores reales como los pronosticados con los dos modelos se distribuyen según una Normal puesto que en todos los casos los valores de Sig >0,05, como se observa en la Tabla 265

Tabla 265. Prueba de Normalidad temporada Octubre 2016-Mayo 2017. Edificio D6

\begin{tabular}{ccccccrr}
\hline & \multicolumn{3}{c}{ Kolmogorov-Smirnov $^{\mathrm{a}}$} & \multicolumn{3}{c}{ Shapiro-Wilk } \\
\cline { 2 - 8 } & Estadístico & gl & Sig. & Estadístico & gl & \multicolumn{1}{c}{ Sig. } \\
\hline kWh_real &, 207 & 8 &, $200^{*}$ &, 907 & 8 &, 332 \\
\hline kWh_pronosticado &, 133 & 8 &, $200^{*}$ &, 965 & 8 &, 856 \\
\hline
\end{tabular}

En la Tabla 266, se observa como las medias de los consumos pronosticados, son inferiores a las medias de los consumos reales del Edificio D6, en un 5,9\%

Tabla 266. Estadísticos de muestras relacionadas. Octubre 2016-Mayo 2017. Edificio D6

\begin{tabular}{lccccc}
\hline & Media & $\begin{array}{c}\text { \% Diferencia } \\
\text { entre medias }\end{array}$ & N & $\begin{array}{c}\text { Desviación } \\
\text { típ. }\end{array}$ & $\begin{array}{c}\text { Error típ. de } \\
\text { la media }\end{array}$ \\
\hline kWh_real & 139778,2500 & & 8 & 93673,87798 & 33118,71717 \\
\hline kWh_pronosticado & 131537,2500 & $-5,9 \%$ & 8 & 75431,51419 & 26669,06760 \\
\hline
\end{tabular}


La Tabla 267 muestra que las diferencias entre las medias no son significativas entre los consumos reales y los pronosticados (sig $>0,05$ ), a pesar de existir ese $-5,9 \%$ de diferencia

Tabla 267. Prueba de muestras relacionadas. Octubre 2016-Mayo 2017. Edificio D6

\begin{tabular}{|c|c|c|c|c|c|c|c|c|c|}
\hline & & \multicolumn{5}{|c|}{ Diferencias relacionadas } & \multirow{3}{*}{$\mathrm{t}$} & \multirow{3}{*}{ gl } & \multirow{3}{*}{$\begin{array}{c}\text { Sig. } \\
\text { (bilateral) }\end{array}$} \\
\hline & & \multirow[t]{2}{*}{ Media } & \multirow{2}{*}{$\begin{array}{l}\text { Desviación } \\
\text { típ. }\end{array}$} & \multirow{2}{*}{$\begin{array}{c}\text { Error típ. } \\
\text { de la media }\end{array}$} & \multicolumn{2}{|c|}{$\begin{array}{l}\text { 95\% Intervalo de confianza } \\
\text { para la diferencia }\end{array}$} & & & \\
\hline & & & & & Inferior & Superior & & & \\
\hline Par 1 & $\begin{array}{c}\text { kWh_real - } \\
\text { kWh_pronosticado }\end{array}$ & 8241,000 & 28972,866 & 10243,455 & $-15980,922$ & 32462,922 & ,805 & 7 & ,448 \\
\hline
\end{tabular}

En la Figura 240, se grafican los consumos reales y pronosticados para la temporada Octubre 2016 - Mayo 2017 para el Edificio D6, y las medias de dichos consumos. Según la prueba paramétrica realizada las diferencias encontradas no son estadísticamente significativas, con un riesgo a estar equivocados del $5 \%$

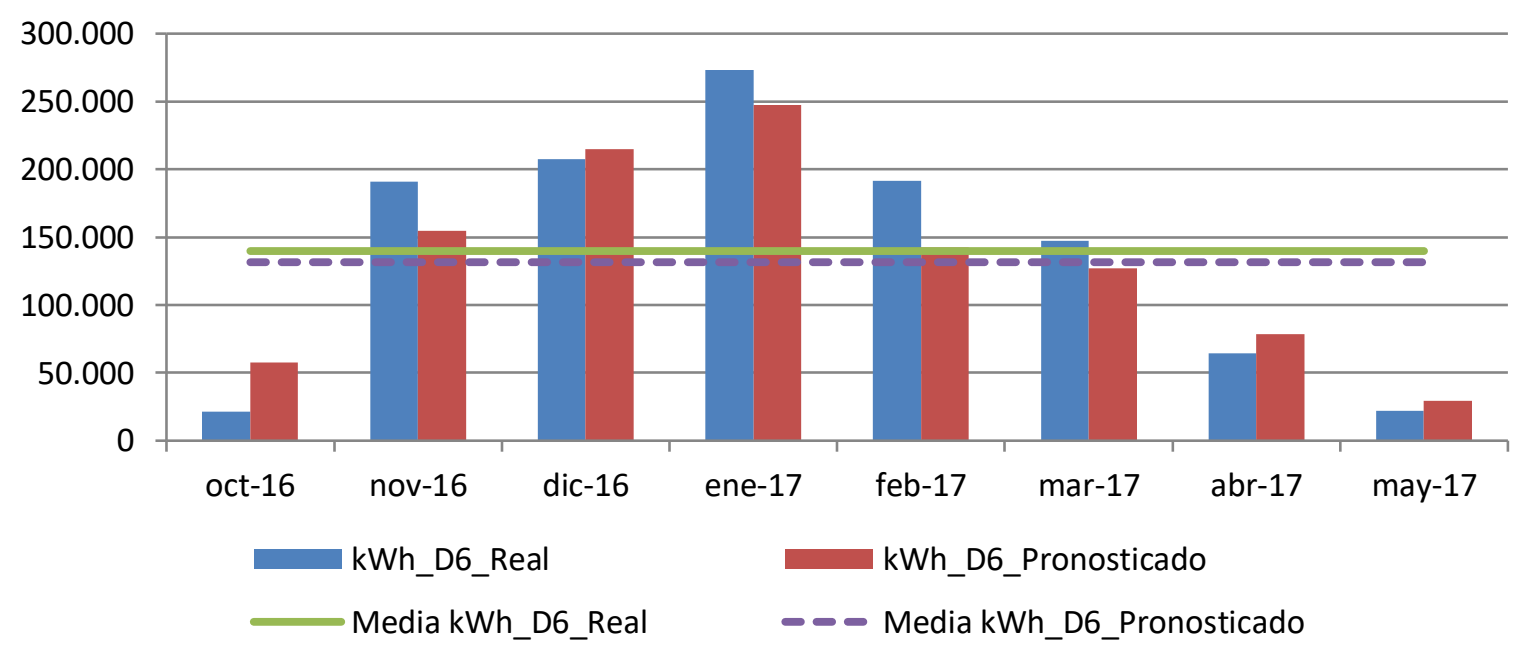

Figura 240. Consumos reales y pronosticados Octubre 2016-Mayo 2017. Edificio D6

Para la temporada Octubre 2017 - Mayo 2018, se comprueba mediante el Test de Shapiro -Wilk que tanto los valores reales como los pronosticados se distribuyen según una Normal puesto que en todos los casos los valores de Sig $>0,05$, como se observa en la Tabla 268

Tabla 268. Prueba de Normalidad temporada Octubre 2017-Mayo 2018. Edificio D6

\begin{tabular}{cccccccr}
\hline & \multicolumn{3}{c}{ Kolmogorov-Smirnov $^{\text {a }}$} & \multicolumn{3}{c}{ Shapiro-Wilk } \\
\cline { 2 - 8 } & Estadístico & gl & Sig. & Estadístico & gl & \multicolumn{1}{c}{ Sig. } \\
\hline kWh_real &, 202 & 8 &, 200 &, 922 & 8 &, 449 \\
\hline kWh_pronosticado &, 220 & 8 &, 200 &, 860 & 8 &, 119 \\
\hline
\end{tabular}


En la Tabla 269, se observa como las medias de los consumos pronosticados, son inferiores a las medias de los consumos reales del Edificio D6, en un $11,5 \%$

Tabla 269. Estadísticos de muestras relacionadas. Octubre 2017-Mayo 2018. Edificio D6

\begin{tabular}{lccrrr}
\hline & Media & $\begin{array}{c}\text { \% Diferencia } \\
\text { entre medias }\end{array}$ & N & $\begin{array}{c}\text { Desviación } \\
\text { típ. }\end{array}$ & $\begin{array}{c}\text { Error típ. de } \\
\text { la media }\end{array}$ \\
\hline $\mathrm{kWh}$ _real & 162565,3750 & & 8 & 107787,64840 & 38108,68856 \\
\hline $\mathrm{kWh}$ _pronosticado & 143798,3750 & $-11,5 \%$ & 8 & 71132,49239 & 25149,13387 \\
\hline
\end{tabular}

La Tabla 270 muestra que las diferencias entre las medias no son significativas entre los consumos reales y los pronosticados (sig > 0,05), a pesar de existir ese $-11,5 \%$ de diferencia

Tabla 270. Prueba de muestras relacionadas. Octubre 2017-Mayo 2018. Edificio D6

\begin{tabular}{|c|c|c|c|c|c|c|c|c|c|}
\hline & & \multicolumn{5}{|c|}{ Diferencias relacionadas } & \multirow{3}{*}{$\mathrm{t}$} & \multirow{3}{*}{ gl } & \multirow{3}{*}{$\begin{array}{c}\text { Sig. } \\
\text { (bilateral) }\end{array}$} \\
\hline & & \multirow[t]{2}{*}{ Media } & \multirow{2}{*}{$\begin{array}{l}\text { Desviación } \\
\text { típ. }\end{array}$} & \multirow{2}{*}{$\begin{array}{c}\text { Error típ. } \\
\text { de la media }\end{array}$} & \multicolumn{2}{|c|}{$\begin{array}{l}\text { 95\% Intervalo de confianza } \\
\text { para la diferencia }\end{array}$} & & & \\
\hline & & & & & Inferior & Superior & & & \\
\hline Par 1 & $\begin{array}{c}\text { kWh_real - } \\
\text { kWh_pronosticado }\end{array}$ & 18767,000 & 47550,996 & 16811,816 & $-20986,627$ & 58520,627 & 1,116 & 7 & 301 \\
\hline
\end{tabular}

En la Figura 241, se grafican los consumos reales y pronosticados para la temporada Octubre 2017 - Mayo 2018 para el Edificio D6, y las medias de dichos consumos. Según la prueba paramétrica realizada las diferencias encontradas no son estadísticamente significativas, con un riesgo a estar equivocados del $5 \%$

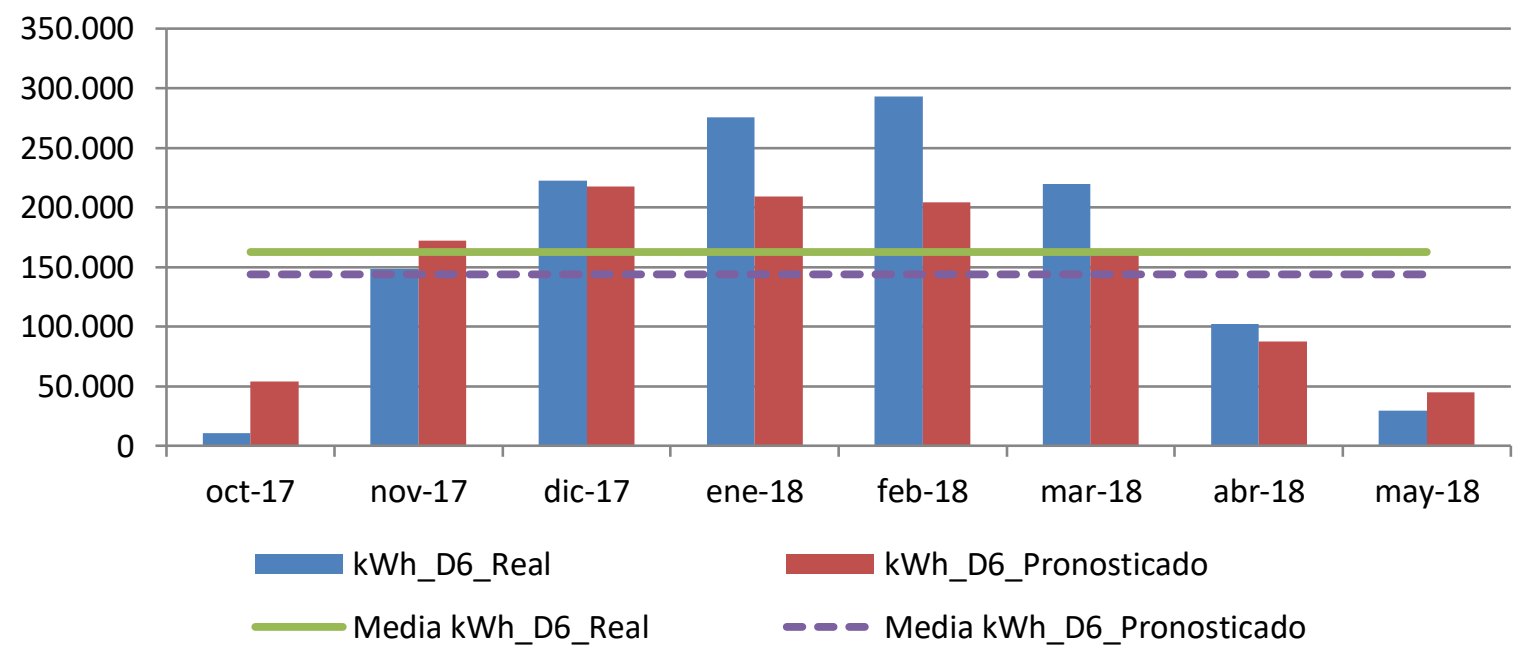

Figura 241. Consumos reales y pronosticados Octubre 2017-Mayo 2018. Edificio D6 
Para el total de las tres temporadas Octubre 2015 - Mayo 2018, se comprueba mediante el Test de Shapiro -Wilk, que los valores reales y los pronosticados se distribuyen según una Normal puesto que en esos casos los valores de Sig $>0,05$, como se observa en la Tabla 271

Tabla 271. Prueba de Normalidad temporada Octubre 2015-Mayo 2018. Edificio D6

\begin{tabular}{ccccrrrr}
\hline & \multicolumn{3}{c}{ Kolmogorov-Smirnov $^{\mathrm{a}}$} & \multicolumn{3}{c}{ Shapiro-Wilk } \\
\cline { 2 - 8 } & Estadístico & gl & Sig. & Estadístico & gl & Sig. \\
\hline kWh_real &, 140 & 24 &, $200^{*}$ &, 945 & 24 &, 214 \\
\hline kWh_pronosticado &, 135 & 24 &, $200^{*}$ &, 942 & 24 &, 183 \\
\hline
\end{tabular}

En la Tabla 272 se observa como las medias de los consumos pronosticados, son inferiores a las medias de los consumos reales del Edificio D6, en un 10,6\%

Tabla 272. Estadísticos de muestras relacionadas. Octubre 2015-Mayo 2018. Edificio D6

\begin{tabular}{lccccc}
\hline & Media & $\begin{array}{c}\text { \% Diferencia } \\
\text { entre medias }\end{array}$ & N & $\begin{array}{c}\text { Desviación } \\
\text { típ. }\end{array}$ & $\begin{array}{c}\text { Error típ. de } \\
\text { la media }\end{array}$ \\
\hline kWh_real & 152220,7729 & & 24 & 97786,33520 & 19960,55209 \\
\hline kWh_pronosticado & 136137,0471 & $-10,6 \%$ & 24 & 64442,75573 & 13154,32243 \\
\hline
\end{tabular}

La Tabla 273 muestra que las diferencias entre las medias no son significativas entre los consumos reales y los pronosticados (sig $>0,05$ ).

Tabla 273. Prueba de muestras relacionadas. Octubre 2015-Mayo 2018. Edificio D6

\begin{tabular}{|c|c|c|c|c|c|c|c|c|}
\hline & \multicolumn{5}{|c|}{ Diferencias relacionadas } & \multirow{3}{*}{$\mathrm{t}$} & \multirow{3}{*}{ gl } & \multirow{3}{*}{$\begin{array}{c}\text { Sig. } \\
\text { (bilateral) }\end{array}$} \\
\hline & \multirow[t]{2}{*}{ Media } & \multirow{2}{*}{$\begin{array}{l}\text { Desviación } \\
\text { típ. }\end{array}$} & \multirow{2}{*}{$\begin{array}{l}\text { Error típ. de } \\
\text { la media }\end{array}$} & \multicolumn{2}{|c|}{$\begin{array}{c}\text { 95\% Intervalo de confianza } \\
\text { para la diferencia }\end{array}$} & & & \\
\hline & & & & Inferior & Superior & & & \\
\hline $\begin{array}{c}\text { kWh_real - } \\
\text { kWh_pronosticado }\end{array}$ & 16083,726 & 50672,492 & 10343,479 & $-5313,391$ & 37480,843 & 1,555 & 23 & 134 \\
\hline
\end{tabular}




\section{AIV.6.5. Estimación de las emisiones de $\mathrm{CO} 2$ evitadas.}

Teniendo en cuenta que el consumir Gas natural se producen 0,252 $\mathrm{kg} \mathrm{CO}_{2} / \mathrm{kWh} \mathrm{E}$. final y que al consumir la energía suministrada por red a partir de Biomasa se producen 0,024 kg $\mathrm{CO}_{2} / \mathrm{kWh}$. final, en la Tabla 274, se muestra las emisiones de $\mathrm{CO}_{2}$ reales para las temporadas octubre 2015 - mayo 2018 y utilizando el Modelo de regresión, las emisiones de $\mathrm{CO}_{2}$ que se hubieran tenido de haber seguido utilizando las calderas de gas natural originales sin el apoyo de la red de calor.

Al no existir diferencias significativas el consumo predicho o pronosticado se ha igualado al consumo real.

Tabla 274. Estimación del ahorro de emisiones de CO2 para el Edificio D6.

\begin{tabular}{|c|c|c|c|c|c|c|c|c|c|c|}
\hline & $\begin{array}{l}\text { kWh_D6 } \\
\text { Gas } \\
\text { Natural }\end{array}$ & $\begin{array}{l}\text { kWh_D6 } \\
\text { Biomasa }\end{array}$ & $\begin{array}{l}\text { kWh_D6 } \\
\text { Real Total }\end{array}$ & $\begin{array}{l}\text { kWh_D6 } \\
\text { Predicho }\end{array}$ & $\begin{array}{l}\text { kg CO2 Real } \\
\text { debido al } \\
\text { consumo de } \\
\text { Gas Natural }\end{array}$ & $\begin{array}{l}\text { kg CO2 } \\
\text { Real } \\
\text { debido a } \\
\text { Biomasa }\end{array}$ & $\begin{array}{l}\text { kg CO2 } \\
\text { Real } \\
\text { debido al } \\
\text { consumo } \\
\text { TOTAL }\end{array}$ & $\begin{array}{c}\text { kg CO2 } \\
\text { que se } \\
\text { hubiera } \\
\text { tenido } \\
\text { debido a } \\
\text { Gas } \\
\text { Natural }\end{array}$ & $\begin{array}{c}\text { Ahorro de } \\
\text { kg CO2 }\end{array}$ & $\begin{array}{l}\text { Ahorro de kg } \\
\text { CO2 } \\
\text { acumulado }\end{array}$ \\
\hline oct-2015 & 0 & 32.180 & 32.180 & 32.180 & 0 & 772 & 772 & 8.109 & 7.337 & 7.337 \\
\hline nov-2015 & 0 & 128.080 & 128.080 & 128.080 & 0 & 3.074 & 3.074 & 32.276 & 29.202 & 36.539 \\
\hline dic-2015 & 0 & 147.210 & 147.210 & 147.210 & 0 & 3.533 & 3.533 & 37.097 & 33.564 & 70.103 \\
\hline ene-2016 & 0 & 172.470 & 172.470 & 172.470 & 0 & 4.139 & 4.139 & 43.462 & 39.323 & 109.426 \\
\hline feb-2016 & 101.645 & 247.290 & 348.935 & 348.935 & 25.615 & 5.935 & 31.550 & 87.932 & 56.382 & 165.808 \\
\hline mar-2016 & 15.254 & 211.400 & 226.654 & 226.654 & 3.844 & 5.074 & 8.918 & 57.117 & 48.199 & 214.008 \\
\hline abr-2016 & 2.159 & 148.810 & 150.969 & 150.969 & 544 & 3.571 & 4.116 & 38.044 & 33.929 & 247.936 \\
\hline may-2016 & 41 & 28.010 & 28.051 & 28.051 & 10 & 672 & 682 & 7.069 & 6.386 & 254.323 \\
\hline oct-2016 & 1.656 & 19.540 & 21.196 & 21.196 & 417 & 469 & 886 & 5.341 & 4.455 & 258.778 \\
\hline nov-2016 & 9.745 & 181.180 & 190.925 & 190.925 & 2.456 & 4.348 & 6.804 & 48.113 & 41.309 & 300.087 \\
\hline dic-2016 & 536 & 206.960 & 207.496 & 207.496 & 135 & 4.967 & 5.102 & 52.289 & 47.187 & 347.274 \\
\hline ene-2017 & 1.408 & 272.070 & 273.478 & 273.478 & 355 & 6.530 & 6.885 & 68.916 & 62.032 & 409.306 \\
\hline feb-2017 & 5.753 & 185.560 & 191.313 & 191.313 & 1.450 & 4.453 & 5.903 & 48.211 & 42.308 & 451.613 \\
\hline mar-2017 & 0 & 147.550 & 147.550 & 147.550 & 0 & 3.541 & 3.541 & 37.183 & 33.641 & 485.255 \\
\hline abr-2017 & 96 & 64.110 & 64.206 & 64.206 & 24 & 1.539 & 1.563 & 16.180 & 14.617 & 499.872 \\
\hline may-2017 & 832 & 21.230 & 22.062 & 22.062 & 210 & 510 & 719 & 5.560 & 4.840 & 504.712 \\
\hline oct-2017 & 0 & 10.750 & 10.750 & 10.750 & 0 & 258 & 258 & 2.709 & 2.451 & 507.163 \\
\hline nov-2017 & 3.312 & 144.720 & 148.032 & 148.032 & 835 & 3.473 & 4.308 & 37.304 & 32.996 & 540.159 \\
\hline dic-2017 & 0 & 222.510 & 222.510 & 222.510 & 0 & 5.340 & 5.340 & 56.073 & 50.732 & 590.892 \\
\hline ene-2018 & 81 & 275.170 & 275.251 & 275.251 & 20 & 6.604 & 6.625 & 69.363 & 62.739 & 653.630 \\
\hline feb-2018 & 0 & 293.190 & 293.190 & 293.190 & 0 & 7.037 & 7.037 & 73.884 & 66.847 & 720.478 \\
\hline mar-2018 & 0 & 219.610 & 219.610 & 219.610 & 0 & 5.271 & 5.271 & 55.342 & 50.071 & 770.549 \\
\hline abr-2018 & 0 & 102.000 & 102.000 & 102.000 & 0 & 2.448 & 2.448 & 25.704 & 23.256 & 793.805 \\
\hline may-2018 & 0 & 29.180 & 29.180 & 29.180 & 0 & 700 & 700 & 7.353 & 6.653 & 800.458 \\
\hline
\end{tabular}

Como se observa durante estas tres temporadas se ha obtenido un ahorro total de 800 Toneladas de $\mathrm{CO}_{2}$, debido al consumo térmico del edificio D6 y únicamente debido al uso de la biomasa en lugar del gas natural. 


\section{AIV.6.6. Estimación del precio máximo de compra a la red.}

Tomando como referencia los precios del gas natural de la Tabla 275 para cada temporada, obtenidos a partir de los datos establecidos en el Capítulo 3, donde se tiene en cuenta el precio por el termino variable y fijo; se puede realizar la estimación del precio máximo de compra de la energía útil a la red de calor para obtener un $0 \%$ de ahorro y un $15 \%$ de ahorro. La Tabla 276, muestral el precio que se pagaría para un ahorro del 15\%

Tabla 275. Precios de referencia para Gas natural y Astilla

\begin{tabular}{|c|c|c|c|c|}
\hline Precios $(€ /(k W h)$ & 2015 & 2016 & 2017 & 2018 \\
\hline Gas Natural & 0,0373 & 0,0306 & 0,0314 & 0,0336 \\
\hline Astilla & 0,0277 & 0,0256 & 0,0254 & 0,0239 \\
\hline $\begin{array}{l}€ / \text { kWh útiles máximos de compra a la red para } \\
\text { un ahorro del } 0,0 \%\end{array}$ & \multicolumn{4}{|c|}{0,03220} \\
\hline $\begin{array}{l}€ / \text { kWh útiles máximos de compra a la red para } \\
\text { un ahorro del } 15,0 \%\end{array}$ & \multicolumn{4}{|c|}{0,02719} \\
\hline
\end{tabular}

Tabla 276. Ahorro Económico por el consumo térmico en el Edificio D6

\begin{tabular}{|c|c|c|c|c|c|c|c|c|c|c|}
\hline & $\begin{array}{c}\text { kWh_D6 } \\
\text { Gas } \\
\text { Natural }\end{array}$ & $\begin{array}{c}\text { kWh_D6_ } \\
\text { Biomasa }\end{array}$ & $\begin{array}{c}\text { kWh_D6 } \\
\text { Real }\end{array}$ & $\begin{array}{c}\text { kWh_D6 } \\
\text { Pronosticado }\end{array}$ & $\begin{array}{c}€ \text { Real } \\
\text { Gas } \\
\text { Natural }\end{array}$ & $\begin{array}{c}€ \text { Real } \\
\text { Biomasa }\end{array}$ & $\begin{array}{l}€ \text { Real } \\
\text { Total }\end{array}$ & $\begin{array}{c}\text { E predicho } \\
\text { Gas } \\
\text { natural }\end{array}$ & $\begin{array}{c}€ \\
\text { Ahorro }\end{array}$ & $€$ Acumulado \\
\hline oct-2015 & 0 & 32.180 & 32.180 & 32.180 & 0 & 875 & 875 & 1.200 & 325 & 325 \\
\hline nov-2015 & 0 & 128.080 & 128.080 & 128.080 & 0 & 3.482 & 3.482 & 4.777 & 1.295 & 1.620 \\
\hline dic-2015 & 0 & 147.210 & 147.210 & 147.210 & 0 & 4.003 & 4.003 & 5.491 & 1.488 & 3.109 \\
\hline ene-2016 & 0 & 172.470 & 172.470 & 172.470 & 0 & 4.689 & 4.689 & 5.278 & 588 & 3.697 \\
\hline feb-2016 & 101.645 & 247.290 & 348.935 & 348.935 & 3.110 & 6.724 & 9.834 & 10.677 & 843 & 4.540 \\
\hline mar-2016 & 15.254 & 211.400 & 226.654 & 226.654 & 467 & 5.748 & 6.215 & 6.936 & 721 & 5.261 \\
\hline$a b r-2016$ & 2.159 & 148.810 & 150.969 & 150.969 & 66 & 4.046 & 4.112 & 4.620 & 507 & 5.768 \\
\hline may-2016 & 41 & 28.010 & 28.051 & 28.051 & 1 & 762 & 763 & 858 & 96 & 5.864 \\
\hline oct-2016 & 1.656 & 19.540 & 21.196 & 21.196 & 51 & 531 & 582 & 649 & 67 & 5.930 \\
\hline nov-2016 & 9.745 & 181.180 & 190.925 & 190.925 & 298 & 4.926 & 5.224 & 5.842 & 618 & 6.548 \\
\hline dic-2016 & 536 & 206.960 & 207.496 & 207.496 & 16 & 5.627 & 5.644 & 6.349 & 706 & 7.254 \\
\hline ene-2017 & 1.408 & 272.070 & 273.478 & 273.478 & 44 & 7.398 & 7.442 & 8.587 & 1.145 & 8.399 \\
\hline feb-2017 & 5.753 & 185.560 & 191.313 & 191.313 & 181 & 5.045 & 5.226 & 6.007 & 781 & 9.181 \\
\hline mar-2017 & 0 & 147.550 & 147.550 & 147.550 & 0 & 4.012 & 4.012 & 4.633 & 621 & 9.802 \\
\hline$a b r-2017$ & 96 & 64.110 & 64.206 & 64.206 & 3 & 1.743 & 1.746 & 2.016 & 270 & 10.072 \\
\hline may-2017 & 832 & 21.230 & 22.062 & 22.062 & 26 & 577 & 603 & 693 & 89 & 10.161 \\
\hline oct-2017 & 0 & 10.750 & 10.750 & 10.750 & 0 & 292 & 292 & 338 & 45 & 10.206 \\
\hline nov-2017 & 3.312 & 144.720 & 148.032 & 148.032 & 104 & 3.935 & 4.039 & 4.648 & 609 & 10.816 \\
\hline dic-2017 & 0 & 222.510 & 222.510 & 222.510 & 0 & 6.050 & 6.050 & 6.987 & 937 & 11.752 \\
\hline ene-2018 & 81 & 275.170 & 275.251 & 275.251 & 3 & 7.482 & 7.485 & 9.248 & 1.764 & 13.516 \\
\hline feb-2018 & 0 & 293.190 & 293.190 & 293.190 & 0 & 7.972 & 7.972 & 9.851 & 1.879 & 15.395 \\
\hline mar-2018 & 0 & 219.610 & 219.610 & 219.610 & 0 & 5.971 & 5.971 & 7.379 & 1.408 & 16.803 \\
\hline abr-2018 & 0 & 102.000 & 102.000 & 102.000 & 0 & 2.773 & 2.773 & 3.427 & 654 & 17.457 \\
\hline may-2018 & 0 & 29.180 & 29.180 & 29.180 & 0 & 793 & 793 & 980 & 187 & 17.644 \\
\hline$€$ Total & & & & & & & 99.829 & 117.473 & & \\
\hline Ahorro (\%) & & & & & & & & & & $15,0 \%$ \\
\hline
\end{tabular}




\section{AlV.7.Edificio D7. Edificio de Telecomunicaciones e Informática.}

\section{AIV.7.1. Obtención de la línea base de referencia energética}

Los datos de partida para la obtención de la línea base de referencia se muestran en la Tabla 277

Tabla 277. Consumos térmicos del edificio D7

\begin{tabular}{lr}
\hline & Consumos térmicos (kWh). D7 \\
\hline oct-12 & 75.227 \\
\hline nov-12 & 163.403 \\
\hline dic-12 & 217.741 \\
\hline ene-13 & 231.815 \\
\hline feb-13 & 222.100 \\
\hline mar-13 & 178.875 \\
\hline abr-13 & 128.571 \\
\hline may-13 & 102.436 \\
\hline oct-13 & 65.408 \\
\hline nov-13 & 168.407 \\
\hline dic-13 & 272.681 \\
\hline ene-14 & 207.919 \\
\hline feb-14 & 185.496 \\
\hline mar-14 & 137.241 \\
\hline abr-14 & 74.250 \\
\hline may-14 & 63.862 \\
\hline Promedio & 155.964 \\
\hline Total (oct-12-may-13) & 1.320 .168 \\
\hline Total (oct-13-may-14) & 1.175 .263 \\
\hline Total (oct-12-may-13) & 2.495 .431 \\
\hline
\end{tabular}

Se disponen de 16 datos para establecer el modelo de regresión, mediante el método de pasos sucesivos. Como se puede ver en la Tabla 278 para el edificio, el método ofrece un modelo de regresión, con una sola variable (Grados Día en base 15, obtenidos con datos cada 30 minutos). El modelo fue construido con un solo paso, incluyendo los Grados día base 15 por ser la variable más significativa (variable con menor valor de Sig $=0,000$ ). El resto de las variables como se observa en la Tabla 279 fueron excluidas del modelo al tener valores de sig $>0,05$.

Tabla 278. Modelos de regresión del Edificio D7

\begin{tabular}{|c|c|c|c|c|c|c|c|}
\hline & \multirow{2}{*}{ Modelo } & \multicolumn{2}{|c|}{$\begin{array}{l}\text { Coeficientes no } \\
\text { estandarizados }\end{array}$} & \multirow{2}{*}{$\mathrm{t}$} & \multirow{2}{*}{ Sig. } & \multicolumn{2}{|c|}{$\begin{array}{l}\text { Intervalo de confianza de } \\
95,0 \% \text { para B }\end{array}$} \\
\hline & & B & Error típ. & & & $\begin{array}{l}\text { Límite } \\
\text { inferior }\end{array}$ & $\begin{array}{l}\text { Límite } \\
\text { superior }\end{array}$ \\
\hline \multirow[t]{2}{*}{1} & (Constante) & $-6543,072$ & 4358,239 & $-1,501$ & 155 & $-15890,564$ & 2804,421 \\
\hline & GD15_30min & 733,335 & 18,306 & 40,059 & ,000 & 694,072 & 772,599 \\
\hline
\end{tabular}


En la Figura 242 se representa el modelo de regresión con sus límites inferior y superior para un nivel de confianza del $95 \%$

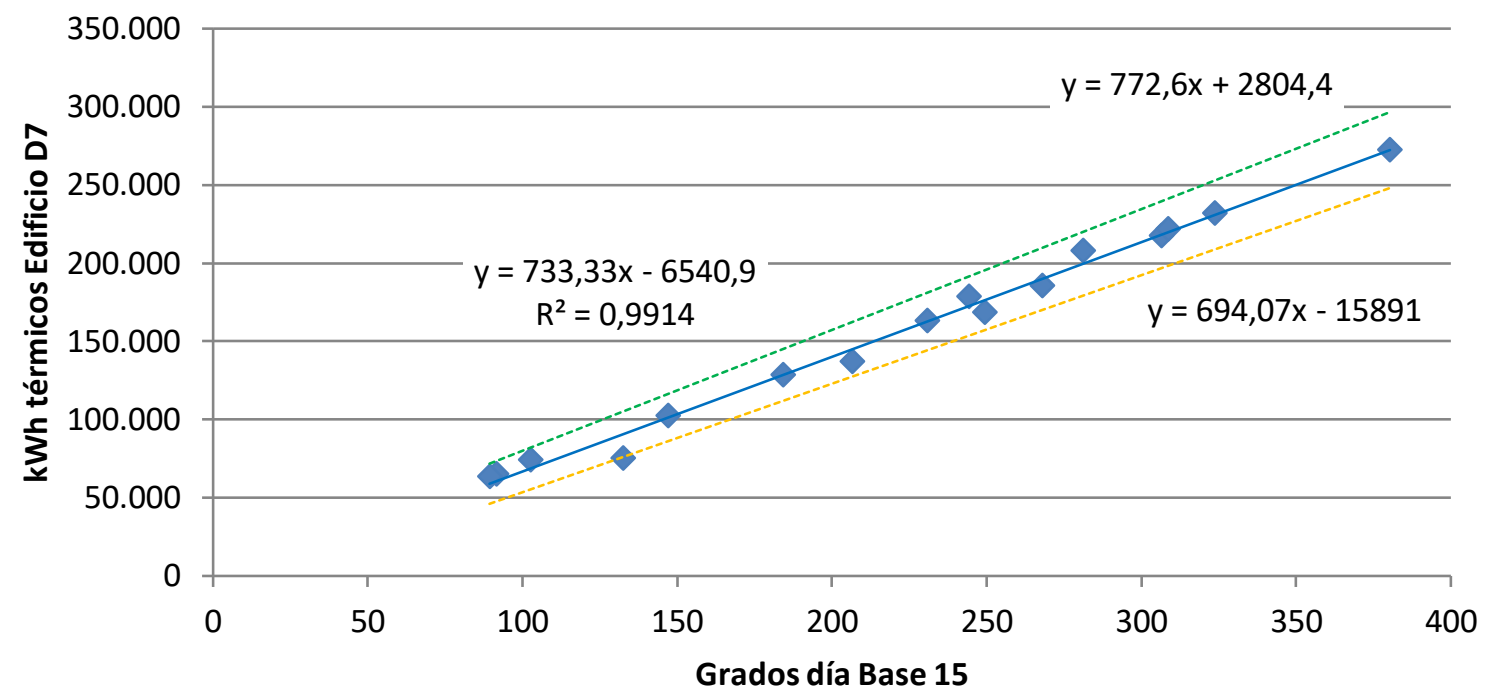
$\rightarrow \quad \mathrm{D} 7(\mathrm{kWh})$
L Lineal (D7 (kWh))
Lineal (D7 lim inferior)
- Lineal (D7 lím superior)

Figura 242. Representación del modelo de regresión lineal simple para el Edificio D7

Tabla 279. Variables excluidas del modelo de región del Edificio D7

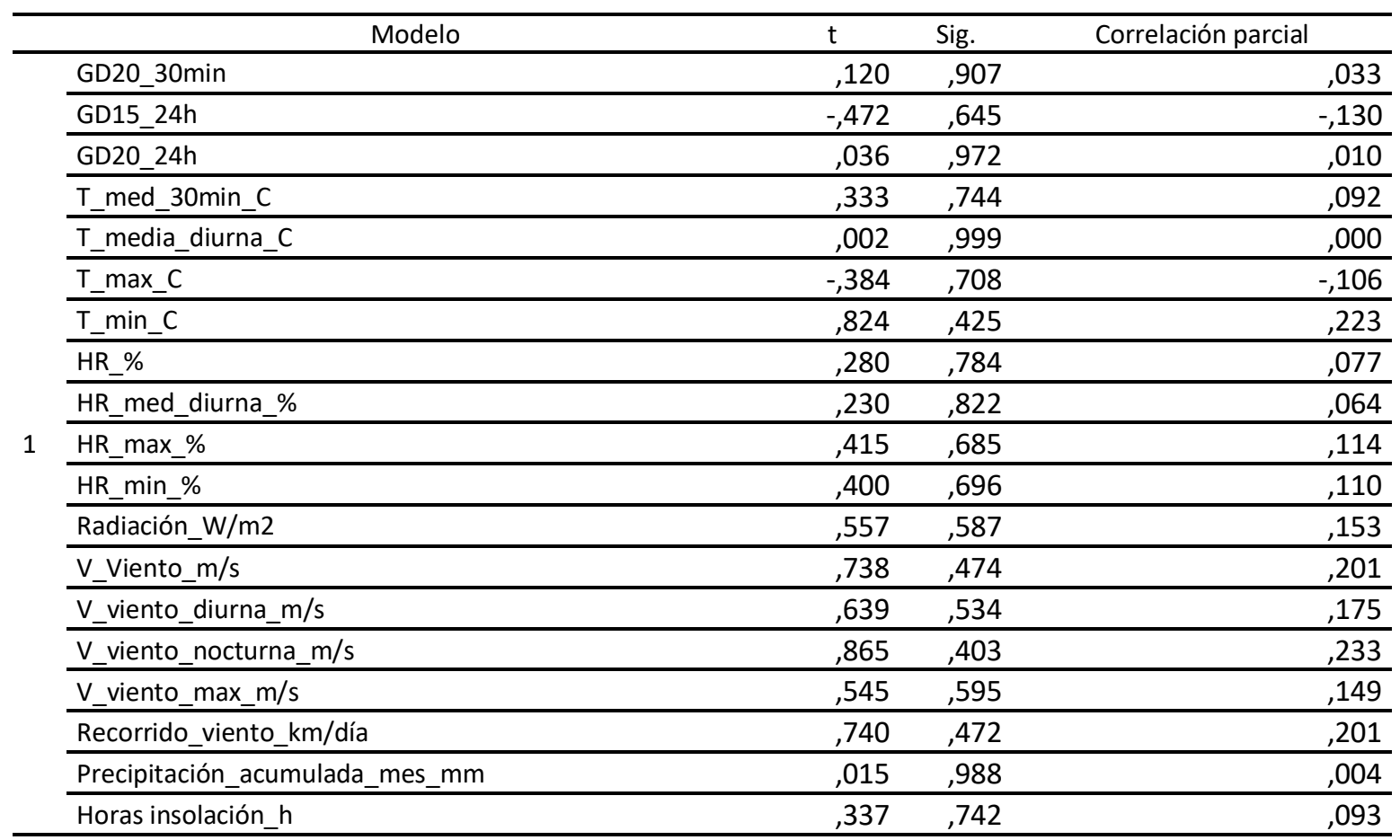


La bondad de los modelos de regresión obtenidos para el edificio D7, se resumen en la Tabla 280

Tabla 280. Resumen de la bondad de los modelos de regresión para el Edificio D7

\begin{tabular}{ccccc}
\hline Modelo & $\mathrm{R}$ & R cuadrado & R cuadrado corregida & $\begin{array}{c}\text { Error típ. de la } \\
\text { estimación }\end{array}$ \\
\hline 1 &, 996 &, 991 &, 991 & 6371,70775 \\
\hline
\end{tabular}

Se observa como el modelo de regresión lineal simple presenta un Coeficiente de Correlación de Pearson (R) de 0,996, lo que indica que las variables están correlacionadas de manera muy fuerte (en la correlación perfecta $\mathrm{R}= \pm 1$ ). La correlación que se produce es directa, al aumentar el valor de los Grados día, aumenta el consumo térmico.

El coeficiente de determinación $\left(R^{2}\right)$, nos indica que con el modelo se podría explicar el $99,1 \%$ de los datos reales obtenidos aceptando un error del $5 \%$.

El error típico de la estimación que nos indica la magnitud de los errores, es decir la parte de la variable dependiente que dejamos sin explicar con el modelo y que describe la variación de la variable respuesta (el Consumo) respecto a la recta de regresión, es de $6.371 \mathrm{kWh}$, lo que representa un 4,1\% del promedio de los consumos que fue de 155.964 kWh.

\section{AIV.7.2. Verificación del cumplimiento de los supuestos estadísticos}

Las condiciones que se deben cumplir en un modelo de regresión son:

\section{- Linealidad de las variables, las variables se encuentran relacionadas de forma lineal.}

Como se observa en la Tabla 278, la pendiente (B), obtuvo un valor de Sig $=0,000$, que al ser $\leq 0,05$, nos indica que podemos rechazar la hipótesis nula de pendiente igual a cero y nos da la evidencia de linealidad entre la variable dependiente ( $k$ Wh del edificio D7) y la independiente (GD15_30min). Al ser el valor de la pendiente positiva, indica una relación directa entre el consumo y los Grados día base 15, calculados con datos cada 30 minutos.

- Normalidad. Todos los valores obtenidos para la variable dependiente (Y), deben estar distribuidos normalmente en cada valor de la variable independiente (X).

Se comprueba la normalidad de las variables y de los residuos mediante el Test de Shapiro - Wilk para muestras pequeñas (menores a 30 observaciones), siendo la hipótesis nula el que la distribución es Normal. 
La Tabla 281, muestra la prueba de normalidad de Shapiro-Wilk y cómo tanto la variable dependiente (consumos del Edificio), como la variable independientes: GD15 poseen una Sig $>0,05$, por lo que aceptamos la hipótesis nula de Normalidad de las variables

Tabla 281. Prueba de normalidad para el edificio D7

\begin{tabular}{lrrrrrr}
\hline & \multicolumn{3}{c}{ Kolmogorov-Smirnov } & \multicolumn{3}{c}{ Shapiro-Wilk } \\
\cline { 2 - 7 } & Estadístico & gl & Sig. & Estadístico & gl & \multicolumn{1}{c}{ Sig. } \\
\hline kWh_D7 &, 139 & 16 &, $200^{*}$ &, 942 & 16 &, 372 \\
\hline GD15_30min &, 109 & 16 &, $200^{*}$ &, 953 & 16 &, 541 \\
\hline
\end{tabular}

- Independencia de los errores. Los errores asociados a los valores de la variable respuesta $(Y)$ deberán ser independientes unos de otros.

Para la comprobación se utiliza el estadístico de Durbin -Watson.

Se comprueba que el Estadístico de Durbin Watson para el nivel de significancia del 5\%, y para el tamaño de la muestra " $n$ " y el número de variables independientes del modelo " $k$ ", se encuentra en el intervalo [dU, 4-dU], de la Tabla 3, intervalo centrado en el 2, que indica la ausencia de autocorrelación.

El valor del Estadístico Durbin-Watson facilitado por el programa SPSS, es 1,693.

En el modelo, $n=16$ y $k=1$, según la Tabla 3 el valor $\mathrm{dU}=1,371$, luego el intervalo que marca la ausencia de correlación es [1,371, 2,629], como el valor del estadístico 1,693 está dentro del intervalo, se acepta la ausencia de autocorrelación

- Homocedasticidad de la varianza. Se pretende comprobar que la varianza de los errores $\left(\sigma^{2}\right)$ es constante para cualquier valor de la variable independiente $(X)$, es decir que el valor medio del cuadrado de la desviación de los errores respecto a su media es constante.

Esta condición indica que no existe correlación entre los residuos y los pronósticos. Se comprueba que el coeficiente de determinación $\mathrm{R}^{2}$, en las relaciones: residuos $\mathrm{y}$ predicciones y entre residuos y variable independiente es nulo o muy próximo a cero, lo que indicará que no existe ningún tipo de correlación en los residuos y que éstos son aleatorios.

Se grafican los diagramas de dispersión de esas relaciones, comprobando que se corresponden a nubes de puntos totalmente aleatorias, sin tendencias ni patrones en sus representaciones gráficas. 
Las Figura 243 y Figura 244, muestran que la relación entre los pronósticos y los residuos, posee un coeficiente de determinación $=0$ y entre la variable independiente (Grados Día Base 15) y los residuos un coeficiente de determinación de $-2,22 \times 10^{-16}$, también prácticamente nulo; por lo que se concluye que no existe ningún tipo de correlación en los residuos y que éstos son aleatorios, siendo la varianza de los residuos constante

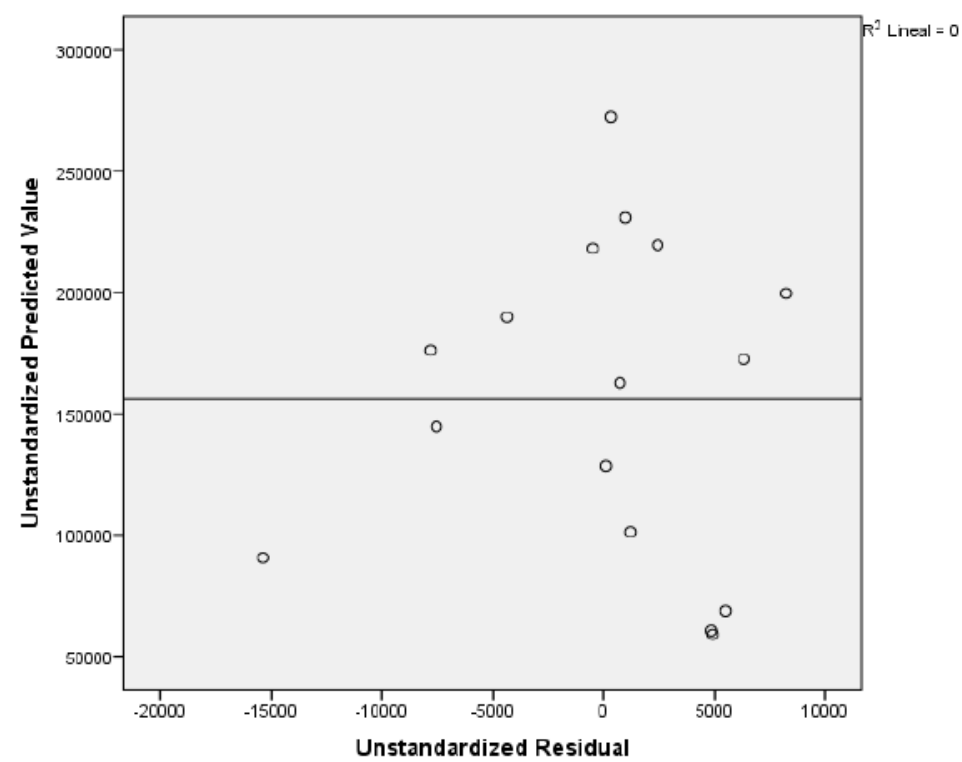

Figura 243. Relación entre los pronósticos y los residuos en el Edificio D7

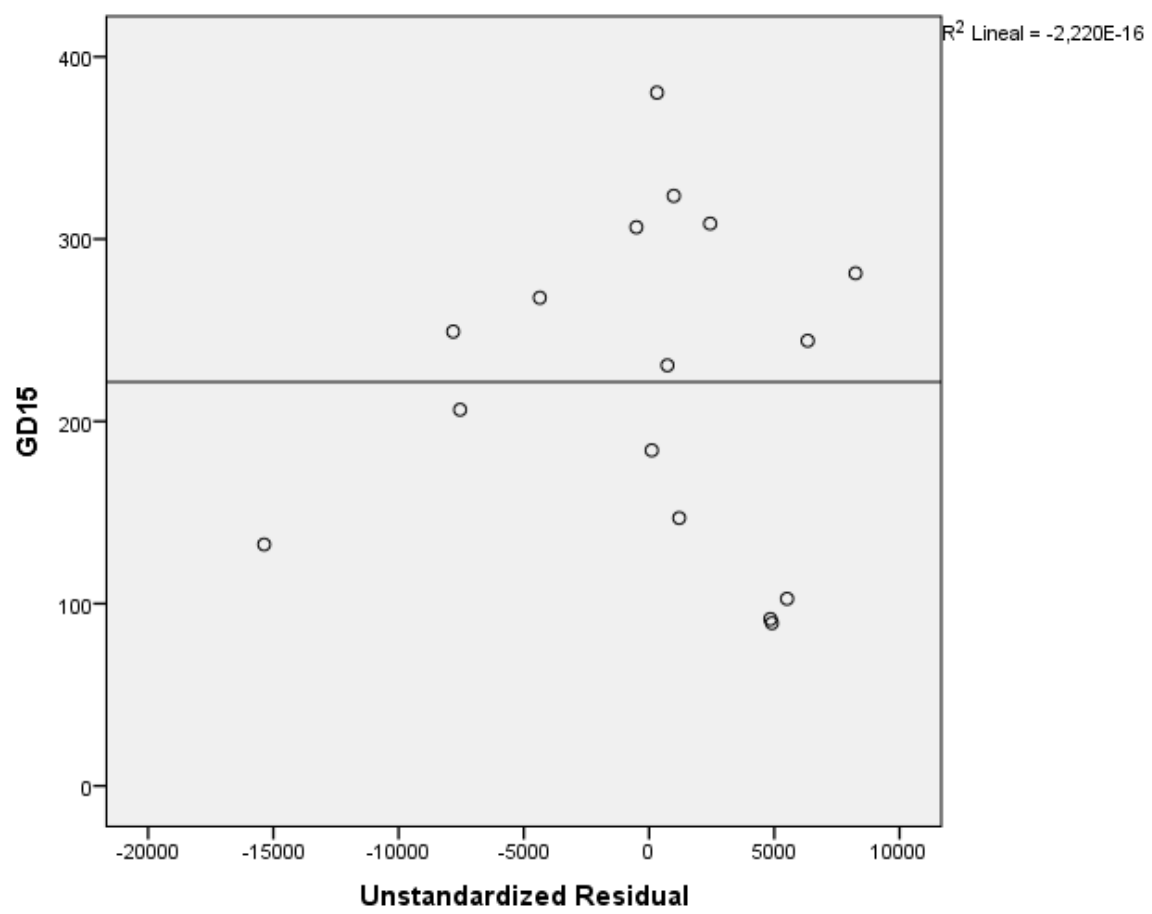

Figura 244. Relación entre GD15 y los residuos en el Edificio D7 


\section{AlV.7.3. Obtención de los consumos térmicos previstos}

Una vez comprobado el cumplimiento de los supuestos estadísticos se acepta el modelo de línea base encontrado para modelizar el consumo del Edificio D7.

$$
\text { kWh_D7_Pronosticado }=-6543,072+733,335 \times \text { GD15_30min }
$$

Con este modelo se procede a predecir los consumos previstos para las temporadas: octubre 2015-mayo 2016, octubre 2016 - mayo 2017 y octubre 2017-mayo 2018, estos consumos se muestran en la Tabla 282, donde "KWh_D7_Real", representa el consumo real, "kWh_D7_Pronosticado", el consumo pronosticado con el Modelo.

Tabla 282. Consumos previstos octubre 2014 - mayo 2017 para el edificio D7.

\begin{tabular}{rrrr}
\hline & GD15 & kWh_D7_Real & kWh_D7_Pronosticado \\
\hline oct-15 & 97,04 & 22.220 & 64.622 \\
\hline nov-15 & 208,36 & 128.080 & 146.256 \\
\hline dic-15 & 300,09 & 124.770 & 213.527 \\
\hline ene-16 & 271,93 & 163.370 & 192.875 \\
\hline feb-16 & 266,36 & 297.336 & 188.790 \\
\hline mar-16 & 276,34 & 200.359 & 196.105 \\
\hline abr-16 & 181,04 & 139.890 & 126.222 \\
\hline may-16 & 99,34 & 25.190 & 66.303 \\
\hline oct-16 & 97,34 & 33.434 & 64.838 \\
\hline nov-16 & 245,69 & 175.576 & 173.630 \\
\hline dic-16 & 337,25 & 145.836 & 240.775 \\
\hline ene-17 & 386,98 & 258.264 & 277.246 \\
\hline feb-17 & 226,76 & 182.550 & 159.748 \\
\hline mar-17 & 203,17 & 150.896 & 142.448 \\
\hline abr-17 & 129,72 & 55.650 & 88.586 \\
\hline may-17 & 54,86 & 14.320 & 33.686 \\
\hline oct-17 & 92,31 & 9.884 & 61.154 \\
\hline nov-17 & 271,60 & 124.350 & 192.632 \\
\hline dic-17 & 341,26 & 173.018 & 243.712 \\
\hline ene-18 & 327,94 & 188.888 & 233.949 \\
\hline feb-18 & 321,27 & 245.226 & 229.052 \\
\hline mar-18 & 255,02 & 217.314 & 180.472 \\
\hline abr-18 & 143,31 & 99.014 & 98.548 \\
\hline may-18 & 78,41 & 23.570 & 2.392 \\
\hline & & &
\end{tabular}




\section{AIV.7.4. Estudio de la existencia de diferencias significativas}

Utilizando la prueba " $\mathrm{t}$ " de Student para muestras relacionadas, podemos concluir que si las variables se distribuyen según una normal y la significación estadística resulta $\leq 0,05$, existen diferencias significativas, con un nivel de confianza del $95 \%$

A continuación se muestra la comparación de medias realizada para cada uno de los tres periodos posteriores a la construcción de la red y para el periodo total hasta mayo de 2018.

Para la temporada Octubre 2015 - Mayo 2016, se comprueba mediante el Test de Shapiro -Wilk que tanto los valores reales como los pronosticados se distribuyen según una Normal puesto que en todos los casos los valores de Sig $>0,05$, como se observa en la Tabla 283

Tabla 283. Prueba de Normalidad temporada Octubre 2015-Mayo 2016. Edificio D7

\begin{tabular}{crrrrrrr}
\hline & \multicolumn{3}{c}{ Kolmogorov-Smirnov $^{\text {a }}$} & \multicolumn{3}{c}{ Shapiro-Wilk } \\
\cline { 2 - 8 } & Estadístico & gl & \multicolumn{1}{c}{ Sig. } & Estadístico & gl & \multicolumn{1}{c}{ Sig. } \\
\hline kWh_real &, 193 & 8 &, $200^{*}$ &, 933 & 8 &, 548 \\
\hline kWh_pronosticado &, 248 & 8 &, 159 &, 865 & 8 &, 135 \\
\hline
\end{tabular}

En la Tabla 284, se observa como las medias de los consumos pronosticados, son superiores a las medias de los consumos reales del Edificio D7, en un 8,5\%

Tabla 284. Estadísticos de muestras relacionadas. Octubre 2015-Mayo 2016. Edificio D7

\begin{tabular}{lccrcc}
\hline & Media & $\begin{array}{c}\text { \% Diferencia } \\
\text { entre medias }\end{array}$ & $\mathrm{N}$ & $\begin{array}{c}\text { Desviación } \\
\text { típ. }\end{array}$ & $\begin{array}{c}\text { Error típ. de } \\
\text { la media }\end{array}$ \\
\hline kWh_real & 137651,8750 & & 8 & 89703,78958 & 31715,07895 \\
\hline kWh_pronosticado & 149337,5000 & $8,5 \%$ & 8 & 59009,40693 & 20862,97590 \\
\hline
\end{tabular}

La Tabla 285 muestra que las diferencias entre las medias no son significativas entre los consumos reales y los pronosticados ( $\operatorname{sig}>0,05$ ), a pesar de existir ese $8,5 \%$ de diferencia

Tabla 285. Prueba de muestras relacionadas. Octubre 2015-Mayo 2016. Edificio D7

\begin{tabular}{|c|c|c|c|c|c|c|c|c|c|}
\hline & & \multicolumn{5}{|c|}{ Diferencias relacionadas } & \multirow{3}{*}{$\mathrm{t}$} & \multirow{3}{*}{ gl } & \multirow{3}{*}{$\begin{array}{c}\text { Sig. } \\
\text { (bilateral) }\end{array}$} \\
\hline & & \multirow[t]{2}{*}{ Media } & \multirow{2}{*}{$\begin{array}{l}\text { Desviación } \\
\text { típ. }\end{array}$} & \multirow{2}{*}{$\begin{array}{c}\text { Error típ. } \\
\text { de la media }\end{array}$} & \multicolumn{2}{|c|}{$\begin{array}{l}\text { 95\% Intervalo de confianza } \\
\text { para la diferencia }\end{array}$} & & & \\
\hline & & & & & Inferior & Superior & & & \\
\hline Par 1 & $\begin{array}{c}\text { kWh_real - } \\
\text { kWh_pronosticado }\end{array}$ & $-11685,625$ & 57893,547 & 20468,460 & $-60085,842$ & 36714,592 &,- 571 & 7 & ,586 \\
\hline
\end{tabular}


En la Figura 245, se grafican los consumos reales y pronosticados para la temporada Octubre 2015 - Mayo 2016 para el Edificio D7, y las medias de dichos consumos. Según la prueba paramétrica realizada las diferencias encontradas no son estadísticamente significativas, por lo que no se puede afirmar la existencia de ahorros en el consumo térmico entre la situación anterior y posterior a la red de calor, con un riesgo a estar equivocados del $5 \%$

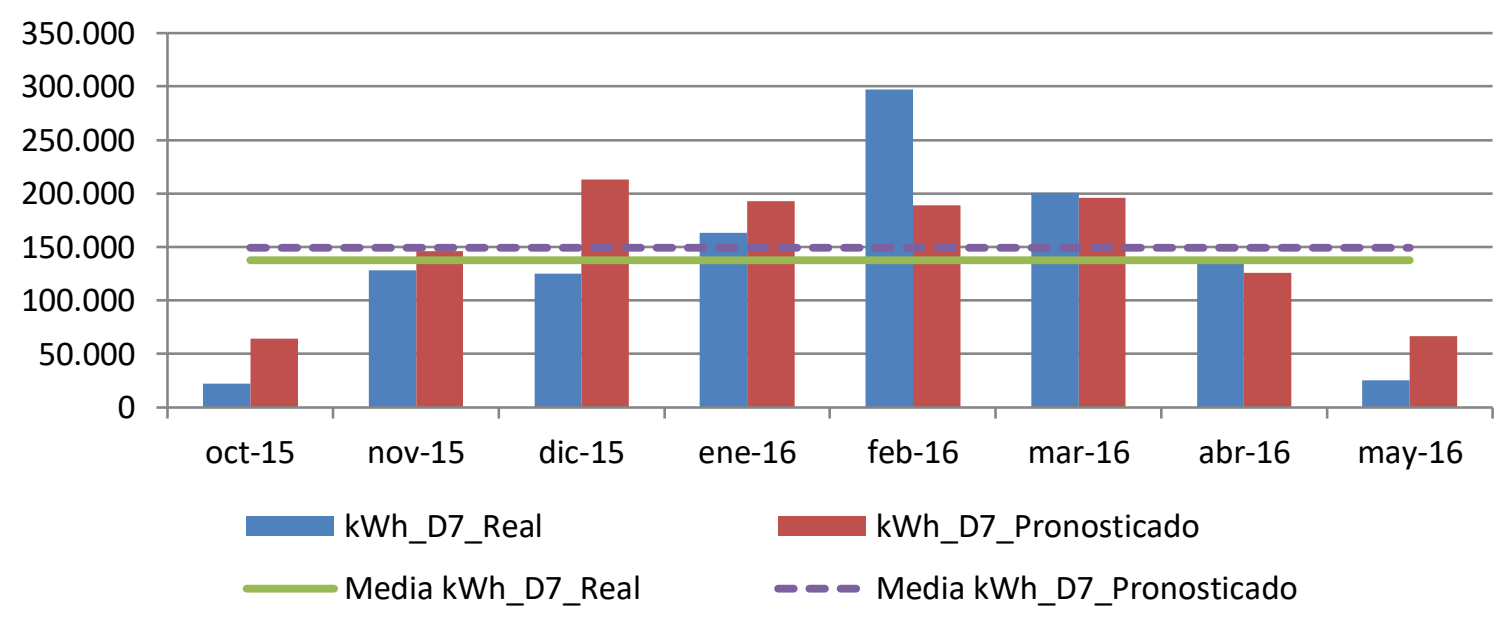

Figura 245. Consumos reales y pronosticados Octubre 2015-Mayo 2016. Edificio D7

Para la temporada Octubre 2016 - Mayo 2017, se comprueba mediante el Test de Shapiro -Wilk que tanto los valores reales como los pronosticados con los dos modelos se distribuyen según una Normal puesto que en todos los casos los valores de Sig >0,05, como se observa en la Tabla 286

Tabla 286. Prueba de Normalidad temporada Octubre 2016-Mayo 2017. Edificio D7

\begin{tabular}{cccccccr}
\hline & \multicolumn{3}{c}{ Kolmogorov-Smirnov $^{\mathrm{a}}$} & \multicolumn{3}{c}{ Shapiro-Wilk } \\
\cline { 2 - 8 } & Estadístico & $\mathrm{gl}$ & \multicolumn{1}{c}{ Sig. } & Estadístico & $\mathrm{gl}$ & \multicolumn{1}{c}{ Sig. } \\
\hline kWh_real &, 213 & 8 &, 200 &, 931 & 8 &, 524 \\
\hline kWh_pronosticado &, 133 & 8 &, 200 &, 965 & 8 &, 856 \\
\hline
\end{tabular}

En la Tabla 287, se observa como las medias de los consumos pronosticados, son superiores a las medias de los consumos reales del Edificio D7, en un 16,2\%

Tabla 287. Estadísticos de muestras relacionadas. Octubre 2016-Mayo 2017. Edificio D7

\begin{tabular}{lccccc}
\hline & Media & $\begin{array}{c}\text { \% Diferencia } \\
\text { entre medias }\end{array}$ & $\mathrm{N}$ & $\begin{array}{c}\text { Desviación } \\
\text { típ. }\end{array}$ & $\begin{array}{c}\text { Error típ. de } \\
\text { la media }\end{array}$ \\
\hline kWh_real & 127065,7500 & & 8 & 84636,74342 & 29923,60760 \\
\hline kWh_pronosticado & 147619,6250 & $16,2 \%$ & 8 & 84219,05197 & 29775,93138 \\
\hline
\end{tabular}


La Tabla 288 muestra que las diferencias entre las medias no son significativas entre los consumos reales y los pronosticados (sig $>0,05$ ), a pesar de existir ese $16,2 \%$ de diferencia

Tabla 288. Prueba de muestras relacionadas. Octubre 2016-Mayo 2017. Edificio D7

\begin{tabular}{|c|c|c|c|c|c|c|c|c|c|}
\hline & & \multicolumn{5}{|c|}{ Diferencias relacionadas } & \multirow{3}{*}{$\mathrm{t}$} & \multirow{3}{*}{$\mathrm{gl}$} & \multirow{3}{*}{$\begin{array}{c}\text { Sig. } \\
\text { (bilateral) }\end{array}$} \\
\hline & & \multirow[t]{2}{*}{ Media } & \multirow{2}{*}{$\begin{array}{l}\text { Desviación } \\
\text { típ. }\end{array}$} & \multirow{2}{*}{$\begin{array}{l}\text { Error típ. } \\
\text { de la media }\end{array}$} & \multicolumn{2}{|c|}{$\begin{array}{l}\text { 95\% Intervalo de confianza } \\
\text { para la diferencia }\end{array}$} & & & \\
\hline & & & & & Inferior & Superior & & & \\
\hline Par 1 & $\begin{array}{c}\text { kWh_real - } \\
\text { kWh_pronosticado }\end{array}$ & $-20553,875$ & 35926,822 & 12702,050 & $-50589,450$ & 9481,700 & $-1,618$ & 7 & 150 \\
\hline
\end{tabular}

En la Figura 246, se grafican los consumos reales y pronosticados para la temporada Octubre 2016 - Mayo 2017 para el Edificio D7, y las medias de dichos consumos. Según la prueba paramétrica realizada las diferencias encontradas no son estadísticamente significativas, con un riesgo a estar equivocados del $5 \%$

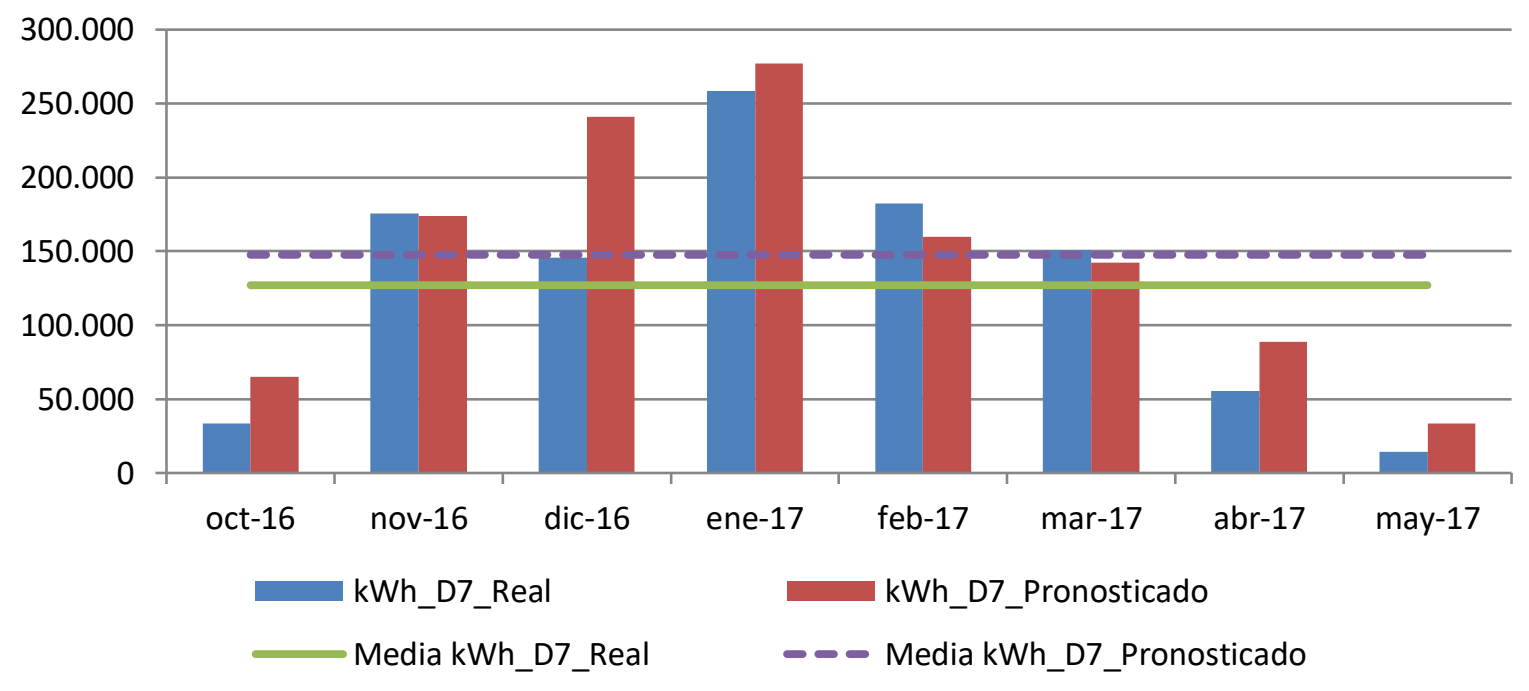

Figura 246. Consumos reales y pronosticados Octubre 2016-Mayo 2017. Edificio D7

Para la temporada Octubre 2017 - Mayo 2018, se comprueba mediante el Test de Shapiro -Wilk que tanto los valores reales como los pronosticados se distribuyen según una Normal puesto que en todos los casos los valores de Sig >0,05, como se observa en la Tabla 289

Tabla 289. Prueba de Normalidad temporada Octubre 2017-Mayo 2018. Edificio D7

\begin{tabular}{ccccccrr}
\hline & \multicolumn{3}{c}{ Kolmogorov-Smirnov $^{\mathrm{a}}$} & \multicolumn{3}{c}{ Shapiro-Wilk } \\
\cline { 2 - 8 } & Estadístico & $\mathrm{gl}$ & Sig. & Estadístico & gl & \multicolumn{1}{c}{ Sig. } \\
\hline kWh_real &, 169 & 8 &, $200^{*}$ &, 936 & 8 &, 569 \\
\hline kWh_pronosticado &, 235 & 8 &, $200^{*}$ &, 883 & 8 &, 201 \\
\hline
\end{tabular}


En la Tabla 290, se observa como las medias de los consumos pronosticados, son superiores a las medias de los consumos reales del Edificio D7, en un 14,9\%

Tabla 290. Estadísticos de muestras relacionadas. Octubre 2017-Mayo 2018. Edificio D7

\begin{tabular}{lccccc}
\hline & Media & $\begin{array}{c}\text { \% Diferencia } \\
\text { entre medias }\end{array}$ & $\mathrm{N}$ & $\begin{array}{c}\text { Desviación } \\
\text { típ. }\end{array}$ & $\begin{array}{c}\text { Error típ. de } \\
\text { la media }\end{array}$ \\
\hline $\mathrm{kWh}$ _real & 135158,0000 & & 8 & 86811,39152 & 30692,46181 \\
\hline $\mathrm{kWh}$ pronosticado & 155238,8750 & $14,9 \%$ & 8 & 90185,60041 & 31885,42481 \\
\hline
\end{tabular}

La Tabla 291 muestra que las diferencias entre las medias no son significativas entre los consumos reales y los pronosticados (sig $>0,05$ ), a pesar de existir ese $14,9 \%$ de diferencia

Tabla 291. Prueba de muestras relacionadas. Octubre 2017-Mayo 2018. Edificio D7

\begin{tabular}{|c|c|c|c|c|c|c|c|c|c|}
\hline & & \multicolumn{5}{|c|}{ Diferencias relacionadas } & \multirow{3}{*}{$\mathrm{t}$} & \multirow{3}{*}{$\mathrm{gl}$} & \multirow{3}{*}{$\begin{array}{c}\text { Sig. } \\
\text { (bilateral) }\end{array}$} \\
\hline & & \multirow{2}{*}{ Media } & \multirow{2}{*}{$\begin{array}{l}\text { Desviación } \\
\text { típ. }\end{array}$} & \multirow{2}{*}{$\begin{array}{c}\text { Error típ. } \\
\text { de la media }\end{array}$} & \multicolumn{2}{|c|}{$\begin{array}{c}\text { 95\% Intervalo de confianza } \\
\text { para la diferencia }\end{array}$} & & & \\
\hline & & & & & Inferior & Superior & & & \\
\hline Par 1 & $\begin{array}{c}\text { kWh_real - } \\
\text { kWh_pronosticado }\end{array}$ & $-20080,875$ & 43360,455 & 15330,236 & $-56331,123$ & 16169,373 & $-1,310$ & 7 & ,232 \\
\hline
\end{tabular}

En la Figura 247, se grafican los consumos reales y pronosticados para la temporada Octubre 2017 - Mayo 2018 para el Edificio D7, y las medias de dichos consumos. Según la prueba paramétrica realizada las diferencias encontradas no son estadísticamente significativas, con un riesgo a estar equivocados del $5 \%$

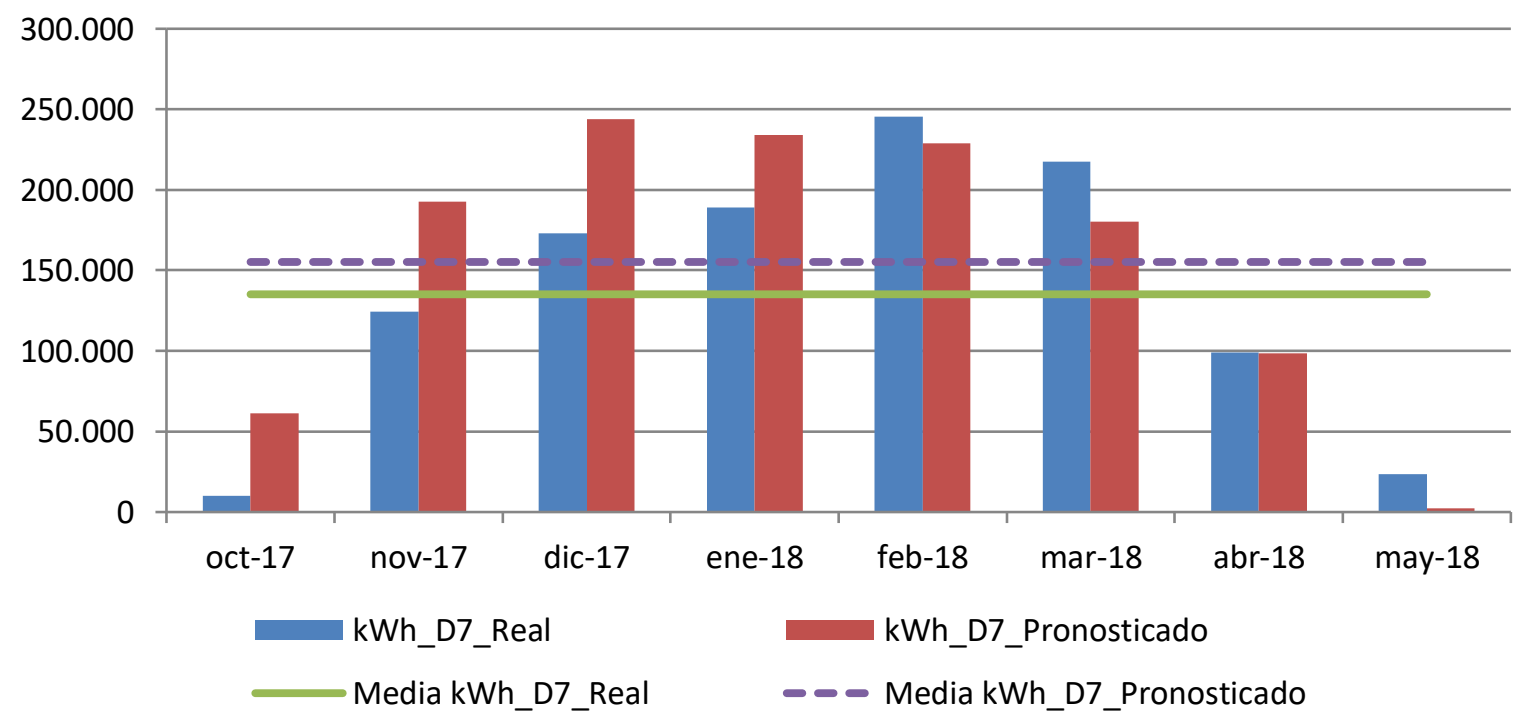

Figura 247. Consumos reales y pronosticados Octubre 2017-Mayo 2018. Edificio D7 
Para el total de las tres temporadas Octubre 2015 - Mayo 2018, se comprueba mediante el Test de Shapiro -Wilk, que los valores reales y los pronosticados se distribuyen según una Normal puesto que en esos casos los valores de Sig $>0,05$, como se observa en la Tabla 292

Tabla 292. Prueba de Normalidad temporada Octubre 2015-Mayo 2018. Edificio D7

\begin{tabular}{cccccccr}
\hline & \multicolumn{3}{c}{ Kolmogorov-Smirnov $^{\mathrm{a}}$} & \multicolumn{3}{c}{ Shapiro-Wilk } \\
\cline { 2 - 8 } & Estadístico & gl & Sig. & Estadístico & gl & Sig. \\
\hline kWh_real &, 135 & 24 &, 200 &, 945 & 24 &, 213 \\
\hline kWh_pronosticado &, 119 & 24 &, 200 &, 957 & 24 &, 381 \\
\hline
\end{tabular}

En la Tabla 293 se observa como las medias de los consumos pronosticados, son superiores a las medias de los consumos reales del Edificio D7, en un 13,1\%

Tabla 293. Estadísticos de muestras relacionadas. Octubre 2015-Mayo 2018. Edificio D7

\begin{tabular}{lccccc}
\hline & Media & $\begin{array}{c}\text { \% Diferencia } \\
\text { entre medias }\end{array}$ & $\mathrm{N}$ & $\begin{array}{c}\text { Desviación } \\
\text { típ. }\end{array}$ & $\begin{array}{c}\text { Error típ. de } \\
\text { la media }\end{array}$ \\
\hline $\mathrm{kWh}$ _real & 133291,9913 & & 24 & 83331,39869 & 17009,95053 \\
\hline $\mathrm{kWh}$ _pronosticado & 150732,0646 & $13,1 \%$ & 24 & 75531,28641 & 15417,75928 \\
\hline
\end{tabular}

La Tabla 294 muestra que las diferencias entre las medias no son significativas entre los consumos reales y los pronosticados (sig $>0,05$ ).

Tabla 294. Prueba de muestras relacionadas. Octubre 2015-Mayo 2018. Edificio D7

\begin{tabular}{|c|c|c|c|c|c|c|c|c|}
\hline & \multicolumn{5}{|c|}{ Diferencias relacionadas } & \multirow{3}{*}{$\mathrm{t}$} & \multirow{3}{*}{ gl } & \multirow{3}{*}{$\begin{array}{c}\text { Sig. } \\
\text { (bilateral) }\end{array}$} \\
\hline & \multirow[t]{2}{*}{ Media } & \multirow{2}{*}{$\begin{array}{l}\text { Desviación } \\
\text { típ. }\end{array}$} & \multirow{2}{*}{$\begin{array}{c}\text { Error típ. de } \\
\text { la media }\end{array}$} & \multicolumn{2}{|c|}{$\begin{array}{l}\text { 95\% Intervalo de confianza } \\
\text { para la diferencia }\end{array}$} & & & \\
\hline & & & & Inferior & Superior & & & \\
\hline $\begin{array}{c}\text { kWh_real - } \\
\text { kWh_pronosticado }\end{array}$ & $-17440,073$ & 44748,550 & 9134,259 & $-36335,729$ & 1455,582 & $-1,909$ & 23 & ,069 \\
\hline
\end{tabular}




\section{AIV.7.5. Estimación de las emisiones de $\mathrm{CO} 2$ evitadas.}

Teniendo en cuenta que el consumir Gas natural se producen 0,252 $\mathrm{kg} \mathrm{CO}_{2} / \mathrm{kWh} \mathrm{E}$. final y que al consumir la energía suministrada por red a partir de Biomasa se producen 0,024 kg $\mathrm{CO}_{2} / \mathrm{kWh}$. final, en la Tabla 295, se muestra las emisiones de $\mathrm{CO}_{2}$ reales para las temporadas octubre 2015 - mayo 2018 y utilizando el Modelo de regresión, las emisiones de $\mathrm{CO}_{2}$ que se hubieran tenido de haber seguido utilizando las calderas de gas natural originales sin el apoyo de la red de calor.

Al no existir diferencias significativas el consumo predicho o pronosticado se ha igualado al consumo real

Tabla 295. Estimación del ahorro de emisiones de CO2 para el Edificio D7.

\begin{tabular}{|c|c|c|c|c|c|c|c|c|c|c|}
\hline & $\begin{array}{l}\text { kWh_D7 } \\
\text { Gas } \\
\text { Natural }\end{array}$ & $\begin{array}{l}\text { kWh_D7 } \\
\text { Biomasa }\end{array}$ & $\begin{array}{l}\text { kWh_D7 } \\
\text { Real Total }\end{array}$ & $\begin{array}{l}\text { kWh_D7 } \\
\text { Predicho }\end{array}$ & $\begin{array}{l}\text { kg CO2 Real } \\
\text { debido al } \\
\text { consumo de } \\
\text { Gas Natural }\end{array}$ & $\begin{array}{l}\text { kg CO2 } \\
\text { Real } \\
\text { debido a } \\
\text { Biomasa }\end{array}$ & $\begin{array}{l}\text { kg CO2 } \\
\text { Real } \\
\text { debido al } \\
\text { consumo } \\
\text { TOTAL }\end{array}$ & $\begin{array}{c}\text { kg CO2 } \\
\text { que se } \\
\text { hubiera } \\
\text { tenido } \\
\text { debido a } \\
\text { Gas } \\
\text { Natural }\end{array}$ & $\begin{array}{c}\text { Ahorro de } \\
\text { kg CO2 }\end{array}$ & $\begin{array}{l}\text { Ahorro de kg } \\
\text { CO2 } \\
\text { acumulado }\end{array}$ \\
\hline oct-2015 & 0 & 22.220 & 22.220 & 22.220 & 0 & 533 & 533 & 5.599 & 5.066 & 5.066 \\
\hline nov-2015 & 0 & 128.080 & 128.080 & 128.080 & 0 & 3.074 & 3.074 & 32.276 & 29.202 & 34.268 \\
\hline dic-2015 & 0 & 124.770 & 124.770 & 124.770 & 0 & 2.994 & 2.994 & 31.442 & 28.448 & 62.716 \\
\hline ene-2016 & 0 & 163.370 & 163.370 & 163.370 & 0 & 3.921 & 3.921 & 41.169 & 37.248 & 99.964 \\
\hline feb-2016 & 60.146 & 237.190 & 297.336 & 297.336 & 15.157 & 5.693 & 20.849 & 74.929 & 54.079 & 154.044 \\
\hline mar-2016 & 26.749 & 173.610 & 200.359 & 200.359 & 6.741 & 4.167 & 10.907 & 50.490 & 39.583 & 193.627 \\
\hline abr-2016 & 2.760 & 137.130 & 139.890 & 139.890 & 696 & 3.291 & 3.987 & 35.252 & 31.266 & 224.892 \\
\hline may-2016 & 170 & 25.020 & 25.190 & 25.190 & 43 & 600 & 643 & 6.348 & 5.705 & 230.597 \\
\hline oct-2016 & 2.264 & 31.170 & 33.434 & 33.434 & 571 & 748 & 1.319 & 8.425 & 7.107 & 237.704 \\
\hline nov-2016 & 496 & 175.080 & 175.576 & 175.576 & 125 & 4.202 & 4.327 & 44.245 & 39.918 & 277.622 \\
\hline dic-2016 & 536 & 145.300 & 145.836 & 145.836 & 135 & 3.487 & 3.622 & 36.751 & 33.128 & 310.750 \\
\hline ene-2017 & 3.984 & 254.280 & 258.264 & 258.264 & 1.004 & 6.103 & 7.107 & 65.083 & 57.976 & 368.726 \\
\hline feb-2017 & 760 & 181.790 & 182.550 & 182.550 & 192 & 4.363 & 4.554 & 46.003 & 41.448 & 410.174 \\
\hline mar-2017 & 536 & 150.360 & 150.896 & 150.896 & 135 & 3.609 & 3.744 & 38.026 & 34.282 & 444.456 \\
\hline abr-2017 & 0 & 55.650 & 55.650 & 55.650 & 0 & 1.336 & 1.336 & 14.024 & 12.688 & 457.145 \\
\hline may-2017 & 0 & 14.320 & 14.320 & 14.320 & 0 & 344 & 344 & 3.609 & 3.265 & 460.410 \\
\hline oct-2017 & 384 & 9.500 & 9.884 & 9.884 & 97 & 228 & 325 & 2.491 & 2.166 & 462.576 \\
\hline nov-2017 & 1.000 & 123.350 & 124.350 & 124.350 & 252 & 2.960 & 3.212 & 31.336 & 28.124 & 490.699 \\
\hline dic-2017 & 2.088 & 170.930 & 173.018 & 173.018 & 526 & 4.102 & 4.629 & 43.601 & 38.972 & 529.671 \\
\hline ene-2018 & 688 & 188.200 & 188.888 & 188.888 & 173 & 4.517 & 4.690 & 47.600 & 42.910 & 572.581 \\
\hline feb-2018 & 3.376 & 241.850 & 245.226 & 245.226 & 851 & 5.804 & 6.655 & 61.797 & 55.142 & 627.723 \\
\hline mar-2018 & 4.304 & 213.010 & 217.314 & 217.314 & 1.085 & 5.112 & 6.197 & 54.763 & 48.566 & 676.289 \\
\hline abr-2018 & 384 & 98.630 & 99.014 & 99.014 & 97 & 2.367 & 2.464 & 24.952 & 22.488 & 698.777 \\
\hline may-2018 & 0 & 23.570 & 23.570 & 23.570 & 0 & 566 & 566 & 5.940 & 5.374 & 704.151 \\
\hline
\end{tabular}

Como se observa durante estas tres temporadas se ha obtenido un ahorro total de 704 Toneladas de $\mathrm{CO}_{2}$, debido al consumo térmico del edificio $\mathrm{D7}$, por el cambio de gas natural a biomasa. 


\section{AIV.7.6. Estimación del precio máximo de compra a la red.}

Tomando como referencia los precios del gas natural de la Tabla 296 para cada temporada, obtenidos a partir de los datos establecidos en el Capítulo 3, donde se tiene en cuenta el precio por el termino variable y fijo; se puede realizar la estimación del precio máximo de compra de la energía útil a la red de calor para obtener un $0 \%$ de ahorro y un 15\% de ahorro. La Tabla 297, muestral el precio que se pagaría para un ahorro del 15\%

Tabla 296. Precios de referencia para Gas natural y Astilla

\begin{tabular}{ccccc}
\hline Precios ( $€ /(\mathrm{kWh})$ & 2015 & 2016 & 2017 & 2018 \\
\hline Gas Natural & 0,0373 & 0,0306 & 0,0314 & 0,0336 \\
\hline Astilla & 0,0277 & 0,0256 & 0,0254 & 0,0239 \\
\hline $\begin{array}{c}€ / \text { kWh útiles máximos de compra a la red para } \\
\text { un ahorro del } 0,0 \%\end{array}$ & 0,03220 & \\
\hline $\begin{array}{c}€ / \text { kWh útiles máximos de compra a la red para } \\
\text { un ahorro del } 15,0 \%\end{array}$ & 0,02719 & \\
\hline
\end{tabular}

Tabla 297. Ahorro Económico por el consumo térmico en el Edificio D7

\begin{tabular}{|c|c|c|c|c|c|c|c|c|c|c|}
\hline & $\begin{array}{c}\text { kWh_D7 } \\
\text { Gas } \\
\text { Natural }\end{array}$ & $\begin{array}{c}\text { kWh_D7_- } \\
\text { Biomasa }\end{array}$ & $\begin{array}{c}\text { kWh_D7 } \\
\text { Real }\end{array}$ & $\begin{array}{c}\text { kWh_D7 } \\
\text { Pronosticado }\end{array}$ & $\begin{array}{c}\text { € Real } \\
\text { Gas } \\
\text { Natural }\end{array}$ & $\begin{array}{c}€ \text { Real } \\
\text { Biomasa }\end{array}$ & $\begin{array}{l}€ \text { Real } \\
\text { Total }\end{array}$ & $\begin{array}{c}\text { E predicho } \\
\text { Gas } \\
\text { natural }\end{array}$ & $\begin{array}{c}€ \\
\text { Ahorro }\end{array}$ & $€$ Acumulado \\
\hline oct-2015 & 0 & 22.220 & 22.220 & 22.220 & 0 & 604 & 604 & 829 & 225 & 225 \\
\hline nov-2015 & 0 & 128.080 & 128.080 & 128.080 & 0 & 3.482 & 3.482 & 4.777 & 1.295 & 1.520 \\
\hline dic-2015 & 0 & 124.770 & 124.770 & 124.770 & 0 & 3.392 & 3.392 & 4.654 & 1.261 & 2.781 \\
\hline ene-2016 & 0 & 163.370 & 163.370 & 163.370 & 0 & 4.442 & 4.442 & 4.999 & 557 & 3.338 \\
\hline feb-2016 & 60.146 & 237.190 & 297.336 & 297.336 & 1.840 & 6.449 & 8.290 & 9.098 & 809 & 4.147 \\
\hline mar-2016 & 26.749 & 173.610 & 200.359 & 200.359 & 819 & 4.720 & 5.539 & 6.131 & 592 & 4.739 \\
\hline$a b r-2016$ & 2.760 & 137.130 & 139.890 & 139.890 & 84 & 3.729 & 3.813 & 4.281 & 468 & 5.206 \\
\hline may-2016 & 170 & 25.020 & 25.190 & 25.190 & 5 & 680 & 686 & 771 & 85 & 5.292 \\
\hline oct-2016 & 2.264 & 31.170 & 33.434 & 33.434 & 69 & 848 & 917 & 1.023 & 106 & 5.398 \\
\hline nov-2016 & 496 & 175.080 & 175.576 & 175.576 & 15 & 4.760 & 4.776 & 5.373 & 597 & 5.995 \\
\hline dic-2016 & 536 & 145.300 & 145.836 & 145.836 & 16 & 3.951 & 3.967 & 4.463 & 495 & 6.491 \\
\hline ene-2017 & 3.984 & 254.280 & 258.264 & 258.264 & 125 & 6.914 & 7.039 & 8.110 & 1.071 & 7.561 \\
\hline feb-2017 & 760 & 181.790 & 182.550 & 182.550 & 24 & 4.943 & 4.967 & 5.732 & 765 & 8.326 \\
\hline mar-2017 & 536 & 150.360 & 150.896 & 150.896 & 17 & 4.088 & 4.105 & 4.738 & 633 & 8.959 \\
\hline$a b r-2017$ & 0 & 55.650 & 55.650 & 55.650 & 0 & 1.513 & 1.513 & 1.747 & 234 & 9.194 \\
\hline may-2017 & 0 & 14.320 & 14.320 & 14.320 & 0 & 389 & 389 & 450 & 60 & 9.254 \\
\hline oct-2017 & 384 & 9.500 & 9.884 & 9.884 & 12 & 258 & 270 & 310 & 40 & 9.294 \\
\hline nov-2017 & 1.000 & 123.350 & 124.350 & 124.350 & 31 & 3.354 & 3.385 & 3.905 & 519 & 9.813 \\
\hline dic-2017 & 2.088 & 170.930 & 173.018 & 173.018 & 66 & 4.648 & 4.713 & 5.433 & 720 & 10.533 \\
\hline ene-2018 & 688 & 188.200 & 188.888 & 188.888 & 23 & 5.117 & 5.140 & 6.347 & 1.206 & 11.739 \\
\hline feb-2018 & 3.376 & 241.850 & 245.226 & 245.226 & 113 & 6.576 & 6.689 & 8.240 & 1.550 & 13.290 \\
\hline mar-2018 & 4.304 & 213.010 & 217.314 & 217.314 & 145 & 5.792 & 5.936 & 7.302 & 1.365 & 14.655 \\
\hline abr-2018 & 384 & 98.630 & 99.014 & 99.014 & 13 & 2.682 & 2.695 & 3.327 & 632 & 15.287 \\
\hline may-2018 & 0 & 23.570 & 23.570 & 23.570 & 0 & 641 & 641 & 792 & 151 & 15.438 \\
\hline$€$ Total & & & & & & & 87.392 & 102.830 & & \\
\hline Ahorro (\%) & & & & & & & & & & $15,0 \%$ \\
\hline
\end{tabular}




\section{AIV.8.Edificio D8. Edificio de Química Fina y Materiales Avanzados (QUIFIMA).}

\section{AIV.8.1.Obtención de la línea base de referencia energética}

Los datos de partida para la obtención de la línea base de referencia se muestran en la Tabla 298

Tabla 298. Consumos térmicos del edificio D8

\begin{tabular}{lr}
\hline & Consumos térmicos $(\mathrm{kWh})$. D8 \\
\hline oct-12 & 28.190 \\
\hline nov-12 & 44.053 \\
\hline dic-12 & 58.473 \\
\hline ene-13 & 61.638 \\
\hline feb-13 & 71.642 \\
\hline mar-13 & 64.884 \\
\hline abr-13 & 45.407 \\
\hline may-13 & 20.377 \\
\hline oct-13 & 21.697 \\
\hline nov-13 & 32.562 \\
\hline dic-13 & 76.564 \\
\hline ene-14 & 67.774 \\
\hline feb-14 & 75.981 \\
\hline mar-14 & 50.114 \\
\hline abr-14 & 20.141 \\
\hline may-14 & 18.148 \\
\hline Promedio & 47.353 \\
\hline Total (oct-12-may-13) & 394.664 \\
\hline Total (oct-13-may-14) & 362.981 \\
\hline Total (oct-12-may-13) & 757.645 \\
\hline
\end{tabular}

Se disponen de 16 datos para establecer el modelo de regresión, mediante el método de pasos sucesivos. Utilizando el programa SPSS V.20, se obtiene el modelo de regresión mediante el método de pasos sucesivos. Como se puede ver en la Tabla 299 para el edificio D8, el método ofrece dos modelos de regresión, uno con una sola variable (Temperatura media) y otro con dos variables (Temperatura media y velocidad del viento diurna).

El primer modelo (modelo de regresión lineal simple) fue construido con un solo paso, incluyendo la Temperatura media por ser la variable más significativa (variable con menor valor de Sig $=0,000$ ) que indica la probabilidad de cometer un error al rechazar que la pendiente de la variable "Temperatura media" es igual a cero, por lo que se acepta que esa variable forma parte del modelo con una pendiente $(B=-5414,103)$. 
El segundo modelo (modelo de regresión lineal múltiple) se construyó en dos pasos, primero entró la Temperatura media y luego entró la siguiente variable que rechazase la Hipótesis nula, (las variables que rechazan la hipótesis nula son las que presentan una pendiente estadísticamente significativa y su probabilidad de cometer el error de rechazar Ho es $\leq 0,05$, para un nivel de confianza del $95 \%$ ), esta variable fue la "velocidad de viento diurna", por presentar un valor de Sig $=0,011$, el resto de las variables como se observa en la Tabla 300 fueron excluidas del modelo al tener valores de sig >0,05.

Tabla 299. Modelos de regresión del Edificio D8

\begin{tabular}{|c|c|c|c|c|c|c|c|}
\hline & \multirow{2}{*}{ Modelo } & \multicolumn{2}{|c|}{$\begin{array}{l}\text { Coeficientes no } \\
\text { estandarizados }\end{array}$} & \multirow{2}{*}{$t$} & \multirow{2}{*}{ Sig. } & \multicolumn{2}{|c|}{$\begin{array}{c}\text { Intervalo de confianza de } \\
95,0 \% \text { para B }\end{array}$} \\
\hline & & B & Error típ. & & & $\begin{array}{l}\text { Límite } \\
\text { inferior }\end{array}$ & $\begin{array}{l}\text { Límite } \\
\text { superior }\end{array}$ \\
\hline \multirow[t]{2}{*}{1} & (Constante) & 91484,519 & 5982,836 & 15,291 & ,000 & 78652,611 & 104316,426 \\
\hline & T_med & $-5414,103$ & 675,136 & $-8,019$ & ,000 & $-6862,126$ & $-3966,079$ \\
\hline \multirow[t]{3}{*}{2} & (Constante) & 63357,055 & 10611,448 & 5,971 & ,000 & 40432,415 & 86281,695 \\
\hline & T_med & $-4991,184$ & 559,145 & $-8,926$ & ,000 & $-6199,144$ & $-3783,224$ \\
\hline & V_viento_diurna_m/s & 8950,190 & 3012,722 & 2,971 & ,011 & 2441,600 & 15458,779 \\
\hline
\end{tabular}

En la Figura 248 se representa el modelo 1 de regresión con sus límites inferior y superior para un nivel de confianza del $95 \%$

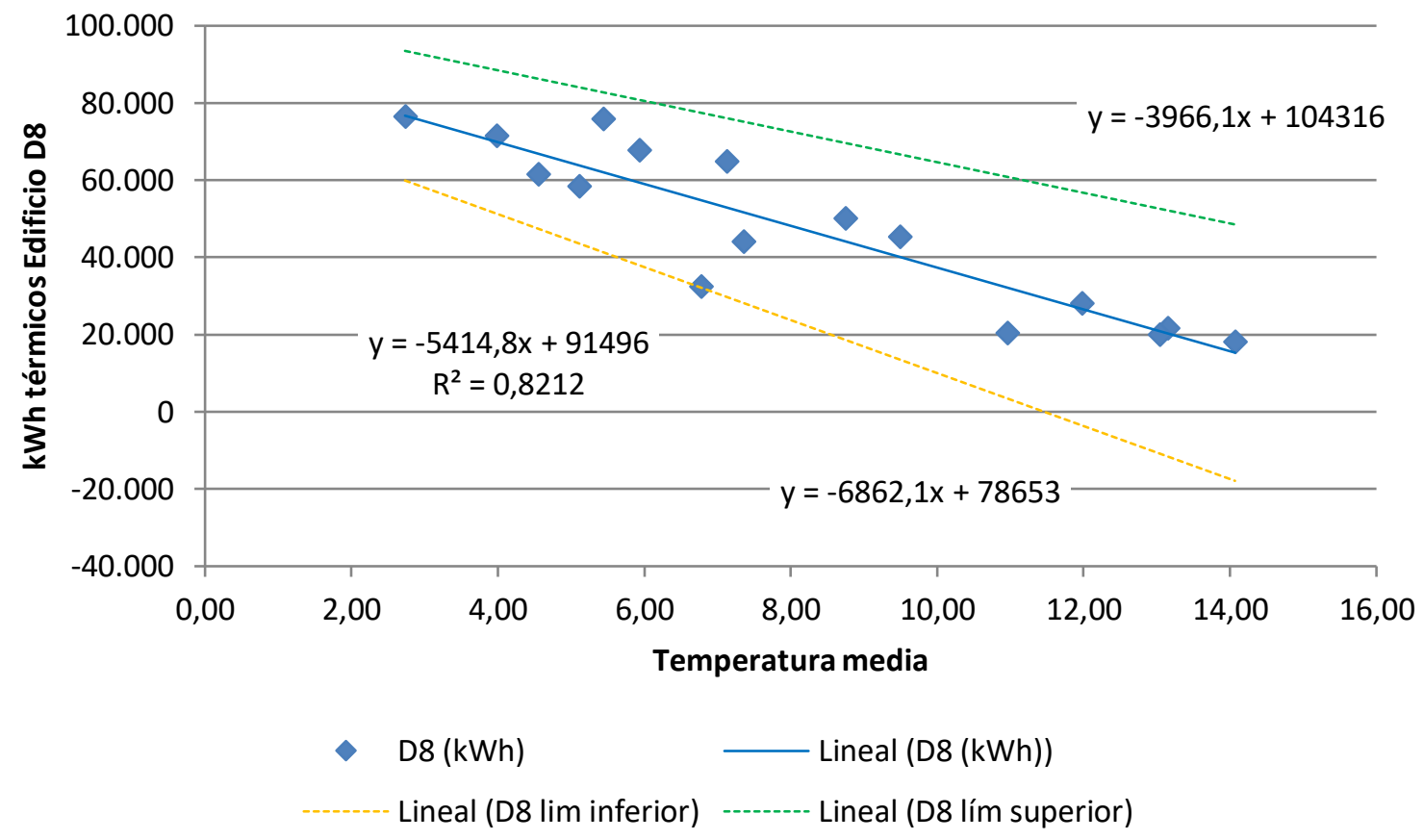

Figura 248. Representación del modelo de regresión lineal simple para el Edificio D8 
En la Figura 249 se representa el modelo 2 de regresión lineal múltiple para el edificio D8

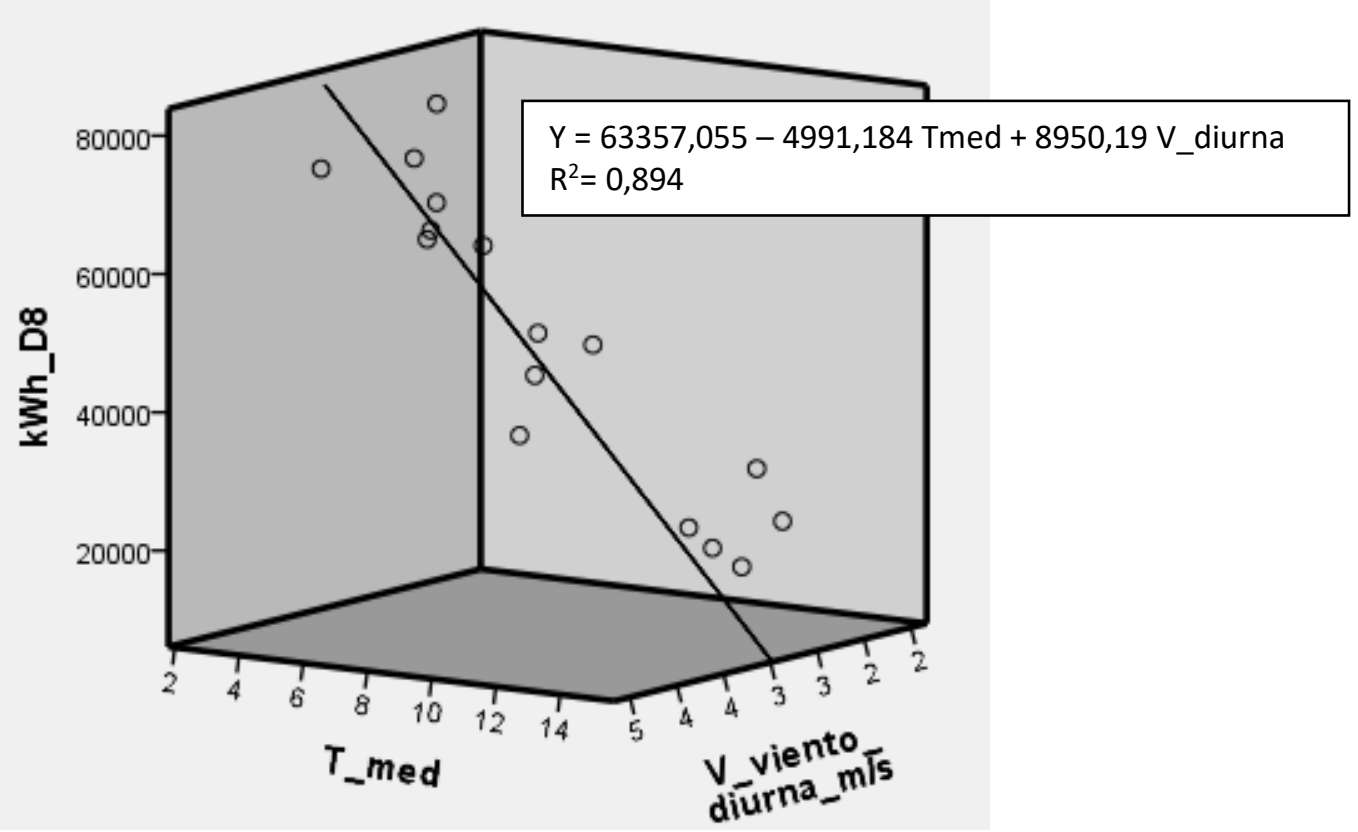

Figura 249. Representación del modelo de regresión lineal múltiple para el Edificio D8

Los valores de la columna $\mathrm{t}$ se obtienen dividiendo el valor de los coeficientes no estandarizados entre sus errores típicos, este estadístico tiende a ser mayor en valor absoluto cuando la hipótesis alternativa es verdadera, es decir cuando la variable posee una pendiente significativa en el modelo de regresión.

En las Tabla 299 y Tabla 300, el estadístico t y su nivel crítico (Sig), permiten contrastar la hipótesis nula consistente en que el coeficiente de regresión vale cero en el modelo; a mayor valor de t, mayor peso en el modelo.

El valor "Sig" corresponde a los valores de probabilidad de los valores de $t$, es la probabilidad de obtener el valor de $t$ si la hipótesis nula fuera cierta, cuando son $\leq 0,05$ se rechaza la hipótesis nula y se concluye que las pendientes son distintas de cero, luego si Sig $>0,05$ se acepta la hipótesis nula de que la pendiente de la variable independiente en el modelo de regresión es igual a cero, no cumpliendo el criterio de entrada en el modelo.

La correlación parcial, que aparece en la Tabla 300 estudia la relación existente entre dos variables cuantitativas cuando se controla o elimina el efecto de terceras variables, en el modelo de regresión lineal, a mayor valor absoluto, mayor relación entre la variable dependiente y la independiente. 
Anexo IV. Desarrollo del análisis de los edificios del Campus Miguel Delibes

Tabla 300. Variables excluidas del modelo de región del Edificio D8

\begin{tabular}{|c|c|c|c|c|}
\hline & Modelo & $\mathrm{t}$ & Sig. & Correlación parcial \\
\hline \multirow{19}{*}{1} & GD15_30min &,- 320 & ,754 &,- 088 \\
\hline & GD20_30min &,- 541 & ,597 &,- 149 \\
\hline & GD15_24h &,- 380 & ,710 &,- 105 \\
\hline & GD20_24h &,- 654 & ,524 &,- 179 \\
\hline & T_media_diurna &,- 052 & ,959 &,- 014 \\
\hline & T_max & ,142 & ,889 &, 039 \\
\hline & T_min &, 044 & ,966 & ,012 \\
\hline & HR_\% &,- 491 & ,631 &,- 135 \\
\hline & HR_med_diurna_\% &,- 321 & ,754 &,- 089 \\
\hline & HR_max_\% &,- 914 & ,378 &,- 246 \\
\hline & HR_min_\% &,- 579 & ,572 &,- 159 \\
\hline & Radiación_W/m2 &, 408 & ,690 &, 113 \\
\hline & V_Viento_m/s & 2,851 & 014 & 620 \\
\hline & V_viento_diurna_m/s & 2,971 & 011 & ,636 \\
\hline & V_viento_nocturna_m/s & 2,513 &, 026 &, 572 \\
\hline & V_viento_max_m/s & 2,682 & ,019 & ,597 \\
\hline & Recorrido_viento_km/día & 2,852 & 014 & 620 \\
\hline & Precipitación_acumulada_mes_mm & 1,543 & 147 & ,393 \\
\hline & Horas insolación_h &, 629 & ,540 &, 172 \\
\hline \multirow{18}{*}{2} & GD15_30min & ,781 &, 450 &, 220 \\
\hline & GD20_30min & ,346 & ,735 & 099 \\
\hline & GD15_24h & ,873 &, 400 & 244 \\
\hline & GD20_24h & ,223 & 827 &, 064 \\
\hline & T_media_diurna &,- 177 & ,862 &,- 051 \\
\hline & T_max &, 563 & ,584 &, 160 \\
\hline & T_min & ,279 & ,785 &, 080 \\
\hline & HR_\% & ,575 & ,576 & ,164 \\
\hline & HR_med_diurna_\% & ,552 & ,591 &, 157 \\
\hline & HR_max_\% & ,604 & ,557 &, 172 \\
\hline & HR_min_\% & ,144 & ,888 &, 041 \\
\hline & Radiación_W/m2 &,- 614 & ,551 &,- 175 \\
\hline & V_Viento_m/s &,- 486 & ,636 &,- 139 \\
\hline & V_viento_nocturna_m/s &,- 700 & ,497 &,- 198 \\
\hline & V_viento_max_m/s & $-1,062$ & ,309 &,- 293 \\
\hline & Recorrido_viento_km/día &,- 474 & ,644 &,- 136 \\
\hline & Precipitación_acumulada_mes_mm & 1,080 & ,301 & ,298 \\
\hline & Horas insolación_h &,- 443 & ,665 &,- 127 \\
\hline
\end{tabular}

La bondad de los modelos de regresión obtenidos para el edificio D8, se resumen en la Tabla 301 
Anexo IV. Desarrollo del análisis de los edificios del Campus Miguel Delibes

Tabla 301. Resumen de la bondad de los modelos de regresión para el Edificio D8

\begin{tabular}{|c|c|c|c|c|}
\hline Modelo & $\mathrm{R}$ & R cuadrado & R cuadrado corregida & $\begin{array}{l}\text { Error típ. de la } \\
\text { estimación }\end{array}$ \\
\hline 1 & $906^{a}$ & 821 & 808 & 9388,55632 \\
\hline 2 &, $945^{b}$ & ,894 & ,877 & 7519,33256 \\
\hline
\end{tabular}

Se observa como el modelo 1 de regresión lineal simple presenta un Coeficiente de Correlación de Pearson ( $\mathrm{R}$ ) inferior en valor absoluto al modelo 2 de regresión lineal múltiple, este coeficiente indica que las variables de los modelos están correlacionadas de manera muy fuerte (en la correlación perfecta $R= \pm 1$ ). La correlación que se produce en ambos modelos es inversa, al aumentar el valor de las variables independientes disminuye el valor de la variable dependiente que es el consumo térmico.

El coeficiente de determinación $\left(R^{2}\right)$, nos indica que con el modelo 1 se podría explicar el $82,1 \%$ de los datos reales obtenidos y el modelo 2 , el porcentaje de aciertos o de explicación asciende al 89,4\%, ambos aceptando un error del 5\%.

El coeficiente de determinación corregido $\left(R^{2}\right.$ corregido) que tiene en cuenta el número de variables independientes incluidas en el modelo y el tamaño de la muestra, reduce el coeficiente de determinación al 80,8\% en el modelo 1 y al 87,7 \% en el modelo 2.

El error típico de la estimación que nos indica la magnitud de los errores, es decir la parte de la variable dependiente que dejamos sin explicar con el modelo y que describe la variación de la variable respuesta (el Consumo) respecto a la recta de regresión, es de $9.388 \mathrm{kWh}$ para el modelo 1 y de $7.519 \mathrm{kWh}$ para el modelo 2, lo que representa un 19,8\% del promedio de los consumos que fue de $47.353 \mathrm{kWh}$ para el modelo 1 y del 15,9\% para el modelo 2. Por tanto aunque el modelo 2 es más preciso, también es aceptado el modelo 1 para la representación de la línea base de los consumos térmicos del edificio D8. 


\section{AIV.8.2. Verificación del cumplimiento de los supuestos estadísticos}

Las condiciones que se deben cumplir en un modelo de regresión son:

- Linealidad de las variables, las variables se encuentran relacionadas de forma lineal.

Como se observa en la Tabla 299, la pendiente (B), para el modelo 1, obtuvo un valor de Sig $=0,000$, que al ser $\leq 0,05$, nos indica que podemos rechazar la hipótesis nula de pendiente igual a cero y nos da la evidencia de linealidad entre la variable dependiente ( $k$ Wh del edificio D8) y la independiente (Temperatura media). Al ser el valor de la pendiente negativa, indica una relación inversa entre el consumo y la Temperatura media.

Para el modelo 2, según la misma Tabla 299, las pendientes de las dos variables introducidas en el modelo obtuvieron unos valores de Sig $=0,000$ para la Temperatura media y de 0,011 para la Velocidad del viento diurna, ambos $\leq 0,05$, lo que nos indica que podemos rechazar la hipótesis nula de pendiente igual a cero y nos da la evidencia de linealidad entre la variable dependiente ( $\mathrm{kWh}$ del edificio D8) y las independientes (Temperatura media y velocidad del viento diurna). Al ser el valor de la primera pendiente negativa, indica una relación inversa entre el consumo y la Temperatura media y de la segunda pendiente positiva, indica relación directa entre el consumo y la velocidad del viento diurna.

- Normalidad. Todos los valores obtenidos para la variable dependiente (Y), deben estar distribuidos normalmente en cada valor de las variables independientes (X).

Se comprueba la normalidad de las variables y de los residuos mediante el Test de Shapiro - Wilk para muestras pequeñas (menores a 30 observaciones), siendo la hipótesis nula el que la distribución es Normal, luego si la probabilidad del estadístico del test es $\leq$ al nivel de significación 0,05 , la hipótesis nula es rechazada y sólo aceptaremos que las variables se distribuyen según una Normal cuando el valor de la significación sea mayor que 0,05 (valor de la significación >0,05) en el Test de Shapiro Wilk.

La Tabla 302, muestra la prueba de normalidad de Shapiro-Wilk y cómo tanto la variable dependiente (consumos del Edificio D8), como las variables independientes: Temperatura media y velocidad de viento nocturna poseen una Sig $>0,05$, por lo que aceptamos la hipótesis nula de Normalidad de las variables 
Tabla 302. Prueba de normalidad para el edificio D8

\begin{tabular}{lrrrrrr}
\hline & \multicolumn{2}{c}{ Kolmogorov-Smirnov } & \multicolumn{3}{c}{ Shapiro-Wilk } \\
\cline { 2 - 7 } & Estadístico & gl & Sig. & Estadístico & gl & Sig. \\
\hline kWh_D8 &, 135 & 16 &, 200 &, 903 & 16 &, 090 \\
\hline T_med &, 150 & 16 &, 200 &, 942 & 16 &, 376 \\
\hline V_viento_nocturna_m/s &, 156 & 16 &, 200 &, 948 & 16 &, 453 \\
\hline
\end{tabular}

- Independencia de los errores. Los errores asociados a los valores de la variable respuesta $(Y)$ deberán ser independientes unos de otros.

Para la comprobación se utiliza el estadístico de Durbin -Watson.

Se comprueba que el Estadístico de Durbin Watson para el nivel de significancia del 5\%, y para el tamaño de la muestra " $n$ " y el número de variables independientes del modelo " $k$ ", se encuentra en el intervalo [dU, 4-dU], de la Tabla 3, intervalo centrado en el 2, que indica la ausencia de autocorrelación.

El valor del Estadístico Durbin-Watson facilitado por el programa SPSS, es:

- para el modelo 1 de 1,641 (Regresión lineal simple)

- para el modelo 2 de 2,702 (Regresión lineal múltiple)

En el modelo $1, \mathrm{n}=16$ y $\mathrm{k}=1$, según la Tabla 3, el valor $\mathrm{dU}=1,371$, luego el intervalo que marca la ausencia de correlación es [1,371, 2,629], como el valor del estadístico 1,641 está dentro del intervalo, se acepta la ausencia de autocorrelación

En el modelo 2, $\mathrm{n}=16$ y $\mathrm{k}=2$, según la Tabla 3 , el valor $\mathrm{dU}=1,539$ y $\mathrm{dL}=0,982$, luego el intervalo que marca la ausencia de correlación es [1,539, 2,461].

Los intervalos $[0,0,982]$ y $[3,018,4]$ indican correlación positiva o negativa respectivamente y las zonas $[0,982,1,539]$ y $[2,461,3,018]$ son zonas no concluyentes; como el valor del estadístico 2,702 está dentro del último intervalo no concluyente, se comprueba la ausencia de autocorrelación, mediante el gráfico de residuos frente al tiempo.

La Figura 250, muestra que la relación entre los residuos y el tiempo, posee un coeficiente de determinación $=0,000964$, prácticamente nulo, por lo que se acepta la ausencia de autocorrelación. 


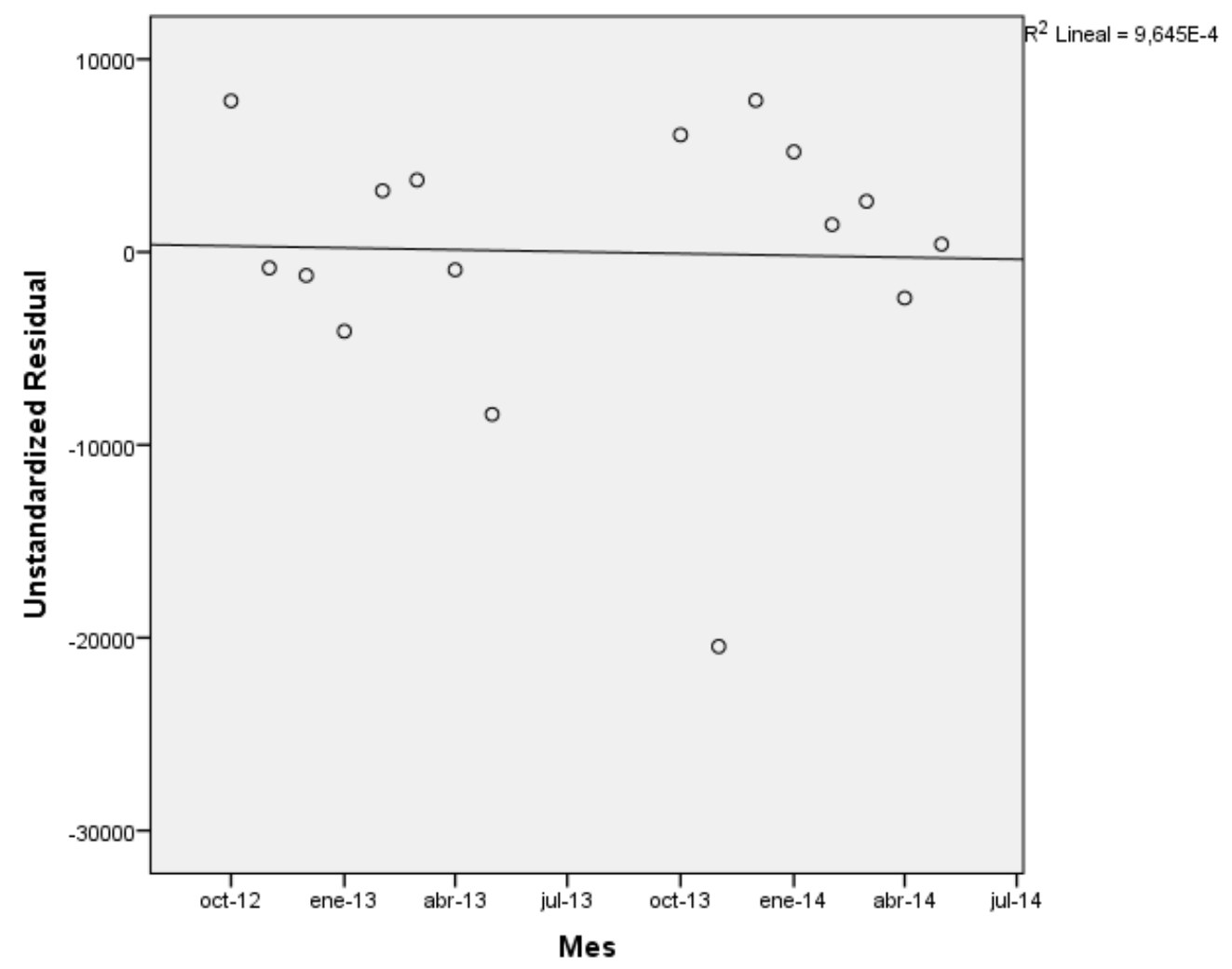

Figura 250. Relación entre los residuos y el tiempo en el Edificio D8. Modelo 2

- Homocedasticidad de la varianza. Se pretende comprobar que la varianza de los errores $\left(\sigma^{2}\right)$ es constante para cualquier valor de la(s) variable(s) independiente(s) (X), es decir que el valor medio del cuadrado de la desviación de los errores respecto a su media es constante.

Esta condición indica que el error es una variable aleatoria que tomará un valor distinto cada vez que se ejecute el modelo y que no existe correlación entre los residuos y los pronósticos.

La forma de comprobar la homocedasticidad es verificando si el coeficiente de determinación $\mathrm{R}^{2}$, que indica la proporción de la variable dependiente ( $\mathrm{Y}$ o consumo del edificio) que puede ser explicada por la variación de las variables independientes (las variables climatológicas), en las relaciones: residuos y predicciones y entre residuos y variables independientes es nulo o muy próximo a cero, lo que indicará que no existe ningún tipo de correlación en los residuos y que éstos son aleatorios.

Se grafican los diagramas de dispersión de esas relaciones, comprobando que se corresponden a nubes de puntos totalmente aleatorias, sin tendencias ni patrones en sus representaciones gráficas. 
Para el modelo 1. Regresión lineal simple, las Figura 251 y Figura 252, muestran que la relación entre los pronósticos y los residuos, posee un coeficiente de determinación = 0 y entre la variable independiente (Temperatura media) y los residuos un coeficiente de determinación también de 0 ; por lo que se concluye que no existe ningún tipo de correlación en los residuos y que éstos son aleatorios, siendo la varianza de los residuos constante.

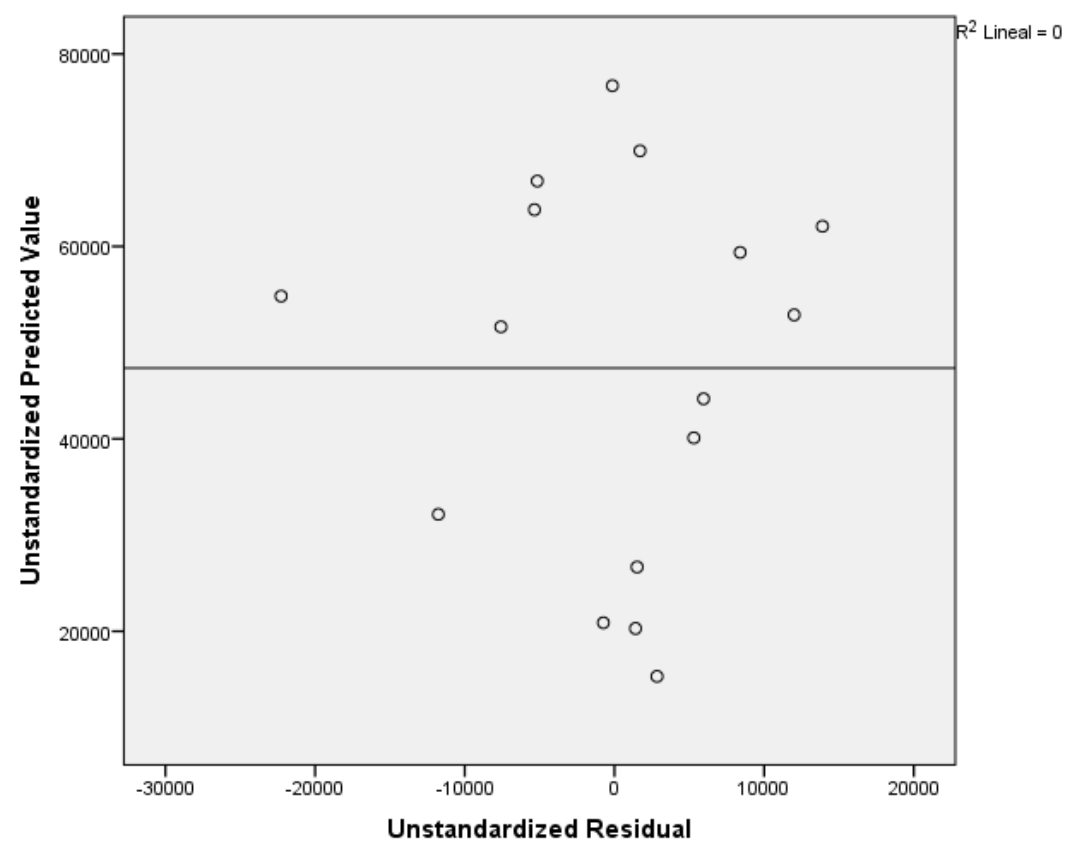

Figura 251. Relación entre los pronósticos y los residuos en el Edificio D8. Modelo 1

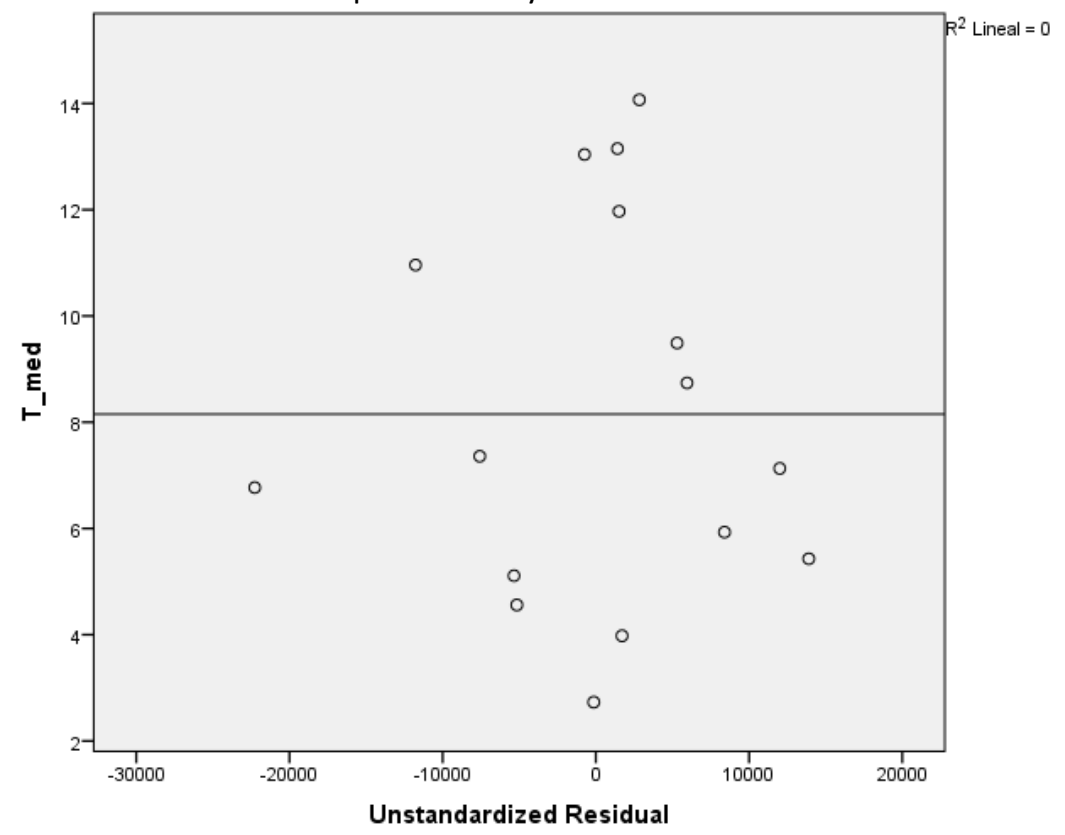

Figura 252. Relación entre la Temperatura media y los residuos en el Edificio D8. Modelo 1 
Para el modelo 2. Regresión lineal múltiple, las Figura 253, Figura 254 y Figura 255, muestran que la relación entre los pronósticos y los residuos, posee un coeficiente de determinación $=1,11 \times 10^{-16}$, cercano a cero, entre la variable independiente (Temperatura media) y los residuos un coeficiente de determinación, también de $1,11 \times 10^{-16}$, también prácticamente nulo y entre la variable independiente (velocidad del viento diurna) y los

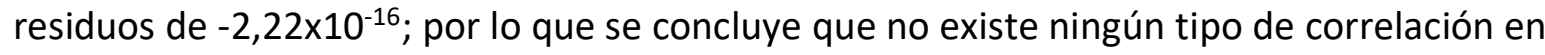
los residuos y que éstos son aleatorios, siendo la varianza de los residuos constante

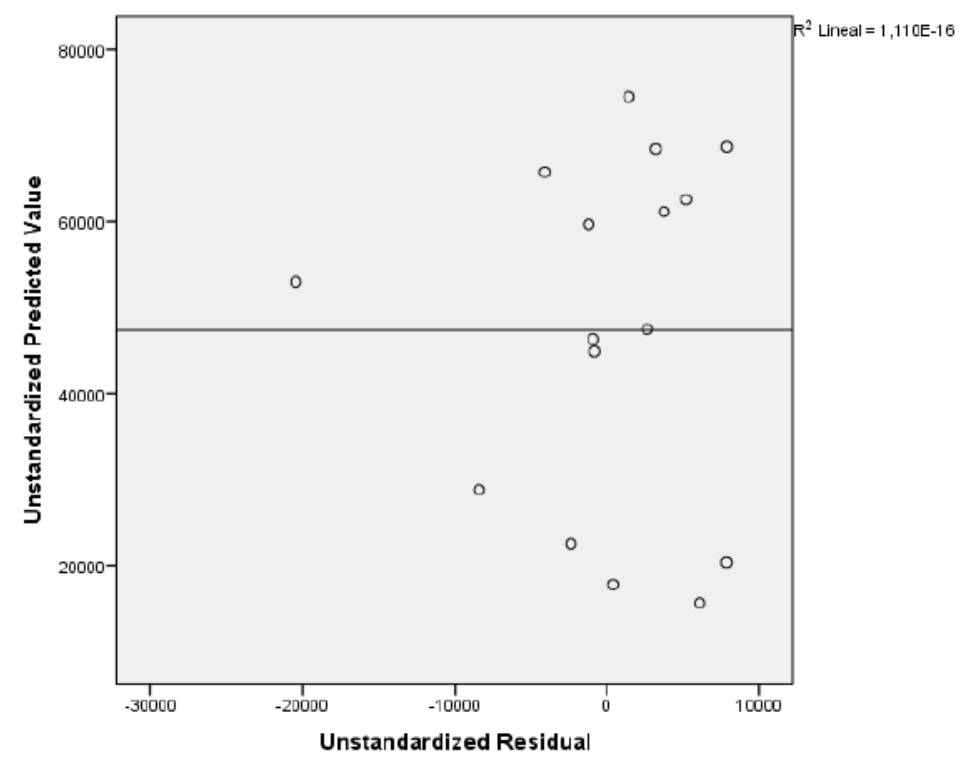

Figura 253. Relación entre los pronósticos y los residuos en el Edificio D8. Modelo 2

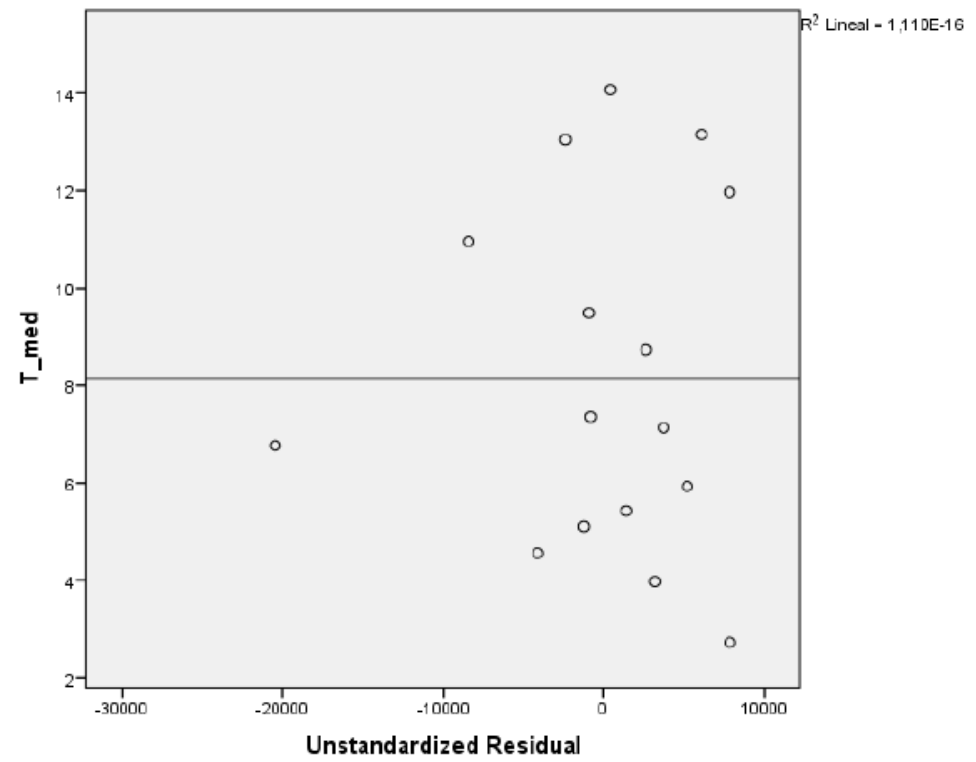

Figura 254. Relación entre la Temperatura media y los residuos en el Edificio D8. Modelo 2 


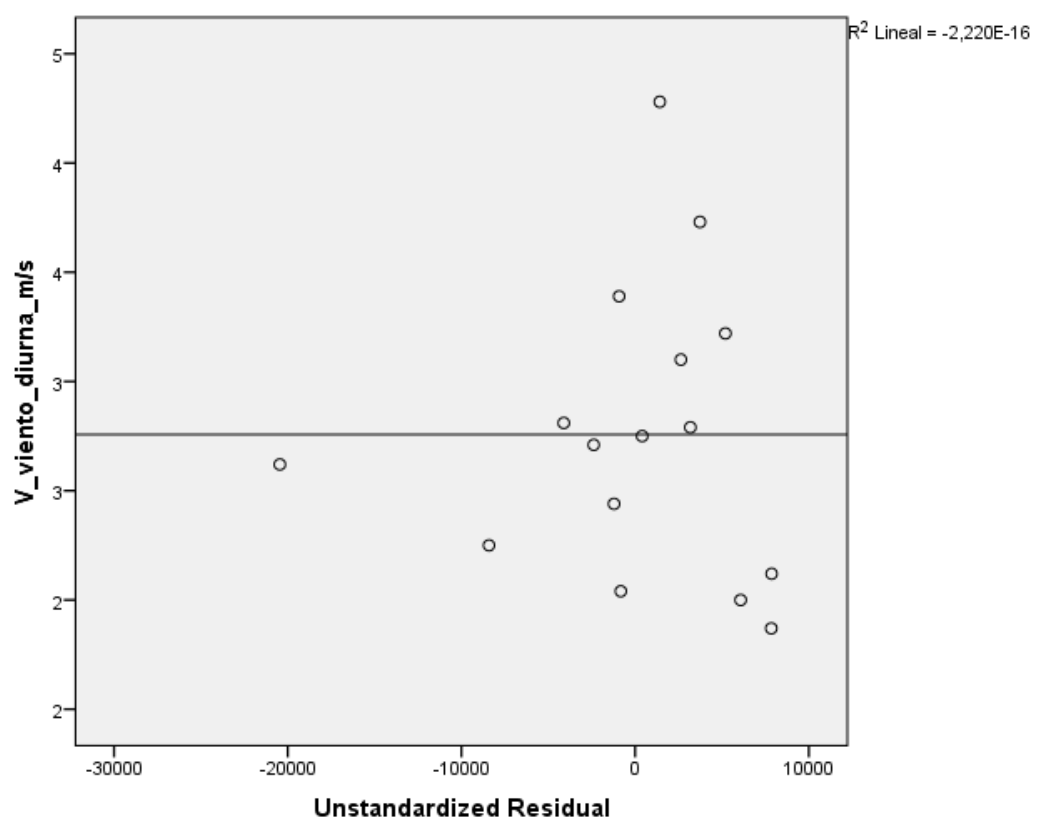

Figura 255. Relación entre la velocidad del viento nocturna y los residuos. Edificio D8. Modelo 2

- Cuando la regresión es lineal múltiple, se comprueba la falta de multicolinealidad o No-Colinealidad entre las variables independientes, es decir que las variables que forman parte del modelo no están correlacionadas entre ellas.

El problema de la multicolinealidad es moderado cuando el índice de condición toma un valor entre 20 y 30 y es grave cuando el índice de condición toma un valor superior a 30. El número de condición mide la sensibilidad de las estimaciones mínimo-cuadráticas ante pequeños cambios en los datos a mayor valor más correlación entre las variables.

La Tabla 303, muestra los índices de condición de las variables del modelo de regresión múltiple, ninguno de ellos supera el valor 20, por lo que no existen evidencias de correlación entre las variables independientes del modelo

Tabla 303. Índice de condición de las variables independientes del Modelo 2 en el Edificio D8

\begin{tabular}{llr}
\hline Modelo & Dimensión & Índice de condición \\
\hline \multirow{3}{*}{2} & 1 & 1,000 \\
\cline { 2 - 3 } & 2 & 4,578 \\
\cline { 2 - 3 } & 3 & 12,127 \\
\hline
\end{tabular}

En cuanto a los índices estadísticos de colinealidad como son los niveles Tolerancia y su inverso que son los Factores de Inflación de la Varianza (FIV). El nivel de tolerancia se 
obtiene restando a 1 el coeficiente de determinación $\left(R^{2}\right)$. Como se observa en la Figura 207, el coeficiente de determinación entre las dos variables independientes es $R^{2}=0,065$, luego la Tolerancia es $T=1-R^{2}=1-0,065=0,935$ y $\mathrm{FIV}=1 / \mathrm{T}=1,069$

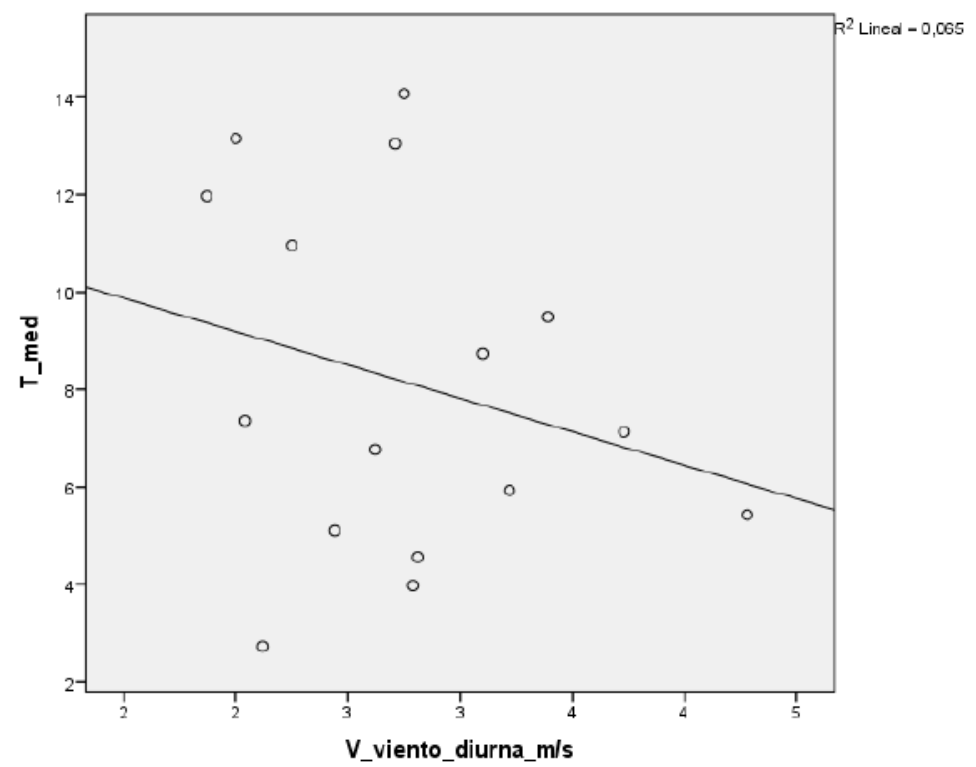

Figura 256. Gráfico de la temperatura media y la velocidad del viento diurna.

Si la Tolerancia toma un valor próximo a la unidad no existirá colinealidad (a mayor tolerancia menor colinealidad), por lo que se podrá deducir que no existe multicolinealidad entre las variables independientes. Pueden existir problemas de colinealidad si algún FIV es superior a 10 , que corresponde con un $R^{2}$ de 0,9 y una Tolerancia menor a 0,1

La Tabla 304, muestra los estadísticos de colinealidad y se observa como la Tolerancia toma valores de 0,935, próxima a 1 y los valores de FIV permanecen por debajo de 10, por lo que no existen problemas de colinealidad entre la temperatura media y la velocidad del viento diurna.

Tabla 304. Estadísticos de colinealidad para los modelos del Edificio D8

\begin{tabular}{|c|c|c|c|}
\hline Modelo & & Tolerancia & FIV \\
\hline 1 & T_med & 1,000 & 1,000 \\
\hline \multirow{2}{*}{2} & T_med & ,935 & 1,069 \\
\hline & V_viento_diurna_m/s & ,935 & 1,069 \\
\hline
\end{tabular}

\section{AIV.8.3. Obtención de los consumos térmicos previstos}


Una vez comprobado el cumplimiento de los supuestos estadísticos se aceptan los modelos de línea base encontrados para modelizar el consumo del Edificio D8.

Modelo 1:

$$
\text { kWh_D8 }=91.484,519-5.414,103 \times \text { T_med }
$$

Modelo 2:

$$
\text { kWh_D8 }=63.357,055-4.991,184 \times \text { T_med }+8.950,19 \times \text { V_viento_diurna }
$$

Con estos modelos se procede a predecir los consumos previstos para las temporadas: octubre 2015-mayo 2016, octubre 2016 - mayo 2017 y octubre 2017-mayo 2018, estos consumos se muestran en la Tabla 305, donde "KWh_D8", representa el consumo real, "kWh_D8_M1", el consumo pronosticado con el Modelo 1 y "kWh_D8_M2", el consumo pronosticado con el Modelo 2.

\begin{tabular}{|c|c|c|c|c|c|c|}
\hline & T_media & V_viento_nocturna & kWh_D8 & kWh_D8_M1 & kWh_D8_M2 & $\begin{array}{l}\text { kWh_D8_M1 - } \\
\text { kWh_D8_M2 }\end{array}$ \\
\hline oct-15 & 12,82 & 1,72 & 8.364 & 22.083 & 14.797 & 7.286 \\
\hline nov-15 & 8,30 & 1,25 & 48.422 & 46.535 & 33.062 & 13.473 \\
\hline dic-15 & 5,33 & 0,97 & 52.355 & 62.634 & 45.474 & 17.160 \\
\hline ene-16 & 6,23 & 2,53 & 56.577 & 57.735 & 54.923 & 2.813 \\
\hline feb-16 & 5,82 & 3,30 & 93.692 & 59.995 & 63.891 & -3.896 \\
\hline mar-16 & 6,14 & 2,66 & 65.365 & 58.226 & 56.470 & 1.757 \\
\hline$a b r-16$ & 9,10 & 2,67 & 43.085 & 42.213 & 41.822 & 391 \\
\hline may-16 & 13,11 & 2,13 & 8.549 & 20.483 & 16.960 & 3.523 \\
\hline oct-16 & 13,48 & 1,08 & 7.817 & 18.501 & 5.703 & 12.798 \\
\hline nov-16 & 6,90 & 1,61 & 63.818 & 54.118 & 43.290 & 10.829 \\
\hline dic-16 & 4,12 & 0,99 & 84.992 & 69.168 & 51.688 & 17.480 \\
\hline ene-17 & 2,52 & 1,31 & 96.064 & 77.862 & 62.541 & 15.321 \\
\hline feb-17 & 6,96 & 2,79 & 66.871 & 53.804 & 53.578 & 226 \\
\hline mar-17 & 9,21 & 2,69 & 61.592 & 41.624 & 41.441 & 183 \\
\hline$a b r-17$ & 12,58 & 2,53 & 28.173 & 23.391 & 23.200 & 191 \\
\hline may-17 & 16,69 & 2,07 & 9.028 & 1.141 & -1.368 & 2.509 \\
\hline oct-17 & 14,71 & 1,50 & 5.806 & 11.836 & 3.312 & 8.524 \\
\hline nov-17 & 6,09 & 1,42 & 64.362 & 58.511 & 45.665 & 12.845 \\
\hline dic-17 & 3,99 & 2,28 & 111.550 & 69.875 & 63.880 & 5.996 \\
\hline ene-18 & 4,42 & 2,23 & 91.069 & 67.551 & 61.226 & 6.325 \\
\hline feb-18 & 3,53 & 2,42 & 95.311 & 72.380 & 67.366 & 5.014 \\
\hline mar-18 & 6,80 & 4,38 & 77.654 & 54.655 & 68.583 & -13.928 \\
\hline$a b r-18$ & 11,15 & 2,77 & 36.472 & 31.137 & 32.522 & -1.385 \\
\hline may-18 & 14,03 & 2,00 & 15.896 & 15.537 & 11.231 & 4.306 \\
\hline
\end{tabular}

Tabla 305. Consumos previstos octubre 2014 - mayo 2017 para el edificio D8.

El dato del consumo de mayo de 2017, en el modelo 2, será anulado puesto que la estimación arroja un valor negativo. En la mayoría de los meses los consumos pronosticados con el modelo 1, son superiores a los pronosticados con el Modelo 2. 


\section{AIV.8.4. Estudio de la existencia de diferencias significativas}

Utilizando el contraste de hipótesis para la comparación de medias para muestras relacionadas, es decir la prueba paramétrica " $\mathrm{t}$ " de Student para muestras relacionadas, podemos concluir que si las variables se distribuyen según una normal y la significación estadística resulta $\leq 0,05$, existen diferencias significativas. En caso contrario no se rechaza la hipótesis nula de igualdad de medias, concluyendo que las diferencias encontradas no son estadísticamente significativas y no van más allá de lo que sería esperable por azar, todo ello con la aceptación de un riesgo de error del 5\%, o lo que es lo mismo un nivel de confianza del $95 \%$

A continuación se muestra la comparación de medias realizada para cada uno de los tres periodos posteriores a la construcción de la red y para el periodo total hasta mayo de 2018.

Para la temporada Octubre 2015 - Mayo 2016, se comprueba mediante el Test de Shapiro -Wilk que tanto los valores reales como los pronosticados con los dos modelos se distribuyen según una Normal puesto que en todos los casos los valores de Sig > 0,05, como se observa en la Tabla 306

Tabla 306. Prueba de Normalidad temporada Octubre 2015-Mayo 2016. Edificio D8

\begin{tabular}{cccccrr}
\hline & \multicolumn{3}{c}{ Kolmogorov-Smirnov $^{\mathrm{a}}$} & \multicolumn{2}{c}{ Shapiro-Wilk } \\
\cline { 2 - 7 } & Estadístico & gl & Sig. & Estadístico & gl & Sig. \\
\hline kWh_real &, 194 & 8 &, 200 &, 926 & 8 &, 481 \\
\hline kWh_pronost_M1 &, 252 & 8 &, 144 &, 839 & 8 &, 073 \\
\hline kWh_pronost_M2 &, 157 & 8 &, 200 &, 927 & 8 &, 492 \\
\hline
\end{tabular}

En la Tabla 307, se observa como las medias tanto de los consumos pronosticados con el Modelo 1, como de los consumos pronosticados con el Modelo 2, son inferiores a las medias de los consumos reales del Edificio D8; un 1,7 \% inferior con la estimación del Modelo 1 y un 13,0 \% inferior con la estimación del Modelo 2

Tabla 307. Estadísticos de muestras relacionadas. Octubre 2015-Mayo 2016. Edificio D8

\begin{tabular}{|c|c|c|c|c|c|c|}
\hline & & Media & $\begin{array}{l}\% \text { Diferencia } \\
\text { entre medias }\end{array}$ & $\mathrm{N}$ & $\begin{array}{c}\text { Desviación } \\
\text { típ. }\end{array}$ & $\begin{array}{c}\text { Error típ. de } \\
\text { la media }\end{array}$ \\
\hline Par & kWh_real & 47051,1250 & & 8 & 28350,76048 & 10023,50749 \\
\hline 1 & kWh_pronost_M1 & 46238,0000 & $-1,7 \%$ & 8 & 16890,61405 & 5971,73387 \\
\hline Par & kWh_real & 47051,1250 & & 8 & 28350,76048 & 10023,50749 \\
\hline 2 & kWh_pronost_M2 & 40924,8750 & $-13,0 \%$ & 8 & 18147,59556 & 6416,14394 \\
\hline
\end{tabular}


La Tabla 308 muestra que las diferencias entre las medias no son significativas entre los consumos reales y los pronosticados con el Modelo 1, ni con el Modelo 2 (sig > 0,05).

Tabla 308. Prueba de muestras relacionadas. Octubre 2015-Mayo 2016. Edificio D8

\begin{tabular}{|c|c|c|c|c|c|c|c|c|c|}
\hline & & \multicolumn{5}{|c|}{ Diferencias relacionadas } & \multirow{3}{*}{$\mathrm{t}$} & \multirow{3}{*}{$\mathrm{gl}$} & \multirow{3}{*}{$\begin{array}{l}\text { Sig. } \\
\text { (bilateral) }\end{array}$} \\
\hline & & \multirow[t]{2}{*}{ Media } & \multirow{2}{*}{$\begin{array}{l}\text { Desviación } \\
\text { típ. }\end{array}$} & \multirow{2}{*}{$\begin{array}{l}\text { Error típ. } \\
\text { de la media }\end{array}$} & \multicolumn{2}{|c|}{$\begin{array}{l}\text { 95\% Intervalo de confianza } \\
\text { para la diferencia } \\
\end{array}$} & & & \\
\hline & & & & & Inferior & Superior & & & \\
\hline Par 1 & $\begin{array}{c}\text { kWh_real - } \\
\text { kWh_pronost_M1 }\end{array}$ & 813,125 & 15227,395 & 5383,697 & $-11917,296$ & 13543,546 & 151 & 7 & ,884 \\
\hline Par 2 & $\begin{array}{c}\text { kWh_real - } \\
\text { kWh_pronost_M2 }\end{array}$ & 6126,250 & 12344,520 & 4364,447 & $-4194,027$ & 16446,527 & 1,404 & 7 & ,203 \\
\hline
\end{tabular}

En la Figura 257, se grafican los consumos reales y pronosticados para la temporada Octubre 2015 - Mayo 2016 para el Edificio D8, y las medias de dichos consumos. Según la prueba paramétrica realizada no son estadísticamente significativas para un nivel de confianza del $95 \%$.

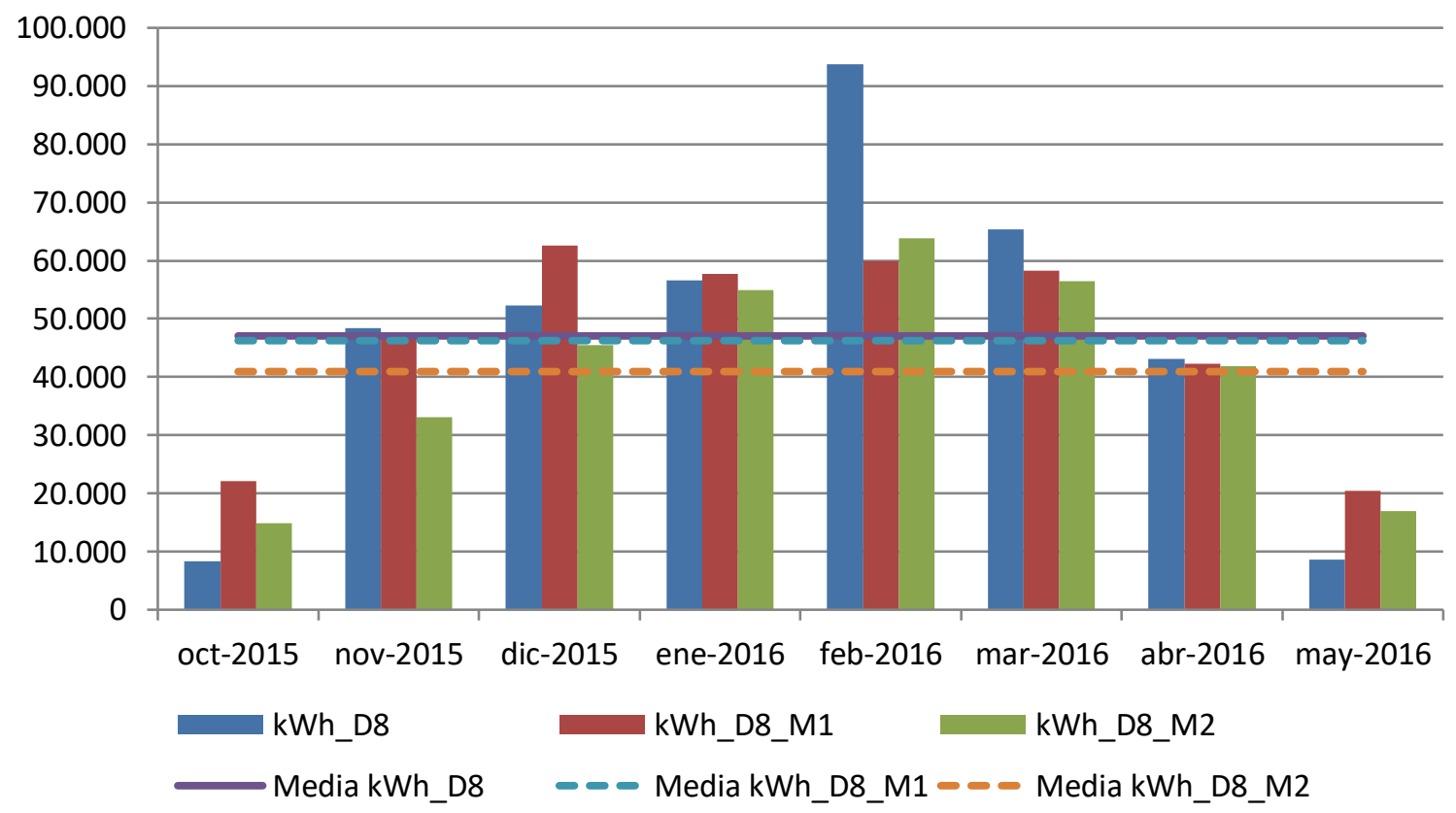

Figura 257. Consumos reales y pronosticados Octubre 2015-Mayo 2016. Edificio D8

Para la temporada Octubre 2016 - Mayo 2017, se comprueba mediante el Test de Shapiro -Wilk que tanto los valores reales como los pronosticados con los dos modelos se distribuyen según una Normal puesto que en todos los casos los valores de Sig > 0,05, como se observa en la Tabla 309. El valor negativo del pronóstico de mayo de 2017, obtenido con el Modelo 2, se ha anulado de la prueba. 
Anexo IV. Desarrollo del análisis de los edificios del Campus Miguel Delibes

Tabla 309. Prueba de Normalidad temporada Octubre 2016-Mayo 2017. Edificio D8

\begin{tabular}{lccrrrrr}
\hline & \multicolumn{4}{c}{ Kolmogorov-Smirnov $^{\text {a }}$} & \multicolumn{3}{c}{ Shapiro-Wilk } \\
\cline { 2 - 9 } & Estadístico & gl & \multicolumn{1}{c}{ Sig. } & Estadístico & gl & \multicolumn{1}{c}{ Sig. } \\
\hline kWh_real &, 234 & 8 &, 200 &, 906 & 8 &, 327 \\
\hline kWh_pronost_M1 &, 166 & 8 &, 200 &, 963 & 8 &, 834 \\
\hline kWh_real (sin Mayo 2017) &, 255 & 7 &, 189 &, 932 & 7 &, 569 \\
\hline kWh_pronost_M2 &, 239 & 7 &, $200^{*}$ &, 923 & 7 &, 490 \\
\hline
\end{tabular}

En la Tabla 310, se observa como las medias tanto de los consumos pronosticados con el Modelo 1, como de los consumos pronosticados con el Modelo 2, son inferiores a las medias de los consumos reales del Edificio D8, un 18,8 \% inferior con la estimación del Modelo 1 y un 31,2 \% inferior con la estimación del Modelo 2

Tabla 310. Estadísticos de muestras relacionadas. Octubre 2016-Abril 2017. Edificio D8

\begin{tabular}{|c|c|c|c|c|c|c|}
\hline & & Media & $\begin{array}{l}\text { \% Diferencia } \\
\text { entre medias }\end{array}$ & $\mathrm{N}$ & $\begin{array}{c}\text { Desviación } \\
\text { típ. }\end{array}$ & $\begin{array}{c}\text { Error típ. de } \\
\text { la media }\end{array}$ \\
\hline Par & kWh_real & 52294,3750 & & 8 & 33484,94190 & 11838,71474 \\
\hline 1 & kWh_pronost_M1 & 42451,1250 & $-18,8 \%$ & 8 & 26394,89300 & 9332,00392 \\
\hline Par & kWh_real & 58475,2857 & & 7 & 30847,16230 & 11659,13144 \\
\hline 2 & kWh_pronost_M2 & 40205,8571 & $-31,2 \%$ & 7 & 19579,73552 & 7400,44442 \\
\hline
\end{tabular}

La Tabla 311, muestra que las diferencias entre las medias son significativas entre los consumos reales y los pronosticados con el Modelo 1 y con el Modelo 2 (sig $\leq 0,05$ )

Tabla 311. Prueba de muestras relacionadas. Octubre 2016-Abril 2017. Edificio D8

\begin{tabular}{|c|c|c|c|c|c|c|c|c|c|}
\hline & & \multicolumn{5}{|c|}{ Diferencias relacionadas } & \multirow{3}{*}{$\mathrm{t}$} & \multirow{3}{*}{ gl } & \multirow{3}{*}{$\begin{array}{c}\text { Sig. } \\
\text { (bilateral) }\end{array}$} \\
\hline & & \multirow{2}{*}{ Media } & \multirow{2}{*}{$\begin{array}{c}\text { Desviación } \\
\text { típ. }\end{array}$} & \multirow{2}{*}{$\begin{array}{c}\text { Error típ. } \\
\text { de la media }\end{array}$} & \multicolumn{2}{|c|}{$\begin{array}{l}\text { 95\% Intervalo de confianza } \\
\text { para la diferencia }\end{array}$} & & & \\
\hline & & & & & Inferior & Superior & & & \\
\hline Par 1 & $\begin{array}{c}\text { kWh_real - } \\
\text { kWh_pronost_M1 }\end{array}$ & 9843,250 & 9778,788 & 3457,324 & 1667,978 & 18018,521 & 2,847 & 7 & 025 \\
\hline Par 2 & $\begin{array}{c}\text { kWh_real - } \\
\text { kWh_pronost_M2 }\end{array}$ & 18269,428 & 12449,290 & 4705,389 & 6755,755 & 29783,102 & 3,883 & 6 & ,008 \\
\hline
\end{tabular}

En la Figura 258, se grafican los consumos reales y pronosticados para la temporada Octubre 2016 - Mayo 2017 para el Edificio D8, y las medias de dichos consumos. Según la prueba paramétrica realizada son estadísticamente significativas las diferencias encontradas entre el consumo real y el pronosticado por el modelo 1 y por el modelo 2 , estas diferencias implica que utilizando la línea base establecida en el Modelo 1, se ha producido un aumento del consumo del $18,8 \%$ y utilizando la línea base establecida con el modelo 2, un aumento del 31,2\%, con la implantación de la red de calor, durante la temporada Octubre 2016 - Mayo 2017, para un nivel de confianza del $95 \%$. 


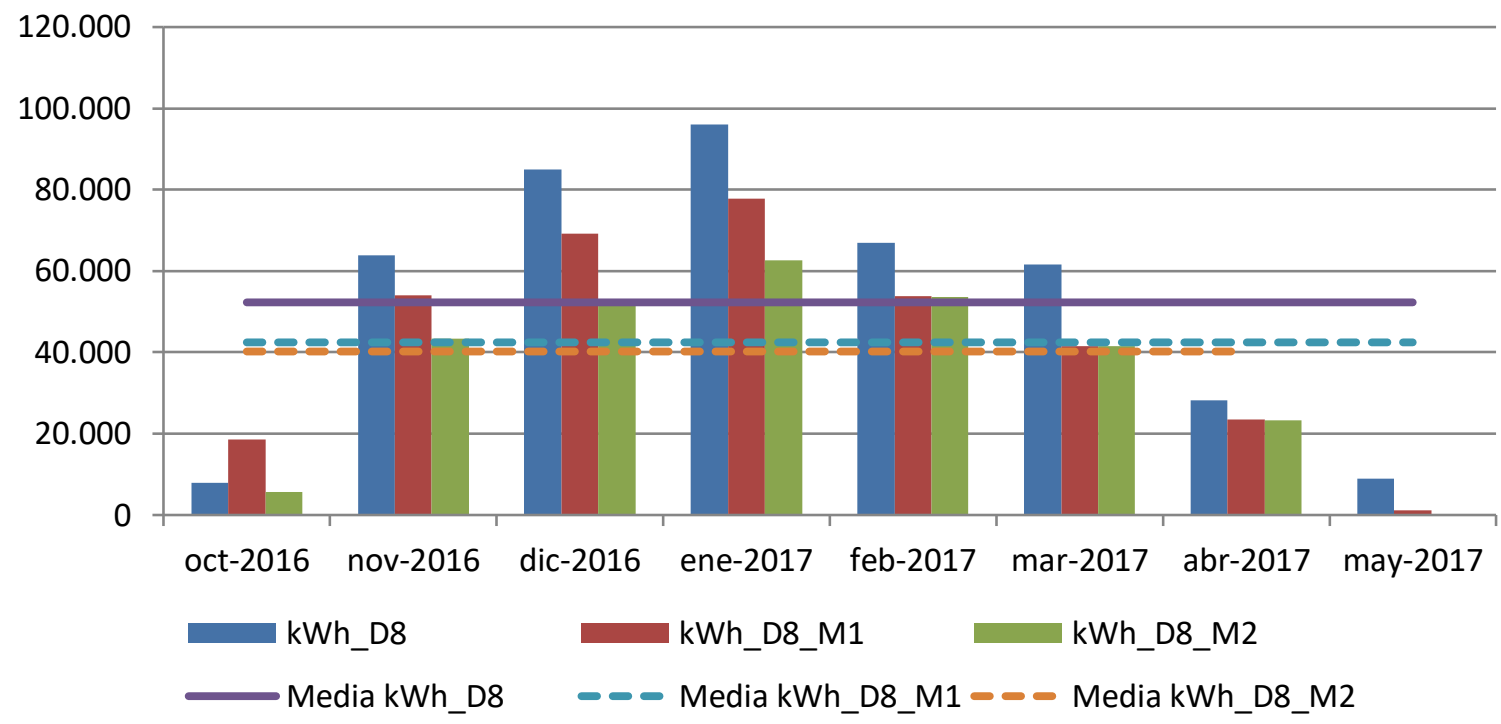

Figura 258. Consumos reales y pronosticados Octubre 2016-Mayo 2017. Edificio D8

Para la temporada Octubre 2017 - Mayo 2018, se comprueba mediante el Test de Shapiro -Wilk que tanto los valores reales como los pronosticados con los dos modelos se distribuyen según una Normal puesto que en todos los casos los valores de Sig >0,05, como se observa en la Tabla 312

Tabla 312. Prueba de Normalidad temporada Octubre 2017-Mayo 2018. Edificio D8

\begin{tabular}{ccccrrrr}
\hline & \multicolumn{3}{c}{ Kolmogorov-Smirnov $^{\mathrm{a}}$} & \multicolumn{3}{c}{ Shapiro-Wilk } \\
\cline { 2 - 8 } & \multicolumn{2}{c}{ Estadístico } & gl & \multicolumn{1}{c}{ Sig. } & Estadístico & gl & Sig. \\
\hline kWh_real &, 154 & 8 &, 200 &, 933 & 8 &, 542 \\
\hline kWh_pronost_M1 &, 236 & 8 &, 200 &, 858 & 8 &, 114 \\
\hline kWh_pronost_M2 &, 244 & 8 &, 177 &, 860 & 8 &, 120 \\
\hline
\end{tabular}

En la Tabla 313 se observa como las medias tanto de los consumos pronosticados con el Modelo 1, como de los consumos pronosticados con el Modelo 2, son inferiores a las medias de los consumos reales del Edificio D8, un 23,4 \% inferior con la estimación del Modelo 1 y un 29,0 \% inferior con la estimación del Modelo 2

Tabla 313. Estadísticos de muestras relacionadas. Octubre 2017-Mayo 2018. Edificio D8

\begin{tabular}{|c|c|c|c|c|c|c|}
\hline & & Media & $\begin{array}{l}\% \text { Diferencia } \\
\text { entre medias }\end{array}$ & $\mathrm{N}$ & $\begin{array}{c}\text { Desviación } \\
\text { típ. }\end{array}$ & $\begin{array}{l}\text { Error típ. de } \\
\text { la media }\end{array}$ \\
\hline Par & kWh_real & 62265,0000 & & 8 & 38904,49878 & 13754,81745 \\
\hline 1 & kWh_pronost_M1 & 47685,2500 & $-23,4 \%$ & 8 & 24655,22624 & 8716,93883 \\
\hline Par & kWh_real & 62265,0000 & & 8 & 38904,49878 & 13754,81745 \\
\hline 2 & kWh_pronost_M2 & 44223,1250 & $-29,0 \%$ & 8 & 25927,59825 & 9166,79027 \\
\hline
\end{tabular}


La Tabla 314 muestra que las diferencias entre las medias son significativas entre los consumos reales y los pronosticados con el Modelo 1 y con el Modelo 2 (sig $\leq 0,05$ ).

Tabla 314. Prueba de muestras relacionadas. Octubre 2017-Mayo 2018. Edificio D8

\begin{tabular}{|c|c|c|c|c|c|c|c|c|c|}
\hline & & \multicolumn{5}{|c|}{ Diferencias relacionadas } & \multirow{3}{*}{$\mathrm{t}$} & \multirow{3}{*}{$\mathrm{gl}$} & \multirow{3}{*}{$\begin{array}{c}\text { Sig. } \\
\text { (bilateral }\end{array}$} \\
\hline & & \multirow{2}{*}{ Media } & \multirow{2}{*}{$\begin{array}{l}\text { Desviación } \\
\text { típ. }\end{array}$} & \multirow{2}{*}{$\begin{array}{l}\text { Error típ. } \\
\text { de la media }\end{array}$} & \multicolumn{2}{|c|}{$\begin{array}{l}\text { 95\% Intervalo de confianza } \\
\text { para la diferencia }\end{array}$} & & & \\
\hline & & & & & Inferior & Superior & & & \\
\hline Par 1 & $\begin{array}{c}\text { kWh_real - } \\
\text { kWh_pronost_M1 }\end{array}$ & 14579,750 & 15781,182 & 5579,490 & 1386,351 & 27773,149 & 2,613 & 7 & ,035 \\
\hline Par 2 & $\begin{array}{c}\text { kWh_real - } \\
\text { kWh_pronost_M2 }\end{array}$ & 18041,875 & 16103,807 & 5693,555 & 4578,755 & 31504,994 & 3,169 & 7 & ,016 \\
\hline
\end{tabular}

En la Figura 259 se grafican los consumos reales y pronosticados para la temporada Octubre 2017 - Mayo 2018 para el Edificio D8, y las medias de dichos consumos. Según la prueba paramétrica realizada son estadísticamente significativas las diferencias encontradas entre el consumo real y el pronosticado por el modelo 1 y por el modelo 2 , estas diferencias implica que utilizando la línea base establecida en el Modelo 1 , se ha producido un aumento del consumo del 23,4 \% y utilizando la línea base establecida con el modelo 2 , un aumento del $29,0 \%$, con la implantación de la red de calor, durante la temporada octubre 2017 - mayo 2018, para un nivel de confianza del $95 \%$.

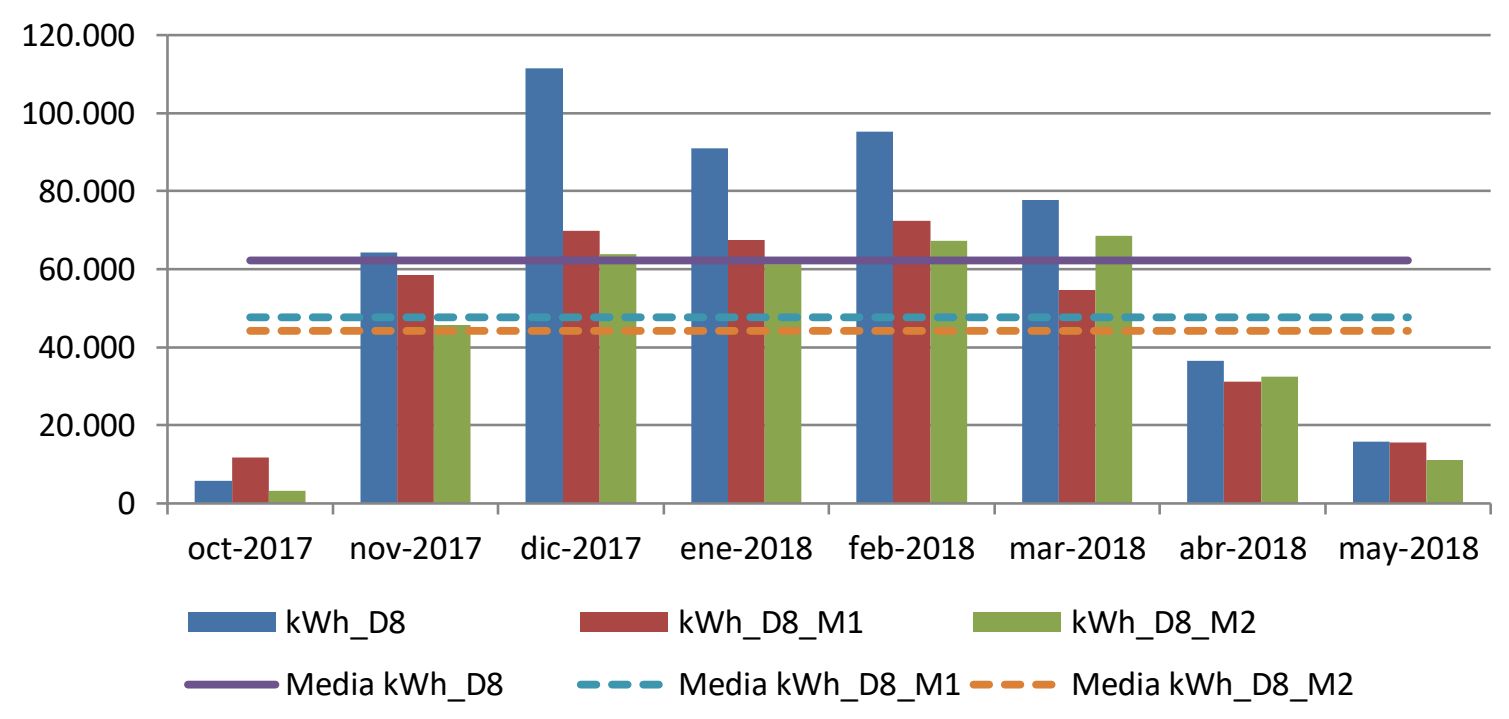

Figura 259. Consumos reales y pronosticados Octubre 2017-Mayo 2018. Edificio D8

Para el total de las tres temporadas Octubre 2015 - Mayo 2018, se comprueba mediante el Test de Shapiro -Wilk, los valores reales como los pronosticados con el Modelo M1 y con el Modelo 2 se distribuyen según una Normal puesto que los valores de Sig $>0,05$, como se observa en la Tabla 315 
Anexo IV. Desarrollo del análisis de los edificios del Campus Miguel Delibes

Tabla 315.Prueba de Normalidad temporada Octubre 2015-Mayo 2018. Edificio D8

\begin{tabular}{lrrrrrr}
\hline & \multicolumn{3}{c}{ Kolmogorov-Smirnov ${ }^{\mathrm{a}}$} & \multicolumn{3}{c}{ Shapiro-Wilk } \\
\cline { 2 - 7 } & Estadístico & gl & \multicolumn{1}{c}{ Sig. } & Estadístico & gl & Sig. \\
\hline kWh_real &, 125 & 24 &, 200 &, 933 & 24 &, 113 \\
\hline kWh_pronost_M1 &, 189 & 24 &, 027 &, 930 & 24 &, 099 \\
\hline kWh_real (sin Mayo 2017) &, 109 & 23 &, 200 &, 942 & 23 &, 203 \\
\hline kWh_pronost_M2 &, 144 & 23 &, 200 &, 921 & 23 &, 071 \\
\hline
\end{tabular}

En la Tabla 316, se observa como las medias tanto de los consumos pronosticados con el Modelo 1, como de los consumos pronosticados con el Modelo 2, son inferiores a las medias de los consumos reales del Edificio D8, un 15,6 \% inferior con la estimación del Modelo 1 y un 25,0 \% inferior con la estimación del Modelo 2

Tabla 316. Estadísticos de muestras relacionadas. Octubre 2015-Mayo 2018. Edificio D8

\begin{tabular}{clccccc}
\hline & & Media & $\begin{array}{c}\text { \% Diferencia } \\
\text { entre medias }\end{array}$ & $\mathrm{N}$ & $\begin{array}{c}\text { Desviación } \\
\text { típ. }\end{array}$ & $\begin{array}{c}\text { Error típ. de } \\
\text { la media }\end{array}$ \\
\hline Par & kWh_real & 53870,1667 & & 24 & 32985,90889 & 6733,22046 \\
\cline { 2 - 7 } 1 & kWh_pronost_M1 & 45458,1250 & $-15,6 \%$ & 24 & 22112,28905 & 4513,65210 \\
\hline Par & kWh_real & 55819,8261 & & 23 & 32282,39556 & 6731,34480 \\
\cline { 2 - 7 } 2 & kWh_pronost_M2 & 41853,2609 & $-25,0 \%$ & 23 & 20650,82885 & 4305,99548 \\
\hline
\end{tabular}

La Tabla 317 muestra que las diferencias entre las medias son significativas entre los consumos reales y los pronosticados con el Modelo 1 y con el Modelo 2 (sig $\leq 0,05)$. Estas diferencias implican que utilizando la línea base establecida en el Modelo 1 , se ha producido un aumento del consumo del 15,6 \% y utilizando la línea base establecida con el modelo 2, un aumento del 25,0\%, con la implantación de la red de calor, durante la temporada octubre 2015 - mayo 2018, para un nivel de confianza del $95 \%$.

Tabla 317. Prueba de muestras relacionadas. Octubre 2015-Mayo 2018. Edificio D8

\begin{tabular}{|c|c|c|c|c|c|c|c|c|c|}
\hline & & \multicolumn{5}{|c|}{ Diferencias relacionadas } & \multirow{3}{*}{$\mathrm{t}$} & \multirow{3}{*}{ gl } & \multirow{3}{*}{$\begin{array}{c}\text { Sig. } \\
\text { (bilateral) }\end{array}$} \\
\hline & & \multirow[t]{2}{*}{ Media } & \multirow{2}{*}{$\begin{array}{l}\text { Desviación } \\
\text { típ. }\end{array}$} & \multirow{2}{*}{$\begin{array}{c}\text { Error típ. } \\
\text { de la media }\end{array}$} & \multicolumn{2}{|c|}{$\begin{array}{l}\text { 95\% Intervalo de confianza } \\
\text { para la diferencia }\end{array}$} & & & \\
\hline & & & & & Inferior & Superior & & & \\
\hline Par 1 & $\begin{array}{c}\text { kWh_real - } \\
\text { kWh_pronost_M1 }\end{array}$ & 8412,042 & 14474,067 & 2954,506 & 2300,179 & 14523,904 & 2,847 & 23 & 009 \\
\hline Par 2 & $\begin{array}{c}\text { kWh_real - } \\
\text { kWh_pronost_M2 }\end{array}$ & 13966,565 & 14406,721 & 3004,009 & 7736,632 & 20196,498 & 4,649 & 22 & 000 \\
\hline
\end{tabular}




\section{AIV.8.5. Estimación de las emisiones de $\mathrm{CO} 2$ evitadas.}

Teniendo en cuenta que el consumir Gas natural se producen 0,252 $\mathrm{kg} \mathrm{CO}_{2} / \mathrm{kWh} \mathrm{E}$. final y que al consumir la energía suministrada por red a partir de Biomasa se producen 0,024 kg $\mathrm{CO}_{2}$ / kWh E. final, en la Tabla 318, se muestra las emisiones de $\mathrm{CO}_{2}$ reales para las temporadas octubre 2015 - mayo 2018 y utilizando el Modelo 2 (por ser el de mayor coeficiente de correlación), las emisiones de $\mathrm{CO}_{2}$ que se hubieran tenido de haber seguido utilizando las calderas de gas natural originales sin el apoyo de la red de calor.

Tabla 318. Estimación del ahorro de emisiones de CO2 para el Edificio D8.

\begin{tabular}{|c|c|c|c|c|c|c|c|c|c|c|}
\hline & $\begin{array}{l}\text { kWh_D8 } \\
\text { Gas } \\
\text { Natural }\end{array}$ & $\begin{array}{l}\text { kWh_D8 } \\
\text { Biomasa }\end{array}$ & $\begin{array}{l}\text { kWh_D8 } \\
\text { Real Total }\end{array}$ & $\begin{array}{c}\text { kWh_D8_ } \\
\text { M2 } \\
\text { Predicho }\end{array}$ & $\begin{array}{l}\text { kg CO2 Real } \\
\text { debido al } \\
\text { consumo de } \\
\text { Gas Natural }\end{array}$ & $\begin{array}{l}\text { kg CO2 } \\
\text { Real } \\
\text { debido a } \\
\text { Biomasa }\end{array}$ & $\begin{array}{l}\text { kg CO2 } \\
\text { Real } \\
\text { debido al } \\
\text { consumo } \\
\text { TOTAL }\end{array}$ & $\begin{array}{c}\text { kg CO2 } \\
\text { que se } \\
\text { hubiera } \\
\text { tenido } \\
\text { debido a } \\
\text { Gas } \\
\text { Natural }\end{array}$ & $\begin{array}{l}\text { Ahorro de } \\
\text { kg CO2 }\end{array}$ & $\begin{array}{l}\text { Ahorro de kg } \\
\text { CO2 } \\
\text { acumulado }\end{array}$ \\
\hline oct-2015 & 0 & 8.364 & 8.364 & 14.797 & 0 & 201 & 201 & 3.729 & 3.528 & 3.528 \\
\hline nov-2015 & 0 & 48.422 & 48.422 & 33.062 & 0 & 1.162 & 1.162 & 8.332 & 7.169 & 10.697 \\
\hline dic-2015 & 0 & 52.355 & 52.355 & 45.474 & 0 & 1.257 & 1.257 & 11.459 & 10.203 & 20.900 \\
\hline ene-2016 & 0 & 56.577 & 56.577 & 54.923 & 0 & 1.358 & 1.358 & 13.841 & 12.483 & 33.383 \\
\hline feb-2016 & 20.417 & 73.275 & 93.692 & 63.891 & 5.145 & 1.759 & 6.904 & 16.100 & 9.197 & 42.580 \\
\hline mar-2016 & 3.564 & 61.801 & 65.365 & 56.470 & 898 & 1.483 & 2.381 & 14.230 & 11.849 & 54.429 \\
\hline abr-2016 & 211 & 42.874 & 43.085 & 41.822 & 53 & 1.029 & 1.082 & 10.539 & 9.457 & 63.886 \\
\hline may-2016 & 0 & 8.549 & 8.549 & 16.960 & 0 & 205 & 205 & 4.274 & 4.069 & 67.955 \\
\hline oct-2016 & 7.817 & 0 & 7.817 & 5.703 & 1.970 & 0 & 1.970 & 1.437 & -533 & 67.422 \\
\hline nov-2016 & 10.737 & 53.081 & 63.818 & 43.290 & 2.706 & 1.274 & 3.980 & 10.909 & 6.929 & 74.351 \\
\hline dic-2016 & 1.536 & 83.456 & 84.992 & 51.688 & 387 & 2.003 & 2.390 & 13.025 & 10.635 & 84.986 \\
\hline ene-2017 & 576 & 95.488 & 96.064 & 62.541 & 145 & 2.292 & 2.437 & 15.760 & 13.323 & 98.310 \\
\hline feb-2017 & 328 & 66.543 & 66.871 & 53.578 & 83 & 1.597 & 1.680 & 13.502 & 11.822 & 110.132 \\
\hline mar-2017 & 272 & 61.320 & 61.592 & 41.441 & 69 & 1.472 & 1.540 & 10.443 & 8.903 & 119.035 \\
\hline abr-2017 & 144 & 28.029 & 28.173 & 23.200 & 36 & 673 & 709 & 5.846 & 5.137 & 124.172 \\
\hline may-2017 & 0 & & & & 0 & 0 & 0 & 0 & 0 & 124.172 \\
\hline oct-2017 & 0 & 5.806 & 5.806 & 3.312 & 0 & 139 & 139 & 835 & 695 & 124.868 \\
\hline nov-2017 & 152 & 64.210 & 64.362 & 45.665 & 38 & 1.541 & 1.579 & 11.508 & 9.928 & 134.796 \\
\hline dic-2017 & 328 & 111.222 & 111.550 & 63.880 & 83 & 2.669 & 2.752 & 16.098 & 13.346 & 148.142 \\
\hline ene-2018 & 184 & 90.885 & 91.069 & 61.226 & 46 & 2.181 & 2.228 & 15.429 & 13.201 & 161.343 \\
\hline feb-2018 & 912 & 94.399 & 95.311 & 67.366 & 230 & 2.266 & 2.495 & 16.976 & 14.481 & 175.824 \\
\hline mar-2018 & 1.512 & 76.142 & 77.654 & 68.583 & 381 & 1.827 & 2.208 & 17.283 & 15.074 & 190.898 \\
\hline abr-2018 & 168 & 36.304 & 36.472 & 32.522 & 42 & 871 & 914 & 8.195 & 7.282 & 198.180 \\
\hline may-2018 & 0 & 15.896 & 15.896 & 11.231 & 0 & 382 & 382 & 2.830 & 2.449 & 200.629 \\
\hline
\end{tabular}

Como se observa durante estas tres temporadas se ha obtenido un ahorro total de 201 Toneladas de $\mathrm{CO}_{2}$, debido al consumo térmico del edificio D8 y únicamente debido al cambio de gas natural por biomasa. 


\section{AIV.8.6. Estimación del precio máximo de compra a la red.}

Tomando como referencia los precios del gas natural de la Tabla 319 para cada temporada, obtenidos a partir de los datos establecidos en el Capítulo 3, donde se tiene en cuenta el precio por el termino variable y fijo; se puede realizar la estimación del precio máximo de compra de la energía útil a la red de calor para obtener un $0 \%$ de ahorro y un $15 \%$ de ahorro. La Tabla 320, muestra el precio que se pagaría para un ahorro del $15 \%$

Tabla 319. Precios de referencia para Gas natural y Astilla

\begin{tabular}{ccccc}
\hline Precios ( $€ /(\mathrm{kWh})$ & 2015 & 2016 & 2017 & 2018 \\
\hline Gas Natural & 0,0373 & 0,0306 & 0,0314 & 0,0336 \\
\hline Astilla & 0,0277 & 0,0256 & 0,0254 & 0,0239 \\
\hline $\begin{array}{c}€ / \text { kWh útiles máximos de compra a la red para } \\
\text { un ahorro del } 0,0 \%\end{array}$ & 0,02391 & \\
\hline $\begin{array}{c}€ / \text { kWh útiles máximos de compra a la red para } \\
\text { un ahorro del } 15,0 \%\end{array}$ & 0,02015 & \\
\hline
\end{tabular}

Tabla 320. Ahorro Económico por el consumo térmico en el Edificio D8

\begin{tabular}{|c|c|c|c|c|c|c|c|c|c|c|}
\hline & $\begin{array}{c}\text { kWh_D8 } \\
\text { _Gas } \\
\text { Natural }\end{array}$ & $\begin{array}{c}\text { kWh_D8_ } \\
\text { Biomasa }\end{array}$ & kWh_D8 & $\begin{array}{c}\text { kWh_D8_ } \\
\text { M2 }\end{array}$ & $\begin{array}{c}€ \text { Real Gas } \\
\text { Natural }\end{array}$ & $\begin{array}{c}€ \text { Real } \\
\text { Biomasa }\end{array}$ & $\begin{array}{l}€ \text { Real } \\
\text { Total }\end{array}$ & $\begin{array}{c}\text { E predicho } \\
\text { Gas } \\
\text { natural }\end{array}$ & $\begin{array}{c}€ \\
\text { Ahorro }\end{array}$ & $€$ Acumulado \\
\hline oct-2015 & 0 & 8.364 & 8.364 & 14.797 & 0 & 169 & 169 & 552 & 383 & 383 \\
\hline nov-2015 & 0 & 48.422 & 48.422 & 33.062 & 0 & 976 & 976 & 1.233 & 257 & 641 \\
\hline dic-2015 & 0 & 52.355 & 52.355 & 45.474 & 0 & 1.055 & 1.055 & 1.696 & 641 & 1.282 \\
\hline ene-2016 & 0 & 56.577 & 56.577 & 54.923 & 0 & 1.140 & 1.140 & 1.681 & 541 & 1.823 \\
\hline feb-2016 & 20.417 & 73.275 & 93.692 & 63.891 & 625 & 1.476 & 2.101 & 1.955 & -146 & 1.677 \\
\hline mar-2016 & 3.564 & 61.801 & 65.365 & 56.470 & 109 & 1.245 & 1.354 & 1.728 & 374 & 2.050 \\
\hline abr-2016 & 211 & 42.874 & 43.085 & 41.822 & 6 & 864 & 870 & 1.280 & 409 & 2.460 \\
\hline may-2016 & 0 & 8.549 & 8.549 & 16.960 & 0 & 172 & 172 & 519 & 347 & 2.806 \\
\hline oct-2016 & 7.817 & 0 & 7.817 & 5.703 & 239 & 0 & 239 & 175 & -65 & 2.742 \\
\hline nov-2016 & 10.737 & 53.081 & 63.818 & 43.290 & 329 & 1.070 & 1.398 & 1.325 & -73 & 2.668 \\
\hline dic-2016 & 1.536 & 83.456 & 84.992 & 51.688 & 47 & 1.682 & 1.729 & 1.582 & -147 & 2.521 \\
\hline ene-2017 & 576 & 95.488 & 96.064 & 62.541 & 18 & 1.924 & 1.942 & 1.964 & 22 & 2.543 \\
\hline feb-2017 & 328 & 66.543 & 66.871 & 53.578 & 10 & 1.341 & 1.351 & 1.682 & 331 & 2.874 \\
\hline mar-2017 & 272 & 61.320 & 61.592 & 41.441 & 9 & 1.236 & 1.244 & 1.301 & 57 & 2.931 \\
\hline abr-2017 & 144 & 28.029 & 28.173 & 23.200 & 5 & 565 & 569 & 728 & 159 & 3.090 \\
\hline oct-2017 & 0 & 5.806 & 5.806 & 3.312 & 0 & 117 & 117 & 104 & -13 & 3.077 \\
\hline nov-2017 & 152 & 64.210 & 64.362 & 45.665 & 5 & 1.294 & 1.299 & 1.434 & 135 & 3.213 \\
\hline dic-2017 & 328 & 111.222 & 111.550 & 63.880 & 10 & 2.241 & 2.251 & 2.006 & -246 & 2.967 \\
\hline ene-2018 & 184 & 90.885 & 91.069 & 61.226 & 6 & 1.831 & 1.838 & 2.057 & 220 & 3.187 \\
\hline feb-2018 & 912 & 94.399 & 95.311 & 67.366 & 31 & 1.902 & 1.933 & 2.264 & 331 & 3.517 \\
\hline mar-2018 & 1.512 & 76.142 & 77.654 & 68.583 & 51 & 1.534 & 1.585 & 2.304 & 719 & 4.237 \\
\hline abr-2018 & 168 & 36.304 & 36.472 & 32.522 & 6 & 732 & 737 & 1.093 & 356 & 4.592 \\
\hline may-2018 & 0 & 15.896 & 15.896 & 11.231 & 0 & 320 & 320 & 377 & 57 & 4.649 \\
\hline$€$ Total & & & & & & & 26.390 & 31.039 & & \\
\hline Ahorro (\%) & & & & & & & & & & $15,0 \%$ \\
\hline
\end{tabular}




\section{AlV.9.Edificio D9. Gimnasio de la Facultad de Educación.}

\section{AIV.9.1. Obtención de la línea base de referencia energética}

Los datos de partida para la obtención de la línea base de referencia se muestran en la Tabla 321

Tabla 321. Consumos térmicos del edificio D9

\begin{tabular}{lr}
\hline & Consumos térmicos (kWh). D9 \\
\hline oct-12 & 16.335 \\
\hline nov-12 & 31.692 \\
\hline dic-12 & 42.168 \\
\hline ene-13 & 44.716 \\
\hline feb-13 & 42.732 \\
\hline mar-13 & 34.135 \\
\hline abr-13 & 25.105 \\
\hline may-13 & 20.021 \\
\hline oct-13 & 12.629 \\
\hline nov-13 & 33.422 \\
\hline dic-13 & 52.571 \\
\hline ene-14 & 39.501 \\
\hline feb-14 & 36.368 \\
\hline mar-14 & 27.453 \\
\hline abr-14 & 14.255 \\
\hline may-14 & 12.328 \\
\hline Promedio & 30.340 \\
\hline Total (oct-12-may-13) & 256.905 \\
\hline Total (oct-13-may-14) & 228.527 \\
\hline Total (oct-12-may-13) & 485.432 \\
\hline
\end{tabular}

Se disponen de 16 datos para establecer el modelo de regresión, mediante el método de pasos sucesivos. Como se puede ver en la Tabla 322 para el edificio, el método ofrece un modelo de regresión, con una sola variable (Grados día Base 15). El modelo fue construido con un solo paso, incluyendo la Grados día Base 15 por ser la variable más significativa (variable con menor valor de Sig $=0,000$ ). El resto de las variables como se observa en la Tabla 323 fueron excluidas del modelo al tener valores de sig $>0,05$.

Tabla 322. Modelos de regresión del Edificio D9

\begin{tabular}{|c|c|c|c|c|c|c|c|}
\hline & \multirow{2}{*}{ Modelo } & \multicolumn{2}{|c|}{ Coeficientes no estandarizados } & \multirow{2}{*}{$\mathrm{t}$} & \multirow{2}{*}{ Sig. } & \multicolumn{2}{|c|}{$\begin{array}{c}\text { Intervalo de confianza de } \\
95,0 \% \text { para B } \\
\end{array}$} \\
\hline & & B & Error típ. & & & Límite inferior & $\begin{array}{l}\text { Límite } \\
\text { superior }\end{array}$ \\
\hline & (Constante) & $-654,602$ & 435,846 & $-1,502$ & ,155 & $-1589,400$ & 280,195 \\
\hline & GD15_30min & 139,864 & 1,831 & 76,398 & 000 & 135,938 & 143,791 \\
\hline
\end{tabular}


En la Figura 260 se representa el modelo de regresión con sus límites inferior y superior para un nivel de confianza del $95 \%$

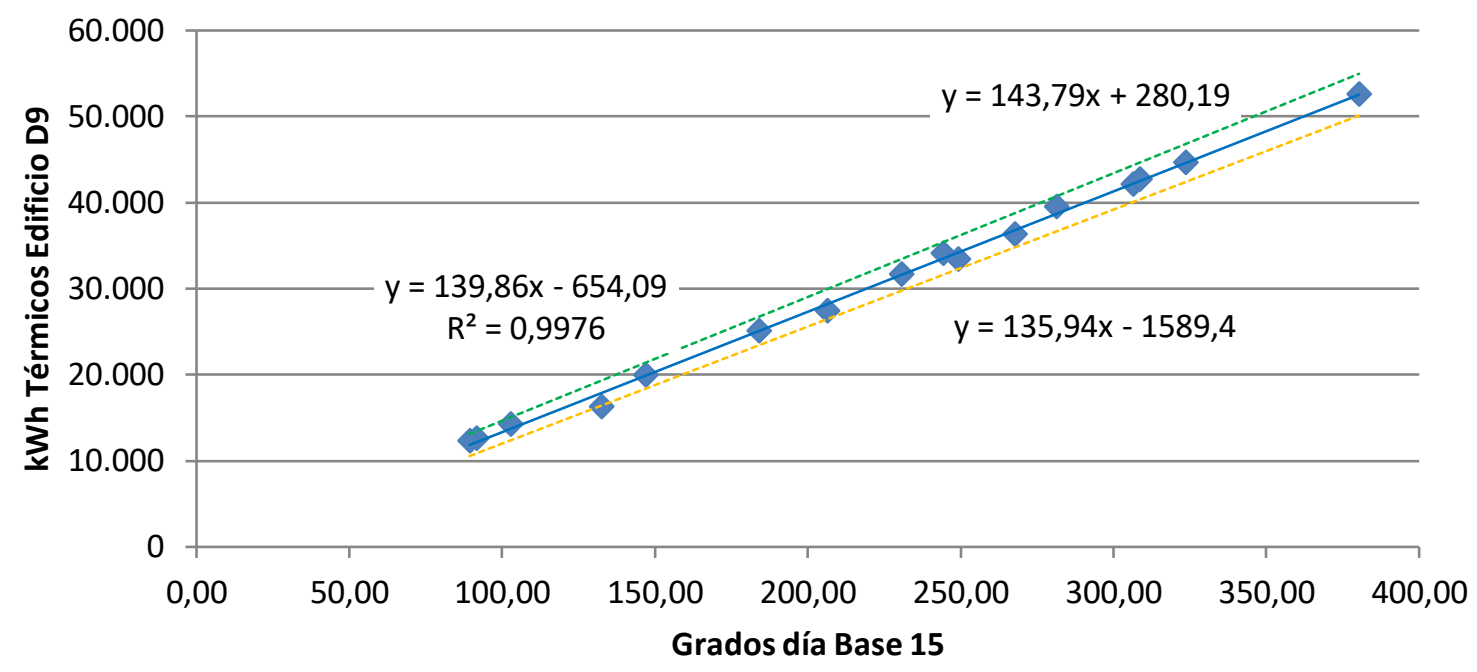

- D9 (kWh) L Lineal (D9 (kWh))

Lineal (D9 lim inferior) -------- Lineal (D9 lím superior)

Figura 260. Representación del modelo de regresión lineal simple para el Edificio D9

Tabla 323. Variables excluidas del modelo de región del Edificio D9

\begin{tabular}{|c|c|c|c|c|}
\hline & Modelo & $\mathrm{t}$ & Sig. & Correlación parcial \\
\hline & GD20_30min & 120 & ,906 & 033 \\
\hline & GD15_24h &,- 471 & 646 &,- 129 \\
\hline & GD20_24h & ,036 & 972 & ,010 \\
\hline & T_med & ,332 & ,745 & 092 \\
\hline & T_media_diurna & ,000 & 1,000 & ,000 \\
\hline & T_max &,- 385 & ,707 &,- 106 \\
\hline & T_min & 824 & ,425 & ,223 \\
\hline & HR_\% &, 280 & ,784 & 078 \\
\hline & HR_med_diurna_\% &, 231 &, 821 & 064 \\
\hline \multirow[t]{10}{*}{1} & HR_max_\% & ,416 & ,684 & ,115 \\
\hline & HR_min_\% &, 400 & ,695 &, 110 \\
\hline & Radiación_W/m2 &, 556 &, 588 & ,152 \\
\hline & V_Viento_m/s & ,739 &, 473 & ,201 \\
\hline & V_viento_diurna_m/s & ,640 &, 534 & ,175 \\
\hline & V_viento_nocturna_m/s & 865 & ,403 & ,233 \\
\hline & V_viento_max_m/s & ,545 &, 595 & ,149 \\
\hline & Recorrido_viento_km/día & ,740 & ,472 & ,201 \\
\hline & Precipitación_acumulada_mes_mm & 016 & ,988 & ,004 \\
\hline & Horas insolación_h & ,336 & ,742 & 093 \\
\hline
\end{tabular}


La bondad de los modelos de regresión obtenidos para el edificio D9, se resumen en la Tabla 324

Tabla 324. Resumen de la bondad de los modelos de regresión para el Edificio D9

\begin{tabular}{ccccc}
\hline Modelo & $\mathrm{R}$ & $\mathrm{R}$ cuadrado & $\mathrm{R}$ cuadrado corregida & $\begin{array}{c}\text { Error típ. de la } \\
\text { estimación }\end{array}$ \\
\hline 1 &, 999 & 998 &, 997 & 637,20334 \\
\hline
\end{tabular}

Se observa como el modelo de regresión lineal simple presenta un Coeficiente de Correlación de Pearson $(\mathrm{R})$ de 0,999 , lo que indica que las variables están correlacionadas de manera muy fuerte (en la correlación perfecta $R= \pm 1$ ). La correlación que se produce es directa, al aumentar el valor de la Grados día Base 15, aumenta el consumo térmico.

El coeficiente de determinación $\left(R^{2}\right)$, nos indica que con el modelo se podría explicar el $99,8 \%$ de los datos reales obtenidos aceptando un error del $5 \%$.

El error típico de la estimación que nos indica la magnitud de los errores, es decir la parte de la variable dependiente que dejamos sin explicar con el modelo y que describe la variación de la variable respuesta (el Consumo) respecto a la recta de regresión, es de 637 $\mathrm{kWh}$, lo que representa un 2,1\% del promedio de los consumos que fue de $30.340 \mathrm{kWh}$.

\section{AIV.9.2. Verificación del cumplimiento de los supuestos estadísticos}

Las condiciones que se deben cumplir en un modelo de regresión son:

- Linealidad de las variables, las variables se encuentran relacionadas de forma lineal.

Como se observa en la Tabla 322, la pendiente (B), obtuvo un valor de Sig $=0,000$, que al ser $\leq 0,05$, nos indica que podemos rechazar la hipótesis nula de pendiente igual a cero y nos da la evidencia de linealidad entre la variable dependiente ( $k W h$ del edificio D9) y la independiente (Grados día Base 15). Al ser el valor de la pendiente positiva, indica una relación directa entre el consumo y los Grados día Base 15.

- Normalidad. Todos los valores obtenidos para la variable dependiente (Y), deben estar distribuidos normalmente en cada valor de la variable independiente $(X)$.

Se comprueba la normalidad de las variables y de los residuos mediante el Test de Shapiro - Wilk para muestras pequeñas, siendo la hipótesis nula el que la distribución es Normal. 
La Tabla 325, muestra la prueba de normalidad de Shapiro-Wilk y cómo tanto la variable dependiente (consumos del Edificio), como la variable independientes: Grados día Base 15 poseen una Sig $>0,05$, por lo que aceptamos la hipótesis nula de Normalidad de las variables

Tabla 325. Prueba de normalidad para el edificio D9

\begin{tabular}{lrrrrrrr}
\hline & \multicolumn{3}{c}{ Kolmogorov-Smirnov } & \multicolumn{3}{c}{ Shapiro-Wilk } \\
\cline { 2 - 8 } & Estadístico & gl & Sig. & Estadístico & gl & \multicolumn{1}{c}{ Sig. } \\
\hline kWh_D9 &, 117 & 16 &, 200 &, 949 & 16 &, 469 \\
\hline GD15_30min &, 109 & 16 &, 200 &, 953 & 16 &, 541 \\
\hline
\end{tabular}

- Independencia de los errores. Los errores asociados a los valores de la variable respuesta $(Y)$ deberán ser independientes unos de otros.

Para la comprobación se utiliza el estadístico de Durbin -Watson.

Se comprueba que el Estadístico de Durbin Watson para el nivel de significancia del 5\%, y para el tamaño de la muestra " $n$ " y el número de variables independientes del modelo " $k$ ", se encuentra en el intervalo [dU, 4-dU], de la Tabla 3, intervalo centrado en el 2, que indica la ausencia de autocorrelación.

El valor del Estadístico Durbin-Watson facilitado por el programa SPSS, es 1,694.

En el modelo, $n=16$ y $\mathrm{k}=1$, según la Tabla 3 el valor $\mathrm{dU}=1,371$ y dL =1,106, luego el intervalo que marca la ausencia de correlación es [1,371, 2,629].

Los intervalos $[0,1,106]$ y $[2,896,4]$ indican correlación positiva o negativa respectivamente y las zonas $[1,106,1,371]$ y $[2,629,2,896]$ son zonas no concluyentes; como el valor del estadístico 1,694 está dentro del intervalo que marca la ausencia de correlación, se concluye que no existe autocorrelación.

- Homocedasticidad de la varianza. Se pretende comprobar que la varianza de los errores $\left(\sigma^{2}\right)$ es constante para cualquier valor de la variable independiente $(X)$, es decir que el valor medio del cuadrado de la desviación de los errores respecto a su media es constante.

Esta condición indica que no existe correlación entre los residuos y los pronósticos. Se comprueba que el coeficiente de determinación $\mathrm{R}^{2}$, en las relaciones: residuos $\mathrm{y}$ predicciones y entre residuos y variable independiente es nulo o muy próximo a cero, lo que indicará que no existe ningún tipo de correlación en los residuos y que éstos son aleatorios. Se grafican los diagramas de dispersión de esas relaciones, comprobando que se corresponden a nubes de puntos totalmente aleatorias, sin tendencias ni patrones en sus representaciones gráficas. 
Las Figura 261 y Figura 262, muestran que la relación entre los pronósticos y los residuos, posee un coeficiente de determinación $=-2,22 \times 10^{-16}$ y entre la variable independiente (Grados día Base 15) y los residuos un coeficiente de determinación, también de -2,22×10 16; por lo que se concluye que no existe ningún tipo de correlación en los residuos y que éstos son aleatorios, siendo la varianza de los residuos constante

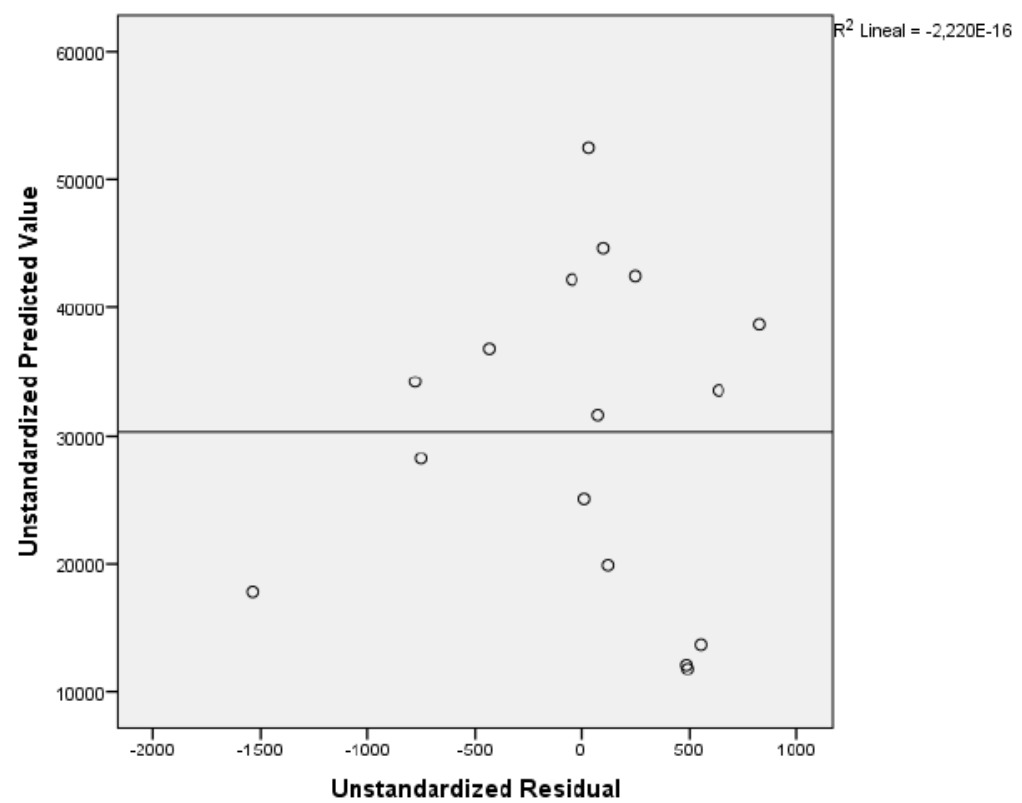

Figura 261. Relación entre los pronósticos y los residuos en el Edificio D9

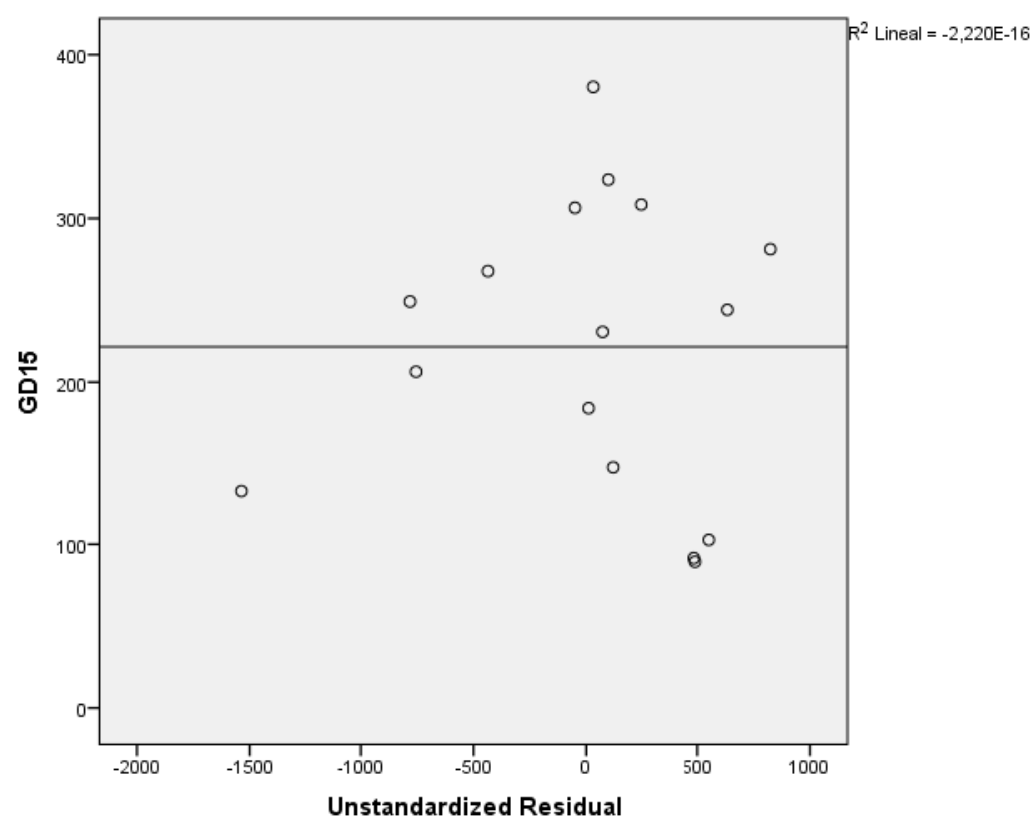

Figura 262. Relación entre Grados día Base 15 y los residuos en el Edificio D9 


\section{AlV.9.3. Obtención de los consumos térmicos previstos}

Una vez comprobado el cumplimiento de los supuestos estadísticos se acepta el modelo de línea base encontrado para modelizar el consumo del Edificio D9.

$$
\text { kWh_D9_Pronosticado }=-654,602+139,864 \times \text { GD15_30min }
$$

Con este modelo se procede a predecir los consumos previstos para las temporadas: octubre 2015-mayo 2016, octubre 2016 - mayo 2017 y octubre 2017-mayo 2018, estos consumos se muestran en la Tabla 326, donde "KWh_D9_Real", representa el consumo real, "kWh_D9_Pronosticado", el consumo pronosticado con el Modelo.

Tabla 326. Consumos previstos octubre 2014 - mayo 2017 para el edificio D9.

\begin{tabular}{rrrr}
\hline & \multicolumn{1}{c}{ GD15 } & kWh_D9_Real & kWh_D9_Pronosticado \\
\hline oct-15 & 97,04 & 10.847 & 12.918 \\
\hline nov-15 & 208,36 & 35.070 & 28.488 \\
\hline dic-15 & 300,09 & 21.527 & 41.318 \\
\hline ene-16 & 271,93 & 27.599 & 37.379 \\
\hline feb-16 & 266,36 & 55.163 & 36.600 \\
\hline mar-16 & 276,34 & 36.551 & 37.995 \\
\hline abr-16 & 181,04 & 29.596 & 24.667 \\
\hline may-16 & 99,34 & 7.715 & 13.239 \\
\hline oct-16 & 97,34 & 10.167 & 12.959 \\
\hline nov-16 & 245,69 & 43.277 & 33.709 \\
\hline dic-16 & 337,25 & 37.629 & 46.515 \\
\hline ene-17 & 386,98 & 55.750 & 53.471 \\
\hline feb-17 & 226,76 & 42.290 & 31.061 \\
\hline mar-17 & 203,17 & 35.130 & 27.761 \\
\hline abr-17 & 129,72 & 8.288 & 17.489 \\
\hline may-17 & 54,86 & 1.706 & 7.018 \\
\hline oct-17 & 92,31 & 4.566 & 12.257 \\
\hline nov-17 & 271,60 & 37.102 & 37.333 \\
\hline dic-17 & 341,26 & 53.819 & 47.075 \\
\hline ene-18 & 327,94 & 45.982 & 45.213 \\
\hline feb-18 & 321,27 & 43.599 & 44.279 \\
\hline mar-18 & 255,02 & 51.291 & 35.014 \\
\hline abr-18 & 143,31 & 24.007 & 19.389 \\
\hline may-18 & 78,41 & 7.171 & 10.312 \\
\hline & & &
\end{tabular}




\section{AIV.9.4. Estudio de la existencia de diferencias significativas}

Utilizando la prueba " $\mathrm{t}$ " de Student para muestras relacionadas, podemos concluir que si las variables se distribuyen según una normal y la significación estadística resulta $\leq 0,05$, existen diferencias significativas, con un nivel de confianza del $95 \%$

A continuación se muestra la comparación de medias realizada para cada uno de los tres periodos posteriores a la construcción de la red y para el periodo total hasta mayo de 2018.

Para la temporada Octubre 2015 - Mayo 2016, se comprueba mediante el Test de Shapiro -Wilk que tanto los valores reales como los pronosticados se distribuyen según una Normal puesto que en todos los casos los valores de Sig $>0,05$, como se observa en la Tabla 327

Tabla 327. Prueba de Normalidad temporada Octubre 2015-Mayo 2016. Edificio D9

\begin{tabular}{crrrrrrr}
\hline & \multicolumn{3}{c}{ Kolmogorov-Smirnov $^{\text {a }}$} & \multicolumn{3}{c}{ Shapiro-Wilk } \\
\cline { 2 - 8 } & Estadístico & gl & Sig. & Estadístico & gl & \multicolumn{1}{c}{ Sig. } \\
\hline kWh_real &, 162 & 8 &, 200 &, 960 & 8 &, 807 \\
\hline kWh_pronosticado &, 248 & 8 &, 159 &, 865 & 8 &, 135 \\
\hline
\end{tabular}

En la Tabla 328, se observa como las medias de los consumos pronosticados, son superiores a las medias de los consumos reales del Edificio D9, en un 3,8\%

Tabla 328. Estadísticos de muestras relacionadas. Octubre 2015-Mayo 2016. Edificio D9

\begin{tabular}{lccccc}
\hline & Media & $\begin{array}{c}\text { \% Diferencia } \\
\text { entre medias }\end{array}$ & $\mathrm{N}$ & $\begin{array}{c}\text { Desviación } \\
\text { típ. }\end{array}$ & $\begin{array}{c}\text { Error típ. de } \\
\text { la media }\end{array}$ \\
\hline kWh_real & 28008,5000 & & 8 & 15171,62234 & 5363,97852 \\
\hline kWh_pronosticado & 29075,5000 & $3,8 \%$ & 8 & 11254,47255 & 3979,05693 \\
\hline
\end{tabular}

La Tabla 329 muestra que las diferencias entre las medias no son significativas entre los consumos reales y los pronosticados (sig $>0,05$ ), a pesar de existir ese $3,8 \%$ de diferencia

Tabla 329. Prueba de muestras relacionadas. Octubre 2015-Mayo 2016. Edificio D9

\begin{tabular}{|c|c|c|c|c|c|c|c|c|c|}
\hline & & \multicolumn{5}{|c|}{ Diferencias relacionadas } & \multirow{3}{*}{$\mathrm{t}$} & \multirow{3}{*}{ gl } & \multirow{3}{*}{$\begin{array}{c}\text { Sig. } \\
\text { (bilateral) }\end{array}$} \\
\hline & & \multirow[t]{2}{*}{ Media } & \multirow{2}{*}{$\begin{array}{l}\text { Desviación } \\
\text { típ. }\end{array}$} & \multirow{2}{*}{$\begin{array}{c}\text { Error típ. } \\
\text { de la media }\end{array}$} & \multicolumn{2}{|c|}{$\begin{array}{l}\text { 95\% Intervalo de confianza } \\
\text { para la diferencia }\end{array}$} & & & \\
\hline & & & & & Inferior & Superior & & & \\
\hline Par 1 & $\begin{array}{c}\text { kWh_real - } \\
\text { kWh_pronosticado }\end{array}$ & $-1067,000$ & 11509,720 & 4069,301 & $-10689,367$ & 8555,367 &,- 262 & 7 & ,801 \\
\hline
\end{tabular}


En la Figura 263, se grafican los consumos reales y pronosticados para la temporada Octubre 2015 - Mayo 2016 para el Edificio D9, y las medias de dichos consumos. Según la prueba paramétrica realizada las diferencias encontradas no son estadísticamente significativas, por lo que no se puede afirmar la existencia de ahorros en el consumo térmico entre la situación anterior y posterior a la red de calor, con un riesgo a estar equivocados del $5 \%$

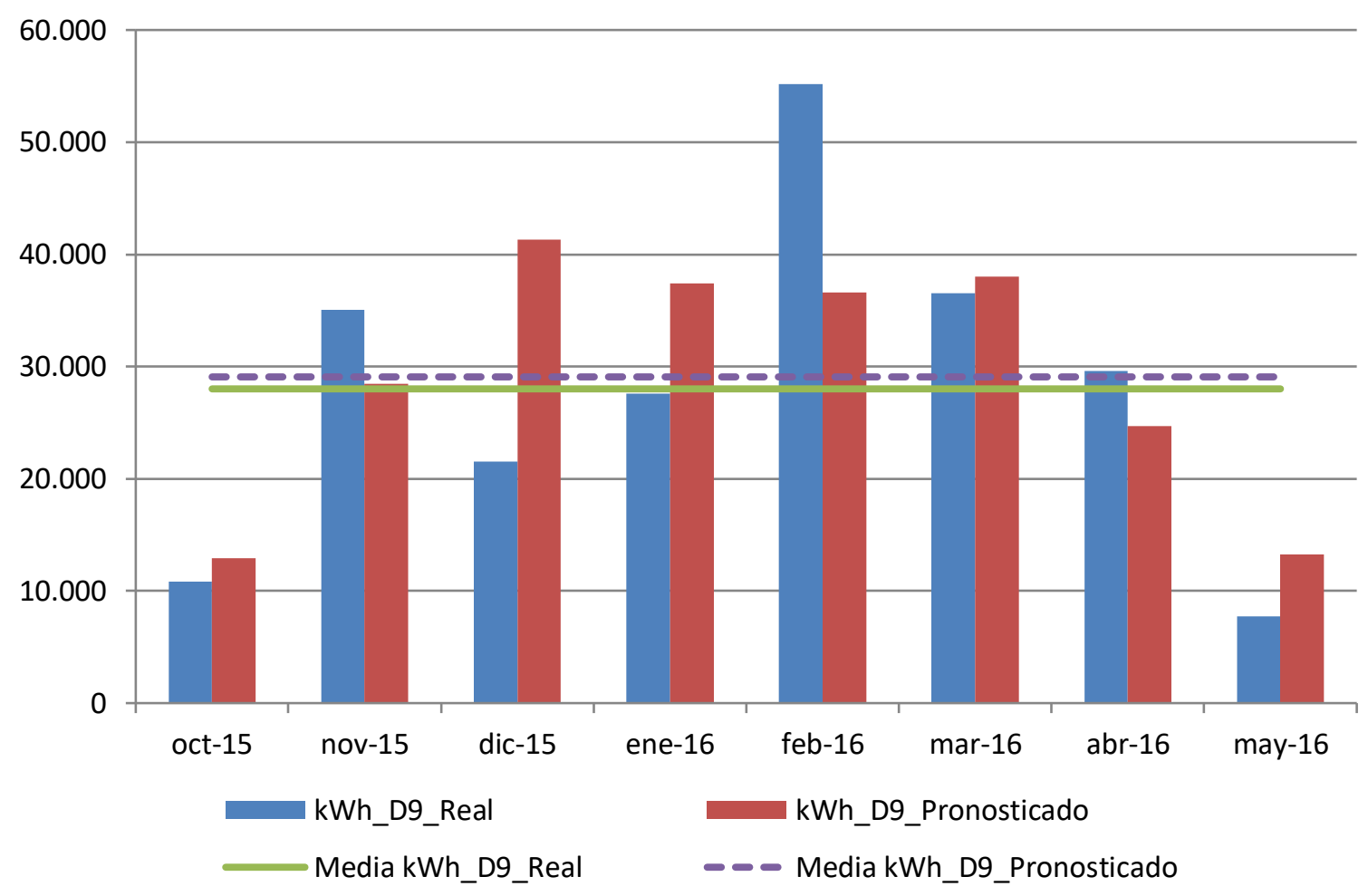

Figura 263. Consumos reales y pronosticados Octubre 2015-Mayo 2016. Edificio D9

Para la temporada Octubre 2016 - Abril 2017, se comprueba mediante el Test de Shapiro -Wilk que tanto los valores reales como los pronosticados con los dos modelos se distribuyen según una Normal puesto que en todos los casos los valores de Sig >0,05, como se observa en la Tabla 330. El número de datos disponibles son 7, dado que el pronóstico para mayo de 2017, resultó un dato negativo.

Tabla 330. Prueba de Normalidad temporada Octubre 2016-Abril 2017. Edificio D9

\begin{tabular}{crrrrrrr}
\hline & \multicolumn{3}{c}{ Kolmogorov-Smirnov $^{\mathrm{a}}$} & \multicolumn{3}{c}{ Shapiro-Wilk } \\
\cline { 2 - 8 } & Estadístico & gl & \multicolumn{1}{c}{ Sig. } & Estadístico & gl & \multicolumn{1}{c}{ Sig. } \\
\hline kWh_real &, 241 & 8 &, 189 &, 897 & 8 &, 270 \\
\hline kWh_pronosticado &, 133 & 8 &, 200 &, 965 & 8 &, 856 \\
\hline
\end{tabular}


En la Tabla 331, se observa como las medias de los consumos pronosticados, son inferiores a las medias de los consumos reales del Edificio D9, en un 1,8\%

Tabla 331. Estadísticos de muestras relacionadas. Octubre 2016-Abril 2017. Edificio D9

\begin{tabular}{llcrcc}
\hline & Media & $\begin{array}{c}\text { \% Diferencia } \\
\text { entre medias }\end{array}$ & $\mathrm{N}$ & $\begin{array}{c}\text { Desviación } \\
\text { típ. }\end{array}$ & $\begin{array}{c}\text { Error típ. de } \\
\text { la media }\end{array}$ \\
\hline $\mathrm{kWh}$ real & 29279,6250 & & 8 & 19770,32993 & 6989,86718 \\
\hline $\mathrm{kWh}$ & $-1,8 \%$ & 8 & 16062,73050 & 5679,03283 \\
\hline
\end{tabular}

La Tabla 332 muestra que las diferencias entre las medias no son significativas entre los consumos reales y los pronosticados (sig $>0,05$ ), a pesar de existir ese $-1,8 \%$ de diferencia

Tabla 332. Prueba de muestras relacionadas. Octubre 2016-Abril 2017. Edificio D9

\begin{tabular}{|c|c|c|c|c|c|c|c|c|c|}
\hline & & \multicolumn{5}{|c|}{ Diferencias relacionadas } & \multirow{3}{*}{$\mathrm{t}$} & \multirow{3}{*}{ gl } & \multirow{3}{*}{$\begin{array}{c}\text { Sig. } \\
\text { (bilateral) }\end{array}$} \\
\hline & & \multirow[t]{2}{*}{ Media } & \multirow{2}{*}{$\begin{array}{l}\text { Desviación } \\
\text { típ. }\end{array}$} & \multirow{2}{*}{$\begin{array}{c}\text { Error típ. } \\
\text { de la media }\end{array}$} & \multicolumn{2}{|c|}{$\begin{array}{l}\text { 95\% Intervalo de confianza } \\
\text { para la diferencia }\end{array}$} & & & \\
\hline & & & & & Inferior & Superior & & & \\
\hline Par 1 & $\begin{array}{c}\text { kWh_real - } \\
\text { kWh_pronosticado }\end{array}$ & 531,750 & 8233,234 & 2910,888 & $-6351,406$ & 7414,906 & 183 & 7 & ,860 \\
\hline
\end{tabular}

En la Figura 264, se grafican los consumos reales y pronosticados para la temporada Octubre 2016 - Abril 2017 para el Edificio D9, y las medias de dichos consumos. Según la prueba paramétrica realizada las diferencias encontradas no son estadísticamente significativas, con un riesgo a estar equivocados del $5 \%$

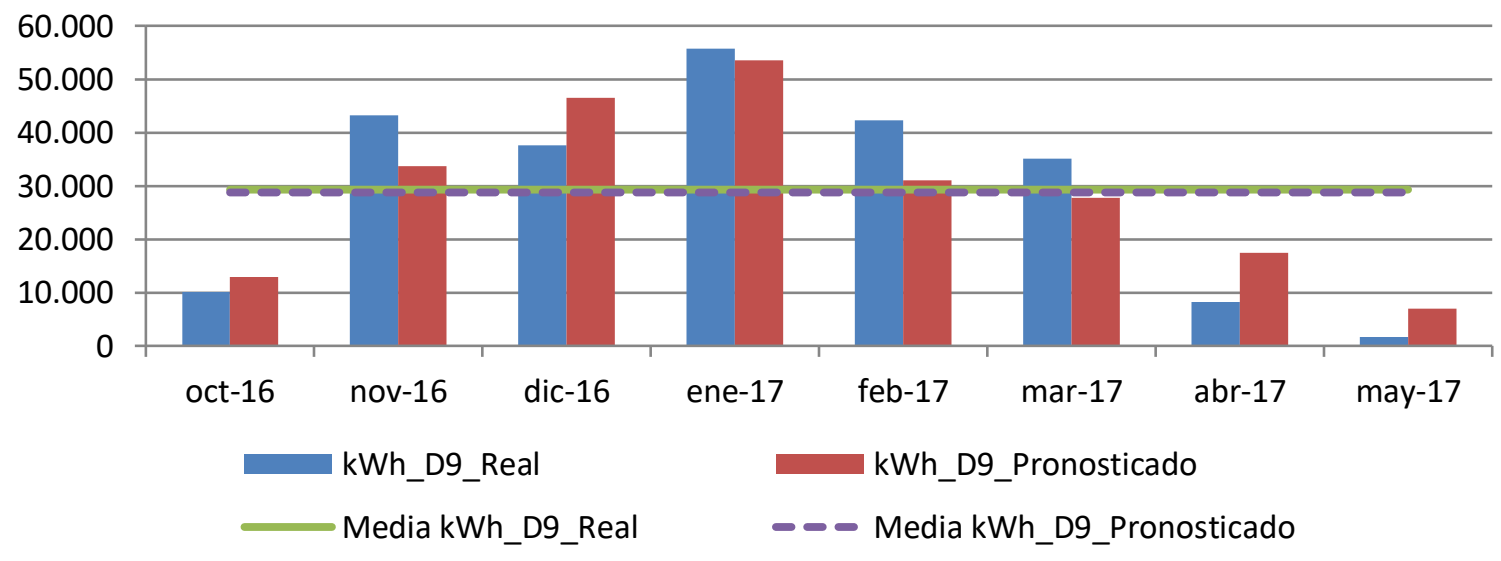

Figura 264. Consumos reales y pronosticados Octubre 2016-Abril 2017. Edificio D9

Para la temporada Octubre 2017 - Mayo 2018, se comprueba mediante el Test de Shapiro -Wilk que tanto los valores reales como los pronosticados se distribuyen según una Normal puesto que en todos los casos los valores de Sig $>0,05$, como se observa en la Tabla 333 
Anexo IV. Desarrollo del análisis de los edificios del Campus Miguel Delibes

Tabla 333. Prueba de Normalidad temporada Octubre 2017-Mayo 2018. Edificio D9

\begin{tabular}{cccccccr}
\hline & \multicolumn{3}{c}{ Kolmogorov-Smirnov $^{\text {a }}$} & \multicolumn{3}{c}{ Shapiro-Wilk } \\
\cline { 2 - 8 } & Estadístico & gl & \multicolumn{1}{c}{ Sig. } & Estadístico & gl & \multicolumn{1}{c}{ Sig. } \\
\hline kWh_real &, 200 & 8 &, 200 &, 878 & 8 &, 181 \\
\hline kWh_pronosticado &, 220 & 8 &, 200 &, 860 & 8 &, 119 \\
\hline
\end{tabular}

En la Tabla 334, se observa como las medias de los consumos pronosticados, son inferiores a las medias de los consumos reales del Edificio D9, en un 6,2\%

Tabla 334. Estadísticos de muestras relacionadas. Octubre 2017-Mayo 2018. Edificio D9

\begin{tabular}{lccrcc}
\hline & Media & $\begin{array}{c}\text { \% Diferencia } \\
\text { entre medias }\end{array}$ & $\mathrm{N}$ & $\begin{array}{c}\text { Desviación } \\
\text { típ. }\end{array}$ & $\begin{array}{c}\text { Error típ. de } \\
\text { la media }\end{array}$ \\
\hline $\mathrm{kWh}$ real & 33442,1250 & & 8 & 19348,78668 & 6840,82913 \\
\hline $\mathrm{kWh}$ _pronosticado & 31359,0000 & $-6,2 \%$ & 8 & 15147,10527 & 5355,31043 \\
\hline
\end{tabular}

La Tabla 335 muestra que las diferencias entre las medias no son significativas entre los consumos reales y los pronosticados (sig $>0,05$ ), a pesar de existir ese $-6,2 \%$ de diferencia

Tabla 335. Prueba de muestras relacionadas. Octubre 2017-Mayo 2018. Edificio D9

\begin{tabular}{|c|c|c|c|c|c|c|c|c|c|}
\hline & & \multicolumn{5}{|c|}{ Diferencias relacionadas } & \multirow{3}{*}{$\mathrm{t}$} & \multirow{3}{*}{ gl } & \multirow{3}{*}{$\begin{array}{c}\text { Sig. } \\
\text { (bilateral) }\end{array}$} \\
\hline & & \multirow[t]{2}{*}{ Media } & \multirow{2}{*}{$\begin{array}{l}\text { Desviación } \\
\text { típ. }\end{array}$} & \multirow{2}{*}{$\begin{array}{l}\text { Error típ. } \\
\text { de la media }\end{array}$} & \multicolumn{2}{|c|}{$\begin{array}{l}\text { 95\% Intervalo de confianza } \\
\text { para la diferencia }\end{array}$} & & & \\
\hline & & & & & Inferior & Superior & & & \\
\hline Par 1 & $\begin{array}{c}\text { kWh_real - } \\
\text { kWh_pronosticado }\end{array}$ & 2083,125 & 7242,310 & 2560,543 & $-3971,598$ & 8137,848 & ,814 & 7 & ,443 \\
\hline
\end{tabular}

En la Figura 265 se grafican los consumos reales y pronosticados para la temporada Octubre 2017 - Mayo 2018 para el Edificio D9, y las medias de dichos consumos. Según la prueba paramétrica realizada las diferencias encontradas no son estadísticamente significativas, con un riesgo a estar equivocados del $5 \%$

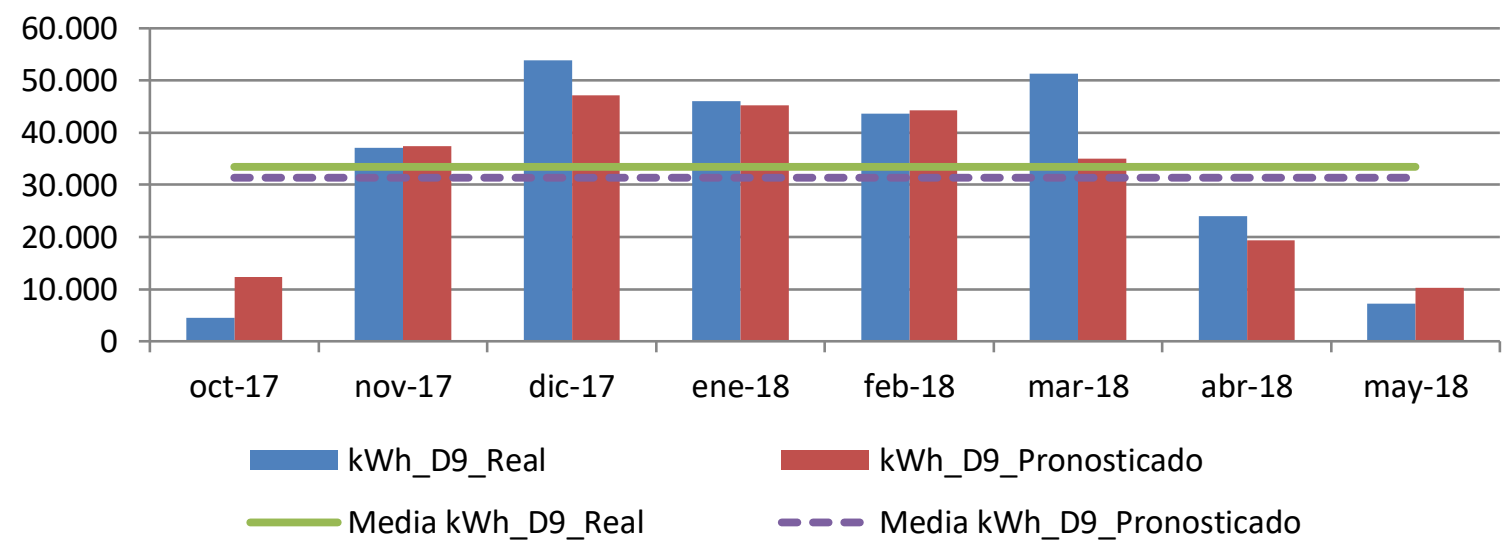

Figura 265. Consumos reales y pronosticados Octubre 2017-Mayo 2018. Edificio D9 
Para el total de las tres temporadas Octubre 2015 - Mayo 2018, se comprueba mediante el Test de Shapiro -Wilk, que los valores reales y los pronosticados se distribuyen según una Normal puesto que en esos casos los valores de Sig $>0,05$, como se observa en la Tabla 336

Tabla 336. Prueba de Normalidad temporada Octubre 2015-Mayo 2018. Edificio D9

\begin{tabular}{ccccccrr}
\hline & \multicolumn{3}{c}{ Kolmogorov-Smirnov $^{\mathrm{a}}$} & \multicolumn{3}{c}{ Shapiro-Wilk } \\
\cline { 2 - 9 } & Estadístico & gl & Sig. & Estadístico & gl & \multicolumn{1}{c}{ Sig. } \\
\hline kWh_real &, 157 & 24 &, 130 &, 925 & 24 &, 074 \\
\hline kWh_pronosticado &, 135 & 24 &, 200 &, 942 & 24 &, 183 \\
\hline
\end{tabular}

En la Tabla 337 se observa como las medias de los consumos pronosticados, son inferiores a las medias de los consumos reales del Edificio D9, en un 1,7\%

Tabla 337. Estadísticos de muestras relacionadas. Octubre 2015-Mayo 2018. Edificio D9

\begin{tabular}{lccccc}
\hline & Media & $\begin{array}{c}\text { \% Diferencia } \\
\text { entre medias }\end{array}$ & $\mathrm{N}$ & $\begin{array}{c}\text { Desviación } \\
\text { típ. }\end{array}$ & $\begin{array}{c}\text { Error típ. de } \\
\text { la media }\end{array}$ \\
\hline $\mathrm{kWh}$ real & 30243,4337 & & 24 & 17566,18831 & 3585,68317 \\
\hline $\mathrm{kWh}$ pronosticado & 29727,3383 & $-1,7 \%$ & 24 & 13722,55665 & 2801,10515 \\
\hline
\end{tabular}

La Tabla 338 muestra que las diferencias entre las medias no son significativas entre los consumos reales y los pronosticados (sig $>0,05)$.

Tabla 338. Prueba de muestras relacionadas. Octubre 2015-Mayo 2018. Edificio D9

\begin{tabular}{|c|c|c|c|c|c|c|c|c|}
\hline & \multicolumn{5}{|c|}{ Diferencias relacionadas } & \multirow{3}{*}{$\mathrm{t}$} & \multirow{3}{*}{$\mathrm{gl}$} & \multirow{3}{*}{$\begin{array}{c}\text { Sig. } \\
\text { (bilateral) }\end{array}$} \\
\hline & \multirow{2}{*}{ Media } & \multirow{2}{*}{$\begin{array}{l}\text { Desviación } \\
\text { típ. }\end{array}$} & \multirow{2}{*}{$\begin{array}{l}\text { Error típ. de } \\
\text { la media }\end{array}$} & \multicolumn{2}{|c|}{$\begin{array}{c}\text { 95\% Intervalo de confianza } \\
\text { para la diferencia }\end{array}$} & & & \\
\hline & & & & Inferior & Superior & & & \\
\hline $\begin{array}{c}\text { kWh_real - } \\
\text { kWh_pronosticado }\end{array}$ & 516,095 & 8867,779 & 1810,128 & $-3228,439$ & 4260,630 & ,285 & 23 & ,778 \\
\hline
\end{tabular}




\section{AIV.9.5. Estimación de las emisiones de $\mathrm{CO} 2$ evitadas.}

Teniendo en cuenta que el consumir Gas natural se producen 0,252 $\mathrm{kg} \mathrm{CO}_{2} / \mathrm{kWh} \mathrm{E}$. final y que al consumir la energía suministrada por red a partir de Biomasa se producen 0,024 $\mathrm{kg}$ $\mathrm{CO}_{2} / \mathrm{kWh}$. final, en la Tabla 339, se muestra las emisiones de $\mathrm{CO}_{2}$ reales para las temporadas octubre 2015 - mayo 2018 y utilizando el Modelo de regresión, las emisiones de $\mathrm{CO}_{2}$ que se hubieran tenido de haber seguido utilizando las calderas de gas natural originales sin el apoyo de la red de calor. Dado que las diferencias entre el consumo real y pronosticado ha resultado ser no significativa se igual el consumo pronosticado al real

Tabla 339. Estimación del ahorro de emisiones de CO2 para el Edificio D9.

\begin{tabular}{|c|c|c|c|c|c|c|c|c|c|c|}
\hline & $\begin{array}{l}\text { kWh_D9 } \\
\text { Gas } \\
\text { Natural }\end{array}$ & $\begin{array}{l}\text { kWh_D9 } \\
\text { Biomasa }\end{array}$ & $\begin{array}{l}\text { kWh_D9 } \\
\text { Real Total }\end{array}$ & $\begin{array}{l}\text { kWh_D9 } \\
\text { Predicho }\end{array}$ & $\begin{array}{l}\text { kg CO2 Real } \\
\text { debido al } \\
\text { consumo de } \\
\text { Gas Natural }\end{array}$ & $\begin{array}{l}\text { kg CO2 } \\
\text { Real } \\
\text { debido a } \\
\text { Biomasa }\end{array}$ & $\begin{array}{l}\text { kg CO2 } \\
\text { Real } \\
\text { debido al } \\
\text { consumo } \\
\text { TOTAL }\end{array}$ & $\begin{array}{c}\text { kg CO2 } \\
\text { que se } \\
\text { hubiera } \\
\text { tenido } \\
\text { debido a } \\
\text { Gas } \\
\text { Natural }\end{array}$ & $\begin{array}{l}\text { Ahorro de } \\
\text { kg CO2 }\end{array}$ & $\begin{array}{l}\text { Ahorro de kg } \\
\text { CO2 } \\
\text { acumulado }\end{array}$ \\
\hline oct-2015 & 0 & 10.847 & 10.847 & 10.847 & 0 & 260 & 260 & 2.733 & 2.473 & 2.473 \\
\hline nov-2015 & 0 & 35.070 & 35.070 & 35.070 & 0 & 842 & 842 & 8.838 & 7.996 & 10.469 \\
\hline dic-2015 & 0 & 21.527 & 21.527 & 21.527 & 0 & 517 & 517 & 5.425 & 4.908 & 15.377 \\
\hline ene-2016 & 0 & 27.599 & 27.599 & 27.599 & 0 & 662 & 662 & 6.955 & 6.293 & 21.670 \\
\hline feb-2016 & 10.984 & 44.179 & 55.163 & 55.163 & 2.768 & 1.060 & 3.828 & 13.901 & 10.073 & 31.743 \\
\hline mar-2016 & 1.364 & 35.187 & 36.551 & 36.551 & 344 & 844 & 1.188 & 9.211 & 8.023 & 39.765 \\
\hline abr-2016 & 1.242 & 28.354 & 29.596 & 29.596 & 313 & 680 & 993 & 7.458 & 6.465 & 46.230 \\
\hline may-2016 & 81 & 7.634 & 7.715 & 7.715 & 20 & 183 & 204 & 1.944 & 1.741 & 47.971 \\
\hline oct-2016 & 3.328 & 6.839 & 10.167 & 10.167 & 839 & 164 & 1.003 & 2.562 & 1.559 & 49.530 \\
\hline nov-2016 & 232 & 43.045 & 43.277 & 43.277 & 58 & 1.033 & 1.092 & 10.906 & 9.814 & 59.344 \\
\hline dic-2016 & 160 & 37.469 & 37.629 & 37.629 & 40 & 899 & 940 & 9.483 & 8.543 & 67.887 \\
\hline ene-2017 & 0 & 55.750 & 55.750 & 55.750 & 0 & 1.338 & 1.338 & 14.049 & 12.711 & 80.598 \\
\hline feb-2017 & 0 & 42.290 & 42.290 & 42.290 & 0 & 1.015 & 1.015 & 10.657 & 9.642 & 90.240 \\
\hline mar-2017 & 208 & 34.922 & 35.130 & 35.130 & 52 & 838 & 891 & 8.853 & 7.962 & 98.202 \\
\hline$a b r-2017$ & 0 & 8.288 & 8.288 & 8.288 & 0 & 199 & 199 & 2.089 & 1.890 & 100.092 \\
\hline may-2017 & 0 & 1.706 & 1.706 & 1.706 & 0 & 41 & 41 & 430 & 389 & 100.481 \\
\hline oct-2017 & 2.160 & 2.406 & 4.566 & 4.566 & 544 & 58 & 602 & 1.151 & 549 & 101.030 \\
\hline nov-2017 & 144 & 36.958 & 37.102 & 37.102 & 36 & 887 & 923 & 9.350 & 8.426 & 109.456 \\
\hline dic-2017 & 128 & 53.691 & 53.819 & 53.819 & 32 & 1.289 & 1.321 & 13.562 & 12.242 & 121.698 \\
\hline ene-2018 & 0 & 45.982 & 45.982 & 45.982 & 0 & 1.104 & 1.104 & 11.587 & 10.484 & 132.181 \\
\hline feb-2018 & 0 & 43.599 & 43.599 & 43.599 & 0 & 1.046 & 1.046 & 10.987 & 9.941 & 142.122 \\
\hline mar-2018 & 624 & 50.667 & 51.291 & 51.291 & 157 & 1.216 & 1.373 & 12.925 & 11.552 & 153.674 \\
\hline abr-2018 & 56 & 23.951 & 24.007 & 24.007 & 14 & 575 & 589 & 6.050 & 5.461 & 159.135 \\
\hline may-2018 & 0 & 7.171 & 7.171 & 7.171 & 0 & 172 & 172 & 1.807 & 1.635 & 160.770 \\
\hline
\end{tabular}

Como se observa durante estas tres temporadas se ha obtenido un ahorro total de 161 Toneladas de $\mathrm{CO}_{2}$, debido al cambio de gas natural a biomasa, en el Edificio D9. 


\section{AIV.9.6. Estimación del precio máximo de compra a la red.}

Tomando como referencia los precios del gas natural de la Tabla 340 para cada temporada, obtenidos a partir de los datos establecidos en el Capítulo 3, donde se tiene en cuenta el precio por el termino variable y fijo; se puede realizar la estimación del precio máximo de compra de la energía útil a la red de calor para obtener un $0 \%$ de ahorro y un 15\% de ahorro. La Tabla 341, muestral el precio que se pagaría para un ahorro del 15\%

Tabla 340. Precios de referencia para Gas natural y Astilla

\begin{tabular}{ccccc}
\hline Precios ( $€ /(\mathrm{kWh})$ & 2015 & 2016 & 2017 & 2018 \\
\hline Gas Natural & 0,0373 & 0,0306 & 0,0314 & 0,0336 \\
\hline Astilla & 0,0277 & 0,0256 & 0,0254 & 0,0239 \\
\hline $\begin{array}{c}€ / \text { kWh útiles máximos de compra a la red para } \\
\text { un ahorro del } 0,0 \%\end{array}$ & 0,03225 & \\
\hline $\begin{array}{c}€ / \text { kWh útiles máximos de compra a la red para } \\
\text { un ahorro del } 15,0 \%\end{array}$ & 0,02728 & \\
\hline
\end{tabular}

Tabla 341. Ahorro Económico por el consumo térmico en el Edificio D9

\begin{tabular}{|c|c|c|c|c|c|c|c|c|c|c|}
\hline & $\begin{array}{c}\text { kWh_D9 } \\
\text { Gas } \\
\text { Natural }\end{array}$ & $\begin{array}{l}\text { kWh_D9_ } \\
\text { Biomasa }\end{array}$ & $\begin{array}{c}\text { kWh_D9 } \\
\text { Real }\end{array}$ & $\begin{array}{c}\text { kWh_D9 } \\
\text { Pronosticado }\end{array}$ & $\begin{array}{l}\text { € Real } \\
\text { Gas } \\
\text { Natural }\end{array}$ & $\begin{array}{c}€ \text { Real } \\
\text { Biomasa }\end{array}$ & $\begin{array}{l}€ \text { Real } \\
\text { Total }\end{array}$ & $\begin{array}{c}\text { € predicho } \\
\text { Gas } \\
\text { natural }\end{array}$ & $\begin{array}{c}€ \\
\text { Ahorro }\end{array}$ & $€$ Acumulado \\
\hline oct-2015 & 0 & 10.847 & 10.847 & 10.847 & 0 & 296 & 296 & 405 & 109 & 109 \\
\hline nov-2015 & 0 & 35.070 & 35.070 & 35.070 & 0 & 957 & 957 & 1.308 & 351 & 460 \\
\hline dic-2015 & 0 & 21.527 & 21.527 & 21.527 & 0 & 587 & 587 & 803 & 216 & 676 \\
\hline ene-2016 & 0 & 27.599 & 27.599 & 27.599 & 0 & 753 & 753 & 845 & 92 & 767 \\
\hline feb-2016 & 10.984 & 44.179 & 55.163 & 55.163 & 336 & 1.205 & 1.541 & 1.688 & 147 & 914 \\
\hline mar-2016 & 1.364 & 35.187 & 36.551 & 36.551 & 42 & 960 & 1.002 & 1.118 & 117 & 1.031 \\
\hline abr-2016 & 1.242 & 28.354 & 29.596 & 29.596 & 38 & 773 & 812 & 906 & 94 & 1.125 \\
\hline may-2016 & 81 & 7.634 & 7.715 & 7.715 & 2 & 208 & 211 & 236 & 25 & 1.150 \\
\hline oct-2016 & 3.328 & 6.839 & 10.167 & 10.167 & 102 & 187 & 288 & 311 & 23 & 1.173 \\
\hline nov-2016 & 232 & 43.045 & 43.277 & 43.277 & 7 & 1.174 & 1.181 & 1.324 & 143 & 1.316 \\
\hline dic-2016 & 160 & 37.469 & 37.629 & 37.629 & 5 & 1.022 & 1.027 & 1.151 & 124 & 1.440 \\
\hline ene-2017 & 0 & 55.750 & 55.750 & 55.750 & 0 & 1.521 & 1.521 & 1.751 & 230 & 1.670 \\
\hline feb-2017 & 0 & 42.290 & 42.290 & 42.290 & 0 & 1.154 & 1.154 & 1.328 & 174 & 1.844 \\
\hline mar-2017 & 208 & 34.922 & 35.130 & 35.130 & 7 & 953 & 959 & 1.103 & 144 & 1.988 \\
\hline$a b r-2017$ & 0 & 8.288 & 8.288 & 8.288 & 0 & 226 & 226 & 260 & 34 & 2.022 \\
\hline may-2017 & 0 & 1.706 & 1.706 & 1.706 & 0 & 47 & 47 & 54 & 7 & 2.029 \\
\hline oct-2017 & 2.160 & 2.406 & 4.566 & 4.566 & 68 & 66 & 133 & 143 & 10 & 2.039 \\
\hline nov-2017 & 144 & 36.958 & 37.102 & 37.102 & 5 & 1.008 & 1.013 & 1.165 & 152 & 2.192 \\
\hline dic-2017 & 128 & 53.691 & 53.819 & 53.819 & 4 & 1.465 & 1.469 & 1.690 & 221 & 2.413 \\
\hline ene-2018 & 0 & 45.982 & 45.982 & 45.982 & 0 & 1.254 & 1.254 & 1.545 & 291 & 2.703 \\
\hline feb-2018 & 0 & 43.599 & 43.599 & 43.599 & 0 & 1.189 & 1.189 & 1.465 & 276 & 2.979 \\
\hline mar-2018 & 624 & 50.667 & 51.291 & 51.291 & 21 & 1.382 & 1.403 & 1.723 & 320 & 3.299 \\
\hline$a b r-2018$ & 56 & 23.951 & 24.007 & 24.007 & 2 & 653 & 655 & 807 & 151 & 3.451 \\
\hline may-2018 & 0 & 7.171 & 7.171 & 7.171 & 0 & 196 & 196 & 241 & 45 & 3.496 \\
\hline$€$ Total & & & & & & & 19.874 & 23.370 & & \\
\hline Ahorro (\%) & & & & & & & & & & $15,0 \%$ \\
\hline
\end{tabular}




\section{AIV.10.Edificio D10. Centro de Idiomas.}

\section{AIV.10.1.Obtención de la línea base de referencia energética}

Los datos de partida para la obtención de la línea base de referencia se muestran en la Tabla 342

Tabla 342. Consumos térmicos del edificio D10

\begin{tabular}{lr}
\hline & Consumos térmicos (kWh). D10 \\
\hline oct-12 & 9.525 \\
\hline nov-12 & 24.605 \\
\hline dic-12 & 51.330 \\
\hline ene-13 & 43.452 \\
\hline feb-13 & 53.877 \\
\hline mar-13 & 36.141 \\
\hline abr-13 & 23.334 \\
\hline may-13 & 5.546 \\
\hline oct-13 & 9.525 \\
\hline nov-13 & 24.605 \\
\hline dic-13 & 51.330 \\
\hline ene-14 & 43.452 \\
\hline feb-14 & 53.877 \\
\hline mar-14 & 36.141 \\
\hline abr-14 & 23.334 \\
\hline may-14 & 5.546 \\
\hline Promedio & 30.976 \\
\hline Total (oct-12-may-13) & 247.810 \\
\hline Total (oct-13-may-14) & 247.810 \\
\hline Total (oct-12-may-13) & 495.620 \\
\hline
\end{tabular}

Se disponen de 16 datos para establecer el modelo de regresión, mediante el método de pasos sucesivos. Como se puede ver en la Tabla 343 para el edificio, el método ofrece un modelo de regresión, con una sola variable (Temperatura media). El modelo fue construido con un solo paso, incluyendo la temperatura media por ser la variable más significativa (variable con menor valor de Sig $=0,000$ ). El resto de las variables como se observa en la Tabla 344 fueron excluidas del modelo al tener valores de sig > 0,05.

Tabla 343. Modelos de regresión del Edificio D10

\begin{tabular}{|c|c|c|c|c|c|c|c|}
\hline \multirow{2}{*}{\multicolumn{2}{|c|}{ Modelo }} & \multicolumn{2}{|c|}{$\begin{array}{l}\text { Coeficientes no } \\
\text { estandarizados }\end{array}$} & \multirow{2}{*}{$\mathrm{t}$} & \multirow{2}{*}{ Sig. } & \multicolumn{2}{|c|}{$\begin{array}{c}\text { Intervalo de confianza de } \\
95,0 \% \text { para B }\end{array}$} \\
\hline & & B & Error típ. & & & $\begin{array}{l}\text { Límite } \\
\text { inferior }\end{array}$ & $\begin{array}{l}\text { Límite } \\
\text { superior }\end{array}$ \\
\hline 1 & (Constante) & 66791,063 & 5167,180 & 12,926 &, 000 & 55708,564 & 77873,563 \\
\hline & T_med & $-4393,782$ & 583,093 & $-7,535$ & ,000 & $-5644,392$ & $-3143,171$ \\
\hline
\end{tabular}


En la Figura 266 se representa el modelo de regresión con sus límites inferior y superior para un nivel de confianza del $95 \%$

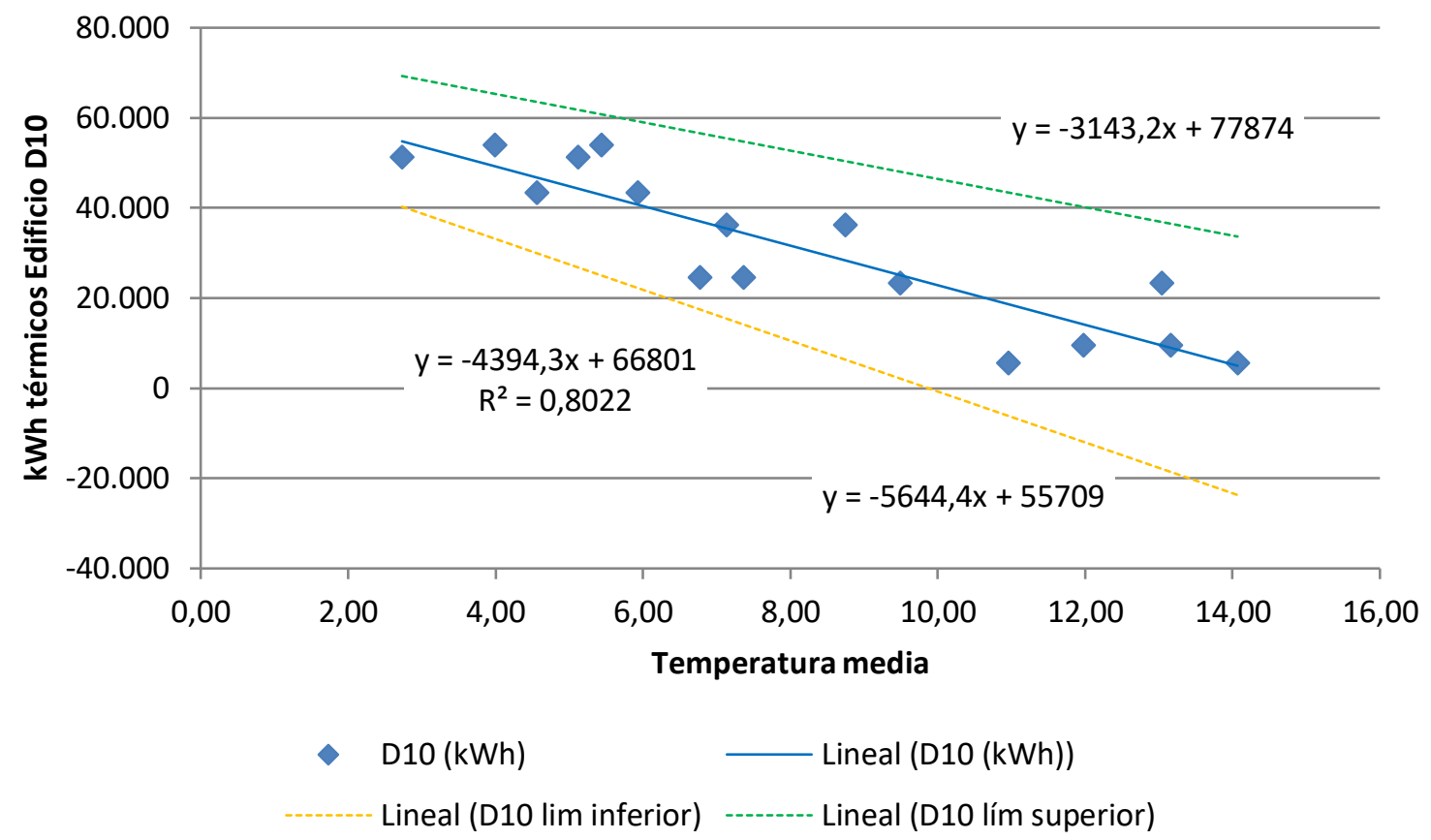

Figura 266. Representación del modelo de regresión lineal simple para el Edificio D10

Tabla 344. Variables excluidas del modelo de región del Edificio D10

\begin{tabular}{|c|c|c|c|c|}
\hline & Modelo & $\mathrm{t}$ & Sig. & Correlación parcial \\
\hline & GD15_30min &,- 247 &, 809 &,- 068 \\
\hline & GD20_30min &,- 872 & ,399 &,- 235 \\
\hline & GD15_24h &,- 751 &, 466 &,- 204 \\
\hline & GD20_24h & $-1,081$ & ,299 &,- 287 \\
\hline & T_media_diurna & ,284 & ,781 &, 079 \\
\hline & T_max & 333 & ,745 & 092 \\
\hline & T_min &,- 457 &, 655 &,- 126 \\
\hline & HR_\% &,- 694 &, 500 &,- 189 \\
\hline & HR_med_diurna_\% &,- 563 &, 583 &,- 154 \\
\hline \multirow[t]{10}{*}{1} & HR_max_\% & $-1,045$ & ,315 &,- 278 \\
\hline & HR_min_\% &,- 707 & ,492 &,- 192 \\
\hline & Radiación_W/m2 &, 336 &, 742 &, 093 \\
\hline & V_Viento_m/s & 2,067 & 059 & ,497 \\
\hline & V_viento_diurna_m/s & 2,136 &, 052 &, 510 \\
\hline & V_viento_nocturna_m/s & 1,871 & 084 & ,461 \\
\hline & V_viento_max_m/s & 1,831 & 090 & ,453 \\
\hline & Recorrido_viento_km/día & 2,053 & 061 &, 495 \\
\hline & Precipitación_acumulada_mes_mm &,- 146 & 886 &,- 041 \\
\hline & Horas insolación_h &, 121 & ,906 &, 033 \\
\hline
\end{tabular}


La bondad de los modelos de regresión obtenidos para el edificio D10, se resumen en la Tabla 345

Tabla 345. Resumen de la bondad de los modelos de regresión para el Edificio D10

\begin{tabular}{ccccc}
\hline Modelo & $\mathrm{R}$ & $\mathrm{R}$ cuadrado & R cuadrado corregida & $\begin{array}{c}\text { Error típ. de la } \\
\text { estimación }\end{array}$ \\
\hline 1 &,- 896 &, 802 &, 788 & 8108,58939 \\
\hline
\end{tabular}

Se observa como el modelo de regresión lineal simple presenta un Coeficiente de Correlación de Pearson (R) de $-0,896$, lo que indica que las variables están correlacionadas de manera muy fuerte (en la correlación perfecta $R= \pm 1$ ). La correlación que se produce es inversa, al aumentar el valor de la Temperatura media, disminuye el consumo térmico.

El coeficiente de determinación $\left(R^{2}\right)$, nos indica que con el modelo se podría explicar el $80,2 \%$ de los datos reales obtenidos aceptando un error del $5 \%$.

El error típico de la estimación que nos indica la magnitud de los errores, es decir la parte de la variable dependiente que dejamos sin explicar con el modelo y que describe la variación de la variable respuesta (el Consumo) respecto a la recta de regresión, es de $8.108 \mathrm{kWh}$, lo que representa un $26,2 \%$ del promedio de los consumos ( $30.976 \mathrm{kWh}$ ).

\section{AIV.10.2.Verificación del cumplimiento de los supuestos estadísticos}

Las condiciones que se deben cumplir en un modelo de regresión son:

- Linealidad de las variables, las variables se encuentran relacionadas de forma lineal.

Como se observa en la Tabla 343, la pendiente (B), obtuvo un valor de Sig $=0,000$, que al ser $\leq 0,05$, nos indica que podemos rechazar la hipótesis nula de pendiente igual a cero y nos da la evidencia de linealidad entre la variable dependiente ( $k$ Wh del edificio D10) y la independiente (Temperatura media). Al ser el valor de la pendiente negativa, indica una relación inversa entre el consumo y la Temperatura media.

- Normalidad. Todos los valores obtenidos para la variable dependiente (Y), deben estar distribuidos normalmente en cada valor de la variable independiente $(X)$.

Se comprueba la normalidad de las variables y de los residuos mediante el Test de Shapiro - Wilk para muestras pequeñas, siendo la hipótesis nula el que la distribución es Normal. 
La Tabla 346, muestra la prueba de normalidad de Shapiro-Wilk y cómo tanto la variable dependiente (consumos del Edificio), como la variable independientes: Temperatura media poseen una Sig $>0,05$, por lo que aceptamos la hipótesis nula de Normalidad de las variables

Tabla 346. Prueba de normalidad para el edificio D10

\begin{tabular}{lrrrrrrr}
\hline & \multicolumn{3}{c}{ Kolmogorov-Smirnov } & \multicolumn{3}{c}{ Shapiro-Wilk } \\
\cline { 2 - 8 } & Estadístico & gl & Sig. & Estadístico & gl & \multicolumn{1}{c}{ Sig. } \\
\hline kWh_D10 &, 141 & 16 &, 200 &, 903 & 16 &, 090 \\
\hline T_med &, 150 & 16 &, 200 &, 942 & 16 &, 376 \\
\hline
\end{tabular}

- Independencia de los errores. Los errores asociados a los valores de la variable respuesta $(Y)$ deberán ser independientes unos de otros.

Para la comprobación se utiliza el estadístico de Durbin -Watson.

Se comprueba que el Estadístico de Durbin Watson para el nivel de significancia del 5\%, y para el tamaño de la muestra " $n$ " y el número de variables independientes del modelo " $k$ ", se encuentra en el intervalo [dU, 4-dU], de la Tabla 3, intervalo centrado en el 2, que indica la ausencia de autocorrelación.

El valor del Estadístico Durbin-Watson facilitado por el programa SPSS, es 1,510.

En el modelo, $\mathrm{n}=16$ y $\mathrm{k}=1$, según la Tabla 3 el valor $\mathrm{dU}=1,371$ y $\mathrm{dL}=1,106$, luego el intervalo que marca la ausencia de correlación es [1,371, 2,629], como el valor del estadístico está dentro de ese intervalo se acepta la ausencia de correlación.

- Homocedasticidad de la varianza. Se pretende comprobar que la varianza de los errores $\left(\sigma^{2}\right)$ es constante para cualquier valor de la variable independiente $(X)$, es decir que el valor medio del cuadrado de la desviación de los errores respecto a su media es constante.

Esta condición indica que no existe correlación entre los residuos y los pronósticos. Se comprueba que el coeficiente de determinación $\mathrm{R}^{2}$, en las relaciones: residuos $\mathrm{y}$ predicciones y entre residuos y variable independiente es nulo o muy próximo a cero, lo que indicará que no existe ningún tipo de correlación en los residuos y que éstos son aleatorios.

Se grafican los diagramas de dispersión de esas relaciones, comprobando que se corresponden a nubes de puntos totalmente aleatorias, sin tendencias ni patrones en sus representaciones gráficas. 
Las Figura 267 y Figura 268, muestran que la relación entre los pronósticos y los residuos, posee un coeficiente de determinación $=0 \mathrm{y}$ entre la variable independiente (Temperatura media) y los residuos un coeficiente de determinación de $1,11 \times 10^{-16}$, se concluye que no existe ningún tipo de correlación en los residuos y que éstos son aleatorios, siendo la varianza de los residuos constante

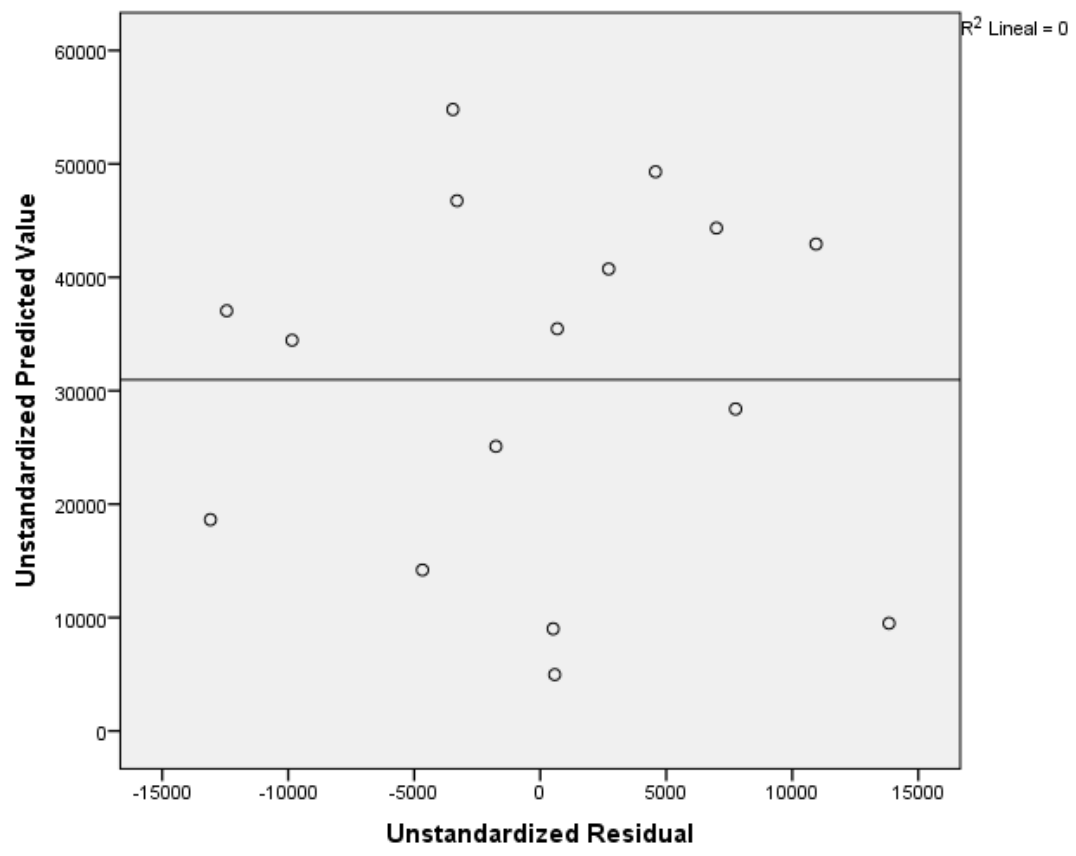

Figura 267. Relación entre los pronósticos y los residuos en el Edificio D10

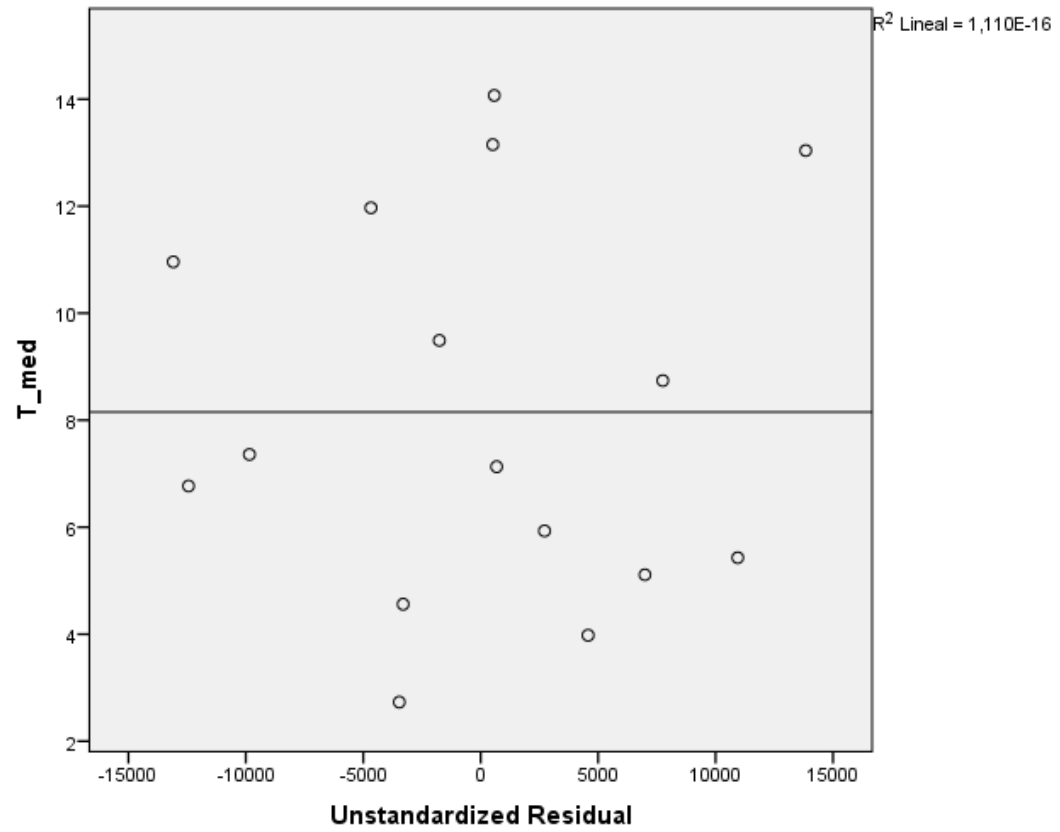

Figura 268. Relación entre Temperatura media y los residuos en el Edificio D10 


\section{AIV.10.3.Obtención de los consumos térmicos previstos}

Una vez comprobado el cumplimiento de los supuestos estadísticos se acepta el modelo de línea base encontrado para modelizar el consumo del Edificio D10.

$$
\text { kWh_D10_Pronosticado }=66791,063-4393,782 \times \text { T_med }
$$

Con este modelo se procede a predecir los consumos previstos para las temporadas: octubre 2015-mayo 2016, octubre 2016 - mayo 2017 y octubre 2017-mayo 2018, estos consumos se muestran en la Tabla 347, donde "KWh_D10_Real", representa el consumo real, "kWh_D10_Pronosticado", el consumo pronosticado con el Modelo. Se prescinde del valor pronosticado para mayo de 2017, por ser un valor imposible, en el estudio de diferencias significativas

Tabla 347. Consumos previstos octubre 2014 - mayo 2017 para el edificio D10.

\begin{tabular}{rrrr}
\hline & T_med & kWh_D10_Real & kWh_D10_Pronosticado \\
\hline oct-15 & 12,82 & 4.183 & 10.468 \\
\hline nov-15 & 8,30 & 26.851 & 30.312 \\
\hline dic-15 & 5,33 & 32.026 & 43.378 \\
\hline ene-16 & 6,23 & 33.481 & 39.402 \\
\hline feb-16 & 5,82 & 54.047 & 41.236 \\
\hline mar-16 & 6,14 & 39.987 & 39.800 \\
\hline abr-16 & 9,10 & 29.457 & 26.805 \\
\hline may-16 & 13,11 & 6.620 & 9.170 \\
\hline oct-16 & 13,48 & 6.261 & 7.561 \\
\hline nov-16 & 6,90 & 30.783 & 36.467 \\
\hline dic-16 & 4,12 & 42.246 & 48.680 \\
\hline ene-17 & 2,52 & 51.733 & 55.736 \\
\hline feb-17 & 6,96 & 35.287 & 36.212 \\
\hline mar-17 & 9,21 & 30.375 & 26.327 \\
\hline abr-17 & 12,58 & 12.121 & 11.530 \\
\hline may-17 & 16,69 & 4.111 & -6.527 \\
\hline oct-17 & 14,71 & 3.499 & 2.153 \\
\hline nov-17 & 6,09 & 27.035 & 40.031 \\
\hline dic-17 & 3,99 & 41.851 & 49.254 \\
\hline ene-18 & 4,42 & 43.756 & 47.368 \\
\hline feb-18 & 3,53 & 44.761 & 51.287 \\
\hline mar-18 & 6,80 & 38.923 & 36.902 \\
\hline abr-18 & 11,15 & 23.478 & 17.817 \\
\hline may-18 & 14,03 & 6.241 & 5.156 \\
\hline & & &
\end{tabular}




\section{AIV.10.4.Estudio de la existencia de diferencias significativas}

Utilizando la prueba " $\mathrm{t}$ " de Student para muestras relacionadas, podemos concluir que si las variables se distribuyen según una normal y la significación estadística resulta $\leq 0,05$, existen diferencias significativas, con un nivel de confianza del $95 \%$

A continuación se muestra la comparación de medias realizada para cada uno de los tres periodos posteriores a la construcción de la red y para el periodo total hasta mayo de 2018.

Para la temporada Octubre 2015 - Mayo 2016, se comprueba mediante el Test de Shapiro -Wilk que tanto los valores reales como los pronosticados se distribuyen según una Normal puesto que en todos los casos los valores de Sig $>0,05$, como se observa en la Tabla 348

Tabla 348. Prueba de Normalidad temporada Octubre 2015-Mayo 2016. Edificio D10

\begin{tabular}{crrrrrrr}
\hline & \multicolumn{3}{c}{ Kolmogorov-Smirnov $^{\text {a }}$} & \multicolumn{3}{c}{ Shapiro-Wilk } \\
\cline { 2 - 8 } & Estadístico & gl & Sig. & Estadístico & gl & \multicolumn{1}{c}{ Sig. } \\
\hline kWh_real &, 214 & 8 &, 200 &, 932 & 8 &, 535 \\
\hline kWh_pronosticado &, 252 & 8 &, 144 &, 839 & 8 &, 073 \\
\hline
\end{tabular}

En la Tabla 349, se observa como las medias de los consumos pronosticados, son superiores a las medias de los consumos reales del Edificio D10, en un 6,1\%

Tabla 349. Estadísticos de muestras relacionadas. Octubre 2015-Mayo 2016. Edificio D10

\begin{tabular}{lccccc}
\hline & Media & $\begin{array}{c}\text { \% Diferencia } \\
\text { entre medias }\end{array}$ & $\mathrm{N}$ & $\begin{array}{c}\text { Desviación } \\
\text { típ. }\end{array}$ & $\begin{array}{c}\text { Error típ. de } \\
\text { la media }\end{array}$ \\
\hline kWh_real & 28331,5000 & & 8 & 16454,70934 & 5817,61828 \\
\hline kWh_pronosticado & 30071,3750 & $6,1 \%$ & 8 & 13707,70754 & 4846,40648 \\
\hline
\end{tabular}

La Tabla 350 muestra que las diferencias entre las medias no son significativas entre los consumos reales y los pronosticados ( $\operatorname{sig}>0,05$ ), a pesar de existir ese $6,1 \%$ de diferencia

Tabla 350. Prueba de muestras relacionadas. Octubre 2015-Mayo 2016. Edificio D10

\begin{tabular}{|c|c|c|c|c|c|c|c|c|c|}
\hline & & \multicolumn{5}{|c|}{ Diferencias relacionadas } & \multirow{3}{*}{$\mathrm{t}$} & \multirow{3}{*}{ gl } & \multirow{3}{*}{$\begin{array}{c}\text { Sig. } \\
\text { (bilateral) }\end{array}$} \\
\hline & & \multirow[t]{2}{*}{ Media } & \multirow{2}{*}{$\begin{array}{l}\text { Desviación } \\
\text { típ. }\end{array}$} & \multirow{2}{*}{$\begin{array}{c}\text { Error típ. } \\
\text { de la media }\end{array}$} & \multicolumn{2}{|c|}{$\begin{array}{l}\text { 95\% Intervalo de confianza } \\
\text { para la diferencia }\end{array}$} & & & \\
\hline & & & & & Inferior & Superior & & & \\
\hline Par 1 & $\begin{array}{c}\text { kWh_real - } \\
\text { kWh_pronosticado }\end{array}$ & $-1739,875$ & 7259,288 & 2566,546 & $-7808,792$ & 4329,042 &,- 678 & 7 & ,520 \\
\hline
\end{tabular}


En la Figura 269, se grafican los consumos reales y pronosticados para la temporada Octubre 2015 - Mayo 2016 para el Edificio D10, y las medias de dichos consumos. Según la prueba paramétrica realizada las diferencias encontradas no son estadísticamente significativas, por lo que no se puede afirmar la existencia de ahorros en el consumo térmico entre la situación anterior y posterior a la red de calor, con un riesgo a estar equivocados del $5 \%$

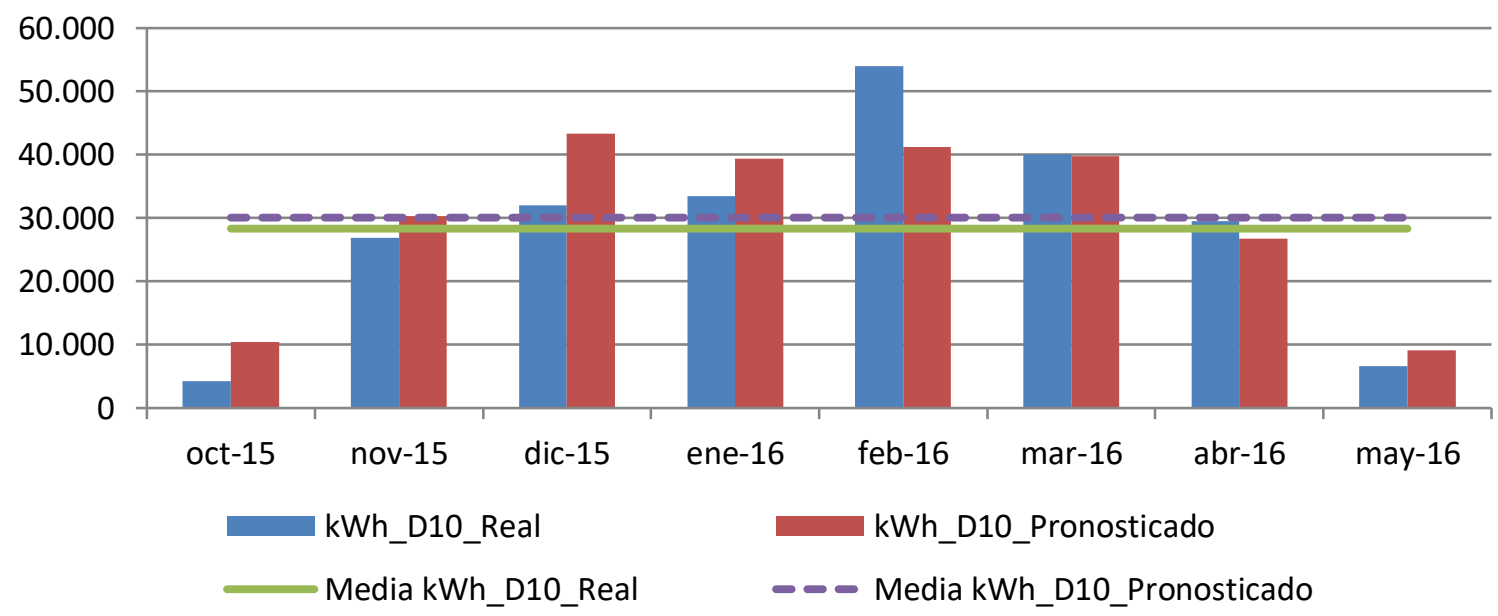

Figura 269. Consumos reales y pronosticados Octubre 2015-Mayo 2016. Edificio D10

Para la temporada Octubre 2016 - Abril 2017, se comprueba mediante el Test de Shapiro -Wilk que tanto los valores reales como los pronosticados con los dos modelos se distribuyen según una Normal puesto que en todos los casos los valores de Sig >0,05, como se observa en la Tabla 351. El número de datos disponibles son 7, dado que el pronóstico para mayo de 2017 , resultó un dato negativo.

Tabla 351. Prueba de Normalidad temporada Octubre 2016-Abril 2017. Edificio D10

\begin{tabular}{cccccrrr}
\hline & \multicolumn{3}{c}{ Kolmogorov-Smirnov $^{\mathrm{a}}$} & \multicolumn{4}{c}{ Shapiro-Wilk } \\
\cline { 2 - 8 } & Estadístico & gl & Sig. & Estadístico & gl & Sig. \\
\hline kWh_real &, 228 & 7 &, 200 &, 949 & 7 &, 721 \\
\hline kWh_pronosticado &, 169 & 7 &, 200 &, 946 & 7 &, 695 \\
\hline
\end{tabular}

En la Tabla 352, se observa como las medias de los consumos pronosticados, son superiores a las medias de los consumos reales del Edificio D10, en un 6,6\%

Tabla 352. Estadísticos de muestras relacionadas. Octubre 2016-Abril 2017. Edificio D10

\begin{tabular}{|c|c|c|c|c|c|}
\hline & Media & $\begin{array}{l}\% \text { Diferencia } \\
\text { entre medias }\end{array}$ & $\mathrm{N}$ & $\begin{array}{c}\text { Desviación } \\
\text { típ. }\end{array}$ & $\begin{array}{l}\text { Error típ. de la } \\
\text { media }\end{array}$ \\
\hline kWh_real & 29829,4286 & & 7 & 15989,52255 & 6043,47146 \\
\hline kWh_pronosticado & 31787,5714 & $6,6 \%$ & 7 & 17923,29861 & 6774,37011 \\
\hline
\end{tabular}


La Tabla 353 muestra que las diferencias entre las medias no son significativas entre los consumos reales y los pronosticados (sig $>0,05$ ), a pesar de existir ese $6,6 \%$ de diferencia

Tabla 353. Prueba de muestras relacionadas. Octubre 2016-Abril 2017. Edificio D10

\begin{tabular}{|c|c|c|c|c|c|c|c|c|c|}
\hline & & \multicolumn{5}{|c|}{ Diferencias relacionadas } & \multirow{3}{*}{$\mathrm{t}$} & \multirow{3}{*}{$\mathrm{gl}$} & \multirow{3}{*}{$\begin{array}{c}\text { Sig. } \\
\text { (bilateral) }\end{array}$} \\
\hline & & \multirow[t]{2}{*}{ Media } & \multirow{2}{*}{$\begin{array}{l}\text { Desviación } \\
\text { típ. }\end{array}$} & \multirow{2}{*}{$\begin{array}{c}\text { Error típ. } \\
\text { de la media }\end{array}$} & \multicolumn{2}{|c|}{$\begin{array}{l}\text { 95\% Intervalo de confianza } \\
\text { para la diferencia }\end{array}$} & & & \\
\hline & & & & & Inferior & Superior & & & \\
\hline Par 1 & $\begin{array}{c}\text { kWh_real - } \\
\text { kWh_pronosticado }\end{array}$ & $-1958,143$ & 3700,657 & 1398,717 & $-5380,680$ & 1464,394 & $-1,400$ & 6 & 211 \\
\hline
\end{tabular}

En la Figura 270, se grafican los consumos reales y pronosticados para la temporada Octubre 2016 - Abril 2017 para el Edificio D10, y las medias de dichos consumos. Según la prueba paramétrica realizada las diferencias encontradas no son estadísticamente significativas, con un riesgo a estar equivocados del $5 \%$

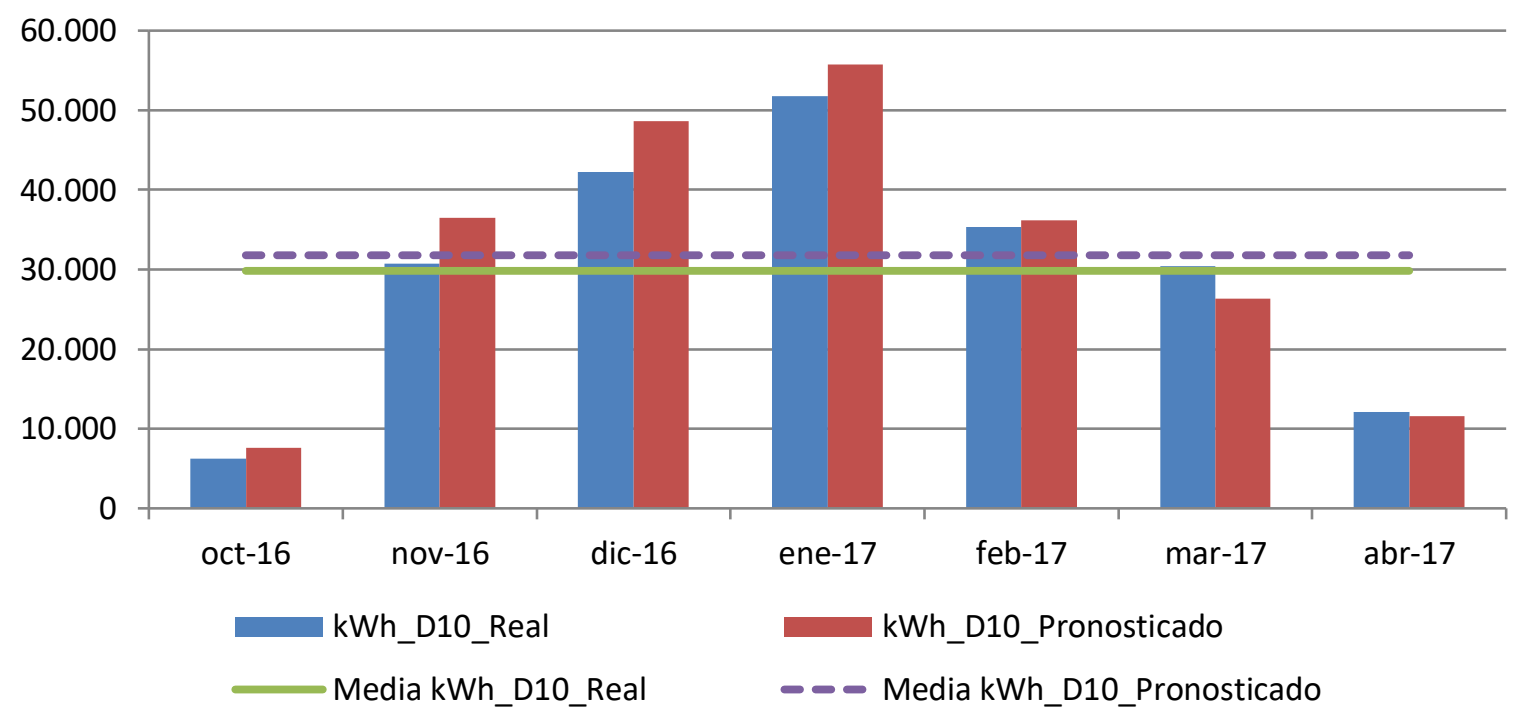

Figura 270. Consumos reales y pronosticados Octubre 2016-Abril 2017. Edificio D10

Para la temporada Octubre 2017 - Mayo 2018, se comprueba mediante el Test de Shapiro -Wilk que tanto los valores reales como los pronosticados se distribuyen según una Normal puesto que en todos los casos los valores de Sig >0,05, como se observa en la Tabla 354

Tabla 354. Prueba de Normalidad temporada Octubre 2017-Mayo 2018. Edificio D10

\begin{tabular}{|c|c|c|c|c|c|c|}
\hline & \multicolumn{3}{|c|}{ Kolmogorov-Smirnov ${ }^{a}$} & \multicolumn{3}{|c|}{ Shapiro-Wilk } \\
\hline & Estadístico & gl & Sig. & Estadístico & gl & Sig. \\
\hline kWh_real & ,231 & 8 & ,200 & ,858 & 8 & ,116 \\
\hline kWh_pronosticado & ,236 & 8 & 200 & ,858 & 8 & 114 \\
\hline
\end{tabular}


En la Tabla 355, se observa como las medias de los consumos pronosticados, son superiores a las medias de los consumos reales del Edificio D10, en un 8,9\%

Tabla 355. Estadísticos de muestras relacionadas. Octubre 2017-Mayo 2018. Edificio D10

\begin{tabular}{lccccc}
\hline & Media & $\begin{array}{c}\text { \% Diferencia } \\
\text { entre medias }\end{array}$ & N & $\begin{array}{c}\text { Desviación } \\
\text { típ. }\end{array}$ & $\begin{array}{c}\text { Error típ. de } \\
\text { la media }\end{array}$ \\
\hline kWh_real & 28693,0000 & & 8 & 16611,68086 & 5873,11609 \\
\hline kWh_pronosticado & 31246,0000 & $8,9 \%$ & 8 & 20008,72660 & 7074,15313 \\
\hline
\end{tabular}

La Tabla 356 muestra que las diferencias entre las medias no son significativas entre los consumos reales y los pronosticados (sig $>0,05$ ), a pesar de existir ese $8,9 \%$ de diferencia

Tabla 356. Prueba de muestras relacionadas. Octubre 2017-Mayo 2018. Edificio D10

\begin{tabular}{|c|c|c|c|c|c|c|c|c|c|}
\hline & & \multicolumn{5}{|c|}{ Diferencias relacionadas } & \multirow{3}{*}{$\mathrm{t}$} & \multirow{3}{*}{ gl } & \multirow{3}{*}{$\begin{array}{c}\text { Sig. } \\
\text { (bilateral) }\end{array}$} \\
\hline & & \multirow[t]{2}{*}{ Media } & \multirow{2}{*}{$\begin{array}{l}\text { Desviación } \\
\text { típ. }\end{array}$} & \multirow{2}{*}{$\begin{array}{l}\text { Error típ. } \\
\text { de la media }\end{array}$} & \multicolumn{2}{|c|}{$\begin{array}{c}\text { 95\% Intervalo de confianza } \\
\text { para la diferencia }\end{array}$} & & & \\
\hline & & & & & Inferior & Superior & & & \\
\hline Par 1 & $\begin{array}{c}\text { kWh_real - } \\
\text { kWh_pronosticado }\end{array}$ & $-2553,000$ & 6168,045 & 2180,733 & $-7709,615$ & 2603,615 & $-1,171$ & 7 & 280 \\
\hline
\end{tabular}

En la Figura 271 se grafican los consumos reales y pronosticados para la temporada Octubre 2017 - Mayo 2018 para el Edificio D10, y las medias de dichos consumos. Según la prueba paramétrica realizada las diferencias encontradas no son estadísticamente significativas, con un riesgo a estar equivocados del $5 \%$

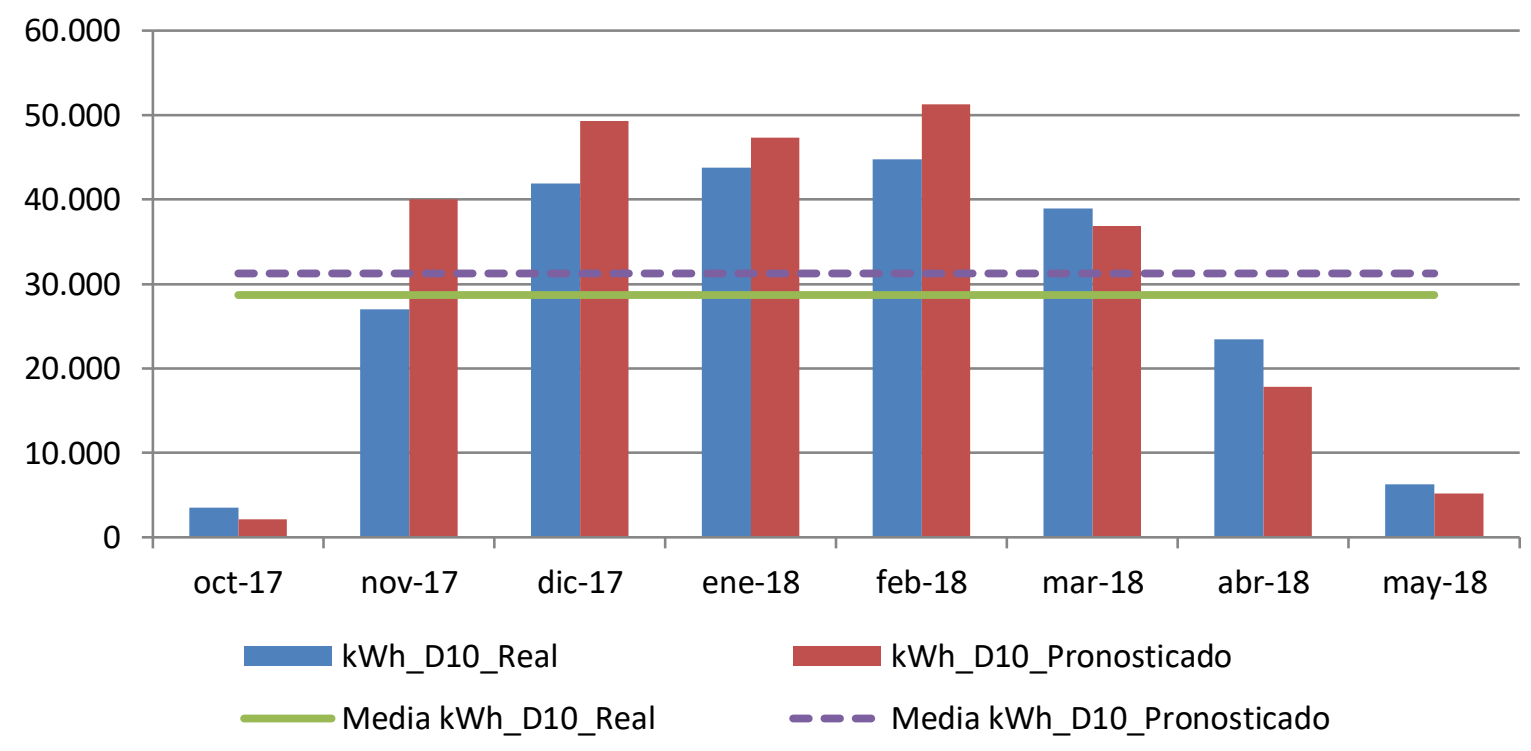

Figura 271. Consumos reales y pronosticados Octubre 2017-Mayo 2018. Edificio D10 
Para el total de las tres temporadas Octubre 2015 - Mayo 2018, se comprueba mediante el Test de Shapiro -Wilk, que los valores reales y los pronosticados se distribuyen según una Normal puesto que en esos casos los valores de Sig $>0,05$, como se observa en la Tabla 357

Tabla 357. Prueba de Normalidad temporada Octubre 2015-Mayo 2018. Edificio D10

\begin{tabular}{ccccccrr}
\hline & \multicolumn{3}{c}{ Kolmogorov-Smirnov $^{\mathrm{a}}$} & \multicolumn{3}{c}{ Shapiro-Wilk } \\
\cline { 2 - 8 } & Estadístico & gl & Sig. & Estadístico & gl & \multicolumn{1}{c}{ Sig. } \\
\hline kWh_real &, 143 & 23 &, 200 &, 923 & 23 &, 077 \\
\hline kWh_pronosticado &, 188 & 23 &, 033 &, 920 & 23 &, 065 \\
\hline
\end{tabular}

En la Tabla 358 se observa como las medias de los consumos pronosticados, son superiores a las medias de los consumos reales del Edificio D10, en un 7,2\%

Tabla 358. Estadísticos de muestras relacionadas. Octubre 2015-Mayo 2018. Edificio D10

\begin{tabular}{lccccc}
\hline & Media & $\begin{array}{c}\text { \% Diferencia } \\
\text { entre medias }\end{array}$ & $\mathrm{N}$ & $\begin{array}{c}\text { Desviación } \\
\text { típ. }\end{array}$ & $\begin{array}{c}\text { Error típ. de } \\
\text { la media }\end{array}$ \\
\hline $\mathrm{kWh}$ _real & 28913,0848 & & 23 & 15623,20752 & 3257,66396 \\
\hline $\mathrm{kWh}$ _pronosticado & 31002,3509 & $7,2 \%$ & 23 & 16592,58321 & 3459,79277 \\
\hline
\end{tabular}

La Tabla 359 muestra que las diferencias entre las medias no son significativas entre los consumos reales y los pronosticados (sig $>0,05$ ).

Tabla 359. Prueba de muestras relacionadas. Octubre 2015-Mayo 2018. Edificio D10

\begin{tabular}{|c|c|c|c|c|c|c|c|c|}
\hline & \multicolumn{5}{|c|}{ Diferencias relacionadas } & \multirow{3}{*}{$\mathrm{t}$} & \multirow{3}{*}{ gl } & \multirow{3}{*}{$\begin{array}{c}\text { Sig. } \\
\text { (bilateral) }\end{array}$} \\
\hline & \multirow[t]{2}{*}{ Media } & \multirow{2}{*}{$\begin{array}{l}\text { Desviación } \\
\text { típ. }\end{array}$} & \multirow{2}{*}{$\begin{array}{l}\text { Error típ. de } \\
\text { la media }\end{array}$} & \multicolumn{2}{|c|}{$\begin{array}{l}\text { 95\% Intervalo de confianza } \\
\text { para la diferencia }\end{array}$} & & & \\
\hline & & & & Inferior & Superior & & & \\
\hline $\begin{array}{c}\text { kWh_real - } \\
\text { kWh pronosticado }\end{array}$ & $-2089,266$ & 5721,506 & 1193,016 & $-4563,431$ & 384,898 & $-1,751$ & 22 & ,094 \\
\hline
\end{tabular}




\section{AIV.10.5.Estimación de las emisiones de $\mathrm{CO} 2$ evitadas.}

Teniendo en cuenta que el consumir Gas natural se producen 0,252 $\mathrm{kg} \mathrm{CO}_{2} / \mathrm{kWh} \mathrm{E}$. final y que al consumir la energía suministrada por red a partir de Biomasa se producen 0,024 $\mathrm{kg}$ $\mathrm{CO}_{2} / \mathrm{kWh}$. final, en la Tabla 360, se muestra las emisiones de $\mathrm{CO}_{2}$ reales para las temporadas octubre 2015 - mayo 2018 y utilizando el Modelo de regresión, las emisiones de $\mathrm{CO}_{2}$ que se hubieran tenido de haber seguido utilizando las calderas de gas natural originales sin el apoyo de la red de calor. Al no haberse obtenido diferencias significativas entre el consumo real y el pronosticado, éste último se ha igualado al consumo real.

Tabla 360. Estimación del ahorro de emisiones de CO2 para el Edificio D10.

\begin{tabular}{|c|c|c|c|c|c|c|c|c|c|c|}
\hline & $\begin{array}{c}\text { kWh_D10 } \\
\text { Gas } \\
\text { Natural }\end{array}$ & $\begin{array}{c}\text { kWh_D10 } \\
\text { Biomasa }\end{array}$ & $\begin{array}{l}\text { kWh_D10 } \\
\text { Real Total }\end{array}$ & $\begin{array}{l}\text { kWh_D10 } \\
\text { Predicho }\end{array}$ & $\begin{array}{l}\text { kg CO2 } \\
\text { Real } \\
\text { debido al } \\
\text { consumo } \\
\text { de Gas } \\
\text { Natural }\end{array}$ & $\begin{array}{c}\text { kg CO2 } \\
\text { Real } \\
\text { debido a } \\
\text { Biomasa }\end{array}$ & $\begin{array}{l}\text { kg CO2 } \\
\text { Real } \\
\text { debido al } \\
\text { consumo } \\
\text { TOTAL }\end{array}$ & $\begin{array}{c}\text { kg CO2 } \\
\text { que se } \\
\text { hubiera } \\
\text { tenido } \\
\text { debido a } \\
\text { Gas } \\
\text { Natural }\end{array}$ & $\begin{array}{c}\text { Ahorro } \\
\text { de kg } \\
\mathrm{CO} 2\end{array}$ & $\begin{array}{l}\text { Ahorro de kg } \\
\text { CO2 } \\
\text { acumulado }\end{array}$ \\
\hline oct-2015 & 0 & 4.183 & 4.183 & 4.183 & 0 & 100 & 100 & 1.054 & 954 & 954 \\
\hline nov-2015 & 0 & 26.851 & 26.851 & 26.851 & 0 & 644 & 644 & 6.766 & 6.122 & 7.076 \\
\hline dic-2015 & 0 & 32.026 & 32.026 & 32.026 & 0 & 769 & 769 & 8.071 & 7.302 & 14.378 \\
\hline ene-2016 & 0 & 33.481 & 33.481 & 33.481 & 0 & 804 & 804 & 8.437 & 7.634 & 22.011 \\
\hline feb-2016 & 13.866 & 40.181 & 54.047 & 54.047 & 3.494 & 964 & 4.458 & 13.620 & 9.161 & 31.173 \\
\hline mar-2016 & 520 & 39.467 & 39.987 & 39.987 & 131 & 947 & 1.078 & 10.077 & 8.998 & 40.171 \\
\hline abr-2016 & 114 & 29.343 & 29.457 & 29.457 & 29 & 704 & 733 & 7.423 & 6.690 & 46.861 \\
\hline may-2016 & 0 & 6.620 & 6.620 & 6.620 & 0 & 159 & 159 & 1.668 & 1.509 & 48.371 \\
\hline oct-2016 & 864 & 5.397 & 6.261 & 6.261 & 218 & 130 & 347 & 1.578 & 1.231 & 49.601 \\
\hline nov-2016 & 288 & 30.495 & 30.783 & 30.783 & 73 & 732 & 804 & 7.757 & 6.953 & 56.554 \\
\hline dic-2016 & 16 & 42.230 & 42.246 & 42.246 & 4 & 1.014 & 1.018 & 10.646 & 9.628 & 66.182 \\
\hline ene-2017 & 8 & 51.725 & 51.733 & 51.733 & 2 & 1.241 & 1.243 & 13.037 & 11.793 & 77.976 \\
\hline feb-2017 & 8 & 35.279 & 35.287 & 35.287 & 2 & 847 & 849 & 8.892 & 8.044 & 86.019 \\
\hline mar-2017 & 344 & 30.031 & 30.375 & 30.375 & 87 & 721 & 807 & 7.655 & 6.847 & 92.866 \\
\hline$a b r-2017$ & 0 & 12.121 & 12.121 & 12.121 & 0 & 291 & 291 & 3.054 & 2.764 & 95.630 \\
\hline may-2017 & 32 & 4.079 & 4.111 & 4.111 & 8 & 98 & 106 & 1.036 & 930 & 96.560 \\
\hline oct-2017 & 0 & 3.499 & 3.499 & 3.499 & 0 & 84 & 84 & 882 & 798 & 97.358 \\
\hline nov-2017 & 0 & 27.035 & 27.035 & 27.035 & 0 & 649 & 649 & 6.813 & 6.164 & 103.522 \\
\hline dic-2017 & 24 & 41.827 & 41.851 & 41.851 & 6 & 1.004 & 1.010 & 10.546 & 9.537 & 113.058 \\
\hline ene-2018 & 96 & 43.660 & 43.756 & 43.756 & 24 & 1.048 & 1.072 & 11.027 & 9.954 & 123.013 \\
\hline feb-2018 & 40 & 44.721 & 44.761 & 44.761 & 10 & 1.073 & 1.083 & 11.280 & 10.196 & 133.209 \\
\hline mar-2018 & 272 & 38.651 & 38.923 & 38.923 & 69 & 928 & 996 & 9.809 & 8.812 & 142.022 \\
\hline abr-2018 & 136 & 23.342 & 23.478 & 23.478 & 34 & 560 & 594 & 5.916 & 5.322 & 147.344 \\
\hline may-2018 & 0 & 6.241 & 6.241 & 6.241 & 0 & 150 & 150 & 1.573 & 1.423 & 148.767 \\
\hline
\end{tabular}

Como se observa durante estas tres temporadas se ha obtenido un ahorro total de 149 Toneladas de $\mathrm{CO}_{2}$, debido al cambio de combustible de gas natural por biomasa en el edificio D10. 


\section{AIV.10.6.Estimación del precio máximo de compra a la red.}

Tomando como referencia los precios del gas natural de la Tabla 361 para cada temporada, obtenidos a partir de los datos establecidos en el Capítulo 3, donde se tiene en cuenta el precio por el termino variable y fijo; se puede realizar la estimación del precio máximo de compra de la energía útil a la red de calor para obtener un $0 \%$ de ahorro y un 15\% de ahorro. La Tabla 362, muestral el precio que se pagaría para un ahorro del 15\%

Tabla 361. Precios de referencia para Gas natural y Astilla

\begin{tabular}{ccccc}
\hline Precios ( $€ /(\mathrm{kWh})$ & 2015 & 2016 & 2017 & 2018 \\
\hline Gas Natural & 0,0373 & 0,0306 & 0,0314 & 0,0336 \\
\hline Astilla & 0,0277 & 0,0256 & 0,0254 & 0,0239 \\
\hline $\begin{array}{c}€ / \text { kWh útiles máximos de compra a la red para } \\
\text { un ahorro del } 0,0 \%\end{array}$ & 0,03223 & \\
\hline $\begin{array}{c}€ / \text { kWh útiles máximos de compra a la red para } \\
\text { un ahorro del } 15,0 \%\end{array}$ & 0,02728 & \\
\hline
\end{tabular}

Tabla 362. Ahorro Económico por el consumo térmico en el Edificio D10

\begin{tabular}{|c|c|c|c|c|c|c|c|c|c|c|}
\hline & $\begin{array}{c}\text { kWh_D10 } \\
\text { _Gas } \\
\text { Natural }\end{array}$ & $\begin{array}{c}\text { kWh_D10_ } \\
\text { Biomasa }\end{array}$ & $\begin{array}{c}\text { kWh_D10 } \\
\text { Real }\end{array}$ & $\begin{array}{c}\text { kWh_D10 } \\
\text { Pronosticado }\end{array}$ & $\begin{array}{c}\text { € Real } \\
\text { Gas } \\
\text { Natural }\end{array}$ & $\begin{array}{c}€ \text { Real } \\
\text { Biomasa }\end{array}$ & $\begin{array}{l}€ \text { Real } \\
\text { Total }\end{array}$ & $\begin{array}{c}\text { Epredicho } \\
\text { Gas } \\
\text { natural }\end{array}$ & $\begin{array}{c}€ \\
\text { Ahorro }\end{array}$ & $€$ Acumulado \\
\hline oct-2015 & 0 & 4.183 & 4.183 & 4.183 & 0 & 114 & 114 & 156 & 42 & 42 \\
\hline nov-2015 & 0 & 26.851 & 26.851 & 26.851 & 0 & 732 & 732 & 1.002 & 269 & 311 \\
\hline dic-2015 & 0 & 32.026 & 32.026 & 32.026 & 0 & 874 & 874 & 1.195 & 321 & 632 \\
\hline ene-2016 & 0 & 33.481 & 33.481 & 33.481 & 0 & 913 & 913 & 1.025 & 111 & 743 \\
\hline feb-2016 & 13.866 & 40.181 & 54.047 & 54.047 & 424 & 1.096 & 1.520 & 1.654 & 133 & 876 \\
\hline mar-2016 & 520 & 39.467 & 39.987 & 39.987 & 16 & 1.077 & 1.093 & 1.224 & 131 & 1.007 \\
\hline abr-2016 & 114 & 29.343 & 29.457 & 29.457 & 3 & 800 & 804 & 901 & 97 & 1.105 \\
\hline may-2016 & 0 & 6.620 & 6.620 & 6.620 & 0 & 181 & 181 & 203 & 22 & 1.127 \\
\hline oct-2016 & 864 & 5.397 & 6.261 & 6.261 & 26 & 147 & 174 & 192 & 18 & 1.145 \\
\hline nov-2016 & 288 & 30.495 & 30.783 & 30.783 & 9 & 832 & 841 & 942 & 101 & 1.246 \\
\hline dic-2016 & 16 & 42.230 & 42.246 & 42.246 & 0 & 1.152 & 1.153 & 1.293 & 140 & 1.386 \\
\hline ene-2017 & 8 & 51.725 & 51.733 & 51.733 & 0 & 1.411 & 1.411 & 1.624 & 213 & 1.599 \\
\hline feb-2017 & 8 & 35.279 & 35.287 & 35.287 & 0 & 962 & 963 & 1.108 & 145 & 1.745 \\
\hline mar-2017 & 344 & 30.031 & 30.375 & 30.375 & 11 & 819 & 830 & 954 & 124 & 1.868 \\
\hline$a b r-2017$ & 0 & 12.121 & 12.121 & 12.121 & 0 & 331 & 331 & 381 & 50 & 1.918 \\
\hline may-2017 & 32 & 4.079 & 4.111 & 4.111 & 1 & 111 & 112 & 129 & 17 & 1.935 \\
\hline oct-2017 & 0 & 3.499 & 3.499 & 3.499 & 0 & 95 & 95 & 110 & 14 & 1.950 \\
\hline nov-2017 & 0 & 27.035 & 27.035 & 27.035 & 0 & 738 & 738 & 849 & 111 & 2.061 \\
\hline dic-2017 & 24 & 41.827 & 41.851 & 41.851 & 1 & 1.141 & 1.142 & 1.314 & 172 & 2.233 \\
\hline ene-2018 & 96 & 43.660 & 43.756 & 43.756 & 3 & 1.191 & 1.194 & 1.470 & 276 & 2.509 \\
\hline feb-2018 & 40 & 44.721 & 44.761 & 44.761 & 1 & 1.220 & 1.221 & 1.504 & 283 & 2.792 \\
\hline mar-2018 & 272 & 38.651 & 38.923 & 38.923 & 9 & 1.054 & 1.064 & 1.308 & 244 & 3.036 \\
\hline$a b r-2018$ & 136 & 23.342 & 23.478 & 23.478 & 5 & 637 & 641 & 789 & 148 & 3.184 \\
\hline may-2018 & 0 & 6.241 & 6.241 & 6.241 & 0 & 170 & 170 & 210 & 39 & 3.223 \\
\hline$€$ Total & & & & & & & 18.311 & 21.534 & & \\
\hline Ahorro (\%) & & & & & & & & & & $15,0 \%$ \\
\hline
\end{tabular}




\section{AIV.11.Edificio D11. Facultad de Educación y Trabajo Social.}

\section{AIV.11.1.Obtención de la línea base de referencia energética}

Utilizando el programa SPSS V.20, se obtiene el modelo de regresión mediante el método de pasos sucesivos. Como se puede ver en la Tabla 363 para el edificio D11, el método ofrece dos modelos de regresión, uno con una sola variable (Temperatura media) y otro con dos variables (Temperatura media y Grados día Base 15).

El primer modelo (modelo de regresión lineal simple) fue construido con un solo paso, incluyendo la Temperatura media por ser la variable más significativa (variable con menor valor de Sig $=0,000$ ) que indica la probabilidad de cometer un error al rechazar que la pendiente de la variable "Temperatura media" es igual a cero, por lo que se acepta que esa variable forma parte del modelo con una pendiente $(B=-12648,948)$.

El segundo modelo (modelo de regresión lineal múltiple) se construyó en dos pasos, primero entró la Temperatura media y luego entró la siguiente variable que rechazase la Hipótesis nula, (las variables que rechazan la hipótesis nula son las que presentan una pendiente estadísticamente significativa y su probabilidad de cometer el error de rechazar Ho es $\leq 0,05$, para un nivel de confianza del $95 \%$ ), esta variable fue los "Grados Día en Base 15 ", por presentar un valor de Sig $=0,032$, el resto de las variables como se observa en la Tabla 364 fueron excluidas del modelo al tener valores de sig > 0,05.

Tabla 363. Modelos de regresión del Edificio D11

\begin{tabular}{|c|c|c|c|c|c|c|c|}
\hline & \multirow{2}{*}{ Modelo } & \multicolumn{2}{|c|}{$\begin{array}{l}\text { Coeficientes no } \\
\text { estandarizados }\end{array}$} & \multirow{2}{*}{$\mathrm{t}$} & \multirow{2}{*}{ Sig. } & \multicolumn{2}{|c|}{$\begin{array}{c}\text { Intervalo de confianza de } \\
95,0 \% \text { para B }\end{array}$} \\
\hline & & B & Error típ. & & & $\begin{array}{l}\text { Límite } \\
\text { inferior }\end{array}$ & $\begin{array}{l}\text { Límite } \\
\text { superior }\end{array}$ \\
\hline \multirow[t]{2}{*}{1} & (Constante) & 187840,052 & 14671,521 & 12,803 & , 000 & 156372,768 & 219307,335 \\
\hline & T_med & $-12648,948$ & 1655,616 & $-7,640$ &, 000 & $-16199,891$ & $-9098,006$ \\
\hline \multirow[t]{3}{*}{2} & (Constante) & 630672,573 & 185019,502 & 3,409 & ,005 & 230962,239 & 1030382,907 \\
\hline & T_med & $-38572,601$ & 10899,956 & $-3,539$ & ,004 & $-62120,524$ & $-15024,679$ \\
\hline & GD15_30min & $-1044,773$ & 435,490 & $-2,399$ & ,032 & $-1985,592$ & $-103,954$ \\
\hline
\end{tabular}

En la Figura 272 se representa el modelo 1 de regresión con sus límites inferior y superior para un nivel de confianza del $95 \%$ 
Anexo IV. Desarrollo del análisis de los edificios del Campus Miguel Delibes

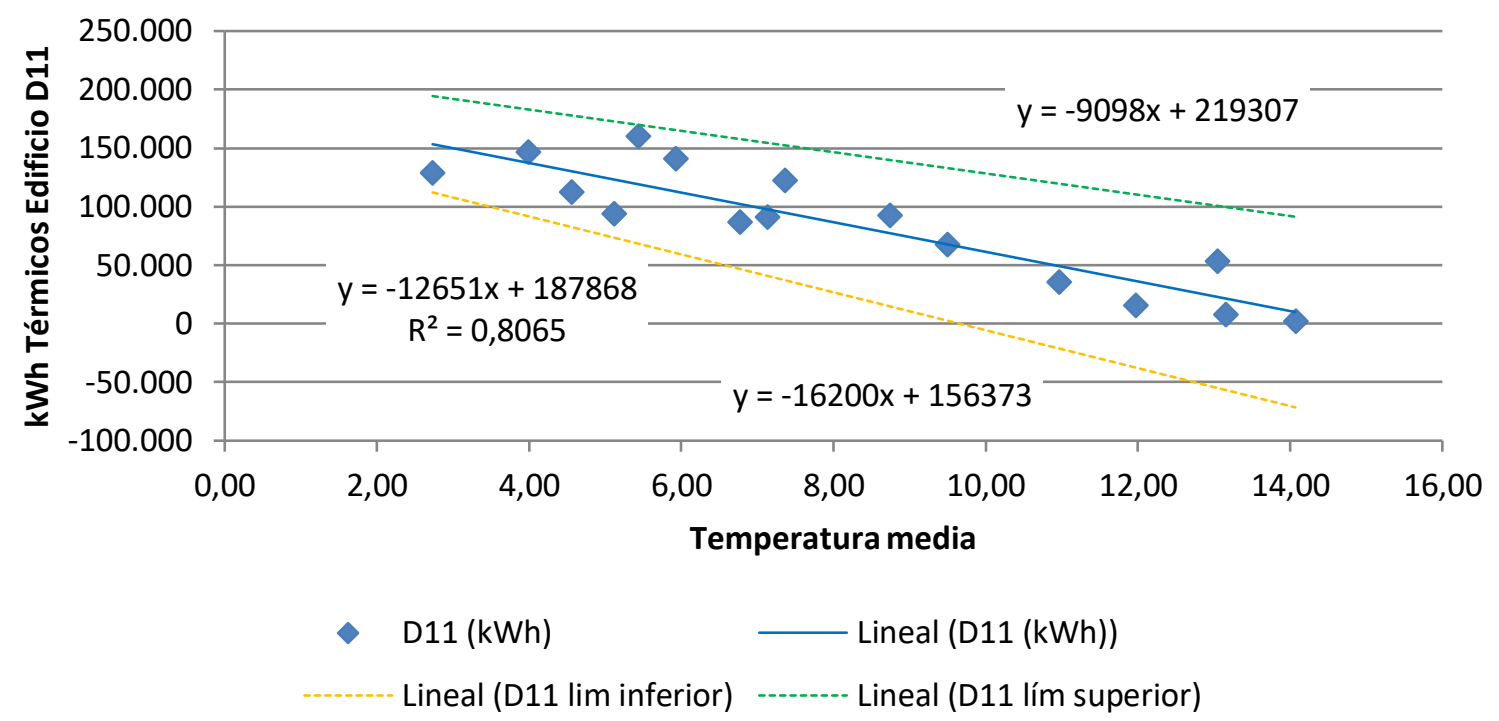

Figura 272. Representación del modelo de regresión lineal simple para el Edificio D11

En la Figura 273 se representa el modelo 2 de regresión lineal múltiple para el edificio D11

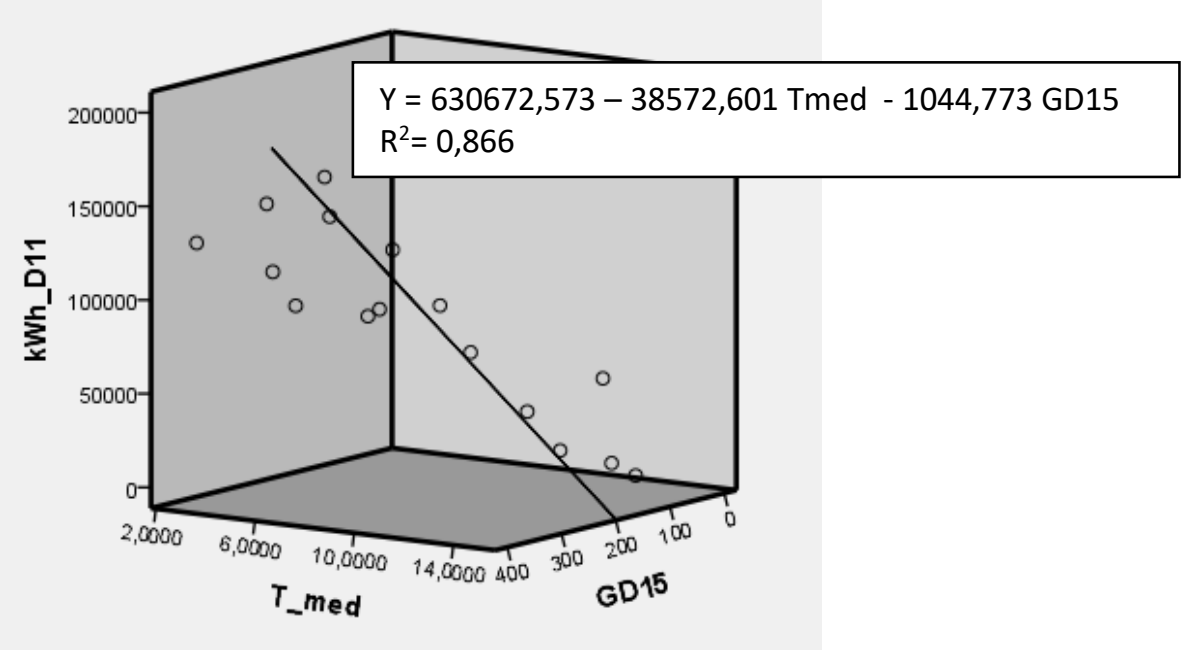

Figura 273. Representación del modelo de regresión lineal múltiple para el Edificio D11

Los valores de la columna $\mathrm{t}$ se obtienen dividiendo el valor de los coeficientes no estandarizados entre sus errores típicos, este estadístico tiende a ser mayor en valor absoluto cuando la hipótesis alternativa es verdadera, es decir cuando la variable posee una pendiente significativa en el modelo de regresión. En las Tabla 363 y Tabla 364, el estadístico t y su nivel crítico (Sig), permiten contrastar la hipótesis nula consistente en que el coeficiente de regresión vale cero en el modelo; a mayor valor de $t$, mayor peso en el modelo. 
El valor "Sig" corresponde a los valores de probabilidad de los valores de $t$, es la probabilidad de obtener el valor de $t$ si la hipótesis nula fuera cierta, cuando son $\leq 0,05$ se rechaza la hipótesis nula y se concluye que las pendientes son distintas de cero, luego si Sig $>0,05$ se acepta la hipótesis nula de que la pendiente de la variable independiente en el modelo de regresión es igual a cero, no cumpliendo el criterio de entrada en el modelo.

La correlación parcial, que aparece en la Tabla 364 estudia la relación existente entre dos variables cuantitativas cuando se controla o elimina el efecto de terceras variables, en el modelo de regresión lineal, a mayor valor absoluto, mayor relación entre la variable dependiente y la independiente.

Tabla 364. Variables excluidas del modelo de región del Edificio D11

\begin{tabular}{|c|c|c|c|c|}
\hline & Modelo & $\mathrm{t}$ & Sig. & Correlación parcial \\
\hline \multirow{19}{*}{1} & GD15_30min & $-2,399$ & 032 &,- 554 \\
\hline & GD20_30min & $-2,351$ & 035 &,- 546 \\
\hline & GD15_24h & $-2,366$ & 036 &,- 539 \\
\hline & GD20_24h & $-2,294$ & 039 &,- 537 \\
\hline & T_media_diurna &,- 062 & ,952 &,- 017 \\
\hline & T_max &,- 276 & ,787 &,- 076 \\
\hline & T_min &,- 168 & 870 &,- 046 \\
\hline & HR_\% &,- 678 &, 510 &,- 185 \\
\hline & HR_med_diurna_\% &,- 501 & 624 &,- 138 \\
\hline & HR_max_\% &,- 968 & 351 &,- 259 \\
\hline & HR_min_\% &,- 603 & ,557 &,- 165 \\
\hline & Radiación_W/m2 & ,341 & ,739 & 094 \\
\hline & V_Viento_m/s & 2,177 & 049 & ,517 \\
\hline & V_viento_diurna_m/s & 2,309 & 038 & ,539 \\
\hline & V_viento_nocturna_m/s & 1,964 & 071 & ,478 \\
\hline & V_viento_max_m/s & 2,352 & 035 & $\overline{5}, 546$ \\
\hline & Recorrido_viento_km/día & 2,183 & ,048 & ,518 \\
\hline & Precipitación_acumulada_mes_mm &, 295 & ,773 & 082 \\
\hline & Horas insolación_h &, 250 & 806 & 069 \\
\hline \multirow{18}{*}{2} & GD20_30min &,- 513 & ,617 &,- 147 \\
\hline & GD15_24h &,- 023 & 982 &,- 017 \\
\hline & GD20_24h & ,231 & 821 & 067 \\
\hline & T_media_diurna & ,123 & ,904 & 036 \\
\hline & T_max & ,112 & ,913 & 032 \\
\hline & T_min &,- 561 &, 585 &,- 160 \\
\hline & HR_\% &,- 727 & ,481 &,- 205 \\
\hline & HR_med_diurna_\% &,- 516 & ,615 &,- 147 \\
\hline & HR_max_\% & $-1,047$ & ,316 &,- 289 \\
\hline & HR_min_\% &,- 456 & 656 &,- 131 \\
\hline & Radiación_W/m2 & ,541 &, 598 & 154 \\
\hline & V_Viento_m/s & 1,684 & ,118 & ,437 \\
\hline & V_viento_diurna_m/s & 1,623 & ,131 & 424 \\
\hline & V_viento_nocturna_m/s & 1,773 & ,102 & 456 \\
\hline & V_viento_max_m/s & 1,589 & ,138 & ,417 \\
\hline & Recorrido_viento_km/día & 1,690 & 117 & ,438 \\
\hline & Precipitación_acumulada_mes_mm &,- 283 & ,782 &,- 081 \\
\hline & Horas insolación_h &,- 099 & 923 &,- 028 \\
\hline
\end{tabular}


La bondad de los modelos de regresión obtenidos para el edificio D11, se resumen en la Tabla 365

Tabla 365. Resumen de la bondad de los modelos de regresión para el Edificio D11

\begin{tabular}{|c|c|c|c|c|}
\hline Modelo & $\mathrm{R}$ & $\mathrm{R}$ cuadrado & R cuadrado corregida & $\begin{array}{c}\text { Error típ. de la } \\
\text { estimación }\end{array}$ \\
\hline 1 &,$- 898^{a}$ & ,807 & 793, & 23023,26149 \\
\hline 2 &,$- 931^{b}$ & ,866 & 845 & 19891,42514 \\
\hline
\end{tabular}

Se observa como el modelo 1 de regresión lineal simple presenta un Coeficiente de Correlación de Pearson $(\mathrm{R})$ inferior en valor absoluto al modelo 2 de regresión lineal múltiple, este coeficiente indica que las variables de los modelos están correlacionadas de manera muy fuerte (en la correlación perfecta $R= \pm 1$ ). La correlación que se produce en ambos modelos es inversa, al aumentar el valor de las variables independientes disminuye el valor de la variable dependiente que es el consumo térmico.

El coeficiente de determinación $\left(R^{2}\right)$, nos indica que con el modelo 1 se podría explicar el $80,7 \%$ de los datos reales obtenidos y el modelo 2 , el porcentaje de aciertos o de explicación asciende al 86,6\%, ambos aceptando un error del 5\%.

El coeficiente de determinación corregido ( $R^{2}$ corregido) que tiene en cuenta el número de variables independientes incluidas en el modelo y el tamaño de la muestra, reduce el coeficiente de determinación al 79,3\% en el modelo 1 y al 84,5 \% en el modelo 2.

El error típico de la estimación que nos indica la magnitud de los errores, es decir la parte de la variable dependiente que dejamos sin explicar con el modelo y que describe la variación de la variable respuesta (el Consumo) respecto a la recta de regresión, es de $23.023 \mathrm{kWh}$ para el modelo 1 y de $19.891 \mathrm{kWh}$ para el modelo 2, lo que representa un $27,2 \%$ del promedio de los consumos que fue de $84.735 \mathrm{kWh}$ para el modelo 1 y del 23,5\% para el modelo 2 .

Por tanto aunque el modelo 2 es más preciso, también es aceptado el modelo 1 para la representación de la línea base de los consumos térmicos del edificio D11. 


\section{AIV.11.2.Verificación del cumplimiento de los supuestos estadísticos}

Las condiciones que se deben cumplir en un modelo de regresión son:

- Linealidad de las variables, las variables se encuentran relacionadas de forma lineal.

Como se observa en la Tabla 363, la pendiente (B), para el modelo 1, obtuvo un valor de Sig $=0,000$, que al ser $\leq 0,05$, nos indica que podemos rechazar la hipótesis nula de pendiente igual a cero y nos da la evidencia de linealidad entre la variable dependiente ( $k W h$ del edificio D11) y la independiente (Temperatura media). Al ser el valor de la pendiente negativa, indica una relación inversa entre el consumo y la Temperatura media.

Para el modelo 2, según la misma Tabla 363, las pendientes de las dos variables introducidas en el modelo obtuvieron unos valores de Sig $=0,004$ para la Temperatura media y de 0,032 para los Grados día Base 15, ambos $\leq 0,05$, lo que nos indica que podemos rechazar la hipótesis nula de pendiente igual a cero y nos da la evidencia de linealidad entre la variable dependiente ( $\mathrm{kWh}$ del edificio D11) y las independientes (Temperatura media y GD15_30min).

- Normalidad. Todos los valores obtenidos para la variable dependiente (Y), deben estar distribuidos normalmente en cada valor de las variables independientes $(X)$.

Se comprueba la normalidad de las variables y de los residuos mediante el Test de Shapiro - Wilk para muestras pequeñas (menores a 30 observaciones), siendo la hipótesis nula el que la distribución es Normal, luego si la probabilidad del estadístico del test es $\leq$ al nivel de significación 0,05 , la hipótesis nula es rechazada y sólo aceptaremos que las variables se distribuyen según una Normal cuando el valor de la significación sea mayor que 0,05 (valor de la significación >0,05) en el Test de Shapiro Wilk.

La Tabla 366, muestra la prueba de normalidad de Shapiro-Wilk y cómo tanto la variable dependiente (consumos del Edificio D11), como las variables independientes: Temperatura media y GD15 poseen una Sig > 0,05, por lo que aceptamos la hipótesis nula de Normalidad de las variables

Tabla 366. Prueba de normalidad para el edificio D11

\begin{tabular}{lcrrrrr}
\hline & \multicolumn{2}{c}{ Kolmogorov-Smirnov } & \multicolumn{3}{c}{ Shapiro-Wilk } \\
\cline { 2 - 7 } & Estadístico & gl & Sig. & Estadístico & gl & Sig. \\
\hline kWh_D8 &, 142 & 16 &, 200 &, 946 & 16 &, 434 \\
\hline T_med & 150 & 16 &, 200 &, 942 & 16 &, 376 \\
\hline GD15_30min &, 109 & 16 &, 200 &, 953 & 16 &, 541 \\
\hline
\end{tabular}


- Independencia de los errores. Los errores asociados a los valores de la variable respuesta $(Y)$ deberán ser independientes unos de otros.

Para la comprobación se utiliza el estadístico de Durbin -Watson.

Se comprueba que el Estadístico de Durbin Watson para el nivel de significancia del 5\%, y para el tamaño de la muestra " $n$ " y el número de variables independientes del modelo " $k$ ", se encuentra en el intervalo [dU, 4-dU], de la Tabla 3, intervalo centrado en el 2, que indica la ausencia de autocorrelación.

El valor del Estadístico Durbin-Watson facilitado por el programa SPSS, es:

- para el modelo 1 de 1,646 (Regresión lineal simple)

- para el modelo 2 de 1,065 (Regresión lineal múltiple)

En el modelo $1, n=16$ y $k=1$, según la Tabla 3 , el valor $d U=1,371$, luego el intervalo que marca la ausencia de correlación es [1,371, 2,629], como el valor del estadístico 1,646 está dentro del intervalo, se acepta la ausencia de autocorrelación

En el modelo 2, $\mathrm{n}=16$ y $\mathrm{k}=2$, según la Tabla 3, el valor $\mathrm{dU}=1,539$ y $\mathrm{dL}=0,982$, luego el intervalo que marca la ausencia de correlación es [1,539, 2,461].

Los intervalos $[0,0,982]$ y $[3,018,4]$ indican correlación positiva o negativa respectivamente y las zonas $[0,982,1,539]$ y $[2,461,3,018]$ son zonas no concluyentes; como el valor del estadístico 1,065 está dentro del último intervalo no concluyente, se comprueba la ausencia de autoc orrelación, mediante el gráfico de residuos frente al tiempo.

La Figura 274, muestra que la relación entre los residuos y el tiempo, posee un coeficiente de determinación $=0,28$, por el $28 \%$ de los residuos podrían ser explicados mediante una relación lineal con el tiempo, por lo que se acepta la existencia de una cierta autocorrelación de los residuos del Modelo 2.

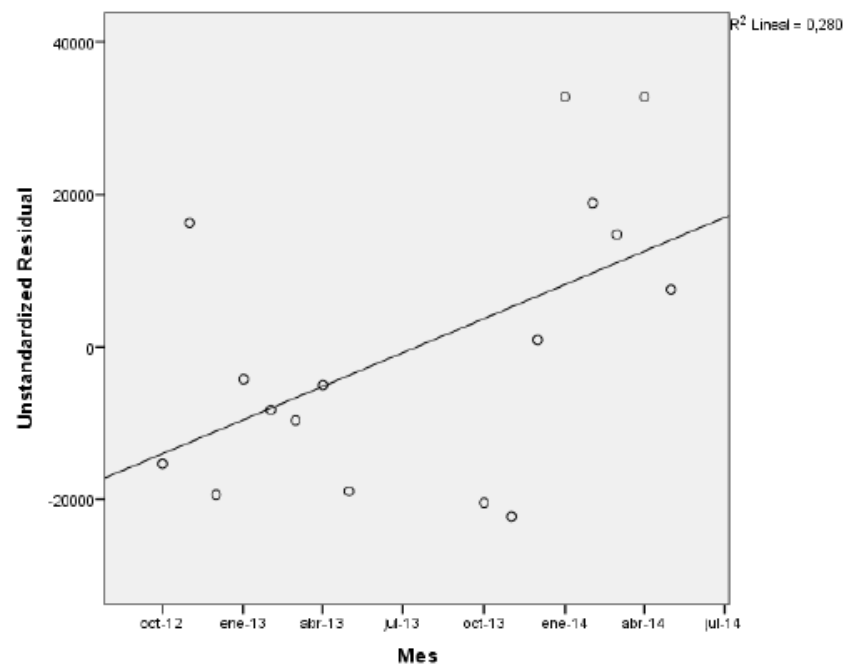

Figura 274. Relación entre los residuos y el tiempo en el Edificio D11. Modelo 2 
- Homocedasticidad de la varianza. Se pretende comprobar que la varianza de los errores $\left(\sigma^{2}\right)$ es constante para cualquier valor de la(s) variable(s) independiente(s) (X), es decir que el valor medio del cuadrado de la desviación de los errores respecto a su media es constante.

Esta condición indica que el error es una variable aleatoria que tomará un valor distinto cada vez que se ejecute el modelo y que no existe correlación entre los residuos y los pronósticos.

La forma de comprobar la homocedasticidad es verificando si el coeficiente de determinación $\mathrm{R}^{2}$, que indica la proporción de la variable dependiente ( $\mathrm{Y}$ o consumo del edificio) que puede ser explicada por la variación de las variables independientes (las variables climatológicas), en las relaciones: residuos y predicciones y entre residuos y variables independientes es nulo o muy próximo a cero, lo que indicará que no existe ningún tipo de correlación en los residuos y que éstos son aleatorios.

Se grafican los diagramas de dispersión de esas relaciones, comprobando que se corresponden a nubes de puntos totalmente aleatorias, sin tendencias ni patrones en sus representaciones gráficas.

Para el modelo 1. Regresión lineal simple, las Figura 275 y Figura 276, muestran que la relación entre los pronósticos y los residuos, posee un coeficiente de determinación $=0$ y entre la variable independiente (Temperatura media) y los residuos un coeficiente de determinación de $-2,22 \times 10^{-6}$ practicamente 0 ; por lo que se concluye que no existe ningún tipo de correlación en los residuos y que éstos son aleatorios, siendo la varianza de los residuos constante.

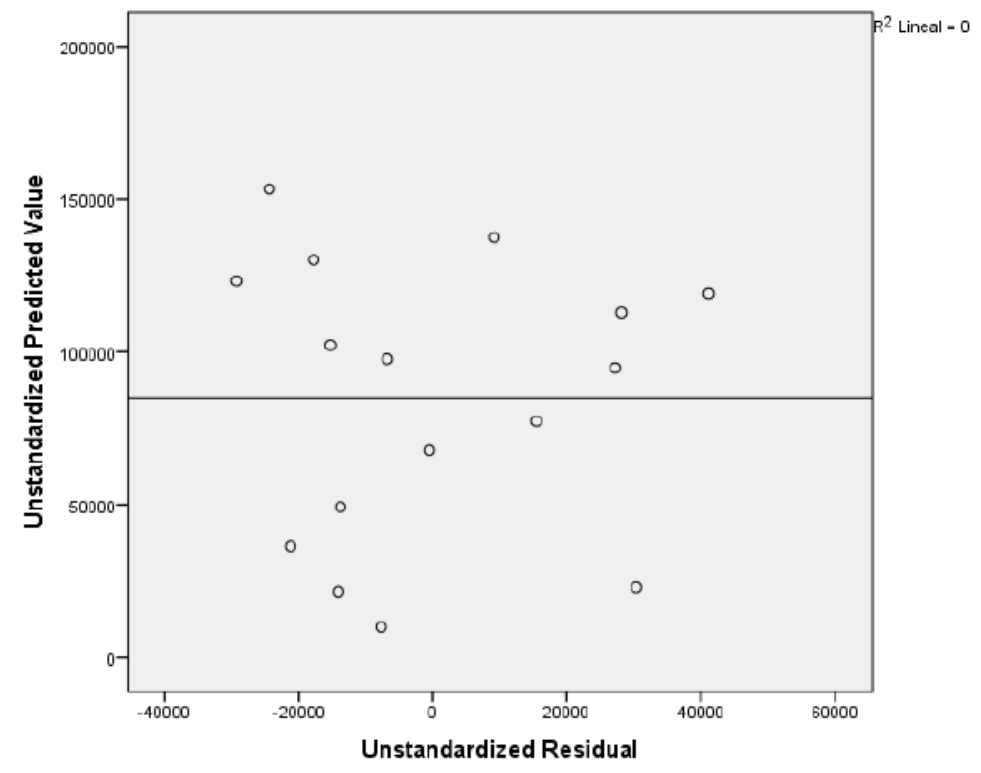

Figura 275. Relación entre los pronósticos y los residuos en el Edificio D11. Modelo 1 


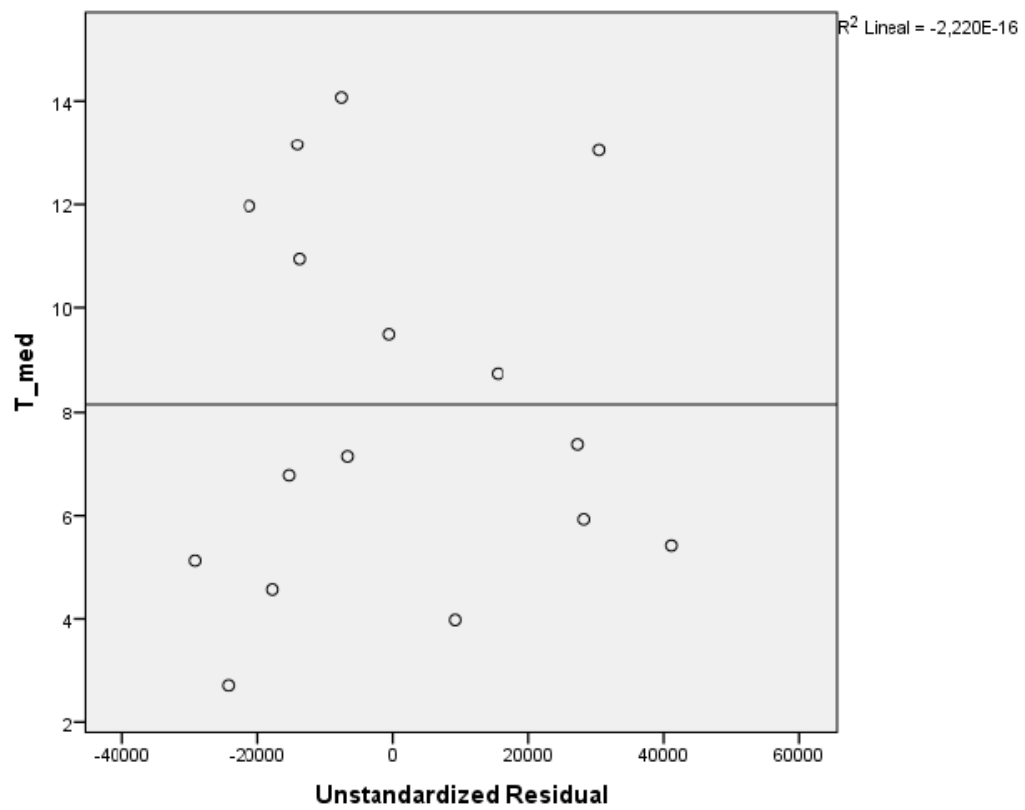

Figura 276. Relación entre la Temperatura media y los residuos en el Edificio D11. Modelo 1

Para el modelo 2. Regresión lineal múltiple, las Figura 277, Figura 278 y Figura 279, muestran que la relación entre los pronósticos y los residuos, posee un coeficiente de determinación $=0$, entre la variable independiente (Temperatura media) y los residuos un coeficiente de determinación, también de $-2,22 \times 10^{-16}$, también prácticamente nulo y entre la variable independiente (GD15) y los residuos de 0; por lo que se concluye que no existe ningún tipo de correlación en los residuos y que éstos son aleatorios, siendo la varianza de los residuos constante.

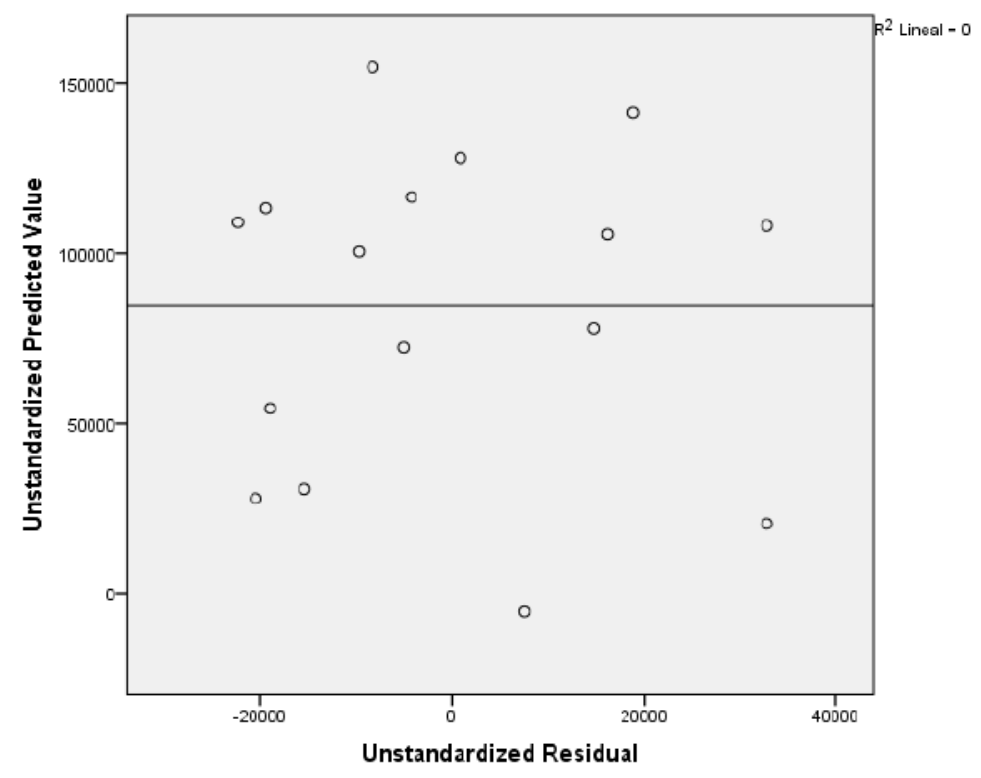

Figura 277. Relación entre los pronósticos y los residuos en el Edificio D11. Modelo 2 


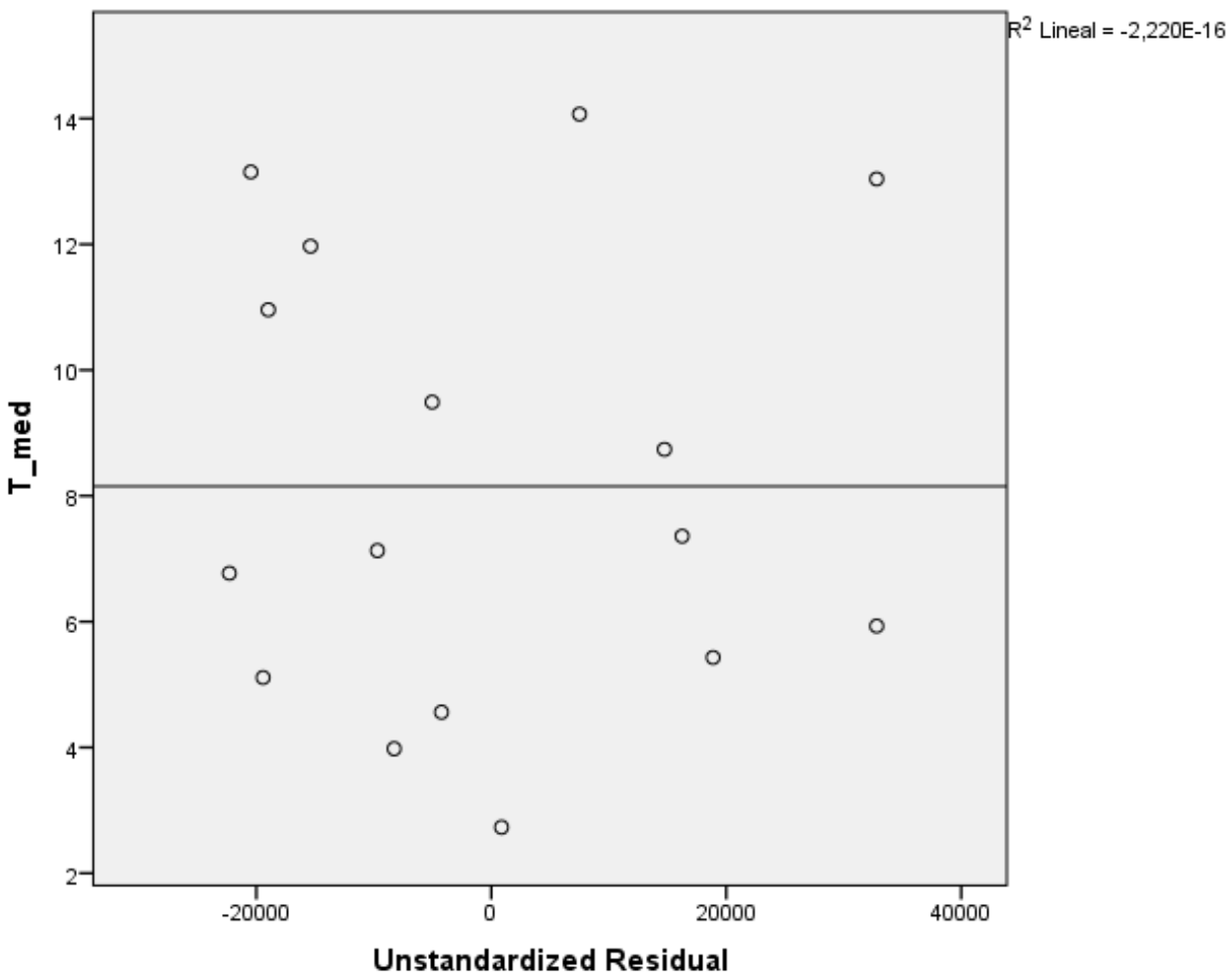

Figura 278. Relación entre la Temperatura media y los residuos en el Edificio D11. Modelo 2

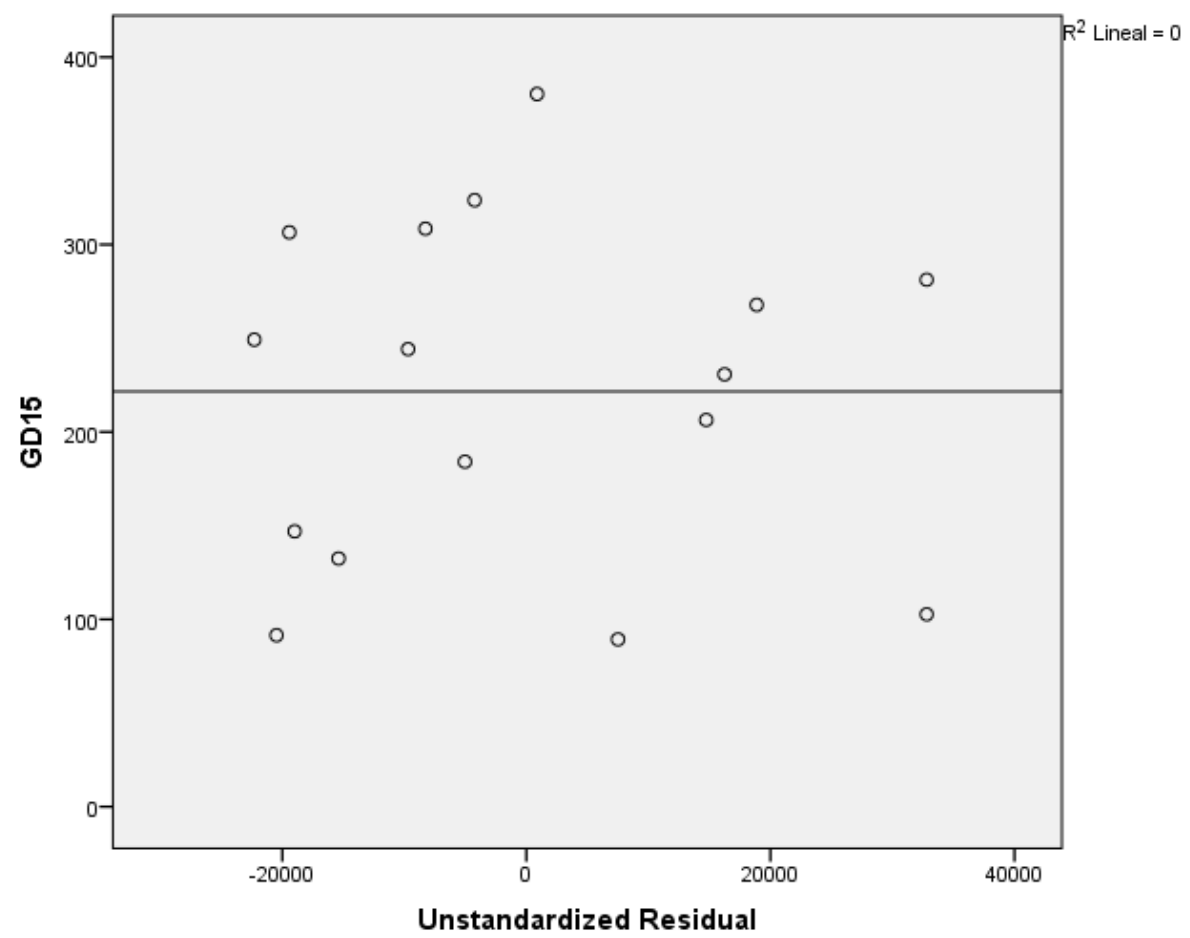

Figura 279. Relación entre Grados día Base 15 y los residuos. Edificio D11. Modelo 2 
- Cuando la regresión es lineal múltiple, se comprueba la falta de multicolinealidad o No-Colinealidad entre las variables independientes, es decir que las variables que forman parte del modelo no están correlacionadas entre ellas.

El problema de la multicolinealidad es moderado cuando el índice de condición toma un valor entre 20 y 30 y es grave cuando el índice de condición toma un valor superior a 30. El número de condición mide la sensibilidad de las estimaciones mínimo-cuadráticas ante pequeños cambios en los datos a mayor valor más correlación entre las variables.

La Tabla 367, muestra los índices de condición de las variables del modelo de regresión múltiple, se observa cómo se supera el valor de 30 en el índice de 77,129 , por lo que se concluye que existe una gran correlación entre las variables independientes del modelo 2 , por lo que este modelo debe ser desechado.

Tabla 367. Índice de condición de las variables independientes del Modelo 2 en el Edificio D11

\begin{tabular}{llr}
\hline Modelo & Dimensión & Índice de condición \\
\hline & 1 & 1,000 \\
\cline { 2 - 3 } 2 & 2 & 3,080 \\
\cline { 2 - 3 } & 3 & 77,129 \\
\hline
\end{tabular}

Esta correlación queda demostrada en la Figura 280, donde se observa que la correlación presenta un coeficiente $R^{2}=0,983$

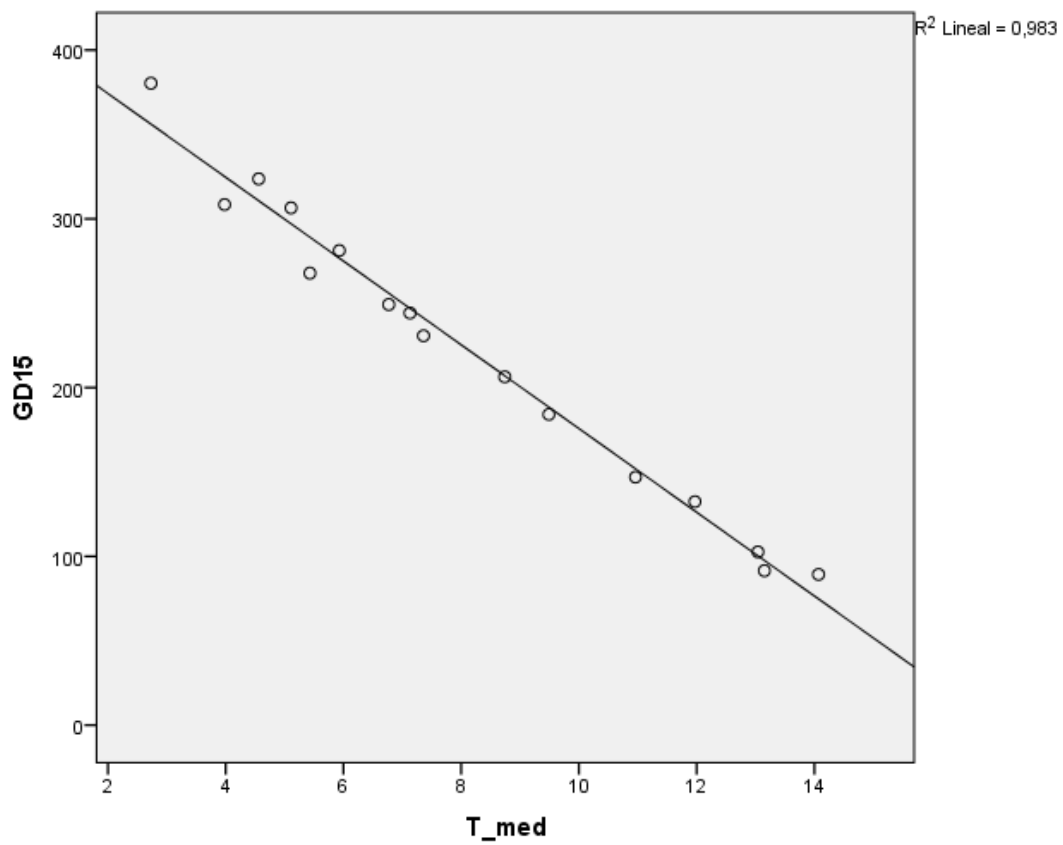

Figura 280. Gráfico de la temperatura media y los Grados día Base 15. 
En cuanto a los índices estadísticos de colinealidad como son los niveles Tolerancia y su inverso que son los Factores de Inflación de la Varianza (FIV). El nivel de tolerancia se obtiene restando a 1 el coeficiente de determinación $\left(R^{2}\right)$. Como se observa en la Figura 280, el coeficiente de determinación entre las dos variables independientes es $R^{2}=0,983$, luego la Tolerancia es $T=1-R^{2}=1-0,983=0,017$ y $\mathrm{FIV}=1 / \mathrm{T}=58,82$

Si la Tolerancia toma un valor próximo a la unidad no existirá colinealidad (a mayor tolerancia menor colinealidad), en este caso el valor está muy alejado de la unidad, por lo que se deduce que existe multicolinealidad entre las variables independientes. Pueden existir problemas de colinealidad si algún FIV es superior a 10 , que corresponde con un $\mathrm{R}^{2}$ de 0,9 y una Tolerancia menor a 0,1 , como es el caso.

La Tabla 368, muestra los estadísticos de colinealidad y se observa como la Tolerancia toma valores de 0,017 , muy lejos de 1 y los valores de FIV son superiores a 10, por lo que existen problemas de colinealidad entre la temperatura media y los GD15, lo que provoca el rechazo del Modelo 2 de regresión lineal.

Tabla 368. Estadísticos de colinealidad para los modelos del Edificio D11

\begin{tabular}{|c|c|c|c|}
\hline Modelo & & Tolerancia & FIV \\
\hline 1 & T_med & 1,000 & 1,000 \\
\hline \multirow{2}{*}{2} & T_med & ,017 & 58,820 \\
\hline & GD15 & ,017 & 58,820 \\
\hline
\end{tabular}

\section{AIV.11.3.Obtención de los consumos térmicos previstos}

Una vez comprobado el cumplimiento de los supuestos estadísticos se acepta el Modelo 1 de línea base encontrado para modelizar el consumo del Edificio D11.

$$
\text { kWh_D11_Pronosticado }=187.840,052-12.648,948 \times \text { T_med }
$$

Con este modelo se procede a predecir los consumos previstos para las temporadas: octubre 2015-mayo 2016, octubre 2016 - mayo 2017 y octubre 2017-mayo 2018, estos consumos se muestran en la Tabla 369, donde "KWh_D11_Real", representa el consumo real, "kWh_D11_Pronosticado", el consumo pronosticado con el Modelo. Se prescinde del valor pronosticado para mayo de 2017, por ser un valor imposible, en el estudio de diferencias significativas 
Tabla 369. Consumos previstos octubre 2014 - mayo 2017 para el edificio D11.

\begin{tabular}{rrrr}
\hline & T_med & kWh_D11_Real & kWh_D11_Pronosticado \\
\hline oct-15 & 12,82 & 8.810 & 25.697 \\
\hline nov-15 & 8,30 & 71.160 & 82.824 \\
\hline dic-15 & 5,33 & 68.390 & 120.437 \\
\hline ene-16 & 6,23 & 77.420 & 108.992 \\
\hline feb-16 & 5,82 & 187.398 & 114.271 \\
\hline mar-16 & 6,14 & 86.570 & 110.139 \\
\hline abr-16 & 9,10 & 60.654 & 72.726 \\
\hline may-16 & 13,11 & 11.790 & 21.959 \\
\hline oct-16 & 13,48 & 23.413 & 17.328 \\
\hline nov-16 & 6,90 & 101.456 & 100.541 \\
\hline dic-16 & 4,12 & 64.092 & 135.702 \\
\hline ene-17 & 2,52 & 143.509 & 156.014 \\
\hline feb-17 & 6,96 & 88.654 & 99.808 \\
\hline mar-17 & 9,21 & 69.390 & 71.351 \\
\hline abr-17 & 12,58 & 32.388 & 28.754 \\
\hline may-17 & 16,69 & 9.030 & -23.230 \\
\hline oct-17 & 14,71 & 5.700 & 1.758 \\
\hline nov-17 & 6,09 & 71.556 & 110.804 \\
\hline dic-17 & 3,99 & 124.822 & 137.354 \\
\hline ene-18 & 4,42 & 123.410 & 131.924 \\
\hline feb-18 & 3,53 & 137.100 & 143.207 \\
\hline mar-18 & 6,80 & 110.644 & 101.795 \\
\hline abr-18 & 11,15 & 55.580 & 46.851 \\
\hline may-18 & 14,03 & 15.860 & 10.404 \\
\hline & & &
\end{tabular}

\section{AIV.11.4.Estudio de la existencia de diferencias significativas}

Utilizando la prueba " $\mathrm{t}$ " de Student para muestras relacionadas, podemos concluir que si las variables se distribuyen según una normal y la significación estadística resulta $\leq 0,05$, existen diferencias significativas, con un nivel de confianza del 95\%

A continuación se muestra la comparación de medias realizada para cada uno de los tres periodos posteriores a la construcción de la red y para el periodo total hasta mayo de 2018.

Para la temporada Octubre 2015 - Mayo 2016, se comprueba mediante el Test de Shapiro -Wilk que tanto los valores reales como los pronosticados se distribuyen según una Normal puesto que en todos los casos los valores de Sig >0,05, como se observa en la Tabla 370 
Anexo IV. Desarrollo del análisis de los edificios del Campus Miguel Delibes

Tabla 370. Prueba de Normalidad temporada Octubre 2015-Mayo 2016. Edificio D11

\begin{tabular}{cccccccr}
\hline & \multicolumn{3}{c}{ Kolmogorov-Smirnov $^{\text {a }}$} & \multicolumn{3}{c}{ Shapiro-Wilk } \\
\cline { 2 - 8 } & Estadístico & gl & \multicolumn{1}{c}{ Sig. } & Estadístico & gl & \multicolumn{1}{c}{ Sig. } \\
\hline kWh_real &, 268 & 8 &, 096 &, 852 & 8 &, 101 \\
\hline kWh_pronosticado &, 252 & 8 &, 144 &, 839 & 8 &, 073 \\
\hline
\end{tabular}

En la Tabla 371, se observa como las medias de los consumos pronosticados, son superiores a las medias de los consumos reales del Edificio D11, en un 14,8\%

Tabla 371. Estadísticos de muestras relacionadas. Octubre 2015-Mayo 2016. Edificio D11

\begin{tabular}{lccccc}
\hline & Media & $\begin{array}{c}\text { \% Diferencia } \\
\text { entre medias }\end{array}$ & N & $\begin{array}{c}\text { Desviación } \\
\text { típ. }\end{array}$ & $\begin{array}{c}\text { Error típ. de } \\
\text { la media }\end{array}$ \\
\hline kWh_real & 71524,0000 & & 8 & 55184,41383 & 19510,63662 \\
\hline kWh_pronosticado & 82130,6250 & $14,8 \%$ & 8 & 39461,89995 & 13951,88853 \\
\hline
\end{tabular}

La Tabla 372 muestra que las diferencias entre las medias no son significativas entre los consumos reales y los pronosticados (sig $>0,05$ ), a pesar de existir ese $14,8 \%$ de diferencia

Tabla 372. Prueba de muestras relacionadas. Octubre 2015-Mayo 2016. Edificio D11

\begin{tabular}{|c|c|c|c|c|c|c|c|c|c|}
\hline & & \multicolumn{5}{|c|}{ Diferencias relacionadas } & \multirow{3}{*}{$\mathrm{t}$} & \multirow{3}{*}{$\mathrm{gl}$} & \multirow{3}{*}{$\begin{array}{c}\text { Sig. } \\
\text { (bilateral) }\end{array}$} \\
\hline & & \multirow[t]{2}{*}{ Media } & \multirow{2}{*}{$\begin{array}{l}\text { Desviación } \\
\text { típ. }\end{array}$} & \multirow{2}{*}{$\begin{array}{l}\text { Error típ. } \\
\text { de la media }\end{array}$} & \multicolumn{2}{|c|}{$\begin{array}{c}95 \% \text { Intervalo de confianza } \\
\text { para la diferencia }\end{array}$} & & & \\
\hline & & & & & Inferior & Superior & & & \\
\hline Par 1 & $\begin{array}{c}\text { kWh_real - } \\
\text { kWh_pronosticado }\end{array}$ & $-10606,625$ & 36604,244 & 12941,554 & $-41208,539$ & 19995,289 &,- 820 & 7 & ,439 \\
\hline
\end{tabular}

En la Figura 281, se grafican los consumos reales y pronosticados para la temporada Octubre 2015 - Mayo 2016 para el Edificio D11, y las medias de dichos consumos. Según la prueba paramétrica realizada las diferencias encontradas no son estadísticamente significativas, por lo que no se puede afirmar la existencia de ahorros en el consumo térmico entre la situación anterior y posterior a la red de calor, con un riesgo a estar equivocados del $5 \%$

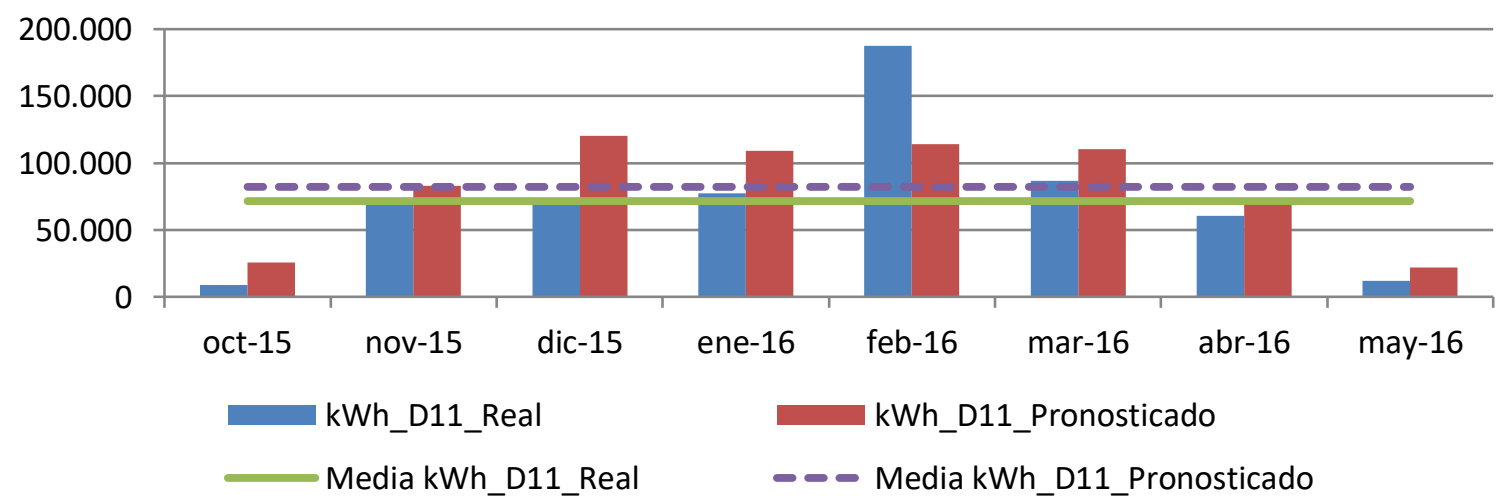

Figura 281. Consumos reales y pronosticados Octubre 2015-Mayo 2016. Edificio D11 
Para la temporada Octubre 2016 - Abril 2017, se comprueba mediante el Test de Shapiro -Wilk que tanto los valores reales como los pronosticados con los dos modelos se distribuyen según una Normal puesto que en todos los casos los valores de Sig >0,05, como se observa en la Tabla 373. El número de datos disponibles son 7 , dado que el pronóstico para mayo de 2017 , resultó un dato negativo.

Tabla 373. Prueba de Normalidad temporada Octubre 2016-Abril 2017. Edificio D11

\begin{tabular}{cccccrrr}
\hline & \multicolumn{3}{c}{ Kolmogorov-Smirnov $^{\mathrm{a}}$} & \multicolumn{3}{c}{ Shapiro-Wilk } \\
\cline { 2 - 8 } & Estadístico & gl & Sig. & Estadístico & gl & \multicolumn{1}{c}{ Sig. } \\
\hline kWh_real &, 133 & 7 &, 200 &, 965 & 7 &, 858 \\
\hline kWh_pronosticado &, 169 & 7 &, 200 &, 946 & 7 &, 695 \\
\hline
\end{tabular}

En la Tabla 374, se observa como las medias de los consumos pronosticados, son superiores a las medias de los consumos reales del Edificio D11, en un 16,6\%

Tabla 374. Estadísticos de muestras relacionadas. Octubre 2016-Abril 2017. Edificio D11

\begin{tabular}{lccccc}
\hline & Media & $\begin{array}{c}\text { \% Diferencia } \\
\text { entre medias }\end{array}$ & $\mathrm{N}$ & $\begin{array}{c}\text { Desviación } \\
\text { típ. }\end{array}$ & $\begin{array}{c}\text { Error típ. de } \\
\text { la media }\end{array}$ \\
\hline $\mathrm{kWh}$ _real & 74700,2857 & & 7 & 41244,52208 & 15588,96405 \\
\hline $\mathrm{kWh}$ _pronosticado & 87071,1429 & $16,6 \%$ & 7 & 51597,57814 & 19502,05143 \\
\hline
\end{tabular}

La Tabla 375 muestra que las diferencias entre las medias no son significativas entre los consumos reales y los pronosticados (sig > 0,05), a pesar de existir ese $16,6 \%$ de diferencia

Tabla 375. Prueba de muestras relacionadas. Octubre 2016-Abril 2017. Edificio D11

\begin{tabular}{|c|c|c|c|c|c|c|c|c|c|}
\hline & & \multicolumn{5}{|c|}{ Diferencias relacionadas } & \multirow{3}{*}{$\mathrm{t}$} & \multirow{3}{*}{$\mathrm{gl}$} & \multirow{3}{*}{$\begin{array}{c}\text { Sig. } \\
\text { (bilateral) }\end{array}$} \\
\hline & & \multirow[t]{2}{*}{ Media } & \multirow{2}{*}{$\begin{array}{l}\text { Desviación } \\
\text { típ. }\end{array}$} & \multirow{2}{*}{$\begin{array}{c}\text { Error típ. } \\
\text { de la media }\end{array}$} & \multicolumn{2}{|c|}{$\begin{array}{c}\text { 95\% Intervalo de confianza } \\
\text { para la diferencia }\end{array}$} & & & \\
\hline & & & & & Inferior & Superior & & & \\
\hline Par 1 & $\begin{array}{c}\text { kWh_real - } \\
\text { kWh pronosticado }\end{array}$ & $-12370,857$ & 27056,817 & 10226,515 & $-37394,239$ & 12652,525 & $-1,210$ & 6 & 272 \\
\hline
\end{tabular}

En la Figura 282, se grafican los consumos reales y pronosticados para la temporada Octubre 2016 - Abril 2017 para el Edificio D11, y las medias de dichos consumos. Según la prueba paramétrica realizada las diferencias encontradas no son estadísticamente significativas, con un riesgo a estar equivocados del $5 \%$ 
Anexo IV. Desarrollo del análisis de los edificios del Campus Miguel Delibes

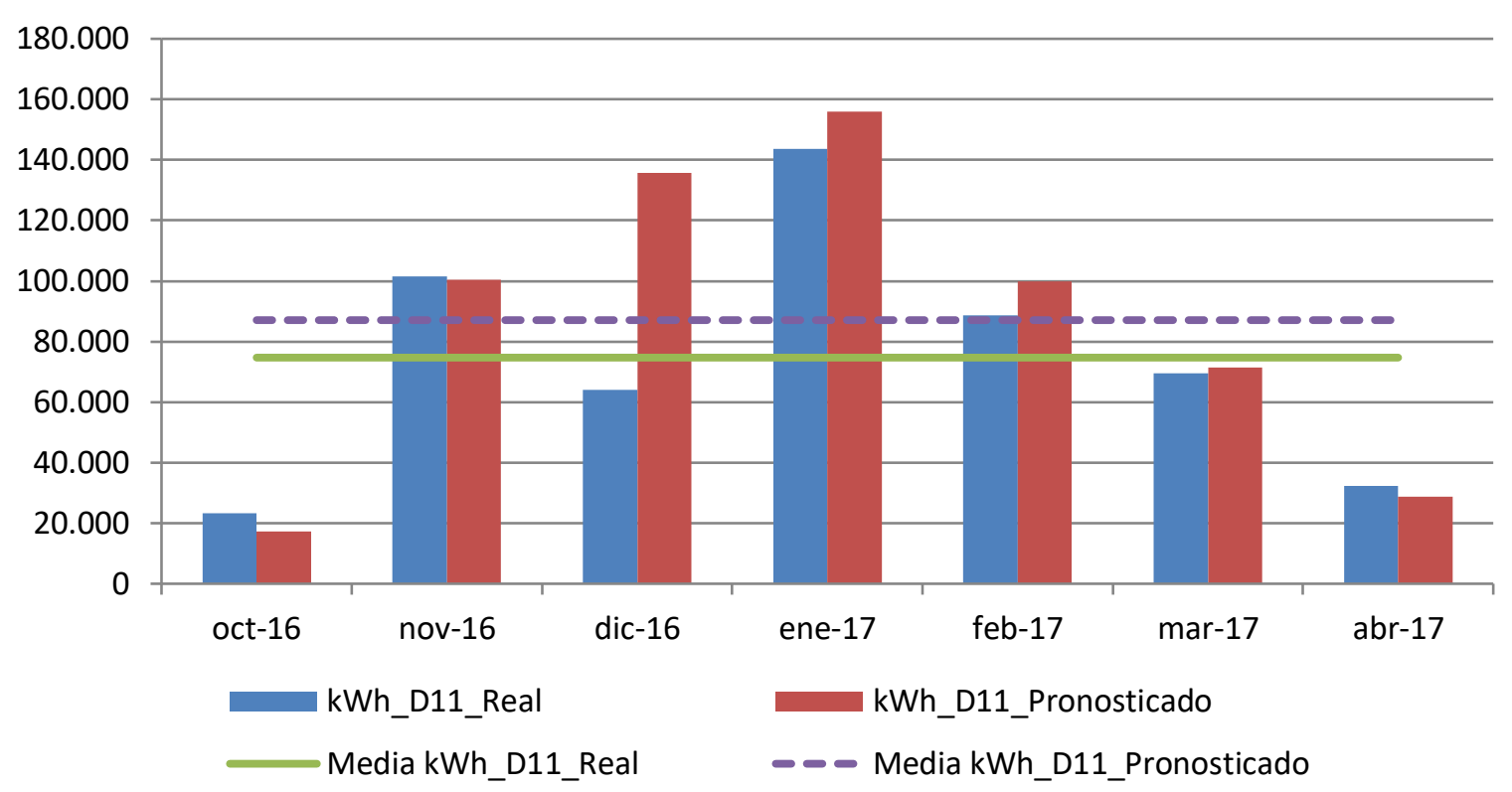

Figura 282. Consumos reales y pronosticados Octubre 2016-Abril 2017. Edificio D11

Para la temporada Octubre 2017 - Mayo 2018, se comprueba mediante el Test de Shapiro -Wilk que tanto los valores reales como los pronosticados se distribuyen según una Normal puesto que en todos los casos los valores de Sig > 0,05, como se observa en la Tabla 376

Tabla 376. Prueba de Normalidad temporada Octubre 2017-Mayo 2018. Edificio D11

\begin{tabular}{cccccccr}
\hline & \multicolumn{3}{c}{ Kolmogorov-Smirnov $^{\mathrm{a}}$} & \multicolumn{3}{c}{ Shapiro-Wilk } \\
\cline { 2 - 8 } & Estadístico & gl & \multicolumn{1}{c}{ Sig. } & Estadístico & gl & \multicolumn{1}{c}{ Sig. } \\
\hline kWh_real &, 221 & 8 &, 200 &, 892 & 8 &, 242 \\
\hline kWh_pronosticado &, 236 & 8 &, 200 &, 858 & 8 &, 114 \\
\hline
\end{tabular}

En la Tabla 377, se observa como las medias de los consumos pronosticados, son superiores a las medias de los consumos reales del Edificio D11, en un 6,1\%

Tabla 377. Estadísticos de muestras relacionadas. Octubre 2017-Mayo 2018. Edificio D11

\begin{tabular}{lccccc}
\hline & Media & $\begin{array}{c}\text { \% Diferencia } \\
\text { entre medias }\end{array}$ & N & $\begin{array}{c}\text { Desviación } \\
\text { típ. }\end{array}$ & $\begin{array}{c}\text { Error típ. de } \\
\text { la media }\end{array}$ \\
\hline kWh_real & 80584,0000 & & 8 & 51258,78769 & 18122,71819 \\
\hline kWh_pronosticado & 85512,1250 & $6,1 \%$ & 8 & 57601,85784 & 20365,33214 \\
\hline
\end{tabular}

La Tabla 378 muestra que las diferencias entre las medias no son significativas entre los consumos reales y los pronosticados ( $\operatorname{sig}>0,05$ ), a pesar de existir ese $6,1 \%$ de diferencia 
Anexo IV. Desarrollo del análisis de los edificios del Campus Miguel Delibes

Tabla 378. Prueba de muestras relacionadas. Octubre 2017-Mayo 2018. Edificio D11

\begin{tabular}{|c|c|c|c|c|c|c|c|c|c|}
\hline & & \multicolumn{5}{|c|}{ Diferencias relacionadas } & \multirow{3}{*}{$\mathrm{t}$} & \multirow{3}{*}{ gl } & \multirow{3}{*}{$\begin{array}{c}\text { Sig. } \\
\text { (bilateral) }\end{array}$} \\
\hline & & \multirow[t]{2}{*}{ Media } & \multirow{2}{*}{$\begin{array}{l}\text { Desviación } \\
\text { típ. }\end{array}$} & \multirow{2}{*}{$\begin{array}{c}\text { Error típ. } \\
\text { de la media }\end{array}$} & \multicolumn{2}{|c|}{$\begin{array}{c}\text { 95\% Intervalo de confianza } \\
\text { para la diferencia }\end{array}$} & & & \\
\hline & & & & & Inferior & Superior & & & \\
\hline Par 1 & $\begin{array}{c}\text { kWh_real - } \\
\text { kWh_pronosticado }\end{array}$ & $-4928,125$ & 16092,396 & 5689,521 & $-18381,704$ & 8525,454 &,- 866 & 7 & ,415 \\
\hline
\end{tabular}

En la Figura 283 se grafican los consumos reales y pronosticados para la temporada Octubre 2017 - Mayo 2018 para el Edificio D11, y las medias de dichos consumos. Según la prueba paramétrica realizada las diferencias encontradas no son estadísticamente significativas, con un riesgo a estar equivocados del $5 \%$

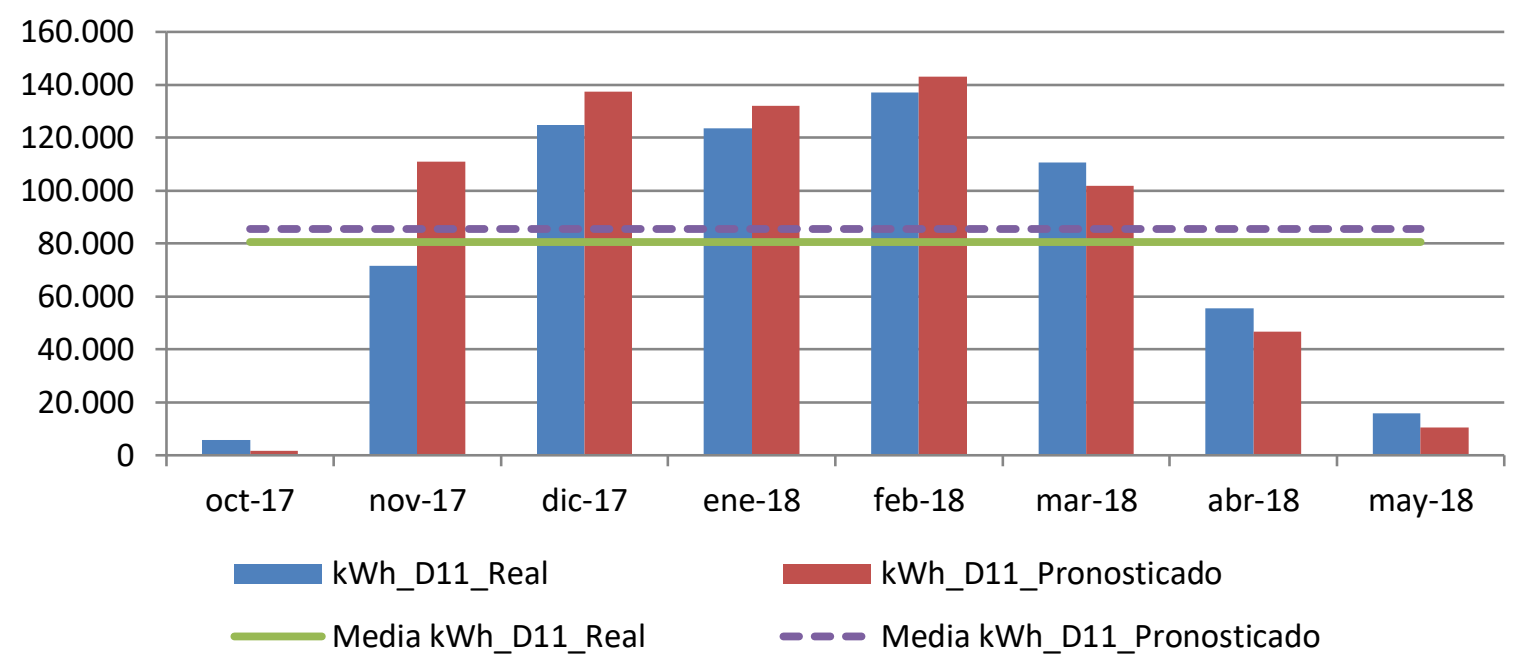

Figura 283. Consumos reales y pronosticados Octubre 2017-Mayo 2018. Edificio D11

Para el total de las tres temporadas Octubre 2015 - Mayo 2018, se comprueba mediante el Test de Shapiro -Wilk, que los valores reales y los pronosticados se distribuyen según una Normal puesto que en esos casos los valores de Sig $>0,05$, como se observa en la Tabla 379

Tabla 379. Prueba de Normalidad temporada Octubre 2015-Mayo 2018. Edificio D11

\begin{tabular}{ccccccr}
\hline & \multicolumn{3}{c}{ Kolmogorov-Smirnov $^{\mathrm{a}}$} & \multicolumn{3}{c}{ Shapiro-Wilk } \\
\cline { 2 - 8 } & Estadístico & gl & Sig. & Estadístico & gl & Sig. \\
\hline kWh_real &, 099 & 23 &, 200 &, 960 & 23 &, 464 \\
\hline kWh_pronosticado &, 188 & 23 &, 033 &, 920 & 23 &, 065 \\
\hline
\end{tabular}

En la Tabla 380 se observa como las medias de los consumos pronosticados, son superiores a las medias de los consumos reales del Edificio D11, en un $12,1 \%$ 
Tabla 380. Estadísticos de muestras relacionadas. Octubre 2015-Mayo 2018. Edificio D11

\begin{tabular}{llcrcr}
\hline & Media & $\begin{array}{c}\text { \% Diferencia } \\
\text { entre medias }\end{array}$ & $\mathrm{N}$ & $\begin{array}{c}\text { Desviación } \\
\text { típ. }\end{array}$ & $\begin{array}{c}\text { Error típ. de } \\
\text { la media }\end{array}$ \\
\hline $\mathrm{kWh}$ _real & 75642,0683 & & 23 & 47793,79323 & 9965,69479 \\
\hline $\mathrm{kWh}$ pronosticado & 84810,4600 & $12,1 \%$ & 23 & 47767,21377 & 9960,15259 \\
\hline
\end{tabular}

La Tabla 381 muestra que las diferencias entre las medias no son significativas entre los consumos reales y los pronosticados (sig $>0,05$ ).

Tabla 381. Prueba de muestras relacionadas. Octubre 2015-Mayo 2018. Edificio D11

\begin{tabular}{|c|c|c|c|c|c|c|c|c|}
\hline & \multicolumn{5}{|c|}{ Diferencias relacionadas } & \multirow{3}{*}{$\mathrm{t}$} & \multirow{3}{*}{ gl } & \multirow{3}{*}{$\begin{array}{c}\text { Sig. } \\
\text { (bilateral) }\end{array}$} \\
\hline & \multirow[t]{2}{*}{ Media } & \multirow{2}{*}{$\begin{array}{l}\text { Desviación } \\
\text { típ. }\end{array}$} & \multirow{2}{*}{$\begin{array}{l}\text { Error típ. de } \\
\text { la media }\end{array}$} & \multicolumn{2}{|c|}{$\begin{array}{l}\text { 95\% Intervalo de confianza } \\
\text { para la diferencia }\end{array}$} & & & \\
\hline & & & & Inferior & Superior & & & \\
\hline $\begin{array}{c}\text { kWh_real - } \\
\text { kWh_pronosticado }\end{array}$ & $-9168,392$ & 26812,880 & 5590,872 & $-20763,150$ & 2426,367 & $-1,640$ & 22 & 115 \\
\hline
\end{tabular}




\section{AIV.11.5.Estimación de las emisiones de $\mathrm{CO} 2$ evitadas.}

Teniendo en cuenta que el consumir Gas natural se producen 0,252 $\mathrm{kg} \mathrm{CO}_{2} / \mathrm{kWh} \mathrm{E}$. final y que al consumir la energía suministrada por red a partir de Biomasa se producen 0,024 kg $\mathrm{kg} \mathrm{CO} 2$ / kWh E. final, en la Tabla 382, se muestra las emisiones de $\mathrm{CO}_{2}$ reales para las temporadas octubre 2015 - mayo 2018 y utilizando el Modelo de regresión, las emisiones de $\mathrm{CO}_{2}$ que se hubieran tenido de haber seguido utilizando las calderas de gas natural originales sin el apoyo de la red de calor. Al no haberse obtenido diferencias significativas entre el consumo real y el pronosticado, éste último se ha igualado al consumo real.

Tabla 382. Estimación del ahorro de emisiones de CO2 para el Edificio D11.

\begin{tabular}{|c|c|c|c|c|c|c|c|c|c|c|}
\hline & $\begin{array}{c}\text { kWh_D11 } \\
\text { Gas } \\
\text { Natural }\end{array}$ & $\begin{array}{c}\text { kWh_D11 } \\
\text { Biomasa }\end{array}$ & $\begin{array}{l}\text { kWh_D11 } \\
\text { Real Total }\end{array}$ & $\begin{array}{l}\text { kWh_D11 } \\
\text { Predicho }\end{array}$ & $\begin{array}{l}\text { kg CO2 } \\
\text { Real } \\
\text { debido al } \\
\text { consumo } \\
\text { de Gas } \\
\text { Natural }\end{array}$ & $\begin{array}{c}\text { kg CO2 } \\
\text { Real } \\
\text { debido a } \\
\text { Biomasa }\end{array}$ & $\begin{array}{l}\text { kg CO2 } \\
\text { Real } \\
\text { debido al } \\
\text { consumo } \\
\text { TOTAL }\end{array}$ & $\begin{array}{c}\text { kg CO2 } \\
\text { que se } \\
\text { hubiera } \\
\text { tenido } \\
\text { debido a } \\
\text { Gas } \\
\text { Natural }\end{array}$ & $\begin{array}{c}\text { Ahorro } \\
\text { de kg } \\
\mathrm{CO} 2\end{array}$ & $\begin{array}{l}\text { Ahorro de kg } \\
\text { CO2 } \\
\text { acumulado }\end{array}$ \\
\hline oct-2015 & 0 & 8.810 & 8.810 & 8.810 & 0 & 211 & 211 & 2.220 & 2.009 & 2.009 \\
\hline nov-2015 & 0 & 71.160 & 71.160 & 71.160 & 0 & 1.708 & 1.708 & 17.932 & 16.224 & 18.233 \\
\hline dic-2015 & 0 & 68.390 & 68.390 & 68.390 & 0 & 1.641 & 1.641 & 17.234 & 15.593 & 33.826 \\
\hline ene-2016 & 0 & 77.420 & 77.420 & 77.420 & 0 & 1.858 & 1.858 & 19.510 & 17.652 & 51.478 \\
\hline feb-2016 & 76.228 & 111.170 & 187.398 & 187.398 & 19.209 & 2.668 & 21.878 & 47.224 & 25.347 & 76.825 \\
\hline mar-2016 & 6.040 & 80.530 & 86.570 & 86.570 & 1.522 & 1.933 & 3.455 & 21.816 & 18.361 & 95.185 \\
\hline abr-2016 & 284 & 60.370 & 60.654 & 60.654 & 72 & 1.449 & 1.520 & 15.285 & 13.764 & 108.950 \\
\hline may-2016 & 0 & 11.790 & 11.790 & 11.790 & 0 & 283 & 283 & 2.971 & 2.688 & 111.638 \\
\hline oct-2016 & 12.513 & 10.900 & 23.413 & 23.413 & 3.153 & 262 & 3.415 & 5.900 & 2.485 & 114.123 \\
\hline nov-2016 & 3.736 & 97.720 & 101.456 & 101.456 & 942 & 2.345 & 3.287 & 25.567 & 22.280 & 136.403 \\
\hline dic-2016 & 2.232 & 61.860 & 64.092 & 64.092 & 563 & 1.485 & 2.047 & 16.151 & 14.104 & 150.507 \\
\hline ene-2017 & 10.209 & 133.300 & 143.509 & 143.509 & 2.573 & 3.199 & 5.772 & 36.164 & 30.392 & 180.900 \\
\hline feb-2017 & 64 & 88.590 & 88.654 & 88.654 & 16 & 2.126 & 2.142 & 22.341 & 20.199 & 201.098 \\
\hline mar-2017 & 0 & 69.390 & 69.390 & 69.390 & 0 & 1.665 & 1.665 & 17.486 & 15.821 & 216.919 \\
\hline$a b r-2017$ & 568 & 31.820 & 32.388 & 32.388 & 143 & 764 & 907 & 8.162 & 7.255 & 224.174 \\
\hline may-2017 & 0 & 9.030 & 9.030 & 9.030 & 0 & 217 & 217 & 2.276 & 2.059 & 226.233 \\
\hline oct-2017 & 0 & 5.700 & 5.700 & 5.700 & 0 & 137 & 137 & 1.436 & 1.300 & 227.533 \\
\hline nov-2017 & 416 & 71.140 & 71.556 & 71.556 & 105 & 1.707 & 1.812 & 18.032 & 16.220 & 243.753 \\
\hline dic-2017 & 2.032 & 122.790 & 124.822 & 124.822 & 512 & 2.947 & 3.459 & 31.455 & 27.996 & 271.749 \\
\hline ene-2018 & 560 & 122.850 & 123.410 & 123.410 & 141 & 2.948 & 3.090 & 31.099 & 28.010 & 299.758 \\
\hline feb-2018 & 0 & 137.100 & 137.100 & 137.100 & 0 & 3.290 & 3.290 & 34.549 & 31.259 & 331.017 \\
\hline mar-2018 & 2.544 & 108.100 & 110.644 & 110.644 & 641 & 2.594 & 3.236 & 27.882 & 24.647 & 355.664 \\
\hline abr-2018 & 440 & 55.140 & 55.580 & 55.580 & 111 & 1.323 & 1.434 & 14.006 & 12.572 & 368.236 \\
\hline may-2018 & 0 & 15.860 & 15.860 & 15.860 & 0 & 381 & 381 & 3.997 & 3.616 & 371.852 \\
\hline
\end{tabular}

Como se observa durante estas tres temporadas se ha obtenido un ahorro total de 372 Toneladas de $\mathrm{CO}_{2}$, debido al cambio de combustible de gas natural por biomasa en el edificio D11. 


\section{AIV.11.6.Estimación del precio máximo de compra a la red.}

Tomando como referencia los precios del gas natural de la Tabla 383 para cada temporada, obtenidos a partir de los datos establecidos en el Capítulo 3, donde se tiene en cuenta el precio por el termino variable y fijo; se puede realizar la estimación del precio máximo de compra de la energía útil a la red de calor para obtener un $0 \%$ de ahorro y un $15 \%$ de ahorro. La Tabla 384, muestral el precio que se pagaría para un ahorro del $15 \%$

Tabla 383. Precios de referencia para Gas natural y Astilla

\begin{tabular}{ccccc}
\hline Precios ( $€ /(\mathrm{kWh})$ & 2015 & 2016 & 2017 & 2018 \\
\hline Gas Natural & 0,0373 & 0,0306 & 0,0314 & 0,0336 \\
\hline Astilla & 0,0277 & 0,0256 & 0,0254 & 0,0239 \\
\hline $\begin{array}{c}€ / \text { kWh útiles máximos de compra a la red para } \\
\text { un ahorro del } 0,0 \%\end{array}$ & 0,03228 & \\
\hline $\begin{array}{c}€ / \text { kWh útiles máximos de compra a la red para } \\
\text { un ahorro del } 15,0 \%\end{array}$ & 0,02710 & \\
\hline
\end{tabular}

Tabla 384. Ahorro Económico por el consumo térmico en el Edificio D11

\begin{tabular}{|c|c|c|c|c|c|c|c|c|c|c|}
\hline & $\begin{array}{c}\text { kWh_D11 } \\
\text { _Gas } \\
\text { Natural }\end{array}$ & $\begin{array}{c}\text { kWh_D11__ } \\
\text { Biomasa }\end{array}$ & $\begin{array}{c}\text { kWh_D11 } \\
\text { Real }\end{array}$ & $\begin{array}{c}\text { kWh_D11 } \\
\text { Pronosticado }\end{array}$ & $\begin{array}{c}\text { € Real } \\
\text { Gas } \\
\text { Natural }\end{array}$ & $\begin{array}{c}€ \text { Real } \\
\text { Biomasa }\end{array}$ & $\begin{array}{l}€ \text { Real } \\
\text { Total }\end{array}$ & $\begin{array}{c}\text { E predicho } \\
\text { Gas } \\
\text { natural }\end{array}$ & $\begin{array}{c}€ \\
\text { Ahorro }\end{array}$ & $€$ Acumulado \\
\hline oct-2015 & 0 & 8.810 & 8.810 & 8.810 & 0 & 239 & 239 & 329 & 90 & 90 \\
\hline nov-2015 & 0 & 71.160 & 71.160 & 71.160 & 0 & 1.928 & 1.928 & 2.654 & 726 & 816 \\
\hline dic-2015 & 0 & 68.390 & 68.390 & 68.390 & 0 & 1.853 & 1.853 & 2.551 & 698 & 1.513 \\
\hline ene-2016 & 0 & 77.420 & 77.420 & 77.420 & 0 & 2.098 & 2.098 & 2.369 & 271 & 1.784 \\
\hline feb-2016 & 76.228 & 111.170 & 187.398 & 187.398 & 2.333 & 3.013 & 5.345 & 5.734 & 389 & 2.173 \\
\hline mar-2016 & 6.040 & 80.530 & 86.570 & 86.570 & 185 & 2.182 & 2.367 & 2.649 & 282 & 2.455 \\
\hline abr-2016 & 284 & 60.370 & 60.654 & 60.654 & 9 & 1.636 & 1.645 & 1.856 & 211 & 2.666 \\
\hline may-2016 & 0 & 11.790 & 11.790 & 11.790 & 0 & 320 & 320 & 361 & 41 & 2.708 \\
\hline oct-2016 & 12.513 & 10.900 & 23.413 & 23.413 & 383 & 295 & 678 & 716 & 38 & 2.746 \\
\hline nov-2016 & 3.736 & 97.720 & 101.456 & 101.456 & 114 & 2.648 & 2.763 & 3.105 & 342 & 3.088 \\
\hline dic-2016 & 2.232 & 61.860 & 64.092 & 64.092 & 68 & 1.676 & 1.745 & 1.961 & 217 & 3.304 \\
\hline ene-2017 & 10.209 & 133.300 & 143.509 & 143.509 & 321 & 3.612 & 3.933 & 4.506 & 573 & 3.878 \\
\hline feb-2017 & 64 & 88.590 & 88.654 & 88.654 & 2 & 2.401 & 2.403 & 2.784 & 381 & 4.259 \\
\hline mar-2017 & 0 & 69.390 & 69.390 & 69.390 & 0 & 1.880 & 1.880 & 2.179 & 298 & 4.557 \\
\hline$a b r-2017$ & 568 & 31.820 & 32.388 & 32.388 & 18 & 862 & 880 & 1.017 & 137 & 4.694 \\
\hline may-2017 & 0 & 9.030 & 9.030 & 9.030 & 0 & 245 & 245 & 284 & 39 & 4.733 \\
\hline oct-2017 & 0 & 5.700 & 5.700 & 5.700 & 0 & 154 & 154 & 179 & 25 & 4.757 \\
\hline nov-2017 & 416 & 71.140 & 71.556 & 71.556 & 13 & 1.928 & 1.941 & 2.247 & 306 & 5.063 \\
\hline dic-2017 & 2.032 & 122.790 & 124.822 & 124.822 & 64 & 3.328 & 3.391 & 3.919 & 528 & 5.591 \\
\hline ene-2018 & 560 & 122.850 & 123.410 & 123.410 & 19 & 3.329 & 3.348 & 4.147 & 799 & 6.390 \\
\hline feb-2018 & 0 & 137.100 & 137.100 & 137.100 & 0 & 3.715 & 3.715 & 4.607 & 891 & 7.281 \\
\hline mar-2018 & 2.544 & 108.100 & 110.644 & 110.644 & 85 & 2.930 & 3.015 & 3.718 & 703 & 7.983 \\
\hline$a b r-2018$ & 440 & 55.140 & 55.580 & 55.580 & 15 & 1.494 & 1.509 & 1.867 & 358 & 8.342 \\
\hline may-2018 & 0 & 15.860 & 15.860 & 15.860 & 0 & 430 & 430 & 533 & 103 & 8.445 \\
\hline$€$ Total & & & & & & & 47.826 & 56.271 & & \\
\hline Ahorro (\%) & & & & & & & & & & $15,0 \%$ \\
\hline
\end{tabular}




\section{AIV.12.Edificio D12. Edificio de I+D.}

\section{AIV.12.1.Obtención de la línea base de referencia energética}

Los datos de partida para la obtención de la línea base de referencia se muestran en la Tabla 385

Tabla 385. Consumos térmicos del edificio D12

\begin{tabular}{lr}
\hline & Consumos térmicos (kWh). D12 \\
\hline oct-12 & 20.755 \\
\hline nov-12 & 39.191 \\
\hline dic-12 & 52.395 \\
\hline ene-13 & 55.517 \\
\hline feb-13 & 53.024 \\
\hline mar-13 & 42.283 \\
\hline abr-13 & 31.248 \\
\hline may-13 & 24.925 \\
\hline oct-13 & 15.683 \\
\hline nov-13 & 41.737 \\
\hline dic-13 & 65.261 \\
\hline ene-14 & 48.884 \\
\hline feb-14 & 45.304 \\
\hline mar-14 & 34.339 \\
\hline abr-14 & 17.680 \\
\hline may-14 & 15.308 \\
\hline Promedio & 37.721 \\
\hline Total (oct-12-may-13) & 319.338 \\
\hline Total (oct-13-may-14) & 284.196 \\
\hline Total (oct-12-may-13) & 603.534 \\
\hline
\end{tabular}

Se disponen de 16 datos para establecer el modelo de regresión, mediante el método de pasos sucesivos. Como se puede ver en la Tabla 386 para el edificio, el método ofrece un modelo de regresión, con una sola variable (Grados Día en base 15, obtenidos con datos cada 30 minutos). El modelo fue construido con un solo paso, incluyendo los Grados día base 15 por ser la variable más significativa (variable con menor valor de Sig $=0,000$ ). El resto de las variables como se observa en la Tabla 387 fueron excluidas del modelo al tener valores de sig $>0,05$.

Tabla 386. Modelos de regresión del Edificio D12

\begin{tabular}{|c|c|c|c|c|c|c|c|}
\hline & \multirow[t]{2}{*}{ Modelo } & \multicolumn{2}{|c|}{$\begin{array}{l}\text { Coeficientes no } \\
\text { estandarizados }\end{array}$} & \multirow[t]{2}{*}{$\mathrm{t}$} & \multirow[t]{2}{*}{ Sig. } & \multicolumn{2}{|c|}{$\begin{array}{c}\text { Intervalo de confianza de } 95,0 \% \\
\text { para B }\end{array}$} \\
\hline & & $\mathrm{B}$ & Error típ. & & & Límite inferior & Límite superior \\
\hline & (Constante) & $-663,549$ & 436,148 & $-1,521$ & 150 & $-1598,993$ & 271,894 \\
\hline & GD15_30min & 173,214 & 1,832 & 94,550 & ,000 & 169,285 & 177,144 \\
\hline
\end{tabular}


En la Figura 284 se representa el modelo de regresión con sus límites inferior y superior para un nivel de confianza del $95 \%$

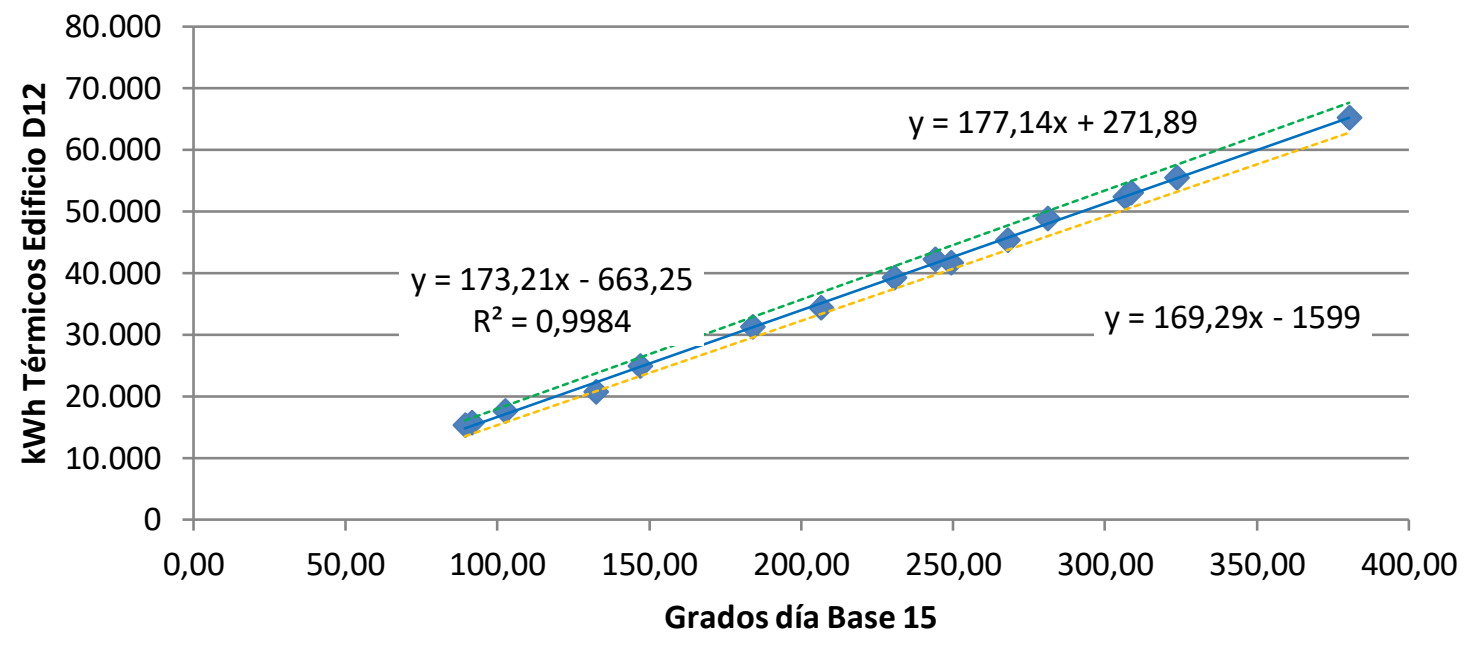

$$
\begin{aligned}
& \rightarrow \quad \mathrm{D} 12(\mathrm{kWh}) \quad \text { Lineal (D12 (kWh)) } \\
& \text { Lineal (D12 lim inferior) -------- Lineal (D12 lím superior) }
\end{aligned}
$$

Figura 284. Representación del modelo de regresión lineal simple para el Edificio D12

\begin{tabular}{|c|c|c|c|c|}
\hline & Modelo & $\mathrm{t}$ & Sig. & Correlación parcial \\
\hline \multirow{19}{*}{1} & GD20_30min &, 040 & ,969 & 011 \\
\hline & GD15_24h &,- 572 & ,577 &,- 157 \\
\hline & GD20_24h &,- 042 & ,967 &,- 012 \\
\hline & T_med_30min_C & ,404 & ,693 & 111 \\
\hline & T_media_diurna_C &, 092 & ,928 &, 025 \\
\hline & T_max_C &,- 299 & ,769 &,- 083 \\
\hline & T_min_C & ,800 & ,438 & ,217 \\
\hline & HR_\% & 199 & ,845 & 055 \\
\hline & HR_med_diurna_\% & 144 & ,887 & 040 \\
\hline & HR_max_\% & ,340 & ,739 & 094 \\
\hline & HR_min_\% & ,315 & ,758 & 087 \\
\hline & Radiación_W/m2 & ,642 &, 532 & 175 \\
\hline & V_Viento_m/s & ,838 & ,417 & ,226 \\
\hline & V_viento_diurna_m/s & ,731 & ,478 & ,199 \\
\hline & V_viento_nocturna_m/s & ,973 & ,348 & ,261 \\
\hline & V_viento_max_m/s & ,619 &, 547 & ,169 \\
\hline & Recorrido_viento_km/día & ,839 & ,416 &, 227 \\
\hline & Precipitación_acumulada_mes_mm &,- 055 & ,957 &,- 015 \\
\hline & Horas insolación_h & ,419 & ,682 & ,115 \\
\hline
\end{tabular}

Tabla 387. Variables excluidas del modelo de región del Edificio D12 
La bondad de los modelos de regresión obtenidos para el edificio D12, se resumen en la Tabla 388

Tabla 388. Resumen de la bondad de los modelos de regresión para el Edificio D12

\begin{tabular}{ccccc}
\hline Modelo & $\mathrm{R}$ & $\mathrm{R}$ cuadrado & $\mathrm{R}$ cuadrado corregida & $\begin{array}{c}\text { Error típ. de la } \\
\text { estimación }\end{array}$ \\
\hline 1 &, 999 &, 998 &, 998 & 637,64415 \\
\hline
\end{tabular}

Se observa como el modelo de regresión lineal simple presenta un Coeficiente de Correlación de Pearson (R) de 0,999, lo que indica que las variables están correlacionadas de manera muy fuerte (en la correlación perfecta $R= \pm 1$ ). La correlación que se produce es directa, al aumentar el valor de los Grados día, aumenta el consumo térmico.

El coeficiente de determinación $\left(\mathrm{R}^{2}\right)$, nos indica que con el modelo se podría explicar el $99,8 \%$ de los datos reales obtenidos aceptando un error del $5 \%$.

El error típico de la estimación que nos indica la magnitud de los errores, es decir la parte de la variable dependiente que dejamos sin explicar con el modelo y que describe la variación de la variable respuesta (el Consumo) respecto a la recta de regresión, es de 638 $\mathrm{kWh}$, lo que representa un $1,7 \%$ del promedio de los consumos que fue de $37.721 \mathrm{kWh}$.

\section{AIV.12.2. Verificación del cumplimiento de los supuestos estadísticos}

Las condiciones que se deben cumplir en un modelo de regresión son:

- Linealidad de las variables, las variables se encuentran relacionadas de forma lineal.

Como se observa en la Tabla 386, la pendiente (B), obtuvo un valor de Sig $=0,000$, que al ser $\leq 0,05$, nos indica que podemos rechazar la hipótesis nula de pendiente igual a cero y nos da la evidencia de linealidad entre la variable dependiente ( $k$ Wh del edificio D12) y la independiente (GD15_30min). Al ser el valor de la pendiente positiva, indica una relación directa entre el consumo y los Grados día base 15.

- Normalidad. Todos los valores obtenidos para la variable dependiente (Y), deben estar distribuidos normalmente en cada valor de la variable independiente $(X)$.

Se comprueba la normalidad de las variables y de los residuos mediante el Test de Shapiro - Wilk para muestras pequeñas (menores a 30 observaciones), siendo la hipótesis nula el que la distribución es Normal. 
La Tabla 389, muestra la prueba de normalidad de Shapiro-Wilk y cómo tanto la variable dependiente (consumos del Edificio), como la variable independientes: GD15 poseen una Sig $>0,05$, por lo que aceptamos la hipótesis nula de Normalidad de las variables

Tabla 389. Prueba de normalidad para el edificio D12

\begin{tabular}{lrrrrrr}
\hline & \multicolumn{3}{c}{ Kolmogorov-Smirnov } & \multicolumn{3}{c}{ Shapiro-Wilk } \\
\cline { 2 - 8 } & Estadístico & gl & Sig. & Estadístico & gl & \multicolumn{1}{c}{ Sig. } \\
\hline kWh_D12 &, 112 & 16 &, 200 &, 950 & 16 &, 489 \\
\hline GD15_30min &, 109 & 16 &, 200 &, 953 & 16 &, 541 \\
\hline
\end{tabular}

- Independencia de los errores. Los errores asociados a los valores de la variable respuesta $(Y)$ deberán ser independientes unos de otros.

Para la comprobación se utiliza el estadístico de Durbin -Watson.

Se comprueba que el Estadístico de Durbin Watson para el nivel de significancia del 5\%, y para el tamaño de la muestra " $n$ " y el número de variables independientes del modelo " $k$ ", se encuentra en el intervalo [dU, 4-dU], de la Tabla 3, intervalo centrado en el 2, que indica la ausencia de autocorrelación.

El valor del Estadístico Durbin-Watson facilitado por el programa SPSS, es 1,583.

En el modelo, $n=16$ y $k=1$, según la Tabla 3 el valor $\mathrm{dU}=1,371$, luego el intervalo que marca la ausencia de correlación es [1,371, 2,629], como el valor del estadístico 1,583 está dentro del intervalo, se acepta la ausencia de autocorrelación

- Homocedasticidad de la varianza. Se pretende comprobar que la varianza de los errores $\left(\sigma^{2}\right)$ es constante para cualquier valor de la variable independiente $(X)$, es decir que el valor medio del cuadrado de la desviación de los errores respecto a su media es constante.

Esta condición indica que no existe correlación entre los residuos y los pronósticos. Se comprueba que el coeficiente de determinación $\mathrm{R}^{2}$, en las relaciones: residuos $\mathrm{y}$ predicciones y entre residuos y variable independiente es nulo o muy próximo a cero, lo que indicará que no existe ningún tipo de correlación en los residuos y que éstos son aleatorios.

Se grafican los diagramas de dispersión de esas relaciones, comprobando que se corresponden a nubes de puntos totalmente aleatorias, sin tendencias ni patrones en sus representaciones gráficas. 
Las Figura 285 y Figura 286, muestran que la relación entre los pronósticos y los residuos, posee un coeficiente de determinación $=0$ y entre la variable independiente (Grados día base 15) y los residuos un coeficiente de determinación también de 0; por lo que se concluye que no existe ningún tipo de correlación en los residuos y que éstos son aleatorios, siendo la varianza de los residuos constante

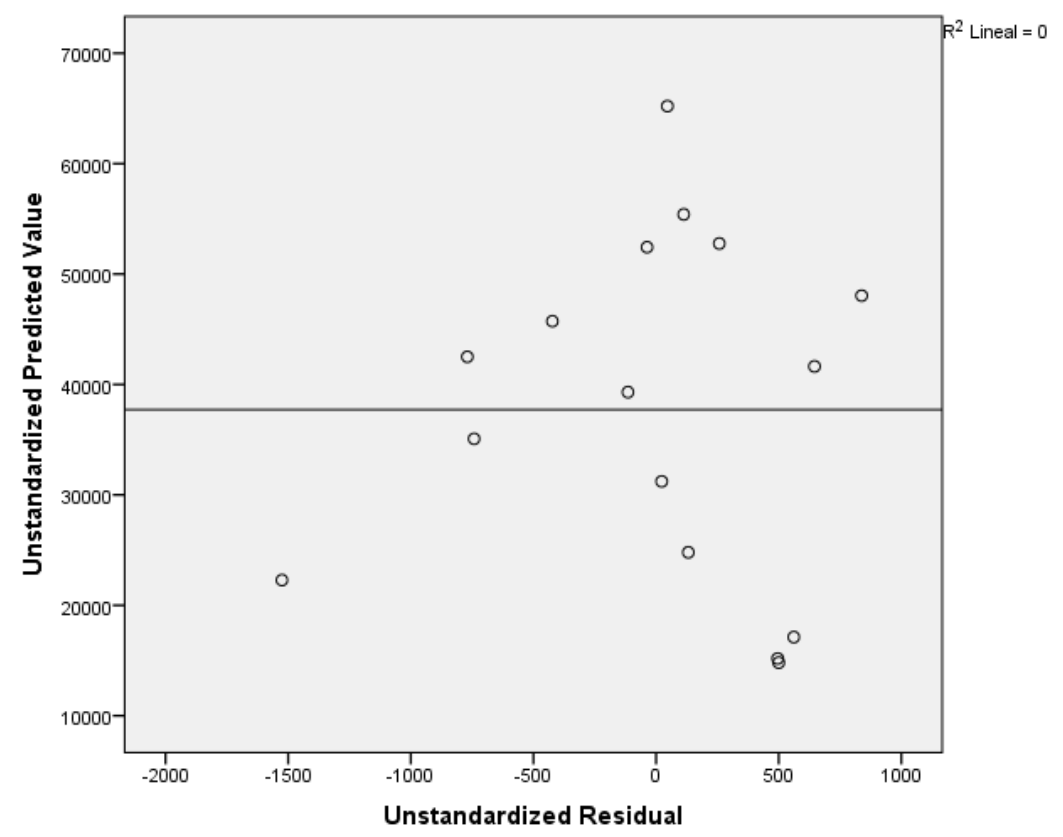

Figura 285. Relación entre los pronósticos y los residuos en el Edificio D12

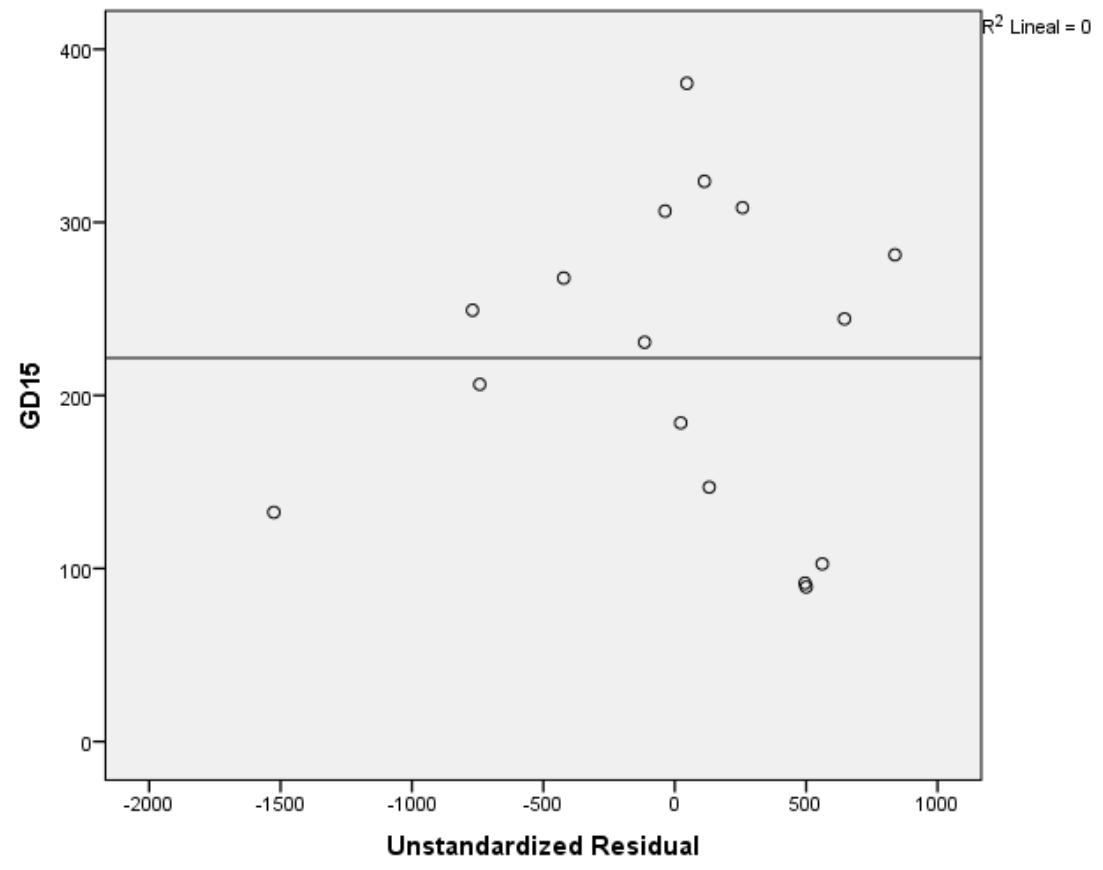

Figura 286. Relación entre GD15 y los residuos en el Edificio D12 


\section{AIV.12.3.Obtención de los consumos térmicos previstos}

Una vez comprobado el cumplimiento de los supuestos estadísticos se acepta el modelo de línea base encontrado para modelizar el consumo del Edificio D12.

$$
\text { kWh_D12_Pronosticado }=-663,549+173,214 \times \text { GD15_30min }
$$

Con este modelo se procede a predecir los consumos previstos para las temporadas: octubre 2015-mayo 2016, octubre 2016 - mayo 2017 y octubre 2017-mayo 2018, estos consumos se muestran en la Tabla 390, donde "KWh_D12_Real", representa el consumo real, "kWh_D12_Pronosticado", el consumo pronosticado con el Modelo.

Tabla 390. Consumos previstos octubre 2014 - mayo 2017 para el edificio D12.

\begin{tabular}{rrrr}
\hline & \multicolumn{1}{c}{ GD15 } & kWh_D12_Real & kWh_D12_Pronosticado \\
\hline oct-15 & 97,04 & 6.590 & 16.146 \\
\hline nov-15 & 208,36 & 36.550 & 35.428 \\
\hline dic-15 & 300,09 & 34.820 & 51.317 \\
\hline ene-16 & 271,93 & 39.180 & 46.439 \\
\hline feb-16 & 266,36 & 58.477 & 45.474 \\
\hline mar-16 & 276,34 & 44.763 & 47.202 \\
\hline abr-16 & 181,04 & 27.410 & 30.696 \\
\hline may-16 & 99,34 & 6.310 & 16.543 \\
\hline oct-16 & 97,34 & 7.600 & 16.197 \\
\hline nov-16 & 245,69 & 35.820 & 41.893 \\
\hline dic-16 & 337,25 & 39.872 & 57.753 \\
\hline ene-17 & 386,98 & 47.548 & 66.368 \\
\hline feb-17 & 226,76 & 33.393 & 38.614 \\
\hline mar-17 & 203,17 & 33.195 & 34.528 \\
\hline abr-17 & 129,72 & 12.700 & 21.806 \\
\hline may-17 & 54,86 & 2.318 & 8.839 \\
\hline oct-17 & 92,31 & 3.530 & 15.327 \\
\hline nov-17 & 271,60 & 33.788 & 46.382 \\
\hline dic-17 & 341,26 & 46.710 & 58.447 \\
\hline ene-18 & 327,94 & 51.528 & 56.141 \\
\hline feb-18 & 321,27 & 59.290 & 54.984 \\
\hline mar-18 & 255,02 & 52.218 & 43.509 \\
\hline abr-18 & 143,31 & 29.262 & 24.159 \\
\hline may-18 & 78,41 & 5.570 & 12.918 \\
\hline & & &
\end{tabular}




\section{AIV.12.4.Estudio de la existencia de diferencias significativas}

Utilizando la prueba " $\mathrm{t}$ " de Student para muestras relacionadas, podemos concluir que si las variables se distribuyen según una normal y la significación estadística resulta $\leq 0,05$, existen diferencias significativas, con un nivel de confianza del $95 \%$

A continuación se muestra la comparación de medias realizada para cada uno de los tres periodos posteriores a la construcción de la red y para el periodo total hasta mayo de 2018.

Para la temporada Octubre 2015 - Mayo 2016, se comprueba mediante el Test de Shapiro -Wilk que tanto los valores reales como los pronosticados se distribuyen según una Normal puesto que en todos los casos los valores de Sig $>0,05$, como se observa en la Tabla 391

Tabla 391. Prueba de Normalidad temporada Octubre 2015-Mayo 2016. Edificio D12

\begin{tabular}{ccccrrrr}
\hline & \multicolumn{3}{c}{ Kolmogorov-Smirnov $^{\mathrm{a}}$} & \multicolumn{3}{c}{ Shapiro-Wilk } \\
\cline { 2 - 8 } & Estadístico & gl & Sig. & Estadístico & gl & \multicolumn{1}{c}{ Sig. } \\
\hline kWh_real &, 192 & 8 &, 200 &, 924 & 8 &, 461 \\
\hline kWh_pronosticado &, 248 & 8 &, 159 &, 865 & 8 &, 135 \\
\hline
\end{tabular}

En la Tabla 392, se observa como las medias de los consumos pronosticados, son superiores a las medias de los consumos reales del Edificio D12, en un 13,8\%

Tabla 392. Estadísticos de muestras relacionadas. Octubre 2015-Mayo 2016. Edificio D12

\begin{tabular}{lccrcc}
\hline & Media & $\begin{array}{c}\text { \% Diferencia } \\
\text { entre medias }\end{array}$ & $\mathrm{N}$ & $\begin{array}{c}\text { Desviación } \\
\text { típ. }\end{array}$ & $\begin{array}{c}\text { Error típ. de } \\
\text { la media }\end{array}$ \\
\hline kWh_real & 31762,5000 & & 8 & 18009,49768 & 6367,31897 \\
\hline kWh_pronosticado & 36155,6250 & $13,8 \%$ & 8 & 13937,85545 & 4927,77605 \\
\hline
\end{tabular}

La Tabla 393 muestra que las diferencias entre las medias no son significativas entre los consumos reales y los pronosticados (sig $>0,05$ ), a pesar de existir ese $13,8 \%$ de diferencia

Tabla 393. Prueba de muestras relacionadas. Octubre 2015-Mayo 2016. Edificio D12

\begin{tabular}{|c|c|c|c|c|c|c|c|c|c|}
\hline & & \multicolumn{5}{|c|}{ Diferencias relacionadas } & \multirow{3}{*}{$\mathrm{t}$} & \multirow{3}{*}{ gl } & \multirow{3}{*}{$\begin{array}{c}\text { Sig. } \\
\text { (bilateral) }\end{array}$} \\
\hline & & \multirow[t]{2}{*}{ Media } & \multirow{2}{*}{$\begin{array}{l}\text { Desviación } \\
\text { típ. }\end{array}$} & \multirow{2}{*}{$\begin{array}{l}\text { Error típ. } \\
\text { de la media }\end{array}$} & \multicolumn{2}{|c|}{$\begin{array}{l}\text { 95\% Intervalo de confianza } \\
\text { para la diferencia }\end{array}$} & & & \\
\hline & & & & & Inferior & Superior & & & \\
\hline Par 1 & $\begin{array}{c}\text { kWh_real - } \\
\text { kWh_pronosticado }\end{array}$ & $-4393,125$ & 8892,714 & 3144,049 & $-11827,620$ & 3041,370 & $-1,397$ & 7 & ,205 \\
\hline
\end{tabular}


En la Figura 287, se grafican los consumos reales y pronosticados para la temporada Octubre 2015 - Mayo 2016 para el Edificio D12, y las medias de dichos consumos. Según la prueba paramétrica realizada las diferencias encontradas no son estadísticamente significativas, por lo que no se puede afirmar la existencia de ahorros en el consumo térmico entre la situación anterior y posterior a la red de calor, con un riesgo a estar equivocados del $5 \%$

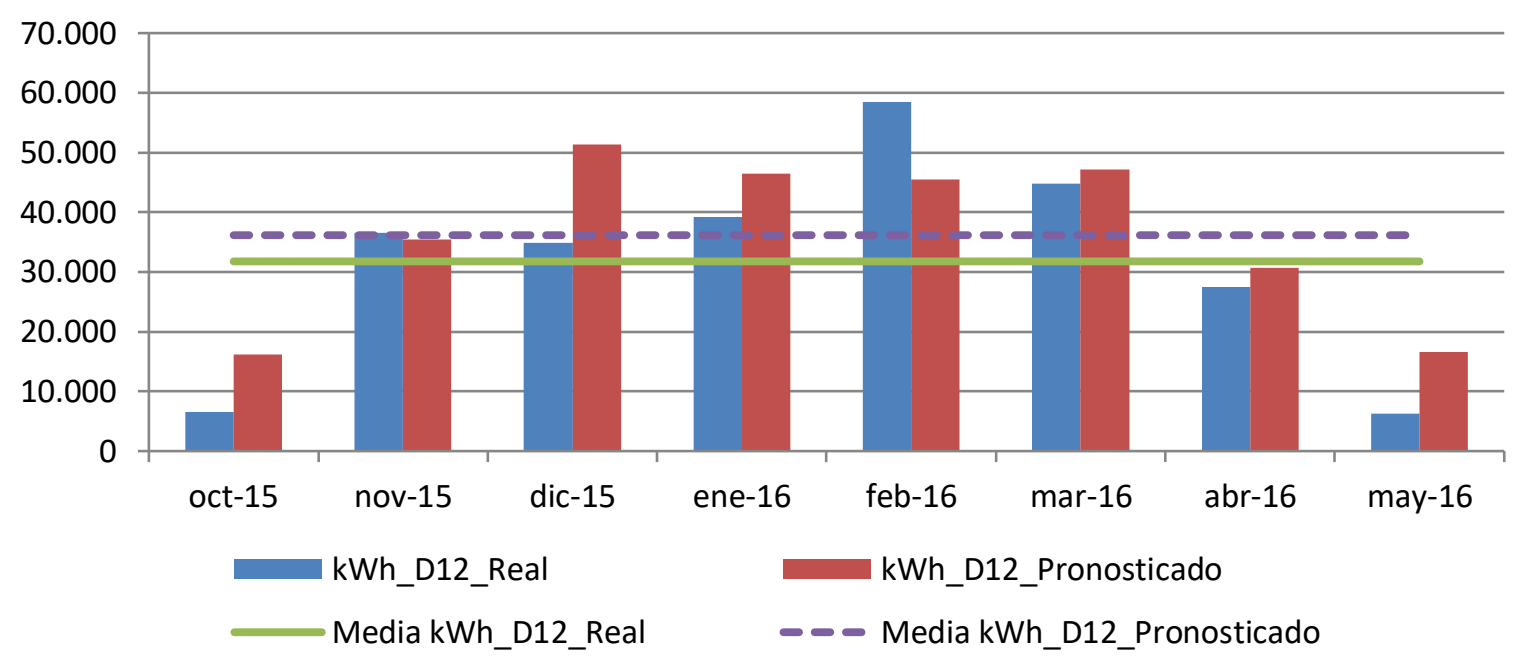

Figura 287. Consumos reales y pronosticados Octubre 2015-Mayo 2016. Edificio D12

Para la temporada Octubre 2016 - Mayo 2017, se comprueba mediante el Test de Shapiro -Wilk que tanto los valores reales como los pronosticados con los dos modelos se distribuyen según una Normal puesto que en todos los casos los valores de Sig >0,05, como se observa en la Tabla 394

Tabla 394. Prueba de Normalidad temporada Octubre 2016-Mayo 2017. Edificio D12

\begin{tabular}{crrrrrrr}
\hline & \multicolumn{3}{c}{ Kolmogorov-Smirnov $^{\mathrm{a}}$} & \multicolumn{3}{c}{ Shapiro-Wilk } \\
\cline { 2 - 8 } & Estadístico & gl & \multicolumn{1}{c}{ Sig. } & Estadístico & gl & \multicolumn{1}{c}{ Sig. } \\
\hline kWh_real &, 280 & 8 &, 064 &, 897 & 8 &, 269 \\
\hline kWh_pronosticado &, 133 & 8 &, 200 &, 965 & 8 &, 856 \\
\hline
\end{tabular}

En la Tabla 395, se observa como las medias de los consumos pronosticados, son superiores a las medias de los consumos reales del Edificio D12, en un $34,6 \%$

Tabla 395. Estadísticos de muestras relacionadas. Octubre 2016-Mayo 2017. Edificio D12

\begin{tabular}{lccrcc}
\hline & Media & $\begin{array}{c}\text { \% Diferencia } \\
\text { entre medias }\end{array}$ & $\mathrm{N}$ & $\begin{array}{c}\text { Desviación } \\
\text { típ. }\end{array}$ & $\begin{array}{c}\text { Error típ. de } \\
\text { la media }\end{array}$ \\
\hline kWh_real & 26555,7500 & & 8 & 16619,35972 & 5875,83098 \\
\hline kWh_pronosticado & 35749,7500 & $34,6 \%$ & 8 & 19892,50766 & 7033,06353 \\
\hline
\end{tabular}


La Tabla 396 muestra que las diferencias entre las medias son significativas entre los consumos reales y los pronosticados (sig $\leq 0,05)$

Tabla 396. Prueba de muestras relacionadas. Octubre 2016-Mayo 2017. Edificio D12

\begin{tabular}{|c|c|c|c|c|c|c|c|c|c|}
\hline & & \multicolumn{5}{|c|}{ Diferencias relacionadas } & \multirow{3}{*}{$\mathrm{t}$} & \multirow{3}{*}{$\mathrm{gl}$} & \multirow{3}{*}{$\begin{array}{c}\text { Sig. } \\
\text { (bilateral) }\end{array}$} \\
\hline & & \multirow[t]{2}{*}{ Media } & \multirow{2}{*}{$\begin{array}{l}\text { Desviación } \\
\text { típ. }\end{array}$} & \multirow{2}{*}{$\begin{array}{c}\text { Error típ. } \\
\text { de la media }\end{array}$} & \multicolumn{2}{|c|}{$\begin{array}{l}\text { 95\% Intervalo de confianza } \\
\text { para la diferencia }\end{array}$} & & & \\
\hline & & & & & Inferior & Superior & & & \\
\hline Par 1 & $\begin{array}{c}\text { kWh_real - } \\
\text { kWh_pronosticado }\end{array}$ & $-9194,000$ & 6129,013 & 2166,933 & $-14317,983$ & $-4070,017$ & $-4,243$ & 7 &, 004 \\
\hline
\end{tabular}

En la Figura 288 se grafican los consumos reales y pronosticados para la temporada Octubre 2016 - Mayo 2017 para el Edificio D12, y las medias de dichos consumos. Según la prueba paramétrica realizada las diferencias encontradas son estadísticamente significativas, con un riesgo a estar equivocados del $5 \%$

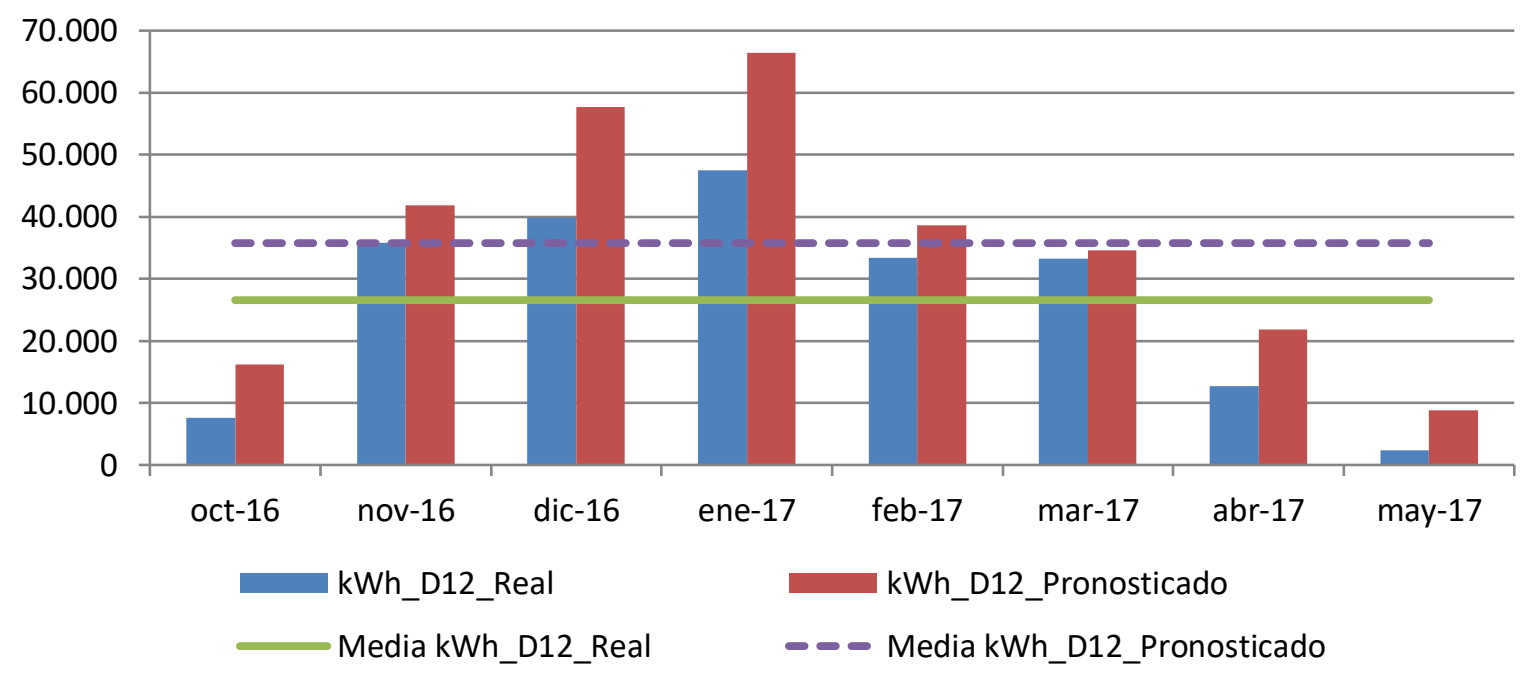

Figura 288. Consumos reales y pronosticados Octubre 2016-Mayo 2017. Edificio D12

Para la temporada Octubre 2017 - Mayo 2018, se comprueba mediante el Test de Shapiro -Wilk que tanto los valores reales como los pronosticados se distribuyen según una Normal puesto que en todos los casos los valores de Sig $>0,05$, como se observa en la Tabla 397

Tabla 397. Prueba de Normalidad temporada Octubre 2017-Mayo 2018. Edificio D12

\begin{tabular}{cccccccr}
\hline & \multicolumn{3}{c}{ Kolmogorov-Smirnov $^{\mathrm{a}}$} & \multicolumn{3}{c}{ Shapiro-Wilk } \\
\cline { 2 - 9 } & Estadístico & gl & Sig. & Estadístico & gl & \multicolumn{1}{c}{ Sig. } \\
\hline kWh_real &, 205 & 8 &, 200 &, 885 & 8 &, 212 \\
\hline kWh_pronosticado &, 220 & 8 &, 200 &, 860 & 8 &, 119 \\
\hline
\end{tabular}


En la Tabla 398, se observa como las medias de los consumos pronosticados, son superiores a las medias de los consumos reales del Edificio D12, en un 10,6\%

Tabla 398. Estadísticos de muestras relacionadas. Octubre 2017-Mayo 2018. Edificio D12

\begin{tabular}{lccrcc}
\hline & Media & $\begin{array}{c}\text { \% Diferencia } \\
\text { entre medias }\end{array}$ & $\mathrm{N}$ & $\begin{array}{c}\text { Desviación } \\
\text { típ. }\end{array}$ & $\begin{array}{c}\text { Error típ. de } \\
\text { la media }\end{array}$ \\
\hline kWh_real & 35237,0000 & & 8 & 21338,06975 & 7544,14691 \\
\hline kWh_pronosticado & 38983,3750 & $10,6 \%$ & 8 & 18758,79860 & 6632,23685 \\
\hline
\end{tabular}

La Tabla 399 muestra que las diferencias entre las medias no son significativas entre los consumos reales y los pronosticados (sig $>0,05$ ), a pesar del $10,6 \%$ de diferencia

Tabla 399. Prueba de muestras relacionadas. Octubre 2017-Mayo 2018. Edificio D12

\begin{tabular}{|c|c|c|c|c|c|c|c|c|c|}
\hline & & \multicolumn{5}{|c|}{ Diferencias relacionadas } & \multirow{3}{*}{$\mathrm{t}$} & \multirow{3}{*}{ gl } & \multirow{3}{*}{$\begin{array}{c}\text { Sig. } \\
\text { (bilateral) }\end{array}$} \\
\hline & & \multirow[t]{2}{*}{ Media } & \multirow{2}{*}{$\begin{array}{l}\text { Desviación } \\
\text { típ. }\end{array}$} & \multirow{2}{*}{$\begin{array}{c}\text { Error típ. } \\
\text { de la media }\end{array}$} & \multicolumn{2}{|c|}{$\begin{array}{l}\text { 95\% Intervalo de confianza } \\
\text { para la diferencia }\end{array}$} & & & \\
\hline & & & & & Inferior & Superior & & & \\
\hline Par 1 & $\begin{array}{c}\text { kWh_real - } \\
\text { kWh_pronosticado }\end{array}$ & $-3746,375$ & 8610,246 & 3044,182 & $-10944,721$ & 3451,971 & $-1,231$ & 7 & ,258 \\
\hline
\end{tabular}

En la Figura 289, se grafican los consumos reales y pronosticados para la temporada Octubre 2017 - Mayo 2018 para el Edificio D12, y las medias de dichos consumos. Según la prueba paramétrica realizada las diferencias encontradas no son estadísticamente significativas, con un riesgo a estar equivocados del $5 \%$

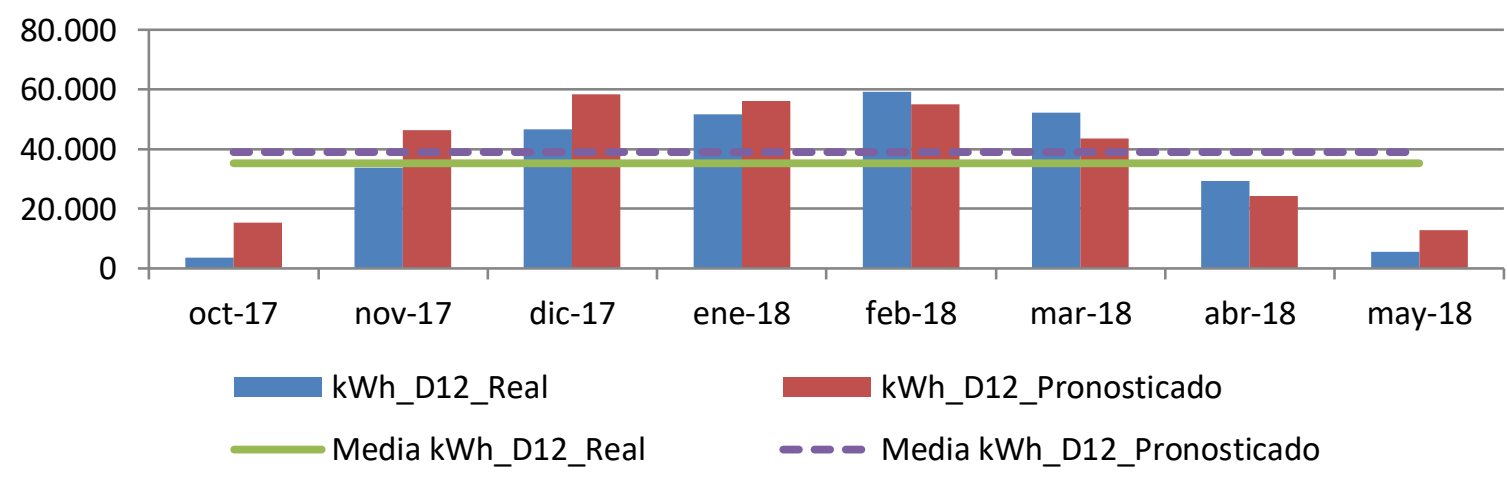

Figura 289. Consumos reales y pronosticados Octubre 2017-Mayo 2018. Edificio D12

Para el total de las tres temporadas Octubre 2015 - Mayo 2018, se comprueba mediante el Test de Shapiro -Wilk, que los valores reales y los pronosticados se distribuyen según una Normal puesto que en esos casos los valores de Sig $>0,05$, como se observa en la Tabla 400 
Tabla 400. Prueba de Normalidad temporada Octubre 2015-Mayo 2018. Edificio D12

\begin{tabular}{ccccrrrr}
\hline & \multicolumn{3}{c}{ Kolmogorov-Smirnov $^{\mathrm{a}}$} & \multicolumn{3}{c}{ Shapiro-Wilk } \\
\cline { 2 - 8 } & Estadístico & gl & Sig. & Estadístico & gl & Sig. \\
\hline kWh_real &, 169 & 24 &, 075 &, 914 & 24 &, 052 \\
\hline kWh_pronosticado &, 135 & 24 &, 200 &, 942 & 24 &, 183 \\
\hline
\end{tabular}

En la Tabla 401 se observa como las medias de los consumos pronosticados, son superiores a las medias de los consumos reales del Edificio D12, en un $18,5 \%$

Tabla 401. Estadísticos de muestras relacionadas. Octubre 2015-Mayo 2018. Edificio D12

\begin{tabular}{lccccc}
\hline & Media & $\begin{array}{c}\text { \% Diferencia } \\
\text { entre medias }\end{array}$ & $\mathrm{N}$ & $\begin{array}{c}\text { Desviación } \\
\text { típ. }\end{array}$ & $\begin{array}{c}\text { Error típ. de } \\
\text { la media }\end{array}$ \\
\hline kWh_real & 31185,0833 & & 24 & 18292,86596 & 3734,01563 \\
\hline kWh_pronosticado & 36962,9167 & $18,5 \%$ & 24 & 16994,53028 & 3468,99397 \\
\hline
\end{tabular}

La Tabla 402 muestra que las diferencias entre las medias son significativas entre los consumos reales y los pronosticados (sig $\leq 0,05)$

Tabla 402. Prueba de muestras relacionadas. Octubre 2015-Mayo 2018. Edificio D12

\begin{tabular}{|c|c|c|c|c|c|c|c|c|}
\hline & \multicolumn{5}{|c|}{ Diferencias relacionadas } & \multirow{3}{*}{$\mathrm{t}$} & \multirow{3}{*}{ gl } & \multirow{3}{*}{$\begin{array}{c}\text { Sig. } \\
\text { (bilateral) }\end{array}$} \\
\hline & \multirow[t]{2}{*}{ Media } & \multirow{2}{*}{$\begin{array}{l}\text { Desviación } \\
\text { típ. }\end{array}$} & \multirow{2}{*}{$\begin{array}{c}\text { Error típ. de } \\
\text { la media }\end{array}$} & \multicolumn{2}{|c|}{$\begin{array}{c}\text { 95\% Intervalo de confianza } \\
\text { para la diferencia }\end{array}$} & & & \\
\hline & & & & Inferior & Superior & & & \\
\hline $\begin{array}{c}\text { kWh_real - } \\
\text { kWh_pronosticado }\end{array}$ & $-5777,833$ & 8014,080 & 1635,867 & $-9161,882$ & $-2393,784$ & $-3,532$ & 23 & ,002 \\
\hline
\end{tabular}




\section{AIV.12.5.Estimación de las emisiones de $\mathrm{CO} 2$ evitadas.}

Teniendo en cuenta que el consumir Gas natural se producen $0,252 \mathrm{~kg} \mathrm{CO}_{2} / \mathrm{kWh} \mathrm{E}$. final y que al consumir la energía suministrada por red a partir de Biomasa se producen 0,024 $\mathrm{kg}$ $\mathrm{CO}_{2} / \mathrm{kWh}$. final, en la Tabla 403, se muestra las emisiones de $\mathrm{CO}_{2}$ reales para las temporadas octubre 2015 - mayo 2018 y utilizando el Modelo de regresión, las emisiones de $\mathrm{CO}_{2}$ que se hubieran tenido de haber seguido utilizando las calderas de gas natural originales sin el apoyo de la red de calor.

Tabla 403. Estimación del ahorro de emisiones de CO2 para el Edificio D12.

\begin{tabular}{|c|c|c|c|c|c|c|c|c|c|c|}
\hline & $\begin{array}{l}\text { kWh_- } \\
\text { D12 Gas } \\
\text { Natural }\end{array}$ & $\begin{array}{c}\text { kWh_- } \\
\text { D12 } \\
\text { Biomasa }\end{array}$ & $\begin{array}{l}\text { kWh_D12 } \\
\text { Real Total }\end{array}$ & $\begin{array}{l}\text { kWh_D12 } \\
\text { Predicho }\end{array}$ & $\begin{array}{l}\text { kg CO2 Real } \\
\text { debido al } \\
\text { consumo de } \\
\text { Gas Natural }\end{array}$ & $\begin{array}{l}\text { kg CO2 } \\
\text { Real } \\
\text { debido a } \\
\text { Biomasa }\end{array}$ & $\begin{array}{l}\text { kg CO2 } \\
\text { Real } \\
\text { debido al } \\
\text { consumo } \\
\text { TOTAL }\end{array}$ & $\begin{array}{c}\text { kg CO2 } \\
\text { que se } \\
\text { hubiera } \\
\text { tenido } \\
\text { debido a } \\
\text { Gas } \\
\text { Natural }\end{array}$ & $\begin{array}{c}\text { Ahorro de } \\
\text { kg CO2 }\end{array}$ & $\begin{array}{l}\text { Ahorro de kg } \\
\text { CO2 } \\
\text { acumulado }\end{array}$ \\
\hline oct-2015 & 0 & 6.590 & 6.590 & 16.146 & 0 & 158 & 158 & 4.069 & 3.911 & 3.911 \\
\hline nov-2015 & 0 & 36.550 & 36.550 & 35.428 & 0 & 877 & 877 & 8.928 & 8.051 & 11.961 \\
\hline dic-2015 & 0 & 34.820 & 34.820 & 51.317 & 0 & 836 & 836 & 12.932 & 12.096 & 24.057 \\
\hline ene-2016 & 0 & 39.180 & 39.180 & 46.439 & 0 & 940 & 940 & 11.703 & 10.762 & 34.820 \\
\hline feb-2016 & 12.177 & 46.300 & 58.477 & 45.474 & 3.069 & 1.111 & 4.180 & 11.460 & 7.280 & 42.099 \\
\hline mar-2016 & 2.793 & 41.970 & 44.763 & 47.202 & 704 & 1.007 & 1.711 & 11.895 & 10.184 & 52.283 \\
\hline abr-2016 & 0 & 27.410 & 27.410 & 30.696 & 0 & 658 & 658 & 7.735 & 7.077 & 59.361 \\
\hline may-2016 & 0 & 6.310 & 6.310 & 16.543 & 0 & 151 & 151 & 4.169 & 4.017 & 63.378 \\
\hline oct-2016 & 1.800 & 5.800 & 7.600 & 16.197 & 454 & 139 & 593 & 4.082 & 3.489 & 66.867 \\
\hline nov-2016 & 0 & 35.820 & 35.820 & 41.893 & 0 & 860 & 860 & 10.557 & 9.697 & 76.564 \\
\hline dic-2016 & 72 & 39.800 & 39.872 & 57.753 & 18 & 955 & 973 & 14.554 & 13.580 & 90.145 \\
\hline ene-2017 & 128 & 47.420 & 47.548 & 66.368 & 32 & 1.138 & 1.170 & 16.725 & 15.554 & 105.699 \\
\hline feb-2017 & 63 & 33.330 & 33.393 & 38.614 & 16 & 800 & 816 & 9.731 & 8.915 & 114.614 \\
\hline mar-2017 & 265 & 32.930 & 33.195 & 34.528 & 67 & 790 & 857 & 8.701 & 7.844 & 122.458 \\
\hline abr-2017 & 0 & 12.700 & 12.700 & 21.806 & 0 & 305 & 305 & 5.495 & 5.190 & 127.648 \\
\hline may-2017 & 368 & 1.950 & 2.318 & 8.839 & 93 & 47 & 140 & 2.227 & 2.088 & 129.736 \\
\hline oct-2017 & 0 & 3.530 & 3.530 & 15.327 & 0 & 85 & 85 & 3.862 & 3.778 & 133.514 \\
\hline nov-2017 & 88 & 33.700 & 33.788 & 46.382 & 22 & 809 & 831 & 11.688 & 10.857 & 144.371 \\
\hline dic-2017 & 0 & 46.710 & 46.710 & 58.447 & 0 & 1.121 & 1.121 & 14.729 & 13.608 & 157.978 \\
\hline ene-2018 & 8 & 51.520 & 51.528 & 56.141 & 2 & 1.236 & 1.238 & 14.147 & 12.909 & 170.887 \\
\hline feb-2018 & 0 & 59.290 & 59.290 & 54.984 & 0 & 1.423 & 1.423 & 13.856 & 12.433 & 183.320 \\
\hline mar-2018 & 888 & 51.330 & 52.218 & 43.509 & 224 & 1.232 & 1.456 & 10.964 & 9.509 & 192.829 \\
\hline$a b r-2018$ & 112 & 29.150 & 29.262 & 24.159 & 28 & 700 & 728 & 6.088 & 5.360 & 198.189 \\
\hline may-2018 & 0 & 5.570 & 5.570 & 12.918 & 0 & 134 & 134 & 3.255 & 3.122 & 201.311 \\
\hline
\end{tabular}

Como se observa durante estas tres temporadas se ha obtenido un ahorro total de 201 Toneladas de $\mathrm{CO}_{2}$, debido al consumo térmico del edificio D12. 


\section{AIV.12.6.Estimación del precio máximo de compra a la red.}

Tomando como referencia los precios del gas natural de la Tabla 404 para cada temporada, obtenidos a partir de los datos establecidos en el Capítulo 3, donde se tiene en cuenta el precio por el termino variable y fijo; se puede realizar la estimación del precio máximo de compra de la energía útil a la red de calor para obtener un $0 \%$ de ahorro y un $15 \%$ de ahorro. La Tabla 405, muestral el precio que se pagaría para un ahorro del 15\%

Tabla 404. Precios de referencia para Gas natural y Astilla

\begin{tabular}{|c|c|c|c|c|}
\hline Precios $(€ /(k W h)$ & 2015 & 2016 & 2017 & 2018 \\
\hline Gas Natural & 0,0373 & 0,0306 & 0,0314 & 0,0336 \\
\hline Astilla & 0,0277 & 0,0256 & 0,0254 & 0,0239 \\
\hline $\begin{array}{l}€ / \text { kWh útiles máximos de compra a la red para } \\
\text { un ahorro del } 0,0 \%\end{array}$ & \multicolumn{4}{|c|}{0,03846} \\
\hline $\begin{array}{l}€ / \text { kWh útiles máximos de compra a la red para } \\
\text { un ahorro del } 15,0 \%\end{array}$ & \multicolumn{4}{|c|}{0,03256} \\
\hline
\end{tabular}

Tabla 405. Ahorro Económico por el consumo térmico en el Edificio D12

\begin{tabular}{|c|c|c|c|c|c|c|c|c|c|c|}
\hline & $\begin{array}{l}\text { kWh_D1 } \\
\text { 2_Gas } \\
\text { Natural }\end{array}$ & $\begin{array}{l}\text { kWh_D12 } \\
\text { _Biomasa }\end{array}$ & $\begin{array}{c}\text { kWh_D1 } \\
2 \text { Real }\end{array}$ & $\begin{array}{c}\text { kWh_D12 } \\
\text { Pronosticado }\end{array}$ & $\begin{array}{l}€ \text { Real } \\
\text { Gas } \\
\text { Natural }\end{array}$ & $\begin{array}{c}€ \text { Real } \\
\text { Biomasa }\end{array}$ & $\begin{array}{l}€ \text { Real } \\
\text { Total }\end{array}$ & $\begin{array}{c}\text { € predicho } \\
\text { Gas } \\
\text { natural }\end{array}$ & $\begin{array}{c}€ \\
\text { Ahorro }\end{array}$ & $€$ Acumulado \\
\hline oct-2015 & 0 & 6.590 & 6.590 & 16.146 & 0 & 215 & 215 & 602 & 388 & 388 \\
\hline nov-2015 & 0 & 36.550 & 36.550 & 35.428 & 0 & 1.190 & 1.190 & 1.321 & 131 & 519 \\
\hline dic-2015 & 0 & 34.820 & 34.820 & 51.317 & 0 & 1.134 & 1.134 & 1.914 & 780 & 1.299 \\
\hline ene-2016 & 0 & 39.180 & 39.180 & 46.439 & 0 & 1.276 & 1.276 & 1.421 & 145 & 1.445 \\
\hline feb-2016 & 12.177 & 46.300 & 58.477 & 45.474 & 373 & 1.508 & 1.880 & 1.392 & -489 & 956 \\
\hline mar-2016 & 2.793 & 41.970 & 44.763 & 47.202 & 85 & 1.367 & 1.452 & 1.444 & -8 & 949 \\
\hline abr-2016 & 0 & 27.410 & 27.410 & 30.696 & 0 & 892 & 892 & 939 & 47 & 995 \\
\hline may-2016 & 0 & 6.310 & 6.310 & 16.543 & 0 & 205 & 205 & 506 & 301 & 1.296 \\
\hline oct-2016 & 1.800 & 5.800 & 7.600 & 16.197 & 55 & 189 & 244 & 496 & 252 & 1.548 \\
\hline nov-2016 & 0 & 35.820 & 35.820 & 41.893 & 0 & 1.166 & 1.166 & 1.282 & 116 & 1.663 \\
\hline dic-2016 & 72 & 39.800 & 39.872 & 57.753 & 2 & 1.296 & 1.298 & 1.767 & 469 & 2.133 \\
\hline ene-2017 & 128 & 47.420 & 47.548 & 66.368 & 4 & 1.544 & 1.548 & 2.084 & 536 & 2.668 \\
\hline feb-2017 & 63 & 33.330 & 33.393 & 38.614 & 2 & 1.085 & 1.087 & 1.212 & 125 & 2.794 \\
\hline mar-2017 & 265 & 32.930 & 33.195 & 34.528 & 8 & 1.072 & 1.081 & 1.084 & 4 & 2.797 \\
\hline abr-2017 & 0 & 12.700 & 12.700 & 21.806 & 0 & 414 & 414 & 685 & 271 & 3.069 \\
\hline may-2017 & 368 & 1.950 & 2.318 & 8.839 & 12 & 63 & 75 & 278 & 202 & 3.271 \\
\hline oct-2017 & 0 & 3.530 & 3.530 & 15.327 & 0 & 115 & 115 & 481 & 366 & 3.637 \\
\hline nov-2017 & 88 & 33.700 & 33.788 & 46.382 & 3 & 1.097 & 1.100 & 1.456 & 356 & 3.994 \\
\hline dic-2017 & 0 & 46.710 & 46.710 & 58.447 & 0 & 1.521 & 1.521 & 1.835 & 314 & 4.308 \\
\hline ene-2018 & 8 & 51.520 & 51.528 & 56.141 & 0 & 1.677 & 1.678 & 1.886 & 209 & 4.517 \\
\hline feb-2018 & 0 & 59.290 & 59.290 & 54.984 & 0 & 1.930 & 1.930 & 1.847 & -83 & 4.434 \\
\hline mar-2018 & 888 & 51.330 & 52.218 & 43.509 & 30 & 1.671 & 1.701 & 1.462 & -239 & 4.194 \\
\hline abr-2018 & 112 & 29.150 & 29.262 & 24.159 & 4 & 949 & 953 & 812 & -141 & 4.053 \\
\hline may-2018 & 0 & 5.570 & 5.570 & 12.918 & 0 & 181 & 181 & 434 & 253 & 4.306 \\
\hline$€$ Total & & & & & & & 24.336 & 28.642 & & \\
\hline Ahorro (\%) & & & & & & & & & & $15,0 \%$ \\
\hline
\end{tabular}


Anexo IV. Desarrollo del análisis de los edificios del Campus Miguel Delibes 


\section{ANEXO V. \\ DESARROLLO DEL ANÁLISIS DE LOS EDIFICIOS \\ DEL CAMPUS RÍO ESGUEVA}

\section{AV.1. Edificio E1. Edificio del Servicio de Mantenimiento.}

\section{AV.1.1. Obtención de la línea base de referencia energética}

Los datos de partida para la obtención de la línea base de referencia se muestran en la Tabla 406

Tabla 406. Consumos térmicos del edificio E1

\begin{tabular}{lr}
\hline & Consumos térmicos (kWh). E1 \\
\hline oct-12 & $18.416,98$ \\
\hline nov-12 & $32.083,02$ \\
\hline dic-12 & $16.490,99$ \\
\hline ene-13 & $17.414,18$ \\
\hline feb-13 & $16.594,82$ \\
\hline mar-13 & $21.437,57$ \\
\hline abr-13 & $16.160,91$ \\
\hline may-13 & $12.901,52$ \\
\hline oct-13 & $6.408,89$ \\
\hline nov-13 & $17.454,78$ \\
\hline dic-13 & $26.636,34$ \\
\hline ene-14 & $14.990,03$ \\
\hline feb-14 & $14.276,27$ \\
\hline mar-14 & $11.000,12$ \\
\hline abr-14 & $5.472,34$ \\
\hline may-14 & $4.761,24$ \\
\hline Promedio & 15.781 \\
\hline Total (oct-12-may-13) & 151.500 \\
\hline Total (oct-13-may-14) & 101.000 \\
\hline Total (oct-12-may-13) & 252.500 \\
\hline
\end{tabular}


Como se puede ver en la Tabla 407 para el edificio, el método ofrece un modelo de regresión, con una sola variable (Grados Día en base 20, obtenidos con datos cada 24 horas). El modelo fue construido con un solo paso, incluyendo los Grados día base 20 cada $24 \mathrm{~h}$, por ser la variable más significativa (variable con menor valor de Sig $=0,006$ ). El resto de las variables como se observa en la Tabla 408 fueron excluidas del modelo al tener valores de sig $>0,05$.

Tabla 407. Modelos de regresión del Edificio E1

\begin{tabular}{|c|c|c|c|c|c|c|c|}
\hline \multirow{2}{*}{\multicolumn{2}{|c|}{ Modelo }} & \multicolumn{2}{|c|}{ Coeficientes no estandarizados } & \multirow[t]{2}{*}{$\mathrm{t}$} & \multirow[t]{2}{*}{ Sig. } & \multicolumn{2}{|c|}{$\begin{array}{l}\text { Intervalo de confianza de } 95,0 \% \\
\text { para B }\end{array}$} \\
\hline & & $\mathrm{B}$ & Error típ. & & & Límite inferior & Límite superior \\
\hline \multirow[t]{2}{*}{1} & (Constante) & $-97,801$ & 5090,328 &,- 019 & ,985 & $-11015,469$ & 10819,867 \\
\hline & GD20_24h & 44,252 & 13,632 & 3,246 &, 006 & 15,014 & 73,489 \\
\hline
\end{tabular}

En la Figura 290 se representa el modelo de regresión con sus límites inferior y superior para un nivel de confianza del $95 \%$

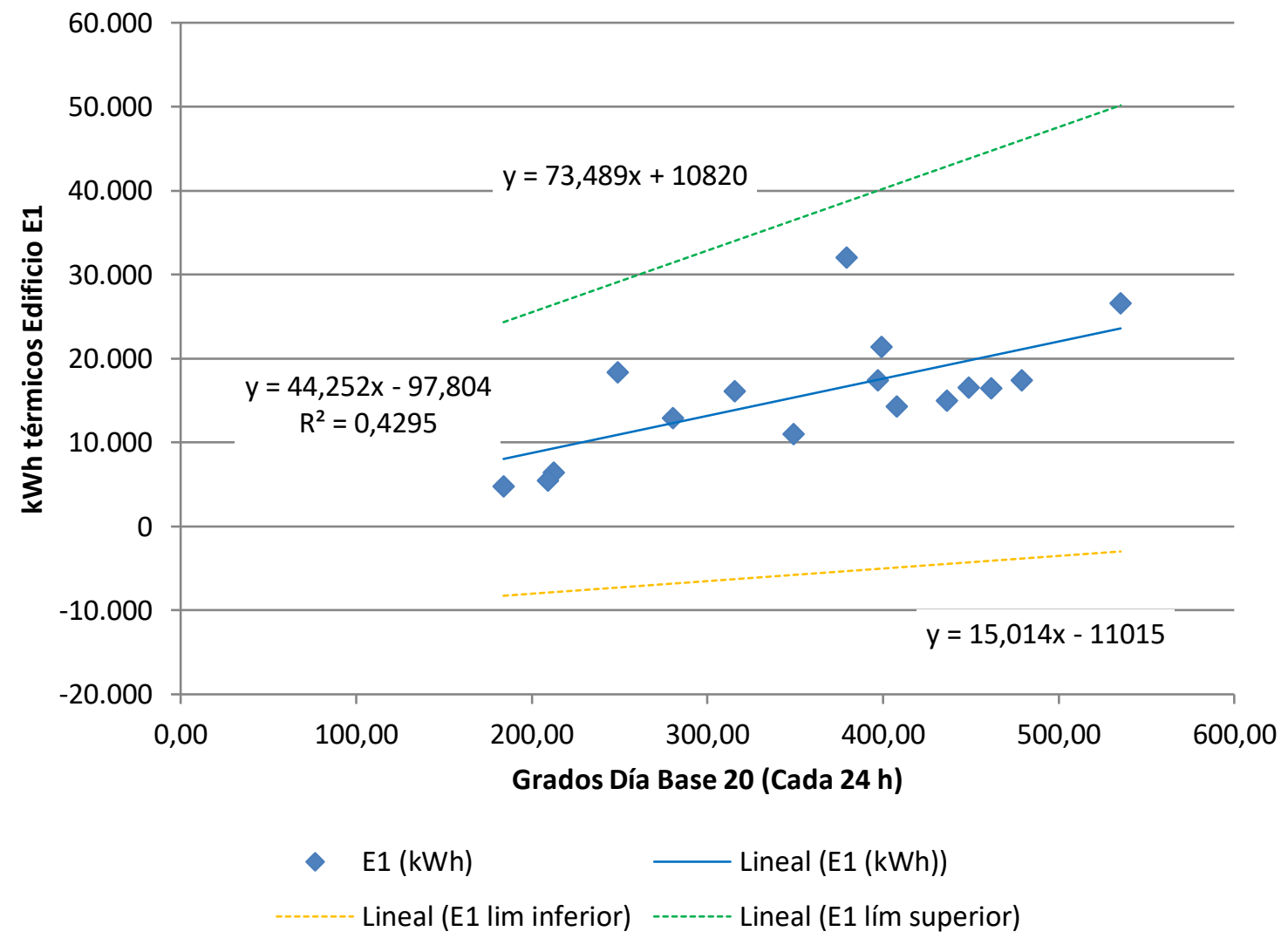

Figura 290. Representación del modelo de regresión lineal simple para el Edificio E1 
Anexo V. Desarrollo del análisis de los edificios del Campus Río Esgueva

Tabla 408. Variables excluidas del modelo de región del Edificio E1

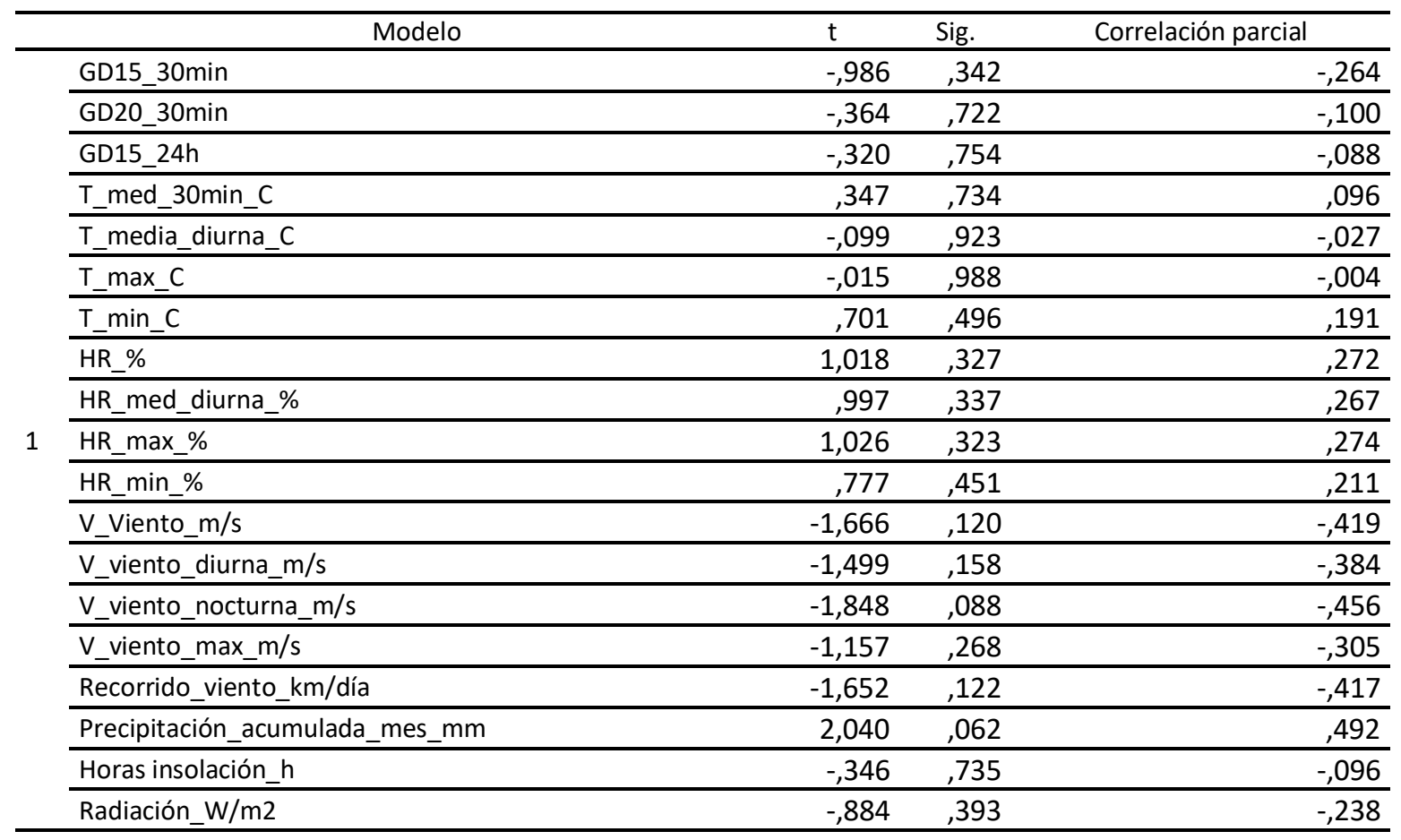

La bondad del modelo de regresión obtenido para el edificio E1, se resumen en la Tabla 409

Tabla 409. Resumen de la bondad del modelo de regresión para el Edificio E1

\begin{tabular}{ccccc}
\hline Modelo & $\mathrm{R}$ & $\mathrm{R}$ cuadrado & R cuadrado corregida & $\begin{array}{c}\text { Error típ. de la } \\
\text { estimación }\end{array}$ \\
\hline 1 &, 655 &, 429 &, 389 & $5.634,0659$ \\
\hline
\end{tabular}

Se observa como el modelo de regresión lineal simple presenta un Coeficiente de Correlación de Pearson ( $R$ ) de 0,655 , lo que indica que las variables están correlacionadas de manera no muy fuerte (en la correlación perfecta $R= \pm 1$ ). La correlación que se produce es directa, al aumentar el valor de los Grados día, aumenta el consumo térmico.

El coeficiente de determinación $\left(R^{2}\right)$, nos indica que con el modelo se podría explicar el $42,9 \%$ de los datos reales obtenidos aceptando un error del $5 \%$.

El error típico de la estimación que nos indica la magnitud de los errores, es decir la parte de la variable dependiente que dejamos sin explicar con el modelo y que describe la variación de la variable respuesta (el Consumo) respecto a la recta de regresión, es de $5.634 \mathrm{kWh}$, lo que representa un 35,7\% del promedio de los consumos que fue de 15.781 kWh. 


\section{AV.1.2. Verificación del cumplimiento de los supuestos estadísticos}

Las condiciones que se deben cumplir en un modelo de regresión son:

\section{- Linealidad de las variables, las variables se encuentran relacionadas de forma lineal.}

Como se observa en la Tabla 407, la pendiente (B), obtuvo un valor de Sig $=0,006$, que al ser $\leq 0,05$, nos indica que podemos rechazar la hipótesis nula de pendiente igual a cero y nos da la evidencia de linealidad entre la variable dependiente ( $\mathrm{kWh}$ del edificio E1) y la independiente (GD20_24h). Al ser el valor de la pendiente positiva, indica una relación directa entre el consumo y los Grados día base 20.

- Normalidad. Todos los valores obtenidos para la variable dependiente (Y), deben estar distribuidos normalmente en cada valor de la variable independiente (X).

Se comprueba la normalidad de las variables y de los residuos mediante el Test de Shapiro - Wilk para muestras pequeñas (menores a 30 observaciones), siendo la hipótesis nula el que la distribución es Normal.

La Tabla 410, muestra la prueba de normalidad de Shapiro-Wilk y cómo tanto la variable dependiente (consumos del Edificio), como la variable independientes: GD20 poseen una Sig $>0,05$, por lo que aceptamos la hipótesis nula de Normalidad de las variables

Tabla 410. Prueba de normalidad para el edificio E1

\begin{tabular}{lrrrrrr}
\hline & \multicolumn{3}{c}{ Kolmogorov-Smirnov } & \multicolumn{3}{c}{ Shapiro-Wilk } \\
\cline { 2 - 7 } & Estadístico & gl & Sig. & Estadístico & gl & Sig. \\
\hline kWh_E1 &, 170 & 16 &, 200 &, 942 & 16 &, 368 \\
\hline GD20_24h &, 139 & 16 &, 200 &, 952 & 16 &, 517 \\
\hline
\end{tabular}

- Independencia de los errores. Los errores asociados a los valores de la variable respuesta $(\mathrm{Y})$ deberán ser independientes unos de otros.

Para la comprobación se utiliza el estadístico de Durbin -Watson.

Se comprueba que el Estadístico de Durbin Watson para el nivel de significancia del 5\%, y para el tamaño de la muestra " $\mathrm{n}$ " y el número de variables independientes del modelo " $\mathrm{k}$ ", se encuentra en el intervalo [dU, 4-dU], de la Tabla 3, intervalo centrado en el 2, que indica la ausencia de autocorrelación.

El valor del Estadístico Durbin-Watson facilitado por el programa SPSS, es 1,286. 
En el modelo, $\mathrm{n}=16$ y $\mathrm{k}=1$, según la Tabla 3 el valor $\mathrm{dU}=1,371$ y dL =1,106, luego el intervalo que marca la ausencia de correlación es [1,371, 2,629].

Los intervalos $[0,1,106]$ y $[2,896,4]$ indican correlación positiva o negativa respectivamente y las zonas $[1,106,1,371]$ y $[2,629,2,896]$ son zonas no concluyentes; como el valor del estadístico 1,286 está dentro del primer intervalo no concluyente, se comprueba la ausencia de autocorrelación, mediante el gráfico de residuos frente al tiempo.

La Figura 291, muestra que la relación entre los residuos y el tiempo, posee un coeficiente de determinación =0,297, bajo, aunque no nulo; por lo que se concluye que existe una baja autocorrelación en los residuos.

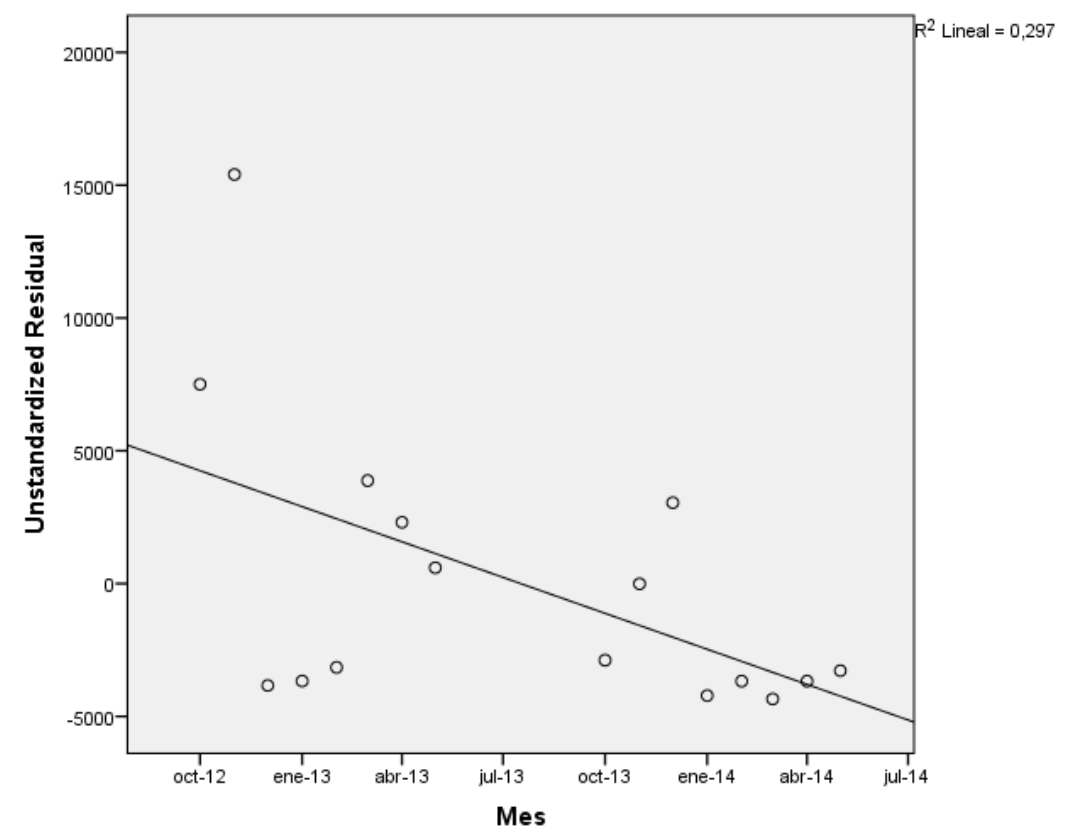

Figura 291. Relación entre los residuos y el tiempo en el Edificio E1

- Homocedasticidad de la varianza. Se pretende comprobar que la varianza de los errores $\left(\sigma^{2}\right)$ es constante para cualquier valor de la variable independiente $(X)$, es decir que el valor medio del cuadrado de la desviación de los errores respecto a su media es constante.

Esta condición indica que no existe correlación entre los residuos y los pronósticos. Se comprueba que el coeficiente de determinación $\mathrm{R}^{2}$, en las relaciones: residuos $\mathrm{y}$ predicciones y entre residuos y variable independiente es nulo o muy próximo a cero, lo que indicará que no existe ningún tipo de correlación en los residuos y que éstos son aleatorios. 
Se grafican los diagramas de dispersión de esas relaciones, comprobando que se corresponden a nubes de puntos totalmente aleatorias, sin tendencias ni patrones en sus representaciones gráficas. Las Figura 292 y Figura 293, muestran que la relación entre los pronósticos y los residuos, posee un coeficiente de determinación $=0$ y entre la variable independiente (Grados día base 20) y los residuos un coeficiente de determinación de $3,331 \times 10^{-16}$; por lo que se concluye que no existe ningún tipo de correlación en los residuos y que éstos son aleatorios, siendo la varianza de los residuos constante.

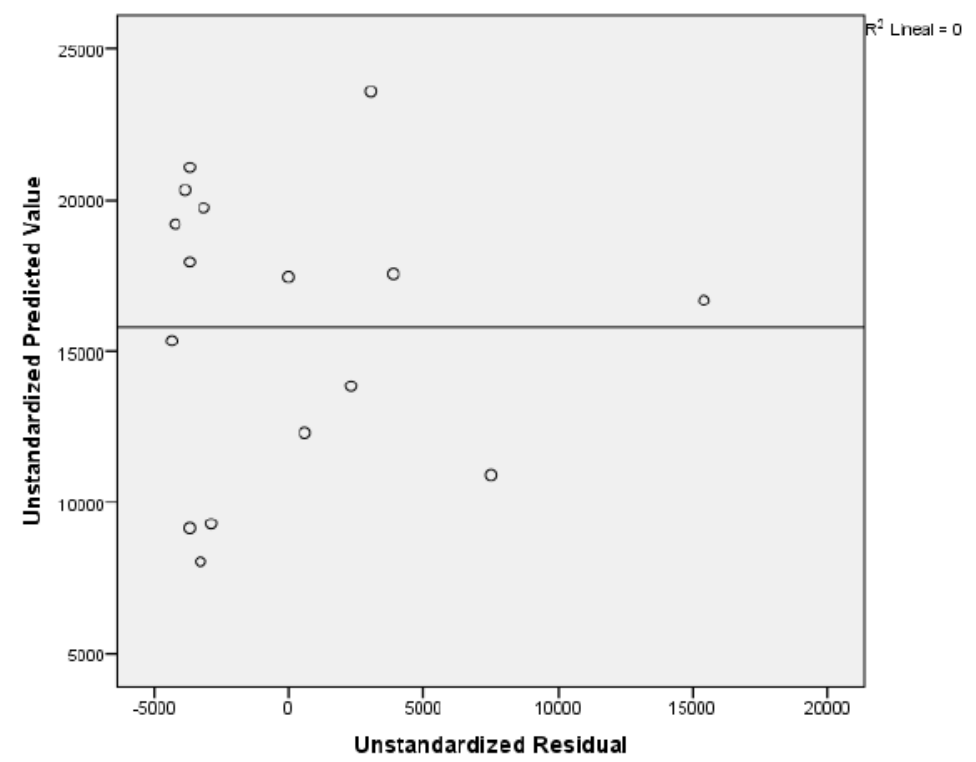

Figura 292. Relación entre los pronósticos y los residuos en el Edificio E1

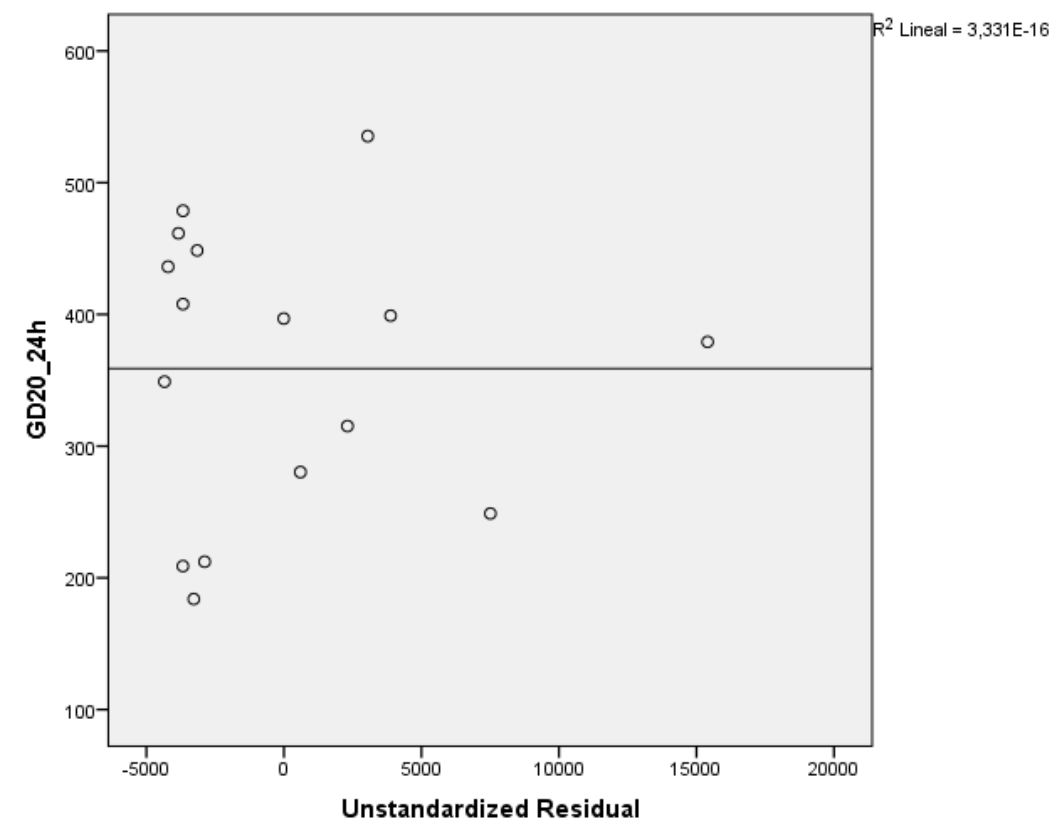

Figura 293. Relación entre GD20_24h y los residuos en el Edificio E1 


\section{AV.1.3. Obtención de los consumos térmicos previstos}

Una vez comprobado el cumplimiento de los supuestos estadísticos se acepta el modelo de línea base encontrado para modelizar el consumo del Edificio E1.

$$
\text { kWh_E1_Pronosticado }=-97,801+44,252 \times \text { GD20_24h }
$$

Con este modelo se procede a predecir los consumos previstos para las temporadas: octubre 2015-mayo 2016, octubre 2016 - mayo 2017 y octubre 2017-mayo 2018, estos consumos se muestran en la Tabla 411, donde "KWh_E1_Real", representa el consumo real redistribuido, "kWh_E1_Pronosticado", el consumo pronosticado con el Modelo.

Tabla 411. Consumos previstos octubre 2014 - mayo 2017 para el edificio E1.

\begin{tabular}{rrrr}
\hline & GD20_24h & kWh_E1_Real & kWh_E1_Pronosticado \\
\hline oct-15 & 222,62 & 2.410 & 9.754 \\
\hline nov-15 & 350,93 & 6.295 & 15.432 \\
\hline dic-15 & 454,81 & 5.973 & 20.028 \\
\hline ene-16 & 426,76 & 4.501 & 18.787 \\
\hline feb-16 & 411,33 & 22.898 & 18.104 \\
\hline mar-16 & 429,57 & 10.846 & 18.912 \\
\hline abr-16 & 326,98 & 8.541 & 14.372 \\
\hline may-16 & 213,46 & 2.444 & 9.348 \\
\hline oct-16 & 202,11 & 2.094 & 8.846 \\
\hline nov-16 & 392,95 & 8.681 & 17.291 \\
\hline dic-16 & 492,22 & 8.311 & 21.684 \\
\hline ene-17 & 542,00 & 15.891 & 23.887 \\
\hline feb-17 & 365,13 & 10.605 & 16.060 \\
\hline mar-17 & 334,51 & 9.821 & 14.705 \\
\hline abr-17 & 222,69 & 3.962 & 9.757 \\
\hline may-17 & 111,78 & 1.035 & 4.849 \\
\hline oct-17 & 164,47 & 1.462 & 7.180 \\
\hline nov-17 & 417,29 & 9.358 & 18.368 \\
\hline dic-17 & 496,27 & 12.659 & 21.863 \\
\hline ene-18 & 482,96 & 14.052 & 21.274 \\
\hline feb-18 & 461,20 & 17.125 & 20.311 \\
\hline mar-18 & 409,12 & 14.234 & 18.007 \\
\hline abr-18 & 265,61 & 6.280 & 11.656 \\
\hline may-18 & 185,14 & 2.132 & 8.095 \\
\hline & & &
\end{tabular}




\section{AV.1.4. Estudio de la existencia de diferencias significativas}

Utilizando la prueba " $\mathrm{t}$ " de Student para muestras relacionadas, podemos concluir que si las variables se distribuyen según una normal y la significación estadística resulta $\leq 0,05$, existen diferencias significativas, con un nivel de confianza del $95 \%$

A continuación se muestra la comparación de medias realizada para cada uno de los tres periodos posteriores a la construcción de la red y para el periodo total hasta mayo de 2018.

Para la temporada Octubre 2015 - Mayo 2016, se comprueba mediante el Test de Shapiro -Wilk que los valores reales no se distribuyen según una Normal (sig $\leq 0,05)$, aunque los pronosticados si (Sig >0,05), como se observa en la Tabla 412

Tabla 412. Prueba de Normalidad temporada Octubre 2015-Mayo 2016. Edificio E1

\begin{tabular}{cccccccr}
\hline & \multicolumn{3}{c}{ Kolmogorov-Smirnov $^{\mathrm{a}}$} & \multicolumn{3}{c}{ Shapiro-Wilk } \\
\cline { 2 - 8 } & Estadístico & gl & Sig. & Estadístico & gl & \multicolumn{1}{c}{ Sig. } \\
\hline kWh_real &, 225 & 8 &, 200 &, 799 & 8 &, 028 \\
\hline kWh_pronosticado &, 226 & 8 &, 200 &, 868 & 8 &, 144 \\
\hline
\end{tabular}

Al no cumplirse la hipótesis de la normalidad de los datos no se puede aplicar la " $\mathrm{t}$ " de Student para analizar si existen diferencias significativas en esta primera temporada.

Para la temporada Octubre 2016 - Mayo 2017, se comprueba mediante el Test de Shapiro -Wilk que tanto los valores reales como los pronosticados con los dos modelos se distribuyen según una Normal puesto que en todos los casos los valores de Sig >0,05, como se observa en la Tabla 413

Tabla 413. Prueba de Normalidad temporada Octubre 2016-Mayo 2017. Edificio E1

\begin{tabular}{cccccccr}
\hline & \multicolumn{3}{c}{ Kolmogorov-Smirnov $^{\text {a }}$} & \multicolumn{3}{c}{ Shapiro-Wilk } \\
\cline { 2 - 8 } & Estadístico & gl & \multicolumn{1}{c}{ Sig. } & Estadístico & gl & \multicolumn{1}{c}{ Sig. } \\
\hline kWh_real &, 186 & 8 &, 200 &, 947 & 8 &, 684 \\
\hline kWh_pronosticado &, 148 & 8 &, 200 &, 969 & 8 &, 888 \\
\hline
\end{tabular}

En la Tabla 414, se observa como las medias de los consumos pronosticados, son superiores a las medias de los consumos reales del Edificio E1, en un 93,8 \%

Tabla 414. Estadísticos de muestras relacionadas. Octubre 2016-Mayo 2017. Edificio E1

\begin{tabular}{lrcrcc}
\hline & Media & $\begin{array}{c}\text { \% Diferencia } \\
\text { entre medias }\end{array}$ & $\mathrm{N}$ & $\begin{array}{c}\text { Desviación } \\
\text { típ. }\end{array}$ & $\begin{array}{c}\text { Error típ. de } \\
\text { la media }\end{array}$ \\
\hline $\mathrm{kWh}$ _real & 7550,0000 & & 8 & 4942,64149 & 1747,48766 \\
\hline $\mathrm{kWh}$ _pronosticado & 14634,8750 & $93,8 \%$ & 8 & 6518,66514 & 2304,69616 \\
\hline
\end{tabular}


La Tabla 415 muestra que las diferencias entre las medias son significativas entre los consumos reales y los pronosticados (sig $\leq 0,05)$

Tabla 415. Prueba de muestras relacionadas. Octubre 2016-Mayo 2017. Edificio E1

\begin{tabular}{|c|c|c|c|c|c|c|c|c|c|}
\hline & & \multicolumn{5}{|c|}{ Diferencias relacionadas } & \multirow{3}{*}{$\mathrm{t}$} & \multirow{3}{*}{$\mathrm{gl}$} & \multirow{3}{*}{$\begin{array}{c}\text { Sig. } \\
\text { (bilateral) }\end{array}$} \\
\hline & & \multirow[t]{2}{*}{ Media } & \multirow{2}{*}{$\begin{array}{l}\text { Desviación } \\
\text { típ. }\end{array}$} & \multirow{2}{*}{$\begin{array}{c}\text { Error típ. } \\
\text { de la media }\end{array}$} & \multicolumn{2}{|c|}{$\begin{array}{l}\text { 95\% Intervalo de confianza } \\
\text { para la diferencia }\end{array}$} & & & \\
\hline & & & & & Inferior & Superior & & & \\
\hline Par 1 & $\begin{array}{c}\text { kWh_real - } \\
\text { kWh_pronosticado }\end{array}$ & $-7084,875$ & 2992,138 & 1057,880 & $-9586,365$ & $-4583,385$ & $-6,697$ & 7 & ,000 \\
\hline
\end{tabular}

En la Figura 294 se grafican los consumos reales y pronosticados para la temporada Octubre 2016 - Mayo 2017 para el Edificio E1, y las medias de dichos consumos. Según la prueba paramétrica realizada las diferencias encontradas son estadísticamente significativas, con un riesgo a estar equivocados del $5 \%$

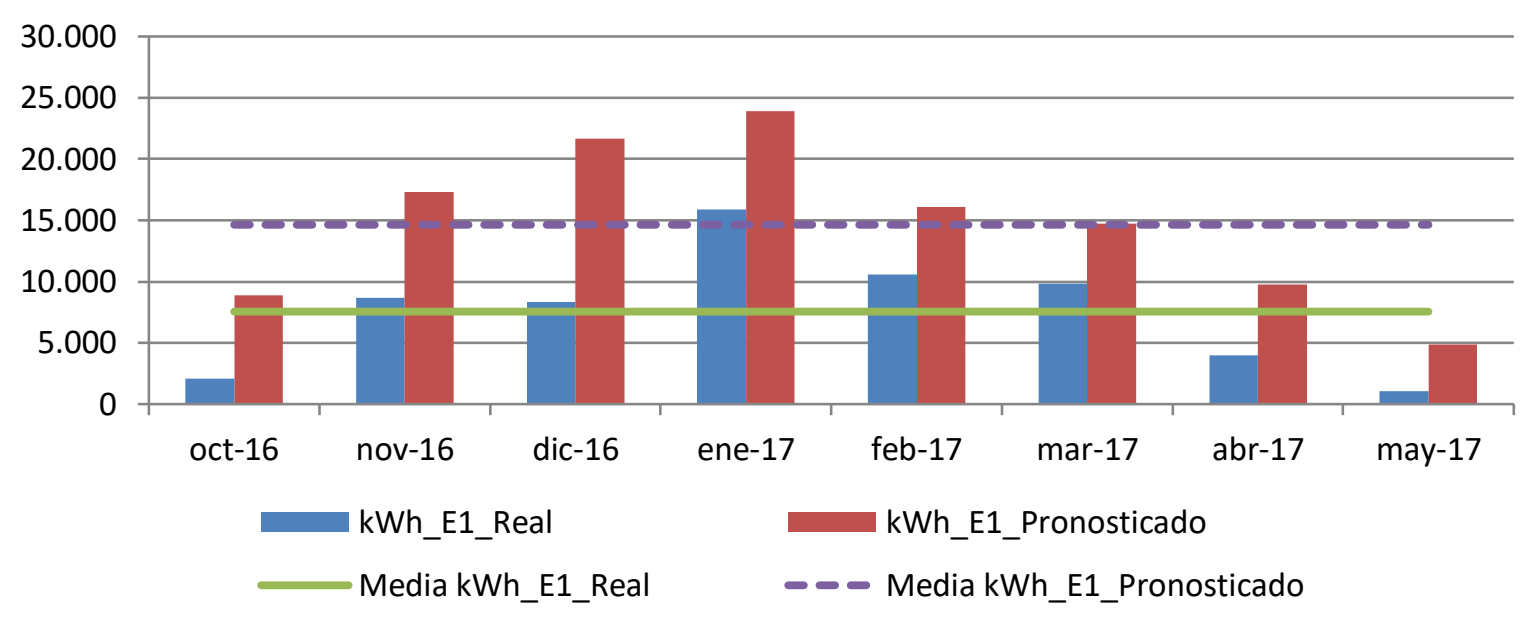

Figura 294. Consumos reales y pronosticados Octubre 2016-Mayo 2017. Edificio E1

Para la temporada Octubre 2017 - Mayo 2018, se comprueba mediante el Test de Shapiro -Wilk que tanto los valores reales como los pronosticados se distribuyen según una Normal puesto que en todos los casos los valores de Sig $>0,05$, como se observa en la Tabla 416

Tabla 416. Prueba de Normalidad temporada Octubre 2017-Mayo 2018. Edificio E1

\begin{tabular}{cccccccr}
\hline & \multicolumn{3}{c}{ Kolmogorov-Smirnov $^{\text {a }}$} & \multicolumn{3}{c}{ Shapiro-Wilk } \\
\cline { 2 - 8 } & Estadístico & gl & Sig. & Estadístico & gl & Sig. \\
\hline kWh_real &, 195 & 8 &, 200 &, 918 & 8 &, 413 \\
\hline kWh_pronosticado &, 266 & 8 &, 099 &, 853 & 8 &, 103 \\
\hline
\end{tabular}


En la Tabla 417, se observa como las medias de los consumos pronosticados, son superiores a las medias de los consumos reales del Edificio E1, en un 64,0\%

Tabla 417. Estadísticos de muestras relacionadas. Octubre 2017-Mayo 2018. Edificio E1

\begin{tabular}{lccccc}
\hline & Media & $\begin{array}{c}\text { \% Diferencia } \\
\text { entre medias }\end{array}$ & N & $\begin{array}{c}\text { Desviación } \\
\text { típ. }\end{array}$ & $\begin{array}{c}\text { Error típ. de } \\
\text { la media }\end{array}$ \\
\hline kWh_real & 9662,7500 & & 8 & 5859,36244 & 2071,59746 \\
\hline kWh_pronosticado & 15844,2500 & $64,0 \%$ & 8 & 5968,58126 & 2110,21214 \\
\hline
\end{tabular}

La Tabla 418 muestra que las diferencias entre las medias son significativas entre los consumos reales y los pronosticados (sig $\leq 0,05$ )

Tabla 418. Prueba de muestras relacionadas. Octubre 2017-Mayo 2018. Edificio E1

\begin{tabular}{|c|c|c|c|c|c|c|c|c|c|}
\hline & & \multicolumn{5}{|c|}{ Diferencias relacionadas } & \multirow{3}{*}{$\mathrm{t}$} & \multirow{3}{*}{ gl } & \multirow{3}{*}{$\begin{array}{c}\text { Sig. } \\
\text { (bilateral) }\end{array}$} \\
\hline & & \multirow[t]{2}{*}{ Media } & \multirow{2}{*}{$\begin{array}{l}\text { Desviación } \\
\text { típ. }\end{array}$} & \multirow{2}{*}{$\begin{array}{c}\text { Error típ. } \\
\text { de la media }\end{array}$} & \multicolumn{2}{|c|}{$\begin{array}{l}\text { 95\% Intervalo de confianza } \\
\text { para la diferencia }\end{array}$} & & & \\
\hline & & & & & Inferior & Superior & & & \\
\hline Par 1 & $\begin{array}{c}\text { kWh_real - } \\
\text { kWh_pronosticado }\end{array}$ & $-6181,500$ & 2200,774 & 778,091 & $-8021,393$ & $-4341,606$ & $-7,944$ & 7 & ,000 \\
\hline
\end{tabular}

En la Figura 295, se grafican los consumos reales y pronosticados para la temporada Octubre 2017 - Mayo 2018 para el Edificio E1, y las medias de dichos consumos. Según la prueba paramétrica realizada las diferencias encontradas son estadísticamente significativas, con un riesgo a estar equivocados del $5 \%$

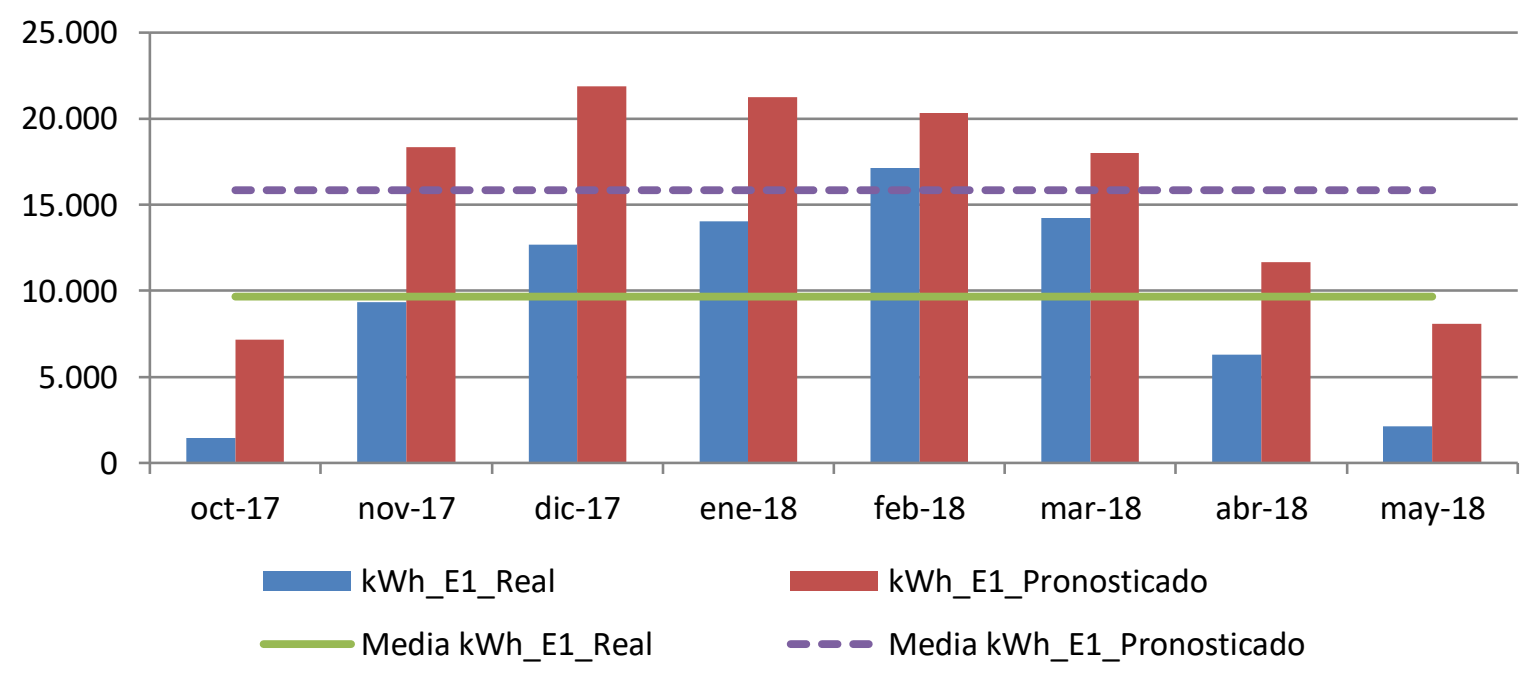

Figura 295. Consumos reales y pronosticados Octubre 2017-Mayo 2018. Edificio E1 
Para el total de las tres temporadas Octubre 2015 - Mayo 2018, se comprueba mediante el Test de Shapiro -Wilk, que los valores reales y los pronosticados se distribuyen según una Normal puesto que en esos casos los valores de Sig $>0,05$, como se observa en la Tabla 419

Tabla 419. Prueba de Normalidad temporada Octubre 2015-Mayo 2018. Edificio E1

\begin{tabular}{cccccccr}
\hline & \multicolumn{3}{c}{ Kolmogorov-Smirnov $^{\mathrm{a}}$} & \multicolumn{3}{c}{ Shapiro-Wilk } \\
\cline { 2 - 8 } & Estadístico & gl & Sig. & Estadístico & gl & Sig. \\
\hline kWh_real &, 103 & 24 &, 200 &, 942 & 24 &, 178 \\
\hline kWh_pronosticado &, 146 & 24 &, 200 &, 942 & 24 &, 177 \\
\hline
\end{tabular}

En la Tabla 420 se observa como las medias de los consumos pronosticados, son superiores a las medias de los consumos reales del Edificio E1, en un $82,8 \%$

Tabla 420. Estadísticos de muestras relacionadas. Octubre 2015-Mayo 2018. Edificio E1

\begin{tabular}{lccccc}
\hline & Media & $\begin{array}{c}\text { \% Diferencia } \\
\text { entre medias }\end{array}$ & $\mathrm{N}$ & $\begin{array}{c}\text { Desviación } \\
\text { típ. }\end{array}$ & $\begin{array}{c}\text { Error típ. de } \\
\text { la media }\end{array}$ \\
\hline kWh_real & 8400,4167 & & 24 & 5683,46771 & 1160,13299 \\
\hline kWh_pronosticado & 15357,0833 & $82,8 \%$ & 24 & 5417,90283 & 1105,92478 \\
\hline
\end{tabular}

La Tabla 421 muestra que las diferencias entre las medias son significativas entre los consumos reales y los pronosticados (sig $\leq 0,05)$

Tabla 421. Prueba de muestras relacionadas. Octubre 2015-Mayo 2018. Edificio E1

\begin{tabular}{|c|c|c|c|c|c|c|c|c|}
\hline & \multicolumn{5}{|c|}{ Diferencias relacionadas } & \multirow{3}{*}{$\mathrm{t}$} & \multirow{3}{*}{ gl } & \multirow{3}{*}{$\begin{array}{c}\text { Sig. } \\
\text { (bilateral) }\end{array}$} \\
\hline & \multirow[t]{2}{*}{ Media } & \multirow{2}{*}{$\begin{array}{l}\text { Desviación } \\
\text { típ. }\end{array}$} & \multirow{2}{*}{$\begin{array}{l}\text { Error típ. de } \\
\text { la media }\end{array}$} & \multicolumn{2}{|c|}{$\begin{array}{c}\text { 95\% Intervalo de confianza } \\
\text { para la diferencia }\end{array}$} & & & \\
\hline & & & & Inferior & Superior & & & \\
\hline $\begin{array}{c}\text { kWh_real - } \\
\text { kWh_pronosticado }\end{array}$ & $-6956,667$ & 3907,076 & 797,529 & $-8606,480$ & $-5306,853$ & $-8,723$ & 23 & 000 \\
\hline
\end{tabular}




\section{AV.1.5. Estimación de las emisiones de $\mathrm{CO} 2$ evitadas.}

Teniendo en cuenta que el consumir Gasóleo se producen 0,311 kg CO 2 / kWh E. final y que al consumir la energía suministrada por red a partir de Biomasa se producen 0,024 kg $\mathrm{CO}_{2} / \mathrm{kWh}$. final, en la Tabla 422, se muestra las emisiones de $\mathrm{CO}_{2}$ reales para las temporadas octubre 2015 - mayo 2018 y utilizando el Modelo de regresión, las emisiones de $\mathrm{CO}_{2}$ que se hubieran tenido de haber seguido utilizando las calderas de gasóleo originales sin el apoyo de la red de calor.

Tabla 422. Estimación del ahorro de emisiones de CO2 para el Edificio E1.

\begin{tabular}{|c|c|c|c|c|c|c|c|c|c|c|}
\hline & $\begin{array}{l}\text { kWh_E1 } \\
\text { Gasóleo }\end{array}$ & $\begin{array}{c}\text { kWh_- } \\
\text { E1 } \\
\text { Biomasa }\end{array}$ & $\begin{array}{l}\text { kWh_E1 } \\
\text { Real Total }\end{array}$ & $\begin{array}{l}\text { kWh_E1 } \\
\text { Predicho }\end{array}$ & $\begin{array}{l}\text { kg CO2 Real } \\
\text { debido al } \\
\text { consumo de } \\
\text { Gasóleo }\end{array}$ & $\begin{array}{c}\text { kg CO2 } \\
\text { Real } \\
\text { debido a } \\
\text { Biomasa }\end{array}$ & $\begin{array}{l}\text { kg CO2 } \\
\text { Real } \\
\text { debido al } \\
\text { consumo } \\
\text { TOTAL }\end{array}$ & $\begin{array}{c}\text { kg CO2 } \\
\text { que se } \\
\text { hubiera } \\
\text { tenido } \\
\text { debido a } \\
\text { Gasóleo }\end{array}$ & $\begin{array}{l}\text { Ahorro de } \\
\text { kg CO2 }\end{array}$ & $\begin{array}{l}\text { Ahorro de kg } \\
\text { CO2 } \\
\text { acumulado }\end{array}$ \\
\hline oct-2015 & 0 & 2.410 & 2.410 & 9.754 & 0 & 58 & 58 & 3.033 & 2.976 & 2.976 \\
\hline nov-2015 & 0 & 6.295 & 6.295 & 15.432 & 0 & 151 & 151 & 4.799 & 4.648 & 7.624 \\
\hline dic-2015 & 0 & 5.973 & 5.973 & 20.028 & 0 & 143 & 143 & 6.229 & 6.085 & 13.709 \\
\hline ene-2016 & 0 & 4.501 & 4.501 & 18.787 & 0 & 108 & 108 & 5.843 & 5.735 & 19.444 \\
\hline feb-2016 & 10.217 & 12.681 & 22.898 & 18.104 & 3.177 & 304 & 3.482 & 5.630 & 2.149 & 21.593 \\
\hline mar-2016 & 101 & 10.745 & 10.846 & 18.912 & 31 & 258 & 289 & 5.881 & 5.592 & 27.185 \\
\hline abr-2016 & 76 & 8.465 & 8.541 & 14.372 & 24 & 203 & 227 & 4.470 & 4.243 & 31.428 \\
\hline may-2016 & 8 & 2.436 & 2.444 & 9.348 & 3 & 58 & 61 & 2.907 & 2.846 & 34.274 \\
\hline oct-2016 & 378 & 1.716 & 2.094 & 8.846 & 117 & 41 & 159 & 2.751 & 2.592 & 36.866 \\
\hline nov-2016 & 262 & 8.419 & 8.681 & 17.291 & 82 & 202 & 284 & 5.378 & 5.094 & 41.960 \\
\hline dic-2016 & 0 & 8.311 & 8.311 & 21.684 & 0 & 199 & 199 & 6.744 & 6.544 & 48.504 \\
\hline ene-2017 & 23 & 15.868 & 15.891 & 23.887 & 7 & 381 & 388 & 7.429 & 7.041 & 55.545 \\
\hline feb-2017 & 39 & 10.566 & 10.605 & 16.060 & 12 & 254 & 266 & 4.995 & 4.729 & 60.274 \\
\hline mar-2017 & 54 & 9.767 & 9.821 & 14.705 & 17 & 234 & 251 & 4.573 & 4.322 & 64.596 \\
\hline abr-2017 & 0 & 3.962 & 3.962 & 9.757 & 0 & 95 & 95 & 3.034 & 2.939 & 67.536 \\
\hline may-2017 & 77 & 958 & 1.035 & 4.849 & 24 & 23 & 47 & 1.508 & 1.461 & 68.997 \\
\hline oct-2017 & 0 & 1.462 & 1.462 & 7.180 & 0 & 35 & 35 & 2.233 & 2.198 & 71.195 \\
\hline nov-2017 & 0 & 9.358 & 9.358 & 18.368 & 0 & 225 & 225 & 5.712 & 5.488 & 76.682 \\
\hline dic-2017 & 0 & 12.659 & 12.659 & 21.863 & 0 & 304 & 304 & 6.799 & 6.496 & 83.178 \\
\hline ene-2018 & 0 & 14.052 & 14.052 & 21.274 & 0 & 337 & 337 & 6.616 & 6.279 & 89.457 \\
\hline feb-2018 & 0 & 17.125 & 17.125 & 20.311 & 0 & 411 & 411 & 6.317 & 5.906 & 95.363 \\
\hline mar-2018 & 0 & 14.234 & 14.234 & 18.007 & 0 & 342 & 342 & 5.600 & 5.258 & 100.621 \\
\hline abr-2018 & 0 & 6.280 & 6.280 & 11.656 & 0 & 151 & 151 & 3.625 & 3.474 & 104.096 \\
\hline may-2018 & 0 & 2.132 & 2.132 & 8.095 & 0 & 51 & 51 & 2.518 & 2.466 & 106.562 \\
\hline
\end{tabular}

Como se observa durante estas tres temporadas se ha obtenido un ahorro total de 107 Toneladas de $\mathrm{CO}_{2}$, debido al consumo térmico del edificio $\mathrm{E} 1$. 


\section{AV.1.6. Estimación del precio máximo de compra a la red.}

Tomando como referencia los precios del gas natural de la Tabla 423 para cada temporada, obtenidos a partir de los datos establecidos en el Capítulo 3, donde se tiene en cuenta el precio por el termino variable y fijo; se puede realizar la estimación del precio máximo de compra de la energía útil a la red de calor para obtener un $0 \%$ de ahorro y un $15 \%$ de ahorro. La Tabla 424, muestral el precio que se pagaría para un ahorro del $15 \%$

Tabla 423. Precios de referencia para Gas natural y Astilla

\begin{tabular}{ccccc}
\hline Precios ( $€ /(\mathrm{kWh})$ & 2015 & 2016 & 2017 & 2018 \\
\hline Gasóleo C & 0,0517 & 0,0437 & 0,0499 & 0,0560 \\
\hline Astilla & 0,0277 & 0,0256 & 0,0254 & 0,0239 \\
\hline $\begin{array}{c}€ / \text { kWh útiles máximos de compra a la red para } \\
\text { un ahorro del 0,0\% }\end{array}$ & 0,0928 & \\
\hline $\begin{array}{c}€ / \text { kWh útiles máximos de compra a la red para } \\
\text { un ahorro del } 15,0 \%\end{array}$ & 0,0804 & \\
\hline
\end{tabular}

Tabla 424. Ahorro Económico por el consumo térmico en el Edificio E1

\begin{tabular}{|c|c|c|c|c|c|c|c|c|c|c|}
\hline & $\begin{array}{l}\text { kWh_E1 } \\
\text { Gasóleo }\end{array}$ & $\begin{array}{c}\text { kWh_E1__ } \\
\text { Biomasa }\end{array}$ & $\begin{array}{c}\text { kWh_E1 } \\
\text { Real }\end{array}$ & $\begin{array}{c}\text { kWh_E1 } \\
\text { Pronosticado }\end{array}$ & $\begin{array}{c}€ \text { Real } \\
\text { Gasóleo }\end{array}$ & $\begin{array}{c}€ \text { Real } \\
\text { Biomasa }\end{array}$ & $\begin{array}{l}€ \text { Real } \\
\text { Total }\end{array}$ & $\begin{array}{c}\text { € predicho } \\
\text { Gasóleo }\end{array}$ & $\begin{array}{c}€ \\
\text { Ahorro }\end{array}$ & $€$ Acumulado \\
\hline oct-2015 & 0 & 2.410 & 2.410 & 9.754 & 0 & 194 & 194 & 504 & 310 & 310 \\
\hline nov-2015 & 0 & 6.295 & 6.295 & 15.432 & 0 & 506 & 506 & 798 & 292 & 602 \\
\hline dic-2015 & 0 & 5.973 & 5.973 & 20.028 & 0 & 480 & 480 & 1.035 & 555 & 1.157 \\
\hline ene-2016 & 0 & 4.501 & 4.501 & 18.787 & 0 & 362 & 362 & 821 & 459 & 1.617 \\
\hline feb-2016 & 10.217 & 12.681 & 22.898 & 18.104 & 446 & 1.020 & 1.466 & 791 & -675 & 942 \\
\hline mar-2016 & 101 & 10.745 & 10.846 & 18.912 & 4 & 864 & 868 & 826 & -42 & 900 \\
\hline abr-2016 & 76 & 8.465 & 8.541 & 14.372 & 3 & 681 & 684 & 628 & -56 & 844 \\
\hline may-2016 & 8 & 2.436 & 2.444 & 9.348 & 0 & 196 & 196 & 409 & 212 & 1.056 \\
\hline oct-2016 & 378 & 1.716 & 2.094 & 8.846 & 17 & 138 & 154 & 387 & 232 & 1.288 \\
\hline nov-2016 & 262 & 8.419 & 8.681 & 17.291 & 11 & 677 & 688 & 756 & 67 & 1.356 \\
\hline dic-2016 & 0 & 8.311 & 8.311 & 21.684 & 0 & 668 & 668 & 948 & 279 & 1.635 \\
\hline ene-2017 & 23 & 15.868 & 15.891 & 23.887 & 1 & 1.276 & 1.277 & 1.192 & -85 & 1.550 \\
\hline feb-2017 & 39 & 10.566 & 10.605 & 16.060 & 2 & 850 & 851 & 801 & -50 & 1.500 \\
\hline mar-2017 & 54 & 9.767 & 9.821 & 14.705 & 3 & 785 & 788 & 734 & -54 & 1.446 \\
\hline$a b r-2017$ & 0 & 3.962 & 3.962 & 9.757 & 0 & 319 & 319 & 487 & 168 & 1.614 \\
\hline may-2017 & 77 & 958 & 1.035 & 4.849 & 4 & 77 & 81 & 242 & 161 & 1.775 \\
\hline oct-2017 & 0 & 1.462 & 1.462 & 7.180 & 0 & 118 & 118 & 358 & 241 & 2.016 \\
\hline nov-2017 & 0 & 9.358 & 9.358 & 18.368 & 0 & 752 & 752 & 917 & 164 & 2.180 \\
\hline dic-2017 & 0 & 12.659 & 12.659 & 21.863 & 0 & 1.018 & 1.018 & 1.091 & 73 & 2.253 \\
\hline ene-2018 & 0 & 14.052 & 14.052 & 21.274 & 0 & 1.130 & 1.130 & 1.191 & 62 & 2.315 \\
\hline feb-2018 & 0 & 17.125 & 17.125 & 20.311 & 0 & 1.377 & 1.377 & 1.137 & -239 & 2.075 \\
\hline mar-2018 & 0 & 14.234 & 14.234 & 18.007 & 0 & 1.144 & 1.144 & 1.008 & -136 & 1.939 \\
\hline abr-2018 & 0 & 6.280 & 6.280 & 11.656 & 0 & 505 & 505 & 653 & 148 & 2.087 \\
\hline may-2018 & 0 & 2.132 & 2.132 & 8.095 & 0 & 171 & 171 & 453 & 282 & 2.369 \\
\hline$€$ Total & & & & & & & 15.798 & 18.167 & & \\
\hline Ahorro (\%) & & & & & & & & & & $15,0 \%$ \\
\hline
\end{tabular}




\section{AV.2. Edificio E2. Facultad de Comercio.}

\section{AV.2.1. Obtención de la línea base de referencia energética}

Los datos de partida para la obtención de la línea base de referencia se muestran en la Tabla 425

Tabla 425. Consumos térmicos del edificio E2

\begin{tabular}{lr}
\hline & Consumos térmicos $(\mathrm{kWh}) . \mathrm{E} 2$ \\
\hline oct-12 & $36.833,95$ \\
\hline nov-12 & $64.166,05$ \\
\hline dic-12 & $47.218,91$ \\
\hline ene-13 & $49.862,29$ \\
\hline feb-13 & $84.570,38$ \\
\hline mar-13 & $66.954,98$ \\
\hline abr-13 & $50.474,64$ \\
\hline may-13 & $30.436,06$ \\
\hline oct-13 & $18.950,83$ \\
\hline nov-13 & $51.613,11$ \\
\hline dic-13 & $120.014,79$ \\
\hline ene-14 & $88.737,04$ \\
\hline feb-14 & $84.511,77$ \\
\hline mar-14 & $78.484,56$ \\
\hline abr-14 & $39.044,51$ \\
\hline may-14 & $33.970,93$ \\
\hline Promedio & 59.115 \\
\hline Total (oct-12-may-13) & 430.517 \\
\hline Total (oct-13-may-14) & 515.328 \\
\hline Total (oct-12-may-13) & 945.845 \\
\hline
\end{tabular}

Como se puede ver en la Tabla 426 para el edificio, el método ofrece un modelo de regresión, con una sola variable (Temperatura mínima). El modelo fue construido con un solo paso, incluyendo la Temp_min, por ser la variable más significativa (variable con menor valor de Sig $=0,000)$. El resto de las variables como se observa en la Tabla 427 fueron excluidas del modelo al tener valores de sig $>0,05$.

Tabla 426. Modelos de regresión del Edificio E2

\begin{tabular}{|c|c|c|c|c|c|c|c|}
\hline \multirow{2}{*}{\multicolumn{2}{|c|}{ Modelo }} & \multicolumn{2}{|c|}{$\begin{array}{l}\text { Coeficientes no } \\
\text { estandarizados }\end{array}$} & \multirow{2}{*}{$\mathrm{t}$} & \multirow{2}{*}{ Sig. } & \multicolumn{2}{|c|}{$\begin{array}{c}\text { Intervalo de confianza de } \\
95,0 \% \text { para B }\end{array}$} \\
\hline & & B & Error típ. & & & $\begin{array}{c}\text { Límite } \\
\text { inferior }\end{array}$ & $\begin{array}{l}\text { Límite } \\
\text { superior }\end{array}$ \\
\hline 1 & (Constante) & 83663,793 & 6067,812 & 13,788 & , 000 & 70649,630 & 96677,957 \\
\hline & $T$ Tmin & $-7896,580$ & 1478,869 & $-5,340$ & ,000 & $-11068,439$ & $-4724,721$ \\
\hline
\end{tabular}


En la Figura 296 se representa el modelo de regresión con sus límites inferior y superior para un nivel de confianza del $95 \%$

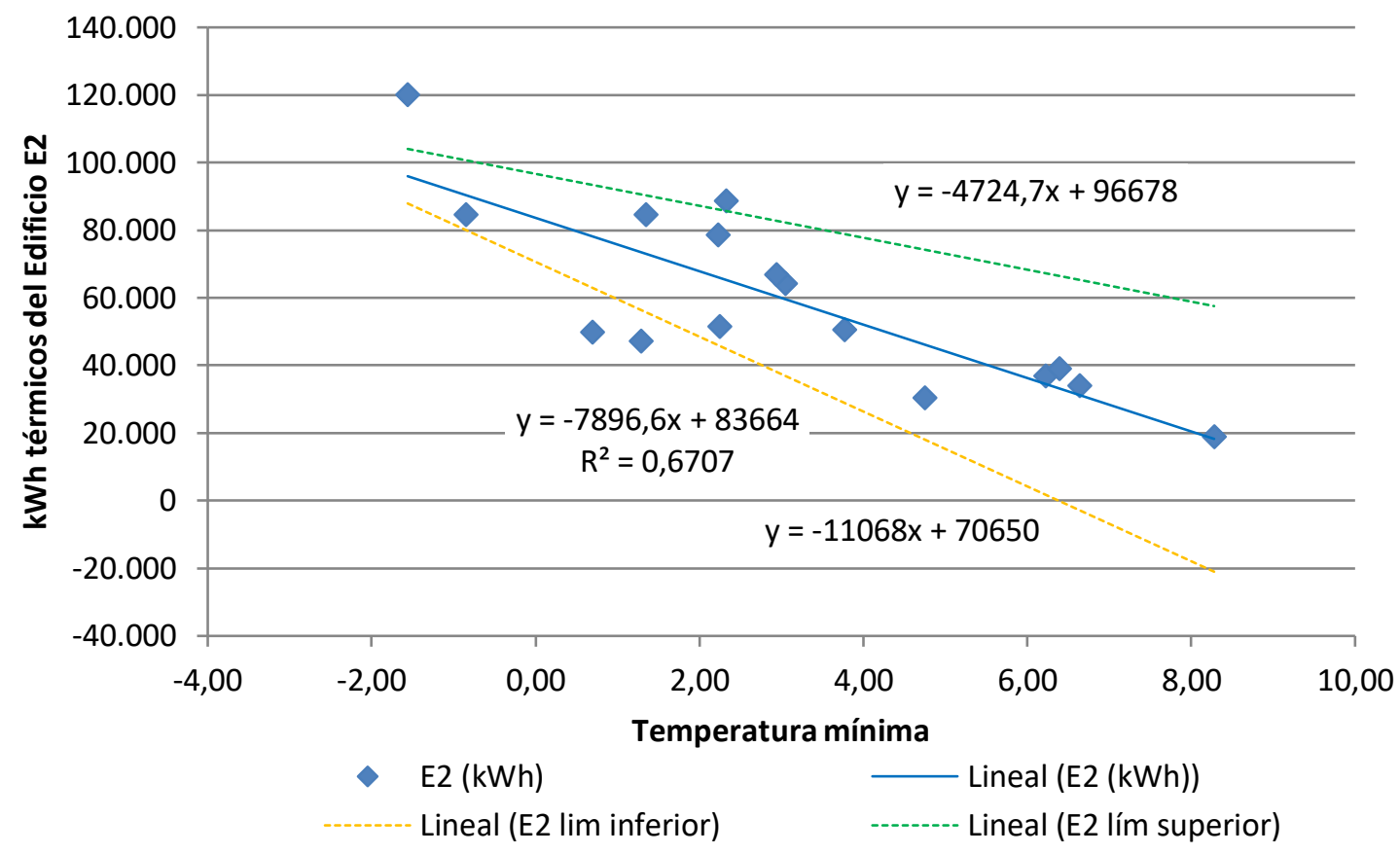

Figura 296. Representación del modelo de regresión lineal simple para el Edificio E2

Tabla 427. Variables excluidas del modelo de región del Edificio E2

\begin{tabular}{|c|c|c|c|c|}
\hline & Modelo & $\mathrm{t}$ & Sig. & Correlación parcial \\
\hline & GD15_30min &,- 214 & ,834 &,- 059 \\
\hline & GD20_30min &,- 273 & ,789 &,- 075 \\
\hline & GD15_24h &,- 233 & 819 &,- 065 \\
\hline & GD20_24h &,- 301 & ,768 &,- 083 \\
\hline & T_med_30min_C &, 292 & ,775 & 081 \\
\hline & T_media_diurna_C & ,289 & ,777 &, 080 \\
\hline & T_max_C & ,526 & ,608 & ,144 \\
\hline & HR_\% &,- 371 & ,717 &,- 102 \\
\hline & HR_med_diurna_\% &,- 303 & ,767 &,- 084 \\
\hline \multirow[t]{10}{*}{1} & HR_max_\% &,- 621 &, 545 &,- 170 \\
\hline & HR_min_\% &,- 494 & 629 &,- 136 \\
\hline & V_Viento_m/s & ,758 & ,462 & 206 \\
\hline & V_viento_diurna_m/s & ,796 & ,440 & ,216 \\
\hline & V_viento_nocturna_m/s & ,709 & ,491 & ,193 \\
\hline & V_viento_max_m $/ \mathrm{s}$ & 822 & ,426 & ,222 \\
\hline & Recorrido_viento_km/día &, 770 & ,455 & ,209 \\
\hline & Precipitación_acumulada_mes_mm &, 164 & 872 &, 045 \\
\hline & Horas insolación_h &,- 059 & ,953 &,- 016 \\
\hline & Radiación_W/m2 &, 130 & ,899 &, 036 \\
\hline
\end{tabular}


La bondad del modelo de regresión obtenido para el edificio E2, se resumen en la Tabla 428

Tabla 428. Resumen de la bondad del modelo de regresión para el Edificio D2

\begin{tabular}{ccccc}
\hline Modelo & $\mathrm{R}$ & R cuadrado & $\begin{array}{c}\text { R cuadrado } \\
\text { corregida }\end{array}$ & $\begin{array}{c}\text { Error típ. de la } \\
\text { estimación }\end{array}$ \\
\hline 1 &,- 819 &, 671 &, 647 & 15840,1721 \\
\hline
\end{tabular}

Se observa como el modelo de regresión lineal simple presenta un Coeficiente de Correlación de Pearson ( $R$ ) de 0,819 , lo que indica que las variables están correlacionadas de manera muy fuerte (en la correlación perfecta $R= \pm 1$ ). La correlación que se produce es inversa, al aumentar el valor de la Temperatura mínima, disminuye el consumo térmico.

El coeficiente de determinación $\left(R^{2}\right)$, nos indica que con el modelo se podría explicar el $67,1 \%$ de los datos reales obtenidos aceptando un error del $5 \%$.

El error típico de la estimación que nos indica la magnitud de los errores, es decir la parte de la variable dependiente que dejamos sin explicar con el modelo y que describe la variación de la variable respuesta (el Consumo) respecto a la recta de regresión, es de $15.840 \mathrm{kWh}$, lo que representa un 26,8\% del promedio de los consumos que fue de 59.115 kWh.

\section{AV.2.2. Verificación del cumplimiento de los supuestos estadísticos}

Las condiciones que se deben cumplir en un modelo de regresión son:

- Linealidad de las variables, las variables se encuentran relacionadas de forma lineal.

Como se observa en la Tabla 426, la pendiente (B), obtuvo un valor de Sig =0,000, que al ser $\leq 0,05$, nos indica que podemos rechazar la hipótesis nula de pendiente igual a cero y nos da la evidencia de linealidad entre la variable dependiente ( $k$ Wh del edificio E2) y la independiente (T_min). Al ser el valor de la pendiente negativa, indica una relación inversa entre el consumo y la Temperatura mínima.

- Normalidad. Todos los valores obtenidos para la variable dependiente (Y), deben estar distribuidos normalmente en cada valor de la variable independiente $(X)$.

Se comprueba la normalidad de las variables y de los residuos mediante el Test de Shapiro - Wilk para muestras pequeñas (menores a 30 observaciones), siendo la hipótesis nula el que la distribución es Normal. 
La Tabla 429, muestra la prueba de normalidad de Shapiro-Wilk y cómo tanto la variable dependiente (consumos del Edificio), como la variable independientes: T_min poseen una Sig $>0,05$, por lo que aceptamos la hipótesis nula de Normalidad de las variables

Tabla 429. Prueba de normalidad para el edificio E2

\begin{tabular}{lrrrrrr}
\hline & \multicolumn{3}{c}{ Kolmogorov-Smirnov } & \multicolumn{3}{c}{ Shapiro-Wilk } \\
\cline { 2 - 8 } & Estadístico & gl & Sig. & Estadístico & gl & \multicolumn{1}{c}{ Sig. } \\
\hline kWh_E2 & 170 & 16 &, 200 &, 953 & 16 &, 545 \\
\hline T_min &, 133 & 16 &, 200 &, 968 & 16 &, 813 \\
\hline
\end{tabular}

- Independencia de los errores. Los errores asociados a los valores de la variable respuesta $(\mathrm{Y})$ deberán ser independientes unos de otros.

Para la comprobación se utiliza el estadístico de Durbin -Watson.

Se comprueba que el Estadístico de Durbin Watson para el nivel de significancia del 5\%, y para el tamaño de la muestra " $n$ " y el número de variables independientes del modelo " $k$ ", se encuentra en el intervalo [dU, 4-dU], de la Tabla 3, intervalo centrado en el 2, que indica la ausencia de autocorrelación.

El valor del Estadístico Durbin-Watson facilitado por el programa SPSS, es 1,149.

En el modelo, $\mathrm{n}=16$ y $\mathrm{k}=1$, según la Tabla 3 el valor $\mathrm{dU}=1,371$ y $\mathrm{dL}=1,106$, luego el intervalo que marca la ausencia de correlación es [1,371, 2,629].

Los intervalos $[0,1,106]$ y $[2,896,4]$ indican correlación positiva o negativa respectivamente y las zonas $[1,106,1,371]$ y $[2,629,2,896]$ son zonas no concluyentes; como el valor del estadístico 1,149 está dentro del primer intervalo no concluyente, se comprueba la ausencia de autocorrelación, mediante el gráfico de residuos frente al tiempo.

La Figura 297, muestra que la relación entre los residuos y el tiempo, posee un coeficiente de determinación $=0,280$, bajo, aunque no nulo; por lo que se concluye que existe una baja autocorrelación en los residuos. 


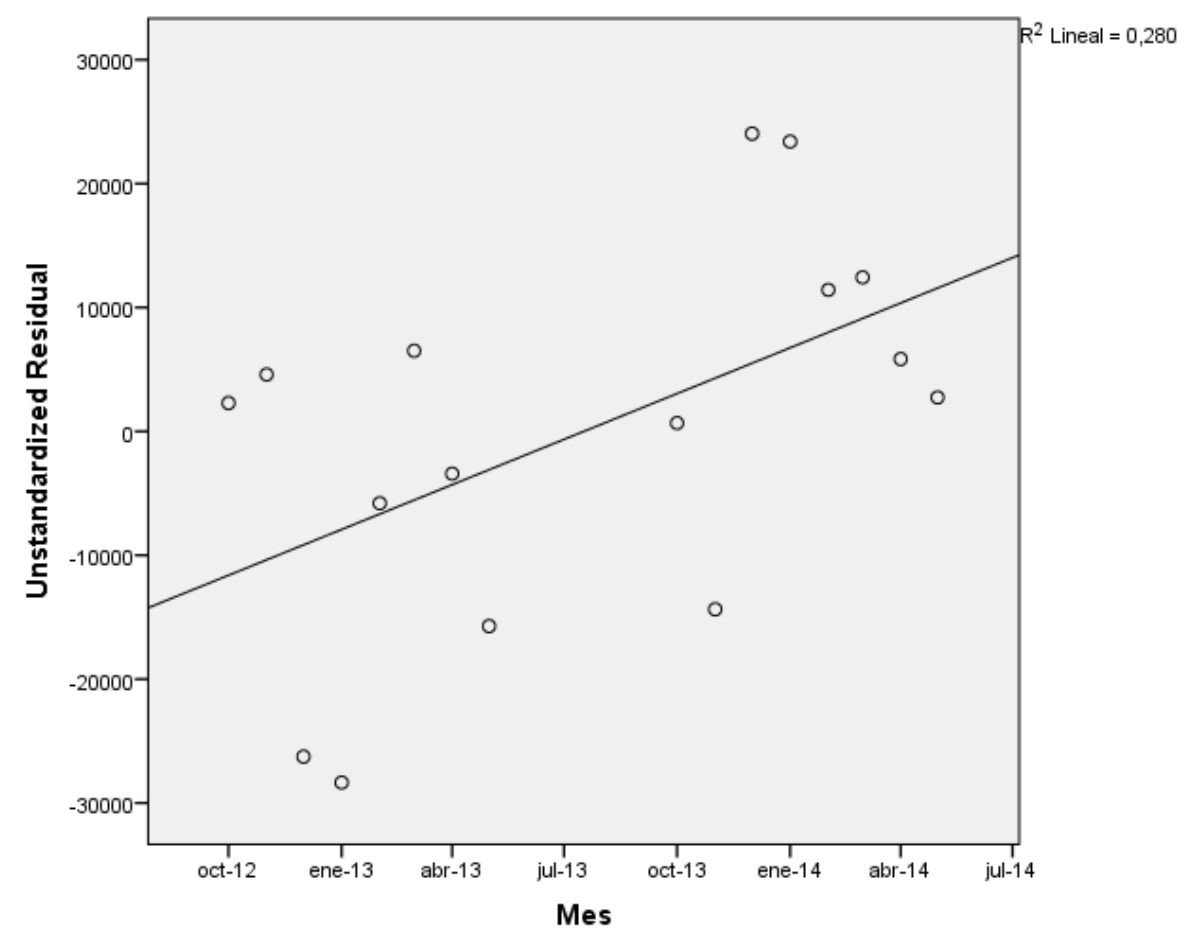

Figura 297. Relación entre los residuos y el tiempo en el Edificio E2

- Homocedasticidad de la varianza. Se pretende comprobar que la varianza de los errores $\left(\sigma^{2}\right)$ es constante para cualquier valor de la variable independiente $(X)$, es decir que el valor medio del cuadrado de la desviación de los errores respecto a su media es constante.

Esta condición indica que no existe correlación entre los residuos y los pronósticos. Se comprueba que el coeficiente de determinación $\mathrm{R}^{2}$, en las relaciones: residuos $\mathrm{y}$ predicciones y entre residuos y variable independiente es nulo o muy próximo a cero, lo que indicará que no existe ningún tipo de correlación en los residuos y que éstos son aleatorios.

Se grafican los diagramas de dispersión de esas relaciones, comprobando que se corresponden a nubes de puntos totalmente aleatorias, sin tendencias ni patrones en sus representaciones gráficas.

Las Figura 298 y Figura 299, muestran que la relación entre los pronósticos y los residuos, posee un coeficiente de determinación $=0$ y entre la variable independiente (T_min) y los residuos un coeficiente de determinación de $-2,22 \times 10^{-16}$; por lo que se concluye que no existe ningún tipo de correlación en los residuos y que éstos son aleatorios, siendo la varianza de los residuos constante. 
Anexo V. Desarrollo del análisis de los edificios del Campus Río Esgueva

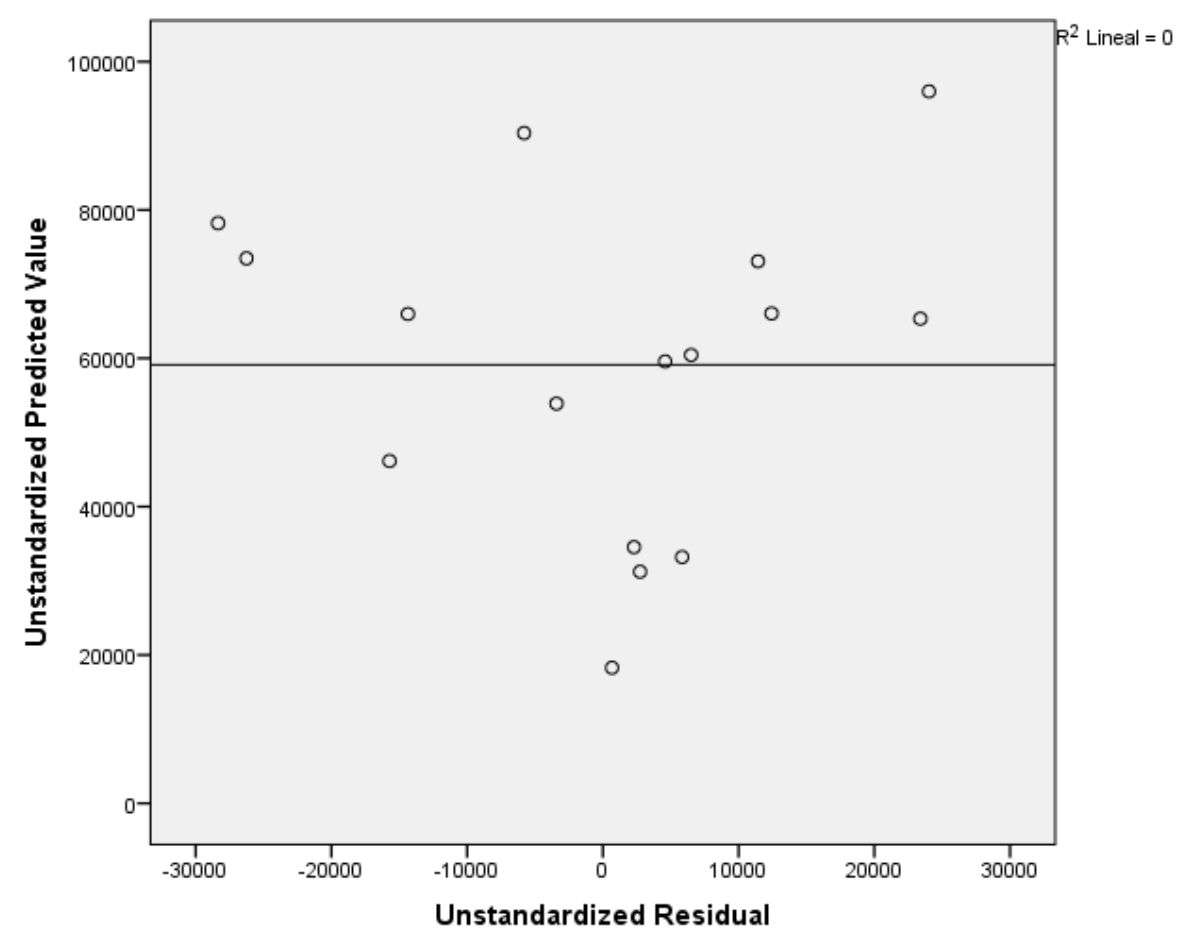

Figura 298. Relación entre los pronósticos y los residuos en el Edificio E2

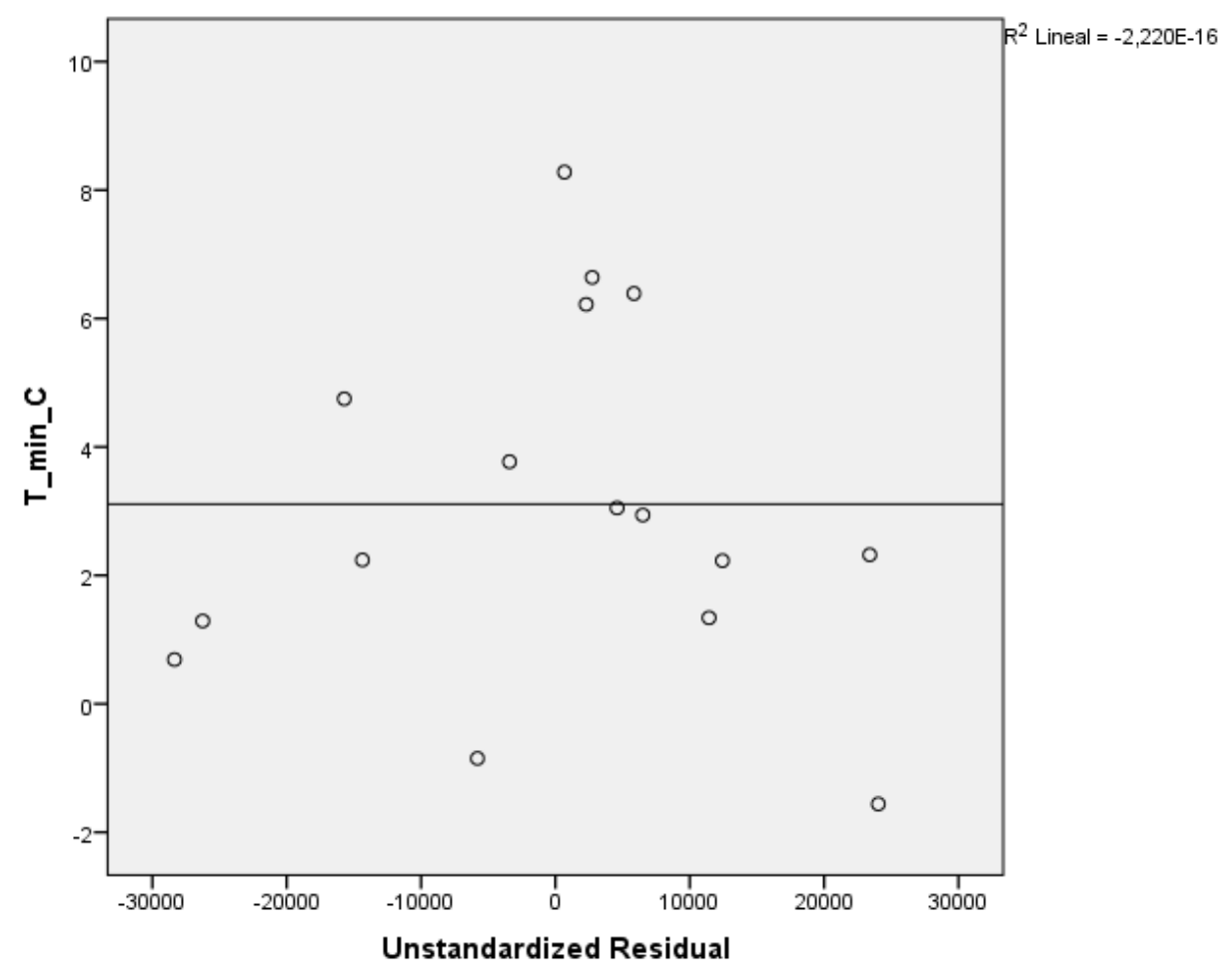

Figura 299. Relación entre T_min y los residuos en el Edificio E2 


\section{AV.2.3. Obtención de los consumos térmicos previstos}

Una vez comprobado el cumplimiento de los supuestos estadísticos se acepta el modelo de línea base encontrado para modelizar el consumo del Edificio E2.

$$
\mathrm{kWh} \_ \text {2_Pronosticado }=83.663,793-7.896,58 \times \mathrm{T} \_\mathrm{min}
$$

Con este modelo se procede a predecir los consumos previstos para las temporadas: octubre 2015-mayo 2016, octubre 2016 - mayo 2017 y octubre 2017-mayo 2018, estos consumos se muestran en la Tabla 430, donde "KWh_E2_Real", representa el consumo real redistribuido, "kWh_E2_Pronosticado", el consumo pronosticado con el Modelo.

Tabla 430. Consumos previstos octubre 2014 - mayo 2017 para el edificio E2.

\begin{tabular}{rrrr}
\hline & \multicolumn{1}{c}{ T_min } & kWh_E2_Real & kWh_E2_Pronosticado \\
\hline oct-15 & 7,50 & 7.380 & 24.439 \\
\hline nov-15 & 4,16 & 49.410 & 50.843 \\
\hline dic-15 & 1,20 & 46.960 & 74.165 \\
\hline ene-16 & 2,63 & 32.190 & 62.931 \\
\hline feb-16 & 1,30 & 144.460 & 73.415 \\
\hline mar-16 & 0,20 & 59.975 & 82.112 \\
\hline abr-16 & 3,83 & 43.230 & 53.417 \\
\hline may-16 & 6,63 & 10.969 & 31.322 \\
\hline oct-16 & 7,14 & 15.025 & 27.295 \\
\hline nov-16 & 2,23 & 68.720 & 66.070 \\
\hline dic-16 & 0,57 & 65.329 & 79.178 \\
\hline ene-17 & $-2,83$ & 98.867 & 105.993 \\
\hline feb-17 & 2,19 & 71.759 & 66.376 \\
\hline mar-17 & 2,59 & 51.050 & 63.235 \\
\hline abr-17 & 3,83 & 18.717 & 53.433 \\
\hline may-17 & 9,02 & 3.965 & 12.419 \\
\hline oct-17 & 6,71 & 5.110 & 30.713 \\
\hline nov-17 & $-0,28$ & 48.158 & 85.872 \\
\hline dic-17 & $-0,44$ & 80.392 & 87.108 \\
\hline ene-18 & 0,66 & 79.450 & 78.485 \\
\hline feb-18 & $-1,96$ & 99.180 & 99.104 \\
\hline mar-18 & 2,74 & 78.870 & 62.030 \\
\hline abr-18 & 5,73 & 33.930 & 38.430 \\
\hline may-18 & 7,82 & 9.060 & 21.892 \\
\hline & & &
\end{tabular}




\section{AV.2.4. Estudio de la existencia de diferencias significativas}

Utilizando la prueba " $\mathrm{t}$ " de Student para muestras relacionadas, podemos concluir que si las variables se distribuyen según una normal y la significación estadística resulta $\leq 0,05$, existen diferencias significativas, con un nivel de confianza del $95 \%$

A continuación se muestra la comparación de medias realizada para cada uno de los tres periodos posteriores a la construcción de la red y para el periodo total hasta mayo de 2018.

Para la temporada Octubre 2015 - Mayo 2016, se comprueba mediante el Test de Shapiro -Wilk que los valores reales no se distribuyen según una Normal (sig $\leq 0,05)$, aunque los pronosticados si (Sig >0,05), como se observa en la Tabla 431

Tabla 431. Prueba de Normalidad temporada Octubre 2015-Mayo 2016. Edificio E1

\begin{tabular}{ccccccc}
\hline & \multicolumn{3}{c}{ Kolmogorov-Smirnov $^{\mathrm{a}}$} & \multicolumn{3}{c}{ Shapiro-Wilk } \\
\cline { 2 - 7 } & Estadístico & $\mathrm{gl}$ & Sig. & Estadístico & $\mathrm{gl}$ & Sig. \\
\hline kWh_real &, 276 & 8 &, 073 &, 812 & 8 &, 038 \\
\hline kWh_pronosticado &, 167 & 8 &, 200 &, 934 & 8 &, 558 \\
\hline
\end{tabular}

Al no cumplirse la hipótesis de la normalidad de los datos no se puede aplicar la " $t$ " de Student para analizar si existen diferencias significativas en esta primera temporada.

Para la temporada Octubre 2016 - Mayo 2017, se comprueba mediante el Test de Shapiro -Wilk que tanto los valores reales como los pronosticados con los dos modelos se distribuyen según una Normal puesto que en todos los casos los valores de Sig >0,05, como se observa en la Tabla 432

Tabla 432. Prueba de Normalidad temporada Octubre 2016-Mayo 2017. Edificio E2

\begin{tabular}{ccccccc}
\hline & \multicolumn{3}{c}{ Kolmogorov-Smirnov $^{\mathrm{a}}$} & \multicolumn{3}{c}{ Shapiro-Wilk } \\
\cline { 2 - 7 } & Estadístico & gl & Sig. & Estadístico & gl & Sig. \\
\hline kWh_real &, 195 & 8 &, 200 &, 929 & 8 &, 508 \\
\hline kWh_pronosticado &, 179 & 8 &, 200 &, 958 & 8 &, 791 \\
\hline
\end{tabular}

En la Tabla 433, se observa como las medias de los consumos pronosticados, son superiores a las medias de los consumos reales del Edificio E2, en un 20,5\%

Tabla 433. Estadísticos de muestras relacionadas. Octubre 2016-Mayo 2017. Edificio E2

\begin{tabular}{lccccc}
\hline & Media & $\begin{array}{c}\text { \% Diferencia } \\
\text { entre medias }\end{array}$ & N & $\begin{array}{c}\text { Desviación } \\
\text { típ. }\end{array}$ & $\begin{array}{c}\text { Error típ. de } \\
\text { la media }\end{array}$ \\
\hline kWh_real & 49179,0000 & & 8 & 33303,07262 & 11774,41424 \\
\hline kWh_pronosticado & 59249,8750 & $20,5 \%$ & 8 & 29138,35913 & 10301,96567 \\
\hline
\end{tabular}


La Tabla 434 muestra que las diferencias entre las medias no son significativas entre los consumos reales y los pronosticados (sig $>0,05$ )

Tabla 434. Prueba de muestras relacionadas. Octubre 2016-Mayo 2017. Edificio E2

\begin{tabular}{|c|c|c|c|c|c|c|c|c|c|}
\hline & & \multicolumn{5}{|c|}{ Diferencias relacionadas } & \multirow{3}{*}{$\mathrm{t}$} & \multirow{3}{*}{ gl } & \multirow{3}{*}{$\begin{array}{c}\text { Sig. } \\
\text { (bilateral) }\end{array}$} \\
\hline & & \multirow[t]{2}{*}{ Media } & \multirow{2}{*}{$\begin{array}{c}\text { Desviación } \\
\text { típ. }\end{array}$} & \multirow{2}{*}{$\begin{array}{l}\text { Error típ. } \\
\text { de la media }\end{array}$} & \multicolumn{2}{|c|}{$\begin{array}{l}\text { 95\% Intervalo de confianza } \\
\text { para la diferencia }\end{array}$} & & & \\
\hline & & & & & Inferior & Superior & & & \\
\hline Par 1 & $\begin{array}{c}\text { kWh_real - } \\
\text { kWh_pronosticado }\end{array}$ & $-10070,875$ & 12205,921 & 4315,445 & $-20275,280$ & 133,530 & $-2,334$ & 7 & 052 \\
\hline
\end{tabular}

En la Figura 300 se grafican los consumos reales y pronosticados para la temporada Octubre 2016 - Mayo 2017 para el Edificio E2, y las medias de dichos consumos. Según la prueba paramétrica realizada las diferencias encontradas no son estadísticamente significativas, con un riesgo a estar equivocados del $5 \%$

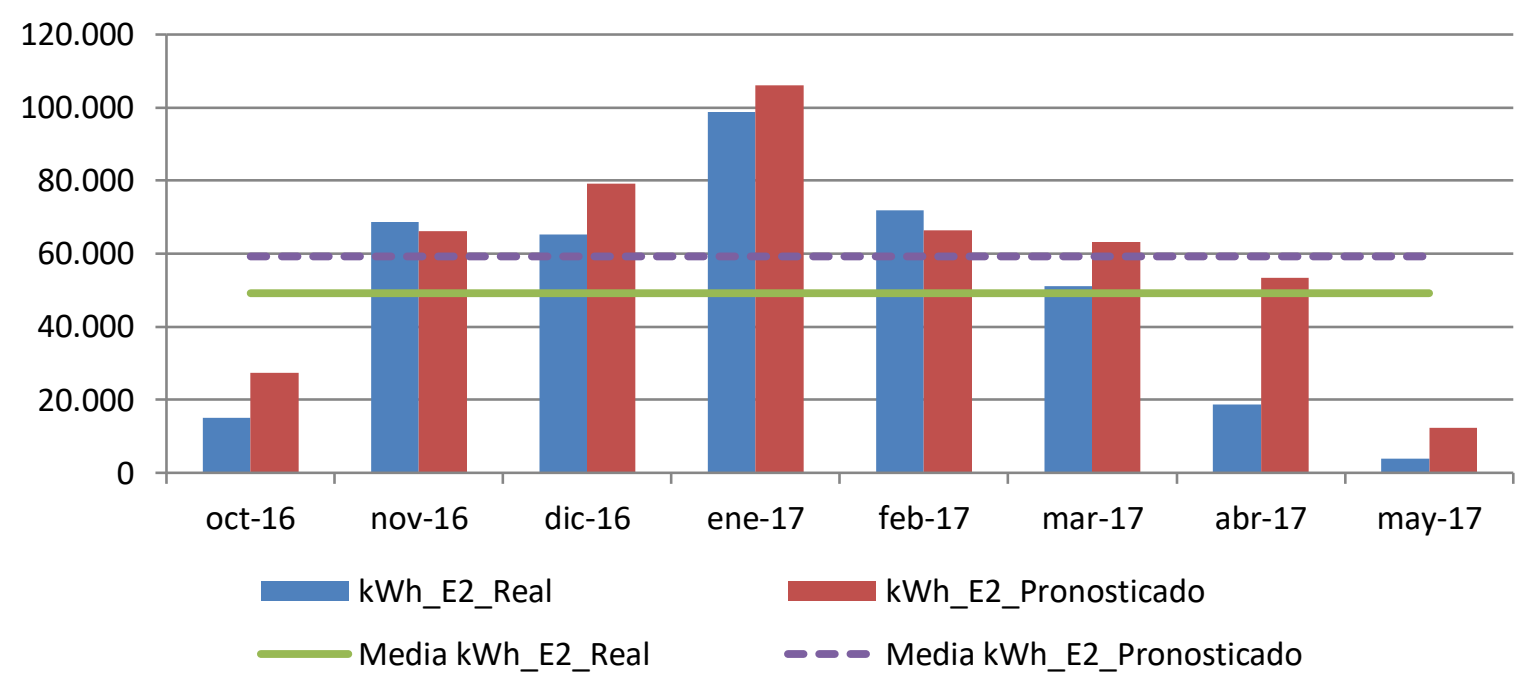

Figura 300. Consumos reales y pronosticados Octubre 2016-Mayo 2017. Edificio E2

Para la temporada Octubre 2017 - Mayo 2018, se comprueba mediante el Test de Shapiro -Wilk que tanto los valores reales como los pronosticados se distribuyen según una Normal puesto que en todos los casos los valores de Sig $>0,05$, como se observa en la Tabla 435

Tabla 435. Prueba de Normalidad temporada Octubre 2017-Mayo 2018. Edificio E2

\begin{tabular}{crrrrrrr}
\hline & \multicolumn{3}{c}{ Kolmogorov-Smirnov $^{\mathrm{a}}$} & \multicolumn{3}{c}{ Shapiro-Wilk } \\
\cline { 2 - 8 } & Estadístico & gl & \multicolumn{1}{c}{ Sig. } & Estadístico & gl & \multicolumn{1}{c}{ Sig. } \\
\hline kWh_real &, 255 & 8 &, 133 &, 899 & 8 &, 282 \\
\hline kWh_pronosticado &, 202 & 8 &, 200 &, 910 & 8 &, 353 \\
\hline
\end{tabular}


En la Tabla 436, se observa como las medias de los consumos pronosticados, son superiores a las medias de los consumos reales del Edificio E2, en un 16,0\%

Tabla 436. Estadísticos de muestras relacionadas. Octubre 2017-Mayo 2018. Edificio E1

\begin{tabular}{lccrcc}
\hline & Media & $\begin{array}{c}\text { \% Diferencia } \\
\text { entre medias }\end{array}$ & $\mathrm{N}$ & $\begin{array}{c}\text { Desviación } \\
\text { típ. }\end{array}$ & $\begin{array}{c}\text { Error típ. de } \\
\text { la media }\end{array}$ \\
\hline kWh_real & 54268,7500 & & 8 & 35557,15965 & 12571,35435 \\
\hline kWh_pronosticado & 62954,2500 & $16,0 \%$ & 8 & 29239,24754 & 10337,63511 \\
\hline
\end{tabular}

La Tabla 437 muestra que las diferencias entre las medias no son significativas entre los consumos reales y los pronosticados (sig $>0,05$ )

Tabla 437. Prueba de muestras relacionadas. Octubre 2017-Mayo 2018. Edificio E2

\begin{tabular}{|c|c|c|c|c|c|c|c|c|c|}
\hline & & \multicolumn{5}{|c|}{ Diferencias relacionadas } & \multirow{3}{*}{$\mathrm{t}$} & \multirow{3}{*}{ gl } & \multirow{3}{*}{$\begin{array}{c}\text { Sig. } \\
\text { (bilateral) }\end{array}$} \\
\hline & & \multirow[t]{2}{*}{ Media } & \multirow{2}{*}{$\begin{array}{l}\text { Desviación } \\
\text { típ. }\end{array}$} & \multirow{2}{*}{$\begin{array}{l}\text { Error típ. } \\
\text { de la media }\end{array}$} & \multicolumn{2}{|c|}{$\begin{array}{l}\text { 95\% Intervalo de confianza } \\
\text { para la diferencia }\end{array}$} & & & \\
\hline & & & & & Inferior & Superior & & & \\
\hline Par 1 & $\begin{array}{c}\text { kWh_real - } \\
\text { kWh_pronosticado }\end{array}$ & $-8685,500$ & 16856,087 & 5959,526 & $-22777,541$ & 5406,541 & $-1,457$ & 7 & ,188 \\
\hline
\end{tabular}

En la Figura 301, se grafican los consumos reales y pronosticados para la temporada Octubre 2017 - Mayo 2018 para el Edificio E2, y las medias de dichos consumos. Según la prueba paramétrica realizada las diferencias encontradas no son estadísticamente significativas, con un riesgo a estar equivocados del $5 \%$

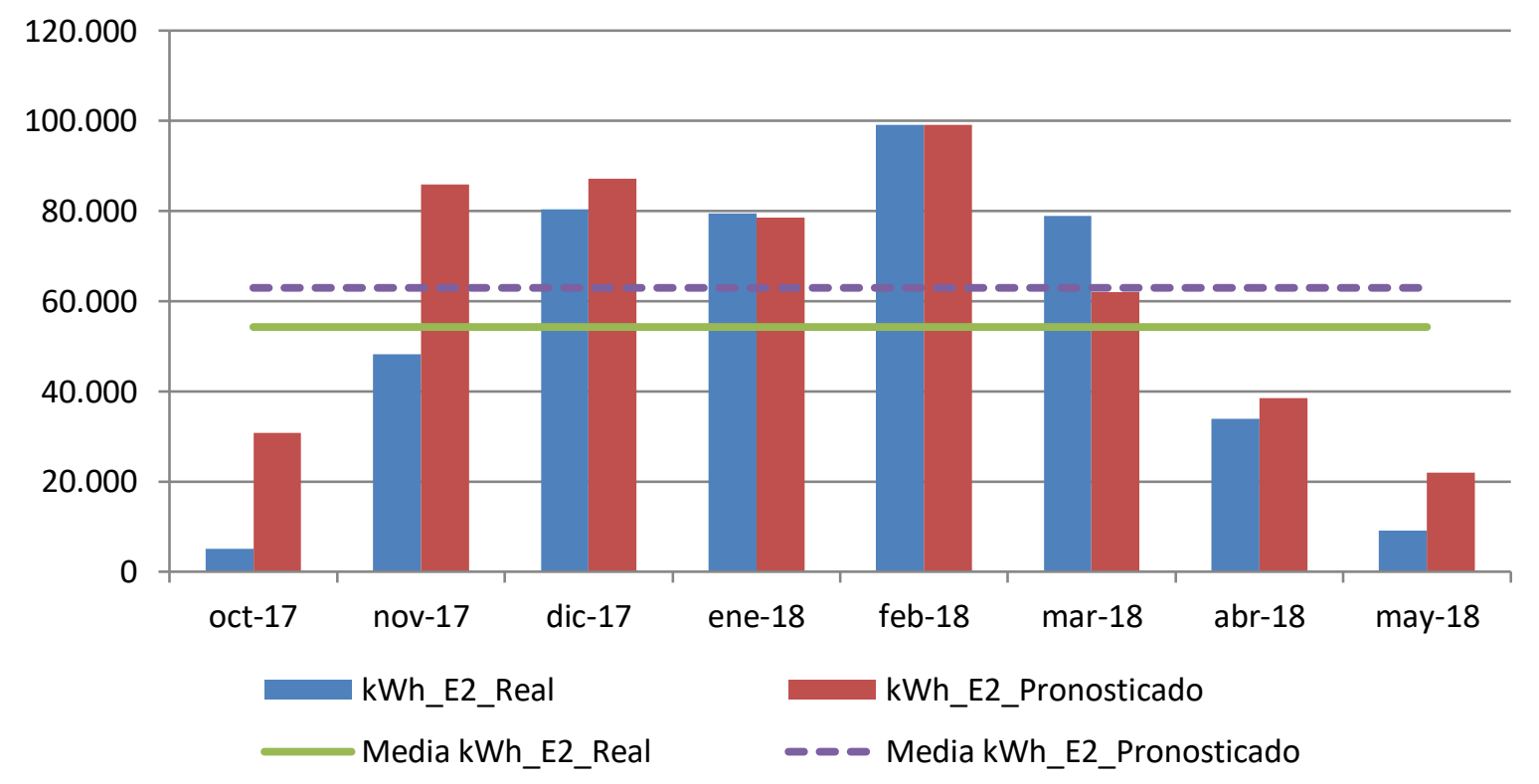

Figura 301. Consumos reales y pronosticados Octubre 2017-Mayo 2018. Edificio E2 
Para el total de las tres temporadas Octubre 2015 - Mayo 2018, se comprueba mediante el Test de Shapiro -Wilk, que los valores reales y los pronosticados se distribuyen según una Normal puesto que en esos casos los valores de Sig $>0,05$, como se observa en la Tabla 438

Tabla 438. Prueba de Normalidad temporada Octubre 2015-Mayo 2018. Edificio E2

\begin{tabular}{cccccccr}
\hline & \multicolumn{3}{c}{ Kolmogorov-Smirnov $^{\mathrm{a}}$} & \multicolumn{4}{c}{ Shapiro-Wilk } \\
\cline { 2 - 8 } & Estadístico & gl & Sig. & Estadístico & gl & Sig. \\
\hline kWh_real &, 107 & 24 &, 200 &, 942 & 24 &, 181 \\
\hline kWh_pronosticado &, 121 & 24 &, 200 &, 966 & 24 &, 581 \\
\hline
\end{tabular}

En la Tabla 439 se observa como las medias de los consumos pronosticados, son superiores a las medias de los consumos reales del Edificio E2, en un $17,0 \%$

Tabla 439. Estadísticos de muestras relacionadas. Octubre 2015-Mayo 2018. Edificio E2

\begin{tabular}{lccccc}
\hline & Media & $\begin{array}{c}\text { \% Diferencia } \\
\text { entre medias }\end{array}$ & $\mathrm{N}$ & $\begin{array}{c}\text { Desviación } \\
\text { típ. }\end{array}$ & $\begin{array}{c}\text { Error típ. de } \\
\text { la media }\end{array}$ \\
\hline kWh_real & 50923,1667 & & 24 & 35800,93178 & 7307,83460 \\
\hline kWh_pronosticado & 59594,8750 & $17,0 \%$ & 24 & 25614,67472 & 5228,57358 \\
\hline
\end{tabular}

La Tabla 440 muestra que las diferencias entre las medias no son significativas entre los consumos reales y los pronosticados (sig $>0,05$ )

Tabla 440. Prueba de muestras relacionadas. Octubre 2015-Mayo 2018. Edificio E2

\begin{tabular}{|c|c|c|c|c|c|c|c|c|}
\hline & \multicolumn{5}{|c|}{ Diferencias relacionadas } & \multirow{3}{*}{$\mathrm{t}$} & \multirow{3}{*}{$\mathrm{gl}$} & \multirow{3}{*}{$\begin{array}{c}\text { Sig. } \\
\text { (bilateral) }\end{array}$} \\
\hline & \multirow[t]{2}{*}{ Media } & \multirow{2}{*}{$\begin{array}{l}\text { Desviación } \\
\text { típ. }\end{array}$} & \multirow{2}{*}{$\begin{array}{c}\text { Error típ. } \\
\text { de la media }\end{array}$} & \multicolumn{2}{|c|}{$\begin{array}{c}\text { 95\% Intervalo de confianza } \\
\text { para la diferencia }\end{array}$} & & & \\
\hline & & & & Inferior & Superior & & & \\
\hline $\begin{array}{c}\text { kWh_real - } \\
\text { kWh_pronosticado }\end{array}$ & $-8671,708$ & 21544,238 & 4397,699 & $-17769,042$ & 425,625 & $-1,972$ & 23 & ,061 \\
\hline
\end{tabular}




\section{AV.2.5. Estimación de las emisiones de $\mathrm{CO} 2$ evitadas.}

Teniendo en cuenta que el consumir Gasóleo se producen 0,311 kg CO 2 / kWh E. final y que al consumir la energía suministrada por red a partir de Biomasa se producen 0,024 kg $\mathrm{CO}_{2} / \mathrm{kWh}$. final, en la Tabla 441, se muestra las emisiones de $\mathrm{CO}_{2}$ reales para las temporadas octubre 2015 - mayo 2018 y utilizando el Modelo de regresión, las emisiones de $\mathrm{CO}_{2}$ que se hubieran tenido de haber seguido utilizando las calderas de gasóleo originales sin el apoyo de la red de calor.

Tabla 441. Estimación del ahorro de emisiones de CO2 para el Edificio E2.

\begin{tabular}{|c|c|c|c|c|c|c|c|c|c|c|}
\hline & kWh_E2 Gasóleo & kWh_E2 Biomasa & $\begin{array}{c}\text { kWh_E2 } \\
\text { Real } \\
\text { Total }\end{array}$ & $\begin{array}{l}\text { kWh_E2 } \\
\text { Predicho }\end{array}$ & $\begin{array}{c}\text { kg CO2 } \\
\text { Real } \\
\text { debido al } \\
\text { consumo } \\
\text { de } \\
\text { Gasóleo }\end{array}$ & $\begin{array}{c}\text { kg CO2 } \\
\text { Real } \\
\text { debido } \\
\text { a } \\
\text { Biomasa }\end{array}$ & $\begin{array}{c}\text { kg CO2 } \\
\text { Real } \\
\text { debido } \\
\text { al } \\
\text { consumo } \\
\text { TOTAL }\end{array}$ & $\begin{array}{c}\text { kg CO2 } \\
\text { que se } \\
\text { hubiera } \\
\text { tenido } \\
\text { debido } \\
\text { a } \\
\text { Gasóleo }\end{array}$ & $\begin{array}{c}\text { Ahorro } \\
\text { de kg } \\
\text { CO2 }\end{array}$ & $\begin{array}{l}\text { Ahorro de } \\
\text { kg } \mathrm{CO} 2 \\
\text { acumulado }\end{array}$ \\
\hline oct-2015 & 0 & 7.380 & 7.380 & 7.380 & 0 & 177 & 177 & 2.295 & 2.118 & 2.118 \\
\hline nov-2015 & 0 & 49.410 & 49.410 & 49.410 & 0 & 1.186 & 1.186 & 15.367 & 14.181 & 16.299 \\
\hline dic-2015 & 0 & 46.960 & 46.960 & 46.960 & 0 & 1.127 & 1.127 & 14.605 & 13.478 & 29.776 \\
\hline ene-2016 & 0 & 32.190 & 32.190 & 32.190 & 0 & 773 & 773 & 10.011 & 9.239 & 39.015 \\
\hline feb-2016 & 65.280 & 79.180 & 144.460 & 144.460 & 20.302 & 1.900 & 22.202 & 44.927 & 22.725 & 61.739 \\
\hline mar-2016 & 4.645 & 55.330 & 59.975 & 59.975 & 1.445 & 1.328 & 2.772 & 18.652 & 15.880 & 77.619 \\
\hline abr-2016 & 1.880 & 41.350 & 43.230 & 43.230 & 585 & 992 & 1.577 & 13.444 & 11.867 & 89.487 \\
\hline may-2016 & 59 & 10.910 & 10.969 & 10.969 & 18 & 262 & 280 & 3.411 & 3.131 & 92.618 \\
\hline oct-2016 & 4.695 & 10.330 & 15.025 & 15.025 & 1.460 & 248 & 1.708 & 4.673 & 2.965 & 95.582 \\
\hline nov-2016 & 3.770 & 64.950 & 68.720 & 68.720 & 1.173 & 1.559 & 2.731 & 21.372 & 18.641 & 114.223 \\
\hline dic-2016 & 1.079 & 64.250 & 65.329 & 65.329 & 336 & 1.542 & 1.878 & 20.317 & 18.440 & 132.663 \\
\hline ene-2017 & 3.207 & 95.660 & 98.867 & 98.867 & 997 & 2.296 & 3.293 & 30.748 & 27.454 & 160.117 \\
\hline feb-2017 & 2.529 & 69.230 & 71.759 & 71.759 & 786 & 1.662 & 2.448 & 22.317 & 19.869 & 179.986 \\
\hline mar-2017 & 0 & 51.050 & 51.050 & 51.050 & 0 & 1.225 & 1.225 & 15.877 & 14.651 & 194.638 \\
\hline abr-2017 & 77 & 18.640 & 18.717 & 18.717 & 24 & 447 & 471 & 5.821 & 5.350 & 199.987 \\
\hline may-2017 & 355 & 3.610 & 3.965 & 3.965 & 110 & 87 & 197 & 1.233 & 1.036 & 201.023 \\
\hline oct-2017 & 0 & 5.110 & 5.110 & 5.110 & 0 & 123 & 123 & 1.589 & 1.467 & 202.490 \\
\hline nov-2017 & 0 & 48.158 & 48.158 & 48.158 & 0 & 1.156 & 1.156 & 14.977 & 13.821 & 216.311 \\
\hline dic-2017 & 0 & 80.392 & 80.392 & 80.392 & 0 & 1.929 & 1.929 & 25.002 & 23.073 & 239.384 \\
\hline ene-2018 & 0 & 79.450 & 79.450 & 79.450 & 0 & 1.907 & 1.907 & 24.709 & 22.802 & 262.186 \\
\hline feb-2018 & 0 & 99.180 & 99.180 & 99.180 & 0 & 2.380 & 2.380 & 30.845 & 28.465 & 290.651 \\
\hline mar-2018 & 0 & 78.870 & 78.870 & 78.870 & 0 & 1.893 & 1.893 & 24.529 & 22.636 & 313.286 \\
\hline abr-2018 & 0 & 33.930 & 33.930 & 33.930 & 0 & 814 & 814 & 10.552 & 9.738 & 323.024 \\
\hline may-2018 & 0 & 9.060 & 9.060 & 9.060 & 0 & 217 & 217 & 2.818 & 2.600 & 325.624 \\
\hline
\end{tabular}

Como se observa durante estas tres temporadas se ha obtenido un ahorro total de 326 Toneladas de $\mathrm{CO}_{2}$, debido al consumo térmico del edificio E2. 


\section{AV.2.6. Estimación del precio máximo de compra a la red.}

Tomando como referencia los precios del gas natural de la Tabla 442 para cada temporada, obtenidos a partir de los datos establecidos en el Capítulo 3, donde se tiene en cuenta el precio por el termino variable y fijo; se puede realizar la estimación del precio máximo de compra de la energía útil a la red de calor para obtener un $0 \%$ de ahorro y un $15 \%$ de ahorro. La Tabla 443, muestral el precio que se pagaría para un ahorro del 15\%

Tabla 442. Precios de referencia para Gas natural y Astilla

\begin{tabular}{ccccc}
\hline Precios ( $€ /(\mathrm{kWh})$ & 2015 & 2016 & 2017 & 2018 \\
\hline Gasóleo C & 0,0517 & 0,0437 & 0,0499 & 0,0560 \\
\hline Astilla & 0,0277 & 0,0256 & 0,0254 & 0,0239 \\
\hline $\begin{array}{c}€ / \text { kWh útiles máximos de compra a la red para } \\
\text { un ahorro del } 0,0 \%\end{array}$ & 0,0497 & \\
\hline $\begin{array}{c}€ / \text { kWh útiles máximos de compra a la red para } \\
\text { un ahorro del } 15,0 \%\end{array}$ & 0,0428 & \\
\hline
\end{tabular}

Tabla 443. Ahorro Económico por el consumo térmico en el Edificio E1

\begin{tabular}{|c|c|c|c|c|c|c|c|c|c|c|}
\hline & kWh_E2Gasóleo & $\begin{array}{c}\text { kWh_E2_- } \\
\text { Biomasa }\end{array}$ & $\begin{array}{c}\text { kWh_E2 } \\
\text { Real }\end{array}$ & $\begin{array}{c}\text { kWh_E2 } \\
\text { Pronosticado }\end{array}$ & $\begin{array}{c}€ \text { Real } \\
\text { Gasóleo }\end{array}$ & $\begin{array}{c}€ \text { Real } \\
\text { Biomasa }\end{array}$ & $\begin{array}{l}€ \text { Real } \\
\text { Total }\end{array}$ & $\begin{array}{c}€ \\
\text { predicho } \\
\text { Gasóleo }\end{array}$ & $\begin{array}{c}€ \\
\text { Ahorro }\end{array}$ & $\begin{array}{c}€ \\
\text { Acumulado }\end{array}$ \\
\hline oct-2015 & 0 & 7.380 & 7.380 & 7.380 & 0 & 316 & 316 & 382 & 66 & 66 \\
\hline nov-2015 & 0 & 49.410 & 49.410 & 49.410 & 0 & 2.115 & 2.115 & 2.554 & 440 & 505 \\
\hline dic-2015 & 0 & 46.960 & 46.960 & 46.960 & 0 & 2.010 & 2.010 & 2.428 & 418 & 923 \\
\hline ene-2016 & 0 & 32.190 & 32.190 & 32.190 & 0 & 1.378 & 1.378 & 1.407 & 29 & 952 \\
\hline feb-2016 & 65.280 & 79.180 & 144.460 & 144.460 & 2.853 & 3.389 & 6.242 & 6.313 & 71 & 1.024 \\
\hline mar-2016 & 4.645 & 55.330 & 59.975 & 59.975 & 203 & 2.368 & 2.571 & 2.621 & 50 & 1.073 \\
\hline abr-2016 & 1.880 & 41.350 & 43.230 & 43.230 & 82 & 1.770 & 1.852 & 1.889 & 37 & 1.111 \\
\hline may-2016 & 59 & 10.910 & 10.969 & 10.969 & 3 & 467 & 470 & 479 & 10 & 1.120 \\
\hline oct-2016 & 4.695 & 10.330 & 15.025 & 15.025 & 205 & 442 & 647 & 657 & 9 & 1.130 \\
\hline nov-2016 & 3.770 & 64.950 & 68.720 & 68.720 & 165 & 2.780 & 2.945 & 3.003 & 58 & 1.188 \\
\hline dic-2016 & 1.079 & 64.250 & 65.329 & 65.329 & 47 & 2.750 & 2.797 & 2.855 & 58 & 1.246 \\
\hline ene-2017 & 3.207 & 95.660 & 98.867 & 98.867 & 160 & 4.094 & 4.254 & 4.933 & 679 & 1.925 \\
\hline feb-2017 & 2.529 & 69.230 & 71.759 & 71.759 & 126 & 2.963 & 3.089 & 3.581 & 492 & 2.417 \\
\hline mar-2017 & 0 & 51.050 & 51.050 & 51.050 & 0 & 2.185 & 2.185 & 2.547 & 362 & 2.779 \\
\hline abr-2017 & 77 & 18.640 & 18.717 & 18.717 & 4 & 798 & 802 & 934 & 132 & 2.912 \\
\hline may-2017 & 355 & 3.610 & 3.965 & 3.965 & 18 & 155 & 172 & 198 & 26 & 2.937 \\
\hline oct-2017 & 0 & 5.110 & 5.110 & 5.110 & 0 & 219 & 219 & 255 & 36 & 2.973 \\
\hline nov-2017 & 0 & 48.158 & 48.158 & 48.158 & 0 & 2.061 & 2.061 & 2.403 & 342 & 3.315 \\
\hline dic-2017 & 0 & 80.392 & 80.392 & 80.392 & 0 & 3.441 & 3.441 & 4.012 & 571 & 3.886 \\
\hline ene-2018 & 0 & 79.450 & 79.450 & 79.450 & 0 & 3.400 & 3.400 & 4.449 & 1.049 & 4.935 \\
\hline feb-2018 & 0 & 99.180 & 99.180 & 99.180 & 0 & 4.245 & 4.245 & 5.554 & 1.309 & 6.244 \\
\hline mar-2018 & 0 & 78.870 & 78.870 & 78.870 & 0 & 3.376 & 3.376 & 4.417 & 1.041 & 7.285 \\
\hline abr-2018 & 0 & 33.930 & 33.930 & 33.930 & 0 & 1.452 & 1.452 & 1.900 & 448 & 7.733 \\
\hline may-2018 & 0 & 9.060 & 9.060 & 9.060 & 0 & 388 & 388 & 507 & 120 & 7.853 \\
\hline$€$ Total & & & & & & & 52.425 & 60.278 & & \\
\hline Ahorro (\%) & & & & & & & & & & $15,0 \%$ \\
\hline
\end{tabular}




\section{AV.3. Edificio E3. Facultad de Filosofía y Letras.}

\section{AV.3.1. Obtención de la línea base de referencia energética}

Los datos de partida para la obtención de la línea base de referencia se muestran en la Tabla 444

Tabla 444. Consumos térmicos del edificio E3

\begin{tabular}{lr}
\hline & Consumos térmicos $(\mathrm{kWh}) . \mathrm{E3}$ \\
\hline oct-12 & 17.828 \\
\hline nov-12 & 158.718 \\
\hline dic-12 & 168.403 \\
\hline ene-13 & 195.511 \\
\hline feb-13 & 241.484 \\
\hline mar-13 & 169.961 \\
\hline abr-13 & 122.600 \\
\hline may-13 & 66.794 \\
\hline oct-13 & 111.527 \\
\hline nov-13 & 235.091 \\
\hline dic-13 & 192.743 \\
\hline ene-14 & 242.403 \\
\hline feb-14 & 160.164 \\
\hline mar-14 & 100.428 \\
\hline abr-14 & 11.239 \\
\hline may-14 & 137.707 \\
\hline Promedio & 1.141 .299 \\
\hline Total (oct-12-may-13) & 1.062 .020 \\
\hline Total (oct-13-may-14) & 2.203 .319 \\
\hline Total (oct-12-may-13) & \\
\hline
\end{tabular}

Se disponen de 16 datos para establecer el modelo de regresión, mediante el método de pasos sucesivos.

Utilizando el programa SPSS V.20, se obtiene el modelo de regresión mediante el método de pasos sucesivos. Como se puede ver en la Tabla 445 para el edificio E3, el método ofrece dos modelos de regresión, uno con una sola variable (Temperatura mínima) y otro con dos variables (Temperatura mínima y velocidad del viento diurna). 
El primer modelo (modelo de regresión lineal simple) fue construido con un solo paso, incluyendo la Temperatura mínima por ser la variable más significativa (variable con menor valor de Sig $=0,000$ ) que indica la probabilidad de cometer un error al rechazar que la pendiente de la variable "Temperatura mínima" es igual a cero, por lo que se acepta que esa variable forma parte del modelo con una pendiente $(B=-26.412,48)$.

El segundo modelo (modelo de regresión lineal múltiple) se construyó en dos pasos, primero entró la Temperatura mínima y luego entró la siguiente variable que rechazase la Hipótesis nula, (las variables que rechazan la hipótesis nula son las que presentan una pendiente estadísticamente significativa y su probabilidad de cometer el error de rechazar Ho es $\leq 0,05$, para un nivel de confianza del $95 \%$ ), esta variable fue la "velocidad de viento diurna", por presentar un valor de Sig $=0,015$, el resto de las variables como se observa en la Tabla 446 fueron excluidas del modelo al tener valores de sig >0,05, en el segundo paso.

Tabla 445. Modelos de regresión del Edificio E3

\begin{tabular}{|c|c|c|c|c|c|c|c|}
\hline & \multirow{2}{*}{ Modelo } & \multicolumn{2}{|c|}{$\begin{array}{l}\text { Coeficientes no } \\
\text { estandarizados }\end{array}$} & \multirow{2}{*}{$\mathrm{t}$} & \multirow{2}{*}{ Sig. } & \multicolumn{2}{|c|}{$\begin{array}{c}\text { Intervalo de confianza de } \\
95,0 \% \text { para B } \\
\end{array}$} \\
\hline & & B & Error típ. & & & $\begin{array}{l}\text { Límite } \\
\text { inferior }\end{array}$ & $\begin{array}{l}\text { Límite } \\
\text { superior }\end{array}$ \\
\hline \multirow[t]{2}{*}{1} & (Constante) & 219817,236 & 12492,242 & 17,596 & ,000 & 193024,042 & 246610,430 \\
\hline & T_min & $-26412,480$ & 3044,655 & $-8,675$ & ,000 & $-32942,615$ & $-19882,346$ \\
\hline \multirow[t]{3}{*}{2} & (Constante) & 130691,591 & 33319,626 & 3,922 & ,002 & 58708,915 & 202674,268 \\
\hline & T_min & $-24484,085$ & 2584,705 & $-9,473$ & ,000 & $-30068,001$ & $-18900,169$ \\
\hline & V_viento_diurna_m/s & 30147,142 & 10726,750 & 2,810 & 015 & 6973,408 & 53320,876 \\
\hline
\end{tabular}

En la Figura 302 se representa el modelo 1 de regresión con sus límites inferior y superior para un nivel de confianza del $95 \%$ 
Anexo V. Desarrollo del análisis de los edificios del Campus Río Esgueva

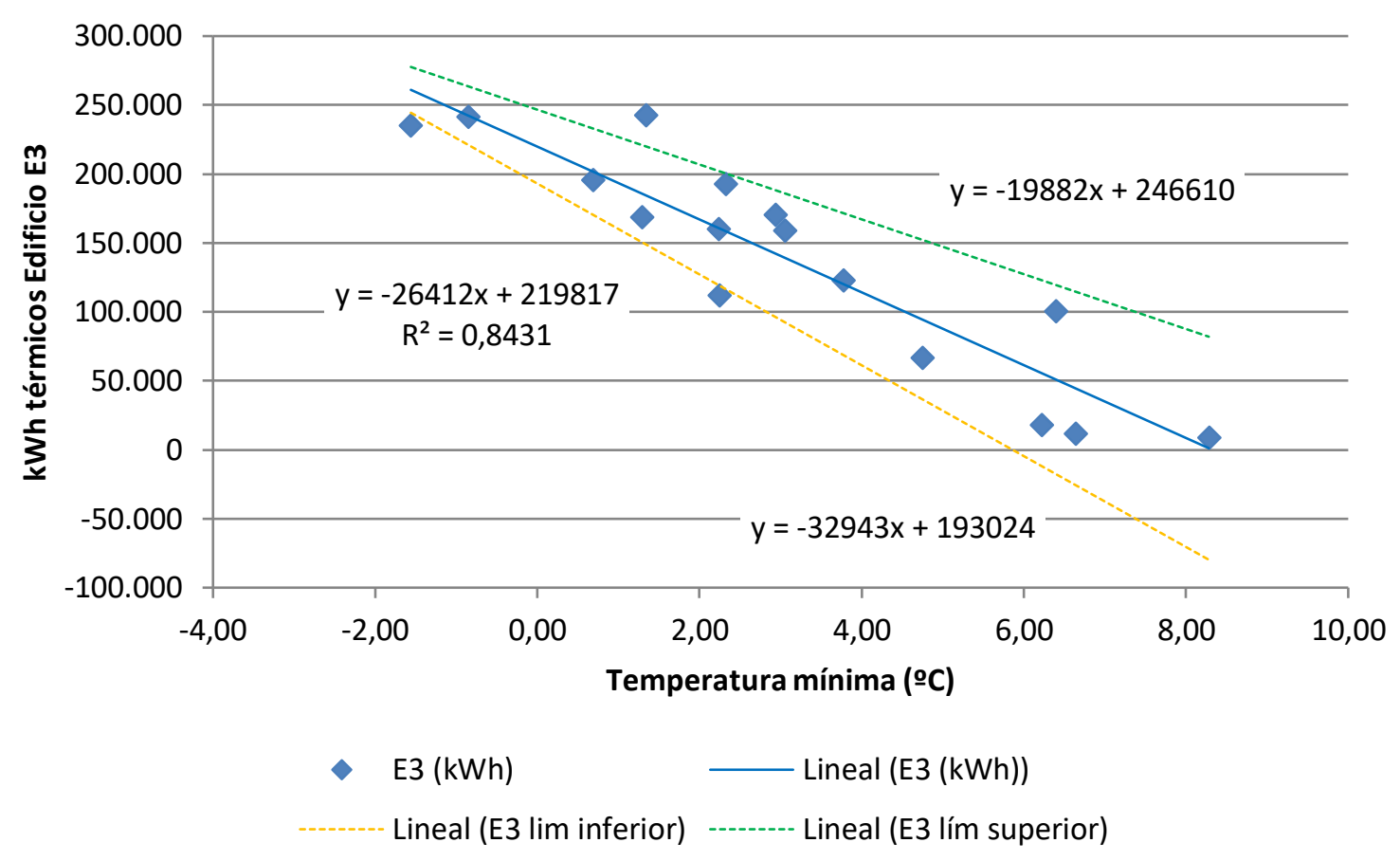

Figura 302. Representación del modelo de regresión lineal simple para el Edificio E3

En la Figura 303 se representa el modelo 2 de regresión lineal múltiple para el edificio E3

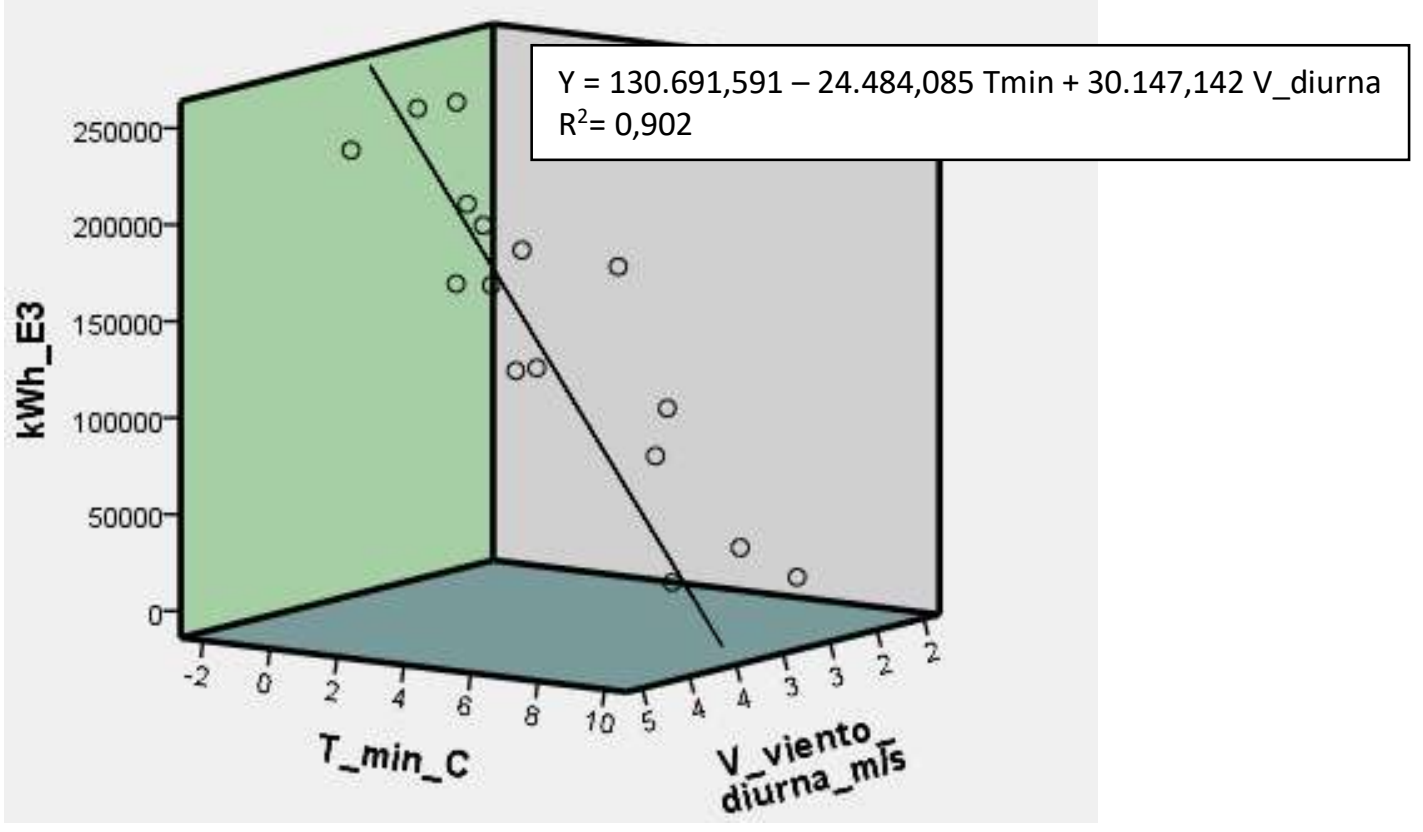

Figura 303. Representación del modelo de regresión lineal múltiple para el Edificio E3 
Los valores de la columna $t$ se obtienen dividiendo el valor de los coeficientes no estandarizados entre sus errores típicos, este estadístico tiende a ser mayor en valor absoluto cuando la hipótesis alternativa es verdadera, es decir cuando la variable posee una pendiente significativa en el modelo de regresión.

En las Tabla 445 y Tabla 446, el estadístico t y su nivel crítico (Sig), permiten contrastar la hipótesis nula consistente en que el coeficiente de regresión vale cero en el modelo; a mayor valor de t, mayor peso en el modelo.

El valor "Sig" corresponde a los valores de probabilidad de los valores de $t$, es la probabilidad de obtener el valor de $t$ si la hipótesis nula fuera cierta, cuando son $\leq 0,05$ se rechaza la hipótesis nula y se concluye que las pendientes son distintas de cero, luego si Sig $>0,05$ se acepta la hipótesis nula de que la pendiente de la variable independiente en el modelo de regresión es igual a cero, no cumpliendo el criterio de entrada en el modelo.

La correlación parcial, que aparece en la Tabla 446 estudia la relación existente entre dos variables cuantitativas cuando se controla o elimina el efecto de terceras variables, en el modelo de regresión lineal, a mayor valor absoluto, mayor relación entre la variable dependiente y la independiente.

Tabla 446. Variables excluidas del modelo de región del Edificio E3

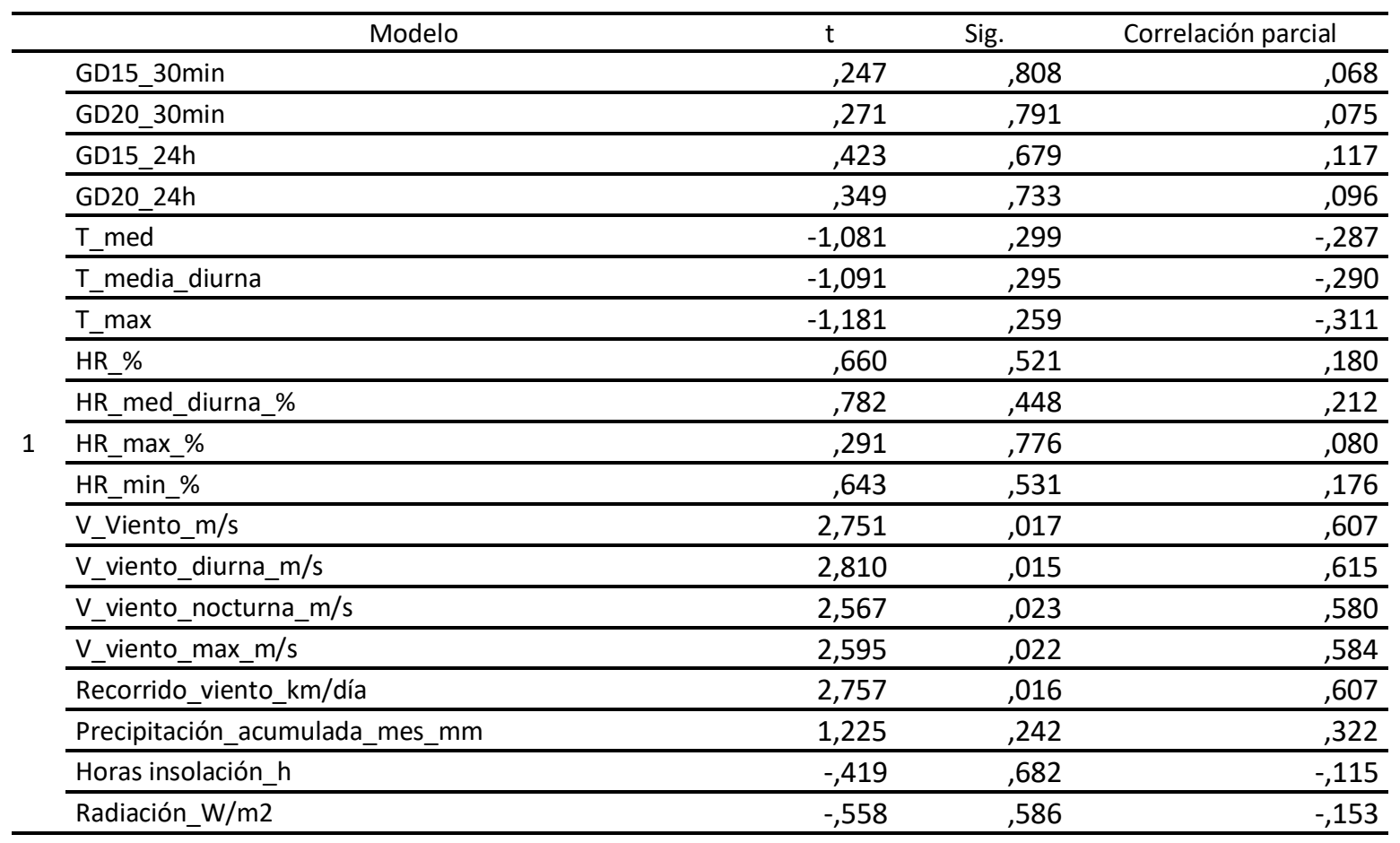




\begin{tabular}{|c|c|c|c|c|}
\hline & Modelo & $\mathrm{t}$ & Sig. & Correlación parcial \\
\hline \multirow{18}{*}{2} & GD15_30min & 871 & ,401 & ,244 \\
\hline & GD20_30min & ,799 & ,440 & ,225 \\
\hline & GD15_24h & ,956 & ,358 & ,266 \\
\hline & GD20_24h & 871 & ,401 & 244 \\
\hline & T_med & $-1,373$ & 195 &,- 369 \\
\hline & T_media_diurna & $-1,349$ & ,202 &,- 363 \\
\hline & T_max & $-1,242$ & ,238 &,- 338 \\
\hline & HR_\% & 1,735 & 108 & ,448 \\
\hline & HR_med_diurna_\% & 1,648 & ,125 & ,430 \\
\hline & HR_max_\% & 1,944 & 076 & ,489 \\
\hline & HR_min_\% & 1,364 & 197 & ,366 \\
\hline & V_Viento_m/s &,- 163 & 873 &,- 047 \\
\hline & V_viento_nocturna_m/s &,- 170 & ,868 &,- 049 \\
\hline & V_viento_max_m/s &,- 712 & ,490 &,- 201 \\
\hline & Recorrido_viento_km/día &,- 127 & ,901 &,- 037 \\
\hline & Precipitación_acumulada_mes_mm & ,641 & ,534 & ,182 \\
\hline & Horas insolación_h & $-1,478$ & 165 &,- 392 \\
\hline & Radiación_W/m2 & $-1,507$ & ,158 &,- 399 \\
\hline
\end{tabular}

La bondad de los modelos de regresión obtenidos para el edificio E3, se resumen en la Tabla 447

Tabla 447. Resumen de la bondad de los modelos de regresión para el Edificio E3

\begin{tabular}{crrrr}
\hline Modelo & $\mathrm{R}$ & R cuadrado & R cuadrado corregida & $\begin{array}{c}\text { Error típ. de la } \\
\text { estimación }\end{array}$ \\
\hline 1 &,- 918 &, 843 &, 832 & 32611,3022 \\
\hline 2 &,- 950 &, 902 &, 887 & 26691,4676 \\
\hline
\end{tabular}

Se observa como el modelo 1 de regresión lineal simple presenta un Coeficiente de Correlación de Pearson (R) inferior en valor absoluto al modelo 2 de regresión lineal múltiple, este coeficiente indica que las variables de los modelos están correlacionadas de manera muy fuerte (en la correlación perfecta $R= \pm 1$ ). La correlación que se produce en ambos modelos es inversa, al aumentar el valor de las variables independientes disminuye el valor de la variable dependiente que es el consumo térmico.

El coeficiente de determinación $\left(R^{2}\right)$, nos indica que con el modelo 1 se podría explicar el $84,3 \%$ de los datos reales obtenidos y el modelo 2 , el porcentaje de aciertos o de explicación asciende al 90,2\%, ambos aceptando un error del 5\%.

El coeficiente de determinación corregido $\left(R^{2}\right.$ corregido) que tiene en cuenta el número de variables independientes incluidas en el modelo y el tamaño de la muestra, reduce el coeficiente de determinación al 83,2\% en el modelo 1 y al 88,7 \% en el modelo 2. 
El error típico de la estimación que nos indica la magnitud de los errores, es decir la parte de la variable dependiente que dejamos sin explicar con el modelo y que describe la variación de la variable respuesta (el Consumo) respecto a la recta de regresión, es de $32.611 \mathrm{kWh}$ para el modelo 1 y de $26.691 \mathrm{kWh}$ para el modelo 2, lo que representa un $23,7 \%$ del promedio de los consumos que fue de $137.707 \mathrm{kWh}$ para el modelo $1 \mathrm{y}$ del $19,4 \%$ para el modelo 2. Por tanto aunque el modelo 2 es más preciso, también es aceptado el modelo 1 para la representación de la línea base de los consumos térmicos del edificio E3.

\section{AV.3.2. Verificación del cumplimiento de los supuestos estadísticos}

Las condiciones que se deben cumplir en un modelo de regresión son:

- Linealidad de las variables, las variables se encuentran relacionadas de forma lineal.

Como se observa en la Tabla 445, la pendiente (B), para el modelo 1, obtuvo un valor de Sig $=0,000$, que al ser $\leq 0,05$, nos indica que podemos rechazar la hipótesis nula de pendiente igual a cero y nos da la evidencia de linealidad entre la variable dependiente (kWh del edificio E3) y la independiente (Temperatura mínima). Al ser el valor de la pendiente negativa, indica una relación inversa entre el consumo y la Temperatura mínima.

Para el modelo 2, según la misma Tabla 445, las pendientes de las dos variables introducidas en el modelo obtuvieron unos valores de Sig $=0,000$ para la Temperatura mínima y de 0,015 para la Velocidad del viento diurna, ambos $\leq 0,05$, lo que nos indica que podemos rechazar la hipótesis nula de pendiente igual a cero y nos da la evidencia de linealidad entre la variable dependiente ( $\mathrm{kWh}$ del edificio E3) y las independientes (Temperatura mínima y velocidad del viento diurna). Al ser el valor de la primera pendiente negativa, indica una relación inversa entre el consumo y la Temperatura media y de la segunda pendiente positiva, indica relación directa entre el consumo y la velocidad del viento diurna.

- Normalidad. Todos los valores obtenidos para la variable dependiente (Y), deben estar distribuidos normalmente en cada valor de las variables independientes $(X)$.

Se comprueba la normalidad de las variables y de los residuos mediante el Test de Shapiro - Wilk para muestras pequeñas (menores a 30 observaciones), siendo la hipótesis nula el que la distribución es Normal, luego si la probabilidad del estadístico del test es $\leq$ al nivel de significación 0,05 , la hipótesis nula es rechazada y sólo aceptaremos que las variables se distribuyen según una Normal cuando el valor de la significación sea mayor que 0,05 (valor de la significación >0,05) en el Test de Shapiro Wilk. 
La Tabla 448, muestra la prueba de normalidad de Shapiro-Wilk y cómo tanto la variable dependiente (consumos del Edificio E3), como las variables independientes: Temperatura mínima y velocidad de viento diurna poseen una Sig $>0,05$, por lo que aceptamos la hipótesis nula de Normalidad de las variables

Tabla 448. Prueba de normalidad para el edificio E3

\begin{tabular}{lrrrrrr}
\hline & \multicolumn{3}{c}{ Kolmogorov-Smirnov } & \multicolumn{3}{c}{ Shapiro-Wilk } \\
\cline { 2 - 8 } & Estadístico & gl & Sig. & Estadístico & gl & \multicolumn{1}{c}{ Sig. } \\
\hline kWh_E3 &, 167 & 16 &, 200 &, 921 & 16 &, 178 \\
\hline T_min &, 133 & 16 &, 200 &, 968 & 16 &, 813 \\
\hline V_viento_diurna_m/s &, 156 & 16 &, 200 &, 948 & 16 &, 453 \\
\hline
\end{tabular}

- Independencia de los errores. Los errores asociados a los valores de la variable respuesta $(Y)$ deberán ser independientes unos de otros.

Para la comprobación se utiliza el estadístico de Durbin -Watson.

Se comprueba que el Estadístico de Durbin Watson para el nivel de significancia del 5\%, y para el tamaño de la muestra " $n$ " y el número de variables independientes del modelo " $k$ ", se encuentra en el intervalo [dU, 4-dU], de la Tabla 3, intervalo centrado en el 2, que indica la ausencia de autocorrelación.

El valor del Estadístico Durbin-Watson facilitado por el programa SPSS, es:

- para el modelo 1 de 1,950 (Regresión lineal simple)

- para el modelo 2 de 2,622 (Regresión lineal múltiple)

En el modelo $1, n=16$ y $k=1$, según la Tabla 3, el valor $d U=1,371$, luego el intervalo que marca la ausencia de correlación es [1,371, 2,629], como el valor del estadístico 1,950 está dentro del intervalo, se acepta la ausencia de autocorrelación

En el modelo 2, $\mathrm{n}=16$ y $\mathrm{k}=2$, según la Tabla 3, el valor $\mathrm{dU}=1,539$ y $\mathrm{dL}=0,982$, luego el intervalo que marca la ausencia de correlación es [1,539, 2,461].

Los intervalos $[0,0,982]$ y $[3,018,4]$ indican correlación positiva o negativa respectivamente y las zonas $[0,982,1,539]$ y $[2,461,3,018]$ son zonas no concluyentes; como el valor del estadístico 2,622 está dentro del último intervalo no concluyente, se comprueba la ausencia de autocorrelación, mediante el gráfico de residuos frente al tiempo.

La Figura 304, muestra que la relación entre los residuos y el tiempo, posee un coeficiente de determinación $=6,78 \times 10^{-8}$, prácticamente nulo, por lo que se acepta la ausencia de autocorrelación. 


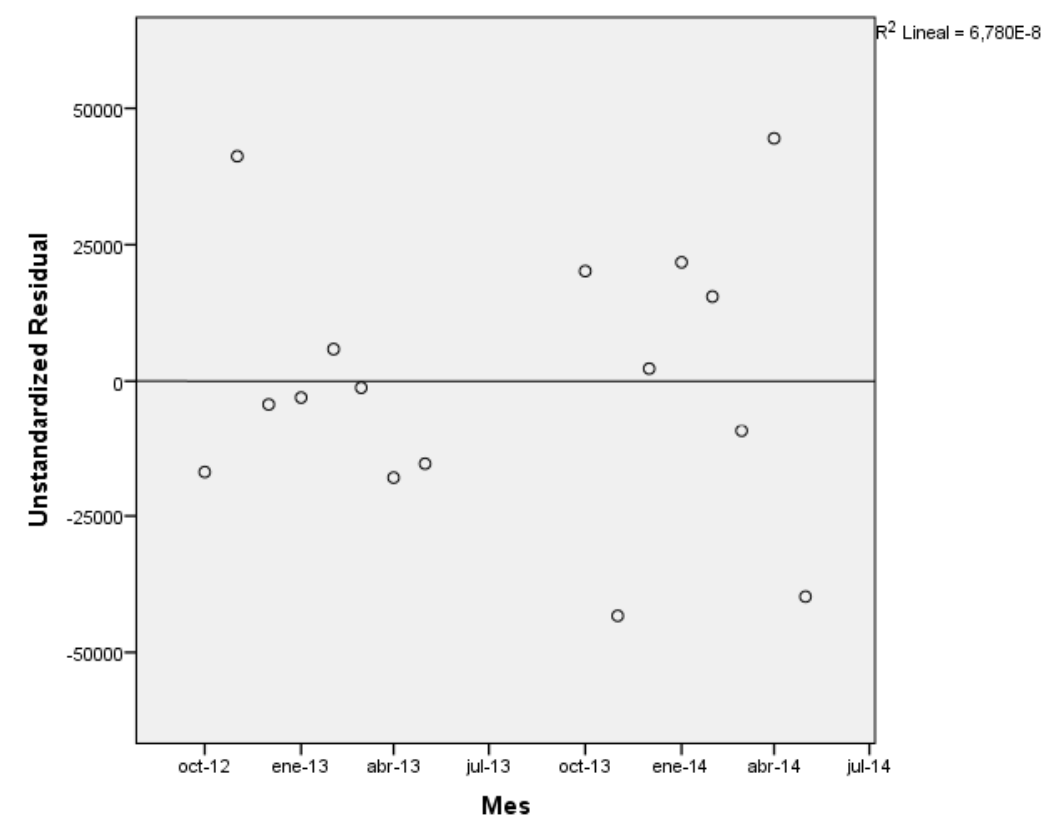

Figura 304. Relación entre los residuos y el tiempo en el Edificio E3. Modelo 2

- Homocedasticidad de la varianza. Se pretende comprobar que la varianza de los errores $\left(\sigma^{2}\right)$ es constante para cualquier valor de la(s) variable(s) independiente(s) (X), es decir que el valor medio del cuadrado de la desviación de los errores respecto a su media es constante.

Esta condición indica que el error es una variable aleatoria que tomará un valor distinto cada vez que se ejecute el modelo y que no existe correlación entre los residuos y los pronósticos.

La forma de comprobar la homocedasticidad es verificando si el coeficiente de determinación $\mathrm{R}^{2}$, que indica la proporción de la variable dependiente ( $\mathrm{Y}$ o consumo del edificio) que puede ser explicada por la variación de las variables independientes (las variables climatológicas), en las relaciones: residuos y predicciones y entre residuos y variables independientes es nulo o muy próximo a cero, lo que indicará que no existe ningún tipo de correlación en los residuos y que éstos son aleatorios. Se grafican los diagramas de dispersión de esas relaciones, comprobando que se corresponden a nubes de puntos totalmente aleatorias, sin tendencias ni patrones en sus representaciones gráficas. Para el modelo 1. Regresión lineal simple, las Figura 305 y Figura 306, muestran que la relación entre los pronósticos y los residuos, posee un coeficiente de determinación = 0 y entre la variable independiente (Temperatura mínima) y los residuos un coeficiente de determinación también de 0 ; por lo que se concluye que no existe ningún tipo de correlación en los residuos y que éstos son aleatorios, siendo la varianza de los residuos constante. 


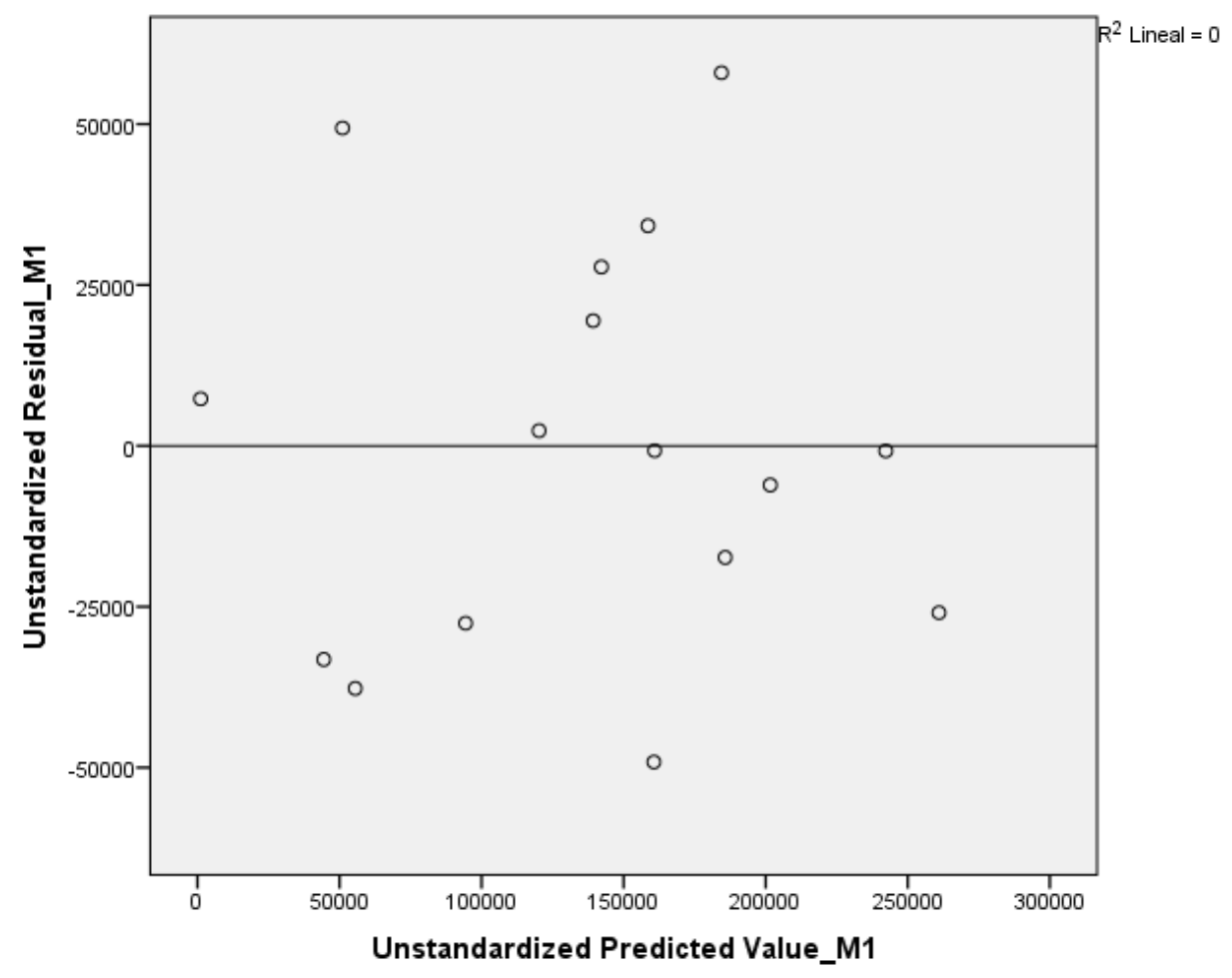

Figura 305. Relación entre los pronósticos y los residuos en el Edificio E3. Modelo 1

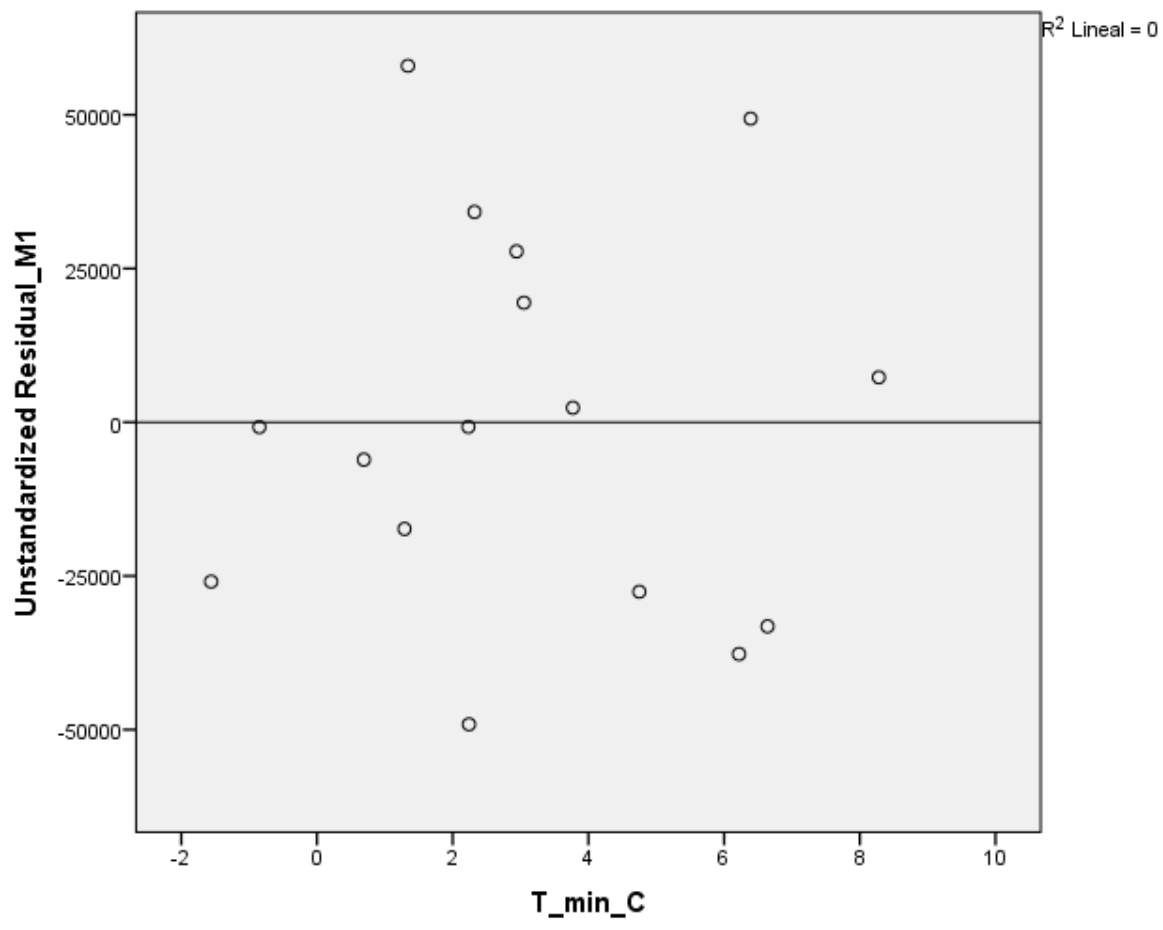

Figura 306. Relación entre la Temperatura media y los residuos en el Edificio E3. Modelo 1 
Para el modelo 2. Regresión lineal múltiple, las Figura 307, Figura 308 y Figura 309, muestran que la relación entre los pronósticos y los residuos, posee un coeficiente de determinación $=0$, entre la variable independiente (Temperatura mínima) y los residuos un coeficiente de determinación, también de 0 y entre la variable independiente (velocidad del viento diurna) y los residuos de 1,11×10-16; prácticamente nulo, por lo que se concluye que no existe ningún tipo de correlación en los residuos y que éstos son aleatorios, siendo la varianza de los residuos constante

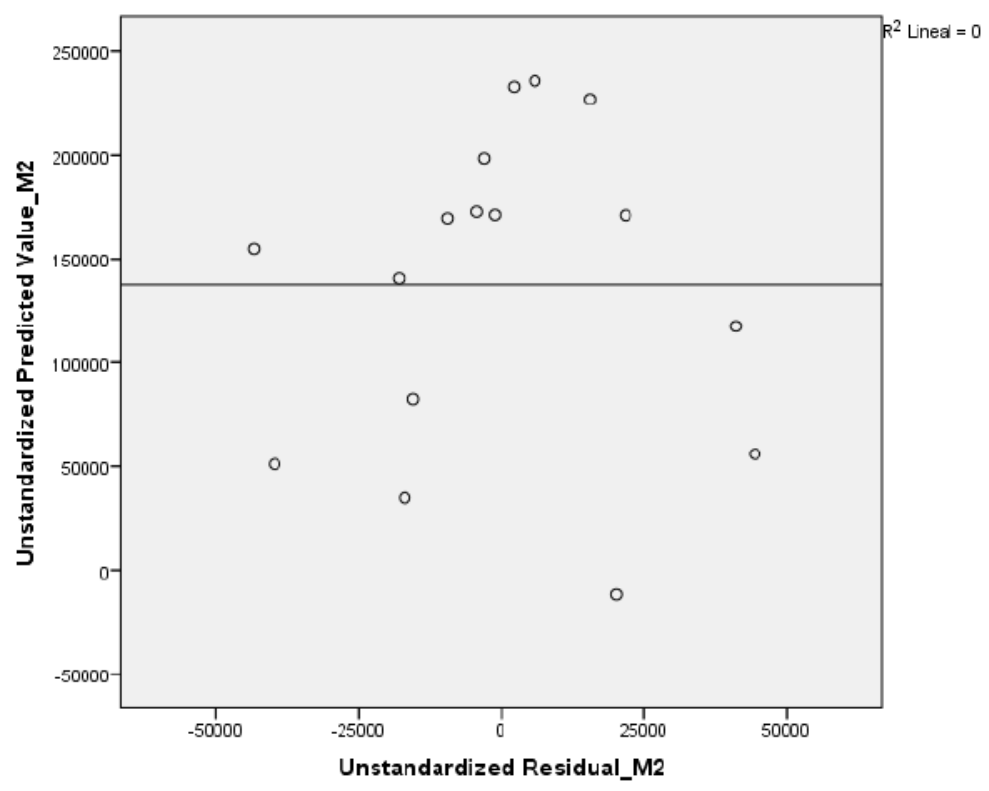

Figura 307. Relación entre los pronósticos y los residuos en el Edificio E3. Modelo 2

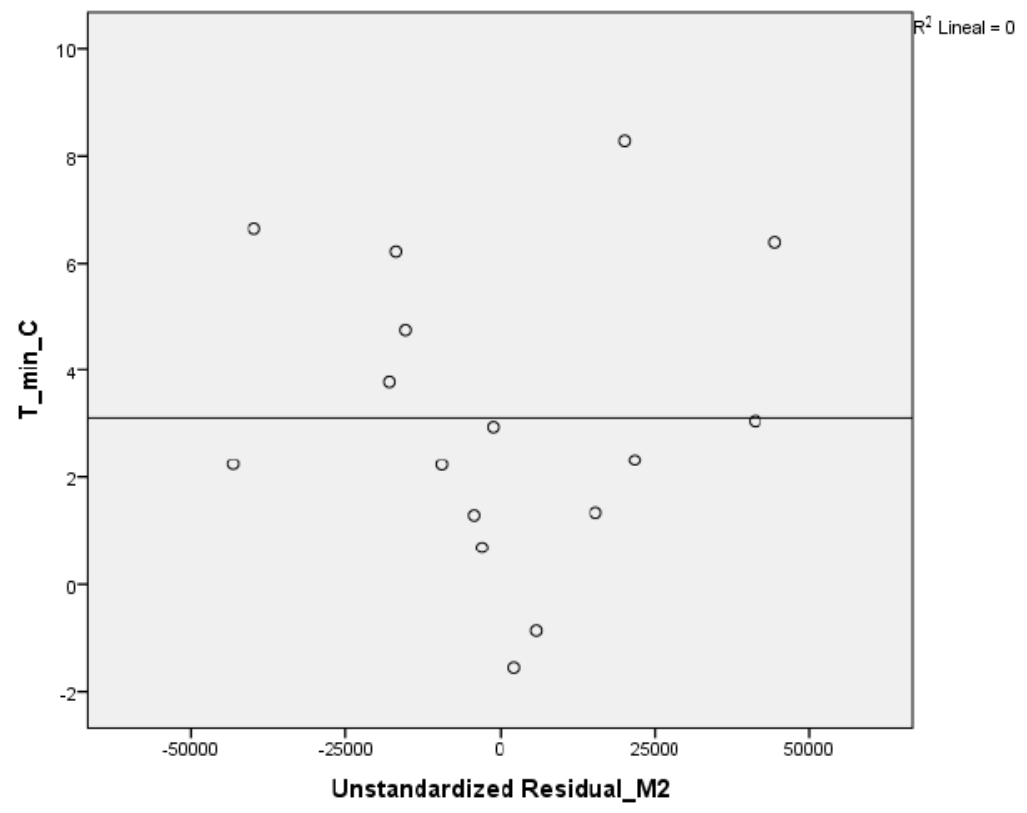

Figura 308. Relación entre la Temperatura media y los residuos en el Edificio E3. Modelo 2 


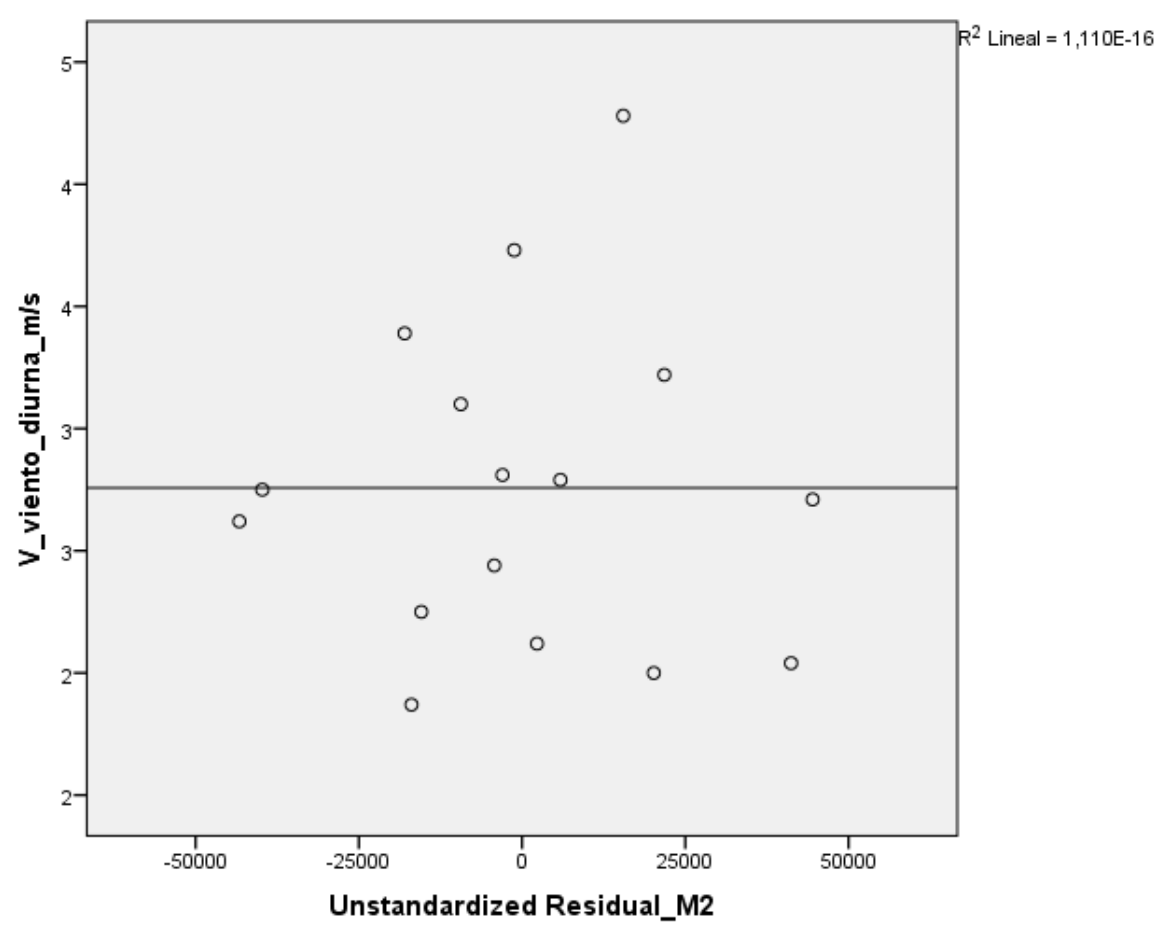

Figura 309. Relación entre la velocidad del viento nocturna y los residuos. Edificio E3. Modelo 2

- Cuando la regresión es lineal múltiple, se comprueba la falta de multicolinealidad o No-Colinealidad entre las variables independientes, es decir que las variables que forman parte del modelo no están correlacionadas entre ellas.

El problema de la multicolinealidad es moderado cuando el índice de condición toma un valor entre 20 y 30 y es grave cuando el índice de condición toma un valor superior a 30 . El número de condición mide la sensibilidad de las estimaciones mínimo-cuadráticas ante pequeños cambios en los datos a mayor valor más correlación entre las variables.

La Tabla 449, muestra los índices de condición de las variables del modelo de regresión múltiple, ninguno de ellos supera el valor 20 , por lo que no existen evidencias de correlación entre las variables independientes del modelo

Tabla 449. Índice de condición de las variables independientes del Modelo 2 en el Edificio E3

\begin{tabular}{llr}
\hline Modelo & Dimensión & Índice de condición \\
\hline & 1 & 1,000 \\
\cline { 2 - 3 } 2 & 2 & 2,732 \\
\cline { 2 - 3 } & 3 & 10,866 \\
\hline
\end{tabular}


En cuanto a los índices estadísticos de colinealidad como son los niveles Tolerancia y su inverso que son los Factores de Inflación de la Varianza (FIV). El nivel de tolerancia se obtiene restando a 1 el coeficiente de determinación $\left(R^{2}\right)$. Como se observa en la Figura 310 , el coeficiente de determinación entre las dos variables independientes es $R^{2}=0,070$, luego la Tolerancia es $T=1-R^{2}=1-0,070=0,930$ y $\mathrm{FIV}=1 / \mathrm{T}=1,076$

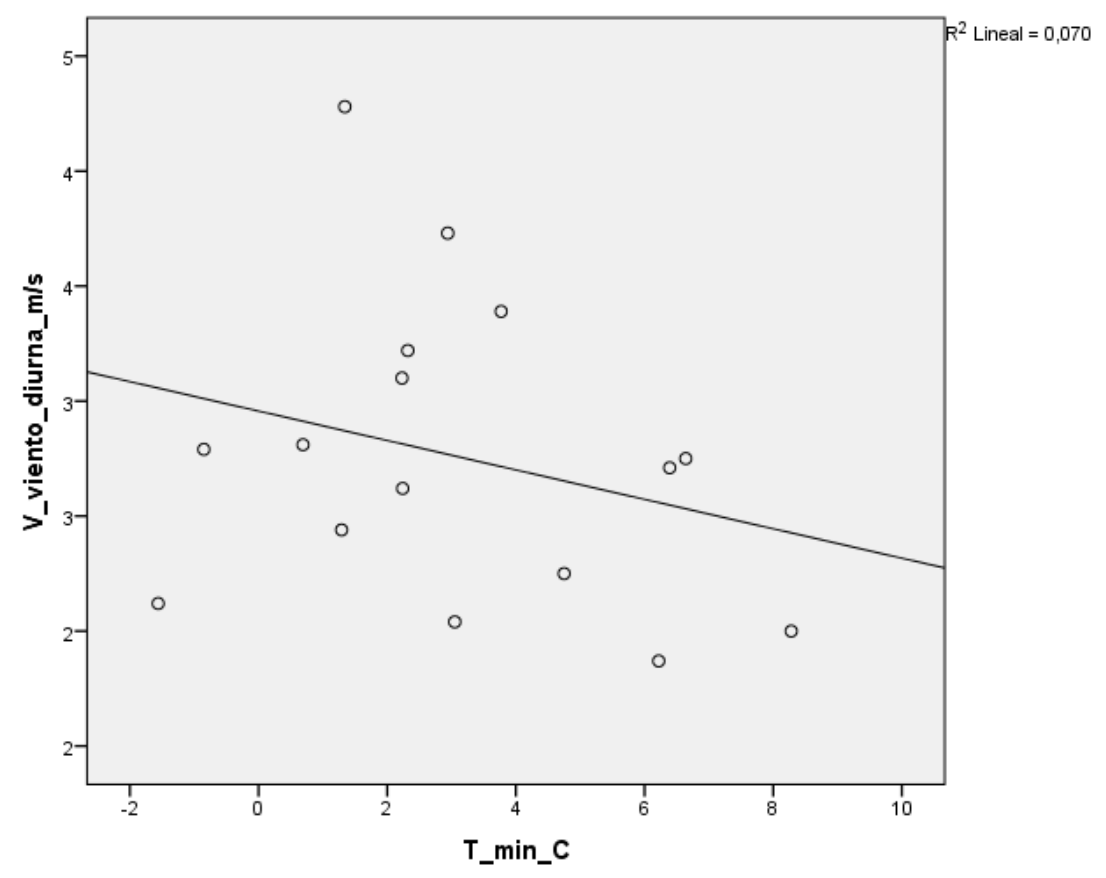

Figura 310. Gráfico de la temperatura mínima y la velocidad del viento diurna.

Si la Tolerancia toma un valor próximo a la unidad no existirá colinealidad (a mayor tolerancia menor colinealidad), por lo que se podrá deducir que no existe multicolinealidad entre las variables independientes. Pueden existir problemas de colinealidad si algún FIV es superior a 10 , que corresponde con un $\mathrm{R}^{2}$ de 0,9 y una Tolerancia menor a 0,1

La Tabla 450, muestra los estadísticos de colinealidad y se observa como la Tolerancia toma valores de 0,930, próxima a 1 y los valores de FIV permanecen por debajo de 10, por lo que no existen problemas de colinealidad entre la temperatura mínima y la velocidad del viento diurna.

Tabla 450. Estadísticos de colinealidad para los modelos del Edificio E3

\begin{tabular}{|c|c|c|c|}
\hline Modelo & & Tolerancia & FIV \\
\hline 1 & T_min & 1,000 & 1,000 \\
\hline \multirow{2}{*}{2} & T_min & ,930 & 1,076 \\
\hline & V_viento_diurna_m/s & ,930 & 1,076 \\
\hline
\end{tabular}




\section{AV.3.3. Obtención de los consumos térmicos previstos}

Una vez comprobado el cumplimiento de los supuestos estadísticos se aceptan los modelos de línea base encontrados para modelizar el consumo del Edificio E3.

Modelo 1: $\quad$ kWh_E3 $=219.817,236-26.412,48 \times$ T_min

Modelo 2: $\quad$ kWh_E3 $=130.691,591-24.484,085$ x T_min $+30.147,142$ x V_viento_diurna

Con estos modelos se procede a predecir los consumos previstos para las temporadas: octubre 2015-mayo 2016, octubre 2016 - mayo 2017 y octubre 2017-mayo 2018, estos consumos se muestran en la Tabla 451, donde "KWh_E3", representa el consumo real, "kWh_E3_M1", el consumo pronosticado con el Modelo 1 y "kWh_E3_M2", el consumo pronosticado con el Modelo 2.

Tabla 451. Consumos previstos octubre 2014 - mayo 2017 para el edificio E3.

\begin{tabular}{rrrrrrr}
\hline & \multirow{2}{*}{ T_mínima } & V_viento_diurna & kWh_E3 & kWh_E3_M1 & kWh_E3_M2 & $\begin{array}{l}\text { kWh_E3_M1 - } \\
\text { kWh_E3_M2 }\end{array}$ \\
\hline oct-15 & 7,50 & 1,72 & 15.000 & 21.724 & -998 & 22.722 \\
\hline nov-15 & 4,16 & 1,25 & 96.450 & 110.038 & 66.461 & 43.577 \\
\hline dic-15 & 1,20 & 0,97 & 72.750 & 188.046 & 130.589 & 57.456 \\
\hline ene-16 & 2,63 & 2,53 & 100.640 & 150.472 & 142.798 & 7.674 \\
\hline feb-16 & 1,30 & 3,30 & 195.869 & 185.536 & 198.492 & -12.956 \\
\hline mar-16 & 0,20 & 2,66 & 108.608 & 214.628 & 205.956 & 8.672 \\
\hline abr-16 & 3,83 & 2,67 & 77.055 & 118.649 & 117.372 & 1.277 \\
\hline may-16 & 6,63 & 16.782 & 44.745 & 32.596 & 12.150 \\
\hline oct-16 & 7,14 & 2,13 & 22.329 & 31.276 & -11.651 & 42.928 \\
\hline nov-16 & 2,23 & 1,08 & 138.878 & 160.970 & 124.577 & 36.393 \\
\hline dic-16 & 0,57 & 1,61 & 117.308 & 204.813 & 146.775 & 58.039 \\
\hline ene-17 & $-2,83$ & 0,99 & 234.302 & 294.505 & 239.477 & 55.028 \\
\hline feb-17 & 2,19 & 1,31 & 176.446 & 161.993 & 161.156 & 836 \\
\hline mar-17 & 2,59 & 2,79 & 150.460 & 151.486 & 148.357 & 3.128 \\
\hline abr-17 & 3,83 & 2,69 & 118.701 & 113.140 & 5.561 \\
\hline may-17 & 9,02 & 2,53 & 53.310 & 110 & 9.206 \\
\hline oct-17 & 6,71 & 2,07 & 13.640 & -18.483 & -27.689 & 31.120 \\
\hline nov-17 & $-0,28$ & 1,50 & 11.920 & 42.709 & 11.589 & 46.866 \\
\hline dic-17 & $-0,44$ & 1,42 & 134.498 & 227.204 & 180.338 & 21.105 \\
\hline ene-18 & 0,66 & 2,28 & 173.668 & 231.336 & 210.232 & 20.720 \\
\hline feb-18 & $-1,96$ & 2,23 & 198.228 & 202.496 & 181.775 & 20.069 \\
\hline mar-18 & 2,74 & 2,42 & 257.218 & 271.463 & 251.394 & -48.124 \\
\hline abr-18 & 5,73 & 4,38 & 214.196 & 147.456 & 195.580 & -5.449 \\
\hline may-18 & 7,82 & 2,77 & 97.846 & 68.518 & 73.966 & -582 \\
\hline & 2,00 & 22.440 & 13.203 & & 13.785 \\
\hline & & & &
\end{tabular}

Los datos pronosticados que han resultado ser negativos serán anulados de los modelos, por representar valores imposibles En la mayoría de los meses los consumos pronosticados con el modelo 1, son superiores a los pronosticados con el Modelo 2 


\section{AV.3.4. Estudio de la existencia de diferencias significativas}

Utilizando el contraste de hipótesis para la comparación de medias para muestras relacionadas, es decir la prueba paramétrica " $\mathrm{t}$ " de Student para muestras relacionadas, podemos concluir que si las variables se distribuyen según una normal y la significación estadística resulta $\leq 0,05$, existen diferencias significativas. En caso contrario no se rechaza la hipótesis nula de igualdad de medias, concluyendo que las diferencias encontradas no son estadísticamente significativas y no van más allá de lo que sería esperable por azar, todo ello con la aceptación de un riesgo de error del 5\%, o lo que es lo mismo un nivel de confianza del $95 \%$

A continuación se muestra la comparación de medias realizada para cada uno de los tres periodos posteriores a la construcción de la red y para el periodo total hasta mayo de 2018.

Para la temporada Octubre 2015 - Mayo 2016, se comprueba mediante el Test de Shapiro -Wilk que tanto los valores reales como los pronosticados con los dos modelos se distribuyen según una Normal puesto que en todos los casos los valores de Sig $>0,05$, como se observa en la Tabla 452 y Tabla 453

Tabla 452. Prueba de Normalidad temporada Octubre 2015-Mayo 2016. Edificio E3. Modelo 1

\begin{tabular}{crrrrrrr}
\hline & \multicolumn{3}{c}{ Kolmogorov-Smirnov $^{\mathrm{a}}$} & \multicolumn{3}{c}{ Shapiro-Wilk } \\
\cline { 2 - 8 } & \multicolumn{1}{c}{ Estadístico } & gl & \multicolumn{1}{c}{ Sig. } & Estadístico & gl & Sig. \\
\hline kWh_real &, 218 & 8 &, 200 &, 908 & 8 &, 338 \\
\hline kWh_pronost_M1 &, 167 & 8 &, 200 &, 934 & 8 &, 558 \\
\hline
\end{tabular}

Tabla 453. Prueba de Normalidad temporada Octubre 2015-Mayo 2016. Edificio E3. Modelo 2

\begin{tabular}{cccccccr}
\hline & \multicolumn{3}{c}{ Kolmogorov-Smirnov $^{\mathrm{a}}$} & \multicolumn{3}{c}{ Shapiro-Wilk } \\
\cline { 2 - 8 } & \multicolumn{1}{c}{ Estadístico } & gl & Sig. & Estadístico & gl & \multicolumn{1}{c}{ Sig. } \\
\hline $\begin{array}{c}\text { kWh_real sin oct } \\
\text { 2015 }\end{array}$ &, 260 & 7 &, 165 &, 913 & 7 &, 418 \\
\hline kWh_pronost_M2 &, 153 & 7 &, 200 &, 947 & 7 &, 703 \\
\hline
\end{tabular}

En la Tabla 454, se observa como las medias tanto de los consumos pronosticados con el Modelo 1, como de los consumos pronosticados con el Modelo 2, son superiores a las medias de los consumos reales del Edificio E3; un 51,3 \% superior con la estimación del Modelo 1 y un 33,8 \% superior con la estimación del Modelo 2. En el Modelo 2, la observación de octubre de 2015, ha sido eliminada por haber sido pronosticado un valor negativo. 
Anexo V. Desarrollo del análisis de los edificios del Campus Río Esgueva

Tabla 454. Estadísticos de muestras relacionadas. Octubre 2015-Mayo 2016. Edificio E3

\begin{tabular}{clrcccc}
\hline & & Media & $\begin{array}{c}\text { \% Diferencia } \\
\text { entre medias }\end{array}$ & N & $\begin{array}{c}\text { Desviación } \\
\text { típ. }\end{array}$ & $\begin{array}{c}\text { Error típ. de la } \\
\text { media }\end{array}$ \\
\hline Par & kWh_real & 85394,2500 & & 8 & 57309,46383 & 20261,95525 \\
\cline { 2 - 7 } 1 & kWh_pronost_M1 & 129229,7500 & $51,3 \%$ & 8 & 69229,71507 & 24476,40049 \\
\hline Par & kWh_real & 95450,5714 & & 7 & 53739,13049 & 20311,48213 \\
\cline { 2 - 7 } 2 & kWh_pronost_M2 & 127752,0000 & $33,8 \%$ & 7 & 63604,82073 & 24040,36255 \\
\hline
\end{tabular}

La Tabla 455 muestra que las diferencias entre las medias son significativas entre los consumos reales y los pronosticados con el Modelo 1 (sig $\leq 0,5)$, pero no lo son con el Modelo 2 (sig > 0,05).

Tabla 455. Prueba de muestras relacionadas. Octubre 2015-Mayo 2016. Edificio E3

\begin{tabular}{|c|c|c|c|c|c|c|c|c|c|}
\hline & & \multicolumn{5}{|c|}{ Diferencias relacionadas } & \multirow{3}{*}{$\mathrm{t}$} & \multirow{3}{*}{$\mathrm{gl}$} & \multirow{3}{*}{$\begin{array}{c}\text { Sig. } \\
\text { (bilateral) }\end{array}$} \\
\hline & & \multirow{2}{*}{ Media } & \multirow{2}{*}{$\begin{array}{l}\text { Desviación } \\
\text { típ. }\end{array}$} & \multirow{2}{*}{$\begin{array}{c}\text { Error típ. } \\
\text { de la media }\end{array}$} & \multicolumn{2}{|c|}{$\begin{array}{l}\text { 95\% Intervalo de confianza } \\
\text { para la diferencia }\end{array}$} & & & \\
\hline & & & & & Inferior & Superior & & & \\
\hline Par 1 & $\begin{array}{c}\text { kWh_real - } \\
\text { kWh_pronost_M1 }\end{array}$ & $-43835,500$ & 45501,703 & 16087,281 & $-81875,876$ & $-5795,124$ & $-2,725$ & 7 & ,030 \\
\hline Par 2 & $\begin{array}{c}\text { kWh_real - } \\
\text { kWh_pronost_M2 }\end{array}$ & $-32301,429$ & 40982,450 & 15489,910 & $-70203,873$ & 5601,016 & $-2,085$ & 6 & ,082 \\
\hline
\end{tabular}

En la Figura 311, se grafican los consumos reales y pronosticados para la temporada Octubre 2015 - Mayo 2016 para el Edificio E3, y las medias de dichos consumos. Según la prueba paramétrica realizada son estadísticamente significativas con el Modelo 1 y no lo son con el Modelo 2, para un nivel de confianza del $95 \%$.

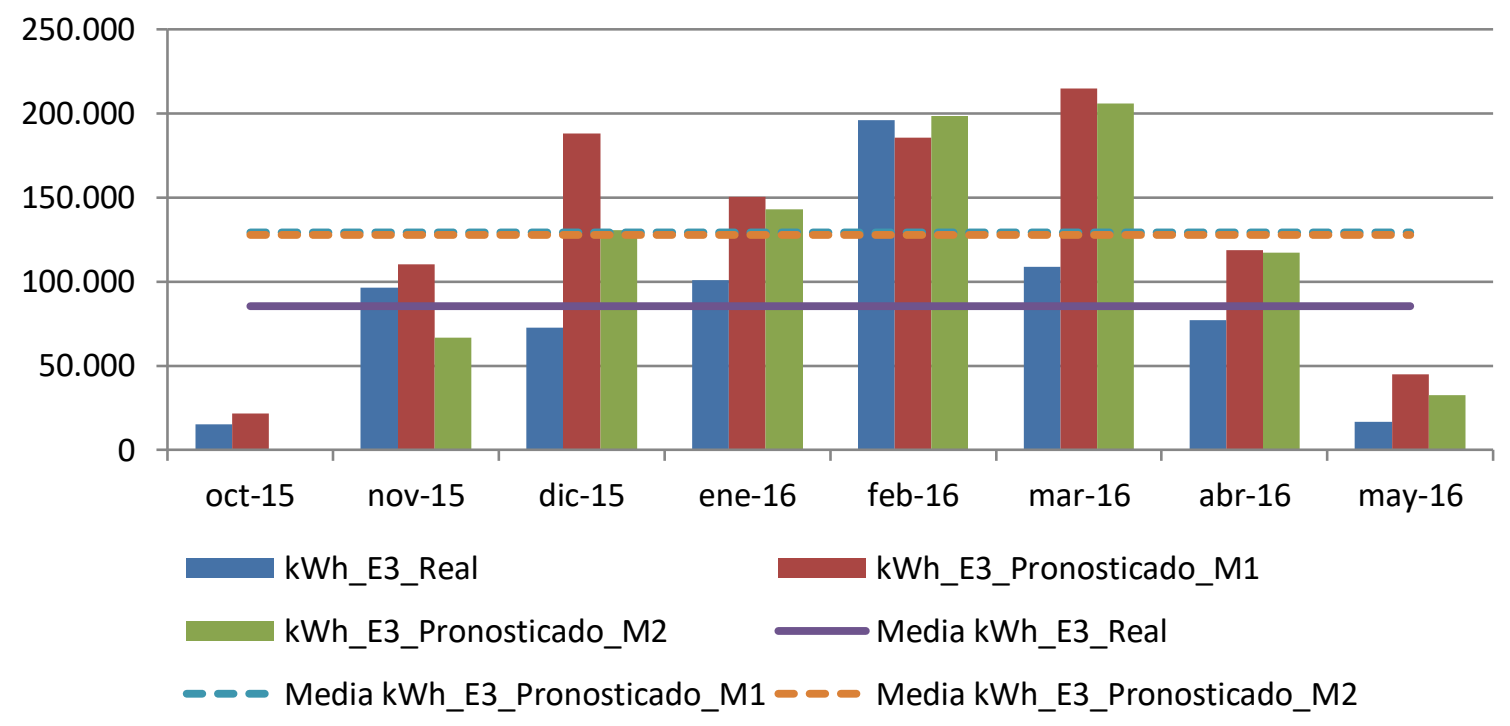

Figura 311. Consumos reales y pronosticados Octubre 2015-Mayo 2016. Edificio E3 
Para la temporada Octubre 2016 - Mayo 2017, se comprueba mediante el Test de Shapiro -Wilk que tanto los valores reales como los pronosticados con los dos modelos se distribuyen según una Normal puesto que en todos los casos los valores de Sig > 0,05, como se observa en la Tabla 456. El valor negativo del pronóstico de mayo de 2017, obtenido con el Modelo 2, se ha anulado de la prueba.

Tabla 456. Prueba de Normalidad temporada Octubre 2016-Mayo 2017. Edificio E3

\begin{tabular}{lrrrrrrr}
\hline & \multicolumn{3}{c}{ Kolmogorov-Smirnov $^{\text {a }}$} & \multicolumn{3}{c}{ Shapiro-Wilk } \\
\cline { 2 - 8 } & Estadístico & gl & Sig. & Estadístico & gl & \multicolumn{1}{c}{ Sig. } \\
\hline kWh_real sin mayo 2017 &, 158 & 7 &, 200 &, 973 & 7 &, 922 \\
\hline kWh_pronost_M1 &, 207 & 7 &, 200 &, 955 & 7 &, 772 \\
\hline kWh_real (sin octubre &, 156 & 6 &, 200 & \multirow{2}{*}{, 986} & 6 &, 978 \\
2016 ni mayo 2017) &, 284 & 6 &, 143 &, 843 & 6 &, 138 \\
\hline kWh_pronost_M2 & & & & & & &
\end{tabular}

En la Tabla 457, se observa como las medias tanto de los consumos pronosticados con el Modelo 1, como de los consumos pronosticados con el Modelo 2, son superiores a las medias de los consumos reales del Edificio E3, un 25,8 \% superior con la estimación del Modelo 1 y un 7,2 \% superior con la estimación del Modelo 2

Tabla 457. Estadísticos de muestras relacionadas. Octubre 2016-Abril 2017. Edificio E3

\begin{tabular}{clccccc}
\hline & & Media & $\begin{array}{c}\text { \% Diferencia } \\
\text { entre medias }\end{array}$ & $N$ & $\begin{array}{c}\text { Desviación } \\
\text { típ. }\end{array}$ & $\begin{array}{c}\text { Error típ. de la } \\
\text { media }\end{array}$ \\
\hline Par & kWh_real & 127576,1429 & & 7 & 72027,69169 & 27223,90853 \\
\cline { 2 - 7 } 1 & kWh_pronost_M1 & 160534,8571 & $25,8 \%$ & 7 & 80052,76823 & 30257,10236 \\
\hline Par & kWh_real & 145117,3333 & & 6 & 60340,38277 & 24633,85811 \\
\cline { 2 - 7 } 2 & kWh_pronost_M2 & 155580,3333 & $7,2 \%$ & 6 & 44635,94459 & 18222,54807 \\
\hline
\end{tabular}

La Tabla 458, muestra que las diferencias entre las medias no son significativas entre los consumos reales y los pronosticados con el Modelo 1 , ni con el Modelo 2 (sig > 0,05)

Tabla 458. Prueba de muestras relacionadas. Octubre 2016-Abril 2017. Edificio E3

\begin{tabular}{|c|c|c|c|c|c|c|c|c|c|}
\hline & & \multicolumn{5}{|c|}{ Diferencias relacionadas } & \multirow{3}{*}{$\mathrm{t}$} & \multirow{3}{*}{ gl } & \multirow{3}{*}{$\begin{array}{c}\text { Sig. } \\
\text { (bilateral) }\end{array}$} \\
\hline & & \multirow[t]{2}{*}{ Media } & \multirow{2}{*}{$\begin{array}{l}\text { Desviación } \\
\text { típ. }\end{array}$} & \multirow{2}{*}{$\begin{array}{c}\text { Error típ. } \\
\text { de la media }\end{array}$} & \multicolumn{2}{|c|}{$\begin{array}{l}\text { 95\% Intervalo de confianza } \\
\text { para la diferencia }\end{array}$} & & & \\
\hline & & & & & Inferior & Superior & & & \\
\hline Par 1 & $\begin{array}{c}\text { kWh_real - } \\
\text { kWh_pronost_M1 }\end{array}$ & $-32958,714$ & 38147,998 & 14418,588 & $-68239,728$ & 2322,299 & $-2,286$ & 6 & 062 \\
\hline Par 2 & $\begin{array}{c}\text { kWh_real - } \\
\text { kWh_pronost_M2 }\end{array}$ & $-10463,000$ & 29191,070 & 11917,204 & $-41097,149$ & 20171,149 &,- 878 & 5 & 420 \\
\hline
\end{tabular}


En la Figura 312, se grafican los consumos reales y pronosticados para la temporada Octubre 2016 - Mayo 2017 para el Edificio E3, y las medias de dichos consumos. Según la prueba paramétrica realizada no son estadísticamente significativas las diferencias encontradas entre el consumo real y el pronosticado por el modelo 1 , ni por el modelo 2, para un nivel de confianza del $95 \%$.

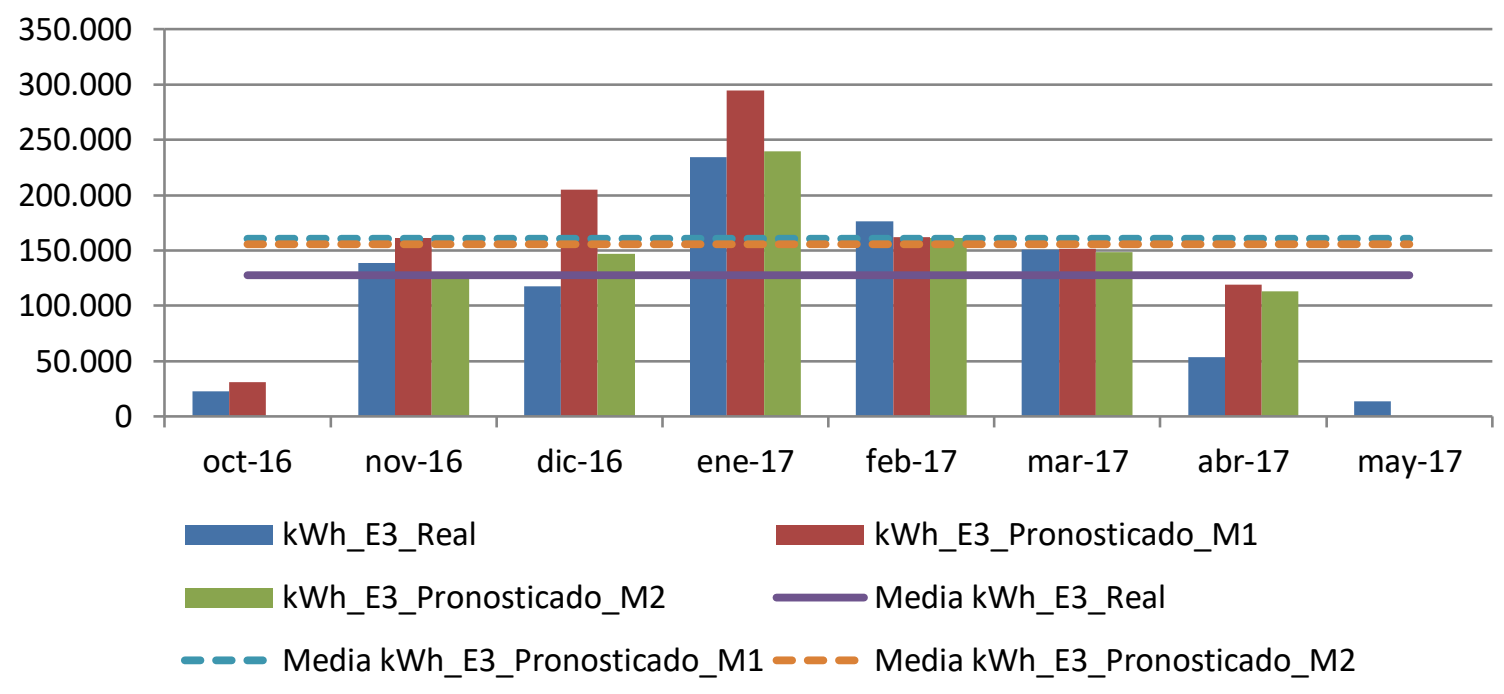

Figura 312. Consumos reales y pronosticados Octubre 2016-Mayo 2017. Edificio E3

Para la temporada Octubre 2017 - Mayo 2018, se comprueba mediante el Test de Shapiro -Wilk que tanto los valores reales como los pronosticados con los dos modelos se distribuyen según una Normal puesto que en todos los casos los valores de Sig >0,05, como se observa en la Tabla 459

Tabla 459. Prueba de Normalidad temporada Octubre 2017-Mayo 2018. Edificio E3

\begin{tabular}{ccccccc}
\hline & \multicolumn{3}{c}{ Kolmogorov-Smirnov $^{\mathrm{a}}$} & \multicolumn{3}{c}{ Shapiro-Wilk } \\
\cline { 2 - 7 } & Estadístico & $\mathrm{gl}$ & Sig. & Estadístico & $\mathrm{gl}$ & Sig. \\
\hline kWh_real &, 154 & 8 &, 200 &, 939 & 8 &, 600 \\
\hline kWh_pronost_M1 &, 202 & 8 &, 200 &, 910 & 8 &, 353 \\
\hline $\begin{array}{c}\text { kWh_real sin mayo } \\
\text { 2018 }\end{array}$ &, 160 & 7 &, 200 &, 963 & 7 &, 846 \\
\hline kWh_pronost_M2 &, 320 & 7 &, 029 &, 877 & 7 &, 213 \\
\hline
\end{tabular}

En la Tabla 460 se observa como las medias tanto de los consumos pronosticados con el Modelo 1, como de los consumos pronosticados con el Modelo 2, son superiores a las medias de los consumos reales del Edificio E3, un 8,5\% superior con la estimación del Modelo 1 y un 1,6 \% superior con la estimación del Modelo 2 
Anexo V. Desarrollo del análisis de los edificios del Campus Río Esgueva

Tabla 460. Estadísticos de muestras relacionadas. Octubre 2017-Mayo 2018. Edificio E3

\begin{tabular}{cllcccc}
\hline & & Media & $\begin{array}{c}\text { \% Diferencia } \\
\text { entre medias }\end{array}$ & $\mathrm{N}$ & $\begin{array}{c}\text { Desviación } \\
\text { típ. }\end{array}$ & $\begin{array}{c}\text { Error típ. de } \\
\text { la media }\end{array}$ \\
\hline Par & kWh_real & 138751,7500 & & 8 & 89273,85383 & 31563,07371 \\
\cline { 2 - 7 } 1 & kWh_pronost_M1 & 150548,1250 & $8,5 \%$ & 8 & 97799,54391 & 34577,36035 \\
\hline Par & kWh_real & 155367,7143 & & 7 & 81983,42492 & 30986,82200 \\
\cline { 2 - 7 } 2 & kWh_pronost_M2 & 157839,1429 & $1,6 \%$ & 7 & 84088,07613 & 31782,30538 \\
\hline
\end{tabular}

La Tabla 461 muestra que las diferencias entre las medias no son significativas entre los consumos reales y los pronosticados con el Modelo 1, ni con el Modelo 2 (sig > 0,05).

Tabla 461. Prueba de muestras relacionadas. Octubre 2017-Mayo 2018. Edificio E3

\begin{tabular}{|c|c|c|c|c|c|c|c|c|c|}
\hline & & \multicolumn{5}{|c|}{ Diferencias relacionadas } & \multirow{3}{*}{$\mathrm{t}$} & \multirow{3}{*}{ gl } & \multirow{3}{*}{$\begin{array}{c}\text { Sig. } \\
\text { (bilateral) }\end{array}$} \\
\hline & & \multirow[t]{2}{*}{ Media } & \multirow{2}{*}{$\begin{array}{c}\text { Desviación } \\
\text { típ. }\end{array}$} & \multirow{2}{*}{$\begin{array}{l}\text { Error típ. } \\
\text { de la media }\end{array}$} & \multicolumn{2}{|c|}{$\begin{array}{l}\text { 95\% Intervalo de confianza } \\
\text { para la diferencia }\end{array}$} & & & \\
\hline & & & & & Inferior & Superior & & & \\
\hline Par 1 & $\begin{array}{c}\text { kWh_real - } \\
\text { kWh_pronost_M1 }\end{array}$ & $-11796,375$ & 49821,889 & 17614,698 & $-53448,517$ & 29855,767 &,- 670 & 7 & ,525 \\
\hline Par 2 & $\begin{array}{c}\text { kWh_real - } \\
\text { kWh_pronost_M2 }\end{array}$ & $-2471,429$ & 27739,910 & 10484,700 & $-28126,566$ & 23183,709 &,- 236 & 6 & 821 \\
\hline
\end{tabular}

En la Figura 313 se grafican los consumos reales y pronosticados para la temporada Octubre 2017 - Mayo 2018 para el Edificio E3, y las medias de dichos consumos. Según la prueba paramétrica realizada no son estadísticamente significativas las diferencias encontradas entre el consumo real y el pronosticado por el modelo 1, ni por el modelo 2, para un nivel de confianza del $95 \%$.

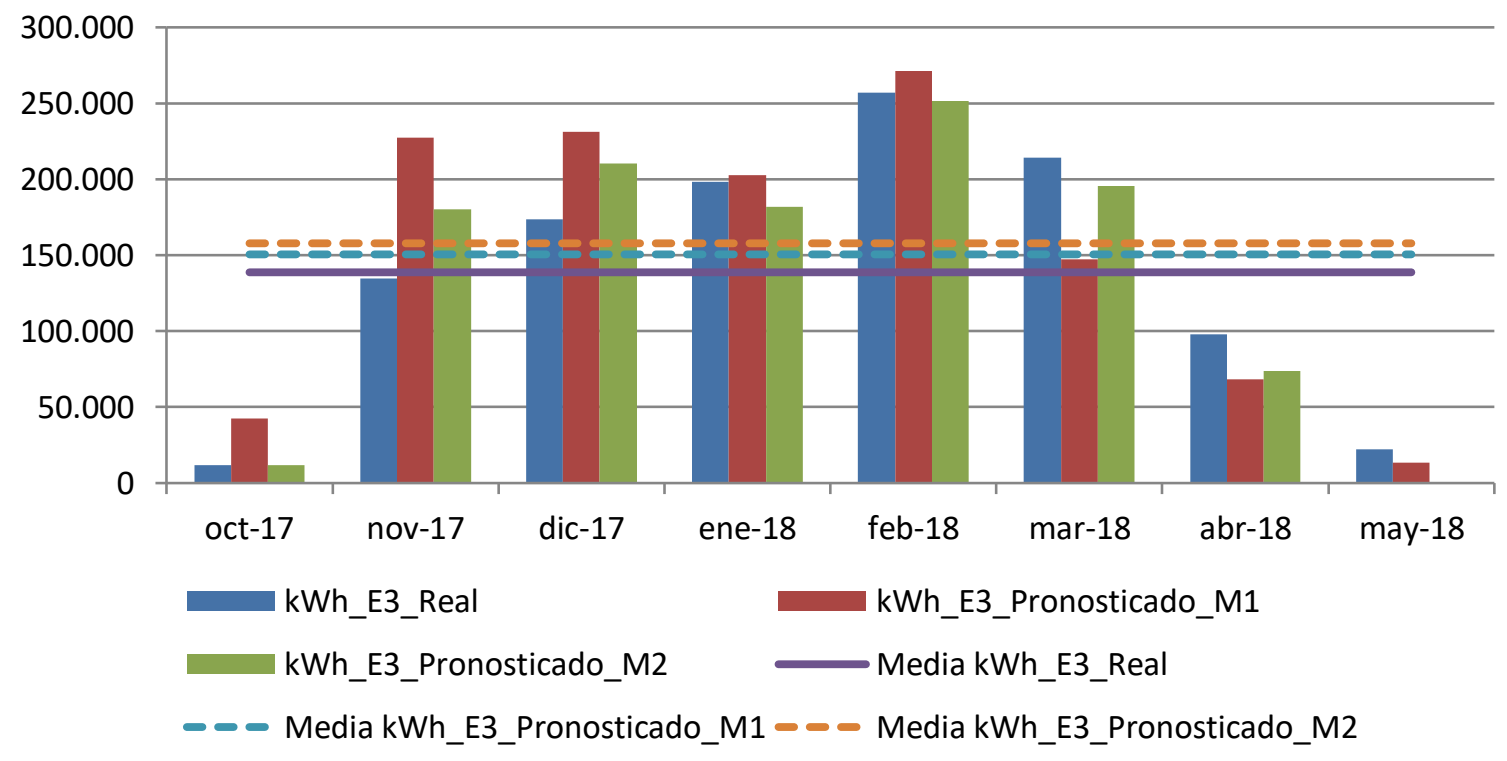

Figura 313. Consumos reales y pronosticados Octubre 2017-Mayo 2018. Edificio E3 
Para el total de las tres temporadas Octubre 2015 - Mayo 2018, se comprueba mediante el Test de Shapiro -Wilk, los valores reales como los pronosticados con el Modelo M1 y con el Modelo 2 se distribuyen según una Normal puesto que los valores de Sig > 0,05, como se observa en la Tabla 462

Tabla 462.Prueba de Normalidad temporada Octubre 2015-Mayo 2018. Edificio E3

\begin{tabular}{lcccccc}
\hline & \multicolumn{3}{c}{ Kolmogorov-Smirnov $^{\mathrm{a}}$} & \multicolumn{3}{c}{ Shapiro-Wilk } \\
\cline { 2 - 7 } & Estadístico & gl & Sig. & Estadístico & gl & Sig. \\
\hline kWh_real (sin mayo 2017) &, 114 & 23 &, 200 &, 952 & 23 &, 319 \\
\hline kWh_pronost_M1 &, 115 & 23 &, 200 &, 960 & 23 &, 463 \\
\hline $\begin{array}{l}\text { kWh_real (sin octubre 2015, } \\
\begin{array}{l}\text { octubre 2016, mayo 2017, } \\
\text { mayo 2018) }\end{array}\end{array}$ &, 081 & 20 & \multirow{2}{*}{, 200} &, 979 & 20 &, 914 \\
\hline kWh_pronost_M2 &, 103 & 20 &, 200 &, 969 & 20 &, 734 \\
\hline
\end{tabular}

En la Tabla 463, se observa como las medias tanto de los consumos pronosticados con el Modelo 1, como de los consumos pronosticados con el Modelo 2, son superiores a las medias de los consumos reales del Edificio E3, un 29,9 \% superior con la estimación del Modelo 1 y un $11,7 \%$ superior con la estimación del Modelo 2

Tabla 463. Estadísticos de muestras relacionadas. Octubre 2015-Mayo 2018. Edificio E3

\begin{tabular}{|c|c|c|c|c|c|c|}
\hline & & Media & $\begin{array}{l}\text { \% Diferencia } \\
\text { entre medias }\end{array}$ & $\mathrm{N}$ & $\begin{array}{c}\text { Desviación } \\
\text { típ. }\end{array}$ & $\begin{array}{c}\text { Error típ. de } \\
\text { la media }\end{array}$ \\
\hline Par & kWh_real & 116791,3478 & & 23 & 74609,82702 & 15557,22436 \\
\hline 1 & kWh_pronost_M1 & 146172,4783 & $29,9 \%$ & 23 & 80579,37024 & 16801,96017 \\
\hline Par & kWh_real & 131321,6000 & & 20 & 68846,29076 & 15394,49861 \\
\hline 2 & kWh_pronost_M2 & 146631,0000 & $11,7 \%$ & 20 & 65097,06174 & 14556,14552 \\
\hline
\end{tabular}

La Tabla 464 muestra que las diferencias entre las medias son significativas entre los consumos reales y los pronosticados con el Modelo 1 (sig $\leq 0,05$ ); pero no con el Modelo 2 (sig $>0,05)$, para un nivel de confianza del $95 \%$.

Tabla 464. Prueba de muestras relacionadas. Octubre 2015-Mayo 2018. Edificio E3

\begin{tabular}{|c|c|c|c|c|c|c|c|c|c|}
\hline & & \multicolumn{5}{|c|}{ Diferencias relacionadas } & \multirow{3}{*}{$\mathrm{t}$} & \multirow{3}{*}{$\mathrm{gl}$} & \multirow{3}{*}{$\begin{array}{c}\text { Sig. } \\
\text { (bilateral) }\end{array}$} \\
\hline & & \multirow[t]{2}{*}{ Media } & \multirow{2}{*}{$\begin{array}{l}\text { Desviación } \\
\text { típ. }\end{array}$} & \multirow{2}{*}{$\begin{array}{c}\text { Error típ. } \\
\text { de la media }\end{array}$} & \multicolumn{2}{|c|}{$\begin{array}{l}\text { 95\% Intervalo de confianza } \\
\text { para la diferencia }\end{array}$} & & & \\
\hline & & & & & Inferior & Superior & & & \\
\hline Par 1 & $\begin{array}{c}\text { kWh_real - } \\
\text { kWh_pronost_M1 }\end{array}$ & $-29381,130$ & 45143,615 & 9413,094 & $-48902,693$ & $-9859,568$ & $-3,121$ & 22 & ,005 \\
\hline Par 2 & $\begin{array}{c}\text { kWh_real - } \\
\text { kWh_pronost_M2 }\end{array}$ & $-15309,400$ & 34236,560 & 7655,528 & $-31332,603$ & 713,803 & $-2,000$ & 19 & 060 \\
\hline
\end{tabular}




\section{AV.3.5. Estimación de las emisiones de $\mathrm{CO} 2$ evitadas.}

Teniendo en cuenta que el consumir Gas natural se producen 0,252 $\mathrm{kg} \mathrm{CO}_{2} / \mathrm{kWh} \mathrm{E}$. final y que al consumir la energía suministrada por red a partir de Biomasa se producen 0,024 kg $\mathrm{CO}_{2} / \mathrm{kWh}$. final, en la Tabla 465, se muestra las emisiones de $\mathrm{CO}_{2}$ reales para las temporadas octubre 2015 - mayo 2018 y utilizando el Modelo 2 (por ser el de mayor coeficiente de correlación), las emisiones de $\mathrm{CO}_{2}$ que se hubieran tenido de haber seguido utilizando las calderas de gas natural originales sin el apoyo de la red de calor.

Tabla 465. Estimación del ahorro de emisiones de CO2 para el Edificio E3.

\begin{tabular}{|c|c|c|c|c|c|c|c|c|c|c|}
\hline & $\begin{array}{l}\text { kWh_E3 } \\
\text { Gas } \\
\text { Natural }\end{array}$ & $\begin{array}{l}\text { kWh_E3 } \\
\text { Biomasa }\end{array}$ & $\begin{array}{l}\text { kWh_E3 } \\
\text { Real Total }\end{array}$ & $\begin{array}{c}\text { kWh_E3_- } \\
\text { M2 } \\
\text { Predicho }\end{array}$ & $\begin{array}{l}\text { kg CO2 Real } \\
\text { debido al } \\
\text { consumo de } \\
\text { Gas Natural }\end{array}$ & $\begin{array}{l}\text { kg CO2 } \\
\text { Real } \\
\text { debido a } \\
\text { Biomasa }\end{array}$ & $\begin{array}{l}\text { kg CO2 } \\
\text { Real } \\
\text { debido al } \\
\text { consumo } \\
\text { TOTAL }\end{array}$ & $\begin{array}{c}\text { kg CO2 } \\
\text { que se } \\
\text { hubiera } \\
\text { tenido } \\
\text { debido a } \\
\text { Gas } \\
\text { Natural }\end{array}$ & $\begin{array}{l}\text { Ahorro de } \\
\text { kg CO2 }\end{array}$ & $\begin{array}{l}\text { Ahorro de kg } \\
\text { CO2 } \\
\text { acumulado }\end{array}$ \\
\hline oct-2015 & 0 & 15.000 & 15.000 & 15.000 & 0 & 360 & 360 & 3.780 & 3.420 & 3.420 \\
\hline nov-2015 & 0 & 96.450 & 96.450 & 96.450 & 0 & 2.315 & 2.315 & 24.305 & 21.991 & 25.411 \\
\hline dic-2015 & 0 & 72.750 & 72.750 & 72.750 & 0 & 1.746 & 1.746 & 18.333 & 16.587 & 41.998 \\
\hline ene-2016 & 0 & 100.640 & 100.640 & 100.640 & 0 & 2.415 & 2.415 & 25.361 & 22.946 & 64.944 \\
\hline feb-2016 & 65.139 & 130.730 & 195.869 & 195.869 & 16.415 & 3.138 & 19.553 & 49.359 & 29.806 & 94.750 \\
\hline mar-2016 & 2.078 & 106.530 & 108.608 & 108.608 & 524 & 2.557 & 3.080 & 27.369 & 24.289 & 119.039 \\
\hline abr-2016 & 65 & 76.990 & 77.055 & 77.055 & 16 & 1.848 & 1.864 & 19.418 & 17.554 & 136.593 \\
\hline may-2016 & 32 & 16.750 & 16.782 & 16.782 & 8 & 402 & 410 & 4.229 & 3.819 & 140.412 \\
\hline oct-2016 & 6.169 & 16.160 & 22.329 & 22.329 & 1.554 & 388 & 1.942 & 5.627 & 3.684 & 144.096 \\
\hline nov-2016 & 2.328 & 136.550 & 138.878 & 138.878 & 587 & 3.277 & 3.864 & 34.997 & 31.133 & 175.229 \\
\hline dic-2016 & 888 & 116.420 & 117.308 & 117.308 & 224 & 2.794 & 3.018 & 29.562 & 26.544 & 201.773 \\
\hline ene-2017 & 2.712 & 231.590 & 234.302 & 234.302 & 683 & 5.558 & 6.242 & 59.044 & 52.803 & 254.576 \\
\hline feb-2017 & 1.016 & 175.430 & 176.446 & 176.446 & 256 & 4.210 & 4.466 & 44.464 & 39.998 & 294.574 \\
\hline mar-2017 & 240 & 150.220 & 150.460 & 150.460 & 60 & 3.605 & 3.666 & 37.916 & 34.250 & 328.824 \\
\hline abr-2017 & 1.320 & 51.990 & 53.310 & 53.310 & 333 & 1.248 & 1.580 & 13.434 & 11.854 & 340.678 \\
\hline may-2017 & 0 & 13.640 & 0 & 0 & 0 & 327 & 327 & 0 & -327 & 340.350 \\
\hline oct-2017 & 80 & 11.840 & 11.920 & 11.920 & 20 & 284 & 304 & 3.004 & 2.700 & 343.050 \\
\hline nov-2017 & 2.408 & 132.090 & 134.498 & 134.498 & 607 & 3.170 & 3.777 & 33.894 & 30.117 & 373.166 \\
\hline dic-2017 & 408 & 173.260 & 173.668 & 173.668 & 103 & 4.158 & 4.261 & 43.764 & 39.503 & 412.670 \\
\hline ene-2018 & 848 & 197.380 & 198.228 & 198.228 & 214 & 4.737 & 4.951 & 49.953 & 45.003 & 457.672 \\
\hline feb-2018 & 1.208 & 256.010 & 257.218 & 257.218 & 304 & 6.144 & 6.449 & 64.819 & 58.370 & 516.042 \\
\hline mar-2018 & 1.656 & 212.540 & 214.196 & 214.196 & 417 & 5.101 & 5.518 & 53.977 & 48.459 & 564.502 \\
\hline abr-2018 & 96 & 97.750 & 97.846 & 97.846 & 24 & 2.346 & 2.370 & 24.657 & 22.287 & 586.789 \\
\hline may-2018 & 0 & 22.440 & 22.440 & 22.440 & 0 & 539 & 539 & 5.655 & 5.116 & 591.905 \\
\hline
\end{tabular}

Como se observa durante estas tres temporadas se ha obtenido un ahorro total de 592 Toneladas de $\mathrm{CO}_{2}$, debido al consumo térmico del edificio $\mathrm{E} 3$. 


\section{AV.3.6. Estimación del precio máximo de compra a la red.}

Tomando como referencia los precios del gas natural de la Tabla 466 para cada temporada, obtenidos a partir de los datos establecidos en el Capítulo 3, donde se tiene en cuenta el precio por el termino variable y fijo; se puede realizar la estimación del precio máximo de compra de la energía útil a la red de calor para obtener un $0 \%$ de ahorro y un $15 \%$ de ahorro. La Tabla 467, muestra el precio que se pagaría para un ahorro del $15 \%$

Tabla 466. Precios de referencia para Gas natural y Astilla

\begin{tabular}{ccccc}
\hline Precios ( $€ /(\mathrm{kWh})$ & 2015 & 2016 & 2017 & 2018 \\
\hline Gas Natural & 0,0373 & 0,0306 & 0,0314 & 0,0336 \\
\hline Astilla & 0,0277 & 0,0256 & 0,0254 & 0,0239 \\
\hline $\begin{array}{c}€ / \text { kWh útiles máximos de compra a la red para } \\
\text { un ahorro del 0,0\% }\end{array}$ & 0,00321 & \\
\hline $\begin{array}{c}€ / \text { kWh útiles máximos de compra a la red para } \\
\text { un ahorro del 15,0\% }\end{array}$ & 0,02778 & \\
\hline
\end{tabular}

Tabla 467. Ahorro Económico por el consumo térmico en el Edificio E3

\begin{tabular}{|c|c|c|c|c|c|c|c|c|c|c|}
\hline & $\begin{array}{c}\text { kWh_E3 } \\
\text { Gas } \\
\text { Natural }\end{array}$ & $\begin{array}{c}\text { kWh_E3_B } \\
\text { iomasa }\end{array}$ & kWh_E3 & $\begin{array}{c}\text { kWh_E3_ } \\
\text { M2 }\end{array}$ & $\begin{array}{c}€ \text { Real Gas } \\
\text { Natural }\end{array}$ & $\begin{array}{c}€ \text { Real } \\
\text { Biomasa }\end{array}$ & $\begin{array}{l}€ \text { Real } \\
\text { Total }\end{array}$ & $\begin{array}{c}\text { E predicho } \\
\text { Gas } \\
\text { natural }\end{array}$ & $\begin{array}{c}€ \\
\text { Ahorro }\end{array}$ & $€$ Acumulado \\
\hline oct-2015 & 0 & 15.000 & 15.000 & 15.000 & 0 & 417 & 417 & 560 & 143 & 143 \\
\hline nov-2015 & 0 & 96.450 & 96.450 & 96.450 & 0 & 2.679 & 2.679 & 3.598 & 918 & 1.061 \\
\hline dic-2015 & 0 & 72.750 & 72.750 & 72.750 & 0 & 2.021 & 2.021 & 2.714 & 693 & 1.754 \\
\hline ene-2016 & 0 & 100.640 & 100.640 & 100.640 & 0 & 2.796 & 2.796 & 3.080 & 284 & 2.037 \\
\hline feb-2016 & 65.139 & 130.730 & 195.869 & 195.869 & 1.993 & 3.632 & 5.625 & 5.994 & 369 & 2.406 \\
\hline mar-2016 & 2.078 & 106.530 & 108.608 & 108.608 & 64 & 2.959 & 3.023 & 3.323 & 300 & 2.706 \\
\hline abr-2016 & 65 & 76.990 & 77.055 & 77.055 & 2 & 2.139 & 2.141 & 2.358 & 217 & 2.924 \\
\hline may-2016 & 32 & 16.750 & 16.782 & 16.782 & 1 & 465 & 466 & 514 & 47 & 2.971 \\
\hline oct-2016 & 6.169 & 16.160 & 22.329 & 22.329 & 189 & 449 & 638 & 683 & 46 & 3.016 \\
\hline nov-2016 & 2.328 & 136.550 & 138.878 & 138.878 & 71 & 3.793 & 3.865 & 4.250 & 385 & 3.401 \\
\hline dic-2016 & 888 & 116.420 & 117.308 & 117.308 & 27 & 3.234 & 3.261 & 3.590 & 328 & 3.730 \\
\hline ene-2017 & 2.712 & 231.590 & 234.302 & 234.302 & 85 & 6.434 & 6.519 & 7.357 & 838 & 4.568 \\
\hline feb-2017 & 1.016 & 175.430 & 176.446 & 176.446 & 32 & 4.873 & 4.905 & 5.540 & 635 & 5.203 \\
\hline mar-2017 & 240 & 150.220 & 150.460 & 150.460 & 8 & 4.173 & 4.181 & 4.724 & 544 & 5.747 \\
\hline abr-2017 & 1.320 & 51.990 & 53.310 & 53.310 & 41 & 1.444 & 1.486 & 1.674 & 188 & 5.935 \\
\hline may-2017 & 0 & 13.640 & 0 & 0 & 0 & 379 & 379 & 0 & -379 & 5.556 \\
\hline oct-2017 & 80 & 11.840 & 11.920 & 11.920 & 3 & 329 & 331 & 374 & 43 & 5.599 \\
\hline nov-2017 & 2.408 & 132.090 & 134.498 & 134.498 & 76 & 3.669 & 3.745 & 4.223 & 478 & 6.077 \\
\hline dic-2017 & 408 & 173.260 & 173.668 & 173.668 & 13 & 4.813 & 4.826 & 5.453 & 627 & 6.704 \\
\hline ene-2018 & 848 & 197.380 & 198.228 & 198.228 & 28 & 5.483 & 5.512 & 6.660 & 1.149 & 7.853 \\
\hline feb-2018 & 1.208 & 256.010 & 257.218 & 257.218 & 41 & 7.112 & 7.153 & 8.643 & 1.490 & 9.343 \\
\hline mar-2018 & 1.656 & 212.540 & 214.196 & 214.196 & 56 & 5.904 & 5.960 & 7.197 & 1.237 & 10.580 \\
\hline$a b r-2018$ & 96 & 97.750 & 97.846 & 97.846 & 3 & 2.715 & 2.719 & 3.288 & 569 & 11.149 \\
\hline may-2018 & 0 & 22.440 & 22.440 & 22.440 & 0 & 623 & 623 & 754 & 131 & 11.280 \\
\hline$€$ Total & & & & & & & 75.270 & 86.549 & & \\
\hline Ahorro (\%) & & & & & & & & & & $15,0 \%$ \\
\hline
\end{tabular}




\section{AV.4. Edificio E4. Escuela de Ingenierías Industriales (Antigua Facultad de Ciencias).}

\section{AV.4.1. Obtención de la línea base de referencia energética}

Los datos de partida para la obtención de la línea base de referencia se muestran en la Tabla 468

Tabla 468. Consumos térmicos del edificio E4

\begin{tabular}{lr}
\hline & Consumos térmicos (kWh). \\
& E4 \\
\hline oct-12 & $14.142,37$ \\
\hline nov-12 & $111.738,28$ \\
\hline dic-12 & $153.433,96$ \\
\hline ene-13 & $181.743,51$ \\
\hline feb-13 & $239.368,54$ \\
\hline mar-13 & $118.256,15$ \\
\hline abr-13 & $79.148,51$ \\
\hline may-13 & $11.168,69$ \\
\hline oct-13 & $25.730,50$ \\
\hline nov-13 & $127.312,99$ \\
\hline dic-13 & $148.501,58$ \\
\hline ene-14 & $114.799,73$ \\
\hline feb-14 & $109.571,54$ \\
\hline mar-14 & $80.574,20$ \\
\hline abr-14 & $30.084,06$ \\
\hline may-14 & $14.875,40$ \\
\hline Promedio & 97.528 \\
\hline Total (oct-12-may-13) & 959.000 \\
\hline Total (oct-13-may-14) & 1.560 .450 \\
\hline Total (oct-12-may-13) & \\
\hline
\end{tabular}

Como se puede ver en la Tabla 469 para el edificio, el método ofrece un modelo de regresión, con una sola variable (Temperatura media). El modelo fue construido con un solo paso, incluyendo la Temperatura media, por ser la variable más significativa (variable con menor valor de Sig $=0,000)$. El resto de las variables como se observa en la Tabla 470 fueron excluidas del modelo al tener valores de sig $>0,05$.

Tabla 469. Modelos de regresión del Edificio E4

\begin{tabular}{|c|c|c|c|c|c|c|c|}
\hline & \multirow[t]{2}{*}{ Modelo } & \multicolumn{2}{|c|}{ Coeficientes no estandarizados } & \multirow[t]{2}{*}{$\mathrm{t}$} & \multirow[t]{2}{*}{ Sig. } & \multicolumn{2}{|c|}{$\begin{array}{c}\text { Intervalo de confianza de } 95,0 \% \\
\text { para B }\end{array}$} \\
\hline & & $\mathrm{B}$ & Error típ. & & & Límite inferior & Límite superior \\
\hline \multirow[t]{2}{*}{1} & (Constante) & 234879,945 & 18312,062 & 12,827 & ,000 & 195604,478 & 274155,411 \\
\hline & T_med & $-16850,392$ & 2066,434 & $-8,154$ & ,000 & $-21282,453$ & $-12418,331$ \\
\hline
\end{tabular}


En la Figura 314 se representa el modelo de regresión con sus límites inferior y superior para un nivel de confianza del $95 \%$

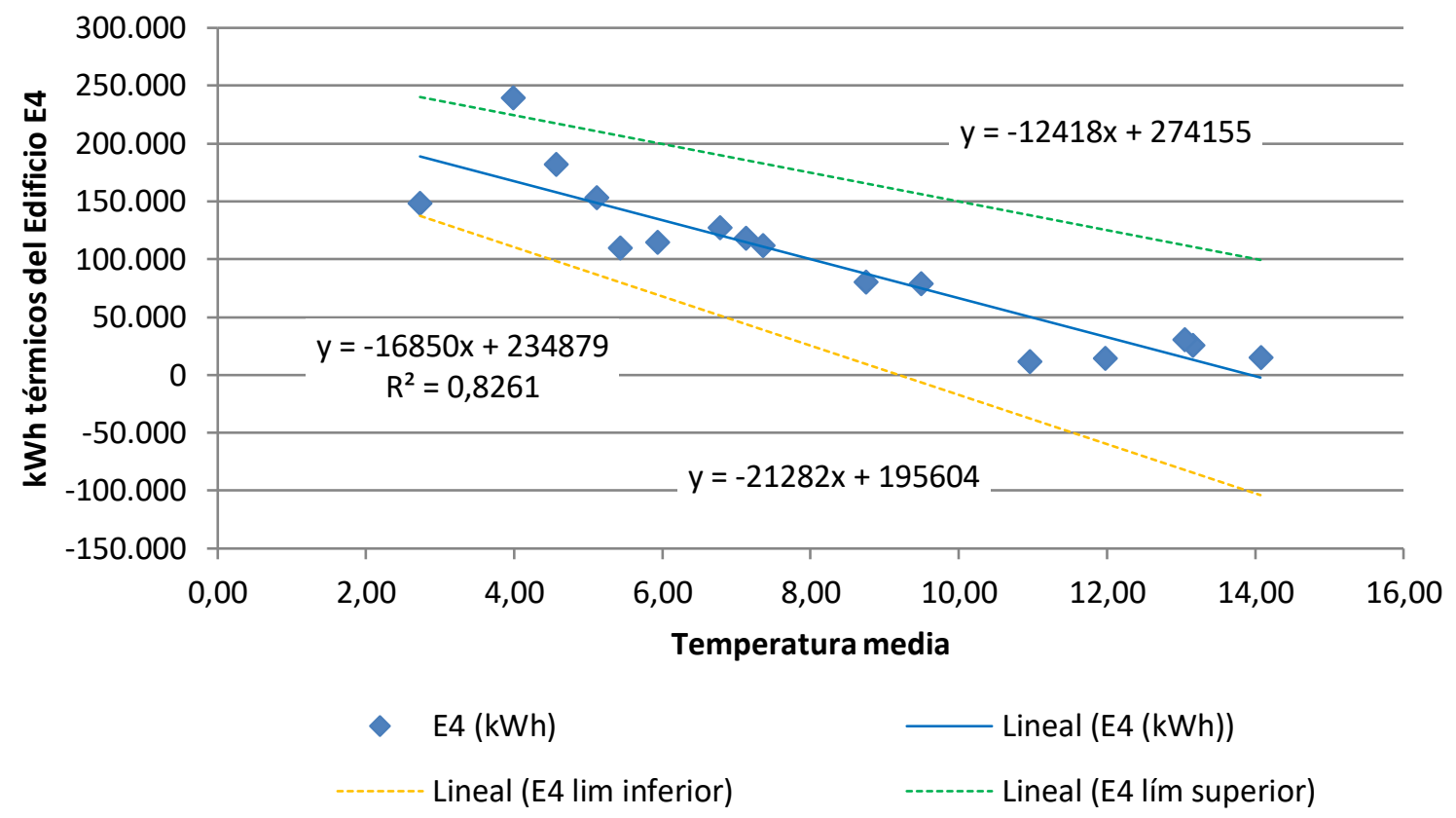

Figura 314. Representación del modelo de regresión lineal simple para el Edificio E4

Tabla 470. Variables excluidas del modelo de región del Edificio E4

\begin{tabular}{|c|c|c|c|c|}
\hline & Modelo & $\mathrm{t}$ & Sig. & Correlación parcial \\
\hline & GD15_30min &,- 725 & ,482 &,- 197 \\
\hline & GD20_30min & $-1,239$ & 237 &,- 325 \\
\hline & GD15_24h & $-1,014$ &, 329 &,- 271 \\
\hline & GD20_24h & $-1,420$ & 179 &,- 367 \\
\hline & T_media_diurna_C &, 552 &, 590 & ,151 \\
\hline & T_max_C & ,380 & 710 & 105 \\
\hline & T_min_C &,- 381 & ,709 &,- 105 \\
\hline & HR_\% &,- 541 & ,597 &,- 148 \\
\hline & HR_med_diurna_\% &,- 547 & ,593 &,- 150 \\
\hline \multirow[t]{10}{*}{1} & HR_max_\% &,- 425 & 678 &,- 117 \\
\hline & HR_min_\% &,- 522 & 611 &,- 143 \\
\hline & V_Viento_m/s &,- 190 &, 852 &,- 053 \\
\hline & V_viento_diurna_m/s &,- 059 & ,954 &,- 016 \\
\hline & V_viento_nocturna_m/s &,- 395 & 699 &,- 109 \\
\hline & V_viento_max_m/s &, 126 & ,902 & 035 \\
\hline & Recorrido_viento_km/día &,- 205 & 841 &,- 057 \\
\hline & Precipitación_acumulada_mes_mm & ,013 & ,990 & 004 \\
\hline & Horas insolación_h & ,467 & 648 & 128 \\
\hline & Radiación_W/m2 & ,023 & ,982 & ,007 \\
\hline
\end{tabular}


La bondad del modelo de regresión obtenido para el edificio E4, se resumen en la Tabla 471

Tabla 471. Resumen de la bondad del modelo de regresión para el Edificio E4

\begin{tabular}{ccccc}
\hline Modelo & $\mathrm{R}$ & $\mathrm{R}$ cuadrado & R cuadrado corregida & $\begin{array}{c}\text { Error típ. de la } \\
\text { estimación }\end{array}$ \\
\hline 1 &,- 909 &, 826 &, 814 & 28736,1742 \\
\hline
\end{tabular}

Se observa como el modelo de regresión lineal simple presenta un Coeficiente de Correlación de Pearson (R) de 0,909, lo que indica que las variables están correlacionadas de manera muy fuerte (en la correlación perfecta $R= \pm 1$ ). La correlación que se produce es directa, al aumentar el valor de los Grados día, aumenta el consumo térmico.

El coeficiente de determinación $\left(R^{2}\right)$, nos indica que con el modelo se podría explicar el $82,6 \%$ de los datos reales obtenidos aceptando un error del $5 \%$.

El error típico de la estimación que nos indica la magnitud de los errores, es decir la parte de la variable dependiente que dejamos sin explicar con el modelo y que describe la variación de la variable respuesta (el Consumo) respecto a la recta de regresión, es de $28.736 \mathrm{kWh}$, lo que representa un 29,5\% del promedio de los consumos que fue de 97.528 kWh.

\section{AV.4.2. Verificación del cumplimiento de los supuestos estadísticos}

Las condiciones que se deben cumplir en un modelo de regresión son:

- Linealidad de las variables, las variables se encuentran relacionadas de forma lineal.

Como se observa en la Tabla 469, la pendiente (B), obtuvo un valor de Sig $=0,000$, que al ser $\leq 0,05$, nos indica que podemos rechazar la hipótesis nula de pendiente igual a cero y nos da la evidencia de linealidad entre la variable dependiente ( $k$ Wh del edificio E4) y la independiente (T_med). Al ser el valor de la pendiente negativa, indica una relación inversa entre el consumo y la Temperatura media.

- Normalidad. Todos los valores obtenidos para la variable dependiente (Y), deben estar distribuidos normalmente en cada valor de la variable independiente $(X)$.

Se comprueba la normalidad de las variables y de los residuos mediante el Test de Shapiro - Wilk para muestras pequeñas (menores a 30 observaciones), siendo la hipótesis nula el que la distribución es Normal. 
La Tabla 472, muestra la prueba de normalidad de Shapiro-Wilk y cómo tanto la variable dependiente (consumos del Edificio), como la variable independientes: GD15 poseen una Sig $>0,05$, por lo que aceptamos la hipótesis nula de Normalidad de las variables

Tabla 472. Prueba de normalidad para el edificio E4

\begin{tabular}{lrrrrrr}
\hline & \multicolumn{2}{c}{ Kolmogorov-Smirnov } & \multicolumn{3}{c}{ Shapiro-Wilk } \\
\cline { 2 - 7 } & Estadístico & gl & Sig. & Estadístico & gl & Sig. \\
\hline kWh_E4 &, 157 & 16 &, 200 &, 935 & 16 &, 295 \\
\hline T_med & ,150 & 16 &, 200 &, 942 & 16 &, 376 \\
\hline
\end{tabular}

- Independencia de los errores. Los errores asociados a los valores de la variable respuesta $(\mathrm{Y})$ deberán ser independientes unos de otros.

Para la comprobación se utiliza el estadístico de Durbin -Watson.

Se comprueba que el Estadístico de Durbin Watson para el nivel de significancia del 5\%, y para el tamaño de la muestra " $n$ " y el número de variables independientes del modelo " $k$ ", se encuentra en el intervalo [dU, 4-dU], de la Tabla 3, intervalo centrado en el 2, que indica la ausencia de autocorrelación.

El valor del Estadístico Durbin-Watson facilitado por el programa SPSS, es 1,405.

En el modelo, $n=16$ y $k=1$, según la Tabla 3 el valor $d U=1,371$ y dL =1,106, luego el intervalo que marca la ausencia de correlación es [1,371, 2,629].

Los intervalos $[0,1,106]$ y $[2,896,4]$ indican correlación positiva o negativa respectivamente y las zonas $[1,106,1,371]$ y $[2,629,2,896]$ son zonas no concluyentes; como el valor del estadístico 1,405 está dentro del intervalo que marca la ausencia de correlación, se concluye que no existe autocorrelación en los residuos.

- Homocedasticidad de la varianza. Se pretende comprobar que la varianza de los errores $\left(\sigma^{2}\right)$ es constante para cualquier valor de la variable independiente $(X)$, es decir que el valor medio del cuadrado de la desviación de los errores respecto a su media es constante.

Esta condición indica que no existe correlación entre los residuos y los pronósticos. Se comprueba que el coeficiente de determinación $\mathrm{R}^{2}$, en las relaciones: residuos $\mathrm{y}$ predicciones y entre residuos y variable independiente es nulo o muy próximo a cero, lo que indicará que no existe ningún tipo de correlación en los residuos y que éstos son aleatorios. Se grafican los diagramas de dispersión de esas relaciones, comprobando que se corresponden a nubes de puntos totalmente aleatorias, sin tendencias ni patrones en sus representaciones gráficas. 
Las Figura 315 y Figura 316, muestran que la relación entre los pronósticos y los residuos, posee un coeficiente de determinación $=0$ y entre la variable independiente (T_med) y los residuos un coeficiente de determinación de $1,11 \times 10^{-16}$; por lo que se concluye que no existe ningún tipo de correlación en los residuos y que éstos son aleatorios, siendo la varianza de los residuos constante.

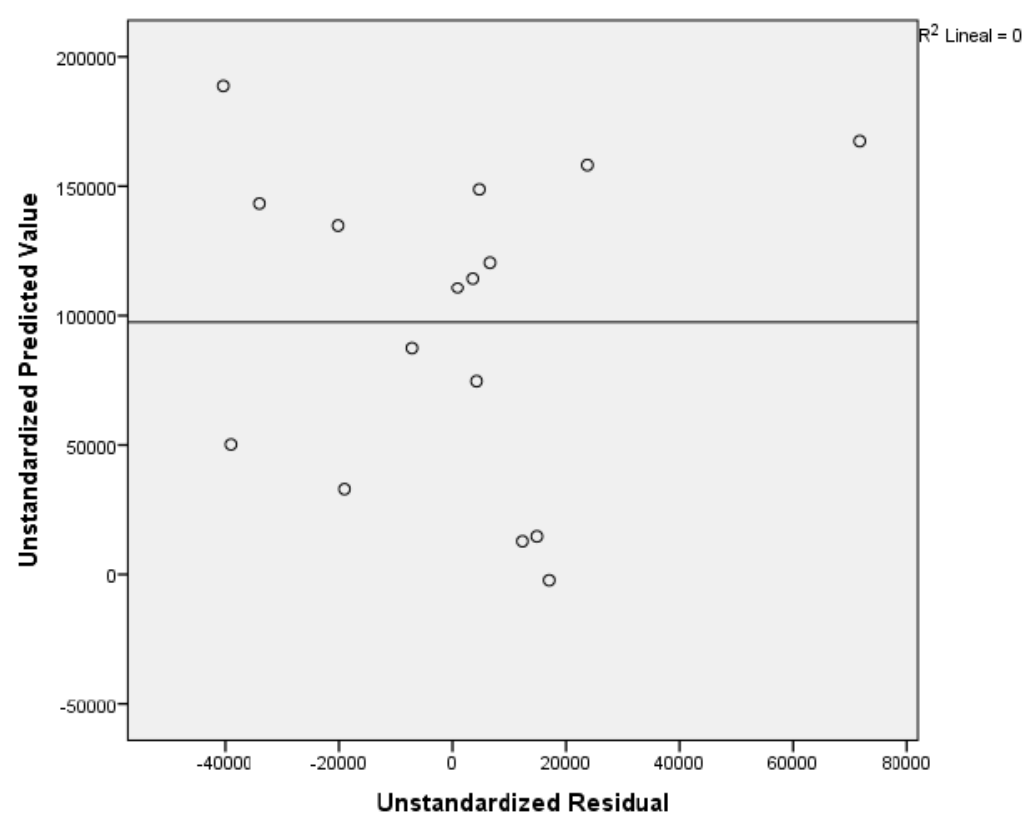

Figura 315. Relación entre los pronósticos y los residuos en el Edificio E4

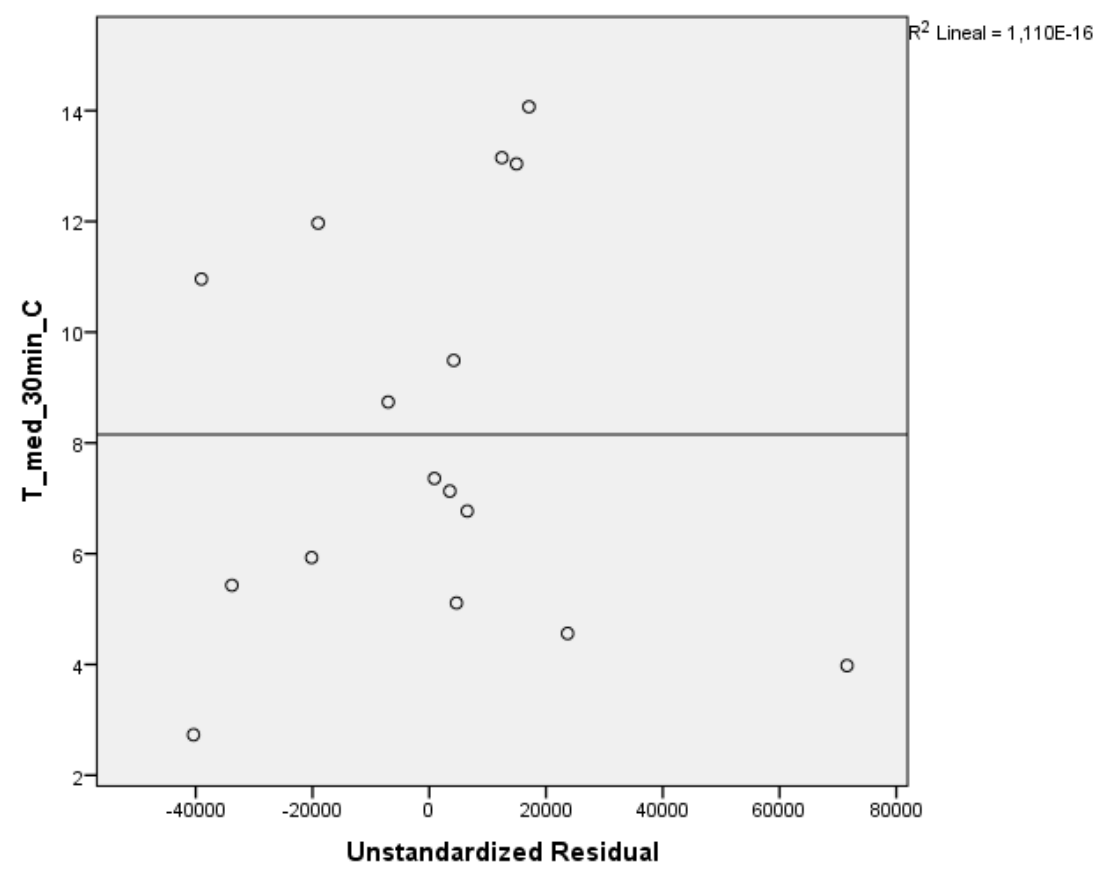

Figura 316. Relación entre GD20_24h y los residuos en el Edificio E4 


\section{AV.4.3. Obtención de los consumos térmicos previstos}

Una vez comprobado el cumplimiento de los supuestos estadísticos se acepta el modelo de línea base encontrado para modelizar el consumo del Edificio E4.

$$
\text { kWh_E4_Pronosticado }=234.879,945-16.850,392 \times \text { T_med }
$$

Con este modelo se procede a predecir los consumos previstos para las temporadas: octubre 2015-mayo 2016, octubre 2016 - mayo 2017 y octubre 2017-mayo 2018, estos consumos se muestran en la Tabla 473, donde "KWh_E4_Real", representa el consumo real redistribuido, "kWh_E4_Pronosticado", el consumo pronosticado con el Modelo.

Tabla 473. Consumos previstos octubre 2014 - mayo 2017 para el edificio E4.

\begin{tabular}{rrrr}
\hline & T_med & kWh_E4_Real & kWh_E4_Pronosticado \\
\hline oct-15 & 12,82 & 8.100 & 18.880 \\
\hline nov-15 & 8,30 & 73.400 & 94.982 \\
\hline dic-15 & 5,33 & 59.700 & 145.089 \\
\hline ene-16 & 6,23 & 42.100 & 129.842 \\
\hline feb-16 & 5,82 & 197.706 & 136.875 \\
\hline mar-16 & 6,14 & 96.973 & 131.370 \\
\hline abr-16 & 9,10 & 65.845 & 81.530 \\
\hline may-16 & 13,11 & 16.189 & 13.901 \\
\hline oct-16 & 13,48 & 13.250 & 7.731 \\
\hline nov-16 & 6,90 & 43.359 & 118.584 \\
\hline dic-16 & 4,12 & 50.061 & 165.424 \\
\hline ene-17 & 2,52 & 53.139 & 192.482 \\
\hline feb-17 & 6,96 & 49.191 & 117.607 \\
\hline mar-17 & 9,21 & 51.117 & 79.699 \\
\hline abr-17 & 12,58 & 17.237 & 22.953 \\
\hline may-17 & 16,69 & 3.184 & -46.299 \\
\hline oct-17 & 14,71 & 4.400 & -13.011 \\
\hline nov-17 & 6,09 & 0 & 132.255 \\
\hline dic-17 & 3,99 & 95.300 & 167.625 \\
\hline ene-18 & 4,42 & 48.500 & 160.390 \\
\hline feb-18 & 3,53 & 64.100 & 175.422 \\
\hline mar-18 & 6,80 & 55.500 & 120.254 \\
\hline abr-18 & 11,15 & 24.100 & 47.060 \\
\hline may-18 & 14,03 & 8.600 & -1.493 \\
\hline & & &
\end{tabular}

Se eliminaran los meses cuyos valores pronosticados sean negativos, por ser valores imposibles. 


\section{AV.4.4. Estudio de la existencia de diferencias significativas}

Utilizando la prueba " $\mathrm{t}$ " de Student para muestras relacionadas, podemos concluir que si las variables se distribuyen según una normal y la significación estadística resulta $\leq 0,05$, existen diferencias significativas, con un nivel de confianza del 95\%

A continuación se muestra la comparación de medias realizada para cada uno de los tres periodos posteriores a la construcción de la red y para el periodo total hasta mayo de 2018.

Para la temporada Octubre 2015 - Mayo 2016, se comprueba mediante el Test de Shapiro -Wilk que los valores reales y los pronosticados se distribuyen según una Normal (Sig $>0,05)$, como se observa en la Tabla 474

Tabla 474. Prueba de Normalidad temporada Octubre 2015-Mayo 2016. Edificio E4

\begin{tabular}{ccccrrrr}
\hline & \multicolumn{3}{c}{ Kolmogorov-Smirnov $^{\mathrm{a}}$} & \multicolumn{3}{c}{ Shapiro-Wilk } \\
\cline { 2 - 9 } & Estadístico & gl & \multicolumn{1}{c}{ Sig. } & Estadístico & gl & \multicolumn{1}{c}{ Sig. } \\
\hline kWh_real &, 227 & 8 &, 200 &, 865 & 8 &, 135 \\
\hline kWh_pronosticado &, 252 & 8 &, 144 &, 839 & 8 &, 073 \\
\hline
\end{tabular}

En la Tabla 475, se observa como las medias de los consumos pronosticados, son superiores a las medias de los consumos reales del Edificio E4, en un $34,4 \%$

Tabla 475. Estadísticos de muestras relacionadas. Octubre 2015-Mayo 2016. Edificio E4

\begin{tabular}{llcrcc}
\hline & Media & $\begin{array}{c}\text { \% Diferencia } \\
\text { entre medias }\end{array}$ & $\mathrm{N}$ & $\begin{array}{c}\text { Desviación } \\
\text { típ. }\end{array}$ & $\begin{array}{c}\text { Error típ. de } \\
\text { la media }\end{array}$ \\
\hline kWh_real & 70001,6250 & & 8 & 59374,02377 & 20991,88742 \\
\hline kWh_pronosticado & 94058,6250 & $34,4 \%$ & 8 & 52569,43618 & 18586,10240 \\
\hline
\end{tabular}

La Tabla 476 muestra que las diferencias entre las medias no son significativas entre los consumos reales y los pronosticados (sig $>0,05$ )

Tabla 476. Prueba de muestras relacionadas. Octubre 2015-Mayo 2016. Edificio E4

\begin{tabular}{|c|c|c|c|c|c|c|c|c|c|}
\hline & & \multicolumn{5}{|c|}{ Diferencias relacionadas } & \multirow{3}{*}{$\mathrm{t}$} & \multirow{3}{*}{$\mathrm{gl}$} & \multirow{3}{*}{$\begin{array}{c}\text { Sig. } \\
\text { (bilateral) }\end{array}$} \\
\hline & & \multirow[t]{2}{*}{ Media } & \multirow{2}{*}{$\begin{array}{l}\text { Desviación } \\
\text { típ. }\end{array}$} & \multirow{2}{*}{$\begin{array}{l}\text { Error típ. } \\
\text { de la media }\end{array}$} & \multicolumn{2}{|c|}{$\begin{array}{l}\text { 95\% Intervalo de confianza } \\
\text { para la diferencia }\end{array}$} & & & \\
\hline & & & & & Inferior & Superior & & & \\
\hline Par 1 & $\begin{array}{c}\text { kWh_real - } \\
\text { kWh_pronosticado }\end{array}$ & $-24057,000$ & 47923,802 & 16943,623 & $-64122,301$ & 16008,301 & $-1,420$ & 7 & 199 \\
\hline
\end{tabular}


En la Figura 317 se grafican los consumos reales y pronosticados para la temporada Octubre 2015 - Mayo 2015 para el Edificio E4, y las medias de dichos consumos. Según la prueba paramétrica realizada las diferencias encontradas no son estadísticamente significativas, con un riesgo a estar equivocados del $5 \%$

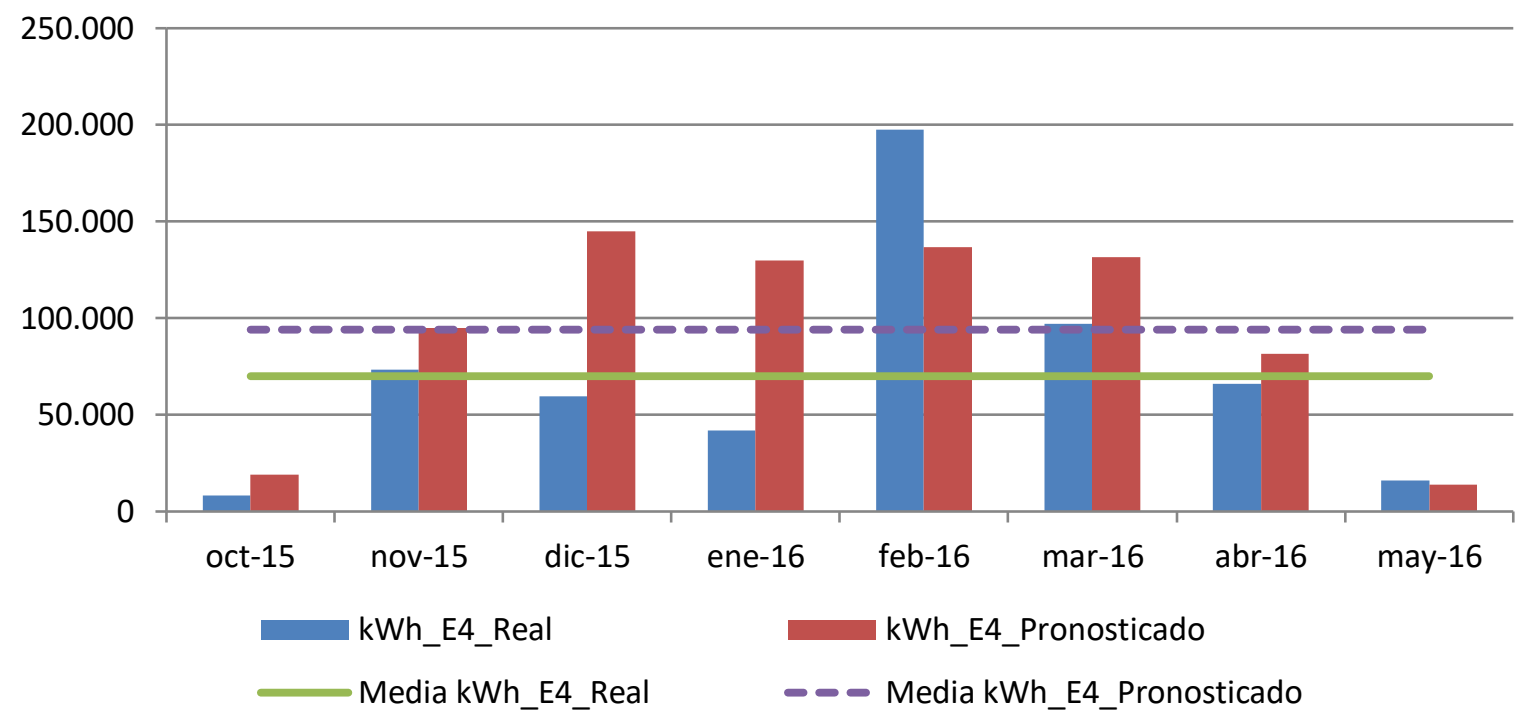

Figura 317. Consumos reales y pronosticados Octubre 2015-Mayo 2016. Edificio E4

Para la temporada Octubre 2016 - Mayo 2017, se comprueba mediante el Test de Shapiro -Wilk que los valores reales no se distribuyen según una Norma (Sig $\leq 0,05$ ), aunque los pronosticados si lo hacen (Sig >0,05), como se observa en la Tabla 477

Tabla 477. Prueba de Normalidad temporada Octubre 2016-Mayo 2017. Edificio E4

\begin{tabular}{cccccccr}
\hline & \multicolumn{3}{c}{ Kolmogorov-Smirnov $^{\mathrm{a}}$} & \multicolumn{3}{c}{ Shapiro-Wilk } \\
\cline { 2 - 8 } & Estadístico & gl & Sig. & Estadístico & gl & Sig. \\
\hline $\begin{array}{c}\text { kWh_real (sin } \\
\text { mayo 2017) }\end{array}$ & ,301 & 7 &, 054 &, 754 & 7 &, 014 \\
\hline kWh_pronosticado &, 169 & 7 &, 200 &, 946 & 7 &, 695 \\
\hline
\end{tabular}

Al no cumplirse la hipótesis de normalidad, no se puede aplicar la prueba t- Student, para analizar si existen diferencias significativas entre las medias de las dos muestras relacionadas.

Para la temporada Octubre 2017 - Mayo 2018, se comprueba mediante el Test de Shapiro -Wilk que tanto los valores reales como los pronosticados se distribuyen según una Normal puesto que en todos los casos los valores de Sig $>0,05$, como se observa en la Tabla 478 
Anexo V. Desarrollo del análisis de los edificios del Campus Río Esgueva

Tabla 478. Prueba de Normalidad temporada Octubre 2017-Mayo 2018. Edificio E4

\begin{tabular}{ccccccr}
\hline & \multicolumn{3}{c}{ Kolmogorov-Smirnov $^{\text {a }}$} & \multicolumn{3}{c}{ Shapiro-Wilk } \\
\cline { 2 - 7 } & Estadístico & gl & Sig. & Estadístico & gl & Sig. \\
\hline $\begin{array}{c}\text { kWh_real (sin } \\
\text { octubre 2017, ni } \\
\text { mayo 2018) }\end{array}$ & 174 & 6 & 200 & ,985 & 6 &, 974 \\
\hline kWh_pronosticado &, 221 & 6 &, 200 &, 856 & 6 &, 175 \\
\hline
\end{tabular}

En la Tabla 479, se observa como las medias de los consumos pronosticados, son superiores a las medias de los consumos reales del Edificio E4, en un 179,3\%

Tabla 479. Estadísticos de muestras relacionadas. Octubre 2017-Mayo 2018. Edificio E4

\begin{tabular}{lccccc}
\hline & Media & $\begin{array}{c}\text { \% Diferencia } \\
\text { entre medias }\end{array}$ & N & $\begin{array}{c}\text { Desviación } \\
\text { típ. }\end{array}$ & $\begin{array}{c}\text { Error típ. de } \\
\text { la media }\end{array}$ \\
\hline kWh_real & 47916,6667 & & 6 & 32948,95547 & 13451,35474 \\
\hline kWh_pronosticado & 133834,3333 & $179,3 \%$ & 6 & 47525,25913 & 19402,10579 \\
\hline
\end{tabular}

La Tabla 480 muestra que las diferencias entre las medias son significativas entre los consumos reales y los pronosticados (sig $\leq 0,05$ )

Tabla 480. Prueba de muestras relacionadas. Octubre 2017-Mayo 2018. Edificio E4

\begin{tabular}{|c|c|c|c|c|c|c|c|c|c|}
\hline & & \multicolumn{5}{|c|}{ Diferencias relacionadas } & \multirow{3}{*}{$\mathrm{t}$} & \multirow{3}{*}{$\mathrm{gl}$} & \multirow{3}{*}{$\begin{array}{c}\text { Sig. } \\
\text { (bilateral) }\end{array}$} \\
\hline & & \multirow[t]{2}{*}{ Media } & \multirow{2}{*}{$\begin{array}{l}\text { Desviación } \\
\text { típ. }\end{array}$} & \multirow{2}{*}{$\begin{array}{c}\text { Error típ. } \\
\text { de la media }\end{array}$} & \multicolumn{2}{|c|}{$\begin{array}{c}\text { 95\% Intervalo de confianza } \\
\text { para la diferencia }\end{array}$} & & & \\
\hline & & & & & Inferior & Superior & & & \\
\hline Par 1 & $\begin{array}{c}\text { kWh_real - } \\
\text { kWh_pronosticado }\end{array}$ & $-85917,667$ & 40158,237 & 16394,531 & $-128061,152$ & $-43774,182$ & $-5,241$ & 5 & ,003 \\
\hline
\end{tabular}

En la Figura 318, se grafican los consumos reales y pronosticados para la temporada Octubre 2017 - Mayo 2018 para el Edificio E4, y las medias de dichos consumos. Según la prueba paramétrica realizada las diferencias encontradas son estadísticamente significativas, con un riesgo a estar equivocados del $5 \%$ 
Anexo V. Desarrollo del análisis de los edificios del Campus Río Esgueva

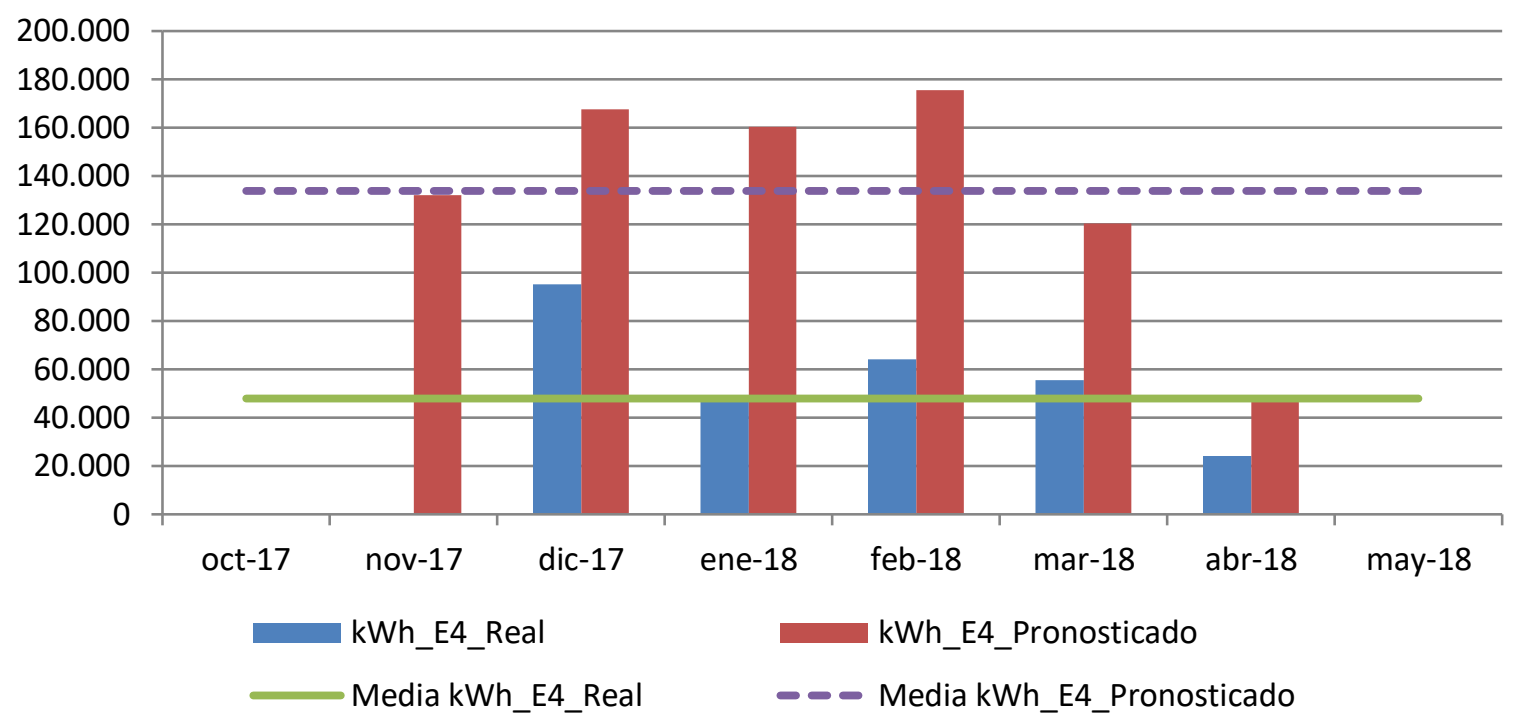

Figura 318. Consumos reales y pronosticados Octubre 2017-Mayo 2018. Edificio E4

Para el total de las tres temporadas Octubre 2015 - Mayo 2018, se comprueba mediante el Test de Shapiro -Wilk, que ni los valores reales, ni los pronosticados se distribuyen según una Normal puesto que en esos casos los valores de Sig $\leq 0,05$, como se observa en la Tabla 481

Tabla 481. Prueba de Normalidad temporada Octubre 2015-Mayo 2018. Edificio E4

\begin{tabular}{ccccccr}
\hline & \multicolumn{3}{c}{ Kolmogorov-Smirnov $^{\mathrm{a}}$} & \multicolumn{3}{c}{ Shapiro-Wilk } \\
\cline { 2 - 8 } & Estadístico & $\mathrm{gl}$ & Sig. & Estadístico & gl & Sig. \\
\hline $\begin{array}{c}\text { kWh_real (sin } \\
\text { mayo 2017, } \\
\begin{array}{c}\text { octubre 2017, } \\
\text { mayo 2018) }\end{array}\end{array}$ &, 189 & 21 &, 047 &, 824 & 21 &, 002 \\
\hline kWh_pronosticado &, 197 & 21 &, 033 &, 898 & 21 &, 032 \\
\hline
\end{tabular}

Al no cumplirse la hipótesis de normalidad, no se puede aplicar la prueba t- Student, para analizar si existen diferencias significativas entre las medias de las dos muestras relacionadas. 


\section{AV.4.5. Estimación de las emisiones de $\mathrm{CO} 2$ evitadas.}

Teniendo en cuenta que el consumir Gasóleo se producen 0,311 kg $\mathrm{CO}_{2} / \mathrm{kWh}$ E. final y que al consumir la energía suministrada por red a partir de Biomasa se producen 0,024 $\mathrm{kg}$ $\mathrm{CO}_{2} / \mathrm{kWh}$. final, en la Tabla 482, se muestra las emisiones de $\mathrm{CO}_{2}$ reales para las temporadas octubre 2015 - mayo 2018 y al no haberse podido justificar la existencia de diferencias significativas, se mantienen los mismos valores reales como predichos para esas temporadas de haber seguido utilizando las calderas de gasóleo originales sin el apoyo de la red de calor.

Tabla 482. Estimación del ahorro de emisiones de CO2 para el Edificio E4.

\begin{tabular}{|c|c|c|c|c|c|c|c|c|c|c|}
\hline & $\begin{array}{l}\text { kWh_E4 } \\
\text { Gasóleo }\end{array}$ & $\begin{array}{c}\text { kWh_- } \\
\text { E4 } \\
\text { Biomasa }\end{array}$ & $\begin{array}{l}\text { kWh_E4 } \\
\text { Real Total }\end{array}$ & $\begin{array}{l}\text { kWh_E4 } \\
\text { Predicho }\end{array}$ & $\begin{array}{l}\mathrm{kg} \mathrm{CO} 2 \text { Real } \\
\text { debido al } \\
\text { consumo de } \\
\text { Gasóleo }\end{array}$ & $\begin{array}{c}\text { kg CO2 } \\
\text { Real } \\
\text { debido a } \\
\text { Biomasa }\end{array}$ & $\begin{array}{l}\text { kg CO2 } \\
\text { Real } \\
\text { debido al } \\
\text { consumo } \\
\text { TOTAL }\end{array}$ & $\begin{array}{c}\text { kg CO2 } \\
\text { que se } \\
\text { hubiera } \\
\text { tenido } \\
\text { debido a } \\
\text { Gasóleo }\end{array}$ & $\begin{array}{l}\text { Ahorro de } \\
\text { kg CO2 }\end{array}$ & $\begin{array}{c}\text { Ahorro de kg } \\
\text { CO2 } \\
\text { acumulado }\end{array}$ \\
\hline oct-2015 & 0 & 8.100 & 8100 & 8.100 & 0 & 194 & 194 & 2.519 & 2.325 & 2.325 \\
\hline nov-2015 & 0 & 73.400 & 73400 & 73.400 & 0 & 1.762 & 1.762 & 22.827 & 21.066 & 23.391 \\
\hline dic-2015 & 0 & 59.700 & 59700 & 59.700 & 0 & 1.433 & 1.433 & 18.567 & 17.134 & 40.524 \\
\hline ene-2016 & 0 & 42.100 & 42100 & 42.100 & 0 & 1.010 & 1.010 & 13.093 & 12.083 & 52.607 \\
\hline feb-2016 & 104.006 & 93.700 & 197706 & 197.706 & 32.346 & 2.249 & 34.595 & 61.486 & 26.892 & 79.499 \\
\hline mar-2016 & 14.373 & 82.600 & 96973 & 96.973 & 4.470 & 1.982 & 6.452 & 30.158 & 23.706 & 103.205 \\
\hline$a b r-2016$ & 8.345 & 57.500 & 65845 & 65.845 & 2.595 & 1.380 & 3.975 & 20.478 & 16.503 & 119.708 \\
\hline may-2016 & 2.689 & 13.500 & 16189 & 16.189 & 836 & 324 & 1.160 & 5.035 & 3.875 & 123.582 \\
\hline oct-2016 & 5.050 & 8.200 & 13250 & 13.250 & 1.571 & 197 & 1.767 & 4.121 & 2.353 & 125.936 \\
\hline nov-2016 & 2.459 & 40.900 & 43359 & 43.359 & 765 & 982 & 1.747 & 13.485 & 11.738 & 137.674 \\
\hline dic-2016 & 13.261 & 36.800 & 50061 & 50.061 & 4.124 & 883 & 5.007 & 15.569 & 10.562 & 148.236 \\
\hline ene-2017 & 3.639 & 49.500 & 53139 & 53.139 & 1.132 & 1.188 & 2.320 & 16.526 & 14.207 & 162.442 \\
\hline feb-2017 & 5.991 & 43.200 & 49191 & 49.191 & 1.863 & 1.037 & 2.900 & 15.298 & 12.398 & 174.840 \\
\hline mar-2017 & 917 & 50.200 & 51117 & 51.117 & 285 & 1.205 & 1.490 & 15.898 & 14.407 & 189.248 \\
\hline$a b r-2017$ & 2.837 & 14.400 & 17237 & 17.237 & 882 & 346 & 1.228 & 5.361 & 4.133 & 193.381 \\
\hline may-2017 & 3.184 & 0 & 0 & 0 & 990 & 0 & 990 & 0 & -990 & 192.390 \\
\hline oct-2017 & 0 & 4.400 & 0 & 0 & 0 & 106 & 106 & 0 & -106 & 192.285 \\
\hline nov-2017 & 0 & 0 & 0 & 0 & 0 & 0 & 0 & 0 & 0 & 192.285 \\
\hline dic-2017 & 0 & 95.300 & 95300 & 95.300 & 0 & 2.287 & 2.287 & 29.638 & 27.351 & 219.636 \\
\hline ene-2018 & 0 & 48.500 & 48500 & 48.500 & 0 & 1.164 & 1.164 & 15.084 & 13.920 & 233.555 \\
\hline feb-2018 & 0 & 64.100 & 64100 & 64.100 & 0 & 1.538 & 1.538 & 19.935 & 18.397 & 251.952 \\
\hline mar-2018 & 0 & 55.500 & 55500 & 55.500 & 0 & 1.332 & 1.332 & 17.261 & 15.929 & 267.881 \\
\hline abr-2018 & 0 & 24.100 & 24100 & 24.100 & 0 & 578 & 578 & 7.495 & 6.917 & 274.797 \\
\hline may-2018 & 0 & 8.600 & 0 & 0 & 0 & 206 & 206 & 0 & -206 & 274.591 \\
\hline
\end{tabular}

Como se observa durante estas tres temporadas se ha obtenido un ahorro total de 275 Toneladas de $\mathrm{CO}_{2}$, debido al cambio de combustible en el edificio E4. 


\section{AV.4.6. Estimación del precio máximo de compra a la red.}

Tomando como referencia los precios del gas natural de la Tabla 483 para cada temporada, obtenidos a partir de los datos establecidos en el Capítulo 3, donde se tiene en cuenta el precio por el termino variable y fijo; se puede realizar la estimación del precio máximo de compra de la energía útil a la red de calor para obtener un $0 \%$ de ahorro y un $15 \%$ de ahorro. La Tabla 484, muestral el precio que se pagaría para un ahorro del $15 \%$

Tabla 483. Precios de referencia para Gas natural y Astilla

\begin{tabular}{ccccc}
\hline Precios (€/(kWh) & 2015 & 2016 & 2017 & 2018 \\
\hline Gasóleo C & 0,0517 & 0,0437 & 0,0499 & 0,0560 \\
\hline Astilla & 0,0277 & 0,0256 & 0,0254 & 0,0239 \\
\hline $\begin{array}{c}€ / \text { kWh útiles máximos de compra a la red para } \\
\text { un ahorro del 0,0\% }\end{array}$ & 0,048145 & \\
\hline $\begin{array}{c}€ / \text { kWh útiles máximos de compra a la red para } \\
\text { un ahorro del 15,0\% }\end{array}$ & 0,040876 & \\
\hline \begin{tabular}{l} 
und \\
\hline
\end{tabular} & & & \\
\hline
\end{tabular}

Tabla 484. Ahorro Económico por el consumo térmico en el Edificio E4

\begin{tabular}{|c|c|c|c|c|c|c|c|c|c|c|}
\hline & $\begin{array}{l}\text { kWh_E4 } \\
\text { Gasóleo }\end{array}$ & $\begin{array}{l}\text { kWh_E4_- } \\
\text { Biomasa }\end{array}$ & $\begin{array}{c}\text { kWh_E4 } \\
\text { Real }\end{array}$ & $\begin{array}{c}\text { kWh_E4 } \\
\text { Pronosticado }\end{array}$ & $\begin{array}{c}€ \text { Real } \\
\text { Gasóleo }\end{array}$ & $\begin{array}{c}€ \text { Real } \\
\text { Biomasa }\end{array}$ & $\begin{array}{l}€ \text { Real } \\
\text { Total }\end{array}$ & $\begin{array}{c}\text { € predicho } \\
\text { Gasóleo }\end{array}$ & $\begin{array}{c}€ \\
\text { Ahorro }\end{array}$ & $€$ Acumulado \\
\hline oct-2015 & 0 & 8.100 & 8100 & 8.100 & 0 & 331 & 331 & 419 & 88 & 88 \\
\hline nov-2015 & 0 & 73.400 & 73400 & 73.400 & 0 & 3.000 & 3.000 & 3.795 & 794 & 882 \\
\hline dic-2015 & 0 & 59.700 & 59700 & 59.700 & 0 & 2.440 & 2.440 & 3.086 & 646 & 1.528 \\
\hline ene-2016 & 0 & 42.100 & 42100 & 42.100 & 0 & 1.721 & 1.721 & 1.840 & 119 & 1.647 \\
\hline feb-2016 & 104.006 & 93.700 & 197706 & 197.706 & 4.545 & 3.830 & 8.375 & 8.640 & 265 & 1.912 \\
\hline mar-2016 & 14.373 & 82.600 & 96973 & 96.973 & 628 & 3.376 & 4.004 & 4.238 & 233 & 2.145 \\
\hline$a b r-2016$ & 8.345 & 57.500 & 65845 & 65.845 & 365 & 2.350 & 2.715 & 2.877 & 162 & 2.307 \\
\hline may-2016 & 2.689 & 13.500 & 16189 & 16.189 & 118 & 552 & 669 & 707 & 38 & 2.346 \\
\hline oct-2016 & 5.050 & 8.200 & 13250 & 13.250 & 221 & 335 & 556 & 579 & 23 & 2.369 \\
\hline nov-2016 & 2.459 & 40.900 & 43359 & 43.359 & 107 & 1.672 & 1.779 & 1.895 & 116 & 2.484 \\
\hline dic-2016 & 13.261 & 36.800 & 50061 & 50.061 & 580 & 1.504 & 2.084 & 2.188 & 104 & 2.588 \\
\hline ene-2017 & 3.639 & 49.500 & 53139 & 53.139 & 182 & 2.023 & 2.205 & 2.652 & 447 & 3.035 \\
\hline feb-2017 & 5.991 & 43.200 & 49191 & 49.191 & 299 & 1.766 & 2.065 & 2.455 & 390 & 3.425 \\
\hline mar-2017 & 917 & 50.200 & 51117 & 51.117 & 46 & 2.052 & 2.098 & 2.551 & 453 & 3.878 \\
\hline$a b r-2017$ & 2.837 & 14.400 & 17237 & 17.237 & 142 & 589 & 730 & 860 & 130 & 4.008 \\
\hline may-2017 & 3.184 & 0 & 0 & 0 & 159 & 0 & 159 & 0 & -159 & 3.849 \\
\hline oct-2017 & 0 & 4.400 & 0 & 0 & 0 & 180 & 180 & 0 & -180 & 3.669 \\
\hline nov-2017 & 0 & 0 & 0 & 0 & 0 & 0 & 0 & 0 & 0 & 3.669 \\
\hline dic-2017 & 0 & 95.300 & 95300 & 95.300 & 0 & 3.895 & 3.895 & 4.755 & 860 & 4.529 \\
\hline ene-2018 & 0 & 48.500 & 48500 & 48.500 & 0 & 1.982 & 1.982 & 2.716 & 734 & 5.262 \\
\hline feb-2018 & 0 & 64.100 & 64100 & 64.100 & 0 & 2.620 & 2.620 & 3.590 & 969 & 6.232 \\
\hline mar-2018 & 0 & 55.500 & 55500 & 55.500 & 0 & 2.269 & 2.269 & 3.108 & 839 & 7.071 \\
\hline$a b r-2018$ & 0 & 24.100 & 24100 & 24.100 & 0 & 985 & 985 & 1.350 & 364 & 7.436 \\
\hline may-2018 & 0 & 8.600 & 0 & 0 & 0 & 352 & 352 & 0 & -352 & 7.084 \\
\hline$€$ Total & & & & & & & 47.215 & 54.299 & & \\
\hline Ahorro (\%) & & & & & & & & & & $15,0 \%$ \\
\hline
\end{tabular}




\section{AV.5. Edificio E5. Edificio Alfonso VIII.}

\section{AV.5.1. Obtención de la línea base de referencia energética}

Los datos de partida para la obtención de la línea base de referencia se muestran en la Tabla 485

Tabla 485. Consumos térmicos del edificio E5

\begin{tabular}{lr}
\hline & Consumos térmicos (kWh). E5 \\
\hline oct-12 & 117.869 \\
\hline nov-12 & 205.331 \\
\hline dic-12 & 303.000 \\
\hline ene-13 & 323.200 \\
\hline feb-13 & 296.940 \\
\hline mar-13 & 303.000 \\
\hline abr-13 & 195.940 \\
\hline may-13 & 101.000 \\
\hline oct-13 & 81.374 \\
\hline nov-13 & 221.626 \\
\hline dic-13 & 303.000 \\
\hline ene-14 & 298.152 \\
\hline feb-14 & 204.363 \\
\hline mar-14 & 101.667 \\
\hline abr-14 & 163.647 \\
\hline may-14 & 142.383 \\
\hline Promedio & 210.156 \\
\hline Total (oct-12-may-13) & 1.846 .280 \\
\hline Total (oct-13-may-14) & 1.516 .212 \\
\hline Total (oct-12-may-13) & 3.362 .492 \\
\hline
\end{tabular}

Como se puede ver en la Tabla 486 para el edificio, el método ofrece un modelo de regresión, con una sola variable (Grados Día en base 15, obtenidos con datos cada 30 minitos). El modelo fue construido con un solo paso, incluyendo los Grados día base 15 cada $30 \mathrm{~min}$, por ser la variable más significativa (variable con menor valor de Sig $=0,000$ ). El resto de las variables como se observa en la Tabla 487 fueron excluidas del modelo al tener valores de sig $>0,05$.

Tabla 486. Modelos de regresión del Edificio E5

\begin{tabular}{|c|c|c|c|c|c|c|c|}
\hline & \multirow[t]{2}{*}{ Modelo } & \multicolumn{2}{|c|}{ Coeficientes no estandarizados } & \multirow[t]{2}{*}{$\mathrm{t}$} & \multirow[t]{2}{*}{ Sig. } & \multicolumn{2}{|c|}{$\begin{array}{c}\text { Intervalo de confianza de } 95,0 \% \\
\text { para B }\end{array}$} \\
\hline & & B & Error típ. & & & Límite inferior & Límite superior \\
\hline \multirow[t]{2}{*}{1} & (Constante) & 29320,001 & 31223,503 & ,939 &, 364 & $-37647,752$ & 96287,755 \\
\hline & GD15_30min & 816,043 & 131,151 & 6,222 & ,000 & 534,752 & 1097,335 \\
\hline
\end{tabular}


En la Figura 319 se representa el modelo de regresión con sus límites inferior y superior para un nivel de confianza del $95 \%$

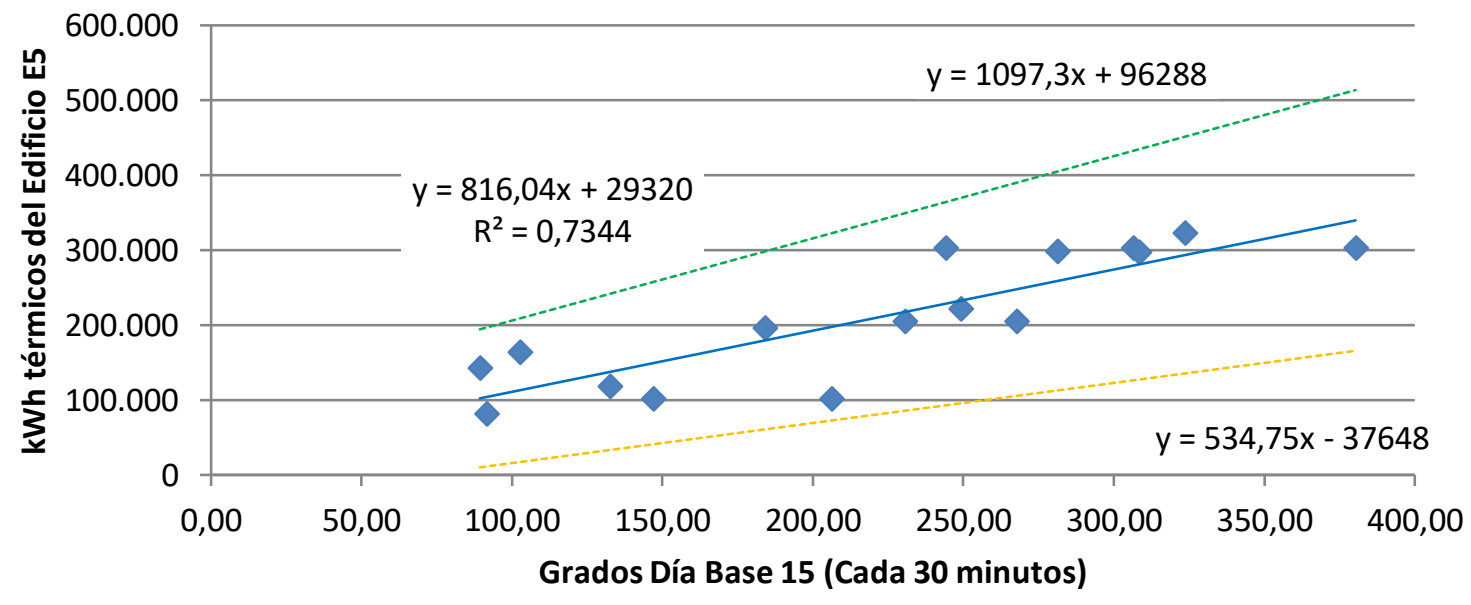

$\rightarrow$ E5 (kWh)

Lineal (E5 (kWh))

Lineal (E5 lim inferior)

Lineal (E5 lím superior)

Figura 319. Representación del modelo de regresión lineal simple para el Edificio E5

Tabla 487. Variables excluidas del modelo de región del Edificio E5

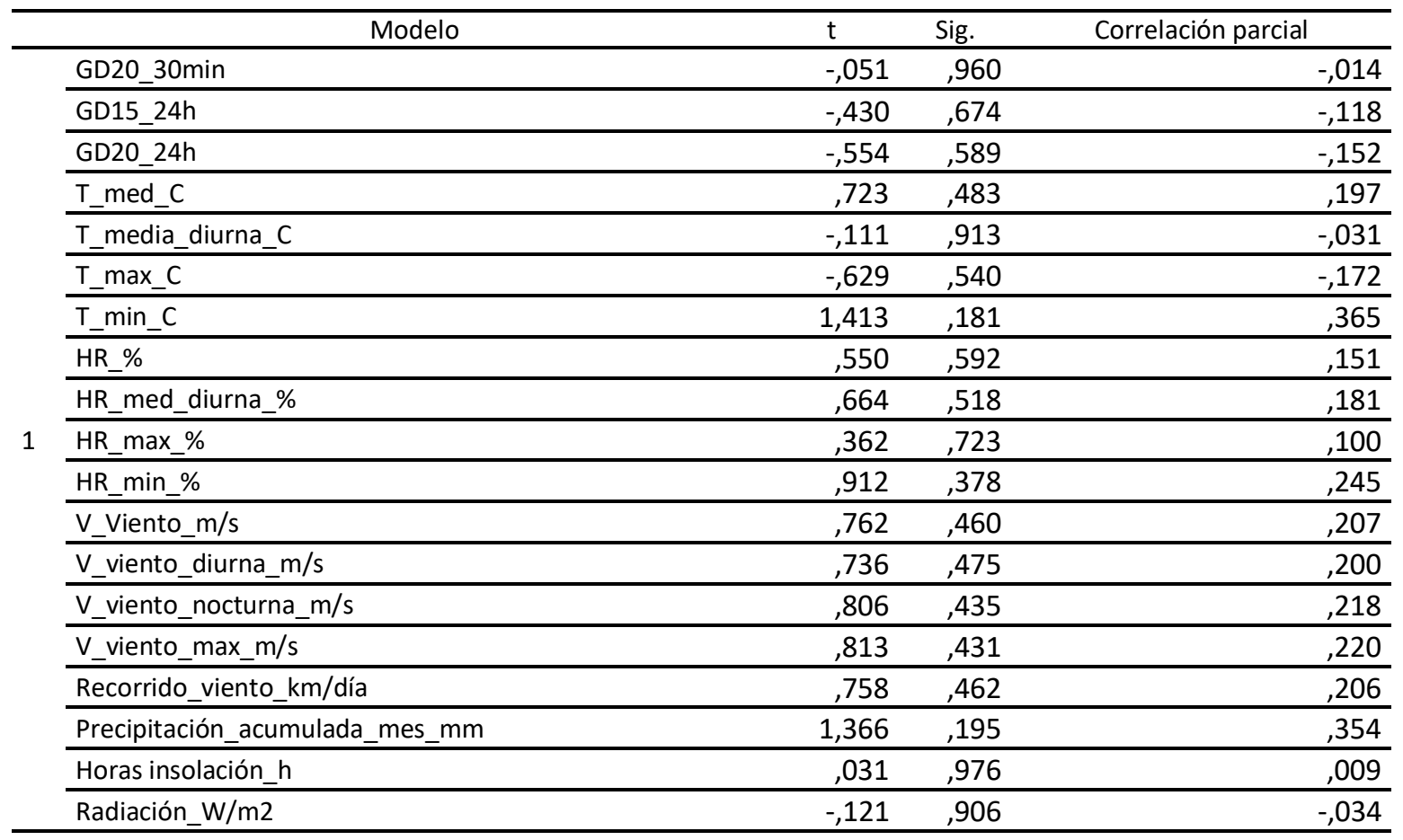


La bondad del modelo de regresión obtenido para el edificio E5, se resumen en la Tabla 488

Tabla 488. Resumen de la bondad del modelo de regresión para el Edificio E5

\begin{tabular}{ccccc}
\hline Modelo & $\mathrm{R}$ & R cuadrado & R cuadrado corregida & $\begin{array}{c}\text { Error típ. de la } \\
\text { estimación }\end{array}$ \\
\hline 1 &, 857 &, 734 &, 715 & 45648,4925 \\
\hline
\end{tabular}

Se observa como el modelo de regresión lineal simple presenta un Coeficiente de Correlación de Pearson (R) de 0,857 , lo que indica que las variables están correlacionadas de manera fuerte (en la correlación perfecta $R= \pm 1$ ). La correlación que se produce es directa, al aumentar el valor de los Grados día, aumenta el consumo térmico.

El coeficiente de determinación $\left(R^{2}\right)$, nos indica que con el modelo se podría explicar el $73,4 \%$ de los datos reales obtenidos aceptando un error del $5 \%$.

El error típico de la estimación que nos indica la magnitud de los errores, es decir la parte de la variable dependiente que dejamos sin explicar con el modelo y que describe la variación de la variable respuesta (el Consumo) respecto a la recta de regresión, es de $45.648 \mathrm{kWh}$, lo que representa un $21,7 \%$ del promedio de los consumos que fue de $210.156 \mathrm{kWh}$.

\section{AV.5.2. Verificación del cumplimiento de los supuestos estadísticos}

Las condiciones que se deben cumplir en un modelo de regresión son:

\section{- Linealidad de las variables, las variables se encuentran relacionadas de forma lineal.}

Como se observa en la Tabla 486, la pendiente (B), obtuvo un valor de Sig $=0,000$, que al ser $\leq 0,05$, nos indica que podemos rechazar la hipótesis nula de pendiente igual a cero y nos da la evidencia de linealidad entre la variable dependiente ( $\mathrm{kWh}$ del edificio E5) y la independiente (GD15_30min). Al ser el valor de la pendiente positiva, indica una relación directa entre el consumo y los Grados día base 15 .

- Normalidad. Todos los valores obtenidos para la variable dependiente (Y), deben estar distribuidos normalmente en cada valor de la variable independiente $(X)$.

Se comprueba la normalidad de las variables y de los residuos mediante el Test de Shapiro - Wilk para muestras pequeñas (menores a 30 observaciones), siendo la hipótesis nula el que la distribución es Normal. 
La Tabla 489, muestra la prueba de normalidad de Shapiro-Wilk y cómo tanto la variable dependiente (consumos del Edificio), como la variable independientes: GD15 poseen una Sig $>0,05$, por lo que aceptamos la hipótesis nula de Normalidad de las variables

Tabla 489. Prueba de normalidad para el edificio E5

\begin{tabular}{lccrrrrr}
\hline & \multicolumn{3}{c}{ Kolmogorov-Smirnov } & \multicolumn{3}{c}{ Shapiro-Wilk } \\
\cline { 2 - 8 } & \multicolumn{1}{c}{ Estadístico } & gl & Sig. & Estadístico & gl & \multicolumn{1}{c}{ Sig. } \\
\hline kWh_E5 &, 220 & 16 &, 038 &, 891 & 16 &, 058 \\
\hline GD15_30min &, 109 & 16 &, 200 &, 953 & 16 &, 541 \\
\hline
\end{tabular}

- Independencia de los errores. Los errores asociados a los valores de la variable respuesta $(Y)$ deberán ser independientes unos de otros.

Para la comprobación se utiliza el estadístico de Durbin -Watson.

Se comprueba que el Estadístico de Durbin Watson para el nivel de significancia del 5\%, y para el tamaño de la muestra " $n$ " y el número de variables independientes del modelo " $k$ ", se encuentra en el intervalo [dU, 4-dU], de la Tabla 3, intervalo centrado en el 2, que indica la ausencia de autocorrelación.

El valor del Estadístico Durbin-Watson facilitado por el programa SPSS, es 1,748.

En el modelo, $\mathrm{n}=16$ y $\mathrm{k}=1$, según la Tabla 3 el valor $\mathrm{dU}=1,371$ y dL =1,106, luego el intervalo que marca la ausencia de correlación es [1,371, 2,629]

Los intervalos $[0,1,106]$ y $[2,896,4]$ indican correlación positiva o negativa respectivamente y las zonas $[1,106,1,371]$ y $[2,629,2,896]$ son zonas no concluyentes; como el valor del estadístico 1,748 está dentro del intervalo de ausencia de correlación, se concluye que no existe autocorrelación en los residuos.

- Homocedasticidad de la varianza. Se pretende comprobar que la varianza de los errores $\left(\sigma^{2}\right)$ es constante para cualquier valor de la variable independiente $(X)$, es decir que el valor medio del cuadrado de la desviación de los errores respecto a su media es constante.

Esta condición indica que no existe correlación entre los residuos y los pronósticos. Se comprueba que el coeficiente de determinación $\mathrm{R}^{2}$, en las relaciones: residuos $\mathrm{y}$ predicciones y entre residuos y variable independiente es nulo o muy próximo a cero, lo que indicará que no existe ningún tipo de correlación en los residuos y que éstos son aleatorios. Se grafican los diagramas de dispersión de esas relaciones, comprobando que se corresponden a nubes de puntos totalmente aleatorias, sin tendencias ni patrones en sus representaciones gráficas. 
Las Figura 320 y Figura 321, muestran que la relación entre los pronósticos y los residuos, posee un coeficiente de determinación $=-2,22 \times 10^{-16}$ y entre la variable independiente (Grados día base 15) y los residuos un coeficiente de determinación de $1,11 \times 10^{-16}$; por lo que se concluye que no existe ningún tipo de correlación en los residuos y que éstos son aleatorios, siendo la varianza de los residuos constante.

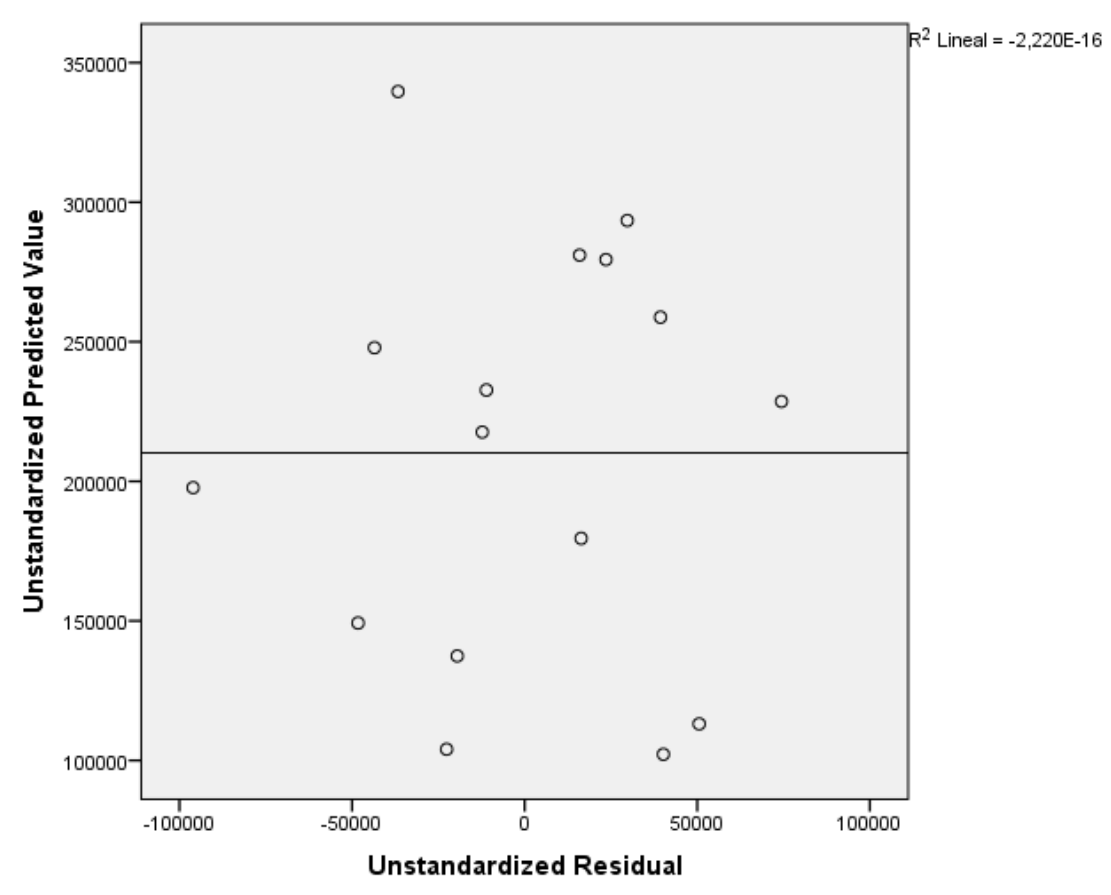

Figura 320. Relación entre los pronósticos y los residuos en el Edificio E5

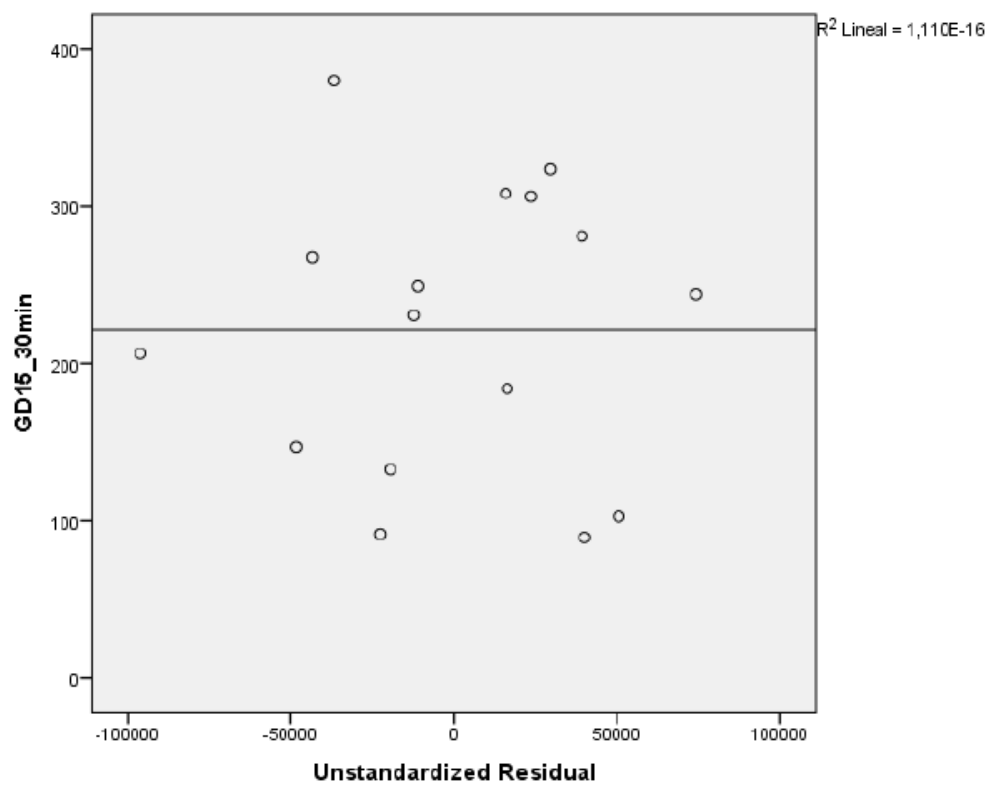

Figura 321. Relación entre GD15_30min y los residuos en el Edificio E5 


\section{AV.5.3. Obtención de los consumos térmicos previstos}

Una vez comprobado el cumplimiento de los supuestos estadísticos se acepta el modelo de línea base encontrado para modelizar el consumo del Edificio E5.

$$
\text { kWh_E5_Pronosticado }=29.320,001+816,043 \times \text { GD15_30min }
$$

Con este modelo se procede a predecir los consumos previstos para las temporadas: octubre 2015-mayo 2016, octubre 2016 - mayo 2017 y octubre 2017-mayo 2018, estos consumos se muestran en la Tabla 490, donde "KWh_E5_Real", representa el consumo real redistribuido, "kWh_E5_Pronosticado", el consumo pronosticado con el Modelo.

Tabla 490. Consumos previstos octubre 2014 - mayo 2017 para el edificio E5.

\begin{tabular}{rrrr}
\hline & GD15_30min & kWh_E5_Real & kWh_E5_Pronosticado \\
\hline oct-15 & 97,04 & 46.600 & 108.511 \\
\hline nov-15 & 208,36 & 200.500 & 199.353 \\
\hline dic-15 & 300,09 & 153.300 & 274.210 \\
\hline ene-16 & 271,93 & 143.600 & 251.229 \\
\hline feb-16 & 266,36 & 356.509 & 246.684 \\
\hline mar-16 & 276,34 & 213.337 & 254.823 \\
\hline abr-16 & 181,04 & 197.436 & 177.058 \\
\hline may-16 & 99,34 & 59.265 & 110.382 \\
\hline oct-16 & 97,34 & 62.832 & 108.751 \\
\hline nov-16 & 245,69 & 198.634 & 229.814 \\
\hline dic-16 & 337,25 & 192.899 & 304.532 \\
\hline ene-17 & 386,98 & 269.378 & 345.116 \\
\hline feb-17 & 226,76 & 218.934 & 214.366 \\
\hline mar-17 & 203,17 & 187.634 & 195.114 \\
\hline abr-17 & 129,72 & 86.924 & 135.178 \\
\hline may-17 & 54,86 & 41.591 & 74.086 \\
\hline oct-17 & 92,31 & 31.700 & 104.653 \\
\hline nov-17 & 271,60 & 183.300 & 250.958 \\
\hline dic-17 & 341,26 & 252.700 & 307.800 \\
\hline ene-18 & 327,94 & 228.300 & 296.935 \\
\hline feb-18 & 321,27 & 296.600 & 291.486 \\
\hline mar-18 & 255,02 & 236.500 & 237.427 \\
\hline abr-18 & 143,31 & 114.600 & 146.264 \\
\hline may-18 & 78,41 & 51.300 & 93.303 \\
\hline & & &
\end{tabular}




\section{AV.5.4. Estudio de la existencia de diferencias significativas}

Utilizando la prueba " $\mathrm{t}$ " de Student para muestras relacionadas, podemos concluir que si las variables se distribuyen según una normal y la significación estadística resulta $\leq 0,05$, existen diferencias significativas, con un nivel de confianza del 95\%

A continuación se muestra la comparación de medias realizada para cada uno de los tres periodos posteriores a la construcción de la red y para el periodo total hasta mayo de 2018.

Para la temporada Octubre 2015 - Mayo 2016, se comprueba mediante el Test de Shapiro -Wilk que los valores reales y pronosticados se distribuyen según una Normal (Sig $>0,05)$, como se observa en la Tabla 491

Tabla 491. Prueba de Normalidad temporada Octubre 2015-Mayo 2016. Edificio E5

\begin{tabular}{crrrrrrr}
\hline & \multicolumn{3}{c}{ Kolmogorov-Smirnov $^{\mathrm{a}}$} & \multicolumn{3}{c}{ Shapiro-Wilk } \\
\cline { 2 - 8 } & Estadístico & gl & \multicolumn{1}{c}{ Sig. } & Estadístico & gl & \multicolumn{1}{c}{ Sig. } \\
\hline kWh_real &, 209 & 8 &, 200 &, 926 & 8 &, 480 \\
\hline kWh_pronosticado &, 248 & 8 &, 159 &, 865 & 8 &, 135 \\
\hline
\end{tabular}

En la Tabla 492, se observa como las medias de los consumos pronosticados, son superiores a las medias de los consumos reales del Edificio E5, en un $18,4 \%$

Tabla 492. Estadísticos de muestras relacionadas. Octubre 2015-Mayo 2016. Edificio E5

\begin{tabular}{lccccc}
\hline & Media & $\begin{array}{c}\text { \% Diferencia } \\
\text { entre medias }\end{array}$ & N & $\begin{array}{c}\text { Desviación } \\
\text { típ. }\end{array}$ & $\begin{array}{c}\text { Error típ. de } \\
\text { la media }\end{array}$ \\
\hline kWh_real & 171318,3750 & & 8 & 97686,40209 & 34537,35867 \\
\hline kWh_pronosticado & 202781,2500 & $18,4 \%$ & 8 & 65664,71757 & 23215,98354 \\
\hline
\end{tabular}

La Tabla 493 muestra que las diferencias entre las medias no son significativas entre los consumos reales y los pronosticados (sig $>0,05$ )

Tabla 493. Prueba de muestras relacionadas. Octubre 2015-Mayo 2016. Edificio E5

\begin{tabular}{|c|c|c|c|c|c|c|c|c|c|}
\hline & & \multicolumn{5}{|c|}{ Diferencias relacionadas } & \multirow{3}{*}{$\mathrm{t}$} & \multirow{3}{*}{ gl } & \multirow{3}{*}{$\begin{array}{c}\text { Sig. } \\
\text { (bilateral) }\end{array}$} \\
\hline & & \multirow{2}{*}{ Media } & \multirow{2}{*}{$\begin{array}{l}\text { Desviación } \\
\text { típ. }\end{array}$} & \multirow{2}{*}{$\begin{array}{c}\text { Error típ. } \\
\text { de la media }\end{array}$} & \multicolumn{2}{|c|}{$\begin{array}{l}\text { 95\% Intervalo de confianza } \\
\text { para la diferencia }\end{array}$} & & & \\
\hline & & & & & Inferior & Superior & & & \\
\hline Par 1 & $\begin{array}{c}\text { kWh_real - } \\
\text { kWh_pronosticado }\end{array}$ & $-31462,875$ & 74574,073 & 26365,916 & $-93808,360$ & 30882,610 & $-1,193$ & 7 & ,272 \\
\hline
\end{tabular}


En la Figura 322 se grafican los consumos reales y pronosticados para la temporada Octubre 2016 - Mayo 2017 para el Edificio E5, y las medias de dichos consumos. Según la prueba paramétrica realizada las diferencias encontradas no son estadísticamente significativas, con un riesgo a estar equivocados del $5 \%$

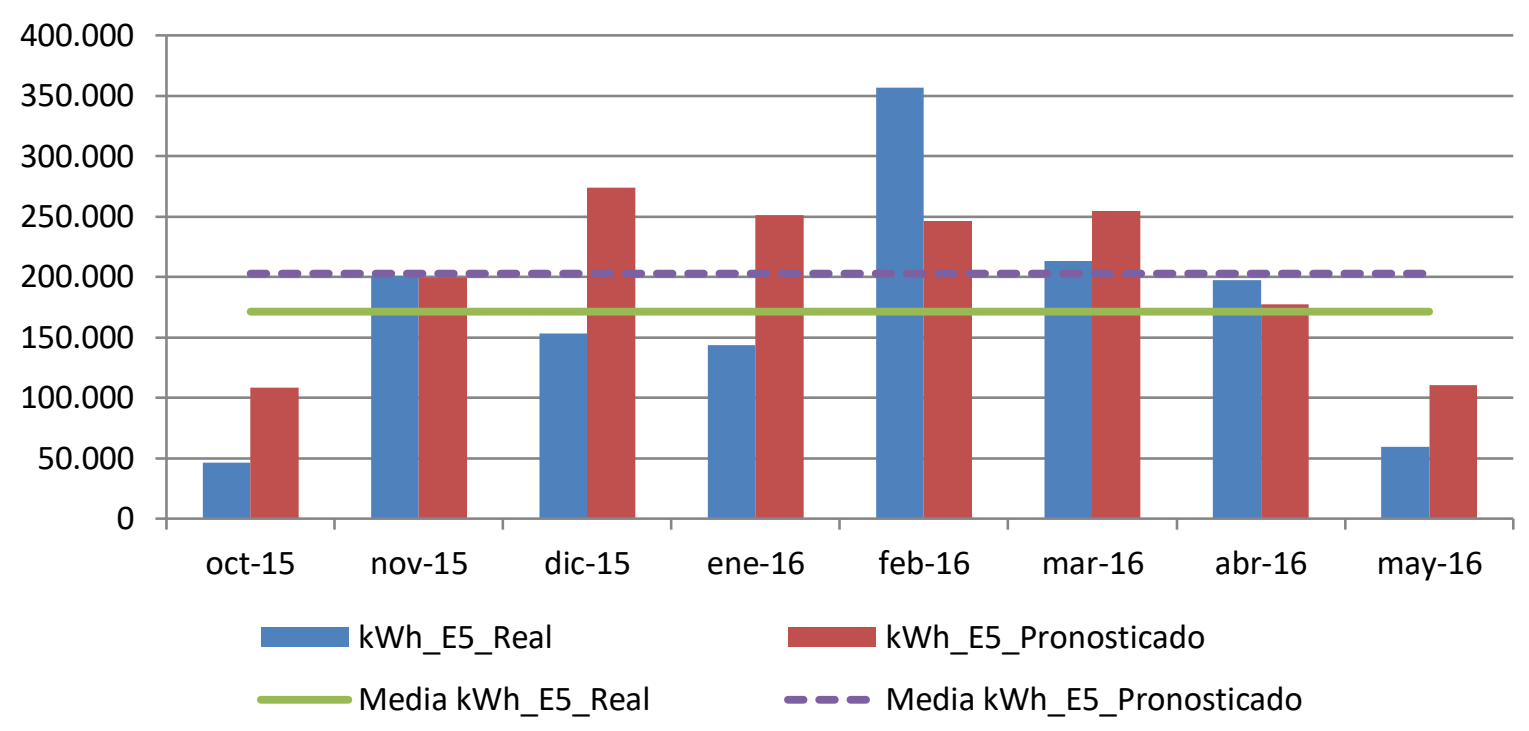

Figura 322. Consumos reales y pronosticados Octubre 2015-Mayo 2016. Edificio E5

Para la temporada Octubre 2016 - Mayo 2017, se comprueba mediante el Test de Shapiro -Wilk que tanto los valores reales como los pronosticados con los dos modelos se distribuyen según una Normal puesto que en todos los casos los valores de Sig >0,05, como se observa en la Tabla 494

Tabla 494. Prueba de Normalidad temporada Octubre 2016-Mayo 2017. Edificio E5

\begin{tabular}{cccccccr}
\hline & \multicolumn{3}{c}{ Kolmogorov-Smirnov $^{\mathrm{a}}$} & \multicolumn{3}{c}{ Shapiro-Wilk } \\
\cline { 2 - 8 } & Estadístico & gl & \multicolumn{1}{c}{ Sig. } & Estadístico & gl & \multicolumn{1}{c}{ Sig. } \\
\hline kWh_real &, 268 & 8 &, 093 &, 902 & 8 &, 302 \\
\hline kWh_pronosticado &, 133 & 8 &, 200 &, 965 & 8 &, 856 \\
\hline
\end{tabular}

En la Tabla 495, se observa como las medias de los consumos pronosticados, son superiores a las medias de los consumos reales del Edificio E5, en un $27,7 \%$

Tabla 495. Estadísticos de muestras relacionadas. Octubre 2016-Mayo 2017. Edificio E5

\begin{tabular}{lccccc}
\hline & Media & $\begin{array}{c}\text { \% Diferencia } \\
\text { entre medias }\end{array}$ & N & $\begin{array}{c}\text { Desviación } \\
\text { típ. }\end{array}$ & $\begin{array}{c}\text { Error típ. de } \\
\text { la media }\end{array}$ \\
\hline kWh_real & 157353,2500 & & 8 & 82394,26328 & 29130,77115 \\
\hline kWh_pronosticado & 200869,6250 & $27,7 \%$ & 8 & 93717,87383 & 33134,27205 \\
\hline
\end{tabular}


La Tabla 496 muestra que las diferencias entre las medias son significativas entre los consumos reales y los pronosticados (sig $\leq 0,05)$

Tabla 496. Prueba de muestras relacionadas. Octubre 2016-Mayo 2017. Edificio E5

\begin{tabular}{|c|c|c|c|c|c|c|c|c|c|}
\hline & & \multicolumn{5}{|c|}{ Diferencias relacionadas } & \multirow{3}{*}{$\mathrm{t}$} & \multirow{3}{*}{ gl } & \multirow{3}{*}{$\begin{array}{c}\text { Sig. } \\
\text { (bilateral) }\end{array}$} \\
\hline & & \multirow[t]{2}{*}{ Media } & \multirow{2}{*}{$\begin{array}{l}\text { Desviación } \\
\text { típ. }\end{array}$} & \multirow{2}{*}{$\begin{array}{l}\text { Error típ. } \\
\text { de la media }\end{array}$} & \multicolumn{2}{|c|}{$\begin{array}{l}\text { 95\% Intervalo de confianza } \\
\text { para la diferencia }\end{array}$} & & & \\
\hline & & & & & Inferior & Superior & & & \\
\hline Par 1 & $\begin{array}{c}\text { kWh_real - } \\
\text { kWh_pronosticado }\end{array}$ & $-43516,375$ & 37014,881 & 13086,737 & $-74461,590$ & $-12571,160$ & $-3,325$ & 7 & 013 \\
\hline
\end{tabular}

En la Figura 323 se grafican los consumos reales y pronosticados para la temporada Octubre 2016 - Mayo 2017 para el Edificio E5, y las medias de dichos consumos. Según la prueba paramétrica realizada las diferencias encontradas son estadísticamente significativas, con un riesgo a estar equivocados del $5 \%$

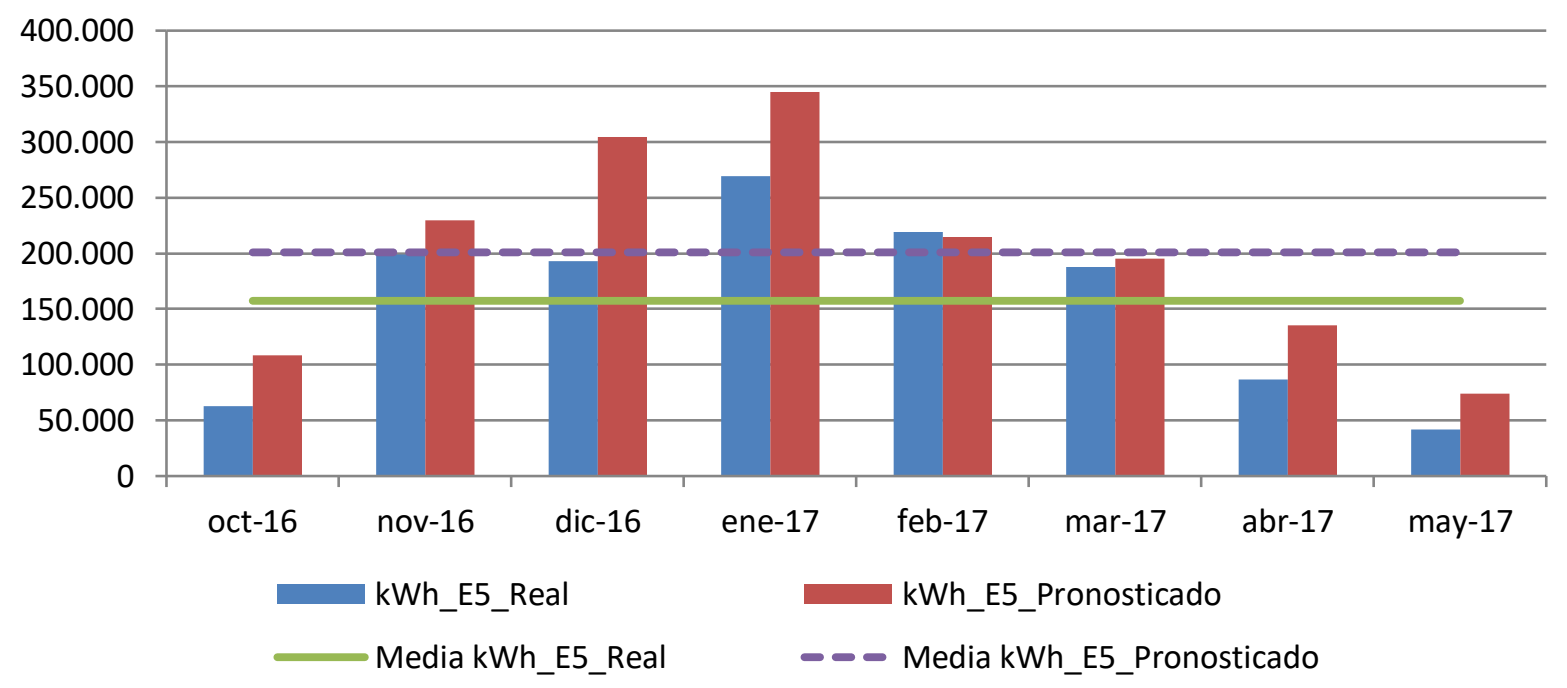

Figura 323. Consumos reales y pronosticados Octubre 2016-Mayo 2017. Edificio E5

Para la temporada Octubre 2017 - Mayo 2018, se comprueba mediante el Test de Shapiro -Wilk que tanto los valores reales como los pronosticados se distribuyen según una Normal puesto que en todos los casos los valores de Sig $>0,05$, como se observa en la Tabla 497

Tabla 497. Prueba de Normalidad temporada Octubre 2017-Mayo 2018. Edificio E5

\begin{tabular}{cccccccr}
\hline & \multicolumn{3}{c}{ Kolmogorov-Smirnov $^{\mathrm{a}}$} & \multicolumn{3}{c}{ Shapiro-Wilk } \\
\cline { 2 - 8 } & Estadístico & gl & \multicolumn{1}{c}{ Sig. } & Estadístico & gl & \multicolumn{1}{c}{ Sig. } \\
\hline kWh_real &, 209 & 8 &, 200 &, 917 & 8 &, 406 \\
\hline kWh_pronosticado &, 220 & 8 &, 200 &, 860 & 8 &, 119 \\
\hline
\end{tabular}


En la Tabla 498, se observa como las medias de los consumos pronosticados, son superiores a las medias de los consumos reales del Edificio E5, en un 23,9\%

Tabla 498. Estadísticos de muestras relacionadas. Octubre 2017-Mayo 2018. Edificio E5

\begin{tabular}{lccrcc}
\hline & Media & $\begin{array}{c}\text { \% Diferencia } \\
\text { entre medias }\end{array}$ & $\mathrm{N}$ & $\begin{array}{c}\text { Desviación } \\
\text { típ. }\end{array}$ & $\begin{array}{c}\text { Error típ. de } \\
\text { la media }\end{array}$ \\
\hline kWh_real & 174375,0000 & & 8 & 97831,84918 & 34588,78199 \\
\hline kWh_pronosticado & 216103,2500 & $23,9 \%$ & 8 & 88376,43605 & 31245,78861 \\
\hline
\end{tabular}

La Tabla 499 muestra que las diferencias entre las medias son significativas entre los consumos reales y los pronosticados (sig $\leq 0,05)$

Tabla 499. Prueba de muestras relacionadas. Octubre 2017-Mayo 2018. Edificio E5

\begin{tabular}{|c|c|c|c|c|c|c|c|c|c|}
\hline & & \multicolumn{5}{|c|}{ Diferencias relacionadas } & \multirow{3}{*}{$\mathrm{t}$} & \multirow{3}{*}{$\mathrm{gl}$} & \multirow{3}{*}{$\begin{array}{c}\text { Sig. } \\
\text { (bilateral) }\end{array}$} \\
\hline & & \multirow[t]{2}{*}{ Media } & \multirow{2}{*}{$\begin{array}{l}\text { Desviación } \\
\text { típ. }\end{array}$} & \multirow{2}{*}{$\begin{array}{c}\text { Error típ. } \\
\text { de la media }\end{array}$} & \multicolumn{2}{|c|}{$\begin{array}{c}\text { 95\% Intervalo de confianza } \\
\text { para la diferencia }\end{array}$} & & & \\
\hline & & & & & Inferior & Superior & & & \\
\hline Par 1 & $\begin{array}{c}\text { kWh_real - } \\
\text { kWh_pronosticado }\end{array}$ & $-41728,250$ & 30496,878 & 10782,275 & $-67224,278$ & $-16232,222$ & $-3,870$ & 7 & ,006 \\
\hline
\end{tabular}

En la Figura 324, se grafican los consumos reales y pronosticados para la temporada Octubre 2017 - Mayo 2018 para el Edificio E5, y las medias de dichos consumos. Según la prueba paramétrica realizada las diferencias encontradas son estadísticamente significativas, con un riesgo a estar equivocados del $5 \%$

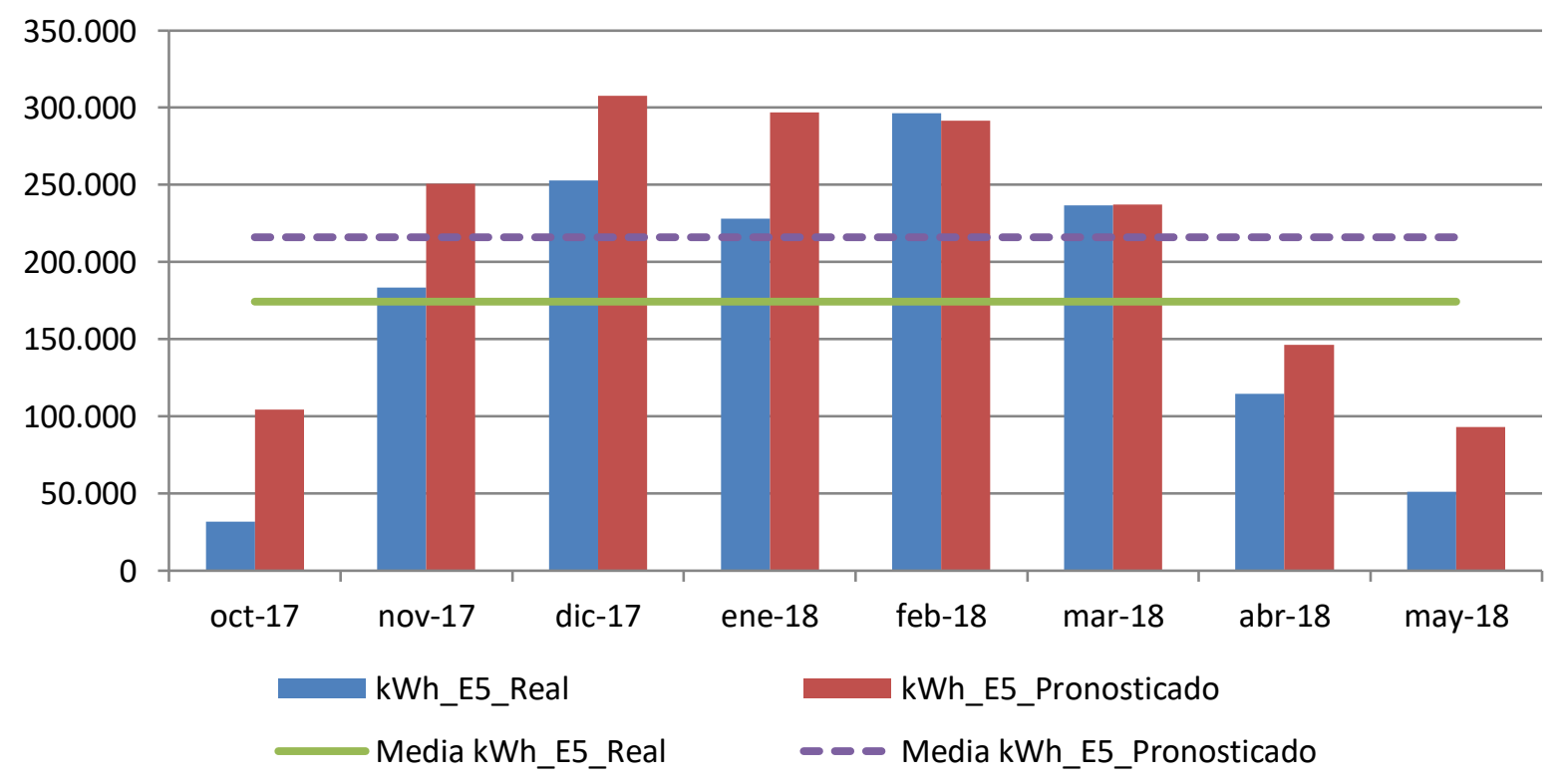

Figura 324. Consumos reales y pronosticados Octubre 2017-Mayo 2018. Edificio E5 
Para el total de las tres temporadas Octubre 2015 - Mayo 2018, se comprueba mediante el Test de Shapiro -Wilk, que los valores reales y los pronosticados se distribuyen según una Normal puesto que en esos casos los valores de Sig $>0,05$, como se observa en la Tabla 500

Tabla 500. Prueba de Normalidad temporada Octubre 2015-Mayo 2018. Edificio E5

\begin{tabular}{ccccccrr}
\hline & \multicolumn{3}{c}{ Kolmogorov-Smirnov $^{\mathrm{a}}$} & \multicolumn{3}{c}{ Shapiro-Wilk } \\
\cline { 2 - 8 } & Estadístico & gl & Sig. & Estadístico & gl & \multicolumn{1}{c}{ Sig. } \\
\hline kWh_real &, 153 & 24 &, 152 &, 946 & 24 &, 226 \\
\hline kWh_pronosticado &, 135 & 24 &, 200 &, 942 & 24 &, 183 \\
\hline
\end{tabular}

En la Tabla 501 se observa como las medias de los consumos pronosticados, son superiores a las medias de los consumos reales del Edificio E5, en un 23,2\%

Tabla 501. Estadísticos de muestras relacionadas. Octubre 2015-Mayo 2018. Edificio E5

\begin{tabular}{lccccc}
\hline & Media & $\begin{array}{c}\text { \% Diferencia } \\
\text { entre medias }\end{array}$ & $\mathrm{N}$ & $\begin{array}{c}\text { Desviación } \\
\text { típ. }\end{array}$ & $\begin{array}{c}\text { Error típ. de } \\
\text { la media }\end{array}$ \\
\hline $\mathrm{kWh}$ _real & 167682,2083 & & 24 & 89110,39802 & 18189,58383 \\
\hline $\mathrm{kWh}$ _pronosticado & 206584,7083 & $23,2 \%$ & 24 & 80064,88539 & 16343,17629 \\
\hline
\end{tabular}

La Tabla 502 muestra que las diferencias entre las medias son significativas entre los consumos reales y los pronosticados (sig $\leq 0,05)$

Tabla 502. Prueba de muestras relacionadas. Octubre 2015-Mayo 2018. Edificio E5

\begin{tabular}{|c|c|c|c|c|c|c|c|c|}
\hline & \multicolumn{5}{|c|}{ Diferencias relacionadas } & \multirow{3}{*}{$\mathrm{t}$} & \multirow{3}{*}{$\mathrm{gl}$} & \multirow{3}{*}{$\begin{array}{c}\text { Sig. } \\
\text { (bilateral) }\end{array}$} \\
\hline & \multirow[t]{2}{*}{ Media } & \multirow{2}{*}{$\begin{array}{l}\text { Desviación } \\
\text { típ. }\end{array}$} & \multirow{2}{*}{$\begin{array}{c}\text { Error típ. de } \\
\text { la media }\end{array}$} & \multicolumn{2}{|c|}{$\begin{array}{l}\text { 95\% Intervalo de confianza } \\
\text { para la diferencia }\end{array}$} & & & \\
\hline & & & & Inferior & Superior & & & \\
\hline $\begin{array}{c}\text { kWh_real - } \\
\text { kWh_pronosticado }\end{array}$ & $-38902,500$ & 49214,322 & 10045,831 & $-59683,886$ & $-18121,114$ & $-3,873$ & 23 & ,001 \\
\hline
\end{tabular}




\section{AV.5.5. Estimación de las emisiones de $\mathrm{CO} 2$ evitadas.}

Teniendo en cuenta que el consumir Gasóleo se producen 0,311 kg $\mathrm{CO}_{2} / \mathrm{kWh} \mathrm{E}$. final y que al consumir la energía suministrada por red a partir de Biomasa se producen 0,024 kg $\mathrm{CO}_{2} / \mathrm{kWh}$. final, en la Tabla 503, se muestra las emisiones de $\mathrm{CO}_{2}$ reales para las temporadas octubre 2015 - mayo 2018 y utilizando el Modelo de regresión, las emisiones de $\mathrm{CO}_{2}$ que se hubieran tenido de haber seguido utilizando las calderas de gasóleo originales sin el apoyo de la red de calor.

Tabla 503. Estimación del ahorro de emisiones de CO2 para el Edificio E5.

\begin{tabular}{|c|c|c|c|c|c|c|c|c|c|c|}
\hline & $\begin{array}{l}\text { kWh_E5 } \\
\text { Gasóleo }\end{array}$ & $\begin{array}{c}\text { kWh_- } \\
\text { E5 } \\
\text { Biomasa }\end{array}$ & $\begin{array}{l}\text { kWh_E5 } \\
\text { Real Total }\end{array}$ & $\begin{array}{l}\text { kWh_E5 } \\
\text { Predicho }\end{array}$ & $\begin{array}{l}\text { kg CO2 Real } \\
\text { debido al } \\
\text { consumo de } \\
\text { Gasóleo }\end{array}$ & $\begin{array}{c}\text { kg CO2 } \\
\text { Real } \\
\text { debido a } \\
\text { Biomasa }\end{array}$ & $\begin{array}{l}\text { kg CO2 } \\
\text { Real } \\
\text { debido al } \\
\text { consumo } \\
\text { TOTAL }\end{array}$ & $\begin{array}{l}\text { kg CO2 } \\
\text { que se } \\
\text { hubiera } \\
\text { tenido } \\
\text { debido a } \\
\text { Gasóleo }\end{array}$ & $\begin{array}{l}\text { Ahorro de } \\
\text { kg CO2 }\end{array}$ & $\begin{array}{l}\text { Ahorro de kg } \\
\text { CO2 } \\
\text { acumulado }\end{array}$ \\
\hline oct-2015 & 0 & 46.600 & 46600 & 108.511 & 0 & 1.118 & 1.118 & 33.747 & 32.629 & 32.629 \\
\hline nov-2015 & 0 & 200.500 & 200500 & 199.353 & 0 & 4.812 & 4.812 & 61.999 & 57.187 & 89.815 \\
\hline dic-2015 & 0 & 153.300 & 153300 & 274.210 & 0 & 3.679 & 3.679 & 85.279 & 81.600 & 171.415 \\
\hline ene-2016 & 0 & 143.600 & 143600 & 251.229 & 0 & 3.446 & 3.446 & 78.132 & 74.686 & 246.101 \\
\hline feb-2016 & 94.059 & 262.450 & 356509 & 246.684 & 29.252 & 6.299 & 35.551 & 76.719 & 41.168 & 287.269 \\
\hline mar-2016 & 9.087 & 204.250 & 213337 & 254.823 & 2.826 & 4.902 & 7.728 & 79.250 & 71.522 & 358.791 \\
\hline abr-2016 & 2.436 & 195.000 & 197436 & 177.058 & 758 & 4.680 & 5.438 & 55.065 & 49.627 & 408.418 \\
\hline may-2016 & 565 & 58.700 & 59265 & 110.382 & 176 & 1.409 & 1.584 & 34.329 & 32.744 & 441.163 \\
\hline oct-2016 & 23.832 & 39.000 & 62832 & 108.751 & 7.412 & 936 & 8.348 & 33.822 & 25.474 & 466.637 \\
\hline nov-2016 & 4.634 & 194.000 & 198634 & 229.814 & 1.441 & 4.656 & 6.097 & 71.472 & 65.375 & 532.012 \\
\hline dic-2016 & 2.999 & 189.900 & 192899 & 304.532 & 933 & 4.558 & 5.490 & 94.709 & 89.219 & 621.231 \\
\hline ene-2017 & 7.078 & 262.300 & 269378 & 345.116 & 2.201 & 6.295 & 8.496 & 107.331 & 98.835 & 720.066 \\
\hline feb-2017 & 1.234 & 217.700 & 218934 & 214.366 & 384 & 5.225 & 5.608 & 66.668 & 61.059 & 781.125 \\
\hline mar-2017 & 1.234 & 186.400 & 187634 & 195.114 & 384 & 4.474 & 4.857 & 60.681 & 55.823 & 836.948 \\
\hline abr-2017 & 524 & 86.400 & 86924 & 135.178 & 163 & 2.074 & 2.237 & 42.041 & 39.804 & 876.752 \\
\hline may-2017 & 2.691 & 38.900 & 41591 & 74.086 & 837 & 934 & 1.770 & 23.041 & 21.270 & 898.023 \\
\hline oct-2017 & 0 & 31.700 & 31700 & 104.653 & 0 & 761 & 761 & 32.547 & 31.786 & 929.809 \\
\hline nov-2017 & 0 & 183.300 & 183300 & 250.958 & 0 & 4.399 & 4.399 & 78.048 & 73.649 & 1.003 .458 \\
\hline dic-2017 & 0 & 252.700 & 252700 & 307.800 & 0 & 6.065 & 6.065 & 95.726 & 89.661 & 1.093 .119 \\
\hline ene-2018 & 0 & 228.300 & 228300 & 296.935 & 0 & 5.479 & 5.479 & 92.347 & 86.868 & 1.179 .986 \\
\hline feb-2018 & 0 & 296.600 & 296600 & 291.486 & 0 & 7.118 & 7.118 & 90.652 & 83.534 & 1.263 .520 \\
\hline mar-2018 & 0 & 236.500 & 236500 & 237.427 & 0 & 5.676 & 5.676 & 73.840 & 68.164 & 1.331 .684 \\
\hline abr-2018 & 0 & 114.600 & 114600 & 146.264 & 0 & 2.750 & 2.750 & 45.488 & 42.738 & 1.374 .422 \\
\hline may-2018 & 0 & 51.300 & 51300 & 93.303 & 0 & 1.231 & 1.231 & 29.017 & 27.786 & 1.402 .208 \\
\hline
\end{tabular}

Como se observa durante estas tres temporadas se ha obtenido un ahorro total de 1.402 Toneladas de $\mathrm{CO}_{2}$, debido al consumo térmico del edificio E5. 


\section{AV.5.6. Estimación del precio máximo de compra a la red.}

Tomando como referencia los precios del gas natural de la Tabla 504 para cada temporada, obtenidos a partir de los datos establecidos en el Capítulo 3, donde se tiene en cuenta el precio por el termino variable y fijo; se puede realizar la estimación del precio máximo de compra de la energía útil a la red de calor para obtener un $0 \%$ de ahorro y un 15\% de ahorro. La Tabla 505, muestral el precio que se pagaría para un ahorro del 15\%

Tabla 504. Precios de referencia para Gas natural y Astilla

\begin{tabular}{ccccc}
\hline Precios ( $€ /(\mathrm{kWh})$ & 2015 & 2016 & 2017 & 2018 \\
\hline Gasóleo C & 0,0517 & 0,0437 & 0,0499 & 0,0560 \\
\hline Astilla & 0,0277 & 0,0256 & 0,0254 & 0,0239 \\
\hline $\begin{array}{c}€ / \text { kWh útiles máximos de compra a la red para } \\
\text { un ahorro del 0,0\% }\end{array}$ & 0,0614 & \\
\hline $\begin{array}{c}€ / \text { kWh útiles máximos de compra a la red para } \\
\text { un ahorro del } 15,0 \%\end{array}$ & 0,05317 & \\
\hline \begin{tabular}{l} 
un \\
\hline
\end{tabular} & & & & \\
\hline
\end{tabular}

Tabla 505. Ahorro Económico por el consumo térmico en el Edificio E5

\begin{tabular}{|c|c|c|c|c|c|c|c|c|c|c|}
\hline & $\begin{array}{l}\text { kWh_E5 } \\
\text { Gasóleo }\end{array}$ & $\begin{array}{c}\text { kWh_E5_- } \\
\text { Biomasa }\end{array}$ & $\begin{array}{c}\text { kWh_E5 } \\
\text { Real }\end{array}$ & $\begin{array}{c}\text { kWh_E5 } \\
\text { Pronosticado }\end{array}$ & $\begin{array}{c}€ \text { Real } \\
\text { Gasóleo }\end{array}$ & $\begin{array}{c}€ \text { Real } \\
\text { Biomasa }\end{array}$ & $\begin{array}{l}€ \text { Real } \\
\text { Total }\end{array}$ & $\begin{array}{c}\text { € predicho } \\
\text { Gasóleo }\end{array}$ & $\begin{array}{c}€ \\
\text { Ahorro }\end{array}$ & $€$ Acumulado \\
\hline oct-2015 & 0 & 46.600 & 46600 & 108.511 & 0 & 2.478 & 2.478 & 5.610 & 3.132 & 3.132 \\
\hline nov-2015 & 0 & 200.500 & 200500 & 199.353 & 0 & 10.661 & 10.661 & 10.307 & -354 & 2.778 \\
\hline dic-2015 & 0 & 153.300 & 153300 & 274.210 & 0 & 8.151 & 8.151 & 14.177 & 6.026 & 8.804 \\
\hline ene-2016 & 0 & 143.600 & 143600 & 251.229 & 0 & 7.635 & 7.635 & 10.979 & 3.344 & 12.147 \\
\hline feb-2016 & 94.059 & 262.450 & 356509 & 246.684 & 4.110 & 13.954 & 18.065 & 10.780 & -7.285 & 4.863 \\
\hline mar-2016 & 9.087 & 204.250 & 213337 & 254.823 & 397 & 10.860 & 11.257 & 11.136 & -121 & 4.741 \\
\hline abr-2016 & 2.436 & 195.000 & 197436 & 177.058 & 106 & 10.368 & 10.475 & 7.737 & -2.737 & 2.004 \\
\hline may-2016 & 565 & 58.700 & 59265 & 110.382 & 25 & 3.121 & 3.146 & 4.824 & 1.678 & 3.682 \\
\hline oct-2016 & 23.832 & 39.000 & 62832 & 108.751 & 1.041 & 2.074 & 3.115 & 4.752 & 1.637 & 5.320 \\
\hline nov-2016 & 4.634 & 194.000 & 198634 & 229.814 & 202 & 10.315 & 10.517 & 10.043 & -475 & 4.845 \\
\hline dic-2016 & 2.999 & 189.900 & 192899 & 304.532 & 131 & 10.097 & 10.228 & 13.308 & 3.080 & 7.925 \\
\hline ene-2017 & 7.078 & 262.300 & 269378 & 345.116 & 353 & 13.946 & 14.300 & 17.221 & 2.922 & 10.847 \\
\hline feb-2017 & 1.234 & 217.700 & 218934 & 214.366 & 62 & 11.575 & 11.637 & 10.697 & -940 & 9.907 \\
\hline mar-2017 & 1.234 & 186.400 & 187634 & 195.114 & 62 & 9.911 & 9.972 & 9.736 & -236 & 9.671 \\
\hline$a b r-2017$ & 524 & 86.400 & 86924 & 135.178 & 26 & 4.594 & 4.620 & 6.745 & 2.125 & 11.796 \\
\hline may-2017 & 2.691 & 38.900 & 41591 & 74.086 & 134 & 2.068 & 2.203 & 3.697 & 1.494 & 13.290 \\
\hline oct-2017 & 0 & 31.700 & 31700 & 104.653 & 0 & 1.685 & 1.685 & 5.222 & 3.537 & 16.827 \\
\hline nov-2017 & 0 & 183.300 & 183300 & 250.958 & 0 & 9.746 & 9.746 & 12.523 & 2.777 & 19.604 \\
\hline dic-2017 & 0 & 252.700 & 252700 & 307.800 & 0 & 13.436 & 13.436 & 15.359 & 1.923 & 21.527 \\
\hline ene-2018 & 0 & 228.300 & 228300 & 296.935 & 0 & 12.139 & 12.139 & 16.628 & 4.490 & 26.016 \\
\hline feb-2018 & 0 & 296.600 & 296600 & 291.486 & 0 & 15.770 & 15.770 & 16.323 & 553 & 26.569 \\
\hline mar-2018 & 0 & 236.500 & 236500 & 237.427 & 0 & 12.575 & 12.575 & 13.296 & 721 & 27.291 \\
\hline abr-2018 & 0 & 114.600 & 114600 & 146.264 & 0 & 6.093 & 6.093 & 8.191 & 2.098 & 29.388 \\
\hline may-2018 & 0 & 51.300 & 51300 & 93.303 & 0 & 2.728 & 2.728 & 5.225 & 2.497 & 31.886 \\
\hline$€$ Total & & & & & & & 212.631 & 244.516 & & \\
\hline Ahorro (\%) & & & & & & & & & & $15,0 \%$ \\
\hline
\end{tabular}




\section{AV.6. Edificio E6. Colegio Mayor Femenino Santa Cruz.}

\section{AV.6.1. Obtención de la línea base de referencia energética}

Los datos de partida para la obtención de la línea base de referencia se muestran en la Tabla 506

Tabla 506. Consumos térmicos del edificio E6

\begin{tabular}{lr}
\hline & Consumos térmicos (kWh). E6 \\
\hline oct-12 & 26.717 \\
\hline nov-12 & 70.411 \\
\hline dic-12 & 69.423 \\
\hline ene-13 & 60.486 \\
\hline feb-13 & 77.600 \\
\hline mar-13 & 62.022 \\
\hline abr-13 & 47.899 \\
\hline may-13 & 31.816 \\
\hline oct-13 & 20.432 \\
\hline nov-13 & 61.042 \\
\hline dic-13 & 86.228 \\
\hline ene-14 & 67.999 \\
\hline feb-14 & 79.509 \\
\hline mar-14 & 51.450 \\
\hline abr-14 & 41.877 \\
\hline may-14 & 22.289 \\
\hline Promedio & 54.825 \\
\hline Total (oct-12-may-13) & 446.374 \\
\hline Total (oct-13-may-14) & 430.826 \\
\hline Total (oct-12-may-13) & 877.200 \\
\hline
\end{tabular}

Como se puede ver en la Tabla 507 para el edificio, el método ofrece un modelo de regresión, con una sola variable (Temperatura media). El modelo fue construido con un solo paso, incluyendo la Temperatura media, por ser la variable más significativa (variable con menor valor de Sig $=0,000)$. El resto de las variables como se observa en la Tabla 508 fueron excluidas del modelo al tener valores de sig $>0,05$.

Tabla 507. Modelos de regresión del Edificio E6

\begin{tabular}{|c|c|c|c|c|c|c|c|}
\hline \multirow{2}{*}{\multicolumn{2}{|c|}{ Modelo }} & \multicolumn{2}{|c|}{ Coeficientes no estandarizados } & \multirow[t]{2}{*}{$t$} & \multirow[t]{2}{*}{ Sig. } & \multicolumn{2}{|c|}{$\begin{array}{l}\text { Intervalo de confianza de } 95,0 \% \\
\text { para B }\end{array}$} \\
\hline & & $B$ & Error típ. & & & Límite inferior & Límite superior \\
\hline 1 & (Constante) & 99745,107 & 4760,636 & 20,952 & ,000 & 89534,559 & 109955,656 \\
\hline & T_med & $-5510,824$ & 537,217 & $-10,258$ & 000 & $-6663,039$ & $-4358,61$ \\
\hline
\end{tabular}


En la Figura 325 se representa el modelo de regresión con sus límites inferior y superior para un nivel de confianza del $95 \%$

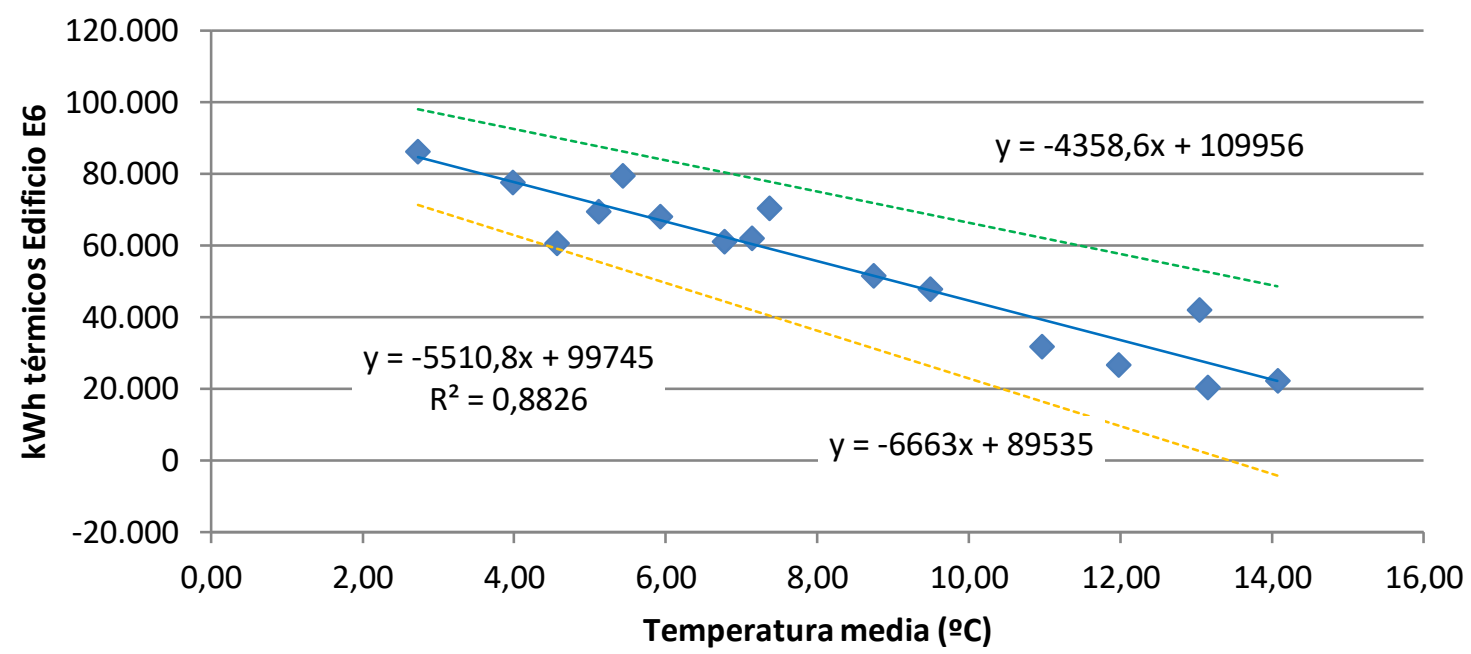

$\begin{array}{ll}\text { E6 (kWh) } & \text { Lineal (E6 (kWh)) } \\ & \text { Lineal (E6 lim inferior) }\end{array}$

Figura 325. Representación del modelo de regresión lineal simple para el Edificio E6

Tabla 508. Variables excluidas del modelo de región del Edificio E6

\begin{tabular}{|c|c|c|c|c|}
\hline & Modelo & $\mathrm{t}$ & Sig. & Correlación parcial \\
\hline \multirow{19}{*}{1} & GD15_30min & $-1,212$ & ,247 &,- 319 \\
\hline & GD20_30min & $-1,448$ & 171 &,- 373 \\
\hline & GD15_24h & $-1,661$ & 121 &,- 418 \\
\hline & GD20_24h & $-1,616$ & 130 &,- 409 \\
\hline & T_media_diurna_C & ,296 & ,772 & 082 \\
\hline & T_max_C & ,126 & ,902 & 035 \\
\hline & T_min_C &,- 409 & ,690 &,- 113 \\
\hline & HR_\% &,- 600 & ,559 &,- 164 \\
\hline & HR_med_diurna_\% &,- 489 & ,633 &,- 134 \\
\hline & HR_max_\% &,- 929 & 370 &,- 250 \\
\hline & HR_min_\% &,- 614 & ,550 &,- 168 \\
\hline & V_Viento_m/s & 1,103 & ,290 & ,293 \\
\hline & V_viento_diurna_m/s & 1,238 & ,238 & ,325 \\
\hline & V_viento_nocturna_m/s & ,944 & ,363 & ,253 \\
\hline & V_viento_max_m/s & 1,357 & 198 & ,352 \\
\hline & Recorrido_viento_km/día & 1,109 & ,288 & ,294 \\
\hline & Precipitación_acumulada_mes_mm & ,252 & 805 & 070 \\
\hline & Horas insolación_h & ,229 & ,822 &, 063 \\
\hline & Radiación_W/m2 & 438 & 669 & 121 \\
\hline
\end{tabular}


La bondad del modelo de regresión obtenido para el edificio E6, se resumen en la Tabla 509

Tabla 509. Resumen de la bondad del modelo de regresión para el Edificio E6

\begin{tabular}{|c|c|c|c|c|}
\hline Modelo & $\mathrm{R}$ & R cuadrado & $\mathrm{R}$ cuadrado corregida & $\begin{array}{c}\text { Error típ. de la } \\
\text { estimación }\end{array}$ \\
\hline 1 &,- 939 & ,883 & ,874 & 7470,6206 \\
\hline
\end{tabular}

Se observa como el modelo de regresión lineal simple presenta un Coeficiente de Correlación de Pearson (R) de 0,939, lo que indica que las variables están correlacionadas de manera muy fuerte (en la correlación perfecta $R= \pm 1$ ). La correlación que se produce es inversa, al aumentar el valor de la Temperatura, disminuye el consumo térmico.

El coeficiente de determinación $\left(R^{2}\right)$, nos indica que con el modelo se podría explicar el $88,3 \%$ de los datos reales obtenidos aceptando un error del $5 \%$.

El error típico de la estimación que nos indica la magnitud de los errores, es decir la parte de la variable dependiente que dejamos sin explicar con el modelo y que describe la variación de la variable respuesta (el Consumo) respecto a la recta de regresión, es de $7.470 \mathrm{kWh}$, lo que representa un $13,6 \%$ del promedio de los consumos que fue de $7.470,62 \mathrm{kWh}$.

\section{AV.6.2. Verificación del cumplimiento de los supuestos estadísticos}

Las condiciones que se deben cumplir en un modelo de regresión son:

\section{- Linealidad de las variables, las variables se encuentran relacionadas de forma lineal.}

Como se observa en la Tabla 507, la pendiente (B), obtuvo un valor de Sig $=0,000$, que al ser $\leq 0,05$, nos indica que podemos rechazar la hipótesis nula de pendiente igual a cero y nos da la evidencia de linealidad entre la variable dependiente ( $\mathrm{kWh}$ del edificio E6) y la independiente (T_med). Al ser el valor de la pendiente negativa, indica una relación inversa entre el consumo y la temperatura media.

- Normalidad. Todos los valores obtenidos para la variable dependiente (Y), deben estar distribuidos normalmente en cada valor de la variable independiente (X).

Se comprueba la normalidad de las variables y de los residuos mediante el Test de Shapiro - Wilk para muestras pequeñas (menores a 30 observaciones), siendo la hipótesis nula el que la distribución es Normal. 
La Tabla 510, muestra la prueba de normalidad de Shapiro-Wilk y cómo tanto la variable dependiente (consumos del Edificio), como la variable independientes: T_med poseen una Sig $>0,05$, por lo que aceptamos la hipótesis nula de Normalidad de las variables

Tabla 510. Prueba de normalidad para el edificio E6

\begin{tabular}{lccrrrrr}
\hline & \multicolumn{3}{c}{ Kolmogorov-Smirnov } & \multicolumn{3}{c}{ Shapiro-Wilk } \\
\cline { 2 - 8 } & Estadístico & gl & Sig. & Estadístico & gl & \multicolumn{1}{c}{ Sig. } \\
\hline kWh_E6 &, 168 & 16 &, 200 &, 939 & 16 &, 337 \\
\hline T_med &, 150 & 16 &, 200 &, 942 & 16 &, 376 \\
\hline
\end{tabular}

- Independencia de los errores. Los errores asociados a los valores de la variable respuesta $(\mathrm{Y})$ deberán ser independientes unos de otros.

Para la comprobación se utiliza el estadístico de Durbin -Watson.

Se comprueba que el Estadístico de Durbin Watson para el nivel de significancia del 5\%, y para el tamaño de la muestra " $n$ " y el número de variables independientes del modelo " $k$ ", se encuentra en el intervalo [dU, 4-dU], de la Tabla 3, intervalo centrado en el 2, que indica la ausencia de autocorrelación.

El valor del Estadístico Durbin-Watson facilitado por el programa SPSS, es 1,950.

En el modelo, $\mathrm{n}=16$ y $\mathrm{k}=1$, según la Tabla 3 el valor $\mathrm{dU}=1,371$ y dL =1,106, luego el intervalo que marca la ausencia de correlación es [1,371, 2,629]

Los intervalos $[0,1,106]$ y $[2,896,4]$ indican correlación positiva o negativa respectivamente y las zonas $[1,106,1,371]$ y $[2,629,2,896]$ son zonas no concluyentes; como el valor del estadístico 1,950 está dentro del intervalo de ausencia de correlación, se concluye que no existe autocorrelación en los residuos.

- Homocedasticidad de la varianza. Se pretende comprobar que la varianza de los errores $\left(\sigma^{2}\right)$ es constante para cualquier valor de la variable independiente $(X)$, es decir que el valor medio del cuadrado de la desviación de los errores respecto a su media es constante.

Esta condición indica que no existe correlación entre los residuos y los pronósticos. Se comprueba que el coeficiente de determinación $\mathrm{R}^{2}$, en las relaciones: residuos $\mathrm{y}$ predicciones y entre residuos y variable independiente es nulo o muy próximo a cero, lo que indicará que no existe ningún tipo de correlación en los residuos y que éstos son aleatorios. Se grafican los diagramas de dispersión de esas relaciones, comprobando que se corresponden a nubes de puntos totalmente aleatorias, sin tendencias ni patrones en sus representaciones gráficas. 
Las Figura 326 y Figura 327, muestran que la relación entre los pronósticos y los residuos, posee un coeficiente de determinación $=0$ y entre la variable independiente (T_med) y los residuos un coeficiente de determinación de $-2,22 \times 10^{-16}$; por lo que se concluye que no existe ningún tipo de correlación en los residuos y que éstos son aleatorios, siendo la varianza de los residuos constante.

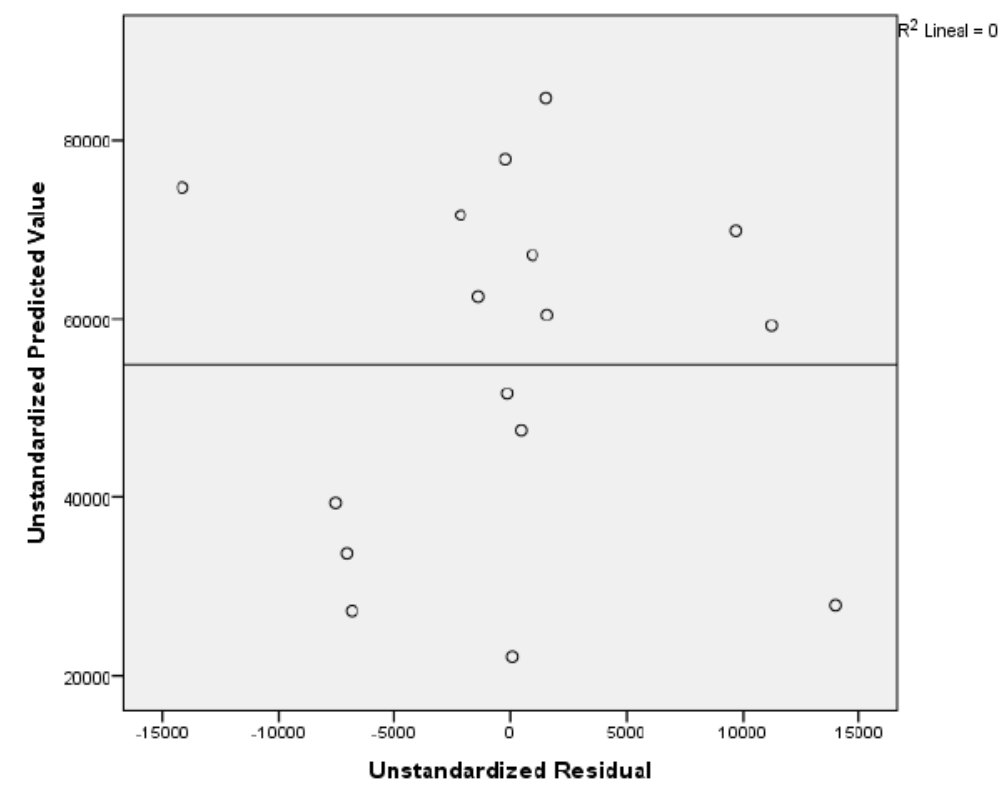

Figura 326. Relación entre los pronósticos y los residuos en el Edificio E6

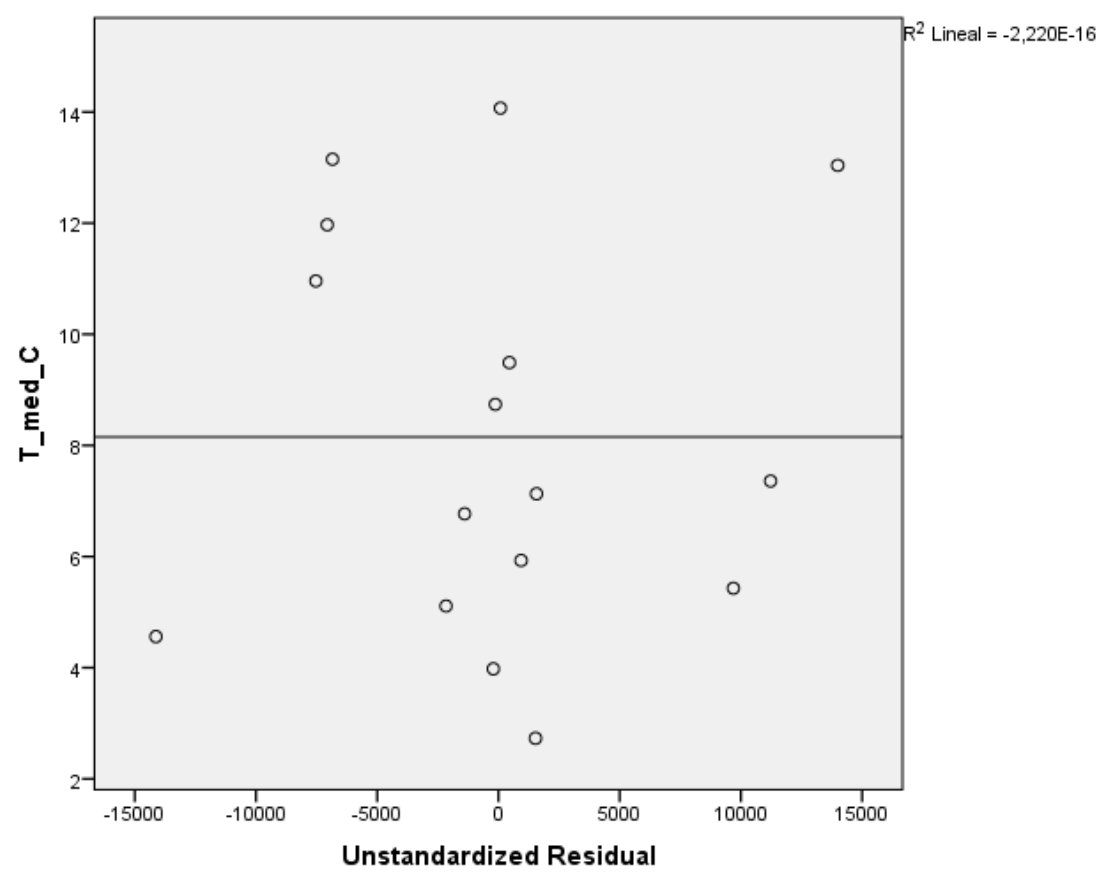

Figura 327. Relación entre T_med y los residuos en el Edificio E6 


\section{AV.6.3. Obtención de los consumos térmicos previstos}

Una vez comprobado el cumplimiento de los supuestos estadísticos se acepta el modelo de línea base encontrado para modelizar el consumo del Edificio E6.

$$
\text { kWh_E6_Pronosticado }=99.745,107-5.510,824 \times \text { T_med }
$$

Con este modelo se procede a predecir los consumos previstos para las temporadas: octubre 2015-mayo 2016, octubre 2016 - mayo 2017 y octubre 2017-mayo 2018, estos consumos se muestran en la Tabla 511, donde "KWh_E6_Real", representa el consumo real redistribuido, "kWh_E6_Pronosticado", el consumo pronosticado con el Modelo.

Tabla 511. Consumos previstos octubre 2014 - mayo 2017 para el edificio E6.

\begin{tabular}{rrrr}
\hline & T_med & kWh_E6_Real & kWh_E6_Pronosticado \\
\hline oct-15 & 12,82 & 18.867 & 29.104 \\
\hline nov-15 & 8,30 & 72.507 & 53.993 \\
\hline dic-15 & 5,33 & 53.670 & 70.376 \\
\hline ene-16 & 6,23 & 57.688 & 65.389 \\
\hline feb-16 & 5,82 & 109.816 & 67.698 \\
\hline mar-16 & 6,14 & 67.548 & 65.889 \\
\hline abr-16 & 9,10 & 61.805 & 49.593 \\
\hline may-16 & 13,11 & 22.683 & 27.474 \\
\hline oct-16 & 13,40 & 28.182 & 25.926 \\
\hline nov-16 & 6,90 & 77.281 & 61.716 \\
\hline dic-16 & 4,12 & 77.584 & 77.035 \\
\hline ene-17 & 2,52 & 93.129 & 85.876 \\
\hline feb-17 & 6,96 & 76.931 & 61.395 \\
\hline mar-17 & 9,21 & 67.113 & 48.993 \\
\hline abr-17 & 12,58 & 32.504 & 30.440 \\
\hline may-17 & 16,69 & 20.749 & 7.785 \\
\hline oct-17 & 14,71 & 23.998 & 18.676 \\
\hline nov-17 & 6,09 & 77.893 & 66.180 \\
\hline dic-17 & 3,99 & 98.278 & 77.747 \\
\hline ene-18 & 4,42 & 89.052 & 75.381 \\
\hline feb-18 & 3,53 & 108.817 & 80.304 \\
\hline mar-18 & 6,80 & 90.765 & 62.257 \\
\hline abr-18 & 11,15 & 41.843 & 38.320 \\
\hline may-18 & 14,03 & 25.939 & 22.443 \\
\hline & & &
\end{tabular}




\section{AV.6.4. Estudio de la existencia de diferencias significativas}

Utilizando la prueba " $\mathrm{t}$ " de Student para muestras relacionadas, podemos concluir que si las variables se distribuyen según una normal y la significación estadística resulta $\leq 0,05$, existen diferencias significativas, con un nivel de confianza del $95 \%$

A continuación se muestra la comparación de medias realizada para cada uno de los tres periodos posteriores a la construcción de la red y para el periodo total hasta mayo de 2018.

Para la temporada Octubre 2015 - Mayo 2016, se comprueba mediante el Test de Shapiro -Wilk que los valores reales y pronosticados se distribuyen según una Normal (Sig $>0,05)$, como se observa en la Tabla 512

Tabla 512. Prueba de Normalidad temporada Octubre 2015-Mayo 2016. Edificio E6

\begin{tabular}{cccccccr}
\hline & \multicolumn{3}{c}{ Kolmogorov-Smirnov $^{\mathrm{a}}$} & \multicolumn{3}{c}{ Shapiro-Wilk } \\
\cline { 2 - 8 } & Estadístico & gl & Sig. & Estadístico & gl & \multicolumn{1}{c}{ Sig. } \\
\hline kWh_real &, 189 & 8 &, 200 &, 930 & 8 &, 520 \\
\hline kWh_pronosticado &, 252 & 8 &, 144 &, 839 & 8 &, 074 \\
\hline
\end{tabular}

En la Tabla 513, se observa como las medias de los consumos pronosticados, son inferiores a las medias de los consumos reales del Edificio E6, en un 7,5\%

Tabla 513. Estadísticos de muestras relacionadas. Octubre 2015-Mayo 2016. Edificio E6

\begin{tabular}{lccccc}
\hline & Media & $\begin{array}{c}\text { \% Diferencia } \\
\text { entre medias }\end{array}$ & $\mathrm{N}$ & $\begin{array}{c}\text { Desviación } \\
\text { típ. }\end{array}$ & $\begin{array}{c}\text { Error típ. de } \\
\text { la media }\end{array}$ \\
\hline kWh_real & 58073,0000 & & 8 & 28781,14220 & 10175,67041 \\
\hline kWh_pronosticado & 53689,5000 & $-7,5 \%$ & 8 & 17192,00865 & 6078,29295 \\
\hline
\end{tabular}

La Tabla 514 muestra que las diferencias entre las medias no son significativas entre los consumos reales y los pronosticados (sig $>0,05$ )

Tabla 514. Prueba de muestras relacionadas. Octubre 2015-Mayo 2016. Edificio E6

\begin{tabular}{|c|c|c|c|c|c|c|c|c|c|}
\hline & & \multicolumn{5}{|c|}{ Diferencias relacionadas } & \multirow{3}{*}{$\mathrm{t}$} & \multirow{3}{*}{ gl } & \multirow{3}{*}{$\begin{array}{c}\text { Sig. } \\
\text { (bilateral) }\end{array}$} \\
\hline & & \multirow{2}{*}{ Media } & \multirow{2}{*}{$\begin{array}{l}\text { Desviación } \\
\text { típ. }\end{array}$} & \multirow{2}{*}{$\begin{array}{c}\text { Error típ. } \\
\text { de la media }\end{array}$} & \multicolumn{2}{|c|}{$\begin{array}{l}\text { 95\% Intervalo de confianza } \\
\text { para la diferencia }\end{array}$} & & & \\
\hline & & & & & Inferior & Superior & & & \\
\hline Par 1 & $\begin{array}{c}\text { kWh_real - } \\
\text { kWh_pronosticado }\end{array}$ & 4383,500 & 19201,951 & 6788,915 & $-11669,733$ & 20436,733 & ,646 & 7 & ,539 \\
\hline
\end{tabular}


En la Figura 328 se grafican los consumos reales y pronosticados para la temporada Octubre 2016 - Mayo 2017 para el Edificio E6, y las medias de dichos consumos. Según la prueba paramétrica realizada las diferencias encontradas no son estadísticamente significativas, con un riesgo a estar equivocados del $5 \%$

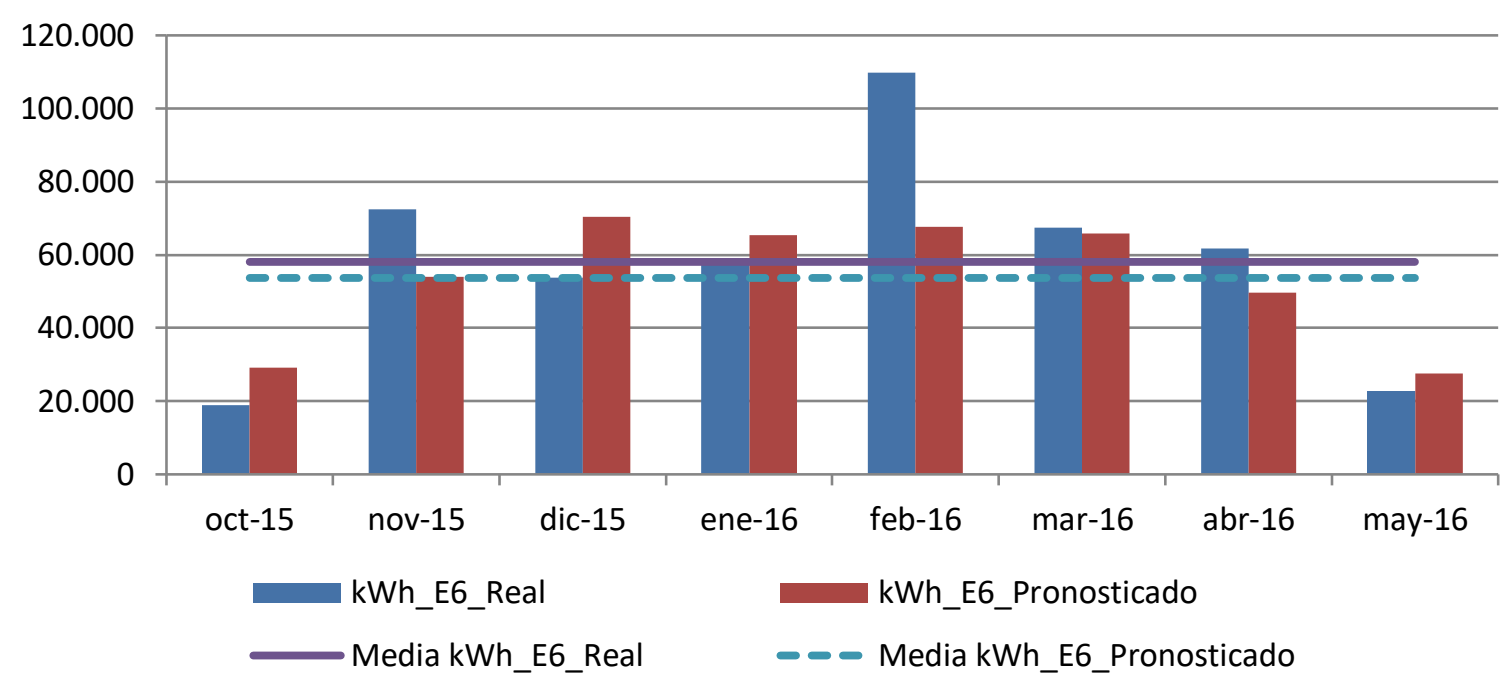

Figura 328. Consumos reales y pronosticados Octubre 2015-Mayo 2016. Edificio E6

Para la temporada Octubre 2016 - Mayo 2017, se comprueba mediante el Test de Shapiro -Wilk que tanto los valores reales como los pronosticados con los dos modelos se distribuyen según una Normal puesto que en todos los casos los valores de Sig >0,05, como se observa en la Tabla 515

Tabla 515. Prueba de Normalidad temporada Octubre 2016-Mayo 2017. Edificio E6

\begin{tabular}{cccccccr}
\hline & \multicolumn{3}{c}{ Kolmogorov-Smirnov $^{\mathrm{a}}$} & \multicolumn{3}{c}{ Shapiro-Wilk } \\
\cline { 2 - 8 } & Estadístico & $\mathrm{gl}$ & \multicolumn{1}{c}{ Sig. } & Estadístico & $\mathrm{gl}$ & \multicolumn{1}{c}{ Sig. } \\
\hline kWh_real &, 240 & 8 &, 197 &, 860 & 8 &, 121 \\
\hline kWh_pronosticado &, 166 & 8 &, 200 &, 963 & 8 &, 836 \\
\hline
\end{tabular}

En la Tabla 516, se observa como las medias de los consumos pronosticados, son inferiores a las medias de los consumos reales del Edificio E6, en un 15,7\%

Tabla 516. Estadísticos de muestras relacionadas. Octubre 2016-Mayo 2017. Edificio E6

\begin{tabular}{lccccc}
\hline & Media & $\begin{array}{c}\text { \% Diferencia } \\
\text { entre medias }\end{array}$ & N & $\begin{array}{c}\text { Desviación } \\
\text { típ. }\end{array}$ & $\begin{array}{c}\text { Error típ. de } \\
\text { la media }\end{array}$ \\
\hline kWh_real & 59184,1250 & & 8 & 27636,27304 & 9770,89804 \\
\hline kWh_pronosticado & 49895,7500 & $-15,7 \%$ & 8 & 26806,91192 & 9477,67460 \\
\hline
\end{tabular}


La Tabla 517 muestra que las diferencias entre las medias son significativas entre los consumos reales y los pronosticados (sig $\leq 0,05)$

Tabla 517. Prueba de muestras relacionadas. Octubre 2016-Mayo 2017. Edificio E6

\begin{tabular}{|c|c|c|c|c|c|c|c|c|c|}
\hline & & \multicolumn{5}{|c|}{ Diferencias relacionadas } & \multirow{3}{*}{$\mathrm{t}$} & \multirow{3}{*}{ gl } & \multirow{3}{*}{$\begin{array}{c}\text { Sig. } \\
\text { (bilateral) }\end{array}$} \\
\hline & & \multirow[t]{2}{*}{ Media } & \multirow{2}{*}{$\begin{array}{l}\text { Desviación } \\
\text { típ. }\end{array}$} & \multirow{2}{*}{$\begin{array}{c}\text { Error típ. } \\
\text { de la media }\end{array}$} & \multicolumn{2}{|c|}{$\begin{array}{l}\text { 95\% Intervalo de confianza } \\
\text { para la diferencia }\end{array}$} & & & \\
\hline & & & & & Inferior & Superior & & & \\
\hline Par 1 & $\begin{array}{c}\text { kWh_real - } \\
\text { kWh_pronosticado }\end{array}$ & 9288,375 & 7092,269 & 2507,496 & 3359,090 & 15217,660 & 3,704 & 7 & ,008 \\
\hline
\end{tabular}

En la Figura 329 se grafican los consumos reales y pronosticados para la temporada Octubre 2016 - Mayo 2017 para el Edificio E6, y las medias de dichos consumos. Según la prueba paramétrica realizada las diferencias encontradas son estadísticamente significativas, con un riesgo a estar equivocados del $5 \%$

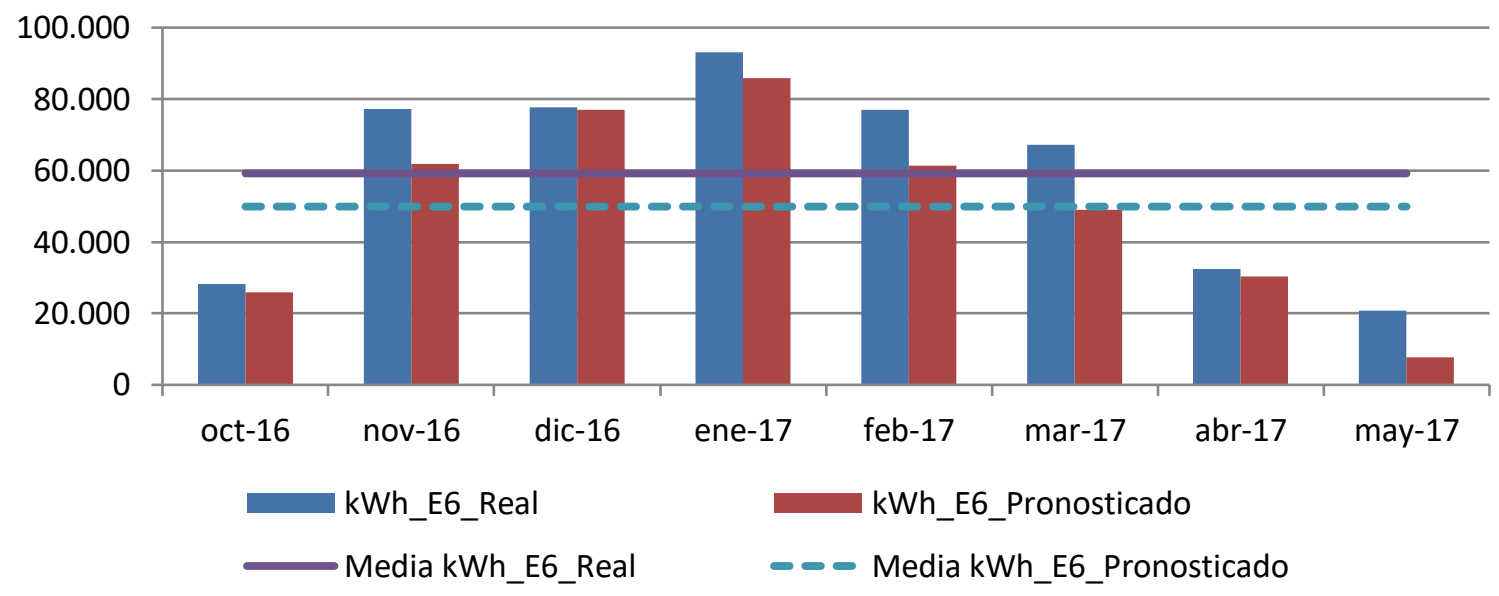

Figura 329. Consumos reales y pronosticados Octubre 2016-Mayo 2017. Edificio E6

Para la temporada Octubre 2017 - Mayo 2018, se comprueba mediante el Test de Shapiro -Wilk que tanto los valores reales como los pronosticados se distribuyen según una Normal puesto que en todos los casos los valores de Sig >0,05, como se observa en la Tabla 518

Tabla 518. Prueba de Normalidad temporada Octubre 2017-Mayo 2018. Edificio E6

\begin{tabular}{cccccccr}
\hline & \multicolumn{3}{c}{ Kolmogorov-Smirnov $^{\mathrm{a}}$} & \multicolumn{3}{c}{ Shapiro-Wilk } \\
\cline { 2 - 8 } & Estadístico & gl & \multicolumn{1}{c}{ Sig. } & Estadístico & gl & \multicolumn{1}{c}{ Sig. } \\
\hline kWh_real &, 222 & 8 &, 200 &, 868 & 8 &, 145 \\
\hline kWh_pronosticado &, 236 & 8 &, 200 &, 858 & 8 &, 114 \\
\hline
\end{tabular}


En la Tabla 519, se observa como las medias de los consumos pronosticados, son inferiores a las medias de los consumos reales del Edificio E6, en un $20,7 \%$

Tabla 519. Estadísticos de muestras relacionadas. Octubre 2017-Mayo 2018. Edificio E6

\begin{tabular}{lccrrr}
\hline & Media & $\begin{array}{c}\text { \% Diferencia } \\
\text { entre medias }\end{array}$ & N & $\begin{array}{c}\text { Desviación } \\
\text { típ. }\end{array}$ & $\begin{array}{c}\text { Error típ. de } \\
\text { la media }\end{array}$ \\
\hline kWh_real & 69573,1250 & & 8 & 33831,05663 & 11961,08478 \\
\hline kWh_pronosticado & 55163,5000 & $-20,7 \%$ & 8 & 25094,56345 & 8872,26799 \\
\hline
\end{tabular}

La Tabla 520 muestra que las diferencias entre las medias son significativas entre los consumos reales y los pronosticados (sig $\leq 0,05$ )

Tabla 520. Prueba de muestras relacionadas. Octubre 2017-Mayo 2018. Edificio E6

\begin{tabular}{|c|c|c|c|c|c|c|c|c|c|}
\hline & & \multicolumn{5}{|c|}{ Diferencias relacionadas } & \multirow{3}{*}{$\mathrm{t}$} & \multirow{3}{*}{ gl } & \multirow{3}{*}{$\begin{array}{c}\text { Sig. } \\
\text { (bilateral) }\end{array}$} \\
\hline & & \multirow[t]{2}{*}{ Media } & \multirow{2}{*}{$\begin{array}{l}\text { Desviación } \\
\text { típ. }\end{array}$} & \multirow{2}{*}{$\begin{array}{l}\text { Error típ. } \\
\text { de la media }\end{array}$} & \multicolumn{2}{|c|}{$\begin{array}{l}\text { 95\% Intervalo de confianza } \\
\text { para la diferencia }\end{array}$} & & & \\
\hline & & & & & Inferior & Superior & & & \\
\hline Par 1 & $\begin{array}{c}\text { kWh_real - } \\
\text { kWh_pronosticado }\end{array}$ & 14409,625 & 10441,461 & 3691,614 & 5680,346 & 23138,904 & 3,903 & 7 & ,006 \\
\hline
\end{tabular}

En la Figura 330, se grafican los consumos reales y pronosticados para la temporada Octubre 2017 - Mayo 2018 para el Edificio E6, y las medias de dichos consumos. Según la prueba paramétrica realizada las diferencias encontradas son estadísticamente significativas, con un riesgo a estar equivocados del $5 \%$

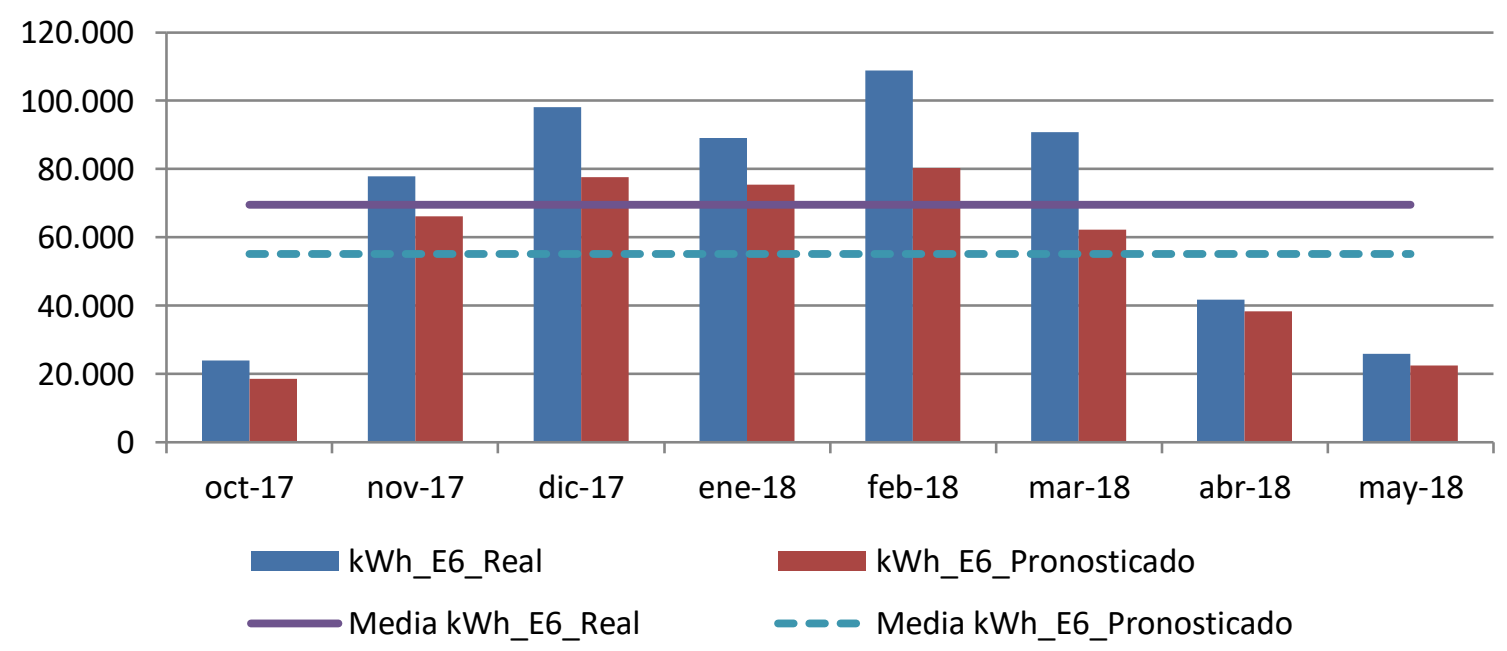

Figura 330. Consumos reales y pronosticados Octubre 2017-Mayo 2018. Edificio E6 
Para el total de las tres temporadas Octubre 2015 - Mayo 2018, se comprueba mediante el Test de Shapiro -Wilk, que los valores reales y los pronosticados se distribuyen según una Normal puesto que en esos casos los valores de Sig $>0,05$, como se observa en la Tabla 521

Tabla 521. Prueba de Normalidad temporada Octubre 2015-Mayo 2018. Edificio E6

\begin{tabular}{ccccccrr}
\hline & \multicolumn{3}{c}{ Kolmogorov-Smirnov $^{\mathrm{a}}$} & \multicolumn{3}{c}{ Shapiro-Wilk } \\
\cline { 2 - 8 } & Estadístico & gl & Sig. & Estadístico & gl & \multicolumn{1}{c}{ Sig. } \\
\hline kWh_real &, 137 & 24 &, 200 &, 930 & 24 &, 096 \\
\hline kWh_pronosticado &, 189 & 24 &, 027 &, 931 & 24 &, 100 \\
\hline
\end{tabular}

En la Tabla 522 se observa como las medias de los consumos pronosticados, son inferiores a las medias de los consumos reales del Edificio E6, en un 15,0\%

Tabla 522. Estadísticos de muestras relacionadas. Octubre 2015-Mayo 2018. Edificio E6

\begin{tabular}{lccccc}
\hline & Media & $\begin{array}{c}\text { \% Diferencia } \\
\text { entre medias }\end{array}$ & $\mathrm{N}$ & $\begin{array}{c}\text { Desviación } \\
\text { típ. }\end{array}$ & $\begin{array}{c}\text { Error típ. de } \\
\text { la media }\end{array}$ \\
\hline kWh_real & 62276,7500 & & 24 & 29340,86802 & 5989,17961 \\
\hline kWh_pronosticado & 52916,2500 & $-15,0 \%$ & 24 & 22482,41957 & 4589,20468 \\
\hline
\end{tabular}

La Tabla 523 muestra que las diferencias entre las medias son significativas entre los consumos reales y los pronosticados (sig $\leq 0,05)$

Tabla 523. Prueba de muestras relacionadas. Octubre 2015-Mayo 2018. Edificio E6

\begin{tabular}{|c|c|c|c|c|c|c|c|c|}
\hline & \multicolumn{5}{|c|}{ Diferencias relacionadas } & \multirow{3}{*}{$\mathrm{t}$} & \multirow{3}{*}{ gl } & \multirow{3}{*}{$\begin{array}{l}\text { Sig. } \\
\text { (bilateral) }\end{array}$} \\
\hline & \multirow[t]{2}{*}{ Media } & \multirow{2}{*}{$\begin{array}{l}\text { Desviación } \\
\text { típ. }\end{array}$} & \multirow{2}{*}{$\begin{array}{l}\text { Error típ. de } \\
\text { la media }\end{array}$} & \multicolumn{2}{|c|}{$\begin{array}{c}\text { 95\% Intervalo de confianza } \\
\text { para la diferencia }\end{array}$} & & & \\
\hline & & & & Inferior & Superior & & & \\
\hline $\begin{array}{c}\text { kWh_real - } \\
\text { kWh_pronosticado }\end{array}$ & 9360,500 & 13348,881 & 2724,829 & 3723,762 & 14997,238 & 3,435 & 23 & ,002 \\
\hline
\end{tabular}




\section{AV.6.5. Estimación de las emisiones de $\mathrm{CO} 2$ evitadas.}

Teniendo en cuenta que al consumir Gas Natural se producen $0,252 \mathrm{~kg} \mathrm{CO}_{2} / \mathrm{kWh} \mathrm{E}$. final y que al consumir la energía suministrada por red a partir de Biomasa se producen 0,024 kg $\mathrm{CO}_{2} / \mathrm{kWh}$. final, en la Tabla 524, se muestra las emisiones de $\mathrm{CO}_{2}$ reales para las temporadas octubre 2015 - mayo 2018 y utilizando el Modelo de regresión, las emisiones de $\mathrm{CO}_{2}$ que se hubieran tenido de haber seguido utilizando las calderas de gas natural originales sin el apoyo de la red de calor.

Tabla 524. Estimación del ahorro de emisiones de CO2 para el Edificio E6.

\begin{tabular}{|c|c|c|c|c|c|c|c|c|c|c|}
\hline & $\begin{array}{c}\text { kWh_E6 } \\
\text { Gas } \\
\text { natural }\end{array}$ & $\begin{array}{c}\text { kWh__ } \\
\text { E6 } \\
\text { Biomasa }\end{array}$ & $\begin{array}{l}\text { kWh_E6 } \\
\text { Real Total }\end{array}$ & $\begin{array}{l}\text { kWh_E6 } \\
\text { Predicho }\end{array}$ & $\begin{array}{l}\text { kg CO2 Real } \\
\text { debido al } \\
\text { consumo de } \\
\text { Gas Natural }\end{array}$ & $\begin{array}{l}\text { kg CO2 } \\
\text { Real } \\
\text { debido a } \\
\text { Biomasa }\end{array}$ & $\begin{array}{l}\text { kg CO2 } \\
\text { Real } \\
\text { debido al } \\
\text { consumo } \\
\text { TOTAL }\end{array}$ & $\begin{array}{c}\text { kg CO2 } \\
\text { que se } \\
\text { hubiera } \\
\text { tenido } \\
\text { debido a } \\
\text { Gas } \\
\text { Natural }\end{array}$ & $\begin{array}{c}\text { Ahorro de } \\
\text { kg CO2 }\end{array}$ & $\begin{array}{l}\text { Ahorro de kg } \\
\text { CO2 } \\
\text { acumulado }\end{array}$ \\
\hline oct-2015 & 0 & 18.867 & 18.867 & 18.867 & 0 & 453 & 453 & 4.754 & 4.302 & 4.302 \\
\hline nov-2015 & 0 & 72.507 & 72.507 & 72.507 & 0 & 1.740 & 1.740 & 18.272 & 16.532 & 20.833 \\
\hline dic-2015 & 0 & 53.670 & 53.670 & 53.670 & 0 & 1.288 & 1.288 & 13.525 & 12.237 & 33.070 \\
\hline ene-2016 & 0 & 57.688 & 57.688 & 57.688 & 0 & 1.385 & 1.385 & 14.537 & 13.153 & 46.223 \\
\hline feb-2016 & 25.685 & 84.131 & 109.816 & 109.816 & 6.473 & 2.019 & 8.492 & 27.674 & 19.182 & 65.405 \\
\hline mar-2016 & 4.595 & 62.953 & 67.548 & 67.548 & 1.158 & 1.511 & 2.669 & 17.022 & 14.353 & 79.758 \\
\hline abr-2016 & 1.502 & 60.303 & 61.805 & 61.805 & 378 & 1.447 & 1.826 & 15.575 & 13.749 & 93.507 \\
\hline may-2016 & 2.841 & 19.842 & 22.683 & 22.683 & 716 & 476 & 1.192 & 5.716 & 4.524 & 98.031 \\
\hline oct-2016 & 9.665 & 18.517 & 28.182 & 28.182 & 2.436 & 444 & 2.880 & 7.102 & 4.222 & 102.253 \\
\hline nov-2016 & 776 & 76.505 & 77.281 & 77.281 & 196 & 1.836 & 2.032 & 19.475 & 17.443 & 119.696 \\
\hline dic-2016 & 16 & 77.568 & 77.584 & 77.584 & 4 & 1.862 & 1.866 & 19.551 & 17.686 & 137.382 \\
\hline ene-2017 & 1.072 & 92.057 & 93.129 & 93.129 & 270 & 2.209 & 2.480 & 23.469 & 20.989 & 158.371 \\
\hline feb-2017 & 40 & 76.891 & 76.931 & 76.931 & 10 & 1.845 & 1.855 & 19.387 & 17.531 & 175.902 \\
\hline mar-2017 & 32 & 67.081 & 67.113 & 67.113 & 8 & 1.610 & 1.618 & 16.912 & 15.294 & 191.196 \\
\hline abr-2017 & 32 & 32.472 & 32.504 & 32.504 & 8 & 779 & 787 & 8.191 & 7.404 & 198.600 \\
\hline may-2017 & 48 & 20.701 & 20.749 & 20.749 & 12 & 497 & 509 & 5.229 & 4.720 & 203.320 \\
\hline oct-2017 & 11.185 & 12.813 & 23.998 & 23.998 & 2.819 & 308 & 3.126 & 6.048 & 2.921 & 206.241 \\
\hline nov-2017 & 144 & 77.749 & 77.893 & 77.893 & 36 & 1.866 & 1.902 & 19.629 & 17.727 & 223.968 \\
\hline dic-2017 & 104 & 98.174 & 98.278 & 98.278 & 26 & 2.356 & 2.382 & 24.766 & 22.384 & 246.351 \\
\hline ene-2018 & 264 & 88.788 & 89.052 & 89.052 & 67 & 2.131 & 2.197 & 22.441 & 20.244 & 266.595 \\
\hline feb-2018 & 72 & 108.745 & 108.817 & 108.817 & 18 & 2.610 & 2.628 & 27.422 & 24.794 & 291.389 \\
\hline mar-2018 & 976 & 89.789 & 90.765 & 90.765 & 246 & 2.155 & 2.401 & 22.873 & 20.472 & 311.861 \\
\hline$a b r-2018$ & 0 & 41.843 & 41.843 & 41.843 & 0 & 1.004 & 1.004 & 10.544 & 9.540 & 321.401 \\
\hline may-2018 & 0 & 25.939 & 25.939 & 25.939 & 0 & 623 & 623 & 6.537 & 5.914 & 327.315 \\
\hline
\end{tabular}

Como se observa durante estas tres temporadas se ha obtenido un ahorro total de 327 Toneladas de $\mathrm{CO}_{2}$, debido al cambio de energía utilizada. 


\section{AV.5.6. Estimación del precio máximo de compra a la red.}

Tomando como referencia los precios del gas natural de la Tabla 525 para cada temporada, obtenidos a partir de los datos establecidos en el Capítulo 3, donde se tiene en cuenta el precio por el termino variable y fijo; se puede realizar la estimación del precio máximo de compra de la energía útil a la red de calor para obtener un $0 \%$ de ahorro y un 15\% de ahorro. La Tabla 526, muestral el precio que se pagaría para un ahorro del $15 \%$

Tabla 525. Precios de referencia para Gas natural y Astilla

\begin{tabular}{|c|c|c|c|c|}
\hline Precios ( $€ /(k W h)$ & 2015 & 2016 & 2017 & 2018 \\
\hline Gas Natural & 0,0373 & 0,0306 & 0,0314 & 0,0336 \\
\hline Astilla & 0,0277 & 0,0256 & 0,0254 & 0,0239 \\
\hline $\begin{array}{l}€ / \text { kWh útiles máximos de compra a la red para } \\
\text { un ahorro del } 0,0 \%\end{array}$ & \multicolumn{4}{|c|}{0,0323} \\
\hline $\begin{array}{l}€ / \text { kWh útiles máximos de compra a la red para } \\
\text { un ahorro del } 15,0 \%\end{array}$ & \multicolumn{4}{|c|}{0,0279} \\
\hline
\end{tabular}

Tabla 526. Ahorro Económico por el consumo térmico en el Edificio E6

\begin{tabular}{|c|c|c|c|c|c|c|c|c|c|c|}
\hline & $\begin{array}{c}\text { kWh_E6 } \\
\text { Gas } \\
\text { natural }\end{array}$ & $\begin{array}{c}\text { kWh_E6_ } \\
\text { Biomasa }\end{array}$ & $\begin{array}{c}\text { kWh_E6 } \\
\text { Real }\end{array}$ & $\begin{array}{c}\text { kWh_E6 } \\
\text { Pronosticado }\end{array}$ & $\begin{array}{c}\text { € Real } \\
\text { Gas } \\
\text { Natural }\end{array}$ & $\begin{array}{c}€ \text { Real } \\
\text { Biomasa }\end{array}$ & $\begin{array}{l}€ \text { Real } \\
\text { Total }\end{array}$ & $\begin{array}{c}\text { € predicho } \\
\text { Gas } \\
\text { Natural }\end{array}$ & $\begin{array}{c}€ \\
\text { Ahorro }\end{array}$ & $€$ Acumulado \\
\hline oct-2015 & 0 & 18.867 & 18.867 & 18.867 & 0 & 526 & 526 & 704 & 177 & 177 \\
\hline nov-2015 & 0 & 72.507 & 72.507 & 72.507 & 0 & 2.023 & 2.023 & 2.705 & 682 & 859 \\
\hline dic-2015 & 0 & 53.670 & 53.670 & 53.670 & 0 & 1.497 & 1.497 & 2.002 & 504 & 1.363 \\
\hline ene-2016 & 0 & 57.688 & 57.688 & 57.688 & 0 & 1.609 & 1.609 & 1.765 & 156 & 1.519 \\
\hline feb-2016 & 25.685 & 84.131 & 109.816 & 109.816 & 786 & 2.347 & 3.133 & 3.360 & 227 & 1.746 \\
\hline mar-2016 & 4.595 & 62.953 & 67.548 & 67.548 & 141 & 1.756 & 1.897 & 2.067 & 170 & 1.916 \\
\hline$a b r-2016$ & 1.502 & 60.303 & 61.805 & 61.805 & 46 & 1.682 & 1.728 & 1.891 & 163 & 2.079 \\
\hline may-2016 & 2.841 & 19.842 & 22.683 & 22.683 & 87 & 554 & 641 & 694 & 54 & 2.133 \\
\hline oct-2016 & 9.665 & 18.517 & 28.182 & 28.182 & 296 & 517 & 812 & 862 & 50 & 2.183 \\
\hline nov-2016 & 776 & 76.505 & 77.281 & 77.281 & 24 & 2.134 & 2.158 & 2.365 & 207 & 2.389 \\
\hline dic-2016 & 16 & 77.568 & 77.584 & 77.584 & 0 & 2.164 & 2.165 & 2.374 & 209 & 2.599 \\
\hline ene-2017 & 1.072 & 92.057 & 93.129 & 93.129 & 34 & 2.568 & 2.602 & 2.924 & 322 & 2.921 \\
\hline feb-2017 & 40 & 76.891 & 76.931 & 76.931 & 1 & 2.145 & 2.147 & 2.416 & 269 & 3.190 \\
\hline mar-2017 & 32 & 67.081 & 67.113 & 67.113 & 1 & 1.872 & 1.873 & 2.107 & 235 & 3.425 \\
\hline abr-2017 & 32 & 32.472 & 32.504 & 32.504 & 1 & 906 & 907 & 1.021 & 114 & 3.538 \\
\hline may-2017 & 48 & 20.701 & 20.749 & 20.749 & 2 & 578 & 579 & 652 & 72 & 3.611 \\
\hline oct-2017 & 11.185 & 12.813 & 23.998 & 23.998 & 351 & 357 & 709 & 754 & 45 & 3.656 \\
\hline nov-2017 & 144 & 77.749 & 77.893 & 77.893 & 5 & 2.169 & 2.174 & 2.446 & 272 & 3.928 \\
\hline dic-2017 & 104 & 98.174 & 98.278 & 98.278 & 3 & 2.739 & 2.742 & 3.086 & 344 & 4.271 \\
\hline ene-2018 & 264 & 88.788 & 89.052 & 89.052 & 9 & 2.477 & 2.486 & 2.992 & 506 & 4.778 \\
\hline feb-2018 & 72 & 108.745 & 108.817 & 108.817 & 2 & 3.034 & 3.036 & 3.656 & 620 & 5.397 \\
\hline mar-2018 & 976 & 89.789 & 90.765 & 90.765 & 33 & 2.505 & 2.538 & 3.050 & 512 & 5.909 \\
\hline abr-2018 & 0 & 41.843 & 41.843 & 41.843 & 0 & 1.167 & 1.167 & 1.406 & 239 & 6.148 \\
\hline may-2018 & 0 & 25.939 & 25.939 & 25.939 & 0 & 724 & 724 & 872 & 148 & 6.296 \\
\hline$€$ Total & & & & & & & 41.874 & 48.170 & & \\
\hline Ahorro (\%) & & & & & & & & & & $15,0 \%$ \\
\hline
\end{tabular}




\section{AV.7. Edificio E7. Instituto de Biología Genética y Molecular.}

\section{AV.7.1. Obtención de la línea base de referencia energética}

Los datos de partida para la obtención de la línea base de referencia se muestran en la Tabla 527

Tabla 527. Consumos térmicos del edificio E7

\begin{tabular}{lr}
\hline & Consumos térmicos (kWh). E7 \\
\hline oct-12 & 7.328 \\
\hline nov-12 & 29.013 \\
\hline dic-12 & 34.243 \\
\hline ene-13 & 30.880 \\
\hline feb-13 & 32.427 \\
\hline mar-13 & 23.298 \\
\hline abr-13 & 18.563 \\
\hline may-13 & 7.021 \\
\hline oct-13 & 12.346 \\
\hline nov-13 & 26.338 \\
\hline dic-13 & 41.230 \\
\hline ene-14 & 36.151 \\
\hline feb-14 & 29.124 \\
\hline mar-14 & 24.955 \\
\hline abr-14 & 15.668 \\
\hline may-14 & 11.334 \\
\hline Promedio & 23.745 \\
\hline Total (oct-12-may-13) & 182.773 \\
\hline Total (oct-13-may-14) & 197.146 \\
\hline Total (oct-12-may-13) & 379.919 \\
\hline
\end{tabular}

Como se puede ver en la Tabla 528 para el edificio, el método ofrece un modelo de regresión, con una sola variable (Grados día en base 15, calculados con datos cada 30 minutos). El modelo fue construido con un solo paso, incluyendo los GD15_30min, por ser la variable más significativa (variable con menor valor de Sig $=0,000$ ). El resto de las variables como se observa en la Tabla 529 fueron excluidas del modelo al tener valores de sig $>0,05$.

Tabla 528. Modelos de regresión del Edificio E7

\begin{tabular}{|c|c|c|c|c|c|c|c|}
\hline \multirow{2}{*}{\multicolumn{2}{|c|}{ Modelo }} & \multicolumn{2}{|c|}{ Coeficientes no estandarizados } & \multirow[t]{2}{*}{$\mathrm{t}$} & \multirow[t]{2}{*}{ Sig. } & \multicolumn{2}{|c|}{$\begin{array}{c}\text { Intervalo de confianza de } 95,0 \% \\
\text { para B }\end{array}$} \\
\hline & & B & Error típ. & & & Límite inferior & Límite superior \\
\hline \multirow[t]{2}{*}{1} & (Constante) & $-437,414$ & 2854,451 &,- 153 & ,880 & $-6559,603$ & 5684,775 \\
\hline & GD15_30min & 109,126 & 11,990 & 9,102 & ,000 & 83,410 & 134,841 \\
\hline
\end{tabular}


En la Figura 331 se representa el modelo de regresión con sus límites inferior y superior para un nivel de confianza del $95 \%$

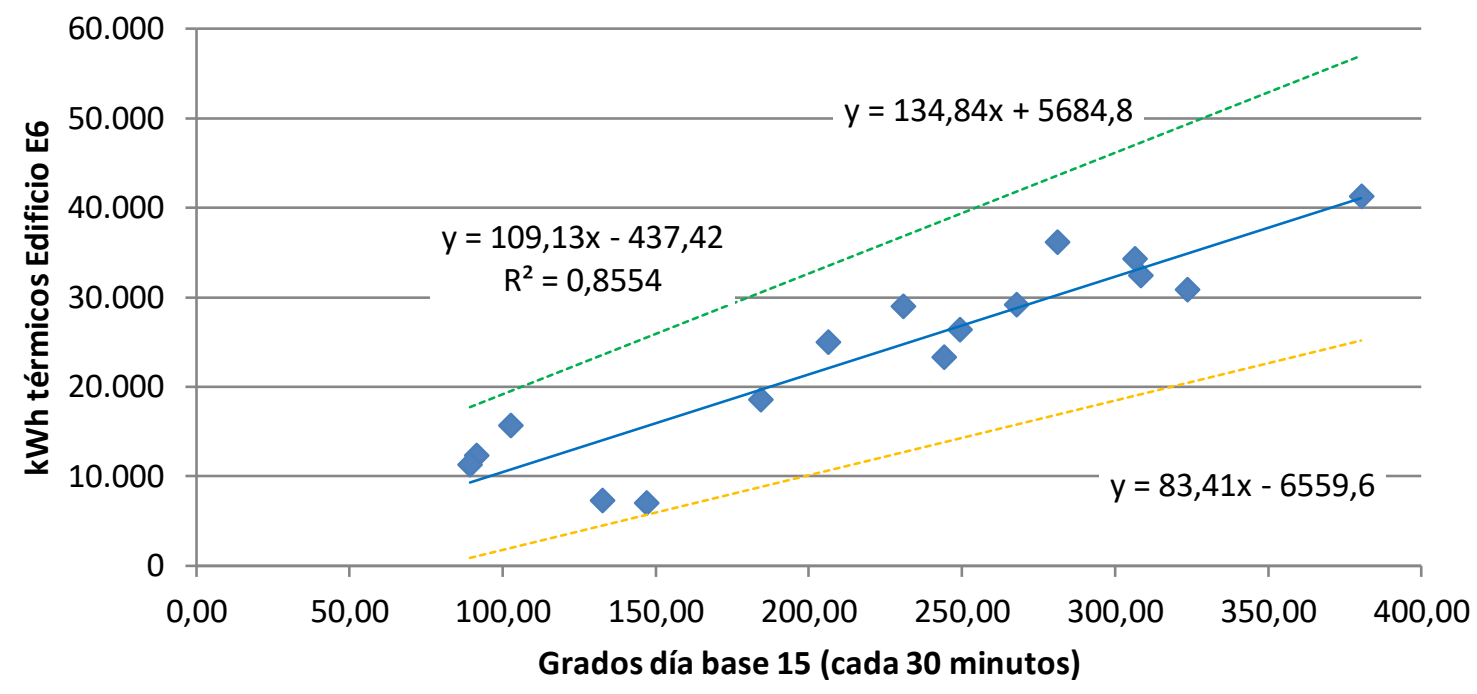

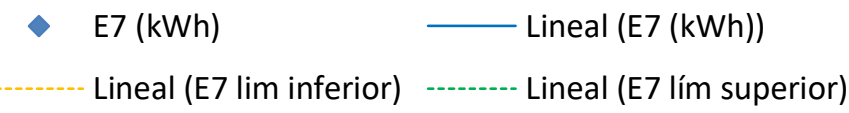

Figura 331. Representación del modelo de regresión lineal simple para el Edificio E7

Tabla 529. Variables excluidas del modelo de región del Edificio E7

\begin{tabular}{|c|c|c|c|c|}
\hline & Modelo & $\mathrm{t}$ & Sig. & Correlación parcial \\
\hline & GD20_30min &,- 235 & ,818 &,- 065 \\
\hline & GD15_24h &,- 046 & ,964 &,- 013 \\
\hline & GD20_24h &,- 252 &, 805 &,- 070 \\
\hline & T_med_C &,- 030 & ,976 &,- 008 \\
\hline & T_media_diurna_C &,- 453 &, 658 &,- 125 \\
\hline & T_max_C &,- 368 &, 719 &,- 102 \\
\hline & T_min_C & ,376 & 713 & ,104 \\
\hline & HR_\% & ,174 &, 865 & ,048 \\
\hline & HR_med_diurna_\% & ,364 &, 722 & , 100 \\
\hline \multirow[t]{10}{*}{1} & HR_max_\% &,- 481 & 638 &,- 132 \\
\hline & HR_min_\% &, 493 & ,630 &, 135 \\
\hline & V_Viento_m/s & ,468 & ,647 &, 129 \\
\hline & V_viento_diurna_m $/ \mathrm{s}$ & ,450 & 660 & ,124 \\
\hline & V_viento_nocturna_m/s &, 507 & 621 & ,139 \\
\hline & V_viento_max_m/s & ,419 & ,682 & ,115 \\
\hline & Recorrido_viento_km/día & ,466 & 649 & ,128 \\
\hline & Precipitación_acumulada_mes_mm & $-1,292$ & ,219 &,- 337 \\
\hline & Horas insolación_h & $-1,529$ & ,150 &,- 390 \\
\hline & Radiación_W/m2 &,- 693 &, 500 &,- 189 \\
\hline
\end{tabular}


La bondad del modelo de regresión obtenido para el edificio E7, se resumen en la Tabla 530

Tabla 530. Resumen de la bondad del modelo de regresión para el Edificio E7

\begin{tabular}{|c|c|c|c|c|}
\hline Modelo & $\mathrm{R}$ & R cuadrado & $\mathrm{R}$ cuadrado corregida & $\begin{array}{c}\text { Error típ. de la } \\
\text { estimación }\end{array}$ \\
\hline 1 & ,925 & ,855 & ,845 & 4173,1832 \\
\hline
\end{tabular}

Se observa como el modelo de regresión lineal simple presenta un Coeficiente de Correlación de Pearson (R) de 0,925, lo que indica que las variables están correlacionadas de manera muy fuerte (en la correlación perfecta $R= \pm 1$ ). La correlación que se produce es directa, al aumentar el valor de los Grados día, aumenta el consumo térmico.

El coeficiente de determinación $\left(R^{2}\right)$, nos indica que con el modelo se podría explicar el $85,5 \%$ de los datos reales obtenidos aceptando un error del $5 \%$.

El error típico de la estimación que nos indica la magnitud de los errores, es decir la parte de la variable dependiente que dejamos sin explicar con el modelo y que describe la variación de la variable respuesta (el Consumo) respecto a la recta de regresión, es de $4.173 \mathrm{kWh}$, lo que representa un 17,6\% del promedio de los consumos que fue de 23.745 kWh.

\section{AV.7.2. Verificación del cumplimiento de los supuestos estadísticos}

Las condiciones que se deben cumplir en un modelo de regresión son:

- Linealidad de las variables, las variables se encuentran relacionadas de forma lineal.

Como se observa en la Tabla 528, la pendiente (B), obtuvo un valor de Sig $=0,000$, que al ser $\leq 0,05$, nos indica que podemos rechazar la hipótesis nula de pendiente igual a cero y nos da la evidencia de linealidad entre la variable dependiente ( $k W h$ del edificio E7) y la independiente (GD15_30min). Al ser el valor de la pendiente positiva, indica una relación directa entre el consumo y los Grados día.

- Normalidad. Todos los valores obtenidos para la variable dependiente (Y), deben estar distribuidos normalmente en cada valor de la variable independiente $(X)$.

Se comprueba la normalidad de las variables y de los residuos mediante el Test de Shapiro - Wilk para muestras pequeñas (menores a 30 observaciones), siendo la hipótesis nula el que la distribución es Normal. 
La Tabla 531, muestra la prueba de normalidad de Shapiro-Wilk y cómo tanto la variable dependiente (consumos del Edificio), como la variable independientes: GD15_30min poseen una Sig $>0,05$, por lo que aceptamos la hipótesis nula de Normalidad de las variables

Tabla 531. Prueba de normalidad para el edificio E7

\begin{tabular}{lrrrrrr}
\hline & \multicolumn{3}{c}{ Kolmogorov-Smirnov } & \multicolumn{3}{c}{ Shapiro-Wilk } \\
\cline { 2 - 8 } & Estadístico & gl & Sig. & Estadístico & gl & \multicolumn{1}{c}{ Sig. } \\
\hline kWh_E7 &, 128 & 16 &, 200 &, 952 & 16 &, 529 \\
\hline GD15_30min &, 109 & 16 &, 200 &, 953 & 16 &, 541 \\
\hline
\end{tabular}

- Independencia de los errores. Los errores asociados a los valores de la variable respuesta $(Y)$ deberán ser independientes unos de otros.

Para la comprobación se utiliza el estadístico de Durbin -Watson.

Se comprueba que el Estadístico de Durbin Watson para el nivel de significancia del 5\%, y para el tamaño de la muestra " $n$ " y el número de variables independientes del modelo " $k$ ", se encuentra en el intervalo [dU, 4-dU], de la Tabla 3, intervalo centrado en el 2, que indica la ausencia de autocorrelación.

El valor del Estadístico Durbin-Watson facilitado por el programa SPSS, es 1,861.

En el modelo, $\mathrm{n}=16$ y $\mathrm{k}=1$, según la Tabla 3 el valor $\mathrm{dU}=1,371$ y dL =1,106, luego el intervalo que marca la ausencia de correlación es [1,371, 2,629]

Los intervalos $[0,1,106]$ y $[2,896,4]$ indican correlación positiva o negativa respectivamente y las zonas $[1,106,1,371]$ y $[2,629,2,896]$ son zonas no concluyentes; como el valor del estadístico 1,861 está dentro del intervalo de ausencia de correlación, se concluye que no existe autocorrelación en los residuos.

- Homocedasticidad de la varianza. Se pretende comprobar que la varianza de los errores $\left(\sigma^{2}\right)$ es constante para cualquier valor de la variable independiente $(X)$, es decir que el valor medio del cuadrado de la desviación de los errores respecto a su media es constante.

Esta condición indica que no existe correlación entre los residuos y los pronósticos. Se comprueba que el coeficiente de determinación $\mathrm{R}^{2}$, en las relaciones: residuos $\mathrm{y}$ predicciones y entre residuos y variable independiente es nulo o muy próximo a cero, lo que indicará que no existe ningún tipo de correlación en los residuos y que éstos son aleatorios. Se grafican los diagramas de dispersión de esas relaciones, comprobando que se corresponden a nubes de puntos totalmente aleatorias, sin tendencias ni patrones en sus representaciones gráficas. 
Las Figura 332 y Figura 333, muestran que la relación entre los pronósticos y los residuos, posee un coeficiente de determinación $=0 \mathrm{y}$ entre la variable independiente (GD15_30min) y los residuos un coeficiente de determinación de 1,11×10-16; por lo que se concluye que no existe ningún tipo de correlación en los residuos y que éstos son aleatorios, siendo la varianza de los residuos constante.

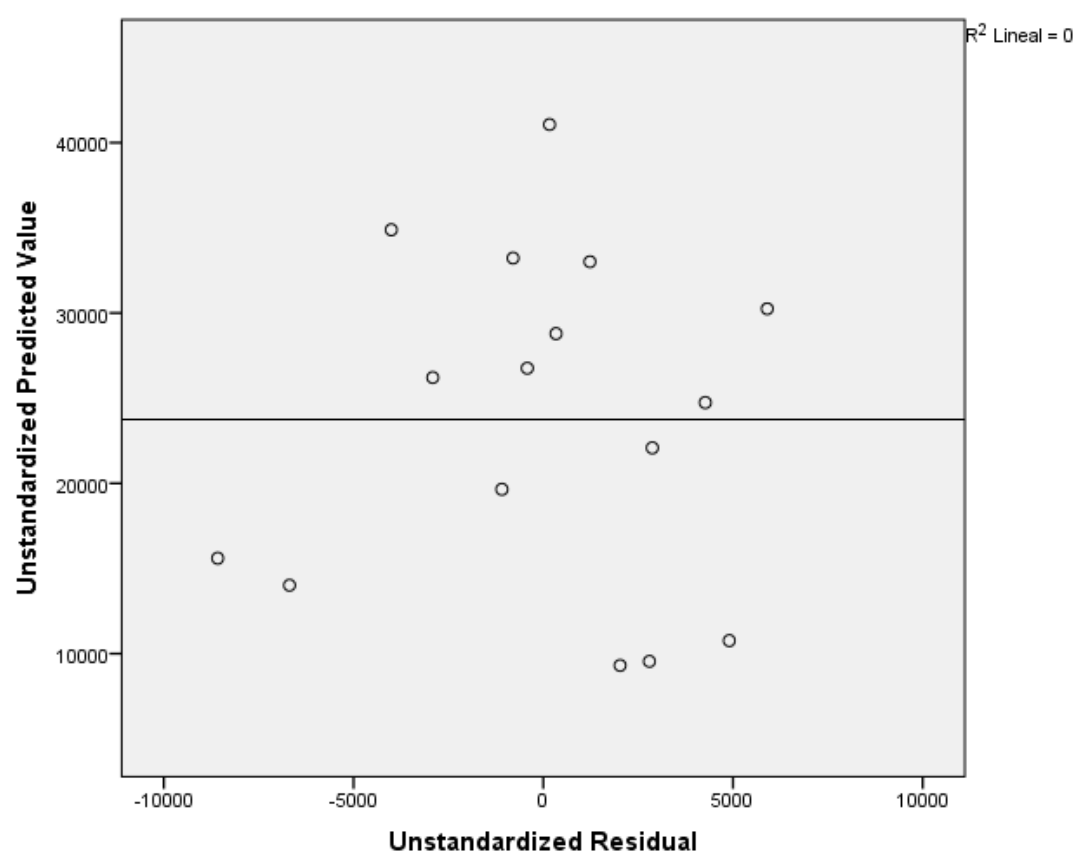

Figura 332. Relación entre los pronósticos y los residuos en el Edificio E7

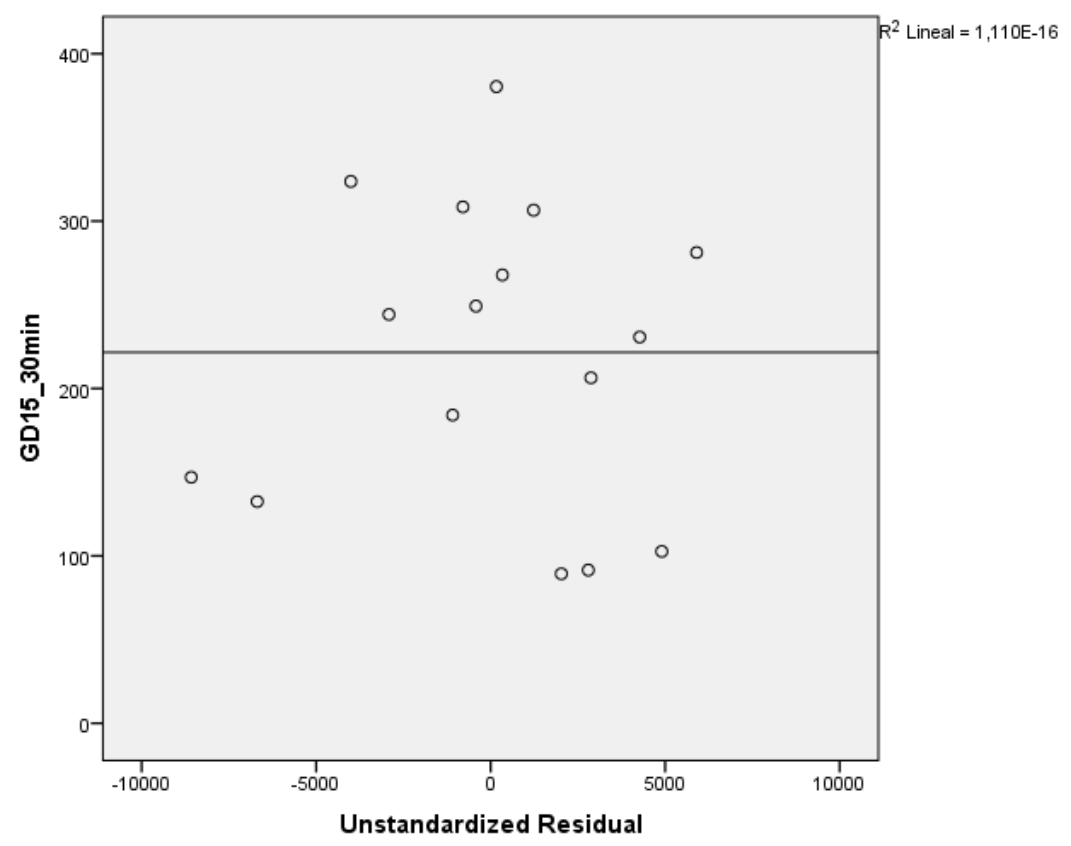

Figura 333. Relación entre GD15_30min y los residuos en el Edificio E7 


\section{AV.7.3. Obtención de los consumos térmicos previstos}

Una vez comprobado el cumplimiento de los supuestos estadísticos se acepta el modelo de línea base encontrado para modelizar el consumo del Edificio E7.

$$
\text { kWh_E7_Pronosticado }=-437,414+109,126 \times \text { GD15_30min }
$$

Con este modelo se procede a predecir los consumos previstos para las temporadas: octubre 2015-mayo 2016, octubre 2016 - mayo 2017 y octubre 2017-mayo 2018, estos consumos se muestran en la Tabla 532, donde "KWh_E7_Real", representa el consumo real redistribuido, "kWh_E7_Pronosticado", el consumo pronosticado con el Modelo.

Tabla 532. Consumos previstos octubre 2014 - mayo 2017 para el edificio E7.

\begin{tabular}{rrrr}
\hline & GD15_30min & kWh_E7_Real & kWh_E7_Pronosticado \\
\hline oct-15 & 97,04 & 4.549 & 10.152 \\
\hline nov-15 & 208,36 & 15.559 & 22.300 \\
\hline dic-15 & 300,09 & 11.035 & 32.311 \\
\hline ene-16 & 271,93 & 30.213 & 29.238 \\
\hline feb-16 & 266,36 & 63.667 & 28.630 \\
\hline mar-16 & 276,34 & 32.434 & 29.718 \\
\hline abr-16 & 181,04 & 22.115 & 19.319 \\
\hline may-16 & 99,34 & 8.218 & 10.403 \\
\hline oct-16 & 97,34 & 9.706 & 10.185 \\
\hline nov-16 & 245,69 & 26.341 & 26.374 \\
\hline dic-16 & 337,25 & 33.256 & 36.365 \\
\hline ene-17 & 386,98 & 37.659 & 41.793 \\
\hline feb-17 & 226,76 & 25.322 & 24.308 \\
\hline mar-17 & 203,17 & 21.876 & 21.734 \\
\hline abr-17 & 129,72 & 13.691 & 13.719 \\
\hline may-17 & 54,86 & 7.778 & 5.549 \\
\hline oct-17 & 92,31 & 5.393 & 9.637 \\
\hline nov-17 & 271,60 & 21.837 & 29.201 \\
\hline dic-17 & 341,26 & 36.608 & 36.803 \\
\hline ene-18 & 327,94 & 38.115 & 35.350 \\
\hline feb-18 & 321,27 & 43.138 & 34.621 \\
\hline mar-18 & 255,02 & 32.745 & 27.392 \\
\hline abr-18 & 143,31 & 22.137 & 15.201 \\
\hline may-18 & 78,41 & 12.372 & 8.119 \\
\hline & & &
\end{tabular}




\section{AV.7.4. Estudio de la existencia de diferencias significativas}

Utilizando la prueba " $\mathrm{t}$ " de Student para muestras relacionadas, podemos concluir que si las variables se distribuyen según una normal y la significación estadística resulta $\leq 0,05$, existen diferencias significativas, con un nivel de confianza del $95 \%$

A continuación se muestra la comparación de medias realizada para cada uno de los tres periodos posteriores a la construcción de la red y para el periodo total hasta mayo de 2018.

Para la temporada Octubre 2015 - Mayo 2016, se comprueba mediante el Test de Shapiro -Wilk que los valores reales y pronosticados se distribuyen según una Normal (Sig $>0,05)$, como se observa en la Tabla 533

Tabla 533. Prueba de Normalidad temporada Octubre 2015-Mayo 2016. Edificio E7

\begin{tabular}{crrrrrrr}
\hline & \multicolumn{3}{c}{ Kolmogorov-Smirnov $^{\mathrm{a}}$} & \multicolumn{3}{c}{ Shapiro-Wilk } \\
\cline { 2 - 8 } & Estadístico & gl & \multicolumn{1}{c}{ Sig. } & Estadístico & gl & \multicolumn{1}{c}{ Sig. } \\
\hline kWh_real &, 194 & 8 &, 200 &, 872 & 8 &, 156 \\
\hline kWh_pronosticado &, 248 & 8 &, 159 &, 865 & 8 &, 135 \\
\hline
\end{tabular}

En la Tabla 534, se observa como las medias de los consumos pronosticados, son inferiores a las medias de los consumos reales del Edificio E7, en un 3,0\%

Tabla 534. Estadísticos de muestras relacionadas. Octubre 2015-Mayo 2016. Edificio E7

\begin{tabular}{lccrrr}
\hline & Media & $\begin{array}{c}\text { \% Diferencia } \\
\text { entre medias }\end{array}$ & $\mathrm{N}$ & $\begin{array}{c}\text { Desviación } \\
\text { típ. }\end{array}$ & $\begin{array}{c}\text { Error típ. de } \\
\text { la media }\end{array}$ \\
\hline kWh_real & 23473,7500 & & 8 & 19091,12343 & 6749,73142 \\
\hline kWh_pronosticado & 22758,8750 & $-3,0 \%$ & 8 & 8781,19690 & 3104,62194 \\
\hline
\end{tabular}

La Tabla 535 muestra que las diferencias entre las medias no son significativas entre los consumos reales y los pronosticados (sig $>0,05$ )

Tabla 535. Prueba de muestras relacionadas. Octubre 2015-Mayo 2016. Edificio E7

\begin{tabular}{|c|c|c|c|c|c|c|c|c|c|}
\hline & & \multicolumn{5}{|c|}{ Diferencias relacionadas } & \multirow{3}{*}{$\mathrm{t}$} & \multirow{3}{*}{ gl } & \multirow{3}{*}{$\begin{array}{c}\text { Sig. } \\
\text { (bilateral) }\end{array}$} \\
\hline & & \multirow{2}{*}{ Media } & \multirow{2}{*}{$\begin{array}{l}\text { Desviación } \\
\text { típ. }\end{array}$} & \multirow{2}{*}{$\begin{array}{c}\text { Error típ. } \\
\text { de la media }\end{array}$} & \multicolumn{2}{|c|}{$\begin{array}{l}\text { 95\% Intervalo de confianza } \\
\text { para la diferencia }\end{array}$} & & & \\
\hline & & & & & Inferior & Superior & & & \\
\hline Par 1 & $\begin{array}{c}\text { kWh_real - } \\
\text { kWh_pronosticado }\end{array}$ & 714,875 & 15919,103 & 5628,253 & $-12593,829$ & 14023,579 & 127 & 7 & 902 \\
\hline
\end{tabular}


En la Figura 334 se grafican los consumos reales y pronosticados para la temporada Octubre 2016 - Mayo 2017 para el Edificio E7, y las medias de dichos consumos. Según la prueba paramétrica realizada las diferencias encontradas no son estadísticamente significativas, con un riesgo a estar equivocados del $5 \%$

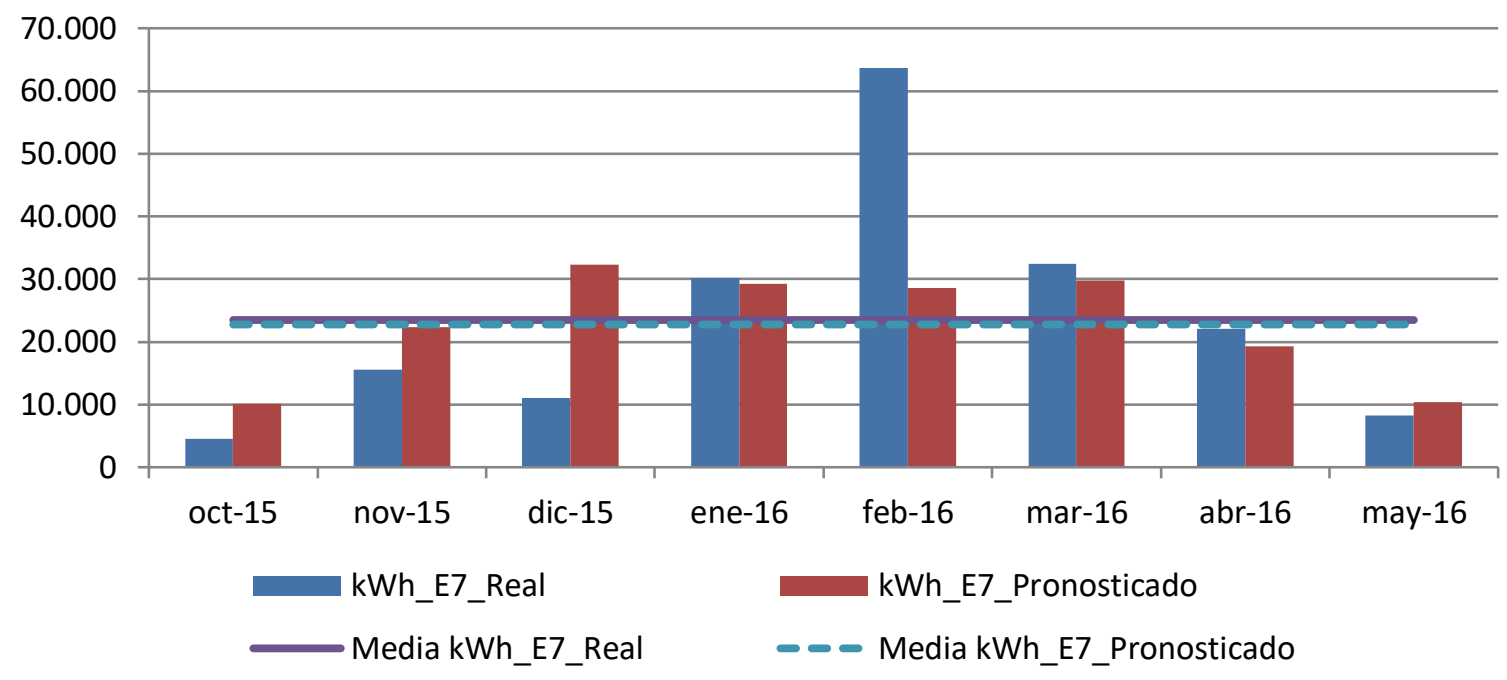

Figura 334. Consumos reales y pronosticados Octubre 2015-Mayo 2016. Edificio E7

Para la temporada Octubre 2016 - Mayo 2017, se comprueba mediante el Test de Shapiro -Wilk que tanto los valores reales como los pronosticados con los dos modelos se distribuyen según una Normal puesto que en todos los casos los valores de Sig >0,05, como se observa en la Tabla 536

Tabla 536. Prueba de Normalidad temporada Octubre 2016-Mayo 2017. Edificio E7

\begin{tabular}{ccccrrrr}
\hline & \multicolumn{3}{c}{ Kolmogorov-Smirnov $^{\mathrm{a}}$} & \multicolumn{3}{c}{ Shapiro-Wilk } \\
\cline { 2 - 9 } & Estadístico & gl & \multicolumn{1}{c}{ Sig. } & Estadístico & gl & Sig. \\
\hline kWh_real &, 152 & 8 &, 200 &, 947 & 8 &, 681 \\
\hline kWh_pronosticado &, 133 & 8 &, 200 &, 965 & 8 &, 856 \\
\hline
\end{tabular}

En la Tabla 537, se observa como las medias de los consumos pronosticados, son superiores a las medias de los consumos reales del Edificio E7, en un 2,5\%

Tabla 537. Estadísticos de muestras relacionadas. Octubre 2016-Mayo 2017. Edificio E7

\begin{tabular}{lccrcc}
\hline & Media & $\begin{array}{c}\text { \% Diferencia } \\
\text { entre medias }\end{array}$ & $\mathrm{N}$ & $\begin{array}{c}\text { Desviación } \\
\text { típ. }\end{array}$ & $\begin{array}{c}\text { Error típ. de } \\
\text { la media }\end{array}$ \\
\hline kWh_real & 21953,6250 & & 8 & 10851,11682 & 3836,44914 \\
\hline kWh_pronosticado & 22503,3750 & $2,5 \%$ & 8 & 12532,37559 & 4430,86388 \\
\hline
\end{tabular}


La Tabla 538 muestra que las diferencias entre las medias no son significativas entre los consumos reales y los pronosticados (sig $>0,05$ )

Tabla 538. Prueba de muestras relacionadas. Octubre 2016-Mayo 2017. Edificio E7

\begin{tabular}{|c|c|c|c|c|c|c|c|c|c|}
\hline & & \multicolumn{5}{|c|}{ Diferencias relacionadas } & \multirow{3}{*}{$\mathrm{t}$} & \multirow{3}{*}{ gl } & \multirow{3}{*}{$\begin{array}{c}\text { Sig. } \\
\text { (bilateral) }\end{array}$} \\
\hline & & \multirow[t]{2}{*}{ Media } & \multirow{2}{*}{$\begin{array}{c}\text { Desviación } \\
\text { típ. }\end{array}$} & \multirow{2}{*}{$\begin{array}{c}\text { Error típ. } \\
\text { de la media }\end{array}$} & \multicolumn{2}{|c|}{$\begin{array}{l}\text { 95\% Intervalo de confianza } \\
\text { para la diferencia }\end{array}$} & & & \\
\hline & & & & & Inferior & Superior & & & \\
\hline Par 1 & $\begin{array}{c}\text { kWh_real - } \\
\text { kWh_pronosticado }\end{array}$ & $-549,750$ & 2090,323 & 739,041 & $-2297,304$ & 1197,804 &,- 744 & 7 & ,481 \\
\hline
\end{tabular}

En la Figura 335 se grafican los consumos reales y pronosticados para la temporada Octubre 2016 - Mayo 2017 para el Edificio E7, y las medias de dichos consumos. Según la prueba paramétrica realizada las diferencias encontradas no son estadísticamente significativas, con un riesgo a estar equivocados del $5 \%$

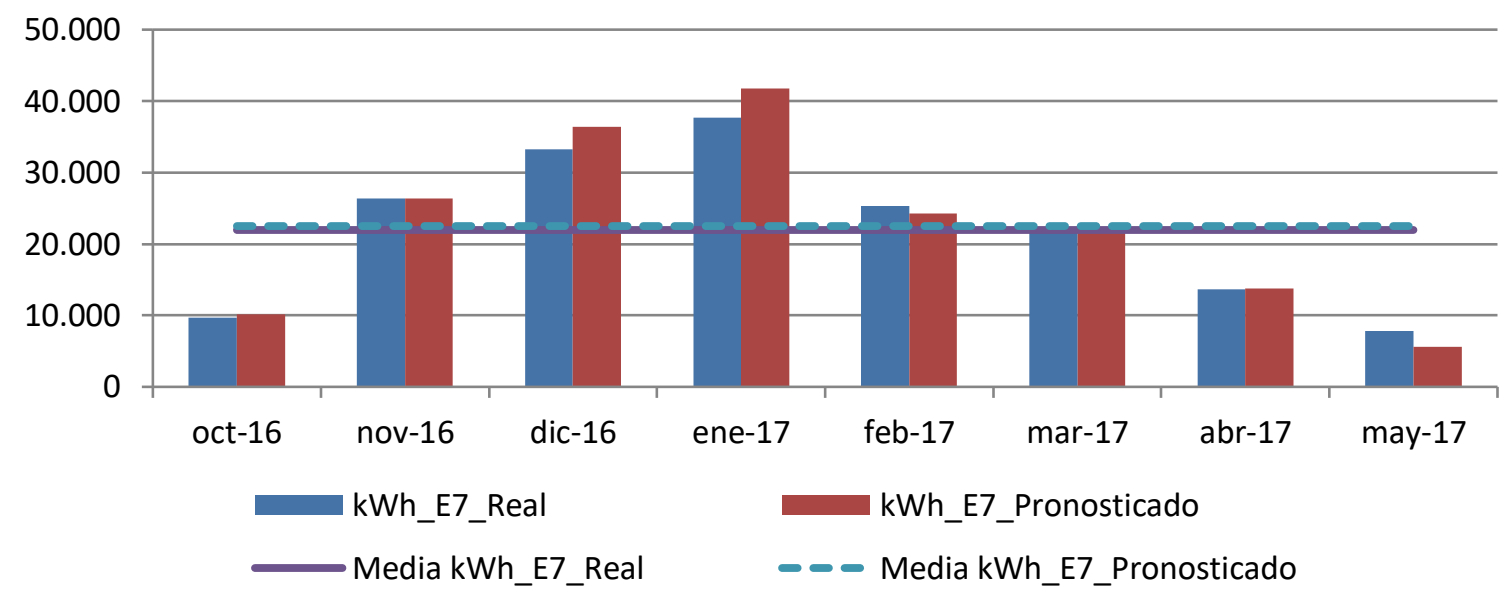

Figura 335. Consumos reales y pronosticados Octubre 2016-Mayo 2017. Edificio E7

Para la temporada Octubre 2017 - Mayo 2018, se comprueba mediante el Test de Shapiro -Wilk que tanto los valores reales como los pronosticados se distribuyen según una Normal puesto que en todos los casos los valores de Sig >0,05, como se observa en la Tabla 539

Tabla 539. Prueba de Normalidad temporada Octubre 2017-Mayo 2018. Edificio E7

\begin{tabular}{cccccccr}
\hline & \multicolumn{3}{c}{ Kolmogorov-Smirnov $^{\mathrm{a}}$} & \multicolumn{3}{c}{ Shapiro-Wilk } \\
\cline { 2 - 8 } & Estadístico & gl & \multicolumn{1}{c}{ Sig. } & Estadístico & gl & \multicolumn{1}{c}{ Sig. } \\
\hline kWh_real &, 179 & 8 &, 200 &, 942 & 8 &, 634 \\
\hline kWh_pronosticado &, 220 & 8 &, 200 &, 860 & 8 &, 119 \\
\hline
\end{tabular}


En la Tabla 540, se observa como las medias de los consumos pronosticados, son inferiores a las medias de los consumos reales del Edificio E7, en un 7,5\%

Tabla 540. Estadísticos de muestras relacionadas. Octubre 2017-Mayo 2018. Edificio E7

\begin{tabular}{lccrcc}
\hline & Media & $\begin{array}{c}\text { \% Diferencia } \\
\text { entre medias }\end{array}$ & $\mathrm{N}$ & $\begin{array}{c}\text { Desviación } \\
\text { típ. }\end{array}$ & $\begin{array}{c}\text { Error típ. de } \\
\text { la media }\end{array}$ \\
\hline $\mathrm{kWh}$ lreal & 26543,1250 & & 8 & 13302,91725 & 4703,29150 \\
\hline $\mathrm{kWh}$ & 24540,5000 & $-7,5 \%$ & 8 & 11818,19556 & 4178,36311 \\
\hline
\end{tabular}

La Tabla 541 muestra que las diferencias entre las medias no son significativas entre los consumos reales y los pronosticados (sig $>0,05$ )

Tabla 541. Prueba de muestras relacionadas. Octubre 2017-Mayo 2018. Edificio E7

\begin{tabular}{|c|c|c|c|c|c|c|c|c|c|}
\hline & & \multicolumn{5}{|c|}{ Diferencias relacionadas } & \multirow{3}{*}{$\mathrm{t}$} & \multirow{3}{*}{$\mathrm{gl}$} & \multirow{3}{*}{$\begin{array}{c}\text { Sig. } \\
\text { (bilateral) }\end{array}$} \\
\hline & & \multirow[t]{2}{*}{ Media } & \multirow{2}{*}{$\begin{array}{l}\text { Desviación } \\
\text { típ. }\end{array}$} & \multirow{2}{*}{$\begin{array}{c}\text { Error típ. } \\
\text { de la media }\end{array}$} & \multicolumn{2}{|c|}{$\begin{array}{l}\text { 95\% Intervalo de confianza } \\
\text { para la diferencia }\end{array}$} & & & \\
\hline & & & & & Inferior & Superior & & & \\
\hline Par 1 & $\begin{array}{c}\text { kWh_real - } \\
\text { kWh_pronosticado }\end{array}$ & 2002,625 & 5545,001 & 1960,454 & $-2633,112$ & 6638,362 & 1,022 & 7 & 341 \\
\hline
\end{tabular}

En la Figura 336, se grafican los consumos reales y pronosticados para la temporada Octubre 2017 - Mayo 2018 para el Edificio E7, y las medias de dichos consumos. Según la prueba paramétrica realizada las diferencias encontradas no son estadísticamente significativas, con un riesgo a estar equivocados del $5 \%$

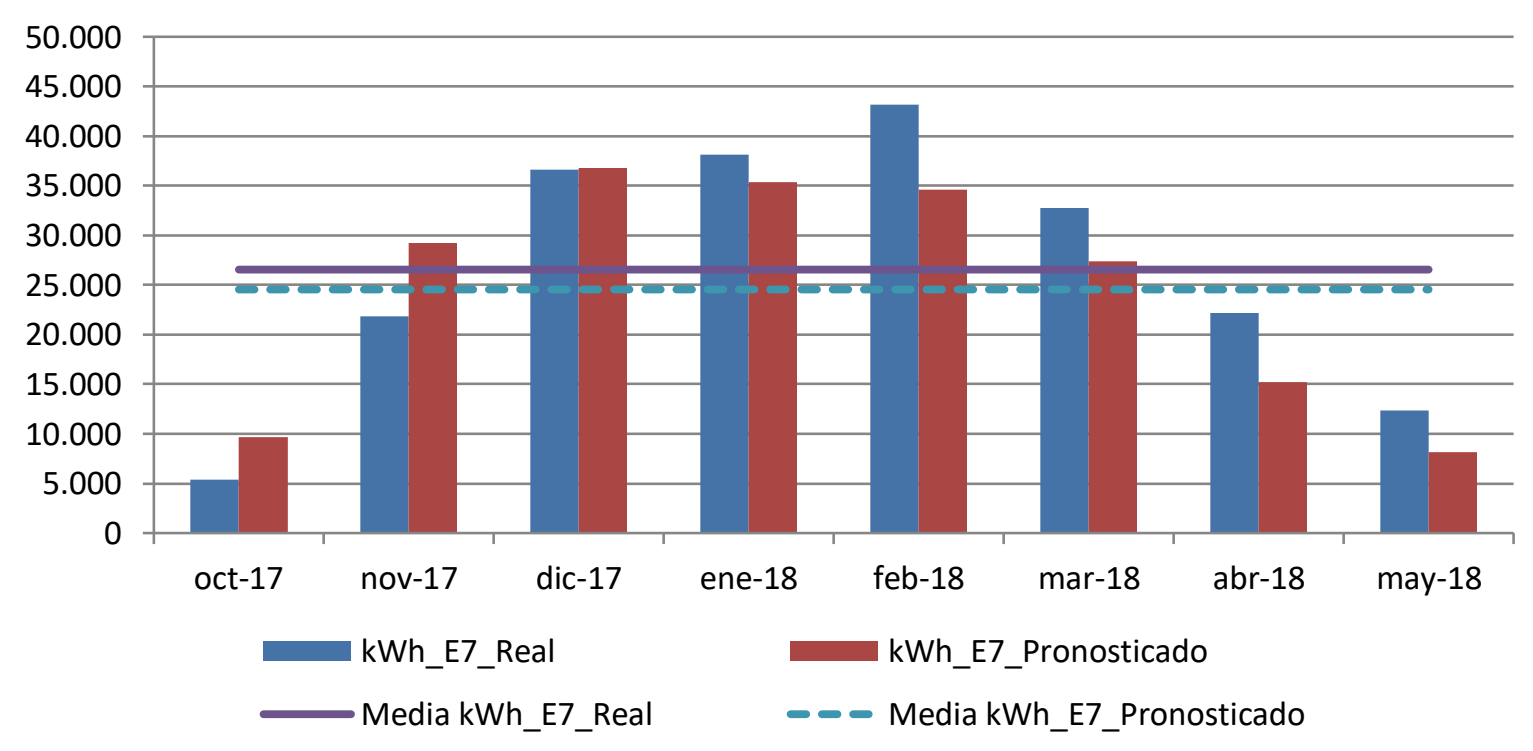

Figura 336. Consumos reales y pronosticados Octubre 2017-Mayo 2018. Edificio E7 
Para el total de las tres temporadas Octubre 2015 - Mayo 2018, se comprueba mediante el Test de Shapiro -Wilk, que los valores reales y los pronosticados se distribuyen según una Normal puesto que en esos casos los valores de Sig $>0,05$, como se observa en la Tabla 542

Tabla 542. Prueba de Normalidad temporada Octubre 2015-Mayo 2018. Edificio E7

\begin{tabular}{ccccccrr}
\hline & \multicolumn{3}{c}{ Kolmogorov-Smirnov $^{\mathrm{a}}$} & \multicolumn{3}{c}{ Shapiro-Wilk } \\
\cline { 2 - 8 } & Estadístico & gl & Sig. & Estadístico & gl & Sig. \\
\hline kWh_real &, 098 & 24 &, 200 &, 938 & 24 &, 148 \\
\hline kWh_pronosticado &, 135 & 24 &, 200 &, 942 & 24 &, 183 \\
\hline
\end{tabular}

En la Tabla 543 se observa como las medias de los consumos pronosticados, son inferiores a las medias de los consumos reales del Edificio E7, en un 3,0\%

Tabla 543. Estadísticos de muestras relacionadas. Octubre 2015-Mayo 2018. Edificio E7

\begin{tabular}{lccccc}
\hline & Media & $\begin{array}{c}\text { \% Diferencia } \\
\text { entre medias }\end{array}$ & $\mathrm{N}$ & $\begin{array}{c}\text { Desviación } \\
\text { típ. }\end{array}$ & $\begin{array}{c}\text { Error típ. de } \\
\text { la media }\end{array}$ \\
\hline kWh_real & 23990,1667 & & 24 & 14297,69157 & 2918,50407 \\
\hline kWh_pronosticado & 23267,5833 & $-3,0 \%$ & 24 & 10706,72715 & 2185,50153 \\
\hline
\end{tabular}

La Tabla 544 muestra que las diferencias entre las medias no son significativas entre los consumos reales y los pronosticados (sig $>0,05$ )

Tabla 544. Prueba de muestras relacionadas. Octubre 2015-Mayo 2018. Edificio E7

\begin{tabular}{|c|c|c|c|c|c|c|c|c|}
\hline & \multicolumn{5}{|c|}{ Diferencias relacionadas } & \multirow{3}{*}{$\mathrm{t}$} & \multirow{3}{*}{ gl } & \multirow{3}{*}{$\begin{array}{c}\text { Sig. } \\
\text { (bilateral) }\end{array}$} \\
\hline & \multirow[t]{2}{*}{ Media } & \multirow{2}{*}{$\begin{array}{l}\text { Desviación } \\
\text { típ. }\end{array}$} & \multirow{2}{*}{$\begin{array}{l}\text { Error típ. de } \\
\text { la media }\end{array}$} & \multicolumn{2}{|c|}{$\begin{array}{c}\text { 95\% Intervalo de confianza } \\
\text { para la diferencia }\end{array}$} & & & \\
\hline & & & & Inferior & Superior & & & \\
\hline $\begin{array}{c}\text { kWh_real - } \\
\text { kWh_pronosticado }\end{array}$ & 722,583 & 9431,214 & 1925,139 & $-3259,869$ & 4705,036 & ,375 & 23 & ,711 \\
\hline
\end{tabular}




\section{AV.7.5. Estimación de las emisiones de $\mathrm{CO} 2$ evitadas.}

Teniendo en cuenta que al consumir Ga Natural se producen $0,252 \mathrm{~kg} \mathrm{CO} 2 / \mathrm{kWh}$. final y que al consumir la energía suministrada por red a partir de Biomasa se producen 0,024 kg $\mathrm{CO}_{2} / \mathrm{kWh}$. final, en la Tabla 545, se muestra las emisiones de $\mathrm{CO}_{2}$ reales para las temporadas octubre 2015 - mayo 2018 y dado que no se han detectado diferencias significativas, las emisiones de $\mathrm{CO}_{2}$ que se hubieran tenido de haber seguido utilizando las calderas de gas natural originales sin el apoyo de la red de calor.

Tabla 545. Estimación del ahorro de emisiones de CO2 para el Edificio E7.

\begin{tabular}{|c|c|c|c|c|c|c|c|c|c|c|}
\hline & $\begin{array}{c}\text { kWh_E7 } \\
\text { Gas } \\
\text { natural }\end{array}$ & $\begin{array}{c}\text { kWh_- } \\
\text { E7 } \\
\text { Biomasa }\end{array}$ & $\begin{array}{l}\text { kWh_E7 } \\
\text { Real Total }\end{array}$ & $\begin{array}{l}\text { kWh_E7 } \\
\text { Predicho }\end{array}$ & $\begin{array}{l}\text { kg CO2 Real } \\
\text { debido al } \\
\text { consumo de } \\
\text { Gas Natural }\end{array}$ & $\begin{array}{l}\text { kg CO2 } \\
\text { Real } \\
\text { debido a } \\
\text { Biomasa }\end{array}$ & $\begin{array}{l}\text { kg CO2 } \\
\text { Real } \\
\text { debido al } \\
\text { consumo } \\
\text { TOTAL }\end{array}$ & $\begin{array}{c}\text { kg CO2 } \\
\text { que se } \\
\text { hubiera } \\
\text { tenido } \\
\text { debido a } \\
\text { Gas } \\
\text { Natural }\end{array}$ & $\begin{array}{c}\text { Ahorro de } \\
\text { kg CO2 }\end{array}$ & $\begin{array}{l}\text { Ahorro de kg } \\
\text { CO2 } \\
\text { acumulado }\end{array}$ \\
\hline oct-2015 & 0 & 4.549 & 4.549 & 4.549 & 0 & 109 & 109 & 1.146 & 1.037 & 1.037 \\
\hline nov-2015 & 0 & 15.559 & 15.559 & 15.559 & 0 & 373 & 373 & 3.921 & 3.547 & 4.585 \\
\hline dic-2015 & 0 & 11.035 & 11.035 & 11.035 & 0 & 265 & 265 & 2.781 & 2.516 & 7.101 \\
\hline ene-2016 & 0 & 30.213 & 30.213 & 30.213 & 0 & 725 & 725 & 7.614 & 6.889 & 13.989 \\
\hline feb-2016 & 30.727 & 32.940 & 63.667 & 63.667 & 7.743 & 791 & 8.534 & 16.044 & 7.510 & 21.499 \\
\hline mar-2016 & 739 & 31.695 & 32.434 & 32.434 & 186 & 761 & 947 & 8.173 & 7.226 & 28.726 \\
\hline abr-2016 & 73 & 22.042 & 22.115 & 22.115 & 18 & 529 & 547 & 5.573 & 5.026 & 33.752 \\
\hline may-2016 & 24 & 8.194 & 8.218 & 8.218 & 6 & 197 & 203 & 2.071 & 1.868 & 35.620 \\
\hline oct-2016 & 4.184 & 5.522 & 9.706 & 9.706 & 1.054 & 133 & 1.187 & 2.446 & 1.259 & 36.879 \\
\hline nov-2016 & 328 & 26.013 & 26.341 & 26.341 & 83 & 624 & 707 & 6.638 & 5.931 & 42.810 \\
\hline dic-2016 & 48 & 33.208 & 33.256 & 33.256 & 12 & 797 & 809 & 8.381 & 7.571 & 50.381 \\
\hline ene-2017 & 0 & 37.659 & 37.659 & 37.659 & 0 & 904 & 904 & 9.490 & 8.586 & 58.967 \\
\hline feb-2017 & 0 & 25.322 & 25.322 & 25.322 & 0 & 608 & 608 & 6.381 & 5.773 & 64.741 \\
\hline mar-2017 & 0 & 21.876 & 21.876 & 21.876 & 0 & 525 & 525 & 5.513 & 4.988 & 69.729 \\
\hline abr-2017 & 0 & 13.691 & 13.691 & 13.691 & 0 & 329 & 329 & 3.450 & 3.122 & 72.850 \\
\hline may-2017 & 496 & 7.282 & 7.778 & 7.778 & 125 & 175 & 300 & 1.960 & 1.660 & 74.510 \\
\hline oct-2017 & 3.048 & 2.345 & 5.393 & 5.393 & 768 & 56 & 824 & 1.359 & 535 & 75.045 \\
\hline nov-2017 & 24 & 21.813 & 21.837 & 21.837 & 6 & 524 & 530 & 5.503 & 4.973 & 80.018 \\
\hline dic-2017 & 0 & 36.608 & 36.608 & 36.608 & 0 & 879 & 879 & 9.225 & 8.347 & 88.365 \\
\hline ene-2018 & 112 & 38.003 & 38.115 & 38.115 & 28 & 912 & 940 & 9.605 & 8.665 & 97.030 \\
\hline feb-2018 & 128 & 43.010 & 43.138 & 43.138 & 32 & 1.032 & 1.064 & 10.871 & 9.806 & 106.836 \\
\hline mar-2018 & 168 & 32.577 & 32.745 & 32.745 & 42 & 782 & 824 & 8.252 & 7.428 & 114.264 \\
\hline abr-2018 & 424 & 21.713 & 22.137 & 22.137 & 107 & 521 & 628 & 5.579 & 4.951 & 119.214 \\
\hline may-2018 & 0 & 12.372 & 12.372 & 12.372 & 0 & 297 & 297 & 3.118 & 2.821 & 122.035 \\
\hline
\end{tabular}

Como se observa durante estas tres temporadas se ha obtenido un ahorro total de 122 Toneladas de $\mathrm{CO}_{2}$, debido al cambio de la energía utilizada. 


\section{AV.7.6. Estimación del precio máximo de compra a la red.}

Tomando como referencia los precios del gas natural de la Tabla 546 para cada temporada, obtenidos a partir de los datos establecidos en el Capítulo 3, donde se tiene en cuenta el precio por el termino variable y fijo; se puede realizar la estimación del precio máximo de compra de la energía útil a la red de calor para obtener un $0 \%$ de ahorro y un 15\% de ahorro. La Tabla 547, muestral el precio que se pagaría para un ahorro del 15\%

Tabla 546. Precios de referencia para Gas natural y Astilla

\begin{tabular}{ccccc}
\hline Precios ( $€ /(\mathrm{kWh})$ & 2015 & 2016 & 2017 & 2018 \\
\hline Gas Natural & 0,0373 & 0,0306 & 0,0314 & 0,0336 \\
\hline Astilla & 0,0277 & 0,0256 & 0,0254 & 0,0239 \\
\hline $\begin{array}{c}€ / \text { kWh útiles máximos de compra a la red para } \\
\text { un ahorro del 0,0\% }\end{array}$ & 0,03208 & \\
\hline $\begin{array}{c}€ / \text { kWh útiles máximos de compra a la red para } \\
\text { un ahorro del 15,0\% }\end{array}$ & 0,02758 \\
\hline
\end{tabular}

Tabla 547. Ahorro Económico por el consumo térmico en el Edificio E7

\begin{tabular}{|c|c|c|c|c|c|c|c|c|c|c|}
\hline & $\begin{array}{c}\text { kWh_E7 } \\
\text { Gas } \\
\text { natural }\end{array}$ & $\begin{array}{l}\text { kWh_E7_- } \\
\text { Biomasa }\end{array}$ & $\begin{array}{c}\text { kWh_E7 } \\
\text { Real }\end{array}$ & $\begin{array}{c}\text { kWh_E7 } \\
\text { Pronosticado }\end{array}$ & $\begin{array}{l}€ \text { Real } \\
\text { Gas } \\
\text { Natural }\end{array}$ & $\begin{array}{c}€ \text { Real } \\
\text { Biomasa }\end{array}$ & $\begin{array}{l}€ \text { Real } \\
\text { Total }\end{array}$ & $\begin{array}{c}\text { € predicho } \\
\text { Gas } \\
\text { Natural }\end{array}$ & $\begin{array}{c}€ \\
\text { Ahorro }\end{array}$ & $€$ Acumulado \\
\hline oct-2015 & 0 & 4.549 & 4.549 & 4.549 & 0 & 125 & 125 & 170 & 44 & 44 \\
\hline nov-2015 & 0 & 15.559 & 15.559 & 15.559 & 0 & 429 & 429 & 580 & 151 & 195 \\
\hline dic-2015 & 0 & 11.035 & 11.035 & 11.035 & 0 & 304 & 304 & 412 & 107 & 303 \\
\hline ene-2016 & 0 & 30.213 & 30.213 & 30.213 & 0 & 833 & 833 & 925 & 91 & 394 \\
\hline feb-2016 & 30.727 & 32.940 & 63.667 & 63.667 & 940 & 908 & 1.849 & 1.948 & 99 & 493 \\
\hline mar-2016 & 739 & 31.695 & 32.434 & 32.434 & 23 & 874 & 897 & 992 & 96 & 589 \\
\hline abr-2016 & 73 & 22.042 & 22.115 & 22.115 & 2 & 608 & 610 & 677 & 67 & 656 \\
\hline may-2016 & 24 & 8.194 & 8.218 & 8.218 & 1 & 226 & 227 & 251 & 25 & 680 \\
\hline oct-2016 & 4.184 & 5.522 & 9.706 & 9.706 & 128 & 152 & 280 & 297 & 17 & 697 \\
\hline nov-2016 & 328 & 26.013 & 26.341 & 26.341 & 10 & 717 & 727 & 806 & 79 & 776 \\
\hline dic-2016 & 48 & 33.208 & 33.256 & 33.256 & 1 & 916 & 917 & 1.018 & 100 & 876 \\
\hline ene-2017 & 0 & 37.659 & 37.659 & 37.659 & 0 & 1.039 & 1.039 & 1.182 & 144 & 1.020 \\
\hline feb-2017 & 0 & 25.322 & 25.322 & 25.322 & 0 & 698 & 698 & 795 & 97 & 1.117 \\
\hline mar-2017 & 0 & 21.876 & 21.876 & 21.876 & 0 & 603 & 603 & 687 & 84 & 1.200 \\
\hline$a b r-2017$ & 0 & 13.691 & 13.691 & 13.691 & 0 & 378 & 378 & 430 & 52 & 1.252 \\
\hline may-2017 & 496 & 7.282 & 7.778 & 7.778 & 16 & 201 & 216 & 244 & 28 & 1.280 \\
\hline oct-2017 & 3.048 & 2.345 & 5.393 & 5.393 & 96 & 65 & 160 & 169 & 9 & 1.289 \\
\hline nov-2017 & 24 & 21.813 & 21.837 & 21.837 & 1 & 602 & 602 & 686 & 83 & 1.373 \\
\hline dic-2017 & 0 & 36.608 & 36.608 & 36.608 & 0 & 1.010 & 1.010 & 1.149 & 140 & 1.512 \\
\hline ene-2018 & 112 & 38.003 & 38.115 & 38.115 & 4 & 1.048 & 1.052 & 1.281 & 229 & 1.741 \\
\hline feb-2018 & 128 & 43.010 & 43.138 & 43.138 & 4 & 1.186 & 1.191 & 1.449 & 259 & 2.000 \\
\hline mar-2018 & 168 & 32.577 & 32.745 & 32.745 & 6 & 898 & 904 & 1.100 & 196 & 2.196 \\
\hline abr-2018 & 424 & 21.713 & 22.137 & 22.137 & 14 & 599 & 613 & 744 & 131 & 2.327 \\
\hline may-2018 & 0 & 12.372 & 12.372 & 12.372 & 0 & 341 & 341 & 416 & 74 & 2.401 \\
\hline$€$ Total & & & & & & & 16.007 & 18.409 & & \\
\hline Ahorro (\%) & & & & & & & & & & $15,0 \%$ \\
\hline
\end{tabular}




\section{AV.8. Edificio E8. Facultad de Ciencias de la Salud.}

\section{AV.8.1. Obtención de la línea base de referencia energética}

Los datos de partida para la obtención de la línea base de referencia se muestran en la Tabla 548

Tabla 548. Consumos térmicos del edificio E8

\begin{tabular}{lr}
\hline & Consumos térmicos \\
\hline oct-12 & \\
\hline nov-12 & E8 \\
\hline dic-12 & 187.728 \\
\hline ene-13 & 192.155 \\
\hline feb-13 & 342.443 \\
\hline mar-13 & 348.845 \\
\hline abr-13 & 381.056 \\
\hline may-13 & 183.948 \\
\hline oct-13 & 62.781 \\
\hline nov-13 & 39.057 \\
\hline dic-13 & 237.231 \\
\hline ene-14 & 443.980 \\
\hline feb-14 & 349.596 \\
\hline mar-14 & 496.930 \\
\hline abr-14 & 367.450 \\
\hline may-14 & 219.679 \\
\hline Promedio & 11.049 \\
\hline Total (oct-12-may-13) & 244.296 \\
\hline Total (oct-13-may-14) & 1.743 .765 \\
\hline Total (oct-12-may-13) & 2.164 .972 \\
\hline
\end{tabular}

Se disponen de 16 datos para establecer el modelo de regresión, mediante el método de pasos sucesivos.

Utilizando el programa SPSS V.20, se obtiene el modelo de regresión mediante el método de pasos sucesivos. Como se puede ver en la Tabla 549 para el edificio E8, el método ofrece dos modelos de regresión, uno con una sola variable (Temperatura mínima) y otro con dos variables (Temperatura mínima y velocidad del viento diurna).

El primer modelo (modelo de regresión lineal simple) fue construido con un solo paso, incluyendo la Temperatura mínima por ser la variable más significativa (variable con menor valor de Sig $=0,000$ ) que indica la probabilidad de cometer un error al rechazar que la pendiente de la variable "Temperatura mínima" es igual a cero, por lo que se acepta que esa variable forma parte del modelo con una pendiente $(B=-44.158,494)$. 
El segundo modelo (modelo de regresión lineal múltiple) se construyó en dos pasos, primero entró la Temperatura mínima y luego entró la siguiente variable que rechazase la Hipótesis nula, (las variables que rechazan la hipótesis nula son las que presentan una pendiente estadísticamente significativa y su probabilidad de cometer el error de rechazar Ho es $\leq 0,05$, para un nivel de confianza del $95 \%$ ), esta variable fue la "velocidad de viento diurna", por presentar un valor de Sig $=0,015$, el resto de las variables como se observa en la Tabla 550 fueron excluidas del modelo al tener valores de sig $>0,05$, en el segundo paso.

Tabla 549. Modelos de regresión del Edificio E8

\begin{tabular}{|c|c|c|c|c|c|c|c|}
\hline & \multirow{2}{*}{ Modelo } & \multicolumn{2}{|c|}{$\begin{array}{l}\text { Coeficientes no } \\
\text { estandarizados }\end{array}$} & \multirow{2}{*}{$\mathrm{t}$} & \multirow{2}{*}{ Sig. } & \multicolumn{2}{|c|}{$\begin{array}{c}\text { Intervalo de confianza de } \\
95,0 \% \text { para B } \\
\end{array}$} \\
\hline & & B & Error típ. & & & $\begin{array}{l}\text { Límite } \\
\text { inferior }\end{array}$ & $\begin{array}{l}\text { Límite } \\
\text { superior }\end{array}$ \\
\hline \multirow[t]{2}{*}{1} & (Constante) & 381573,782 & 36199,641 & 10,541 & ,000 & 303933,275 & 459214,290 \\
\hline & T_min & $-44158,494$ & 8822,708 & $-5,005$ & ,000 & $-63081,320$ & $-25235,668$ \\
\hline \multirow[t]{3}{*}{2} & (Constante) & 88655,039 & 87752,034 & 1,010 & 331 & $-100921,704$ & 278231,783 \\
\hline & T_min & $-37820,664$ & 6807,193 & $-5,556$ & ,000 & $-52526,711$ & $-23114,617$ \\
\hline & V_viento_diurna_m/s & 99081,056 & 28250,440 & 3,507 & ,004 & 38049,690 & 160112,422 \\
\hline
\end{tabular}

En la Figura 337 se representa el modelo 1 de regresión con sus límites inferior y superior para un nivel de confianza del $95 \%$

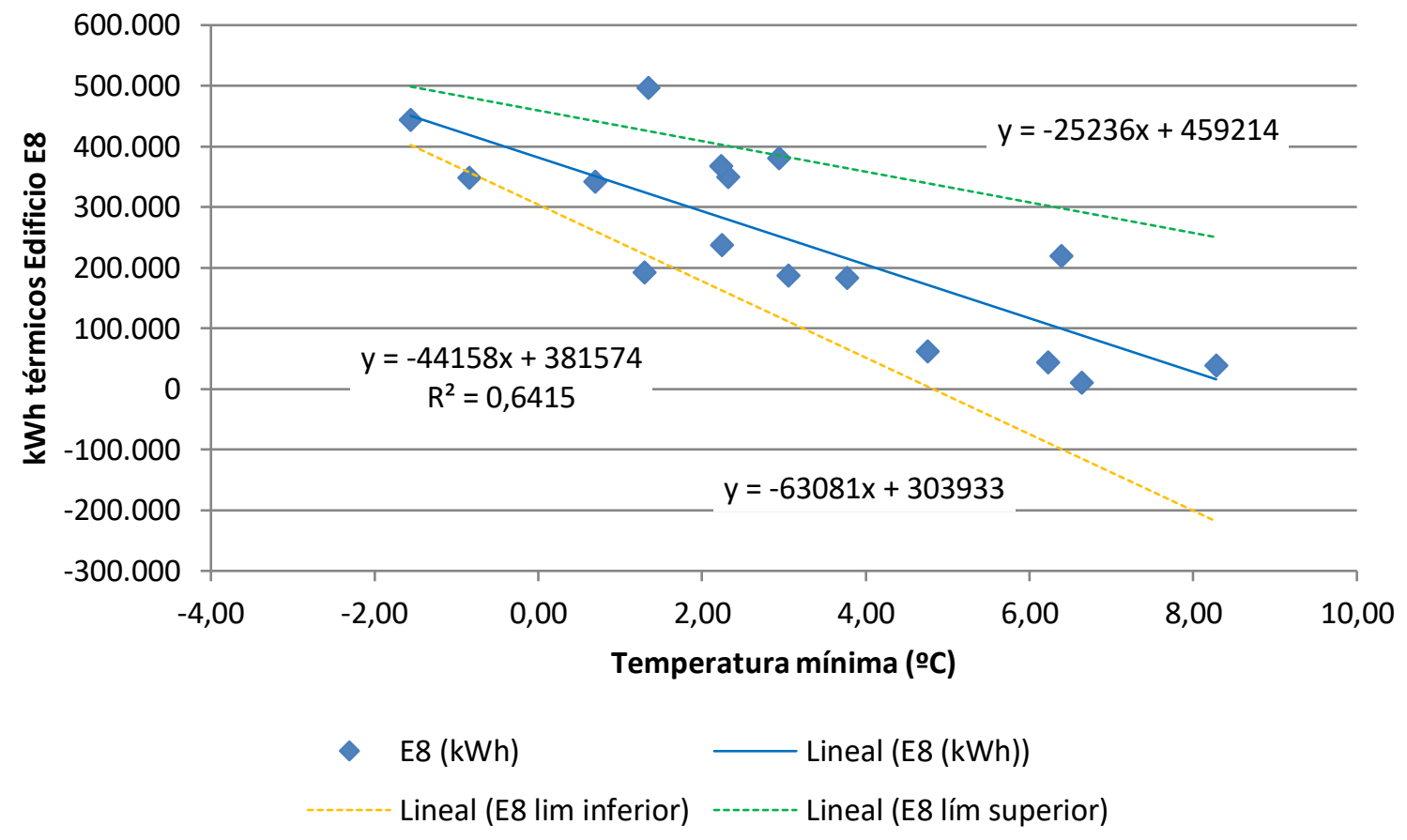

Figura 337. Representación del modelo de regresión lineal simple para el Edificio E8 
En la Figura 338 se representa el modelo 2 de regresión lineal múltiple para el edificio E8

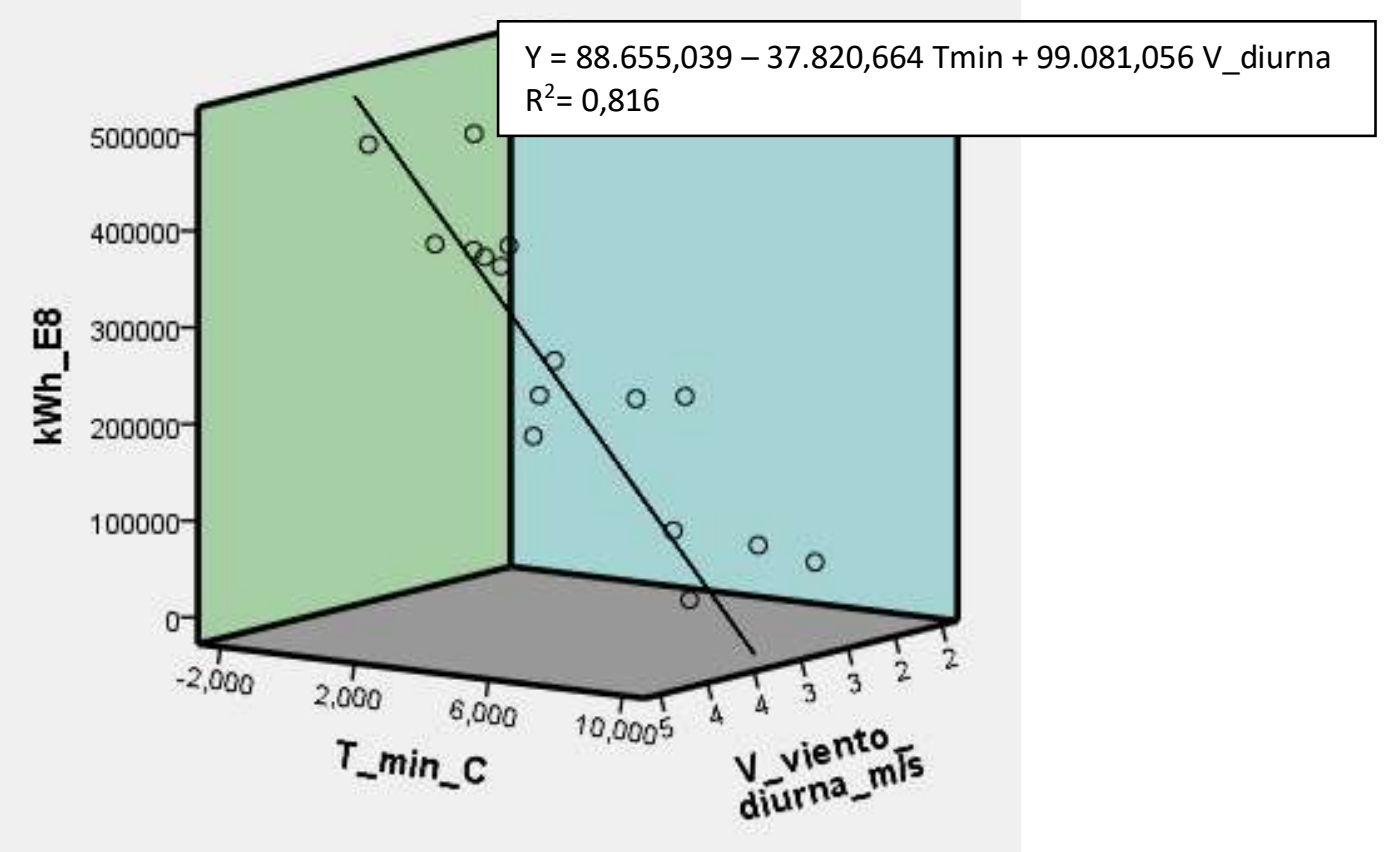

Figura 338. Representación del modelo de regresión lineal múltiple para el Edificio E8

Los valores de la columna $\mathrm{t}$ se obtienen dividiendo el valor de los coeficientes no estandarizados entre sus errores típicos, este estadístico tiende a ser mayor en valor absoluto cuando la hipótesis alternativa es verdadera, es decir cuando la variable posee una pendiente significativa en el modelo de regresión.

En las Tabla 549 y Tabla 550, el estadístico t y su nivel crítico (Sig), permiten contrastar la hipótesis nula consistente en que el coeficiente de regresión vale cero en el modelo; a mayor valor de t, mayor peso en el modelo.

El valor "Sig" corresponde a los valores de probabilidad de los valores de $t$, es la probabilidad de obtener el valor de t si la hipótesis nula fuera cierta, cuando son $\leq 0,05$ se rechaza la hipótesis nula y se concluye que las pendientes son distintas de cero, luego si Sig $>0,05$ se acepta la hipótesis nula de que la pendiente de la variable independiente en el modelo de regresión es igual a cero, no cumpliendo el criterio de entrada en el modelo.

La correlación parcial, que aparece en la Tabla 550 estudia la relación existente entre dos variables cuantitativas cuando se controla o elimina el efecto de terceras variables, en el modelo de regresión lineal, a mayor valor absoluto, mayor relación entre la variable dependiente y la independiente. 
Anexo V. Desarrollo del análisis de los edificios del Campus Río Esgueva

Tabla 550. Variables excluidas del modelo de región del Edificio E8

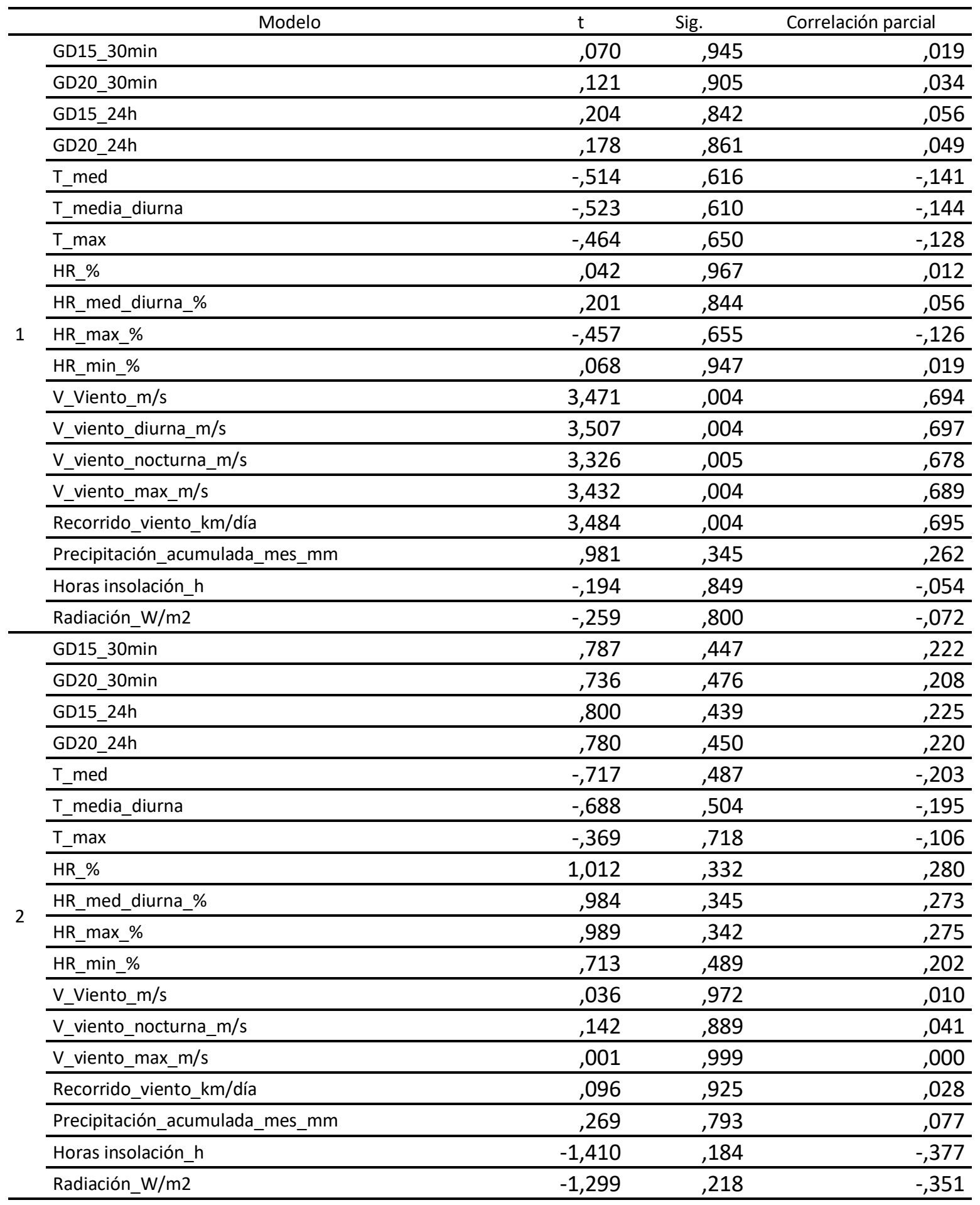


La bondad de los modelos de regresión obtenidos para el edificio E8, se resumen en la Tabla 551

Tabla 551. Resumen de la bondad de los modelos de regresión para el Edificio E8

\begin{tabular}{|c|c|c|c|c|}
\hline Modelo & $\mathrm{R}$ & R cuadrado & R cuadrado corregida & $\begin{array}{l}\text { Error típ. de la } \\
\text { estimación }\end{array}$ \\
\hline 1 &,- 801 & 641 & ,616 & 94500,0444 \\
\hline 2 &,- 903 & 816 & ,787 & 70295,8236 \\
\hline
\end{tabular}

Se observa como el modelo 1 de regresión lineal simple presenta un Coeficiente de Correlación de Pearson (R) inferior en valor absoluto al modelo 2 de regresión lineal múltiple, este coeficiente indica que las variables de los modelos están correlacionadas de manera muy fuerte (en la correlación perfecta $R= \pm 1$ ). La correlación que se produce en ambos modelos es inversa, al aumentar el valor de las variables independientes disminuye el valor de la variable dependiente que es el consumo térmico.

El coeficiente de determinación $\left(R^{2}\right)$, nos indica que con el modelo 1 se podría explicar el $64,1 \%$ de los datos reales obtenidos y el modelo 2 , el porcentaje de aciertos o de explicación asciende al 81,6\%, ambos aceptando un error del 5\%.

El coeficiente de determinación corregido $\left(R^{2}\right.$ corregido) que tiene en cuenta el número de variables independientes incluidas en el modelo y el tamaño de la muestra, reduce el coeficiente de determinación al 61,6\% en el modelo 1 y al 78,7 \% en el modelo 2.

El error típico de la estimación que nos indica la magnitud de los errores, es decir la parte de la variable dependiente que dejamos sin explicar con el modelo y que describe la variación de la variable respuesta (el Consumo) respecto a la recta de regresión, es de $94.500 \mathrm{kWh}$ para el modelo 1 y de $70.296 \mathrm{kWh}$ para el modelo 2, lo que representa un $38,7 \%$ del promedio de los consumos que fue de $244.296 \mathrm{kWh}$ para el modelo $1 \mathrm{y}$ del 28,8\% para el modelo 2. Por tanto aunque el modelo 2 es más preciso, también es aceptado el modelo 1 para la representación de la línea base de los consumos térmicos del edificio E8. 


\section{AV.8.2. Verificación del cumplimiento de los supuestos estadísticos}

Las condiciones que se deben cumplir en un modelo de regresión son:

\section{- Linealidad de las variables, las variables se encuentran relacionadas de forma lineal.}

Como se observa en la Tabla 549, la pendiente (B), para el modelo 1, obtuvo un valor de Sig $=0,000$, que al ser $\leq 0,05$, nos indica que podemos rechazar la hipótesis nula de pendiente igual a cero y nos da la evidencia de linealidad entre la variable dependiente (kWh del edificio E8) y la independiente (Temperatura mínima). Al ser el valor de la pendiente negativa, indica una relación inversa entre el consumo y la Temperatura mínima.

Para el modelo 2, según la misma Tabla 549, las pendientes de las dos variables introducidas en el modelo obtuvieron unos valores de Sig $=0,000$ para la Temperatura mínima y de 0,004 para la Velocidad del viento diurna, ambos $\leq 0,05$, lo que nos indica que podemos rechazar la hipótesis nula de pendiente igual a cero y nos da la evidencia de linealidad entre la variable dependiente ( $\mathrm{kWh}$ del edificio E8) y las independientes (Temperatura mínima y velocidad del viento diurna). Al ser el valor de la primera pendiente negativa, indica una relación inversa entre el consumo y la Temperatura media y de la segunda pendiente positiva, indica relación directa entre el consumo y la velocidad del viento diurna.

- Normalidad. Todos los valores obtenidos para la variable dependiente (Y), deben estar distribuidos normalmente en cada valor de las variables independientes $(X)$.

Se comprueba la normalidad de las variables y de los residuos mediante el Test de Shapiro - Wilk para muestras pequeñas (menores a 30 observaciones), siendo la hipótesis nula el que la distribución es Normal, luego si la probabilidad del estadístico del test es $\leq$ al nivel de significación 0,05, la hipótesis nula es rechazada y sólo aceptaremos que las variables se distribuyen según una Normal cuando el valor de la significación sea mayor que 0,05 (valor de la significación >0,05) en el Test de Shapiro Wilk.

La Tabla 552, muestra la prueba de normalidad de Shapiro-Wilk y cómo tanto la variable dependiente (consumos del Edificio E8), como las variables independientes: Temperatura media y velocidad de viento nocturna poseen una Sig $>0,05$, por lo que aceptamos la hipótesis nula de Normalidad de las variables 
Tabla 552. Prueba de normalidad para el edificio E8

\begin{tabular}{lrrrrrrr}
\hline & \multicolumn{3}{c}{ Kolmogorov-Smirnov } & \multicolumn{3}{c}{ Shapiro-Wilk } \\
\cline { 2 - 8 } & Estadístico & gl & Sig. & Estadístico & gl & \multicolumn{1}{c}{ Sig. } \\
\hline kWh_E8 &, 178 & 16 &, 190 &, 939 & 16 &, 335 \\
\hline T_min &, 133 & 16 &, 200 &, 968 & 16 &, 813 \\
\hline V_viento_nocturna_m/s &, 156 & 16 &, 200 &, 948 & 16 &, 453 \\
\hline
\end{tabular}

- Independencia de los errores. Los errores asociados a los valores de la variable respuesta $(Y)$ deberán ser independientes unos de otros.

Para la comprobación se utiliza el estadístico de Durbin -Watson.

Se comprueba que el Estadístico de Durbin Watson para el nivel de significancia del 5\%, y para el tamaño de la muestra " $n$ " y el número de variables independientes del modelo " $k$ ", se encuentra en el intervalo [dU, 4-dU], de la Tabla 3, intervalo centrado en el 2, que indica la ausencia de autocorrelación.

El valor del Estadístico Durbin-Watson facilitado por el programa SPSS, es:

- para el modelo 1 de 1,477 (Regresión lineal simple)

- para el modelo 2 de 2,059 (Regresión lineal múltiple)

En el modelo $1, n=16$ y $k=1$, según la Tabla 3 , el valor $d U=1,371$, luego el intervalo que marca la ausencia de correlación es [1,371, 2,629], como el valor del estadístico 1,477 está dentro del intervalo, se acepta la ausencia de autocorrelación

En el modelo 2, $\mathrm{n}=16$ y $\mathrm{k}=2$, según la Tabla 3, el valor $\mathrm{dU}=1,539$ y $\mathrm{dL}=0,982$, luego el intervalo que marca la ausencia de correlación es [1,539, 2,461].

Los intervalos $[0,0,982]$ y $[3,018,4]$ indican correlación positiva o negativa respectivamente y las zonas $[0,982,1,539]$ y $[2,461,3,018]$ son zonas no concluyentes; como el valor del estadístico 2,059 está dentro del intervalo de ausencia de autocorrelación, se acepta que los residuos no están correlacionados.

- Homocedasticidad de la varianza. Se pretende comprobar que la varianza de los errores $\left(\sigma^{2}\right)$ es constante para cualquier valor de la(s) variable(s) independiente(s) (X), es decir que el valor medio del cuadrado de la desviación de los errores respecto a su media es constante.

Esta condición indica que el error es una variable aleatoria que tomará un valor distinto cada vez que se ejecute el modelo y que no existe correlación entre los residuos y los pronósticos. 
La forma de comprobar la homocedasticidad es verificando si el coeficiente de determinación $\mathrm{R}^{2}$, que indica la proporción de la variable dependiente ( $\mathrm{Y}$ o consumo del edificio) que puede ser explicada por la variación de las variables independientes (las variables climatológicas), en las relaciones: residuos y predicciones y entre residuos y variables independientes es nulo o muy próximo a cero, lo que indicará que no existe ningún tipo de correlación en los residuos y que éstos son aleatorios.

Se grafican los diagramas de dispersión de esas relaciones, comprobando que se corresponden a nubes de puntos totalmente aleatorias, sin tendencias ni patrones en sus representaciones gráficas. Para el modelo 1. Regresión lineal simple, las Figura 339 y Figura 340, muestran que la relación entre los pronósticos y los residuos, posee un coeficiente de determinación $=-2,22 \times 10^{-16}$ y entre la variable independiente (Temperatura mínima) y los residuos un coeficiente de determinación de 0 ; por lo que se concluye que no existe ningún tipo de correlación en los residuos y que éstos son aleatorios, siendo la varianza de los residuos constante.

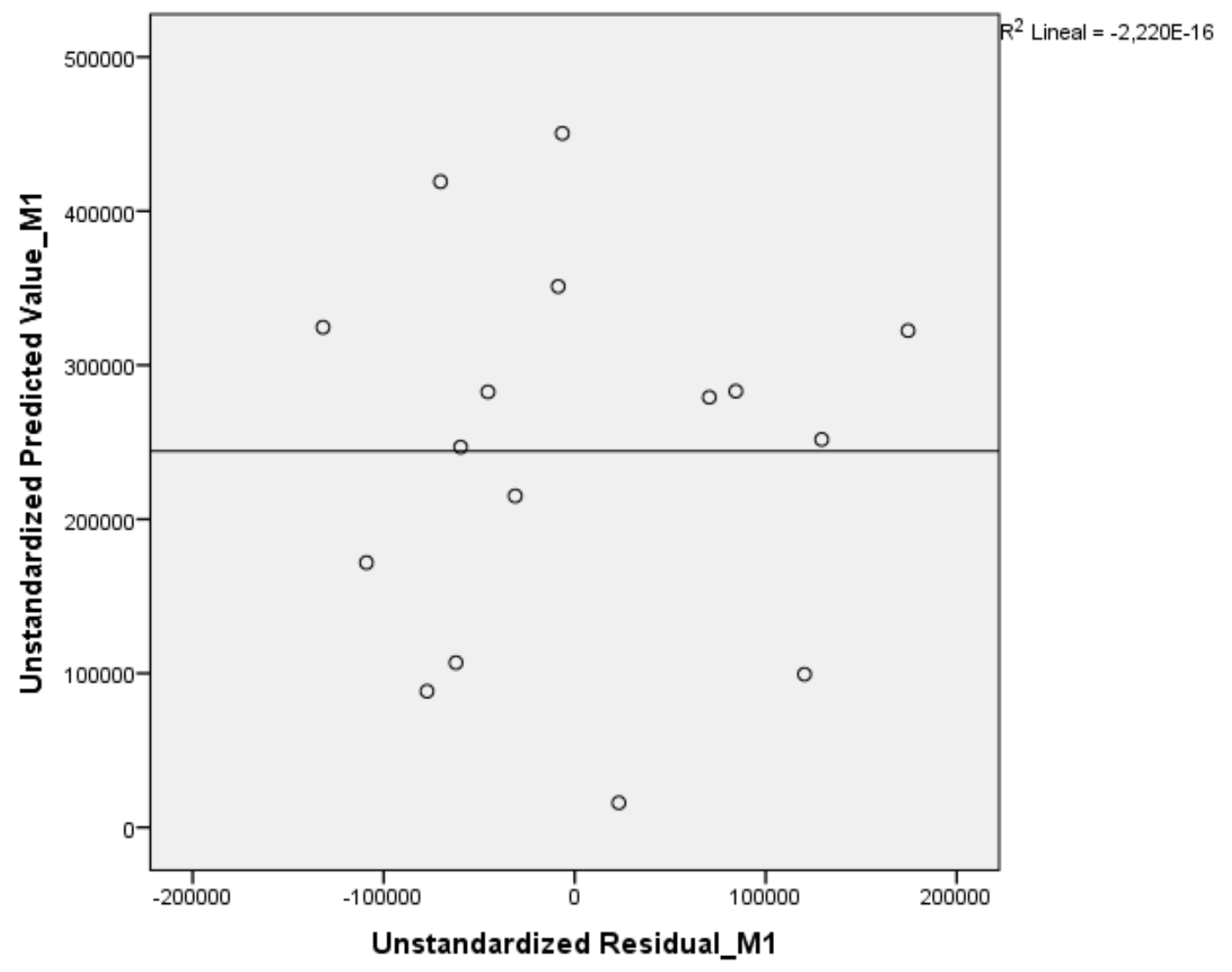

Figura 339. Relación entre los pronósticos y los residuos en el Edificio E8. Modelo 1 


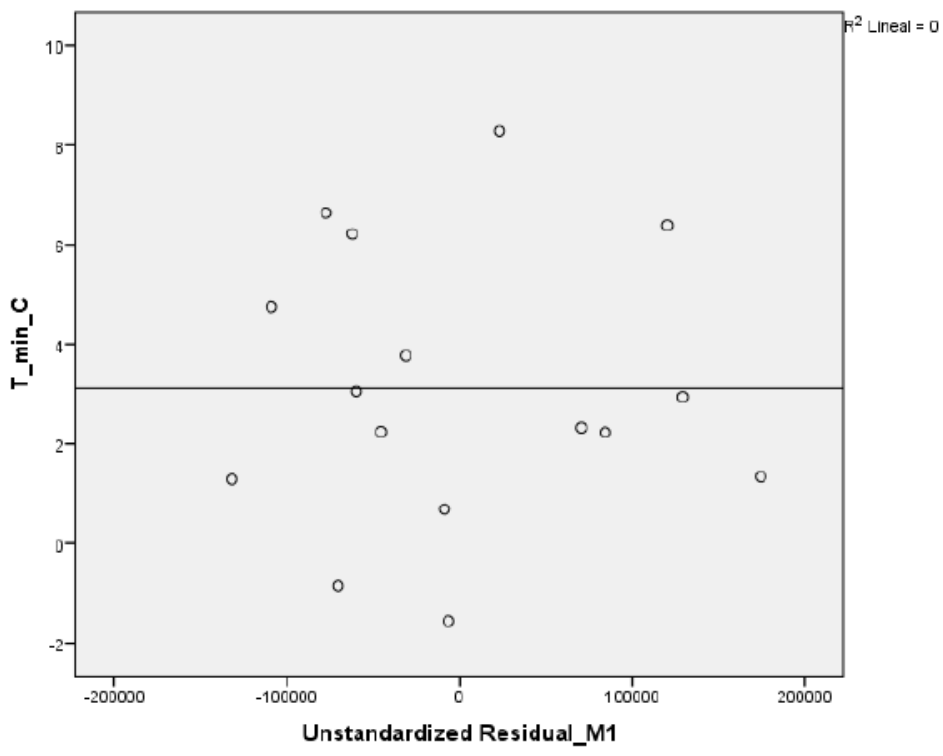

Figura 340. Relación entre la Temperatura media y los residuos en el Edificio E8. Modelo 1

Para el modelo 2. Regresión lineal múltiple, las Figura 341, Figura 342 y Figura 343, muestran que la relación entre los pronósticos y los residuos, posee un coeficiente de determinación $=-2,22 \times 10^{-16}$, entre la variable independiente (Temperatura mínima) y los residuos un coeficiente de determinación, también de 0 y entre la variable independiente (velocidad del viento diurna) y los residuos de 0,452 , por lo que se concluye que existe una pequeña correlación en los residuos y la velocidad del viento diurna, lo que hace que el Modelo 2 sea descartado.

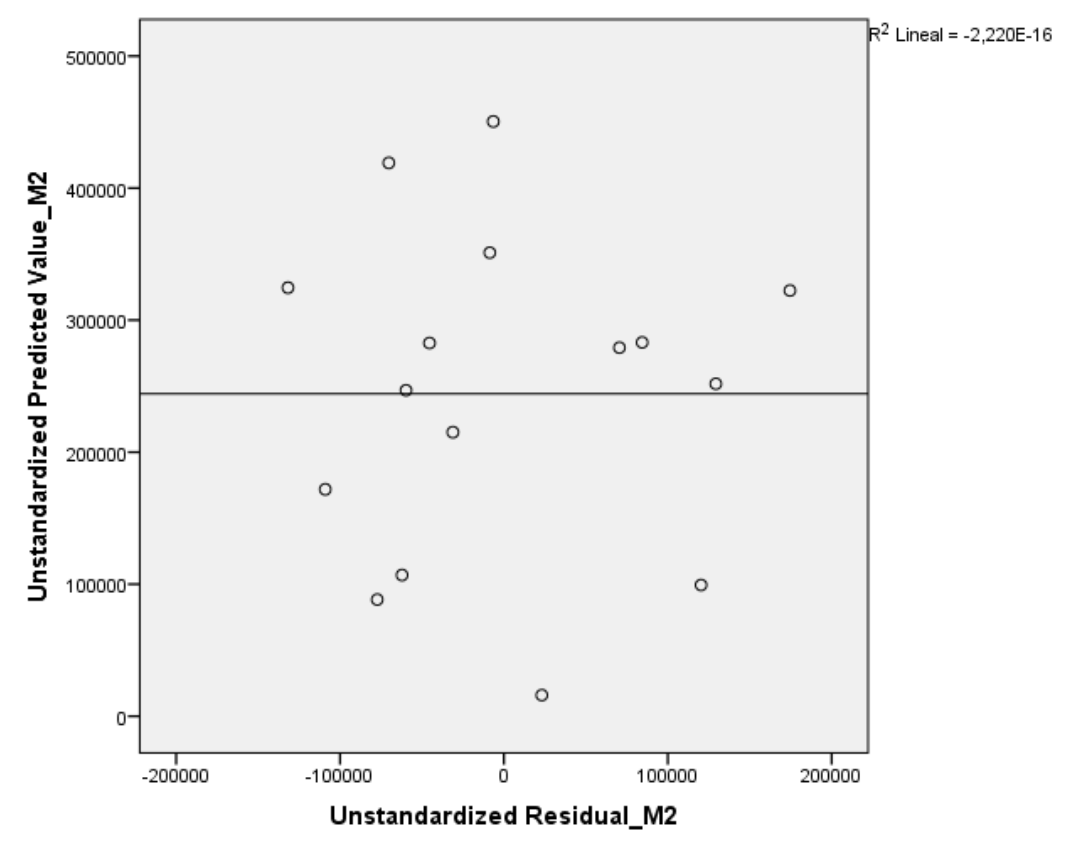

Figura 341. Relación entre los pronósticos y los residuos en el Edificio E8. Modelo 2 


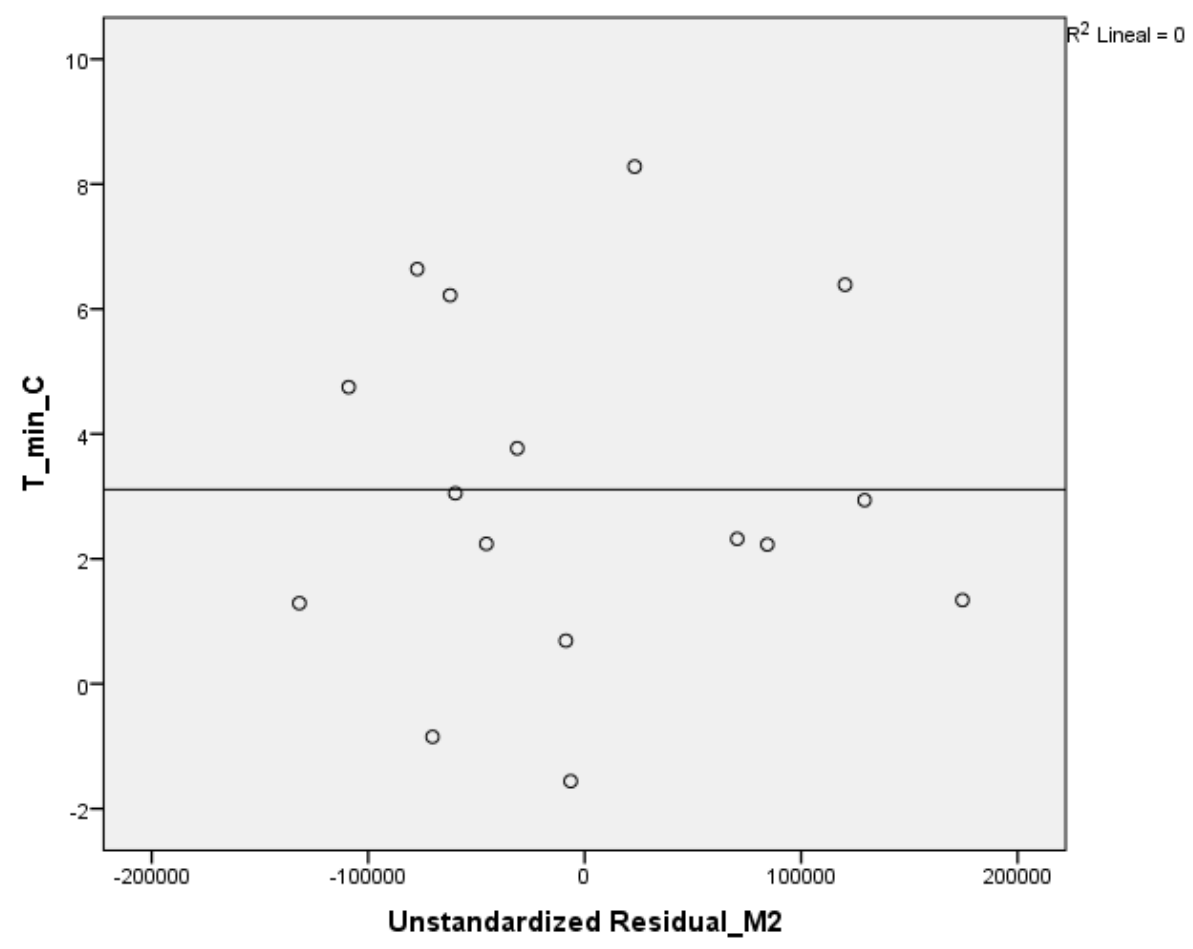

Figura 342. Relación entre la Temperatura media y los residuos en el Edificio E8. Modelo 2

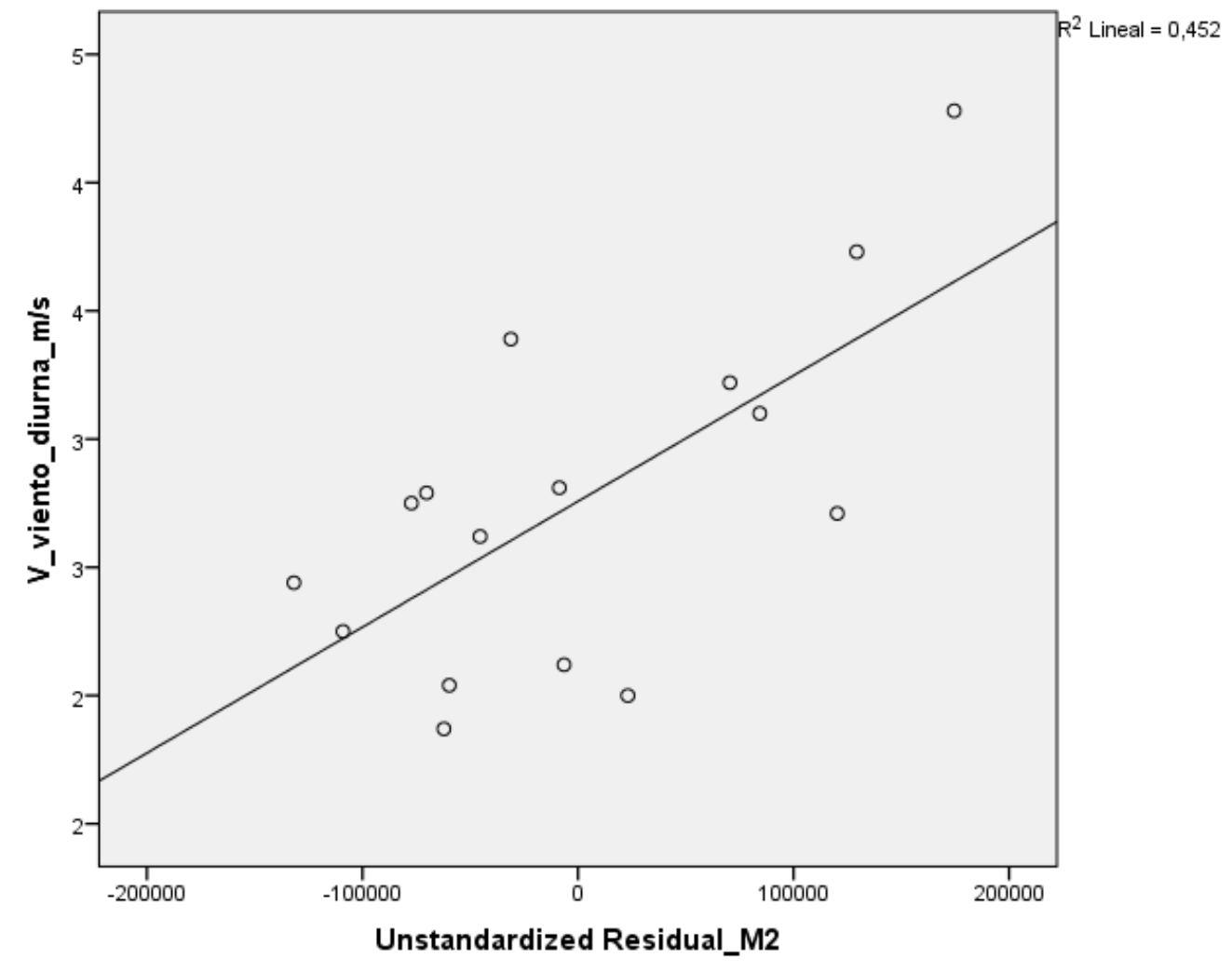

Figura 343. Relación entre la velocidad del viento nocturna y los residuos. Edificio E8. Modelo 2 
- Cuando la regresión es lineal múltiple, se comprueba la falta de multicolinealidad o No-Colinealidad entre las variables independientes, es decir que las variables que forman parte del modelo no están correlacionadas entre ellas.

El problema de la multicolinealidad es moderado cuando el índice de condición toma un valor entre 20 y 30 y es grave cuando el índice de condición toma un valor superior a 30. El número de condición mide la sensibilidad de las estimaciones mínimo-cuadráticas ante pequeños cambios en los datos a mayor valor más correlación entre las variables.

La Tabla 553, muestra los índices de condición de las variables del modelo de regresión múltiple, ninguno de ellos supera el valor 20, por lo que no existen evidencias de correlación entre las variables independientes del modelo

Tabla 553. Índice de condición de las variables independientes del Modelo 2 en el Edificio E8

\begin{tabular}{llr}
\hline Modelo & Dimensión & Índice de condición \\
\hline \multirow{2}{*}{2} & 1 & 1,000 \\
\cline { 2 - 3 } & 2 & 2,732 \\
\cline { 2 - 3 } & 3 & 10,866 \\
\hline
\end{tabular}

En cuanto a los índices estadísticos de colinealidad como son los niveles Tolerancia y su inverso que son los Factores de Inflación de la Varianza (FIV). El nivel de tolerancia se obtiene restando a 1 el coeficiente de determinación $\left(R^{2}\right)$. Como se observa en la Figura 344 , el coeficiente de determinación entre las dos variables independientes es $R^{2}=0,070$, luego la Tolerancia es $T=1-R^{2}=1-0,070=0,930$ y $\mathrm{FIV}=1 / \mathrm{T}=1,076$

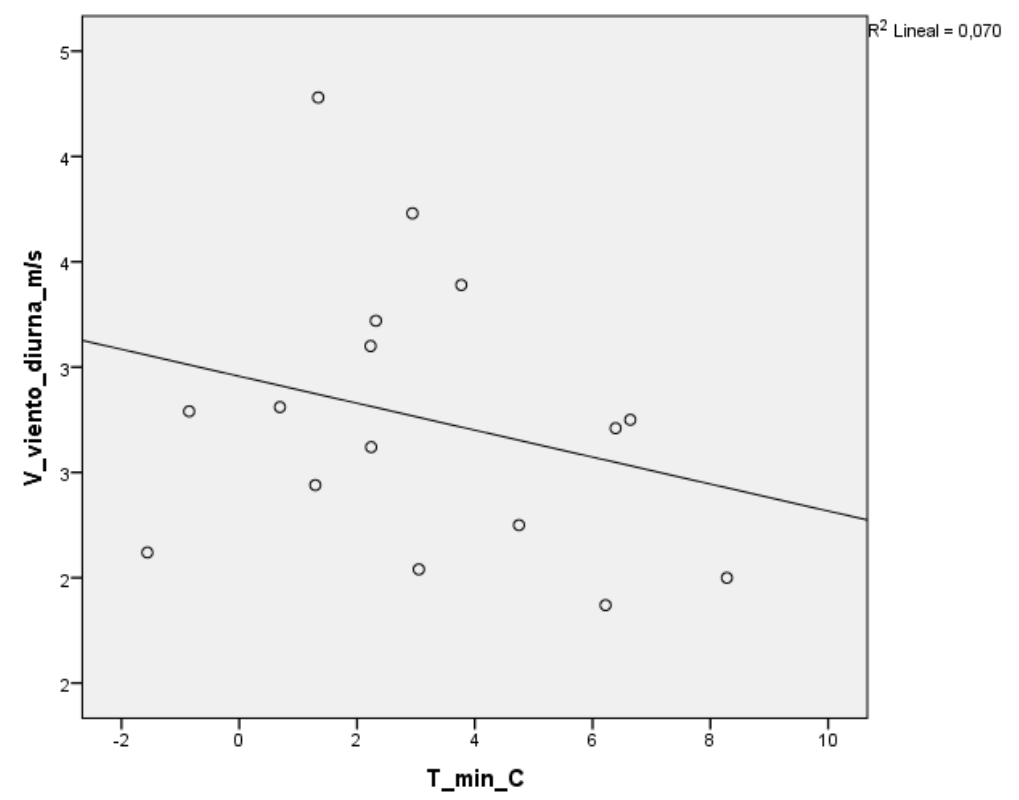

Figura 344. Gráfico de la temperatura mínima y la velocidad del viento diurna. 
Si la Tolerancia toma un valor próximo a la unidad no existirá colinealidad (a mayor tolerancia menor colinealidad), por lo que se podrá deducir que no existe multicolinealidad entre las variables independientes. Pueden existir problemas de colinealidad si algún FIV es superior a 10 , que corresponde con un $R^{2}$ de 0,9 y una Tolerancia menor a 0,1

La Tabla 554, muestra los estadísticos de colinealidad y se observa como la Tolerancia toma valores de 0,930, próxima a 1 y los valores de FIV permanecen por debajo de 10, por lo que no existen problemas de colinealidad entre la temperatura mínima y la velocidad del viento diurna.

Tabla 554. Estadísticos de colinealidad para los modelos del Edificio E8

\begin{tabular}{clcc}
\hline Modelo & & Tolerancia & FIV \\
\hline 1 & T_min & 1,000 & 1,000 \\
\multirow{2}{*}{2} & T_min &, 930 & 1,076 \\
\cline { 2 - 4 } & V_viento_diurna_m/s &, 930 & 1,076 \\
\hline
\end{tabular}

\section{AV.8.3. Obtención de los consumos térmicos previstos}

Una vez comprobado el cumplimiento de los supuestos estadísticos se aceptan los modelos de línea base encontrados para modelizar el consumo del Edificio E8.

Modelo 1: $\quad$ kWh_E8 $=381.573,782-44.158,494 \times$ T_min

Modelo 2: kWh_E8 $=88.655,039-37.820,664 \times$ T_min $+99.081,056 \times$ V_viento_diurna

Con estos modelos se procede a predecir los consumos previstos para las temporadas: octubre 2015-mayo 2016, octubre 2016 - mayo 2017 y octubre 2017-mayo 2018, estos consumos se muestran en la Tabla 555, donde "KWh_E8", representa el consumo real, "kWh_E8_M1", el consumo pronosticado con el Modelo 1 y "kWh_E8_M2", el consumo pronosticado con el Modelo 2.

El modelo 2, ha sido descartado por presentar una cierta correlación los residuos con la velocidad de viento diurna 
Anexo V. Desarrollo del análisis de los edificios del Campus Río Esgueva

Tabla 555. Consumos previstos octubre 2014 - mayo 2017 para el edificio E8.

\begin{tabular}{|c|c|c|c|c|c|c|}
\hline & T_mínima & V_viento_nocturna & kWh_E8 & kWh_E8_M1 & kWh_E8_M2 & $\begin{array}{l}\text { kWh_E8_M1 - } \\
\text { kWh_E8_M2 }\end{array}$ \\
\hline oct-15 & 7,50 & 1,72 & 52.860 & 50.385 & -24.293 & 74.678 \\
\hline nov-15 & 4,16 & 1,25 & 288.652 & 198.036 & 54.816 & 143.221 \\
\hline dic-15 & 1,20 & 0,97 & 212.113 & 328.455 & 139.621 & 188.835 \\
\hline ene-16 & 2,63 & 2,53 & 274.832 & 265.636 & 240.416 & 25.220 \\
\hline feb-16 & 1,30 & 3,30 & 452.764 & 324.259 & 366.841 & -42.582 \\
\hline mar-16 & 0,20 & 2,66 & 316.817 & 372.899 & 344.397 & 28.502 \\
\hline$a b r-16$ & 3,83 & 2,67 & 266.496 & 212.432 & 208.237 & 4.195 \\
\hline may-16 & 6,63 & 2,13 & 56.485 & 88.874 & 48.944 & 39.930 \\
\hline oct-16 & 7,14 & 1,08 & 70.515 & 66.356 & -74.729 & 141.085 \\
\hline nov-16 & 2,23 & 1,61 & 337.657 & 283.189 & 163.581 & 119.608 \\
\hline dic-16 & 0,57 & 0,99 & 303.434 & 356.489 & 165.740 & 190.749 \\
\hline ene-17 & $-2,83$ & 1,31 & 440.599 & 506.443 & 325.590 & 180.853 \\
\hline feb-17 & 2,19 & 2,79 & 347.129 & 284.898 & 282.149 & 2.749 \\
\hline mar-17 & 2,59 & 2,69 & 295.002 & 267.331 & 257.050 & 10.282 \\
\hline$a b r-17$ & 3,83 & 2,53 & 114.519 & 212.520 & 194.243 & 18.278 \\
\hline may-17 & 9,02 & 2,07 & 29.943 & -16.836 & -47.091 & 30.256 \\
\hline oct-17 & 6,71 & 1,50 & 29.261 & 85.470 & -16.809 & 102.278 \\
\hline nov-17 & $-0,28$ & 1,42 & 240.790 & 393.923 & 239.894 & 154.029 \\
\hline dic-17 & $-0,44$ & 2,28 & 316.883 & 400.833 & 331.470 & 69.363 \\
\hline ene-18 & 0,66 & 2,23 & 335.954 & 352.614 & 284.515 & 68.099 \\
\hline feb-18 & $-1,96$ & 2,42 & 399.029 & 467.919 & 401.959 & 65.960 \\
\hline mar-18 & 2,74 & 4,38 & 351.334 & 260.594 & 418.758 & -158.164 \\
\hline abr-18 & 5,73 & 2,77 & 153.387 & 128.619 & 146.526 & -17.907 \\
\hline may-18 & 7,82 & 2,00 & 38.661 & 36.140 & -9.166 & 45.306 \\
\hline
\end{tabular}

Los datos pronosticados que han resultado ser negativos serán anulados de los modelos, por representar valores imposibles En la mayoría de los meses los consumos pronosticados con el modelo 1, son superiores a los pronosticados con el Modelo 2

\section{AV.8.4. Estudio de la existencia de diferencias significativas}

Utilizando el contraste de hipótesis para la comparación de medias para muestras relacionadas, es decir la prueba paramétrica " $\mathrm{t}$ " de Student para muestras relacionadas, podemos concluir que si las variables se distribuyen según una normal y la significación estadística resulta $\leq 0,05$, existen diferencias significativas. En caso contrario no se rechaza la hipótesis nula de igualdad de medias, concluyendo que las diferencias encontradas no son estadísticamente significativas y no van más allá de lo que sería esperable por azar, todo ello con la aceptación de un riesgo de error del 5\%, o lo que es lo mismo un nivel de confianza del $95 \%$ 
A continuación se muestra la comparación de medias realizada para cada uno de los tres periodos posteriores a la construcción de la red y para el periodo total hasta mayo de 2018.

Para la temporada Octubre 2015 - Mayo 2016, se comprueba mediante el Test de Shapiro -Wilk que tanto los valores reales como los pronosticados con los dos modelos se distribuyen según una Normal puesto que en todos los casos los valores de Sig > 0,05, como se observa en la Tabla 556 y Tabla 557

Tabla 556. Prueba de Normalidad temporada Octubre 2015-Mayo 2016. Edificio E8. Modelo 1

\begin{tabular}{cccccccr}
\hline & \multicolumn{2}{c}{ Kolmogorov-Smirnov $^{\mathrm{a}}$} & \multicolumn{3}{c}{ Shapiro-Wilk } \\
\cline { 2 - 8 } & Estadístico & $\mathrm{gl}$ & \multicolumn{1}{c}{ Sig. } & Estadístico & $\mathrm{gl}$ & \multicolumn{1}{c}{ Sig. } \\
\hline kWh_real &, 203 & 8 &, 200 &, 915 & 8 &, 394 \\
\hline kWh_pronost_M1 &, 167 & 8 &, 200 &, 934 & 8 &, 558 \\
\hline
\end{tabular}

Tabla 557. Prueba de Normalidad temporada Octubre 2015-Mayo 2016. Edificio E8. Modelo 2

\begin{tabular}{cccccccr}
\hline & \multicolumn{3}{c}{ Kolmogorov-Smirnov $^{\mathrm{a}}$} & \multicolumn{3}{c}{ Shapiro-Wilk } \\
\cline { 2 - 8 } & Estadístico & gl & Sig. & Estadístico & gl & \multicolumn{1}{c}{ Sig. } \\
\hline $\begin{array}{c}\text { kWh_real sin oct } \\
\text { 2015 }\end{array}$ &, 213 & 7 &, 200 &, 936 & 7 &, 601 \\
\hline kWh_pronost_M2 &, 159 & 7 &, 200 &, 919 & 7 &, 465 \\
\hline
\end{tabular}

En la Tabla 558, se observa como las medias tanto de los consumos pronosticados con el Modelo 1, como de los consumos pronosticados con el Modelo 2, son inferiores a las medias de los consumos reales del Edificio E8; un 4,2\% \% inferior con la estimación del Modelo 1 y un 24,9 \% superior con la estimación del Modelo 2. En el Modelo 2, la observación de octubre de 2015 , ha sido eliminada por haber sido pronosticado un valor negativo.

Tabla 558. Estadísticos de muestras relacionadas. Octubre 2015-Mayo 2016. Edificio E8

\begin{tabular}{clccccc}
\hline & & Media & $\begin{array}{c}\text { \% Diferencia } \\
\text { entre medias }\end{array}$ & N & Desviación típ. & $\begin{array}{c}\text { Error típ. de la } \\
\text { media }\end{array}$ \\
\hline Par & kWh_real & 240127,3750 & & 8 & 133592,33528 & 47232,02310 \\
\cline { 2 - 6 } 1 & kWh_pronost_M1 & 230122,0000 & $-4,2 \%$ & 8 & 115743,86979 & 40921,63760 \\
\hline Par & kWh_real & 266879,8571 & & 7 & 118918,35258 & 44946,91246 \\
\cline { 2 - 7 } 2 & kWh_pronost_M2 & 200467,4286 & $-24,9 \%$ & 7 & 127755,05034 & 48286,87028 \\
\hline
\end{tabular}

La Tabla 559 muestra que las diferencias entre las medias no son significativas entre los consumos reales y los pronosticados ni con el Modelo 1, ni con el Modelo 2 (sig > 0,5). 
Tabla 559. Prueba de muestras relacionadas. Octubre 2015-Mayo 2016. Edificio E8

\begin{tabular}{|c|c|c|c|c|c|c|c|c|c|}
\hline & & \multicolumn{5}{|c|}{ Diferencias relacionadas } & \multirow{3}{*}{$\mathrm{t}$} & \multirow{3}{*}{$\mathrm{gl}$} & \multirow{3}{*}{$\begin{array}{c}\text { Sig. } \\
\text { (bilateral) }\end{array}$} \\
\hline & & \multirow[t]{2}{*}{ Media } & \multirow{2}{*}{$\begin{array}{l}\text { Desviación } \\
\text { típ. }\end{array}$} & \multirow{2}{*}{$\begin{array}{l}\text { Error típ. } \\
\text { de la media }\end{array}$} & \multicolumn{2}{|c|}{$\begin{array}{c}\text { 95\% Intervalo de confianza } \\
\text { para la diferencia }\end{array}$} & & & \\
\hline & & & & & Inferior & Superior & & & \\
\hline Par 1 & $\begin{array}{c}\text { kWh_real - } \\
\text { kWh_pronost_M1 }\end{array}$ & 10005,375 & 79881,378 & 28242,332 & $-56777,128$ & 76787,878 & ,354 & 7 & 734 \\
\hline Par 2 & $\begin{array}{c}\text { kWh_real - } \\
\text { kWh_pronost_M2 }\end{array}$ & 66412,429 & 83505,436 & 31562,088 & $-10817,219$ & 143642,076 & 2,104 & 6 & ,080 \\
\hline
\end{tabular}

En la Figura 345, se grafican los consumos reales y pronosticados para la temporada Octubre 2015 - Mayo 2016 para el Edificio E8, y las medias de dichos consumos. Según la prueba paramétrica realizada son estadísticamente significativas con el Modelo 1 y no lo son con el Modelo 2, para un nivel de confianza del $95 \%$.

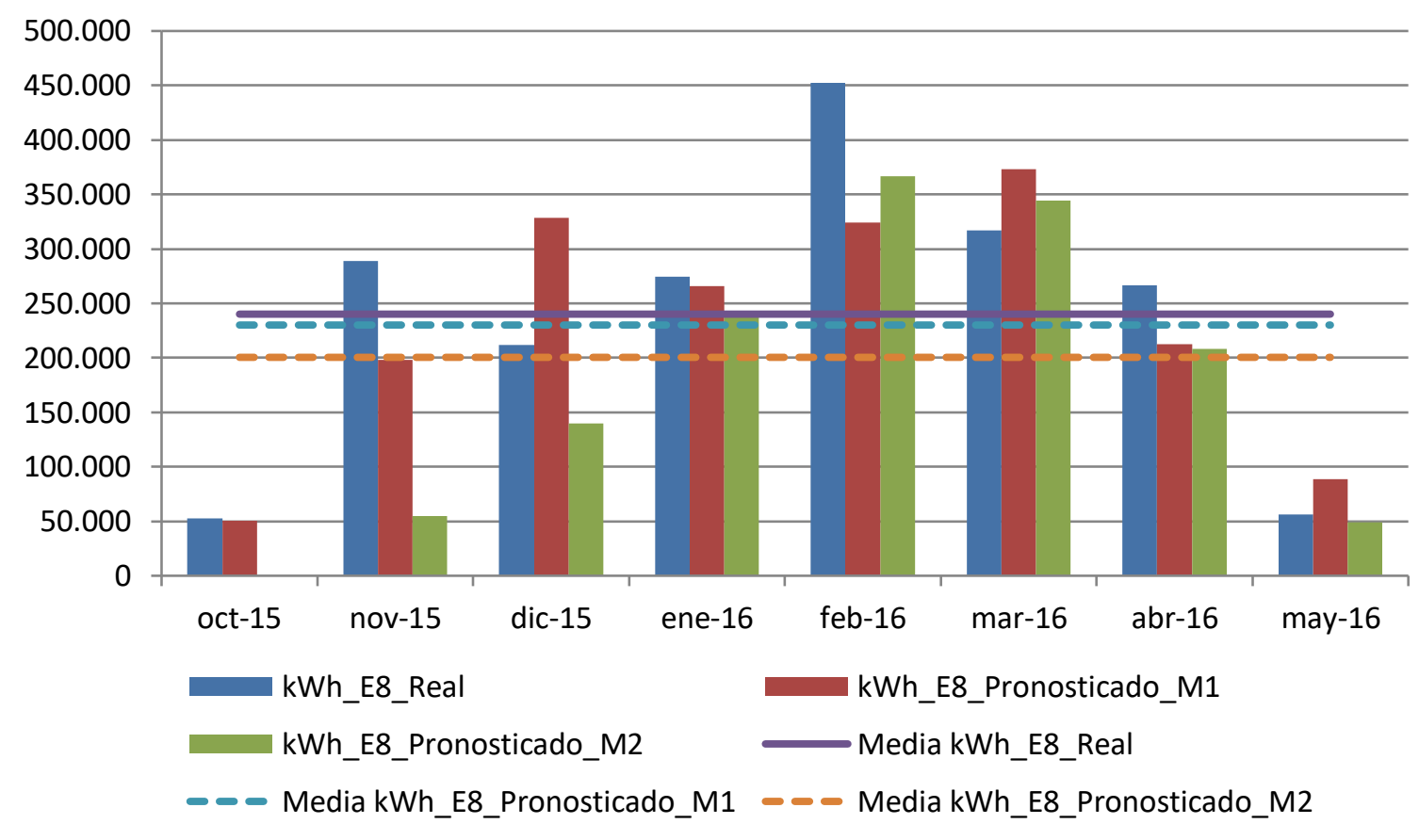

Figura 345. Consumos reales y pronosticados Octubre 2015-Mayo 2016. Edificio E8

Para la temporada Octubre 2016 - Mayo 2017, se comprueba mediante el Test de Shapiro -Wilk que tanto los valores reales como los pronosticados con los dos modelos se distribuyen según una Normal puesto que en todos los casos los valores de Sig >0,05, como se observa en la Tabla 560. El valor negativo del pronóstico de mayo de 2017, obtenido con el Modelo 2, se ha anulado de la prueba. 
Anexo V. Desarrollo del análisis de los edificios del Campus Río Esgueva

Tabla 560. Prueba de Normalidad temporada Octubre 2016-Mayo 2017. Edificio E8

\begin{tabular}{lrrrrrr}
\hline & \multicolumn{4}{c}{ Kolmogorov-Smirnov $^{\mathrm{a}}$} & \multicolumn{3}{c}{ Shapiro-Wilk } \\
\cline { 2 - 8 } & Estadístico & $\mathrm{gl}$ & \multicolumn{1}{c}{ Sig. } & Estadístico & $\mathrm{gl}$ & \multicolumn{1}{c}{ Sig. } \\
\hline kWh_real sin mayo 2017 &, 281 & 7 &, 100 &, 896 & 7 &, 306 \\
\hline kWh_pronost_M1 &, 207 & 7 &, 200 &, 955 & 7 &, 772 \\
\hline kWh_real (sin octubre &, 291 & 6 &, 122 &, 897 & 6 &, 357 \\
2016 ni mayo 2017) &, 211 & 6 &, 200 &, 905 & 6 &, 406 \\
\hline kWh_pronost_M2 & & & & & &
\end{tabular}

En la Tabla 561, se observa como las medias de los consumos pronosticados con el Modelo 1, son superiores a las medias de los consumos reales del Edificio E8, en un 3,6\% y las medias de los consumos pronosticados con el Modelo 2, son inferiores a las medias de los consumos reales del Edificio E8, un 24,5\%.

Tabla 561. Estadísticos de muestras relacionadas. Octubre 2016-Abril 2017. Edificio E8

\begin{tabular}{clccccc}
\hline & & Media & $\begin{array}{c}\text { \% Diferencia } \\
\text { entre } \\
\text { medias }\end{array}$ & $N$ & Desviación típ. & $\begin{array}{c}\text { Error típ. de la } \\
\text { media }\end{array}$ \\
\hline \multirow{2}{*}{$\begin{array}{c}\text { Par } \\
1\end{array}$} & kWh_real & 272693,5714 & & 7 & 132470,82871 & 50069,26696 \\
\cline { 2 - 7 } & kWh_pronost_M1 & 282460,8571 & $3,6 \%$ & 7 & 133838,57283 & 50586,22565 \\
\hline Par & kWh_real & 306390,0000 & & 6 & 107333,36127 & 43818,66125 \\
\cline { 2 - 7 } 2 & kWh_pronost_M2 & 231392,1667 & $-24,5 \%$ & 6 & 66927,47454 & 27323,02707 \\
\hline
\end{tabular}

La Tabla 562, muestra que las diferencias entre las medias no son significativas entre los consumos reales y los pronosticados con el Modelo 1 , ni con el Modelo 2 (sig > 0,05)

Tabla 562. Prueba de muestras relacionadas. Octubre 2016-Abril 2017. Edificio E8

\begin{tabular}{|c|c|c|c|c|c|c|c|c|c|}
\hline & & \multicolumn{5}{|c|}{ Diferencias relacionadas } & \multirow{3}{*}{$\mathrm{t}$} & \multirow{3}{*}{ gl } & \multirow{3}{*}{$\begin{array}{c}\text { Sig. } \\
\text { (bilateral) }\end{array}$} \\
\hline & & \multirow[t]{2}{*}{ Media } & \multirow{2}{*}{$\begin{array}{l}\text { Desviación } \\
\text { típ. }\end{array}$} & \multirow{2}{*}{$\begin{array}{l}\text { Error típ. } \\
\text { de la media }\end{array}$} & \multicolumn{2}{|c|}{$\begin{array}{l}\text { 95\% Intervalo de confianza } \\
\text { para la diferencia }\end{array}$} & & & \\
\hline & & & & & Inferior & Superior & & & \\
\hline Par 1 & $\begin{array}{c}\text { kWh_real - } \\
\text { kWh_pronost_M1 }\end{array}$ & $-9767,2861$ & 62861,096 & 23759,261 & $-67904,103$ & 48369,531 &,- 411 & 6 & ,695 \\
\hline Par 2 & $\begin{array}{c}\text { kWh_real - } \\
\text { kWh_pronost_M2 }\end{array}$ & 74997,833 & 90288,186 & 36859,997 & $-19753,807$ & 169749,473 & 2,035 & 5 & ,098 \\
\hline
\end{tabular}

En la Figura 346, se grafican los consumos reales y pronosticados para la temporada Octubre 2016 - Mayo 2017 para el Edificio E8, y las medias de dichos consumos. Según la prueba paramétrica realizada no son estadísticamente significativas las diferencias encontradas entre el consumo real y el pronosticado por el modelo 1, ni por el modelo 2, para un nivel de confianza del $95 \%$. 
Anexo V. Desarrollo del análisis de los edificios del Campus Río Esgueva

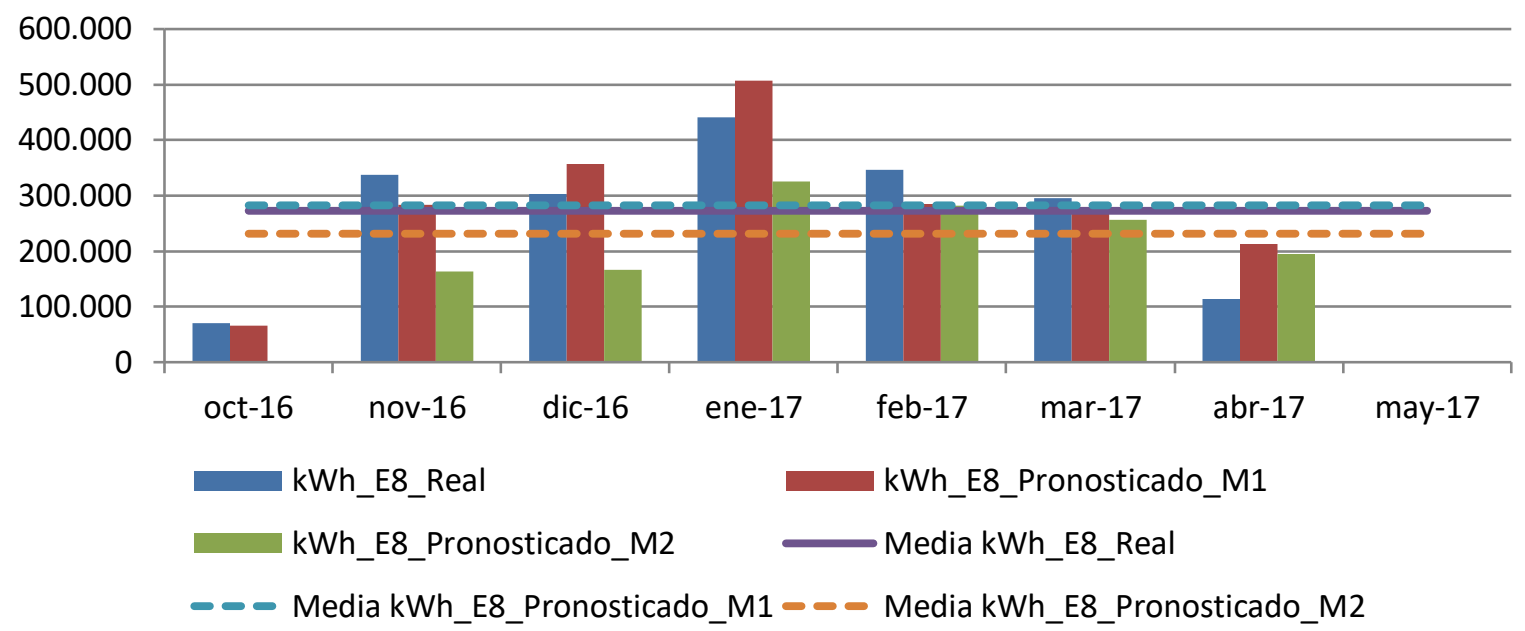

Figura 346. Consumos reales y pronosticados Octubre 2016-Mayo 2017. Edificio E8

Para la temporada Octubre 2017 - Mayo 2018, se comprueba mediante el Test de Shapiro -Wilk que tanto los valores reales como los pronosticados con los dos modelos se distribuyen según una Normal puesto que en todos los casos los valores de Sig >0,05, como se observa en la Tabla 563

Tabla 563. Prueba de Normalidad temporada Octubre 2017-Mayo 2018. Edificio E8

\begin{tabular}{ccccccc}
\hline & \multicolumn{3}{c}{ Kolmogorov-Smirnov $^{\mathrm{a}}$} & \multicolumn{3}{c}{ Shapiro-Wilk } \\
\cline { 2 - 7 } & Estadístico & gl & Sig. & Estadístico & gl & Sig. \\
\hline kWh_real &, 220 & 8 &, 200 &, 889 & 8 &, 229 \\
\hline kWh_pronost_M1 &, 202 & 8 &, 200 &, 910 & 8 &, 353 \\
\hline $\begin{array}{c}\text { kWh_real sin } \\
\text { octubre 2017, ni } \\
\text { mayo 2018 }\end{array}$ &, 244 & 6 &, 200 &, 932 & 6 &, 592 \\
\hline kWh_pronost_M2 &, 163 & 6 &, 200 &, 956 & 6 &, 788 \\
\hline
\end{tabular}

En la Tabla 564 se observa como las medias tanto de los consumos pronosticados con el Modelo 1, como de los consumos pronosticados con el Modelo 2, son superiores a las medias de los consumos reales del Edificio E8, un 14,0 \% superior con la estimación del Modelo 1 y un 1,4\% superior con la estimación del Modelo 2

Tabla 564. Estadísticos de muestras relacionadas. Octubre 2017-Mayo 2018. Edificio E8

\begin{tabular}{|c|c|c|c|c|c|c|}
\hline & & Media & $\begin{array}{l}\% \text { Diferencia } \\
\text { entre medias }\end{array}$ & $\mathrm{N}$ & $\begin{array}{c}\text { Desviación } \\
\text { típ. }\end{array}$ & $\begin{array}{c}\text { Error típ. de } \\
\text { la media }\end{array}$ \\
\hline Par & kWh_real & 233162,3750 & & 8 & 143865,20387 & 50864,03062 \\
\hline 1 & kWh_pronost_M1 & 265764,0000 & $14 \%$ & 8 & 163509,07284 & 57809,18709 \\
\hline Par & kWh_real & 299562,8333 & & 6 & 88339,90874 & 36064,61672 \\
\hline 2 & kWh_pronost_M2 & 303853,6667 & $1,4 \%$ & 6 & 102768,81025 & 41955,19110 \\
\hline
\end{tabular}


La Tabla 565 muestra que las diferencias entre las medias no son significativas entre los consumos reales y los pronosticados con el Modelo 1, ni con el Modelo 2 ( $\operatorname{sig}>0,05$ ).

Tabla 565. Prueba de muestras relacionadas. Octubre 2017-Mayo 2018. Edificio E8

\begin{tabular}{|c|c|c|c|c|c|c|c|c|c|}
\hline & & \multicolumn{5}{|c|}{ Diferencias relacionadas } & \multirow{3}{*}{$\mathrm{t}$} & \multirow{3}{*}{ gl } & \multirow{3}{*}{$\begin{array}{c}\text { Sig. } \\
\text { (bilateral) }\end{array}$} \\
\hline & & \multirow[t]{2}{*}{ Media } & \multirow{2}{*}{$\begin{array}{l}\text { Desviación } \\
\text { típ. }\end{array}$} & \multirow{2}{*}{$\begin{array}{l}\text { Error típ. } \\
\text { de la media }\end{array}$} & \multicolumn{2}{|c|}{$\begin{array}{l}95 \% \text { Intervalo de confianza } \\
\text { para la diferencia }\end{array}$} & & & \\
\hline & & & & & Inferior & Superior & & & \\
\hline Par 1 & $\begin{array}{c}\text { kWh_real - } \\
\text { kWh_pronost_M1 }\end{array}$ & $-32601,625$ & 74671,458 & 26400,347 & $-95028,526$ & 29825,276 & $-1,235$ & 7 & ,257 \\
\hline Par 2 & $\begin{array}{c}\text { kWh_real - } \\
\text { kWh_pronost_M2 }\end{array}$ & $-4290,833$ & 38342,511 & 15653,264 & $-44528,830$ & 35947,164 &,- 274 & 5 & ,795 \\
\hline
\end{tabular}

En la Figura 347 se grafican los consumos reales y pronosticados para la temporada Octubre 2017 - Mayo 2018 para el Edificio E8, y las medias de dichos consumos. Según la prueba paramétrica realizada no son estadísticamente significativas las diferencias encontradas entre el consumo real y el pronosticado por el modelo 1, ni por el modelo 2, para un nivel de confianza del $95 \%$.

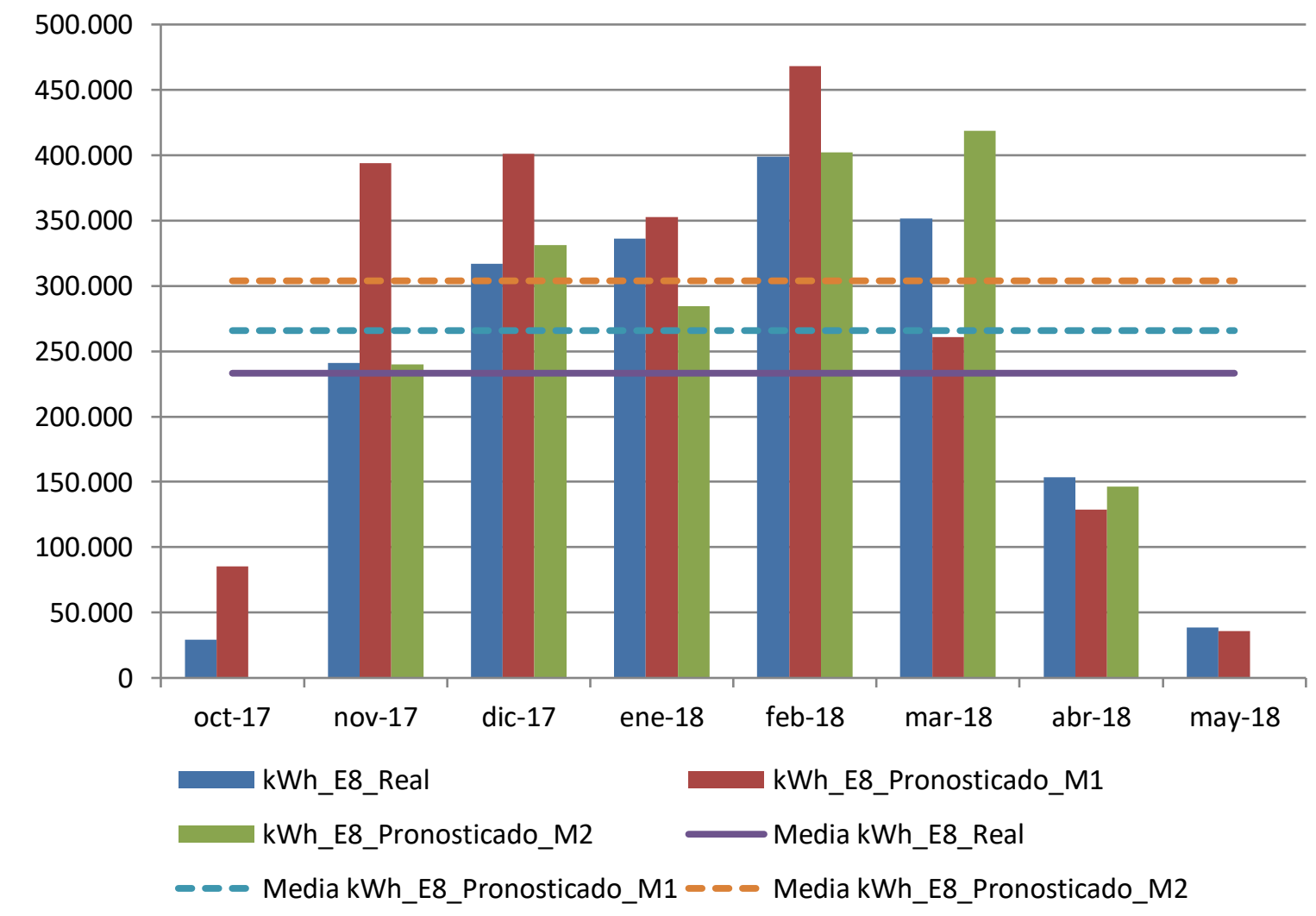

Figura 347. Consumos reales y pronosticados Octubre 2017-Mayo 2018. Edificio E8 
Para el total de las tres temporadas Octubre 2015 - Mayo 2018, se comprueba mediante el Test de Shapiro -Wilk, los valores reales como los pronosticados con el Modelo M1 y con el Modelo 2 se distribuyen según una Normal puesto que los valores de Sig > 0,05, como se observa en la Tabla 566

Tabla 566. Prueba de Normalidad temporada Octubre 2015-Mayo 2018. Edificio E8

\begin{tabular}{lcccccc}
\hline & \multicolumn{3}{c}{ Kolmogorov-Smirnov ${ }^{\mathrm{a}}$} & \multicolumn{3}{c}{ Shapiro-Wilk } \\
\cline { 2 - 7 } & Estadístico & $\mathrm{gl}$ & Sig. & Estadístico & gl & Sig. \\
\hline kWh_real (sin mayo 2017) &, 166 & 23 &, 102 &, 917 & 23 &, 057 \\
\hline kWh_pronost_M1 &, 115 & 23 &, 200 &, 960 & 23 &, 463 \\
\hline $\begin{array}{l}\text { kWh_real (sin octubre 2015, } \\
\begin{array}{l}\text { octubre 2016, mayo 2017, } \\
\text { mayo 2018) }\end{array}\end{array}$ &, 165 & 20 &, 158 &, 935 & 20 &, 189 \\
\hline kWh_pronost_M2 &, 088 & 20 &, 200 &, 973 & 20 &, 826 \\
\hline
\end{tabular}

En la Tabla 567, se observa como las medias de los consumos pronosticados con el Modelo 1, son superiores a las medias de los consumor reales del Edificio E8, en un 4,4\%, y las medias de los consumos pronosticados con el Modelo 2, son inferiores a las medias de los consumos reales del Edificio E8, un 16,9\%

Tabla 567. Estadísticos de muestras relacionadas. Octubre 2015-Mayo 2018. Edificio E8

\begin{tabular}{|c|c|c|c|c|c|c|}
\hline & & Media & $\begin{array}{l}\% \text { Diferencia } \\
\text { entre medias }\end{array}$ & $\mathrm{N}$ & $\begin{array}{c}\text { Desviación } \\
\text { típ. }\end{array}$ & $\begin{array}{c}\text { Error típ. de } \\
\text { la media }\end{array}$ \\
\hline Par & kWh_real & 247616,2174 & & 23 & 131705,93478 & 27462,58582 \\
\hline 1 & kWh_pronost_M1 & 258448,4348 & $4,4 \%$ & 23 & 134719,07028 & 28090,86800 \\
\hline Par & kWh_real & 276656,8500 & & 20 & 115119,54804 & 25741,51350 \\
\hline 2 & kWh_pronost_M2 & 229896,9000 & $-16,9 \%$ & 20 & 119844,01835 & 26797,93717 \\
\hline
\end{tabular}

La Tabla 568 muestra que las diferencias entre las medias son significativas entre los consumos reales y los pronosticados con el Modelo 2 (sig $\leq 0,05$ ); pero no con el Modelo 1 (sig > 0,05), para un nivel de confianza del $95 \%$. Pero el Modelo 2 fue descartado por presentar una cierta correlación entre los residuos y la variables independiente velocidad del viento diurna, por lo que se concluye que no se han encontrado diferencias significativas entre los consumos reales y los pronosticados.

Tabla 568. Prueba de muestras relacionadas. Octubre 2015-Mayo 2018. Edificio E8

\begin{tabular}{|c|c|c|c|c|c|c|c|c|c|}
\hline & & \multicolumn{5}{|c|}{ Diferencias relacionadas } & \multirow{3}{*}{$\mathrm{t}$} & \multirow{3}{*}{ gl } & \multirow{3}{*}{$\begin{array}{c}\text { Sig. } \\
\text { (bilateral) }\end{array}$} \\
\hline & & \multirow[t]{2}{*}{ Media } & \multirow{2}{*}{$\begin{array}{l}\text { Desviación } \\
\text { típ. }\end{array}$} & \multirow{2}{*}{$\begin{array}{l}\text { Error típ. } \\
\text { de la media }\end{array}$} & \multicolumn{2}{|c|}{$\begin{array}{l}\text { 95\% Intervalo de confianza } \\
\text { para la diferencia }\end{array}$} & & & \\
\hline & & & & & Inferior & Superior & & & \\
\hline Par 1 & $\begin{array}{c}\text { kWh_real - } \\
\text { kWh_pronost_M1 }\end{array}$ & $-10832,217$ & 72199,210 & 15054,576 & $-42053,497$ & 20389,062 &,- 720 & 22 & 479 \\
\hline Par 2 & $\begin{array}{c}\text { kWh_real - } \\
\text { kWh_pronost_M2 }\end{array}$ & 46759,950 & 77144,720 & 17250,084 & 10655,110 & 82864,790 & 2,711 & 19 & ,014 \\
\hline
\end{tabular}




\section{AV.8.5. Estimación de las emisiones de $\mathrm{CO} 2$ evitadas.}

Teniendo en cuenta que el consumir Gas natural se producen 0,252 $\mathrm{kg} \mathrm{CO}_{2} / \mathrm{kWh} \mathrm{E}$. final y que al consumir la energía suministrada por red a partir de Biomasa se producen 0,024 kg $\mathrm{CO}_{2} / \mathrm{kWh}$. final, en la Tabla 569, se muestra las emisiones de $\mathrm{CO}_{2}$ reales para las temporadas octubre 2015 - mayo 2018 y considerando que no se han encontrado diferencias significativas, las emisiones de $\mathrm{CO}_{2}$ que se hubieran tenido de haber seguido utilizando las calderas de gas natural originales sin el apoyo de la red de calor.

Tabla 569. Estimación del ahorro de emisiones de CO2 para el Edificio E8.

\begin{tabular}{|c|c|c|c|c|c|c|c|c|c|c|}
\hline & $\begin{array}{l}\text { kWh_E8 } \\
\text { Gas } \\
\text { Natural }\end{array}$ & $\begin{array}{l}\text { kWh_E8 } \\
\text { Biomasa }\end{array}$ & $\begin{array}{l}\text { kWh_E8 } \\
\text { Real Total }\end{array}$ & $\begin{array}{c}\text { kWh_E8_- } \\
\text { M2 } \\
\text { Predicho }\end{array}$ & $\begin{array}{l}\text { kg CO2 Real } \\
\text { debido al } \\
\text { consumo de } \\
\text { Gas Natural }\end{array}$ & $\begin{array}{l}\text { kg CO2 } \\
\text { Real } \\
\text { debido a } \\
\text { Biomasa }\end{array}$ & $\begin{array}{l}\text { kg CO2 } \\
\text { Real } \\
\text { debido al } \\
\text { consumo } \\
\text { TOTAL }\end{array}$ & $\begin{array}{c}\text { kg CO2 } \\
\text { que se } \\
\text { hubiera } \\
\text { tenido } \\
\text { debido a } \\
\text { Gas } \\
\text { Natural }\end{array}$ & $\begin{array}{l}\text { Ahorro de } \\
\text { kg CO2 }\end{array}$ & $\begin{array}{l}\text { Ahorro de kg } \\
\text { CO2 } \\
\text { acumulado }\end{array}$ \\
\hline oct-2015 & 0 & 52.860 & 52.860 & 52.860 & 0 & 1.269 & 1.269 & 13.321 & 12.052 & 12.052 \\
\hline nov-2015 & 0 & 288.652 & 288.652 & 288.652 & 0 & 6.928 & 6.928 & 72.740 & 65.813 & 77.865 \\
\hline dic-2015 & 0 & 212.113 & 212.113 & 212.113 & 0 & 5.091 & 5.091 & 53.452 & 48.362 & 126.227 \\
\hline ene-2016 & 0 & 274.832 & 274.832 & 274.832 & 0 & 6.596 & 6.596 & 69.258 & 62.662 & 188.888 \\
\hline feb-2016 & 69.449 & 383.315 & 452.764 & 452.764 & 17.501 & 9.200 & 26.701 & 114.097 & 87.396 & 276.284 \\
\hline mar-2016 & 6.275 & 310.542 & 316.817 & 316.817 & 1.581 & 7.453 & 9.034 & 79.838 & 70.804 & 347.088 \\
\hline abr-2016 & 528 & 265.968 & 266.496 & 266.496 & 133 & 6.383 & 6.516 & 67.157 & 60.641 & 407.728 \\
\hline may-2016 & 0 & 56.485 & 56.485 & 56.485 & 0 & 1.356 & 1.356 & 14.234 & 12.879 & 420.607 \\
\hline oct-2016 & 14.513 & 56.002 & 70.515 & 70.515 & 3.657 & 1.344 & 5.001 & 17.770 & 12.768 & 433.375 \\
\hline nov-2016 & 4.184 & 333.473 & 337.657 & 337.657 & 1.054 & 8.003 & 9.058 & 85.090 & 76.032 & 509.407 \\
\hline dic-2016 & 424 & 303.010 & 303.434 & 303.434 & 107 & 7.272 & 7.379 & 76.465 & 69.086 & 578.493 \\
\hline ene-2017 & 3.744 & 436.855 & 440.599 & 440.599 & 944 & 10.485 & 11.428 & 111.031 & 99.603 & 678.096 \\
\hline feb-2017 & 3.304 & 343.825 & 347.129 & 347.129 & 833 & 8.252 & 9.084 & 87.477 & 78.392 & 756.488 \\
\hline mar-2017 & 1.128 & 293.874 & 295.002 & 295.002 & 284 & 7.053 & 7.337 & 74.341 & 67.003 & 823.492 \\
\hline abr-2017 & 464 & 114.055 & 114.519 & 114.519 & 117 & 2.737 & 2.854 & 28.859 & 26.005 & 849.496 \\
\hline may-2017 & 224 & 29.719 & 0 & 0 & 56 & 713 & 770 & 0 & -770 & 848.727 \\
\hline oct-2017 & 1.808 & 27.453 & 29.261 & 29.261 & 456 & 659 & 1.115 & 7.374 & 6.259 & 854.986 \\
\hline nov-2017 & 1.968 & 238.822 & 240.790 & 240.790 & 496 & 5.732 & 6.228 & 60.679 & 54.451 & 909.437 \\
\hline dic-2017 & 2.056 & 314.827 & 316.883 & 316.883 & 518 & 7.556 & 8.074 & 79.855 & 71.781 & 981.218 \\
\hline ene-2018 & 2.944 & 333.010 & 335.954 & 335.954 & 742 & 7.992 & 8.734 & 84.660 & 75.926 & 1.057 .144 \\
\hline feb-2018 & 944 & 398.085 & 399.029 & 399.029 & 238 & 9.554 & 9.792 & 100.555 & 90.763 & 1.147 .908 \\
\hline mar-2018 & 1.464 & 349.870 & 351.334 & 351.334 & 369 & 8.397 & 8.766 & 88.536 & 79.770 & 1.227 .678 \\
\hline abr-2018 & 280 & 153.107 & 153.387 & 153.387 & 71 & 3.675 & 3.745 & 38.654 & 34.908 & 1.262 .586 \\
\hline may-2018 & 0 & 38.661 & 38.661 & 38.661 & 0 & 928 & 928 & 9.743 & 8.815 & 1.271 .401 \\
\hline
\end{tabular}

Como se observa durante estas tres temporadas se ha obtenido un ahorro total de 1.271 Toneladas de $\mathrm{CO}_{2}$, debido al cambio del tipo de energía consumida. 


\section{AV.8.6. Estimación del precio máximo de compra a la red.}

Tomando como referencia los precios del gas natural de la Tabla 570 para cada temporada, obtenidos a partir de los datos establecidos en el Capítulo 3, donde se tiene en cuenta el precio por el termino variable y fijo; se puede realizar la estimación del precio máximo de compra de la energía útil a la red de calor para obtener un $0 \%$ de ahorro y un $15 \%$ de ahorro. La Tabla 571, muestra el precio que se pagaría para un ahorro del 15\%

Tabla 570. Precios de referencia para Gas natural y Astilla

\begin{tabular}{ccccc}
\hline Precios ( $€ /(\mathrm{kWh})$ & 2015 & 2016 & 2017 & 2018 \\
\hline Gas Natural & 0,0373 & 0,0306 & 0,0314 & 0,0336 \\
\hline Astilla & 0,0277 & 0,0256 & 0,0254 & 0,0239 \\
\hline $\begin{array}{c}€ / \text { kWh útiles máximos de compra a la red para } \\
\text { un ahorro del 0,0\% }\end{array}$ & 0,003202 & \\
\hline $\begin{array}{c}€ / \text { kWh útiles máximos de compra a la red para } \\
\text { un ahorro del 15,0\% }\end{array}$ & 0,02778 & \\
\hline
\end{tabular}

Tabla 571. Ahorro Económico por el consumo térmico en el Edificio E8

\begin{tabular}{|c|c|c|c|c|c|c|c|c|c|c|}
\hline & $\begin{array}{c}\text { kWh_E8 } \\
\text { Gas } \\
\text { Natural }\end{array}$ & $\begin{array}{c}\text { kWh_E8_B } \\
\text { iomasa }\end{array}$ & kWh_E8 & $\begin{array}{c}\text { kWh_E8_ } \\
M 2\end{array}$ & $\begin{array}{c}€ \text { Real Gas } \\
\text { Natural }\end{array}$ & $\begin{array}{c}€ \text { Real } \\
\text { Biomasa }\end{array}$ & $\begin{array}{l}€ \text { Real } \\
\text { Total }\end{array}$ & $\begin{array}{c}\text { E predicho } \\
\text { Gas } \\
\text { natural }\end{array}$ & $\begin{array}{c}€ \\
\text { Ahorro }\end{array}$ & $€$ Acumulado \\
\hline oct-2015 & 0 & 52.860 & 52.860 & 52.860 & 0 & 1.468 & 1.468 & 1.972 & 503 & 503 \\
\hline nov-2015 & 0 & 288.652 & 288.652 & 288.652 & 0 & 8.019 & 8.019 & 10.767 & 2.748 & 3.251 \\
\hline dic-2015 & 0 & 212.113 & 212.113 & 212.113 & 0 & 5.892 & 5.892 & 7.912 & 2.019 & 5.271 \\
\hline ene-2016 & 0 & 274.832 & 274.832 & 274.832 & 0 & 7.635 & 7.635 & 8.410 & 775 & 6.046 \\
\hline feb-2016 & 69.449 & 383.315 & 452.764 & 452.764 & 2.125 & 10.648 & 12.774 & 13.855 & 1.081 & 7.126 \\
\hline mar-2016 & 6.275 & 310.542 & 316.817 & 316.817 & 192 & 8.627 & 8.819 & 9.695 & 876 & 8.002 \\
\hline abr-2016 & 528 & 265.968 & 266.496 & 266.496 & 16 & 7.389 & 7.405 & 8.155 & 750 & 8.752 \\
\hline may-2016 & 0 & 56.485 & 56.485 & 56.485 & 0 & 1.569 & 1.569 & 1.728 & 159 & 8.912 \\
\hline oct-2016 & 14.513 & 56.002 & 70.515 & 70.515 & 444 & 1.556 & 2.000 & 2.158 & 158 & 9.069 \\
\hline nov-2016 & 4.184 & 333.473 & 337.657 & 337.657 & 128 & 9.264 & 9.392 & 10.332 & 940 & 10.010 \\
\hline dic-2016 & 424 & 303.010 & 303.434 & 303.434 & 13 & 8.418 & 8.431 & 9.285 & 854 & 10.864 \\
\hline ene-2017 & 3.744 & 436.855 & 440.599 & 440.599 & 118 & 12.136 & 12.253 & 13.835 & 1.581 & 12.446 \\
\hline feb-2017 & 3.304 & 343.825 & 347.129 & 347.129 & 104 & 9.551 & 9.655 & 10.900 & 1.245 & 13.690 \\
\hline mar-2017 & 1.128 & 293.874 & 295.002 & 295.002 & 35 & 8.164 & 8.199 & 9.263 & 1.064 & 14.754 \\
\hline abr-2017 & 464 & 114.055 & 114.519 & 114.519 & 15 & 3.168 & 3.183 & 3.596 & 413 & 15.167 \\
\hline may-2017 & 224 & 29.719 & 0 & 0 & 7 & 826 & 833 & 0 & -833 & 14.334 \\
\hline oct-2017 & 1.808 & 27.453 & 29.261 & 29.261 & 57 & 763 & 819 & 919 & 99 & 14.434 \\
\hline nov-2017 & 1.968 & 238.822 & 240.790 & 240.790 & 62 & 6.634 & 6.696 & 7.561 & 865 & 15.298 \\
\hline dic-2017 & 2.056 & 314.827 & 316.883 & 316.883 & 65 & 8.746 & 8.810 & 9.950 & 1.140 & 16.438 \\
\hline ene-2018 & 2.944 & 333.010 & 335.954 & 335.954 & 99 & 9.251 & 9.350 & 11.288 & 1.938 & 18.376 \\
\hline feb-2018 & 944 & 398.085 & 399.029 & 399.029 & 32 & 11.059 & 11.091 & 13.407 & 2.317 & 20.693 \\
\hline mar-2018 & 1.464 & 349.870 & 351.334 & 351.334 & 49 & 9.719 & 9.769 & 11.805 & 2.036 & 22.729 \\
\hline$a b r-2018$ & 280 & 153.107 & 153.387 & 153.387 & 9 & 4.253 & 4.263 & 5.154 & 891 & 23.620 \\
\hline may-2018 & 0 & 38.661 & 38.661 & 38.661 & 0 & 1.074 & 1.074 & 1.299 & 225 & 23.845 \\
\hline$€$ Total & & & & & & & 159.399 & 183.244 & & \\
\hline Ahorro (\%) & & & & & & & & & & $15,0 \%$ \\
\hline
\end{tabular}




\section{AV.9. Edificio E13. Facultad de Económicas.}

\section{AV.9.1. Obtención de la línea base de referencia energética}

Los datos de partida para la obtención de la línea base de referencia se muestran en la Tabla 572

Tabla 572. Consumos térmicos del edificio E13

\begin{tabular}{lr}
\hline & Consumos térmicos (kWh). E13 \\
\hline oct-12 & 26.441 \\
\hline nov-12 & 233.547 \\
\hline dic-12 & 246.803 \\
\hline ene-13 & 231.986 \\
\hline feb-13 & 231.133 \\
\hline mar-13 & 192.983 \\
\hline abr-13 & 106.846 \\
\hline may-13 & 53.047 \\
\hline oct-13 & 22 \\
\hline nov-13 & 143.684 \\
\hline dic-13 & 273.337 \\
\hline ene-14 & 336.166 \\
\hline feb-14 & 259.725 \\
\hline mar-14 & 148.360 \\
\hline abr-14 & 86.292 \\
\hline may-14 & 13.279 \\
\hline Promedio & 161.478 \\
\hline Total (oct-12-may-13) & 1.322 .786 \\
\hline Total (oct-13-may-14) & 260.865 \\
\hline Total (oct-12-may-13) & 2.583 .651 \\
\hline
\end{tabular}

Como se puede ver en la Tabla 573 para el edificio, el método ofrece un modelo de regresión, con una sola variable (Temperatura máxima). El modelo fue construido con un solo paso, incluyendo la T_max, por ser la variable más significativa (variable con menor valor de Sig $=0,000$ ). El resto de las variables como se observa en la Tabla 574 fueron excluidas del modelo al tener valores de sig >0,05.

Tabla 573. Modelos de regresión del Edificio E13

\begin{tabular}{|c|c|c|c|c|c|c|}
\hline \multirow{2}{*}{ Modelo } & \multicolumn{2}{|c|}{ Coeficientes no estandarizados } & \multirow[t]{2}{*}{$\mathrm{t}$} & \multirow{2}{*}{ Sig. } & \multicolumn{2}{|c|}{$\begin{array}{c}\text { Intervalo de confianza de } 95,0 \% \\
\text { para B }\end{array}$} \\
\hline & $\mathrm{B}$ & Error típ. & & & Límite inferior & Límite superior \\
\hline 1 (Constante) & 461136,517 & 35607,692 & 12,950 & 000 & 384765,613 & 537507,420 \\
\hline T_max & $-21706,507$ & 2463,567 & $-8,811$ & 000 & $-26990,334$ & $-16422,680$ \\
\hline
\end{tabular}


En la Figura 348 se representa el modelo de regresión con sus límites inferior y superior para un nivel de confianza del $95 \%$

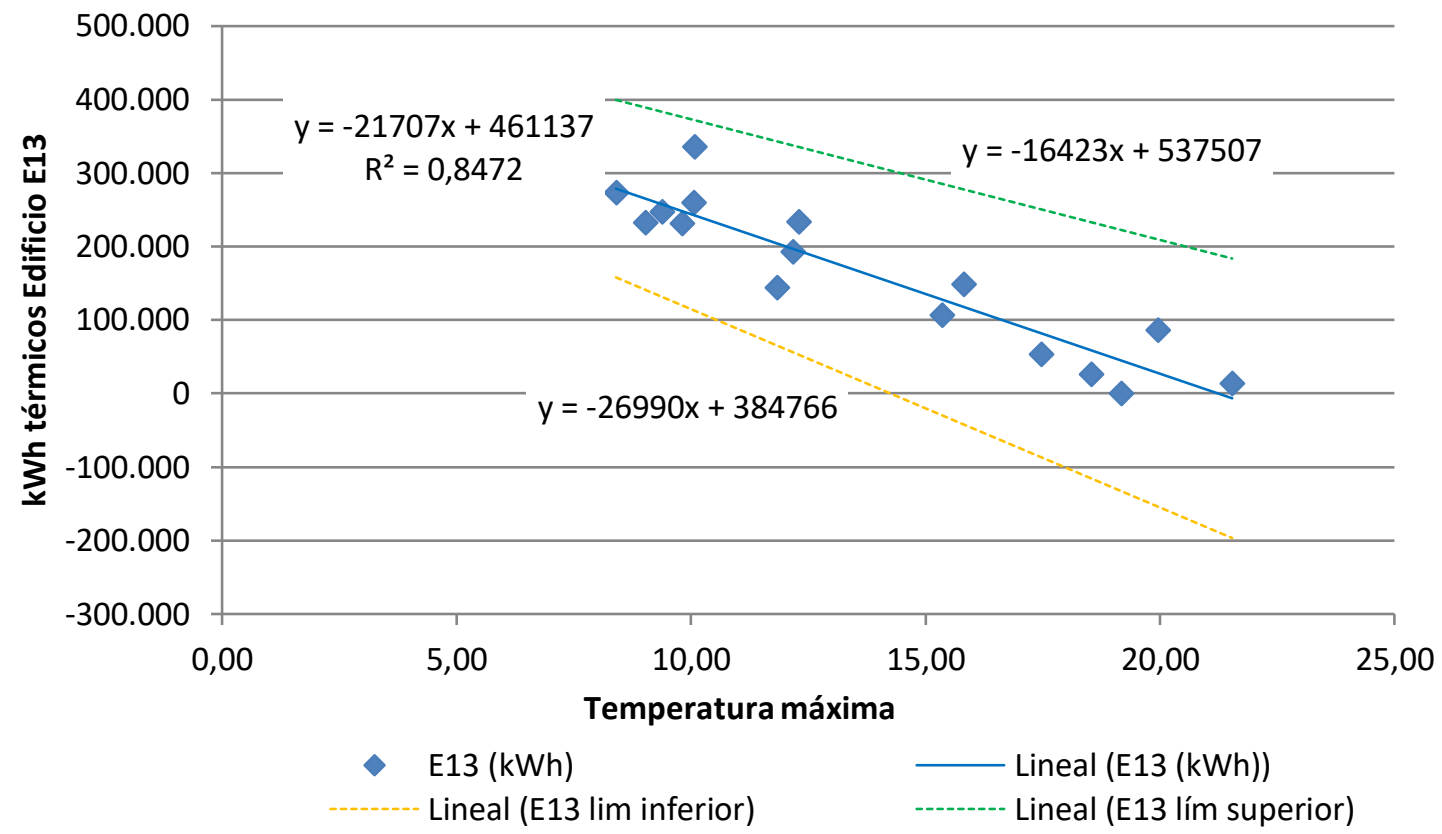

Figura 348. Representación del modelo de regresión lineal simple para el Edificio E13

Tabla 574. Variables excluidas del modelo de región del Edificio E13

\begin{tabular}{|c|c|c|c|c|}
\hline & Modelo & $\mathrm{t}$ & Sig. & Correlación parcial \\
\hline & GD15_30min &,- 019 &, 985 &,- 005 \\
\hline & GD20_30min & 012 & 990 & ,003 \\
\hline & GD15_24h &,- 202 & 843 &,- 056 \\
\hline & GD20_24h &,- 106 & ,918 &,- 029 \\
\hline & T_med_C & 194 & 849 & ,054 \\
\hline & T_media_diurna_C & ,277 & ,786 & 077 \\
\hline & T_min_C &,- 100 & ,922 &,- 028 \\
\hline & HR_\% &,- 599 &, 559 &,- 164 \\
\hline & HR_med_diurna_\% &,- 379 & ,711 &,- 105 \\
\hline \multirow[t]{10}{*}{1} & HR_max_\% &,- 808 & ,434 &,- 219 \\
\hline & HR_min_\% &,- 300 & 769 &,- 083 \\
\hline & V_Viento_m/s & 1,254 & ,232 & ,329 \\
\hline & V_viento_diurna_m/s & 1,174 & ,261 & ,310 \\
\hline & V_viento_nocturna_m $/ \mathrm{s}$ & 1,358 & ,198 & ,352 \\
\hline & V_viento_max_m/s & 1,088 & ,296 & ,289 \\
\hline & Recorrido_viento_km/día & 1,260 &, 230 & 330 \\
\hline & Precipitación_acumulada_mes_mm &,- 027 & ,979 &,- 008 \\
\hline & Horas insolación_h &,- 230 & 822 &,- 064 \\
\hline & Radiación_W/m2 & ,487 & 634 & 134 \\
\hline
\end{tabular}


La bondad del modelo de regresión obtenido para el edificio E13, se resumen en la Tabla 575

Tabla 575. Resumen de la bondad del modelo de regresión para el Edificio E13

\begin{tabular}{|c|c|c|c|c|}
\hline Modelo & $\mathrm{R}$ & R cuadrado & R cuadrado corregida & $\begin{array}{c}\text { Error típ. de la } \\
\text { estimación }\end{array}$ \\
\hline 1 &,- 920 & ,847 & ,836 & 42191,6259 \\
\hline
\end{tabular}

Se observa como el modelo de regresión lineal simple presenta un Coeficiente de Correlación de Pearson (R) de 0,920, lo que indica que las variables están correlacionadas de manera muy fuerte (en la correlación perfecta $R= \pm 1$ ). La correlación que se produce es inversa, al aumentar el valor de la Temperatura máxima, disminuye el consumo térmico.

El coeficiente de determinación $\left(R^{2}\right)$, nos indica que con el modelo se podría explicar el $84,7 \%$ de los datos reales obtenidos aceptando un error del $5 \%$.

El error típico de la estimación que nos indica la magnitud de los errores, es decir la parte de la variable dependiente que dejamos sin explicar con el modelo y que describe la variación de la variable respuesta (el Consumo) respecto a la recta de regresión, es de $42.192 \mathrm{kWh}$, lo que representa un $26,1 \%$ del promedio de los consumos que fue de 161.478 kWh.

\section{AV.9.2. Verificación del cumplimiento de los supuestos estadísticos}

Las condiciones que se deben cumplir en un modelo de regresión son:

\section{- Linealidad de las variables, las variables se encuentran relacionadas de forma lineal.}

Como se observa en la Tabla 573, la pendiente (B), obtuvo un valor de Sig $=0,000$, que al ser $\leq 0,05$, nos indica que podemos rechazar la hipótesis nula de pendiente igual a cero y nos da la evidencia de linealidad entre la variable dependiente ( $k$ Wh del edificio E13) y la independiente (T_max). Al ser el valor de la pendiente negativa, indica una relación inversa entre el consumo y la Temperatura máxima.

- Normalidad. Todos los valores obtenidos para la variable dependiente (Y), deben estar distribuidos normalmente en cada valor de la variable independiente (X).

Se comprueba la normalidad de las variables y de los residuos mediante el Test de Shapiro - Wilk para muestras pequeñas (menores a 30 observaciones), siendo la hipótesis nula el que la distribución es Normal. 
La Tabla 576, muestra la prueba de normalidad de Shapiro-Wilk y cómo tanto la variable dependiente (consumos del Edificio), como la variable independientes: T_max poseen una Sig $>0,05$, por lo que aceptamos la hipótesis nula de Normalidad de las variables

Tabla 576. Prueba de normalidad para el edificio E13

\begin{tabular}{lccrrrrr}
\hline & \multicolumn{3}{c}{ Kolmogorov-Smirnov } & \multicolumn{3}{c}{ Shapiro-Wilk } \\
\cline { 2 - 8 } & Estadístico & gl & Sig. & Estadístico & gl & \multicolumn{1}{c}{ Sig. } \\
\hline kWh_E13 &, 185 & 16 &, 144 &, 941 & 16 &, 365 \\
\hline T_max &, 196 & 16 &, 103 &, 902 & 16 &, 087 \\
\hline
\end{tabular}

- Independencia de los errores. Los errores asociados a los valores de la variable respuesta $(Y)$ deberán ser independientes unos de otros.

Para la comprobación se utiliza el estadístico de Durbin -Watson.

Se comprueba que el Estadístico de Durbin Watson para el nivel de significancia del 5\%, y para el tamaño de la muestra " $n$ " y el número de variables independientes del modelo " $k$ ", se encuentra en el intervalo [dU, 4-dU], de la Tabla 3, intervalo centrado en el 2, que indica la ausencia de autocorrelación.

El valor del Estadístico Durbin-Watson facilitado por el programa SPSS, es 1,233.

En el modelo, $\mathrm{n}=16$ y $\mathrm{k}=1$, según la Tabla 3 el valor $\mathrm{dU}=1,371$ y dL =1,106, luego el intervalo que marca la ausencia de correlación es [1,371, 2,629]

Los intervalos $[0,1,106]$ y $[2,896,4]$ indican correlación positiva o negativa respectivamente y las zonas $[1,106,1,371]$ y $[2,629,2,896]$ son zonas no concluyentes; como el valor del estadístico 1,233 está dentro del primer intervalo no concluyente, se comprueba la correlación, mediante el gráfico de residuos y tiempo.

La Figura 349, muestra que la relación entre los residuos y el tiempo, posee un coeficiente de determinación $=0,179$, bajo, aunque no nulo; por lo que se concluye que existe una baja autocorrelación en los residuos. 


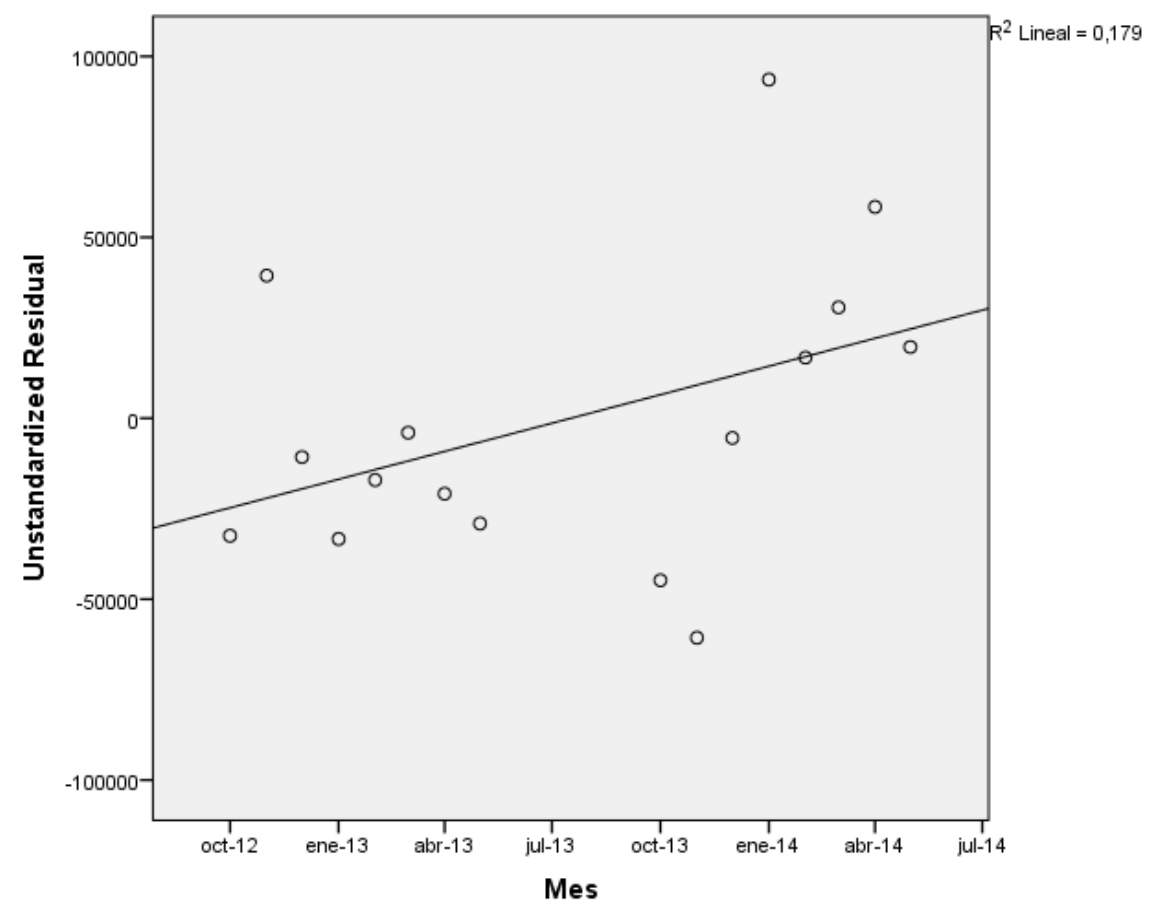

Figura 349. Relación entre los residuos y el tiempo en el Edificio E13

- Homocedasticidad de la varianza. Se pretende comprobar que la varianza de los errores $\left(\sigma^{2}\right)$ es constante para cualquier valor de la variable independiente $(X)$, es decir que el valor medio del cuadrado de la desviación de los errores respecto a su media es constante.

Esta condición indica que no existe correlación entre los residuos y los pronósticos. Se comprueba que el coeficiente de determinación $\mathrm{R}^{2}$, en las relaciones: residuos y predicciones y entre residuos y variable independiente es nulo o muy próximo a cero, lo que indicará que no existe ningún tipo de correlación en los residuos y que éstos son aleatorios. Se grafican los diagramas de dispersión de esas relaciones, comprobando que se corresponden a nubes de puntos totalmente aleatorias, sin tendencias ni patrones en sus representaciones gráficas.

Las Figura 350 y Figura 351, muestran que la relación entre los pronósticos y los residuos, posee un coeficiente de determinación $=-2,22 \times 10^{-16} \mathrm{y}$ entre la variable independiente (T_max) y los residuos un coeficiente de determinación de 0 ; por lo que se concluye que no existe ningún tipo de correlación en los residuos y que éstos son aleatorios, siendo la varianza de los residuos constante. 


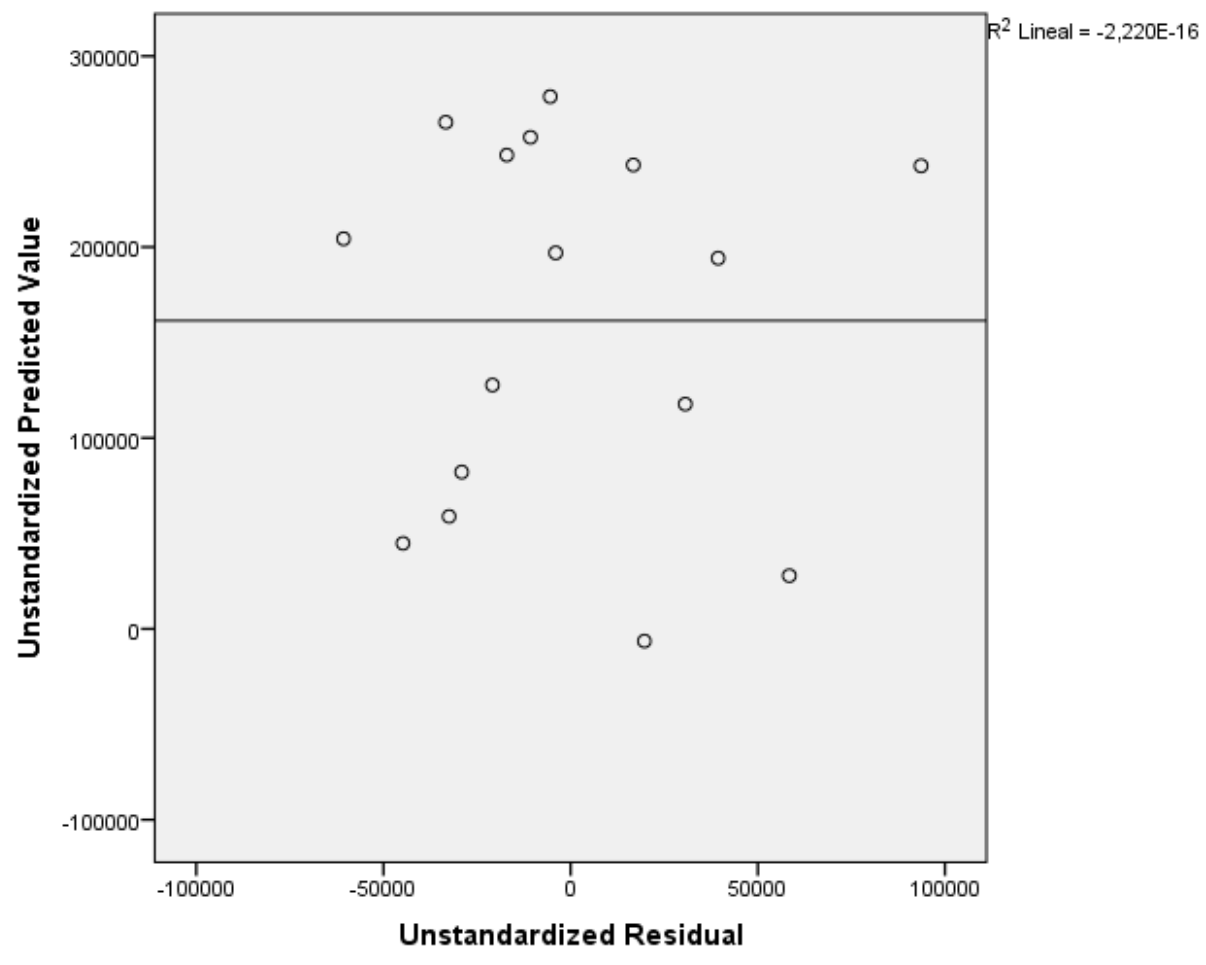

Figura 350. Relación entre los pronósticos y los residuos en el Edificio E13

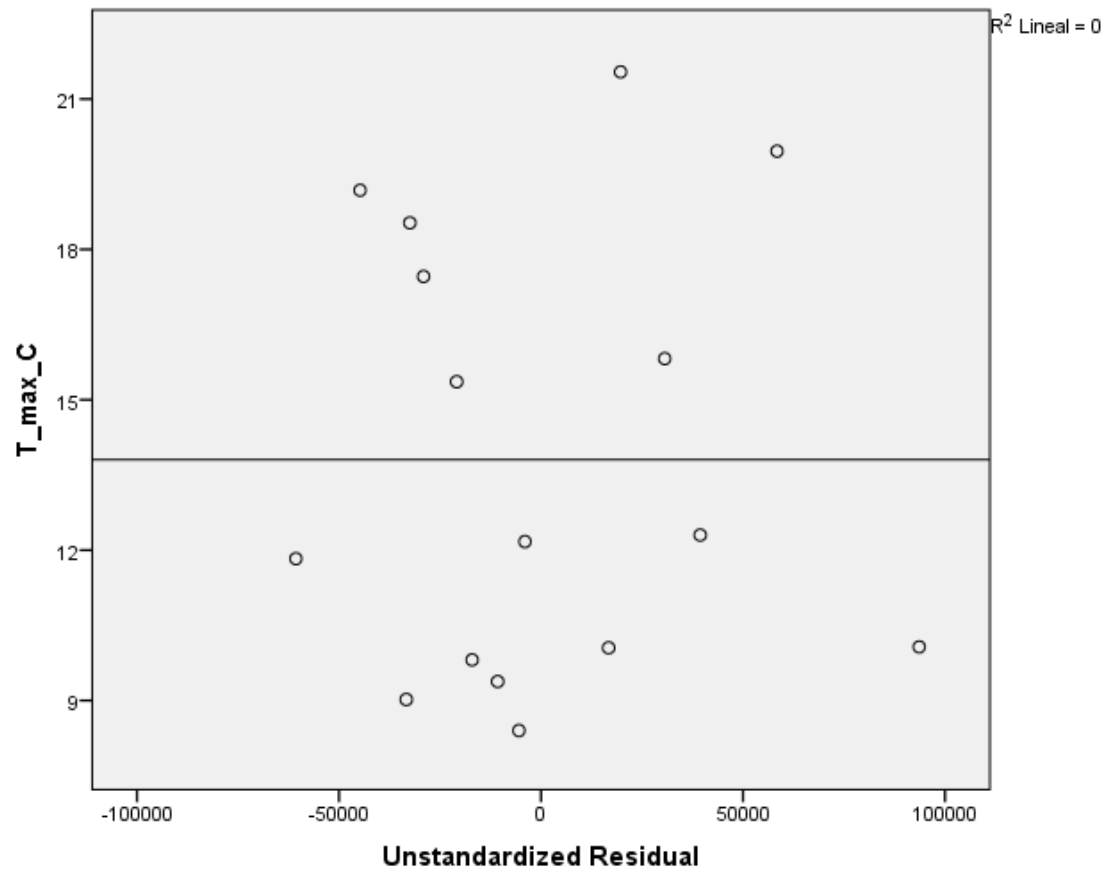

Figura 351. Relación entre T_max y los residuos en el Edificio E13 


\section{AV.9.3. Obtención de los consumos térmicos previstos}

Una vez comprobado el cumplimiento de los supuestos estadísticos se acepta el modelo de línea base encontrado para modelizar el consumo del Edificio E13.

$$
\text { kWh_E13_Pronosticado }=461.136,517-21.706,507 \times \text { T_max }
$$

Con este modelo se procede a predecir los consumos previstos para las temporadas: octubre 2015-mayo 2016, octubre 2016 - mayo 2017 y octubre 2017-mayo 2018, estos consumos se muestran en la Tabla 577, donde "KWh_E13_Real", representa el consumo real redistribuido, "kWh_E13_Pronosticado", el consumo pronosticado con el Modelo.

Tabla 577. Consumos previstos octubre 2014 - mayo 2017 para el edificio E13.

\begin{tabular}{rrrr}
\hline & \multicolumn{1}{c}{ T_max } & kWh_E13_Real & kWh_E13_Pronosticado \\
\hline oct-15 & 19,10 & 34.000 & 46.528 \\
\hline nov-15 & 14,00 & 203.190 & 157.238 \\
\hline dic-15 & 11,21 & 149.940 & 217.877 \\
\hline ene-16 & 10,33 & 165.700 & 236.950 \\
\hline feb-16 & 11,01 & 367.886 & 222.245 \\
\hline mar-16 & 12,83 & 236.912 & 182.663 \\
\hline abr-16 & 15,40 & 175.949 & 126.835 \\
\hline may-16 & 20,04 & 32.710 & 26.033 \\
\hline oct-16 & 21,78 & 29.981 & -11.729 \\
\hline nov-16 & 12,44 & 262.380 & 191.079 \\
\hline dic-16 & 9,53 & 218.390 & 254.365 \\
\hline ene-17 & 9,88 & 386.780 & 246.690 \\
\hline feb-17 & 12,59 & 264.570 & 187.797 \\
\hline mar-17 & 16,71 & 179.680 & 98.365 \\
\hline abr-17 & 21,07 & 78.670 & 3.838 \\
\hline may-17 & 24,49 & 23.570 & -70.407 \\
\hline oct-17 & 24,51 & 18.590 & -70.904 \\
\hline nov-17 & 14,38 & 176.720 & 149.077 \\
\hline dic-17 & 9,18 & 264.900 & 261.850 \\
\hline ene-18 & 8,99 & 287.620 & 265.890 \\
\hline feb-18 & 9,79 & 307.970 & 248.583 \\
\hline mar-18 & 11,48 & 253.030 & 211.918 \\
\hline abr-18 & 17,30 & 118.064 & 85.549 \\
\hline may-18 & 20,59 & 22.920 & 14.207 \\
\hline & & &
\end{tabular}

En el estudio de la existencia de diferencias significativas, se prescindirá de los meses en los que los valores pronosticados han sido negativos, por resultar ser valores imposibles, estos meses son octubre 2016, mayo 2017 y octubre 2017. 


\section{AV.9.4. Estudio de la existencia de diferencias significativas}

Utilizando la prueba " $\mathrm{t}$ " de Student para muestras relacionadas, podemos concluir que si las variables se distribuyen según una normal y la significación estadística resulta $\leq 0,05$, existen diferencias significativas, con un nivel de confianza del $95 \%$

A continuación se muestra la comparación de medias realizada para cada uno de los tres periodos posteriores a la construcción de la red y para el periodo total hasta mayo de 2018.

Para la temporada Octubre 2015 - Mayo 2016, se comprueba mediante el Test de Shapiro -Wilk que los valores reales y pronosticados se distribuyen según una Normal (Sig $>0,05$ ), como se observa en la Tabla 578

Tabla 578. Prueba de Normalidad temporada Octubre 2015-Mayo 2016. Edificio E13

\begin{tabular}{cccccccr}
\hline & \multicolumn{3}{c}{ Kolmogorov-Smirnov $^{\mathrm{a}}$} & \multicolumn{4}{c}{ Shapiro-Wilk } \\
\cline { 2 - 8 } & Estadístico & gl & Sig. & Estadístico & gl & \multicolumn{1}{c}{ Sig. } \\
\hline kWh_real &, 174 & 8 &, 200 &, 929 & 8 &, 506 \\
\hline kWh_pronosticado &, 169 & 8 &, 200 &, 892 & 8 &, 246 \\
\hline
\end{tabular}

En la Tabla 579, se observa como las medias de los consumos pronosticados, son inferiores a las medias de los consumos reales del Edificio E13, en un 11,0\%

Tabla 579. Estadísticos de muestras relacionadas. Octubre 2015-Mayo 2016. Edificio E13

\begin{tabular}{lcccrc}
\hline & Media & $\begin{array}{c}\text { \% Diferencia } \\
\text { entre medias }\end{array}$ & $\mathrm{N}$ & $\begin{array}{c}\text { Desviación } \\
\text { típ. }\end{array}$ & $\begin{array}{c}\text { Error típ. de } \\
\text { la media }\end{array}$ \\
\hline $\mathrm{kWh}$.real & 170785,8750 & & 8 & 108584,10062 & 38390,27694 \\
\hline kWh_pronosticado & 152046,1250 & $-11,0 \%$ & 8 & 80252,80231 & 28373,65036 \\
\hline
\end{tabular}

La Tabla 580 muestra que las diferencias entre las medias no son significativas entre los consumos reales y los pronosticados (sig $>0,05$ )

Tabla 580. Prueba de muestras relacionadas. Octubre 2015-Mayo 2016. Edificio E13

\begin{tabular}{|c|c|c|c|c|c|c|c|c|c|}
\hline & & \multicolumn{5}{|c|}{ Diferencias relacionadas } & \multirow{3}{*}{$\mathrm{t}$} & \multirow{3}{*}{ gl } & \multirow{3}{*}{$\begin{array}{c}\text { Sig. } \\
\text { (bilateral) }\end{array}$} \\
\hline & & \multirow[t]{2}{*}{ Media } & \multirow{2}{*}{$\begin{array}{l}\text { Desviación } \\
\text { típ. }\end{array}$} & \multirow{2}{*}{$\begin{array}{l}\text { Error típ. } \\
\text { de la media }\end{array}$} & \multicolumn{2}{|c|}{$\begin{array}{l}\text { 95\% Intervalo de confianza } \\
\text { para la diferencia }\end{array}$} & & & \\
\hline & & & & & Inferior & Superior & & & \\
\hline Par 1 & $\begin{array}{c}\text { kWh_real - } \\
\text { kWh_pronosticado }\end{array}$ & 18739,750 & 71476,402 & 25270,724 & $-41016,017$ & 78495,517 & ,742 & 7 & ,482 \\
\hline
\end{tabular}


En la Figura 352 se grafican los consumos reales y pronosticados para la temporada Octubre 2016 - Mayo 2017 para el Edificio E13, y las medias de dichos consumos. Según la prueba paramétrica realizada las diferencias encontradas no son estadísticamente significativas, con un riesgo a estar equivocados del $5 \%$

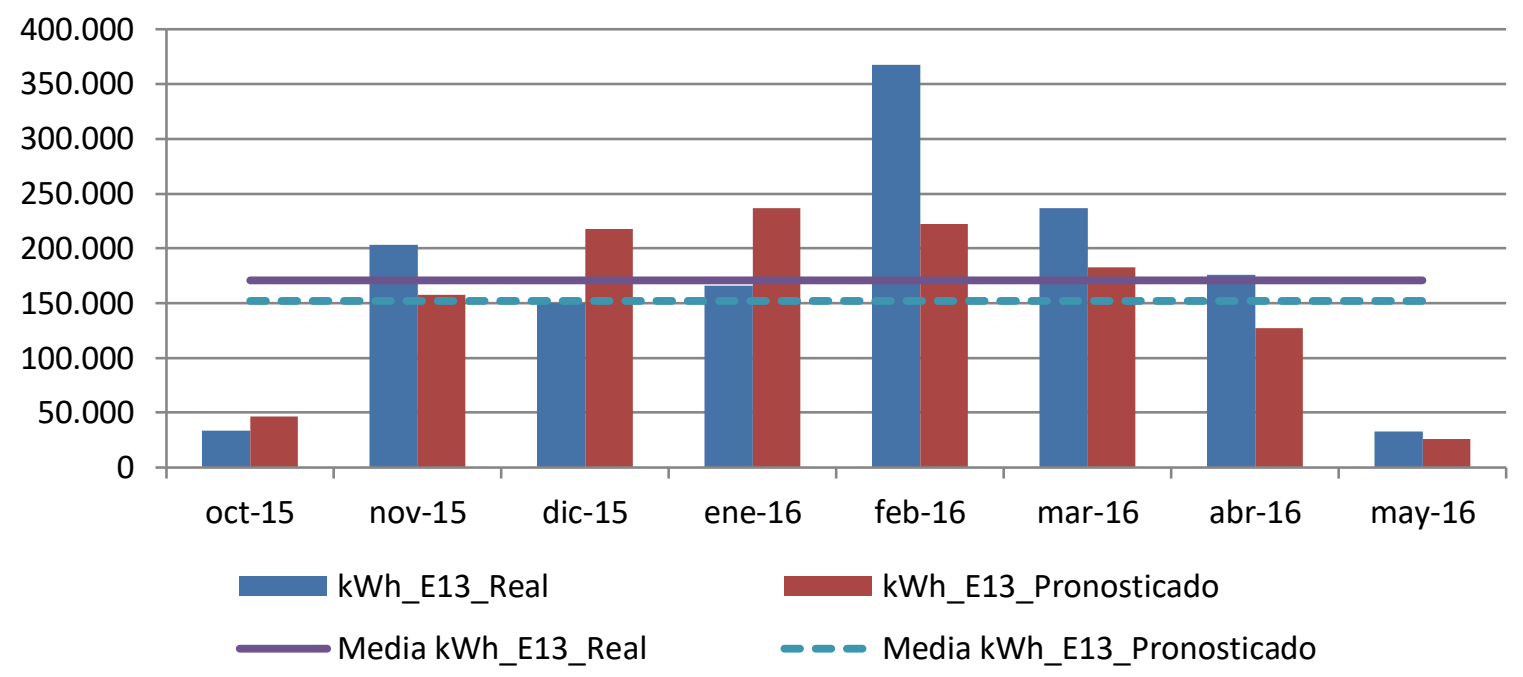

Figura 352. Consumos reales y pronosticados Octubre 2015-Mayo 2016. Edificio E13

Para la temporada Octubre 2016 - Mayo 2017, se comprueba mediante el Test de Shapiro -Wilk que tanto los valores reales como los pronosticados con los dos modelos se distribuyen según una Normal puesto que en todos los casos los valores de Sig >0,05, como se observa en la Tabla 581

Tabla 581. Prueba de Normalidad temporada Octubre 2016-Mayo 2017. Edificio E13

\begin{tabular}{cccccccr}
\hline & \multicolumn{3}{c}{ Kolmogorov-Smirnov $^{\mathrm{a}}$} & \multicolumn{3}{c}{ Shapiro-Wilk } \\
\cline { 2 - 8 } & Estadístico & gl & Sig. & Estadístico & gl & Sig. \\
\hline $\begin{array}{c}\text { kWh_real sin octubre } \\
\text { 2016, ni mayo 2017 }\end{array}$ &, 208 & 6 &, 200 &, 974 & 6 &, 916 \\
\hline kWh_pronosticado &, 266 & 6 &, 200 &, 891 & 6 &, 323 \\
\hline
\end{tabular}

En la Tabla 582 se observa como las medias de los consumos pronosticados, son inferiores a las medias de los consumos reales del Edificio E13, en un $29,4 \%$

Tabla 582. Estadísticos de muestras relacionadas. Octubre 2016-Mayo 2017. Edificio E13

\begin{tabular}{lccrrc}
\hline & Media & $\begin{array}{c}\text { \% Diferencia } \\
\text { entre medias }\end{array}$ & N & $\begin{array}{c}\text { Desviación } \\
\text { típ. }\end{array}$ & $\begin{array}{c}\text { Error típ. de } \\
\text { la media }\end{array}$ \\
\hline kWh_real & 231745,0000 & & 6 & 102345,40630 & 41782,33716 \\
\hline kWh_pronosticado & 163689,0000 & $-29,4 \%$ & 6 & 96189,68543 & 39269,27464 \\
\hline
\end{tabular}


La Tabla 583 muestra que las diferencias entre las medias son significativas entre los consumos reales y los pronosticados (sig $\leq 0,05)$

Tabla 583. Prueba de muestras relacionadas. Octubre 2016-Mayo 2017. Edificio E13

\begin{tabular}{|c|c|c|c|c|c|c|c|c|c|}
\hline & & \multicolumn{5}{|c|}{ Diferencias relacionadas } & \multirow{3}{*}{$\mathrm{t}$} & \multirow{3}{*}{ gl } & \multirow{3}{*}{$\begin{array}{c}\text { Sig. } \\
\text { (bilateral) }\end{array}$} \\
\hline & & \multirow[t]{2}{*}{ Media } & \multirow{2}{*}{$\begin{array}{l}\text { Desviación } \\
\text { típ. }\end{array}$} & \multirow{2}{*}{$\begin{array}{l}\text { Error típ. } \\
\text { de la media }\end{array}$} & \multicolumn{2}{|c|}{$\begin{array}{l}\text { 95\% Intervalo de confianza } \\
\text { para la diferencia }\end{array}$} & & & \\
\hline & & & & & Inferior & Superior & & & \\
\hline Par 1 & $\begin{array}{c}\text { kWh_real - } \\
\text { kWh_pronosticado }\end{array}$ & 68056,000 & 57130,688 & 23323,506 & 8101,020 & 128010,980 & 2,918 & 5 & ,033 \\
\hline
\end{tabular}

En la Figura 353 se grafican los consumos reales y pronosticados para la temporada Octubre 2016 - Mayo 2017 para el Edificio E13, y las medias de dichos consumos. Según la prueba paramétrica realizada las diferencias encontradas son estadísticamente significativas, con un riesgo a estar equivocados del $5 \%$

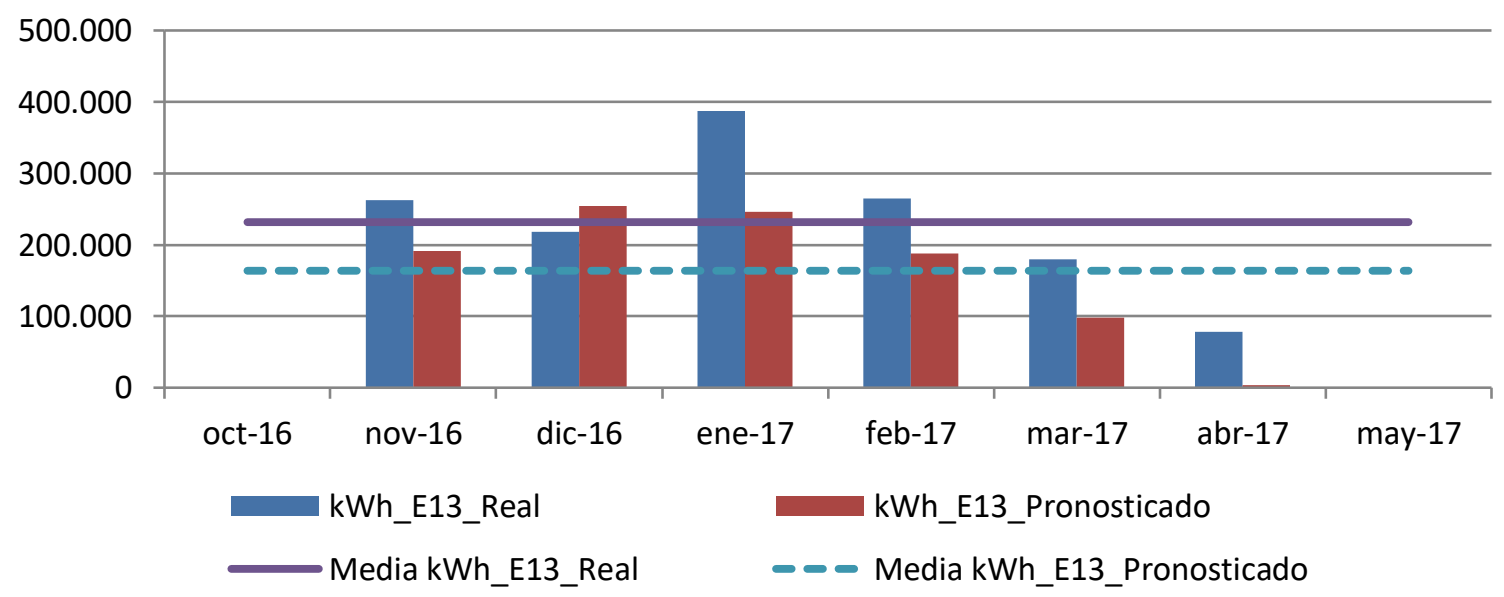

Figura 353. Consumos reales y pronosticados Octubre 2016-Mayo 2017. Edificio E13

Para la temporada Octubre 2017 - Mayo 2018, se comprueba mediante el Test de Shapiro -Wilk que tanto los valores reales como los pronosticados se distribuyen según una Normal puesto que en todos los casos los valores de Sig $>0,05$, como se observa en la Tabla 584

Tabla 584. Prueba de Normalidad temporada Octubre 2017-Mayo 2018. Edificio E13

\begin{tabular}{cccccccr}
\hline & \multicolumn{3}{c}{ Kolmogorov-Smirnov $^{\text {a }}$} & \multicolumn{4}{c}{ Shapiro-Wilk } \\
\cline { 2 - 8 } & Estadístico & gl & Sig. & Estadístico & gl & Sig. \\
\hline $\begin{array}{l}\text { kWh_real sin } \\
\text { octubre 2017 }\end{array}$ &, 251 & 7 &, 200 &, 899 & 7 &, 326 \\
\hline kWh_pronosticado &, 212 & 7 &, 200 &, 881 & 7 &, 232 \\
\hline
\end{tabular}


En la Tabla 585, se observa como las medias de los consumos pronosticados, son inferiores a las medias de los consumos reales del Edificio E13, en un 13,6\%

Tabla 585. Estadísticos de muestras relacionadas. Octubre 2017-Mayo 2018. Edificio E13

\begin{tabular}{lcccrc}
\hline & Media & $\begin{array}{c}\text { \% Diferencia } \\
\text { entre medias }\end{array}$ & N & $\begin{array}{c}\text { Desviación } \\
\text { típ. }\end{array}$ & $\begin{array}{c}\text { Error típ. de } \\
\text { la media }\end{array}$ \\
\hline kWh_real & 204460,5714 & & 7 & 103949,09989 & 39289,06676 \\
\hline kWh_pronosticado & 176724,8571 & $-13,6 \%$ & 7 & 97543,45824 & 36867,96179 \\
\hline
\end{tabular}

La Tabla 586 muestra que las diferencias entre las medias son significativas entre los consumos reales y los pronosticados (sig $>0,05$ )

Tabla 586. Prueba de muestras relacionadas. Octubre 2017-Mayo 2018. Edificio E13

\begin{tabular}{|c|c|c|c|c|c|c|c|c|c|}
\hline & & \multicolumn{5}{|c|}{ Diferencias relacionadas } & \multirow{3}{*}{$\mathrm{t}$} & \multirow{3}{*}{ gl } & \multirow{3}{*}{$\begin{array}{c}\text { Sig. } \\
\text { (bilateral) }\end{array}$} \\
\hline & & \multirow[t]{2}{*}{ Media } & \multirow{2}{*}{$\begin{array}{l}\text { Desviación } \\
\text { típ. }\end{array}$} & \multirow{2}{*}{$\begin{array}{c}\text { Error típ. } \\
\text { de la media }\end{array}$} & \multicolumn{2}{|c|}{$\begin{array}{l}\text { 95\% Intervalo de confianza } \\
\text { para la diferencia }\end{array}$} & & & \\
\hline & & & & & Inferior & Superior & & & \\
\hline Par 1 & $\begin{array}{c}\text { kWh_real - } \\
\text { kWh_pronosticado }\end{array}$ & 27735,714 & 19195,902 & 7255,369 & 9982,466 & 45488,962 & 3,823 & 6 & ,009 \\
\hline
\end{tabular}

En la Figura 354, se grafican los consumos reales y pronosticados para la temporada Octubre 2017 - Mayo 2018 para el Edificio E13, y las medias de dichos consumos. Según la prueba paramétrica realizada las diferencias encontradas son estadísticamente significativas, con un riesgo a estar equivocados del $5 \%$

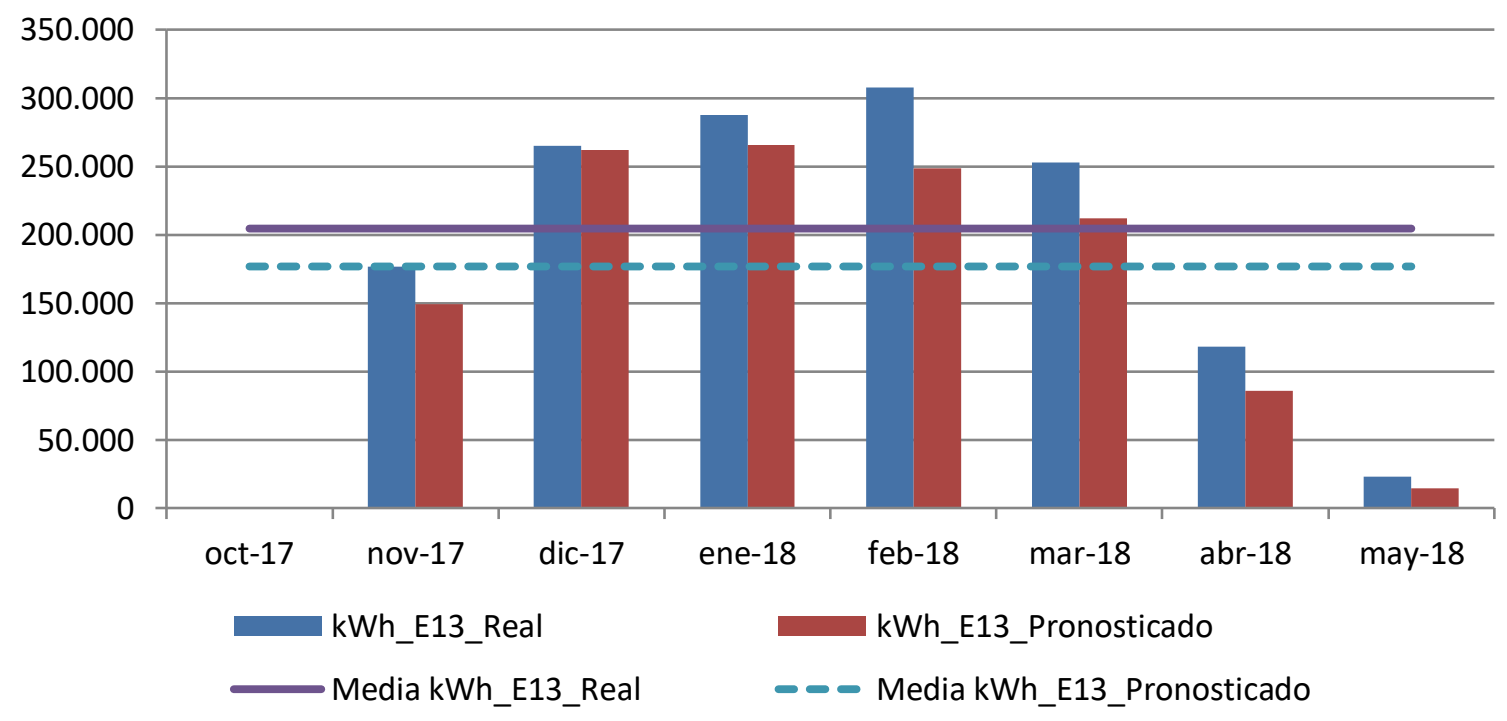

Figura 354. Consumos reales y pronosticados Octubre 2017-Mayo 2018. Edificio E13 
Para el total de las tres temporadas Octubre 2015 - Mayo 2018, se comprueba mediante el Test de Shapiro -Wilk, que los valores reales se distribuyen según una Normal puesto que Sig > 0,05: pero los pronosticados no se distribuyen según una Normal (sig $\leq 0,05)$, como se observa en la Tabla 587

Tabla 587. Prueba de Normalidad temporada Octubre 2015-Mayo 2018. Edificio E13

\begin{tabular}{ccccccrr}
\hline & \multicolumn{3}{c}{ Kolmogorov-Smirnov $^{\mathrm{a}}$} & \multicolumn{3}{c}{ Shapiro-Wilk } \\
\cline { 2 - 8 } & Estadístico & gl & Sig. & Estadístico & gl & \multicolumn{1}{c}{ Sig. } \\
\hline kWh_real &, 088 & 21 &, 200 &, 964 & 21 &, 606 \\
\hline kWh_pronosticado &, 158 & 21 &, 182 &, 900 & 21 &, 035 \\
\hline
\end{tabular}

Al no cumplirse la hipótesis de normalidad, no se puede aplicar la prueba paramétrica de la T-student para analizar si la diferencias encontradas en las medias son significativas, por lo que se concluye que no se han detectado tales diferencias. 


\section{AV.9.5. Estimación de las emisiones de $\mathrm{CO} 2$ evitadas.}

Teniendo en cuenta que al consumir Gas Natural se producen $0,252 \mathrm{~kg} \mathrm{CO}_{2} / \mathrm{kWh} \mathrm{E}$. final y que al consumir la energía suministrada por red a partir de Biomasa se producen 0,024 kg $\mathrm{CO}_{2} / \mathrm{kWh}$. final, en la Tabla 588, se muestra las emisiones de $\mathrm{CO}_{2}$ reales para las temporadas octubre 2015 - mayo 2018 y dado que no se han detectado diferencias significativas, las emisiones de $\mathrm{CO}_{2}$ que se hubieran tenido de haber seguido utilizando las calderas de gas natural originales sin el apoyo de la red de calor.

Tabla 588. Estimación del ahorro de emisiones de CO2 para el Edificio E13.

\begin{tabular}{|c|c|c|c|c|c|c|c|c|c|c|}
\hline & $\begin{array}{l}\text { kWh__ } \\
\text { E13 Gas } \\
\text { natural }\end{array}$ & $\begin{array}{c}\text { kWh_- } \\
\text { E13 } \\
\text { Biomasa }\end{array}$ & $\begin{array}{l}\text { kWh_E13 } \\
\text { Real Total }\end{array}$ & $\begin{array}{l}\text { kWh_E13 } \\
\text { Predicho }\end{array}$ & $\begin{array}{l}\text { kg CO2 Real } \\
\text { debido al } \\
\text { consumo de } \\
\text { Gas Natural }\end{array}$ & $\begin{array}{l}\text { kg CO2 } \\
\text { Real } \\
\text { debido a } \\
\text { Biomasa }\end{array}$ & $\begin{array}{l}\text { kg CO2 } \\
\text { Real } \\
\text { debido al } \\
\text { consumo } \\
\text { TOTAL }\end{array}$ & $\begin{array}{c}\text { kg CO2 } \\
\text { que se } \\
\text { hubiera } \\
\text { tenido } \\
\text { debido a } \\
\text { Gas } \\
\text { Natural }\end{array}$ & $\begin{array}{c}\text { Ahorro de } \\
\text { kg CO2 }\end{array}$ & $\begin{array}{l}\text { Ahorro de kg } \\
\text { CO2 } \\
\text { acumulado }\end{array}$ \\
\hline oct-2015 & 0 & 34.000 & 34.000 & 34.000 & 0 & 816 & 816 & 8.568 & 7.752 & 7.752 \\
\hline nov-2015 & 0 & 203.190 & 203.190 & 203.190 & 0 & 4.877 & 4.877 & 51.204 & 46.327 & 54.079 \\
\hline dic-2015 & 0 & 149.940 & 149.940 & 149.940 & 0 & 3.599 & 3.599 & 37.785 & 34.186 & 88.266 \\
\hline ene-2016 & 0 & 165.700 & 165.700 & 165.700 & 0 & 3.977 & 3.977 & 41.756 & 37.780 & 126.045 \\
\hline feb-2016 & 99.226 & 268.660 & 367.886 & 367.886 & 25.005 & 6.448 & 31.453 & 92.707 & 61.254 & 187.300 \\
\hline mar-2016 & 27.252 & 209.660 & 236.912 & 236.912 & 6.868 & 5.032 & 11.899 & 59.702 & 47.802 & 235.102 \\
\hline abr-2016 & 3.239 & 172.710 & 175.949 & 175.949 & 816 & 4.145 & 4.961 & 44.339 & 39.378 & 274.480 \\
\hline may-2016 & 0 & 32.710 & 32.710 & 32.710 & 0 & 785 & 785 & 8.243 & 7.458 & 281.938 \\
\hline oct-2016 & 5.081 & 24.900 & 0 & 0 & 1.280 & 598 & 1.878 & 0 & -1.878 & 280.060 \\
\hline nov-2016 & 3.160 & 259.220 & 262.380 & 262.380 & 796 & 6.221 & 7.018 & 66.120 & 59.102 & 339.162 \\
\hline dic-2016 & 120 & 218.270 & 218.390 & 218.390 & 30 & 5.238 & 5.269 & 55.034 & 49.766 & 388.928 \\
\hline ene-2017 & 80 & 386.700 & 386.780 & 386.780 & 20 & 9.281 & 9.301 & 97.469 & 88.168 & 477.095 \\
\hline feb-2017 & 600 & 263.970 & 264.570 & 264.570 & 151 & 6.335 & 6.486 & 66.672 & 60.185 & 537.281 \\
\hline mar-2017 & 640 & 179.040 & 179.680 & 179.680 & 161 & 4.297 & 4.458 & 45.279 & 40.821 & 578.102 \\
\hline abr-2017 & 0 & 78.670 & 78.670 & 78.670 & 0 & 1.888 & 1.888 & 19.825 & 17.937 & 596.038 \\
\hline may-2017 & 0 & 23.570 & 0 & 0 & 0 & 566 & 566 & 0 & -566 & 595.473 \\
\hline oct-2017 & 0 & 18.590 & 0 & 0 & 0 & 446 & 446 & 0 & -446 & 595.027 \\
\hline nov-2017 & 0 & 176.720 & 176.720 & 176.720 & 0 & 4.241 & 4.241 & 44.533 & 40.292 & 635.319 \\
\hline dic-2017 & 0 & 264.900 & 264.900 & 264.900 & 0 & 6.358 & 6.358 & 66.755 & 60.397 & 695.716 \\
\hline ene-2018 & 0 & 287.620 & 287.620 & 287.620 & 0 & 6.903 & 6.903 & 72.480 & 65.577 & 761.293 \\
\hline feb-2018 & 0 & 307.970 & 307.970 & 307.970 & 0 & 7.391 & 7.391 & 77.608 & 70.217 & 831.510 \\
\hline mar-2018 & 4.120 & 248.910 & 253.030 & 253.030 & 1.038 & 5.974 & 7.012 & 63.764 & 56.751 & 888.262 \\
\hline$a b r-2018$ & 944 & 117.120 & 118.064 & 118.064 & 238 & 2.811 & 3.049 & 29.752 & 26.703 & 914.965 \\
\hline may-2018 & 0 & 22.920 & 22.920 & 22.920 & 0 & 550 & 550 & 5.776 & 5.226 & 920.191 \\
\hline
\end{tabular}

Como se observa durante estas tres temporadas se ha obtenido un ahorro total de 920 Toneladas de $\mathrm{CO}_{2}$, debido al cambio de la energía utilizada. 


\section{AV.9.6. Estimación del precio máximo de compra a la red.}

Tomando como referencia los precios del gas natural de la Tabla 589 para cada temporada, obtenidos a partir de los datos establecidos en el Capítulo 3, donde se tiene en cuenta el precio por el termino variable y fijo; se puede realizar la estimación del precio máximo de compra de la energía útil a la red de calor para obtener un $0 \%$ de ahorro y un 15\% de ahorro. La Tabla 590, muestral el precio que se pagaría para un ahorro del 15\%

Tabla 589. Precios de referencia para Gas natural y Astilla

\begin{tabular}{ccccc}
\hline Precios (€/(kWh) & 2015 & 2016 & 2017 & 2018 \\
\hline Gas Natural & 0,0373 & 0,0306 & 0,0314 & 0,0336 \\
\hline Astilla & 0,0277 & 0,0256 & 0,0254 & 0,0239 \\
\hline $\begin{array}{c}€ / \text { kWh útiles máximos de compra a la red para } \\
\text { un ahorro del 0,0\% }\end{array}$ & 0,03166 & \\
\hline $\begin{array}{c}€ / \text { kWh útiles máximos de compra a la red para } \\
\text { un ahorro del } 15,0 \%\end{array}$ & 0,02740 \\
\hline
\end{tabular}

Tabla 590. Ahorro Económico por el consumo térmico en el Edificio E13

\begin{tabular}{|c|c|c|c|c|c|c|c|c|c|c|}
\hline & $\begin{array}{l}\text { kWh_- } \\
\text { E13 Gas } \\
\text { natural }\end{array}$ & $\begin{array}{c}\text { kWh_E13_ } \\
\text { Biomasa }\end{array}$ & $\begin{array}{c}\text { kWh_E13 } \\
\text { Real }\end{array}$ & $\begin{array}{c}\text { kWh_E13 } \\
\text { Pronosticado }\end{array}$ & $\begin{array}{c}\text { € Real } \\
\text { Gas } \\
\text { Natural }\end{array}$ & $\begin{array}{c}€ \text { Real } \\
\text { Biomasa }\end{array}$ & $\begin{array}{l}€ \text { Real } \\
\text { Total }\end{array}$ & $\begin{array}{c}\text { Epredicho } \\
\text { Gas } \\
\text { Natural }\end{array}$ & $\begin{array}{c}€ \\
\text { Ahorro }\end{array}$ & $€$ Acumulado \\
\hline oct-2015 & 0 & 34.000 & 34.000 & 34.000 & 0 & 932 & 932 & 1.268 & 337 & 337 \\
\hline nov-2015 & 0 & 203.190 & 203.190 & 203.190 & 0 & 5.567 & 5.567 & 7.579 & 2.012 & 2.348 \\
\hline dic-2015 & 0 & 149.940 & 149.940 & 149.940 & 0 & 4.108 & 4.108 & 5.593 & 1.484 & 3.833 \\
\hline ene-2016 & 0 & 165.700 & 165.700 & 165.700 & 0 & 4.540 & 4.540 & 5.070 & 530 & 4.363 \\
\hline feb-2016 & 99.226 & 268.660 & 367.886 & 367.886 & 3.036 & 7.361 & 10.398 & 11.257 & 860 & 5.223 \\
\hline mar-2016 & 27.252 & 209.660 & 236.912 & 236.912 & 834 & 5.745 & 6.579 & 7.250 & 671 & 5.893 \\
\hline abr-2016 & 3.239 & 172.710 & 175.949 & 175.949 & 99 & 4.732 & 4.831 & 5.384 & 553 & 6.446 \\
\hline may-2016 & 0 & 32.710 & 32.710 & 32.710 & 0 & 896 & 896 & 1.001 & 105 & 6.551 \\
\hline oct-2016 & 5.081 & 24.900 & 0 & 0 & 155 & 682 & 838 & 0 & -838 & 5.713 \\
\hline nov-2016 & 3.160 & 259.220 & 262.380 & 262.380 & 97 & 7.103 & 7.199 & 8.029 & 830 & 6.543 \\
\hline dic-2016 & 120 & 218.270 & 218.390 & 218.390 & 4 & 5.981 & 5.984 & 6.683 & 698 & 7.241 \\
\hline ene-2017 & 80 & 386.700 & 386.780 & 386.780 & 3 & 10.596 & 10.598 & 12.145 & 1.547 & 8.788 \\
\hline feb-2017 & 600 & 263.970 & 264.570 & 264.570 & 19 & 7.233 & 7.252 & 8.307 & 1.056 & 9.844 \\
\hline mar-2017 & 640 & 179.040 & 179.680 & 179.680 & 20 & 4.906 & 4.926 & 5.642 & 716 & 10.560 \\
\hline$a b r-2017$ & 0 & 78.670 & 78.670 & 78.670 & 0 & 2.156 & 2.156 & 2.470 & 315 & 10.875 \\
\hline may-2017 & 0 & 23.570 & 0 & 0 & 0 & 646 & 646 & 0 & -646 & 10.229 \\
\hline oct-2017 & 0 & 18.590 & 0 & 0 & 0 & 509 & 509 & 0 & -509 & 9.719 \\
\hline nov-2017 & 0 & 176.720 & 176.720 & 176.720 & 0 & 4.842 & 4.842 & 5.549 & 707 & 10.426 \\
\hline dic-2017 & 0 & 264.900 & 264.900 & 264.900 & 0 & 7.258 & 7.258 & 8.318 & 1.060 & 11.486 \\
\hline ene-2018 & 0 & 287.620 & 287.620 & 287.620 & 0 & 7.881 & 7.881 & 9.664 & 1.783 & 13.269 \\
\hline feb-2018 & 0 & 307.970 & 307.970 & 307.970 & 0 & 8.438 & 8.438 & 10.348 & 1.909 & 15.179 \\
\hline mar-2018 & 4.120 & 248.910 & 253.030 & 253.030 & 138 & 6.820 & 6.959 & 8.502 & 1.543 & 16.722 \\
\hline abr-2018 & 944 & 117.120 & 118.064 & 118.064 & 32 & 3.209 & 3.241 & 3.967 & 726 & 17.448 \\
\hline may-2018 & 0 & 22.920 & 22.920 & 22.920 & 0 & 628 & 628 & 770 & 142 & 17.590 \\
\hline$€$ Total & & & & & & & 117.206 & 134.796 & & \\
\hline Ahorro (\%) & & & & & & & & & & $15,0 \%$ \\
\hline
\end{tabular}




\section{AV.10. Edificio E14. Aulario Campus Esgueva.}

\section{AV.10.1.Obtención de la línea base de referencia energética}

Los datos de partida para la obtención de la línea base de referencia se muestran en la Tabla 591

Tabla 591. Consumos térmicos del edificio E14

\begin{tabular}{lr}
\hline & Consumos térmicos (kWh). E14 \\
\hline oct-12 & 25.019 \\
\hline nov-12 & 65.981 \\
\hline dic-12 & 70.700 \\
\hline ene-13 & 56.717 \\
\hline feb-13 & 54.283 \\
\hline mar-13 & 40.277 \\
\hline abr-13 & 32.185 \\
\hline may-13 & 28.487 \\
\hline oct-13 & 1.616 \\
\hline nov-13 & 55.254 \\
\hline dic-13 & 69.059 \\
\hline ene-14 & 51.061 \\
\hline feb-14 & 53.630 \\
\hline mar-14 & 46.470 \\
\hline abr-14 & 17.641 \\
\hline may-14 & 8.218 \\
\hline Promedio & 42.287 \\
\hline Total (oct-12-may-13) & 373.650 \\
\hline Total (oct-13-may-14) & 302.950 \\
\hline Total (oct-12-may-13) & 676.599 \\
\hline
\end{tabular}

Como se puede ver en la Tabla 592 para el edificio, el método ofrece un modelo de regresión, con una sola variable (Grados Día en base 20, obtenidos con datos cada 24 horas). El modelo fue construido con un solo paso, incluyendo los Grados día base 20 cada $24 \mathrm{~h}$, por ser la variable más significativa (variable con menor valor de Sig $=0,000$ ). El resto de las variables como se observa en la Tabla 593 fueron excluidas del modelo al tener valores de sig $>0,05$.

Tabla 592. Modelos de regresión del Edificio E14

\begin{tabular}{|c|c|c|c|c|c|c|c|}
\hline \multirow{2}{*}{\multicolumn{2}{|c|}{ Modelo }} & \multicolumn{2}{|c|}{ Coeficientes no estandarizados } & \multirow[t]{2}{*}{$t$} & \multirow[t]{2}{*}{ Sig. } & \multicolumn{2}{|c|}{$\begin{array}{c}\text { Intervalo de confianza de } 95,0 \% \\
\text { para B }\end{array}$} \\
\hline & & $B$ & Error típ. & & & Límite inferior & Límite superior \\
\hline \multirow[t]{2}{*}{1} & (Constante) & $-24047,456$ & 7667,493 & $-3,136$ & ,007 & $-40492,593$ & $-7602,318$ \\
\hline & GD20_24h & 184,862 & 20,534 & 9,003 & ,000 & 140,822 & 228,902 \\
\hline
\end{tabular}


En la Figura 355 se representa el modelo de regresión con sus límites inferior y superior para un nivel de confianza del $95 \%$

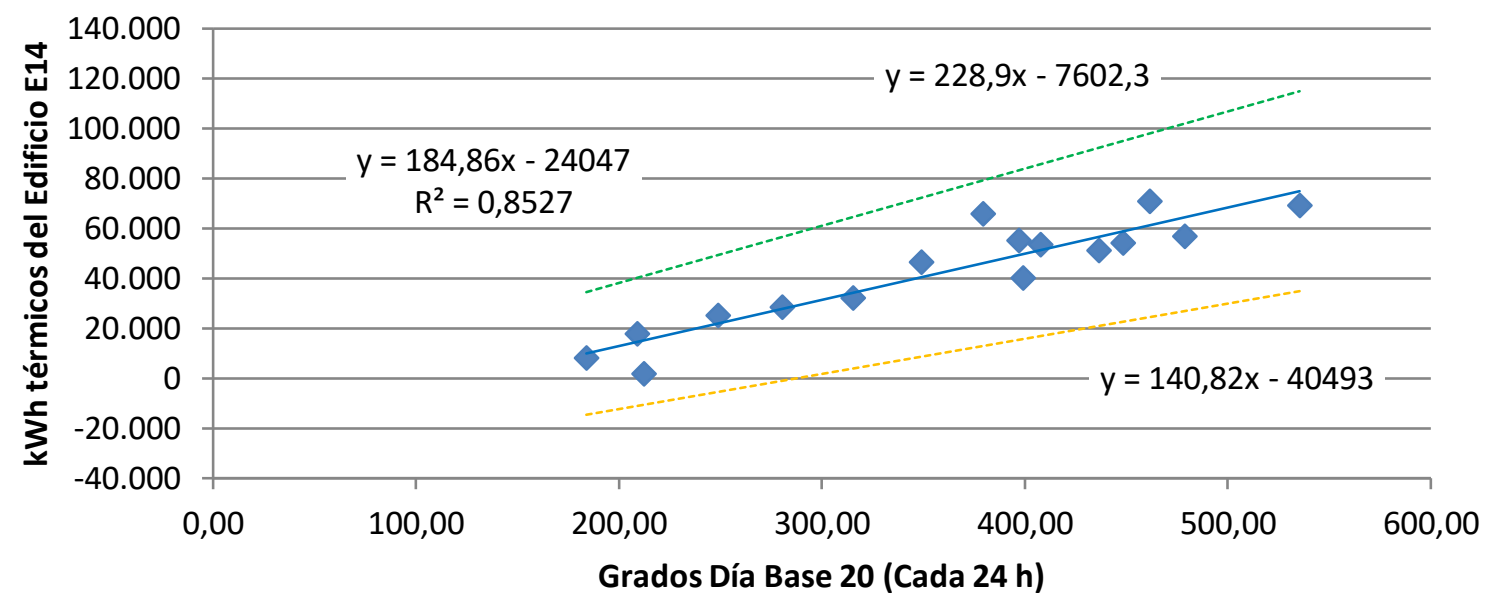

E14 (kWh)

Lineal (E14 lim inferior)
Lineal $(\mathrm{E} 14(\mathrm{kWh}))$

Lineal (E14 lím superior)

Figura 355. Representación del modelo de regresión lineal simple para el Edificio E14

Tabla 593. Variables excluidas del modelo de región del Edificio E14

\begin{tabular}{|c|c|c|c|c|}
\hline & Modelo & $\mathrm{t}$ & Sig. & Correlación parcial \\
\hline & GD15_30min &,- 446 &, 663 &,- 123 \\
\hline & GD20_30_min &,- 078 & ,939 &,- 022 \\
\hline & GD15_24h &,- 289 & ,778 &,- 080 \\
\hline & T_med_C &,- 416 & 684 &,- 115 \\
\hline & T_media_diurna_C &,- 242 & 812 &,- 067 \\
\hline & T_max_C &,- 355 & ,728 &,- 098 \\
\hline & T_min_C &,- 671 &, 514 &,- 183 \\
\hline & HR_\% &,- 284 & ,781 &,- 079 \\
\hline & HR_med_diurna_\% &,- 174 &, 864 &,- 048 \\
\hline \multirow[t]{10}{*}{1} & HR_max_\% &,- 394 & ,700 &,- 109 \\
\hline & HR_min_\% &,- 106 & ,917 &,- 029 \\
\hline & V_Viento_m/s &,- 781 & 449 &,- 212 \\
\hline & V_viento_diurna_m $/ \mathrm{s}$ &,- 704 & ,494 &,- 192 \\
\hline & V_viento_nocturna_m $/ \mathrm{s}$ &,- 849 & 411 &,- 229 \\
\hline & V_viento_max_m/s &,- 578 &, 573 &,- 158 \\
\hline & Recorrido_viento_km/día &,- 780 & 449 &,- 211 \\
\hline & Precipitación_acumulada_mes_mm &,- 170 & 867 &,- 047 \\
\hline & Horas insolación_h &,- 422 & 680 &,- 116 \\
\hline & Radiación_W/m2 &,- 135 & 895 &,- 037 \\
\hline
\end{tabular}


La bondad del modelo de regresión obtenido para el edificio E14, se resumen en la Tabla 594

Tabla 594. Resumen de la bondad del modelo de regresión para el Edificio E14

\begin{tabular}{ccccc}
\hline Modelo & $\mathrm{R}$ & R cuadrado & R cuadrado corregida & $\begin{array}{c}\text { Error típ. de la } \\
\text { estimación }\end{array}$ \\
\hline 1 &, 923 &, 853 &, 842 & 8486,5182 \\
\hline
\end{tabular}

Se observa como el modelo de regresión lineal simple presenta un Coeficiente de Correlación de Pearson (R) de 0,923, lo que indica que las variables están correlacionadas de manera fuerte (en la correlación perfecta $R= \pm 1$ ). La correlación que se produce es directa, al aumentar el valor de los Grados día, aumenta el consumo térmico.

El coeficiente de determinación $\left(R^{2}\right)$, nos indica que con el modelo se podría explicar el $85,3 \%$ de los datos reales obtenidos aceptando un error del $5 \%$.

El error típico de la estimación que nos indica la magnitud de los errores, es decir la parte de la variable dependiente que dejamos sin explicar con el modelo y que describe la variación de la variable respuesta (el Consumo) respecto a la recta de regresión, es de $8.487 \mathrm{kWh}$, lo que representa un 20,1\% del promedio de los consumos que fue de 42.287 kWh.

\section{AV.10.2.Verificación del cumplimiento de los supuestos estadísticos}

Las condiciones que se deben cumplir en un modelo de regresión son:

\section{- Linealidad de las variables, las variables se encuentran relacionadas de forma lineal.}

Como se observa en la Tabla 592, la pendiente (B), obtuvo un valor de Sig $=0,000$, que al ser $\leq 0,05$, nos indica que podemos rechazar la hipótesis nula de pendiente igual a cero y nos da la evidencia de linealidad entre la variable dependiente ( $\mathrm{kWh}$ del edificio E14) y la independiente (GD20_24h). Al ser el valor de la pendiente positiva, indica una relación directa entre el consumo y los Grados día base 20.

- Normalidad. Todos los valores obtenidos para la variable dependiente (Y), deben estar distribuidos normalmente en cada valor de la variable independiente (X).

Se comprueba la normalidad de las variables y de los residuos mediante el Test de Shapiro - Wilk para muestras pequeñas (menores a 30 observaciones), siendo la hipótesis nula el que la distribución es Normal. 
La Tabla 595, muestra la prueba de normalidad de Shapiro-Wilk y cómo tanto la variable dependiente (consumos del Edificio), como la variable independientes: GD20 poseen una Sig $>0,05$, por lo que aceptamos la hipótesis nula de Normalidad de las variables

Tabla 595. Prueba de normalidad para el edificio E14

\begin{tabular}{lrrrrrrr}
\hline & \multicolumn{3}{c}{ Kolmogorov-Smirnov } & \multicolumn{3}{c}{ Shapiro-Wilk } \\
\cline { 2 - 8 } & Estadístico & gl & Sig. & Estadístico & gl & \multicolumn{1}{c}{ Sig. } \\
\hline kWh_E14 &, 159 & 16 &, 200 &, 941 & 16 &, 360 \\
\hline GD20_24h &, 139 & 16 &, 200 &, 952 & 16 &, 517 \\
\hline
\end{tabular}

- Independencia de los errores. Los errores asociados a los valores de la variable respuesta $(\mathrm{Y})$ deberán ser independientes unos de otros.

Para la comprobación se utiliza el estadístico de Durbin -Watson.

Se comprueba que el Estadístico de Durbin Watson para el nivel de significancia del 5\%, y para el tamaño de la muestra " $n$ " y el número de variables independientes del modelo " $k$ ", se encuentra en el intervalo [dU, 4-dU], de la Tabla 3, intervalo centrado en el 2, que indica la ausencia de autocorrelación.

El valor del Estadístico Durbin-Watson facilitado por el programa SPSS, es 1,603.

En el modelo, $\mathrm{n}=16$ y $\mathrm{k}=1$, según la Tabla 3 el valor $\mathrm{dU}=1,371$ y dL =1,106, luego el intervalo que marca la ausencia de correlación es [1,371, 2,629]

Los intervalos $[0,1,106]$ y $[2,896,4]$ indican correlación positiva o negativa respectivamente y las zonas $[1,106,1,371]$ y $[2,629,2,896]$ son zonas no concluyentes; como el valor del estadístico 1,603 está dentro del intervalo de ausencia de correlación, se concluye que no existe autocorrelación en los residuos.

- Homocedasticidad de la varianza. Se pretende comprobar que la varianza de los errores $\left(\sigma^{2}\right)$ es constante para cualquier valor de la variable independiente $(X)$, es decir que el valor medio del cuadrado de la desviación de los errores respecto a su media es constante.

Esta condición indica que no existe correlación entre los residuos y los pronósticos. Se comprueba que el coeficiente de determinación $\mathrm{R}^{2}$, en las relaciones: residuos $\mathrm{y}$ predicciones y entre residuos y variable independiente es nulo o muy próximo a cero, lo que indicará que no existe ningún tipo de correlación en los residuos y que éstos son aleatorios. Se grafican los diagramas de dispersión de esas relaciones, comprobando que se corresponden a nubes de puntos totalmente aleatorias, sin tendencias ni patrones en sus representaciones gráficas. 
Las Figura 356 y Figura 357, muestran que la relación entre los pronósticos y los residuos, posee un coeficiente de determinación $=1,11 \times 10^{-16} \mathrm{y}$ entre la variable independiente (Grados día base 20) y los residuos un coeficiente de determinación de $-2,22 \times 10^{-16}$; por lo que se concluye que no existe ningún tipo de correlación en los residuos y que éstos son aleatorios, siendo la varianza de los residuos constante.

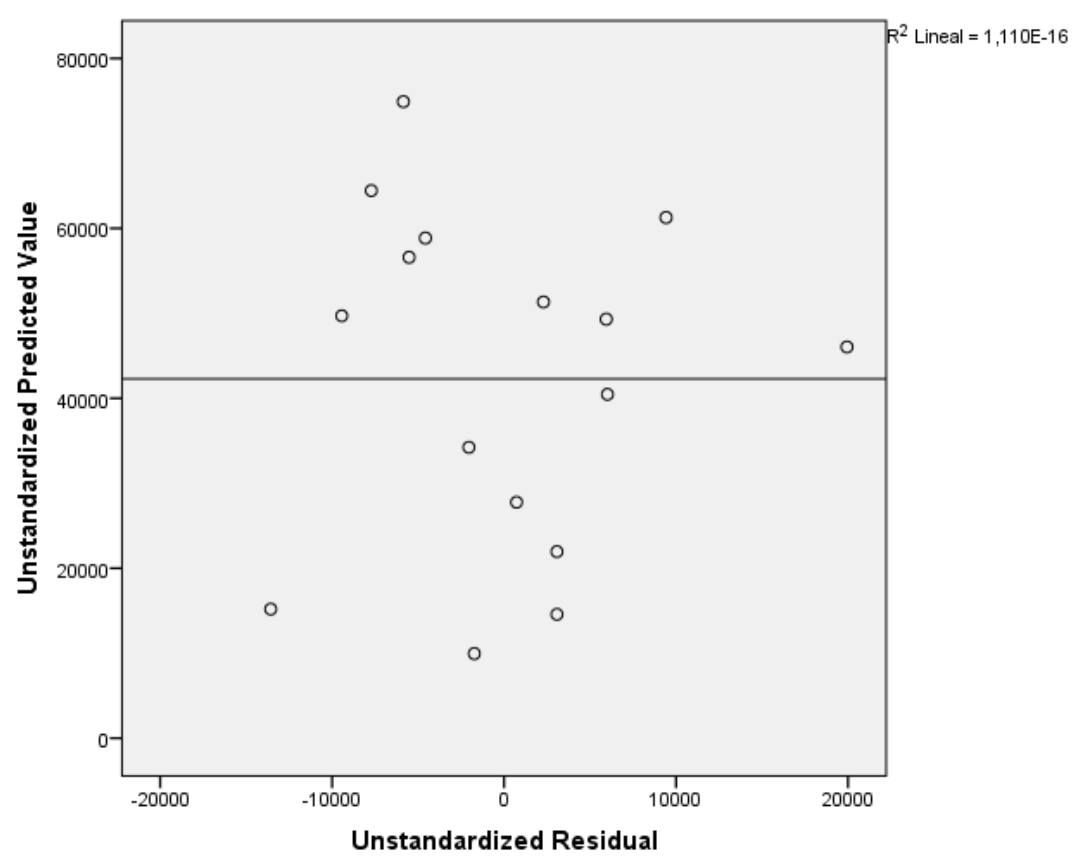

Figura 356. Relación entre los pronósticos y los residuos en el Edificio E14

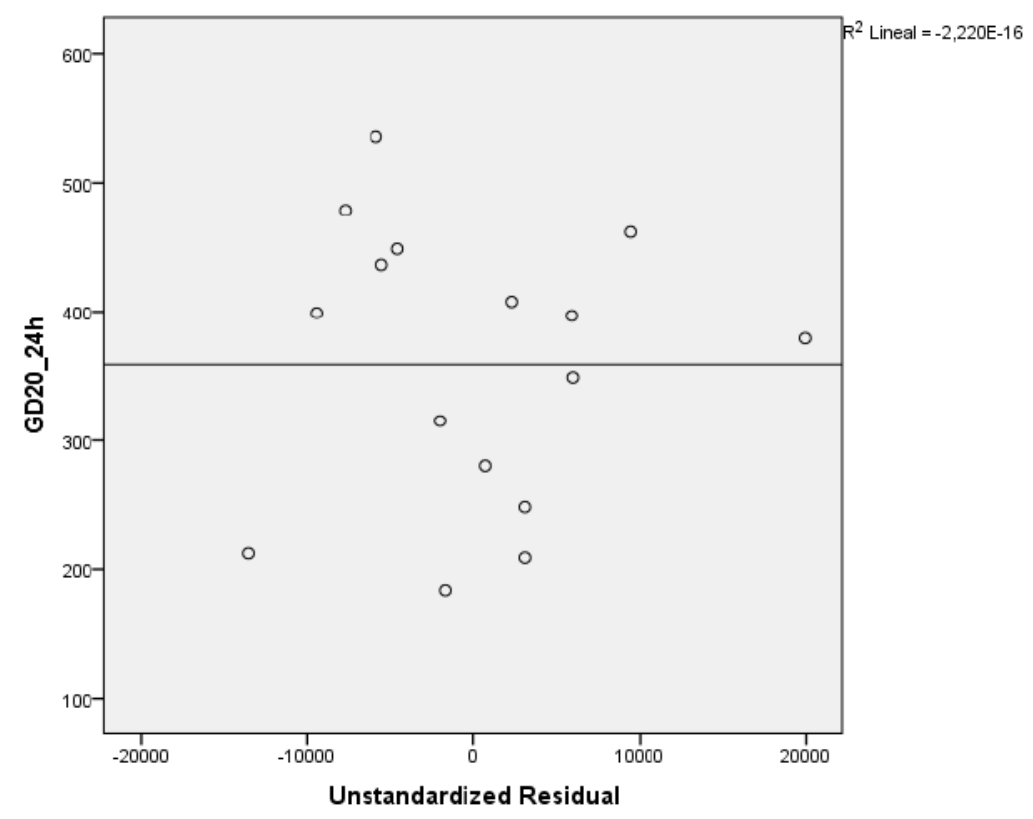

Figura 357. Relación entre GD20_24h y los residuos en el Edificio E14 


\section{AV.10.3.Obtención de los consumos térmicos previstos}

Una vez comprobado el cumplimiento de los supuestos estadísticos se acepta el modelo de línea base encontrado para modelizar el consumo del Edificio E14.

$$
\mathrm{kWh} \text { E14_Pronosticado }=-24.047,456+184,862 \times \text { GD20_24h }
$$

Con este modelo se procede a predecir los consumos previstos para las temporadas: octubre 2015-mayo 2016, octubre 2016 - mayo 2017 y octubre 2017-mayo 2018, estos consumos se muestran en la Tabla 596, donde "KWh_E14_Real", representa el consumo real redistribuido, "kWh_E14_Pronosticado", el consumo pronosticado con el Modelo.

Tabla 596. Consumos previstos octubre 2014 - mayo 2017 para el edificio E14.

\begin{tabular}{rrrr}
\hline & GD20_24h & kWh_E14_Real & kWh_E14_Pronosticado \\
\hline oct-15 & 222,62 & 9.687 & 17.107 \\
\hline nov-15 & 350,93 & 38.632 & 40.826 \\
\hline dic-15 & 454,81 & 55.921 & 60.030 \\
\hline ene-16 & 426,76 & 39.537 & 54.844 \\
\hline feb-16 & 411,33 & 102.472 & 51.992 \\
\hline mar-16 & 429,57 & 42.448 & 55.364 \\
\hline abr-16 & 326,98 & 31.991 & 36.399 \\
\hline may-16 & 213,46 & 11.087 & 15.413 \\
\hline oct-16 & 202,11 & 7.812 & 13.315 \\
\hline nov-16 & 392,95 & 38.585 & 48.594 \\
\hline dic-16 & 492,22 & 63.199 & 66.945 \\
\hline ene-17 & 542,00 & 70.886 & 76.148 \\
\hline feb-17 & 365,13 & 40.723 & 43.451 \\
\hline mar-17 & 334,51 & 31.425 & 37.791 \\
\hline abr-17 & 222,69 & 12.601 & 17.119 \\
\hline may-17 & 111,78 & 769 & -3.384 \\
\hline oct-17 & 164,47 & 1 & 6.357 \\
\hline nov-17 & 417,29 & 24.942 & 53.094 \\
\hline dic-17 & 496,27 & 69.441 & 67.694 \\
\hline ene-18 & 482,96 & 62.464 & 65.233 \\
\hline feb-18 & 461,20 & 65.539 & 61.211 \\
\hline mar-18 & 409,12 & 48.603 & 51.583 \\
\hline abr-18 & 265,61 & 29.414 & 25.054 \\
\hline may-18 & 185,14 & 5.144 & 10.178 \\
\hline & & &
\end{tabular}

En el estudio de la existencia de diferencias significativas, el mes de mayo de 2017, no será tenido en cuenta por ser negativo el valor pronosticado en ese mes. 


\section{AV.10.4.Estudio de la existencia de diferencias significativas}

Utilizando la prueba " $\mathrm{t}$ " de Student para muestras relacionadas, podemos concluir que si las variables se distribuyen según una normal y la significación estadística resulta $\leq 0,05$, existen diferencias significativas, con un nivel de confianza del $95 \%$

A continuación se muestra la comparación de medias realizada para cada uno de los tres periodos posteriores a la construcción de la red y para el periodo total hasta mayo de 2018.

Para la temporada Octubre 2015 - Mayo 2016, se comprueba mediante el Test de Shapiro -Wilk que los valores reales y pronosticados se distribuyen según una Normal (Sig $>0,05$ ), como se observa en la Tabla 597

Tabla 597. Prueba de Normalidad temporada Octubre 2015-Mayo 2016. Edificio E14

\begin{tabular}{ccccrrrr}
\hline & \multicolumn{3}{c}{ Kolmogorov-Smirnov $^{\mathrm{a}}$} & \multicolumn{4}{c}{ Shapiro-Wilk } \\
\cline { 2 - 9 } & Estadístico & gl & Sig. & Estadístico & gl & \multicolumn{1}{c}{ Sig. } \\
\hline kWh_real &, 237 & 8 &, 200 &, 874 & 8 &, 164 \\
\hline kWh_pronosticado &, 226 & 8 &, 200 &, 868 & 8 &, 144 \\
\hline
\end{tabular}

En la Tabla 598, se observa como las medias de los consumos pronosticados, son superiores a las medias de los consumos reales del Edificio E14, en un $0,1 \%$

Tabla 598. Estadísticos de muestras relacionadas. Octubre 2015-Mayo 2016. Edificio E14

\begin{tabular}{lccccc}
\hline & Media & $\begin{array}{c}\text { \% Diferencia } \\
\text { entre medias }\end{array}$ & $\mathrm{N}$ & $\begin{array}{c}\text { Desviación } \\
\text { típ. }\end{array}$ & $\begin{array}{c}\text { Error típ. de } \\
\text { la media }\end{array}$ \\
\hline kWh_real & 41471,8750 & & 8 & 29193,83451 & 10321,57917 \\
\hline kWh_pronosticado & 41496,8750 & $0,1 \%$ & 8 & 17426,33562 & 6161,14005 \\
\hline
\end{tabular}

La Tabla 599 muestra que las diferencias entre las medias no son significativas entre los consumos reales y los pronosticados (sig $>0,05$ )

Tabla 599. Prueba de muestras relacionadas. Octubre 2015-Mayo 2016. Edificio E14

\begin{tabular}{|c|c|c|c|c|c|c|c|c|c|}
\hline & & \multicolumn{5}{|c|}{ Diferencias relacionadas } & \multirow{3}{*}{$\mathrm{t}$} & \multirow{3}{*}{$\mathrm{gl}$} & \multirow{3}{*}{$\begin{array}{c}\text { Sig. } \\
\text { (bilateral) }\end{array}$} \\
\hline & & \multirow[t]{2}{*}{ Media } & \multirow{2}{*}{$\begin{array}{l}\text { Desviación } \\
\text { típ. }\end{array}$} & \multirow{2}{*}{$\begin{array}{c}\text { Error típ. } \\
\text { de la media }\end{array}$} & \multicolumn{2}{|c|}{$\begin{array}{l}\text { 95\% Intervalo de confianza } \\
\text { para la diferencia }\end{array}$} & & & \\
\hline & & & & & Inferior & Superior & & & \\
\hline Par 1 & $\begin{array}{c}\text { kWh_real - } \\
\text { kWh_pronosticado }\end{array}$ & $-25,000$ & 20922,481 & 7397,214 & $-17516,632$ & 17466,632 &,- 003 & 7 & ,997 \\
\hline
\end{tabular}


En la Figura 358 se grafican los consumos reales y pronosticados para la temporada Octubre 2016 - Mayo 2017 para el Edificio E14, y las medias de dichos consumos. Según la prueba paramétrica realizada las diferencias encontradas no son estadísticamente significativas, con un riesgo a estar equivocados del $5 \%$

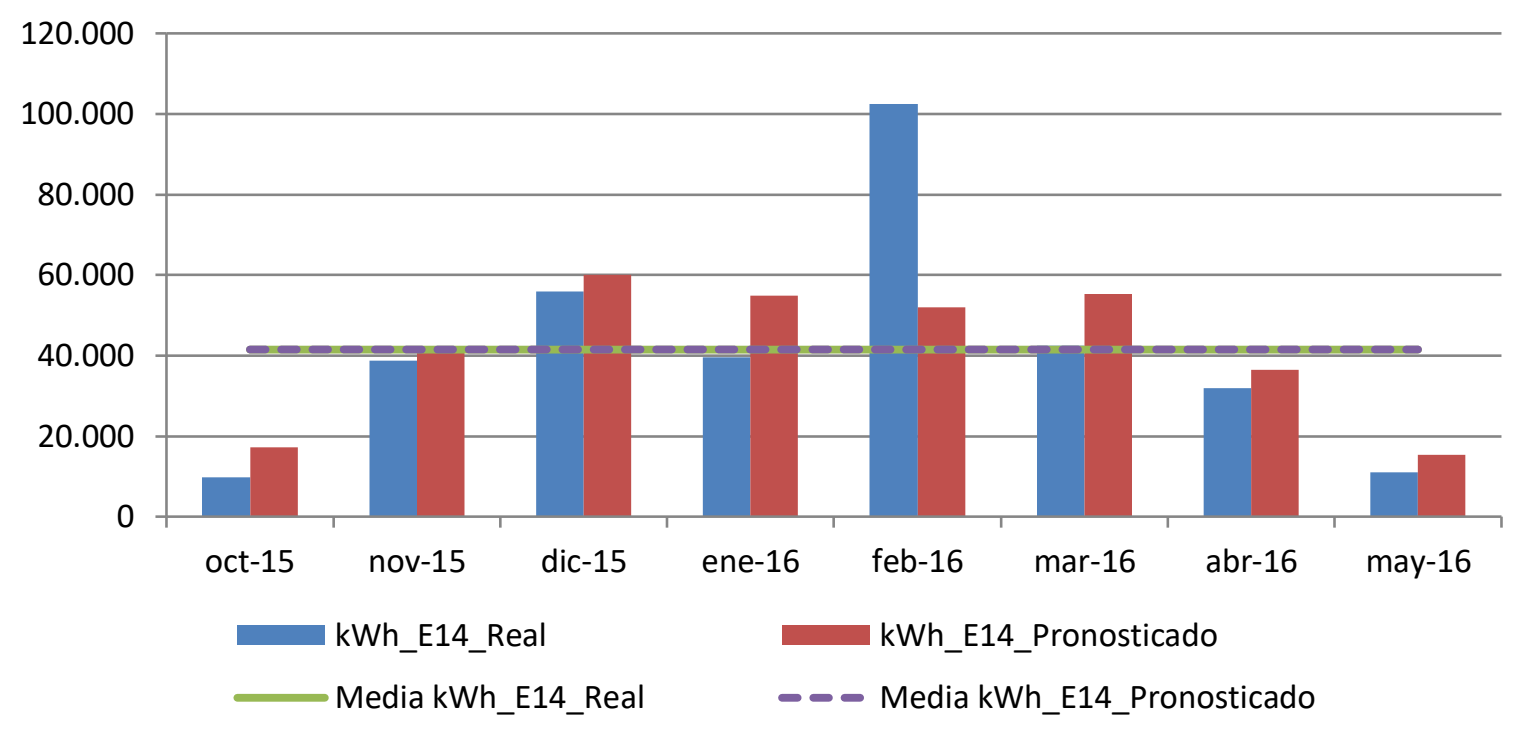

Figura 358. Consumos reales y pronosticados Octubre 2015-Mayo 2016. Edificio E14

Para la temporada Octubre 2016 - Mayo 2017, se comprueba mediante el Test de Shapiro -Wilk que tanto los valores reales como los pronosticados con los dos modelos se distribuyen según una Normal puesto que en todos los casos los valores de Sig >0,05, como se observa en la Tabla 600

Tabla 600. Prueba de Normalidad temporada Octubre 2016-Mayo 2017. Edificio E14

\begin{tabular}{cccccccr}
\hline & \multicolumn{3}{c}{ Kolmogorov-Smirnov $^{\text {a }}$} & \multicolumn{3}{c}{ Shapiro-Wilk } \\
\cline { 2 - 8 } & Estadístico & gl & Sig. & Estadístico & gl & Sig. \\
\hline $\begin{array}{c}\text { kWh_real sin } \\
\text { mayo 2017 }\end{array}$ &, 166 & 7 &, 200 &, 942 & 7 &, 654 \\
\hline kWh_pronosticado &, 155 & 7 &, 200 &, 948 & 7 &, 713 \\
\hline
\end{tabular}

En la Tabla 601, se observa como las medias de los consumos pronosticados, son superiores a las medias de los consumos reales del Edificio E14, en un 14,4\%

Tabla 601. Estadísticos de muestras relacionadas. Octubre 2016-Mayo 2017. Edificio E14

\begin{tabular}{lccccc}
\hline & Media & $\begin{array}{c}\text { \% Diferencia } \\
\text { entre medias }\end{array}$ & $\mathrm{N}$ & $\begin{array}{c}\text { Desviación } \\
\text { típ. }\end{array}$ & $\begin{array}{c}\text { Error típ. de } \\
\text { la media }\end{array}$ \\
\hline $\mathrm{kWh}$ _real & 37890,1429 & & 7 & 23536,51858 & 8895,96784 \\
\hline $\mathrm{kWh}$ _pronosticado & 43337,5714 & $14,4 \%$ & 7 & 23384,50538 & 8838,51225 \\
\hline
\end{tabular}


La Tabla 602 muestra que las diferencias entre las medias son significativas entre los consumos reales y los pronosticados (sig $\leq 0,05)$

Tabla 602. Prueba de muestras relacionadas. Octubre 2016-Mayo 2017. Edificio E14

\begin{tabular}{|c|c|c|c|c|c|c|c|c|c|}
\hline & & \multicolumn{5}{|c|}{ Diferencias relacionadas } & \multirow{3}{*}{$\mathrm{t}$} & \multirow{3}{*}{ gl } & \multirow{3}{*}{$\begin{array}{c}\text { Sig. } \\
\text { (bilateral) }\end{array}$} \\
\hline & & \multirow[t]{2}{*}{ Media } & \multirow{2}{*}{$\begin{array}{c}\text { Desviación } \\
\text { típ. }\end{array}$} & \multirow{2}{*}{$\begin{array}{c}\text { Error típ. } \\
\text { de la media }\end{array}$} & \multicolumn{2}{|c|}{$\begin{array}{l}\text { 95\% Intervalo de confianza } \\
\text { para la diferencia }\end{array}$} & & & \\
\hline & & & & & Inferior & Superior & & & \\
\hline Par 1 & $\begin{array}{c}\text { kWh_real - } \\
\text { kWh_pronosticado }\end{array}$ & $-5447,429$ & 2339,628 & 884,296 & $-7611,224$ & $-3283,633$ & $-6,160$ & 6 & ,001 \\
\hline
\end{tabular}

En la Figura 359 se grafican los consumos reales y pronosticados para la temporada Octubre 2016 - Mayo 2017 para el Edificio E14, y las medias de dichos consumos. Según la prueba paramétrica realizada las diferencias encontradas son estadísticamente significativas, con un riesgo a estar equivocados del $5 \%$

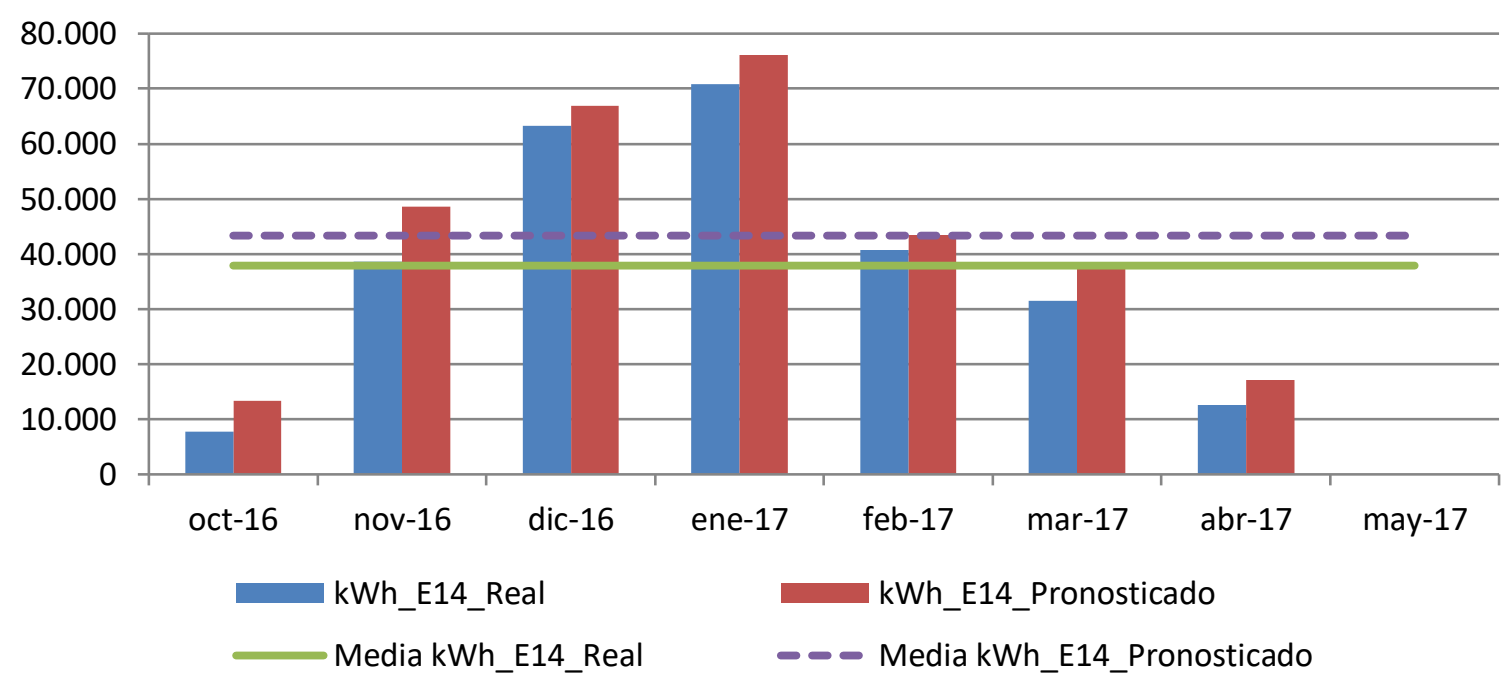

Figura 359. Consumos reales y pronosticados Octubre 2016-Mayo 2017. Edificio E14

Para la temporada Octubre 2017 - Mayo 2018, se comprueba mediante el Test de Shapiro -Wilk que tanto los valores reales como los pronosticados se distribuyen según una Normal puesto que en todos los casos los valores de Sig $>0,05$, como se observa en la Tabla 603

Tabla 603. Prueba de Normalidad temporada Octubre 2017-Mayo 2018. Edificio E14

\begin{tabular}{cccccccr}
\hline & \multicolumn{3}{c}{ Kolmogorov-Smirnov $^{\mathrm{a}}$} & \multicolumn{3}{c}{ Shapiro-Wilk } \\
\cline { 2 - 9 } & Estadístico & gl & \multicolumn{1}{c}{ Sig. } & Estadístico & gl & \multicolumn{1}{c}{ Sig. } \\
\hline kWh_real &, 188 & 8 &, 200 &, 905 & 8 &, 321 \\
\hline kWh_pronosticado &, 266 & 8 &, 099 &, 853 & 8 &, 103 \\
\hline
\end{tabular}


En la Tabla 604, se observa como las medias de los consumos pronosticados, son superiores a las medias de los consumos reales del Edificio E14, en un 11,4\%

Tabla 604. Estadísticos de muestras relacionadas. Octubre 2017-Mayo 2018. Edificio E14

\begin{tabular}{lccrcc}
\hline & Media & $\begin{array}{c}\text { \% Diferencia } \\
\text { entre medias }\end{array}$ & N & $\begin{array}{c}\text { Desviación } \\
\text { típ. }\end{array}$ & $\begin{array}{c}\text { Error típ. de } \\
\text { la media }\end{array}$ \\
\hline kWh_real & 38193,5000 & & 8 & 27321,40936 & 9659,57692 \\
\hline kWh_pronosticado & 42550,5000 & $11,4 \%$ & 8 & 24933,43372 & 8815,30003 \\
\hline
\end{tabular}

La Tabla 605 muestra que las diferencias entre las medias no son significativas entre los consumos reales y los pronosticados (sig $>0,05$ )

Tabla 605. Prueba de muestras relacionadas. Octubre 2017-Mayo 2018. Edificio E14

\begin{tabular}{|c|c|c|c|c|c|c|c|c|c|}
\hline & & \multicolumn{5}{|c|}{ Diferencias relacionadas } & \multirow{3}{*}{$\mathrm{t}$} & \multirow{3}{*}{ gl } & \multirow{3}{*}{$\begin{array}{c}\text { Sig. } \\
\text { (bilateral) }\end{array}$} \\
\hline & & \multirow[t]{2}{*}{ Media } & \multirow{2}{*}{$\begin{array}{l}\text { Desviación } \\
\text { típ. }\end{array}$} & \multirow{2}{*}{$\begin{array}{c}\text { Error típ. } \\
\text { de la media }\end{array}$} & \multicolumn{2}{|c|}{$\begin{array}{l}\text { 95\% Intervalo de confianza } \\
\text { para la diferencia }\end{array}$} & & & \\
\hline & & & & & Inferior & Superior & & & \\
\hline Par 1 & $\begin{array}{c}\text { kWh_real - } \\
\text { kWh_pronosticado }\end{array}$ & $-4357,000$ & 10445,425 & 3693,016 & $-13089,594$ & 4375,594 & $-1,180$ & 7 & 277 \\
\hline
\end{tabular}

En la Figura 360, se grafican los consumos reales y pronosticados para la temporada Octubre 2017 - Mayo 2018 para el Edificio E14, y las medias de dichos consumos. Según la prueba paramétrica realizada las diferencias encontradas no son estadísticamente significativas, con un riesgo a estar equivocados del $5 \%$

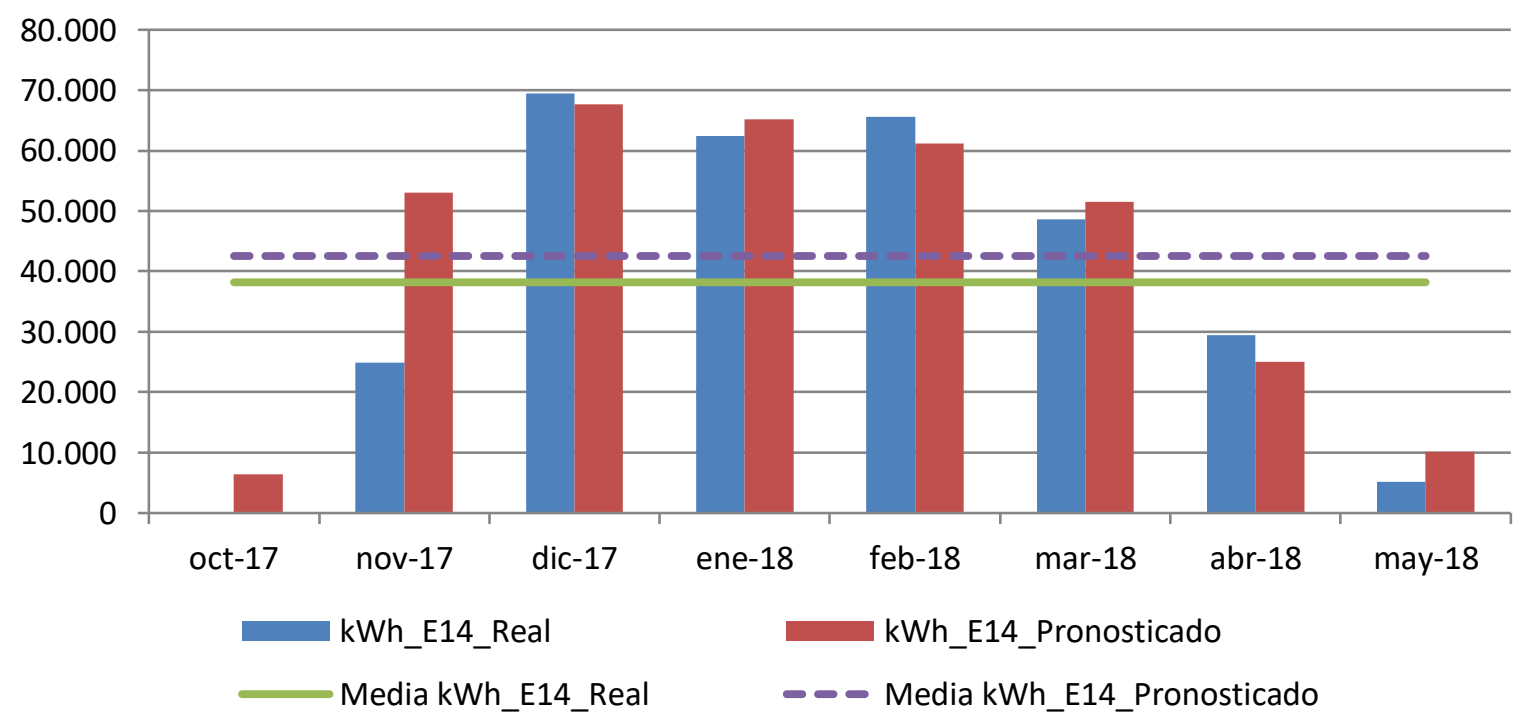

Figura 360. Consumos reales y pronosticados Octubre 2017-Mayo 2018. Edificio E14 
Para el total de las tres temporadas Octubre 2015 - Mayo 2018, se comprueba mediante el Test de Shapiro -Wilk, que los valores reales y los pronosticados se distribuyen según una Normal puesto que en esos casos los valores de Sig $>0,05$, como se observa en la Tabla 606

Tabla 606. Prueba de Normalidad temporada Octubre 2015-Mayo 2018. Edificio E14

\begin{tabular}{cccccccr}
\hline & \multicolumn{3}{c}{ Kolmogorov-Smirnov $^{\mathrm{a}}$} & \multicolumn{3}{c}{ Shapiro-Wilk } \\
\cline { 2 - 8 } & Estadístico & gl & Sig. & Estadístico & gl & Sig. \\
\hline kWh_real &, 111 & 23 &, 200 &, 959 & 23 &, 436 \\
\hline kWh_pronosticado &, 146 & 23 &, 200 &, 932 & 23 &, 121 \\
\hline
\end{tabular}

En la Tabla 607 se observa como las medias de los consumos pronosticados, son superiores a las medias de los consumos reales del Edificio E14, en un 8,1 \%

Tabla 607. Estadísticos de muestras relacionadas. Octubre 2015-Mayo 2018. Edificio E14

\begin{tabular}{lccccc}
\hline & Media & $\begin{array}{c}\text { \% Diferencia } \\
\text { entre medias }\end{array}$ & N & $\begin{array}{c}\text { Desviación } \\
\text { típ. }\end{array}$ & $\begin{array}{c}\text { Error típ. de } \\
\text { la media }\end{array}$ \\
\hline kWh_real & 39241,4783 & & 23 & 25740,26568 & 5367,21642 \\
\hline kWh_pronosticado & 42423,5652 & $8,1 \%$ & 23 & 21074,89930 & 4394,42028 \\
\hline
\end{tabular}

La Tabla 608 muestra que las diferencias entre las medias no son significativas entre los consumos reales y los pronosticados (sig $>0,05$ )

Tabla 608. Prueba de muestras relacionadas. Octubre 2015-Mayo 2018. Edificio E14

\begin{tabular}{|c|c|c|c|c|c|c|c|c|}
\hline & \multicolumn{5}{|c|}{ Diferencias relacionadas } & \multirow{3}{*}{$\mathrm{t}$} & \multirow{3}{*}{$\mathrm{gl}$} & \multirow{3}{*}{$\begin{array}{c}\text { Sig. } \\
\text { (bilateral) }\end{array}$} \\
\hline & \multirow[t]{2}{*}{ Media } & \multirow{2}{*}{$\begin{array}{l}\text { Desviación } \\
\text { típ. }\end{array}$} & \multirow{2}{*}{$\begin{array}{l}\text { Error típ. de } \\
\text { la media }\end{array}$} & \multicolumn{2}{|c|}{$\begin{array}{c}\text { 95\% Intervalo de confianza } \\
\text { para la diferencia }\end{array}$} & & & \\
\hline & & & & Inferior & Superior & & & \\
\hline $\begin{array}{c}\text { kWh_real - } \\
\text { kWh_pronosticado }\end{array}$ & $-3182,087$ & 13462,990 & 2807,227 & $-9003,920$ & 2639,747 & $-1,134$ & 22 & ,269 \\
\hline
\end{tabular}




\section{AV.10.5.Estimación de las emisiones de CO2 evitadas.}

Teniendo en cuenta que el consumir Gasóleo se producen 0,311 kg $\mathrm{CO}_{2} / \mathrm{kWh}$ E. final y que al consumir la energía suministrada por red a partir de Biomasa se producen 0,024 kg $\mathrm{CO}_{2} / \mathrm{kWh}$. final, en la Tabla 609, se muestra las emisiones de $\mathrm{CO}_{2}$ reales para las temporadas octubre 2015 - mayo 2018 y dado que no se han detectado diferencias significativas, las emisiones de $\mathrm{CO}_{2}$ que se hubieran tenido de haber seguido utilizando las calderas de gasóleo originales sin el apoyo de la red de calor.

Tabla 609. Estimación del ahorro de emisiones de CO2 para el Edificio E14.

\begin{tabular}{|c|c|c|c|c|c|c|c|c|c|c|}
\hline & $\begin{array}{c}\text { kWh_- } \\
\text { E14 } \\
\text { Gasóleo }\end{array}$ & $\begin{array}{c}\text { kWh__ } \\
\text { E14 } \\
\text { Biomasa }\end{array}$ & $\begin{array}{l}\text { kWh_E14 } \\
\text { Real Total }\end{array}$ & $\begin{array}{l}\text { kWh_E14 } \\
\text { Predicho }\end{array}$ & $\begin{array}{l}\text { kg CO2 Real } \\
\text { debido al } \\
\text { consumo de } \\
\text { Gasóleo }\end{array}$ & $\begin{array}{l}\text { kg CO2 } \\
\text { Real } \\
\text { debido a } \\
\text { Biomasa }\end{array}$ & $\begin{array}{l}\text { kg CO2 } \\
\text { Real } \\
\text { debido al } \\
\text { consumo } \\
\text { TOTAL }\end{array}$ & $\begin{array}{c}\text { kg CO2 } \\
\text { que se } \\
\text { hubiera } \\
\text { tenido } \\
\text { debido a } \\
\text { Gasóleo }\end{array}$ & $\begin{array}{l}\text { Ahorro de } \\
\text { kg CO2 }\end{array}$ & $\begin{array}{l}\text { Ahorro de kg } \\
\text { CO2 } \\
\text { acumulado }\end{array}$ \\
\hline oct-2015 & 0 & 9.687 & 9687 & 9.687 & 0 & 232 & 232 & 3.013 & 2.780 & 2.780 \\
\hline nov-2015 & 0 & 38.632 & 38632 & 38.632 & 0 & 927 & 927 & 12.015 & 11.087 & 13.868 \\
\hline dic-2015 & 0 & 55.921 & 55921 & 55.921 & 0 & 1.342 & 1.342 & 17.391 & 16.049 & 29.917 \\
\hline ene-2016 & 0 & 39.537 & 39537 & 39.537 & 0 & 949 & 949 & 12.296 & 11.347 & 41.264 \\
\hline feb-2016 & 37.866 & 64.606 & 102472 & 102.472 & 11.776 & 1.551 & 13.327 & 31.869 & 18.542 & 59.806 \\
\hline mar-2016 & 2.470 & 39.978 & 42448 & 42.448 & 768 & 959 & 1.728 & 13.201 & 11.474 & 71.280 \\
\hline abr-2016 & 1.441 & 30.550 & 31991 & 31.991 & 448 & 733 & 1.181 & 9.949 & 8.768 & 80.047 \\
\hline may-2016 & 3.018 & 8.069 & 11087 & 11.087 & 939 & 194 & 1.132 & 3.448 & 2.316 & 82.363 \\
\hline oct-2016 & 2.706 & 5.106 & 7812 & 7.812 & 842 & 123 & 964 & 2.430 & 1.465 & 83.829 \\
\hline nov-2016 & 1.103 & 37.482 & 38585 & 38.585 & 343 & 900 & 1.242 & 12.000 & 10.757 & 94.586 \\
\hline dic-2016 & 3.832 & 59.367 & 63199 & 63.199 & 1.192 & 1.425 & 2.617 & 19.655 & 17.038 & 111.624 \\
\hline ene-2017 & 54 & 70.832 & 70886 & 70.886 & 17 & 1.700 & 1.717 & 22.046 & 20.329 & 131.953 \\
\hline feb-2017 & 31 & 40.692 & 40723 & 40.723 & 10 & 977 & 986 & 12.665 & 11.679 & 143.632 \\
\hline mar-2017 & 0 & 31.425 & 31425 & 31.425 & 0 & 754 & 754 & 9.773 & 9.019 & 152.651 \\
\hline abr-2017 & 601 & 12.000 & 12601 & 12.601 & 187 & 288 & 475 & 3.919 & 3.444 & 156.095 \\
\hline may-2017 & 31 & 738 & 0 & 0 & 10 & 18 & 27 & 0 & -27 & 156.067 \\
\hline oct-2017 & 0 & 1 & 1 & 1 & 0 & 0 & 0 & 0 & 0 & 156.068 \\
\hline nov-2017 & 0 & 24.942 & 24942 & 24.942 & 0 & 599 & 599 & 7.757 & 7.158 & 163.226 \\
\hline dic-2017 & 0 & 69.441 & 69441 & 69.441 & 0 & 1.667 & 1.667 & 21.596 & 19.930 & 183.156 \\
\hline ene-2018 & 0 & 62.464 & 62464 & 62.464 & 0 & 1.499 & 1.499 & 19.426 & 17.927 & 201.083 \\
\hline feb-2018 & 0 & 65.539 & 65539 & 65.539 & 0 & 1.573 & 1.573 & 20.383 & 18.810 & 219.892 \\
\hline mar-2018 & 0 & 48.603 & 48603 & 48.603 & 0 & 1.166 & 1.166 & 15.116 & 13.949 & 233.842 \\
\hline abr-2018 & 0 & 29.414 & 29414 & 29.414 & 0 & 706 & 706 & 9.148 & 8.442 & 242.283 \\
\hline may-2018 & 0 & 5.144 & 5144 & 5.144 & 0 & 123 & 123 & 1.600 & 1.476 & 243.760 \\
\hline
\end{tabular}

Como se observa durante estas tres temporadas se ha obtenido un ahorro total de 244 Toneladas de $\mathrm{CO}_{2}$, debido al cambio de la energía utilizada. 


\section{AV.10.6.Estimación del precio máximo de compra a la red.}

Tomando como referencia los precios del gas natural de la Tabla 610 para cada temporada, obtenidos a partir de los datos establecidos en el Capítulo 3, donde se tiene en cuenta el precio por el termino variable y fijo; se puede realizar la estimación del precio máximo de compra de la energía útil a la red de calor para obtener un $0 \%$ de ahorro y un 15\% de ahorro. La Tabla 611, muestral el precio que se pagaría para un ahorro del 15\%

Tabla 610. Precios de referencia para Gas natural y Astilla

\begin{tabular}{ccccc}
\hline Precios ( $€ /(\mathrm{kWh})$ & 2015 & 2016 & 2017 & 2018 \\
\hline Gasóleo C & 0,0517 & 0,0437 & 0,0499 & 0,0560 \\
\hline Astilla & 0,0277 & 0,0256 & 0,0254 & 0,0239 \\
\hline $\begin{array}{c}€ / \text { kWh útiles máximos de compra a la red para } \\
\text { un ahorro del 0,0\% }\end{array}$ & 0,049515 & \\
\hline $\begin{array}{c}€ / \text { kWh útiles máximos de compra a la red para } \\
\text { un ahorro del } 15,0 \%\end{array}$ & 0,042700 & \\
\hline
\end{tabular}

Tabla 611. Ahorro Económico por el consumo térmico en el Edificio E14

\begin{tabular}{|c|c|c|c|c|c|c|c|c|c|c|}
\hline & $\begin{array}{c}\text { kWh_E1 } \\
\text { 4Gasóle } \\
\text { o }\end{array}$ & $\begin{array}{c}\text { kWh_E14_- } \\
\text { Biomasa }\end{array}$ & $\begin{array}{c}\text { kWh_E1 } \\
4 \text { Real }\end{array}$ & $\begin{array}{c}\text { kWh_E14 } \\
\text { Pronosticado }\end{array}$ & $\begin{array}{l}€ \text { Real } \\
\text { Gasóleo }\end{array}$ & $\begin{array}{c}€ \text { Real } \\
\text { Biomasa }\end{array}$ & $\begin{array}{l}€ \text { Real } \\
\text { Total }\end{array}$ & $\begin{array}{c}\text { € predicho } \\
\text { Gasóleo }\end{array}$ & $\begin{array}{c}€ \\
\text { Ahorro }\end{array}$ & $€$ Acumulado \\
\hline oct-2015 & 0 & 9.687 & 9687 & 9.687 & 0 & 414 & 414 & 501 & 87 & 87 \\
\hline nov-2015 & 0 & 38.632 & 38632 & 38.632 & 0 & 1.650 & 1.650 & 1.997 & 348 & 435 \\
\hline dic-2015 & 0 & 55.921 & 55921 & 55.921 & 0 & 2.388 & 2.388 & 2.891 & 503 & 938 \\
\hline ene-2016 & 0 & 39.537 & 39537 & 39.537 & 0 & 1.688 & 1.688 & 1.728 & 40 & 978 \\
\hline feb-2016 & 37.866 & 64.606 & 102472 & 102.472 & 1.655 & 2.759 & 4.413 & 4.478 & 65 & 1.042 \\
\hline mar-2016 & 2.470 & 39.978 & 42448 & 42.448 & 108 & 1.707 & 1.815 & 1.855 & 40 & 1.082 \\
\hline abr-2016 & 1.441 & 30.550 & 31991 & 31.991 & 63 & 1.304 & 1.367 & 1.398 & 31 & 1.113 \\
\hline may-2016 & 3.018 & 8.069 & 11087 & 11.087 & 132 & 345 & 476 & 484 & 8 & 1.121 \\
\hline oct-2016 & 2.706 & 5.106 & 7812 & 7.812 & 118 & 218 & 336 & 341 & 5 & 1.126 \\
\hline nov-2016 & 1.103 & 37.482 & 38585 & 38.585 & 48 & 1.600 & 1.649 & 1.686 & 37 & 1.163 \\
\hline dic-2016 & 3.832 & 59.367 & 63199 & 63.199 & 167 & 2.535 & 2.702 & 2.762 & 59 & 1.223 \\
\hline ene-2017 & 54 & 70.832 & 70886 & 70.886 & 3 & 3.025 & 3.027 & 3.537 & 510 & 1.733 \\
\hline feb-2017 & 31 & 40.692 & 40723 & 40.723 & 2 & 1.738 & 1.739 & 2.032 & 293 & 2.026 \\
\hline mar-2017 & 0 & 31.425 & 31425 & 31.425 & 0 & 1.342 & 1.342 & 1.568 & 226 & 2.252 \\
\hline$a b r-2017$ & 601 & 12.000 & 12601 & 12.601 & 30 & 512 & 542 & 629 & 86 & 2.338 \\
\hline may-2017 & 31 & 738 & 0 & 0 & 2 & 32 & 33 & 0 & -33 & 2.305 \\
\hline oct-2017 & 0 & 1 & 1 & 1 & 0 & 0 & 0 & 0 & 0 & 2.305 \\
\hline nov-2017 & 0 & 24.942 & 24942 & 24.942 & 0 & 1.065 & 1.065 & 1.245 & 180 & 2.485 \\
\hline dic-2017 & 0 & 69.441 & 69441 & 69.441 & 0 & 2.965 & 2.965 & 3.465 & 500 & 2.985 \\
\hline ene-2018 & 0 & 62.464 & 62464 & 62.464 & 0 & 2.667 & 2.667 & 3.498 & 831 & 3.816 \\
\hline feb-2018 & 0 & 65.539 & 65539 & 65.539 & 0 & 2.799 & 2.799 & 3.670 & 872 & 4.687 \\
\hline mar-2018 & 0 & 48.603 & 48603 & 48.603 & 0 & 2.075 & 2.075 & 2.722 & 646 & 5.334 \\
\hline$a b r-2018$ & 0 & 29.414 & 29414 & 29.414 & 0 & 1.256 & 1.256 & 1.647 & 391 & 5.725 \\
\hline may-2018 & 0 & 5.144 & 5144 & 5.144 & 0 & 220 & 220 & 288 & 68 & 5.793 \\
\hline$€$ Total & & & & & & & 38.629 & 44.423 & & \\
\hline Ahorro (\%) & & & & & & & & & & $15,0 \%$ \\
\hline
\end{tabular}




\section{AV.11. Edificio E15. Escuela de Ingenierías Industriales (Sede Paseo del Cauce).}

\section{AV.11.1.Obtención de la línea base de referencia energética}

Los datos de partida para la obtención de la línea base de referencia se muestran en la Tabla 612

Tabla 612. Consumos térmicos del edificio E15

\begin{tabular}{lr}
\hline & Consumos térmicos (kWh). E15 \\
\hline oct-12 & 14.487 \\
\hline nov-12 & 211.446 \\
\hline dic-12 & 285.072 \\
\hline ene-13 & 254.609 \\
\hline feb-13 & 314.998 \\
\hline mar-13 & 236.366 \\
\hline abr-13 & 146.559 \\
\hline may-13 & 50.082 \\
\hline oct-13 & 2.235 \\
\hline nov-13 & 187.533 \\
\hline dic-13 & 318.094 \\
\hline ene-14 & 258.821 \\
\hline feb-14 & 276.638 \\
\hline mar-14 & 208.852 \\
\hline abr-14 & 116.325 \\
\hline may-14 & 18.881 \\
\hline Promedio & 1.513 .619 \\
\hline Total (oct-12-may-13) & 1.387 .379 \\
\hline Total (oct-13-may-14) & 2.900 .998 \\
\hline Total (oct-12-may-13) & \\
\hline
\end{tabular}

Se disponen de 16 datos para establecer el modelo de regresión, mediante el método de pasos sucesivos.

Utilizando el programa SPSS V.20, se obtiene el modelo de regresión mediante el método de pasos sucesivos. Como se puede ver en la Tabla 613 para el edificio E15, el método ofrece dos modelos de regresión, uno con una sola variable (Temperatura media) y otro con dos variables (Temperatura media y velocidad del viento máxima). El primer modelo (modelo de regresión lineal simple) fue construido con un solo paso, incluyendo la Temperatura media por ser la variable más significativa (variable con menor valor de Sig = 0,000 ) que indica la probabilidad de cometer un error al rechazar que la pendiente de la variable "Temperatura media" es igual a cero, por lo que se acepta que esa variable forma parte del modelo con una pendiente $(B=-29.001,808)$. 
El segundo modelo (modelo de regresión lineal múltiple) se construyó en dos pasos, primero entró la Temperatura media y luego entró la siguiente variable que rechazase la Hipótesis nula, (las variables que rechazan la hipótesis nula son las que presentan una pendiente estadísticamente significativa y su probabilidad de cometer el error de rechazar Ho es $\leq 0,05$, para un nivel de confianza del $95 \%$ ), esta variable fue la "velocidad de viento máxima", por presentar un valor de Sig $=0,045$, el resto de las variables como se observa en la Tabla 614 fueron excluidas del modelo al tener valores de sig $>0,05$, en el segundo paso.

Tabla 613. Modelos de regresión del Edificio E15

\begin{tabular}{|c|c|c|c|c|c|c|c|}
\hline & \multirow{2}{*}{ Modelo } & \multicolumn{2}{|c|}{$\begin{array}{l}\text { Coeficientes no } \\
\text { estandarizados }\end{array}$} & \multirow{2}{*}{$\mathrm{t}$} & \multirow{2}{*}{ Sig. } & \multicolumn{2}{|c|}{$\begin{array}{c}\text { Intervalo de confianza de } \\
95,0 \% \text { para B } \\
\end{array}$} \\
\hline & & B & Error típ. & & & $\begin{array}{l}\text { Límite } \\
\text { inferior }\end{array}$ & $\begin{array}{l}\text { Límite } \\
\text { superior }\end{array}$ \\
\hline \multirow[t]{2}{*}{1} & (Constante) & 417713,362 & 23371,853 & 17,872 &, 000 & 367585,721 & 467841,002 \\
\hline & T_med & $-29001,808$ & 2637,409 & $-10,996$ &, 000 & $-34658,488$ & $-23345,128$ \\
\hline \multirow[t]{3}{*}{2} & (Constante) & 299729,447 & 57081,978 & 5,251 &, 000 & 176411,331 & 423047,563 \\
\hline & T_med & $-28070,125$ & 2368,975 & $-11,849$ &, 000 & $-33187,985$ & $-22952,265$ \\
\hline & V_viento_max_m/s & 15392,005 & 6941,947 & 2,217 &, 045 & 394,839 & 30389,170 \\
\hline
\end{tabular}

En la Figura 361 se representa el modelo 1 de regresión con sus límites inferior y superior para un nivel de confianza del $95 \%$

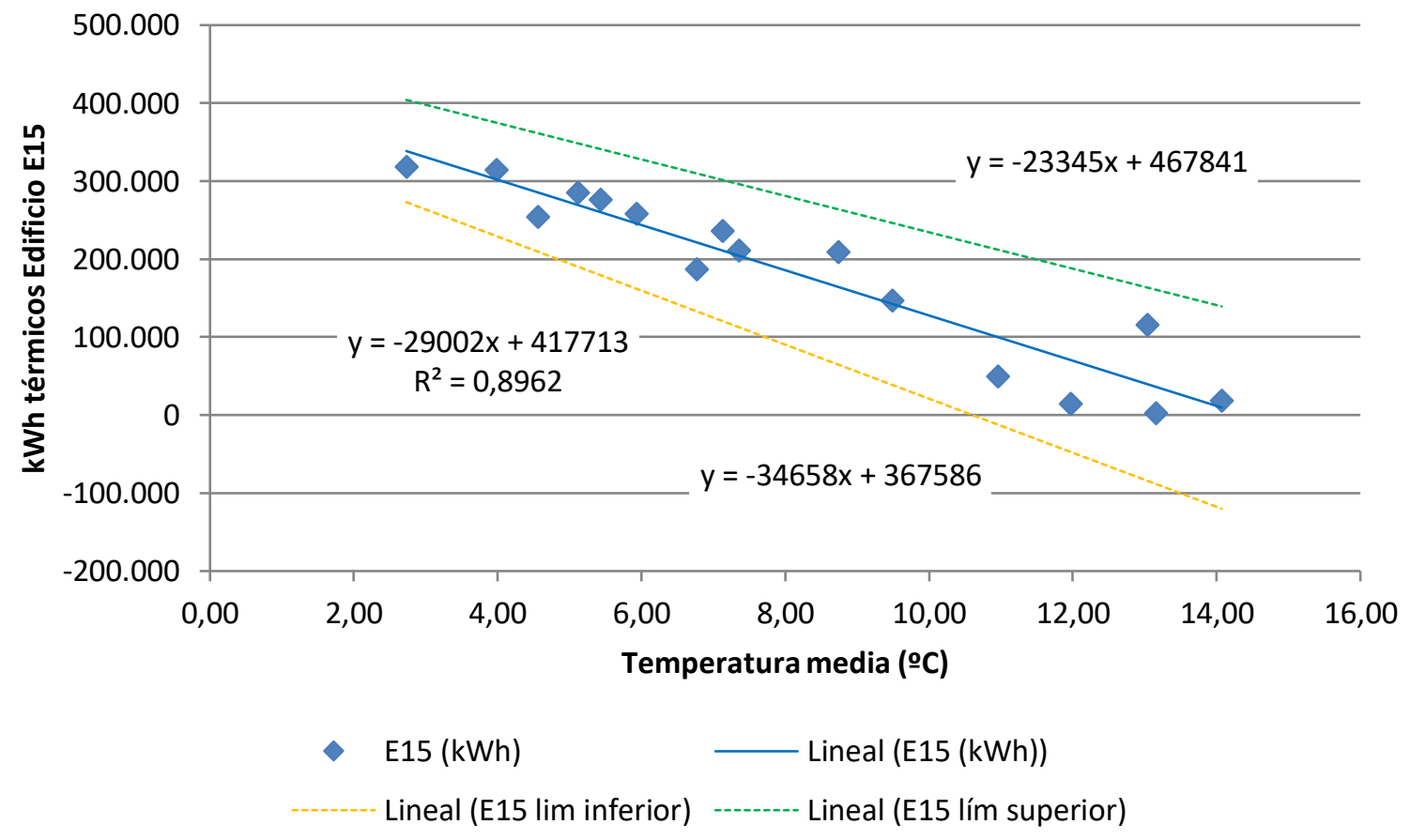

Figura 361. Representación del modelo de regresión lineal simple para el Edificio E15 
En la Figura 362 se representa el modelo 2 de regresión lineal múltiple para el edificio E15

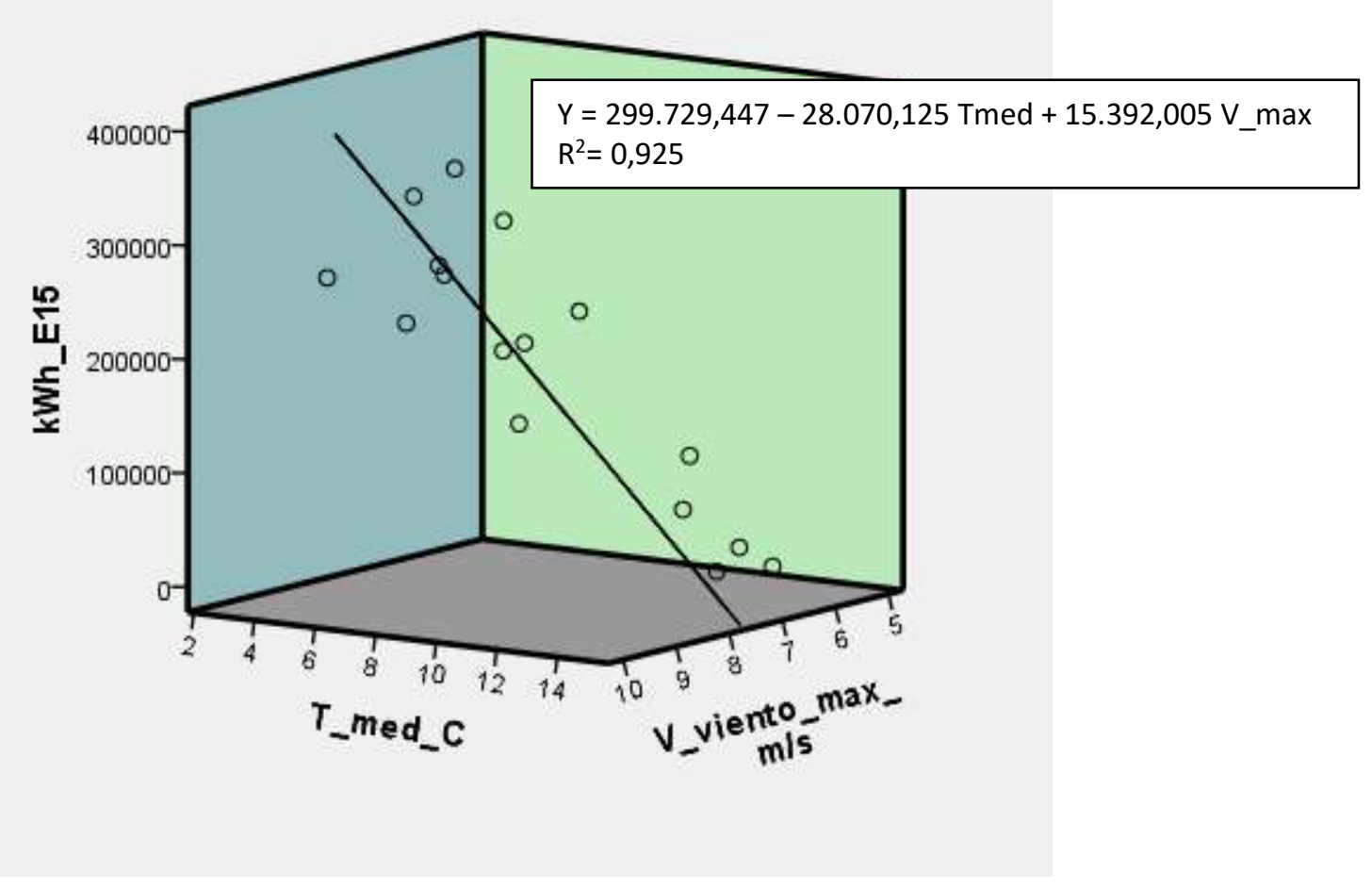

Figura 362. Representación del modelo de regresión lineal múltiple para el Edificio E15

Los valores de la columna $\mathrm{t}$ se obtienen dividiendo el valor de los coeficientes no estandarizados entre sus errores típicos, este estadístico tiende a ser mayor en valor absoluto cuando la hipótesis alternativa es verdadera, es decir cuando la variable posee una pendiente significativa en el modelo de regresión.

En las Tabla 613 y Tabla 614, el estadístico t y su nivel crítico (Sig), permiten contrastar la hipótesis nula consistente en que el coeficiente de regresión vale cero en el modelo; a mayor valor de $t$, mayor peso en el modelo.

El valor "Sig" corresponde a los valores de probabilidad de los valores de $t$, es la probabilidad de obtener el valor de $t$ si la hipótesis nula fuera cierta, cuando son $\leq 0,05$ se rechaza la hipótesis nula y se concluye que las pendientes son distintas de cero, luego si Sig $>0,05$ se acepta la hipótesis nula de que la pendiente de la variable independiente en el modelo de regresión es igual a cero, no cumpliendo el criterio de entrada en el modelo. La correlación parcial, que aparece en la Tabla 614 estudia la relación existente entre dos variables cuantitativas cuando se controla o elimina el efecto de terceras variables, en el modelo de regresión lineal, a mayor valor absoluto, mayor relación entre la variable dependiente y la independiente. 
Anexo V. Desarrollo del análisis de los edificios del Campus Río Esgueva

Tabla 614. Variables excluidas del modelo de región del Edificio E15

\begin{tabular}{|c|c|c|c|c|}
\hline & Modelo & $\mathrm{t}$ & Sig. & Correlación parcial \\
\hline \multirow{19}{*}{1} & GD15_30min &,- 442 & ,666 &,- 122 \\
\hline & GD20_30min &,- 586 &, 568 &,- 160 \\
\hline & GD15_24h &,- 969 & ,350 &,- 260 \\
\hline & GD20_24h &,- 738 & ,473 &,- 201 \\
\hline & T_media_diurna &, 851 & ,410 &, 230 \\
\hline & T_max &, 503 & ,623 & ,138 \\
\hline & T_min & $-1,042$ & ,316 &,- 278 \\
\hline & HR_\% & $-1,489$ & 160 &,- 382 \\
\hline & HR_med_diurna_\% & $-1,268$ & ,227 &,- 332 \\
\hline & HR_max_\% & $-1,973$ & 070 &,- 480 \\
\hline & HR_min_\% & $-1,262$ & ,229 &,- 330 \\
\hline & V_Viento_m/s & 2,091 &, 057 &, 502 \\
\hline & V_viento_diurna_m/s & 2,179 & ,048 &, 517 \\
\hline & V_viento_nocturna_m/s & 1,922 & 077 &, 470 \\
\hline & V_viento_max_m/s & 2,217 &, 045 &, 524 \\
\hline & Recorrido_viento_km/día & 2,084 & ,057 &, 500 \\
\hline & Precipitación_acumulada_mes_mm &, 050 & 960 & 014 \\
\hline & Horas insolación_h & ,818 & 428 & 221 \\
\hline & Radiación_W/m2 & 1,096 & ,293 & ,291 \\
\hline \multirow{18}{*}{2} & GD15_30min & ,437 & 670 & 125 \\
\hline & GD20_30min & 134 & 896 &, 039 \\
\hline & GD15_24h &,- 095 & ,926 &,- 027 \\
\hline & GD20_24h &,- 026 & ,980 &,- 007 \\
\hline & T_media_diurna & ,803 & ,438 &, 226 \\
\hline & T_max & ,794 & ,443 & 223 \\
\hline & T_mín &,- 945 & ,363 &,- 263 \\
\hline & HR_\% &,- 726 & ,482 &,- 205 \\
\hline & HR_med_diurna_\% &,- 656 & ,524 &,- 186 \\
\hline & HR_max_\% &,- 884 & ,394 &,- 247 \\
\hline & HR_min_\% &,- 691 & ,503 &,- 195 \\
\hline & V_Viento_m/s &,- 183 & ,858 &,- 053 \\
\hline & V_viento_diurna_m/s &,- 034 & 974 &,- 010 \\
\hline & V_viento_nocturna_m/s &,- 244 &, 811 &,- 070 \\
\hline & Recorrido_viento_km/día &,- 207 & ,840 &,- 060 \\
\hline & Precipitación_acumulada_mes_mm &,- 666 & ,518 &,- 189 \\
\hline & Horas insolación_h &,- 045 & 965 &,- 013 \\
\hline & Radiación_W/m2 &, 410 & ,689 & ,118 \\
\hline
\end{tabular}


La bondad de los modelos de regresión obtenidos para el edificio E15, se resumen en la Tabla 615

Tabla 615. Resumen de la bondad de los modelos de regresión para el Edificio E15

\begin{tabular}{ccccc}
\hline Modelo & $\mathrm{R}$ & $\mathrm{R}$ cuadrado & $\mathrm{R}$ cuadrado corregida & $\begin{array}{c}\text { Error típ. de la } \\
\text { estimación }\end{array}$ \\
\hline 1 &,- 947 &, 896 &, 889 & 36676,2442 \\
\hline 2 &,- 962 &, 925 &, 913 & 32420,9823 \\
\hline
\end{tabular}

Se observa como el modelo 1 de regresión lineal simple presenta un Coeficiente de Correlación de Pearson (R) inferior en valor absoluto al modelo 2 de regresión lineal múltiple, este coeficiente indica que las variables de los modelos están correlacionadas de manera muy fuerte (en la correlación perfecta $\mathrm{R}= \pm 1$ ). La correlación que se produce en ambos modelos es inversa, al aumentar el valor de las variables independientes disminuye el valor de la variable dependiente que es el consumo térmico.

El coeficiente de determinación $\left(R^{2}\right)$, nos indica que con el modelo 1 se podría explicar el $89,6 \%$ de los datos reales obtenidos y el modelo 2 , el porcentaje de aciertos o de explicación asciende al 92,5\%, ambos aceptando un error del 5\%.

El coeficiente de determinación corregido $\left(R^{2}\right.$ corregido) que tiene en cuenta el número de variables independientes incluidas en el modelo y el tamaño de la muestra, reduce el coeficiente de determinación al 88,9\% en el modelo 1 y al 91,3\% en el modelo 2.

El error típico de la estimación que nos indica la magnitud de los errores, es decir la parte de la variable dependiente que dejamos sin explicar con el modelo y que describe la variación de la variable respuesta (el Consumo) respecto a la recta de regresión, es de $36.676 \mathrm{kWh}$ para el modelo $1 \mathrm{y}$ de $32.421 \mathrm{kWh}$ para el modelo 2, lo que representa un $20,2 \%$ del promedio de los consumos que fue de $181.312 \mathrm{kWh}$ para el modelo $1 \mathrm{y}$ del 17,9\% para el modelo 2 . Por tanto aunque el modelo 2 es más preciso, también es aceptado el modelo 1 para la representación de la línea base de los consumos térmicos del edificio E15. 


\section{AV.11.2.Verificación del cumplimiento de los supuestos estadísticos}

Las condiciones que se deben cumplir en un modelo de regresión son:

- Linealidad de las variables, las variables se encuentran relacionadas de forma lineal.

Como se observa en la Tabla 613, la pendiente (B), para el modelo 1, obtuvo un valor de Sig $=0,000$, que al ser $\leq 0,05$, nos indica que podemos rechazar la hipótesis nula de pendiente igual a cero y nos da la evidencia de linealidad entre la variable dependiente (kWh del edificio E15) y la independiente (Temperatura media). Al ser el valor de la pendiente negativa, indica una relación inversa entre el consumo y la Temperatura media.

Para el modelo 2, según la misma Tabla 613, las pendientes de las dos variables introducidas en el modelo obtuvieron unos valores de Sig $=0,000$ para la Temperatura media y de 0,045 para la Velocidad del viento máxima, ambos $\leq 0,05$, lo que nos indica que podemos rechazar la hipótesis nula de pendiente igual a cero y nos da la evidencia de linealidad entre la variable dependiente ( $\mathrm{kWh}$ del edificio E15) y las independientes (Temperatura media y velocidad del viento máxima). Al ser el valor de la primera pendiente negativa, indica una relación inversa entre el consumo y la Temperatura media y de la segunda pendiente positiva, indica relación directa entre el consumo y la velocidad del viento máxima.

- Normalidad. Todos los valores obtenidos para la variable dependiente (Y), deben estar distribuidos normalmente en cada valor de las variables independientes $(X)$.

Se comprueba la normalidad de las variables y de los residuos mediante el Test de Shapiro - Wilk para muestras pequeñas (menores a 30 observaciones), siendo la hipótesis nula el que la distribución es Normal, luego si la probabilidad del estadístico del test es $\leq$ al nivel de significación 0,05 , la hipótesis nula es rechazada y sólo aceptaremos que las variables se distribuyen según una Normal cuando el valor de la significación sea mayor que 0,05 (valor de la significación $>0,05$ ) en el Test de Shapiro Wilk.

La Tabla 616, muestra la prueba de normalidad de Shapiro-Wilk y cómo tanto la variable dependiente (consumos del Edificio E15), como las variables independientes: Temperatura media y velocidad de viento máxima poseen una Sig $>0,05$, por lo que aceptamos la hipótesis nula de Normalidad de las variables 
Tabla 616. Prueba de normalidad para el edificio E15

\begin{tabular}{lcrrrrr}
\hline & \multicolumn{3}{c}{ Kolmogorov-Smirnov } & \multicolumn{3}{c}{ Shapiro-Wilk } \\
\cline { 2 - 8 } & Estadístico & gl & Sig. & Estadístico & gl & \multicolumn{1}{c}{ Sig. } \\
\hline kWh_E15 &, 161 & 16 &, 200 &, 899 & 16 &, 079 \\
\hline T_med &, 150 & 16 &, 200 &, 942 & 16 &, 376 \\
\hline V_viento_máx_m/s &, 159 & 16 &, 200 &, 924 & 16 &, 195 \\
\hline
\end{tabular}

- Independencia de los errores. Los errores asociados a los valores de la variable respuesta $(Y)$ deberán ser independientes unos de otros.

Para la comprobación se utiliza el estadístico de Durbin -Watson.

Se comprueba que el Estadístico de Durbin Watson para el nivel de significancia del 5\%, y para el tamaño de la muestra " $n$ " y el número de variables independientes del modelo " $k$ ", se encuentra en el intervalo [dU, 4-dU], de la Tabla 3, intervalo centrado en el 2, que indica la ausencia de autocorrelación.

El valor del Estadístico Durbin-Watson facilitado por el programa SPSS, es:

- para el modelo 1 de 1,041 (Regresión lineal simple)

- para el modelo 2 de 1,623 (Regresión lineal múltiple)

En el modelo $1, n=16$ y $k=1$, según la Tabla 3, el valor $d U=1,371$, luego el intervalo que marca la ausencia de correlación es [1,371, 2,629].

Los intervalos $[0,1,106]$ y $[2,896,4]$ indican correlación positiva o negativa respectivamente y las zonas $[1,106,1,371]$ y $[2,629,2,896]$ son zonas no concluyentes; como el valor del estadístico 1,041 está dentro del intervalo de correlación positiva, se concluye que los residuos del Modelo 1, presentan correlación y no se puede admitir el Módelo 1 cómo válido.

En el modelo $2, \mathrm{n}=16$ y $\mathrm{k}=2$, según la Tabla 3 , el valor $\mathrm{dU}=1,539$ y $\mathrm{dL}=0,982$, luego el intervalo que marca la ausencia de correlación es [1,539, 2,461].

Los intervalos $[0,0,982]$ y $[3,018,4]$ indican correlación positiva o negativa respectivamente y las zonas $[0,982,1,539]$ y $[2,461,3,018]$ son zonas no concluyentes; como el valor del estadístico 1,623 está dentro del intervalo de ausencia de correlación, se acepta que los residuos del Modelo 2, no están correlacionados. 
- Homocedasticidad de la varianza. Se pretende comprobar que la varianza de los errores $\left(\sigma^{2}\right)$ es constante para cualquier valor de la(s) variable(s) independiente(s) (X), es decir que el valor medio del cuadrado de la desviación de los errores respecto a su media es constante.

Esta condición indica que el error es una variable aleatoria que tomará un valor distinto cada vez que se ejecute el modelo y que no existe correlación entre los residuos y los pronósticos.

La forma de comprobar la homocedasticidad es verificando si el coeficiente de determinación $\mathrm{R}^{2}$, que indica la proporción de la variable dependiente ( $\mathrm{Y}$ o consumo del edificio) que puede ser explicada por la variación de las variables independientes (las variables climatológicas), en las relaciones: residuos y predicciones y entre residuos y variables independientes es nulo o muy próximo a cero, lo que indicará que no existe ningún tipo de correlación en los residuos y que éstos son aleatorios. Se grafican los diagramas de dispersión de esas relaciones, comprobando que se corresponden a nubes de puntos totalmente aleatorias, sin tendencias ni patrones en sus representaciones gráficas. Para el modelo 1. Regresión lineal simple, las Figura 363 y Figura 364, muestran que la relación entre los pronósticos y los residuos, posee un coeficiente de determinación $=0$ y entre la variable independiente (Temperatura media) y los residuos un coeficiente de determinación de $1,11 \times 10^{-16}$; por lo que se concluye que no existe ningún tipo de correlación en los residuos y que éstos son aleatorios, siendo la varianza de los residuos constante.

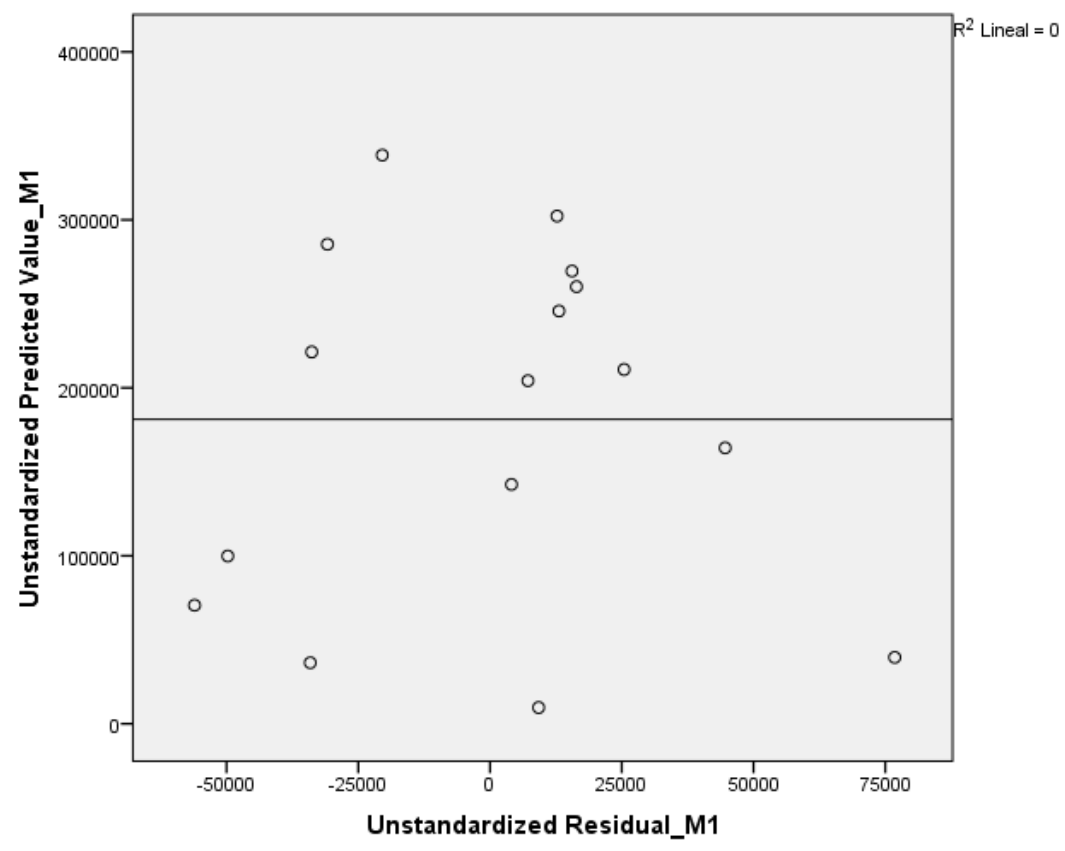

Figura 363. Relación entre los pronósticos y los residuos en el Edificio E15. Modelo 1 


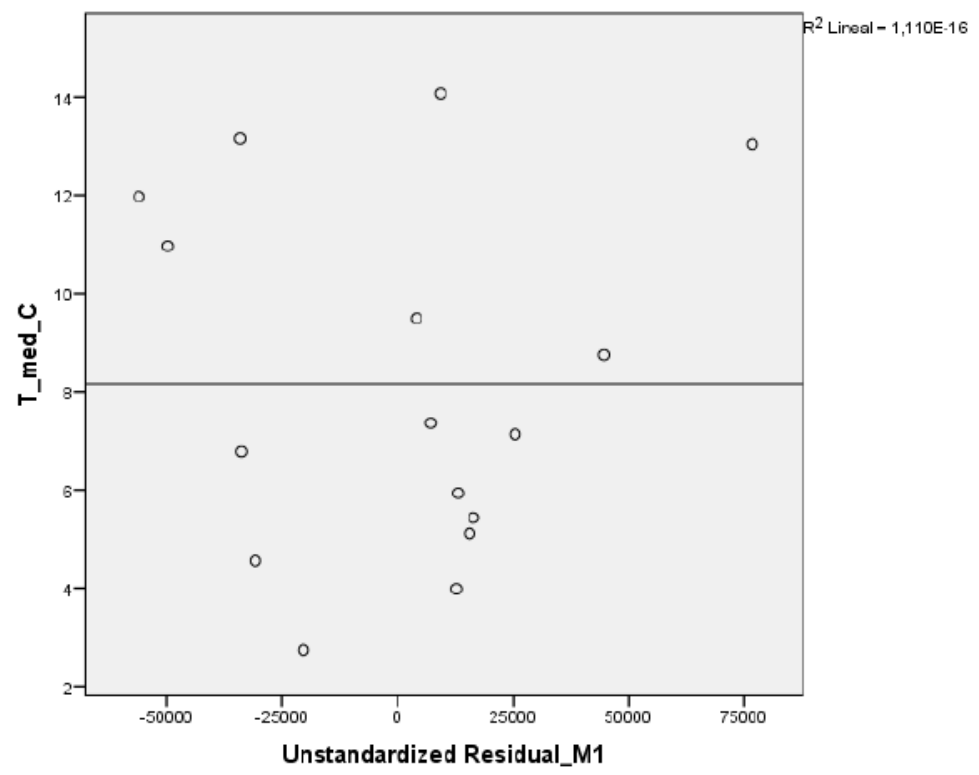

Figura 364. Relación entre la Temperatura media y los residuos en el Edificio E15. Modelo 1

Para el modelo 2. Regresión lineal múltiple, la Figura 365, Figura 366 y Figura 367, muestran que la relación entre los pronósticos y los residuos, posee un coeficiente de determinación $=2,22 \times 10^{-16}$, entre la variable independiente (Temperatura media) y los residuos un coeficiente de determinación, de $-2,22 \times 10^{-16}$ y entre la variable independiente (velocidad del viento máxima) y los residuos, también de de $-2,22 \times 10^{-16}$; prácticamente nulo, por lo que se concluye que no existe ningún tipo de correlación en los residuos y que éstos son aleatorios, siendo la varianza de los residuos constante

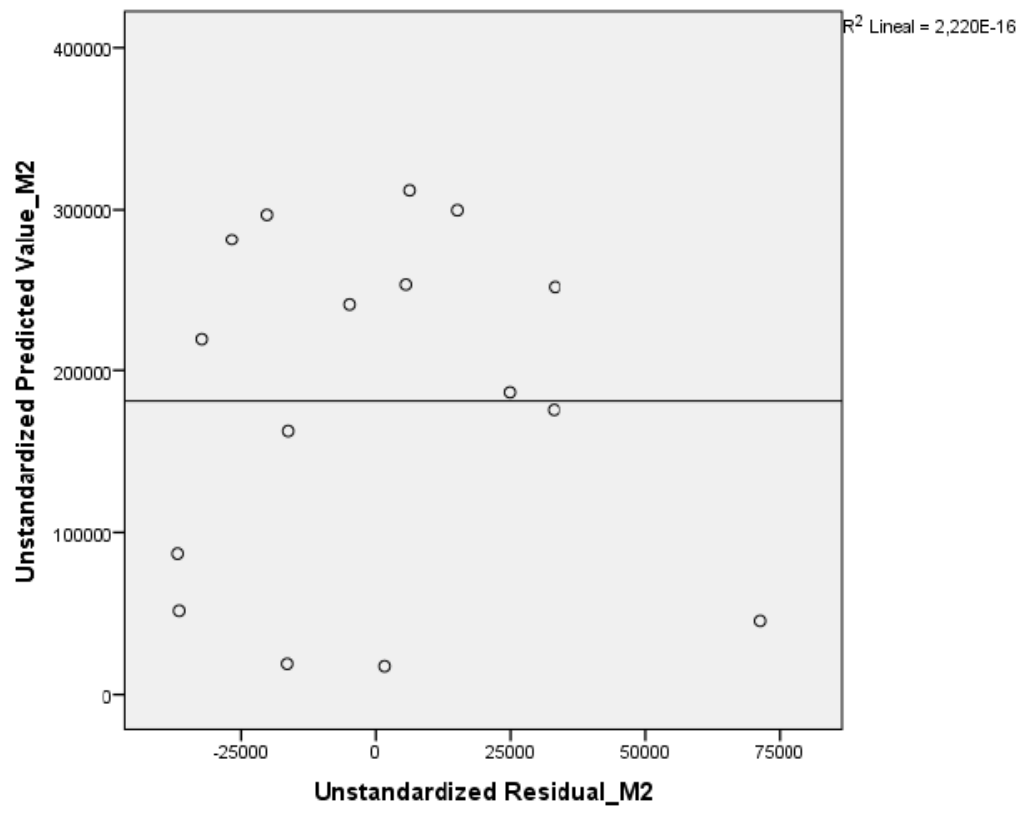

Figura 365. Relación entre los pronósticos y los residuos en el Edificio E15. Modelo 2 


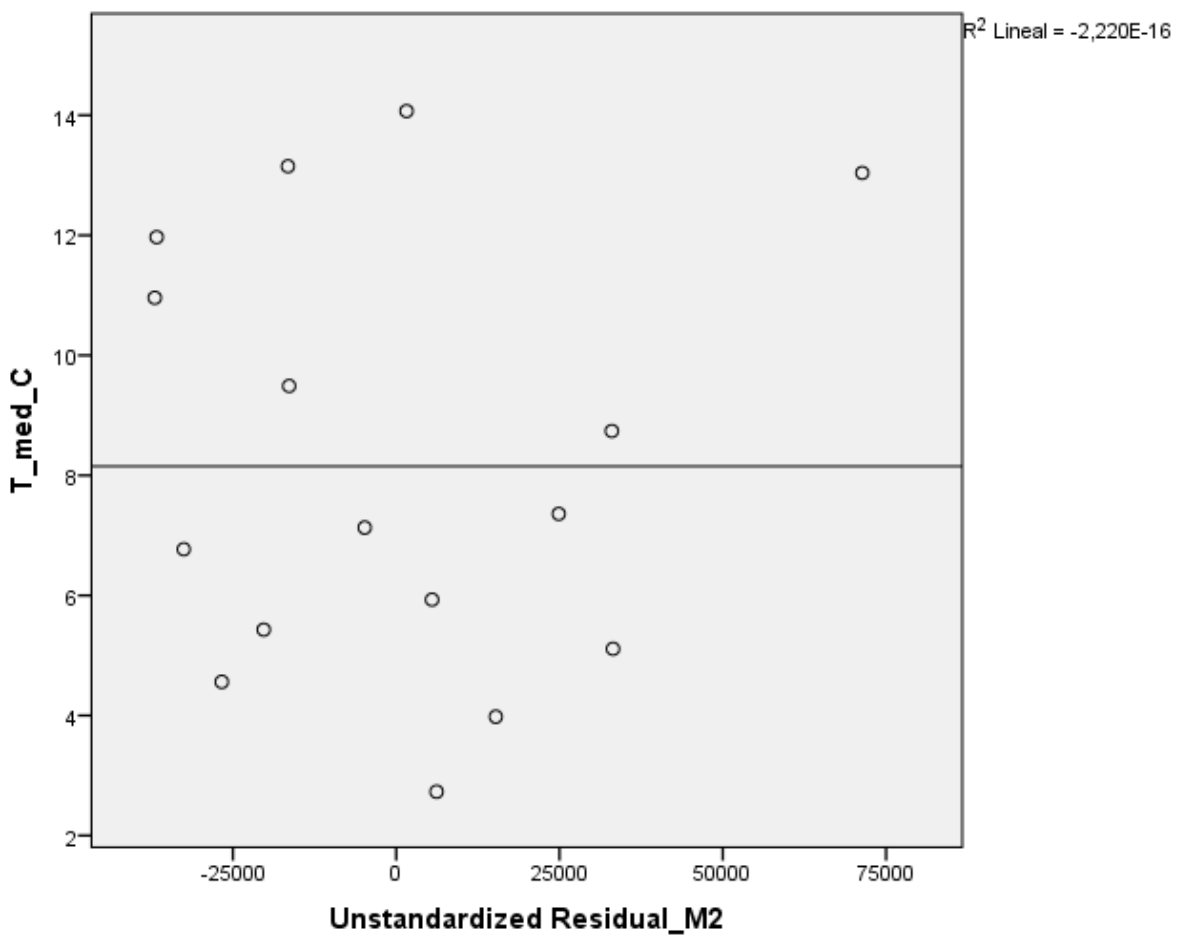

Figura 366. Relación entre la Temperatura media y los residuos en el Edificio E15. Modelo 2

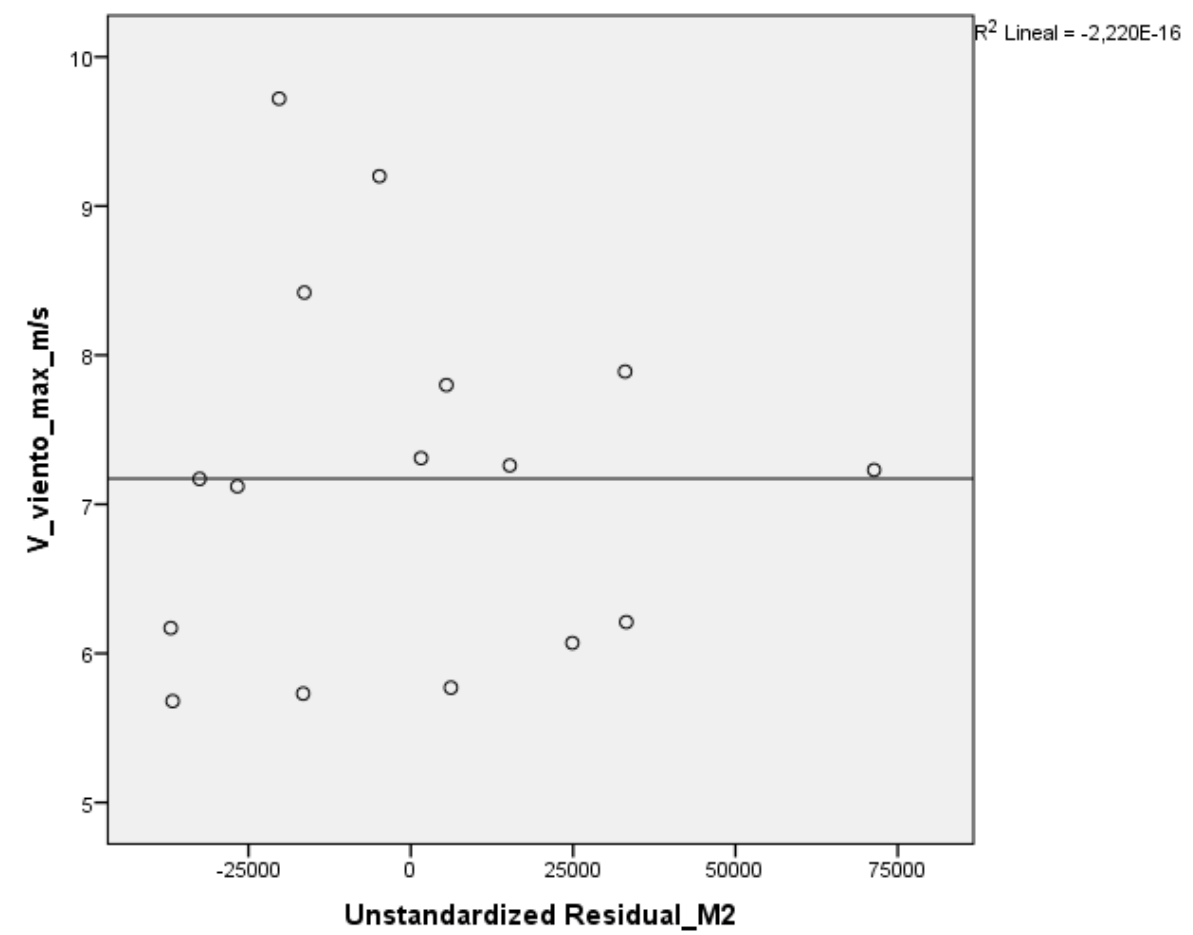

Figura 367.Relación entre la velocidad máxima y los residuos. Edificio E15. Modelo 2 
- Cuando la regresión es lineal múltiple, se comprueba la falta de multicolinealidad o No-Colinealidad entre las variables independientes, es decir que las variables que forman parte del modelo no están correlacionadas entre ellas.

El problema de la multicolinealidad es moderado cuando el índice de condición toma un valor entre 20 y 30 y es grave cuando el índice de condición toma un valor superior a 30. El número de condición mide la sensibilidad de las estimaciones mínimo-cuadráticas ante pequeños cambios en los datos a mayor valor más correlación entre las variables.

La Tabla 617, muestra los índices de condición de las variables del modelo de regresión múltiple, ninguno de ellos supera el valor 20, por lo que no existen evidencias de correlación entre las variables independientes del modelo

Tabla 617. Índice de condición de las variables independientes del Modelo 2 en el Edificio E15

\begin{tabular}{llr}
\hline Modelo & Dimensión & Índice de condición \\
\hline \multirow{2}{*}{2} & 1 & 1,000 \\
\cline { 2 - 3 } & 2 & 4,900 \\
\cline { 2 - 3 } & 3 & 15,740 \\
\hline
\end{tabular}

En cuanto a los índices estadísticos de colinealidad como son los niveles Tolerancia y su inverso que son los Factores de Inflación de la Varianza (FIV). El nivel de tolerancia se obtiene restando a 1 el coeficiente de determinación $\left(R^{2}\right)$. Como se observa en la Figura 368 , el coeficiente de determinación entre las dos variables independientes es $R^{2}=0,031$, luego la Tolerancia es $T=1-R^{2}=1-0,031=0,969$ y $\mathrm{FIV}=1 / \mathrm{T}=1,032$

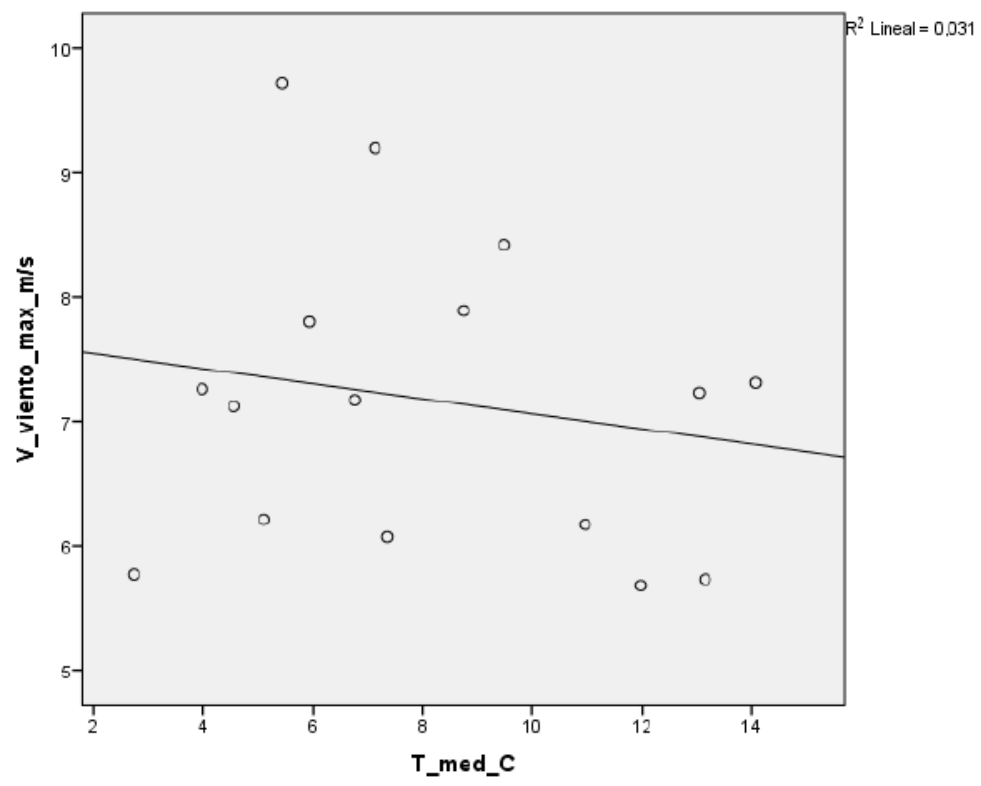

Figura 368. Gráfico de la temperatura mínima y la velocidad del viento máxima. 
Si la Tolerancia toma un valor próximo a la unidad no existirá colinealidad (a mayor tolerancia menor colinealidad), por lo que se podrá deducir que no existe multicolinealidad entre las variables independientes. Pueden existir problemas de colinealidad si algún FIV es superior a 10 , que corresponde con un $R^{2}$ de 0,9 y una Tolerancia menor a 0,1

La Tabla 618, muestra los estadísticos de colinealidad y se observa como la Tolerancia toma valores de 0,969, próxima a 1 y los valores de FIV permanecen por debajo de 10, por lo que no existen problemas de colinealidad entre la temperatura media y la velocidad del viento máxima.

Tabla 618. Estadísticos de colinealidad para los modelos del Edificio E15

\begin{tabular}{|c|c|c|c|}
\hline Modelo & & Tolerancia & FIV \\
\hline 1 & T_med & 1,000 & 1,000 \\
\hline \multirow{2}{*}{2} & T_med & ,969 & 1,032 \\
\hline & V_viento_maxima_m/s & ,969 & 1,032 \\
\hline
\end{tabular}

\section{AV.11.3.Obtención de los consumos térmicos previstos}

Una vez comprobado el cumplimiento de los supuestos estadísticos se acepta sólo el Modelo 2 como línea base para modelizar el consumo del Edificio E15.

Modelo 1: $\quad$ kWh_E15 $=417.713,362-29.001,808 \times$ T_med ( No aceptado)

Modelo 2: $\quad$ kWh_E15 $=299.729,447-28.070,125 \times$ T_med $+15.392,005$ x V_viento_max

Con el Modelo 2 se procede a predecir los consumos previstos para las temporadas: octubre 2015-mayo 2016, octubre 2016 - mayo 2017 y octubre 2017-mayo 2018, estos consumos se muestran en la Tabla 619, donde "KWh_E15", representa el consumo real, "kWh_E15_M1", el consumo que hubiera sido pronosticado con el Modelo 1, si hubiera sido aceptado y "kWh_E15_M2", el consumo pronosticado con el Modelo 2. 
Anexo V. Desarrollo del análisis de los edificios del Campus Río Esgueva

Tabla 619. Consumos previstos octubre 2014 - mayo 2017 para el edificio E15.

\begin{tabular}{rrrrrrr}
\hline & \multicolumn{1}{l}{ T_media } & \multicolumn{1}{l}{ V_viento_máx } & \multicolumn{1}{l}{ kWh_E15 } & kWh_E15_M1 & kWh_E15_M2 & $\begin{array}{r}\text { kWh_E15_M1 - } \\
\text { kWh_E15_M2 }\end{array}$ \\
\hline oct-15 & 12,82 & 5,64 & 53.000 & 45.952 & 26.722 & 19.230 \\
\hline nov-15 & 8,30 & 4,31 & 173.200 & 176.936 & 133.017 & 43.920 \\
\hline dic-15 & 5,33 & 3,53 & 126.100 & 263.153 & 204.463 & 58.690 \\
\hline ene-16 & 6,23 & 6,82 & 167.500 & 236.908 & 229.750 & 7.157 \\
\hline feb-16 & 5,82 & 8,02 & 269.211 & 249.057 & 259.882 & -10.825 \\
\hline mar-16 & 6,14 & 7,14 & 174.003 & 239.541 & 237.150 & 2.391 \\
\hline abr-16 & 9,10 & 7,49 & 122.200 & 153.776 & 159.609 & -5.832 \\
\hline may-16 & 13,11 & 5,79 & 35.033 & 37.374 & 20.768 & 16.606 \\
\hline oct-16 & 13,40 & 4,22 & 37.197 & 29.227 & -11.278 & 40.505 \\
\hline nov-16 & 6,90 & 3,95 & 192.797 & 217.576 & 166.810 & 50.766 \\
\hline dic-16 & 4,12 & 1,81 & 181.536 & 298.199 & 211.889 & 86.310 \\
\hline ene-17 & 2,52 & 2,53 & 283.796 & 344.727 & 268.005 & 76.722 \\
\hline feb-17 & 6,96 & 4,48 & 205.600 & 215.886 & 173.386 & 42.500 \\
\hline mar-17 & 9,21 & 4,15 & 170.464 & 150.622 & 105.160 & 45.462 \\
\hline abr-17 & 12,58 & 3,86 & 53.800 & 52.982 & 6.129 & 46.854 \\
\hline may-17 & 16,69 & 4,92 & 13.800 & -66.245 & -93.027 & 26.783 \\
\hline oct-17 & 14,71 & 5,22 & 8.772 & -8.927 & -32.849 & 23.922 \\
\hline nov-17 & 6,09 & 4,89 & 137.564 & 241.071 & 204.085 & 36.986 \\
\hline dic-17 & 3,99 & 4,94 & 220.020 & 301.946 & 263.678 & 38.268 \\
\hline ene-18 & 4,42 & 3,73 & 247.100 & 289.490 & 232.978 & 56.512 \\
\hline feb-18 & 3,53 & 6,32 & 267.216 & 315.398 & 297.978 & 17.420 \\
\hline mar-18 & 6,80 & 10,33 & 227.864 & 220.425 & 267.823 & -47.398 \\
\hline abr-18 & 11,15 & 7,49 & 96.348 & 94.451 & 102.148 & -7.697 \\
\hline may-18 & 14,03 & 6,46 & 26.700 & 10.897 & 5.375 & 5.522 \\
\hline & & & & &
\end{tabular}

Los datos pronosticados que han resultado ser negativos serán anulados del Modelo 2, por representar valores imposibles.

\section{AV.11.4.Estudio de la existencia de diferencias significativas}

Utilizando el contraste de hipótesis para la comparación de medias para muestras relacionadas, es decir la prueba paramétrica " $\mathrm{t}$ " de Student para muestras relacionadas, podemos concluir que si las variables se distribuyen según una normal y la significación estadística resulta $\leq 0,05$, existen diferencias significativas. En caso contrario no se rechaza la hipótesis nula de igualdad de medias, concluyendo que las diferencias encontradas no son estadísticamente significativas y no van más allá de lo que sería esperable por azar, todo ello con la aceptación de un riesgo de error del 5\%, o lo que es lo mismo un nivel de confianza del $95 \%$

A continuación se muestra la comparación de medias realizada para cada uno de los tres periodos posteriores a la construcción de la red y para el periodo total hasta mayo de 2018, utilizando únicamente los datos pronosticados con el Modelo 2. 
Para la temporada Octubre 2015 - Mayo 2016, se comprueba mediante el Test de Shapiro -Wilk que tanto los valores reales como los pronosticados se distribuyen según una Normal puesto que en todos los casos los valores de Sig $>0,05$, como se observa en la Tabla 620.

Tabla 620. Prueba de Normalidad temporada Octubre 2015-Mayo 2016. Edificio E15. Modelo 2

\begin{tabular}{cccccrrr}
\hline & \multicolumn{3}{c}{ Kolmogorov-Smirnov $^{\text {a }}$} & \multicolumn{3}{c}{ Shapiro-Wilk } \\
\cline { 2 - 8 } & \multicolumn{2}{c}{ Estadístico } & gl & \multicolumn{1}{c}{ Sig. } & Estadístico & gl & Sig. \\
\hline kWh_real &, 199 & 8 &, 200 &, 942 & 8 &, 634 \\
\hline kWh_pronost_M2 &, 188 & 8 &, 200 &, 878 & 8 &, 179 \\
\hline
\end{tabular}

En la Tabla 621, se observa que la media de los consumos pronosticados con el Modelo 2, es superior a la media del consumo real del Edificio E15; un 4,2\%.

Tabla 621. Estadísticos de muestras relacionadas. Octubre 2015-Mayo 2016. Edificio E15

\begin{tabular}{|c|c|c|c|c|c|}
\hline & Media & $\begin{array}{l}\text { \% Diferencia } \\
\text { entre medias }\end{array}$ & $\mathrm{N}$ & $\begin{array}{c}\text { Desviación } \\
\text { típ. }\end{array}$ & $\begin{array}{c}\text { Error típ. de la } \\
\text { media }\end{array}$ \\
\hline kWh_real & 140030,8750 & & 8 & 74457,36075 & 26324,65235 \\
\hline kWh_pronost_M2 & 158920,1250 & $4,2 \%$ & 8 & 93072,96564 & 32906,26257 \\
\hline
\end{tabular}

La Tabla 622 muestra que las diferencias entre las medias no son significativas entre los consumos reales y los pronosticados con el Modelo 2 (sig $>0,05)$.

Tabla 622. Prueba de muestras relacionadas. Octubre 2015-Mayo 2016. Edificio E15

\begin{tabular}{|c|c|c|c|c|c|c|c|c|}
\hline & \multicolumn{5}{|c|}{ Diferencias relacionadas } & \multirow{3}{*}{$\mathrm{t}$} & \multirow{3}{*}{ gl } & \multirow{3}{*}{$\begin{array}{c}\text { Sig. } \\
\text { (bilateral) }\end{array}$} \\
\hline & \multirow[t]{2}{*}{ Media } & \multirow{2}{*}{$\begin{array}{l}\text { Desviación } \\
\text { típ. }\end{array}$} & \multirow{2}{*}{$\begin{array}{c}\text { Error típ. } \\
\text { de la media }\end{array}$} & \multicolumn{2}{|c|}{$\begin{array}{l}\text { 95\% Intervalo de confianza } \\
\text { para la diferencia }\end{array}$} & & & \\
\hline & & & & Inferior & Superior & & & \\
\hline $\begin{array}{c}\text { kWh_real - } \\
\text { kWh_pronost_M2 }\end{array}$ & $-18889,250$ & 46512,819 & 16444,765 & $-57774,940$ & 19996,440 & $-1,149$ & 7 & ,288 \\
\hline
\end{tabular}

En la Figura 369, se grafican los consumos reales y pronosticados para la temporada Octubre 2015 - Mayo 2016 para el Edificio E15, y las medias de dichos consumos. Según la prueba paramétrica realizada no son estadísticamente significativas, para un nivel de confianza del $95 \%$. 


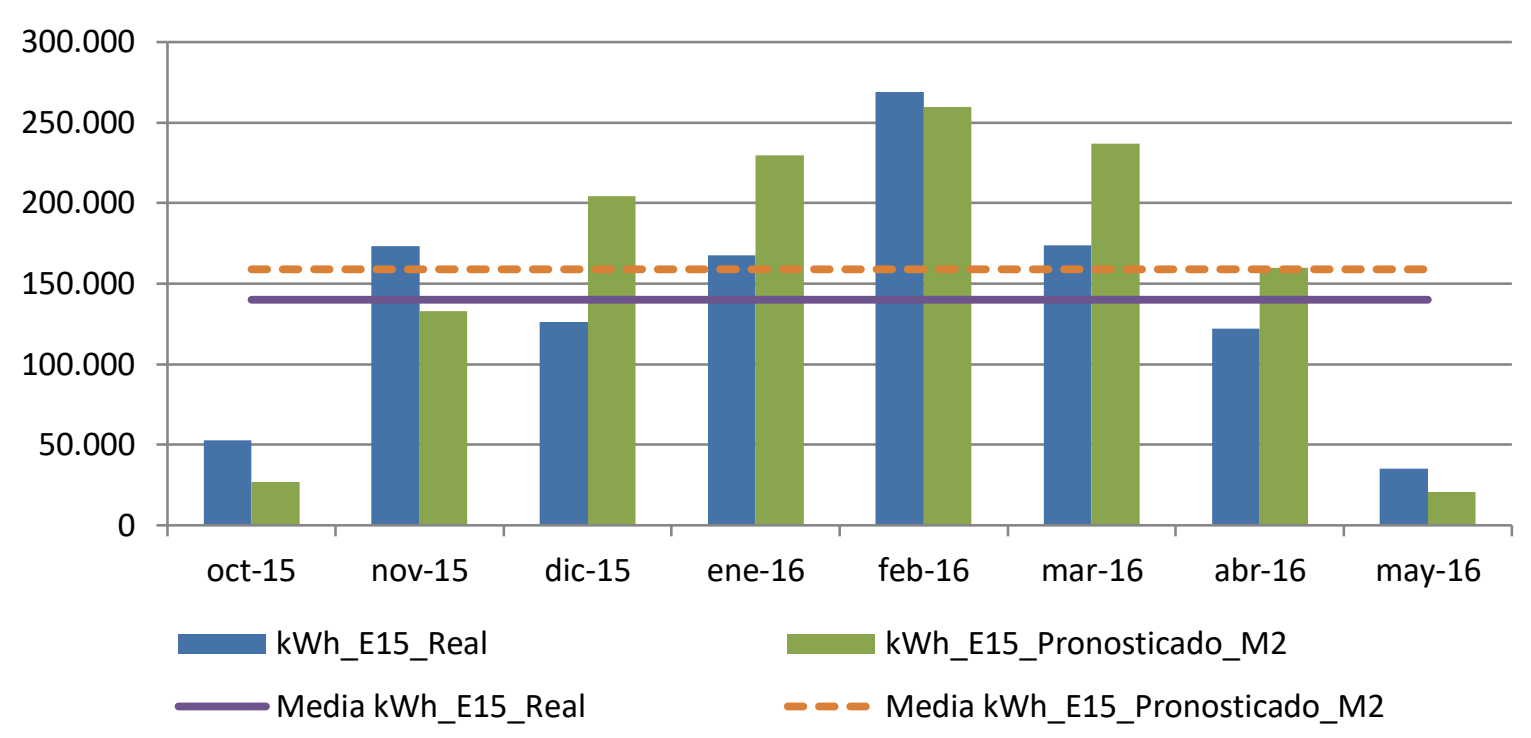

Figura 369. Consumos reales y pronosticados Octubre 2015-Mayo 2016. Edificio E15

Para la temporada Octubre 2016 - Mayo 2017, se comprueba mediante el Test de Shapiro -Wilk que tanto los valores reales como los pronosticados se distribuyen según una Normal puesto que en todos los casos los valores de Sig $>0,05$, como se observa en la Tabla 623

Tabla 623. Prueba de Normalidad temporada Octubre 2016-Mayo 2017. Edificio E15

\begin{tabular}{|c|c|c|c|c|c|c|}
\hline & \multicolumn{3}{|c|}{ Kolmogorov-Smirnov ${ }^{\mathrm{a}}$} & \multicolumn{3}{|c|}{ Shapiro-Wilk } \\
\hline & Estadístico & $\mathrm{gl}$ & Sig. & Estadístico & $\mathrm{gl}$ & Sig. \\
\hline $\begin{array}{l}\text { kWh_real (sin octubre } \\
2016 \text { ni mayo 2017) }\end{array}$ & ,275 & 6 & 174 & ,913 & 6 & ,456 \\
\hline kWh_pronost_M2 & ,217 & 6 & ,200* & ,962 & 6 & ,835 \\
\hline
\end{tabular}

En la Tabla 624, se observa como la media de los consumos pronosticados con el Modelo 2 , es inferior a la media del consumo real del Edificio E15, un 14,4\%.

Tabla 624. Estadísticos de muestras relacionadas. Octubre 2016-Abril 2017. Edificio E15

\begin{tabular}{lccccc}
\hline & Media & $\begin{array}{c}\text { \% Diferencia } \\
\text { entre medias }\end{array}$ & $\mathrm{N}$ & $\begin{array}{c}\text { Desviación } \\
\text { típ. }\end{array}$ & $\begin{array}{c}\text { Error típ. de la } \\
\text { media }\end{array}$ \\
\hline $\mathrm{kWh}$ _real & 181332,1667 & & 6 & 74299,15129 & 30332,50150 \\
\hline $\mathrm{kWh}$ _pronost_M2 & 155229,8333 & $-14,4 \%$ & 6 & 90697,62152 & 37027,14893 \\
\hline
\end{tabular}

La Tabla 625, muestra que las diferencias entre las medias no son significativas entre los consumos reales y los pronosticados con el Modelo 1, ni con el Modelo 2 ( $\operatorname{sig}>0,05$ ) 
Tabla 625. Prueba de muestras relacionadas. Octubre 2016-Abril 2017. Edificio E15

\begin{tabular}{|c|c|c|c|c|c|c|c|c|}
\hline & \multicolumn{5}{|c|}{ Diferencias relacionadas } & \multirow{3}{*}{$\mathrm{t}$} & \multirow{3}{*}{ gl } & \multirow{3}{*}{$\begin{array}{c}\text { Sig. } \\
\text { (bilateral) }\end{array}$} \\
\hline & \multirow{2}{*}{ Media } & \multirow{2}{*}{$\begin{array}{l}\text { Desviación } \\
\text { típ. }\end{array}$} & \multirow{2}{*}{$\begin{array}{c}\text { Error típ. } \\
\text { de la media }\end{array}$} & \multicolumn{2}{|c|}{$\begin{array}{l}\text { 95\% Intervalo de confianza } \\
\text { para la diferencia }\end{array}$} & & & \\
\hline & & & & Inferior & Superior & & & \\
\hline $\begin{array}{c}\text { kWh_real - } \\
\text { kWh_pronost_M2 }\end{array}$ & 26102,333 & 32658,451 & 13332,757 & $-8170,609$ & 60375,276 & 1,958 & 5 & 108 \\
\hline
\end{tabular}

En la Figura 370, se grafican los consumos reales y pronosticados para la temporada Octubre 2016 - Mayo 2017 para el Edificio E15, y las medias de dichos consumos. Según la prueba paramétrica realizada no son estadísticamente significativas las diferencias encontradas entre el consumo real y el pronosticado por el modelo 2, para un nivel de confianza del $95 \%$.

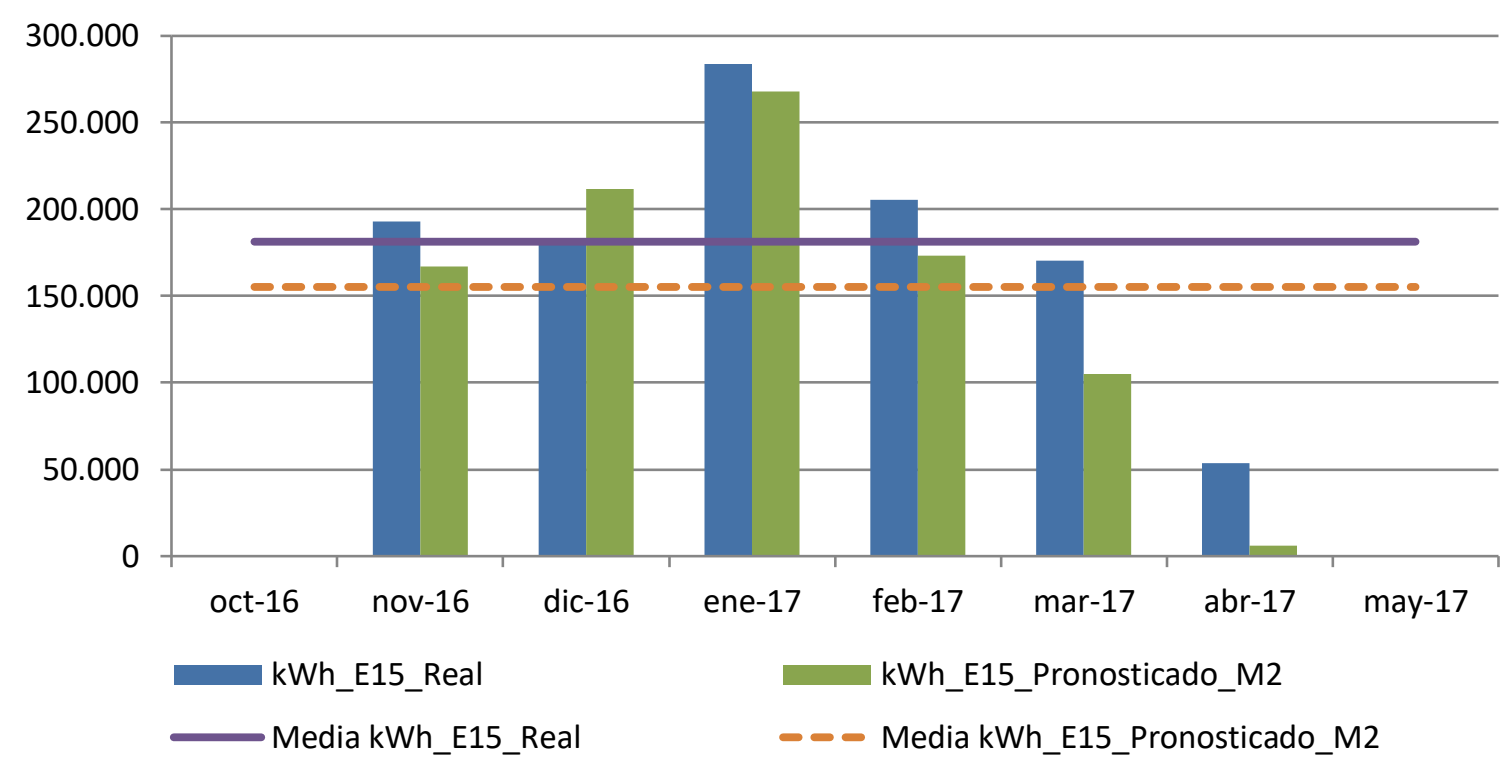

Figura 370. Consumos reales y pronosticados Octubre 2016-Mayo 2017. Edificio E15

Para la temporada Octubre 2017 - Mayo 2018, se comprueba mediante el Test de Shapiro -Wilk que tanto los valores reales como los pronosticados se distribuyen según una Normal puesto que en todos los casos los valores de Sig $>0,05$, como se observa en la Tabla 626

Tabla 626. Prueba de Normalidad temporada Octubre 2017-Mayo 2018. Edificio E15

\begin{tabular}{ccccccc}
\hline & \multicolumn{3}{c}{ Kolmogorov-Smirnov $^{\mathrm{a}}$} & \multicolumn{3}{c}{ Shapiro-Wilk } \\
\cline { 2 - 7 } & Estadístico & gl & Sig. & Estadístico & gl & Sig. \\
\hline $\begin{array}{c}\text { kWh_real sin } \\
\text { octubre 2017 }\end{array}$ &, 265 & 7 &, 147 &, 902 & 7 &, 343 \\
\hline kWh_pronost_M2 &, 244 & 7 &, 200 &, 870 & 7 &, 186 \\
\hline
\end{tabular}


En la Tabla 627 se observa como la media de los consumos pronosticados con el Modelo 2 , es superior a la media del consumo real del Edificio E15, un $12,4 \%$.

Tabla 627. Estadísticos de muestras relacionadas. Octubre 2017-Mayo 2018. Edificio E15

\begin{tabular}{lcccrc}
\hline & Media & $\begin{array}{c}\text { \% Diferencia } \\
\text { entre medias }\end{array}$ & $\mathrm{N}$ & $\begin{array}{c}\text { Desviación } \\
\text { típ. }\end{array}$ & \multicolumn{1}{c}{$\begin{array}{c}\text { Error típ. de } \\
\text { la media }\end{array}$} \\
\hline kWh_real & 174687,4286 & & 7 & 89539,00532 & 33842,56296 \\
\hline kWh_pronost_M2 & 196295,0000 & $12,4 \%$ & 7 & 105448,71309 & 39855,86727 \\
\hline
\end{tabular}

La Tabla 628 muestra que las diferencias entre las medias no son significativas entre los consumos reales y los pronosticados con el Modelo 2 (sig $>0,05$ ).

Tabla 628. Prueba de muestras relacionadas. Octubre 2017-Mayo 2018. Edificio E15

\begin{tabular}{|c|c|c|c|c|c|c|c|c|}
\hline & \multicolumn{5}{|c|}{ Diferencias relacionadas } & \multirow{3}{*}{$\mathrm{t}$} & \multirow{3}{*}{ gl } & \multirow{3}{*}{$\begin{array}{c}\text { Sig. } \\
\text { (bilateral) }\end{array}$} \\
\hline & \multirow{2}{*}{ Media } & \multirow{2}{*}{$\begin{array}{l}\text { Desviación } \\
\text { típ. }\end{array}$} & \multirow{2}{*}{$\begin{array}{l}\text { Error típ. } \\
\text { de la media }\end{array}$} & \multicolumn{2}{|c|}{$\begin{array}{l}\text { 95\% Intervalo de confianza } \\
\text { para la diferencia }\end{array}$} & & & \\
\hline & & & & Inferior & Superior & & & \\
\hline $\begin{array}{c}\text { kWh_real - } \\
\text { kWh_pronost_M2 }\end{array}$ & $-21607,571$ & 32387,506 & 12241,327 & $-51561,019$ & 8345,876 & $-1,765$ & 6 & 128 \\
\hline
\end{tabular}

En la Figura 371 se grafican los consumos reales y pronosticados para la temporada Octubre 2017 - Mayo 2018 para el Edificio E15, y las medias de dichos consumos. Según la prueba paramétrica realizada no son estadísticamente significativas las diferencias encontradas entre el consumo real y el pronosticado por el modelo 2, para un nivel de confianza del $95 \%$.

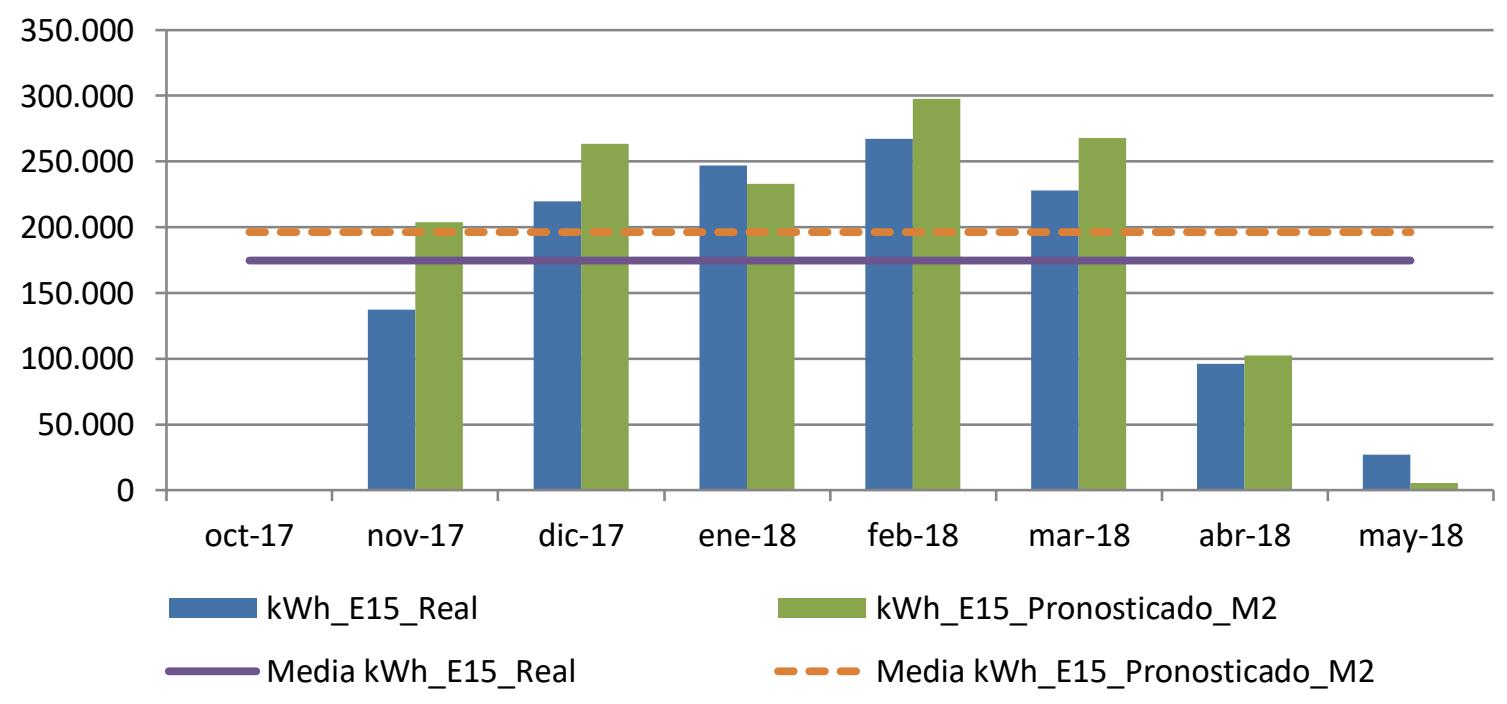

Figura 371. Consumos reales y pronosticados Octubre 2017-Mayo 2018. Edificio E15 
Para el total de las tres temporadas Octubre 2015 - Mayo 2018, se comprueba mediante el Test de Shapiro -Wilk, si los valores reales y los pronosticados con el Modelo M2 se distribuyen según una Normal, se observa que los valores reales si se corresponden con una Normal, (Sig $>0,05$ ), pero los pronosticados, no (Sig $\leq 0,5)$, como se observa en la Tabla 629, luego no se puede aplicar la pruebas paramétrica para el estudio de diferencias significativas.

Tabla 629.Prueba de Normalidad temporada Octubre 2015-Mayo 2018. Edificio E15

\begin{tabular}{lcccccc}
\hline & \multicolumn{3}{c}{ Kolmogorov-Smirnov ${ }^{\mathrm{a}}$} & \multicolumn{3}{c}{ Shapiro-Wilk } \\
\cline { 2 - 7 } & Estadístico & gl & Sig. & Estadístico & gl & Sig. \\
\hline $\begin{array}{l}\text { kWh_real (sin octubre 2016, } \\
\text { mayo 2017, octubre 2017) }\end{array}$ &, 140 & 21 &, 200 &, 952 & 21 & \multirow{2}{*}{, 368} \\
\hline kWh_pronost_M2 &, 164 & 21 &, 142 &, 904 & 21 &, 041 \\
\hline
\end{tabular}

En la Tabla 630, se observa que la media de los consumos pronosticados con el Modelo 2, es superior a la media del consum real en un 4,2 \%, pero al no poderse aplicar la prueba paramétrica no se puede concluir que esta diferencia sea o no significativa

Tabla 630. Estadísticos de muestras relacionadas. Octubre 2015-Mayo 2018. Edificio E15

\begin{tabular}{|c|c|c|c|c|c|}
\hline & Media & $\begin{array}{l}\text { \% Diferencia } \\
\text { entre medias }\end{array}$ & $\mathrm{N}$ & $\begin{array}{c}\text { Desviación } \\
\text { típ. }\end{array}$ & $\begin{array}{c}\text { Error típ. de } \\
\text { la media }\end{array}$ \\
\hline kWh_real & 163383,4286 & & 21 & 78007,25941 & 17022,57957 \\
\hline kWh_pronost_M2 & 170324,0476 & $4,2 \%$ & 21 & 93705,32478 & 20448,17828 \\
\hline
\end{tabular}




\section{AV.11.5.Estimación de las emisiones de CO2 evitadas.}

Teniendo en cuenta que el consumir Gas natural se producen $0,252 \mathrm{~kg} \mathrm{CO}_{2} / \mathrm{kWh} \mathrm{E}$. final y que al consumir la energía suministrada por red a partir de Biomasa se producen 0,024 kg $\mathrm{CO}_{2}$ / kWh E. final, en la Tabla 631, se muestra las emisiones de $\mathrm{CO}_{2}$ reales para las temporadas octubre 2015 - mayo 2018 y al no haberse detectado diferencias significativas, utilizando el consumo real como el pronosticado, las emisiones de $\mathrm{CO}_{2}$ que se hubieran tenido de haber seguido utilizando las calderas de gas natural originales sin el apoyo de la red de calor.

Tabla 631. Estimación del ahorro de emisiones de CO2 para el Edificio E15.

\begin{tabular}{|c|c|c|c|c|c|c|c|c|c|c|}
\hline & $\begin{array}{l}\text { kWh_E1 } \\
\text { 5Gas } \\
\text { Natural }\end{array}$ & $\begin{array}{c}\text { kWh_E1 } \\
\text { 5Biomas } \\
\text { a }\end{array}$ & $\begin{array}{l}\text { kWh_E15 } \\
\text { Real Total }\end{array}$ & $\begin{array}{c}\text { kWh_E15_ } \\
\text { M2 } \\
\text { Predicho }\end{array}$ & $\begin{array}{l}\text { kg CO2 Real } \\
\text { debido al } \\
\text { consumo de } \\
\text { Gas Natural }\end{array}$ & $\begin{array}{l}\text { kg CO2 } \\
\text { Real } \\
\text { debido a } \\
\text { Biomasa }\end{array}$ & $\begin{array}{l}\text { kg CO2 } \\
\text { Real } \\
\text { debido al } \\
\text { consumo } \\
\text { TOTAL }\end{array}$ & $\begin{array}{c}\text { kg CO2 } \\
\text { que se } \\
\text { hubiera } \\
\text { tenido } \\
\text { debido a } \\
\text { Gas } \\
\text { Natural }\end{array}$ & $\begin{array}{l}\text { Ahorro de } \\
\text { kg CO2 }\end{array}$ & $\begin{array}{l}\text { Ahorro de kg } \\
\text { CO2 } \\
\text { acumulado }\end{array}$ \\
\hline oct-2015 & 0 & 53.000 & 53.000 & 53.000 & 0 & 1.272 & 1.272 & 13.356 & 12.084 & 12.084 \\
\hline nov-2015 & 0 & 173.200 & 173.200 & 173.200 & 0 & 4.157 & 4.157 & 43.646 & 39.490 & 51.574 \\
\hline dic-2015 & 0 & 126.100 & 126.100 & 126.100 & 0 & 3.026 & 3.026 & 31.777 & 28.751 & 80.324 \\
\hline ene-2016 & 0 & 167.500 & 167.500 & 167.500 & 0 & 4.020 & 4.020 & 42.210 & 38.190 & 118.514 \\
\hline feb-2016 & 44.811 & 224.400 & 269.211 & 269.211 & 11.292 & 5.386 & 16.678 & 67.841 & 51.163 & 169.678 \\
\hline mar-2016 & 9.303 & 164.700 & 174.003 & 174.003 & 2.344 & 3.953 & 6.297 & 43.849 & 37.552 & 207.229 \\
\hline abr-2016 & 0 & 122.200 & 122.200 & 122.200 & 0 & 2.933 & 2.933 & 30.794 & 27.862 & 235.091 \\
\hline may-2016 & 11.633 & 23.400 & 35.033 & 35.033 & 2.932 & 562 & 3.493 & 8.828 & 5.335 & 240.426 \\
\hline oct-2016 & 8.497 & 28.700 & 0 & 0 & 2.141 & 689 & 2.830 & 0 & -2.830 & 237.596 \\
\hline nov-2016 & 6.697 & 186.100 & 192.797 & 192.797 & 1.688 & 4.466 & 6.154 & 48.585 & 42.431 & 280.027 \\
\hline dic-2016 & 4.136 & 177.400 & 181.536 & 181.536 & 1.042 & 4.258 & 5.300 & 45.747 & 40.447 & 320.474 \\
\hline ene-2017 & 496 & 283.300 & 283.796 & 283.796 & 125 & 6.799 & 6.924 & 71.517 & 64.592 & 385.066 \\
\hline feb-2017 & 0 & 205.600 & 205.600 & 205.600 & 0 & 4.934 & 4.934 & 51.811 & 46.877 & 431.943 \\
\hline mar-2017 & 664 & 169.800 & 170.464 & 170.464 & 167 & 4.075 & 4.243 & 42.957 & 38.714 & 470.658 \\
\hline abr-2017 & 0 & 53.800 & 53.800 & 53.800 & 0 & 1.291 & 1.291 & 13.558 & 12.266 & 482.924 \\
\hline may-2017 & 0 & 13.800 & 0 & 0 & 0 & 331 & 331 & 0 & -331 & 482.593 \\
\hline oct-2017 & 672 & 8.100 & 0 & 0 & 169 & 194 & 364 & 0 & -364 & 482.229 \\
\hline nov-2017 & 464 & 137.100 & 137.564 & 137.564 & 117 & 3.290 & 3.407 & 34.666 & 31.259 & 513.488 \\
\hline dic-2017 & 320 & 219.700 & 220.020 & 220.020 & 81 & 5.273 & 5.353 & 55.445 & 50.092 & 563.579 \\
\hline ene-2018 & 0 & 247.100 & 247.100 & 247.100 & 0 & 5.930 & 5.930 & 62.269 & 56.339 & 619.918 \\
\hline feb-2018 & 16 & 267.200 & 267.216 & 267.216 & 4 & 6.413 & 6.417 & 67.338 & 60.922 & 680.840 \\
\hline mar-2018 & 864 & 227.000 & 227.864 & 227.864 & 218 & 5.448 & 5.666 & 57.422 & 51.756 & 732.596 \\
\hline abr-2018 & 48 & 96.300 & 96.348 & 96.348 & 12 & 2.311 & 2.323 & 24.280 & 21.956 & 754.552 \\
\hline may-2018 & 0 & 26.700 & 26.700 & 26.700 & 0 & 641 & 641 & 6.728 & 6.088 & 760.640 \\
\hline
\end{tabular}

Como se observa durante estas tres temporadas se ha obtenido un ahorro total de 761 Toneladas de $\mathrm{CO}_{2}$, debido al cambio de tipo de energía consumida en el edificio E15. 


\section{AV.11.6.Estimación del precio máximo de compra a la red.}

Tomando como referencia los precios del gas natural de la Tabla 632 para cada temporada, obtenidos a partir de los datos establecidos en el Capítulo 3, donde se tiene en cuenta el precio por el termino variable y fijo; se puede realizar la estimación del precio máximo de compra de la energía útil a la red de calor para obtener un $0 \%$ de ahorro y un $15 \%$ de ahorro. La Tabla 633, muestra el precio que se pagaría para un ahorro del $15 \%$

Tabla 632. Precios de referencia para Gas natural y Astilla

\begin{tabular}{ccccc}
\hline Precios ( $€ /(\mathrm{kWh})$ & 2015 & 2016 & 2017 & 2018 \\
\hline Gas Natural & 0,0373 & 0,0306 & 0,0314 & 0,0336 \\
\hline Astilla & 0,0277 & 0,0256 & 0,0254 & 0,0239 \\
\hline $\begin{array}{c}€ / \text { kWh útiles máximos de compra a la red para } \\
\text { un ahorro del } 0,0 \%\end{array}$ & 0,003176 & \\
\hline $\begin{array}{c}€ / \text { kWh útiles máximos de compra a la red para } \\
\text { un ahorro del } 15,0 \%\end{array}$ & 0,02753 & \\
\hline
\end{tabular}

Tabla 633. Ahorro Económico por el consumo térmico en el Edificio E15

\begin{tabular}{|c|c|c|c|c|c|c|c|c|c|c|}
\hline & $\begin{array}{c}\text { kWh_E1 } \\
\text { 5_Gas } \\
\text { Natural }\end{array}$ & $\begin{array}{c}\text { kWh_E15_ } \\
\text { Biomasa }\end{array}$ & $\begin{array}{c}\text { kWh_E1 } \\
5\end{array}$ & $\begin{array}{c}\text { kWh_E15_ } \\
\text { M2 }\end{array}$ & $\begin{array}{c}€ \text { Real Gas } \\
\text { Natural }\end{array}$ & $\begin{array}{c}€ \text { Real } \\
\text { Biomasa }\end{array}$ & $\begin{array}{l}€ \text { Real } \\
\text { Total }\end{array}$ & $\begin{array}{c}\text { € predicho } \\
\text { Gas } \\
\text { natural }\end{array}$ & $\begin{array}{c}€ \\
\text { Ahorro }\end{array}$ & $€$ Acumulado \\
\hline oct-2015 & 0 & 53.000 & 53.000 & 53.000 & 0 & 1.459 & 1.459 & 1.977 & 518 & 518 \\
\hline nov-2015 & 0 & 173.200 & 173.200 & 173.200 & 0 & 4.768 & 4.768 & 6.460 & 1.692 & 2.210 \\
\hline dic-2015 & 0 & 126.100 & 126.100 & 126.100 & 0 & 3.472 & 3.472 & 4.704 & 1.232 & 3.442 \\
\hline ene-2016 & 0 & 167.500 & 167.500 & 167.500 & 0 & 4.611 & 4.611 & 5.126 & 514 & 3.956 \\
\hline feb-2016 & 44.811 & 224.400 & 269.211 & 269.211 & 1.371 & 6.178 & 7.549 & 8.238 & 689 & 4.645 \\
\hline mar-2016 & 9.303 & 164.700 & 174.003 & 174.003 & 285 & 4.534 & 4.819 & 5.324 & 506 & 5.151 \\
\hline abr-2016 & 0 & 122.200 & 122.200 & 122.200 & 0 & 3.364 & 3.364 & 3.739 & 375 & 5.526 \\
\hline may-2016 & 11.633 & 23.400 & 35.033 & 35.033 & 356 & 644 & 1.000 & 1.072 & 72 & 5.598 \\
\hline oct-2016 & 8.497 & 28.700 & 0 & 0 & 260 & 790 & 1.050 & 0 & -1.050 & 4.548 \\
\hline nov-2016 & 6.697 & 186.100 & 192.797 & 192.797 & 205 & 5.123 & 5.328 & 5.900 & 571 & 5.119 \\
\hline dic-2016 & 4.136 & 177.400 & 181.536 & 181.536 & 127 & 4.884 & 5.010 & 5.555 & 545 & 5.664 \\
\hline ene-2017 & 496 & 283.300 & 283.796 & 283.796 & 16 & 7.799 & 7.815 & 8.911 & 1.096 & 6.760 \\
\hline feb-2017 & 0 & 205.600 & 205.600 & 205.600 & 0 & 5.660 & 5.660 & 6.456 & 796 & 7.556 \\
\hline mar-2017 & 664 & 169.800 & 170.464 & 170.464 & 21 & 4.675 & 4.695 & 5.353 & 657 & 8.213 \\
\hline$a b r-2017$ & 0 & 53.800 & 53.800 & 53.800 & 0 & 1.481 & 1.481 & 1.689 & 208 & 8.421 \\
\hline may-2017 & 0 & 13.800 & 0 & 0 & 0 & 380 & 380 & 0 & -380 & 8.041 \\
\hline oct-2017 & 672 & 8.100 & 0 & 0 & 21 & 223 & 244 & 0 & -244 & 7.797 \\
\hline nov-2017 & 464 & 137.100 & 137.564 & 137.564 & 15 & 3.774 & 3.789 & 4.320 & 531 & 8.327 \\
\hline dic-2017 & 320 & 219.700 & 220.020 & 220.020 & 10 & 6.048 & 6.058 & 6.909 & 850 & 9.178 \\
\hline ene-2018 & 0 & 247.100 & 247.100 & 247.100 & 0 & 6.803 & 6.803 & 8.303 & 1.500 & 10.678 \\
\hline feb-2018 & 16 & 267.200 & 267.216 & 267.216 & 1 & 7.356 & 7.357 & 8.978 & 1.622 & 12.300 \\
\hline mar-2018 & 864 & 227.000 & 227.864 & 227.864 & 29 & 6.249 & 6.278 & 7.656 & 1.378 & 13.677 \\
\hline abr-2018 & 48 & 96.300 & 96.348 & 96.348 & 2 & 2.651 & 2.653 & 3.237 & 585 & 14.262 \\
\hline may-2018 & 0 & 26.700 & 26.700 & 26.700 & 0 & 735 & 735 & 897 & 162 & 14.424 \\
\hline$€$ Total & & & & & & & 96.379 & 110.803 & & \\
\hline Ahorro (\%) & & & & & & & & & & $15,0 \%$ \\
\hline
\end{tabular}




\section{BIBLIOGRAFÍA}

Abghari, S., García-Martín, E., Johansson, C., Lavesson, N., \& Grahn, H. (2017). Trend Analysis to automatically identify heat program changes. Energy Procedia, 116, 407-415. doi.org/10.1016/j.egypro.2017.05.088.

Adobe Experience Cloud Help. (s.f.). Nivel de confianza e intervalo de confianza. Recuperado el 27 de octubre de 2018, de https://marketing.adobe.com/resources/help/es_ES/rec/c_Confidence_Level_and _Confidence_Interval.html

AENOR. Asociación Española de Normalización. (2009). UNE-EN ISO 15927-6:2009. Comportamiento higrotérmico de edificios. Cálculo y presentación de datos climáticos. Parte 6: Diferencias acumuladas de temperatura (en grados por día). (ISO 15927-6:2007). Recuperado el 1 de noviembre de 2018, de https://www.une.org/encuentra-tu-norma/busca-tu-norma/norma/?c=N0043434

AENOR. Asociación Española de Normalización. (2018). UNE-EN ISO 50001:2018. Sistemas de gestión de la energía. Requisitos con orientación para su uso. (ISO 50001:2018). Recuperado el 31 de octubre de 2018, de https://www.une.org/encuentra-tunorma/busca-tu-norma/norma?c=N0060594

Agencia Chilena de Eficiencia Energética. AchEE. (Abril de 2014). Guia de Apoyo al Desarrollo de Diagnósticos Energéticos para Instituciones de Educación Superior (IES). Recuperado el 7 de Febrero de 2019, de http://www.pucv.cl/uuaa/site/artic/20160701/asocfile/20160701115559/gu_a_a poyo_al_desarrollo_de_diagn_sticos_energ_ticos_para_ies_achee_.pdf

Ahmad, M., Mourshed, M., Mundow, D., Sisinni, M., \& Rezgui, Y. (2016). Building energy metering and environmental monitoring - A state-of-the-art review and directions for future research. Energy and Building, 120, 85-102. doi.org/10.1016/j.enbuild.2016.03.059.

Amaral, A., Rodrigues, E., Rodrigues Gaspar, A., \& Gomes, A. (2018). Review on performance aspects of nearly zero-energy districts. Sustainable Cities and Society(43), 406-420. doi.org/10.1016/j.scs.2018.08.039.

Andric, I., Pina, A., Ferrào, P., Fournier, J., Lacarriere, B., \& Le Corre, O. (2017). Assessing the feasibility of using the heat demand-outdoor temperature function for a long- 
term district heat demand forecast. Energy Procedia, 116, 460-469. doi.org/10.1016/j.egypro.2017.05.093.

Anta, J. (13 de septiembre de 2017). De paseo por el Campus Universitario. Recuperado el 21 de noviembre de 2018, de https://jesusantaroca.wordpress.com/2017/09/13/de-paseo-por-el-campusuniversitario/

Antunez, C. (s.f.). Tablas Estadísticas para Econometría. Recuperado el 28 de octubre de 2018, de https://www.monografias.com/trabajos-pdf4/tablas-estadisticaseconometria/tablas-estadisticas-econometria.pdf

Aranda, A., Ferreira, G., Mainar-Toledo, M., Scarpellini, S., \& Llera Sastresa, E. (2012). Multiple regression models to predict the annual energy consumption in the Spanish banking sector. Energy and Buildings, 49, 380-387, doi:10.1016/J.ENBUILD.2012.02.040.

Arregi, B., \& Garay, R. (2017). Regression analysis of the energy consumption of tertiary buildings. Energy Procedia, 122, 9-14, doi:10.1016/J.EGYPRO.2017.07.290.

ASHRAE. (2014). Guideline 14-2014 -- Measurement of Energy, Demand, and Water Savings. Recuperado el 29 de octubre de 2018, de https://www.techstreet.com/ashrae/standards/guideline-14-2014-measurementof-energy-demand-and-watersavings?gateway_code=ashrae\&product_id=1888937

Asociación de Empresas de Eficiencia Energética. A3e. (2015). Curso de Auditor Energético en la Edificación. Volumen III. Madrid.

Asociación de Empresas de Redes de Calor y Frío ADHAC. (2018). Censo de redes de Calor y Frío. Recuperado el 06 de diciembre de 2018, de http://www.adhac.es/Priv/ClientsImages/AsociacionPerso8_1540226118.pdf

Atalla, T., Gualdi, S., \& Lanza, A. (2018). A global degree days database for energy-related applications. Energy, 143, 1048-1055, doi:10.1016/j.energy.2017.10.134.

Averfalk, H., \& Werner, S. (2017). Essential improvements in future district heating systems. Energy Procedia, 116, 217-225. doi.org/10.1016/j.egypro.2017.05.069.

Belsley, D., Kuh, E., \& Welsch, R. (2005). Regression diagnostics: Identifying influential data and sources of collinearity (Vol. ISBN 9780471058564. DOI:10.1002/0471725153). New York: 1980 John Wiley \& Sons.

Bilous, I., Deshko, V., \& Sukhodub, I. (2018). Parametric analysis of external and internal factors influence on building energy performance using non-linear multivariate regression models. Journal of Building Engineering, 20, 327-336, doi:10.1016/J.JOBE.2018.07.021.

BP. (Junio de 2018). BP Statistical Review of word Energy. June 2018. 67th Edition. Recuperado el 19 de Octubre de 2018, de https://www.bp.com/content/dam/bp/en/corporate/pdf/energyeconomics/statistical-review/bp-stats-review-2018-full-report.pdf 
Bromley, M. (21 de diciembre de 2009). Degree Days. Understanding Heating and Cooling Degree Days. Recuperado el 7 de febrero de 2019, de https://www.degreedays.net/introduction\#Why_are_heating_degree_days_useful

Bush, R., \& Bale, C. (2017). The role of intermediaries in the transition to district heating. Energy Procedia. The 15th International Symposium on district Heating and Cooling., 116, 490-499. doi.org/10.1016/j.egypro.2017.05.098.

Bush, R., Bale, C., \& Taylor, P. (2016). Realising local government visions for developing district heating: Experiences from a learning country. Energy Policy, 98, 84-96. doi.org/10.1016/j.enpol.2016.08.013.

Cano Herrador, C., Valbuena García, F., Muñoz Martín, J., Rey Martínez, F., \& Navas Gracia, L. (2014). Calefacción de distrito urbana con biomasa de la Universidad de Valladolid. Objetivo 20/20/20. Recuperado el 24 de octubre de 2018, de http://www.conama11.vsf.es/conama10/download/files/conama2014/CT\%20201 4/1896712037.pdf

Capítulo 18. Análisis de regresión lineal. El procedimiento de Regresión lineal. Guia SPSS. (s.f.). Recuperado el 28 de octubre de 2018, de http://halweb.uc3m.es/esp/Personal/personas/jmmarin/esp/GuiaSPSS/18reglin.p df

Castro Flores, J., Lacarriere, B., Chiu, J., \& Martín, V. (2017). Assessing the technoeconomic impact of low temperatures subnets in conventional district heating networks. Energy Procedia, 116, 260-271. https://doi.org/10.1016/j.egypro.2017.05.073.

Centro Tecnológico de Eficiencia y Sostenibilidad Energética (ENERGYLAB). (8 de octubre de 2014). Metodología para abordar un Proyecto de EE: "Potocolo de Medida y Verificación de Ahorros Energéticos IPMVP". Recuperado el 29 de octubre de 2018, de $\quad$ https://www.fenercom.com/pages/pdf/formacion/14-1008_Jornada\%20sobre\%20HERRAMIENTAS\%20DE\%20GESTION\%20DE\%20LA\%20EN ERGIA/04-METODOLOGIA-PARA-ABORDAR-UN-PROYECTO-DE-EFICIENCIAENERGETICA-IPMVP-fenercom-2014

Comisión Europea. (2016). Comunicación de la Comisión al Parlamento Europeo, al Consejo, al Comité económico y social Europeo y al Comité de las Regiones. Estrategia de la UE relativa a la calefacción y la refrigeración. Recuperado el 23 de octubre de 2018, de https://ec.europa.eu/transparency/regdoc/rep/1/2016/ES/12016-51-ES-F1-1.PDF

Commission to the European Parliament. (10 de octubre de 2017). Communication from the Commission to the European Parliament, the Council, the European Economic and Social Committee and the Committee of the Regions. Energy Roadmap 2050. Recuperado el 20 de octubre de 2018, de https://eur-lex.europa.eu/legalcontent/EN/ALL/?uri=CELEX\%3A52011DC0885

Consejo de Ministros. Gobierno de España. (2011). Plan de Energías Renovables (PER) 2011-2020. Madrid. 
Convención Marco de las Naciones Unidas sobre el Cambio Climático. (noviembre de 2007). Unidos por el clima. Recuperado el 17 de octubre de 2018, de https://unfccc.int/resource/docs/publications/unitingonclimate_spa.pdf

Cruz Ramírez, A. P. (s.f.). Pruebas de Hipótesis para una muestra. Recuperado el 27 de octubre de 2018, de https://www.monografias.com/trabajos30/prueba-dehipotesis/prueba-de-hipotesis.shtml

De Rosa, M., Bianco, V., Scarpa, F., \& Tagliafico, L. (2014). Heating and cooling building energy demand evaluation; A simplified model and a modified degree days approach. Applied Energy, 128, 217-229, 10.1016/j.apenergy.2014.04.067.

Delmastro, C., Mutani, G., \& Schranz, L. (2015). Advantages of Coupling a Woody Biomass Cogeneration Plant with a District Heating Network for a Sustainable Built Environment: A Case Study in Luserna San Giovanni (Torino, Italy). Energy Procedia, 78, 794-799, doi:10.1016/J.EGYPRO.2015.11.102.

DHC Technology Platform. (Marzo de 2012). District Heating and Cooling. A vision towards 2020-2030-2050. Recuperado el 24 de octubre de 2018, de https://www.euroheat.org/wp-content/uploads/2016/04/DHC-Vision-for-DHC2012.pdf

Díaz, T. (2 de febrero de 2016). España, el octavo país de la UE con más dependencia energética. Recuperado el 15 de octubre de 2018, de El Economista.es: https://www.eleconomista.es/empresas-

finanzas/noticias/7331172/02/16/Espana-el-octavo-pais-de-la-UE-con-masdependencia-energetica-.html

Dirección General de Política Energética y Minas. (31 de diciembre de 2016). Resolución de 29 de diciembre de 2016, de la Dirección General de Política Energética y Minas, por la que se publica la tarifa de último recurso de gas natural. Recuperado el 6 de diciembre de 2018, de https://www.boe.es/diario_boe/txt.php?id=BOE-A-201612600

Dirección General de Política Energética y Minas. (30 de marzo de 2017). Resolución de 24 de marzo de 2017, de la Dirección General de Política Energética y Minas, por la que se publica la tarifa de último recurso de gas natural. Recuperado el 6 de diciembre de 2018, de https://www.boe.es/diario_boe/txt.php?id=BOE-A-20173412

Dirección General de Política Energética y Minas. (29 de septiembre de 2017). Resolución de 25 de septiembre de 2017, de la Dirección General de Política Energética y Minas, por la que se publica la tarifa de último recurso de gas natural. Recuperado el 6 de diciembre de 2018, de https://www.boe.es/diario_boe/txt.php?id=BOE-A2017-11062

Dirección General de Política Energética y Minas. (28 de diciembre de 2017). Resolución de 26 de diciembre de 2017, de la Dirección General de Política Energética y Minas, por la que se publica la tarifa de último recurso de gas natural. Recuperado el 06 
de diciembre de 2018, de https://www.boe.es/diario_boe/txt.php?id=BOE-A-201715610

Dirección General de Política Energética y Minas. (29 de junio de 2017). Resolución de 28 de junio de 2017, de la Dirección General de Política Energética y Minas, por la que se publica la tarifa de último recurso de gas natural. Recuperado el 6 de diciembre de 2018, de https://www.boe.es/diario_boe/txt.php?id=BOE-A-2017-7484

Dirección General de Política Energética y Minas. (31 de marzo de 2018). Resolución de 22 de marzo de 2018, de la Dirección General de Política Energética y Minas, por la que se publica la tarifa de último recurso de gas natural. Recuperado el 06 de diciembre de 2018, de https://www.boe.es/diario_boe/txt.php?id=BOE-A-20184437

Dirección General de Política Energética y Minas. (29 de septiembre de 2018). Resolución de 25 de septiembre de 2018, de la Dirección General de Política Energética y Minas, por la que se publica la tarifa de último recurso de gas natural. Recuperado el 06 de diciembre de 2018, de https://www.boe.es/diario_boe/txt.php?id=BOE-A2018-13190

Dirección General de Política Energética y Minas. (30 de junio de 2018). Resolución de 28 de junio de 2018, de la Dirección General de Política Energética y Minas, por la que se publica la tarifa de último recurso de gas natural. Recuperado el 06 de diciembre de 2018, de https://www.boe.es/boe/dias/2018/06/30/pdfs/BOE-A2018-9035.pdf

Dorotić, H., Pukšec, T., \& Duić, N. (2018). Multi-objective optimization of district heating and cooling systems for a one-year. Energy, Available online 30 November 2018. doi:10.1016/j.energy.2018.11.149.

Efficiency Valuation Organization (EVO). (Septiembre de 2010). Protocolo Internacional de Medida y Verificación. Volumen 1. Recuperado el 28 de octubre de 2018, de http://old.acee.cl/?q=system/files/IPMVP\%202010\%20-\%20Volumen\%20I\%20\%20Espa\%C3\%B1ol.pdf

Efficiency Valuation Organization (EVO). (Junio de 2014). International Performance Measurement and Verification Protocol. Core Concepts. Recuperado el 29 de octubre de 2018, de http://www.minimiseusa.com/images/Core\%20Concepts\%20\%20EVO\%20IPMVP\% 202014_Dec2014-3.pdf

El Parlamento Europeo y el Consejo de la Unión Europea. (5 de junio de 2009). DIRECTIVA 2009/28/CE DEL PARLAMENTO EUROPEO Y DEL CONSEJO de 23 de abril de 2009 relativa al fomento del uso de energía procedente de fuentes renovables y por la que se modifican y se derogan las Directivas 2001/77/CE y 2003/30/CE. Recuperado el 20 de octubre de 2018, de https://www.boe.es/doue/2009/140/L00016-00062.pdf

El Parlamento Europeo y el Consejo de la Unión Europea. (18 de junio de 2010). DIRECTIVA 2010/31/UE DEL PARLAMENTO EUROPEO Y DEL CONSEJO de 19 de 
mayo de 2010 relativa a la eficiencia energética de los edificios. Recuperado el 20 de octubre de 2018, de https://www.boe.es/doue/2010/153/L00013-00035.pdf

El Parlamento Europeo y el Consejo de la Unión Europea. (14 de noviembre de 2012). DIRECTIVA 2012/27/UE DEL PARLAMENTO EUROPEO Y DEL CONSEJO de 25 de octubre de 2012 relativa a la eficiencia energética, por la que se modifican las Directivas 2009/125/CE y 2010/30/UE, y por la que se derogan las Directivas 2004/8/CE y 2006/32/CE. Recuperado el 20 de octubre de 2018, de https://www.boe.es/doue/2012/315/L00001-00056.pdf

El Parlamento Europeo y el Consejo de la Unión Europea. (19 de junio de 2018). DIRECTIVA (UE) 2018/844 DEL PARLAMENTO EUROPEO Y DEL CONSEJO de 30 de mayo de 2018 por la que se modifica la Directiva 2010/31/UE relativa a la eficiencia energética de los edificios y la Directiva 2012/27/UE relativa a la eficiencia energética. Recuperado el 20 de octubre de 2018, de https://www.boe.es/doue/2018/156/L00075-00091.pdf

Encinas, A.G. (9 de enero de 2017). La UVA completa el campus Miguel Delibes 20 años después. $\quad$ Norte de Castilla, págs. https://www.elnortedecastilla.es/valladolid/201701/09/completa-campus-migueldelibes-20170106200628.html. Obtenido de https://www.elnortedecastilla.es/valladolid/201701/09/completa-campus-migueldelibes-20170106200628.html

Ente Regional de la Energía de Castilla y León (EREN). Junta de Castilla y León. (2016). Estrategia de Eficiencia Energética de Castilla y Leín 2016-2020. EEE-CyL2016/2020. Recuperado el 22 de octubre de 2018, de https://energia.jcyl.es/web/jcyl/Energia/es/Plantilla100/1284777945631/_/__

EOI. Escuela de Organización Industrial. (15 de Noviembre de 2015). Master en Energías Renovables y Mercado Energético. Recuperado el 9 de marzo de 2019, de https://www.eoi.es/blogs/merme/energia-primaria-transformacion-y-consumosen-espana-evolucion-global-de-la-demanda-de-energia/

Ericsson, K., \& Werner, S. (2016). The introduction and expansion of biomass use in Swedish district heating systems. Biomass Bioenergy, 94, 57-65, doi:10.1016/J.BIOMBIOE.2016.08.011.

Euronet. (s.f.). Euronet 50-50 max. Recuperado el 7 de febrero de 2019, de Herramientas para el cálculo de Ahorros Energéticos: http://www.euronet5050max.eu/es/energy-savings-calculation-tool?id=51

Europa Press. (28 de 07 de 2011). El IBGM de Valladolid cuenta con un microscopio confocal con características únicas en España. Recuperado el 25 de noviembre de 2018, de https://www.europapress.es/castilla-y-leon/noticia-ibgm-valladolidcuenta-microscopio-confocal-caracteristicas-unicas-espana-20110728124656.html

Europa Press. (27 de enero de 2017). Castilla y León, Quinta CCAA con más emisiones de CO2 del país. Recuperado el 22 de octubre de 2018, de 
https://www.europapress.es/castilla-y-leon/noticia-cyl-quinta-ccaa-masemisiones-co2-pais-20170127175102.html

European Parliament. (19 de Julio de 2018). Effort sharing regulation, 2021-2030 Limiting Member States' carbon emissions. Recuperado el 20 de octubre de 2018, de http://www.europarl.europa.eu/RegData/etudes/BRIE/2016/589799/EPRS_BRI(20 16)589799_EN.pdf

Eurostat. (2 de septiembre de 2015). España es el país europeo que más aumentó sus emisiones de CO2 desde 1990. Recuperado el 19 de 10 de 2018, de Troposfera: http://www.troposfera.org/news/11659/39/Eurostat-Espana-es-el-tercer-paiseuropeo-que-mas-aumento-sus-emisiones-de-CO2-desde-1990/

Eurostat. (mayo de 2018). Estadísticas de los precios del gas natural. Recuperado el 2 de diciembre de 2018, de https://ec.europa.eu/eurostat/statisticsexplained/index.php?title=Natural_gas_price_statistics/es\#Precios_del_gas_natur al_para_consumidores_no_dom.C3.A9sticos

Eurostat. (2018). What kind of energy do we consume in the EU? Recuperado el 16 de octubre de 2018, de https://ec.europa.eu/eurostat/cache/infographs/energy/bloc3a.html

EVO, E. V. (2014). International Performance Measurement and Verification Protocol (IPMVP). Recuperado el 29 de octubre de 2018, de https://evoworld.org/en/products-services-mainmenu-en/protocols/ipmvp

Federación Española de Municipios y Provincias (FEMP). (2011). Eficiencia Energética en dependencias municipales. Recuperado el 7 de febrero de 2019, de http://www.redciudadesclima.es/sites/default/files/97a9d2195549da7f51cd21c7a 4ffec7a.pdf

Federación Española de Municipios y Provincias. FEMP. (2011). Climatización Urbana en las ciudades españolas. Recuperado el 10 de marzo de 2019, de http://www.redciudadesclima.es/sites/default/files/b7e75a5a739b40b44fc98ecaa d533842.pdf

Ferreira, A., Ferreira, A., Cardin, O., \& Leitao, P. (2015). Extension of holonic paradigm to smart grids. IFAC PapersOnLine, 48-3, 1099-1104. doi.org/10.1016/j.ifacol.2015.06.230.

Fumo, N., \& Rafe Biswas, M. (2015). Regression analysis for prediction of residential energy consumption. Renew. Sustain. Renewable and Sustainable Energy Reviews, 47, 332-343, doi:10.1016/J.RSER.2015.03.035.

Fundación General de la Universidad de Valladolid. (FUNGE). (s.f.). Apartamentos Cardenal Mendoza. Recuperado el 11 de noviembre de 2018, de http://funge.uva.es/residencias-universitarias/apartamentos-cardenal-mendoza/

Gaoa, L., Cuia, X., Nia, J., Leib, W., Huangb, T., Baib, C., \& Yanga, J. (2017). Technologies in Smart District Heating System. Energy Procedia, 142, 1829-1834. doi.org/10.1016/j.egypro.2017.12.571. 
Generalitat de Catalunya. Institut Català d'Energia. Asociación de Empresas de Redes de Calor y Frío. ADHAC. (abril de 2011). Guía Básica de Redes de Distrito de Calor y Frío. Recuperado el 21 de octubre de 2018, de http://www.idae.es/uploads/documentos/documentos_20110502_Guia_Basica_R edes_de_Calor_y_de_Frio_ES_5e18b14a.pdf

Generalitat de Catalunya. Institut Català d'Energia. Asociación de Empresas de Redes de Calor y Frío. ADHAC. (Mayo de 2012). Guía integral de desarrollo de proyectos de redes de distrito de calor y frío. Recuperado el 23 de octubre de 2018, de http://www.adhac.es/priv/clientsimages/asociacionperso6_1338538783.pdf

Golden, A., Woodbury, K., Carpenter, J., \& O’Neill, Z. (2017). Change point and degree day baseline regression models in industrial facilities. Energy and Buildings, 144, 30-41, doi:10.1016/j.enbuild.2017.03.024.

Good, N., Martínez Ceseña, E. A., \& Mancarella, P. (2017). Ten questions concerning smart districts. Building and Environment, 118, 362-376. doi.org/10.1016/j.buildenv.2017.03.037.

Granderson, J., \& Price, P. (2014). Development and application of a statistical methodology to evaluate the predictive accuracy of building energy baseline models. Energy, 66, 981-990. doi.org/10.1016/j.energy.2014.01.074.

Hanna, R., Ghonima, M., Kleissl, J., Tynan, G., \& Victor, D. (2017). Evaluating business models for microgrids: Interactions of technology and policy. Energy Policy, 103, 47-61. doi.org/10.1016/j.enpol.2017.01.010.

Howell, S., Rezgui, Y., Hippolyte, J., Jayan, B., \& Li, H. (2017). Towards the next generation of smart grids: Semantic and holonic multiagent management of distributed energy resources. Renewable and Sustainable Energy Reviews, 77, 193-214. doi.org/10.1016/j.rser.2017.03.107.

Huerta, M., Portela, J., \& Pastor, A. (2010). Calefacción urbana o de distrito, , ¿un sistema energéticamente más sostenible? Recuperado el 31 de octubre de 2018, de XVIII Congreso Nacional de Ingeniería Mecánica: https://docplayer.es/6804813Calefaccion-urbana-o-de-distrito-un-sistema-energeticamente-massostenible.html

IBM. (2011). IBM SPSS Statistics Software. (V20). Obtenido de IBM SPSS Software. Available online: https://www.ibm.com/analytics/spss-statistics-software (accessed

IDAE. (16 de julio de 2011). Proyecto SECH-SPAHOUSEC. Análisis del consumo energético del sector residencial en España. Informe final. Recuperado el 29 de septiembre de 2018, de http://www.idae.es/uploads/documentos/documentos_Informe_SPAHOUSEC_AC C_f68291a3.pdf

IDAE. Dirección de Energías Renovables. Departamento de Biomasa y Residuos. (20 de noviembre de 2018). Informe de Precios de la Biomasa para Usos Térmicos. Datos 
correspondientes al 2o Trimestre de 2018. Recuperado el 5 de diciembre de 2018, de

http://www.idae.es/sites/default/files/estudios_informes_y_estadisticas/informe_ precios_biomasa_usos_termicos_2t_2018.pdf

InfoRiego. (s.f.). Datos Agroclimáticos. Recuperado el 31 de octubre de 2018, de http://www.inforiego.org/opencms/opencms/info_meteo/construir/index.html

Internacional Energy Agency (IEA). (2016). World Energy Outlook. 2016. Recuperado el 20 de octubre de 2018, de https://webstore.iea.org/download/direct/202?fileName=WEO2016.pdf

Internacional Energy Agency (IEA). (2017). Market Report Series: Energy Efficiency 2017. Analysis and Forecasts to 2022. Recuperado el 20 de octubre de 2018, de https://webstore.iea.org/download/direct/160

Internacional Energy Agency (IEA). (2017). World Energy Outlook 2017. Executive Summary. Recuperado el 20 de octubre de 2018, de https://www.iea.org/Textbase/npsum/weo2017SUM.pdf

International Energy Agency (IEA). (2017). World energy balances. Overview 2017 edition. Recuperado el 13 de octubre de 2018, de https://www.iea.org/publications/freepublications/publication/WorldEnergyBalan ces20170verview.pdf

International Energy Agency (IEA). (March de 2018). Global Energy \& CO2 Status Report 2017. Recuperado el 17 de octubre de 2018, de https://www.iea.org/publications/freepublications/publication/GECO2017.pdf

Khabdullin, A., Khabdullina, Z., Khabdullina, G., Lauka, D., \& Blumberga, D. (2017). Demand response analysis methodology in district heating system. Energy Procedia, 128, 539-543. doi.org/10.1016/j.egypro.2017.09.004.

Kim, J., \& Weidlich, I. (2017). Identification of Individual District Heating Network Conditions using Equivalent Full Load Cycles. . Energy Procedia, 116, 343-350. doi.org/10.1016/j.egypro.2017.05.081.

Kolokotsa, D. (2016). The role of smart grids in the building sector. Energy and Building, 116, 703-708. doi.org/10.1016/j.enbuild.2015.12.033.

La Comisión Europea. (2 de agosto de 2016). Recomendación (UE) 2016/1318 de la Comisión de 29 de julio de 2016 para promover los edificios de consumo de energía casi nulo y las mejores prácticas para garantizar que antes de fin de 2020 todos los edificios nuevos sean de consumo de energía casi nulo. Recuperado el 20 de octubre de 2018, de https://www.boe.es/doue/2016/208/L00046-00057.pdf

Laakkonen, L., Korpela, T., Kaivosoja, J., Vilkko, M., Majanne, Y., \& Nurmoranta, M. (2017). Predictive supply Temperature Optimization of district Heating Networks Using Delay Distributions. The 15th International Symposium on district Heating and Cooling. Energy Procedia, 116, 297-309. doi.org/10.1016/j.egypro.2017.05.076. 
Lake, A., Rezaie, B., \& Beyerlein, S. (2017). Review of district heating and cooling systems for a sustainable future. Renewable and Sustainable Energy Reviews, 67, 417-425. doi.org/10.1016/j.rser.2016.09.061.

Lara, S. (2017). Análisis del funcionamiento de la Red de calefacción centralizada "Univeridad de Valladolid". Escuela de Ingenierías Industriales. UVA.

Lee, J., Kim, H., \& Im, S. (2017). Comparative Analysis between District Heating and Geothermal Heat Pump System. Energy Procedia, 116, 403-406, doi:10.1016/J.EGYPRO.2017.05.087.

Liang, X., Hong, T., \& Qiping Shen, G. (2016). Improving the accuracy of energy baseline models for commercial buildings with occupancy data. Applied energy, 179, 247260. doi.org/10.1016/j.apenergy.2016.06.141.

Lissardy, G. (17 de noviembre de 2017). El origen del misterioso vapor que sale del pavimento en las calles de Nueva York (y por qué es tan importante para la ciudad). Recuperado el 24 de octubre de 2018, de https://www.bbc.com/mundo/noticiasinternacional-41911000

Lorenzo, S. (29 de marzo de 2017). Red de calor urbana con biomasa forestal de la Universidad de Valladolid. Recuperado el 6 de noviembre de 2018, de http://www.lifeopere.org/sites/default/files/jornada_final_opere_sergio_lorenzo.pdf

Lund, H., Alberg-Ostergaard, P., Chang, M., Werner, S., Svendsen, S., Sorknæs, P., . . . Möller, B. (2018). The status of 4th generation district heating: Research and results. Energy, 164, 147-159. doi.org/10.1016/j.energy.2018.08.206.

Lund, H., Duic, N., Alberg-Ostergaard, P., \& Mathiesen, B. (2018). Future district heating systems and technologies: On the role of smart energy systems and 4th generation district heating. Energy, 165. Part A, 614-619. doi.org/10.1016/j.energy.2018.09.115.

Lund, H., Möller, B., Mathiesen, B., \& Dyrelund, A. (2010). The role of district heating in future renewable energy systems. Energy, 35, 1381-1390. doi.org/10.1016/j.energy.2009.11.023.

Lund, H., Werner, S., Wiltshire, R., Svendsen, S., Thorsen, J. E., Hvelplund, F., \& Vad Mathiesen, B. (2014). 4th Generation District Heating (4GDH): Integrating smart thermal grids into future sustainable energy systems. Energy, 68, 1-11. doi.org/10.1016/j.energy.2014.02.089.

Mahía, R. (marzo de 2010). Conceptos básicos sobre la Autocorrelación en el modelo básico de regresión lineal. Recuperado el octubre 28 de 2018, de https://www.uam.es/personal_pdi/economicas/rarce/pdf/autocorrel.pdf

Mártil, I. (17 de noviembre de 2014). Consumo y derroche de energía en el planeta: ¿podemos resistir? Recuperado el 15 de octubre de 2018, de https://blogs.publico.es/econonuestra/2014/11/17/consumo-y-derroche-deenergia-en-el-planeta-podemos-resistir/ 
Mazhar, A., Liu, S., \& Shukla, A. (2018). A state of art review on the district heating systems. Renewable and Sustainable Energy Reviews, 96, 420-439. doi.org/10.1016/j.rser.2018.08.005.

Meng, Q., \& Mourshed, M. (2017). Degree-day based non-domestic building energy analytics and modelling should use building and type specific base temperatures. Energy and Buildings, 155, 260-268, doi:10.1016/j.enbuild.2017.09.034.

Mertz, T., Serra, S. H., Reneaume, \& J.M. (2017). A MINLP optimization of the configuration and the design of a district heating network: study case on an existing site. Energy Procedia, 116, 236-248. doi.org/10.1016/j.egypro.2017.05.071.

Ministerio de Agricultura y Pesca, Alimentación y Medio Ambiente. Gobierno de España. (marzo de 2018). Inventario Nacional de emisiones a la atmósfera. Emisiones de gases de efecto invernadero. Serie 1990-2016. Informe Resumen. Recuperado el 19 de octubre de 2018, de https://www.miteco.gob.es/es/calidad-y-evaluacionambiental/temas/sistema-espanol-de-inventario-sei-

/documentoresumeninventariogei_tcm30-444543.pdf

Ministerio de Agricultura y Pesca, alimentación y Medio Ambiente. MAPAMA. (2016). Objetivos de reducción de emisiones de gases de efecto invernadero. Recuperado el 11 de enero de 2017, de http://www.mapama.gob.es/es/cambioclimatico/temas/mitigacion-politicas-y-medidas/objetivos.aspx\#

Ministerio de Energía, Turismo y Agenda Digital. Gobierno de España. (26 de abril de 2017). Plan Nacional de Acción de Eficiencia Energética 2017-2020. Recuperado el 20 de octubre de 2018, de https://ec.europa.eu/energy/sites/ener/files/documents/es_neeap_2017_es.pdf

Ministerio de Energía, Turismo y Agenda Digital. Gobierno de España. (enero de 2018). La Energía en España. 2016. Recuperado el 22 de octubre de 2018, de https://ceiden.com/wp-content/uploads/2018/01/La-Energ\%C3\%ADa-enEspa\%C3\%B1a-2016.pdf

Ministerio de Fomento. Gobierno de España. (2017). ERESEE 2017. Actualización 2017 de la estrategia a largo plazo para la rehabilitación energética en el sector de la edificación en España. Recuperado el 29 de septiembre de 2018, de https://www.fomento.gob.es/recursos_mfom/pdf/24003A4D-449E-4B93-8CA57217CFC61802/143398/20170524REVISIONESTRATEGIA.pdf

Ministerio para la Transición Ecológica (MITECO). Gobierno de España. (Febrero de 2019). Plan Nacional Integrado de Energía y Clima (PNIEC) 2021-2030. Recuperado el 9 de marzo de 2019, de https://www.miteco.gob.es/images/es/documentoresumendelborradorplannacion alintegradodeenergiayclima2021-2030_tcm30-487

Ministerio para la Transición Ecológica. Gobierno de España. (2018). Emisiones de gases de efecto invernadero en España. Recuperado el 19 de octubre de 2018, de 
https://www.miteco.gob.es/es/cambio-climatico/temas/mitigacion-politicas-ymedidas/emisiones.aspx

Ministerios de Industria, Energía y Turismo y Ministerio de Fomento. (20 de julio de 2014). Factores de emisión de $\mathrm{CO} 2$ y coeficientes de paso a energía primaria de diferentes fuentes de energía final consumidas en el sector de edificios en España. Recuperado el 7 de febrero de 2019, de https://energia.gob.es/desarrollo/EficienciaEnergetica/RITE/Reconocidos/Reconoc idos/Otros\%20documentos/Factores_emision_CO2.pdf

Navidi, W. (2006). Estadística para ingenieros y científicos. México: McGraw-Hill. Interamericana de México. ISBN: 9701056299.

Nord, N., Schmidt, D., \& Dagmar, A. (2017). Necessary Measures to Include more Distributed renewable energy Sources into District Heating System. The 15th International Symposium on district Heating and Cooling. Energy Procedia, 116, 48 57. doi.org/10.1016/j.egypro.2017.05.054.

Pavicevic, M., Novosel, T., Puksec, T., \& Duic, N. (2017). Hourly optimization and sizing of district heating systems considering building refurbishment - Case study for the city of Zagreb. Energy, 137, 1264-1276. doi.org/10.1016/j.energy.2017.06.105.

Permai, S., \& Tanty, H. (2018). Linear regression model using bayesian approach for energy performance of residential building. . Procedia Computer Science, 135, 671677, doi:10.1016/J.PROCS.2018.08.219.

Persson, U., \& Münster, M. (2016). Current and future prospects for heat recovery from waste in European district heating systems: A literature and data review. Energy, 110, 116-128. https://doi.org/10.1016/j.energy.2015.12.074.

Poquet, R., Sastre, J., \& Crespo, F. (2014). Eficiencia energética: como evitar errores estadísticos en la Medida y Verificación (Primera ed., Vols. ISBN: 978-84-16048-809). Valencia: Obrapropia.

PREFIERES. Portal de Eficiencia y Rehabilitación. (11 de enero de 2016). District Heating en la UVa. Recuperado el 31 de octubre de 2018, de http://www.prefieres.es/districtheating-en-la-uva\#

Prieto, P. (20 de noviembre de 2011). Crecer o decrecer: That is the question. Recuperado el 13 de octubre de 2018, de Tlaxcala: http://www.tlaxcalaint.org/article.asp?reference $=6256$

Quiquerez, L., Lachal, B., Monnard, M., \& Faessler, J. (2017). The role of district heating in achieving sustainable cities: comparative analysis of different heat scenarios for Geneva. The 15th International Symposium on district Heating and Cooling. Energy Procedia, 116, 78-90. doi.org/10.1016/j.egypro.2017.05.057.

Rämä, M., \& Sipila, K. (2017). Transition to low temperature distribution in existing systems. The 15th International Symposium on district Heating and Cooling. Energy Procedia, 116, 58-68. doi.org/10.1016/j.egypro.2017.05.055. 
Ramalle Gómara, E., \& Andrés de Llano, J. (2003). Utilización de métodos robustos en la estadística inferencial. Aten Primaria, 32 (3), 177-182.

REN21. Renewable Energy Policy Network fot the 21st Century. (2017). Avanzando en la transición mundial hacia la energía renovable. Recuperado el 20 de octubre de 2018, de http://www.ren21.net/wp-content/uploads/2017/07/178399_GSR_2017_KEY-FINDINGS_Spanish_lowres.pdf

Reynolds, J., Rezgui, Y., \& Hippolyte, J. L. (2017). Upscaling energy control from building to districts: Current limitations and future perspectives. Sustainable Cities and Society, 35, 816-829. doi.org/10.1016/j.scs.2017.05.012.

Roth, J., \& Rajagopal, R. (2018). Benchmarking building energy efficiency using quantile regression. . Energy, 152, 866-876, doi:10.1016/J.ENERGY.2018.02.108.

Sakamoto, T., Takase, K., Matsuhashi, R., \& Managi, S. (2016). Baseline of the projection under a structural change in energy demand. Energy Policy, 98, 274-289. doi.org/10.1016/j.enpol.2016.08.035.

Sandvall, A., Ahlgren, E., \& Ekvall, T. (2017). Cost-efficiency of urban heating strategiesModelling scale effects of low-energy building heat supply. Energy Strateg Reviews, 18, 212-223, doi:10.1016/J.ESR.2017.10.003.

Sathayea, J., Murtishawa, S., Pricea, L., Lefrancb, M., Royc, J., Winklerd, H., \& SpaldingFecherd, R. (2004). Multiproject baselines for evaluation of electric power projects. Energy Policy, 32, 1303-1317. doi.org/10.1016/S0301-4215(03)00098-3.

Sayegh, M., Danielewicz, J., Nannou, T., Miniewicz, M., Jadwiszczak, P., Piekarska, K., \& Jouhara, H. (2017). Trends of European research and development in district heating technologies. Renewable and Sustainable Energy Reviews, 68, Part 2, 11831192. doi.org/10.1016/j.rser.2016.02.023.

Schmidt, D., Kallert, A., Blesl, M., Svendsen, S., Li, H., Nord, N., \& Sipila, K. (2017). Low Temperature District Heating for Future. Energy Systems. Energy Procedia, 116, 2638. doi.org/10.1016/j.egypro.2017.05.052.

Scott Armstrong, J. (2012). Illusions in Regression Analysis. Recuperado el 27 de octubre de 2018, de International Journal of Forecasting: http://www.academia.edu/1105970/Illusions_in_Regression_Analysis

Secretariado de REN21 Renewable Energy Policy Network for the 21st Century. (2016). Energías Renovables 2016. Reporte de la situación mundial. Hallazgos Clave 2016. ISBN 978-3-9818107-3-8. París.

Sede Electrónica del Catastro. (s.f.). Consulta y certificación de Bien Inmueble. Recuperado el 25 de noviembre de 2018, de https://www1.sedecatastro.gob.es/CYCBienInmueble/OVCConCiud.aspx?del=47\& mun=900\&UrbRus $=U \&$ RefC $=7734733$ UM5173D0001FK \&Apenom $=$ \&esBice $=\&$ RCBic e1=\&RCBice2=\&DenoBice=\&from=nuevoVisor

Strachan, N. (2011). Business-as-Unusual: Existing policies in energy model baselines. Energy Economics, 33, 153-160. doi.org/10.1016/j.eneco.2010.10.009. 
Trejo, A. (s.f.). Inferencia estadística. Recuperado el 27 de octubre de 2018, de https://slideplayer.es/slide/1610760/

Tsolar. (23 de junio de 2018). Kioto-Paría. Evolución de emisiones GEI en España. Recuperado el 19 de octubre de 2018, de http://tsolar.com.es/blog/post/kiotoparis-evolucion-de-emisiones-gei-en-espana

Ulseth, R., Byskov, K., Georges, L., Justo, M., \& Utne, A. (2017). Measured load profiles and heat use for "low energy buildings" with heat supply from district heating. Energy Procedia, 116, 180-190. doi.org/10.1016/j.egypro.2017.05.066.

United Nations Environment Programme (UNEP). (2015). District Energy in Cities. Unlocking the Potencial of Energy Efficiency and Renewable Energy. Recuperado el 21 de octubre de 2018, de https://wedocs.unep.org/bitstream/handle/20.500.11822/9317/-

District_energy_in_cities_unlocking_the_potential_of_energy_efficiency_and_ren ewable_ene.pdf?sequence=2\&isAllowed=y

Universidad de Cádiz (UCA). (s.f.). Regresión simple y múltiple. Recuperado el 27 de octubre de 2018, de http://www.uca.edu.sv/matematica/upload_w/file/REGRESION\%20SIMPLE\%20Y\% 20MULTIPLE.pdf

Universidad de Jaén. (s.f.). Capítulo 9. Regresión lineal simple. Recuperado el 28 de octubre de 2018, de http://www4.ujaen.es/ dmontoro/Metodos/Tema\%209.pdf

Universidad de Sevilla. (s.f.). Estadístico de contraste. Recuperado el 27 de octubre de 2018, de http://ocwus.us.es/metodos-de-investigacion-y-diagnostico-eneducacion/analisis-de-datos-en-la-investigacioneducativa/Bloque_II/page_59.htm/

Universidad de Valladolid (UVA). (2018). Historia de la Facultad de Comercio de Valladolid. Recuperado el 22 de noviembre de 2018, de http://www2.emp.uva.es/index.php/historia-de-la-facultad-de-comercio-devalladolid/

Universidad de Valladolid (UVA). (s.f.). Relación de bienes inmuebles de la Universidad de Valladolid. Recuperado el 21 de noviembre de 2018, de http://portaldetransparencia.uva.es/_documentos/Relacion-de-Inmuebles2018.pdf

Universidad de Valladolid (UVA), Junta de Castilla y León, Sociedad Pública de Infraestructuras y Medio Ambiente (SOMACyL). (29 de octubre de 2015). Red Calor UVA. (Mundimag Audiovisual) Recuperado el 4 de noviembre de 2018, de https://www.youtube.com/watch?v=glaHMyDns_c

Universidad de Valladolid. (s.f.). Apartamentos Cardenal Mendoza. Recuperado el 11 de noviembre 2018, de http://www.uva.es/export/sites/uva/6.vidauniversitaria/6.13.alojamientos/6.13.0 1.cardenalmendoza/index.html 
UPONOR. (s.f.). Guía de microrredes de distrito de calor y frío. Edición I. Recuperado el 22 de octubre de 2018, de https://www.google.com/search?client=firefoxb\&ei=NevNW7GKGYL4adPAjoAD\&q=Gu\%C3\%ADa+de+microrredes+de+distrito+de + calor+y+fr\%C3\%ADo.+Edici\%C3\%B3n+l.\&oq=Gu\%C3\%ADa+de+microrredes+de+di strito+de+calor+y+fr\%C3\%ADo.+Edici\%C3\%B3n+l.\&gs_l=psy-ab.12...25912318.259

Van Deventer, J., Derhamy, H., Atta, K., \& Delsing, J. (2017). Service Oriented Architecture enabling the 4th Generation of District Heating. Energy Procedia, 116, 500-509. doi:10.1016/J.EGYPRO.2017.05.096.

Vanhoudt, D., Claessens, B., Desmedt, J., \& Johansson, C. (2017). Status of the Horizon 2020 Storm Project. The 15th International Symposium on district Heating and Cooling. Energy Procedia, 116, 170-179. doi.org/10.1016/j.egypro.2017.05.065.

Verbai, Z., Lakatos, A., \& Kalmár, F. (2014). Prediction of energy demand for heating of residential buildings using variable degree day. Energy, 76, 780-787. doi.org/10.1016/j.energy.2014.08.075.

Wahlroos, M., Pärssinen, M., Manner, J., \& Syri, S. (2017). Utilizing data center waste heat in district heating e Impacts on energy efficiency and prospects for lowtemperature district heating networks. Energy, 140, 1228-1238. doi.org/10.1016/j.energy.2017.08.078.

Werner, S. (2017). District heating and cooling in Sweden. Energy, 126, 419-429. doi.org/10.1016/j.energy.2017.03.052.

Werner, S. (2017). International review of district heating and cooling. Energy, 137, 617631. doi.org/10.1016/j.energy.2017.04.045.

Winterscheid, C, Holler, S., \& Dalenbäck, J.-O. (2017). Integration of solar thermal systems into existing district heating systems. Energy Procedia, 116, 158-169. https://doi.org/10.1016/j.energy.2017.04.159.

Winterscheid, C., Dalenbäck, J., \& Holler, S. (2017). Integration of solar thermal systems in existing district heating systems. Energy, 137, 579-585. doi.org/10.1016/j.energy.2017.04.159.

Wojdyga, K., \& Chorzelski, M. (2017). Chances for polish heating systems. Energy Procedia, 116, 106-118. doi.org/10.1016/j.egypro.2017.05.059.

Wouters, C. (2015). Towards a regulatory framework for microgrids-The Singapore experience. Sustainable Cities and Society, 15, 22-32. doi.org/10.1016/j.scs.2014.10.007.

Ziemele, J., Gravelsins, A., Blumberga, A., \& Blumberga, D. (2016). The effect of energy efficiency improvements on the development of 4th generation district heating. Energy Procedia, 95, 522-527. doi.org/10.1016/j.egypro.2016.09.079. 


\section{REFERENCIAS}

1. Prieto, P. (20 de noviembre de 2011). Crecer o decrecer: That is the question. Recuperado el 13 de octubre de 2018, de Tlaxcala: http://www.tlaxcalaint.org/article.asp? reference $=6256$

2. BP. (Junio de 2018). BP Statistical Review of word Energy. June 2018. 67th Edition. Recuperado el 19 de Octubre de 2018, de https://www.bp.com/content/dam/bp/en/corporate/pdf/energyeconomics/statistical-review/bp-stats-review-2018-full-report.pdf

3. International Energy Agency (IEA). (2017). World energy balances. Overview 2017 edition. Recuperado el 13 de octubre de 2018, de https://www.iea.org/publications/freepublications/publication/WorldEnergyBalanc es20170verview.pdf

4. Díaz, T. (2 de febrero de 2016). España, el octavo país de la UE con más dependencia energética. Recuperado el 15 de octubre de 2018, de El Economista.es: https://www.eleconomista.es/empresas-finanzas/noticias/7331172/02/16/Espanael-octavo-pais-de-la-UE-con-mas-dependencia-energetica-.html

5. Ente Regional de la Energía de Castilla y León (EREN). Junta de Castilla y León. (2016). Estrategia de Eficiencia Energética de Castilla y Leín 2016-2020. EEE-CyL2016/2020. Recuperado el 22 de octubre de 2018, de https://energia.jcyl.es/web/jcyl/Energia/es/Plantilla100/1284777945631/ / /

6. Eurostat. (2018). What kind of energy do we consume in the EU? Recuperado el 16 de octubre de 2018, de https://ec.europa.eu/eurostat/cache/infographs/energy/bloc-3a.html

7. Mártil, I. (17 de noviembre de 2014). Consumo y derroche de energía en el planeta: ¿podemos resistir? Recuperado el 15 de octubre de 2018, de https://blogs.publico.es/econonuestra/2014/11/17/consumo-y-derroche-deenergia-en-el-planeta-podemos-resistir/

8. Ministerio de Fomento. Gobierno de España. (2017). ERESEE 2017. Actualización 2017 de la estrategia a largo plazo para la rehabilitación energética en el sector de la edificación en España. Recuperado el 29 de septiembre de 2018, de 
https://www.fomento.gob.es/recursos mfom/pdf/24003A4D-449E-4B93-8CA57217CFC61802/143398/20170524REVISIONESTRATEGIA.pdf

9. IDAE. (16 de julio de 2011). Proyecto SECH-SPAHOUSEC. Análisis del consumo energético del sector residencial en España. Informe final. Recuperado el 29 de septiembre de 2018, de http://www.idae.es/uploads/documentos/documentos Informe SPAHOUSEC ACC f68291a3.pdf

10. Convención Marco de las Naciones Unidas sobre el Cambio Climático. (noviembre de 2007). Unidos por el clima. Recuperado el 17 de octubre de 2018, de https://unfccc.int/resource/docs/publications/unitingonclimate spa.pdf

11. Secretariado de REN21 Renewable Energy Policy Network for the 21st Century. (2016). Energías Renovables 2016. Reporte de la situación mundial. Hallazgos Clave 2016. ISBN 978-3-9818107-3-8. París.

12. International Energy Agency (IEA). (March de 2018). Global Energy \& CO2 Status Report 2017. Recuperado el 17 de octubre 2018, de https://www.iea.org/publications/freepublications/publication/GECO2017.pdf

13. Ministerio de Agricultura y Pesca, alimentación y Medio Ambiente. MAPAMA. (2016). Objetivos de reducción de emisiones de gases de efecto invernadero. Recuperado el 11 de enero de 2017, de http://www.mapama.gob.es/es/cambioclimatico/temas/mitigacion-politicas-y-medidas/objetivos.aspx\#

14. Eurostat. (2 de septiembre de 2015). España es el país europeo que más aumentó sus emisiones de CO2 desde 1990. Recuperado el 19 de 10 de 2018, de Troposfera: http://www.troposfera.org/news/11659/39/Eurostat-Espana-es-el-tercer-paiseuropeo-que-mas-aumento-sus-emisiones-de-CO2-desde-1990/

15. Tsolar. (23 de junio de 2018). Kioto-Paría. Evolución de emisiones GEl en España. Recuperado el 19 de octubre de 2018, de http://tsolar.com.es/blog/post/kiotoparis-evolucion-de-emisiones-gei-en-espana

16. Ministerio para la Transición Ecológica. Gobierno de España. (2018). Emisiones de gases de efecto invernadero en España. Recuperado el 19 de octubre de 2018, de https://www.miteco.gob.es/es/cambio-climatico/temas/mitigacion-politicas-ymedidas/emisiones.aspx

17. Ministerio de Agricultura y Pesca, Alimentación y Medio Ambiente. Gobierno de España. (marzo de 2018). Inventario Nacional de emisiones a la atmósfera. Emisiones de gases de efecto invernadero. Serie 1990-2016. Informe Resumen. Recuperado el 19 de octubre de 2018, de https://www.miteco.gob.es/es/calidad-yevaluacion-ambiental/temas/sistema-espanol-de-inventario-sei/documentoresumeninventariogei tcm30-444543.pdf 
18. European Parliament. (19 de Julio de 2018). Effort sharing regulation, 2021-2030 Limiting Member States' carbon emissions. Recuperado el 20 de octubre de 2018, de http://www.europarl.europa.eu/RegData/etudes/BRIE/2016/589799/EPRS BRI(201 6)589799 EN.pdf

19. Europa Press. (27 de enero de 2017). Castilla y León, Quinta CCAA con más emisiones de CO2 del país. Recuperado el 22 de octubre de 2018, de https://www.europapress.es/castilla-y-leon/noticia-cyl-quinta-ccaa-mas-emisionesco2-pais-20170127175102.html

20. Internacional Energy Agency (IEA). (2017). World Energy Outlook 2017. Executive Summary. Recuperado el 20 de octubre de 2018, de https://www.iea.org/Textbase/npsum/weo2017SUM.pdf

21. Internacional Energy Agency (IEA). (2016). World Energy Outlook. 2016. Recuperado el 20 de octubre de 2018, de https://webstore.iea.org/download/direct/202?fileName=WEO2016.pdf

22. Internacional Energy Agency (IEA). (2017). Market Report Series: Energy Efficiency 2017. Analysis and Forecasts to 2022. Recuperado el 20 de octubre de 2018, de https://webstore.iea.org/download/direct/160

23. El Parlamento Europeo y el Consejo de la Unión Europea. (19 de junio de 2018). DIRECTIVA (UE) 2018/844 DEL PARLAMENTO EUROPEO Y DEL CONSEJO de 30 de mayo de 2018 por la que se modifica la Directiva 2010/31/UE relativa a la eficiencia energética de los edificios y la Directiva 2012/27/UE relativa a la eficiencia energética. Recuperado el 20 de octubre de 2018, de https://www.boe.es/doue/2018/156/L00075-00091.pdf

24. Commission to the European Parliament. (10 de octubre de 2017). Communication from the Commission to the European Parliament, the Council, the European Economic and Social Committee and the Committee of the Regions. Energy Roadmap 2050. Recuperado el 20 de octubre de 2018, de https://eurlex.europa.eu/legal-content/EN/ALL/?uri=CELEX\%3A52011DC0885

25. El Parlamento Europeo y el Consejo de la Unión Europea. (5 de junio de 2009). DIRECTIVA 2009/28/CE DEL PARLAMENTO EUROPEO Y DEL CONSEJO de 23 de abril de 2009 relativa al fomento del uso de energía procedente de fuentes renovables y por la que se modifican y se derogan las Directivas 2001/77/CE y 2003/30/CE. Recuperado el 20 de octubre de 2018, de https://www.boe.es/doue/2009/140/L00016-00062.pdf

26. El Parlamento Europeo y el Consejo de la Unión Europea. (18 de junio de 2010). DIRECTIVA 2010/31/UE DEL PARLAMENTO EUROPEO Y DEL CONSEJO de 19 de mayo de 2010 relativa a la eficiencia energética de los edificios. Recuperado el 20 de octubre de 2018, de https://www.boe.es/doue/2010/153/L00013-00035.pdf 
27. El Parlamento Europeo y el Consejo de la Unión Europea. (14 de noviembre de 2012). DIRECTIVA 2012/27/UE DEL PARLAMENTO EUROPEO Y DEL CONSEJO de 25 de octubre de 2012 relativa a la eficiencia energética, por la que se modifican las Directivas 2009/125/CE y 2010/30/UE, y por la que se derogan las Directivas 2004/8/CE y 2006/32/CE. Recuperado el 20 de octubre de 2018, de https://www.boe.es/doue/2012/315/L00001-00056.pdf

28. La Comisión Europea. (2 de agosto de 2016). Recomendación (UE) 2016/1318 de la Comisión de 29 de julio de 2016 para promover los edificios de consumo de energía casi nulo y las mejores prácticas para garantizar que antes de fin de 2020 todos los edificios nuevos sean de consumo de energía casi nulo. Recuperado el 20 de octubre de 2018, de https://www.boe.es/doue/2016/208/L00046-00057.pdf

29. REN21. Renewable Energy Policy Network fot the 21st Century. (2017). Avanzando en la transición mundial hacia la energía renovable. Recuperado el 20 de octubre de 2018, de http://www.ren21.net/wp-content/uploads/2017/07/178399 GSR 2017 KEY-FINDINGS Spanish lowres.pdf

30. Ministerio de Energía, Turismo y Agenda Digital. Gobierno de España. (26 de abril de 2017). Plan Nacional de Acción de Eficiencia Energética 2017-2020. Recuperado el 20 de octubre de 2018, de https://ec.europa.eu/energy/sites/ener/files/documents/es neeap_2017_es.pdf

31. Consejo de Ministros. Gobierno de España. (2011). Plan de Energías Renovables (PER) 2011-2020. Madrid.

32. Ministerio para la Transición Ecológica (MITECO). Gobierno de España. (Febrero de 2019). Plan Nacional Integrado de Energía y Clima (PNIEC) 2021-2030. Recuperado el 9 de marzo de 2019, de https://www.miteco.gob.es/images/es/documentoresumendelborradorplannaciona lintegradodeenergiayclima2021-2030 tcm30-487

33. Generalitat de Catalunya. Institut Català d'Energia. Asociación de Empresas de Redes de Calor y Frío. ADHAC. (abril de 2011). Guía Básica de Redes de Distrito de Calor y Frío. Recuperado el 21 de octubre de 2018, de http://www.idae.es/uploads/documentos/documentos 20110502 Guia Basica Re des de Calor y de Frio ES 5E48b14a.pdf

34. Generalitat de Catalunya. Institut Català d'Energia. Asociación de Empresas de Redes de Calor y Frío. ADHAC. (Mayo de 2012). Guía integral de desarrollo de proyectos de redes de distrito de calor y frío. Recuperado el 23 de octubre de 2018, de http://www.adhac.es/priv/clientsimages/asociacionperso6 1338538783.pdf

35. United Nations Environment Programme (UNEP). (2015). District Energy in Cities. Unlocking the Potencial of Energy Efficiency and Renewable Energy. Recuperado el 21 de octubre de 2018, de https://wedocs.unep.org/bitstream/handle/20.500.11822/9317/- 
District energy in cities unlocking the potential of energy efficiency and rene wable ene.pdf?sequence $=2 \&$ isAllowed $=y$

36. Van Deventer, J., Derhamy, H., Atta, K., \& Delsing, J. (2017). Service Oriented Architecture enabling the 4th Generation of District Heating. Energy Procedia, 116, 500-509. doi:10.1016/J.EGYPRO.2017.05.096

37. Lee, J., Kim, H., \& Im, S. (2017). Comparative Analysis between District Heating and Geothermal Heat Pump System. Energy Procedia, 116, 403-406, doi:10.1016/J.EGYPRO.2017.05.087.

38. Ericsson, K., \& Werner, S. (2016). The introduction and expansion of biomass use in Swedish district heating systems. Biomass Bioenergy, 94, 57-65, doi:10.1016/J.BIOMBIOE.2016.08.011.

39. Sandvall, A., Ahlgren, E., \& Ekvall, T. (2017). Cost-efficiency of urban heating strategies-Modelling scale effects of low-energy building heat supply. Energy Strateg Reviews, 18, 212-223, doi:10.1016/J.ESR.2017.10.003.

40. Delmastro, C., Mutani, G., \& Schranz, L. (2015). Advantages of Coupling a Woody Biomass Cogeneration Plant with a District Heating Network for a Sustainable Built Environment: A Case Study in Luserna San Giovanni (Torino, Italy). Energy Procedia, 78, 794-799, doi:10.1016/J.EGYPRO.2015.11.102.

41. Bush, R., Bale, C., \& Taylor, P. (2016). Realising local government visions for developing district heating: Experiences from a learning country. Energy Policy, 98, 84-96. doi.org/10.1016/j.enpol.2016.08.013.

42. Wouters, C. (2015). Towards a regulatory framework for microgrids-The Singapore experience. Sustainable Cities and Society, 15, 22-32. doi.org/10.1016/j.scs.2014.10.007.

43. Hanna, R., Ghonima, M., Kleissl, J., Tynan, G., \& Victor, D. (2017). Evaluating business models for microgrids: Interactions of technology and policy. Energy Policy, 103, 4761. doi.org/10.1016/j.enpol.2017.01.010.

44. Wojdyga, K., \& Chorzelski, M. (2017). Chances for polish heating systems. Energy Procedia, 116, 106-118. doi.org/10.1016/j.egypro.2017.05.059.

45. Lund, H., Möller, B., Mathiesen, B., \& Dyrelund, A. (2010). The role of district heating in future renewable energy systems. Energy, 35, 1381-1390. doi.org/10.1016/j.energy.2009.11.023.

46. Kolokotsa, D. (2016). The role of smart grids in the building sector. Energy and Building, 116, 703-708. doi.org/10.1016/j.enbuild.2015.12.033.

47. Laakkonen, L., Korpela, T., Kaivosoja, J., Vilkko, M., Majanne, Y., \& Nurmoranta, M. (2017). Predictive supply Temperature Optimization of district Heating Networks 
Using Delay Distributions. The 15th International Symposium on district Heating and Cooling. Energy Procedia, 116, 297-309. doi.org/10.1016/j.egypro.2017.05.076.

48. Bush, R., \& Bale, C. (2017). The role of intermediaries in the transition to district heating. Energy Procedia. The 15th International Symposium on district Heating and Cooling., 116, 490-499. doi.org/10.1016/j.egypro.2017.05.098.

49. Ziemele, J., Gravelsins, A., Blumberga, A., \& Blumberga, D. (2016). The effect of energy efficiency improvements on the development of 4th generation district heating. Energy Procedia, 95, 522-527. doi.org/10.1016/j.egypro.2016.09.079

50. UPONOR. (s.f.). Guía de microrredes de distrito de calor y frío. Edición I. Recuperado el 22 de octubre de 2018, de https://www.google.com/search?client=firefoxb\&ei=NevNW7GKGYL4adPAjoAD\&q=Gu\%C3\%ADa+de+microrredes+de+distrito+de+ calor+y+fr\%C3\%ADo.+Edici\%C3\%B3n+l.\&oq=Gu\%C3\%ADa+de+microrredes+de+distr ito+de+calor+y+fr\%C3\%ADo.+Edici\%C3\%B3n+l.\&gs I=psy-ab.12..25912318.259

51. Lake, A., Rezaie, B., \& Beyerlein, S. (2017). Review of district heating and cooling systems for a sustainable future. Renewable and Sustainable Energy Reviews, 67, 417-425. doi.org/10.1016/j.rser.2016.09.061.

52. Werner, S. (2017). District heating and cooling in Sweden. Energy, 126, 419-429. doi.org/10.1016/j.energy.2017.03.052.

53. Schmidt, D., Kallert, A., Blesl, M., Svendsen, S., Li, H., Nord, N., \& Sipila, K. (2017). Low Temperature District Heating for Future. Energy Systems. Energy Procedia, 116, 26-38. doi.org/10.1016/j.egypro.2017.05.052.

54. Averfalk, H., \& Werner, S. (2017). Essential improvements in future district heating systems. Energy Procedia, 116, 217-225. doi.org/10.1016/j.egypro.2017.05.069.

55. Rämä, M., \& Sipila, K. (2017). Transition to low temperature distribution in existing systems. The 15th International Symposium on district Heating and Cooling. Energy Procedia, 116, 58-68. doi.org/10.1016/j.egypro.2017.05.055.

56. Wahlroos, M., Pärssinen, M., Manner, J., \& Syri, S. (2017). Utilizing data center waste heat in district heating e Impacts on energy efficiency and prospects for lowtemperature district heating networks. Energy, 140, 1228-1238. doi.org/10.1016/j.energy.2017.08.078.

57. Persson, U., \& Münster, M. (2016). Current and future prospects for heat recovery from waste in European district heating systems: A literature and data review. Energy, 110, 116-128. https://doi.org/10.1016/j.energy.2015.12.074.

58. Nord, N., Schmidt, D., \& Dagmar, A. (2017). Necessary Measures to Include more Distributed renewable energy Sources into District Heating System. The 15th International Symposium on district Heating and Cooling. Energy Procedia, 116, 48 57. doi.org/10.1016/j.egypro.2017.05.054. 
59. Castro Flores, J., Lacarriere, B., Chiu, J., \& Martín, V. (2017). Assessing the technoeconomic impact of low temperatures subnets in conventional district heating networks. Energy Procedia, 116, 260-271. https://doi.org/10.1016/j.egypro.2017.05.073.

60. Lund, H., Werner, S., Wiltshire, R., Svendsen, S., Thorsen, J. E., Hvelplund, F., \& Vad Mathiesen, B. (2014). 4th Generation District Heating (4GDH): Integrating smart thermal grids into future sustainable energy systems. Energy, 68, 1-11. doi.org/10.1016/j.energy.2014.02.089.

61. Comisión Europea. (2016). Comunicación de la Comisión al Parlamento Europeo, al Consejo, al Comité económico y social Europeo y al Comité de las Regiones. Estrategia de la UE relativa a la calefacción y la refrigeración. Recuperado el 23 de octubre de 2018, de https://ec.europa.eu/transparency/regdoc/rep/1/2016/ES/12016-51-ES-F1-1.PDF

62. Lissardy, G. (17 de noviembre de 2017). El origen del misterioso vapor que sale del pavimento en las calles de Nueva York (y por qué es tan importante para la ciudad). Recuperado el 24 de octubre de 2018, de https://www.bbc.com/mundo/noticiasinternacional-41911000

63. DHC Technology Platform. (Marzo de 2012). District Heating and Cooling. A vision towards 2020-2030-2050. Recuperado el 24 de octubre de 2018, de https://www.euroheat.org/wp-content/uploads/2016/04/DHC-Vision-for-DHC2012.pdf

64. Cano Herrador, C., Valbuena García, F., Muñoz Martín, J., Rey Martínez, F., \& Navas Gracia, L. (2014). Calefacción de distrito urbana con biomasa de la Universidad de Valladolid. Objetivo 20/20/20. Recuperado el 24 de octubre de 2018, de http://www.conama11.vsf.es/conama10/download/files/conama2014/CT\%202014/ 1896712037.pdf

65. Asociación de Empresas de Redes de Calor y Frío ADHAC. (2018). Censo de redes de Calor y Frío. Recuperado el 06 de diciembre de 2018, de http://www.adhac.es/Priv/ClientsImages/AsociacionPerso8 1540226118.pdf

66. Howell, S., Rezgui, Y., Hippolyte, J., Jayan, B., \& Li, H. (2017). Towards the next generation of smart grids: Semantic and holonic multiagent management of distributed energy resources. Renewable and Sustainable Energy Reviews, 77, 193 214. doi.org/10.1016/j.rser.2017.03.107.

67. Ahmad, M., Mourshed, M., Mundow, D., Sisinni, M., \& Rezgui, Y. (2016). Building energy metering and environmental monitoring - A state-of-the-art review and directions for future research. Energy and Building, 120, 85-102. doi.org/10.1016/j.enbuild.2016.03.059. 
68. Ferreira, A., Ferreira, A., Cardin, O., \& Leitao, P. (2015). Extension of holonic paradigm to smart grids. IFAC PapersOnLine, 48-3, 1099-1104. doi.org/10.1016/j.ifacol.2015.06.230.

69. Reynolds, J., Rezgui, Y., \& Hippolyte, J. L. (2017). Upscaling energy control from building to districts: Current limitations and future perspectives . Sustainable Cities and Society, 35, 816-829. doi.org/10.1016/j.scs.2017.05.012.

70. Mazhar, A., Liu, S., \& Shukla, A. (2018). A state of art review on the district heating systems. Renewable and Sustainable Energy Reviews, 96, 420-439. doi.org/10.1016/j.rser.2018.08.005.

71. Gaoa, L., Cuia, X., Nia, J., Leib, W., Huangb, T., Baib, C., \& Yanga, J. (2017). Technologies in Smart District Heating System. Energy Procedia, 142, 1829-1834. doi.org/10.1016/j.egypro.2017.12.571.

72. Lund, H., Duic, N., Alberg-Ostergaard, P., \& Mathiesen, B. (2018). Future district heating systems and technologies: On the role of smart energy systems and 4th generation district heating. Energy, 165. Part A, 614-619. doi.org/10.1016/j.energy.2018.09.115.

73. Lund, H; Alberg-Ostergaard, P; Chang, M; Werner, S; Svendsen, S; Sorknæs, P; Thorsen, J.E; Hvelplund, F; Mortensen, B.O.G; Mathiesen, B.V; Bojesen, C; Duic, N; Zhang, X; Möller, B. (2018). The status of 4th generation district heating: Research and results. Energy, 164, 147-159. doi.org/10.1016/j.energy.2018.08.206.

74. Dorotić, H., Pukšec, T., \& Duić, N. (2018). Multi-objective optimization of district heating and cooling systems for a one-year. Energy, Available online 30 November 2018. doi:10.1016/j.energy.2018.11.149.

75. Sayegh, M., Danielewicz, J., Nannou, T., Miniewicz, M., Jadwiszczak, P., Piekarska, K., \& Jouhara, H. (2017). Trends of European research and development in district heating technologies. Renewable and Sustainable Energy Reviews, 68, Part 2, 11831192. doi.org/10.1016/j.rser.2016.02.023.

76. Good, N., Martínez Ceseña, E. A., \& Mancarella, P. (2017). Ten questions concerning smart districts. Building and Environment, 118, 362-376. doi.org/10.1016/j.buildenv.2017.03.037.

77. Amaral, A., Rodrigues, E., Rodrigues Gaspar, A., \& Gomes, A. (2018). Review on performance aspects of nearly zero-energy districts. Sustainable Cities and Society(43), 406-420. doi.org/10.1016/j.scs.2018.08.039.

78. AENOR. Asociación Española de Normalización. (2018). UNE-EN ISO 50001:2018. Sistemas de gestión de la energía. Requisitos con orientación para su uso. (ISO 50001:2018). Recuperado el 31 de octubre de 2018, de https://www.une.org/encuentra-tu-norma/busca-tu-norma/norma?c=N0060594 
79. PREFIERES. Portal de Eficiencia y Rehabilitación. (11 de enero de 2016). District Heating en la UVa. Recuperado el 31 de octubre de 2018, de http://www.prefieres.es/district-heating-en-la-uva\#

80. Huerta, M., Portela, J., \& Pastor, A. (2010). Calefacción urbana o de distrito, , ¿un sistema energéticamente más sostenible? Recuperado el 31 de octubre de 2018, de XVIII Congreso Nacional de Ingeniería Mecánica: https://docplayer.es/6804813Calefaccion-urbana-o-de-distrito-un-sistema-energeticamente-mas-sostenible.html

81. Bilous, I., Deshko, V., \& Sukhodub, I. (2018). Parametric analysis of external and internal factors influence on building energy performance using non-linear multivariate regression models. Journal of Building Engineering, 20, 327-336, doi:10.1016/J.JOBE.2018.07.021.

82. Permai, S., \& Tanty, H. (2018). Linear regression model using bayesian approach for energy performance of residential building. . Procedia Computer Science, 135, 671677, doi:10.1016/J.PROCS.2018.08.219.

83. Roth, J., \& Rajagopal, R. (2018). Benchmarking building energy efficiency using quantile regression. Energy, 152, 866-876, doi:10.1016/J.ENERGY.2018.02.108.

84. Fumo, N., \& Rafe Biswas, M. (2015). Regression analysis for prediction of residential energy consumption. Renew. Sustain. Renewable and Sustainable Energy Reviews, 47, 332-343, doi:10.1016/J.RSER.2015.03.035.

85. Arregi, B., \& Garay, R. (2017). Regression analysis of the energy consumption of tertiary buildings. Energy Procedia, 122, 9-14, doi:10.1016/J.EGYPRO.2017.07.290.

86. Aranda, A., Ferreira, G., Mainar-Toledo, M., Scarpellini, S., \& Llera Sastresa, E. (2012). Multiple regression models to predict the annual energy consumption in the Spanish banking sector. Energy and Buildings, 49, 380-387, doi:10.1016/J.ENBUILD.2012.02.040.

87. Werner, S. (2017). International review of district heating and cooling. Energy, 137, 617-631. doi.org/10.1016/j.energy.2017.04.045.

88. Verbai, Z., Lakatos, A., \& Kalmár, F. (2014). Prediction of energy demand for heating of residential buildings using variable degree day. Energy, 76, 780-787. doi.org/10.1016/j.energy.2014.08.075.

89. Golden, A., Woodbury, K., Carpenter, J., \& O'Neill, Z. (2017). Change point and degree day baseline regression models in industrial facilities. Energy and Buildings, 144, 30-41, doi:10.1016/j.enbuild.2017.03.024.

90. Meng, Q., \& Mourshed, M. (2017). Degree-day based non-domestic building energy analytics and modelling should use building and type specific base temperatures. Energy and Buildings, 155, 260-268, doi:10.1016/j.enbuild.2017.09.034. 
91. Atalla, T., Gualdi, S., \& Lanza, A. (2018). A global degree days database for energyrelated applications. Energy, 143, 1048-1055, doi:10.1016/j.energy.2017.10.134.

92. De Rosa, M., Bianco, V., Scarpa, F., \& Tagliafico, L. (2014). Heating and cooling building energy demand evaluation; A simplified model and a modified degree days approach. Applied Energy, 128, 217-229, 10.1016/j.apenergy.2014.04.067.

93. Sathayea, J., Murtishawa, S., Pricea, L., Lefrancb, M., Royc, J., Winklerd, H., \& Spalding-Fecherd, R. (2004). Multiproject baselines for evaluation of electric power projects. Energy Policy, 32, 1303-1317. doi.org/10.1016/S0301-4215(03)00098-3.

94. Sakamoto, T., Takase, K., Matsuhashi, R., \& Managi, S. (2016). Baseline of the projection under a structural change in energy demand. Energy Policy, 98, 274-289. doi.org/10.1016/j.enpol.2016.08.035.

95. Strachan, N. (2011). Business-as-Unusual: Existing policies in energy model baselines. Energy Economics, 33, 153-160. doi.org/10.1016/j.eneco.2010.10.009.

96. Liang, X., Hong, T., \& Qiping Shen, G. (2016). Improving the accuracy of energy baseline models for commercial buildings with occupancy data. Applied energy, 179, 247-260. doi.org/10.1016/j.apenergy.2016.06.141.

97. Quiquerez, L., Lachal, B., Monnard, M., \& Faessler, J. (2017). The role of district heating in achieving sustainable cities: comparative analysis of different heat scenarios for Geneva. The 15th International Symposium on district Heating and Cooling. Energy Procedia, 116, 78-90. doi.org/10.1016/j.egypro.2017.05.057.

98. InfoRiego. (s.f.). Datos Agroclimáticos. Recuperado el 31 de octubre de 2018, de http://www.inforiego.org/opencms/opencms/info meteo/construir/index.html

99. AENOR. Asociación Española de Normalización. (2009). UNE-EN ISO 15927-6:2009. Comportamiento higrotérmico de edificios. Cálculo y presentación de datos climáticos. Parte 6: Diferencias acumuladas de temperatura (en grados por día). (ISO 15927-6:2007). Recuperado el 1 de noviembre de 2018, de https://www.une.org/encuentra-tu-norma/busca-tu-norma/norma/?c=N0043434

100. IBM. (2011). IBM SPSS Statistics Software. (V20). Obtenido de IBM SPSS Software. Available online: https://www.ibm.com/analytics/spss-statistics-software (accessed)

101. Universidad de Sevilla. (s.f.). Estadístico de contraste. Recuperado el 27 de octubre de 2018, de http://ocwus.us.es/metodos-de-investigacion-y-diagnostico-eneducacion/analisis-de-datos-en-la-investigacion-educativa/Bloque II/page 59.htm/

102. Adobe Experience Cloud Help. (s.f.). Nivel de confianza e intervalo de confianza. Recuperado el 27 de octubre de 2018, de https://marketing.adobe.com/resources/help/es ES/rec/c Confidence Level and Confidence Interval.html 
103. Mahía, R. (marzo de 2010). Conceptos básicos sobre la Autocorrelación en el modelo básico de regresión lineal. Recuperado el octubre 28 de 2018, de https://www.uam.es/personal_pdi/economicas/rarce/pdf/autocorrel.pdf

104. Antunez, C. (s.f.). Tablas Estadísticas para Econometría. Recuperado el 28 de octubre de 2018, de https://www.monografias.com/trabajos-pdf4/tablas-estadisticaseconometria/tablas-estadisticas-econometria.pdf

105. Belsley, D., Kuh, E., \& Welsch, R. (2005). Regression diagnostics: Identifying influential data and sources of collinearity (Vol. ISBN 9780471058564. DOI:10.1002/0471725153). New York: 1980 John Wiley \& Sons.

106. Universidad de Valladolid (UVA), Junta de Castilla y León, Sociedad Pública de Infraestructuras y Medio Ambiente (SOMACyL). (29 de octubre de 2015). Red Calor UVA. (Mundimag Audiovisual) Recuperado el 4 de noviembre de 2018, de https://www.youtube.com/watch?v=glaHMyDns c

107. Lorenzo, S. (29 de marzo de 2017). Red de calor urbana con biomasa forestal de la Universidad de Valladolid. Recuperado el 6 de noviembre de 2018, de http://www.lifeopere.org/sites/default/files/jornada final_opere sergio lorenzo.pdf

108. Universidad de Valladolid (UVA). (s.f.). Relación de bienes inmuebles de la Universidad de Valladolid. Recuperado el 21 de noviembre de 2018, de http://portaldetransparencia.uva.es/ documentos/Relacion-de-Inmuebles-2018.pdf

109. EOI. Escuela de Organización Industrial. (15 de Noviembre de 2015). Master en Energías Renovables y Mercado Energético. Recuperado el 9 de marzo de 2019, de https://www.eoi.es/blogs/merme/energia-primaria-transformacion-y-consumos-enespana-evolucion-global-de-la-demanda-de-energia/

110. Ministerios de Industria, Energía y Turismo y Ministerio de Fomento. (20 de julio de 2014). Factores de emisión de CO2 y coeficientes de paso a energía primaria de diferentes fuentes de energía final consumidas en el sector de edificios en España. Recuperado el 7 de febrero de 2019, de https://energia.gob.es/desarrollo/EficienciaEnergetica/RITE/Reconocidos/Reconocid os/Otros\%20documentos/Factores emision CO2.pdf

111. Lara, S. (2017). Análisis del funcionamiento de la Red de calefacción centralizada "Univeridad de Valladolid". Escuela de Ingenierías Industriales. UVA.

112. Eurostat. (mayo de 2018). Estadísticas de los precios del gas natural. Recuperado el 2 de diciembre de 2018, de https://ec.europa.eu/eurostat/statisticsexplained/index.php?title=Natural gas price statistics/es\#Precios del gas natural _para_consumidores no dom.C3.A9sticos

113. Dirección General de Política Energética y Minas. (31 de diciembre de 2016). Resolución de 29 de diciembre de 2016, de la Dirección General de Política 
Energética y Minas, por la que se publica la tarifa de último recurso de gas natural. Recuperado el 6 de diciembre de 2018, de https://www.boe.es/diario boe/txt.php?id=BOE-A-2016-12600

114. Dirección General de Política Energética y Minas. (30 de marzo de 2017). Resolución de 24 de marzo de 2017, de la Dirección General de Política Energética y Minas, por la que se publica la tarifa de último recurso de gas natural. Recuperado el 6 de diciembre de 2018, de https://www.boe.es/diario boe/txt.php?id=BOE-A-20173412

115. Dirección General de Política Energética y Minas. (29 de junio de 2017). Resolución de 28 de junio de 2017, de la Dirección General de Política Energética y Minas, por la que se publica la tarifa de último recurso de gas natural. Recuperado el 6 de diciembre de 2018, de https://www.boe.es/diario boe/txt.php?id=BOE-A-20177484

116. Dirección General de Política Energética y Minas. (29 de septiembre de 2017). Resolución de 25 de septiembre de 2017, de la Dirección General de Política Energética y Minas, por la que se publica la tarifa de último recurso de gas natural. Recuperado el 6 de diciembre de 2018, de https://www.boe.es/diario boe/txt.php?id=BOE-A-2017-11062

117. Dirección General de Política Energética y Minas. (28 de diciembre de 2017). Resolución de 26 de diciembre de 2017, de la Dirección General de Política Energética y Minas, por la que se publica la tarifa de último recurso de gas natural. Recuperado el 06 de diciembre de 2018, de https://www.boe.es/diario boe/txt.php?id=BOE-A-2017-15610

118. Dirección General de Política Energética y Minas. (31 de marzo de 2018). Resolución de 22 de marzo de 2018, de la Dirección General de Política Energética y Minas, por la que se publica la tarifa de último recurso de gas natural. Recuperado el 06 de diciembre de 2018, de https://www.boe.es/diario boe/txt.php?id=BOE-A-2018$\underline{4437}$

119. Dirección General de Política Energética y Minas. (30 de junio de 2018). Resolución de 28 de junio de 2018, de la Dirección General de Política Energética y Minas, por la que se publica la tarifa de último recurso de gas natural. Recuperado el 06 de diciembre de 2018, de https://www.boe.es/boe/dias/2018/06/30/pdfs/BOE-A-20189035.pdf

120. Dirección General de Política Energética y Minas. (29 de septiembre de 2018). Resolución de 25 de septiembre de 2018, de la Dirección General de Política Energética y Minas, por la que se publica la tarifa de último recurso de gas natural. Recuperado el 06 de diciembre de 2018, de https://www.boe.es/diario boe/txt.php?id=BOE-A-2018-13190 
121. IDAE. Dirección de Energías Renovables. Departamento de Biomasa y Residuos. (20 de noviembre de 2018). Informe de Precios de la Biomasa para Usos Térmicos. Datos correspondientes al 20 Trimestre de 2018. Recuperado el 5 de diciembre de 2018, de

http://www.idae.es/sites/default/files/estudios informes y estadisticas/informe $p$ recios biomasa usos termicos $2 \mathrm{t}$ 2018.pdf

122. Euronet. (s.f.). Euronet 50-50 max. Recuperado el 7 de febrero de 2019, de Herramientas para el cálculo de Ahorros Energéticos: http://www.euronet5050max.eu/es/energy-savings-calculation-tool?id $=51$

123. Bromley, M. (21 de diciembre de 2009). Degree Days. Understanding Heating and Cooling Degree Days. Recuperado el 7 de febrero de 2019, de https://www.degreedays.net/introduction\#Why are heating degree days useful

124. Federación Española de Municipios y Provincias (FEMP). (2011). Eficiencia Energética en dependencias municipales. Recuperado el 7 de febrero de 2019, de http://www.redciudadesclima.es/sites/default/files/97a9d2195549da7f51cd21c7a4f fec7a.pdf

125. Agencia Chilena de Eficiencia Energética. AchEE. (Abril de 2014). Guia de Apoyo al Desarrollo de Diagnósticos Energéticos para Instituciones de Educación Superior (IES). Recuperado el 7 de Febrero de 2019, de http://www.pucv.cl/uuaa/site/artic/20160701/asocfile/20160701115559/gu a ap oyo al desarrollo de diagn sticos energ ticos para ies achee.pdf

126. Federación Española de Municipios y Provincias. FEMP. (2011). Climatización Urbana en las ciudades españolas. Recuperado el 10 de marzo de 2019, de http://www.redciudadesclima.es/sites/default/files/b7e75a5a739b40b44fc98ecaad 533842.pdf

127. Andric, I., Pina, A., Ferrào, P., Fournier, J., Lacarriere, B., \& Le Corre, O. (2017). Assessing the feasibility of using the heat demand-outdoor temperature function for a long-term district heat demand forecast. Energy Procedia, 116, 460-469. doi.org/10.1016/j.egypro.2017.05.093.

128. Granderson, J., \& Price, P. (2014). Development and application of a statistical methodology to evaluate the predictive accuracy of building energy baseline models. Energy, 66, 981-990. doi.org/10.1016/j.energy.2014.01.074.

129. Kim, J., \& Weidlich, I. (2017). Identification of Individual District Heating Network Conditions using Equivalent Full Load Cycles. . Energy Procedia, 116, 343-350. doi.org/10.1016/j.egypro.2017.05.081.

130. Vanhoudt, D., Claessens, B., Desmedt, J., \& Johansson, C. (2017). Status of the Horizon 2020 Storm Project. The 15th International Symposium on district Heating and Cooling. Energy Procedia, 116, 170-179. doi.org/10.1016/j.egypro.2017.05.065. 
131. Abghari, S., García-Martín, E., Johansson, C., Lavesson, N., \& Grahn, H. (2017). Trend Analysis to automatically identify heat program changes. Energy Procedia, 116, 407415. doi.org/10.1016/j.egypro.2017.05.088.

132. Ulseth, R., Byskov, K., Georges, L., Justo, M., \& Utne, A. (2017). Measured load profiles and heat use for "low energy buildings" with heat supply from district heating. Energy Procedia, 116, 180-190. doi.org/10.1016/j.egypro.2017.05.066.

133. Khabdullin, A., Khabdullina, Z., Khabdullina, G., Lauka, D., \& Blumberga, D. (2017). Demand response analysis methodology in district heating system. Energy Procedia, 128, 539-543. doi.org/10.1016/j.egypro.2017.09.004.

134. Winterscheid, C, Holler, S., \& Dalenbäck, J.-O. (2017). Integration of solar thermal systems into existing district heating systems. Energy Procedia, 116, 158-169. https://doi.org/10.1016/j.energy.2017.04.159.

135. Winterscheid, C., Dalenbäck, J., \& Holler, S. (2017). Integration of solar thermal systems in existing district heating systems. Energy, 137, 579-585. doi.org/10.1016/j.energy.2017.04.159.

136. Pavicevic, M., Novosel, T., Puksec, T., \& Duic, N. (2017). Hourly optimization and sizing of district heating systems considering building refurbishment - Case study for the city of Zagreb. Energy, 137, 1264-1276. doi.org/10.1016/j.energy.2017.06.105.

137. Mertz, T., Serra, S. H., Reneaume, \& J.M. (2017). A MINLP optimization of the configuration and the design of a district heating network: study case on an existing site. Energy Procedia, 116, 236-248. doi.org/10.1016/j.egypro.2017.05.071.

138. Centro Tecnológico de Eficiencia y Sostenibilidad Energética (ENERGYLAB). (8 de octubre de 2014). Metodología para abordar un Proyecto de EE: "Potocolo de Medida y Verificación de Ahorros Energéticos IPMVP". Recuperado el 29 de octubre de 2018, de https://www.fenercom.com/pages/pdf/formacion/14-1008 Jornada\%20sobre\%20HERRAMIENTAS\%20DE\%20GESTION\%20DE\%20LA\%20ENE RGIA/O4-METODOLOGIA-PARA-ABORDAR-UN-PROYECTO-DE-EFICIENCIAENERGETICA-IPMVP-fenercom-2014

139. Asociación de Empresas de Eficiencia Energética. A3e. (2015). Curso de Auditor Energético en la Edificación. Volumen III. Madrid.

140. Efficiency Valuation Organization (EVO). (Septiembre de 2010). Protocolo Internacional de Medida y Verificación. Volumen 1. Recuperado el 28 de octubre de 2018, de http://old.acee.cl/?q=system/files/IPMVP\%202010\%20\%20Volumen\%201\%20-\%20Espa\%C3\%B1ol.pdf

141. ASHRAE. (2014). Guideline 14-2014 -- Measurement of Energy, Demand, and Water Savings. Recuperado el 29 de octubre de 2018, de https://www.techstreet.com/ashrae/standards/guideline-14-2014-measurement-ofenergy-demand-and-water-savings?gateway code=ashrae\&product id=1888937 
142. EVO, E. V. (2014). International Performance Measurement and Verification Protocol (IPMVP). Recuperado el 29 de octubre de 2018, de https://evoworld.org/en/products-services-mainmenu-en/protocols/ipmvp

143. Efficiency Valuation Organization (EVO). (Junio de 2014). International Performance Measurement and Verification Protocol. Core Concepts. Recuperado el 29 de octubre de 2018, de http://www.minimiseusa.com/images/Core\%20Concepts\%20\%20EVO\%20IPMVP\%2 02014_Dec2014-3.pdf

144. Poquet, R., Sastre, J., \& Crespo, F. (2014). Eficiencia energética: como evitar errores estadísticos en la Medida y Verificación (Primera ed., Vols. ISBN: 978-84-16048-809). Valencia: Obrapropia.

145. Trejo, A. (s.f.). Inferencia estadística. Recuperado el 27 de octubre de 2018, de https://slideplayer.es/slide/1610760/

146. Cruz Ramírez, A. P. (s.f.). Pruebas de Hipótesis para una muestra. Recuperado el 27 de octubre de 2018, de https://www.monografias.com/trabajos30/prueba-dehipotesis/prueba-de-hipotesis.shtml

147. Scott Armstrong, J. (2012). Illusions in Regression Analysis. Recuperado el 27 de octubre de 2018, de International Journal of Forecasting: http://www.academia.edu/1105970/Illusions in Regression Analysis

148. Universidad de Cádiz (UCA). (s.f.). Regresión simple y múltiple. Recuperado el 27 de octubre de 2018, de http://www.uca.edu.sv/matematica/upload w/file/REGRESION\%20SIMPLE\%20Y\%2 OMULTIPLE.pdf

149. Universidad de Jaén. (s.f.). Capítulo 9. Regresión lineal simple. Recuperado el 28 de octubre de 2018, de http://www4.ujaen.es/ dmontoro/Metodos/Tema\%209.pdf

150. Capítulo 18. Análisis de regresión lineal. El procedimiento de Regresión lineal. Guia SPSS. (s.f.). Recuperado el 28 de octubre de 2018, de http://halweb.uc3m.es/esp/Personal/personas/immarin/esp/GuiaSPSS/18reglin.pdf

151. Ramalle Gómara, E., \& Andrés de Llano, J. (2003). Utilización de métodos robustos en la estadística inferencial. Aten Primaria, 32 (3), 177-182.

152. Navidi, W. (2006). Estadística para ingenieros y científicos. México: McGraw-Hill. Interamericana de México. ISBN: 9701056299.

153. Universidad de Valladolid. (s.f.). Apartamentos Cardenal Mendoza. Recuperado el 11 de noviembre de 2018, de http://www.uva.es/export/sites/uva/6.vidauniversitaria/6.13.alojamientos/6.13.01. cardenalmendoza/index.html 
154. Fundación General de la Universidad de Valladolid. (FUNGE). (s.f.). Apartamentos Cardenal Mendoza. Recuperado el 11 de noviembre de 2018, de http://funge.uva.es/residencias-universitarias/apartamentos-cardenal-mendoza/

155. Encinas, A.G. (9 de enero de 2017). La UVA completa el campus Miguel Delibes 20 años después. El Norte de Castilla. Obtenido el 14 de noviembre de 2018 de https://www.elnortedecastilla.es/valladolid/201701/09/completa-campus-migueldelibes-20170106200628.html

156. Anta, J. (13 de septiembre de 2017). De paseo por el Campus Universitario. Recuperado el 21 de noviembre de 2018, de https://jesusantaroca.wordpress.com/2017/09/13/de-paseo-por-el-campusuniversitario/

157. Universidad de Valladolid (UVA). (2018). Historia de la Facultad de Comercio de Valladolid. Recuperado el 22 de noviembre de 2018, de http://www2.emp.uva.es/index.php/historia-de-la-facultad-de-comercio-devalladolid/

158. Europa Press. (28 de 07 de 2011). El IBGM de Valladolid cuenta con un microscopio confocal con características únicas en España. Recuperado el 25 de noviembre de 2018, de https://www.europapress.es/castilla-y-leon/noticia-ibgm-valladolidcuenta-microscopio-confocal-caracteristicas-unicas-espana-20110728124656.html

159. Sede Electrónica del Catastro. (s.f.). Consulta y certificación de Bien Inmueble. Recuperado el 25 de noviembre de 2018, de https://www1.sedecatastro.gob.es/CYCBienInmueble/OVCConCiud.aspx?del=47\&m un=900\&UrbRus=U\&RefC $=7734733$ UM5173D0001FK\&Apenom $=$ \&esBice $=\&$ RCBicE4= \&RCBice $2=\&$ DenoBice $=$ \&from $=$ nuevoVisor 


\section{LISTADO DE TABLAS}

Tabla 1. Objetivos energéticos y medioambientales en la Unión Europea y España ...................... 15

Tabla 2. Características de las tuberías según su material ..................................................... 20

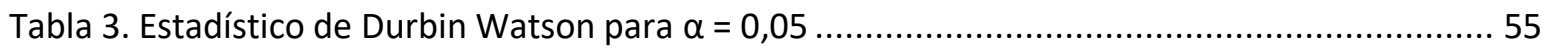

Tabla 4. Hipótesis nulas y alternativas de la investigación ....................................................... 59

Tabla 5. Resumen de características de los Edificios del Campus Miguel Delibes ........................ 79

Tabla 6. Resumen de características de los Edificios del Campus Río Esgueva ............................. 81

Tabla 7. Datos climáticos utilizados en la investigación. Grados día .......................................... 85

Tabla 8. Datos climáticos utilizados en la investigación. Temperaturas ....................................... 86

Tabla 9. Datos climáticos utilizados en la investigación. Humedad Relativa ................................ 87

Tabla 10. Datos climáticos utilizados en la investigación. Velocidad del viento ............................ 88

Tabla 11. Datos climáticos. Recorrido, precipitación, horas de sol y radiación ............................ 89

Tabla 12. Consumo de combustibles fósiles de los edificios del Campus Miguel Delibes (kWh).... 94

Tabla 13. Consumo de biomasa de los edificios del Campus Miguel Delibes (kWh) ..................... 95

Tabla 14. Consumo total térmico de los edificios del Campus Miguel Delibes (kWh)................... 96

Tabla 15. Consumo de combustibles fósiles de los edificios del Campus Río Esgueva (kWh) .........97

Tabla 16. Consumo de biomasa de los edificios del Campus Río Esgueva (kWh) .......................... 98

Tabla 17. Consumo total térmico de los edificios del Campus Río Esgueva (kWh) ....................... 99

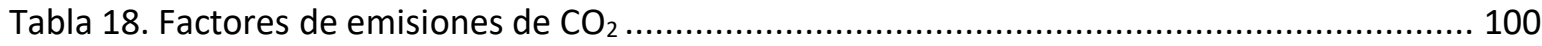

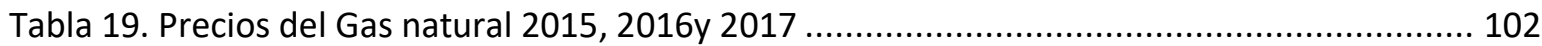

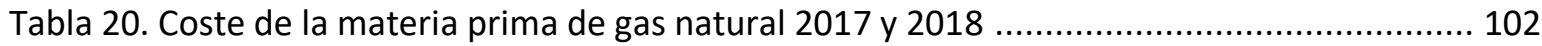

Tabla 21. Evolución de las Tarifas de Último Recurso T1 y T2, 2017 y 2018 ................................ 103

Tabla 22. Precios del Gasóleo C y de la Biomasa 2015, 2016, 2017 y 2018 .................................. 104

Tabla 23.Precios de referencia variables para Gas natural, Gasóleo y Astilla 2015 2018............. 104

Tabla 24.Precios de referencia totales para Gas natural, Gasóleo y Astilla 2015 2018............... 105

Tabla 25. Resumen de los modelos encontrados para el Edificio D1 .................................... 108

Tabla 26. Resumen del cumplimiento de los supuestos de regresión. Edificio D1 ..................... 108

Tabla 27. Resultado de las diferencias significativas encontradas. Edificio D1 ........................... 109

Tabla 28. Resumen de resultados. Edificio D1........................................................................... 110

Tabla 29. Resumen de los modelos encontrados para el Edificio D2 ........................................ 112

Tabla 30. Resumen del cumplimiento de los supuestos de regresión. Edificio D2 ..................... 112

Tabla 31. Resultado de las diferencias significativas encontradas. Edificio D2 ......................... 113

Tabla 32. Resumen de resultados. Edificio D2 ................................................................... 114

Tabla 33. Resumen de los modelos encontrados para el Edificio D3 ........................................ 116

Tabla 34. Resumen del cumplimiento de los supuestos de regresión. Edificio D3 ....................... 116

Tabla 35. Resultado de las diferencias significativas encontradas. Edificio D3 ........................... 117

Tabla 36. Resumen de resultados. Edificio D3........................................................................ 118 
Tabla 37. Resumen de los modelos encontrados para el Edificio D4 …................................ 120

Tabla 38. Resumen del cumplimiento de los supuestos de regresión. Edificio D4 ..................... 120

Tabla 39. Resultado de las diferencias significativas encontradas. Edificio D4 ........................... 121

Tabla 40. Resumen de resultados. Edificio D4.......................................................................... 122

Tabla 41. Resumen de los modelos encontrados para el Edificio D5 ....................................... 124

Tabla 42. Resumen del cumplimiento de los supuestos de regresión. Edificio D5 ...................... 124

Tabla 43. Resultado de las diferencias significativas encontradas. Edificio D5 .......................... 125

Tabla 44. Resumen de resultados. Edificio D5 ................................................................... 126

Tabla 45. Resumen de los modelos encontrados para el Edificio D6 ..................................... 128

Tabla 46. Resumen del cumplimiento de los supuestos de regresión. Edificio D6 ...................... 128

Tabla 47. Resultado de las diferencias significativas encontradas. Edificio D6 ........................... 129

Tabla 48. Resumen de resultados. Edificio D6...................................................................... 130

Tabla 49. Resumen de los modelos encontrados para el Edificio D7 ...................................... 132

Tabla 50. Resumen del cumplimiento de los supuestos de regresión. Edificio D7 ..................... 132

Tabla 51. Resultado de las diferencias significativas encontradas. Edificio D7 .......................... 133

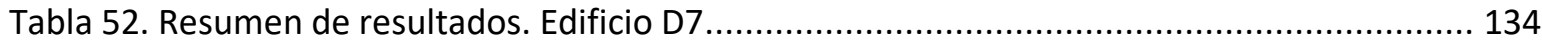

Tabla 53. Resumen de los modelos encontrados para el Edificio D8 ...................................... 136

Tabla 54. Resumen del cumplimiento de los supuestos de regresión. Edificio D8 ...................... 136

Tabla 55. Resultado de las diferencias significativas encontradas. Edificio D8 ........................... 137

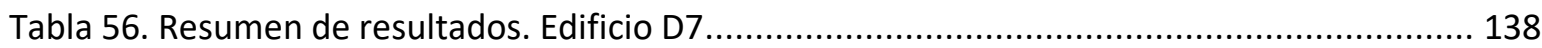

Tabla 57. Resumen de los modelos encontrados para el Edificio D9 ...................................... 140

Tabla 58. Resumen del cumplimiento de los supuestos de regresión. Edificio D9 ...................... 140

Tabla 59. Resultado de las diferencias significativas encontradas. Edificio D7 ........................... 141

Tabla 60. Resumen de resultados. Edificio D9........................................................................ 142

Tabla 61. Resumen de los modelos encontrados para el Edificio D10 ...................................... 144

Tabla 62. Resumen del cumplimiento de los supuestos de regresión. Edificio D10 ..................... 144

Tabla 63. Resultado de las diferencias significativas encontradas. Edificio D10 ......................... 145

Tabla 64. Resumen de resultados. Edificio D10 .................................................................. 146

Tabla 65. Resumen de los modelos encontrados para el Edificio D11 .................................... 148

Tabla 66. Resumen del cumplimiento de los supuestos de regresión. Edificio D11 ................... 148

Tabla 67. Resultado de las diferencias significativas encontradas. Edificio D11 ......................... 149

Tabla 68. Resumen de resultados. Edificio D11 ........................................................................ 150

Tabla 69. Resumen de los modelos encontrados para el Edificio D12 ..................................... 152

Tabla 70. Resumen del cumplimiento de los supuestos de regresión. Edificio D12 …................ 152

Tabla 71. Resultado de las diferencias significativas encontradas. Edificio D12 ....................... 153

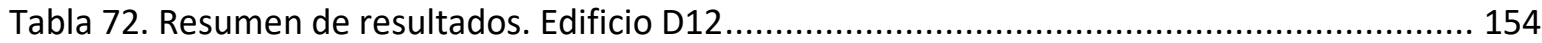

Tabla 73. Resumen de modelos de regresión simple. Campus Miguel Delibes .......................... 155

Tabla 74. Resumen de modelos de regresión múltiple. Campus Miguel Delibes......................... 155

Tabla 75. Resumen de diferencias significativas regresión simple. Campus Miguel Delibes.......... 158

Tabla 76. Resumen de diferencias significativas regresión múltiple. Campus Miguel Delibes ...... 158

Tabla 77. Resumen de características de los edificios del Campus Miguel Delibes ..................... 159

Tabla 78. Consumo Real térmico de los edificios del Campus Miguel Delibes (kWh) ................. 160

Tabla 79. Consumo Pronosticado térmico de los edificios del Campus Miguel Delibes (kWh) ..... 161

Tabla 80. Resumen de ahorro de energía térmica del Campus Miguel Delibes (kWh) ................ 162

Tabla 81. Ahorro de emisiones CO2 del Campus Miguel Delibes (kg CO2) ............................... 163

Tabla 82. Precios máximos de compra de la energía a la red de calor ....................................... 164 


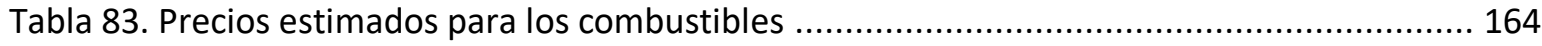

Tabla 84. Resumen de los modelos encontrados para el Edificio E1 ...................................... 167

Tabla 85. Resumen del cumplimiento de los supuestos de regresión. Edificio E1 ....................... 167

Tabla 86. Resultado de las diferencias significativas encontradas. Edificio E1 ............................ 168

Tabla 87. Resumen de resultados. Edificio E1 ..................................................................... 169

Tabla 88. Resumen de los modelos encontrados para el Edificio E2 ....................................... 171

Tabla 89. Resumen del cumplimiento de los supuestos de regresión. Edificio E1 ...................... 171

Tabla 90. Resultado de las diferencias significativas encontradas. Edificio E2 ......................... 172

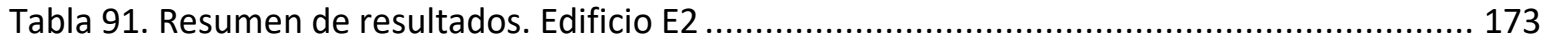

Tabla 92. Resumen de los modelos encontrados para el Edificio E3 ....................................... 175

Tabla 93. Resumen del cumplimiento de los supuestos de regresión. Edificio E3 ....................... 175

Tabla 94. Resultado de las diferencias significativas encontradas. Edificio E3 .......................... 176

Tabla 95. Resumen de resultados. Edificio E3 ....................................................................... 177

Tabla 96. Resumen de los modelos encontrados para el Edificio E4 ....................................... 179

Tabla 97. Resumen del cumplimiento de los supuestos de regresión. Edificio E4 ...................... 179

Tabla 98. Resultado de las diferencias significativas encontradas. Edificio E4 .......................... 180

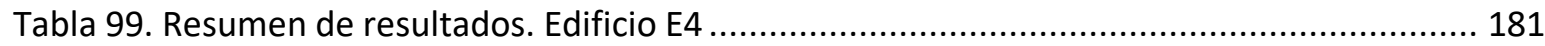

Tabla 100. Resumen de los modelos encontrados para el Edificio E5 ..................................... 183

Tabla 101. Resumen del cumplimiento de los supuestos de regresión. Edificio E5 ..................... 183

Tabla 102. Resultado de las diferencias significativas encontradas. Edificio E5 ........................ 184

Tabla 103. Resumen de resultados. Edificio E5 .................................................................. 185

Tabla 104.Resumen de los modelos encontrados para el Edificio E6 ..................................... 187

Tabla 105. Resumen del cumplimiento de los supuestos de regresión. Edificio E6 ..................... 187

Tabla 106. Resultado de las diferencias significativas encontradas. Edificio E6 ......................... 188

Tabla 107. Resumen de resultados. Edificio E6 ...................................................................... 189

Tabla 108. Resumen de los modelos encontrados para el Edificio E7 ........................................ 191

Tabla 109. Resumen del cumplimiento de los supuestos de regresión. Edificio E7 ..................... 191

Tabla 110. Resultado de las diferencias significativas encontradas. Edificio E6 ........................ 192

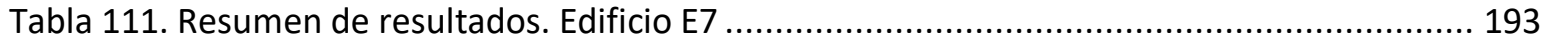

Tabla 112. Resumen de los modelos encontrados para el Edificio E8 ................................... 195

Tabla 113. Resumen del cumplimiento de los supuestos de regresión. Edificio E8 ..................... 195

Tabla 114. Resultado de las diferencias significativas encontradas. Edificio E8 ......................... 196

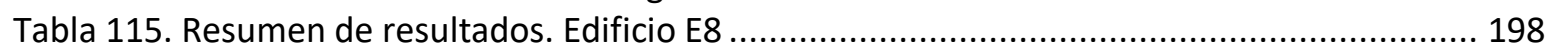

Tabla 116. Resumen de los modelos encontrados para el Edificio E13 ..................................... 200

Tabla 117. Resumen del cumplimiento de los supuestos de regresión. Edificio E13 ................... 200

Tabla 118. Resultado de las diferencias significativas encontradas. Edificio E6 ......................... 201

Tabla 119. Resumen de resultados. Edificio E13 ................................................................... 202

Tabla 120. Resumen de los modelos encontrados para el Edificio E14 .................................... 204

Tabla 121. Resumen del cumplimiento de los supuestos de regresión. Edificio E14 .................... 204

Tabla 122. Resultado de las diferencias significativas encontradas. Edificio E14 ...................... 205

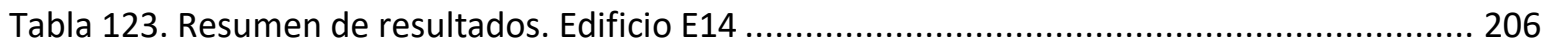

Tabla 124. Resumen de los modelos encontrados para el Edificio E15 .................................. 208

Tabla 125. Resumen del cumplimiento de los supuestos de regresión. Edificio E15 ................... 208

Tabla 126. Resultado de las diferencias significativas encontradas. Edificio E15 ........................ 209

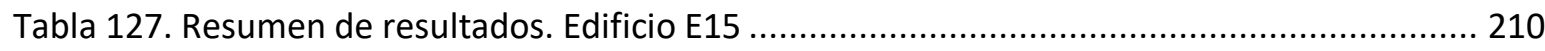

Tabla 128. Resumen de modelos de regresión simple. Campus Río Esgueva............................. 211 
Tabla 129. Resumen de modelos de regresión múltiple. Campus Río Esgueva ........................... 211

Tabla 130. Resumen de diferencias significativas regresión simple. Campus Río Esgueva ........... 213

Tabla 131. Resumen de diferencias significativas regresión múltiple. Campus Río Esgueva.......... 213

Tabla 132. Resumen de características de los edificios del Campus Río Esgueva........................ 214

Tabla 133. Consumo Real térmico de los edificios del Campus Río Esgueva (kWh).................... 215

Tabla 134. Consumo Pronosticado térmico de los edificios del Campus Río Esgueva (kWh) ........ 216

Tabla 135. Resumen de ahorro de energía térmica del Campus Río Esgueva (kWh) .................. 217

Tabla 136. Ahorro de emisiones CO2 del Campus Río Esgueva (kg CO2) .................................. 218

Tabla 137. Precios máximos de compra de la energía a la red de calor .................................... 219

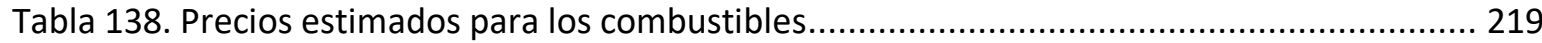

Tabla 139. Resumen de modelos de regresión simple. UVA...................................................... 221

Tabla 140. Resumen de modelos de regresión múltiple UVA ................................................ 222

Tabla 141. Resumen de diferencias significativas regresión simple UVA .................................. 224

Tabla 142. Resumen de diferencias significativas regresión múltiple UVA................................ 224

Tabla 143. Resumen de características de los edificios de la UVA ........................................... 225

Tabla 144. Consumo Real térmico y pronosticado de los edificios de la UVA (kWh) .................. 226

Tabla 145. Precios máximos de compra de la energía a la red de calor ................................... 228

Tabla 146. Precios estimados para los combustibles.............................................................. 228

Tabla 147. Porcentaje de energía proveniente de Biomasa y de combustibles fósiles. UVA ........ 229

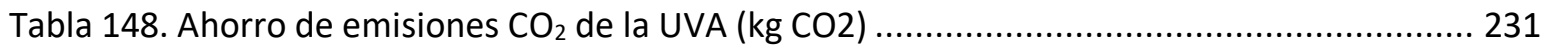

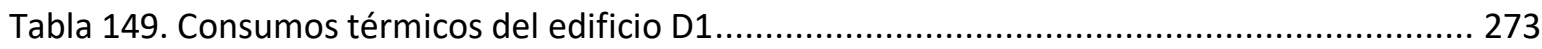

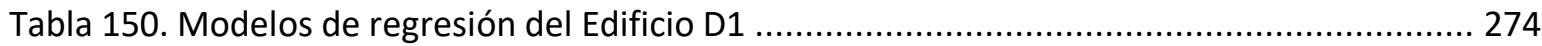

Tabla 151. Variables excluidas del modelo de región del Edificio D1 ........................................ 276

Tabla 152. Resumen de la bondad de los modelos de regresión para el Edificio D1 ................... 277

Tabla 153. Prueba de normalidad para el edificio D1 .............................................................. 279

Tabla 154. Índice de condición de las variables independientes del Modelo 2 en el EdificioD1 ... 283

Tabla 155. Estadísticos de colinealidad para los modelos del Edificio D1 .................................. 284

Tabla 156. Consumos previstos octubre 2014 - mayo 2017 para el edificio D1......................... 285

Tabla 157. Prueba de Normalidad temporada Octubre 2015-Mayo 2016. Edificio D1 ................ 286

Tabla 158. Estadísticos de muestras relacionadas. Octubre 2015-Mayo 2016. Edificio D1.......... 286

Tabla 159. Prueba de muestras relacionadas. Octubre 2015-Mayo 2016. Edificio D1................. 286

Tabla 160. Prueba de Normalidad temporada Octubre 2016-Abril 2017. Edificio D1.................. 287

Tabla 161. Estadísticos de muestras relacionadas. Octubre 2016-Abril 2017. Edificio D1 ............ 288

Tabla 162. Prueba de muestras relacionadas. Octubre 2016-Abril 2017. Edificio D1 .................. 288

Tabla 163. Prueba de Normalidad temporada Octubre 2017-Mayo 2018. Edificio D1 ................ 289

Tabla 164. Estadísticos de muestras relacionadas. Octubre 2017-Mayo 2018. Edificio D1.......... 290

Tabla 165. Prueba de muestras relacionadas. Octubre 2017-Mayo 2018. Edificio D1................. 290

Tabla 166.Prueba de Normalidad temporada Octubre 2015-Mayo 2018. Edificio D1 ................. 291

Tabla 167. Estadísticos de muestras relacionadas. Octubre 2015-Mayo 2018. Edificio D1........... 291

Tabla 168. Prueba de muestras relacionadas. Octubre 2015-Mayo 2018. Edificio D1................ 291

Tabla 169. Estimación del ahorro de emisiones de CO2 para el Edificio D1............................. 292

Tabla 170. Precios de referencia para Gas natural y Astilla ..................................................... 293

Tabla 171. Ahorro Económico por el consumo térmico en el Edificio D1 ................................. 293

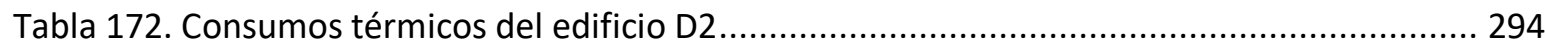

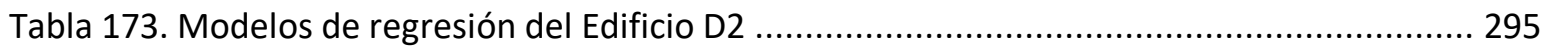

Tabla 174. Variables excluidas del modelo de región del Edificio D2 ....................................... 296 
Tabla 175. Resumen de la bondad de los modelos de regresión para el Edificio D2 .................. 296

Tabla 176. Prueba de normalidad para el edificio D2 .......................................................... 297

Tabla 177. Consumos previstos octubre 2014 - mayo 2017 para el edificio D2 ........................ 300

Tabla 178. Prueba de Normalidad temporada Octubre 2015-Mayo 2016. Edificio D2 ................ 301

Tabla 179. Estadísticos de muestras relacionadas. Octubre 2015-Mayo 2016. Edificio D2 ........... 301

Tabla 180. Prueba de muestras relacionadas. Octubre 2015-Mayo 2016. Edificio D2................. 301

Tabla 181. Prueba de Normalidad temporada Octubre 2016-Mayo 2017. Edificio D2 ................ 302

Tabla 182. Estadísticos de muestras relacionadas. Octubre 2016-Mayo 2017. Edificio D2........... 302

Tabla 183. Prueba de muestras relacionadas. Octubre 2016-Mayo 2017. Edificio D2 ................. 303

Tabla 184. Prueba de Normalidad temporada Octubre 2017-Mayo 2018. Edificio D2 ................ 303

Tabla 185. Estadísticos de muestras relacionadas. Octubre 2017-Mayo 2018. Edificio D2.......... 304

Tabla 186. Prueba de muestras relacionadas. Octubre 2017-Mayo 2018. Edificio D2................ 304

Tabla 187. Prueba de Normalidad temporada Octubre 2015-Mayo 2018. Edificio D2 ............... 305

Tabla 188. Estadísticos de muestras relacionadas. Octubre 2015-Mayo 2018. Edificio D2........... 305

Tabla 189. Prueba de muestras relacionadas. Octubre 2015-Mayo 2018. Edificio D2 ................. 305

Tabla 190. Estimación del ahorro de emisiones de CO2 para el Edificio D2 . ............................. 306

Tabla 191. Precios de referencia para Gas natural y Astilla .................................................... 307

Tabla 192. Ahorro Económico por el consumo térmico en el Edificio D2 .................................. 307

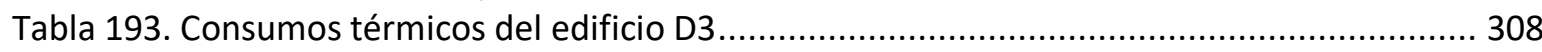

Tabla 194. Modelos de regresión del Edificio D3 …............................................................ 308

Tabla 195. Variables excluidas del modelo de región del Edificio D3 .......................................... 309

Tabla 196. Resumen de la bondad de los modelos de regresión para el Edificio D3 .................... 310

Tabla 197. Prueba de normalidad para el edificio D3 .............................................................. 311

Tabla 198. Consumos previstos octubre 2014 - mayo 2017 para el edificio D3......................... 313

Tabla 199. Prueba de Normalidad temporada Octubre 2015-Mayo 2016. Edificio D3 ................ 314

Tabla 200. Estadísticos de muestras relacionadas. Octubre 2015-Mayo 2016. Edificio D3........... 314

Tabla 201. Prueba de muestras relacionadas. Octubre 2015-Mayo 2016. Edificio D3................. 314

Tabla 202. Prueba de Normalidad temporada Octubre 2016-Mayo 2017. Edificio D3 ................ 315

Tabla 203. Estadísticos de muestras relacionadas. Octubre 2016-Mayo 2017. Edificio D3........... 316

Tabla 204. Prueba de muestras relacionadas. Octubre 2016-Mayo 2017. Edificio D3................ 316

Tabla 205. Prueba de Normalidad temporada Octubre 2017-Mayo 2018. Edificio D3 ................. 317

Tabla 206. Estadísticos de muestras relacionadas. Octubre 2017-Mayo 2018. Edificio D3........... 317

Tabla 207. Prueba de muestras relacionadas. Octubre 2017-Mayo 2018. Edificio D3................ 317

Tabla 208. Prueba de Normalidad temporada Octubre 2015-Mayo 2018. Edificio D3 ................ 318

Tabla 209. Estadísticos de muestras relacionadas. Octubre 2015-Mayo 2018. Edificio D3........... 318

Tabla 210. Prueba de muestras relacionadas. Octubre 2015-Mayo 2018. Edificio D3................. 319

Tabla 211. Estimación del ahorro de emisiones de CO2 para el Edificio D3............................. 320

Tabla 212. Precios de referencia para Gas natural y Astilla ................................................... 321

Tabla 213. Ahorro Económico por el consumo térmico en el Edificio D3 ..................................... 321

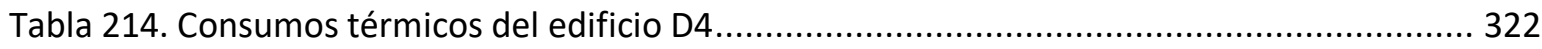

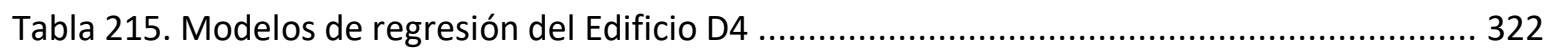

Tabla 216. Variables excluidas del modelo de región del Edificio D4 ....................................... 323

Tabla 217. Resumen de la bondad de los modelos de regresión para el Edificio D4 ................... 324

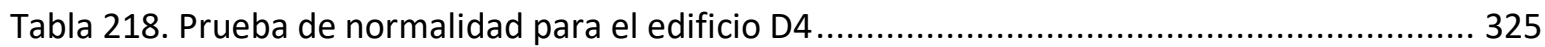

Tabla 219. Consumos previstos octubre 2014 - mayo 2017 para el edificio D4......................... 328

Tabla 220. Prueba de Normalidad temporada Octubre 2015-Mayo 2016. Edificio D4 ................ 329 
Tabla 221. Estadísticos de muestras relacionadas. Octubre 2015-Mayo 2016. Edificio D4.......... 329

Tabla 222. Prueba de muestras relacionadas. Octubre 2015-Mayo 2016. Edificio D4................ 329

Tabla 223. Prueba de Normalidad temporada Octubre 2016-Abril 2017. Edificio D4 ................. 330

Tabla 224. Estadísticos de muestras relacionadas. Octubre 2016-Abril 2017. Edificio D4 ............ 331

Tabla 225. Prueba de muestras relacionadas. Octubre 2016-Abril 2017. Edificio D4 .................. 331

Tabla 226. Prueba de Normalidad temporada Octubre 2017-Mayo 2018. Edificio D4 ................ 332

Tabla 227. Estadísticos de muestras relacionadas. Octubre 2017-Mayo 2018. Edificio D4........... 332

Tabla 228. Prueba de muestras relacionadas. Octubre 2017-Mayo 2018. Edificio D4.................. 332

Tabla 229. Prueba de Normalidad temporada Octubre 2015-Mayo 2018. Edificio D4 ................ 333

Tabla 230. Estadísticos de muestras relacionadas. Octubre 2015-Mayo 2018. Edificio D4........... 333

Tabla 231. Prueba de muestras relacionadas. Octubre 2015-Mayo 2018. Edificio D4................. 333

Tabla 232. Estimación del ahorro de emisiones de CO2 para el Edificio D4............................. 334

Tabla 233. Precios de referencia para Gas natural y Astilla .................................................... 335

Tabla 234. Ahorro Económico por el consumo térmico en el Edificio D4 .................................. 335

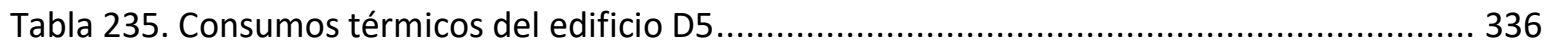

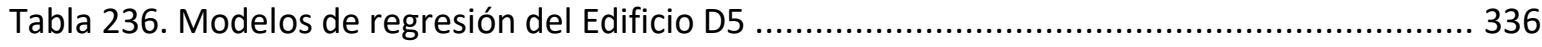

Tabla 237. Variables excluidas del modelo de región del Edificio D5 ....................................... 337

Tabla 238. Resumen de la bondad de los modelos de regresión para el Edificio D5 ................... 338

Tabla 239. Prueba de normalidad para el edificio D5 ............................................................. 339

Tabla 240. Consumos previstos octubre 2014 - mayo 2017 para el edificio D5......................... 341

Tabla 241. Prueba de Normalidad temporada Octubre 2015-Mayo 2016. Edificio D5 ................ 342

Tabla 242. Estadísticos de muestras relacionadas. Octubre 2015-Mayo 2016. Edificio D5........... 342

Tabla 243. Prueba de muestras relacionadas. Octubre 2015-Mayo 2016. Edificio D5................. 342

Tabla 244. Prueba de Normalidad temporada Octubre 2016-Mayo 2017. Edificio D5 ................ 343

Tabla 245. Estadísticos de muestras relacionadas. Octubre 2016-Mayo 2017. Edificio D5.......... 344

Tabla 246. Prueba de muestras relacionadas. Octubre 2016-Mayo 2017. Edificio D5.................. 344

Tabla 247. Prueba de Normalidad temporada Octubre 2017-Mayo 2018. Edificio D5 ................ 345

Tabla 248. Estadísticos de muestras relacionadas. Octubre 2017-Mayo 2018. Edificio D5........... 345

Tabla 249. Prueba de muestras relacionadas. Octubre 2017-Mayo 2018. Edificio D5................. 345

Tabla 250. Prueba de Normalidad temporada Octubre 2015-Mayo 2018. Edificio D5 ................ 346

Tabla 251. Estadísticos de muestras relacionadas. Octubre 2015-Mayo 2018. Edificio D5.......... 346

Tabla 252. Prueba de muestras relacionadas. Octubre 2015-Mayo 2018. Edificio D5.................. 346

Tabla 253. Estimación del ahorro de emisiones de CO2 para el Edificio D5............................... 347

Tabla 254. Precios de referencia para Gas natural y Astilla ................................................... 348

Tabla 255. Ahorro Económico por el consumo térmico en el Edificio D5 .................................. 348

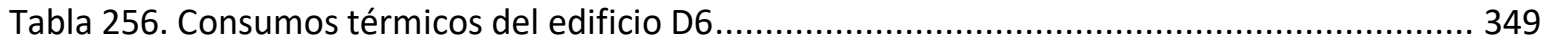

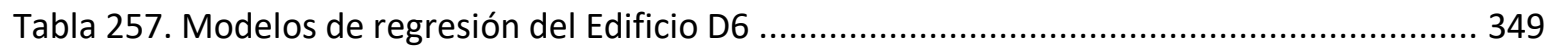

Tabla 258. Variables excluidas del modelo de región del Edificio D6 ........................................ 350

Tabla 259. Resumen de la bondad de los modelos de regresión para el Edificio D6 .................... 351

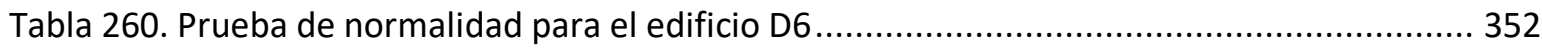

Tabla 261. Consumos previstos octubre 2014 - mayo 2017 para el edificio D6.......................... 354

Tabla 262. Prueba de Normalidad temporada Octubre 2015-Mayo 2016. Edificio D6 ................ 355

Tabla 263. Estadísticos de muestras relacionadas. Octubre 2015-Mayo 2016. Edificio D6.......... 355

Tabla 264. Prueba de muestras relacionadas. Octubre 2015-Mayo 2016. Edificio D6................ 355

Tabla 265. Prueba de Normalidad temporada Octubre 2016-Mayo 2017. Edificio D6 ................. 356

Tabla 266. Estadísticos de muestras relacionadas. Octubre 2016-Mayo 2017. Edificio D6........... 356 
Tabla 267. Prueba de muestras relacionadas. Octubre 2016-Mayo 2017. Edificio D6.

Tabla 268. Prueba de Normalidad temporada Octubre 2017-Mayo 2018. Edificio D6

Tabla 269. Estadísticos de muestras relacionadas. Octubre 2017-Mayo 2018. Edificio D6........... 358

Tabla 270. Prueba de muestras relacionadas. Octubre 2017-Mayo 2018. Edificio D6.................. 358

Tabla 271. Prueba de Normalidad temporada Octubre 2015-Mayo 2018. Edificio D6 ................ 359

Tabla 272. Estadísticos de muestras relacionadas. Octubre 2015-Mayo 2018. Edificio D6........... 359

Tabla 273. Prueba de muestras relacionadas. Octubre 2015-Mayo 2018. Edificio D6................. 359

Tabla 274. Estimación del ahorro de emisiones de CO2 para el Edificio D6. ................................ 360

Tabla 275. Precios de referencia para Gas natural y Astilla ...................................................... 361

Tabla 276. Ahorro Económico por el consumo térmico en el Edificio D6 ................................... 361

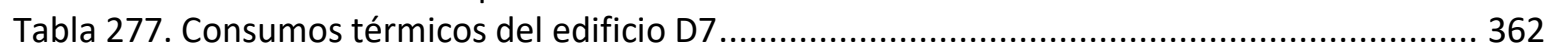

Tabla 278. Modelos de regresión del Edificio D7 ................................................................ 362

Tabla 279. Variables excluidas del modelo de región del Edificio D7 ......................................... 363

Tabla 280. Resumen de la bondad de los modelos de regresión para el Edificio D7 .................... 364

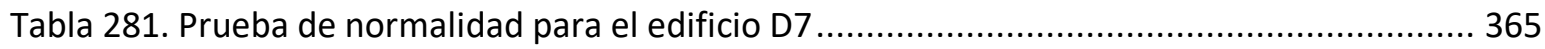

Tabla 282. Consumos previstos octubre 2014 - mayo 2017 para el edificio D7......................... 367

Tabla 283. Prueba de Normalidad temporada Octubre 2015-Mayo 2016. Edificio D7 ................ 368

Tabla 284. Estadísticos de muestras relacionadas. Octubre 2015-Mayo 2016. Edificio D7........... 368

Tabla 285. Prueba de muestras relacionadas. Octubre 2015-Mayo 2016. Edificio D7................. 368

Tabla 286. Prueba de Normalidad temporada Octubre 2016-Mayo 2017. Edificio D7 ................ 369

Tabla 287. Estadísticos de muestras relacionadas. Octubre 2016-Mayo 2017. Edificio D7........... 369

Tabla 288. Prueba de muestras relacionadas. Octubre 2016-Mayo 2017. Edificio D7................. 370

Tabla 289. Prueba de Normalidad temporada Octubre 2017-Mayo 2018. Edificio D7 ................ 370

Tabla 290. Estadísticos de muestras relacionadas. Octubre 2017-Mayo 2018. Edificio D7........... 371

Tabla 291. Prueba de muestras relacionadas. Octubre 2017-Mayo 2018. Edificio D7................ 371

Tabla 292. Prueba de Normalidad temporada Octubre 2015-Mayo 2018. Edificio D7 ................ 372

Tabla 293. Estadísticos de muestras relacionadas. Octubre 2015-Mayo 2018. Edificio D7.......... 372

Tabla 294. Prueba de muestras relacionadas. Octubre 2015-Mayo 2018. Edificio D7................. 372

Tabla 295. Estimación del ahorro de emisiones de CO2 para el Edificio D7. ............................. 373

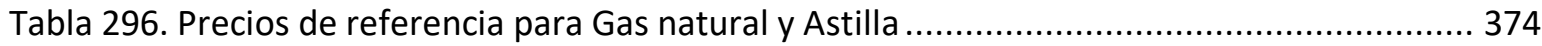

Tabla 297. Ahorro Económico por el consumo térmico en el Edificio D7 ................................. 374

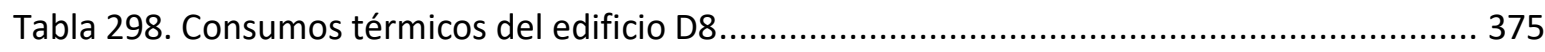

Tabla 299. Modelos de regresión del Edificio D8 …........................................................... 376

Tabla 300. Variables excluidas del modelo de región del Edificio D8 ........................................378

Tabla 301. Resumen de la bondad de los modelos de regresión para el Edificio D8 ................... 379

Tabla 302. Prueba de normalidad para el edificio D8 ........................................................... 381

Tabla 303. Índice de condición de las variables independientes del Modelo 2 en el Edificio D8 .. 385

Tabla 304. Estadísticos de colinealidad para los modelos del Edificio D8 ................................. 386

Tabla 305. Consumos previstos octubre 2014 - mayo 2017 para el edificio D8.......................... 387

Tabla 306. Prueba de Normalidad temporada Octubre 2015-Mayo 2016. Edificio D8 ................ 388

Tabla 307. Estadísticos de muestras relacionadas. Octubre 2015-Mayo 2016. Edificio D8........... 388

Tabla 308. Prueba de muestras relacionadas. Octubre 2015-Mayo 2016. Edificio D8................. 389

Tabla 309. Prueba de Normalidad temporada Octubre 2016-Mayo 2017. Edificio D8 ................ 390

Tabla 310. Estadísticos de muestras relacionadas. Octubre 2016-Abril 2017. Edificio D8 ............ 390

Tabla 311. Prueba de muestras relacionadas. Octubre 2016-Abril 2017. Edificio D8 .................. 390

Tabla 312. Prueba de Normalidad temporada Octubre 2017-Mayo 2018. Edificio D8 ................ 391 
Tabla 313. Estadísticos de muestras relacionadas. Octubre 2017-Mayo 2018. Edificio D8........... 391

Tabla 314. Prueba de muestras relacionadas. Octubre 2017-Mayo 2018. Edificio D8................. 392

Tabla 315.Prueba de Normalidad temporada Octubre 2015-Mayo 2018. Edificio D8 .................. 393

Tabla 316. Estadísticos de muestras relacionadas. Octubre 2015-Mayo 2018. Edificio D8........... 393

Tabla 317. Prueba de muestras relacionadas. Octubre 2015-Mayo 2018. Edificio D8................. 393

Tabla 318. Estimación del ahorro de emisiones de CO2 para el Edificio D8 ............................... 394

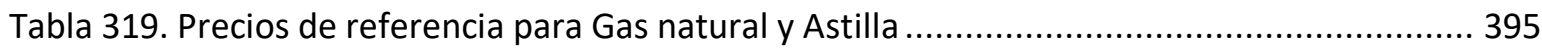

Tabla 320. Ahorro Económico por el consumo térmico en el Edificio D8 ................................... 395

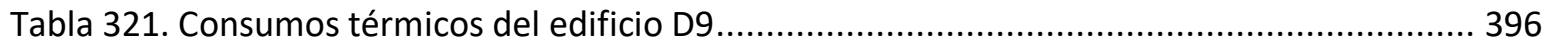

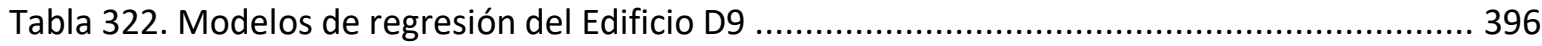

Tabla 323. Variables excluidas del modelo de región del Edificio D9 ......................................... 397

Tabla 324. Resumen de la bondad de los modelos de regresión para el Edificio D9 .................. 398

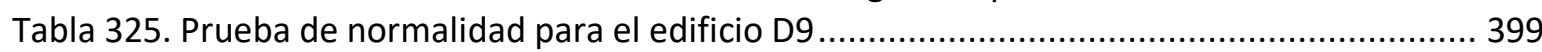

Tabla 326. Consumos previstos octubre 2014 - mayo 2017 para el edificio D9.......................... 401

Tabla 327. Prueba de Normalidad temporada Octubre 2015-Mayo 2016. Edificio D9 ................ 402

Tabla 328. Estadísticos de muestras relacionadas. Octubre 2015-Mayo 2016. Edificio D9........... 402

Tabla 329. Prueba de muestras relacionadas. Octubre 2015-Mayo 2016. Edificio D9................. 402

Tabla 330. Prueba de Normalidad temporada Octubre 2016-Abril 2017. Edificio D9.................. 403

Tabla 331. Estadísticos de muestras relacionadas. Octubre 2016-Abril 2017. Edificio D9 ........... 404

Tabla 332. Prueba de muestras relacionadas. Octubre 2016-Abril 2017. Edificio D9 .................. 404

Tabla 333. Prueba de Normalidad temporada Octubre 2017-Mayo 2018. Edificio D9 ................ 405

Tabla 334. Estadísticos de muestras relacionadas. Octubre 2017-Mayo 2018. Edificio D9.......... 405

Tabla 335. Prueba de muestras relacionadas. Octubre 2017-Mayo 2018. Edificio D9................. 405

Tabla 336. Prueba de Normalidad temporada Octubre 2015-Mayo 2018. Edificio D9 ................ 406

Tabla 337. Estadísticos de muestras relacionadas. Octubre 2015-Mayo 2018. Edificio D9.......... 406

Tabla 338. Prueba de muestras relacionadas. Octubre 2015-Mayo 2018. Edificio D9.................. 406

Tabla 339. Estimación del ahorro de emisiones de CO2 para el Edificio D9. .............................. 407

Tabla 340. Precios de referencia para Gas natural y Astilla .................................................. 408

Tabla 341. Ahorro Económico por el consumo térmico en el Edificio D9.................................. 408

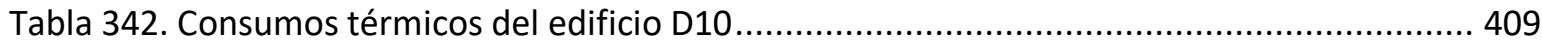

Tabla 343. Modelos de regresión del Edificio D10 ................................................................. 409

Tabla 344. Variables excluidas del modelo de región del Edificio D10 ..................................... 410

Tabla 345. Resumen de la bondad de los modelos de regresión para el Edificio D10 ................. 411

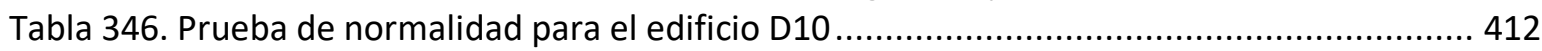

Tabla 347. Consumos previstos octubre 2014 - mayo 2017 para el edificio D10....................... 414

Tabla 348. Prueba de Normalidad temporada Octubre 2015-Mayo 2016. Edificio D10 .............. 415

Tabla 349. Estadísticos de muestras relacionadas. Octubre 2015-Mayo 2016. Edificio D10_....... 415

Tabla 350. Prueba de muestras relacionadas. Octubre 2015-Mayo 2016. Edificio D10............... 415

Tabla 351. Prueba de Normalidad temporada Octubre 2016-Abril 2017. Edificio D10................. 416

Tabla 352. Estadísticos de muestras relacionadas. Octubre 2016-Abril 2017. Edificio D10 .......... 416

Tabla 353. Prueba de muestras relacionadas. Octubre 2016-Abril 2017. Edificio D10 ............... 417

Tabla 354. Prueba de Normalidad temporada Octubre 2017-Mayo 2018. Edificio D10 ............. 417

Tabla 355. Estadísticos de muestras relacionadas. Octubre 2017-Mayo 2018. Edificio D10........ 418

Tabla 356. Prueba de muestras relacionadas. Octubre 2017-Mayo 2018. Edificio D10............... 418

Tabla 357. Prueba de Normalidad temporada Octubre 2015-Mayo 2018. Edificio D10 .............. 419

Tabla 358. Estadísticos de muestras relacionadas. Octubre 2015-Mayo 2018. Edificio D10........ 419 
Tabla 359. Prueba de muestras relacionadas. Octubre 2015-Mayo 2018. Edificio D10.............. 419

Tabla 360. Estimación del ahorro de emisiones de CO2 para el Edificio D10 ........................... 420

Tabla 361. Precios de referencia para Gas natural y Astilla .................................................... 421

Tabla 362. Ahorro Económico por el consumo térmico en el Edificio D10 .................................. 421

Tabla 363. Modelos de regresión del Edificio D11 .................................................................. 422

Tabla 364. Variables excluidas del modelo de región del Edificio D11 ..................................... 424

Tabla 365. Resumen de la bondad de los modelos de regresión para el Edificio D11 ................ 425

Tabla 366. Prueba de normalidad para el edificio D11 ........................................................... 426

Tabla 367. Índice de condición de las variables independientes del Modelo 2 en el Edificio D11 431

Tabla 368. Estadísticos de colinealidad para los modelos del Edificio D11 .............................. 432

Tabla 369. Consumos previstos octubre 2014 - mayo 2017 para el edificio D11....................... 433

Tabla 370. Prueba de Normalidad temporada Octubre 2015-Mayo 2016. Edificio D11 .............. 434

Tabla 371. Estadísticos de muestras relacionadas. Octubre 2015-Mayo 2016. Edificio D11........ 434

Tabla 372. Prueba de muestras relacionadas. Octubre 2015-Mayo 2016. Edificio D11............... 434

Tabla 373. Prueba de Normalidad temporada Octubre 2016-Abril 2017. Edificio D11............... 435

Tabla 374. Estadísticos de muestras relacionadas. Octubre 2016-Abril 2017. Edificio D11 ......... 435

Tabla 375. Prueba de muestras relacionadas. Octubre 2016-Abril 2017. Edificio D11 ............... 435

Tabla 376. Prueba de Normalidad temporada Octubre 2017-Mayo 2018. Edificio D11 ............. 436

Tabla 377. Estadísticos de muestras relacionadas. Octubre 2017-Mayo 2018. Edificio D11........ 436

Tabla 378. Prueba de muestras relacionadas. Octubre 2017-Mayo 2018. Edificio D11............... 437

Tabla 379. Prueba de Normalidad temporada Octubre 2015-Mayo 2018. Edificio D11 ............... 437

Tabla 380. Estadísticos de muestras relacionadas. Octubre 2015-Mayo 2018. Edificio D11........ 438

Tabla 381. Prueba de muestras relacionadas. Octubre 2015-Mayo 2018. Edificio D11............... 438

Tabla 382. Estimación del ahorro de emisiones de CO2 para el Edificio D11. ............................. 439

Tabla 383. Precios de referencia para Gas natural y Astilla ........................................................ 440

Tabla 384. Ahorro Económico por el consumo térmico en el Edificio D11 .................................. 440

Tabla 385. Consumos térmicos del edificio D12 .................................................................. 441

Tabla 386. Modelos de regresión del Edificio D12 ............................................................ 441

Tabla 387. Variables excluidas del modelo de región del Edificio D12 .................................... 442

Tabla 388. Resumen de la bondad de los modelos de regresión para el Edificio D12 ................ 443

Tabla 389. Prueba de normalidad para el edificio D12 ........................................................... 444

Tabla 390. Consumos previstos octubre 2014 - mayo 2017 para el edificio D12....................... 446

Tabla 391. Prueba de Normalidad temporada Octubre 2015-Mayo 2016. Edificio D12 .............. 447

Tabla 392. Estadísticos de muestras relacionadas. Octubre 2015-Mayo 2016. Edificio D12 ........ 447

Tabla 393. Prueba de muestras relacionadas. Octubre 2015-Mayo 2016. Edificio D12 ............... 447

Tabla 394. Prueba de Normalidad temporada Octubre 2016-Mayo 2017. Edificio D12 .............. 448

Tabla 395. Estadísticos de muestras relacionadas. Octubre 2016-Mayo 2017. Edificio D12........ 448

Tabla 396. Prueba de muestras relacionadas. Octubre 2016-Mayo 2017. Edificio D12 ............... 449

Tabla 397. Prueba de Normalidad temporada Octubre 2017-Mayo 2018. Edificio D12 .............. 449

Tabla 398. Estadísticos de muestras relacionadas. Octubre 2017-Mayo 2018. Edificio D12 ........ 450

Tabla 399. Prueba de muestras relacionadas. Octubre 2017-Mayo 2018. Edificio D12 ............... 450

Tabla 400. Prueba de Normalidad temporada Octubre 2015-Mayo 2018. Edificio D12 ............. 451

Tabla 401. Estadísticos de muestras relacionadas. Octubre 2015-Mayo 2018. Edificio D12 ........ 451

Tabla 402. Prueba de muestras relacionadas. Octubre 2015-Mayo 2018. Edificio D12 ............... 451

Tabla 403. Estimación del ahorro de emisiones de CO2 para el Edificio D12 ........................... 452

Tabla 404. Precios de referencia para Gas natural y Astilla ...................................................... 453 
Tabla 405. Ahorro Económico por el consumo térmico en el Edificio D12 ............................... 453

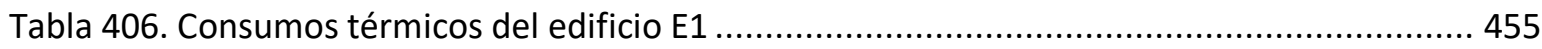

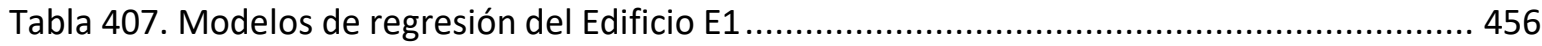

Tabla 408. Variables excluidas del modelo de región del Edificio E1 ......................................... 457

Tabla 409. Resumen de la bondad del modelo de regresión para el Edificio E1 ......................... 457

Tabla 410. Prueba de normalidad para el edificio E1 .............................................................. 458

Tabla 411. Consumos previstos octubre 2014 - mayo 2017 para el edificio E1. ......................... 461

Tabla 412. Prueba de Normalidad temporada Octubre 2015-Mayo 2016. Edificio E1................. 462

Tabla 413. Prueba de Normalidad temporada Octubre 2016-Mayo 2017. Edificio E1................. 462

Tabla 414. Estadísticos de muestras relacionadas. Octubre 2016-Mayo 2017. Edificio E1 ........... 462

Tabla 415. Prueba de muestras relacionadas. Octubre 2016-Mayo 2017. Edificio E1 ................. 463

Tabla 416. Prueba de Normalidad temporada Octubre 2017-Mayo 2018. Edificio E1................ 463

Tabla 417. Estadísticos de muestras relacionadas. Octubre 2017-Mayo 2018. Edificio E1 ........... 464

Tabla 418. Prueba de muestras relacionadas. Octubre 2017-Mayo 2018. Edificio E1 ................. 464

Tabla 419. Prueba de Normalidad temporada Octubre 2015-Mayo 2018. Edificio E1................. 465

Tabla 420. Estadísticos de muestras relacionadas. Octubre 2015-Mayo 2018. Edificio E1 .......... 465

Tabla 421. Prueba de muestras relacionadas. Octubre 2015-Mayo 2018. Edificio E1 ................. 465

Tabla 422. Estimación del ahorro de emisiones de CO2 para el Edificio E1................................ 466

Tabla 423. Precios de referencia para Gas natural y Astilla .................................................... 467

Tabla 424. Ahorro Económico por el consumo térmico en el Edificio E1 ................................. 467

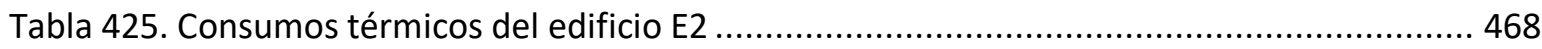

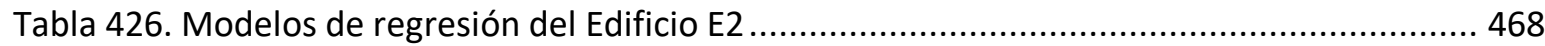

Tabla 427. Variables excluidas del modelo de región del Edificio E2 …................................... 469

Tabla 428. Resumen de la bondad del modelo de regresión para el Edificio D2 ........................ 470

Tabla 429. Prueba de normalidad para el edificio E2 ........................................................ 471

Tabla 430. Consumos previstos octubre 2014 - mayo 2017 para el edificio E2 . ......................... 474

Tabla 431. Prueba de Normalidad temporada Octubre 2015-Mayo 2016. Edificio E1................. 475

Tabla 432. Prueba de Normalidad temporada Octubre 2016-Mayo 2017. Edificio E2 2................. 475

Tabla 433. Estadísticos de muestras relacionadas. Octubre 2016-Mayo 2017. Edificio E2 _.......... 475

Tabla 434. Prueba de muestras relacionadas. Octubre 2016-Mayo 2017. Edificio E2 ................ 476

Tabla 435. Prueba de Normalidad temporada Octubre 2017-Mayo 2018. Edificio E2 ................ 476

Tabla 436. Estadísticos de muestras relacionadas. Octubre 2017-Mayo 2018. Edificio E1 .......... 477

Tabla 437. Prueba de muestras relacionadas. Octubre 2017-Mayo 2018. Edificio E2 ................ 477

Tabla 438. Prueba de Normalidad temporada Octubre 2015-Mayo 2018. Edificio E2 2................. 478

Tabla 439. Estadísticos de muestras relacionadas. Octubre 2015-Mayo 2018. Edificio E2 ........... 478

Tabla 440. Prueba de muestras relacionadas. Octubre 2015-Mayo 2018. Edificio E2 ................ 478

Tabla 441. Estimación del ahorro de emisiones de CO2 para el Edificio E2 .............................. 479

Tabla 442. Precios de referencia para Gas natural y Astilla ..................................................... 480

Tabla 443. Ahorro Económico por el consumo térmico en el Edificio E1 .................................... 480

Tabla 444. Consumos térmicos del edificio E3 ................................................................. 481

Tabla 445. Modelos de regresión del Edificio E3 ................................................................. 482

Tabla 446. Variables excluidas del modelo de región del Edificio E3 ....................................... 484

Tabla 447. Resumen de la bondad de los modelos de regresión para el Edificio E3 .................... 485

Tabla 448. Prueba de normalidad para el edificio E3 ............................................................ 487

Tabla 449. Índice de condición de las variables independientes del Modelo 2 en el Edificio E3 ... 491

Tabla 450. Estadísticos de colinealidad para los modelos del Edificio E3 .................................. 492 
Tabla 451. Consumos previstos octubre 2014 - mayo 2017 para el edificio E3.

Tabla 452. Prueba de Normalidad temporada Octubre 2015-Mayo 2016. Edificio E3. Modelo 1.494 Tabla 453. Prueba de Normalidad temporada Octubre 2015-Mayo 2016. Edificio E3. Modelo 2 494 Tabla 454. Estadísticos de muestras relacionadas. Octubre 2015-Mayo 2016. Edificio E3 ........... 495 Tabla 455. Prueba de muestras relacionadas. Octubre 2015-Mayo 2016. Edificio E3 ................. 495 Tabla 456. Prueba de Normalidad temporada Octubre 2016-Mayo 2017. Edificio E3................. 496 Tabla 457. Estadísticos de muestras relacionadas. Octubre 2016-Abril 2017. Edificio E3............ 496 Tabla 458. Prueba de muestras relacionadas. Octubre 2016-Abril 2017. Edificio E3 ................... 496 Tabla 459. Prueba de Normalidad temporada Octubre 2017-Mayo 2018. Edificio E3................. 497 Tabla 460. Estadísticos de muestras relacionadas. Octubre 2017-Mayo 2018. Edificio E3 ........... 498 Tabla 461. Prueba de muestras relacionadas. Octubre 2017-Mayo 2018. Edificio E3 ................. 498 Tabla 462.Prueba de Normalidad temporada Octubre 2015-Mayo 2018. Edificio E3 ................ 499 Tabla 463. Estadísticos de muestras relacionadas. Octubre 2015-Mayo 2018. Edificio E3 ........... 499 Tabla 464. Prueba de muestras relacionadas. Octubre 2015-Mayo 2018. Edificio E3 ................. 499 Tabla 465. Estimación del ahorro de emisiones de CO2 para el Edificio E3 ............................... 500 Tabla 466. Precios de referencia para Gas natural y Astilla ................................................... 501 Tabla 467. Ahorro Económico por el consumo térmico en el Edificio E3 ................................. 501

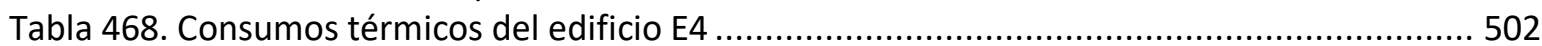
Tabla 469. Modelos de regresión del Edificio E4 ..................................................................... 502

Tabla 470. Variables excluidas del modelo de región del Edificio E4 ........................................ 503

Tabla 471. Resumen de la bondad del modelo de regresión para el Edificio E4 .......................... 504

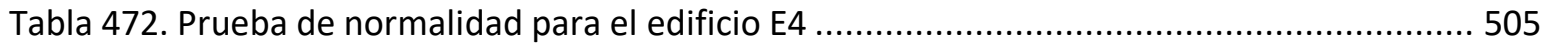

Tabla 473. Consumos previstos octubre 2014 - mayo 2017 para el edificio E4. ....................... 507

Tabla 474. Prueba de Normalidad temporada Octubre 2015-Mayo 2016. Edificio E4................. 508

Tabla 475. Estadísticos de muestras relacionadas. Octubre 2015-Mayo 2016. Edificio E4 ........... 508

Tabla 476. Prueba de muestras relacionadas. Octubre 2015-Mayo 2016. Edificio E4 ................. 508

Tabla 477. Prueba de Normalidad temporada Octubre 2016-Mayo 2017. Edificio E4................ 509

Tabla 478. Prueba de Normalidad temporada Octubre 2017-Mayo 2018. Edificio E4................. 510

Tabla 479. Estadísticos de muestras relacionadas. Octubre 2017-Mayo 2018. Edificio E4 ........... 510

Tabla 480. Prueba de muestras relacionadas. Octubre 2017-Mayo 2018. Edificio E4 ................. 510

Tabla 481. Prueba de Normalidad temporada Octubre 2015-Mayo 2018. Edificio E4................. 511

Tabla 482. Estimación del ahorro de emisiones de CO2 para el Edificio E4................................. 512

Tabla 483. Precios de referencia para Gas natural y Astilla ..................................................... 513

Tabla 484. Ahorro Económico por el consumo térmico en el Edificio E4 ................................. 513

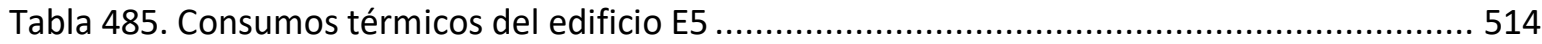

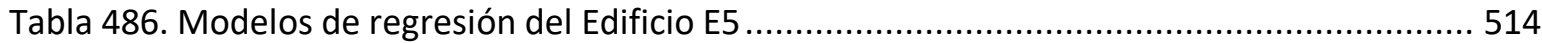

Tabla 487. Variables excluidas del modelo de región del Edificio E5 ...................................... 515

Tabla 488. Resumen de la bondad del modelo de regresión para el Edificio E5 ......................... 516

Tabla 489. Prueba de normalidad para el edificio E5 .............................................................. 517

Tabla 490. Consumos previstos octubre 2014 - mayo 2017 para el edificio E5. ....................... 519

Tabla 491. Prueba de Normalidad temporada Octubre 2015-Mayo 2016. Edificio E5................. 520

Tabla 492. Estadísticos de muestras relacionadas. Octubre 2015-Mayo 2016. Edificio E5 ........... 520

Tabla 493. Prueba de muestras relacionadas. Octubre 2015-Mayo 2016. Edificio E5 ................. 520

Tabla 494. Prueba de Normalidad temporada Octubre 2016-Mayo 2017. Edificio E5................. 521

Tabla 495. Estadísticos de muestras relacionadas. Octubre 2016-Mayo 2017. Edificio E5 ........... 521

Tabla 496. Prueba de muestras relacionadas. Octubre 2016-Mayo 2017. Edificio E5 .................. 522 
Tabla 497. Prueba de Normalidad temporada Octubre 2017-Mayo 2018. Edificio E5................. 522

Tabla 498. Estadísticos de muestras relacionadas. Octubre 2017-Mayo 2018. Edificio E5 ........... 523

Tabla 499. Prueba de muestras relacionadas. Octubre 2017-Mayo 2018. Edificio E5 ................. 523

Tabla 500. Prueba de Normalidad temporada Octubre 2015-Mayo 2018. Edificio E5................. 524

Tabla 501. Estadísticos de muestras relacionadas. Octubre 2015-Mayo 2018. Edificio E5 ........... 524

Tabla 502. Prueba de muestras relacionadas. Octubre 2015-Mayo 2018. Edificio E5 ................. 524

Tabla 503. Estimación del ahorro de emisiones de CO2 para el Edificio E5.............................. 525

Tabla 504. Precios de referencia para Gas natural y Astilla ..................................................... 526

Tabla 505. Ahorro Económico por el consumo térmico en el Edificio E5 ................................. 526

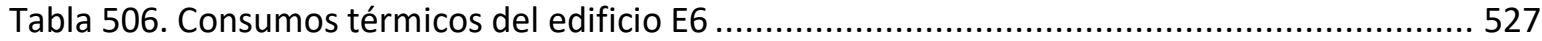

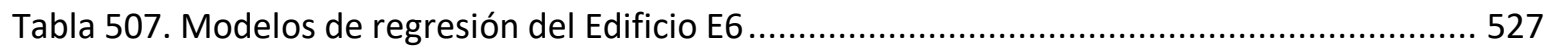

Tabla 508. Variables excluidas del modelo de región del Edificio E6 ....................................... 528

Tabla 509. Resumen de la bondad del modelo de regresión para el Edificio E6......................... 529

Tabla 510. Prueba de normalidad para el edificio E6 ............................................................... 530

Tabla 511. Consumos previstos octubre 2014 - mayo 2017 para el edificio E6. ........................ 532

Tabla 512. Prueba de Normalidad temporada Octubre 2015-Mayo 2016. Edificio E6................ 533

Tabla 513. Estadísticos de muestras relacionadas. Octubre 2015-Mayo 2016. Edificio E6 ........... 533

Tabla 514. Prueba de muestras relacionadas. Octubre 2015-Mayo 2016. Edificio E6 ................. 533

Tabla 515. Prueba de Normalidad temporada Octubre 2016-Mayo 2017. Edificio E6................. 534

Tabla 516. Estadísticos de muestras relacionadas. Octubre 2016-Mayo 2017. Edificio E6 ........... 534

Tabla 517. Prueba de muestras relacionadas. Octubre 2016-Mayo 2017. Edificio E6 .................. 535

Tabla 518. Prueba de Normalidad temporada Octubre 2017-Mayo 2018. Edificio E6................. 535

Tabla 519. Estadísticos de muestras relacionadas. Octubre 2017-Mayo 2018. Edificio E6 ........... 536

Tabla 520. Prueba de muestras relacionadas. Octubre 2017-Mayo 2018. Edificio E6 ................. 536

Tabla 521. Prueba de Normalidad temporada Octubre 2015-Mayo 2018. Edificio E6................. 537

Tabla 522. Estadísticos de muestras relacionadas. Octubre 2015-Mayo 2018. Edificio E6 ........... 537

Tabla 523. Prueba de muestras relacionadas. Octubre 2015-Mayo 2018. Edificio E6 ................. 537

Tabla 524. Estimación del ahorro de emisiones de CO2 para el Edificio E6 ............................... 538

Tabla 525. Precios de referencia para Gas natural y Astilla .................................................... 539

Tabla 526. Ahorro Económico por el consumo térmico en el Edificio E6 .................................. 539

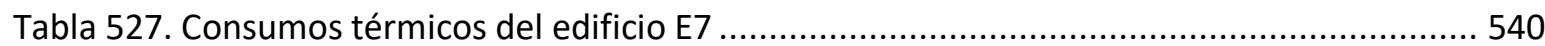

Tabla 528. Modelos de regresión del Edificio E7 ................................................................... 540

Tabla 529. Variables excluidas del modelo de región del Edificio E7 .......................................... 541

Tabla 530. Resumen de la bondad del modelo de regresión para el Edificio E7 .........................542

Tabla 531. Prueba de normalidad para el edificio E7 ......................................................... 543

Tabla 532. Consumos previstos octubre 2014 - mayo 2017 para el edificio E7. ....................... 545

Tabla 533. Prueba de Normalidad temporada Octubre 2015-Mayo 2016. Edificio E7................. 546

Tabla 534. Estadísticos de muestras relacionadas. Octubre 2015-Mayo 2016. Edificio E7 ........... 546

Tabla 535. Prueba de muestras relacionadas. Octubre 2015-Mayo 2016. Edificio E7 .................. 546

Tabla 536. Prueba de Normalidad temporada Octubre 2016-Mayo 2017. Edificio E7................. 547

Tabla 537. Estadísticos de muestras relacionadas. Octubre 2016-Mayo 2017. Edificio E7 ........... 547

Tabla 538. Prueba de muestras relacionadas. Octubre 2016-Mayo 2017. Edificio E7 ................ 548

Tabla 539. Prueba de Normalidad temporada Octubre 2017-Mayo 2018. Edificio E7................. 548

Tabla 540. Estadísticos de muestras relacionadas. Octubre 2017-Mayo 2018. Edificio E7 ........... 549

Tabla 541. Prueba de muestras relacionadas. Octubre 2017-Mayo 2018. Edificio E7 .................. 549

Tabla 542. Prueba de Normalidad temporada Octubre 2015-Mayo 2018. Edificio E7.................. 550 
Tabla 543. Estadísticos de muestras relacionadas. Octubre 2015-Mayo 2018. Edificio E7 ........... 550

Tabla 544. Prueba de muestras relacionadas. Octubre 2015-Mayo 2018. Edificio E7 ................. 550

Tabla 545. Estimación del ahorro de emisiones de CO2 para el Edificio E7............................... 551

Tabla 546. Precios de referencia para Gas natural y Astilla ........................................................ 552

Tabla 547. Ahorro Económico por el consumo térmico en el Edificio E7 .................................... 552

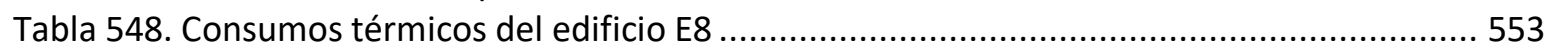

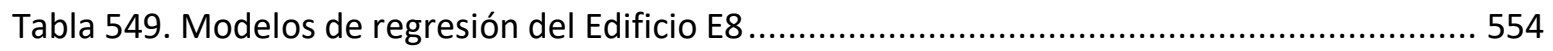

Tabla 550. Variables excluidas del modelo de región del Edificio E8 ......................................... 556

Tabla 551. Resumen de la bondad de los modelos de regresión para el Edificio E8 ..................... 557

Tabla 552. Prueba de normalidad para el edificio E8 ............................................................. 559

Tabla 553. Índice de condición de las variables independientes del Modelo 2 en el Edificio E8 ... 563

Tabla 554. Estadísticos de colinealidad para los modelos del Edificio E8 .................................. 564

Tabla 555. Consumos previstos octubre 2014 - mayo 2017 para el edificio E8. ........................ 565

Tabla 556. Prueba de Normalidad temporada Octubre 2015-Mayo 2016. Edificio E8. Modelo 1. 566

Tabla 557. Prueba de Normalidad temporada Octubre 2015-Mayo 2016. Edificio E8. Modelo 2. 566

Tabla 558. Estadísticos de muestras relacionadas. Octubre 2015-Mayo 2016. Edificio E8 ........... 566

Tabla 559. Prueba de muestras relacionadas. Octubre 2015-Mayo 2016. Edificio E8 ................. 567

Tabla 560. Prueba de Normalidad temporada Octubre 2016-Mayo 2017. Edificio E8................. 568

Tabla 561. Estadísticos de muestras relacionadas. Octubre 2016-Abril 2017. Edificio E8............. 568

Tabla 562. Prueba de muestras relacionadas. Octubre 2016-Abril 2017. Edificio E8.................... 568

Tabla 563. Prueba de Normalidad temporada Octubre 2017-Mayo 2018. Edificio E8................. 569

Tabla 564. Estadísticos de muestras relacionadas. Octubre 2017-Mayo 2018. Edificio E8 ........... 569

Tabla 565. Prueba de muestras relacionadas. Octubre 2017-Mayo 2018. Edificio E8 ................. 570

Tabla 566. Prueba de Normalidad temporada Octubre 2015-Mayo 2018. Edificio E8.................. 571

Tabla 567. Estadísticos de muestras relacionadas. Octubre 2015-Mayo 2018. Edificio E8 ........... 571

Tabla 568. Prueba de muestras relacionadas. Octubre 2015-Mayo 2018. Edificio E8 ................. 571

Tabla 569. Estimación del ahorro de emisiones de CO2 para el Edificio E8............................... 572

Tabla 570. Precios de referencia para Gas natural y Astilla .................................................... 573

Tabla 571. Ahorro Económico por el consumo térmico en el Edificio E8 …............................... 573

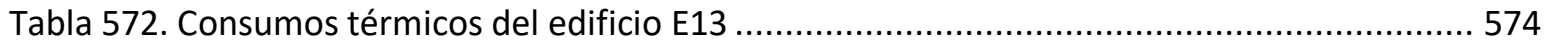

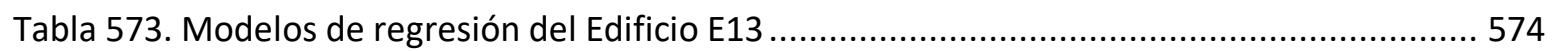

Tabla 574. Variables excluidas del modelo de región del Edificio E13 ...................................... 575

Tabla 575. Resumen de la bondad del modelo de regresión para el Edificio E13 ........................ 576

Tabla 576. Prueba de normalidad para el edificio E13 ............................................................ 577

Tabla 577. Consumos previstos octubre 2014 - mayo 2017 para el edificio E13. ...................... 580

Tabla 578. Prueba de Normalidad temporada Octubre 2015-Mayo 2016. Edificio E13............... 581

Tabla 579. Estadísticos de muestras relacionadas. Octubre 2015-Mayo 2016. Edificio E13 ......... 581

Tabla 580. Prueba de muestras relacionadas. Octubre 2015-Mayo 2016. Edificio E13 ............... 581

Tabla 581. Prueba de Normalidad temporada Octubre 2016-Mayo 2017. Edificio E13................ 582

Tabla 582. Estadísticos de muestras relacionadas. Octubre 2016-Mayo 2017. Edificio E13 ......... 582

Tabla 583. Prueba de muestras relacionadas. Octubre 2016-Mayo 2017. Edificio E13 ............... 583

Tabla 584. Prueba de Normalidad temporada Octubre 2017-Mayo 2018. Edificio E13............... 583

Tabla 585. Estadísticos de muestras relacionadas. Octubre 2017-Mayo 2018. Edificio E13 ......... 584

Tabla 586. Prueba de muestras relacionadas. Octubre 2017-Mayo 2018. Edificio E13 ................ 584

Tabla 587. Prueba de Normalidad temporada Octubre 2015-Mayo 2018. Edificio E13............... 585

Tabla 588. Estimación del ahorro de emisiones de CO2 para el Edificio E13............................. 586 
Tabla 589. Precios de referencia para Gas natural y Astilla .................................................. 587

Tabla 590. Ahorro Económico por el consumo térmico en el Edificio E13 ............................... 587

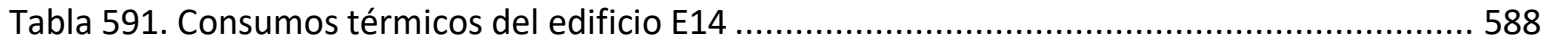

Tabla 592. Modelos de regresión del Edificio E14 ................................................................. 588

Tabla 593. Variables excluidas del modelo de región del Edificio E14 ...................................... 589

Tabla 594. Resumen de la bondad del modelo de regresión para el Edificio E14 ......................... 590

Tabla 595. Prueba de normalidad para el edificio E14 ........................................................ 591

Tabla 596. Consumos previstos octubre 2014 - mayo 2017 para el edificio E14. ....................... 593

Tabla 597. Prueba de Normalidad temporada Octubre 2015-Mayo 2016. Edificio E14............... 594

Tabla 598. Estadísticos de muestras relacionadas. Octubre 2015-Mayo 2016. Edificio E14 ......... 594

Tabla 599. Prueba de muestras relacionadas. Octubre 2015-Mayo 2016. Edificio E14 ............... 594

Tabla 600. Prueba de Normalidad temporada Octubre 2016-Mayo 2017. Edificio E14............... 595

Tabla 601. Estadísticos de muestras relacionadas. Octubre 2016-Mayo 2017. Edificio E14 ......... 595

Tabla 602. Prueba de muestras relacionadas. Octubre 2016-Mayo 2017. Edificio E14 ................ 596

Tabla 603. Prueba de Normalidad temporada Octubre 2017-Mayo 2018. Edificio E14............... 596

Tabla 604. Estadísticos de muestras relacionadas. Octubre 2017-Mayo 2018. Edificio E14 ......... 597

Tabla 605. Prueba de muestras relacionadas. Octubre 2017-Mayo 2018. Edificio E14 ............... 597

Tabla 606. Prueba de Normalidad temporada Octubre 2015-Mayo 2018. Edificio E14............... 598

Tabla 607. Estadísticos de muestras relacionadas. Octubre 2015-Mayo 2018. Edificio E14 ......... 598

Tabla 608. Prueba de muestras relacionadas. Octubre 2015-Mayo 2018. Edificio E14 ............... 598

Tabla 609. Estimación del ahorro de emisiones de CO2 para el Edificio E14............................. 599

Tabla 610. Precios de referencia para Gas natural y Astilla .....................................................60 600

Tabla 611. Ahorro Económico por el consumo térmico en el Edificio E14 ................................600

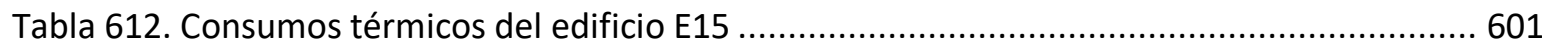

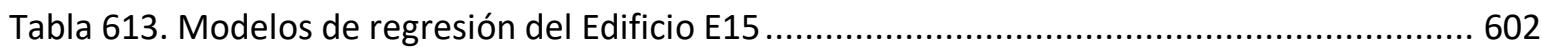

Tabla 614. Variables excluidas del modelo de región del Edificio E15 ........................................604

Tabla 615. Resumen de la bondad de los modelos de regresión para el Edificio E15 .................. 605

Tabla 616. Prueba de normalidad para el edificio E15 ........................................................ 607

Tabla 617. Índice de condición de las variables independientes del Modelo 2 en el Edificio E15 . 611

Tabla 618. Estadísticos de colinealidad para los modelos del Edificio E15 .............................612

Tabla 619. Consumos previstos octubre 2014 - mayo 2017 para el edificio E15. ..................... 613

Tabla 620. Prueba de Normalidad temporada Octubre 2015-Mayo 2016. Edificio E15. Modelo 2614

Tabla 621. Estadísticos de muestras relacionadas. Octubre 2015-Mayo 2016. Edificio E15 ......... 614

Tabla 622. Prueba de muestras relacionadas. Octubre 2015-Mayo 2016. Edificio E15 ................614

Tabla 623. Prueba de Normalidad temporada Octubre 2016-Mayo 2017. Edificio E15............... 615

Tabla 624. Estadísticos de muestras relacionadas. Octubre 2016-Abril 2017. Edificio E15.......... 615

Tabla 625. Prueba de muestras relacionadas. Octubre 2016-Abril 2017. Edificio E15 ................ 616

Tabla 626. Prueba de Normalidad temporada Octubre 2017-Mayo 2018. Edificio E15............... 616

Tabla 627. Estadísticos de muestras relacionadas. Octubre 2017-Mayo 2018. Edificio E15 ......... 617

Tabla 628. Prueba de muestras relacionadas. Octubre 2017-Mayo 2018. Edificio E15 ............... 617

Tabla 629.Prueba de Normalidad temporada Octubre 2015-Mayo 2018. Edificio E15 ............... 618

Tabla 630. Estadísticos de muestras relacionadas. Octubre 2015-Mayo 2018. Edificio E15 ........ 618

Tabla 631. Estimación del ahorro de emisiones de CO2 para el Edificio E15............................619

Tabla 632. Precios de referencia para Gas natural y Astilla ...................................................... 620

Tabla 633. Ahorro Económico por el consumo térmico en el Edificio E15 ................................ 620 


\section{LISTADO DE FIGURAS}

Figura 1. Distribución del consumo de energía final por sectores en el mundo, UE y España. 2016. 7 Figura 2. Distribución del consumo de energía final por sectores en Castilla y León. 2014 ............. 7

Figura 3. Evolución de las emisiones de $\mathrm{CO}_{2}$ mundiales desde 2000 hasta 2017 .......................... 9

Figura 4. Índice de evolución de las emisiones de CO2 en España (1990-2017) ........................... 10

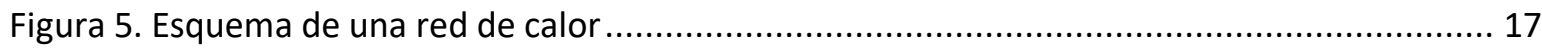

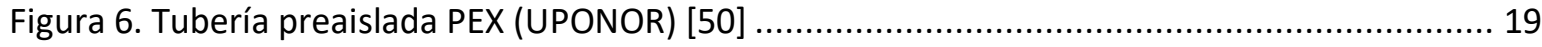

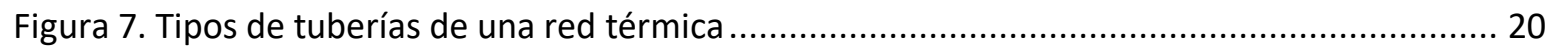

Figura 8. Evolución del número de redes de calor y frío en España $(2013-2018)$.......................... 31

Figura 9. Distribución del número de redes en España por Comunidades. 2018 .......................... 32

Figura 10. Distribución de la potencia instalada en redes en España por Comunidades. 2018....... 32

Figura 11. Distribución porcentual del número de redes y potencia por Comunidades. 2018........ 33

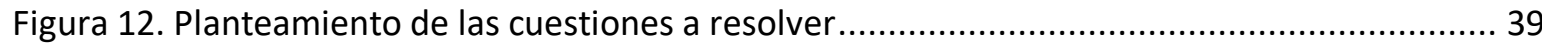

Figura 13. Metodología utilizada en la investigación.............................................................. 44

Figura 14. Esquema de la situación de los edificios antes y después de su conexión a la red ......... 49

Figura 15. Intervalos de rechazo de autocorrelación según el estadístico DW ............................ 54

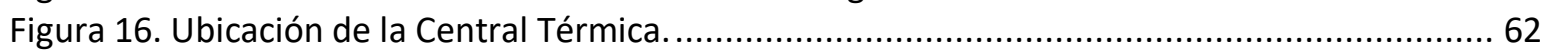

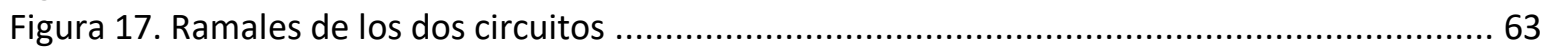

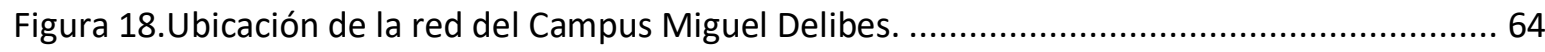

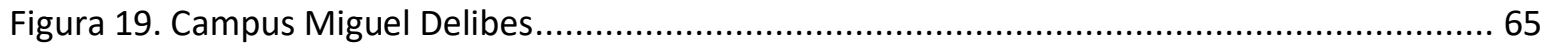

Figura 20. Esquema de ubicación de los edificios del Ramal del Campus Miguel Delibes.............. 65

Figura 21. Ubicación del segundo ramal. Campus Río Esgueva y Zonas deportivas....................... 66

Figura 22. Ubicación del Campus Río Esgueva ...................................................................... 67

Figura 23. Esquema de ubicación de los edificios de la UVA del Ramal del Campus Río Esgueva ... 67

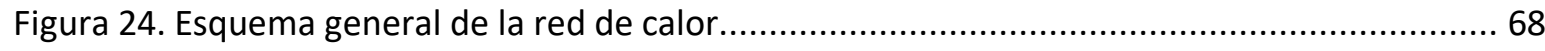

Figura 25. Vista posterior de la Central Térmica. Fachada Noroeste ........................................ 69

Figura 26. Fachada principal de la Central Térmica. Suroeste. (Lorenzo, 2017) [107] .................. 69

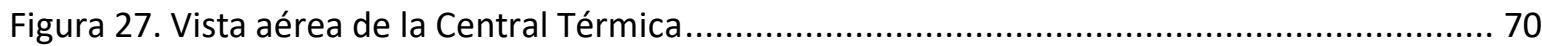

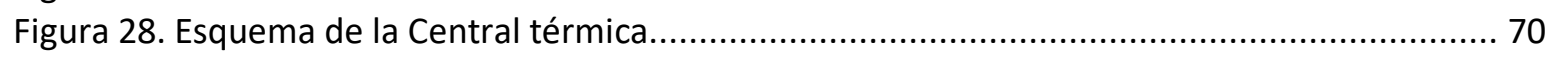

Figura 29. Calderas iniciales. . (Lorenzo, 2017) [107] ............................................................ 71

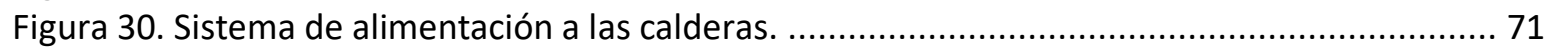

Figura 31. Granulometría de la astilla. (Lorenzo, 2017) [107] ................................................ 72

Figura 32. Líneas de llenado del silo. (Lorenzo, 2017) [107] .................................................. 72

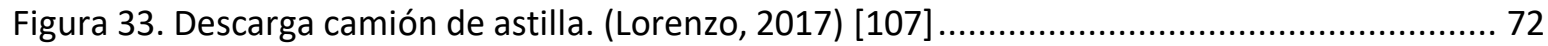

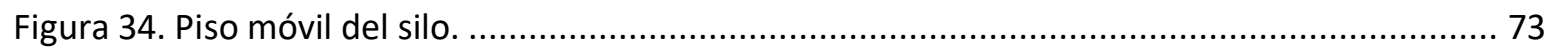

Figura 35. Tornillo sinfín desde el silo a la alimentación de las calderas. (Lorenzo, 2017) [107] ..... 73

Figura 36. Depósitos de inercia. (Lorenzo, 2017) [107] ....................................................... 74 
Figura 37. Sistema multiciclónico y filtro de mangas. (Lorenzo, 2017) [107] ............................. 74

Figura 38. Grupos de bombeo del circuito secundario. (Lorenzo, 2017) [107] ........................... 75

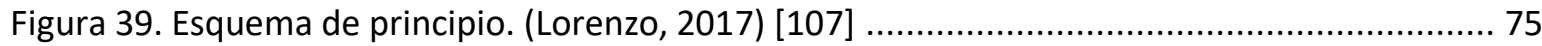

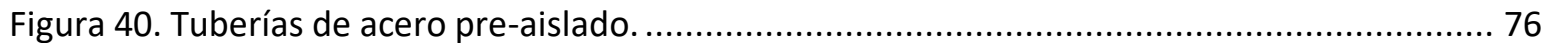

Figura 41. Red de distribución enterrada. (Lorenzo, 2017) [107] ........................................... 76

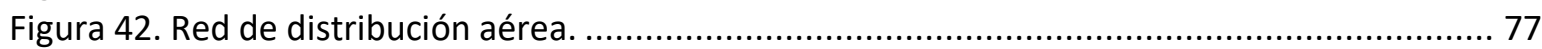

Figura 43. Esquema de la subestación de intercambio en cada edificio. (Lorenzo, 2017) [107] ..... 78

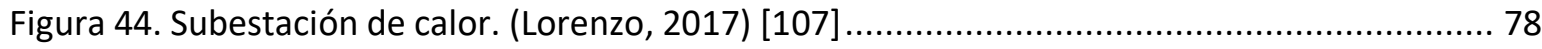

Figura 45. Subestación de calor. . (Lorenzo, 2017) [107] ......................................................... 78

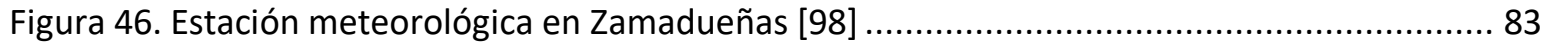

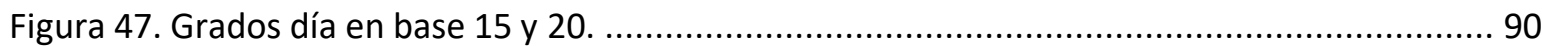

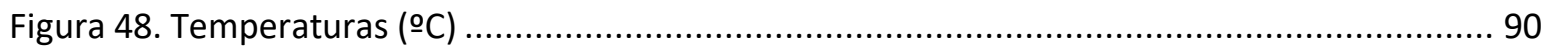

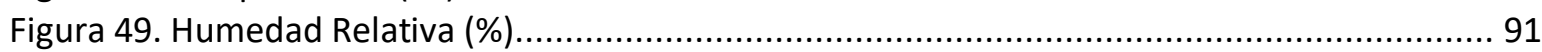

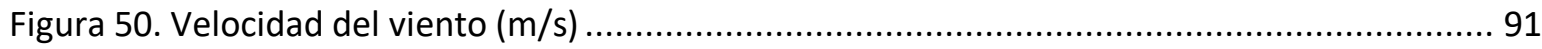

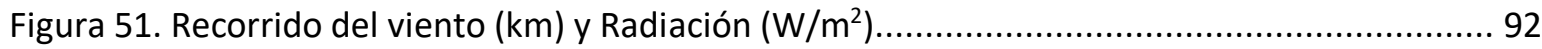

Figura 52. Precipitación acumulada $(\mathrm{mm})$ y Horas de sol ...................................................... 92

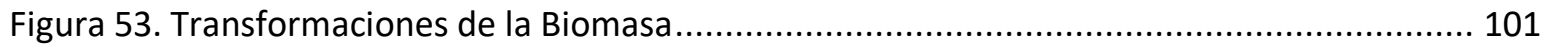

Figura 54. Evolución de los precios de los combustibles 2015-2018 ....................................... 104

Figura 55. Ubicación del Edificio D1 en el croquis del campus Miguel Delibes........................... 107

Figura 56. Representación de los consumos pronosticados para el Edificio D1. 2015-2018 ......... 108

Figura 57. Consumos reales y pronosticados Octubre 2015-Mayo 2018. Edificio D1 ................. 109

Figura 58. Consumo acumulado real y pronosticado. Octubre 2015-Mayo 2018. Edificio D1 ...... 110

Figura 59. Ubicación del Edificio D2 en el croquis del campus Miguel Delibes.......................... 111

Figura 60. Representación de los consumos pronosticados para el Edificio D2. 2015-2018 ........ 112

Figura 61. Consumos reales y pronosticados Octubre 2015-Mayo 2018. Edificio D2 ................. 113

Figura 62. Consumo acumulado real y pronosticado. Octubre 2015-Mayo 2018. Edificio D2 ...... 114

Figura 63. Ubicación del Edificio D3 en el croquis del campus Miguel Delibes........................... 115

Figura 64. Representación de los consumos pronosticados para el Edificio D3. 2015-2018 ......... 116

Figura 65. Consumos reales y pronosticados Octubre 2015-Mayo 2018. Edificio D3 ................. 117

Figura 66. Consumo acumulado real y pronosticado. Octubre 2015-Mayo 2018. Edificio D3 ...... 118

Figura 67. Ubicación del Edificio D4 en el croquis del campus Miguel Delibes........................... 119

Figura 68. Representación de los consumos pronosticados para el Edificio D4. 2015-2018 ......... 120

Figura 69. Consumos reales y pronosticados Octubre 2015-Mayo 2018. Edificio D4 ................. 121

Figura 70. Consumo acumulado real y pronosticado. Octubre 2015-Mayo 2018. Edificio D4 ...... 122

Figura 71. Ubicación del Edificio D5 en el croquis del campus Miguel Delibes......................... 123

Figura 72. Representación de los consumos pronosticados para el Edificio D5. 2015-2018 ......... 124

Figura 73. Consumos reales y pronosticados Octubre 2015-Mayo 2018. Edificio D5 ................. 125

Figura 74. Consumo acumulado real y pronosticado. Octubre 2015-Mayo 2018. Edificio D5 ...... 126

Figura 75. Ubicación del Edificio D6 en el croquis del campus Miguel Delibes........................... 127

Figura 76. Representación de los consumos pronosticados para el Edificio D6. 2015-2018 ........ 128

Figura 77. Consumos reales y pronosticados Octubre 2015-Mayo 2018. Edificio D6 ................. 129

Figura 78. Consumo acumulado real y pronosticado. Octubre 2015-Mayo 2018. Edificio D6 ...... 130

Figura 79. Ubicación del Edificio D7 en el croquis del campus Miguel Delibes......................... 131

Figura 80. Representación de los consumos pronosticados para el Edificio D7. 2015-2018 ......... 132

Figura 81. Consumos reales y pronosticados Octubre 2015-Mayo 2018. Edificio D7 .................. 133

Figura 82. Consumo acumulado real y pronosticado. Octubre 2015-Mayo 2018. Edificio D7 ...... 134 
Figura 83. Ubicación del Edificio D8 en el croquis del campus Miguel Delibes.......................... 135

Figura 84. Representación de los consumos pronosticados para el Edificio D8. 2015-2018 ........ 136

Figura 85. Consumos reales y pronosticados Octubre 2015-Mayo 2018. Edificio D8 .................. 137

Figura 86. Consumo acumulado real y pronosticado. Octubre 2015-Mayo 2018. Edificio D8 ...... 138

Figura 87. Ubicación del Edificio D9 en el croquis del campus Miguel Delibes......................... 139

Figura 88. Representación de los consumos pronosticados para el Edificio D9. 2015-2018 ......... 140

Figura 89. Consumos reales y pronosticados Octubre 2015-Mayo 2018. Edificio D9 ................. 141

Figura 90. Consumo acumulado real y pronosticado. Octubre 2015-Mayo 2018. Edificio D9 ...... 142

Figura 91. Ubicación del Edificio D10 en el croquis del campus Miguel Delibes......................... 143

Figura 92. Representación de los consumos pronosticados para el Edificio D10. 2015-2018 ....... 144

Figura 93. Consumos reales y pronosticados Octubre 2015-Mayo 2018. Edificio D10 ............... 145

Figura 94. Consumo acumulado real y pronosticado. Octubre 2015-Mayo 2018. Edificio D10 .... 146

Figura 95. Ubicación del Edificio D11 en el croquis del campus Miguel Delibes......................... 147

Figura 96. Representación de los consumos pronosticados para el Edificio D11. 2015-2018 ....... 148

Figura 97. Consumos reales y pronosticados Octubre 2015-Mayo 2018. Edificio D11 ................ 149

Figura 98. Consumo acumulado real y pronosticado. Octubre 2015-Mayo 2018. Edificio D11 .... 150

Figura 99. Ubicación del Edificio D12 en el croquis del campus Miguel Delibes........................ 151

Figura 100. Representación de los consumos pronosticados para el Edificio D12. 2015-2018 ..... 152

Figura 101. Consumos reales y pronosticados Octubre 2015-Mayo 2018. Edificio D12 .............. 153

Figura 102. Consumo acumulado real y pronosticado. Octubre 2015-Mayo 2018. Edificio D12... 154

Figura 103. Consumo real acumulado y pronosticado (kWh). Campus Miguel Delibes ............... 162

Figura 104. Emisiones reales acumuladas y pronosticadas (kg CO2). Campus Miguel Delibes ..... 163

Figura 105. Ubicación del Edificio E1 en el croquis del campus Río Esgueva.............................. 166

Figura 106. Representación de los consumos pronosticados para el Edificio E1. 2015-2018 ....... 167

Figura 107. Consumos reales y pronosticados Octubre 2015-Mayo 2018. Edificio E1................ 168

Figura 108. Consumo acumulado real y pronosticado. Octubre 2015-Mayo 2018. Edificio E1 ..... 169

Figura 109. Ubicación del Edificio E2 en el croquis del campus Río Esgueva.............................. 170

Figura 110. Representación de los consumos pronosticados para el Edificio E2. 2015-2018 ....... 171

Figura 111. Consumos reales y pronosticados Octubre 2015-Mayo 2018. Edificio E2 ................ 172

Figura 112. Consumo acumulado real y pronosticado. Octubre 2015-Mayo 2018. Edificio E2 ..... 173

Figura 113. Ubicación del Edificio E3 en el croquis del campus Río Esgueva ............................ 174

Figura 114. Representación de los consumos pronosticados para el Edificio E3. 2015-2018 ....... 175

Figura 115. Consumos reales y pronosticados Octubre 2015-Mayo 2018. Edificio E3................. 176

Figura 116. Consumo acumulado real y pronosticado. Octubre 2015-Mayo 2018. Edificio E3 ..... 177

Figura 117. Ubicación del Edificio E4 en el croquis del campus Río Esgueva ............................. 178

Figura 118. Representación de los consumos pronosticados para el Edificio E4. 2015-2018 ....... 179

Figura 119. Consumos reales y pronosticados Octubre 2015-Mayo 2018. Edificio E4................ 180

Figura 120. Consumo acumulado real y pronosticado. Octubre 2015-Mayo 2018. Edificio E4 ..... 181

Figura 121. Ubicación del Edificio E5 en el croquis del campus Río Esgueva ............................... 182

Figura 122. Representación de los consumos pronosticados para el Edificio E5. 2015-2018 ....... 183

Figura 123. Consumos reales y pronosticados Octubre 2015-Mayo 2018. Edificio E5................. 184

Figura 124. Consumo acumulado real y pronosticado. Octubre 2015-Mayo 2018. Edificio E5 .... 185

Figura 125. Ubicación del Edificio E6 en el croquis del campus Río Esgueva............................ 186

Figura 126. Representación de los consumos pronosticados para el Edificio E6. 2015-2018 ....... 187

Figura 127. Consumos reales y pronosticados Octubre 2015-Mayo 2018. Edificio E6................. 188

Figura 128. Consumo acumulado real y pronosticado. Octubre 2015-Mayo 2018. Edificio E6 ..... 189 
Figura 129. Ubicación del Edificio E7 en el croquis del campus Río Esgueva.............................. 190

Figura 130. Representación de los consumos pronosticados para el Edificio E7. 2015-2018 ....... 191

Figura 131. Consumos reales y pronosticados Octubre 2015-Mayo 2018. Edificio E7................. 192

Figura 132. Consumo acumulado real y pronosticado. Octubre 2015-Mayo 2018. Edificio E7 ..... 193

Figura 133. Ubicación del Edificio E8 en el croquis del campus Río Esgueva............................. 194

Figura 134. Representación de los consumos pronosticados para el Edificio E8. 2015-2018 ....... 196

Figura 135. Consumos reales y pronosticados Octubre 2015-Mayo 2018. Edificio E8................ 197

Figura 136. Consumo acumulado real y pronosticado. Octubre 2015-Mayo 2018. Edificio E8 ..... 197

Figura 137. Ubicación del Edificio E13 en el croquis del campus Río Esgueva........................... 199

Figura 138. Representación de los consumos pronosticados para el Edificio E13. 2015-2018...... 200

Figura 139. Consumos reales y pronosticados Octubre 2015-Mayo 2018. Edificio E13............... 201

Figura 140. Consumo acumulado real y pronosticado. Octubre 2015-Mayo 2018. Edificio E13 ... 202

Figura 141. Ubicación del Edificio E14 en el croquis del campus Río Esgueva ............................ 203

Figura 142. Representación de los consumos pronosticados para el Edificio E14. 2015-2018...... 204

Figura 143. Consumos reales y pronosticados Octubre 2015-Mayo 2018. Edificio E14............... 205

Figura 144. Consumo acumulado real y pronosticado. Octubre 2015-Mayo 2018. Edificio E14 ... 206

Figura 145. Ubicación del Edificio E15 en el croquis del campus Río Esgueva .......................... 207

Figura 146. Representación de los consumos pronosticados para el Edificio E15. 2015-2018..... 208

Figura 147. Consumos reales y pronosticados Octubre 2015-Mayo 2018. Edificio E15............... 209

Figura 148. Consumo acumulado real y pronosticado. Octubre 2015-Mayo 2018. Edificio E15 ... 210

Figura 149. Consumo real acumulado y pronosticado (kWh). Campus Río Esgueva..................... 217

Figura 150. Emisiones reales acumuladas y pronosticadas (kg CO2). Campus Río Esgueva .......... 218

Figura 151. Consumo real acumulado y pronosticado (kWh). Campus Río Esgueva.................... 227

Figura 152. Emisiones reales acumuladas y pronosticadas (kg CO2). UVA .................................. 231

Figura 153. Intervalos de confianza en una distribución normal. ............................................. 243

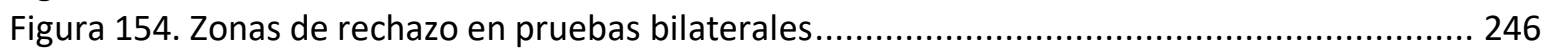

Figura 155. Ubicación Apartamentos Cardenal Mendoza (D1)............................................... 255

Figura 156. Fotografía de los Apartamentos Cardenal Mendoza (D1) . .................................. 256

Figura 157. Biblioteca de los Apartamentos Cardenal Mendoza (D2) ...................................... 256

Figura 158. Centro de Transferencia de Tecnologías Aplicadas. CTTA. (D3) ............................. 256

Figura 159. Fotografías del Centro de Transferencia de Tecnologías Aplicadas. CTTA. (D3) ........ 257

Figura 160. Biblioteca - Aulario Miguel Delibes (D4) ............................................................... 257

Figura 161. Fotografías de la Biblioteca - Aulario Miguel Delibes (D4) ...................................... 257

Figura 162. Instituto Universitario de Oftalmología Aplicada. IOBA. (D5) ................................ 258

Figura 163. Fotografías del Instituto Universitario de Oftalmología Aplicada. IOBA. (D5) ........... 258

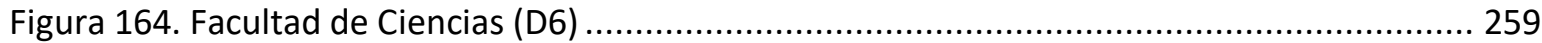

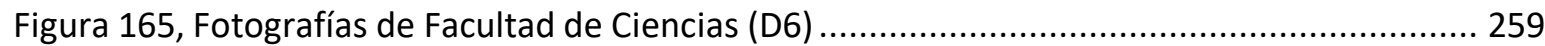

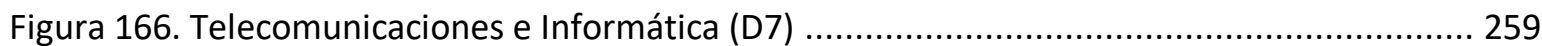

Figura 167. Fotografía de Telecomunicaciones e Informática (D7) ........................................... 260

Figura 168. Edificio Química Fina y Materiales Avanzados (QUIFIMA) (D8) .............................. 260

Figura 169. Fotografías del Edificio Química Fina y Materiales Avanzados (QUIFIMA) (D8) ......... 260

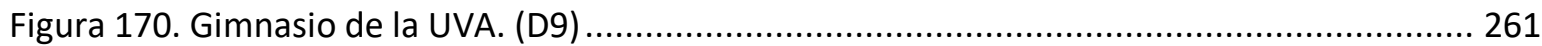

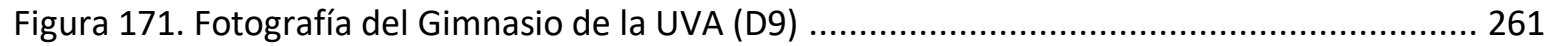

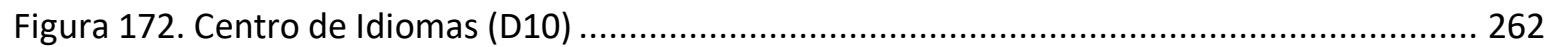

Figura 173. Fotografía del Centro de Idiomas (D10) ............................................................... 262

Figura 174. Facultad de Educación y Trabajo Social (D11) ........................................................ 262 
Figura 175. Fotografía Facultad de Educación y Trabajo Social (D11) .................................... 263

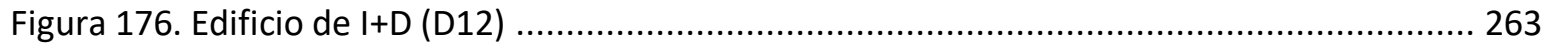

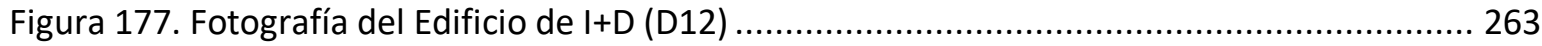

Figura 178. Edificio del Servicio de Mantenimiento (E1) ........................................................ 264

Figura 179. Fotografía de edificio del servicio de mantenimiento (E1) .................................... 264

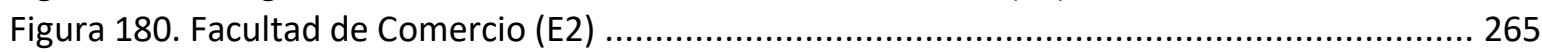

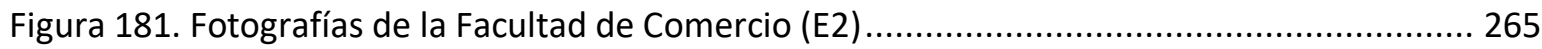

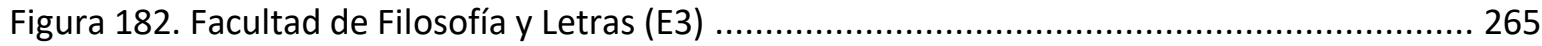

Figura 183. Fotografías de la Facultad de Filosofía y Letras (E3) ........................................... 266

Figura 184. Antigua Facultad de Ciencias. Escuela de Ingenierías Industriales (E4).................... 266

Figura 185. Fotografías Antigua Facultad de Ciencias. Escuela de Ingenierías Industriales (E4) ... 266

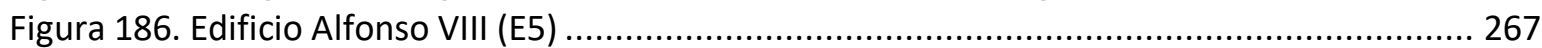

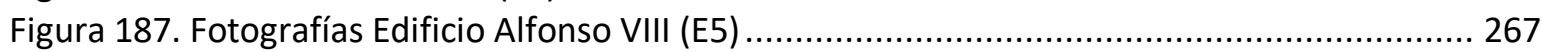

Figura 188. Colegio Mayor Femenino Santa Cruz (E6) ........................................................... 268

Figura 189. Fotografías del Colegio Mayor Femenino Santa Cruz (E6) ..................................... 268

Figura 190. Instituto de Biología Genética y Molecular. (IBGM) (E7) ...................................... 268

Figura 191. Fotografías del Instituto de Biología Genética y Molecular. (IBGM) (E7) ................. 269

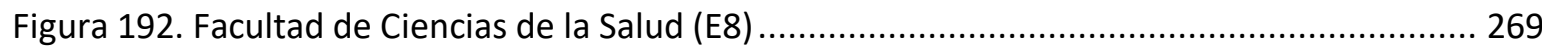

Figura 193. Fotografías Facultad de Ciencias de la Salud (E8) ............................................... 270

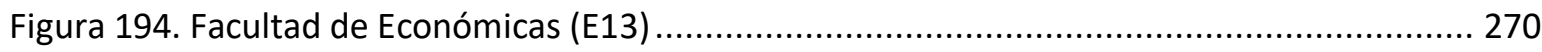

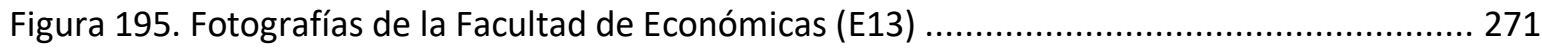

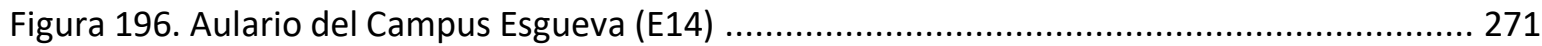

Figura 197. Fotografías del Aulario del Campus Esgueva (E14)........................................... 271

Figura 198. Escuela de Ingenierías Industriales (sede Paseo del Cauce) (E15) .......................... 272

Figura 199. Fotografías de la Escuela de Ingenierías Industriales (sede Paseo del Cauce) (E15) ... 272

Figura 200. Representación del modelo de regresión lineal simple para el Edificio D1 ................ 275

Figura 201. Representación del modelo de regresión lineal múltiple para el Edificio D1 ............ 275

Figura 202. Relación entre los pronósticos y los residuos en el Edificio D1. Modelo 1 ................ 280

Figura 203. Relación entre la Temperatura media y los residuos en el Edificio D1. Modelo 1 ...... 281

Figura 204. Relación entre los pronósticos y los residuos en el Edificio D1. Modelo 2 ................ 282

Figura 205. Relación entre la Temperatura media y los residuos en el Edificio D1. Modelo 2 ...... 282

Figura 206. Relación entre la velocidad nocturna y los residuos. Edificio D1. Modelo 2 ............. 282

Figura 207. Gráfico de la temperatura media y la velocidad del viento nocturno....................... 283

Figura 208. Consumos reales y pronosticados Octubre 2015-Mayo 2016. Edificio D1 ............... 287

Figura 209. Consumos reales y pronosticados Octubre 2016-Abril 2017. Edificio D1................. 289

Figura 210. Consumos reales y pronosticados Octubre 2017-Mayo 2018. Edificio D1 ............... 290

Figura 211. Representación del modelo de regresión lineal simple para el Edificio D2 ............... 295

Figura 212. Relación entre los pronósticos y los residuos en el Edificio D2 ............................... 298

Figura 213. Relación entre GD15 y los residuos en el Edificio D2 ............................................ 299

Figura 214. Consumos reales y pronosticados Octubre 2015-Mayo 2016. Edificio D2 ............... 302

Figura 215. Consumos reales y pronosticados Octubre 2016-Mayo 2017. Edificio D2 …............ 303

Figura 216. Consumos reales y pronosticados Octubre 2017-Mayo 2018. Edificio D2 ............... 304

Figura 217. Representación del modelo de regresión lineal simple para el Edificio D3 …........... 309

Figura 218. Relación entre los pronósticos y los residuos en el Edificio D3 ................................. 312

Figura 219. Relación entre GD15 y los residuos en el Edificio D3 ........................................... 312

Figura 220. Consumos reales y pronosticados Octubre 2015-Mayo 2016. Edificio D3 ................ 315 
Listado de Figuras

Figura 221. Consumos reales y pronosticados Octubre 2016-Mayo 2017. Edificio D3 ................ 316

Figura 222. Consumos reales y pronosticados Octubre 2017-Mayo 2018. Edificio D3 ............... 318

Figura 223. Representación del modelo de regresión lineal simple para el Edificio D4 ................ 323

Figura 224. Relación entre los residuos y el tiempo en el Edificio D4 ...................................... 326

Figura 225. Relación entre los pronósticos y los residuos en el Edificio D4 .............................. 327

Figura 226. Relación entre Temperatura media y los residuos en el Edificio D4 ........................ 327

Figura 227. Consumos reales y pronosticados Octubre 2015-Mayo 2016. Edificio D4 ................ 330

Figura 228. Consumos reales y pronosticados Octubre 2016-Abril 2017. Edificio D4 .................. 331

Figura 229. Consumos reales y pronosticados Octubre 2017-Mayo 2018. Edificio D4 ................ 332

Figura 230. Representación del modelo de regresión lineal simple para el Edificio D5 ............... 337

Figura 231. Relación entre los pronósticos y los residuos en el Edificio D5 ................................. 340

Figura 232. Relación entre GD15 y los residuos en el Edificio D5 ......................................... 340

Figura 233. Consumos reales y pronosticados Octubre 2015-Mayo 2016. Edificio D5 ................ 343

Figura 234. Consumos reales y pronosticados Octubre 2016-Mayo 2017. Edificio D5 ................ 344

Figura 235. Consumos reales y pronosticados Octubre 2017-Mayo 2018. Edificio D5 ................ 345

Figura 236. Representación del modelo de regresión lineal simple para el Edificio D6 ............... 350

Figura 237. Relación entre los pronósticos y los residuos en el Edificio D6 ............................... 353

Figura 238. Relación entre GD15 y los residuos en el Edificio D6 .......................................... 353

Figura 239. Consumos reales y pronosticados Octubre 2015-Mayo 2016. Edificio D6 ................ 356

Figura 240. Consumos reales y pronosticados Octubre 2016-Mayo 2017. Edificio D6 ................ 357

Figura 241. Consumos reales y pronosticados Octubre 2017-Mayo 2018. Edificio D6 ................ 358

Figura 242. Representación del modelo de regresión lineal simple para el Edificio D7 ............... 363

Figura 243. Relación entre los pronósticos y los residuos en el Edificio D7 ................................ 366

Figura 244. Relación entre GD15 y los residuos en el Edificio D7 ............................................. 366

Figura 245. Consumos reales y pronosticados Octubre 2015-Mayo 2016. Edificio D7 ................ 369

Figura 246. Consumos reales y pronosticados Octubre 2016-Mayo 2017. Edificio D7 ................. 370

Figura 247. Consumos reales y pronosticados Octubre 2017-Mayo 2018. Edificio D7 ................ 371

Figura 248. Representación del modelo de regresión lineal simple para el Edificio D8 ............... 376

Figura 249. Representación del modelo de regresión lineal múltiple para el Edificio D8 ............. 377

Figura 250. Relación entre los residuos y el tiempo en el Edificio D8. Modelo 2........................ 382

Figura 251. Relación entre los pronósticos y los residuos en el Edificio D8. Modelo 1 ................ 383

Figura 252. Relación entre la Temperatura media y los residuos en el Edificio D8. Modelo 1 ...... 383

Figura 253. Relación entre los pronósticos y los residuos en el Edificio D8. Modelo 2 ................. 384

Figura 254. Relación entre la Temperatura media y los residuos en el Edificio D8. Modelo 2 ...... 384

Figura 255. Relación entre la velocidad del viento nocturna y los residuos. Edificio D8. Modelo 2385

Figura 256. Gráfico de la temperatura media y la velocidad del viento diurna. ........................ 386

Figura 257. Consumos reales y pronosticados Octubre 2015-Mayo 2016. Edificio D8 ................ 389

Figura 258. Consumos reales y pronosticados Octubre 2016-Mayo 2017. Edificio D8 ................ 391

Figura 259. Consumos reales y pronosticados Octubre 2017-Mayo 2018. Edificio D8 ................ 392

Figura 260. Representación del modelo de regresión lineal simple para el Edificio D9 ............... 397

Figura 261. Relación entre los pronósticos y los residuos en el Edificio D9............................... 400

Figura 262. Relación entre Grados día Base 15 y los residuos en el Edificio D9......................... 400

Figura 263. Consumos reales y pronosticados Octubre 2015-Mayo 2016. Edificio D9 ................ 403

Figura 264. Consumos reales y pronosticados Octubre 2016-Abril 2017. Edificio D9.................. 404

Figura 265. Consumos reales y pronosticados Octubre 2017-Mayo 2018. Edificio D9 ................ 405

Figura 266. Representación del modelo de regresión lineal simple para el Edificio D10 ............. 410 
Figura 267. Relación entre los pronósticos y los residuos en el Edificio D10 ............................ 413

Figura 268. Relación entre Temperatura media y los residuos en el Edificio D10 ..................... 413

Figura 269. Consumos reales y pronosticados Octubre 2015-Mayo 2016. Edificio D10 .............. 416

Figura 270. Consumos reales y pronosticados Octubre 2016-Abril 2017. Edificio D10 ............... 417

Figura 271. Consumos reales y pronosticados Octubre 2017-Mayo 2018. Edificio D10 .............. 418

Figura 272. Representación del modelo de regresión lineal simple para el Edificio D11 ............. 423

Figura 273. Representación del modelo de regresión lineal múltiple para el Edificio D11 ........... 423

Figura 274. Relación entre los residuos y el tiempo en el Edificio D11. Modelo 2 ....................... 427

Figura 275. Relación entre los pronósticos y los residuos en el Edificio D11. Modelo 1 ............... 428

Figura 276. Relación entre la Temperatura media y los residuos en el Edificio D11. Modelo $1 . . .429$

Figura 277. Relación entre los pronósticos y los residuos en el Edificio D11. Modelo 2 .............. 429

Figura 278. Relación entre la Temperatura media y los residuos en el Edificio D11. Modelo 2 .... 430

Figura 279. Relación entre Grados día Base 15 y los residuos. Edificio D11. Modelo 2 ................ 430

Figura 280. Gráfico de la temperatura media y los Grados día Base 15................................... 431

Figura 281. Consumos reales y pronosticados Octubre 2015-Mayo 2016. Edificio D11 .............. 434

Figura 282. Consumos reales y pronosticados Octubre 2016-Abril 2017. Edificio D11 ................ 436

Figura 283. Consumos reales y pronosticados Octubre 2017-Mayo 2018. Edificio D11 .............. 437

Figura 284. Representación del modelo de regresión lineal simple para el Edificio D12 ............. 442

Figura 285. Relación entre los pronósticos y los residuos en el Edificio D12 .............................. 445

Figura 286. Relación entre GD15 y los residuos en el Edificio D12 ........................................ 445

Figura 287. Consumos reales y pronosticados Octubre 2015-Mayo 2016. Edificio D12 .............. 448

Figura 288. Consumos reales y pronosticados Octubre 2016-Mayo 2017. Edificio D12 .............. 449

Figura 289. Consumos reales y pronosticados Octubre 2017-Mayo 2018. Edificio D12 .............. 450

Figura 290. Representación del modelo de regresión lineal simple para el Edificio E1 ............... 456

Figura 291. Relación entre los residuos y el tiempo en el Edificio E1 ...................................... 459

Figura 292. Relación entre los pronósticos y los residuos en el Edificio E1 ................................. 460

Figura 293. Relación entre GD20_24h y los residuos en el Edificio E1 ...................................... 460

Figura 294. Consumos reales y pronosticados Octubre 2016-Mayo 2017. Edificio E1 ................. 463

Figura 295. Consumos reales y pronosticados Octubre 2017-Mayo 2018. Edificio E1................. 464

Figura 296. Representación del modelo de regresión lineal simple para el Edificio E2 .............. 469

Figura 297. Relación entre los residuos y el tiempo en el Edificio E2 .................................... 472

Figura 298. Relación entre los pronósticos y los residuos en el Edificio E2 .............................. 473

Figura 299. Relación entre T_min y los residuos en el Edificio E2 ............................................. 473

Figura 300. Consumos reales y pronosticados Octubre 2016-Mayo 2017. Edificio E2 ................. 476

Figura 301. Consumos reales y pronosticados Octubre 2017-Mayo 2018. Edificio E2 ................. 477

Figura 302. Representación del modelo de regresión lineal simple para el Edificio E3 .............. 483

Figura 303. Representación del modelo de regresión lineal múltiple para el Edificio E3............. 483

Figura 304. Relación entre los residuos y el tiempo en el Edificio E3. Modelo 2 ........................ 488

Figura 305. Relación entre los pronósticos y los residuos en el Edificio E3. Modelo 1 ................ 489

Figura 306. Relación entre la Temperatura media y los residuos en el Edificio E3. Modelo 1 ...... 489

Figura 307. Relación entre los pronósticos y los residuos en el Edificio E3. Modelo 2 ................ 490

Figura 308. Relación entre la Temperatura media y los residuos en el Edificio E3. Modelo 2 ...... 490

Figura 309. Relación entre la velocidad del viento nocturna y los residuos. Edificio E3. Modelo 2491

Figura 310. Gráfico de la temperatura mínima y la velocidad del viento diurna. ....................... 492

Figura 311. Consumos reales y pronosticados Octubre 2015-Mayo 2016. Edificio E3 ................. 495

Figura 312. Consumos reales y pronosticados Octubre 2016-Mayo 2017. Edificio E3................. 497 
Listado de Figuras

Figura 313. Consumos reales y pronosticados Octubre 2017-Mayo 2018. Edificio E3................. 498

Figura 314. Representación del modelo de regresión lineal simple para el Edificio E4 ............... 503

Figura 315. Relación entre los pronósticos y los residuos en el Edificio E4 ................................ 506

Figura 316. Relación entre GD20_24h y los residuos en el Edificio E4 ....................................... 506

Figura 317. Consumos reales y pronosticados Octubre 2015-Mayo 2016. Edificio E4 ................ 509

Figura 318. Consumos reales y pronosticados Octubre 2017-Mayo 2018. Edificio E4................. 511

Figura 319. Representación del modelo de regresión lineal simple para el Edificio E5 ............... 515

Figura 320. Relación entre los pronósticos y los residuos en el Edificio E5 ............................... 518

Figura 321. Relación entre GD15_30min y los residuos en el Edificio E5 ................................ 518

Figura 322. Consumos reales y pronosticados Octubre 2015-Mayo 2016. Edificio E5................. 521

Figura 323. Consumos reales y pronosticados Octubre 2016-Mayo 2017. Edificio E5.................. 522

Figura 324. Consumos reales y pronosticados Octubre 2017-Mayo 2018. Edificio E5................. 523

Figura 325. Representación del modelo de regresión lineal simple para el Edificio E6 ............... 528

Figura 326. Relación entre los pronósticos y los residuos en el Edificio E6 .............................. 531

Figura 327. Relación entre T_med y los residuos en el Edificio E6 ......................................... 531

Figura 328. Consumos reales y pronosticados Octubre 2015-Mayo 2016. Edificio E6................ 534

Figura 329. Consumos reales y pronosticados Octubre 2016-Mayo 2017. Edificio E6................ 535

Figura 330. Consumos reales y pronosticados Octubre 2017-Mayo 2018. Edificio E6................. 536

Figura 331. Representación del modelo de regresión lineal simple para el Edificio E7 ............... 541

Figura 332. Relación entre los pronósticos y los residuos en el Edificio E7 ............................... 544

Figura 333. Relación entre GD15_30min y los residuos en el Edificio E7 .................................. 544

Figura 334. Consumos reales y pronosticados Octubre 2015-Mayo 2016. Edificio E7................ 547

Figura 335. Consumos reales y pronosticados Octubre 2016-Mayo 2017. Edificio E7................ 548

Figura 336. Consumos reales y pronosticados Octubre 2017-Mayo 2018. Edificio E7................. 549

Figura 337. Representación del modelo de regresión lineal simple para el Edificio E8 ............... 554

Figura 338. Representación del modelo de regresión lineal múltiple para el Edificio E8............... 555

Figura 339. Relación entre los pronósticos y los residuos en el Edificio E8. Modelo 1 ................. 560

Figura 340. Relación entre la Temperatura media y los residuos en el Edificio E8. Modelo 1 ...... 561

Figura 341. Relación entre los pronósticos y los residuos en el Edificio E8. Modelo 2 ................ 561

Figura 342. Relación entre la Temperatura media y los residuos en el Edificio E8. Modelo 2 ...... 562

Figura 343. Relación entre la velocidad del viento nocturna y los residuos. Edificio E8. Modelo 2562

Figura 344. Gráfico de la temperatura mínima y la velocidad del viento diurna. ....................... 563

Figura 345. Consumos reales y pronosticados Octubre 2015-Mayo 2016. Edificio E8................. 567

Figura 346. Consumos reales y pronosticados Octubre 2016-Mayo 2017. Edificio E8.................. 569

Figura 347. Consumos reales y pronosticados Octubre 2017-Mayo 2018. Edificio E8................. 570

Figura 348. Representación del modelo de regresión lineal simple para el Edificio E13.............. 575

Figura 349. Relación entre los residuos y el tiempo en el Edificio E13 .................................... 578

Figura 350. Relación entre los pronósticos y los residuos en el Edificio E13 ............................. 579

Figura 351. Relación entre T_max y los residuos en el Edificio E13 .......................................... 579

Figura 352. Consumos reales y pronosticados Octubre 2015-Mayo 2016. Edificio E13............... 582

Figura 353. Consumos reales y pronosticados Octubre 2016-Mayo 2017. Edificio E13................ 583

Figura 354. Consumos reales y pronosticados Octubre 2017-Mayo 2018. Edificio E13............... 584

Figura 355. Representación del modelo de regresión lineal simple para el Edificio E14.............. 589

Figura 356. Relación entre los pronósticos y los residuos en el Edificio E14 ............................... 592

Figura 357. Relación entre GD20_24h y los residuos en el Edificio E14 …................................ 592

Figura 358. Consumos reales y pronosticados Octubre 2015-Mayo 2016. Edificio E14............... 595 
Figura 359. Consumos reales y pronosticados Octubre 2016-Mayo 2017. Edificio E14............... 596

Figura 360. Consumos reales y pronosticados Octubre 2017-Mayo 2018. Edificio E14 ............... 597

Figura 361. Representación del modelo de regresión lineal simple para el Edificio E15.............. 602

Figura 362. Representación del modelo de regresión lineal múltiple para el Edificio E15 ............ 603

Figura 363. Relación entre los pronósticos y los residuos en el Edificio E15. Modelo 1................608

Figura 364. Relación entre la Temperatura media y los residuos en el Edificio E15. Modelo 1 .... 609

Figura 365. Relación entre los pronósticos y los residuos en el Edificio E15. Modelo 2 ...............609

Figura 366. Relación entre la Temperatura media y los residuos en el Edificio E15. Modelo 2 .... 610

Figura 367. Relación entre la velocidad máxima y los residuos. Edificio E15. Modelo 2 ............... 610

Figura 368. Gráfico de la temperatura mínima y la velocidad del viento máxima...................... 611

Figura 369. Consumos reales y pronosticados Octubre 2015-Mayo 2016. Edificio E15.............. 615

Figura 370. Consumos reales y pronosticados Octubre 2016-Mayo 2017. Edificio E15............... 616

Figura 371. Consumos reales y pronosticados Octubre 2017-Mayo 2018. Edificio E15............... 617 